Protecting the Body in War and Combat

Metal Body Armour in Bronze Age Europe

Marianne Modulnger 
Marianne Mödlinger

Protecting the Body in War and Combat Metal Body Armour in Bronze Age Europe 
Österreichische Akademie der Wissenschaften Philosophisch-historische Klasse

Oriental and European Archaeology

Volume 6

Series Editor: Barbara Horejs

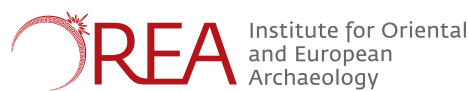

Publication Coordination: Estella Weiss-Krejci

Editorial Assistant: Jörg Weilhartner 
Marianne Mödlinger

\section{Protecting the Body in War and Combat}

Metal Body Armour in Bronze Age Europe 
Accepted by the Publication Committee of the Division of Humanities and the Social Sciences of the Austrian Academy of Sciences:

Michael Alram, Bert Fragner, Hermann Hunger, Sigrid Jalkotzy-Deger, Brigitte Mazohl, Franz Rainer,

Oliver Jens Schmitt, Peter Wiesinger and Waldemar Zacharasiewicz

Printed with the support of the Austrian Science Fund (FWF) PUB-337-G25

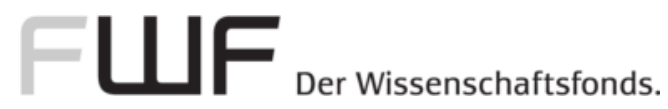

Open Access: Wo nicht anders festgehalten, ist diese Publikation lizenziert unter der Creative Commons Lizenz Namensnennung 4.0

Open access: Except where otherwise noted, this work is licensed

under a Creative Commons Attribution 4.0 Unported License. To view a copy of this licence, visit http://creativecommons.org/licenses/by/4.0/

This publication has undergone the process of anonymous, international peer review. The paper used for this publication was made from chlorine-free bleached cellulose and is aging-resistant and free of acidifying substances.

English language editing: Steven Matthews Copy editing: Jörg Weilhartner, Estella Weiss-Krejci Graphics and layout: Berger Crossmedia, 1050 Wien

Coverdesign: Mario Börner, Angela Schwab

Some rights reserved

ISBN 978-3-7001-7741-8

Copyright $(\mathcal{2} 2017$ by

Austrian Academy of Sciences

Vienna

Printing and binding: Prime Rate kft., Budapest

http://epub.oeaw.ac.at/7741-8

http://verlag.oeaw.ac.at

Printed and bound in the EU 


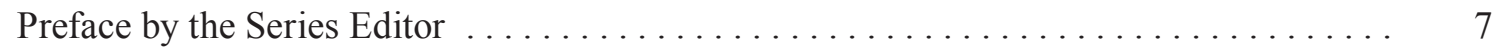

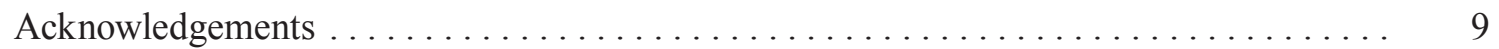

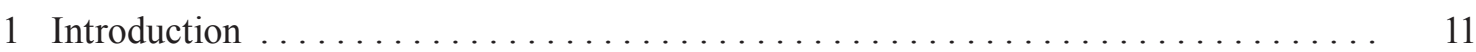

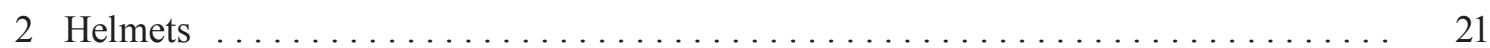

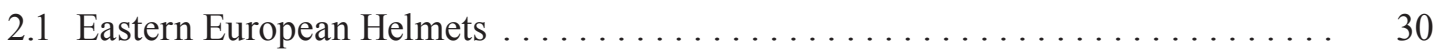

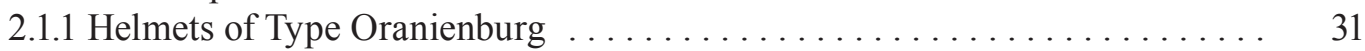

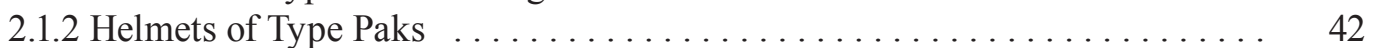

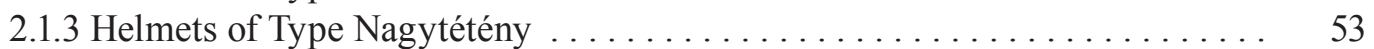

2.1.4 Helmets of Type Pişcolt . . . . . . . . . . . . . . . . . . . . . 57

2.1.5 Single Helmet Types, Cheek Plates, Knobs and Possible Fragments . . . . . 69

2.1.6 Outlook to the Iron Age: Italian Cap Helmets . . . . . . . . . . . . . 83

2.2 Western European Helmets $\ldots \ldots \ldots$. . . . . . . . . . . . . . . . . . . . . . . . . . 90

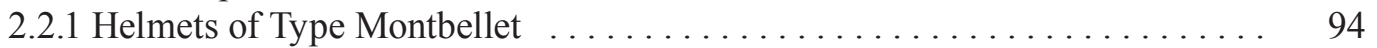

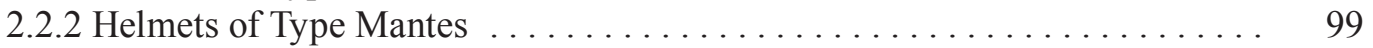

2.2 .3 Helmets of Type Lueg . . . . . . . . . . . . . . . . . . . . 103

2.2.4 Helmets of Type Biebesheim ............................. 109

2.2.5 Helmets of Type Bernières d'Ailly $\ldots \ldots \ldots \ldots \ldots \ldots \ldots \ldots \ldots \ldots . \ldots \ldots$

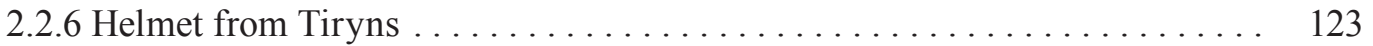

2.2.7 Single Helmet types and Potential Helmet Finds . . . . . . . . . . . . . . . . 125

2.2.8 Outlook to the Iron Age: Italian Crested Helmets . . . . . . . . . . . . . . . . 126

2.3 Horned Helmets . . . . . . . . . . . . . . . . . . . . . . . . . . . . . . . . . . . . . 137

2.4 Analyses Helmets . . . . . . . . . . . . . . . . . . . . . . . . . . . . . . . . . . 148

2.4.1 Chemical Characterisation - Cap Helmets . . . . . . . . . . . . . . . . 149

2.4.2 Chemical Characterisation - Crested Helmets ............... 156

2.4.3 Metallographic Characterisation and Construction - Cap Helmets .... . . 158

2.4.4 Metallographic Characterisation and Construction - Crested Helmets .... 167

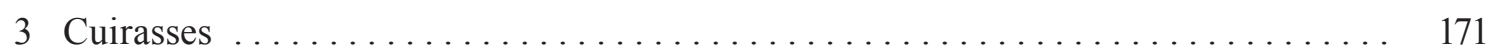

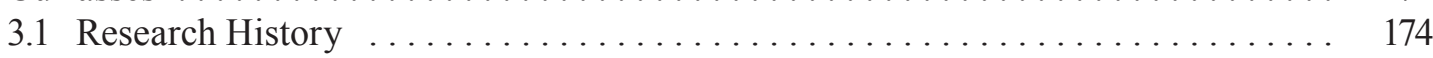

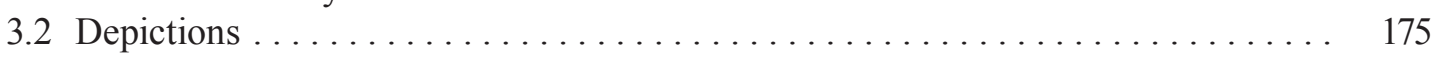

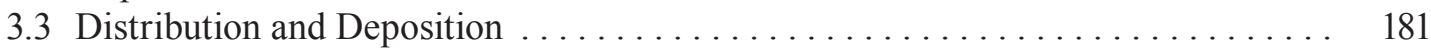

3.4 Chronology and Typology $\ldots \ldots \ldots \ldots$. . . . . . . . . . . . . . . . . . . . . . . . . 184

3.5 Decoration .......................................... 188

3.6 Cuirass Fragments and Potential Cuirass Finds ................... 191

3.7 Construction . . . . . . . . . . . . . . . . . . . . . . . . . . . . . . . 195

3.8 Analyses . . . . . . . . . . . . . . . . . . . . . . . . . . . . . . . 202

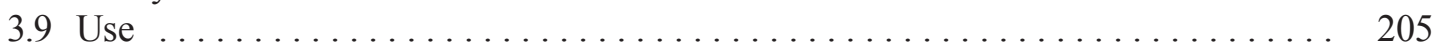

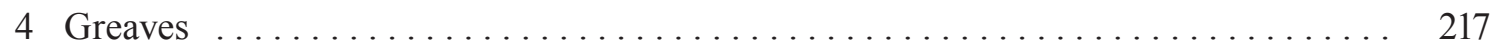

4.1 Greaves of Class I, Subclass A . . . . . . . . . . . . . . . . . . . . . . 222

4.1.1 Greaves of Type Desmontà . . . . . . . . . . . . . . . . . . . . . 222

4.1.2 Greaves of Type Lengyeltóti . . . . . . . . . . . . . . . . . . . . 227

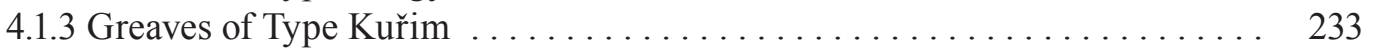

4.1.4 Single Types and Miniature Greaves . . . . . . . . . . . . . . . 237

4.2 Greaves of Class I, Subclass B . . . . . . . . . . . . . . . . . . 241

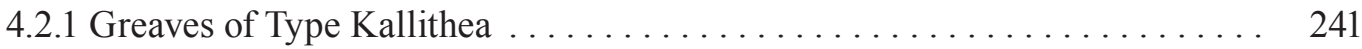


4.3 Greaves of Class I, Subclass C . . . . . . . . . . . . . . . . . . . . . 245

4.3.1 Greaves of Type Grammichele ....................... 245

4.4 Greaves of Class I, Subclass D . . . . . . . . . . . . . . . . . . . . . . . . 247

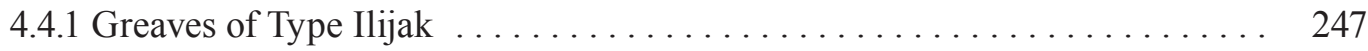

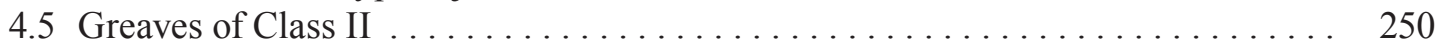

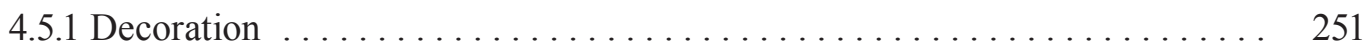

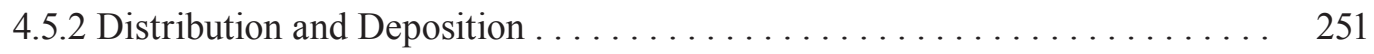

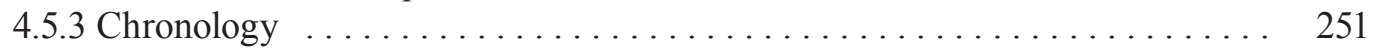

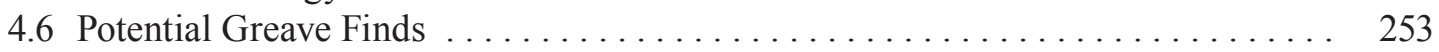

4.7 Analyses and Construction . . . . . . . . . . . . . . . . . . . . 254

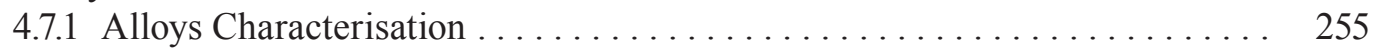

4.7.2 Manufacturing Process - Microstructural Observations . . . . . . . . . . 257

4.7.3 Manufacturing Process - Macroscopic Observations $\ldots \ldots \ldots \ldots \ldots .260$

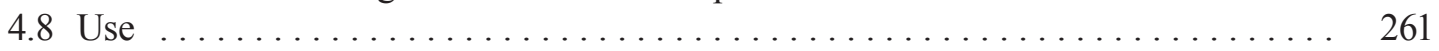

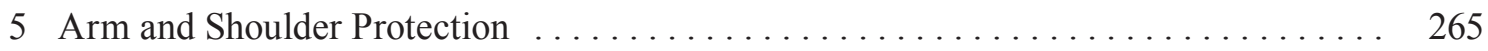

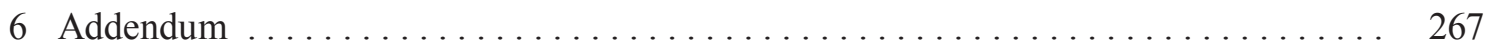

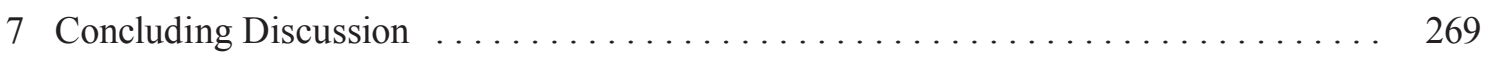

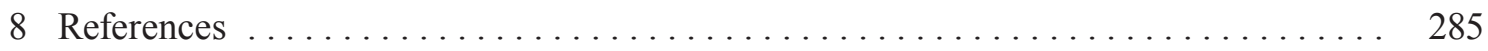

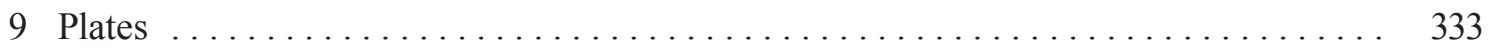




\section{Preface by the Series Editor}

The sixth volume of the Oriental and European Archaeology series examines body armour in Bronze Age Europe in a detailed and holistic study. The series' aims of connecting research in European and Oriental archaeology by focusing on big topics and questions for both connected cultural zones is well represented in the current volume. The presented monograph 'Protecting the Body in War and Combat: Metal Body Armour in Bronze Age Europe' by Marianne Mödlinger continues the focus of the peer-reviewed OREA series in discussing general themes for a broader scientific community. The four volumes published so far dealt with proto-urbanisation, exchange systems, interaction and societies in their environmental contexts, material sources, metallurgy and transfer of knowledge in prehistory. Each volume focuses on huge geographical-cultural areas, such as Anatolia and the Aegean, the Aegean and the Near East, Anatolia and southeastern Europe as well as northern Arabia. The present monograph is also embedded in a vast geographical context, reaching from the Mediterranean to Europe.

Body armour is - like offensive metal weapons - a significant element in the Bronze Age period and is known all over the continent. This distinct object category not only contains an important information source of war and combat; its relation with complex deposition systems and symbolisms of power and wealth also opens a window into the social and cultural dimensions of Bronze Age societies in the vast area between Scandinavia, the Iberian Peninsula and Cyprus. The innovative approach of the author Marianne Mödlinger lies in the analysis of the potential use and function of body armour with a wide range of methods. By integrating compositional analyses, micro- and macrostructural features, shaping processes, repairs and scales of deformation, she offers new insights into the manufacture and use of helmets, greaves and cuirasses. Mödlinger's broad study not only provides new primary analytical data, but - not less important - also a collection of altogether c. 230 body armour objects between the Mediterranean and Europe. Her detailed discussion of their geographical distribution, chronological position, typological classification and material characteristics leads to a new reference work for a broad scientific community. Thanks to the author's engagement in collecting all available data and in additional sampling a representative group of objects, her results offer sustainable conclusions regarding the use and function of Bronze Age metal body armour.

The Schrödinger program of the Austrian Science Fund (FWF) and the European CHARISMA key action program have funded the author's studies. My sincere thanks go to the FWF for financing this publication including editing, layout and print procedures. I warmly thank Steven Matthews for native speaker corrections and Estella Weiss-Krejci (OREA) for editing the manuscript.

Finally, I wish the author a broad international and interested readership taking over her outlook in the concluding chapter to continue material analyses of body armour and weaponry in the future.

Barbara Horejs

Director of the Institute for Oriental and European Archaeology

Vienna, 10 February 2017 


\section{ORIENTAL AND EUROPEAN ARCHAEOLOGY}

Vol. 1 B. Horejs - M. Mehofer (eds.), Western Anatolia before Troy. Proto-Urbanisation in the $4^{\text {th }}$ Millenium BC? Proceedings of the International Symposium held at the Kunsthistorisches Museum Wien, Vienna, Austria, 21-24 November, 2012 (Vienna 2014).

Vol. 2 B. Eder - R. Pruzsinszky (eds.), Policies of Exchange. Political Systems and Modes of Interaction in the Aegean and the Near East in the $2^{\text {nd }}$ Millennium B.C.E. Proceedings of the International Symposium at the University of Freiburg, Institute for Archaeological Studies, 30 ${ }^{\text {th }}$ May-2 $2^{\text {nd }}$ June, 2012 (Vienna 2015).

Vol. 3 M. Bartelheim - B. Horejs - R. Krauß (eds.), Von Baden bis Troia. Ressourcennutzung, Metallurgie und Wissenstransfer. Eine Jubiläumsschrift für Ernst Pernicka (Rahden/Westf. 2016).

Vol. 4 M. Luciani (ed.), The Archaeology of North Arabia. Oases and Landscapes. Proceedings of the International Congress held at the University of Vienna, 5-8 December, 2013 (Vienna 2016).

Vol. 5 Barbara Horejs, Çukuriçi Höyük 1. Anatolia and the Aegean from the $7^{\text {th }}$ to the $3^{\text {rd }}$ Millennium BC. With contributions by Christopher Britsch, Stefan Grasböck, Bogdana Milić, Lisa Peloschek, Maria Röcklinger and Christoph Schwall (Vienna 2017). 


\section{Acknowledgements}

First, I would like to thank the Austrian Science Fund (FWF) and the FP7/Marie Curie actions, which supported this research with the Schrödinger-fellowship no. J 3109-G21. This publication received additional financial support from the Austrian Science Fund (project no. PUB 337G25). Furthermore, my research has also been supported by the European Commission under the $7^{\text {th }}$ Framework Programme through the Key Action CHARISMA (Grant Agreement $n$. 228330). Special thanks go to the FWF-Schrödinger team, especially to Reinhard Schmidt and Robert Gass, who helped me with the paperwork of the project.

The preparation of this monograph has seen a significant improvement by criticism from (in alphabetic order): Dirk Brandherm (Queen's University Belfast); Albrecht Jockenhövel (Münster); Steven Matthews (Groningen Institute of Archaeology); Barry Molloy (University College Dublin); Tudor Soroçeanu (Berlin); Marion Uckelmann (Durham) and the four anonymous reviewers, although they would not necessarily agree with all herein and whatever remains is my sole responsibility. Special thanks to all of them!

I would like to give all my sincere thanks to everyone in the museums with Bronze Age armour supporting me by the access to their finds and the support with additional material of the finds (in alphabetic order): Jacqueline Balen (Arheološki muzej u Zagrebu, Zagreb); Dorin Barbu (Muzeul National Brukenthal, Sibiu); Juraj Bartík (Archeologické múzeum SNM, Bratislava); Ioan Bejinariu (Muzeul Judeţean de Istorie şi Arlă-Zalău, Zalău); Magdaléna Bekessová (Podtatranské Múzeum, Poprad); Katalin Biro (Magyar Nemzeti Múzeum, Budapest); Marianna Bressan (Soprintendenza per i beni archeologici del Veneto); Jean Duriaud (G.R.A.T.); Béla Eöry (Balatonberény); Ioannis Georganas (Hellenic International Studies in the Arts); Adrian Georgescu (Muzeul National Brukenthal, Sibiu); Paul Gleirscher (Landesmuseum Kärnten, Klagenfurt); Florin Gogaltan (Muzeul Naţional de Istorie a Transilvaniei, Cluj); Andras Gulyás (Tessedik Sámuel Múzeum, Szarvas); Attila Nándor Hágó (Muzeul Municipal Carei Nagykárolyi Városi Múzeum, Carei/Nagykároly); Birgit Heide (Landesmuseum, Mainz); Michael Hemm (Montanmuseum, Altböckstein); Szilvia Honti (Somogy Megyei Múzeumok Igazgatósága, Kaposvár); Duncan Hook (British Museum, London); Tomislav Hršak (Arheološki Muzej, Osijek); Vesna Isabegovic (Muzej istočne Bosne posjeduje); Georg Kandutsch (Kärnten); Raimund Kastler (Carolinum Augusteum, Salzburg); Anton Kern (Naturhistorisches Museum, Vienna); Vesna Koprivnik (Regional Museum, Maribor); Sieglinge Köberl (Kammerhofmuseum, Bad Aussee); Marta Kučerová (Múzeum v Kežmarku, Kežmarok); András Liska (Erkel Ferenc Múzeum, Gyula); Sabin A. Luca (Muzeul National Brukenthal, Sibiu); Guido Mark (Heimatkunde- und Museumsverein, Wattens-Volders); Dragoş Măndescu (Muzeul Judeţean, Argeş); Maria Maric (Franjevački muzej i galerija, Livno); Liviu Marta (Muzeul Judeţean, Satu Mare); Marko Mele (Universalmuseum Joanneum, Schloss Eggenberg, Graz); Benoît Mille (C2RMF, Paris); Mónika Merczi (Balassa Bálint Múzeum, Esztergom); Marija Mihaljević (Gradski muzej Nova Gradiška); Sanjin Mihelić (Arheološki muzej u Zagrebu, Zagreb); Lidija Miklik-Lozuk (Muzej Slavonski Brod, Slavonski Brod); Ivan Mirnik (Arheološki muzej u Zagrebu, Zagreb); Róbert Müller (Balatoni Múzeum, Keszthely); Gabriella Nadorfi (Szent István Király Múzeum, Székesfehérvár); Marcella Nagy (Vas Megyei Múzeumok Igazgatósága, Szombathely); János Németi (Muzeul Municipal Carei/Nagykárolyi Városi Múzeum, Carei/Nagykároly); Váradyné Péterfi (Városi Múzeum, Paks); Nataša Perić (Muzej istočne Bosne posjeduje, Tuzla); Tamás Pusztai (Herman Ottó Múzeum, Miskolc); Hans Reschreiter (Naturhistorisches Museum, Vienna); Mihai Rotea (Muzeul Naţional de Istorie a 
Transilvaniei, Cluj-Napoca); Milan Salaš (Moravské zemské muzeum, Brno); Paul Scrobotă (Muzeul de Istorie şi Ştiinţele Naturii, Aiud); Ildikó Szathmári (Magyar Nemzeti Múzeum, Budapest); Blanka Veselá (Muzeum Prostějovska, Prostějov); Alain Villes (Musée d'Archéologie Nationale, Saint-Germain-en-Laye); Maria Vintilă (Muzeul de Istorie şi Ştiinţele Naturii, Aiud); Marián and Marek Vizdal (Prešovská Univerzita, Prešov); Márta Vizi (Wosinsky Mór Megyei Múzeum, Szekszárd); Marina Volonté (Museo Civico, Cremona) and Quanyu Wang (British Museum, London).

I am also very grateful to the following persons who helped me during my project with literature, photographs, discussions and advice (in alphabetic order): Tiberius Bader (Hemmingen); Holger Baitinger (Römisch-Germanisches Zentralmuseum, Mainz); Daria G. Banchieri (Museo Civico Archeologico di Villa Mirabello, Varese); Sandrine Berthelot (Musée de Normandie, Ville de Caen); Jean-Claude Blanchet (Musée Antoine Vivenel, Compiégne); Erich Claßen (Archäologische Staatssammlung, Munich); Noëmi Daucé (Musée des Beaux-Arts et d'Archéologie, Besançon); Yannis Galanakis (Ashmolean Museum, University of Oxford); Uta Halle (Senator für Kultur, Landesarchäologie Bremen); Svend Hansen (Deutsches Archäologisches Institut, Berlin); Norbert Hefermehl (Heimatmuseum, Biebesheim); Guido Helmig (Archäologische Bodenforschung Basel-Stadt, Basel); Frank Hildebrandt (Museum für Kunst und Gewerbe, Hamburg); Christiano Iaia (Newcastle University); Mateusz Jaeger (Adam Mickiewicz University, Poznań); Detlef Jantzen (Landesamt für Kultur und Denkmalpflege, Schwerin); Katharina Kalser (Krems); Viktoria Kíss (Magyar Tudományos Akadémia, Budapest); Peter König (Heidelberg); Jovan Koledin (Muzej Vojvodine, Novi Sad); Anne-Sophie Leclerc (Musée départemental de Préhistoire d'Île-de-France, Nemours); János Makkay (MTA Régészeti Intézet); Cyril Marcigny (INRAP); Hartmut Matthäus (Universität Erlangen); Yvette Mottier (Stallikon, Zurich, Switzerland); Angela Di Niro (Museo Sannitico di Campobasso); Elisabeth Nowotny (Zentrum für Museale Sammlungswissenschaften, Donau-Universität Krems); Claudia Pankau (Johann Wolfgang Goethe-Universität, Frankfurt); Andrijana Pravidur (Zemaljski Muzej Bosne e Hercegovina, Sarajevo); Ivonne Przemuß (Universität Jena); Alexandre Rodrigues (Município de Vale de Cambra); Andrea Salimbeti and Raffaele d'Amato (Turin); Paola Salzani (Museo civico archeologico di Cologna Veneta, Cologna Veneta); Heiner Schwarzberg (Archäologische Staatssammlung, Munich); Daniel Simonin (Musée départemental de Préhistoire d'Île-de-France, Nemours); Margarita Sofou (Archaeological Museum of Nauplion, Nauplion); Lothar Sperber (Speyer); Tobias Springer (Germanisches Nationalmuseum, Nürnberg); Richard Stone (Metropolitan Museum of Art); Daniel Suter (Historisches Museum Basel); Ádám Szabó (Magyar Nemzeti Museum, Budapest, and University of Pécs); Gábor V. Szabó (Eötvös Loránd University, Budapest); Karin Tansem (Museum Alta, Alta); Pinka Taratori (Archaeological Museum of Nauplion, Nauplion); Gerhard Tomedi (Universität Innsbruck); Neva Trampuž-Orel (Narodni muzej Slovenije, Ljubljana); Ivan Vranić (Arheološki Institut, Belgrade); David Vogt (Kulturhistorisk Museum, Oslo); Eugene Warmenbol (Université Libre de Bruxelles, Bruxelles); Sylvie Watelet (C2RMF, Versailles); Birgit Wendel (Badisches Landesmuseum, Karlsruhe); Rainer-Maria Weiss (Stiftung Historische Museen Hamburg, Archäologisches Museum Hamburg, Helms-Museum); Malcolm Wiener (INSTAP); Stefan Wirth (Université de Bourgogne, Dijon) and Rebecca Wrightson (Higgins Armoury Museum, Worcester).

Boundless thanks goes to the English-language editor of my manuscript, Steven Matthews. He saved the reader not only from questionable 'Denglish', but also, apart from such delightful stylistic pearls such as helmets floating in space ('30 cm above the ground'), and other questionable things as a 'small cow plastic', significantly reduced many inconsistencies (I am afraid that some, nevertheless, remain). For all remaining oddities, errors, and assumptions I am the only one to blame.

Last, but not least, the most special thanks go to my daughter Helene for the time I spent writing and not with her. 


\section{Introduction}

Since the first studies on Bronze Age armour the number of helmets, greaves and cuirasses has increased significantly. This monograph provides for the first time an overview of all metal body armour from the European Bronze Age and aims to achieve a holistic view, not only from a typo-chronological perspective but also in focusing on the manufacture and usage of such armour. This was enabled through the re-evaluation of central and eastern European finds in particular and their material analyses. The monograph is divided in three main chapters, dealing with helmets, greaves and cuirasses respectively. In each chapter the research history, distribution and chronology, as well as manufacture and use of the different classes of armour is discussed. Only shields are not discussed in the following, since M. Uckelmann recently published them in an extensive study. ${ }^{1}$

Details of the development, manufacture and use of Bronze Age metal body armour has remained unclear for large parts of Europe, even after more than a century of research. The focus of previous studies was usually on typo-chronological aspects, while other topics such as manufacturing techniques, actual use and technological observations were rarely included in the studies or even considered as chronologically relevant. The study of Bronze Age warfare, be it theoretical or derived from a more practical, experimental approach, has become rather fashionable during the last decades, resulting in many publications and a wide variety of interpretations of how weaponry was used and how warfare took place. Compared to arms, studies of the use of armour have remained rather traditional, focusing on typology and cultural interactions with only a few significant exceptions. Among these are the work on shields by M. Uckelmann, which also incorporated a range of metallurgical analysis, the application of radiocarbon analyses to their dating, as well as use-wear analysis and experiments, and of B. Molloy, which also used use-wear analysis and experiments. ${ }^{2}$

Studies concentrating on Bronze Age cuirasses, greaves and helmets, especially where aspects of manufacture and use are concerned, nevertheless remain scarce, and usually focus on finds from the same find spot $^{3}$ or single finds. ${ }^{4}$ Metallurgical analysis or the study of chemical composition of armour is even scarcer: only a handful of objects had been analysed previously and the few studies undertaken are to be found spread over single papers and rarely referencing each other. ${ }^{5}$ C. Clausing, who studied greaves, is the only one to use as the basis of their typological classification the different methods of production and aspects of their technological design, such as the way that the greaves fix on the leg. ${ }^{6}$ So far, only H. Hencken saw, documented and described the majority of Bronze Age and Early Iron Age helmets in detail, though following the classification of G. v. Merhart.? He also identified and described evidence of usewear, such as damage from weapon impacts, and thus his study is seminal in this tradition for Bronze Age armour. For cuirasses, only a recent study by the author includes any metallurgical

\footnotetext{
Uckelmann 2012.

Molloy 2004; Uckelmann 2011; Uckelmann 2012; Molloy 2013.

E.g. Schauer 1982d; Mottier 1988.

E.g. Born - Hansen 1992; Born - Hansen 2001; Clausing 2005; Molloy 2013.

E.g. Born - Hansen 1992; Born - Hansen 2001; Lehoërff 2008; Taratori et al. 2008; Lippert 2011.

Clausing 2002

v. Merhart 1941; Hencken 1971.
} 
study and use-wear analysis, alongside a complete overview of this class of Bronze Age body armour. $^{8}$

Despite the fact that the experimental manufacture of Bronze Age weapons has a long history of research, ${ }^{9}$ similar studies concerning armour, especially body armour, are rare to nonexistent. Experimental studies have so far only been carried out on shields ${ }^{10}$ and the Dendra panoply. ${ }^{11}$ The shields have been studied in terms of both manufacture and use, whereas the Dendra panoply has only been studied in respect of its use. The major reason for the lack of further experiments certainly lies in the scarcity of skills required to reproduce bronze sheet objects with replica Bronze Age tools and in particular a lack of understanding concerning material characterisation, such as chemical composition and microstructure, of the original Bronze Age finds. Combining the results of material characterisation and identifiable manufacture- and use-wear traces, a good understanding of how the object was produced can be achieved, as we hope to demonstrate in this volume. Only with this evidential base can the reproduction of such armour be successfully achieved with the technologies identified and for tests of its usability and efficacy to have archaeological relevance.

To interpret warfare, combat and the actual use or efficacy of armour, it is important not only to understand the archaeological evidence but also the material characteristics of the bronze armour and social environments in which they were used. This is one of the gaps, which the author aims to close with this publication. Thus, this volume aims not only to be an extensive corpus of Bronze Age body armour, including the archaeological information, literature and depictions of the armour, but also one concerned with the application of metallurgical perspectives, incorporating both previous and newly carried out analyses of this armour. This publication focuses on both traditional artefact studies and metallurgical studies, including also the reconstruction of the manufacture of the armour, technological developments and innovation as well as use-wear analyses.

Unfortunately, many of the armour known today to archaeologists derives from illegal excavations, has no known find spot and context, and is currently in private collections (at least 17 helmets and some greaves are known to the author). Despite their doubtful provenance, they were sold and re-sold through different auction houses, and usually cannot be studied in detail. This publication includes also these 'new' finds, even though the publication of these finds might run the risk of raising their monetary value. Certain institutions, such as the German Archaeological Institute (DAI), prohibit the academic publication of finds without firm provenances, or of dubious acquisition, from private collections. This is laudable. However, there is also a need for academics to be aware of finds, especially those of forms poorly attested through archaeological recovery or in public collections, such as our metal armour. The inclusion of these finds here does not in any way infer that the illegal acquisition of archaeological materials is supported, or the collecting of finds for private collections. Also, the inclusion of such finds in genuine academic publications is not to be believed to encourage in any way their illegal collection or curation. This is in accordance also with the recent statement of the 'Committee on the Illicit Trade in Cultural Material' of the European Association of Archaeologists. ${ }^{12}$ It is, nevertheless, important to bring to light such important finds for the benefit of research and to present them alongside already known examples of their class, to at least slightly increase the small material framework that survives to us of this rare category of Bronze Age equipment.

The author documented, studied and analysed all accessible helmets, greaves and cuirasses in eastern Europe and some of the armour from western Europe, which significantly increased the number of armour studied and analysed in detail. The importance of carrying out studies

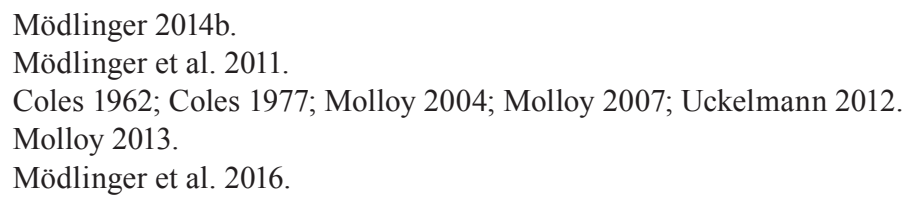


directly on the object cannot be emphasised enough: only in this way is it possible to confidently identify armour fragments as such, for example, distinguishing fragments formerly interpreted as parts of a helmet of Type Paks as being parts of decorated flat discs. ${ }^{13}$ Moreover, such direct study of the objects allows for the documentation of otherwise unrecognised traces of manufacture and use not only on the outside, but also on the inside and backside of the armour, dimensions that only rarely appear in published studies.

Since the distribution of Bronze Age body armour ranges from Iberia in the west to Cyprus in the east and from Sicily in the south to Sweden in the north, as well as in the Near East, it covers a wide geographical study area. Such a large area inevitably comes afflicted with numerous regional chronological systems, with differing phases and horizons, which have to be aligned in order to enable the visualisation of chronological development and to pinpoint the appearance and trade of specific types. As it is the scheme most widely used, we will follow the chronological classification of P. Reinecke, as updated by H. Müller-Karpe, despite ranging beyond the territory for which it was devised, as a supra-regional scheme. The numbered phases of this scheme have therefore been prefixed with regionally relevant phase names, primarily derived from characteristic metalwork deposits. Thus, these phases provide still the most useful descriptive tool for the discussion of chronology. The recent work of J. Sperber suggested new absolute dates for these phases, representing formerly so-called 'high' dates. ${ }^{14}$ The validity of his dates and the compatibility with the phases of Müller-Karpe is still debated. ${ }^{15}$ Similarly 'high' dates have also been suggested for the British Bronze Age, ${ }^{16}$ which are applicable to the western European or Atlantic Bronze Age.

The chronological classification used in the following is based on the dendro-chronological dates from the lake-shore settlements northwest of the Alps, which provide precise dating evidence for the $11^{\text {th }}-9^{\text {th }}$ centuries BC (Fig. 1.1) ${ }^{17}$ This chronological scheme was developed mainly for the western part of the Urnfield Culture but is also valid for wide parts of the eastern part of the Urnfield Culture and compatible with its various horizons of associated deposits (Depotfundstufen).

The different classes of armour have rather wide distribution patterns, which span over different geographical areas and time periods (Fig. 1.2). It is our aim to discover the reasons for this pattern and the background of exchange - its frequency and direction, the benefits accrued, the bonds made or the antagonisms created - that resulted in it. ${ }^{18}$ The definition exchange includes any transfer or displacement of material goods or people between individuals or groups in a spatial or temporal sense. With such displacement, a shift in value and perception of the object or person might be accompanied, which might also result in different depositional practices (see e.g. the cuirass from Saint-Germain-du-Plain). Distribution patterns of Bronze Age armour and any other object type depend on several factors, which influenced the archaeological record: ${ }^{19}$

1. Armour was circulated between regions but, as a result of the differing life-cycles (e.g. recycling, deposition) of individual objects or regions, much armour never or only scarcely entered the archaeological record.

2. Specific classes and types of armour were not available to groups in certain areas, be it for socio-cultural reasons (taboos) or simple economic unavailability (consumption) perhaps due to loss, recycling or deposition - before reaching such regions.

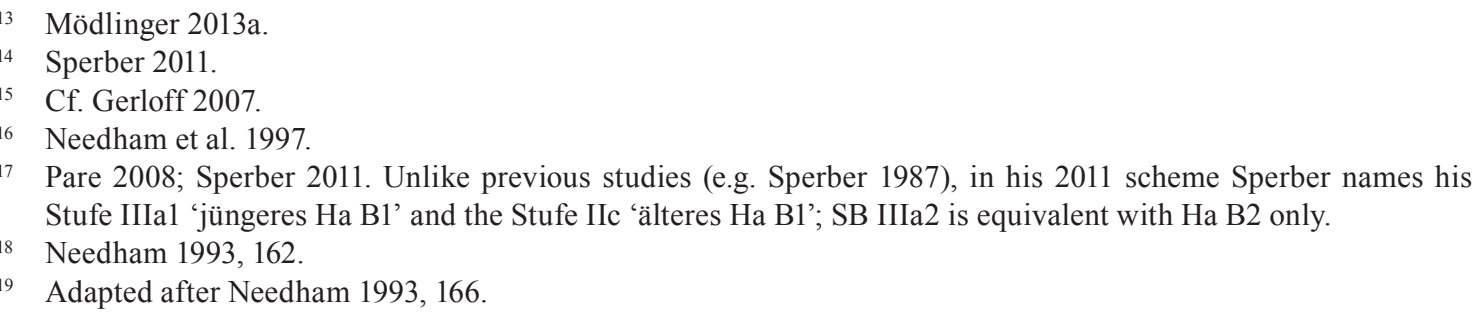




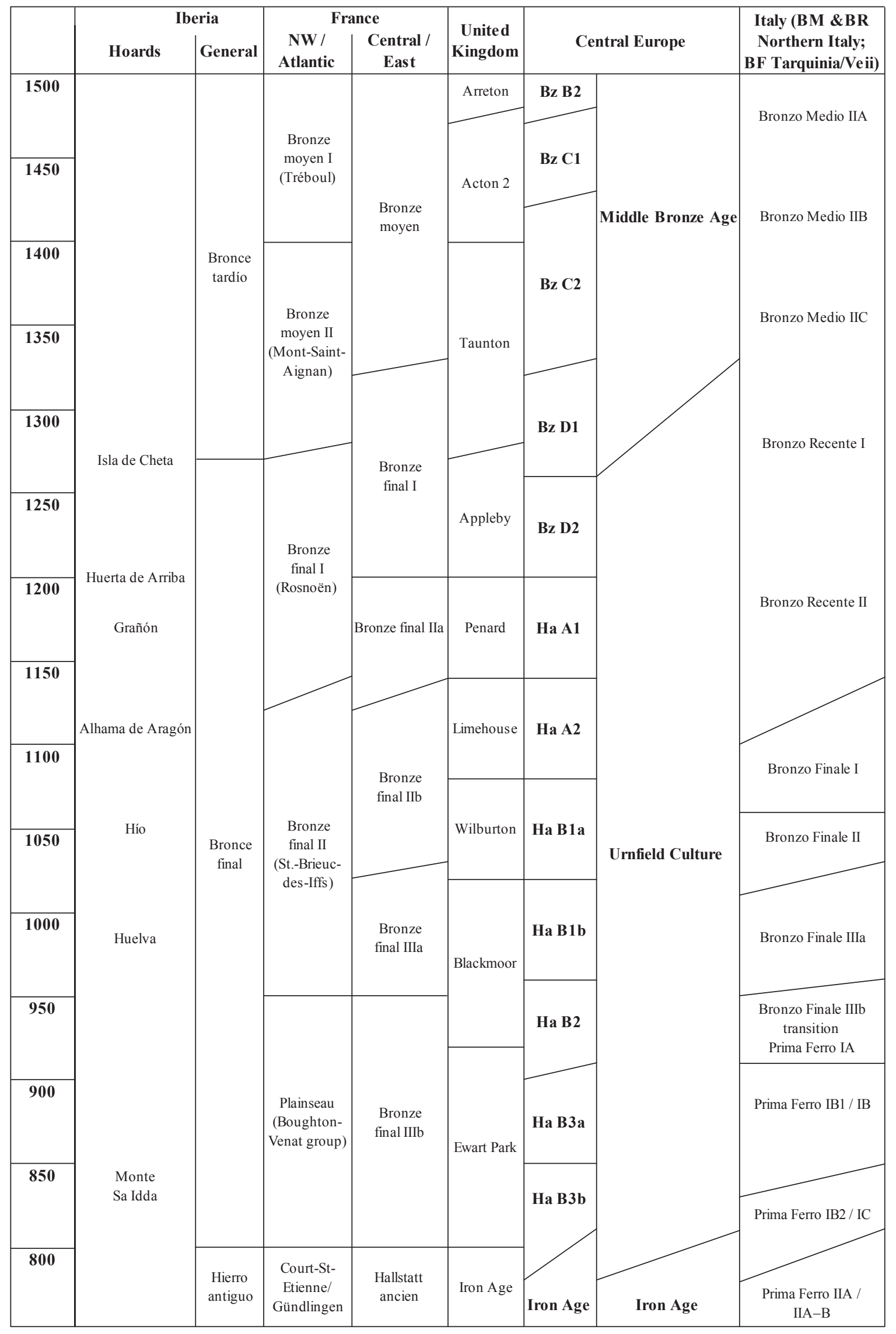

Fig. 1.1 Synchronised version of the relevant chronological systems mentioned in the text (1500-800 BC).

Iberia (including Monte Sa Idda, Sardinia): Roberts et al. 2013; France: Milcent 2012; Roberts et al. 2013; United Kingdom: Matthews forthcoming; central Europe: Pare 2008; Sperber 2011; Italy: de Marinis 1999; Iaia 2005; 


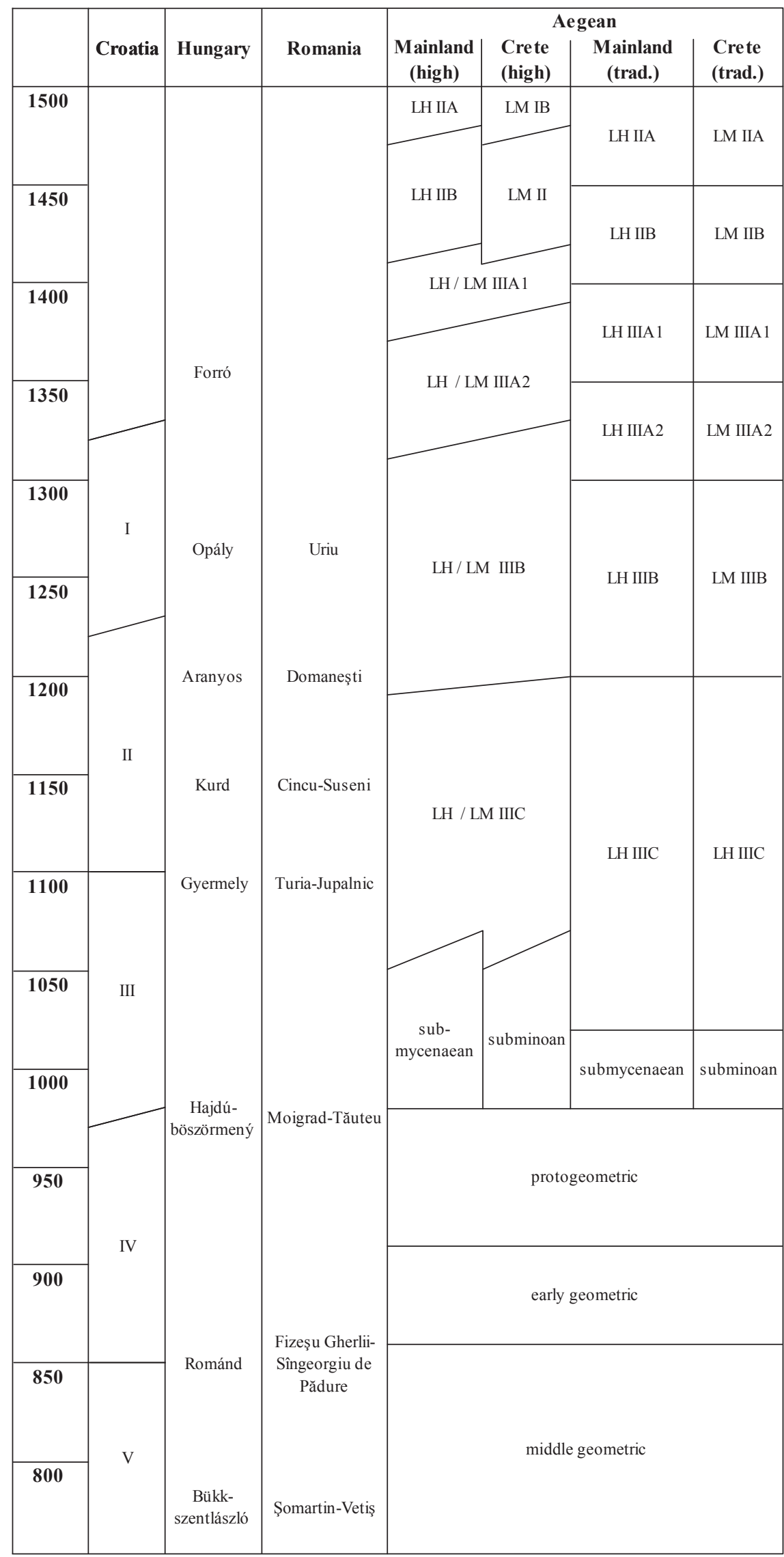

Fig. 1.1 continued.

Croatia: Vinski-Gasparini 1973; Hungary: Mozsolics 2000; Romania: Petrescu-Dîmboviţa 1978; Aegean: Manning 2010; Uckelmann 2012. 


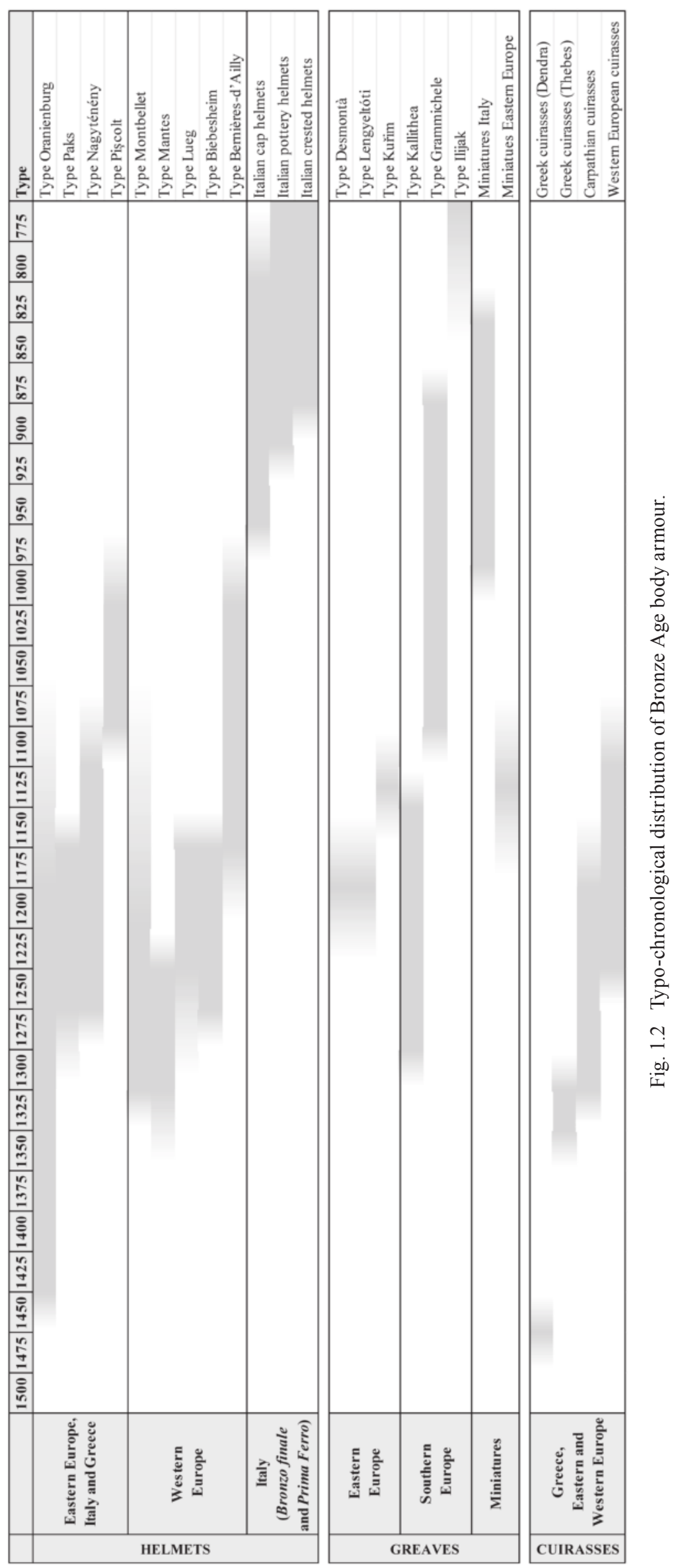


3. People were simply not interested in the specific class or type of armour for various reasons (e.g. another type of armour was considered 'better', being more effective or simply matching better the aesthetic or cultural expectations).

In truth, these distribution maps are in fact 'recovery maps', and need not necessarily represent original patterns of circulation or frequency accurately, and at best give only a vague idea of it. As such, it is necessary to rethink for instance the generalisation of western European helmets deposited in rivers and eastern European helmets deposited in associated deposits. ${ }^{20}$ These different deposition practices involving cuirasses, greaves and helmets will be discussed in their corresponding chapters.

Moreover, one has to take into account that it is not possible to completely reconstruct the spatial, temporal and social distance between the original production site and the ultimate find location, nor postulate the means of transmission or the significance or value attached to the objects as received by the recipients. ${ }^{21}$ The armour producing workshop does not necessarily need to be in the centre of a distribution of a specific class or type of armour but could just as likely be located somewhere else (as shown e.g. by the finds of socketed axes Type Mälar in Scandinavia and the workshops producing them in the Baltic). Thus, the documentation and publication of casting moulds and related casting evidence relating to the manufacture of Bronze Age armour is of significant importance, technologically and in relation to its spatial and chronological aspects. Once such production centres or areas are located, it is possible to reconstruct the technological and social constraints placed on production, its local imitations, as well as degree of receptiveness to stylistic or technological influences or the exploitation of local resources in a more reliable manner.

S. P. Needham ${ }^{22}$ is correct in his observation on the degree to which our archaeological distributions, as maps of archaeological recovery, do no accurately reflect past scales of circulation. However, archaeological 'distribution maps' must also be understood to be maps of what are specifically archaeological types, delineated as valid entities from the extant recovery record. Therefore, when discussing the spatial occurrence of such types, they have valid distributional value, as they contain the finds upon which these types have been identified. Here, then we use the term 'distribution' specifically to denote such archaeologically identified types.

In order to avoid a protracted discussion of whether or not finds deposited together belong to a specific category of deposit, such as 'hoard' (meaning it was deposited for the purpose of safe keeping until recovery), 'scrap hoard' (again only temporarily deposited and intended for recycling), or 'votive deposit' (as in a sacrificial offering), the neutral expression 'associated deposit' is used. There exists a wide and varied literature on the matter, which has been perhaps best addressed by R. Bradley, whilst S. P. Needham has attempted to construct a classification system for such deposits. ${ }^{23}$ Our various categories of bronze armour derive from a number of such instances, and we have here adopted the neutral term 'associated deposit' to describe such agglomerations of finds. Given the scope of our research, both spatially and temporally, these associated deposits inevitably vary in form and purpose. Therefore, where such purpose is clear and unambiguous we have identified them as such, as in the case of the votive deposits from Piller Sattel or Škocjan.

The distribution area of metal body armour in the European Bronze Age varies widely and rarely overlaps. From the United Kingdom and Ireland only shields are known. The Iberian Peninsula has produced only a few fragments of crested helmets, though the depiction of likely Type Herzsprung shields on local stelae may also suggest their use in this region. Helmets and greaves but no cuirasses or shields have been found in Italy. Despite the cuirasses of Dendra and Thebes, only a small number of greaves and helmets, and no metal shields, are known from

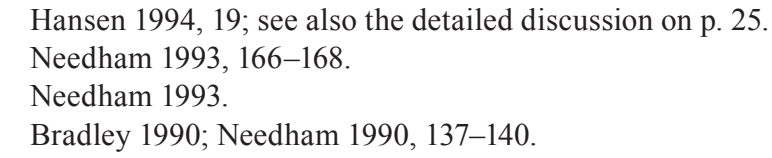


Greece. From France, helmets, greaves and cuirasses are known (the latter two only in central and eastern France), but no shields. In Germany, the distribution area of (organic) shields and helmets overlap, whilst only two greaves and one potential cuirass are known. In the central Alps, a small number of greaves, helmets and a miniature cuirass were found. From Poland and the Ukraine, three single helmets are known - all of different types. It is only in the Carpathian Basin that all four types of armour can be found. Nonetheless, there is only the associated deposit of Nadap, Hungary, where fragments from all types of armour were found together: one almost complete helmet of Type Oranienburg, fragments of helmet(s) of Type Paks, four greaves of Type Lengyeltóti and Desmontà, and one fragment each of a cuirass and a shield. The second almost complete assemblage of armour is reported from Grave 12 at Dendra, Greece, which contained a greave, the unique panoply, and a boar tusk helmet with bronze cheek plates, whilst the body was probably also covered by a wooden shield.

Apart from the Greek armour and the Čaka find (the case of Volders/Tyrol is not secure yet), the different classes of armour appear to have generally been deposited as parts of associated deposits or as single finds, often in wet locations. In central Europe, this appears to coincide with the disappearance of sword graves, which amongst the eastern Urnfield Culture had already occurred by Bronze D2, ${ }^{24}$ and followed by the western Urnfield Culture shortly after. In the eastern Urnfield Culture, the number of graves generally increases from the early Hallstatt B1 to Hallstatt B3, ${ }^{25}$ but with swords no longer included as grave goods, this being common as of Hallstatt A2 in the western area of the eastern Urnfield Culture and in the eastern area already since Bz D2. ${ }^{26}$ Comparing the total number of swords and spearheads in graves up to these periods with that for contemporary armour, it is perhaps not surprising that just one grave find from the eastern Urnfield Culture (Čaka) is known so far. In the western Urnfield Culture, swords were no longer buried with the deceased from Ha B1b on, with only a few more recent graves occurring (e.g. Weinheim). Graves with swords reappear only later, from Ha B3 onwards, c. $950 \mathrm{BC}$, whilst the use of cemeteries is no longer common, ${ }^{27}$ indicating differing sepulchral traditions. During the same period, river depositions, as in those from the upper Rhine increase, indicating a shift in burial traditions from graves to rivers. Thus, there is no certain indication that armour was excluded from (whichever type of) sepulchral practice, and we might assume similar depositional practices for both arms and armour for the wider Urnfield Culture.

The combination of material value and work invested in the production of armour certainly suggests a high status and prestigious object, which were used and worn by economical and socially potent persons. But did such bronze body armour serve in combat? And if so, how were the different elements of armour combined?

With the exception of the Dendra grave, which contained a probable complete set of armour, no further sets of armour, comprising cuirass, greaves and helmet, are known. Therefore, all reconstructions, assemblages or combinations of such armour must ultimately be hypothetical. ${ }^{28}$ It is also likely that a combination of metal and organic body armour was used, of which the latter rarely survives. Whilst the overlapping distribution and chronological contemporaneity of types might be useful indicators for reconstructing sets of armour, different types of the same class were clearly used at the same time (e.g. the fragments of different helmet types in the associated deposit of Nadap), which may reflect different selection processes for specific purposes, as for instance with the different types of armour seen on the Sardinian bronze figurines.

It is extremely unlikely that bronze armour was worn as a plain metal protection alone: greaves were worn over or sewn on to an organic wrapping; helmets had an organic inlay or

24 Hereafter Bz D2. Similar also for Bronze C (Bz C), Bronze D (Bz D), and so on.

25 Hereafter Ha B1 and B3. Similar also for Hallstatt A (Ha A), Hallstatt B (Ha B), and so on.

26 In detail, see: Sperber 2011, 34-35.

27 Sperber 2011, 31.

28 For example, as depicted in Marzatico - Gleirscher 2004, fig. 11b; Milcent 2012, title page. 
were worn above an organic cap; the cuirasses were worn over a leather, woollen, felt or textile jerkin, which may have been fixed inside the cuirass, as on the Carpathian and western European cuirasses, while the organic lining was attached directly onto the metal on the Greek examples.

Consequently, bronze armour cannot be considered as less effective than organic armour. Instead, the combination of organic inlay or organic protection worn underneath the bronze armour would have offered an effective, additional layer of protection, with the combined effect considered as far functional as purely organic armour alone. Repairs and traces of use on all classes of armour, as well as the fact that there can be no symbolic object without the reality of what it signifies, indicate that not only weapons but bronze armour were used in combat, be it in a violent melee, in individual sparing or even ritual combat. Thus, it can be concluded that bronze armour did not serve just as a high-status ceremonial version of more effective organic protection but guaranteed instead a higher level of protection and was certainly used as such. This, of course, does not indicate that the armour was used exclusively for fighting for it fulfilled the equally important function as a symbol of wealth, social status or power of its owner or society to which its wearer belonged.

Finally, this volume aims to achieve a more holistic study of European Bronze Age body armour, its manufacture and its use. It is the wish of the author that it may serve also as a base for further experimental studies in both production and utility of helmets, cuirasses and greaves, which would undoubtedly provide further important insights into Bronze Age life, and how armour was part of it: be it in respect of its practical and utilitarian use or aspects of its important ceremonial and symbolic functions. 



\section{Helmets}

Around 120 metal helmets from the European Bronze Age are presently known. These helmets are widely distributed all over Europe, with just a few exceptions (Fig. 2.1) ${ }^{29}$ These include the Nordic region, where only two bronze helmets from Viksø have been found. Helmets are also unknown from Ireland and the British Isles. Finds of helmets are also scarce in the Iberian Peninsula, with only a few fragments from a small number of associated deposits being known, though there are several more depictions of helmets on contemporary stelae. European Bronze Age helmets can be divided typologically and geographical into two main groups: western European helmets, which comprise cap helmets without knob, cap helmets with a crest and crested helmets, and central and eastern European cap helmets with knob.

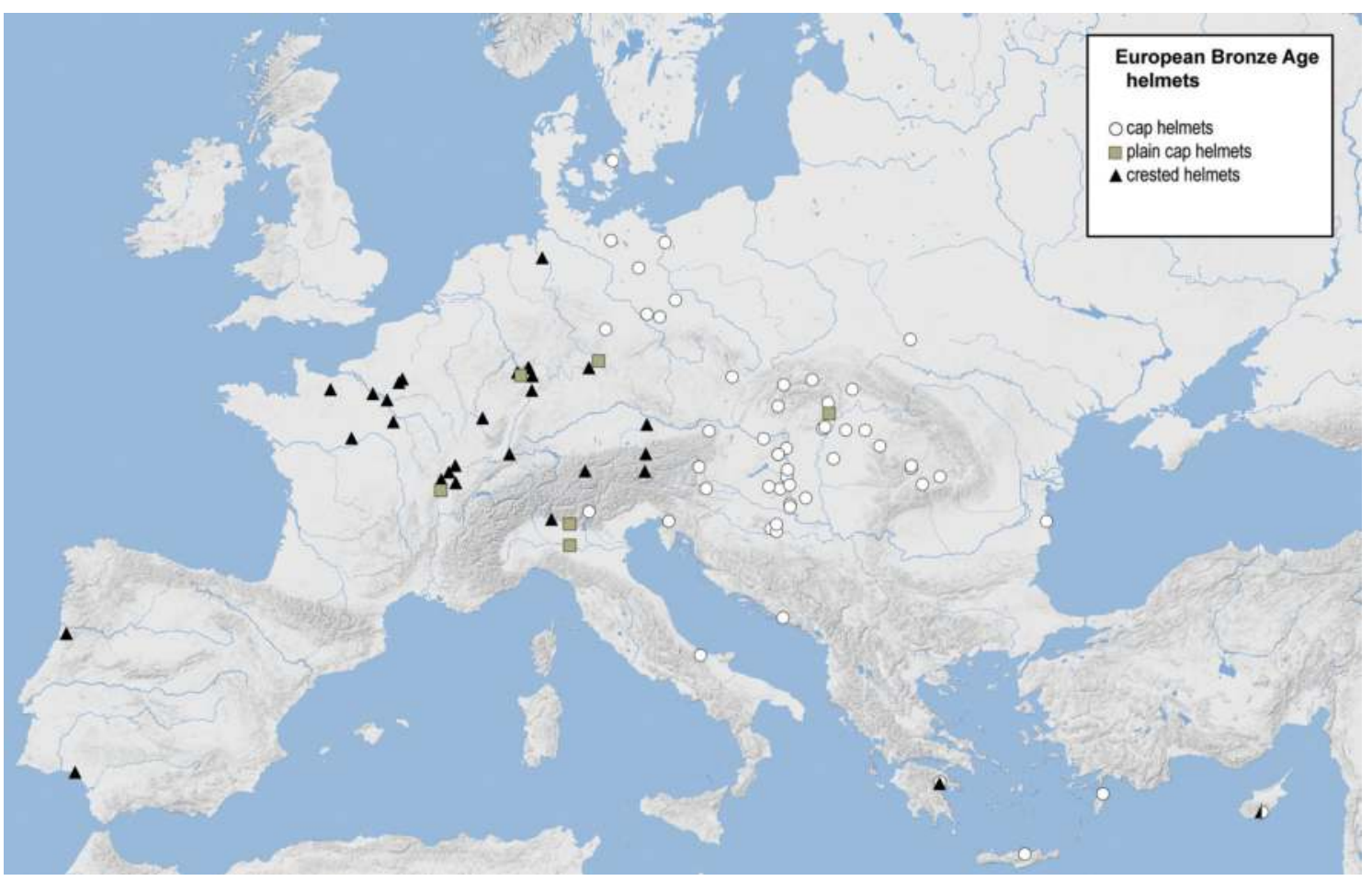

Fig. 2.1 Archaeological distribution of Bronze Age helmets. $\bigcirc$ Cap helmets. $\square$ Plain cap helmets (Type Montbellet). $\Delta$ Crested helmets. Helmets with unknown or unsecure find locations are not mapped.

Even before the first scientific publications of helmet finds of the $19^{\text {th }}$ century had appeared, the early helmets from Pass Lueg and Bernières d'Ailly had been incorporated rapidly into contemporary art connected with the end of the Iron Age and the depiction of Vercingetorix. The most famous of these were produced by F.-E. Ehrmann and others, who combined elements of these two helmets. ${ }^{30}$

29 Mödlinger 2016a; Mödlinger 2016b.

30 F.-É. Ehrmann 1869: Vercingétorix appelant les Gaulois à la défense d'Alésia, Musée d'Art Roger-Quilliot, Clermont Ferrand; H.-P. Motte 1886: Vercingétorix se rendant au camp de César, Musée Crozatier, Le Puy-enVelay; L.-N. Royer 1899, using the Pass Lueg helmet: Vercingétorix jette ses armes aux pieds de César, Musée Crozatier, Le Puy-en-Velay. 
The first comprehensive study of Bronze Age helmets was by G. v. Merhart in the 1940s, ${ }^{31}$ and much of his classification remains valid. He distinguished helmets formed from a single bronze sheet (Kappenhelme [cap helmets] and Glockenhelme [bell helmets]) and those constructed from two sheets (glatte Kammhelme mit runder Haube [undecorated crested helmets with round cap], glatte Kammhelme mit Spitzhaube [undecorated crested helmets with pointed cap], and verzierte Kammhelme mit Pickelhaube [decorated crested helmets with spiked cap]). The helmet from Pass Lueg as well as the two helmets from Škocjan were assumed to be deviant types. G. v. Merhart's study was based on the entry of E. Sprockhoff in the 'Reallexikon der Vorgeschichte', ${ }^{32}$ who divided Bronze Age helmets into cap helmets, bell helmets and crested helmets. Nevertheless, it is v. Merhart's study which remains the more widely cited of these early works. Based on new finds, A. Mozsolics subsequently separated G. v. Merhart's groups A and B into three types: Type Kisköszeg with hemispherical cap, Type Hajdúböszörmény with bell shaped cap and Type Lúčky with conical cap. ${ }^{33}$ In a further, more comprehensive study, H. Hencken discussed all European Bronze Age and Early Iron Age helmets discovered up to the 1970s, which represents the most extensive monograph on helmets. He divided the helmets into bell helmets (conical and rounded), Italian and non-Italian crested helmets (both distinguished between round/conical cap and pointed cap), cap helmets (helmets without knobs or sockets; helmets with star decoration; helmets with cast knobs; helmets with plain socket) and finally conical helmets with double crest. However, he did not significantly modify G. v. Merhart's classification. ${ }^{34} \mathrm{~J}$. Borchhardt published just one year after Hencken his wide study on 'Homerische Helme', which focussed mainly on Aegean and oriental helmets. ${ }^{35}$ P. Schauer discussed the development and typology of helmets in several studies, claiming an origin for European helmets in the eastern Mediterranean. ${ }^{36}$ With the recent discovery of the two new helmets from Anlauftal and Piller Sattel, the discussion on the chronology of the crested helmets of Type Lueg led to several new publications with different chronological approaches. ${ }^{37} \mathrm{D}$. Brandherm analysed the connection between western European and eastern Mediterranean crested helmets and their development, influence and chronology, based on their cap profiles, and pointed out the potential connection between crested and horned helmets. ${ }^{38}$ With the identification of so far unrecognised fragments of greaves (cat. nos. 186-187) and potentially also a helmet in the cemetery of Volders, Tyrol, L. Sperber also recently discussed the origin, chronology and typology of these crested helmets. ${ }^{39}$ As is evident, the chronology and origin of European bronze helmets remains very much a matter of discussion.

Since the traditional classification of types for helmets never incorporated the full range of attributes needed to understand both technological and stylistic dimensions, a new hierarchical scheme of classification is proposed (Fig. 2.2). So far, numerical approaches to artefact taxonomy ${ }^{40}$ which usually attempt to incorporate all attributes, have rarely produced meaningful type classifications. There is then clearly still a need to make value judgements on those attributes deemed most important to the archaeologist, and which are considered to have been meaningfully selected in the past. ${ }^{41}$ Therefore, a form of nested, hierarchical approach to attribute classification, ${ }^{42}$ which groups selected attributes, or 'primary' variables, according to tech-

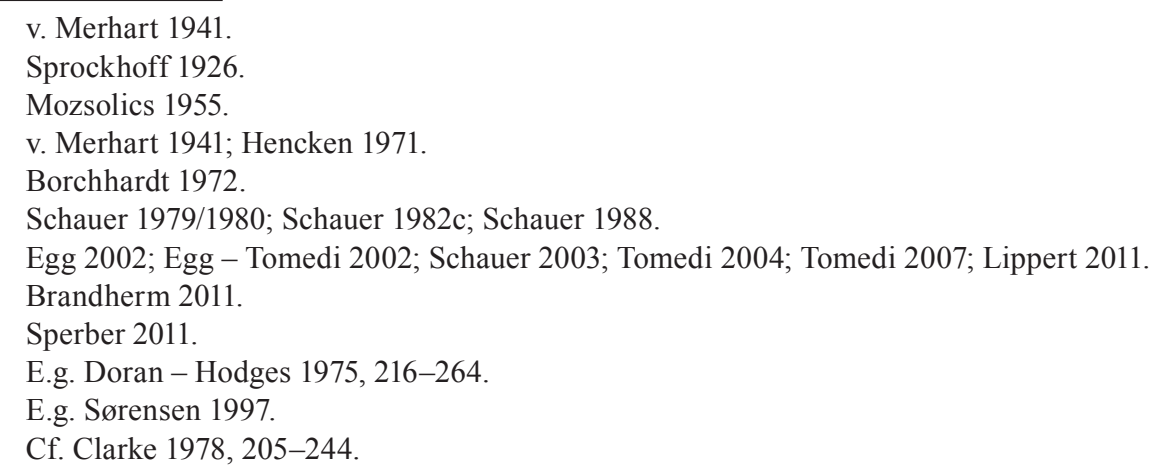




\section{helmets}
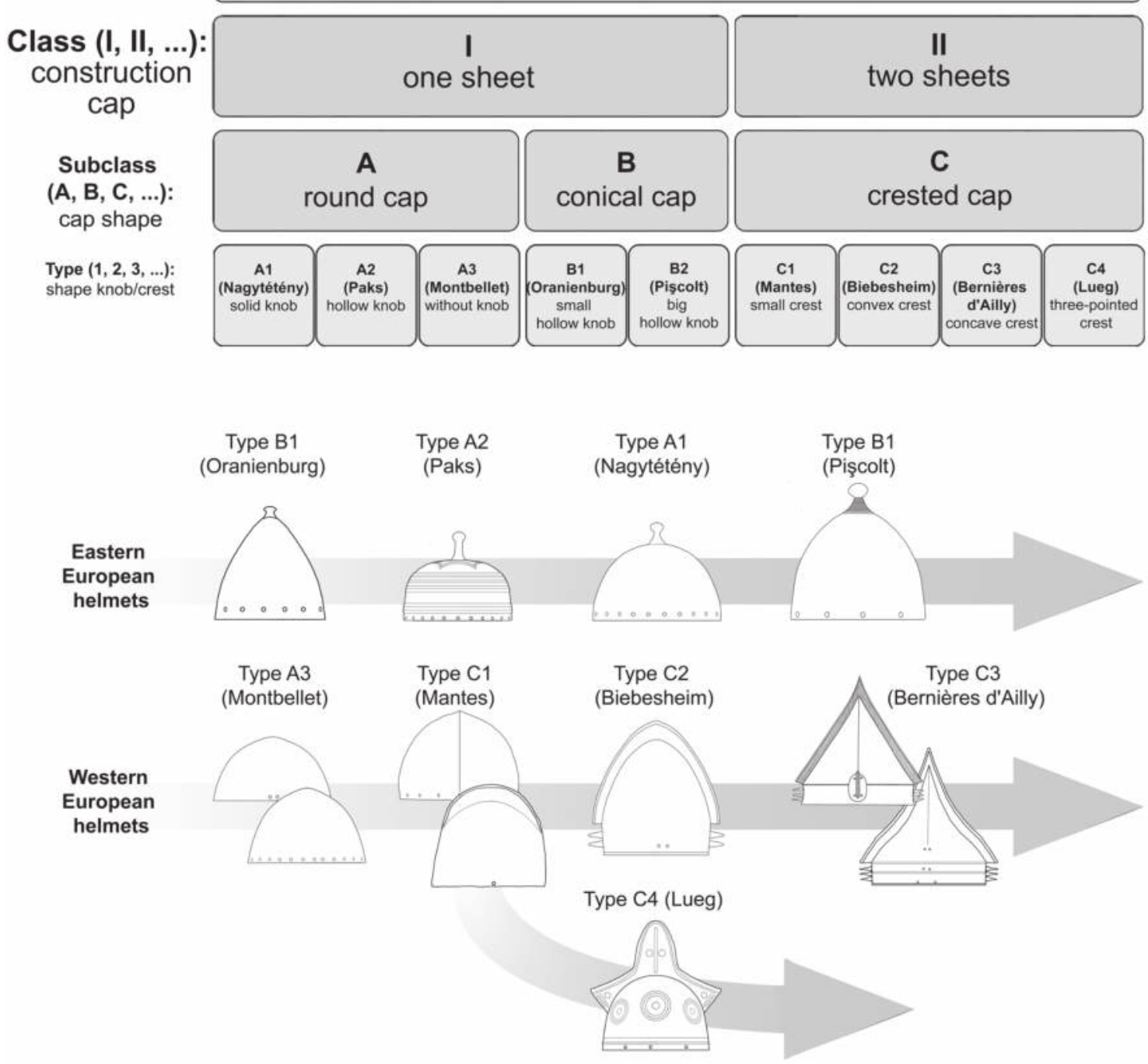

Fig. 2.2 Classification and development of eastern and western European Bronze Age helmets. Each helmet type specified consists of at least three helmets. Other helmet types, represented by less than three helmets such as Type Szczecin-Zdroje (cat. no. 59), Type Malpensa (cat. no. 61), and Type Viksø (cat. no. 121), all fall under Class IA and are described in Chapter 2.1.5 (cat. nos. 59 and 61) and in Chapter 2.3 (cat. no. 121) respectively. Only helmets of Type Tiryns (cat. no. 120) fall under Class IIC. Both helmet types Montbellet and Oranienburg derive from organic ancestors, though from different geographical regions.

nological and stylistic dimensions ${ }^{43}$ is used. The latter can be defined as effecting the form of artefacts without effecting the overall engineering of its function, which here is termed a 'type'. The former concerns aspects of technology, which we have termed a 'Class'. Each can incorporate further levels of variation or subclasses but the types, as stylistic aspects, will always derive from the organisation of the different classes, as illustrated in Fig. 2.2.

The geographical separation between western European crested helmets (including cap helmets without knob, hereafter: helmets of Type Montbellet) and eastern European cap helmets remains constant for several centuries during the Late Bronze Age, suggesting separate regional workshops and working traditions, and potentially also material requisitions (Fig. 2.1). This appears to have led only occasionally to an exchange of helmets, as the rare examples of import/

43 Needham 1983, 30-33, fig. 127. 
export demonstrate, such as the helmet of Type Montbellet from Szikzó (cat. no. 74), the unprovenanced crested helmet (cat. no. 100), and the helmet of Type Pişcolt from Monte Altino (cat. no. 49). As will be discussed in detail in this chapter, we can determine the development of both crested and cap helmet from organic precursors, from different geographical areas, and not necessarily just from Near Eastern ancestors alone (Fig. 2.2). While these western European helmets seem to derive from local organic head protection, the eastern European metal helmets instead have their origin in the Aegean, as we can see from the development of helmets of Type Oranienburg.

Without question, the oldest European metal helmets are the helmets of Type Oranienburg from Knossos (cat. no. 2) and an unprovenanced helmet of the same type with boar tusk decoration (cat. no. 1). The latter has an incised decoration of boar tusks, arranged in the same way as on actual boar tusk helmets. This makes this piece a perfect transitional form between the older boar tusk helmets proper and the helmets of Type Oranienburg and suggests a date prior to that of the helmet from Knossos but after the helmet from Dendra (cat. no. 63), indicating a rather rapid adoption of metal around $1400 \mathrm{BC}$ in the construction of helmets. ${ }^{44}$ This is so far the oldest European metal helmet type, which clearly derived from the Aegean boar tusk helmets, spreading quickly into the Carpathian Basin and northwards as far as Biecz in Poland. These finds indicate a main period of use for the helmets of Type Oranienburg from the $15^{\text {th }}$ century in Greece and as late as the $13^{\text {th }}$ century in eastern Europe. Helmets Type Paks, Type Nagytétény, and Type Pişcolt then followed these helmets.

The origin of crested helmets in western Europe is a more particularised case. Though not considered as 'real' crested helmets so far, helmets of Type Mantes, which bear a basic crest or ridge on the cap, can be considered the local precursor of crested helmets of Type Biebesheim, Bernières d'Ailly and Lueg. Therefore, helmets of Type Montbellet with their plain, undecorated caps, whose distribution overlaps more with western European crested helmets than with eastern European cap helmets, are most likely older than Type Mantes, and might be considered the oldest helmet type for western Europe, developing locally from organic ancestors and having a rather long lifespan. ${ }^{45} \mathrm{~A}$ very similar development from basic, undecorated cap helmets to crested helmets can also be identified in Mesopotamia, where a plain, undecorated Sumerian cap helmet found in Ur ( $2^{\text {nd }}$ half of the $3^{\text {rd }}$ millennium BC) also bears a basic ridge ${ }^{46}$ similar to Type Mantes. Only shortly after, more elaborate helmets with organic crests appear (see the helmet on the tropaion from Mari).

Ancestors to or, more likely, simply older metal helmets than the European ones, are found in the Near East, such as the three bronze cap helmets from the early dynastic III king's grave at Ur, and the depiction of a cap helmet at Lagash (middle of $3^{\text {rd }}$ millennium BC) ${ }^{47}$ Sumerian or Acadian helmets are further depicted on the so-called battle stelae, as well as other stelae from Nasiriya and Sippar. ${ }^{48}$ From Mari, three further depictions of helmets are known, comprising a small relief of a warrior or god wearing a helmet, the head of a warrior made out of alabaster, and the remnants of a fresco from the palace. ${ }^{49}$ No metal helmets but only their depiction - and/ or depictions of head protection, be it organic or a combination of organic materials with metal - are known from Egypt, noted from the XIX dynasty onwards. ${ }^{50}$ The oldest depictions of Syrian helmets ${ }^{51}$ derive from three statuettes from Tell-el Judeideh dated to the $1^{\text {st }}$ half of the $3^{\text {rd }}$ millennium BC. The helmets did not change much during the following centuries, as the depiction of a Syrian legate with three helmets in a tomb from the second half of the $15^{\text {th }}$ century BC

4 Mödlinger 2013a.

45 See Chapter 2.2.1, p. 94.

46 Borchhardt 1972, 94, pl. 19.2-3.

47 Borchhardt 1972, 94-95, pl. 19.

48 Borchhardt 1972, 95, pls. 12.1; 21.1.

49 Borchhardt 1972, 96, pls. 19.4; 21.2-3.

50 Borchhardt 1972, 88-89.

51 Borchhardt 1972, 90-93, pls. 23-24. 
shows. The same tomb bears depictions of three further helmets, one potentially made out of metal. ${ }^{52}$ Further depictions of Syrian helmets are known from the coach body of Thutmose IV (Thutmose defeats the Syrians). From Israel, no helmets but depictions of philistine helmets or crowns (?) are documented (Beth Shan, Tell Halaf and Tell el Farah). ${ }^{53}$

Less so, amongst the small number of actual metal helmets, the more numerous depictions of helmets from the Aegean and the Near East demonstrate a wide variety of different types from the $3^{\text {rd }}-2^{\text {nd }}$ millennium $B C$. Certainly, there were influences flowing from one type to another, and there was not necessarily any straight line of development. We have to bear in mind why helmets were invented and that the need for body and head protection arose significantly with the growing effectiveness of arms and the appearance of new fighting techniques. Therefore, we do not necessarily need to look for the ancestor of all cap helmets and/or crested helmets but might give more weight to local organic ancestors, particularly in the case of crested helmets. That does not necessarily mean we have to neglect influences or adaption of other metal helmets but rather that we must also take into account the possibility of the independent development of helmets.

Excluding the Greek helmets and cheek plates with known find circumstances (Dendra, Knossos, Ialysos, and Tiryns), the Bronze Age European helmets are deposited either in associated deposits, votive deposits, or in wet contexts, such as rivers. Only the cemetery of Volders, Austria, might contain potential fragments of a crested helmet. ${ }^{54}$ In the following discussion, only helmets with known find circumstances are taken into account (Tab. 2.1).

\begin{tabular}{l|c|c|c}
\hline Context & $\begin{array}{c}\text { Eastern Europe } \\
\text { (helmets Class I, } \\
\text { apart Type A3) }\end{array}$ & $\begin{array}{c}\text { Western Europe } \\
\text { (helmets Class II, } \\
\text { and Type A3) }\end{array}$ & Total \\
\hline associated deposit & $31(45 \%)$ & $17(34 \%)$ & $48(40 \%)$ \\
\hline votive deposit & 3 & 1 & 4 \\
\hline river/bog & $8(11 \%)$ & $26(52 \%)$ & $34(28 \%)$ \\
\hline grave (Greece only) & 4 & 1 & 5 \\
\hline unknown & $23(33 \%)$ & $5(10 \%)$ & $28(23 \%)$ \\
\hline total & $\mathbf{6 9}$ & $\mathbf{5 0}$ & $\mathbf{1 1 9}$ \\
\hline
\end{tabular}

Tab. 2.1 Bronze Age helmets: find context of helmets in western Europe (i.e. crested helmets) and eastern Europe (i.e. cap helmets). Helmets of Type Montbellet are considered according to their main appearance as western European helmet type. The organic cap or helmet from Fiavé and the helmets from Viksø are not considered in the table.

The only bog find seems to be the single finds of the helmets from Sehlsdorf (cat. no. 41) and Iseo (cat. no. 76), as well as the associated deposits from Biecz (cat. no. 3) and Viksø (cat. no. 121), while the helmets from the associated deposit of Bernières d'Ailly were deposited $10 \mathrm{~m}$ away from the moat of château d'Ailly in a humid zone (a previous bog?) (cat. nos. 101-110). The generalisation that western European helmets were deposited in rivers and eastern European helmets in associated deposits ${ }^{55}$ has to be slightly revised. As visible in Tab. 2.1, western European helmets were not in every case deposited in rivers or wet contexts, whilst at least a third of the western European helmets known (mainly represented by fragments) derive from associated deposits. Several associated deposits with fragments of Type Bernières d'Ailly are known from the Iberian Peninsula as well as central France (Huelva, Monte do Crasto, Larnaud). We have to note that in these associated deposits, helmets are present only in a severely fragmented state or even by a single fragment only. As indicated by the presence of these fragments in French and Iberian associated deposits, we might identify even more fragments of hel-

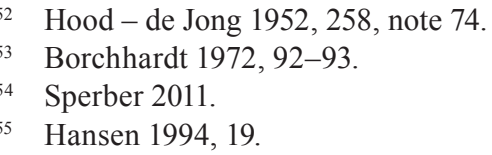


mets in western European associated deposits. So far, only three associated deposits with complete examples of Type Mantes, Biebesheim and Bernières d'Ailly are known (Oggiono-Ello, Le Theil and Bernières d'Ailly). Only two examples of Type Bernières d'Ailly were actually deposited in rivers (Armancourt, Mainz), while all helmets of Type Biebesheim, with the exception of the associated deposit from Le Theil, were deposited in rivers. As the fragmented helmet from Roxheim demonstrates - which must also have been burnt before its deposition - not only complete helmets but also fragmented ones, as well as potentially just fragments, were deposited in rivers. The lack of river finds of helmet fragments most likely relates to their small size and therefore unlikely recovery, as well as to the difficulty in identifying such fragments as such. The most probable explanation for the lack of river deposits is that these remains were not retained or collected rather than that there was an actual lack of deposition in rivers. ${ }^{56}$

Helmets Type Montbellet are known only as complete deposited objects, which again might also be related to the difficulty in identifying their fragments as such. The Northern Italian and French finds were deposited in wet contexts (rivers and bog), while the imported find from Szikzó derives from an associated deposit, indicating the adoption of local depositional habits, whilst the find circumstances and the associated finds of the two alleged German associated deposit finds from Thonberg and Wonsheim are not secure (cat. nos. 72 and 73). The central Alpine helmets of Type Lueg (cat. nos. 83-85) so far demonstrate the widest variation in depositional circumstances and condition: the partially preserved helmet from the Piller Sattel is part of a votive deposit, the partially preserved helmet from Anlauftal is a single river find, and the complete helmet from Pass Lueg was most likely part of an associated deposit.

The deposition practice in eastern Europe differs slightly from western Europe, since most of the helmets with known find spots derive from associated deposits (45\%). Only six helmets $(9 \%)$ were found in rivers. Unlike the western European helmets, a significantly higher percentage of eastern European helmets lack any information regarding their find spot $(10 \%$ versus $33 \%)$.

Around a third, meaning nine out of the 33 secure associated deposit finds from eastern Europe contain complete or almost complete helmets (Biecz, Lúčky, Keresztéte, Nadap, Sâg (fragmented), Mezőnyárád, Endrőd, Şoarş, Batina), and more than half of them are helmets of Type Oranienburg. When deposited in associated deposits, usually only one fragment of the helmet or, most likely, one fragment per helmet is present (associated deposits with more than one helmet fragment include Pázmándfalu and Nadap), as recently shown for shields. ${ }^{57}$ More than half of the helmet fragments derive from the cap, whilst a quarter of them are knobs, and a further quarter of them are complete or fragmented cheek plates. The helmets from the votive deposit from Škocjan are all fragmented. Further complete helmets derive from rivers. The six helmets deposited in rivers are helmets of Type Oranienburg (Oranienburg, Dunaföldvár), one helmet of Type Paks (Paks), one helmet of Type Nagytétény (Nagytétény), one helmet of Type Pişcolt (Endrőd) and a single helmet of Type (Type Szczecin-Zdroje). The find spot for the helmet of Type Pişcolt from 'Mantova' is a recent invention (cat. no. 50).

As for the construction of other bronze sheet objects, the initial step is the casting of a flat, thin disc of tin-bronze, which is flattened and expended by several cycles of annealing, quenching - in order to avoid the formation of brittle metal phases - and hammering in an open die (Fig. 2.3). The primary use of an open die instead of a high bowed stake with rounded face is indicated by the profile of the cap helmets, which have a significantly thicker rim, a rather thin, delicate middle section and again a slightly thicker cross section at the top of the cap. The manufacture of cap helmets is discussed in detail for helmets of Type Pişcolt, ${ }^{58}$ which includes also the process of casting-on of the knob or socket.

The production steps described are also valid for all other cap helmets despite the creation of rivet holes. While rivet holes on the thicker helmets of Type Pişcolt are mainly cast and widened

\footnotetext{
56 See mainly Sperber 2006a; Sperber 2006b.

57 Mödlinger et al. 2013; Mödlinger - El Morr 2014.

58 See Chapter 2.4, p. 148
} 

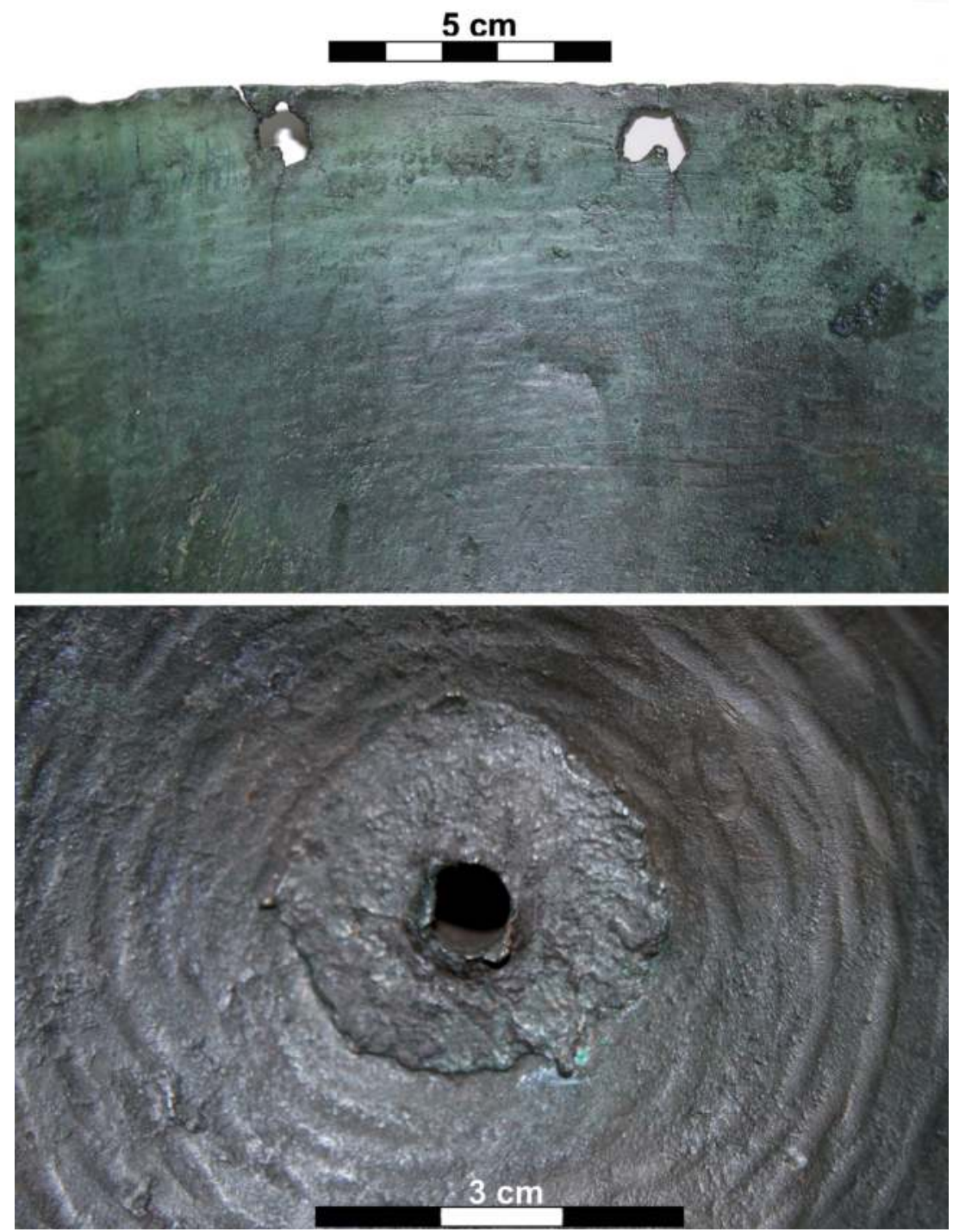

Fig. 2.3 Hammering traces on the inside of the helmets of Type Pişcolt from Şoarş, Romania (above) and Pişcolt, Romania (below).

afterwards, we find that they are generally punched through from the outside to the inside on the other, much thinner, helmet types. Some helmets though, such as the helmet of Type Oranienburg from Oranienburg, show rivet holes, which were punched through from the inside to the outside. The production of the bronze sheets for crested helmets follows the same principle as the manufacture of cap helmets. We might also assume for crested helmets the use of an open die for flattening and expanding the cast bronze disc to achieve their three-dimensional, semi-spherical shape. One of the halves or plates also had folds or tabs on the crest, which were then folded over the edge of the crest of the other half of the helmet. The two halves were additionally held together front and back by rivets of various form and shapes just above the rim at the place where the two plates or halves overlap. Moreover, some of the helmets of Type Bernières d'Ailly bear on their sides riveted on, hollow bronze attachments of various shapes to hold organic decorative elements. Crested helmets with thin rim might have a wire, around which the rim was folded, in order to stabilise the helmet (types Lueg, Biebesheim and Bernières d'Ailly). The older, more solid helmets of Type Mantes did not need such reinforcement. Helmets with such a rim usually do not have rivet holes all along the edge, indicating that a separate organic cap was worn under the metal helmet. But not only is the production of the two main helmet forms different, the amount of bronze used for the helmets itself differs from type to type (Fig. 2.4). 


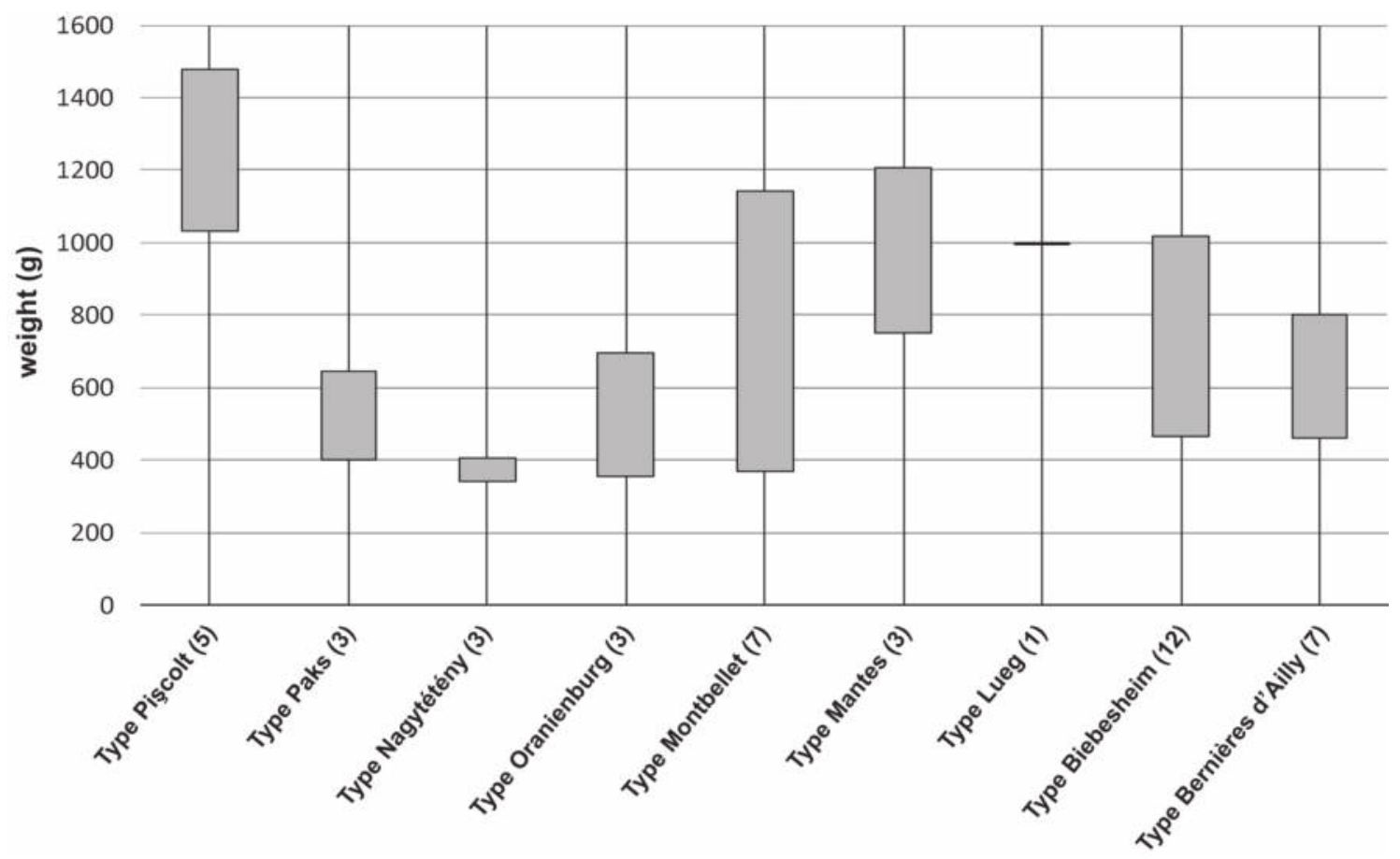

Fig. 2.4 Weight distribution of different types of Bronze Age helmets. Only complete helmets are included.

Traces of use on Bronze Age helmets are generally rare, which indicates either a non-practical or ritual use as armour - though due to the higher level of protection they offered in comparison with organic headgear, this seems unlikely - or a short duration of use, obviously with skilled (or lucky) owners, and their deposition after combat and repair. No helmet has evidence of any complete perforation, such as by spear or sword, as is known from Bronze Age shields ${ }^{59}$ but they do show side impacts, most likely from sword edges. These sword impacts are found on helmets of Type Pişcolt (Hajdúböszörmény; cat. no. 44), helmets of Type Nagytétény (Brodi/Ternopil; cat. no. 38), helmets of Type Oranienburg - the helmet from Oranienburg (cat. no. 4) has at least three severe sword impacts on the side, whilst the one from Dunaföldvár (cat. no. 10) has four almost parallel, linear impressions, which might also be the result of sword impacts -, crested helmets of Type Biebesheim (Blainville, Auxonne and Montmacq A and B, with the latter being river finds cat. nos. 92, 94, 96 and 97), and helmets of Type Montbellet from Brancere and Wonsheim (cat. nos. 73 and 75). The helmet of Type Mantes from Oggiono-Ello (cat. no. 81) bears an impression similar to a sword cut on the front or back (Fig. 2.5). Another helmet of Type Mantes - the Leitfossil from Mantes itself (cat. no. 79) - bears a round impression, though whether this can be associated with a weapon impact or is due to depositional processes is not clear. Additional to the sword impact, which seems to have almost split the helmet, the cap helmet with solid knob from Brody/Ternopil also bears a round impression opposite the sword impact.

In order to increase the comfort of wearing bronze helmets and to absorb the shock of potential weapon impacts, an organic cap was worn directly under the helmet or the helmet contained an organic lining, which was attached by means of the rivets on the helmets. We also have to consider a combination of different organic materials. For example, Aristotle notes in his history of animals the use of sponges for helmets and greaves to better absorb weapon impacts. ${ }^{60}$ The helmet from Thonberg also shows (as do many helmets of Type Pişcolt) ${ }^{61}$ a black band of different corrosion products on the outside, right above the rim, indicating the presence of an attached organic lining.

\footnotetext{
59 Uckelmann 2012.

60 Aristotle V, 16 in Buchholz et al. 2010, 142.

61 See Chapter 2.4, Fig. 2.49.
} 


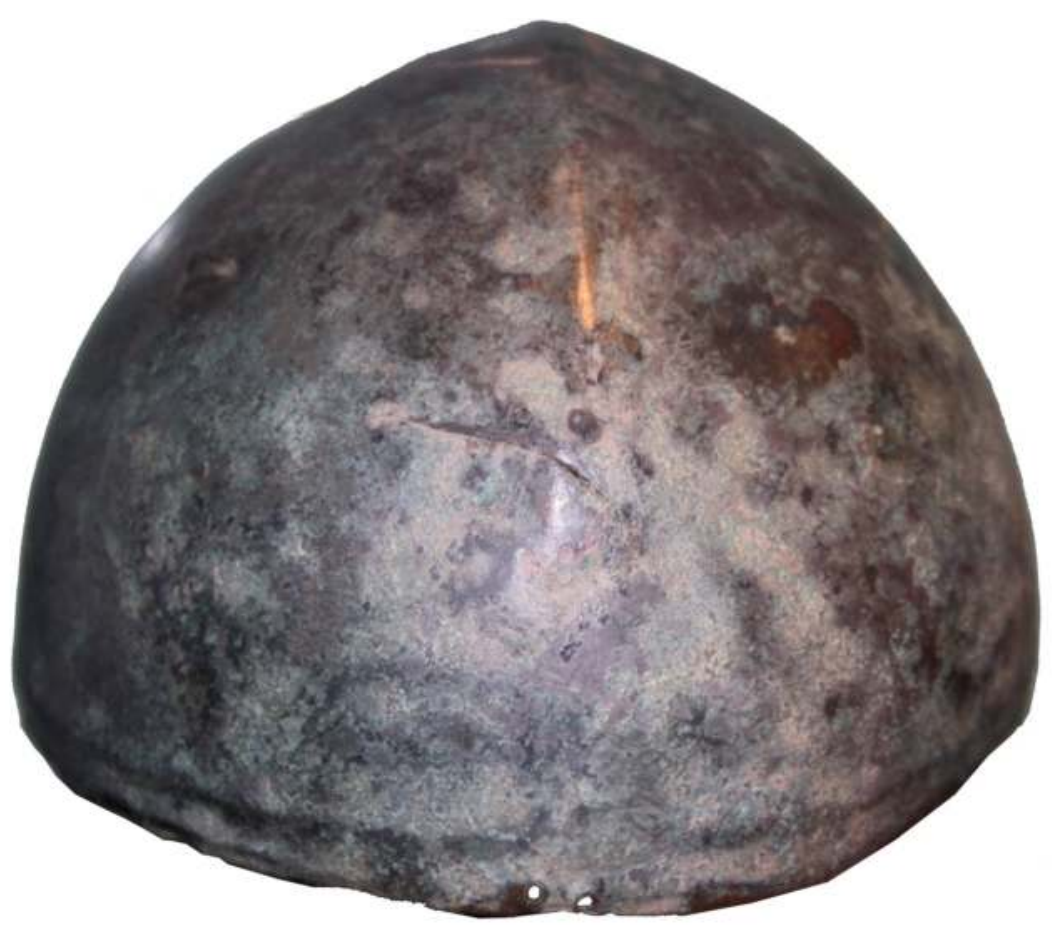

Fig. 2.5 Helmet of Type Mantes from Oggiono-Ello, Italy. Note the potential sword impact on the front or back.

Repairs to the helmets do not necessarily provide secure indications of their use as armour in combat. Certain repairs, such as on the helmet of Type Pişcolt from Pişcolt (cat. no. 48), were most likely carried out during the production of the helmet due to material defects or manufacturing mistakes (Fig. 2.6). Helmet F from Bernières d'Ailly (cat. no. 106) also underwent considerable repair, with the attachment of a large bronze plate or sheet, secured with rivets besides
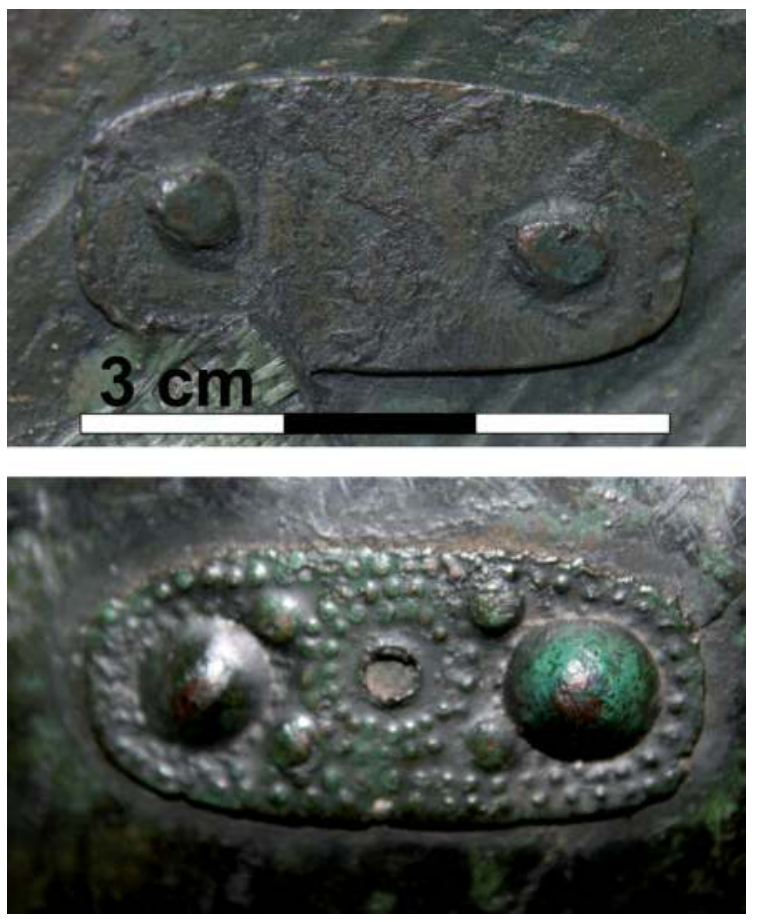

Fig. 2.6 Helmet of Type Pişcolt from the eponym find spot in Romania. Details of the riveted on decorated bronze on the outside of the helmet (below). On the inside, another sheet was applied (above). The overlapping hammering traces indicate that it was applied during the manufacture process. 
one of the lateral attachments on the cap. ${ }^{62}$ It seems rather unlikely that this extensive repair occurred during manufacture, as the plate has a much higher occurrence of lead than found on the actual crest. ${ }^{63}$ It might therefore indicate the use of the helmet in combat and therefore that the helmets were deposited after they had been used.

The number of repairs on helmets of Type Biebesheim - and therefore an indicator of their extent of use - is particularly high. The helmet from Biebesheim (cat. no. 86) bears on the front and back one pair of rivets. On one side, the lower rivet was replaced with a brace to fix an ancient crack, leaving no space to apply another or the original rivet again. The crest from the helmet of Paris (cat. no. 98) bears a crack running from the edge to the beginning of the cap. This crack had already been repaired during the manufacture of the helmet by means of a short, round wire, which passes through from the outside to the inside through holes punched either side of the crack. The helmet from Seurre (cat. no. 99) also demonstrates a repair to the crest. A small bronze sheet was riveted to the crest on the upper third of the helmet with two flat rivets, most likely to cover a crack. Cracks on the same area on the helmet from Blainville, however, appear to have remained unrepaired. All damage on these three helmets is in the same area, on the half of the crest around which the other half was folded over.

\subsection{Eastern European Helmets}

Eastern European helmets comprise all helmets Class I apart helmets of Type Montbellet, which are distributed in western Europe. Helmets with knob and round or conical cap as helmets of Type Oranienburg, Type Paks, Type Nagytétény, and Type Pişcolt are distributed mainly in eastern Europe (Fig. 2.7). The caps on all these helmets are made of one single metal sheet with

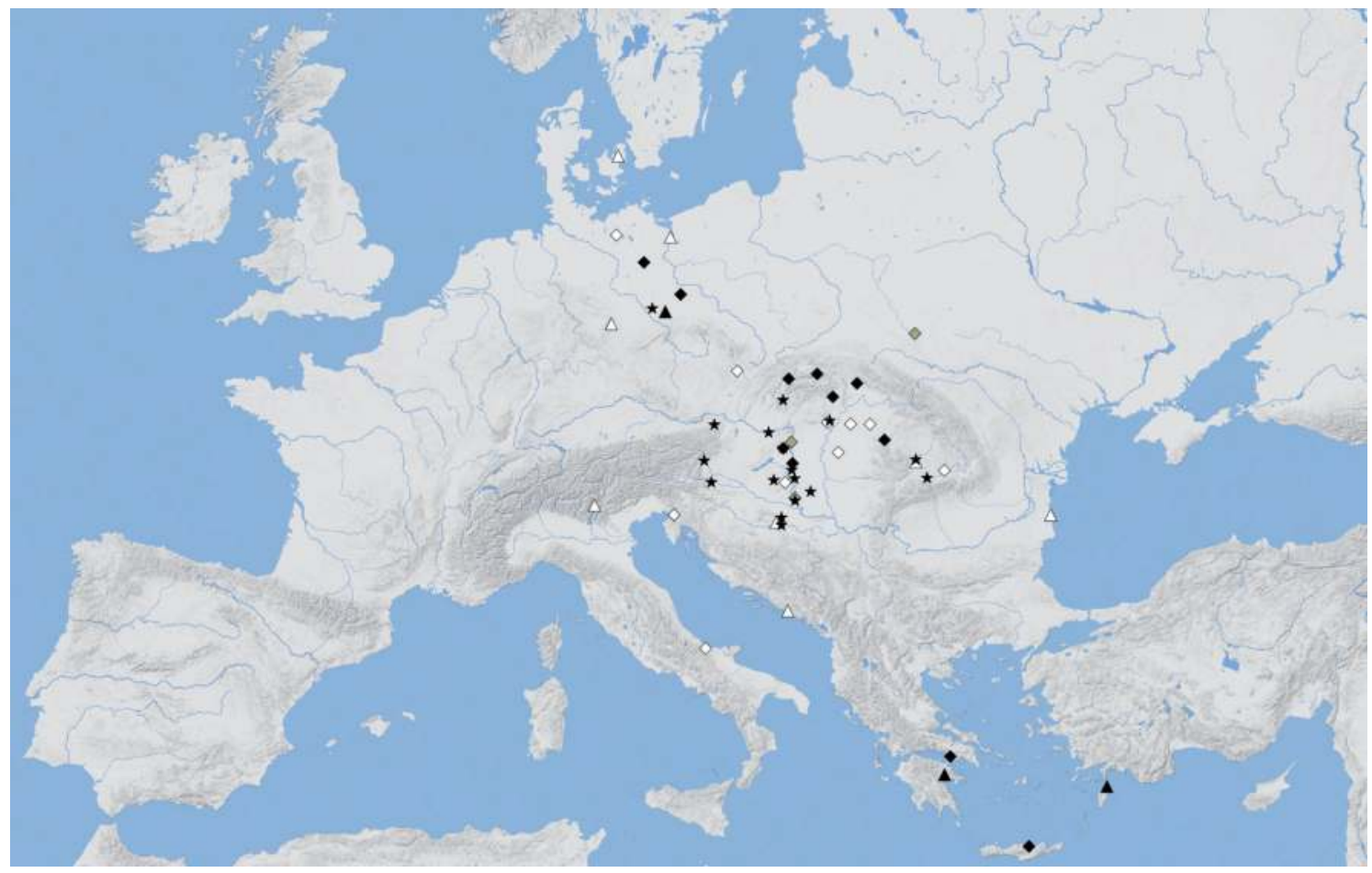

Fig. 2.7 Archaeological distribution of eastern European Bronze Age helmets: $\bullet$ Helmets of Type Oranienburg.

$\star$ Helmets of Type Paks. $\diamond$ (grey) Helmets of Type Nagytétény. $\diamond$ Helmets of Type Pişcolt. $\boldsymbol{\Delta}$ Greek cheek plates. $\triangle$ Single helmet types, cheek plates and knobs. Helmets with unknown or unsecure find location are not mapped.

62 Hencken 1971, 67, fig. 45.

63 Brun et al. in preparation. 
a normally cast-on knob or socket positioned in the centre of the top. In a few cases, the knob was also riveted on or made out of the same metal sheet as the cap. The knob served to hold a plume or crest made out of organic material, such as that known from older depictions of boar tusk helmets. Helmets Type Oranienburg can be considered the oldest European helmets. ${ }^{64}$ In eastern Europe, helmets of Type Paks, Type Nagytétény, and Type Pişcolt follow them. ${ }^{65}$

\subsubsection{Helmets of Type Oranienburg}

The description and interpretation of the helmets of Type Oranienburg was recently published elsewhere by the author. ${ }^{66}$ Most of the helmets of Type Oranienburg are complete or at least were deposited complete but damaged after deposition: Nadap (cat. no. 9), Knossos (cat. no. 2). Consequently, only the Slovakian finds from Spišská Belá (cat. no. 6) and Žaškov (cat. no. 5) retain the spool-shaped knobs. Though the helmet from Keresztéte survives now as just a single fragment, an earlier photograph published by Mozsolics demonstrates that it had originally been recovered intact, and therefore had been deposited complete. ${ }^{67}$

Helmets Type Oranienburg are rather thin and light compared to the later heavy and solid helmets of Type Pişcolt. Inside the helmets, we can note horizontal traces of hammering. All helmets of Type Oranienburg resemble each other closely in profile, size and weight. As described in detail for helmets of Type Pişcolt, ${ }^{68}$ as well as on helmets of Type Oranienburg, the knob or spool-like knob was usually cast-on in the centre of the conical cap. The origin of the form of the spool-shaped knob might be skeuomorphic, reflecting the closing of the top of leather paddings or organic helmets with a band, such as on boar tusk helmets. ${ }^{69}$ Doing so, results in a spool-shaped form, as seen for example on the ivory plaques from Mycenae. Generally, depictions of helmets with spool-shaped knobs are known from the Argolid and Crete until LH/LM IIIA. ${ }^{70}$ Unfortunately, the upper parts of the cap on the helmets from Dunaföldvár (cat. no. 10) and Keresztéte (cat. no. 8) are no longer preserved, but based on their comparison with other related helmets, it seems likely that they too bore a similar knob. Unlike the central European helmets, the helmets from Knossos and the related unprovenanced helmet (cat. no. 1) show a different attachment or construction of the knob. While the knob from the Knossos helmet was not cast-on to the cap, but rather held in place by seven rivets, the knob of the unprovenanced helmet was worked up directly out of the sheet of the helmet. Moreover, this helmet is the only helmet of Type Oranienburg decorated, having abstract motifs in the form of incised decoration of running spirals and boar tusks, arranged in the same way as that known from real boar tusk helmets. According to the decoration, an Aegean or even Greek origin for the helmet seems very likely. ${ }^{71}$ The different manufacturing processes of these two Aegean helmets most likely indicates a production site separate from those of the European helmets of Type Oranienburg.

Rivet holes are regularly distributed parallel to the lower edge of the cap on the helmets of Type Oranienburg. Only the helmet from Biecz (cat. no. 3) has just rivet holes on the broader sides, with three each side to most likely attach cheek plates, and three further holes on the neck to attach a neck guard. The lack of further rivet holes indicates the use of an organic cap worn separately under the helmet. The helmets with regularly distributed rivet holes most likely had an inner padding permanently attached to the helmet, wrapped around to the outside surface and fixed with the rivets all along the edge from both outside and inside, as indicated by the band of different corrosion products on the outside of the helmets right above the rim, as seen

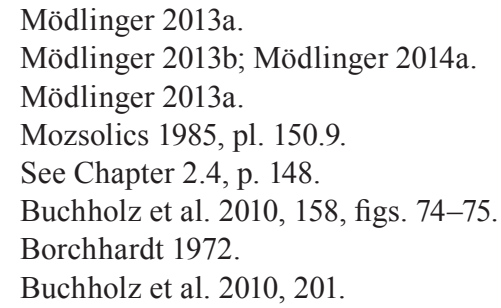




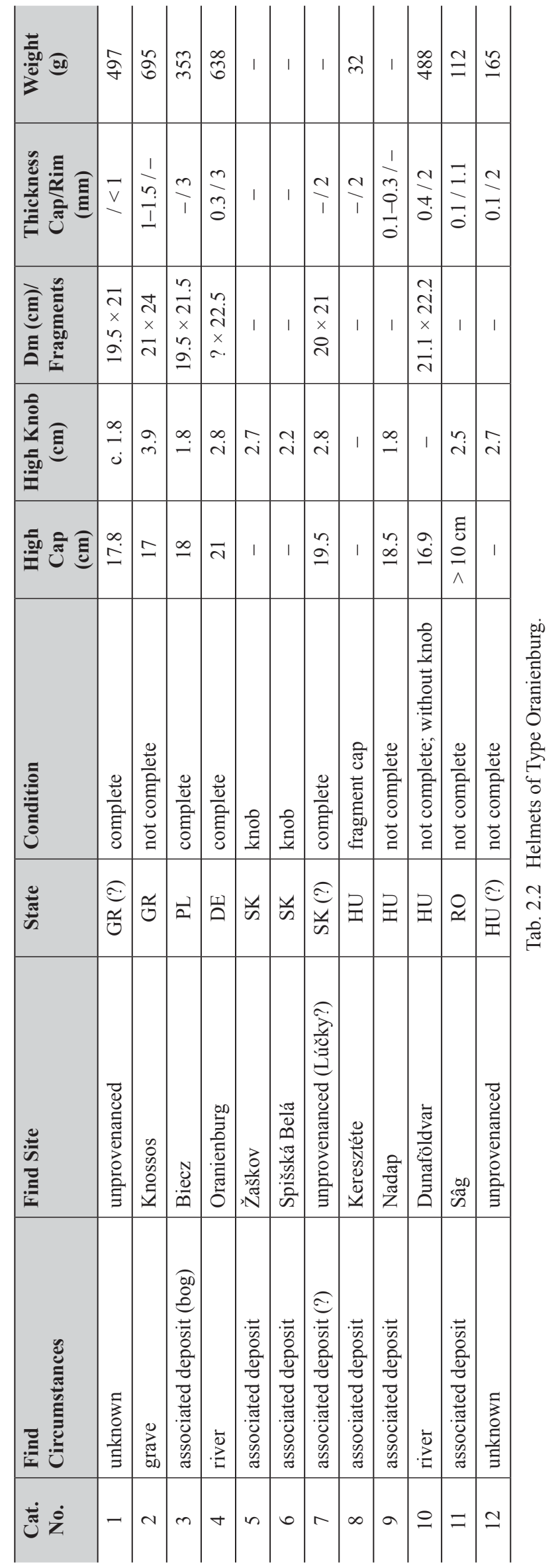


on the helmet from Dunaföldvár. The rivet holes were usually punched through from the outside to the inside of the helmet, with only the rivet holes on the helmet from Oranienburg (cat. no. 4) having been punched from the inside to the outside.

To permit the wearer of these helmets a greater degree of movement of the head, the four helmets from Oranienburg, Lúčky (?) (cat. no. 7), Keresztéte and Biecz show a small alteration to the lower edge of the profile. This is in the form of either the removal of a shallow semi-circular area or a gentler upward curve in its line. ${ }^{72}$ Here again, the helmet from Biecz is slightly different, having a larger cut-out in the front and a smaller one at the back.

In order to stabilise the helmet, they usually have a much thicker rim. Some helmets, such as the one from Biecz, even show hammering traces on the base of the rim in order to broaden and flatten it even more to increase stability.

\subsubsection{Research History}

Conical cap helmets with small, spool-shaped knobs or, as in the following, helmets of Type Oranienburg, were described first as Kegelhelme by v. Merhart, within his group of bell helmets. $^{73}$ This included at the time the helmets from Oranienburg, Biecz and Lúčky. Mozsolics subsequently called them 'helmets of the Lúčky type' or later as 'helmets with spool-like knob' ${ }^{74}$ Hencken, however, retained the classification of v. Merhart, calling them 'conical bell helmets', dividing them from the 'rounded helmets of Type Pişcolt'. ${ }^{75}$ Moreover, he added to his group of conical bell helmets the new finds from Žaškov, Spišská Belá, Keresztéte, and Knossos. Borchhardt included in his Kegelhelme corpus the helmets from Biecz, Oranienburg, Keresztéte, Lúčky and Csönge. ${ }^{76}$ However, the helmet from Csönge dates to Ha C/D and its shape is different from other helmets of Type Oranienburg. Therefore, this helmet will not be discussed here. More recently, Clausing has discussed helmets of Type Oranienburg as Helme mit konischer Kalotte und Scheitelknauf. ${ }^{77}$ He augmented Hencken's group of conical helmets of Type Pişcolt with new finds from Sâg (cat. no. 11), Dunaföldvár and Nadap. In the following, we have added another unprovenanced helmet, which was sold at Christie's in New York on 18 December $1998 .^{78}$ Analyses of its alloy composition and the microstructure of the metallic matrix carried out by the Metropolitan Museum of Art clearly demonstrated the authenticity of the helmet. ${ }^{79}$ Another helmet of Type Oranienburg, unfortunately unprovenanced, was recently published. ${ }^{80}$ Today, twelve helmets of Type Oranienburg, including the unprovenanced helmets, are therefore known (Tab. 2.2).

\subsubsection{Distribution and Deposition}

The twelve helmets of Type Oranienburg have, in their recovery, a rather wide archaeological distribution, ranging from the Havel-Oder region in northern Germany to the Carpathian Basin and the Aegean (Fig. 2.8). Since these helmets do not closely resemble any other form of helmet, we have to assume a close connection between them and the regions they were found in. Further finds of imported Aegean goods found in the Havel-Oder region indicate the existence of such connections. This includes the spearhead from the associated deposit at Kyhna, ${ }^{81}$ as well as

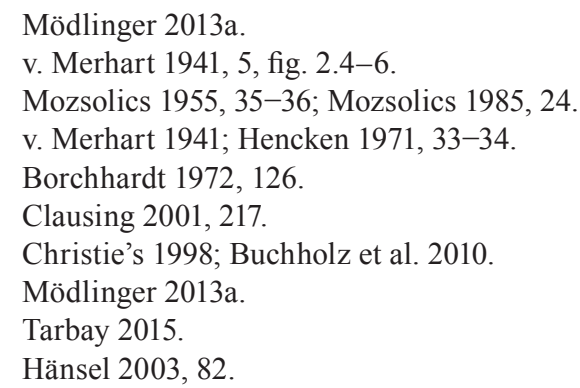




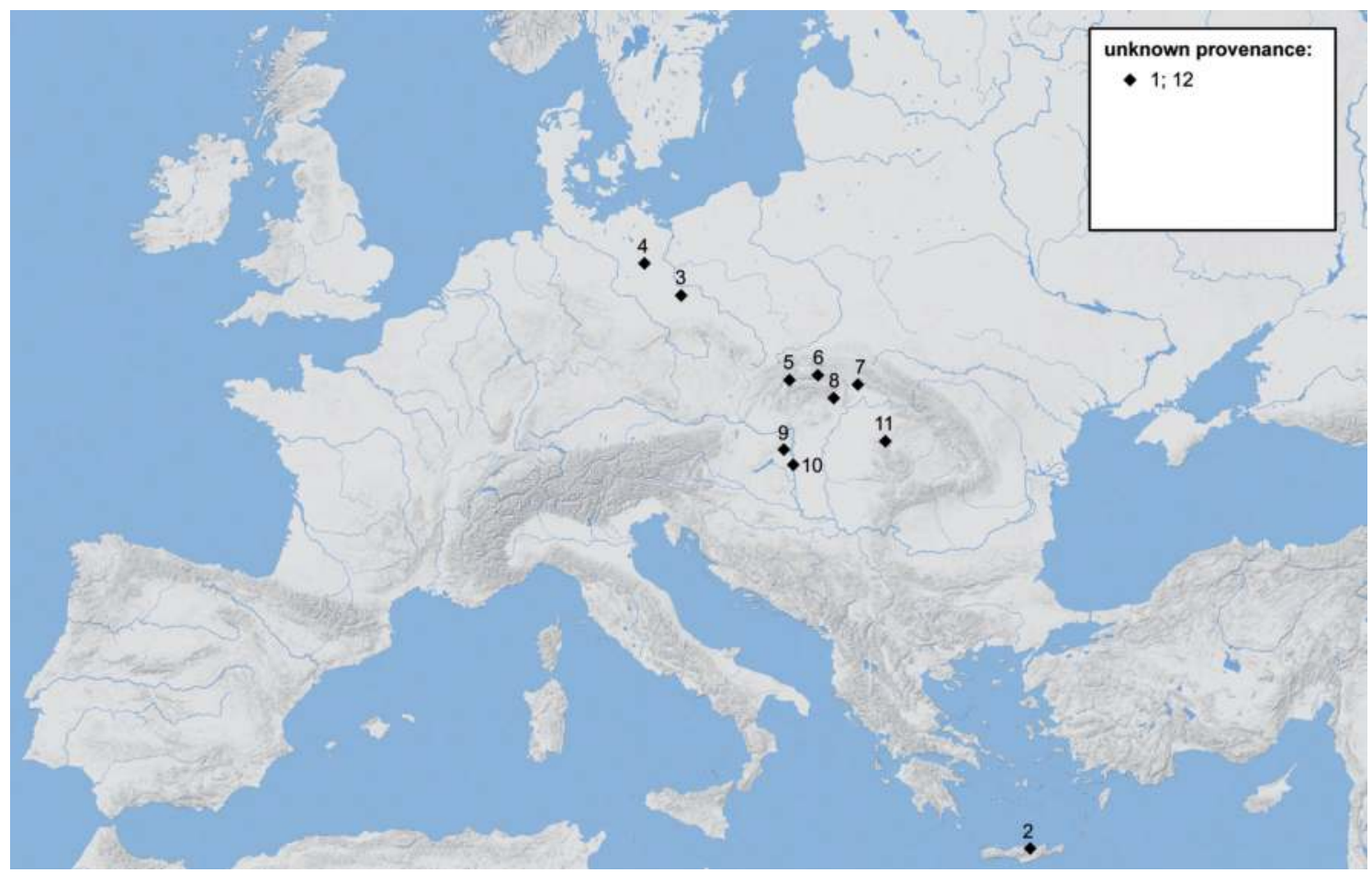

Fig. 2.8 Archaeological distribution of helmets of Type Oranienburg: 1. Unprovenanced; 2. Knossos; 3. Biecz; 4. Oranienburg; 5. Žaškov; 6. Spišská Belá; 7. Lúčky (?); 8. Keresztéte; 9. Nadap; 10. Dunaföldvar; 11. Sâg; 12. Unprovenanced. Numbers correspond to the catalogue numbers.

the fact that such high quality sheet metalworking in bronze is scarce in the Nordic Bronze Age during this period. If we rule out the idea that all helmets of Type Oranienburg were exported from the Aegean, their wide distribution suggests a potentially large production area.

While Hencken saw the area of production for his 'conical helmets bell helmets' generally in the region of Slovakia, H. Buchholz and colleagues assumed for the unprovenanced helmet a production area north of the Gulf of Corinth or in the Peloponnese. ${ }^{82}$ M. S. F. Hood and P. de Jong suggested different centres of production but with an ultimate origin in the Aegean, if not specifically in the Minoan culture. ${ }^{83}$ They mentioned that the lighter Biecz helmet was of 'worse' quality than the Knossos helmet and therefore more likely produced 'at some provincial centre'. ${ }^{84}$ While the latter interpretation is questionable (the helmet is certainly not of poorer quality), an Aegean origin for helmets of Type Oranienburg seems, based on those examples so far recovered, extremely likely. The question of provenance, however, can only be reliably addressed by means of detailed material analyses, preferable by the application of lead isotope analyses, of all helmets of Type Oranienburg. Even when taking into account different habits of deposition and recycling, the relatively high number of helmets of Type Oranienburg in the Carpathian Basin is surprising. For these helmets, we might consider a second, this time local, production area, with an initial production centre in the Aegean for some helmets, such as that of Biecz, and then exported northwards.

So far, only almost complete helmets and knobs of helmets of Type Oranienburg are known. Fragments from the cap are unknown, though there is a possibly lost cap fragment from the associated deposit from Žaškov. ${ }^{85}$ This pattern might be either connected with depositional practices in general or the difficulties in clearly identifying fragments of bronze sheets as com-

82 Hencken 1971, 9; Buchholz et al. 2010, 201.

83 Hood - de Jong 1952, 258.

84 Hood - de Jong 1952, 259, note 86.

85 Hencken 1971, fig. 17a-c. 
ing from a helmet. Unlike the partly contemporary helmets of Type Paks, the deposition of helmets of Type Oranienburg follows no recognisable pattern, with complete helmets known as grave finds (Knossos), river finds (Dunaföldvár and Oranienburg), and associated with associated deposits (though mainly only in the form of the knobs). Moreover, the composition of those associated deposits with helmets of Type Oranienburg is also different. While the helmet from Biecz was allegedly deposited with two ingot torques and one triangular blade of an Early Bronze Age dagger of Type Oder-Elbe, the helmet from Nadap derives from one of the largest European Bronze Age associated deposits, which includes almost all categories of known bronze objects. ${ }^{86}$ It is furthermore the only associated deposit that contains fragments of all the different categories of Bronze Age defensive armour. The associated deposit from Keresztéte consists of the helmet, one cauldron with both triangular handles and a thick, round-sectioned wire that served for the cauldron's suspension-handle, a biconical jug of sheet bronze, a fragmented bronze disc, spearheads (one with a profiled knob, three similar examples, and a smaller spearhead), 16 bracelets (with round cross-section and chevron decoration, one of which has a rhomboid cross-section), and one ring. ${ }^{87}$ In addition to the helmet, the associated deposit from Sâg contains a vessel of Type Hajdúböszörmény, a handle of another vessel, further vessel fragments with cross-shaped handles, a spearhead, several bracelets, phalerae fragments, five bronze cups of Type Kirkendrup and Fuchsstadt, sickle fragments, a fragment of a knife, a possible fragment of a saw, and two knobbed axes with double V-ribs. ${ }^{88}$ The find circumstances of the associated deposit from Lúčky are not completely certain, as it was purchased from an itinerant salesperson, so the composition of the associated deposit remains questionable. For example, some of the allegedly associated objects, such as the situla of Type Hajdúböszörmény and a cauldron with cross-shaped handles, show significantly different corrosion from that on the helmet. The associated deposit from Žaškov comprises the spool-shaped knob of the helmet, knobbed axes, a knobbed chisel, rings, two spearheads, the hilt of a sword of Type Liptau, a bowl of Type Satteldorf, pins, sickles, and two ingots. Lastly, the associated deposit from Spišská Belá consists of the spool-shaped knob of the helmet of three spearheads, parts of two cups of Type Spišská Belá and four plain bracelets (one with rhomboid section, three with oval section). Part of the associated deposit is now missing, including four spearheads, three knobbed axes (one with ribs parallel to the rim of the knob, two with Schnabeltülle), a round object, and four bracelets. ${ }^{89}$

\subsubsection{Chronology}

The development of the first European metal helmets and the rapid adoption of metal in their construction, is clearly demonstrated by three Greek helmets: the boar tusk helmet with metal cheek plates from Dendra (cat. no. 63), which is the oldest, the single decorated example of a helmet of Type Oranienburg, and the helmet of Type Oranienburg from Knossos. The latter is considered the oldest European metal helmet so far and therefore is the oldest helmet of Type Oranienburg with spool-shaped knob. It is dated to the $15^{\text {th }}$ century $\mathrm{BC},{ }^{90}$ while the Dendra grave 12 with the boar tusk helmet is dated to the first half of the $15^{\text {th }}$ century $\mathrm{BC} . .^{91}$ The cheek plates on both helmets closely resemble each other, testifying to a close relationship between them. ${ }^{92}$ Unfortunately, the cheek plates of the unprovenanced helmet have not survived. Though the Dendra helmet is still a boar tusk helmet, it demonstrates in its use of bronze for the cheek plates, the first adoption in Europe of metal in the construction of helmets. We can assume then

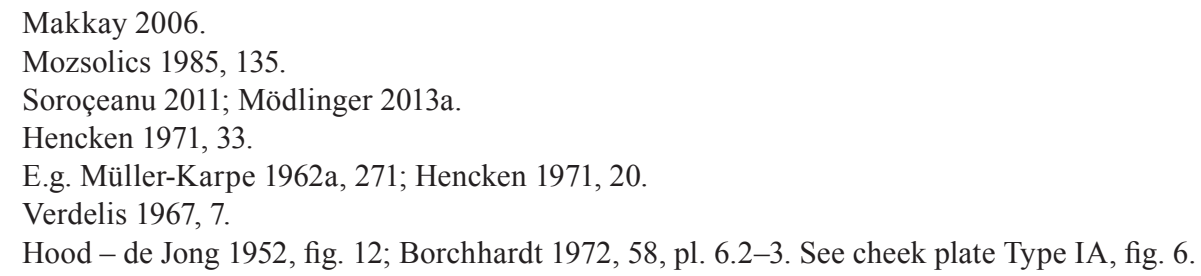


that the unprovenanced helmet is more recent, since it is manufactured completely from metal. It closely resembles the helmet from Knossos in its profile and shape (even when considering the heavily fragmented state of the Knossos helmet at the time of its discovery), and spoolshaped knob, and forms, in association with its abstract decoration of boar tusks, the bridge to the older boar tusk helmets with spool-shaped knob, as seen on the ivory appliqués from Mycenae and on further depictions from Mycenae and Delos. ${ }^{93}$ We can therefore date the unprovenanced helmet to around $1400 \mathrm{BC}$, having an intermediary position as a transitional form between the older boar tusk helmets proper from Dendra and the helmet of Type Oranienburg from Knossos. Such a premise is consistent with dates in Late Helladic II ${ }^{94}$ and LM IIIA respectively, being the middle of the $15^{\text {th }}$ century $\mathrm{BC}$, in accordance with its decoration. ${ }^{95}$

This helmet also suggests the possibility that the Aegean depictions of boar tusk helmets might actually represent decorated metal helmets and not true organic boar tusk helmets. Also, the contemporaneity of boar tusk helmets and bronze helmets might be indicated by the $13^{\text {th }}$ century BC frescos at Pylos: white coloured boar tusk helmets, yellow (bronze?) helmets with several registers similar to the first helmets, whilst further yellow (bronze?) helmets with bosses, nose guards and knobs are depicted together. ${ }^{96}$ The ship fresco from Thera-Akrotiri $\left(16^{\text {th }}\right.$ century BC) also depicts both white boar tusk helmets and yellow (bronze?) helmets with knobs. The helmets hang from the ship timbers right above their owners. One of the Mycenae frescos (c. $1400 \mathrm{BC}$ ) also depicts a similar yellow (bronze?) helmet with knob, ${ }^{97}$ which resembles the later European helmets of Type Pişcolt or cap helmets with solid knob, but is most likely not connected with them.

Another early helmet of Type Oranienburg with spool-shaped knob is the helmet from Biecz, Poland. B. Hänsel convincingly concluded that the helmet from Biecz was deposited together with an Únětice dagger and ingot torques, which might suggest a deposition late in the Early Bronze Age (around 1600 BC).$^{98}$ Significant effort has been expended in attempting to explain the contradiction of such a helmet deposited together with Early Bronze Age objects, including suggesting that the life span of the dagger was prolonged, ${ }^{99}$ the find context, ${ }^{100}$ or even the helmet, ignored. ${ }^{101}$ Nevertheless, after Hänsel discussed in detail the circumstances surrounding the finds and their first recording, there can be little doubt regarding the unity of the associated deposit. ${ }^{102}$ In doing so, Hänsel follows the interpretation of Hencken, who was severely criticised for concluding so. ${ }^{103}$

One must bear in mind that the associated deposit from Biecz is not the only one where significantly earlier objects were deposited together with much later ones. Similar cases include the Spindlersfelder associated deposit (Bz B/C-Ha B1) and the Mušov associated deposit ( $\mathrm{Bz} \mathrm{Cl}-$ Ha A). Moreover, if we consider a possibly earlier date for the Middle Bronze Age in the Carpathian Basin ${ }^{104}$ and a longer duration of the Unětice culture in the Oder region, we might infer similar depositional circumstances for the Spindlersfeld associated deposit. The composition of the Biecz associated deposit is also significantly different from other Urnfield period associated deposits. The presence of further Aegean objects in the same region (such as the spearhead in the associated deposit from Kyhna), might suggest that the associated deposit from Biecz

93 Borchhardt 1972, cat. nos. 3-5, 9.

94 Hereafter LH II. Similar also for Late Helladic I (LH I), Late Helladic IIIA (LH IIIA), and so on.

95 Buchholz et al. 2010, 193, 201; Mödlinger 2013a.

96 Borchhardt 1972, pls. 5.1; 11.1.

97 Borchhardt 1972, pl. 37.3.

98 Hänsel 2003, 77-84.

99 Goetze 1984, 36.

100 Breddin 1969, 42; Schauer 1988, 185, note 37.

101 Billig 1963, 247.

102 Hänsel 2003, 80.

103 Hencken was criticised by: e.g. Sprockhoff 1956, 85; v. Merhart 1956/1957, 144; Hachmann 1957, 176; Gimbutas 1965, 58.

104 Della Casa - Fischer 1997. 
included bronzes which were collected over a longer time span, including a helmet which was imported or at least heavily influenced by the Aegean. B. Hänsel thus pleads for a dating of both the associated deposit and the helmet to the Early Bronze Age. ${ }^{105}$

Dating the Biecz helmet to the late Early Bronze Age would make it the oldest European helmet, and consequently undermine the above suggested development - from boar tusk helmets to the first European metal helmets in the Aegean - with the unprovenanced helmet as a direct connection between the boar tusk helmets and helmets of Type Oranienburg. On the basis of the close relationship in their profile, shape and weight of the helmet from Knossos and the presence of Early Bronze Age finds in the Biecz associated deposit, it is more reasonable to date the helmet and the deposition of the associated deposit to no earlier than the later Middle Bronze Age or Bz C2 (14 $4^{\text {th }}$ century BC). This would make the helmet from Biecz slightly later in date than that from Knossos. ${ }^{106}$ The Biecz helmet would nevertheless remain one of the oldest bronze helmets from central and eastern Europe (if the helmets from Oranienburg and Dunaföldvár were not also placed in their rivers earlier).

The helmets from Nadap, ${ }^{107}$ Spišská Belá, Žaškov, and Keresztéte ${ }^{108}$ can all be dated to $\mathrm{Bz}$ D-Ha A1. While the associated deposits from Žaškov and Spišská Belá are dated generally to Ha A by M. Novotná, the associated deposit from Keresztéte is more specifically dated to early Ha A or Ha A1. ${ }^{109}$ The associated deposits from Lúčky and Sâg are dated according to the presence of fragments of vessels of Type Hajdúböszörmény, which date to Ha B1, even though the find spot and the association of the finds from Lúčky are not secure. ${ }^{110}$ The helmets from Oranienburg and Dunaföldvár were found in rivers, and therefore can only be dated based on their resemblance to other helmets of Type Oranienburg. M. Egg and G. Waurick dated the helmet from Oranienburg to the $12^{\text {th }}-13^{\text {th }}$ century BC. ${ }^{111}$ G. Szabo dated the helmet from Dunaföldvár to Ha A-B, following É. Petres' date for Nadap and Mozsolics' date for Keresztéte. ${ }^{112}$

Ironically, the helmet from Biecz, which is chronologically the closest to the Aegean helmets or perhaps even an export from there, is the find located the furthest distance from the Aegean. As pointed out before, it is likely that this helmet dates to $\mathrm{Bz}$ C2 (14 th century BC), which is chronologically closer to the helmet from Knossos $\left(15^{\text {th }}\right.$ century $\left.\mathrm{BC}\right)$ and the just slightly older unprovenanced helmet. Briefly, we can note that, excluding the helmets from Biecz and Knossos, all helmets of Type Oranienburg with firm find circumstances, as well as associated finds (Nadap, Spišská Belá, Žaškov, Keresztéte) all date to Bz D-Ha Al or, according to the presence of vessels of alleged Type Hajdúböszörmény at Sâg, as late as Ha B1. Taking into account their development in the Aegean and the alleged finds from the associated deposit of Biecz, it is reasonable to assume that the helmets of Type Oranienburg found in other associated deposits can be regarded as belonging to the oldest objects within each associated deposit. In the case of the associated deposit from Sâg, which was deposited in Ha B1, the helmet of Type Oranienburg was likely an antique object. Assuming this is the case, it suggests a main period of use for helmets of Type Oranienburg from the $15^{\text {th }}$ century in Greece down to the $13^{\text {th }}$ century BC in eastern Europe.

\section{Catalogue}

Cat. no. 1. Unprovenanced (Greece?) - complete helmet. Measurements: height: $17.8 \mathrm{~cm}$; diameter: $19.5 \times 21 \mathrm{~cm}$; thickness: cap: $<1 \mathrm{~mm}$; knob: $1-2.5 \mathrm{~mm}$; knob: height: circa $1.8 \mathrm{~cm}$;

105 Hänsel 2003, 77-84.

106 Cf. Mödlinger 2013a.

107 Most recently: Uckelmann 2012.

108 Schauer 1988, 183.

109 Müller-Karpe 1959, 158, note 3; Novotná 1964, 21; v. Brunn 1968; Mozsolics 1985, 135.

110 Patay 1969, 205; Soroçeanu - Lakó 1981, 156; Schauer 1988, 184-191.

111 Egg-Waurick 1990, 14.

112 Petres 1983, 58; Mozsolics 1985, 24; Szabó 1994, 224. 
weight: 497g - private collection - Pl. 1.1. References: Christie's 1998; Born 2009, fig. 24; Buchholz et al. 2010; Mödlinger 2013a.

Before appearing on the market in Massachusetts in 1952, the helmet and other possibly associated finds had already been offered to the Museum of Fine Arts in Boston. ${ }^{113}$ As indicated by the nature of the corrosion, the helmet was most likely found in a grave close to the sea. The knob is the only known one on a Bronze Age helmet, which was worked up directly out of the sheet of the helmet. Inside the helmet, horizontal traces of hammering can be observed. ${ }^{114}$ Also, two ancient repairs can be identified, including a $5.5 \mathrm{~cm}$ long crack repaired by a now lost bronze sheet patch, which was fixed on both sides of the crack by two rivets, which are also now lost. Since the repair did not affect the decoration, it might be possible that the helmet already underwent repair during manufacture, before the decoration was applied. ${ }^{115} \mathrm{~A}$ further crack immediately below the knob was also repaired with the addition of three rivets and a bronze sheet patch, while two further cracks from the knob downwards were left unrepaired. The depressed knob and the latter cracks might have resulted from an impact sustained during fighting, or a consequence of post-depositional processes. The punched and probably originally infilled decoration consists of registers of punched ornament, with two below the finial and two above the bottom edge. From the top down to the rim, the registers become broader, as can also be observed on the actual boar tusk helmets. The registers are all filled with simplified boartusk motifs. The lowest register also bears four counter-clockwise running spirals. The 'lines' making up the patterns are similar to the ladder motif seen on the well-known Cypriot 'White slip Ware'. ${ }^{116}$ Similar decoration can also be found on LH III ceramics (e.g. Kallithea, Crete or Tiryns), bronze vessels (e.g. Knossos), and silver vessels and gold cups (e.g. Mycenae, Dendra). The central and broadest register lacks any decoration or indication of gilding or silvering. ${ }^{117}$ Parallels for such a large blank register in combination with others filled with boar tusks are scarce, though blank registers in general are known, such as the ceramic vase from Isopata (grave 5) or the marble engraving from Ayia Irini, Keos. Spiral decoration is so far unknown on other bronze helmets or from their depiction. The closest similarity can be seen in the depicted circles on the ivory miniature helmet from Knossos. Similar spirals are known from Gournia, Crete, on Late Minoan II $^{118}$ ceramics, and on a bronze pan from Isopata, Crete. As Buchholz and colleagues pointed out, usually only precious goods or luxury objects have such spiral decoration. ${ }^{119}$ The helmet was sold at an auction at Christie's in New York on 18 December $1998 .{ }^{120}$

Cat. no. 2. Knossos, Crete, Greece - grave find (grave no. 5) - fragmented helmet. Measurements: height: $17 \mathrm{~cm}$; diameter: $24 \times 21 \mathrm{~cm}$; knob height: $3.9 \mathrm{~cm}$; diameter at the knob's base: $5 \mathrm{~cm}$; thickness: $1-1.5 \mathrm{~mm}$; total weight helmet: $695 \mathrm{~g}$; Cheek plates measurements: $16.5 \times 9 \mathrm{~cm}$;

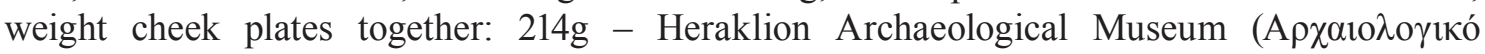

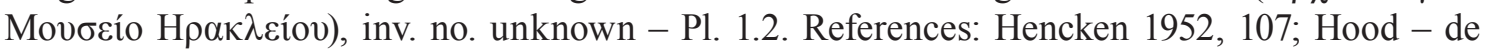
Jong 1952, 252-260, pls. 50-51; 52a; Matz 1956, 126; Ventris - Chadwick 1956, 377, fig. 26A; Zervos 1956, fig. 719; Hachmann 1957, 176; Marinatos 1959, 113; Schachermeyr 1960, 63, 66, fig. 54; Yalouris 1960, 55; Müller-Karpe 1962a, 271-272; Borchhardt 1972, 56-60, cat. no. 11.I; Hencken 1971, 20, fig. 3e-g; Bouzek 1981, 21-23, fig. 1.1, 3; Kilian-Dirlmeier 1985, 196-197, 199, tab. 1; Schauer 1988, 183; Vasilakis 1999, 114, fig. on the right; Clausing 2001, 218; Buchholz et al. 2010; Mödlinger 2013a.

113 Buchholz et al. 2010, 139, 192.

114 Buchholz et al. 2010, fig. 57.

115 Buchholz et al. 2010, 149.

116 Cf. Mödlinger 2013a.

117 Buchholz et al. 2010, 156.

118 Hereafter LM II. Similar also Late Minoan I (LM I), Late Minoan IIA (LM IIA), and so on.

119 Buchholz et al. 2010, 180.

120 Christie's 1998. 
After two years of excavation at Ayios Ioannis and the new hospital site in Knossos, the helmet was published in 1952. It was found in grave V from the latter site. With it were a spearhead and a rapier, as well as stone vases (three of alabaster and two of other materials). In close vicinity to the helmet, a lead disc $5.5 \mathrm{~cm}$ in diameter with a cover of bronze was found. The disc might have served as an extra weight attached to an organic neck guard, so that it would not shift about. Unfortunately, the tomb chamber collapsed and left the helmet smashed into over a hundred fragments. As a consequence, any possible traces of use or manufacture that may have been preserved are almost impossible to detect. The Knossos helmet is the only helmet of Type Oranienburg with surviving cheek plates. It is not clear if the cheek plates overlapped with the bottom of the helmet or if they were fitted edge to edge. Both cheek plates have 18 small rivet holes between $1.5-2 \mathrm{~mm}$ in diameter. ${ }^{121}$

Cat. no. 3. Biecz (Beitzsch), woj. Lubuskie, Poland - associated deposit (bog find) - complete helmet. Measurements: height: $16.2 \mathrm{~cm}$ (cap); $1.8 \mathrm{~cm}(\mathrm{knob})$; diameter: $19.5 \times 21.5 \mathrm{~cm}$; weight: $353 \mathrm{~g}$ - British Museum, reg. Num. 1868.1228.248 - Pl. 1.3. References: Klemm n.d. V, 13 ('Kopfbekleidung. Helme'); Klemm 1851, 52, note 2; Klemm 1854, 157; Lindenschmit 1858, pl. 1.1; Kemble 1863, 52, 170, pl. 12.6; Klemm 1868, no. 429 ('bei Pförten'); Genthe 1874, 170-171; Dahn 1881, 48; British Museum Guide 1904, 97; Uenze 1938, 37, 83; v. Merhart 1941, 11, fig. 2.6; Hencken 1952; Hundt 1955, 105; Sprockhoff 1956, 85; v. Merhart 1956/1957, 144; Hachmann 1957, 176; Gimbutas 1965, 58; Patay 1969, 205, note 122; Hencken 1971, 33, fig. 13c-d; 37; Borchhardt 1972, 127, cat. no. 28.1; Bukowski - Dąbrowski 1972, 116; Bouzek 1981, 23, fig. 1.2, 4; Jażdżewski 1981, 288; Otto 1981, 60; Goetze 1984, 36; Schauer 1988, 185; Blajer 1990, 28, 33, 102; Egg - Waurick 1990, 14; Uenze 1990, 23, 41, no. 51, pl. 5.2; Albrecht 1991; Calzecchi-Onesti 1991, 74, fig. 3; 76, no. 4; Clausing 2001, 218; Hänsel 2003, 77-84, fig. 2; Clausing 2005, 36-38; Buchholz et al. 2010, 201; Mödlinger 2013a.

The helmet was likely found together with two ingot torques and one triangular blade of a dagger of Type Oder-Elbe below a pine trunk in a peat bog in 1847. The associated deposit was purchased from Johannes Gustav Klemm (collection in Dresden) and is today kept by the British Museum, London. Analyses carried out at the British Museum in 1952 mention the presence of small fragments of charred oak and plum wood inside the cap of the helmet. These were not observed in 2013 when the helmet was studied by the author.

Cat. no. 4. Oranienburg, Lkr. Oberhavel, Brandenburg, Germany - single river find (river Havel) - complete helmet. Measurements: height: $21 \mathrm{~cm}$; diameter: approx. $22.5 \mathrm{~cm}$; thickness: 0.3-3mm; knob height: $2.8 \mathrm{~cm}$; weight: $638 \mathrm{~g}$ - Heimatmuseum Oranienburg, inv. no. III.51 - Pl. 1.4. References: Sprockhoff 1930, 44, pl. 9a; v. Merhart 1941, 11, fig. 2.4; Hencken 1971, 33, 37, fig. 13e; Borchhardt 1972, 127, cat. no. 28.2; Bouzek 1981, 23, fig. 2.3; Albrecht 1991; Clausing 2001, 218; Hänsel 2003, 82, fig. 1; Born 2009, figs. 21-22; Lippert 2011, 31; Mödlinger 2013a.

The helmet was recovered from the river Havel as a single find before the 1930s. On one side of the helmet at least three severe sword impacts are visible.

Cat. no. 5. Žaškov, okr. Dolný Kubín, Slovakia - associated deposit - knob. Measurements: height: $2.7 \mathrm{~cm}$; diameter: $2.1 \mathrm{~cm}$ (above), $1 \mathrm{~cm}$ (shaft), $2.8 \mathrm{~cm}$ (base); weight unknown - Slovenské národné múzeum Martin, inv. no. 3504 - Pl. 1.5. References: Hampel 1892, 173; Eisner 1933; Novotná 1964, 21; Novotná 1970, 53-56; Hencken 1971, 37, fig. 17a-c; Müller-Karpe 1980, pl. 387.B; Mozsolics 1985, 24; Schauer 1988, 183; Calzecchi-Onesti 1991, 75, fig. 4b, no. 3; Novotná 1991, 14, no. 5; 24, no. 18; Hansen 1994, 509, CS 731; Clausing 2001, 218; Furmánek - Novotná 2006, 38, nos. 173-177; Mörtz 2011a, 370; Mödlinger 2013a.

Other than the date, having been found in June 1876, the find circumstances of the associated deposit are unknown. As well as the spool-shaped knob of the helmet, the associated deposit

121 Mödlinger 2013a. 
consists of rings, a bowl of Type Satteldorf, knobbed axes, two spearheads, the hilt of an early Type Liptau sword, pins, a knobbed chisel, sickles, and two ingots. A fragment of a helmet cap is depicted by Hencken ${ }^{122}$ but was not found at the museum. Fragments of the cap of a helmet are still attached to the cast-on, spool-shaped knob, however. The knob itself had been repaired, where the upper part was cast onto the lower, thus resulting in the upper part being solid, with only the lower being spool-like in cross-section. From the inside of the helmet, a drop of metal from the upper and later repaired part of the knob can be seen inside the central hole, which once passed completely through the original knob. ${ }^{123}$

Cat. no. 6. Spišská Belá, okr. Kežmarok, Slovakia - associated deposit I (1891) - knob. Measurements: height: $2.2 \mathrm{~cm}$; diameter: $2.2 \mathrm{~cm}$ (above), $1 \mathrm{~cm}$ (shaft), $3.2 \mathrm{~cm}$ (base); weight unknown Podtatranské Múzeum Poprad, inv. no. MK 882 - Pl. 1.6. References: Novotná 1964; Novotná 1970, 53-56; Hencken 1971, 33, 35, fig. 15f-h; Schauer 1988, 184; Calzecchi-Onesti 1991, 76, no. 2; Novotná 1991, 22, nos. 10-11, pl. 19.A3; Clausing 2001, 218; Vachta 2008, 123, list V.1.5, no. 14; Mörtz 2011a, 370; Mödlinger 2013a.

As well as the parts of the spool-shaped knob from a helmet, the associated deposit consists of two cups, four plain bracelets and three spearheads. Other finds, namely three knobbed axes, four bracelets, four spearheads and a round object, are now missing. ${ }^{124}$

Cat. no. 7. Unprovenanced (probably Lúčky, okr. Ružomberok, Slovakia) - associated deposit (?) - complete helmet. Measurements: height: $19.5 \mathrm{~cm}$; diameter: $20 \times 21 \mathrm{~cm}$; knob: height: c. $2.8 \mathrm{~cm}$; weight: unknown - Archeologické múzeum SNM, 4518 - Pl. 1.7. References: v. Merhart 1941, 11, fig. 2.5; v. Merhart 1952, 63, 70; Mozsolics 1955, 42, 44, fig. 9.1; MüllerKarpe 1959, 114, 204; Novotná 1970, 53-56; Hencken 1971, 32, fig. 13a-b; Borchhardt 1972, 127, cat. no. 28.4; Bouzek 1981, 23, fig. 2.1; Calzecchi-Onesti 1991, 76, no. 1; Novotná 1991, 47, no. 48; 58, no. 54; Clausing 2001, 218; Mödlinger 2013a.

The actual find location of this possible associated deposit is unknown, though it is usually named as coming from Lúčky. An itinerant salesperson sold the helmet and other bronzes to the museum in Martin. The helmet was supposedly found together with a situla of Type Hajdúböszörmény and a cauldron with cross-shaped handles. The corrosion of the three objects is significantly different, ${ }^{125}$ which might indicate that the objects were not originally associated, though the composition of the associated deposit resembles that from Mezökövesd, which contained a helmet of Type Pişcolt (cat. no. 45). The helmet is partly broken and distorted. On the inside, horizontal traces of hammering are visible. Over $1.2 \mathrm{~cm}$ above the rivet holes, a small step or stage with respect to the rest of the cap is visible on the inside of the helmet. In this area, several vertical cracks, caused by material tension, are visible.

Cat. no. 8. Keresztéte, kom. Borsod-Abaúj-Zemplén, Hungary - associated deposit - two fragments. Measurements: $12 \times 5.3 \mathrm{~cm}$; weight: $32 \mathrm{~g}-$ Magyar Nemzeti Múzeum, inv. no. 31/1941/8 - Pl. 1.8. References: Mozsolics 1955, 41, fig. 7.7; Müller-Karpe 1959, 158; Hencken 1971, 39, fig. 18a; Kemenczei 1984, 149, no. 17; Mozsolics 1985, 24, 135, 388, pl. 150.9; Schauer 1988, 184; Patay 1990, 19, no. 3; Hansen 1994, 541, H 330; Clausing 2001, 218; Vachta 2008, 123, list V.1.5, no. 4; Mörtz 2011a, 362; Mödlinger 2013a.

The associated deposit was found during ploughing at the end of the 1930s and consists of the helmet without knob, a cauldron, a bronze boss (diameter $11.5 \mathrm{~cm}$ ), five spearheads, 16 bracelets and rings, and a biconical jug of sheet bronze. Today, only two fragments (soldered together) from the helmet survive, with the rest of the helmet probably having been lost during the Second World War.

122 Hencken 1971, fig. 17c.

123 Cf. Mödlinger 2013a.

124 Hencken 1971, 33.

125 Hencken 1971, 32. 
Cat. no. 9. Nadap, kom. Fejér, Hungary - associated deposit - almost complete helmet. Measurements: height (total): $18.5 \mathrm{~cm}$; thickness (cap): $0.1-0.3 \mathrm{~mm}$; height (knob): $1.8 \mathrm{~cm}$; diameter (knob base): $2.2 \mathrm{~cm}$; weight: not possible to measure, since the helmet is permanently attached to a modern bronze sheet - Szent István Király Múzeum, Székesfehérvár, no inv. no. - Pl. 2.9. References: Petres 1983, 57, fig. 1a-b; Schauer 1988, 184, fig. 4; Calzecchi-Onesti 1991, 77, no. 12; 1994, 546, H451; Jankovits 1998/1999, fig. 1.2; Jankovits 1999/2000, fig. 1.2; Clausing 2001, 218; Makkay 2006, 7, pl. I; Uckelmann 2012, 18-19; Mödlinger 2013a.

The associated deposit was found in spring 1970 at Jánoshegy, most likely as a consequence of the heavy ploughing in the autumn of $1969 .{ }^{126}$ Over an area of about $25 \mathrm{sqm}$ more than 350 bronze objects and several thousands of sherds were recovered over the following months. Mozsolics and S. Hansen refer to 713 objects with approximately 80 fragments, whilst M. Uckelmann mentions 628 objects/fragments, and J. Makkay 567 or 568 objects. ${ }^{127}$

The associated deposit from Nadap is the only associated deposit containing likely fragments of all categories of defensive armour, comprising a helmet of Type Oranienburg, fragments helmets of Type Paks (see cat. no. 27), two pairs of greaves (see cat. nos. 165. 170-172), a fragment of a shield of Type Nyírtura, further possible fragments from the edge of a shield, and a fragment of a cuirass (see cat. no. 132). The associated deposit also contained the hilts of two Type Dreiwulst swords, fragments from 13 flange hilted swords, fragments from eight flange hilted daggers, 15 spearheads, two ferrules, five socketed hammers, ten different chisels and punches, an anvil, ten socketed axes and fragments of another, four winged axes and the fragments of a further five, 28 sickles, fragments of eight knives, fragments of possibly 12 saws, fragments of two sceptres (?), a razor of variant Ciumeşti, two razors of Type Großmugl, variant Mixnitz, a fragment of a razor of Type Großmugl, variant Mesić, and two handles of further razors, a total of 14 vessels, including bronze vessels of Type A, variant A2, a bronze cup of Type Gusen, a bronze cup of Type Gusen/Blatnica, fragments of eight bronze cups of Type Blatnica, a further bronze cup and bowl, a sieve, fragments of six fibulae, four pins and two pin heads, neck rings, 31arm rings and three fragments, nine arm bands and three fragments, fragments of four arm spirals, pendants, three belt plates and fragments of a further two, 17 more belt sheet fragments, pieces of bronze, casting cakes, off-casts, four different tutuli, ten bronze pearls, four scales (?), a large phalerae or star-like decorated disc, ${ }^{128} 17$ smaller phalerae, Riemenverteiler, four fragments of three phalerae or mirrors, potential fragments of a miniature wagon, three rings, further unidentified fragments and objects, and a large quantity of sherds, most likely from a pot containing the bronzes. The list of associated finds differs across various publications, and the above is based on that of M. Uckelmann. ${ }^{129}$

Presently, less than a third of the helmet's cap survives. What remains is severely corroded and has several cracks. Seven rivet holes differing in size from $5-8 \mathrm{~mm}$ in diameter are still preserved. They were punched through from the outside to the inside of the helmet.

Cat. no. 10. Dunaföldvár, kom. Tolna, Hungary - single river find (river Danube) - complete helmet. Measurements: height (without knob): $16.9 \mathrm{~cm}$; diameter: $21.1 \times 22.2 \mathrm{~cm}$; thickness: $2 \mathrm{~mm}$ (rim); 0.4mm (cap); weight: 488g - Adám Béri Balogh Museum Szekszárd, inv. no. O.93.33.1 Pl. 2.10. References: Szabó 1994, 219, pl. 1; Clausing 2001, 218; Mörtz 2011a, 369; Mödlinger 2013a.

The helmet was bought from the private collection of Lajos Dánó by the museum after it was found in the Danube at Dunaföldvár in 1986. Despite the knob having been broken off and lost, the helmet is complete. Two cracks can be identified but otherwise the cap does not show any significant damage.

\footnotetext{
126 Makkay 2006.

127 Mozsolics 1985, 151; Hansen 1994, 546; Makkay 2006, 6; Uckelmann 2012, 18.

128 Mödlinger 2013b.

129 Uckelmann 2012, 17.
} 
Cat. no. 11. Sâg (Sîg), jud. Sălaj, Romania - associated deposit - almost complete helmet. Measurements: height incomplete cap: $10 \mathrm{~cm}$; knob: height: $2.5 \mathrm{~cm}$; thickness: $0.1 \mathrm{~mm}$ (cap); $1.1 \mathrm{~mm}$ (rim); weight: $56 \mathrm{~g}$ (cap); $56 \mathrm{~g}$ (knob) - Muzeul Judeţean de Istorie şi Artă-Zalău, no inv. no. - Pl. 2.11. References: Petrescu-Dîmboviţa 1977, 134, pl. 318.14; Soroçeanu - Lakó 1981, 147, 153, fig. 9.4; Schauer 1988, 184-185, fig. 5.8; Rusu 1990, 77; Clausing 2001, 218; Soroçeanu 2008, 58, nos. 17-19; Vachta 2008, 123, list V.1.5, no. 12; Mörtz 2011a, 370; Soroçeanu 2011, 237, fig. 17; Mödlinger 2013a.

The associated deposit was found in 1972 in Sâg (Sălaj) at a depth of $60 \mathrm{~cm}$, approximately $150 \mathrm{~m}$ west of the new school building. The associated deposit consists of the helmet, a situla of Type Hajdúböszörmény, further situla fragments with cross-shaped handles, a handle of a vessel, bracelets, phalerae, five bronze cups of types Kirkendrup and Fuchsstadt, sickles, a spearhead, two knobbed axes, and a possible fragment of a saw. The heavily corroded fragments of the helmet's cap, as well as the knob, were sand blasted and are now in a delicate condition. The central hole of the knob is only $3 \mathrm{~mm}$ deep and of not much practical use.

Cat. no. 12. Unprovenanced (Hungary?) - knob with three fragments of the cap. Measurements: knob: height: $2.7 \mathrm{~cm}$; width: base $2.7 \mathrm{~cm}$; weight: $40 \mathrm{~g}$; fragment 1: $13.2 \times 6.2 \mathrm{~cm}$, thickness 0.1-2cm, weight $90 \mathrm{~g}$; fragment 2: $7.9 \times 3.6 \mathrm{~cm}$, thickness $0.1 \mathrm{~cm}$, weight $24 \mathrm{~g}$; fragment 3: $4.8 \times$ $1.9 \mathrm{~cm}$, thickness $0.2 \mathrm{~cm}$, weight $11 \mathrm{~g}$ - Hadtorteneti Muzeum, Budapest inv.no. 1993.791.II - Pl. 2.12. References: Tarbay 2015, figs. 6, 15.3.

The assemblage of different objects, including fragments of the helmet, were acquired by the museum in the early 1990s. The exact find spot and find circumstances are unknown. The assemblage contains a flange hilted sword with pommel tang of Type Allerona, three flange hilted knives of Type Pustiměř, a helmet of Type Oranienburg, a pair of greaves of Type Desmontà (cat. nos. 166-167), a cup of Type Fuchsstadt, a ribbed tube and further sheet metal fragments.

J. G. Tarbay points out that due to the condition of the objects in the assemblage (all of the objects show damage due to intentional destruction, such as bending, crushing, melting, and/or breakage), they were very likely associated and dates the deposit to Ha B1.

From the helmet, only the central, cast-on and undecorated knob, and three fragments of the cap, survive, and all have been seriously damaged by exposure to fire.

\subsubsection{Helmets of Type Paks}

Helmets Type Paks are the only eastern European decorated helmet type. Only a few other helmets from southern and eastern Europe are also decorated, such as the helmet from SzczecinZdroje (cat. no. 59), an unprovenanced helmet of Type Oranienburg (cat. no. 2), and the only crested helmet in eastern Europe, which is unprovenanced (cat. no. 100). The thin, delicate hemispherical cap of helmets of Type Paks has a central, cast-on knob. According to the decoration, we can distinguish two variants of the helmet type, being those with two or three horizontal ribs above the many rivet holes placed immediately above the rim, and those with both ribs and central star decoration around the knob. The star motif consists of individual arcs arranged in a ring, with the ends of the arcs facing outwards, which are then encircled by ribs.

In the case of fragments, distinguishing between the two variants can be rather difficult, especially where only rim fragments have survived. Bronze sheet fragments from decorated bronze discs, which also have the same star-motif, have also often been mistaken for helmets. Analysis of the relevant fragments in their various museum collections by the author has established that, with the exception of the two fragments from Pázmándfalu (cat. no. 26), all fragments with star motif most likely belong to these discs and not to helmets. ${ }^{130}$ These disc fragments are completely flat and usually show a natural rather than broken edge parallel to the rib

130 For details, see Mödlinger 2013b, 65. 
decoration. Most of the fragments were published only in the form of poor quality drawings and without accompanying photograph, making it impossible to reconstruct their shape and size with precision. The misidentification of disc fragments as coming from helmets, such as in the case of the fragments from the associated deposits at Nagyvejke, Poljanci I, and Veliko Nabrđe, is therefore not surprising.

The star motif found on helmets and discs is also known on other objects, including bronze and ceramic cups, as well as the bronze sheet object from Sacoti, Romania, which might be a fragment of a belt plate. ${ }^{131}$ The star motif first appears on cast bronze objects during the Middle Bronze Age in southeastern and central Europe. Here, the motif consisted of a circular arrangement of separate arcs with points that usually did not meet. Similar decoration occurs on the pommel discs of solid-hilted swords and disc-headed axes from central and southern Europe. ${ }^{132}$ As the decorative motif developed, the ends of the individual arcs become joined, forming the star-like shape. The developed star motif on these decorated discs represents the first bronze sheet object to bear this decoration, and seems to have taken place as early as Bz D2 or with the beginning of Ha A1. The motif then spread northwards, where it was adopted onto these helmets. It is possible that the helmets of Type Paks without star motif are somewhat earlier but as the find circumstances of the only two complete examples of helmets of Type Paks without star motif are unknown, there is currently no way to be sure. The later adoption of the star motif onto bronze cups ${ }^{133}$ was probably influenced not only by its occurrence on the cap helmets but also on garland-decorated pottery, while its appearance on pottery cups was likely influenced only by the helmets of Type Paks, decorated with the star motif. The star motif appears to have largely gone out of fashion on sheet-bronze objects such as helmets by Ha A2 and on bronze cups by Ha B1.

Today, there are at least seven complete helmets of Type Paks with rib and star decoration, and two complete helmets of Type Paks with rib decoration only. On the basis of two helmets with rib (unprovenanced; cat. no. 21), and rib and star decoration (Žiar nad Hronom; cat. no. 16), found together with their cheek plates intact, we can assign similar cheek plates, such as those from Wöllersdorf (cat. no. 30), Hočko Pohorje (cat. no. 31), Uioara de Sus (cat. no. 32), Újszőny/ Komárom (cat. no. 33), Pázmándfalu (cat. no. 35), and Mezőnyárád (cat. no. 34), to this helmet type. The kidney-shaped cheek plates have a convex middle section with rivet holes lining the edge. In addition, the cheek plate fragments from Hočko Pohorje and Uioara de Sus have rivet holes across the embossed section to attach an organic lining. One of the two fragments from Uioara de Sus, however, shows no rivet holes on the preserved fragment. Fragments of further helmets of Type Paks are known from eight different find spots.

Assuming that the fragments of helmets in deposits do not come from a single helmet but belong instead to different helmets, having been deposited as pars pro toto, wherein the fragment stands in for the whole, as recently suggested for shields from the associated deposits from Otok Privlaka, Croatia, and Keszőhidegkút, Hungary, ${ }^{134}$ then the total number of individual helmets of Type Paks known would be at least nine, the number of separate cheek plates seven and the total number of fragments of further helmets at least fourteen (the associated deposits with more than one fragment are Nadap (two fragments; cat. no. 27) and Pázmándfalu (four fragments)). With the most recent Hungarian find from Pázmándfalu, we know of between 26 and $30^{135}$ examples of helmets of Type Paks, making it the most well represented of all known Bronze Age helmets (Tab. 2.3).

\footnotetext{
131 Mödlinger 2013b.

132 Coblenz 1951, 156, note 69; Martin 2009, 49, note 89; Mödlinger 2013b, 68-71.

133 Mödlinger 2013b, nos. 67-70, pl. 5.

134 Mödlinger - El Morr 2014; Mödlinger et al. 2014.

135 The varying numbers result from the fact that we do not know if the fragments from deposits such as Nadap or Pázmándfalu belong to a single helmet or perhaps come from several individual helmets.
} 


\begin{tabular}{|c|c|c|c|c|c|c|c|c|c|c|c|c|c|c|c|c|c|c|c|}
\hline 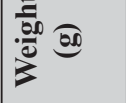 & 1 & तิ & 号 & I & 1 & 1 & 1 & $\begin{array}{l}\dot{f} \\
\mathrm{n}\end{array}$ & $\overrightarrow{0}$ & $\infty$ & 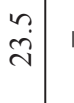 & 1 & 1 & तु & $1 \%$ & \begin{tabular}{l|l}
$n$ \\
0
\end{tabular} & 1 & 1 & \\
\hline 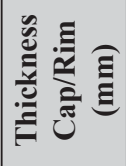 & 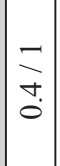 & $\begin{array}{l}\vec{J} \\
\vec{\partial} \\
0\end{array}$ & $\begin{array}{l}\overline{1} \\
\stackrel{m}{0}\end{array}$ & \begin{tabular}{l}
$N$ \\
\multirow{2}{*}{} \\
$\stackrel{0}{0}$
\end{tabular} & I & 1 & $\begin{array}{l}\alpha \\
0 \\
y \\
c\end{array}$ & 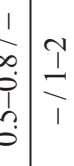 & I & 1 & \begin{tabular}{l|l}
$m$ & \\
$\infty$ & 1 \\
0 & 1 \\
$\dot{0}$ & \multicolumn{2}{c}{} \\
$\dot{0}$ & 0
\end{tabular} & 1 & 1 & 1 & a & $\begin{array}{l}0 \\
\dot{0} \\
\dot{0} \\
\end{array}$ & 1 & 1 & \\
\hline 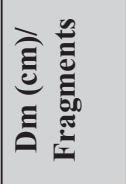 & 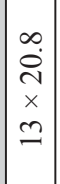 & $\begin{array}{l}\stackrel{o}{2} \\
\dot{T} \\
x \\
\underline{y} \\
\underline{I}\end{array}$ & $\mid \begin{array}{l}n \\
2 \\
i \\
x \\
0 \\
\\
=\end{array}$ & 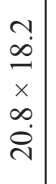 & $\begin{array}{l}n \\
\tilde{\lambda}\end{array}$ & । & $\begin{array}{l}\alpha \\
x \\
\alpha \\
\alpha \\
0\end{array}$ & 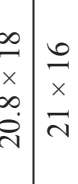 & $\begin{array}{l}7 \\
\dot{+} \\
\dot{x} \\
0\end{array}$ & 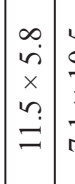 & 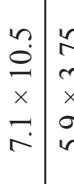 & 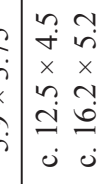 & $\mid \begin{array}{cc}\hat{r} & \hat{n} \\
\infty & i \\
x & x \\
\vec{a} & \hat{r}\end{array}$ & I & I & 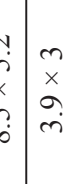 & 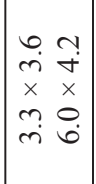 & 1 & \\
\hline 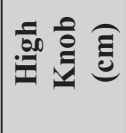 & 1 & 1 & $\ddot{n}$ & in & $\begin{array}{l}n \\
a \\
\ddot{g} \\
\end{array}$ & ' & 1 & in in & 1 & 1 & 1 & 1 & 1 & $\stackrel{+}{+}$ & F & I & 1 & 1 & \\
\hline 己َ & $\stackrel{n}{m}$ & $\vec{m}$ & $\stackrel{?}{=}$ & $\overrightarrow{\mathrm{a}}$ & 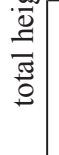 & । & । & 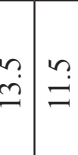 & I & 1 & 1 & 1 & 1 & 1 & 1 & । & 1 & & \\
\hline
\end{tabular}

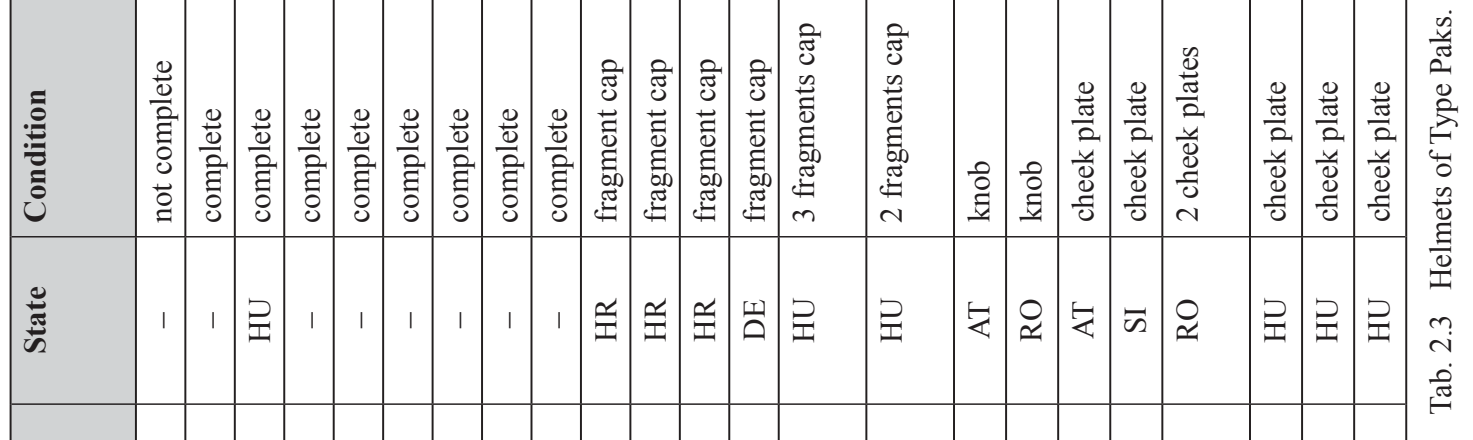

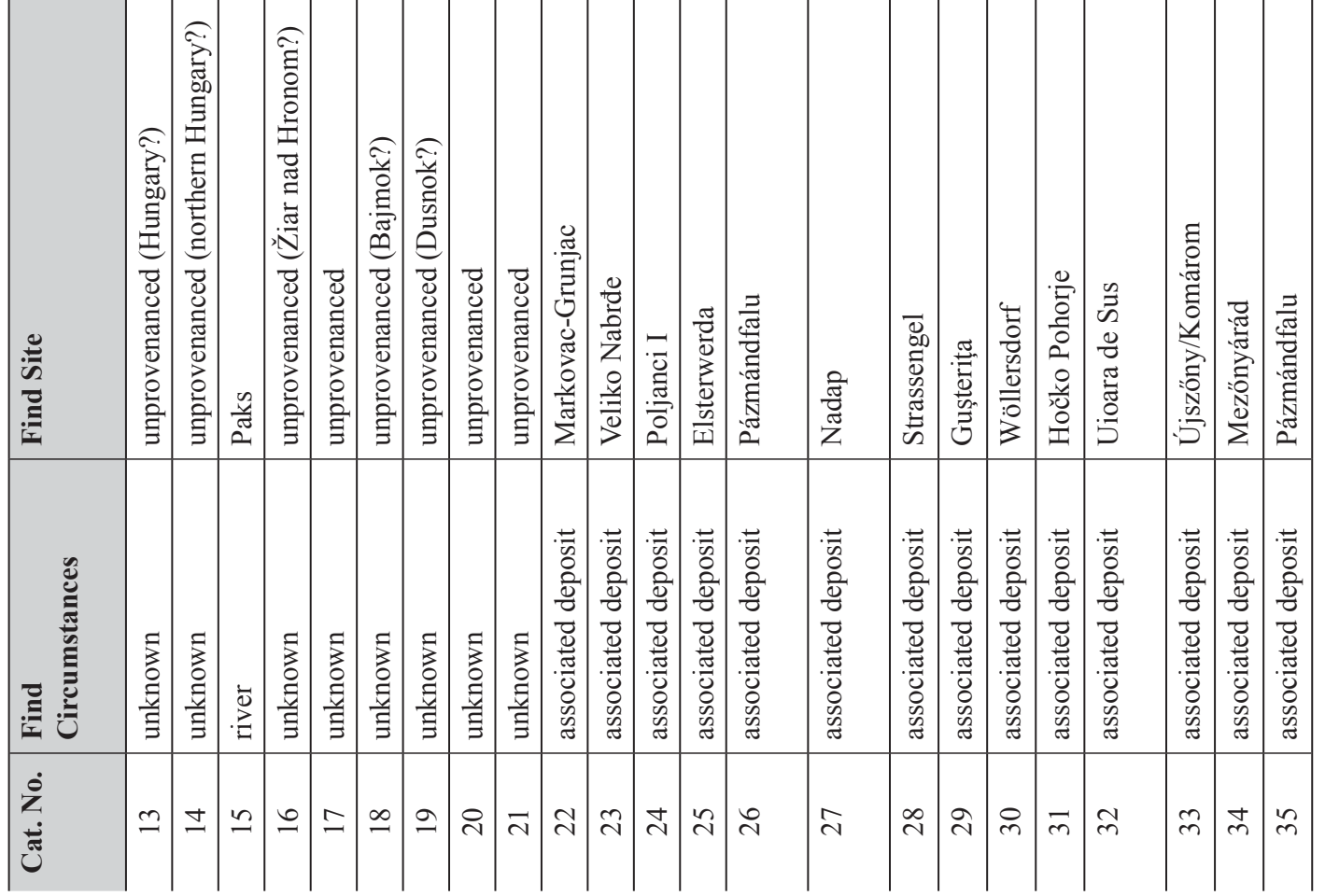




\subsubsection{Research History}

J. Hampel was the first to describe the helmet of Type Paks, which at the time was represented by only a single example. Due to a lack of similar finds, it was misidentified as a bowl. ${ }^{136}$ It was later recognised as a helmet by v. Merhart, and included as part of his group of 'decorated cap helmets', despite the fact that all other examples in this group are without knob. ${ }^{137}$ It was Hencken who provided an alternative corpus of 'cap helmets with star decoration' and added further, possibly related fragments. ${ }^{138}$ Soon after, Borchhardt discussed these helmets following the classification of v. Merhart and included in his group of 'decorated caps with knob or top' the unprovenanced helmet cat. no. 13 and the helmets from Straßengel (cat. no. 28), Szczecin-Zdroje (cat. no. 59), Fermo and Cuneo. ${ }^{139}$ The group of helmets of Type Paks was most recently expanded upon by Clausing. ${ }^{140}$ It has been during the last 15 years, however, that the number of helmets of Type Paks has significantly increased, especially in terms of complete examples, including both new finds and previously unpublished examples. These complete helmets includes those from Žiar nad Hronom, ${ }^{141}$ and from the Danube at Paks (cat. no. 15). ${ }^{142}$ The helmet from Paks represents the only known complete helmet with a reliable provenance. Two illegally found and sold helmets, presumably deriving from Bajmok and Dusnok (cat. nos. 18 and 19), were recently published by G. V. Szabó ${ }^{143}$ Two further unprovenanced helmets were sold in 2002 and again later (cat. nos. 20 and 21). ${ }^{144}$ Another helmet was sold in 2002 in Basel (cat. no. 17). ${ }^{145} \mathrm{~A}$ further helmet (or the helmet from Bajmok) was presented to the museum of Subotica, Serbia, 25 years ago. ${ }^{146}$ The current location of these five or six helmets remains unknown.

As well as the bronze sheet fragments, which were recently identified as belonging to decorated discs rather than helmets of Type Paks, further bronze sheet fragments previously associated with helmets of Type Paks were also recently excluded. ${ }^{147}$ This includes fragments from Uioara de Sus, ${ }^{148}$ Palotaboszók, ${ }^{149}$ Bizovacs, ${ }^{150}$ Bonyhád, ${ }^{151}$ Keszőhidegkut, ${ }^{152}$ Suseni ${ }^{153}$ and Guşteriţa. ${ }^{154}$ Another fragment from Uioara de Sus may, however, indeed belong to a helmet of Type Paks (inv. no. III-6003). ${ }^{155}$ The $3 \times 2.5 \mathrm{~cm}$ fragment has rivet holes parallel to the edge with a distance of $1 \mathrm{~cm}$ between each one and above the rivet holes three preserved ribs parallel to the rim. The potential knobs from helmets of Type Paks from the associated deposits from Špălnaca and Techirghiol, Romania (cat. nos. 68 and 69) ${ }^{156}$ cannot be added to the list of helmets of Type Paks due to their poor preservation, with both knobs being highly fragmented, and missing both the upper and lower end, and are therefore discussed separately in Chapter 2.1.6.

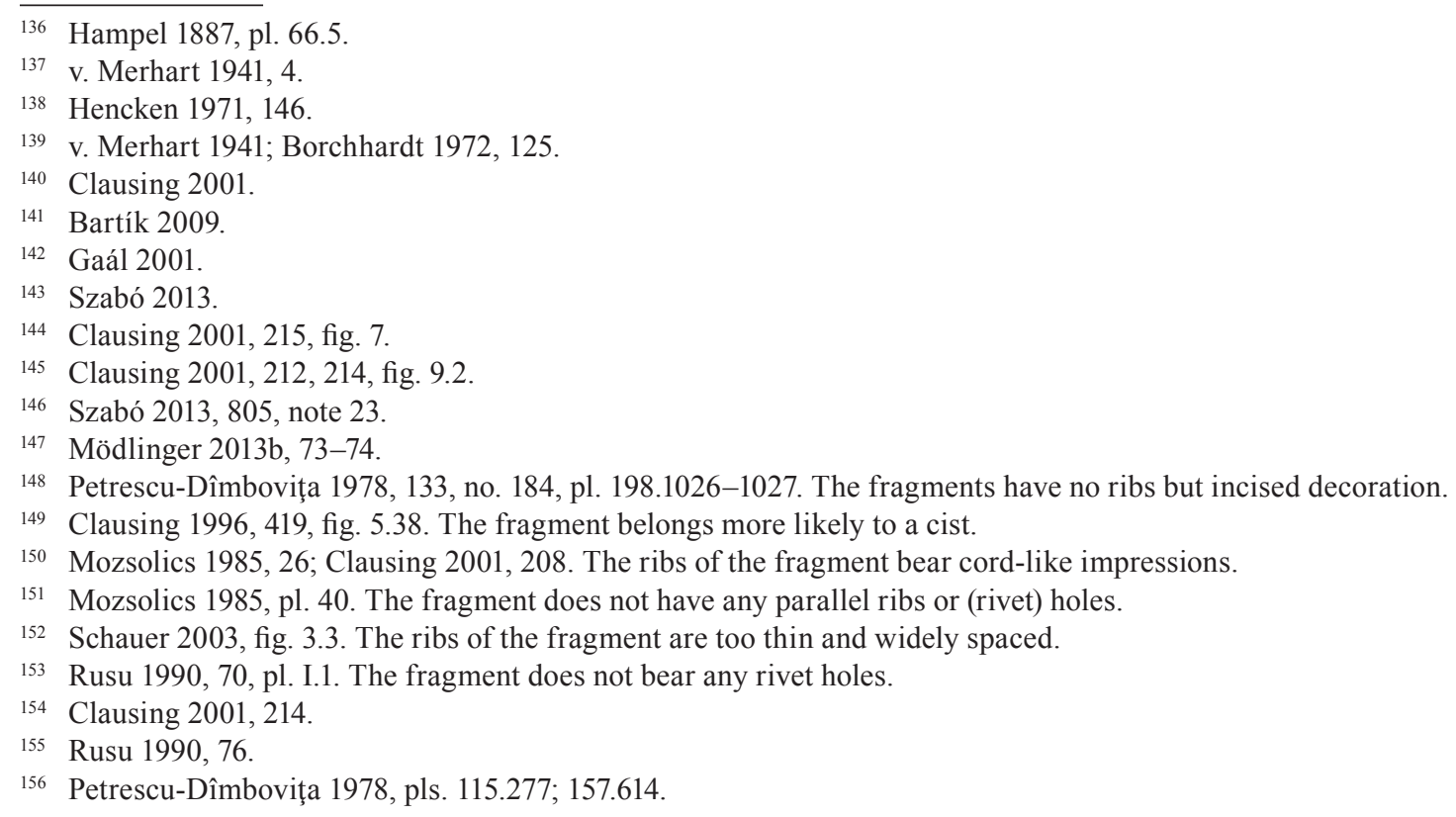




\subsubsection{Distribution and Deposition}

The helmets were deposited either complete, as single finds in rivers, or as fragments of cap or knob in associated deposits. The only complete helmet with secure find circumstances is the helmet from Paks, with the find circumstances of all other complete helmets being unknown. One unprovenanced helmet (cat. no. 21) was reputedly found together with two disc pendants, two bracelets and an arrow head. ${ }^{157}$ Due to the history of the find, however, the veracity of the association must be questioned.

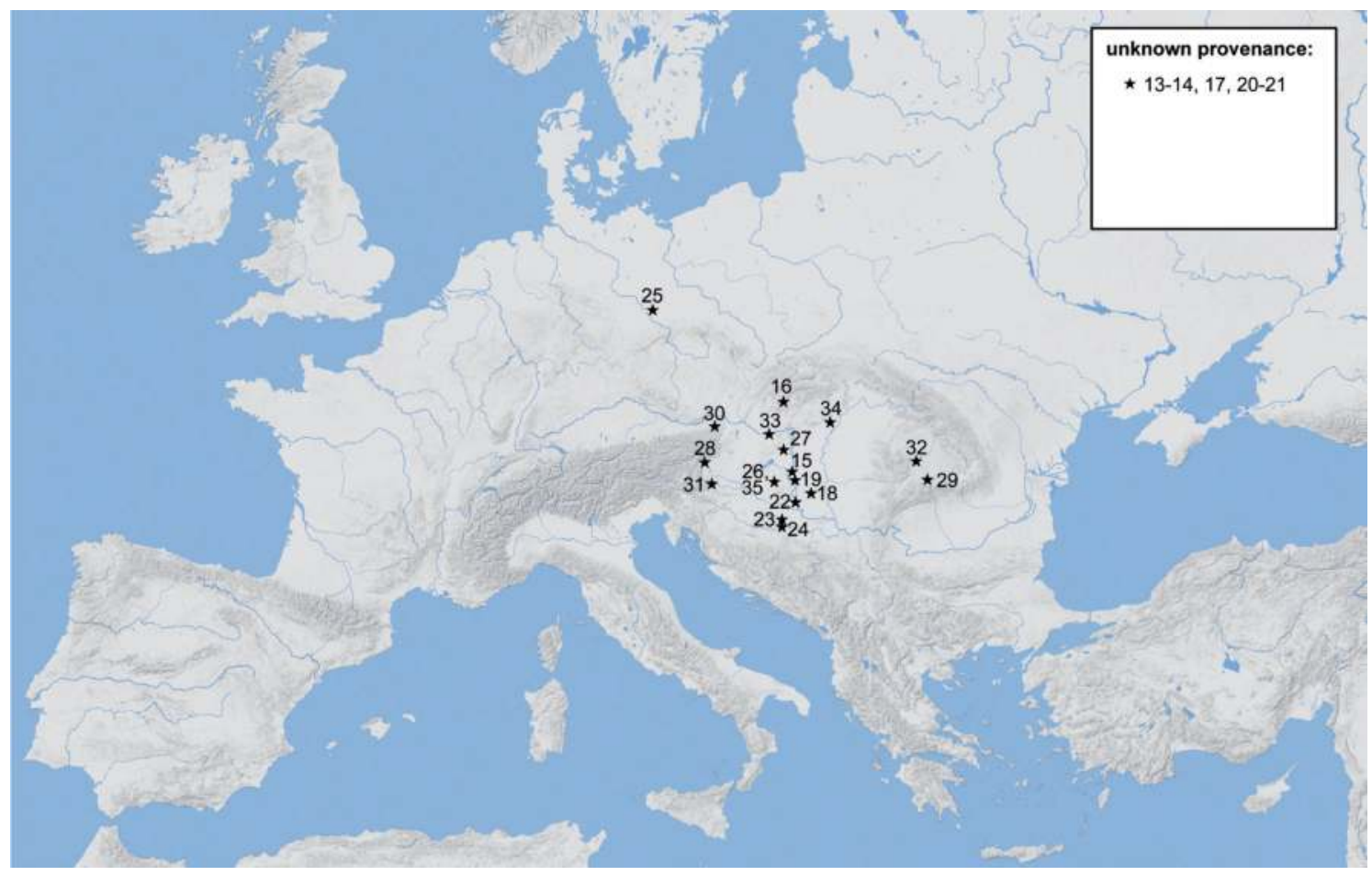

Fig. 2.9 Archaeological distribution of helmets of Type Paks: 13-14. Unprovenanced; 15. Paks; 16. Žiar nad Hronom (?); 17. Unprovenanced; 18. Bajmok (?); 19. Dusnok (?); 20-21. Unprovenanced; 22. Markovac-Grunjac; 23. Veliko Nabrđe; 24. Poljanci; 25. Elsterwerda; 26. Pázmándfalu; 27. Nadap; 28. Strassengel; 29. Guşteriţa; 30. Wöllersdorf; 31. Hočko Pohorje; 32. Uioara de Sus; 33. Újszőny/Komárom; 34. Mezőnyárád; 35. Pázmándfalu. Numbers correspond to the catalogue numbers.

The main distribution area of these helmets reaches from the Carpathian Basin until the beginning of the eastern Alps (Fig. 2.9). Associated deposits with fragments of helmets of Type Paks are known from Elsterwerda, Germany (cat. no. 25), in the north, to Guşteriţa, Romania (cat. no. 29), in the east, and from Straßengel, Austria, in the west, to Poljanci, Croatia (cat. no. 24), in the south. Two bronze sheet fragments from the Nadap associated deposit, Hungary ${ }^{158}$ also belong to helmets of Type Paks. These were placed in the same associated deposit as an older helmet of Type Oranienburg (cat. no. 9). ${ }^{159}$

\subsubsection{Chronology}

Complete helmets per se cannot be accurately dated, since their find circumstances are unknown or because they frequently occur as single finds, such as the helmet from Paks. The

\footnotetext{
157 Born - Hansen 2001, 64, fig. 58.

158 Makkay 2006, pl. 5.10-11.

159 See cat. no. 9 and Mödlinger 2013a.
} 
chronological classification is therefore based on the various associated deposits which contain fragments of helmets of Type Paks. So far, we can only assign these helmet fragments to the general group of helmets of Type Paks, rather than to any of the two specific variants, but aspects of chronological variation are at least apparent, on the basis of the occurrence of rib decoration only or ribs and star motif.

The associated deposits are dated, without exception, to the period $\mathrm{Bz} \mathrm{D}-\mathrm{Ha} \mathrm{A}$, on the basis of those from Wöllersdorf, ${ }^{160}$ Veliko Nabrđe (cat. no. 23), ${ }^{161}$ Poljanci I ${ }^{162}$ Nadap, ${ }^{163}$ and Guşteriţa, ${ }^{164}$ and to Ha A in the case of Hočko Pohorje. ${ }^{165}$ Some of these associated deposits can be narrowly associated with Ha A1, including those from Markovac-Grunjac (cat. no. 22), ${ }^{166}$ Straßengel, ${ }^{167}$ Elsterwerda, ${ }^{168}$ Mezőnyárád, ${ }^{169}$ Uioara de Sus, ${ }^{170}$ Újszőny/Komárom ${ }^{171}$ and Pázmándfalu. ${ }^{172}$

Decorated discs, such as those with star motif and their precursors, all fall within a very limited chronological horizon of $\mathrm{Bz} \mathrm{D}-\mathrm{Ha} \mathrm{A} 1$ based on these associated deposits, indicating a rapid adoption of known decorative elements, such as the ring-and-dot and circular arrangement of arcs of 'star motif'. ${ }^{173}$ The distribution of the different types of discs widens with the increasing complexity of the decoration. ${ }^{174}$ The distribution area of the discs with star motif overlaps then with the distribution for helmets of Type Paks, indicating their direct influence and rapid adaption of the motif for the helmets in Ha A1, which is confirmed by the narrow chronological range of most of the deposits to this phase.

It remains unclear why the ring-and-dot motif was not also adopted to decorate the helmets. The motif is also lacking on bronze cups, while the rib decoration of the helmets was transformed into a row of bosses on cups. It seems as if the helmets of Type Paks had largely gone out of use during Ha A2 (in so much as they are not recognised amongst the finds record for this phase). Considering the geographical distribution and chronological classification of discs, helmets and cups, the Ha A1 helmets of Type Paks seem the most likely medium by which the star motif was transmitted from the southeastern European Bz D-Ha A1 discs to the northwestern European Ha A2-Ha B1 decorated bronze cups. ${ }^{175}$

\section{Catalogue}

\section{Helmets Type Paks with Rib and Star Decoration}

Cat. no. 13. Unprovenanced (Hungary?) - almost complete helmet. Measurements: height: $13.5 \mathrm{~cm}$; diameter: $13.0 \times 20.8 \mathrm{~cm}$; weight: not possible to measure, since fixed with modern bronze sheet - Magyar Nemzeti Múzeum, inv. no. 62.1.213 - Pl. 2.13. References: Hampel 1886a, pl. LXVI.5a-b; Hampel 1887, pl. 66.5a-b; Mozsolics 1955, 37, fig. 3; Müller-Karpe 1959, 113; Kemenczei 1979, 79-80, fig. 4.5; Born - Hansen 2001, 63, fig. 56; Clausing 2001, 215; Gaál 2001, 49; Schauer 2003, 196, fig. 3.1; Mödlinger 2013b, cat. no. 50.

\footnotetext{
60 Pittioni 1954, 534; Müller-Karpe 1962a, 272.

61 Vinski-Gasparini 1973, 186.

162 Miklik-Lozuk 2009.

163 Makkay 2006; Uckelmann 2012.

164 Petrescu-Dîmboviţa 1978, 120-122.

165 Črešnar 2010, 52.

166 Jovanović 2010, 81.

167 Clausing 2001, 214.

168 Martin 2009, 120.

169 Kemenczei 1984, 51.

170 Petrescu-Dîmboviţa 1978, 132-135; Mozsolics 1985, 25.

171 Mozsolics 1985, 25.

172 Szabó 2013, 811

173 Mödlinger 2013b.

174 See Mödlinger 2013b, figs. 1, 5.

175 Martin 2009, 46; Mödlinger 2013b.
} 
The helmet was joined together with modern bronze sheets during restoration before 1954 . Today, the original helmet is riveted together with these recent metal sheets.

Cat. no. 14. Unprovenanced (Northern Hungary?) - almost complete helmet. Measurements: height: $13.1 \mathrm{~cm}$; diameter: $17.2 \times 20.9 \mathrm{~cm}$; weight: $292 \mathrm{~g}$ - Magyar Nemzeti Múzeum, inv. no. 77.4.1 - Pl. 2.14. References: Kemenczei 1979, 79-89, figs. 1-3; Mozsolics 1985, 25, 208, pl. 136.2; Born - Hansen 2001, 62, fig. 55; Clausing 2001, 215, fig. 7.1; Gaál 2001, 46-49; Mödlinger 2013b, cat. no. 51.

The helmet was bought by the Magyar Nemzeti Múzeum from a private collection in 1977, decades after its discovery. The former owner suggested a find location in the border region between Hungary and Slovakia, close to the Danube.

Cat. no. 15. Paks, kom. Tolna, Hungary - single river find (river Danube) - complete helmet. Measurements: height: $11.5 \mathrm{~cm}(\mathrm{cap}), 3.5 \mathrm{~cm}(\mathrm{knob})$; diameter: $17.0 \times 20.5 \mathrm{~cm}$; thickness: $0.3-1$ (rim); weight: 340g - Városi Múzeum Paks, inv. no. 2002.11 - Pl. 2.15. References: Clausing 2001, 215, fig. 9.1; Gaál 2001, 46-47, figs. 4-5; Mödlinger 2013b, cat. no. 52.

The helmet was found by J. Bányai amongst the sand of a popular swimming location belonging to Paks in 1999. The helmet is complete and was only slightly compressed during its recovery. A year later, the finder sold the helmet to the Városi Múzeum in Paks.

Cat. no. 16. Unprovenanced (most likely Žiar nad Hronom, okr. Žiar nad Hronom, Slovakia?) - find circumstances unknown - complete helmet. Measurements: height: $12.1 \mathrm{~cm}$ (knob: 5.5cm); diameter: $20.8 \times 18.2 \mathrm{~cm}($ knob: $12.5 \times 36.0 \mathrm{~mm})$; cheek plates: $11.0 \times 8.4 \mathrm{~cm}$; thickness: cap edge: $0.8 \mathrm{~mm}$; cheek plates: approx. $0.5 \mathrm{~mm}$; weight: cap $385 \mathrm{~g}$, cheek plates: $33.3 \mathrm{~g}$ and $39 \mathrm{~g}-$ Archeologické múzeum SNM, inv. no. AP 75.990 - Pl. 3.16. References: Bartík 2009, 37-48, figs. 1-6; Mödlinger 2013b, cat. no. 53.

The helmet was donated to the Archeologické múzeum SNM by PhDr. Jiří Janošík, CSc in 2008.

Cat. no. 17. Unprovenanced - complete helmet. Measurements: height: $19.5 \mathrm{~cm}$; max. diameter: $22.5 \mathrm{~cm}$; weight: unknown - present repository unknown; sold at the auction Cahn in Basel on 19. October 2002; formerly in private hands in North Rhine-Westphalia, Germany - Pl. 2.17. References: Clausing 2001, 212, 214-215, fig. 9.2; Cahn Auktionskatalog 2002, 64, no. 315, pl. 57.315; Mödlinger 2013b, cat. no. 54.

Cat. no. 18. Unprovenanced (Bajmok, Serbia?) - complete helmet. Measurements unknown Pl. 3.18. References: Mödlinger 2013b, 77, fig. 6.A1; Szabó 2013, 805, fig. 11.

The helmet with rib and star decoration (four ribs arranged in a star shape on the top, six ribs about the middle, and three ribs at the rim) was presented to the Municipal Museum of Subotica, Serbia, in February 2011. Another similar, or perhaps even the same, helmet had been presented to the museum some 25 years ago. ${ }^{176}$ The current location of the helmet is unknown.

Cat. no. 19. Unprovenanced (Dusnok, Hungary?) - complete helmet. Measurements unknown - Pl. 3.19. References: Mödlinger 2013b, 77-78, fig. 6.A2; Szabó 2013, 806, fig. 12.1.

The helmet was offered for sale by a person working in Dusnok, Hungary, on a dredging boat at the end of the 1990s. The helmet was sold later in Germany. ${ }^{177}$

17 Szabó 2013, 805.

177 Szabó 2013, 806. 


\section{Helmets Type Paks with Rib Decoration}

Cat. no. 20. Unprovenanced - complete helmet. Measurements: height: $18.5 \mathrm{~cm}$; diameter: 20.8 $\times 18.0 \mathrm{~cm}$; thickness: $0.5-0.8 \mathrm{~mm}$; knob: height: $5 \mathrm{~cm}$; hole in the knob: $3.2 \mathrm{~cm}$ deep; knob diameter: $1.6 \times 1.5 \mathrm{~cm}$; base diameter: $3.6 \times 3.0 \mathrm{~cm}$; helmet weight: $345 \mathrm{~g}-$ present repository unknown; Guttmann collection, inv. no. AG 246 - Pl. 3.20. References: Born - Hansen 2001, 61-65, 175, 231-235, 270, 323, figs. 178-182, pls. IX-X; Clausing 2001, 215, fig. 7.2; Schauer 2003, fig. 2; Christie's 2002; Mödlinger 2013b, cat. no. 59.

The helmet was sold at auction at Christie's in London on 6 November 2002. ${ }^{178}$

Cat. no. 21. Unprovenanced - complete helmet. Measurements: height: $16.5 \mathrm{~cm}$; diameter: $21 \times$ $16.0 \mathrm{~cm}$; thickness: $1-2 \mathrm{~mm}(\mathrm{rim})$; left cheek plate: $11.2 \times 7.4 \mathrm{~cm}$; right cheek plate: $11.4 \times 7.8 \mathrm{~cm}$; knob: height: $5 \mathrm{~cm}$; rectangular opening: $0.9 \times 1.0 \mathrm{~cm}$, deepness $5 \mathrm{~cm}$; thickness knob: on top $1.8 \mathrm{~cm}$, in the middle $1.5 \mathrm{~cm}$ and on the base $2.7 \mathrm{~cm}$; helmet weight: without cheek plates $407 \mathrm{~g}$; left cheek plate: $36 \mathrm{~g}$; right cheek plate: $40 \mathrm{~g}$; total weight: $483 \mathrm{~g}$ - present repository unknown; Guttmann collection, inv. no. AG 1126 - Pl. 3.21. References: Born - Hansen 2001, 62-66, 68, 74, 175, 235-236, 242, 270, figs. 183-191, pls. XI-XII; Clausing 2001, 215, fig. 7.3; Hermann Historica 2008; Mödlinger 2013b, cat. no. 60.

The helmet was reputedly found with a number of other objects, including two disc pendants, two bracelets and one arrow tip. ${ }^{179}$ The helmet was part of the Guttmann collection (bought in Munich in 1994) and put up for auction (Lot 4, not sold) at Christie's in London on 28 April 2004. It was later sold at Hermann Historica on 8 October 2008, ${ }^{180}$ but has recently reappeared on the art market in Vöcklabruck, Austria, at the Galerie Kunst der Antike.

\section{Fragments}

Cat. no. 22. Markovac-Grunjac, Serbia - associated deposit - fragment. Measurements: $6 \times$ 4.1cm; weight: $10.1 \mathrm{~g}$ - Gradski muzej Vršac, inv. no. 10.755 - Pl. 3.22. References: Jovanović 2010, 70, 98, pl. 59.497; Mödlinger 2013b, cat. no. 55.

The associated deposit was discovered in 1958 and consists of 1008 objects with a total weight of $19.3 \mathrm{~kg}$, which makes it the largest Bronze Age associated deposit from Serbia. Almost all objects are fragmented or represented by unsuccessful casts. Another fragment from the associated deposit is also possibly from a helmet. ${ }^{181}$ The associated deposit also contains a fragment of a greave Type Lengyeltóti (cat. no. 182). Single objects from the associated deposit have been published by various authors. ${ }^{182}$

Cat. no. 23. Veliko Nabrđe, Osječko-baranjska županija, Croatia - associated deposit fragment. Measurements: $11.5 \times 5.8 \mathrm{~cm}$; weight: $28 \mathrm{~g}$ - Arheološki muzej u Zagrebu, inv. no. 10.237 - Pl. 3.23. References: Vinski-Gasparini 1973, 186, pl. 44.2; Hansen 1994, 574, JU 315; Clausing 2001, 216, fig. 8.5, 11; Schauer 2003, fig. 3.6; Karavanić 2009, 111-118; Mödlinger 2013b, cat. no. 56 .

The associated deposit was found during field work in 1922. No further information is available. It consists of 224 bronze objects, comprising arm rings, pendants, pins, fibulae, buttons, fragments of vessels, greaves of Type Kuřim (cat. nos. 191-192), helmet and appliqués, spearheads, fragments of flange hilted swords of Type Reutlingen, sickles, socketed axes, winged axes, saws, rings, bands, wires, stabs, and rolls. ${ }^{183}$

\footnotetext{
178 Christie's 2002.

179 Born - Hansen 2001, 64, 73, fig. 58.

180 Hermann Historica 2008.

181 Jovanović 2010, pl. 59.481.

182 E.g. Vasič 1994; Harding 1995; Vasič 1999; Vasič 2003.

183 Vinski-Gasparini 1973, 186, 221.
} 
Cat. no. 24. Poljanci I, Brodsko-posavska županija, Croatia - associated deposit - fragment. Measurements: $10.5 \mathrm{~cm} \times 7.1 \mathrm{~cm}$; thickness: $0.4-0.08 \mathrm{~mm}$; weight $23.5 \mathrm{~g}-$ Brodsko Posavlje Muzej Slavonski Brod, inv. no. A-1805 - Pl. 3.24. References: Vinski-Gasparini 1973, 87, 183, 218, pl. 48.31; Clausing 2001, 210, 216, fig. 8.9; Clausing 2003, fig. 65.50; Schauer 2003, fig. 3.8; Karavanić 2009, 101, no. 39; 116-118; Miklik-Lozuk 2009, 69, cat. no. 88; Mödlinger 2013b, cat. no. 57.

The associated deposit was found in 1958 during ploughing and consists of 178 bronze objects stored in a ceramic vessel. The associated deposit comprised arm rings, neck rings, fibulae, decorated discs, buttons, pendants, a small cow figurine made of bronze, pins, fragments of flange hilted swords, knives, winged axes, chisels, sickles as well as fragments of a helmet and the fragment of a greave (cat. no. 163) ${ }^{184}$ Vinski-Gasparini published only 55 objects from the associated deposit. ${ }^{185}$

Cat. no. 25. Elsterwerda, Lkr. Elbe-Elster, Brandenburg, Germany - associated deposit fragment. Measurements: $5.9 \times 3.75 \mathrm{~cm}$; thickness: $0.25-0.3 \mathrm{~mm}$; weight: unknown - Landesmuseum Sachsen-Anhalt, Halle, inv. no. 10.727 - Pl. 3.25. References: Bornschein - Gandert 1929, 145-146; Sprockhoff 1937, 8, fig. 3; Agde 1939, 170, fig. 4; Grünberg 1943, 78, 91; v. Brunn 1968, 143, 156, 317, no. 57; Hansen 1994; Clausing 2001, 208-216; Martin 2009, 99, no. 133d, pl. 41.133d; Mörtz 2011a; Mörtz 2011b, 102; Mödlinger 2013b, cat. no. 58.

The associated deposit was found around 1887 in the centre of a small hill in a ceramic vessel. The bronzes have a total weight of $3.2 \mathrm{~kg}$. As well as the helmet fragment, the associated deposit consists of possible fragments of a situla of Type Hajdúböszörmény, four fragments of sword blade(s), ${ }^{186}$ two fragments of spearhead, 53 fragments of sickles, 15 fragments of winged and knobed axes, six fragments of knives (one modified to a punch), six fragments of saws, 14 fragments of bracelets, a fragment of a pin and a spiral, two buttons, 32 fragments of rings, eight further fragments of jewellery, two fragments of ingot (three others which were modified to chisels and punch), wire, bronze sheet fragments, 64 fragments of casting cake and several other unidentified fragments. ${ }^{187}$

Cat. no. 26. Pázmándfalu, Hungary - associated deposit I - four fragments. Measurements unknown. References: Mödlinger 2013b, 77, fig. 6.A2; Szabó 2013, 811; Szabó 2016, 182-184, fig. 18.

For description of the associated deposit, see cat. no. 131.

Cat. no. 27. Nadap, Kom. Fehér, Hungary - associated deposit - two fragments. Measurements: $9.1 \times 8.7 \mathrm{~cm} ; 7.7 \times 5.9 \mathrm{~cm}-$ Szent István Király Múzeum Székesfehérvár, inv. no. unknown - Pl. 3.27. References: Petres 1983, 61-62, fig. 10; Makkay 2006, 7, pl. V.10-11; Uckelmann 2012.

For description of the associated deposit, see cat. no. 9.

Knobs

Cat. no. 28. Straßengel, Styria, Austria - associated deposit - fragment of a knob. Measurements: height: $4.4 \mathrm{~cm}$; diameter: $1.4 \mathrm{~cm}$ (knob), $2.8 \mathrm{~cm}$ (base); weight: $63.2 \mathrm{~g}$ - Universalmuseum Joanneum Graz, inv. no. 7219 - Pl. 4.28. References: Pittioni 1954, 517; Müller-Karpe 1959, 113, note 5, 277, pl. 126.A1; Hencken 1971, 155, fig. 122; Primas 1986, 91-92, no. 527; Hansen 1994, 526, A 498; Clausing 2001, 214-215; Gleirscher 2007, 48-53, fig. 4.4; Mödlinger 2013b, cat. no. 61.

\footnotetext{
184 Miklik-Lozuk 2009, 45.

185 Vinski-Gasparini 1973.

186 Wüstemann 2004, nos. 628-629, 629 A, 655.

187 After Martin 2009, 99, no. 133.
} 
The associated deposit was found in 1891 in two ceramic vessels. As well as the knob, the initial contents comprised a fragment of an axe, ${ }^{188}$ sword fragments, fragments of spearhead(s), and knife fragments, ${ }^{189}$ as well as fragments of arm rings, bracelets, bronze sheets, and a cast handle. Further finds were also later brought to the museum, including sickles, ${ }^{190}$ another sword fragment, ${ }^{191}$ a fragment of a spearhead, another arm ring fragment, and a cast disc with loops on the back.

Cat. no. 29. Guşterița (Szent Erzsébet/Hammersdorf), Romania - associated deposit - fragment of a knob. Measurements: height: $4.1 \mathrm{~cm}$; diameter knob: $1.96 \mathrm{~cm}$; shaft lenght: $2.81 \mathrm{~cm}$; diameter hole in knob: $8 \mathrm{~mm}$; diameter base: $2.0 \times 1.8 \mathrm{~cm}$; diameter hole on the base: $4.5 \mathrm{~mm}$; weight: unknown - Muzeul National Brukenthal, archaeological collection, inv. no. 546 (old and new) - Pl. 4.29. References: Reissenberger 1872; Gooss 1876, 226; Hampel 1886a, 56; Hampel 1892, 143-155; v. Merhart 1941, 12, note 15, no. 10; Holste 1951, 24-27; Mozsolics 1955, 39; Petrescu-Dîmboviţa 1960, 148; Holste 1962, pl. 8; Petrescu-Dîmboviţa 1978, 120-122, no. 141, pl. 115.277; Bader 1983, 38, no. 22; Schauer 1988, 184; Rusu 1990, 70-71, pl. V.5; Bader 1991, 92, no. 190; Clausing 2001, 215, fig. 10; Gleirscher 2007, 48-53, fig. 4.2; Soroçeanu 2008, 85, no. 33-34; Mödlinger 2013b, cat. no. 62.

G. v. Merhart dated the associated deposit on the basis of similar early Hungarian associated deposits of Bz D-Ha A. G. Kossack placed the associated deposit more narrowly in Ha A1, and Mozsolics, on the basis of later finds at the Magyar Nemzeti Múzeum, to the transitionary horizon between Ha A and Ha B. ${ }^{192}$ M. Petrescu-Dîmboviţa notes some older Bz D objects in the associated deposit, and assigns the deposition of the associated deposit to Ha A, as does MüllerKarpe.${ }^{193}$ M. Rusu placed the associated deposit in Ha A1, as does Schauer. ${ }^{194}$ M. Gimbutas dated it to Bz D. ${ }^{195}$ It is clear that the associated deposit can only be dated accurate if all various objects in the different museums were studied systematically.

\section{Cheek Plates}

Cat. no. 30. Wöllersdorf, Lower Austria, Austria - associated deposit - fragments. Measurements: $8.5 \times 5.2 \mathrm{~cm}$; thickness: $0.7-0.8 \mathrm{~mm}$; weight: $28 \mathrm{~g}-$ Naturhistorisches Museum, Vienna, inv. no. 37.404 - Pl. 4.30. References: Szombathy 1905, 42, pl. 1.38; Pittioni 1954, 411-414, figs. 287, 417, 814, note 686; Müller-Karpe 1959, 108-110, 113-114, 226, pls. 135.B, 136; MüllerKarpe 1962a, 272; Hencken 1971, 179, fig. 146; Borchardt 1972, 44, fig. 6.A3; Primas 1986, no. 499; Bartík 2009, 44; Mödlinger 2013b, cat. no. 63.

The associated deposit was found before 1905. As well as the cheek plate, the associated deposit comprises a fragment of a knife, two bronze sheets, a median-winged axe, a knobbed axe, a fragment of another axe, three fragments of sword blade(s), two pin fragments, one fragment of an arm ring, two cast discs, a sheet buckle, a decorated bronze sheet, fragments of twisted neck rings, a bronze bar and 14 sickles. The cheek plate survives only as a fragment of its lower end. In the central area it is slightly raised. Around the flattened rim there is a row of holes to hold the organic lining. A wire ring, still attached in the hole at the end, indicates that the cheek plate could have been fixed with the second cheek plate right under the chin.

Cat. no. 31. Hočko Pohorje, (Maribor), Slovenia - associated deposit - fragment. Measurements: $3.9 \times 3 \mathrm{~cm}$; weight: $3.5 \mathrm{~g}$ - Pokrajinski muzej Maribor, inv. no. 2146 - Pl. 4.31. Referenc-

\footnotetext{
188 Mayer 1977, no. 1113.

189 Ř́hovský 1972, nos. 43, 292.

190 Primas 1986, nos. 479, 492, 527.

191 Schauer 1971, no. 598 .

192 v. Merhart 1941, 13; Kossack 1954, 17; Mozsolics 1955, 46.

193 Petrescu-Dîmboviţa 1960, 148; Müller-Karpe 1962a, 271.

194 Rusu 1963, 184; Schauer 1988, 184.

195 Gimbutas 1965, 328.
} 
es: Baš 1933, 37; Smodič 1955, 92; Müller-Karpe 1959, 279; Pahič 1962, 189, 193; Pahič 1975, 330; Gabrovec 1983, 75; Hansen 1994, 564, JU 96; Kajzer 1995, 177-196; Šinkovec 1995, 178 [no. 13], pls. 83.168, 156.5; Črešnar 2010, 52; Mörtz 2011a, 371; Mödlinger 2013b, cat. no. 64.

The associated deposit was discovered in 1932 during field work. More than $12 \mathrm{~kg}$ of the associated deposit were taken to a smelting company, and only $4 \mathrm{~kg}$ now survive. Since inventory numbers were not immediately allocated by the museum, the certainty of which finds belong to the associated deposit is not entirely clear. Presently, the associated deposit is divided into three association groups, represented by those objects of certain association, those of probable association, and those recently attributed to the associated deposit.

Cat. no. 32. Uioara de Sus (Felsőmarosújvár), jud. Alba, Romania - associated deposit fragments of two cheek plates. Measurements: ca. $3.3 \times 3.6 \mathrm{~cm}$ and $6.0 \times 4.2 \mathrm{~cm}-$ Muzeul de istorie Cluj, inv. no. III 6005 and III 5319 - Pl. 4.32. References: Petrescu-Dîmboviţa 1960; Rusu 1963, 184-187; Hencken 1971, 180, fig. 148a-b; Petrescu-Dîmboviţa 1978, 132-135, pl. 198.1025, 1030; Mozsolics 1985, 25; Rusu 1990, 76; Schauer 2003, 197, fig. 3.5-6; Mödlinger 2013b, cat. no. 65 .

The associated deposit was found in 1909 during excavations after an axe had appeared during ploughing. The associated deposit weighed some 1.1 tons, and consisted of about 5812 objects buried in a deep pit some $1.2 \mathrm{~m}$ deep and with a diameter of $1.5 \mathrm{~m}$. After the excavation, further pieces of rough bronze, as well as a piece of pure tin, were also found. ${ }^{196}$ The associated deposit was bought by the Muzeul de istorie Cluj, though some objects from the associated deposit now also belong to the museum in Gothenburg. Petrescu-Dîmboviţa lists nine fragments of helmets and seven cuirass fragments. ${ }^{197} \mathrm{M}$. Rusu notes that three knobs (?), one cylindrical, one tubular and one with a ribbed cross section (inv. no. III 6158, III 6154 and III 6178), are part of the deposit. ${ }^{198}$ However, these knobs do not look like other knobs known from helmets, which are much smaller. Here, only the fragments of the two cheek plates are considered as coming from a helmet.

Cat. no. 33. Újszőny/Komárom, kom. Komárom-Esztergom, Hungary - associated deposit fragment. Measurements and weight unknown - Magyar Nemzeti Múzeum, Budapest, inv. no. 64/1885/1-36; the cheek plate fragment cannot be found - Pl. 4.33. References: Hampel 1886b, pl. CXXV.25, 29; Hampel 1887, pl. CXXV.47; Lindgren 1938, note 26; v. Brunn 1954, 293, note 24; Schauer 1975, 310; Müller-Karpe 1980, pl. 376.B; Peschel 1984, 84; Mozsolics 1985, 25, 207; Patay 1990, 52, no. 74; Hansen 1994, 556, H 746.

The associated deposit was bought from a merchant in 1885, saying the find location was Újszőny. Hampel mentioned the find location might have actually been Bánhida or the surrounding of Tata. ${ }^{199}$ Today, the associated deposit contains fragments of a cup of Type Blatnica, fragments of another cup of unknown type, two fragments of knobbed axes, one sickle and 13 further sickle fragments, two fragments of sword blade(s), a fragment of a cheek plate, a hilt from a razor, massive open arm ring, broad arm ring with $\mathrm{C}$-shaped cross section, one fragment of an arm ring with torsion, wire spiral, rings, three cast tutuli, seven different phalerae, five different buttons, two bronze sheet fragments, bronze stick and five unidentified bronze fragments.

Cat. no. 34. Mezőnyárád, kom. Borsod-Abaúj-Zemplén, Hungary - associated deposit - one almost complete cheek plate. Measurements: $7.9 \times 10.5 \mathrm{~cm}$; weight unknown - Herman Ottó Muzeum Miskolc, inv. no. 74.38.1 (not to be found in the museum) - Pl. 4.34. References: Kemenczei 1979, 51, 83, note 14; Kemenczei 1984, 149, no. 20; Mozsolics 1985, 149-150; Patay

\footnotetext{
196 Petrescu-Dîmboviţa 1978, 132.

197 Petrescu-Dîmboviţa 1978, 133: nine fragments of helmet (pl. 198.1023-1030) and seven fragments of cuirass (pl. 198.1031-1033). See Chapter 3, p. 171.

198 Rusu 1990, 76, pl. II.2-3.

199 Hampel 1886b; Hampel 1887.
} 
1990, 19, no. 4; Hansen 1994, 545, H 426; Hellebrandt 1999/2000; Born - Hansen 2001, 64, fig. 57; Vachta 2008, 123, list V.1.5, no. 9; Mödlinger 2013b, cat. no. 66.

The associated deposit consists of 56 pieces, comprising a vessel with triangular attachments, two cups of Type Blatnice, one vessel, nine spearheads, two arm spirals, eight bracelets, two fragmented phalerae, 33 spirals, a necklace, and a single cheek plate.

Cat. no. 35. Pázmándfalu, Hungary - associated deposit I - fragmented. Measurements unknown. References: Mödlinger 2013b, 77, fig. 6.A2; Szabó 2013, 811; Szabó 2016, 182-184, fig. 18.

For description of the associated deposit, see cat. no. 131.

\subsubsection{Helmets of Type Nagytétény}

The helmets of Type Nagytétény bear a small, solid knob on the cap. The knobs rise from a base in the shape of a disc. The shape of those knobs which are plain and undecorated resembles that on helmets of Type Pişcolt, though smaller. Without the application of radiography, we cannot say if the knob was cast on, and then additionally fixed with the lining disc, or if the knob was cast separately with a 'rivet' at the base, which then passed through a small central hole in the cap and was fixed with a lining disc.

The hemispherical cap of these helmets is thinner at the centre, with a maximum thickness of just $0.2-0.4 \mathrm{~mm}$ (e.g. cat.no. 38), and gets thicker toward the rim, with a thickness of $2-2.5 \mathrm{~mm}$ (e.g. cat. no. 39). These helmets weigh less than a third of the average weight of the helmets of Type Pişcolt.

The helmet from Nagytétény (cat. no. 37) has 25 rivet holes running along the edge, each with a diameter of $0.4-0.6 \mathrm{~cm}$, punched from the outside to the inside. On the inside of the helmets from Batina (cat. no. 36), and the two unprovenanced helmets (cat. nos. 39 and 40), traces of hammering are clearly visible. ${ }^{200}$ Inside one of the unprovenanced helmets (cat. no. 40), vertical radial traces are visible on the upper area, and horizontal traces on the lower area, and again vertical traces close to the rim. The helmet from Brodi/Termopil (cat. no. 38) has 14 rivet holes along the edge. The rivet holes were punched through from the inside to the outside, while the cap was placed on a small ring, as indicated by the round impression all around the rivet holes. On the outside of the helmet, all along the rim and above the rivet holes, the corrosion differs, indicating the application of an organic lining, which was bent from the inside to the outside and fixed with rivets. Hammering traces parallel to the rim are visible all over the inner surface. The edge is thicker than the cap and flattened, so it bends slightly inwards. The helmet from the Römisch-Germanisches Zentralmuseum Mainz (cat. no. 39) has 17 rivet holes with a diameter of 4-5mm, which were applied from the inside to the outside. The organic filling of the helmet was folded on to the outside to a height of about $1.5 \mathrm{~cm}$, as visible from the different corrosion products above the rim on the outside of the cap. During restoration, around the rivet holes the impressions left by the lining discs for the rivets were just possible to discern. No rivets or lining discs are now preserved. The outside of the helmet is covered with vertical traces of polishing. One of the unprovenanced helmets (cat. no. 40) has a row of 27 rivet holes, with a diameter of $0.4-0.6 \mathrm{~cm}$, running parallel to the rim. The rivet holes were punched through from the outside to the inside of the helmet, as indicated by the supplanted sheet metal. The patina of the cap indicates that the inner lining of the helmet was fixed by means of the rivets on the outside as well, reaching up to a height of $2.2-2.5 \mathrm{~cm}$ above the rim. While attaching the knob to the cap, the metal sheet was slightly deformed. On one side, the knob bears a casting failure. On the inner side of the helmet, a $2.4 \times 2.5 \mathrm{~cm}$ lining disc with a centrally visible flat-headed rivet supports the attachment of the knob. ${ }^{201}$

200 Clausing 2001, fig. 2; Clausing 2005, 31-38, figs. 1-5.

201 Clausing 2005, 31-38, figs. 1-5. 


\subsubsection{Research History}

Hencken included in his group of 'cap helmets with cast knobs' the helmets from Cuneo, Veji, Batina, and Nagytétény. ${ }^{202}$ Schauer used the same grouping but excluded without explanation the helmet from Cuneo, and added the fragment of a knob from Škocjan. ${ }^{203}$ Borchhardt included in his group of schlichte Kappen mit Knauf only the helmets from Nagytétény and Batina. ${ }^{204}$ Based on the three new finds, comprising the possible 'Hungary' helmet and the one from the Ukraine, this helmet type can now be characterised more precisely. The decorated helmets from Cuneo and Veji have been excluded because of their decoration, and the different dimensions (such as thickness) and profile, of both cap and knob. They are associated with more recent Iron Age types, even though on the helmet from Cuneo the method of joining cap and knob is the same as on the helmets of Type Nagytétény. Presently, five helmets of Type Nagytétény are known (Tab. 2.4).

\begin{tabular}{|c|c|c|c|c|c|c|c|c|c|}
\hline $\begin{array}{l}\text { Cat. } \\
\text { No. }\end{array}$ & $\begin{array}{l}\text { Find } \\
\text { Circumstances }\end{array}$ & Find Site & State & $\begin{array}{l}\text { Condi- } \\
\text { tion }\end{array}$ & $\begin{array}{l}\text { High } \\
\text { Cap } \\
\text { (cm) }\end{array}$ & $\begin{array}{l}\text { High } \\
\text { Knob } \\
(\mathrm{cm})\end{array}$ & Dm (cm) & $\begin{array}{c}\text { Thickness } \\
\text { Cap/Rim } \\
(\mathrm{mm})\end{array}$ & $\begin{array}{c}\text { Weight } \\
\text { (g) }\end{array}$ \\
\hline 36 & $\begin{array}{l}\text { associated } \\
\text { deposit (?) }\end{array}$ & $\begin{array}{l}\text { unprovenanced } \\
\text { (Batina?) }\end{array}$ & - & $\begin{array}{l}\text { almost } \\
\text { complete }\end{array}$ & 15.4 & 3 & $\begin{array}{c}18.8 \times \\
23.2\end{array}$ & - & 643 \\
\hline 37 & river & Nagytétény & HU & complete & 12.5 & 3.5 & $\begin{array}{c}20.4 \times \\
22.3\end{array}$ & $0.2 / 1.2$ & 402 \\
\hline 38 & unknown & Brodi/Ternopil & UA & complete & 14 & 3 & $20 \times 21.6$ & - & - \\
\hline 39 & unknown & unprovenanced & - & complete & 13.3 & 3.5 & $22 \times 22.7$ & $0.22 / 4$ & 530 \\
\hline 40 & unknown & unprovenanced & - & complete & c. 14 & 4.1 & $\begin{array}{c}21.8 \times \\
23.5\end{array}$ & $-/ 2-2.5$ & - \\
\hline
\end{tabular}

Tab. 2.4 Helmets of Type Nagytétény.

\subsubsection{Distribution and Deposition}

Since four out of the five helmets are unprovenanced or have unsecure find histories (cat. nos. 36, 38-40), little can be said regarding the depositional norms for this type of helmet. We know only that the helmet from Nagytétény was dredged with a 'rapier Type E' from the Danube in 1952. ${ }^{205}$ This helmet and the unprovenanced helmet said to be from 'Batina' (cat. no. 36), point to a distribution in the Carpathian Basin, and extends as far as northwestern Ukraine (Fig. 2.10). The helmet from Brodi/Termopil was said to have been discovered as a single find, though as the finder was apparently in a hurry, it is possible they would have missed any other associated finds. The extent to which this helmet type was originally distributed will only be revealed as further finds are made.

\subsubsection{Chronology}

Due to their unknown or uncertain find circumstances, the helmet from Batina and the two unprovenanced helmets cannot be provided with a secure chronological association. J. Harmatta dates the helmet from Batina to late Ha B, and v. Merhart dates it to early Ha C. ${ }^{206}$ Mozsolics notes that the helmet from Batina is older than that from Haydúböszörmény, ${ }^{207}$ and dates the

\footnotetext{
202 Hencken 1971.

203 Schauer 1988, 182.

204 Borchhardt 1972, 121-124.

205 Kemenczei 1988, 42, no. 173.

206 Mozsolics 1955, 35.

207 Foltiny 1961, 187.
} 


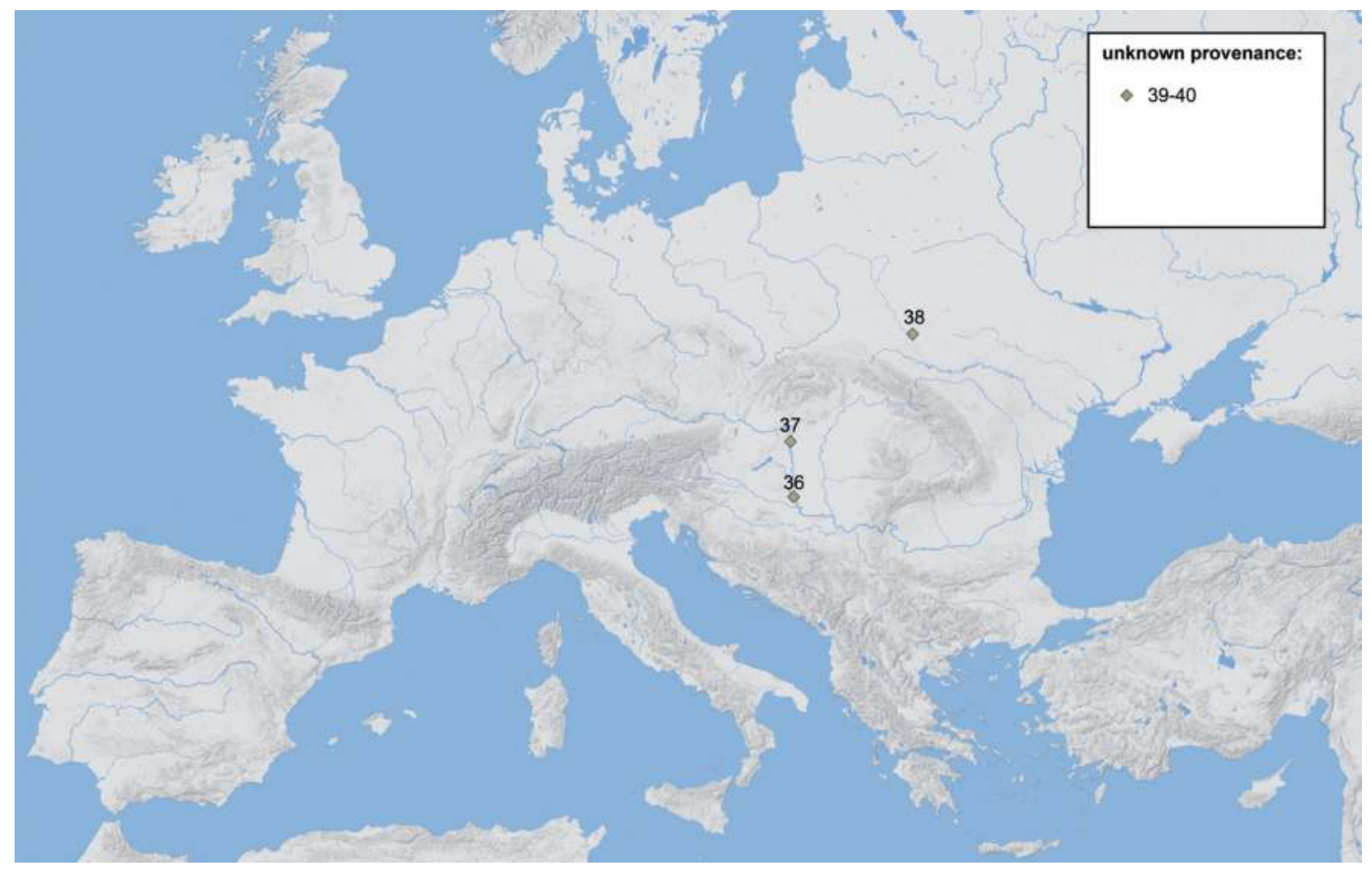

Fig. 2.10 Archaeological distribution of helmets of Type Nagytétény: 36. Unprovenanced, probably Batina; 37. Nagytétény; 38. Brody/Ternopil; 39-40. Unprovenanced. Numbers correspond to the catalogue numbers.

helmet from Nagytétény to Ha B. ${ }^{208}$ Clausing instead dates the helmet to the $9^{\text {th }}-8^{\text {th }}$ century BC. ${ }^{209}$ According to J. Šimić, the helmet belongs to the older Dalj group. ${ }^{210}$ The two unprovenanced helmets (cat. nos. 39 and 40) are also dated by Clausing to the $9^{\text {th }}$ century BC. ${ }^{211}$

However, if the helmet from Nagytéteny is indeed an associated find, and can be related to the rapier with which it was dredged in 1952, then the consequences for its chronology are significant. The rapier belongs to those of Type $\mathrm{E}$ in the classification of T. Kemenczei. ${ }^{212}$ These rapiers are closely related to the late Middle Bronze Age or early Urnfield period rapiers of types $\mathrm{B}$ and $\mathrm{C}(\mathrm{Bz} \mathrm{C} 2 / \mathrm{D})$, which would indicate that they were possibly contemporary with both helmets of Type Oranienburg and helmets of Type Paks. Based on stylistic similarity, helmets of Type Nagytétény more closely resemble a smaller, lighter version of helmets of Type Pişcolt with a rounder cap. The large number of rivet holes and the thin cap, common to both helmets of Type Paks and most of the helmets of Type Oranienburg, instead point to influences from an older type than that of helmets of Type Pişcolt. We might therefore posit a development from helmets of Type Oranienburg to helmets of Type Nagytétény, dated to Bz D/Ha A, and then to helmets of Type Pişcolt.

\section{Catalogue}

Cat. no. 36. Unprovenanced (probably Batina, Osječko-baranjska županija, Croatia (former Kiskőszeg, Hungary) - associated deposit (?) - complete helmet. Measurements: height: $18.4 \mathrm{~cm}$ (helmet), $3 \mathrm{~cm}$ (knob); diameter: $18.8 \times 23.2 \mathrm{~cm}$; weight: $643 \mathrm{~g}$ - Römisch-Germanisches Zentralmuseum Mainz, inv. no. O.1756 - Pl. 5.36. References: Reinecke 1907, 42, fig. 6h; v.

\footnotetext{
208 Mozsolics 1955, 37.

209 Clausing 2005, 34.

210 Šimić 2008,66 , fig $11 ; 179$.

211 Clausing 2005, 34, 38.

212 Kemenczei 1988, 42, no. 173.
} 
Merhart 1941, 5, fig. 2.2; Harmatta 1948, 109-111; Mozsolics 1955, 35, fig. 1; Foltiny 1961, 178, 187, pl. 71.1; Hencken 1971, 158-159, fig. 120a-e; Schauer 1988, 182, note 12, fig. 3; 189, note 65; Egg - Waurick 1990, 41, no. 7.7; Clausing 2001, 206-207, fig. 4.2; Clausing 2005, 34, 38; Bader 2008, 179, cat. no. 50.

In 1910, after being found during work in a vineyard in the north of Batina/Kisköszeg, the helmet was bought by the collector J. Frey. As well as a number of other objects, he also mentions fragments of two further helmets but in poor condition, so does not purchase them. ${ }^{213}$ The location of these possible helmet fragments is unknown. E. Foltiny provides a somewhat different description: the Römisch-Germanisches Zentralmuseum Mainz bought on May 27 in 1902 several bronzes from the merchant Fejér, Budapest, which originate from the former Komitat Bács-Bodrog and supposedly belonged together. ${ }^{214}$ Besides several rings, a spiral, fibula, and 12 bronze sheet discs, the helmet was also mentioned. E. Foltiny concluded that the find spot Batina is uncertain and the objects were recovered from several different places in the former Komitat Bács-Bodrog and the Komitat Liptau. ${ }^{215} \mathrm{He}$ named seven museums keeping finds from Batina, comprising Vienna, Budapest, Berlin, Sombor, Subotica, Keszthely and Pécs, and suggests that there might have been more. Since the finds associated with the deposit from Batina in the Natural History Museum in Vienna range from the Neolithic to the Roman Period, a single associated deposit seems extremely unlikely.

Unfortunately, the helmet from Batina was damaged during the Second World War and had to be partly restored. As a consequence, the original weight of the helmet might have been higher. Inside the helmet, primarily close to the rim, marks from a tool with sharp edges are visible.

Cat. no. 37. Nagytétény, kom. Budapest, Hungary - river find (river Danube) - complete helmet. Measurements: height: $16.5 \mathrm{~cm}$ (cap); $3.5 \mathrm{~cm}$ (knob); diameter: $20.4 \times 22.3 \mathrm{~cm}$ (cap), $2.1 \mathrm{~cm}$ (knob); thickness: 1-1.2mm (rim), 0.2mm (cap); weight: $402 \mathrm{~g}$ - Magyar Nemzeti Múzeum, inv. no. 81/1952/1 (52.81.1) - Pl. 5.37. References: Mozsolics 1955, 36, fig. 2; Hencken 1971, 149, fig. 117a-b; Borchhardt 1972, 122, fig. 15; Mozsolics 1985, 25, 155, pl. 136.3; Schauer 1988, 189, note 66; Clausing 2001, 207, fig. 4.1; Clausing 2005, 34, 38.

The helmet was dredged with a 'rapier Type E' from the Danube in 1952. ${ }^{216}$

Cat. no. 38. Brody/Ternopil, obl. Ternopil, Ukraine - single find (?) - complete helmet. Measurements: height: $14 \mathrm{~cm}$; knob: height: $3 \mathrm{~cm}$; diameter: $20 \times 21.6 \mathrm{~cm}-$ private collection Pl. 5.38. References: unpublished.

The find circumstances, including the exact location, are unknown. It was said to have been found in the forest near to Brody/Ternopil, Ukraine, close to a river, at a depth of c. $80-100 \mathrm{~cm}$, as a single find. The person who found the helmet was 'in a hurry', and did not observe any other bronzes together with the helmet. ${ }^{217}$ The helmet appeared on a Ukrainian internet forum at the end of 2013 and attempts were made to sell it in November 28, 2013, at Violity Auctions. However, the seller broke the auction guidelines, and the sale was closed. The current location of the helmet is unknown.

Cat. no. 39. Unprovenanced - complete helmet. Measurements: height: $16.8 \mathrm{~cm}$; diameter: $22 \times$ $22.7 \mathrm{~cm}$; thickness $0.22-4 \mathrm{~mm}$; knob: height: $3.5 \mathrm{~cm}$, attached with rivets; diameter of the pommel of the knob: $2.24 \mathrm{~cm}$; diameter knob disc: $4.3 \times 4.6 \mathrm{~cm}$; diameter lining disc: $3.2 \times 3.5 \mathrm{~cm}$; weight: 530g - Römisch-Germanisches Zentralmuseum Mainz, inv. no. O.42514 - Pl. 5.39. References: Clausing 2001, 199-200, figs. 1-3; Clausing 2005, 34, 38.

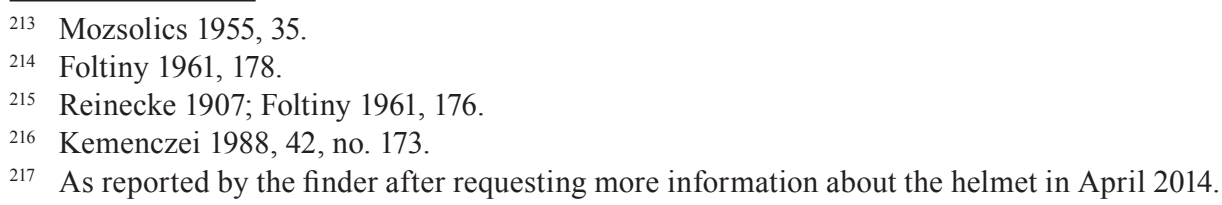


The find circumstances and find location are unknown. The helmet was bought by the museum before 2001.

Cat. no. 40. Unprovenanced - complete helmet. Measurements: height: 18.7 or $17.3 \mathrm{~cm}$; diameter cap: $21.8 \times 23.5 \mathrm{~cm}$; thickness: $2 \mathrm{~mm}$, on the rim $2.3 \times 2.5 \mathrm{~cm}$; knob: height: c. $4.3 \mathrm{~cm}$; diameter: base: $3.6 \mathrm{~cm}$; shaft: $1.1 \mathrm{~cm}$; pommel: $2.4 \mathrm{~cm}$; weight: unknown - private collection - Pl. 5.40 . References: Clausing 2005, 31-38, figs. 1-5.

The find circumstances and find location are unknown. The helmet was sold at an auction of the Jean-David Cahn AG in Basel before 2005 and again at another auction of the Jean-David Cahn AG in Basel on September 16, 2010, listed as no. 311, and noted as coming from 'northern Europe'.

\subsubsection{Helmets of Type Pişcolt}

Helmets Type Pişcolt are rather large and, in proportion to their width, relatively high. Their height ranges from $18-27.5 \mathrm{~cm}$ and the diameter at the rim from $19-23 \mathrm{~cm}$. The weight ranges from 1032-1478g, differing significantly from the much lighter helmets of Class I (see Fig. 2.2), and especially from helmets of Type Oranienburg, which never weigh more than $700 \mathrm{~g} .{ }^{218}$ The higher weight is, apart from the size of this helmet type, also due to the thickness of the cap, which can be up to $5 \mathrm{~mm}$ at the rim or up to $3 \mathrm{~mm}$ at the top of the helmet's cap. The helmets do not have any Ausschnitt (cut out or opening) as identified on the rim of helmets of Type Oranienburg. ${ }^{219}$

The helmets have a row of rivet holes running parallel to the rim. Unlike helmets of Type Paks or helmets of Type Nagytétény, the number of rivet holes on these helmets is only between c. 6-14, which is significantly lower. Given the size and diameter of the helmets and the presence of rivet holes, it is clear that there would have been an organic inlay or an organic cap would have been worn underneath the helmet. This organic inlay or cap was placed inside and the edge of the opening bent outwards and fixed with rivets to the outside of the bronze helmet, as indicated by different colour corrosion products on the outside of the helmets, usually reaching from the rim to a few millimetres above the rivet holes, resulting in a much darker area of corrosion. ${ }^{220}$ These darker areas have been identified on the helmets from Mezökövesd (cat. no. 45) and Hajdúböszörmény (cat. no. 44), as well as on three unprovenanced helmets (cat. nos. 50,52 and 53). ${ }^{221}$

The knob on the unprovenanced helmet cat. no. 53 has a vertical hole, which was closed with a cast-on on the inside of the helmet. Inside the hole, some organic filling might have been preserved, as might possibly be the case in the knob of the unprovenanced helmet cat. no. 52.222

The caps of the helmets of Type Pişcolt are plain and undecorated. Only the central knob is decorated, about the shaft, with either several horizontal lines (such as those from Sehlsdorf, Škocjan, Mezökövesd, Şoarş (cat. no. 47), and the unprovenanced helmet cat. no. 51) or with additional herringbone ornamentation (those from Pişcolt, Slúžin, and five unprovenanced helmets (cat. nos. 50, 52-55). The only exceptions are the helmet from Endröd (cat. no. 46), where the shaft of the knob is additionally decorated with chevrons infilled with hatching, and the helmet from Monte Altino, where the knob is undecorated. All of the knobs have a tubular hole, which passes through its entire length.

Two similar knobs from Škocjan (cat. nos. 57 and 58), where the helmet caps have not survived, can be related to those found on the helmets of Type Pişcolt, based on their profile, shape and decoration, wherein the cast-on, solid knobs have a stepped base and a plain shank. The

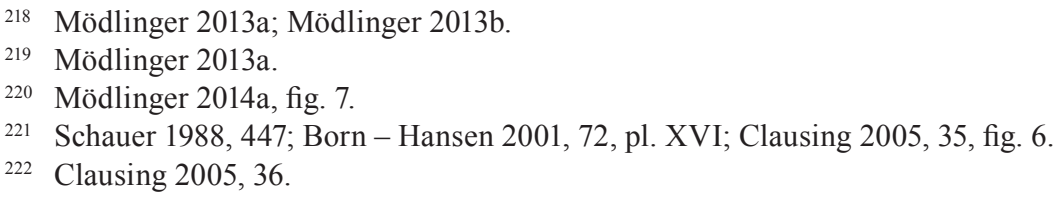


head of one of the knobs has broken off and the whole fragment has been distorted by heat. The lack of a tubular hole, however, makes this knob different from all other knobs related to or actually belonging to helmets of Type Pişcolt. The other knob from Škocjan has the central, tubular hole found on the knobs from the helmets of Type Pişcolt. C. Iaia associated the knobs from Škocjan with Italian cap helmets, ${ }^{223}$ most likely based on a fragment from the rim of a helmet, possibly of this type of helmet, which they associated together with the two knobs.

Due to their size and weight, as well as the lack of any decoration on the solid cap, helmets of Type Pişcolt are clearly distinguishable from the much smaller, thinner, and lighter helmets of Types Paks, Oranienburg, and Nagytétény, as well as the more recent decorated Italian helmets with solid knobs. In comparison with these much lighter and smaller helmets, the larger size and compactness of the helmets of Type Pişcolt, which also permitted the application of a thicker, higher protective organic inlay, must surely represent an improvement in the level of protection for the person wearing it. The fact that helmets of Type Pişcolt were used in combat is indicated by traces of weapon damage, such as that on the helmet from Hajdúböszörmény.

A number of the helmets also show traces of repair, as well as evidence of use-wear. The helmet from Pişcolt (cat. no. 48) had applied in the centre of the cap a small decorated bronze sheet, which was riveted on. On the inside of the helmet, it is supported with a further rectangular, undecorated bronze sheet. ${ }^{224}$ These likely cover a hole or crack, which was hidden by means of the small decorated bronze sheet. Several such cracks are present on the cap of the helmet from Endröd. One of these cracks was repaired during the Bronze Age with a rectangular plate of bronze attached to the inside the helmet by means of a large, flat-headed rivet. ${ }^{225}$

\subsubsection{Research History}

G. v. Merhart was the first to describe helmets of Type Pişcolt as Glockenhelme, Knaufhelme and ungarische Helme. ${ }^{226}$ Amongst these he included the helmets of Type Oranienburg from Oranienburg, Biecz, and Lúčky, as well as the Italian helmets from Tarquinia (though noted that these helmets were to be addressed separately). Soon after, Mozsolics described helmets of Type Pişcolt as glockenförmige Helme or Typ Hajdúböszörmény. ${ }^{227}$ Hencken discussed them as 'rounded bell helmets', and Clausing as Helme mit glockenförmiger Kalotte und durchlochtem Scheitelknauf. ${ }^{228}$ Both Hencken and Clausing included Italian cap helmets as well as the helmets from Tarquinia, an Italian helmet now kept at the museum in Karlsruhe, Germany, and the helmet from Populonia, Italy, amongst their group of helmets.

Unlike these Italian helmets, the Carpathian helmets of Type Pişcolt, as well as the helmets of Type Pişcolt from Monte Altino (cat. no. 49) and the unprovenanced helmet cat. no. 50, are all undecorated and have a particularly large, high cap. The central knob is usually decorated with horizontal lines on the shaft. Those Italian helmets previously associated with the helmets of Type Pişcolt are rather thin and delicate, are decorated, have a hemispherical cap and a more flattened knobs. Consequently, these helmets are not associated with the group of helmets of Type Pişcolt in the following, and are discussed as a separate, distinct group. ${ }^{229}$

At present, thirteen complete or almost complete helmets of Type Pişcolt, two knobs and one further potential fragment of a helmet of Type Pişcolt, are known. ${ }^{230}$ Two further knobs, those from Škocjan, are also related to this type of helmet (Tab. 2.5).

223 Iaia 2005, 49-50, fig. 5.3.

224 Mödlinger 2014a, fig. 6.

225 Mödlinger 2014a, fig. 4.left.

226 v. Merhart 1941

227 Mozsolics 1955, 38.

228 Hencken 1971; Clausing 2001.

229 See Chapter 2.1.6, p. 83.

230 Hencken 1971, 43; Mozsolics 2000, pl. 40.14; Mödlinger 2014a. See cat. no. 56. 


\begin{tabular}{|c|c|c|c|c|c|c|c|c|c|}
\hline $\begin{array}{l}\text { Cat. } \\
\text { No. }\end{array}$ & $\begin{array}{l}\text { Find } \\
\text { Circumstances }\end{array}$ & Find Site & State & $\begin{array}{l}\text { Condi- } \\
\text { tion }\end{array}$ & $\begin{array}{l}\text { High } \\
\text { Cap } \\
\text { (cm) }\end{array}$ & $\begin{array}{c}\text { High } \\
\text { Knob } \\
(\mathrm{cm})\end{array}$ & $\begin{array}{c}\mathrm{Dm}(\mathrm{cm}) / \\
\text { Fragments }\end{array}$ & $\begin{array}{c}\text { Thickness } \\
\text { Cap/Rim } \\
\text { (mm) }\end{array}$ & $\begin{array}{c}\text { Weight } \\
\text { (g) }\end{array}$ \\
\hline 41 & bog & Sehlsdorf & $\mathrm{DE}$ & complete & 18.4 & 6.8 & $22.2 \times 23.2$ & $-/ 2.5-2.7$ & 1455 \\
\hline 42 & $\begin{array}{l}\text { associated } \\
\text { deposit }\end{array}$ & Služín & $\mathrm{CZ}$ & knob & - & 6.2 & - & - & - \\
\hline 43 & votive deposit & Škocjan & SLO & knob & - & 6.4 & - & - & - \\
\hline 44 & $\begin{array}{l}\text { associated } \\
\text { deposit }\end{array}$ & $\begin{array}{l}\text { Hajdúböször- } \\
\text { mény }\end{array}$ & $\mathrm{HU}$ & complete & 25.5 & 5.8 & $20.5 \times 23.5$ & $<1 / 3$ & 1338 \\
\hline 45 & $\begin{array}{l}\text { associated } \\
\text { deposit }\end{array}$ & Mezőkövesd & $\mathrm{HU}$ & $\begin{array}{l}\text { not } \\
\text { complete }\end{array}$ & 23.5 & 6.2 & 22.5 & $-/ 2$ & 1340 \\
\hline 46 & river & Endrőd & $\mathrm{HU}$ & complete & 26.1 & 6.2 & $19 \times 23.2$ & $<1 / 5$ & 1032 \\
\hline 47 & $\begin{array}{l}\text { associated } \\
\text { deposit }\end{array}$ & Şoarş & $\mathrm{RO}$ & $\begin{array}{l}\text { not } \\
\text { complete }\end{array}$ & 25 & 6.1 & - & $<1 / 4-5$ & 524 \\
\hline 48 & $\begin{array}{l}\text { associated } \\
\text { deposit }\end{array}$ & Pişcolt & RO & $\begin{array}{l}\text { not } \\
\text { complete }\end{array}$ & 18 & 6.5 & 22 & $<1 / 4$ & 1094 \\
\hline 49 & unknown & $\begin{array}{l}\text { Monte Altino } \\
(?)\end{array}$ & IT (?) & complete & - & - & $23.5 \times 21$ & - & - \\
\hline 50 & unknown & unprovenanced & - & complete & 20.5 & 6.1 & $22.7 \times 23.5$ & $0.8 / 4$ & 1478 \\
\hline 51 & unknown & unprovenanced & - & $\begin{array}{l}\text { not } \\
\text { complete }\end{array}$ & 17 & 6.1 & $20.5 \times 24.9$ & $\begin{array}{c}0.5-1 / \\
2-3\end{array}$ & 912 \\
\hline 52 & unknown & unprovenanced & - & complete & 21.5 & 4.5 & $19.5 \times 21.3$ & $1.2 / 3.5$ & 1150 \\
\hline 53 & unknown & unprovenanced & - & complete & \multicolumn{2}{|c|}{ total height: c. 24} & c. 21 & $-/ 2.5$ & - \\
\hline 54 & unknown & unprovenanced & - & complete & \multicolumn{2}{|c|}{ total height: c. 25} & - & - & - \\
\hline 55 & unknown & unprovenanced & - & complete & 19.1 & 6.4 & $23.5 \times 25$ & $-/ 2$ & c. 1400 \\
\hline 56 & $\begin{array}{l}\text { associated } \\
\text { deposit }\end{array}$ & Bonyhád & $\mathrm{HU}$ & $\begin{array}{l}\text { fragment } \\
\text { cap }\end{array}$ & - & - & - & - & - \\
\hline 57 & votive deposit & Škocjan & SI & knob & - & 4.7 & - & - & - \\
\hline 58 & votive deposit & Škocjan & SI & knob & - & 2.3 & - & - & - \\
\hline
\end{tabular}

Tab. 2.5 Helmets of Type Pişcolt.

Recently, an alleged helmet of Type Pişcolt was sold at auction at Hermann Historica in Munich on 15 October 2012 and again on 21 April 2016. ${ }^{231}$ The origin of the helmet is sadly unknown, though it previously belonged to a 'private collection in Vienna from the 1960s'. Elsewhere, we have discussed in some detail the likelihood that it is in fact a forgery ${ }^{232}$ that is unless we are willing to accept the possibility, however unlikely, that an original helmet cap underwent a significant degree of later modification. Therefore, the helmet will not be considered in the following. Another complete helmet of Type Pişcolt is also currently on sale (cat. no. 55).

Almost all helmets of Type Pişcolt with known find circumstances derive from associated deposits, the exception being the helmets from Škocjan (votive deposit) and Sehlsdorf (single find), which was found in a bog. The presence of sand inside the knob of one unprovenanced helmet (cat. no. 52) might also indicate that it had been deposited in water. As will be discussed below, we can clearly distinguish helmets of Type Pişcolt from the older helmets of Type Oranienburg and helmets of Type Paks, in terms of their typo-chronological basis, and in

\footnotetext{
231 Hermann Historica 2012; Hermann Historica 2016.
}

232 Mödlinger 2014a. 
respect of their manufacture and chemical composition. We can, therefore, postulate a separate development of this helmet type in the Carpathian Basin.

\subsubsection{Distribution and Deposition}

Helmets Type Pişcolt are mainly found in the Carpathian Basin. From the 16 helmets known (including the fragment from Bonyhád, cat. no. 56), the find location of seven of the helmets is either unknown (cat. nos. 50-55) or is unsecure (cat. no. 49). Due to the corrosion of the unprovenanced helmet cat. no. 50, a wet context was assumed for it in $1892,{ }^{233}$ which was copied since then. It has to be pointed out that the corrosion does not show any specific features supporting this claim. In the case of the remaining nine helmets, six derive from the Carpathian Basin (Hajdúböszörmény, Mezökövesd, Endröd, Şoarş, Pișcolt, Bonyhád), or can be connected to this region on the basis of following the Danube and Morava upstream (Služín; cat. no. 42). One helmet is known from Sehlsdorf, Germany, and the knob of a further example was found in the votive deposit from Škocjan, Slovenia. Two further knobs likely to be from helmets of Type Pişcolt were found together in the same votive deposit. Helmets Type Pişcolt therefore have a distribution ranging from Sehlsdorf in the northwest to Monte Altino in the south (Fig. 2.11). The helmets from Škocjan, Sehlsdorf, and those from Monte Altino and the unprovenanced helmet cat. no. 50, are most likely imports from the Carpathian Basin. ${ }^{234}$ The helmet from Sehlsdorf, when taken alongside the situlae of Type Hajdúböszörmény (such as those from Siem/Aalborg and Granzin/Lübz) and the bronze cups of Type Jenišovice, attest to the exchange networks between the Carpathian Basin and northern Germany, and more generally the area west of the Baltic Sea, which is also evident in the sharing of various traditions, including depositional practices. ${ }^{235}$

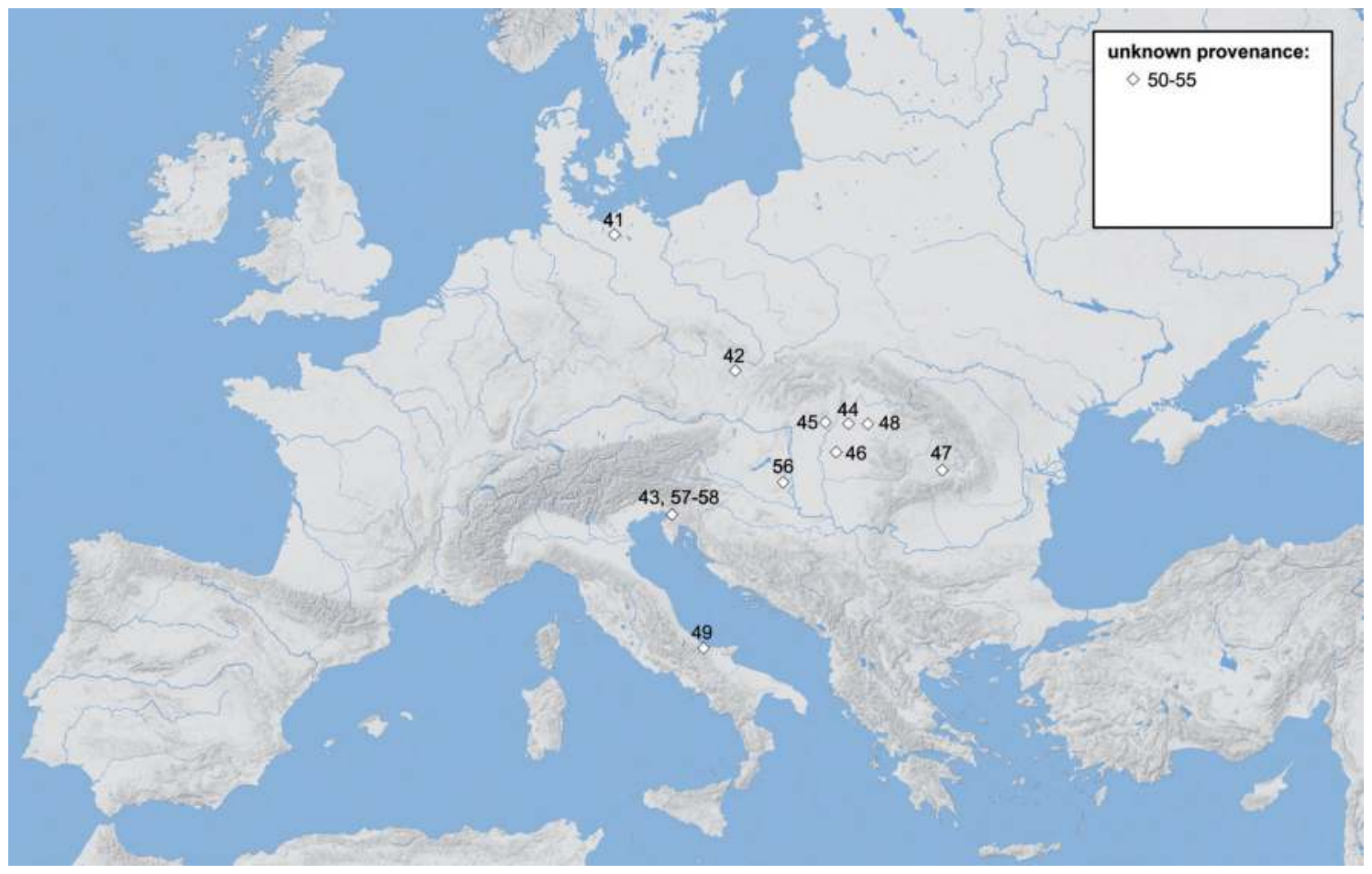

Fig. 2.11 Archaeological distribution of helmets of Type Pişcolt: 41. Sehlsdorf; 42. Služín; 43. Škocjan; 44. Hajdúböszörmény; 45. Mezőkövesd; 46. Endrőd; 47. Şoarş; 48. Pişcolt; 49. Monte Altino (?); 50-55. Unprovenanced; 56. Bonyhád; 57-58. Škocjan. Numbers correspond to the catalogue numbers.

\footnotetext{
233 Pertusi 1892, 3, no. 26.

234 Mozsolics 1972, 373, 393.

235 Born - Hansen 1992, 354.
} 
The helmet from Endröd represents a single find from a wet context, as might the unprovenanced helmets cat. nos. 50 and 52. The helmet from Sehlsdorf, which was found in a bog, can also be connected to this depositional group. The large copper carbonates in the cracks on the unprovenanced helmet cat. no. 51, however, might instead indicate its deposition in soil. ${ }^{236} \mathrm{Sev}-$ en of the helmets of Type Pişcolt with known find circumstances derive from associated deposits or votive deposits. ${ }^{237}$ Those from associated deposits include the helmets from Služín, Bonyhád, Mezőkövesd, Hajdúböszörmény Pişcolt, and Şoarş. The composition of these associated deposits varies widely. The associated deposit from Služín consists of 22 complete, destroyed or fragmentary bronze objects (12 sickles, seven socketed axes, the knob of a helmet of Type Pişcolt, a tube/socket, and fragment of a sword blade) placed in a ceramic vessel. The lack of ornaments in this associated deposit is unusual for deposits of the Lausitzer group of the Urnfield culture but common in the Carpathian Basin. ${ }^{238}$ The associated deposit from Bonyhád is also largely comprised of fragmented bronzes. As well as the helmet of Type Pişcolt fragment, it consisted of more than 200 objects, including fragmented spearheads, knife, daggers, chisel, sickles, rings, arm rings, belt buckles, pins, fragments of a bronze cup, spirals, several bronze sheet fragments, perhaps from vessels, as well as winged and socketed axes. ${ }^{239}$ At Mezőkövesd, the bronzes were instead deposited complete, with the bronze objects placed inside a ceramic vessel. The bronzes had also been placed inside one another, with two arm spirals with twisted ends having been placed inside the helmet, which in turn had been placed inside a bronze situla of Type Hajdúböszörmény. The ceramic vessel also contained fragments of two bronze Type B1 vessels placed as a cover over the situla. The associated deposit from Hajdúböszörmény instead contains both fragments and complete objects. ${ }^{240}$ In addition to the helmet, the associated deposit consists of a situla of Type Hajdúböszörmény, the handles of two other situlae, a cup of Type Jenišovice-Kirkendrup, two bronze buckets with cruciform handles, ${ }^{241} 20-30$ swords (five of Sprockhoff Type IIa, two of Sprockhoff Type IIc, four metal hilted swords with flat pommel, two metal hilted swords with oval knob, six Type Schalenknauf swords, and three blade fragments which are now lost). The rather small associated deposit from Pişcolt consists of the helmet and a bronze cup, which can be dated only broadly to Ha A. ${ }^{242}$ The limited contents might be due to the find circumstances, as the associated deposit was found during the construction of a road in 1969, and under such conditions it is not unlikely that not all bronzes were recovered. Amongst these associated deposits, the most problematic composition is for that from Şoarş. Since its discovery, the composition of the associated deposit varies significantly from author to author (see Tab. 2.6). ${ }^{243}$

The composition, sales history and find circumstances of the Şoarş associated deposit was first documented by G. F. Weber, ${ }^{244}$ who noted that only part of the deposit was sold to the Ackner collection. ${ }^{245}$ Weber himself donated four socketed axes to the Brukenthal Museum in 1836. According to J. Neigebaur, however, the contents of the associated deposit is somewhat different, being comprised of three spearheads, a helmet and a fibula (probably roman). ${ }^{246}$ According to C. Gooss, most of the objects from the associated deposit were sold to a private collection in Hannover (the second helmet, over 30 socketed axes, and the fibula, repeating the mistake of

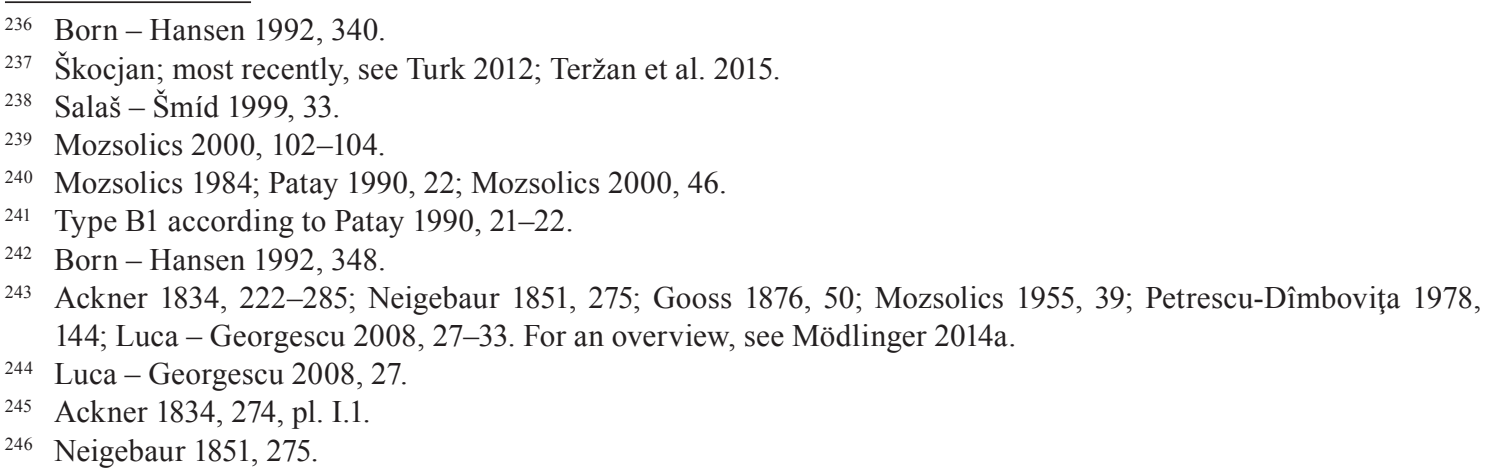




\begin{tabular}{l|c|c|c|c|c}
\hline Author & Axes & Helmets & Spearheads & Sickles & Varia \\
\hline $\begin{array}{l}\text { Luca - Georgescu 2008, } \\
\text { citing Weber (who bought the hoard) }\end{array}$ & $>30$ & 2 & 2 & 2 & \\
\hline $\begin{array}{l}\text { Ackner 1834: Weber sold to Ackner } \\
\text { collection }\end{array}$ & 1 & $1^{\text {st }}$ helmet & 1 & 1 & \\
\hline $\begin{array}{l}\text { Luca - Georgescu 2008, citing Weber: } \\
\text { donation 1836 to Brukenthal Museum }\end{array}$ & 4 & & & & \\
\hline Neigebaur 1851 & $>30$ & $2^{\text {nd }}$ helmet & & & fibula (?) \\
\hline $\begin{array}{l}\text { Gooss 1876: finds sold to private collection } \\
\text { in Hannover }\end{array}$ & 30 & 2 & 2 & few & mace head \\
\hline Mozsolics 1955 & 21 and $>9$ & 2 & 2 & 2 & \\
\hline Petrescu-Dîmboviţa 1978 & (min. 3 Hannover) & $(1$ Hannover) & & \\
\hline Schauer 1988 & 21 & 2 & 2 & few & mace head \\
\hline
\end{tabular}

Tab. 2.6 Composition of the associated deposit of Şoarş according to different authors.

Neigebaur). ${ }^{247}$ To increase confusion, Hampel noted another associated deposit from Şoarş, similarly found by Roma and also containing a helmet. ${ }^{248}$ Reputedly, this associated deposit was also sold to a private collector in Hannover. Mozsolics stated that 30 axes were found inside the now missing helmet. Leaving aside the issue of whether or not 30 such axes could fit inside a Bronze Age helmet, Mozsolics notes that the contents of the first associated deposit, comprising two spearheads, a mace head and a few sickles, were also deposited inside the helmet. ${ }^{249}$ This is also the first time that the mace head is noted as being associated with the associated deposit, which likely stems from it having been depicted on the same plate as the Şoarş associated deposit in the publication of Ackner. ${ }^{250}$ Petrescu-Dîmboviţa, however, depicts a spearhead, a sickle, five axes, the helmet, as well as a part of a second helmet, as belonging to just one associated deposit, and briefly mentions that over 30 axes, two sickles and two spearheads were found inside the two helmets. ${ }^{251}$ According to Petrescu-Dîmboviţa, 21 axes were deposited inside the helmet, and despite the problems that would be involved in achieving such a circumstances, it is further repeated by Schauer. ${ }^{252}$ One helmet and three axes are reported as held by a private collection in Hannover according to Petrescu-Dîmboviţa. ${ }^{253}$ The only bronzes which now survive from the associated deposit (associated deposits) of Şoarş are one helmet, one spearhead with flat, rhombic blade, a sickle of Type Uioara 9, a socketed axe with herringbone decoration, two socketed axes of Type Wanzek 2.b.7, one socketed axe of Type Wanzek 2.b.6.a or Boroffka-Ridiche 2.b.6.a.3-0/3, and an axe with concave mouth. ${ }^{254}$ Since the second helmet from Şoarş was never depicted, ${ }^{255}$ we cannot be sure if it is represented amongst the already known helmets of Type Pişcolt (or other helmet types!) from private collections. Hencken favoured the unprovenanced helmet from the Lipperheide collection (cat. no. 54), a view which was rejected by Schauer. ${ }^{256}$ Alternatively, one of the unprovenanced helmets cat. nos. 52 and 53 might be the lost second helmet from Şoarş. We cannot, however, be certain that the helmet survives, or for that matter fully trust the veracity of the claims that it existed in the first place. We

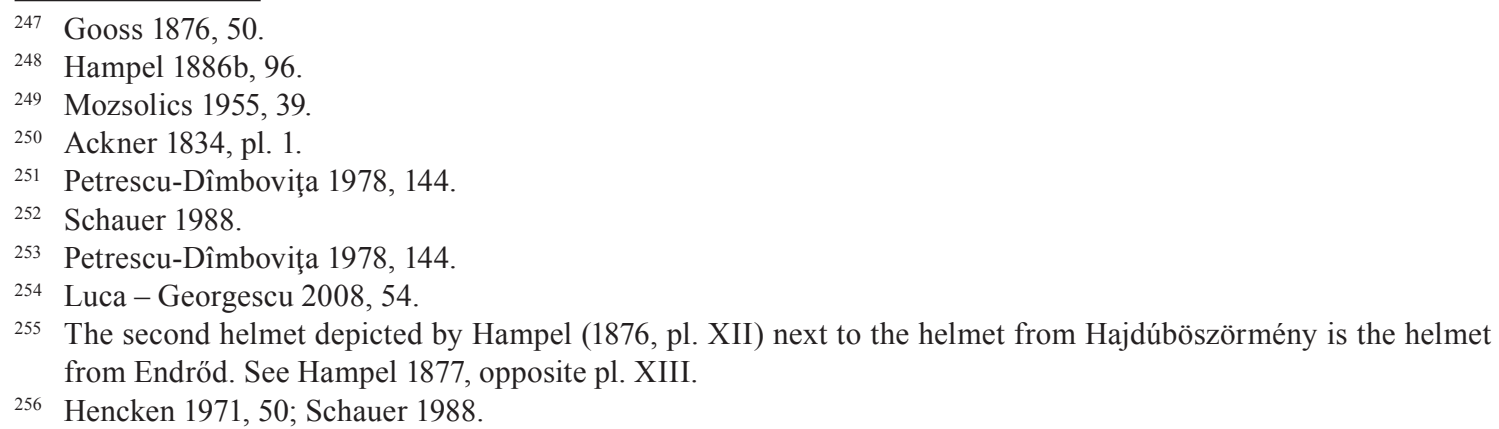


can therefore note only that a possible second helmet, potentially associated with the known helmet from Şoarş, was sold to a private collection in Hannover in the mid- $19^{\text {th }}$ century. ${ }^{257}$ There are also speculations about a second helmet from the Hajdúböszörmény associated deposit, but which no longer survives. ${ }^{258}$ Consequently, we must also consider the possibility that one of the helmets of Type Pişcolt with uncertain provenience might originally be from Hajdúböszörmény.

\subsubsection{Chronology}

G. v. Merhart argued that helmets of Type Pişcolt are more recent than the helmets of Type Oranienburg. ${ }^{259}$ Schauer, however, suggests that the knobs of helmets of Type Pişcolt attest to helmets of Type Pişcolt being partly contemporary with helmets of Type Oranienburg, a view repeated by Born and Hansen. ${ }^{260}$ It is now clear that helmets of Type Oranienburg, dating to the $15^{\text {th }}-13^{\text {th }}$ century BC, are significantly older than helmets of Type Pișcolt, and that the helmets of Type Oranienburg found in the later Ha B1 associated deposits from Lúčky and Sâg are relics or antiques associated with much later objects. ${ }^{261}$ Prototypes for such large, heavy Bronze Age helmets are so far unknown, though we might consider the older helmets of Type Nagytétény with solid knob, given their similarities in profile and shape, as possible ancestors. Only Hencken argued, on the basis of broad similarities in shape, for a direct connection with Greek boar tusk helmets and their role as potential prototypes. ${ }^{262}$ Apart their chronological distance, and also according to the recovery area, their local development in the Carpathian Basin seems more likely.

Of the 15 secure helmets of Type Pişcolt, as well as the potential fragment from Bonyhád, only the associated deposits from Služín, Hajdúböszörmény, Mezőkövesd, Şoarş, and Pişcolt, can be considered useful in determining a chronological classification for helmets of Type Pişcolt. The votive deposit from Škocjan has a rather wide chronological time frame, stretching from the $12^{\text {th }}$ to $8^{\text {th }}$ century $\mathrm{BC},{ }^{263}$ and provides little basis for narrowing the chronological range for the helmets of Type Pişcolt, though most parts of the deposit seem to belong to Ha B. The remaining associated deposits with helmets of Type Pişcolt, however, are more uniformly attributable to Ha B1. The associated deposit from Služín is dated, on the basis of the socketed axes, to the Rohod period, and according to the associated ceramic vessels more specifically to $\mathrm{Ha}$ A2/Ha B1, though tending more to the beginning of $\mathrm{Ha} \mathrm{B} 1$ and depositional Křenůvky horizon. More recently, M. Salaš has agreed upon a more general attribution to Ha B1. ${ }^{264}$ The associated deposit from Hajdúböszörmény provides the basis for the Hajdúböszörmény horizon ${ }^{265}$ which is associated with Ha B1. ${ }^{266}$ Given its similarity to the associated deposit from Hajdúböszörmény, the associated deposit from Mezőkövesd is also dated to Ha B1. ${ }^{267}$ The associated deposit from Şoarş is associated with Transylvanian Bronze Age IV. ${ }^{268} \mathrm{~S}$. A. Luca and A. Georgescu dated the associated deposit to the Moigrad-Tăuteu period, relative with Ha B1, as does Rusu. ${ }^{269}$ The associated deposit from Pişcolt is dated accordingly to $\mathrm{Ha} \mathrm{B},{ }^{270}$ or more specifically to $\mathrm{Ha} \mathrm{B} 1 .{ }^{271}$

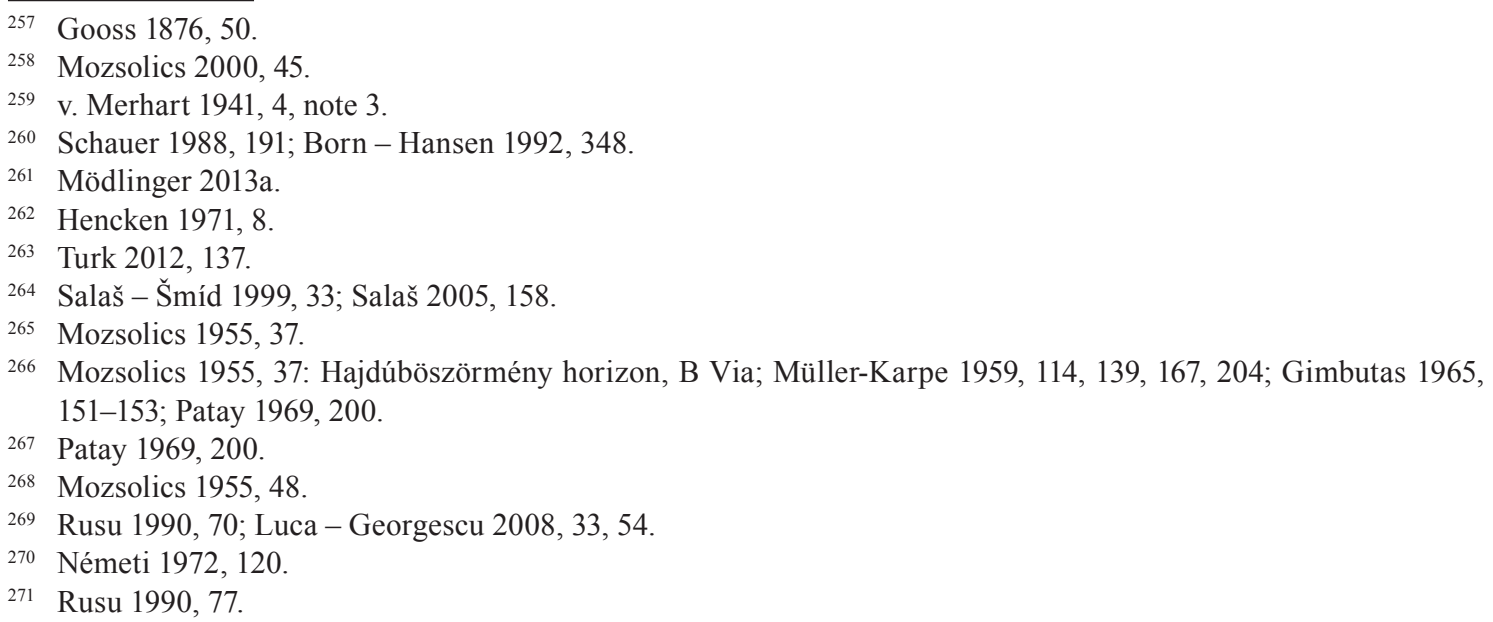


The clear association of helmets of Type Pişcolt with Ha B1 provides a reasonable basis for attributing unprovenanced helmets of Type Pişcolt, as well as those single finds, such as the helmets from Endröd and Sehlsdorf, to the same phase. The helmet of Type Pişcolt from Monte Altino might also represent a further potentially later deposition (and not necessarily later production), as in Italy the persistence of the shape of helmets of Type Pişcolt up to the beginning Iron Age and adaption of it by pottery cap helmets might indicate. ${ }^{272}$

Catalogue

Cat. no. 41. Sehlsdorf, Lkr. Parchim, Mecklenburg-Vorpommern, Germany - single find (?) - complete helmet. Measurements: height: $25.2 \mathrm{~cm}$; $6.8 \mathrm{~cm}$ (knob); diameter: $22.2-23.2 \mathrm{~cm}$; thickness: $2.5-2.7 \mathrm{~mm}$ (rim); weight: $1455 \mathrm{~g}$ - Landesamt für Kultur und Denkmalpflege Mecklenburg-Vorpommern, inv. no. 315 (?) - Pl. 6.41. References: Beltz 1910, 253; Sprockhoff 1930, 44; v. Merhart 1941, 11; Sprockhoff 1956, 85; Drescher 1958, 52; Hencken 1971, 43, fig. 21g-h; Borchhardt 1972, 129, cat. no. 29.5; Keiling 1987, 96, fig. 50; Schauer 1988, 188; Albrecht 1991, 13-16; Calzecchi-Onesti 1991, 77, no. 8; Born - Hansen 1992, 344; Hundt 1997, no. 132, pl. 39.2; Götter und Helden 1999, 257, no. 154; Born - Hansen 2001, 79; Clausing 2001, 219; Hänsel 2003; Schmidt 2004, 87-95, 195, cat. no. 50, fig. page 92; Clausing 2005, 36; Mörtz 2011a, 367; Mödlinger 2014a, figs. 2, 12, cat. no. 1.

The helmet is supposedly a single find recovered during peat cutting in 1836.

Cat. no. 42. Služín, Okr. Prostějov, Czech Republic - associated deposit - knob. Measurements: height: $6.5 \mathrm{~cm}$; diameter base: $6.2 \mathrm{~cm}$ - Muzeum Prostějov, inv. no. 143.668 - Pl. 6.42 . References: Salaš - Šmíd 1999, 19, 31, figs. 7.2; 10.21; Clausing 2001, 219; Clausing 2005, 36-37; Salaš 2005, 502-514, pl. 424.21; Mödlinger 2014a, figs. 3, 12, cat. no. 2.

In summer 1997 in the south of Služín, at Zábrusky, 13 storage pits attributed to the Lausitzer group of the Urnfield culture were found. In the northern half of one of these storage pits, just $30 \mathrm{~cm}$ below the ground, a ceramic vessel, covered with the base of another ceramic vessel with a hole, was uncovered. The vessel contained 22 complete, destroyed and fragmented bronze objects, comprising the knob of a helmet, seven socketed axes with the blades all pointing north or northwest, 12 sickles with the decorated side upside, a cast tube or socket, and a fragment of a sword blade. ${ }^{273}$

Cat. no. 43. Škocjan, Obalno-kraška, Slovenia - votive deposit - knob. Measurements: height: $6.4 \mathrm{~cm}$; weight: $248 \mathrm{~g}$ - Naturhistorisches Museum, Vienna, inv. no. 47.626 - Pl. 6.43. References: Szombathy 1913, 149, fig. 94; v. Merhart 1941, 12, fig. 2.10 left; Hencken 1971, 48, fig. 26a-c; Borgna 1999, 158, fig. 5; Clausing 2001, 219; Clausing 2005, 36; Mödlinger 2014a, figs. $3,10,12$, cat. no. 3 .

The votive deposit from Škocjan contains over 600 metal objects and fragments (mainly fragmented and deliberately destroyed arms and armour). First objects were discovered in 1909, which led to first excavations by the Prähistorische Kommission, $k$. u. k. Naturhistorisches Hofmuseum (today the Natural History Museum Vienna).

Cat. no. 44. Hajdúböszörmény, Hajdú-Bihar megye, Hungary - associated deposit - complete helmet. Measurements: height: $25.5 \mathrm{~cm}$ (cap), $5.8 \mathrm{~cm}$ (knob); diameter: $20.5 \times 23.5 \mathrm{~cm}$; thickness: 3mm (rim); weight: $1338 \mathrm{~g}$ (not 2335g or 2355g!) - Magyar Nemzeti Múzeum, inv. no. 33/1858/3 - Pl. 6.44. References: Graffenried 1860, 372-374, figs. 66-72; Hampel 1876, pl. XII; Hampel 1886b, 74, pl. XXXIII.2; Hampel 1892, 49-58; v. Merhart 1941, 11, fig. 2.12; v. Merhart 1952, 5; Kossack 1954, 27, no. 1; Mozsolics 1955, 37, 48, fig. 4; Müller-Karpe 1959, 114, 139 ,

272 See Chapter 2.1.6, p. 83.

273 Salaš - Šmíd 1999, 33. 
167, 204; Gimbutas 1965, 151-153; Patay 1969, 200; Hencken 1971, 44, fig. 21d-f; Borchhardt 1972, 129, cat. no. 29.2; Mozsolics 1984, 81-93; Kemenczei 1988, 57; Patay 1990, 21, no. 7; Calzecchi-Onesti 1991, 77, no. 10; Kovács 1992, 45, fig. 29; Soroçeanu 1995, 65; Mozsolics 2000, 45, no. 5, pl. 30.5; Clausing 2001, 120; Clausing 2005, 36; Vachta 2008, 123, list V.1.5. no. 1; Mörtz 2011a, 367; Mödlinger 2014a, figs. 1, 7, 12, cat. no. 5.

The associated deposit was found close to Csege hill in 1858, and some of its contents reached the Magyar Nemzeti Múzeum, with further objects from the associated deposit only coming to the museum later, whilst some appear to have been melted down immediately after it was discovered. Some finds from the deposit are housed at the Reformed College at Debrecen. For detailed description of the associated deposit and its history, see Mozsolics. ${ }^{274}$

Cat. no. 45. Mezökövesd, Borsod-Abaúj-Zemplén megye, Hungary - associated deposit complete helmet. Measurements: height: $23.5 \mathrm{~cm}$ (cap); $6.2 \mathrm{~cm}$ (knob); diameter: $22.5 \mathrm{~cm}$; thickness: 2-3mm (rim); weight: 1340g - Magyar Nemzeti Múzeum, inv. no. 60.2.2 - P1. 6.45. References: Patay 1969, 173, 190, figs. 1-8, pls. 41-45; Hencken 1971, 44-45, fig. 21a-c; Kemenczei 1984, 149, no. 19; Schauer 1988, 188; Patay 1990, 23, nos. 19-20; Calzecchi-Onesti 1991, 77, no. 11; Mozsolics 2000, 55, no. 5, pl. 52.3; Clausing 2001, 219; Clausing 2005, 36; Soroçeanu 2005, 408; Vachta 2008, 123, list V.1.5. no. 8; Mörtz 2011a, 367; Mödlinger 2014a, figs. 1, 7, 12, cat. no. 6 .

The associated deposit was found during levelling work in 1959 at a depth of $60-65 \mathrm{~cm} .{ }^{275} \mathrm{~A}$ ceramic vessel contained a situla of Type Hajdúböszörmény, in which the helmet had been placed, with the knob pointing downwards. Due to pressure from above, the knob perforated the base of the situla. Inside the helmet, two arm spirals were found. The situla itself was covered with two bronze vessels of Type B1. ${ }^{276}$

Cat. no. 46. Endrőd (Gyomaendrőd), Békés megye, Hungary - single river find (river Körös) - complete helmet. Measurements: height: $26.1 \mathrm{~cm}$ (cap), $6.2 \mathrm{~cm}$ (knob); diameter: $19 \times 23.2 \mathrm{~cm}$; thickness: up to 5mm (rim) - Erkel Ferenc Múzeum Gyula, inv. no. 60.113.1 - Pl. 6.46. References: Hampel 1886a, pl. XXXIII.1-2; Sprockhoff 1930, 46; v. Merhart 1941, 11, fig. 2.11; Mozsolics 1955, 38, fig. 5.1; Hencken 1971, 45, fig. 2; Borchhardt 1972, 129, cat. no. 129.1; Schauer 1988, 188; Makkay 1989, 181, pl. 28; Calzecchi-Onesti 1991, 77, no. 99; Clausing 2001, 120; Clausing 2005, 36; Mödlinger 2014a, fig. 1.4, cat. no. 7.

The helmet was found in the bed of the river Körösök in or before 1874 .

Cat. no. 47. Şoarş (Sáros/Scharosch), jud. Braşov, Romania - associated deposit - half preserved. Measurements: height: $25 \mathrm{~cm}$ (cap), $6.1 \mathrm{~cm}$ (knob); diameter: approximately $23 \mathrm{~cm}$; weight: 524g - Muzeul Naţional Brukenthal, Sibiu, inv. no. 11.992 = A 4685 - Pl. 6.47. References: Ackner 1834, 274, pl. I.1; Neigebaur 1851, 275; v. Arneth 1851, 289; Gooss 1876, 50; v. Merhart 1941, 11, fig. 2.7; Mozsolics 1955, 39, fig. 5.2; Hencken 1971, 50-51, fig. 27c-e; Németi 1972, 115; Petrescu-Dîmboviţa 1977, 135, pl. 324.8; Petrescu-Dîmboviţa 1978, 144, pl. 243.B9; Wollmann 1982; Bader 1983, 122, no. 421; Mozsolics 1985, 25, note 119; Schauer 1988, 188; Rusu 1990, 69, pl. V.1; Calzecchi-Onesti 1991, 77, no. 16; Born - Hansen 1992, 346-348, fig. I; Clausing 2001, 219; Hansen 2001, 80; Clausing 2005, 36; Ciugudean et al. 2006, 27-33, 51, 54, pls. XI-XIII; Vachta 2008, 123, list V.1.5, no. 13; Mödlinger 2014a, fig. 3.1, cat. no. 8.

The find circumstances of the associated deposit, most likely discovered in the vicinity of Şoarş, are unknown. The associated deposit was purchased from Sinti or Romanies by F. Weber, the evangelic priest from Şoarş, before 1834. ${ }^{277}$

\footnotetext{
274 Mozsolics 1985, 102-104; Mozsolics 2000, 43-47.

275 Patay 1969, fig. 1.

276 Patay 1969; Patay 1990, 23.

277 For composition of the associated deposit, see Tab. 2.6 and Chapter 2.1.4.2.
} 
Cat. no. 48. Pişcolt, jud. Satu Mare, Romania - associated deposit - complete helmet. Measurements: height: $18 \mathrm{~cm}$; knob: height: $6.5 \mathrm{~cm}$; diameter: $22 \mathrm{~cm}$; weight: $1094 \mathrm{~g}$ - Muzeul Municipal Carei (Nagykárolyi Városi Múzeum), inv. no. 2290 - Pl. 7.48. References: Németi 1972, 113-117, figs. 1-2, pls. 26.1-2; 27.1-4; Schauer 1988, 188, fig. 7; Rusu 1990, 77, pl. V.6; Calzecchi-Onesti 1991, 80, no. 17; Born - Hansen 1992, 384; Clausing 2001, 219; Clausing 2005, 36; Soroçeanu 2008, 47, no. 10; Vachta 2008, 123, list V.1.5, no. 11; Németi 2009, 65-67; Mödlinger 2014a, fig. 3.2, cat. no. 9 .

The helmet was found in 1969 at via Veche 'Livada' Öregszölö, when several trees were removed during the preparation for the construction of a road. The helmet was most likely found together with a bronze cup of Type Fuchsstadt. ${ }^{278}$

Cat. no. 49. Monte Altino, prov. Campobasso, Italy - find circumstances unknown - complete helmet. Measurements: height: $27.5 \mathrm{~cm}$; diameter: $23.5 \times 21 \mathrm{~cm}-$ Museo Provinciale Sannitico, Campobasso, inv. no. 1250 - Pl. 7.49. References: Sogliano 1889; Calzecchi-Onesti 1991, 68, 80, no. 18, figs. 1-2; Clausing 2001, 219; Clausing 2005, 36; Iaia 2005, 45-46, cat. no. 1, fig. 4.1; Mödlinger 2014a, fig. 14, cat. no. 14.

The find circumstances and find date of the helmet are unknown. The helmet was already noted in the inventory of the museum in 1889.

Cat. no. 50. Unprovenanced (formerly known as 'Mantova', prov. Mantua, Lombardia, Italy) - complete helmet. Measurements: height: 26.6cm; $6.1 \mathrm{~cm}$ (knob); diameter: $22.7 \times$ $23.5 \mathrm{~cm}$; base of the knob: diameter $6.2 \mathrm{~cm}$; thickness cap: $0.8-4 \mathrm{~mm}$; weight: $1478 \mathrm{~g}(1280 \mathrm{~g}$ according to Pertusi 1892) - Antikenmuseum Berlin (Lipperheide collection), inv. no. L 68 - Pl. 7.50. References: Pertusi 1892, 3, no. 26; v. Wieser 1894, pl. 7.43; v. Lipperheide 1896, 128, no. 230b; Schröder 1912, 24, fig. 15; Szombathy 1913, 149, fig. 93; v. Merhart 1941, 12, no. 18, note 15; Hencken 1971, 50, fig. 28; Borchhardt 1972, 129, no. 29.11; Mozsolics 1972, 373-374, $393-$ 394; Schauer 1988, 182, 188, 447, fig. K 54a-c; Pflug 1989, 65, no. 35; Egg - Waurick 1990, 41, no. 7.5, fig. 8.2; Calzecchi-Onesti 1991, 80, no. 19; Born - Hansen 1992, 345; Born - Hansen 2001, 79, 251, fig. 200; Clausing 2001, 219, fig. 28; Clausing 2005, 36; Iaia 2005, 46, fig. 4.2; Mödlinger 2014a, figs. 3, 12, cat. no. 4.

The helmet was purchased from the Amilcare Ancona collection in Milan, with the note that according to its colour, it might have derived from water. ${ }^{279}$ It is unknown from whom the Amilcare Ancona collection bought the helmet and where it might have come from. As v. Merhart pointed out, ${ }^{280}$ the find spot 'Mantova' was added only later, ${ }^{281}$ probably according to a misunderstanding.

Cat. no. 51. Unprovenanced - complete helmet. Measurements: height: $23.1 \mathrm{~cm} ; 6.1 \mathrm{~cm}(\mathrm{knob})$; diameter: $20.5 \times 24.9 \mathrm{~cm}$ - Museum Berlin (formerly: Museum für Völkerkunde, Leipzig; Grossenhain, Saxony), Zschille Collection; inv. no. 13.167 - Pl. 7.51. References: Forrer 1894, no. 12; v. Merhart 1941, 12, fig. 2.7; Mozsolics 1955, 38, fig. 5.3; Hoffmann 1961, 98; Patay 1969, 191; Hencken 1971, 50, 54, fig. 29a-c; Schauer 1988, 188; Albrecht 1991, 13; Calzecchi-Onesti 1991, 80, no. 20; Born - Hansen 1992, 339-356; Born - Hansen 2001, 251, fig. 201; Clausing 2001, 220; Clausing 2005, 36-37; Mödlinger 2014a, figs. 3, 12, cat. no. 10.

The actual find spot remains unknown. The collection was purchased in New York before 1896 by R. Zschille. The helmet had been repaired several times, riveting different brass plates to the inside of the rim of the helmet, covering also the rivet holes. ${ }^{282}$

\footnotetext{
278 Martin 2009, 168.

279 Pertusi 1892, 3, no. 26.

280 v. Merhart 1941, 12, note 18.

281 Szombathy 1913.

282 Born - Hansen 1992, 340.
} 
Cat. no. 52. Unprovenanced - complete helmet. Measurements: height: $21.5 \mathrm{~cm}$ (cap); diameter: $21.3 \times 19.5 \mathrm{~cm}$; thickness of the edge: $1.2-3.5 \mathrm{~mm}$; knob: height: $4.5 \mathrm{~cm}$; base diameter: $3.9 \mathrm{~cm}$; opening: $7 \mathrm{~mm}$ deep; weight: $1150 \mathrm{~g}$ - present repository unknown; Guttmann collection, inv. no. AG 1000 - Pl. 7.52. References: Born - Hansen 2001, 72, 175, 245-250, 270, figs. 195, 199, $202-$ 203, pl. XVI; Clausing 2001, 219; Clausing 2005, 36-37; Hermann Historica 2005b; Eisenberg Price 2006, 37, no. 73; Mödlinger 2014a, figs. 2, 12, cat. no. 11; Alexander Ancient Art 2017.

The helmet was part of the Guttmann collection and was put up for auction (Lot 9, not sold) at Christie's in London on 28 April 2004. It was sold on 19 October 2005 at Hermann Histori$\mathrm{ca}^{283}$ and again in 2007 at Royal-Athena Galleries. ${ }^{284}$ Its current location is unknown. On the basis of traces of sand/chips inside the helmet, it has been suggested that it was recovered from a water context. ${ }^{285}$ Further details are unknown.

Cat. no. 53. Unprovenanced - complete helmet. Measurements: height: $24 \mathrm{~cm}$; diameter. approx. $21 \mathrm{~cm}$; thickness: $2.5 \mathrm{~mm}$ (rim) - sold at an auction of 'Gorny und Mosch' in Munich December 13, 2003; no. 12 - Pl. 8.53. References: Clausing 2005, 36-38, fig. 6; Mödlinger 2014a, cat. no. 12 .

The origin of the helmet is unknown, as is the current location.

Cat. no. 54. Unprovenanced - complete helmet. Measurements: approximately $25 \mathrm{~cm}$ (total height) - Königliche Museen Berlin, lost during World War II - Pl. 8.54. References: v. Merhart 1941, 12; Hencken 1971, 50, fig. 28; Mödlinger 2014a, fig. 2, cat. no. 13.

The helmet belonged to the Lipperheide collection and was lent to the Königliche Museen zu Berlin in 1905 but after the World War II it went missing. ${ }^{286}$ A surviving picture published by Hencken shows that the helmet belongs to the group of helmets of Type Pişcolt.

Cat. no. 55. Unprovenanced - complete helmet. Measurements: total height: $25.5 \mathrm{~cm}$ (total height); knob: height: $6.4 \mathrm{~cm}$; diameter pommel: $3.4 \times 3.5 \mathrm{~cm}$; diameter base knob: $5.85 .8 \mathrm{~cm}$; weight: c. $1400 \mathrm{~g}$ - Pl. 8.55. References: Phoenix Ancient Art 2012, 32-33, no. 8.

The helmet presumably derives from an ex-European private collection from the 1990s. It was put up for auction (Lot 210, not sold) at Christie's, New York on June 10, 2010 and is currently (June 2017) on sale at Phoenix Ancient Art in Geneva. The helmet has 14 rivet holes, which were most likely cast, and during the manufacturing processes were enlarged by being punched through. The helmet does not have a significantly thicker rim than that of the cap, as noted on other helmets of Type Pişcolt.

Cat. no. 56. Bonyhád, Tolna megye, Hungary - associated deposit - fragment. Measurements: ca. 15 × 18cm. Magyar Nemzeti Múzeum, inv. no. 107/1889/167 - Pl. 8.56. References: Hampel 1892, pl. CLIII.7, 10; Wosinsky 1896, 381-392; Hencken 1971, 43; Mozsolics 1985, 102104, no. 75 , pl. 40.14 .

The exact find spot of the associated deposit is unknown. It consists of more than 200 objects, including fragmented spearheads, daggers, knife, sickles, chisel, arm rings, rings, pins, belt buckles, spirals, fragments of a bronze cup, several bronze sheet fragments (vessels?), as well as socketed and winged axes. ${ }^{287}$

The bronze sheet was folded over twice. On one side, rivet holes are visible as well as differing corrosion products parallel to the slightly stripped edge, which is common on bronze helmets. Usually, helmets of Type Pişcolt are much larger about the rim or edge than that of the

\footnotetext{
283 Hermann Historica 2005b.

284 Eisenberg - Price 2006, 37, no. 73.

285 Born - Hansen 1992, 245.

286 Hencken 1971, 50.

287 Mozsolics 2000, 102-104.
} 
fragment from Bonyhád, and therefore its attribution to the group of helmets of Type Pişcolt is not entirely certain.

\section{Related Helmets}

Cat. no. 57. Škocjan, Obalno-kraška, Slovenia - votive deposit - knob. Measurements: height: $4.7 \mathrm{~cm}$. Museo Civico, Trieste, inv. no. 47.627 - Pl. 8.57. References: Szombathy 1913, 149; v. Merhart 1941, 12, fig. 2.10 right; Hencken 1971, 157, fig. 126a-c; Borgna 1999, 158, fig. 5; Clausing 2001, 219; Clausing 2005, 36; Teržan et al. 2015.

The cast-on, solid knob has a stepped base and a plain shank.

Cat. no. 58. Škocjan, Obalno-kraška, Slovenia - votive deposit - knob. Measurements: height: c. $2.3 \mathrm{~cm}$. Museo Civico, Trieste, inv. no. 47.628 - P1. 8.58. References: Szombathy 1913, 149; Hencken 1971, 157, fig. 126d-e; Clausing 2001, 219.

The cast-on, solid knob has a stepped base and a plain shank. The head of the knob has broken off and the whole fragment has been distorted by heat. The lack of a tubular hole makes this knob different from all other knobs related to or found attached to helmets of Type Pişcolt.

\subsubsection{Single Helmet Types, Cheek Plates, Knobs and Possible Fragments}

Two complete bronze helmets, as well as a unique helmet from Malpensa, potential helmet knobs, and several cheek plates and fragment, potentially related to helmets, will be discussed in the following. An overview on the finds discussed is provided in Tab. 2.7, and their recovery mapped in Fig. 2.12. ${ }^{288}$

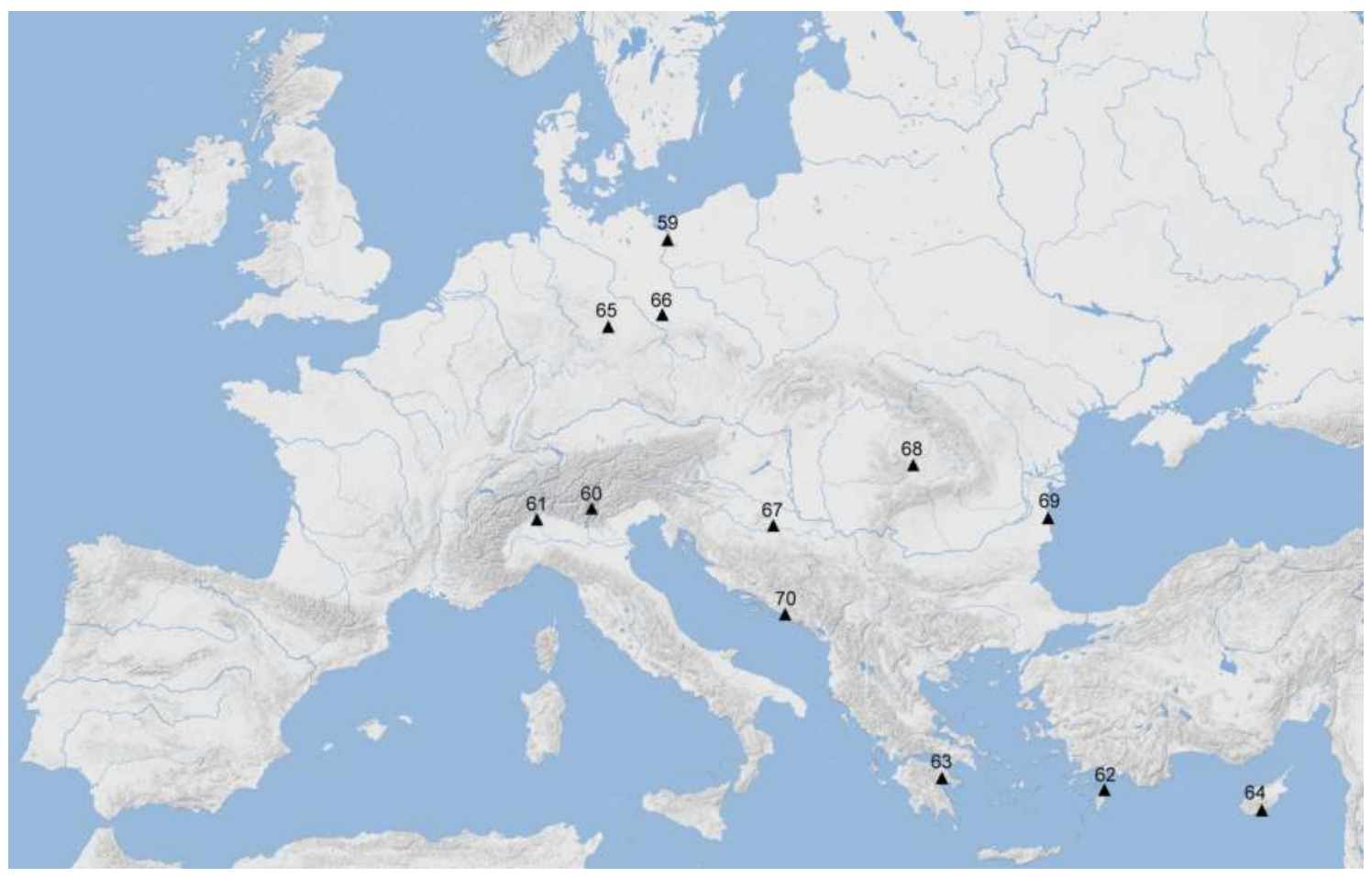

Fig. 2.12 Archaeological distribution of single cap helmet types, cheek plates and sockets/knobs: 59. SzczecinZdroje; 60. Fiave; 61. Malpensa; 62. Ialysos; 63. Dendra; 64. Kourion; 65. Schmiedehausen; 66. Weißig; 67. Podcrkavlje; 68. Şpălnaca; 69. Techirghiol; 70. Grepci. Numbers correspond to the catalogue numbers.

288 For the Viksø helmets, see Chapter 2.3. 


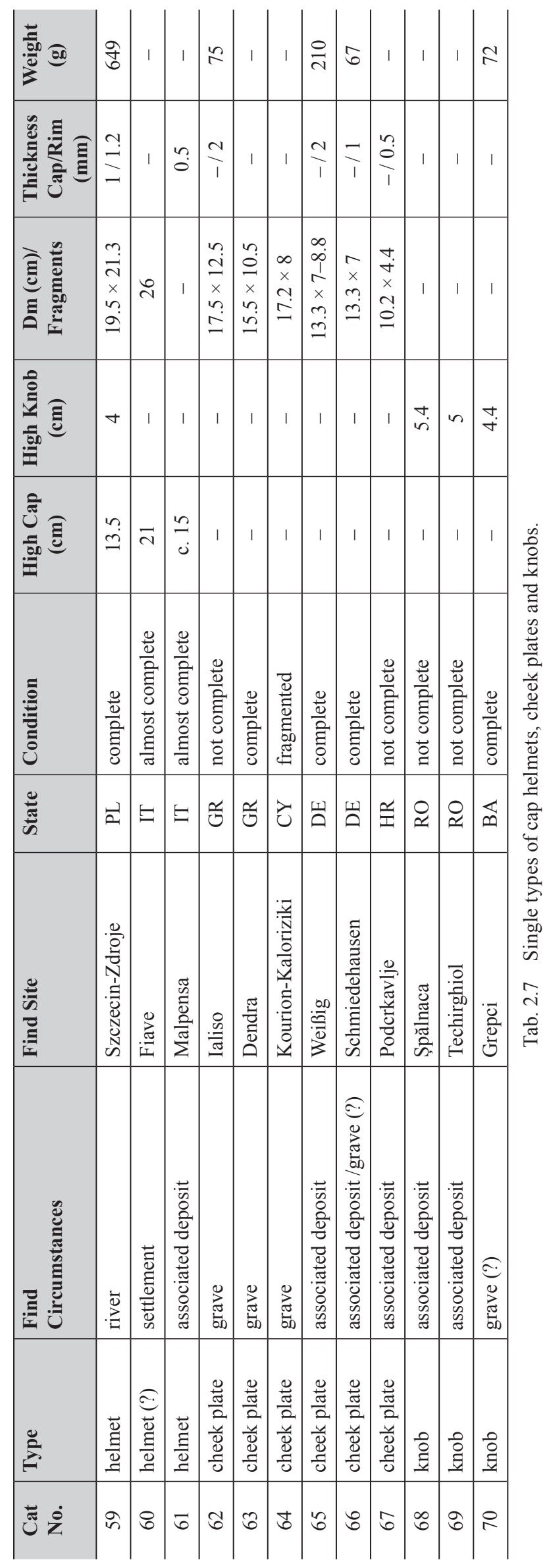




\subsubsection{Single Helmet Types}

Only three complete helmets are described in the group of single helmet types, represented by the bronze helmet from Szczecin-Zdroje (cat. no. 59), the helmet from Malpensa (cat. no. 61) and the organic cap or helmet from Fiavé-Carera (cat. no. 60). The helmet from Szczecin-Zdroje, the single example of its Type Szczecin-Zdroje, with unique decoration of ribs and bosses, still lacks adequate classification. The cast socket is fixed on the calotte with four rivets. Around the socket, the helmet is decorated with three parallel, concentric rows of punched dots. Above the row of rivet holes, totalling eighteen with just one rivet surviving in place, two ribs and one row of punched dots was applied. The central zone of the helmet is decorated with double circles of pellet decoration with a central boss. ${ }^{289}$ Clausing most recently included it amongst his group of 'cap helmets with ribs and bosses', together with the Italian finds from Fermo, three helmets from Tarquinia, and an unprovenanced helmet from the museum in Karlsruhe. ${ }^{290}$ Hencken associated the helmet with his group of 'cap helmets and others with plain socket', which includes not only the above mentioned helmets from Tarquinia and Fermo but also fragments from Straßengel, Škocjan, Guşteriţa, Špălnaca and Techirghiol. ${ }^{291}$ G. v. Merhart regarded the unique helmet as an import but did not specify from where. ${ }^{292}$ According to finds with similar decoration (see below), a local production or at least a production in the (north)eastern zone of the Urnfield culture seems most likely.

Since the helmet from Szczecin-Zdroje is a single find from the river Oder, we have no relative information, such as associated finds, upon which to establish its chronological classification. Hencken notes that the decorative elements are common between the Elbe and Vistula during Ha B3 and the beginning of the Iron Age, relative with period V-VI of the Nordic Bronze Age, indicating a date in the $8^{\text {th }}$ century $\mathrm{BC}$ or perhaps later ${ }^{293}$ However, similar decorative elements are already present during the Late Bronze Age. The horizontal ribs can be found on helmets of Type Paks, ${ }^{294}$ though not on the Italian helmets with which the helmet from SzczecinZdroje was associated. ${ }^{295}$ The pellets are of uniform size (apart the central bosses in the circles), which is also uncommon on Early Iron Age Italian armour. The double circles made out of pellets with the large central boss can however be found on the complete cuirass from the Danube (cat. no. 134), on one of the cuirasses from Jura (cat. no. 138), on the helmets from Tiryns (cat. no. 120) and Pass Lueg, as well as on bronze sheets from Salaš Noćajski, Serbia, ${ }^{296}$ Guşteriţa, Romania, ${ }^{297}$ Pila del Brancon, Italy, ${ }^{298}$ Dresden-Dobritz, Germany, ${ }^{299}$ and from an Iron Age devotion from Sicily. ${ }^{300}$ Similar decoration is also known on sheet fragments from Techirghiol. ${ }^{301}$ Sadly, the fragments are too small to reconstruct the object they were once part of. The riveted-on socket from the helmet from Szczecin-Zdroje does not point to a later date, despite its apparent similarity to those helmets with riveted on socket from Grepci (cat. no. 70), Tarquinia and Fermo, since earlier riveted-on knobs are also known, as demonstrated by the helmet of Type Oranienburg from Knossos (cat. no. 2). A date relative to Bz D-Ha A for the helmet from Szczecin-Zdroje seems, therefore, to be most reasonable.

289 Albrecht 1991

290 Clausing 2001, 217.

291 Hencken 1971, 155-162.

292 v. Merhart 1941, 11.

293 Hencken 1971, 159.

294 See Chapter 2.1.2.

295 Clausing 2001, 217.

296 Vasić 1994, pl. 38.13.

297 Bronze sheet fragment: Rusu 1990, 73, pl. V.5.

298 Bronze sheet fragment: Salzani 1998, fig. 2.138.

299 Bronze cup: Martin 2009, pl. 30.119.

300 Egg 1983, fig. 2.4-5.

301 Petrescu-Dîmboviţa 1978, pl. 215.17-19. 
The helmet from Malpensa (cat. no. 61) is a unique and at present the single example of Type Malpensa. It derives from the same associated deposit as the greaves (cat. nos. 160-161, 179). The deposit is dated accordingly to the greaves to Ha Al and contained furthermore ingots and ingot fragments, three spearheads and a fragment of further spearhead, two axes and a further axe fragment, two sickles and further fragment, and fragments of bronze sheet recently confirmed as a helmet. ${ }^{302}$

It consists of a very thin bronze sheet with eight strips, reaching from the upper third of the cap to the base, similar to the medieval Spangenhelme. The strips are bent inwards at the base. Inside the helmet, much thicker bronze sheets were fixed, their edge fitting beneath the inward bent strips, in this way protecting the whole head with bronze. Impressions upon the bronze and broken off sheet fragments on the top of the helmet indicate the former presence of a cast-on knob, which was not recovered. Chemical and microstructural analyses were carried out by the author in summer 2015. Two detailed publications on the associated deposit and the helmet in particular were recently published. ${ }^{303}$

The development and improvement of arms would have had a mutually dependant relationship with contemporary improvements in defensive armour, irrespective of the material either were made of. Before the appearance of metal armour, and certainly following its appearance, we can rightly assume considerable diversity of form in organic armour, as is demonstrated by its depiction on various media in the Near East and on Sardinian bronze figurines. ${ }^{304}$ Compared with Europe, the Aegean and the Near East provide a much richer source for the reconstruction of organic helmets. Whilst no complete helmets are preserved, we can reconstruct them from their depictions, and from those non-perishable components used in their construction, such as in the case of boar tusks. The work of Borchhardt represents an early discussion concerning the details of the types, distribution and chronology of Aegean organic helmets, including boar tusk helmets and zonal helmets, of which many depictions and miniatures are known. ${ }^{305}$

The only surviving organic European Bronze Age helmet is from Fiavé-Carera, TrentinoAlto Adige, Italy. ${ }^{306}$ The frame of the helmet was made of spliced branches of spruce. Small branches of viburnum were wrapped in spirals around them and additionally secured with reed, and therein providing a higher protective 'buffer' than that of leather helmets alone. This helmet may then also have been furnished with a leather covering. In Mariupol, Ukraine, the use of boar tusks on organic caps as head protection might already have been developed during the Neolithic. ${ }^{307}$ Rectangular boar tusk plates were found upon the skull, breast and knees of skeletons. The plates were arranged horizontally rather than vertically, as on the later Aegean boar tusk helmets. Contemporary boar tusk blades are also known from graves from the Cortaillod culture in Chamblandes, Switzerland. ${ }^{308}$

Bronze sheet fragments from Lakkithra (Grave $\Delta$ ), which resemble the ones from Kallithea, were, as were the fragments from Tiryns, interpreted as parts of bronze or organic cuirasses. ${ }^{309}$ However, we now know, thanks to the benefit of more recent finds that the fragments from Kallithea and Lakkithra most likely belong to tiara-like helmets or headgear (also known as 'feather crown', or 'feather-headgear'). A good example of such a helmet is that from the tholosgrave at Praisos-Foutoula, which is dated to c. $1200 \mathrm{BC} .{ }^{310}$ The cylindrical helmet is bucketshaped and decorated with alternating single, horizontal ribs of rows and ornamental rivets. Another, $16 \mathrm{~cm}$ high, similar head gear is known from a grave in Portes-Kephalovryson (1200-

\footnotetext{
302 de Marinis et al. $(2009,148)$ originally noted that these fragments might potentially belong to a helmet.

303 de Marinis 2016; Gambari et al. 2017.

304 Lilliu 1966; Borchhardt 1972.

305 Borchhardt 1972.

306 Perini 1987, 190.

307 Makarenko 1934, 135-153, figs. 11, 15.

308 Twelve plates in three rows with holes on each end, found under the skull, see Borchhardt 1972, 29.

309 Paulík 1968, 54, fig. 8.1; Schauer 1982d, 126-127. See also Chapter 3.6.

310 Deger-Jalkotzy 2006, 714.
} 
$1100 \mathrm{BC}){ }^{311}$ The head gear has a cylindrical shape with an oval section and straight sides. It is decorated with bronze strips with horizontal ribs alternating with horizontal lines of ornamental rivets. Both ends of the helmet bear wider bronze bands with relief ridges at the edges. ${ }^{312}$ The 16 strips and the rivets were fixed to an internal head gear made of tightly knitted straw. ${ }^{313}$ Depictions of such headgear are e.g. known from captured sea people (mainly Peleset) and fighting sea people from both the land and sea battles from the Medinet Habu frieses. An organic cap was worn under the bucket-shaped bronze sheet band. On the top of the helmet, all along the bronze sheet band, different organic materials could be applied, such as feathers, or reed.

Catalogue

Cat. no. 59. Szczecin-Zdroje (Finkenwalde or Stettin), woj. Zachodniopomorskie, Poland single river find (river Oder) - complete - height: $13.5 \mathrm{~cm}$ (cap), $4 \mathrm{~cm}$ (socket); diameter. $19.5 \times$ $21.3 \mathrm{~cm}$; thickness: $1-1.2 \mathrm{~mm}$ (rim); $0.2-0.3 \mathrm{~cm}$ (calotte); weight: $646-649 \mathrm{~g}$. Museum für Vorund Frühgeschichte Berlin, inv. no. Ic 3669 - Pl. 9.59. References: Schuchhardt 1912/1913; Sprockhoff 1926, 292; Sprockhoff 1930, 44; v. Merhart 1941, 23, fig. 8.4; Hencken 1971, 157158, fig. 127; Schauer 1988, 193, fig. 9; Albrecht 1991; Born - Hoffmann 1992; Born - Hansen 2001, 74, fig. 59; Clausing 2001, 217; Menghin - Hänsel 1997, 132 (with fig.).

The helmet was found in the river Oder in 1909 and brought to the museum in Berlin in 1910. Further finds include a bronze sword and a spearhead with 'silver or copper inlays', but they might not be associated with the helmet. ${ }^{314}$

Cat. no. 60. Fiavé-Carera, Trentino-Alto Adige, Italy - settlement find - complete. Measurements: $21 \mathrm{~cm}$; diameter: $21.5 \mathrm{~cm}$; outer diameter: $26 \mathrm{~cm}$; diameter spruce: $15 \times 8 \mathrm{~mm}$; diameter snowball bush: $12 \times 2 \mathrm{~mm}$; diameter reed cord: average $4 \mathrm{~mm}$. Museo delle Palafitte del Lago di Ledro, inv. no. FpC 75.454 - Pl. 9.60. References: Bill 1979, 98, fig. 1; Perini 1987, 190, 360361, figs. 76-78, 178, pl. XXXIII; Perini 1990, 253-265; Born - Hansen 2001, 60, fig. 54.

The organic helmet or head protection was recovered from the Early to Middle Bronze Age settlement of Fiavé-Carera, Italy.

Cat. no. 61. Malpensa, reg. Lombardia, Italy - associated deposit (?) - fragments of a helmet. Measurements: $9 \times 4.6 \mathrm{~cm}$ (inv. no. 21.885); $10.2 \times 8.6 \mathrm{~cm}$ (inv. no. 25.820); $10.5 \times 7$ (inv. no. 25.821); $6.4 \times 3.3 \mathrm{~cm}$ (inv. no. 25.823 ); thickness: $0.1 \mathrm{~cm}$; weight: $240 \mathrm{~g}$. Museo Civico Archeologico di Varese, inv. nos. 21.885, 25.820, 25.821, 25.823. References: de Marinis 1979, 511-514; Mira-Bonomi 1979, 125; Mozsolics 1985; de Marinis 1988, 161-163; Peroni 1989, 88, 278; Hansen 1994, 14; Clausing 2002, 155; de Marinis 2009, 148-154; de Marinis 2016, figs. 13-17; Gambari et al. 2017, figs. 2-17.

The associated deposit contained three greaves (cat. nos. 160-161, 179), ingots and ingot fragments, three spearheads and a fragment of further spearhead, two axes and a further axe fragment, two sickles and further fragment, and fragments of bronze sheet recently confirmed as a helmet.

\subsubsection{Cheek Plates}

Hencken was the first to discuss Bronze Age cheek plates. ${ }^{315}$ He distinguished two basic shapes amongst the Minoan-Mycenaean sphere, which differ from the U-shaped cheek plates known

\footnotetext{
311 Moschos 2009, figs. 1-2.

312 Cf. Mödlinger 2014b, 28.

313 Papadopoulos 1999, pl. LIXb; Kolonas 2001, 260.

314 Riemer 1997, 132.

315 Hencken 1971, 179-182.
} 
from the Near East (e.g. Boghazköy). Hencken's Type 1, which has its origin amongst the Minoan-Mycenaean world, is triangular in shape with more or less curved sides and a small projection. This type of cheek plate can be connected with the boar tusk helmets. Several depictions on helmets of apparently different materials, are known from the middle and late Mycenaean period. ${ }^{316}$ The finds from the Carpathian Basin, as well as from Middle Europe, were related by Hencken to this type and dated to Bz D-Ha A2 (Weißig, Schmiedehausen). Hencken's Type 2 has a similar shape as Type 1 but incorporates an additional projection to protect the cheekbone and jaw. Type 2 is known from LM II or the $15^{\text {th }}$ century BC onwards, mainly in combination with boar tusk helmets and 'conical bell helmets', as known from Aegean graves and depictions. ${ }^{317}$ Their use may have lasted until the $11^{\text {th }}$ century BC, as the cheek plate from grave 28 in Tiryns suggests. Borchhardt divided Bronze Age cheek plates into four different groups, represented by his Type I-IV. ${ }^{318}$ Type I has a projection to protect the cheekbone (Knossos, Dendra, Tiryns, Hagia Triada and Wöllersdorf), Type II is decorated (A: Pass Lueg, Agros; B: Boğazköy), Type III has pointed ends and a parallel step to the edge (Ialysos, Weißig, Schmiedehausen; Katsamba, Isopata, Mykenai), and Type IV has a rounded edge (Altin Tepe).

More recently, K. Peschel distinguished three different types of cheek plates, ${ }^{319}$ with Type A having a double bowed front edge (depictions: Pylos, Hagia Triada; ${ }^{320}$ finds: Knossos, Dendra, (Mycenae), Tiryns), Type B a single bowed front edge (depictions: Keos, ${ }^{321}$ Katsamba, Isopata, ${ }^{322}$ Mycenae; finds: Ialysos, Lueg, Podcrakavlje-Slavonski Brod, Weißig, Schmiedehausen), and Type C having a single bowed front edge and raised middle part (finds: Wöllersdorf, Uioara de Sus). Schauer mentions a cheek plate and further fragments of helmets from the deposit of Brodski Varoš. ${ }^{323}$ However, the rectangular edges of these bronze sheets, as well as their decoration, does not resemble any of the other known cheek plates.

The very few surviving bronze cheek plates compared to the relatively high number of preserved bronze helmets might suggest a greater use of organic cheek plates, ${ }^{324}$ perhaps attached not to the helmet but to the organic inlay of the helmets. The conspicuous absence of bronze cheek plates might also suggest that they were purposefully separated before deposition. Some helmets, however, clearly did not incorporate cheek plates at all, such as those of Type Biebesheim, which appear to have used only a chin strap. Presently, six helmets with cheek plates are known, comprising a helmet of Type Lueg from Pass Lueg (cat. no. 83), the helmets of Type Paks from Žiar nad Hronom (cat. no. 16), and one unprovenanced helmet (cat. no. 21). The boar tusk helmet from Dendra, the helmet from Knossos, and the helmet from Tiryns, also have bronze cheek plates. Clearly, bronze cheek plates are not exclusively associated with helmets only produced in bronze, and were compatible with both bronze and organic helmets. On all the above named helmets both cheek plates were preserved. The 'bronze collar' from Kourion-Kaloriziki was recently identified during a new evaluation of the bronze sheets as comprising two cheek plates (cat. no. 64). ${ }^{325}$ However, the interpretation of the bronze bands found in the same grave as coming from a helmet, to which the cheek plates belonged, ${ }^{326}$ can be questioned, since holes for attaching these bands to the organic cap of the helmet would certainly have to be more numerous than they are and positioned closer to the inner rim. The grave is the

\footnotetext{
316 Katsamba, Crete: LH II/1450-1400 BC (Hencken 1971, fig. 3d); Megaron-frieze at Mycenae (Hencken 1971, fig. 9a).

317 Hencken 1971, 18, 179.

318 Borchhardt 1972, 72, fig. 6.

319 Peschel 1984, 71, fig. 7.

320 Hencken 1971, fig. 7c.

321 Caskey 1966, 375, pl. 90 b.

322 LH II/1450-1400 BC.

323 Schauer 1982b, 135; Schauer 2003, fig. 4.4.

324 Bartík 2009, 44.

325 Matthäus - Schumacher-Matthäus 2014.

326 Matthäus - Schumacher-Matthäus 2014, 69-70, figs. 21-22.
} 
oldest from the Kaloriziki cemetery, and is dated on the basis of the associated pottery to the beginning of the $11^{\text {th }}$ century BC and LC III. ${ }^{327}$

As well as those associated with helmets, several individual examples of cheek plates are also known. Unlike those from the Mediterranean area, most of the cheek plates from central and northern Europe have come from associated deposits, the only exception being if the associated deposit from Schmiedehausen is in fact a grave (cat. no. 65). Many of these cannot be associated with specific helmet types, but the relative date of the associated deposits and their associations can provide important clues as to their likely attribution. However, no cheek plates are known from western Europe. It is reasonable to assume that the decoration on the cheek plates is connected with the decoration on the helmet, as is suggested by the decoration on the five preserved helmets with cheek plates. Moreover, on the basis of similar shape, as well as the decoration, we can associate some of the single cheek plates with specific helmet types.

As indicated by both the chronological proximity and close morphological similarity between the cheek plates on the unprovenanced helmet (cat. no. 20) and the helmet from Žiar nad Hronom, the cheek plates from Wöllersdorf, Hočko Pohorje, Uioara de Sus, Újszőny/ Komárom and Mezőnyárád, can be associated with helmets of Type Paks. ${ }^{328}$

A close relationship between the cheek plate from the Bz D-Ha A2 associated deposit from Podcrkavlje-Slavonski Brod (cat. no. 67) ${ }^{329}$ with the only decorated crested helmet, the unprovenanced helmet cat. no. 100, which is related to the western European helmets of Type Biebesheim, seems reasonable, since both have wheel decoration of similar size. Except for the Bz D-Ha A1 greaves Type Lengyeltóti, armour with wheel decoration is unknown. Interestingly, the rim of the cheek plate is folded outwards.

The deposit (or possible grave) from Schmiedehausen was dated by C. Eckhart to around $1100 \mathrm{BC}$, as does Borchhardt. ${ }^{330}$ The fragment of cheek plate has two holes at one end to attach it to the helmet. On the other end at least one hole for the chin strap is visible. The two lines of pellets parallel to the rim suggest its production during $\mathrm{Bz} \mathrm{D}-\mathrm{Ha} \mathrm{A} 1,{ }^{331}$ and is most likely of local manufacture. ${ }^{332}$ Assuming similar decoration for both cheek plates and helmet, the only helmets with pellet decoration are those helmets similar to that from Szczecin-Zdroje. Other helmets with pellet decoration, such as those of Type Lueg, are significantly older, and in the case of the helmet from Tiryns, have a different form of cheek plate. An association with helmets of Type Biebesheim seems less likely since they are without decoration and appear to have been used with chin straps rather than cheek plates.

Dated variously to Bz D-Ha A1/late period III, the cheek plate from Weißig (cat. no. 66) was associated with helmets of Type Lueg ${ }^{333}$ and the cheek plate from Ialysos ${ }^{334}$ (cat. no. 62). The cheek plate from Weißig has two holes at the tip, perhaps used to secure the cord that attaches it to the helmet and also under the chin, or to be able to hang up the helmet. The two rivet holes for attaching the cheek plate to the helmet are spaced c. $6 \mathrm{~cm}$ apart. Apart from those from the Aegean, ${ }^{335}$ similar cheek plates are unknown. Establishing a relationship between the use of cheek plates with those helmets with more localised distributions, such as Type Biebesheim, or western European helmets in general, does not seem likely. All helmets of this type have a maximum of three rivet (?) holes positioned very close to one another on both sides of the helmet, immediately above the edge, which served more likely for the attachment of a chin strap (the only exception being the two unprovenanced helmets of Type Montbellet (cat. nos. 77 and 78),

327 Matthäus - Schumacher-Matthäus 2014, 54.

328 Mödlinger 2013b.

329 Vinski-Gasparini 1973, 217.

330 Eckhart 1962/1963, 301; Borchhardt 1972, 136.

331 Jockenhövel 1974, 39.

332 Peschel 1984, 72.

333 Kleemann 1941/1942.

334 Hood - de Jong 1952, 260.

335 Such as the cheek plate from Ialysos (LH IIIA) and in the depictions from Katsamba and Isopata (Borchhardt 1972, 72). 
the Type Mantes helmet from Mainz, and another unprovenanced helmet (cat. no. 100), related to Type Biebesheim). Helmets Type Paks also have a completely different type of cheek plate. It therefore seems more likely that the Weißig cheek plate belongs to an as yet unknown form of bronze or organic helmet.

Even though the chronological classification, the application of organic inlay and the method of attachment to the helmet is different from Aegean cheek plates, the similarities in shape and profile are obvious, and therefore point to influences from or development in the Aegean region.

\section{Catalogue}

\section{Cheek Plates of Helmets Type Paks}

See Section 2.1.2.

\section{Aegean Cheek Plates / Associated Ones}

Cat. no. 62. Ialysos, Greece - grave - fragment. Measurements: $17.5 \times 12.5 \mathrm{~cm}$; weight: $75 \mathrm{~g}-$ British Museum, inv. no. 36.1872.6-20.50 - Pl. 9.62. References: Walters 1899, 211, pl. XIII.I; Kukahn 1936, 2, 6; Lorimer 1950, 211, pl. 13.1; Hood - de Jong 1952, 258, note 70; Yalouris 1960, 55; Müller-Karpe 1962a, 271; Wace - Stubbings 1962, 515; Verdelis 1967, 43; Hencken 1971, 11, 26, fig. 9b; Müller-Karpe 1980, 774, no. 114.

The cheek plate was recovered from a group of Mycenaean tombs in 1872 by the British consul in Rhodes. It is heavily fragmented and severely corroded, and no pure metal survives. The cheek plate has small holes running parallel to the edges used to fix the organic inlay with twine, some of which is still preserved (Chapter 2.4, Fig. 2.50).

Cat. no. 63. Dendra, Peloponnese, Greece - grave 12 - complete. Measurements: $15.5 \times$ $10.5 \mathrm{~cm}$ - Archaeological Museum of Nafplion, inv. no. unknown - Pl. 9.63. References: Verdelis 1967, 42-44, suppl. 20.1-2; Borchhardt 1972, pl. 6; Mödlinger 2013a.

For further details on the find circumstances and the alleged grave associations, see cat. no. 123. The cheek plates have a similar shape as the one from Knossos but are a little broader and shorter. The left cheek plate consists of various fragments and repairs. The right cheek plate is missing almost the whole front area, but the rest is in somewhat better condition and not as corroded as the left cheek plate. Both cheek plates have small holes running parallel to the edge, which served to fix the organic inlay with twine, some of which is still preserved on the left cheek plate. ${ }^{336}$

Cat. no. 64. Kourion-Kaloriziki, Limassol, Cyprus - grave 40 - two fragmented cheek plates. Measurements: c. $17.2 \times 8 \mathrm{~cm}-$ Kourion Museum, Episkopi inv. no. unknown - Pl. 9.64. References: Mc Fadden 1954, 140, no. 35, pl. 26.35; Catling 1964, 143, no. e, pl. 17e; Benson 1973, 49-50; Bouzek 1988; Kytlicová 1988a; Bouzek 1997, 92, fig. 75; Matthäus - SchumacherMatthäus 2014, figs. 19-20.

The grave, dated to LC III, was discovered by robbers in 1903. Some of the finds were illegally sold but the police were able to rescue some, such as the golden sceptre. In 1953, McFadden undertook further excavations and discovered the shaft grave, which had been covered by a bench of sandstone, which is where the robbers had stopped, allowing for the recovery of further finds. On this bench were several ceramic vessels, a fragmented bronze cup, a bronze amphora covered with a sieve and fragments of a bronze wand or stick. The amphora contained the cremated remains of what was likely a female, along with a bronze ring, an amber bead, a golden pin, twelve small bow fibulae, and a small grind stone. In between this bench and the western wall of the shaft grave a ceramic oinochoe, an iron dagger, and several bronze fragments were documented. The robbed part of the grave also contained a further bronze spear-

336 Verdelis 1967, 43 . 
head. Another robbed bronze amphora allegedly covered with a sieve and containing a cremation, twelve gold sheets with rosette-motif, and more ceramic, is now lost. The preserved golden sceptre was found below (or perhaps inside?) the amphora. A small and a large bronze tripod were also stolen by the robbers but were rescued by the police. ${ }^{337}$

The grave is the oldest from the Kaloriziki cemetery, and demonstrates significant Aegean influence, as indicated by the double burial, the rite of cremation, the associated weapons, and the presence of older luxury objects. It can be connected with other tombs that show Aegean influence, such as grave 201-202 from the North Cemetery in Knossos, grave XXVIII in Tiryns, and the burials in the so-called Heroon at Lefkandi. ${ }^{338}$

The cheek plates had previously been misinterpreted as being a bronze collar, ${ }^{339}$ perhaps a consequence of all the fragments not being fully published until 2014. ${ }^{340}$

The holes along the rim of the cheek plates indicate the attachment of an organic lining to the inside face. Both cheek plates are similarly decorated with three rossettes with six leaves surrounded by a circle along the backside, and three smaller, similar ones on the front side, with each positioned relative to the chin, cheek bone and eye brow. The motifs are produced with pellet decoration. Larger pellets are randomly distributed in between the rosettes.

No similar cheek plates are known but from the region of the eastern Mediterranean, the largely contemporary helmet from Tiryns (cat. no. 120) provides a useful parallel. The cheek plates are the only reference to helmets from the transitionary period from the Late Bronze Age to the Early Iron Age on Cyprus.

Cat. no. 65. Weißig, Lkr. Meißen, Saxony, Germany - associated deposit - complete. Measurements: $13.3 \times 7-8.8 \mathrm{~cm}$; thickness: ca. $2 \mathrm{~mm}$; weight: $210,1 \mathrm{~g}-$ Staatliches Museum für Archäologie Chemnitz, inv. no. S113/43 - P1. 9.65. References: Kleemann 1941/1942, 74, 134, fig. 13; Hood - de Jong 1952, 260; Hencken 1971, 180, fig. 147b; Borchhardt 1972, 136, pl. 44.12; Peschel 1984; v. Brunn 1968, 74, 344, pl. 178.6. ${ }^{341}$

The associated deposit was found in 1853 during ploughing between Weißig and Leckwitz. The bronzes were found in a ceramic vessel, which is now lost. The associated deposit consists of ten fragments of sword blade(s), five spearheads, one cheek plate of a helmet, 13 complete and fragmented palstaves, 16 complete and broken winged axes, nine further fragments of axe, two small chisels, two fragments of twisted bronze, fragments of knives, a fragment of razor, more than 140 fragments of sickles, fragments of bronze cups, fragments of pins, fragments of foot rings, several different bronze sheet fragments, fragments from eight almost complete arm rings and bands, fragments of wire, fragments of one torque (?), fragments of ingot and sprue/ waster. In other collections, there are further fragments reputedly from the same associated deposit. ${ }^{342}$ In Bautzen there are eight sickles and associated fragments, in Berlin a fragment of pin, a winged axe and five further fragments, and sickles, in Freiberg a winged axe, a spearhead fragment, and sickles, in Görlitz and Leipzig there are sickles, in the British Museum a complete sickle and several fragments, in Zittau there is a fragment of a pin, and in a private collection a further pin.

The cheek plate from the right side of the helmet is slightly curved and the edges are bent over to hold the now missing organic inlay. On the upper part there are two holes to attach it to the helmet. Two further holes served to fix the chin strap.

\footnotetext{
Matthäus - Schumacher-Matthäus 2014.

Matthäus - Schumacher-Matthäus 2014.

Bouzek 1988; Kytlicová 1988a; Bouzek 1997, 92, fig. 75.

McFadden 1954, pl. 26.35; Catling 1964, pl. 17c; Matthäus - Schumacher-Matthäus 2014, figs. 19-20.

341 Older literature, mainly from the $19^{\text {th }}$ century, which discuss the associated deposit in general are noted by $\mathrm{v}$. Brunn 1968, 345.

342 v. Brunn 1968, 345.
} 


\section{Single Types of Cheek Plates}

Cat. no. 66. Schmiedehausen, Lkr. Weimarer Land, Thüringen, Germany - associated deposit or grave - right cheek plate. Measurements: $13.3 \times 7 \mathrm{~cm}$; thickness: $1 \mathrm{~mm}$; weight: $67 \mathrm{~g}-$ Vorgeschichtliches Museum der Friedrich-Schiller-Universität Jena, inv. no. III 55.255 - Pl. 9.66. References: Eichorn 1904, 132; Eckhart 1962/1963, 301, no. 6, pl. 30; Hencken 1971, 179, fig. 147a; Borchhardt 1972, 72, 136, fig. 6, pl. 44.3-4; Peschel 1984, 67-72, 83-85, fig. 5.1; v. Brunn 1959, 7.

H. Eichorn describes in 1904 a circle of elevated stones buried within a layer of ash, wherein the bronzes and a human jaw, now lost, were found sometime before 1897. ${ }^{343}$ The associated deposit presently consists of the cheek place, three bracelets and two neck rings. It was originally held by a private collection.

Cat. no. 67. Podcrkavlje-Slavonski Brod, Brodsko-posavska županija, Croatia - associated deposit - fragment of a cheek plate. Measurements: $10.2 \times 4.4 \mathrm{~cm}-$ Zemaljski Muzej Bosne e Hercegovina, inv. no. 3734 and 3730 - Pl. 9.67. References: Holste 1951, 6, pl. 8.27; Peroni 1956, 75, 88, 90; Vinski-Gasparini 1973, 217, pl. 66.37; Müller-Karpe 1980, 805, no. 314; Bouzek 1981, 25, note 19, fig. 4.3; Hansen 1994, 569, JU 220; Clausing 2002, 183, fig. 24.3; Kudelić 2007, 22; Karavanić 2009, 100, no. 37; 116-118.

The associated deposits from Podcrkavle, found in 1862 at 'Dvorišta', and Slavonski Brod ('Biliš'), were brought to the museum in 1868, and were probably mixed. This 'associated deposit' comprised 277 objects, including arm rings, buttons, discs, pins, fibulae, bronze sheets, pendants, wire, fragments of swords of Type Brodski Varoš, spearheads, daggers, socketed axes, knives, razors, saws, sickles and raw bronze. ${ }^{344}$

\subsubsection{Sockets of Other Helmet Types}

The sockets from Špălnaca (cat. no. 67) and Techirghiol (cat. no. 68) are entirely undecorated. On the basis of their shape they most likely came from helmets of Type Paks, though the lack of decoration might suggest their origin amongst another, as yet unknown type or variant of bronze helmet, or even organic head protection.

The top of the socket from Špălnaca is missing. The hole passes through the centre, and the shank is undecorated. The current location of the socket in unknown, for it is not in Bucharest, ${ }^{345}$ Gothenburg, Aiud or Budapest. ${ }^{346}$ A fragment of the socket of a helmet, as well as other possible fragments of another (?) helmet, are known from the Ha Al associated deposit from Techirghiol. ${ }^{347}$ The decoration on the three sheet fragments look similar to that found on the helmet of Szczecin-Zdroje. ${ }^{348}$ The socket is undecorated, and can be dated to Ha A1, ${ }^{349}$ only based on the associated deposit associations.

At Grepci in Bosnia-Herzegovina, an Early Iron Age deposit was recovered (cat. no. 70). Together with a bronze flange hilted sword, an iron spearhead, bronze ferrule, a bronze ring, a grindstone and an iron fragment, and the bronze knob of a helmet. The knob is riveted onto the cap with three flat headed rivets. On the inside, the rivets are additionally fixed with lining discs. The tubular shaft ends in an oval knob which is decorated with vertical lines of herringbone ornament. Only the parts of the cap attached to the knob are preserved. No human bone or cremation was found but the combination of objects reflects more the inventory of an Early Iron

343 Eichorn 1904, 132

344 Vinski-Gasparini 1973, 217, pls. 66-68.

345 Petrescu-Dîmboviţa (1978, 128-129) and pers. comm. G. Trohani.

346 Gothenburg: pers. comm. E.-B. Filipsson; Aiud: pers. comm. P. Scrobotă; Budapest: pers. comm. I. Szathmári.

347 Aricescu 1965, 25, fig. 5, 12-14.

348 Petrescu-Dîmbovița 1978, pl. 215.17-19.

349 Hencken 1971, 160, fig. 130.5. 
Age grave than it does an associated non-sepulchral deposit, and it is therefore possible that the human remains were overlooked during the building of the new church and its cemetery.

Catalogue

Cat. no. 68. Špălnaca, jud. Alba, Romania - associated deposit - fragment of a possible socket - height: $5.4 \mathrm{~cm}$; diameter: $1.8 \mathrm{~cm}$ (shaft). Muzeul de Istorie Aiud, inv. no. 312.314 - Pl. 9.68 . References: Dumitrescu 1938, 221, fig. 15.4; Hencken 1971, 160, fig. 129; Petrescu-Dîmboviţa 1978, 127, no. 177, pl. 157.614; Bader 1983, 33, nos. 16-17; Bader 1991, 123, nos. 315-316; Hansen 1994, 593, RO 425; Clausing 2001, 214; Soroçeanu 2008, 37, no. 2.

The associated deposit was found by Matei Nandru during fieldwork in the area of 'Dudău' in August 1887.350 The bronzes were buried approximately $60 \mathrm{~cm}$ deep in the soil, in a pit some $110 \mathrm{~cm}$ in diameter, and there may have been an ash layer at the base of the pit. The total weight was perhaps $1-1.2$ tons. The associated deposit was bought by the museum for 1.400 Lei in 1888. Already it was noted that a large part of the associated deposit had disappeared. ${ }^{351}$ The associated deposit was formerly kept at the Muzeul National de Istorie Romaniei. Today, it is stored in a number of different museums, in Aiud, Bucharest, Cluj, Deva and Budapest. At the museum in Bucharest, it was recored under the inventory numbers 98-107, and listed more than 530 objects. Most of these objects could no longer be located as early as the $1930 \mathrm{~s}^{352}$ In 1958, just 501 objects of the 1058 originally listed were found to still be present in Budapest. ${ }^{353}$

Cat. no. 69. Techirghiol, jud. Constanța, Romania - associated deposit - fragments of a possible socket. Measurements: c. $5 \times 2.7 \mathrm{~cm}$. Muzeul de Arheologie Constanța, inv. no. 533-537 Pl. 9.69. References: Rusu 1963, 187; Aricescu 1965, 24, fig. 5.15; Aricescu 1970, 32; Hencken 1971, 160, fig. 130; Petrescu-Dîmboviţa 1978, 136, no. 192, pl. 215.A16-A19; Rusu 1990, 76, pl. II.4, 10; Bader 1991, 83, no. 135.

The associated deposit was found on the side of a little hill close to a lake in 1959. It was recovered at a depth of approximately $70 \mathrm{~cm}$. The associated deposit had a total weight of about $2.4 \mathrm{~kg}$ and consisted of 28 objects, including ten sickles, three socketed axes, sword fragments, four casting cakes fragments, sheet fragments, the possible socket of a helmet.

Cat. no. 70. Grepci, Bosnia-Herzegovina - associated deposit/grave (?) - knob - diameter base: $6 \mathrm{~cm}$; diameter top: $1.8 \mathrm{~cm}$; diameter shaft: $0.7 \mathrm{~cm}$; height: $4.4 \mathrm{~cm}$; weight: $72 \mathrm{~g}-$ Franjevački muzej i galerija Livno, no inv. no. - Pl. 9.70. References: Marijan 1995, 54, no. 4, pls. 1.4; 2.4; Clausing 2001, 207, fig. 5.

The associated deposit or grave find from Grepci consists of bronzes and an iron spearhead. The helmet might represent a relic or antique of the Bronze Age.

\subsubsection{Possible Fragments of Helmets}

The Bz D-Ha A1 associated deposit from Bizovac, Croatia, was discovered in 1895. The 333 bronzes were placed inside a ceramic vessel, including the potential helmet fragment, fragments from a situla of Type Kurd, decorated discs, sword fragments, daggers, spearheads, saws, socketed axes, bracelets, sickles, casting cakes, and more. ${ }^{354}$ Clausing rejects the fragment as being from a helmet, apparently following Mozsolics who suggested it was more likely a fragment of

\footnotetext{
350 Kossack 1954, 17; Rusu 1963, 184; Berciu 1966, 43.

351 Dumitrescu 1938, 195

352 Dumitrescu 1938, 195.

353 Petrescu-Dîmbovița 1978, 129.

354 Hansen 1994, 560, JU 19; Karavanić 2009, 95, no. 5; Mörtz 2011a, 368.
} 
a cuirass. ${ }^{355}$ The c. $12 \times 12 \mathrm{~cm}$ fragment has a rim with a parallel row of holes, positioned roughly $1 \mathrm{~cm}$ away from each other. ${ }^{356}$ The fragmentary decoration, and two ribs with cord-like impressions parallel to rim, is unknown on other helmets. ${ }^{357}$

A small bronze fragment from the Bz D-Ha Al associated deposit of Poljanci IV, Croatia, might also derive from a helmet (Brodsko Posavlje Muzej Slavonski Brod, inv. no. A-4032). The $6.5 \times 3.3 \mathrm{~cm}$ fragment has one rivet and clear traces of hammering on both sides. ${ }^{358}$ On the outside, a black band of corrosion is visible, as known from other helmets, such as the helmet of Type Pişcolt from Mezökövesd, indicating the original presence of organic material positioned against the bronze.

The small number of associated finds in graves from the cemetery of Volders is attributable to a several reasons, including the generally reduced number of grave goods used during this period, the use of the 'ustrina' funeral process ('ustrina' indicates the site of a historical funeral pyre, which is not identical with the position of the grave), as well as the nature of the excavation itself (with most of the graves having been opened from the side, rather than from above, and only the core of the grave, such as the urn and content of the stone lining, being documented). We also have to consider the possibility that the remains of later burials were interned in earlier graves. ${ }^{359}$ Grave 322 contains only objects, which had been included in the cremation process, such as a metal hilted sword of Type Wörschach, a fragment of a double-edged razor, an astragalus and five sherds of three bowls. The fragments most likely belonging to defensive armour are the three small, deformed and partially molten bronze sheets, having a bent edge and decorated with several small bosses and one large big boss measuring $28 \mathrm{~mm}$ in diameter. Whilst the greaves from Canosa (cat. nos. 193-194), have similar but smaller bosses, and the helmets of Type Biebesheim, such as those from Blainville, Paris, Montmacq A and Chalonsur-Saône, have the same large single boss decoration, there are no more exact parallels.

A further potential helmet fragment is known from an early Ha B1 grave from Acholshausen, Germany. ${ }^{360}$ The fragment, which was burnt during the funeral, consists of a large bronze cone with a slightly rectangular shaped shaft base, which was most likely cast on a metal sheet. However, similar sockets are unknown, though the vertical ribs on the whole shaft suggest a possible relationship with the sockets on the helmets of Type Pişcolt. If the object is indeed a socket, it is of an as yet unknown helmet type.

The associated deposit of Pila del Brancon, Italy, was found in 1993 during agricultural work $1.5 \mathrm{~km}$ to the south of the Middle Bronze Age cemetery of Olmo, on the bank of the river Tartaro. ${ }^{361}$ It is very possible that the deposit was not completely recovered. Presently, it consists of 51 spearheads and fragments, ten swords and fragments, including Type Allerona, Type Cetona and Type Arco, two daggers of Type Santa Agata and Pertosa, 28 spearheads, one fragment of a winged axe, 73 bronze sheet fragments, and nails. The associated deposit is dated to c. 1200 BC. ${ }^{362}$ All objects appear to have been intentionally destroyed, bent or broken and exposed to fire. K. Jankovits interprets most of the bronze sheet fragments as the remnants of defensive armour, including helmet, cuirass and greaves, as does Bietti Sestieri and colleagues. ${ }^{363}$ The potential helmet of Type Pişcolt fragment (VR 26.605) has six holes running parallel to the rim. ${ }^{364}$ The rivet holes were punched through using a ring die, which is rather unlikely for helmets of Type Pişcolt. The fragment has a smooth, natural edge or rim on the left side, clearly indicating that it could not have come from a helmet (the cap of helmets of Type

\footnotetext{
355 Mozsolics 1985, 26; Clausing 2001, 208.

356 Vinski-Gasparini 1973, 212, pl. 35.13.

357 Schauer 2003, 197, fig. 4.2.

358 Miklik-Lozuk 2004, 32, pl. 8.5; Miklik-Lozuk 2009, 47, 109, cat. no. 263.

359 Sperber 2011, 7.

360 Schauer 1982a, 341; Wilbertz 1982, pls. 54-61; Sperber 2011, 25-26, fig. 9.1; Bietti Sestieri et al. 2013.

361 Salzani 1994; Salzani 1998.

362 Bietti Sestieri et al. 2013.

363 Jankovits 1999/2000, 189; Bietti Sestieri et al. 2013.

364 Jankovits 1999/2000, fig. 1.1.
} 
Pişcolt is made out of one single bronze sheet). One of the sheet fragments has decorative elements (consisting of two circles made out of pellet decoration with central boss) similar to other body armour, such as the helmets from Tyrins, Pass Lueg and Szczecin-Zdroje, as well as the cuirasses from the Danube (cat. no. 134) and Jura (cat. no. 138). Other bronze sheets with the same motif derive from Salaš Noćajski, Serbia, ${ }^{365}$ Guşteriţa, Romania, ${ }^{366}$ Dresden-Dobritz, Germany, ${ }^{367}$ and from an Iron Age devotion from Sicily. ${ }^{368}$ The fragment from Pila del Brancon does not have any original rim or edge surviving, making it almost impossible to reconstruct or discern its relation to any original form.

The associated deposit from Suseni (Gyergyóújfalu), Romania, was found in 1924. The bronzes have been placed inside a ceramic vessel. The associated deposit consists of ten axes, 15 sickles and a further 11 fragments, four knives, one bronze vessel, seven fragments of sword blade(s), eight fragments of spearhead, 32 arm rings and related fragments, a fragment of a pin, seven Posamenterie-fibulae and associated fragments, a button, eleven fragments of a bronze belt, one socket (?), one bronze object with two nails (?), three fragments of raw bronze, a gold wire measuring $15 \mathrm{~cm}$, and one gold pearl (?) which was sold. ${ }^{369}$ The possible fragment of a helmet (stored at the Muzeul de Arheologie - Istorie in Târgu Mureş: inv. nos. 53 and 73) is a bronze sheet with three ribs parallel to the edge, similar to the fragments from Uioara de Sus but without any rivet holes running parallel to the edge. ${ }^{370}$ It remains uncertain if the bronze sheet was without doubt part of a helmet.

The associated deposit from Uioara de Sus (Felső-Marosujvár), Romania, was found in 1909 during excavations after an axe had appeared during ploughing. The associated deposit weighs approximately 1.1 tons, and consists of some 5812 objects, which had been buried in a $1.2 \mathrm{~m}$ deep pit with a diameter of $1.5 \mathrm{~m}$. After the excavation, further pieces of rough bronze, as well as a piece of pure tin, were found. ${ }^{371}$ The associated deposit was bought by the Muzeul de istorie, Cluj. Some objects from the same associated deposit are today in the museum in Gothenburg. Petrescu-Dîmboviţa mentions nine fragments of helmet and seven fragments of cuirass. ${ }^{372}$ Rusu notes that one of the fragments is similar to the helmets from Škocjan and Tarquinia. ${ }^{373} \mathrm{He}$ also suggests that several other bronze sheet fragments are from helmets. ${ }^{374}$ However, based on the nature of the decoration, as well as the narrow distance between the rivet (?) holes, this seems very unlikely.

\subsubsection{Bronze Objects Formerly Interpreted as Fragments or Sockets of Helmets}

Bronze sheet fragments with parallel ribs and parallel rows of large bosses have often been interpreted as coming from helmets. This includes fragments from Brodski Varoš, Croatia, ${ }^{375}$ Debeli Vrh, Slovenia, ${ }^{376}$ Mačkovac-Crišnjevi, Croatia, ${ }^{377}$ Vrsač-Majdan, Serbia, ${ }^{378}$

\footnotetext{
365 Vasić 1994, pl. 38.13.

366 Bronze sheet fragment: Rusu 1990, 73, pl. V.5.

367 Bronze cup: Martin 2009, pl. 30.119.

368 Egg 1983, fig. 2.4-5.

369 Petrescu-Dîmboviţa 1977, 107.

370 Rusu 1963, 184, 208; Rusu 1990, 76, pls. I.1; IV.2.

371 Petrescu-Dîmbovița 1978, 132.

372 Petrescu-Dîmboviţa 1978, pl. 198.1023-1030 (potential helmet fragments), pl. 198.1031-1033 (potential cuirass fragments).

373 Rusu 1990, 76.

374 Rusu 1990, pl. II.11-15, 17-23 = inv. no. III 6025; III 7526; III 5795; III 5997; III 7413; III 7448. Rusu notes furthermore three sockets (?): one cylindrical, one tubular and one with a ribbed cross section (inv. no. III 6158, III 6154 and III 6178) from the same deposit (Rusu 1990, 76, pl. II.2-3). However, these sockets do not resemble those found on any helmet, which are much smaller.

375 Vinski-Gasparini 1973, 95, 212, pl. 57.2; Schauer 2003, fig. 3.9-13.

376 Čerče - Šinkovec 1995b, 159, 168, pls. 66.79; 152.18; Karavanić 2009, 117.

377 Karavanić 2006, fig. 6; Karavanić 2009, 118.

378 Rusu 1990, 77, note 26, pl. IV.5.
} 
Keszőhidegkút, Hungary, ${ }^{379}$ Bonyhad, Hungary, and Rinyaszentkirály, Hungary. ${ }^{380}$ Compared with the similar bronze sheets from Nadap, Hungary, ${ }^{381}$ it is clear that these actually belong to belt plates.

Further objects interpreted as parts of (organic) helmets are cast, hollow sockets. They usually have an oval, hollow base, which can also be stepped and ridged along its length, from the smaller end from the base to the socket, and a round, thin and long socket on top. Some of them still contain wires with a quadratic cross-section, which are usually bent inside. An unequivocal interpretation of their use, however, is still lacking. They might have served as parts of chariots or as metal end of organic helmets, as Paulík suggests, ${ }^{382}$ though the latter still lacks important associational evidence. Examples are known from Služín, Czech Republic, ${ }^{383}$ Polešovice, Czech Republic, ${ }^{384}$ Kisterenye, Hungary (Magyar Nemzeti Múzeum), Mušov 2, Czech Republic, ${ }^{385}$ Přestavlky, Czech Republic, ${ }^{386}$ Poljanci I, Croatia, ${ }^{387}$ and Mačkovac-Crišnjevi, Croatia. ${ }^{388}$

Mozsolics notes that three plane, $>1-2 \mathrm{~mm}$ thick fragments from the associated deposit from Szentgáloskér (Kurd horizon BVb/Ha A1), might belong to a helmet or vessel. ${ }^{389}$ Instead, they seem to be the unfinished work in the manufacture of bronze sheets for the production of a much larger bronze sheet object. The associated deposit is stored at the Magyar Nemzeti Múzeum, Hungary (inv. nos. 4/1886/100-101, 103).

The associated deposit from Jászkarajenő was found in a field in a ceramic pot. From the 227 pieces recovered just 162 are listed in the inventory of the Magyar Nemzeti Múzeum, meaning that some one third of the associated deposit is now lost. The associated deposit, which is associated with the Gyermely horizon $\mathrm{BVc} / \mathrm{Ha} \mathrm{A} 1,390$ contains fragments of a vessel and no helmet (inv. no. 16/1933/149-150). ${ }^{391}$

The associated deposit from Dolné Janíky, Slovakia, was found in 1963 at a depth of $50 \mathrm{~cm}$ in a ceramic vessel during ploughing. ${ }^{392}$ It is possible that the associated deposit was not recovered completely. Currently, the associated deposit comprises a saw, an anvil, two belt buckles, a possible socket from a leather (?) helmet, several fragments of tools and jewellery, two possible gravers for making arm rings, and a melted fragment of bronze. Paulík compares the possible socket (height: $3.2 \mathrm{~cm}$; diameter $1-3 \mathrm{~cm}$ ) with the one from Straßengel as well as other tubeapplications from the Velatice culture. ${ }^{393}$ However, it bears no similarity to confirmed helmet sockets. The object is stored at the Archeologický ústav SAV in Nitra, Slovakia (unknown inv. no.).

M. Rind and Schauer published the fragments from Abensberg as potential helmet fragments. ${ }^{394}$ However, the rim is surrounded by a kind of metal fastener and fixed with a flat-headed rivet. Further fragments have an inwards bent rim, shaped as if to surround a wire (the latter missing?). Due to the fact that the find is not consistent with the form of other helmets, and its provenance uncertain, having been recovered illegally by a metal detectorist, it cannot be securely dated to the Bronze Age.

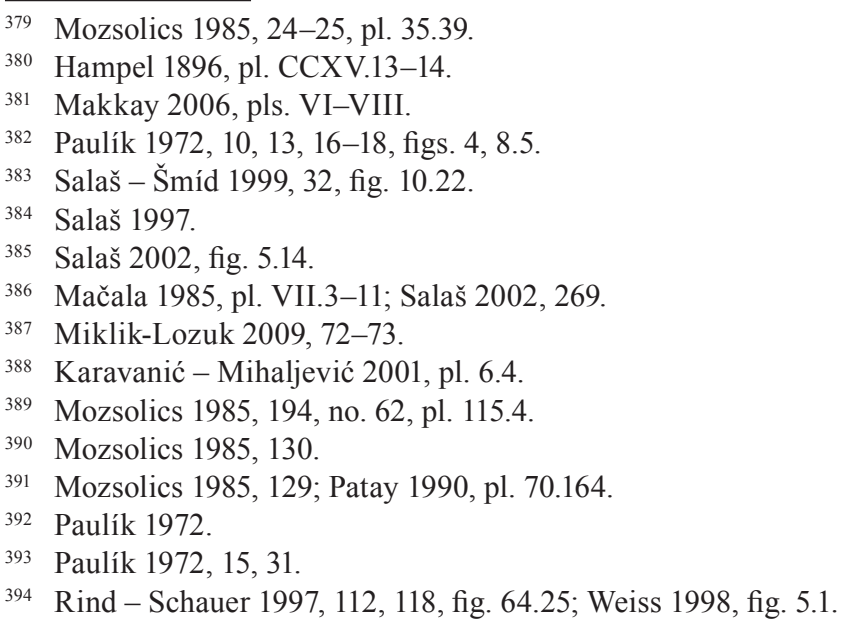


The potential socket of a helmet from the $\mathrm{Bz}$ D-Ha A associated deposit from Mixnitz, Austria ${ }^{395}$ held at the Universalmuseum Joanneum (inv. no. 22.593 (1158)), might in fact be part of a chariot, a similar example of which is known from Staudach. ${ }^{396}$ The fragment from Mixnitz has a rather short socket, a wide hole and is formed from sheet metal rather than cast, as other sockets and knobs are.

A potential fragment of a helmet from an associated deposit from the Rabenwand bei Bad Aussee, Austria, more closely resembles the head of a pin than the socket or knob of a helmet. ${ }^{397}$ The fragment is stored at the Kammerhofmuseum Bad Aussee, Austria (unknown inv. no.).

S. A. Luca and A. Georgescu mention a possible fragment of a helmet found in Ciceu-Corabia, Romania. ${ }^{398}$ The associated deposit was found in 1968 in a Ha B settlement. The contents of the associated deposit had been placed in a ceramic vessel. Earlier, G. Marinescu had suggested that the fragments were from a helmet and a cuirass. ${ }^{399}$ However, none of the fragments resemble any known cuirass or helmet.

Rusu notes a possible fragment of a helmet in the associated deposit from Băleni, Romania, but provides neither photograph nor drawing of the relevant fragment. ${ }^{400}$ Petrescu-Dîmboviţa has described the deposit but here no bronze fragment, which might be part of a helmet, can be identified, though a socket-like object is depicted, as is a bronze sheet with narrow holes parallel to the edge, and a double (finger?) ring. ${ }^{401}$ None of these objects has any similarity with other known helmets. It appears unlikely that the associated deposit contains a fragment of a helmet. The associated deposit is stored at the Muzeul de Istorie Galaţi, Romania (inv. no. 7.393-427).

The associated deposit from Cincu, Romania, was discovered in 1888 in a field. ${ }^{402}$ The fragment interpreted by Rusu as a part of a helmet ${ }^{403}$ seems more likely to be part of a belt. The ribs and dots arranged in a single row in the middle of the 'helmet', as well as the single pellet and roundel, does not have any parallels amongst known helmets. The fragment is stored at the Muzeul National Brukenthal in Sibiu, Romania (inv. no. A $4750=12.066$ ).

The associated deposit from Dipşa, Romania, was found close to 'La Buturugi' in the southeast of the village in 1911, and contained around 406 objects. ${ }^{404}$ According to that listed by $\mathrm{H}$. Ciugudean and colleagues ${ }^{405}$ the associated deposit contains 138 sickles, 46 axes (39 of them socketed axes), six socketed hammers and anvils, nine fragmented knives, 16 saw blades, four chisels, eight fragments of swords of types Uriu/Aranyos and Reutlingen, ten daggers, seven spearheads, a disc-butted axe, 23 bracelets of different types, three fibula fragments, four neck rings, six pendants, an ornamented belt, two buttons, 36 fragments of bronze sheet from vessels, including at least two cups, cauldrons or situlae, seven bronze bars, and 262 ingots. The total weight of the associated deposit is about $72.8 \mathrm{~kg}$ of bronze. The alloy composition of 49 of the objects were studied by XRF by T. Kienlin and E. Pernicka. ${ }^{406}$ Petrescu-Dîmboviţa depicts a conical, funnel-like bronze object from the associated deposit, which was interpreted by Rusu as the possible knob of a helmet ${ }^{407}$ but which seems more likely to be a casting sprue or waster. Petrescu-Dîmboviţa does not depict the other fragments from the associated deposit, which were interpreted by Rusu as parts of a helmet. ${ }^{408}$ These fragments are also not mentioned by

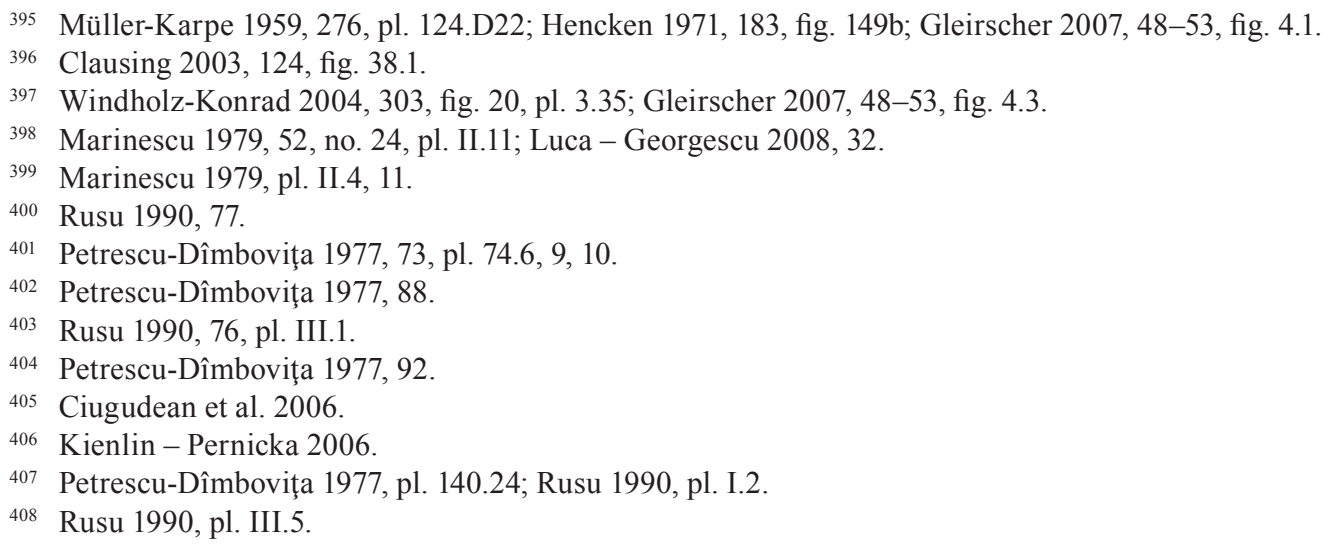


Ciugudean and colleagues. ${ }^{409}$ The reconstruction of the possible helmet by Rusu can be doubted based on the lack of any scale and in having no equivalents amongst known helmets. ${ }^{410}$ The fragments concerned are stored at the Muzeul National Brukenthal in Sibiu, Romania (inv. no. A 5718-19).

The Ha A associated deposit from Slatioara-Sacoţi, Romania, was found at a depth of $50 \mathrm{~cm}$ in August 1959. ${ }^{411}$ A ceramic vessel was found to hold five axes and axe fragments, two spearheads, five sickles and associated fragments, two neck rings, two fragments of knives, 21 bracelets, a bar (?), two spirals, casting cake, a fibula, an unidentified bronze object, and a decorated bronze sheet interpreted as a spiral arm guard by I. Nania and S. Holtei ${ }^{412}$ Both ends of this 6.4 $\times 3.1 \mathrm{~cm}$ bronze sheet fragment are bent around a wire, and instead was interpreted by Rusu as a helmet. ${ }^{413}$ However, the decoration on the fragment has no equivalent amongst known helmets. It seems more likely that the fragment is from a belt. The fragment is stored at the Muzeul Judeţean Argeş, Romania (inv. no. 1298; 1323).

With the exception of helmets, discs or cups, other sheet bronze objects decorated with a star motif are extremely rare, being represented only by a fragment from Sacoţi, Romania. The fragment is flat, and not bent as suggested by the sketch of Rusu, and therefore unlikely to be from a helmet.

The second deposit from Vîlcele, Romania, was found sometime before 1982. The associated deposit consists of 51 bronze objects and has a total weight of $2.4 \mathrm{~kg}$. The associated deposit was stored in a ceramic vessel and consists of a fragment of a fibula, six arm rings and related fragments, one or two spirals, an ingot, a spearhead and socket fragment, five axes and axe fragments, a blade fragment, 18 sickles and related fragments, a fragment of a knife, a fragment of twisted wire, a loop, a bronze bar, a possible fragment of a neck ring, a possible fragment of an arm ring, a fragment of a pin, three casting cakes, and a decorated bronze sheet. ${ }^{414}$ Rusu interprets one sheet fragment (Muzeul de Istorie Cluj, Romania, inv. no. 67.799; ANr. 48) as coming from a helmet, which he compares with the helmet from Fermo, Italy. ${ }^{415}$ However, the fragment is flat and the decoration is unlike that on any known helmet, and seems more likely to derive from a belt plate. ${ }^{416}$

\subsubsection{Outlook to the Iron Age: Italian Cap Helmets}

Italian Bronze Age metal helmets are rare, currently comprised of just the five helmets from Iseo, Oggiono-Ello, Brancere, 'Mantua' and 'Monte Altino'. The remaining bronze helmets from Italy all date to the Iron Age or prima età del ferro (Tab. 2.8). The details of the latter will be briefly discussed. Eight bronze helmets with decorated cap and cast-on or riveted on knob, as well as five decorated cap helmets without knob, derive mainly from the central Italian necropolis of Tarquinia, Populonia, Fermo and Veii.

Two cap helmets with knob are unprovenanced, and are lacking information concerning find spot and context. One of these, which is presently held in Karlsruhe, might derive from Tarquinia. The second was recently sold at Hermann Historica on 6 November 2013 and again, having been restored, on 5 November 2014. On 30 October 2015 it was put up for auction once again, but not sold (Fig. 2.13.8). ${ }^{417}$ The find location was not listed at either sale. Fragments belonging to potential decorated Italian cap helmets are also known from Škocjan (Fig. 2.14).

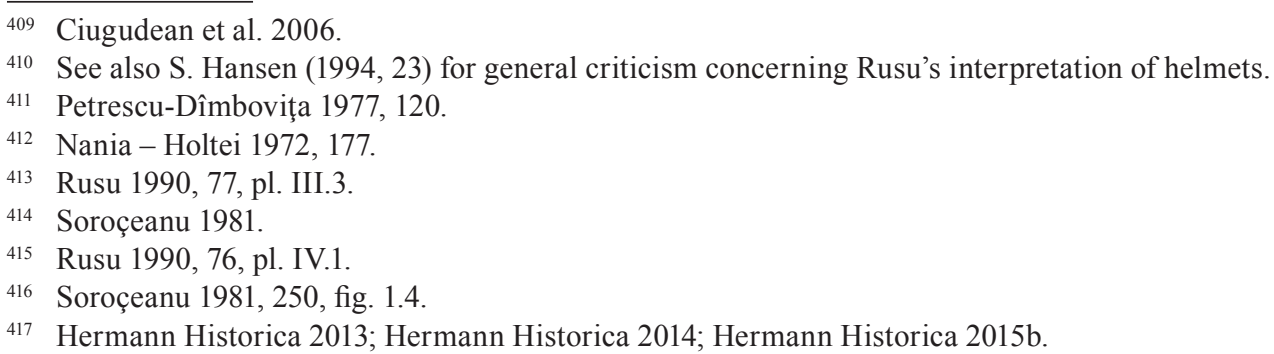




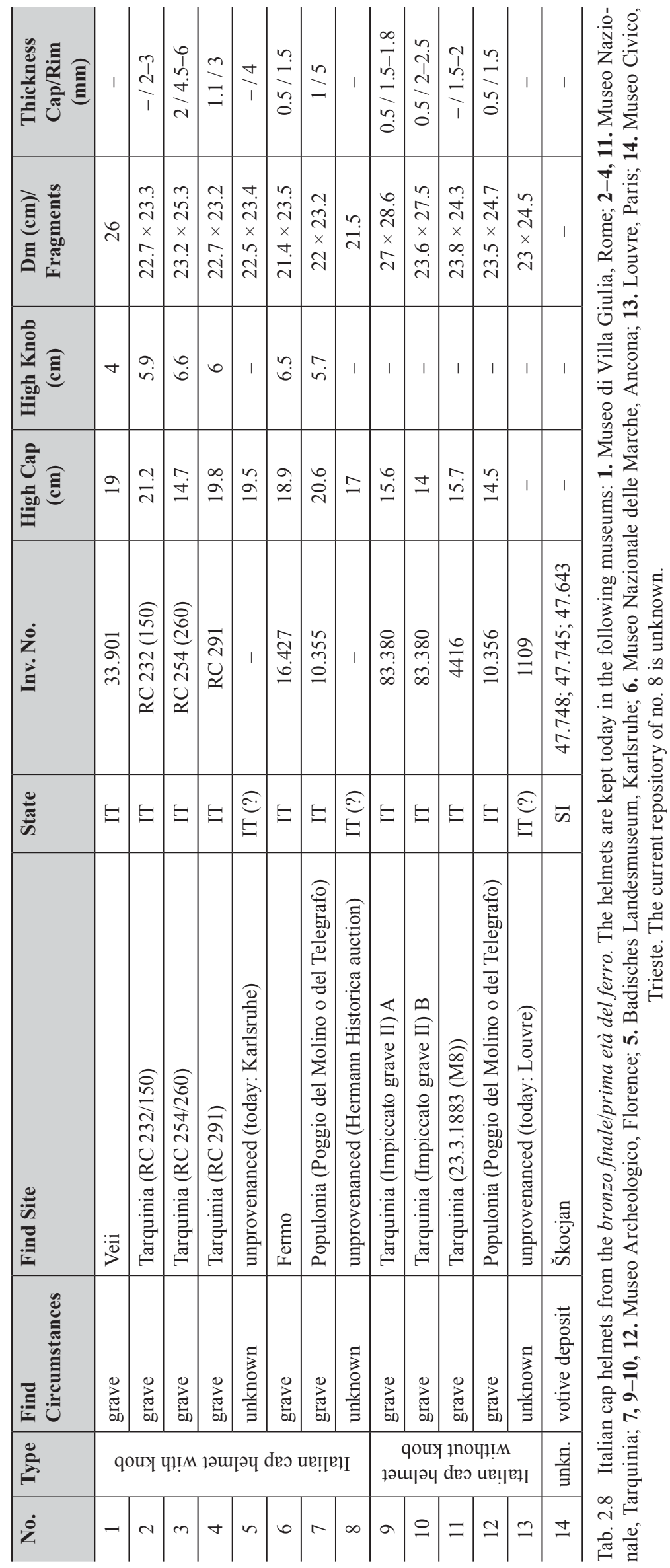



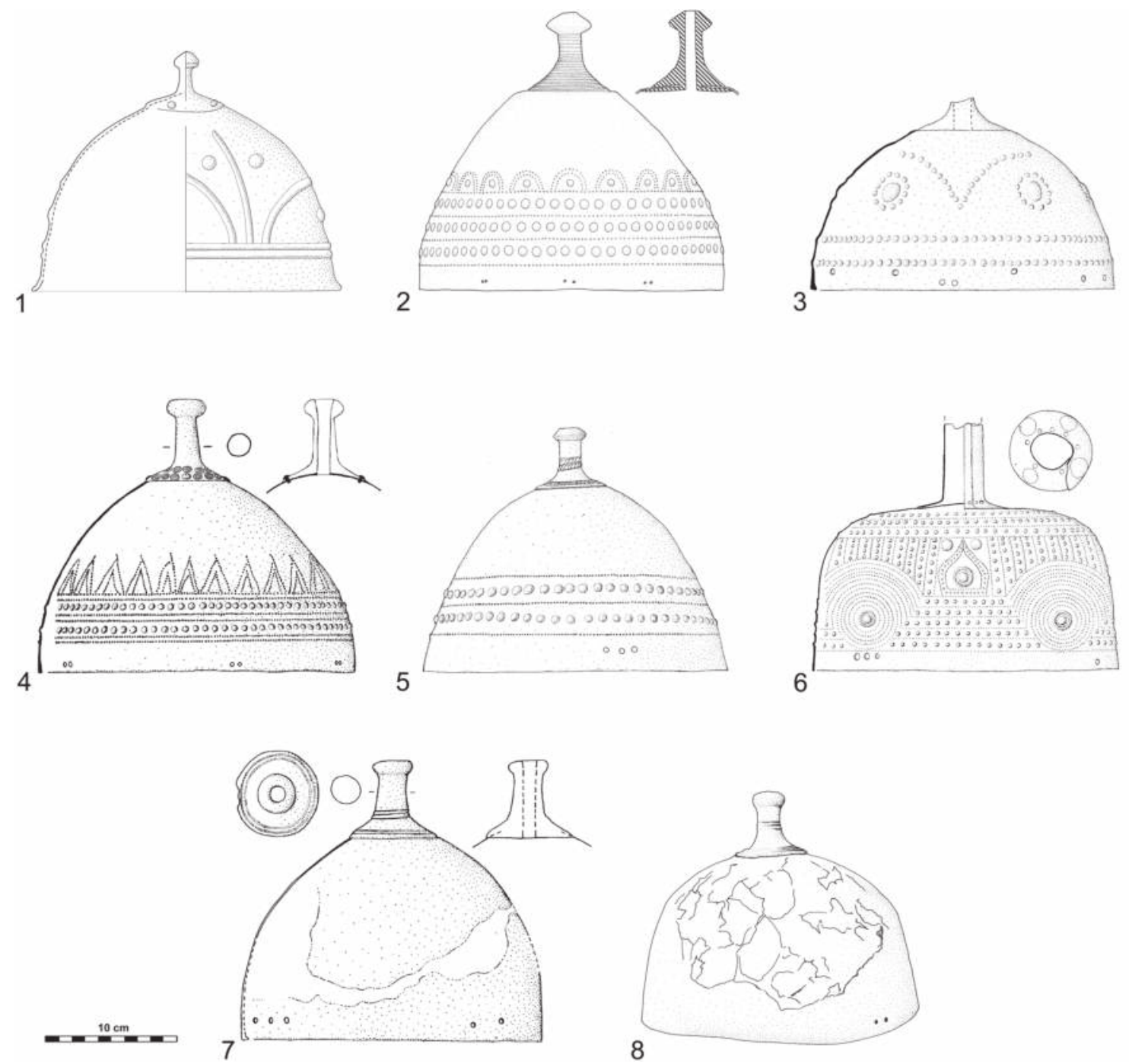

Fig. 2.13 Italian cap helmets with knob or socket: 1. Veii (grave 431) (after Clausing 2001, 203, fig. 4.3); 2. Tarquinia RC 232 (150) (after Hencken 1971, fig. 23); 3. Tarquinia RC 254; 4. Tarquinia RC 291; 5. Unprovenanced (today kept in Karlsruhe); 6. Fermo; 7. Poggio-Populonia; 8. Unprovenanced (before restoration, Hermann Historica 2013; drawing by the author). Numbers relate to those in Table 2.8 (drawings after Iaia 2005, if not indicated otherwise).

These helmets were probably produced during the end of bronzo finale and the initial phase of the prima età del ferro, with their deposition most likely occurring during the prima età del ferro I.

The continuity and development of metal helmets from bronzo finale to prima età del ferro can also be seen in the production of pottery replicas of the metal armour. From bronzo finale, helmet-like covers for urns are known from the Italian protovillanovian Tolfa-Allumiere group. ${ }^{418}$ These urn lids have a squeezed, flat hemispherical shape, with their representation of actual helmets being distorted by symbolic imitation or artistic freedom. The oldest pottery replica of a bronze helmet appears to be that from the tomb of Montorgano 2, Sasso di Furbara, ${ }^{419}$ and already more closely resembles the metal helmets of prima età del ferro than it does those of the preceding Bronze Age. These pottery replicas become common across southern Etruria and Campania, and were deposited in graves from the $10^{\text {th }}-9^{\text {th }}$ century BC. Though the decoration of pottery replicas differs significantly from that on contemporary bronze helmets, being

418 Iaia 2005, 107, fig. 40a-c; Iaia 2013a.

419 Iaia 2005, 109, fig. 40d. 

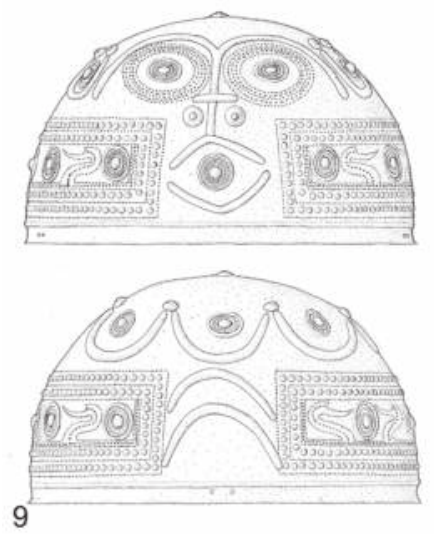
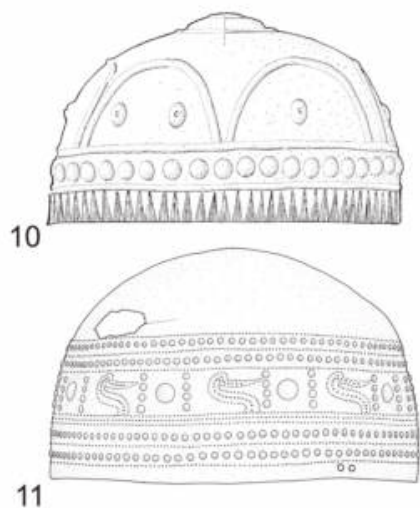

11
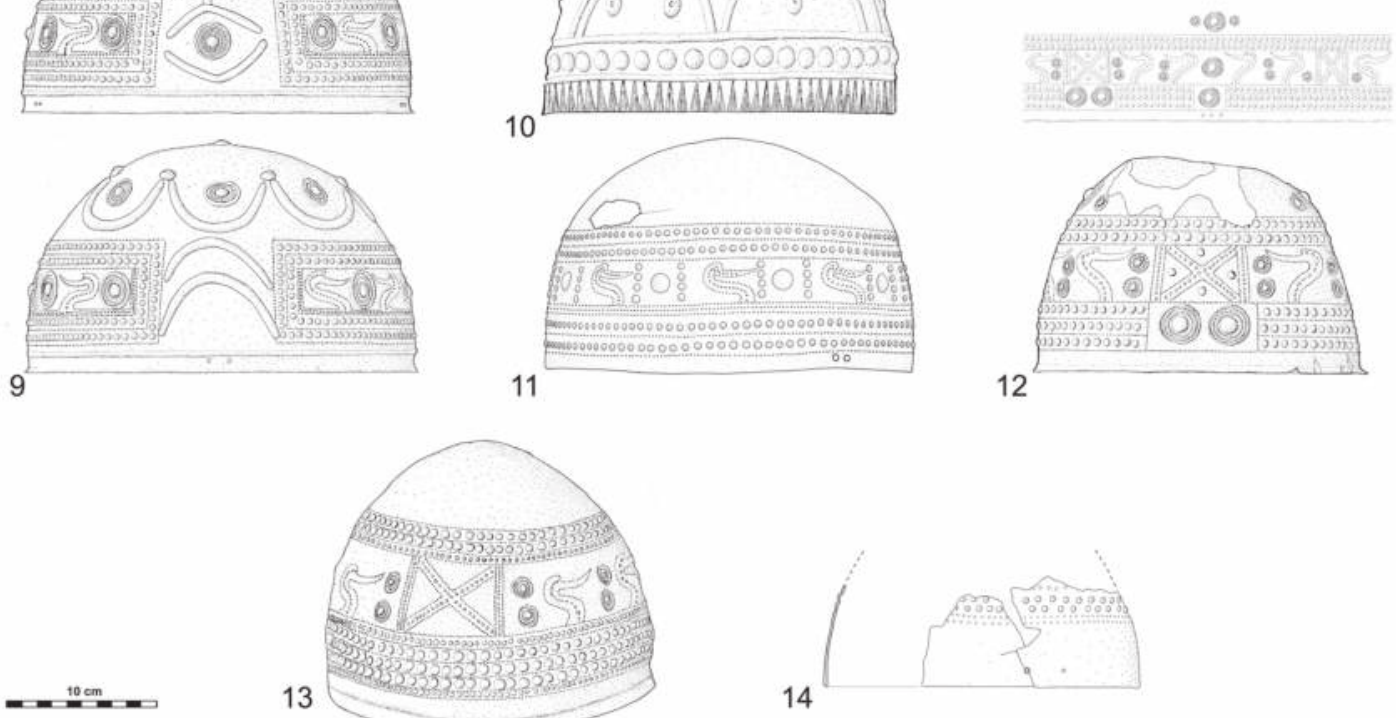

13
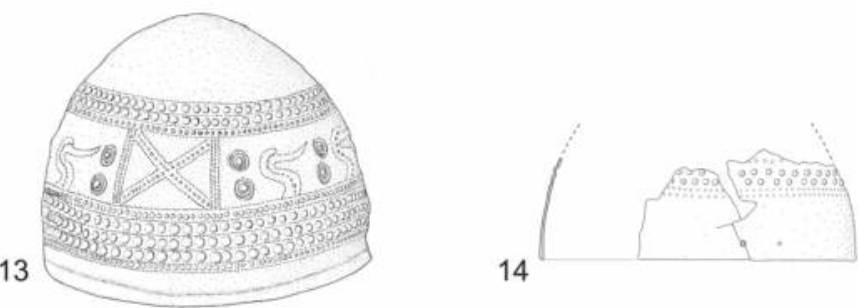

Fig. 2.14 Italian cap helmets without knob or socket: 9-10. Tarquinia (grave II); 11. Tarquinia 23.3.1883 (M8) (after Hencken 1971, fig. 109); 12. Populonia (Poggio del Molino o del Telegrafo); 13. Unprovenanced (today at the Louvre); 14. Škocjan. Numbers relate to those in Table 2.8 (drawings after Iaia 2005, if not indicated otherwise).

more geometric in design, their affinity based on form and shape is obvious, with even the holes along the rim having been imitated. The most realistic of these pottery replicas derive from Tarquinia. The replica helmet from Monte San Angelo/Veii, dated to the beginning of prima età del ferro IA, even has a knob with a stepped shaft, similar to that of Ha B1 helmets of Type Pişcolt, while other replicas resemble the older helmets of Type Pişcolt in the shape of the cap. ${ }^{420}$ With 35 pottery replica helmets having been documented from the cemetery of Pontecagnano, it provides an important site for reconstructing the development of pottery replica of bronze cap helmets. ${ }^{421}$ During site phase IA, the replica helmets closely resemble helmets of Type Pişcolt, indicating a possible knowledge of this type of helmet from the Carpathian Basin, despite the fact that no helmets of Type Pişcolt are so far known from Campania. The closest find is the helmet of Type Pişcolt from Monte Altino, Campobasso (cat. no. 49). In site phase IB instead, the cap of the pottery replica helmets becomes more conical and the knob demonstrates a considerable variation in form and shape, including human and animal figures, roofs, etc. ${ }^{422}$ No metal helmets are known from Pontecagnano.

Italian decorated cap helmets were never classified as a single regional group until the work of Iaia, ${ }^{423}$ and were instead usually associated with broader types and groups of helmets. ${ }^{424}$ For example, v. Merhart and Hencken both associated the two helmets from Tarquinia (RC 232/150), and the unprovenanced helmet from Karlsruhe (probably also from Tarquinia) with helmets of Type Pişcolt. ${ }^{425}$ The helmets from Cuneo and Veii were associated with the helmets of Nagytétény and Batina within the group of 'cap helmets with cast knob', ${ }^{426}$ and the helmets from Fermo and Tarquinia (RC 260) with the group of 'cap helmets and others with plain

420 E.g. one helmet from Pontecagnano, see Iaia 2005, fig. $41 \mathrm{~b}$.

421 Gastaldi 1998.

422 Iaia 2005, 111.

423 Iaia 2005.

424 E.g. v. Merhart 1941; Hencken 1971; Clausing 2001.

425 v. Merhart 1941; Hencken 1971, 45-48.

426 Hencken 1971, 149-151. 
socket'. ${ }^{427}$ The helmet from Cuneo, Italy, a single find recovered from the bed of the river Gesso between 1855 and 1870, is usually discussed together with other Bronze Age (Italian) helmets, despite the fact that it is dated significantly later. F. M. Gambari dates the helmet to the early $5^{\text {th }}$ century BC, as does Clausing, ${ }^{428}$ whilst Hencken dates the helmet based on the saw-tooth edge of the disc to Ha C/D. ${ }^{429}$ Given this dating it will not be discussed in detail in the following. The three cap helmets without knob from Tarquinia were discussed by Hencken alongside the Bronze Age group of helmets of Type Montbellet. ${ }^{430}$ Clausing assigned most of Italian cap helmets without knob to his group of 'cap helmets without knob', which includes both Bronze Age and Iron Age helmets. Most of the Italian decorated cap helmets with knob or socket were included in his group of 'cap helmets with rib and boss decoration'. ${ }^{431} \mathrm{He}$ included in this group the helmet from Tarquinia ( $\mathrm{RC} 232, \mathrm{RC} 254, \mathrm{RC} 291$ ), the unprovenanced helmet from Karlsruhe, and the helmets from Fermo and Szczecin-Zdroje. The fragments from Škocjan and the helmet from Populonia might also be related to this group. Due to its chronological association with the beginning of the Late Bronze Age and the stylistically different decoration, we have excluded the helmet of Szczecin-Zdroje from the list of Italian cap helmets. Clausing also included the only plain, undecorated Italian cap helmet with knob (chamber tomb 1, inv. no. 10.355), from Populonia, with the helmets of Type Pişcolt. ${ }^{432}$ Due to the distribution of rivet holes, shape, thickness of the metal sheet, and decoration of the knob, we cannot agree with his classification for this helmet, and have instead assigned this helmet to the group of Italian cap helmets with knob or socket.

More recently, Italian cap helmets were discussed by Iaia. ${ }^{433} \mathrm{He}$ characterised less a specific type but instead a broad group ('gruppo San Canziano-Tarquinia') of diverse Italian helmets, unified by the shape of their cap and the cast-on or riveted on knob. To his group A belong the two knobs from Škocjan, which are related here instead to helmets of Type Pişcolt, ${ }^{434}$ while group B (with variants) includes the helmets from Tarquinia (RC 232), an unprovenanced helmet (no. 5 in Tab. 2.08), and Populonia (chamber tomb 1, inv. no. 10.355). The helmet from Tarquinia (RC 291) with riveted on knob is related to group B, as are two potentially related fragments from Škocjan. ${ }^{435}$ Iaia considers the third helmet from Tarquinia (RC 254), and that from Veii with solid knob, as unique pieces, since their knobs were riveted and not cast-on. ${ }^{436}$ The helmets with knob in fact demonstrate three different types of knob application, with most having cast-on knobs, one of the helmets from Tarquinia (RC 291) has a knob that is riveted on, whilst the knob on the helmet from Veii is also riveted on and solid.

Two undecorated rim fragments from Škocjan, each having two rivet holes and a rather high cap profile, ${ }^{437}$ probably derive from double crested helmets of Type Novilara, and were most likely one of the last objects deposited in the cave in which they were found. ${ }^{438}$

\subsubsection{Italian Cap Helmets with Knob or Socket}

The cap helmet from Veii (Grotta Gramiccia, grave 431) has a large, cast knob, which is attached onto the cap with rivets. The rim is bent outwards, and above the rim are two raised

427 Hencken 1971, 155-157.

428 Ridella 1994; Gambari 2000, 207; Clausing 2001, 204.

429 Hencken 1971, 151.

430 Hencken 1971, 130-138.

431 Clausing 2001, 216-217, 220.

432 Clausing 2001, 219.

433 Iaia 2005, 47-63.

434 See Chapter 2.1.4, p. 57.

435 Hencken 1971, 51, fig. 26e; Iaia 2005, 53, fig. 7.9-10.

436 Iaia 2005, 49.

437 Naturhistorisches Museum, Vienna, inv. no. 45.635; Hencken 1971, 48-50, fig. 26d.

438 See Hencken (1971, fig. 133) and Teržan (1990, 61, fig. 8.1) for another fragment of a helmet of Type Novilara from Škocjan. 
mouldings. Above these, there is a series of arches with one boss in the centre of each. The knob of the helmet is attached by means of three rivets, which are no longer visible on the inside of the helmet due to the nature of the restoration and installation of supplementary material. Hencken dates the grave and the helmet to the $8^{\text {th }}$ or late $9^{\text {th }}$ century BC. ${ }^{439}$ Schauer associates it with site phase IIA or IIB at Veii, as does A. Berardinetti and L. Drago (Veio IIA). ${ }^{440}$ Iaia recently dated the helmet 'a campana svasata, con apice pieno e inchiodato' to Veii IIA, relative to Tarquinia IIA1..$^{44}$

The helmet from Tarquinia (RC 232/150) served as the lid for an urn, which contained a cremation and two bronze horse-bits. The helmet is slightly dented on the top and decorated with four rows of small bosses and three rows of larger bosses between them. Above, there is a double arch of small bosses, surrounding one larger boss. Small rivet holes are positioned in pairs parallel to the rim. The shank of the cast-on knob is decorated with horizontal lines. The knob of the socket is flattened. Iaia considers the helmet from Tarquinia (RC 232/150) as the oldest of his group 'San Canziano-Tarquinia', variant B and dates it to a transitionary horizon between the end of bronzo finale and the beginning of prima età del ferro, on the basis of its decoration, which resembles that on Kirkendrup-Jenišovice bronzes. ${ }^{442}$ According to Hencken, the helmet dates to the late $10^{\text {th }}$ to $8^{\text {th }}$ century $\mathrm{BC}$, and which Schauer attributes to the late Villanova period. $^{443}$

The knob of a further helmet from Tarquinia (RC 254/260), now broken, had been cast-on. Around the rim, there is an irregular row of holes, and above them a row of bosses. On the front, the bosses appear to be arranged so as to resemble eyes and eyebrows. The helmet is dated to the beginning of prima età del ferro. ${ }^{444}$

The cast knob of a further helmet from Tarquinia (RC 291) is attached to the cap by four rivets. The knob is decorated with stamped rings and dot ornamentation. Parallel to the rim, there are pairs of small holes. When the helmet was found, fragments of organic lining, possibly leather and wood, were also discovered as well. ${ }^{445}$ The cap is decorated with rows of small and large bosses and dots, some in the form of triangles. Helbig also notes eleven fragments of bronze sheet with embossed decoration, and on the rim attached hooks for securing a bronze ring, from which the pendant rings hang. These were found directly beneath the helmet. The helmet is dated no later than the initial phase of prima età del ferro.

An unprovenanced helmet (no. 5 in Tab. 2.08), was bought from a dealer, and little is known concerning its history, though Tarquinia or its surrounding vicinity are suspected as being its area of origin. An urn might have been found together with the helmet. This urn shows similar corrosion as that on the helmet and is decorated with classic bird and boat motif (Vogelsonnenbarke). ${ }^{446}$ On back and front of the helmet two rivet holes are present, with three rivet holes having been applied to each side. Above the rivet holes, the cap is decorated with three rows of small bosses and two rows of large bosses. The knob is cast-on. Hencken notes a possible bronze attachment for the helmet in the shape of a trident with three human figurines on top. ${ }^{477}$ There are no contemporary examples for such attachments, with the closest being the Celtic helmet from Filottrano, Italy. The authenticity of the attachment for the Italian cap helmet is not secure. The helmet is dated to the $9^{\text {th }}$ or early $8^{\text {th }}$ century $\mathrm{BC}$ based on the decoration on the knob, which is similar to that on the helmet from Populonia, and on the cap, also seen on one of the helmets from Tarquinia (RC 232), as well as the associated vessel. ${ }^{448}$

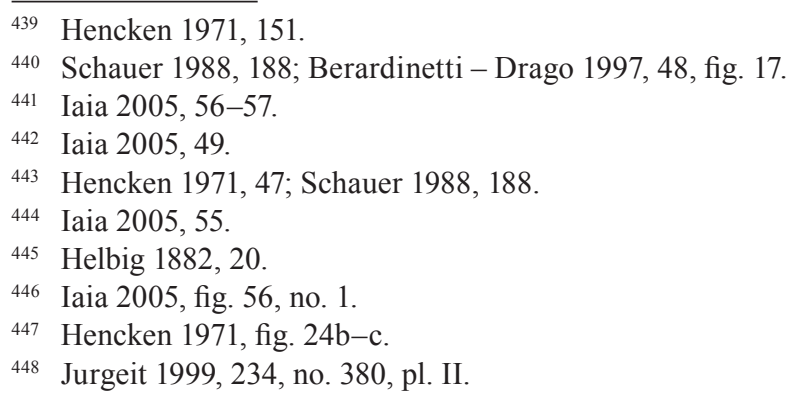


On the front and back of the helmet from Fermo, a central hole was applied immediately above the rim, whilst on the sides there are three holes above the rim. Unlike on other helmets, the cap is complete and does not have a central hole under the riveted-on socket. This socket was made out of a bronze sheet bent into a tube. The lower ends are bent outwards and fixed to the cap with four rivets. Seven further holes in the cap surround the tube at its base. The helmet is decorated with both small and large bosses, arranged in horizontal and vertical rows, as well as in circles. Between these circles, crested Villanovan helmets are depicted, as known from the Villanovan helmet from Bisenzio (Villanovan IIB). Iaia dates the helmet to the central phase of prima età del ferro $\mathrm{I} .{ }^{449}$

In Poggio del Molino o del Telegrafo, Populonia, two cremation burials and two inhumation burials were found in a single grave. Recovered from the same grave, which was clearly reused over a considerable period, was a decorated cap helmet without knob. ${ }^{450}$ The grave appears to have been first used in the $9^{\text {th }}$ century BC and was possibly still in use as late as the $8^{\text {th }}$ century BC. As well as the helmet(s), a bronze axe, two ferrules, a fibula, and amber and glass jewellery were found.

The other Italian cap helmet with cast-on knob, which was put up for auction at Hermann Historica four times ${ }^{451}$ allegedly derives from the Italian antiquities market where it was bought in the 1980s. The undecorated cap of the helmet is severely corroded and almost completely destroyed, with the surviving fragments having been joined together with wax. Only the lower part of the cap remains intact, along with the knob. The shaft of the knob is decorated with three central horizontal lines and two further lines on the base of the knob, and is similar to that found on the helmets from Populonia and Karlsruhe. On both sides of the helmet, immediately above the rim, there are two rivet holes, positioned close to one another.

Possible helmet fragments from Škocjan may also belong to the group of Italian cap helmets. $^{452}$

\subsubsection{Italian Cap Helmets Without Knob or Socket}

The cap helmet without knob from Populonia, Poggio del Molino o del Telegrafo, which derives from the same grave as a decorated cap helmet with knob, is dated to site phase 1B1. The three cap helmets without knob from Tarquinia are all dated to Tarquinia IIA1. ${ }^{453}$

The helmet from Populonia and an unprovenanced helmet (no. 13 in Tab. 2.08) have almost the same decoration. Horizontal lines of pellets and bosses on the base and top of the cap encompass a central band of water bird heads motif with concentric ring and dot decoration in front of them, as well as alternating zones of geometric decoration, including a cross formed of pellet and boss decoration, within vertical pellet and boss lines.

From the Impiccato grave II, Tarquinia, a cap helmet, which was covering the urn, was recovered, as well as another bronze object ${ }^{454}$ interpreted as a helmet or ceremonial basin. ${ }^{455}$ The decoration of the front of the cap helmet suggests a human face. ${ }^{456}$ The sides and the back are instead covered with upside down arches and inside are bosses in concentric circles. Toward the rim, the cap is decorated with three lines of small dots and in between two lines of bosses, arranged in a rectangular shape so as to surround four bird heads, and in between them bosses or 'sun-discs' consisting of several concentric circles. The second helmet is flattened and distorted, and is without rivet holes. It is decorated with a line of chevrons and above of it are two

\footnotetext{
449 Iaia 2005,57 , no. 13, fig. 9.

450 Iaia 2005, 59, no. 14, fig. 10.

451 Hermann Historica 2013; Hermann Historica 2014; Hermann Historica 2015b; Hermann Historica 2017.

452 Iaia 2005, 49-50, fig. 5.3.

453 Iaia 2005, 58-61.

454 Hencken 1971, 135, fig. 108; Clausing 2001, 221; Iaia 2005, 63, no. 18, fig. 12, pl. Xc.

455 Delpino 2005, 343-358.

456 Iaia 2005, 62, no. 17, fig. 12, pl. Xa-b.
} 
horizontal ribs, which enclose a line of bosses. Further ribs form large arches and fill the central part of the cap. Inside the arches, one or two bosses with a central impression were applied.

From another grave from Tarquinia, found the 23.3.1883 (M8), one more helmet is known. ${ }^{457}$ It is stored in the Museo Archeologico Nazionale, Tarquinia (inv. no. 4416). The helmet has four pairs of holes along the lower edge. It is decorated with two concentric bands of three smaller bosses, and in between them two rows of larger bosses. In the middle, there is a decorated band of birds heads, separated by vertical lines of larger bosses. ${ }^{458}$

\subsection{Western European Helmets}

Western European helmets comprise all helmets of Class II and helmets of Type Montbellet (Fig. 2.2). In western Europe and the eastern Alpine region, the helmet cap is usually made of two bronze sheets, joined together by folding, which form a central crest. The only exception are helmets of Type Montbellet and some of the helmets of Type Mantes, the latter bearing only a basic ridge. The date of almost all western European helmets is a matter of discussion, since they usually occur only as single finds or derive from helmet-only deposits. So far, we can distinguish four main types of crested helmets (in chronological order): Type Mantes with a basic ridge, Type Lueg with a three-pointed crest, Type Biebesheim with a conical, rounded crest and Type Bernières d'Ailly with a triangular, pointed crest. The recovery area of types Mantes, Biebesheim and Bernières d'Ailly overlap, as it partly does also with helmets of Type Montbellet (Fig. 2.15). Therefore, and as pointed out later (Chapter 2.2.1), they are discussed together with the other western European helmets.

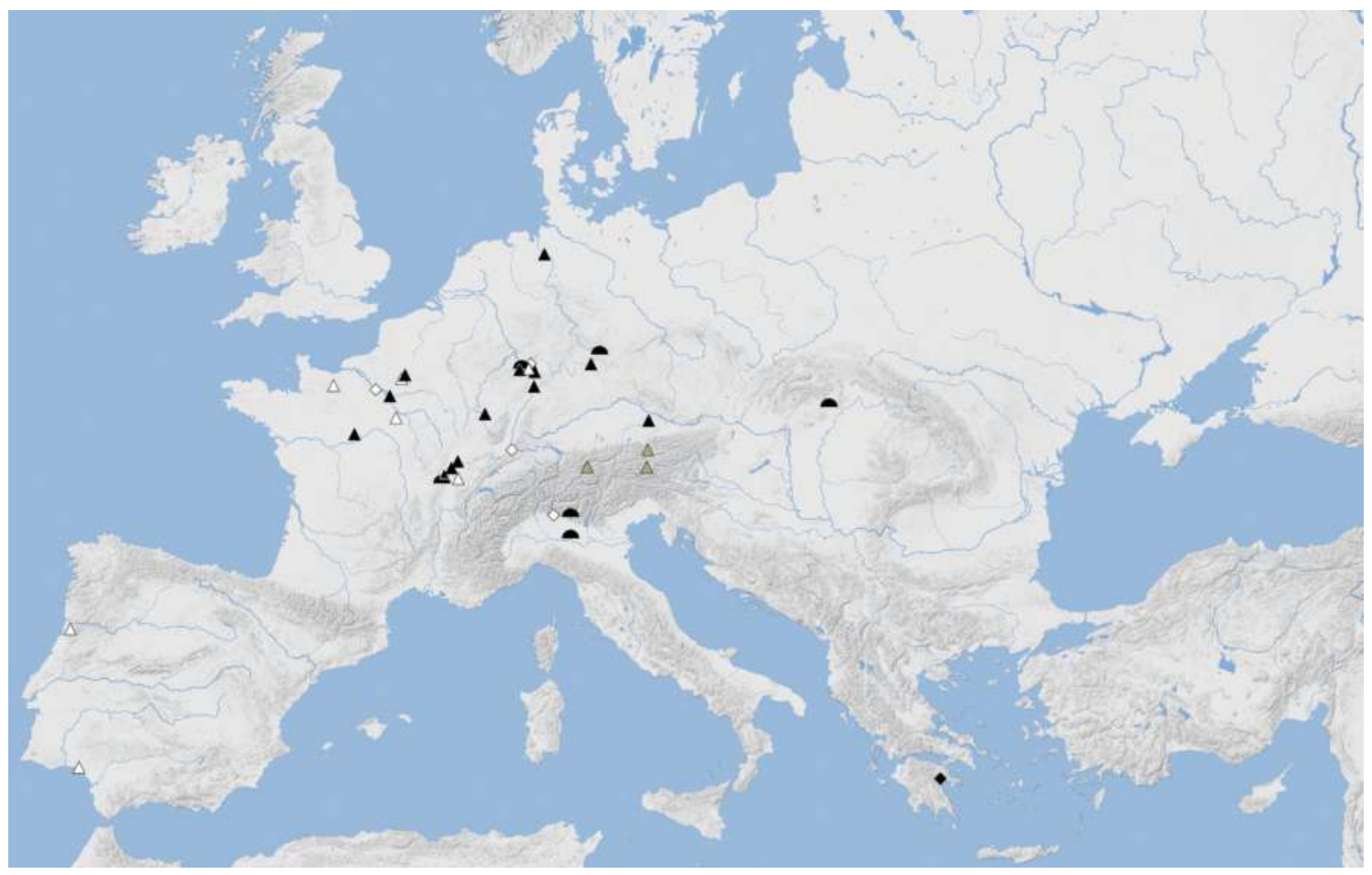

Fig. 2.15 Archaeological distribution of western European Bronze Age helmets: $~$ Helmets of Type Montbellet. $\diamond$ Helmets of Type Mantes. $\triangle$ (grey) Helmets of Type Lueg. $\Delta$ Helmets of Type Biebesheim. $\triangle$ Helmets of Type Bernières d'Ailly. Helmets with unknown or unsecure find location are not mapped.

457 Hencken 1968, 194; Hencken 1971, 135, fig. 109; Schauer 1982c, 705; Clausing 2001, 221.

458 Iaia 2005, no. 16, fig. 11. 


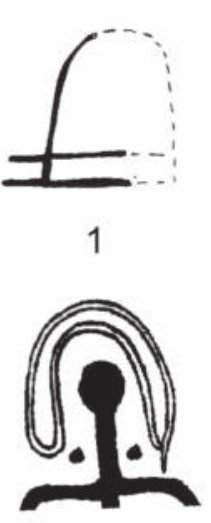

6

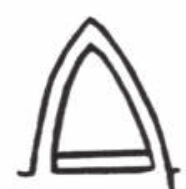

2

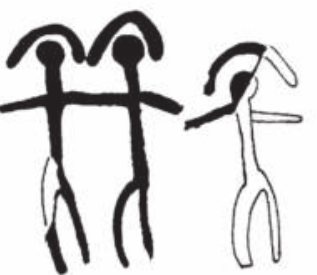

7

3

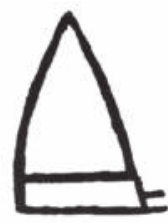

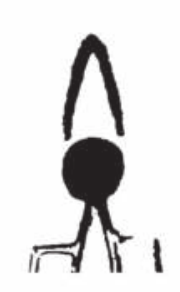

10
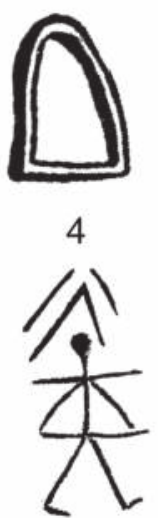

8

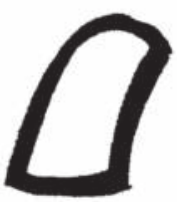

5

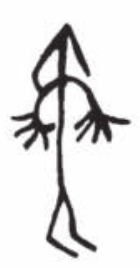

9

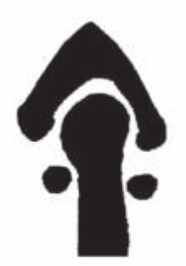

11

Fig. 2.16 Helmets and headgear depicted on Iberian stelae (after Harrison 2004, fig. 7.12 and Ripoll Perelló 1963) (not to scale). Crested helmets with rivets (1-3) and other helmets or headgear (4-12): 1. Valencia de Alcántara III; 2. Santa Ana de Trujillo; 3. Zarza de Montánchez; 4. Solana de Cabañas; 5. Cabeza del Buey III; 6. Cabeza del Buey I; 7. Zarza Capilla III; 8. Setefilla; 9. Almargen; 10. Las Herencias I; 11. Ategua; 12. Barranc de la Gasulla.

The known corpus of crested helmets, comprising some 40 examples, and helmets of Type Montbellet were found mainly in northern and central France, western Germany, western Austria, and northwestern Switzerland. Fragments and depictions of European crested helmets are also known from Portugal and Spain. Helmets of Type Bernières d'Ailly and Type Biebesheim show an overlapping distribution between the Seine and Oise and the middle part of the Rhine. Helmets of Type Mantes instead range from northern Italy to Mantes in the northwest and Mainz in the northeast, overlapping with Type Biebesheim. The recovery area of Type Lueg in the western Austrian Alps does not overlap with any other helmet type.

Depictions of crested helmets are restricted to the southwestern area of the Iberian Peninsula. ${ }^{459}$ None of the northern stelae depicts helmets. ${ }^{460}$ The distribution area of actual finds of crested helmets and these depictions do not overlap. The oldest stelae with helmets show pointed helmets with convex profile, while the more recent stelae show horned helmets ${ }^{461}$ and helmets with a straight-sided profile (Fig. 2.16). ${ }^{462}$ The crest is never clearly indicated, but we can recognise the typical decorative rivets of crested helmets. The profile of the depicted helmets resembles those of Type Bernières d'Ailly, as indicated by the long conical rivets and the double horizontal line of the base. The interpretation of the depicted helmets as Type Bernières d'Ailly instead of Type Biebesheim is also more consistent with the distribution of the actual helmets. So far, around ten depictions of crested helmets are either known as separate motifs or worn by

459 The Iberian stelae with the central depiction of (mainly Type Herzsprung) shields date to the end of the Atlantic Bronze Age (Bronce Final I-II) (e.g. Uckelmann 2012, 128) but also thought to be of more recent origin in the $9^{\text {th }} / 8^{\text {th }}$ century BC (Celestino Pérez - López-Ruiz 2006). For the chronological discussion and overview: see Burgess 1991, 39; Harrison 2004, 84, fig. 6.1; Brandherm 2008; Brandherm 2011; Mederos Martín 2012.

460 Stary 1994, 39.

461 See Chapter 2.3, p. 137.

462 Celestino Pérez - López-Ruiz 2006, 91, fig. 3. 
a warrior. ${ }^{463}$ Most of the helmets worn by human figures have either a thick, round shape or a thinner, pointed 'V'-shaped form. ${ }^{464}$ The stele from Santa Ana de Trujillo, ${ }^{465}$ Subtype II B after Almagro-Gorbea, ${ }^{466}$ might actually depict two helmets inside one another, which is rather unusual, since normally only one helmet per stelae is depicted. Since only the outer helmet has recognisable rivets, we might alternatively interpret the inner one as the organic inlay of a crested helmet. This may also be the case for the helmet depictions made of double lines on the stelae from Serefilla and Cabeza del Buey I. ${ }^{467}$ Similarly the round head protection around the head of the human figure from the stele at Cabeza del Buey I might also be a depiction of organic head protection.

The origin of European crested helmets as well as their chronology is still a matter of discussion. Most recently, Brandherm ${ }^{468}$ related the development of the shape and profile of the cap of Western European crested helmets to that of eastern Mediterranean cap helmets, with the former developing from the latter. However, the Alpine crested helmets of Type Lueg are considered older than the western European crested helmets, and are not connected to any eastern Mediterranean cap development. Hencken, Borchhardt and Schauer also emphasised an origin in the Near East. ${ }^{469}$ R. v. Laur-Belart suggests helmets of Type Mantes as potential ancestors of crested helmets, ${ }^{470}$ but Brandherm argues that their simple shape alone does not necessarily indicate an older type. ${ }^{471}$ A. Lippert sees the origin of crested helmets not in the Near East but as a local development out of previous organic bi-valve helmets. ${ }^{472}$ Egg and Tomedi date the helmets of Type Lueg already to $\mathrm{Bz} \mathrm{C}$, interpreting them as one of the oldest metal helmets and consequently reject any potential origin in the Aegean or the Near East. ${ }^{473}$ This is criticised by Schauer due to the wide chronological variation seen in the votive deposit from the Piller Sattel (Bz C2-Ha A/B1) and the unsecure association of the finds from the Pass Lueg deposit. ${ }^{474}$ Lippert recently suggested a slightly diverse approach for the development of crested helmets, placing Type Bernières d'Ailly at the beginning, in the $13^{\text {th }} / 12^{\text {th }}$ century BC. ${ }^{475}$ Accordingly, Type Bernières d'Ailly would be followed by Type Biebesheim ( $12^{\text {th }} / 11^{\text {th }}$ century $\left.B C\right)$, which he connects with two ceramic helmets from Veii (graves nos. 4-5, necropolis Quattro Fontanili) and Populonia. Connecting the helmet from Tiryns with the ones of Type Lueg, he dates the latter to the $11^{\text {th }}$ century as well, noting that Type Lueg and the earliest Italian helmets overlap chronologically. ${ }^{476}$ The Italian crested helmets made of ceramic and bronze then dominate his following period IIIB.

Seeing in helmets of Type Mantes the origin of both central and western European helmets would finally put an end to the discussion of whether or not the crested helmets derive from Near Eastern or Aegean crested archetypes. Despite this, there is still the impression that an eastern origin is sought by some authors, based on two depictions and a crested Anatolian (?) helmet without any known find context or date as the basis for its argument: ${ }^{477}$ the depiction of a boar tusk helmet from a $16^{\text {th }}$ century silver vase from Mycenae, grave round $\mathrm{A}$, grave $\mathrm{IV}^{478}$ and the warrior stele from Hattuša-Bogazköy, Anatolia $\left(14^{\text {th }} / 13^{\text {th }}\right.$ century BC). It is usually over-

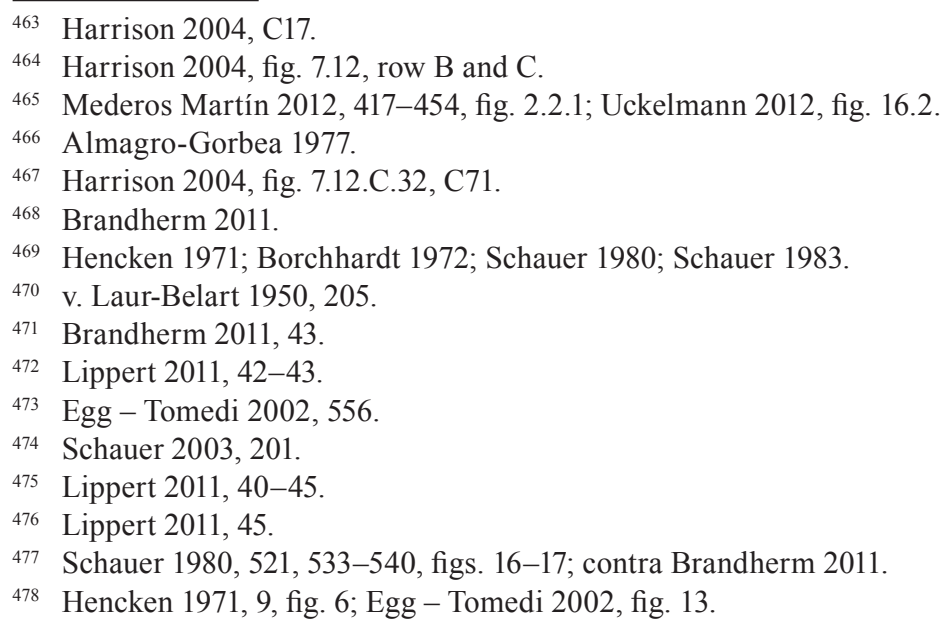


looked that this boar tusk helmet from Mycenae shows an organic crest (as indicated by the parallel lines), as also found on many other depictions, ${ }^{479}$ which clearly indicate organic crests. The Hattuša-Bogazköy helmet also shows what is obviously an organic crest (tail?), which starts on the forehead and reaches the middle of the back of the person wearing the helmet (there does not seem to be a separation between crest and tail), as known from the relief of Suppiluliuma II at Hattuša. The oldest known crested helmet of eastern Mediterranean origin unfortunately lacks any information concerning find circumstances or location. ${ }^{480}$ Its cap has a conical profile and not, as older depicted helmets, a convex profile. Brandherm interprets these helmets as more recent than the western European crested helmets and sees a possible influence on this helmet from the western European crested helmets. ${ }^{481}$ There are no known depictions similar to this helmet and its date remains unclear. Schauer argues that based on this helmet, a development from crested helmets made out of one piece of bronze to later ones made of two halves joined together at the crest must have taken place. ${ }^{482}$

We cannot ignore the fact that knowledge of Mediterranean helmets may indeed have influenced the production or development of Late Bronze Age European helmets - but not in the form of direct prototypes. Such knowledge is demonstrated by the presence of a fragment from a Mediterranean pointed helmet in the deposit from the Río Huelva. ${ }^{483}$ Schauer identified it as part of an Urartian/Syrian helmet. ${ }^{484}$

Due to the small number of crested metal helmets from the Aegean and Near East (the late $11^{\text {th }}$ century BC helmet from Tiryns, one of the Ur-helmets and the most likely more recent 'Anatolian' helmet), ${ }^{485}$ which are both typologically and chronological diverse, the argument for the local development of European crested helmets gains more weight. This process might have occurred with the imitation of organic helmets or, more likely, with the development of crests on cap helmets. ${ }^{486}$ The development of crests out of cap helmets is supported by three massive cap helmets - found in Mantes, Oggiono-Ello and Mainz - with a central ridge or little crest and one massive helmet with a little crest, and already made out of two bronze sheets (Weil). All helmets belong to helmets of Type Mantes. These helmets might be the crucial point for the development of crested helmets. Here, the relationship of Type Mantes and Type Biebesheim and between types Mantes and Type Lueg is of particularly interest.

Besides stylistic approaches, the development from a simple hemispherical cap to a shape which leaves more space above the head and increases also the buffer zone during weapon impact (as we evidenced on Type Biebesheim), thus supporting a 'gliding' of the blade along the helmet's side rather than allowing to 'hack' right into it (i.e. so that the angle of impact is not $90^{\circ}$ but higher), improves the protective aspects of the helmet - a surely convincing argument for the person using the helmet as head protection. Further similarities between cap helmets of Type Mantes and Type Biebesheim are the growing crest, the rising cap, the (initial?) flat-headed rivets on some helmets of Type Biebesheim and the partly straight rim (Le Theil). Between Type Mantes and Type Lueg, the hemispherical shape of the cap, the flat rivets and the inwards bent rim without a wire indicate a close connection. ${ }^{487}$ According to these similarities, we identify helmets of Type Mantes not only as the precursor of Type Biebesheim, but also of Type Lueg. Besides the shared characteristics, this is also supported by the compactness and thickness of the bronze sheet and the lack of any fine decoration on the helmets of Type Mantes,

\footnotetext{
479 Borchhardt 1972, suppl. E.

480 Schauer 1980, 533, figs. 16-17.

481 Brandherm 2011, 47, fig. 4.

482 Schauer 2003, 201.

483 Brandherm 2011, 43.

484 Schauer 1983, 185, fig. 5a-b.

485 Stary 1994, 41, fig. 2.

486 Brandherm 2011, 43.

487 Despite the Pass Lueg helmet being in between western and eastern European helmets, influence from the east concerning the shape of the cap cannot be excluded if we do not want to regard the origin of the cap's profile amongst the western, but rather massive helmets of Type Montbellet.
} 
which is far from the delicate structure and decoration of the later helmets of Type Lueg and Type Biebesheim and which would make development in the opposite direction rather unlikely.

\subsubsection{Helmets of Type Montbellet}

Helmets of Type Montbellet are undecorated, plain cap helmets with a hemispherical cap, which were made from a single bronze sheet. The rim at the top of the cap is thicker than the sides, ${ }^{488}$ because of the use of an open die for the production of the helmet. ${ }^{489}$ The rim of the helmet from Iseo is bent inwards, possibly to fix an organic lining or to make the cap more resistant. This is also noted on the helmet of Type Mantes from Oggiono-Ello and those of Type Lueg. Just at the fold on the helmet from Iseo, holes were applied: in front and back were placed two holes, and to the sides, with three holes on each side (diameter 3-4mm). On the front and back of the helmet from Brancere, one single hole is visible, whilst each side has seven, most likely to attach cheek plates than a chin strap; most of these holes are torn. The helmet from Montbellet has instead just one hole each on each side, while the helmets from Szikszó and Wonsheim have two on each side. The helmet from Thonberg has an additionally two holes on both the front and back. The quality of the photographs of the today lost, unprovenanced helmets cat. nos. 7778 do not permit any detailed description. It is only possible to note that both bear a high number of rivet holes; interestingly, the same weight is published for both helmets (Tab. 2.9). However, their different form and shape indicates two different helmets and not the same find known under two names.

\begin{tabular}{l|l|l|c|l|c|c|c|c}
\hline $\begin{array}{l}\text { Cat. } \\
\text { No. }\end{array}$ & Find & Find Site & State & Condition & $\begin{array}{c}\text { High } \\
\text { Total } \\
(\mathbf{c m})\end{array}$ & $\begin{array}{c}\text { Dm } \\
(\mathbf{c m})\end{array}$ & $\begin{array}{c}\text { Thickness } \\
\text { Cap/Rim } \\
(\mathbf{m m})\end{array}$ & $\begin{array}{c}\text { Weight } \\
(\mathbf{g})\end{array}$ \\
\hline 71 & river & Montbellet & FR & not complete & 14.5 & $22 \times 18.5$ & $0.6-1 /-$ & - \\
\hline 72 & associated deposit (?) & Thonberg & DE & complete & 13.7 & $17.5 \times 21.6$ & $2-3 / 5$ & 678 \\
\hline 73 & associated deposit (?) & Wonsheim & DE & complete & 12 & $18.6 \times 22$ & 1.5 & 563 \\
\hline 74 & associated deposit & Szikszó & HU & complete & 14.4 & $18 \times 21.7$ & $-/ 3$ & 638 \\
\hline 75 & river & Brancere & IT & complete & 14 & $17 \times 21.5$ & - & 370 \\
\hline 76 & bog & Iseo & IT & complete & 11 & $16.5 \times 19$ & - & - \\
\hline 77 & unknown & unprovenanced & - & lost & - & - & - & 1140 \\
\hline 78 & unknown & unprovenanced & - & lost & 14 & $23 \times 21.5$ & - & 1140 \\
\hline
\end{tabular}

Tab. 2.9 Helmets of Type Montbellet.

\subsubsection{Research History}

G. v. Merhart subdivided helmets made of one piece of bronze into group A, the Kappenhelme, and group B, the Glockenhelme, which have a more conical or bell shape. ${ }^{490}$ Hencken used the terminology of v. Merhart and divided cap helmets into several different groups: conical bell helmets; rounded bell helmets; cap helmets with stars; cap helmets with cast knobs; cap helmets and others with plain sockets; cap helmets without knobs or sockets. He included in the latter group also helmets of Type Mantes and the Iron Age helmets from Tarquinia, Cuevas de Vinromá, Býčí skála, as well as a potential helmet from Cumae and the more recent helmet from Schoonaarde (see below) ${ }^{491}$ Thus, only the six helmets from Montbellet, Thonberg, Wonsheim,

\footnotetext{
488 E.g. Schauer 1982c, fig. 10.

489 For the production method, see Mödlinger 2014a.

490 v. Merhart 1941.

491 Hencken 1971, 124-137.
} 
Szikszó, Brancere and Iseo are associated with the helmets of Type Montbellet. G. v. Merhart notes another helmet, presumably from Rome (cat. no. 77), ${ }^{492}$ which was part of the collection of Amilcare Ancona, Milan, but not the later Zschille collection, as a comparison of the photographs of the two helmets indicate. ${ }^{493}$ The helmet from the Zschille collection (cat. no. 78) was destroyed during the Second World War, as noted by Hencken; ${ }^{494}$ the location of the helmet from 'Rome' remains unknown. As well as these six helmets, Schauer included in his group of undecorated cap helmets also those of Type Mantes from Oggiono-Ello and Mainz, as well as the unfinished, potential helmets or vessels from Ehingen. ${ }^{495}$ In addition, he associated the helmet from Brancere with decorated cap helmets. Most likely, the so-called helmets from Ehingen, Baden Württemberg, Germany, ${ }^{496}$ are not helmets at all, since they are too small and there are no rivet holes to attach a chin strap or cheek plates. Moreover, their shape, with wide-open edge, is not found on any other helmet so far. If they are unfinished helmets or vessels though, according to Hencken ${ }^{497}$ they already are so thin that it seems impossible to thin them even more to achieve the shape of a functional helmet. In any case, the probable type of helmet (or vessel?) cannot be detected. The associated deposit is dated to the beginning of $\mathrm{Ha} \mathrm{B1}{ }^{498}$

The helmet from Schoonaarde is usually associated together with other helmets of Type Montbellet ${ }^{499}$ or considered as potentially Celtic in origin. ${ }^{500}$ It is the only plain cap helmet, which was not found within the area of the Urnfield culture; the exact find circumstances allegedly a single find from the river Scheldt - are unknown. As on the helmets from Iseo and Brancere, the rim of the helmet is bent inwards, maybe to fix an organic lining or to make the cap more resistant. On the sides of the helmet from Schoonaarde are two small gaps were we can see a wire which passes through the inwards bent rim. It seems as if the wire here formed tiny loops, maybe to attach a chin strap. The helmet is also the only plain cap helmet with decoration: three lines parallel to the rim are engraved on the outside. Considering the unique decoration, the inwards folded rim with wire and the loops it forms, we might indeed interpret it as a more recent helmet, which is not necessarily connected with helmets of Type Montbellet.

Both v. Merhart and Hencken did not find a satisfactory explanation for the origin of helmets of Type Montbellet. ${ }^{501}$ Schauer connects the European cap helmets with depictions on Assyrian and Egyptian reliefs (Luxor, Abydos, Abu Simbel and Medinet Habu), referring to the depicted Shardana helmets, indicating they might also represent metal helmets and not only organic head protection, as suggested by Borchhardt. ${ }^{502}$ Schauer locates the precursors of the European plain cap helmets between Egypt and the Caspian Sea ${ }^{503}$ However, his connection between European cap helmets with Persian helmets with gold and silver applications from the $13^{\text {th }}-12^{\text {th }}$ century BC seems somewhat farfetched. ${ }^{504}$

The more narrowly defined types of cap helmets used here, as opposed to that previously described, ${ }^{505}$ based on that of undecorated, plain cap helmets (Type Montbellet) and those cap helmets with central ridge or basic crest (Type Mantes) and others ${ }^{506}$ allows the clearer visualisation of the development of these two types. It seems rather unlikely that cap helmets with

\footnotetext{
492 v. Merhart 1941, 5, 10, fig. 1.6.

493 Pertusi 1892, 3, no. 21, pl. VIII.6; Forrer 1894, 2, pl. IV.27.

494 Hencken 1971, 144.

495 Schauer 1982c, 704-705.

496 Hencken 1971, 183, fig. 151; Schauer 1980, 525; Schauer 1982c, fig. 12.

497 Hencken 1971, 185.

498 Schauer 1980, 525; Schauer 1982c, 719.

499 E.g. Hencken 1971, 126; Warmenbol 1992, 101-103; Moore - Armada 2011, 305.

500 Schauer 1982c, 704.

501 v. Merhart 1941; Hencken 1971.

502 Borchhardt 1972, 109; Schauer 1982c, 721.

503 Schauer 1982c, 724.

504 Schauer 1980, 530, fig. 9-11.

505 v. Merhart 1941; Hencken 1971; Schauer 1982c.

506 See Chapter 2.1, p. 30.
} 
ridge or basic crest are older than basic cap helmets; consequently, we interpret the latter as older than helmets of Type Mantes but having a longer life span.

We also have to consider them a local invention, developing out of organic head protection, which had been in use at least since the Early/Middle Bronze Age (see e.g. the conical head protection from Fiavé-Carera, Italy (cat. no. 60) ${ }^{507}$ Helmets Type Montbellet are without doubt the most basic metal helmets and show the closest form to the human head. Assuming the first helmets of Type Montbellet are older than Type Mantes, would make them also the precursor of the later western European crested helmets, from Type Mantes with basic crest, to types Lueg, Biebesheim and Bernières d'Ailly with elaborated crest, and finally the Italian crested helmets. Moreover, we have to take into account that the find spots of helmets of Type Montbellet, despite the single find at Szikszó (most likely an import), only overlaps with the find area of western European crested helmets.

Most of the helmets of Type Bernières d'Ailly, all those of Type Lueg, as well as helmets of Type Montbellet, the helmets from Iseo and those of Type Mantes (helmets from Mantes and Oggiono-Ello), have an inwardly bent rim, usually enclosing a wire. Such is never observed on eastern European helmets, apart the unprovenanced crested helmet (cat. no. 100). While the shape of the cap changed with the development of the crest in western Europe, its basic shape remained with the crested helmets of Type Lueg - though the latter is a much thinner, more delicate version of the rather massive helmets of Type Montbellet. Thus, it is in the form of the cap helmet, rather than in the development of the crested helmet, that we find connections with Eastern European prototypes, which, as helmets of Type Oranienburg demonstrate, themselves surely had Aegean precursors. Due to the basic, easy to produce shape of plain cap helmets such as helmets of Type Montbellet, we might reasonably assume that such helmets continued to exist even after the development of more elaborate types; though their number is rather small, we suggest that they were a long-lived phenomenon.

A similar development from plain, undecorated cap helmets to crested helmets can also be noted in Mesopotamia: the oldest metal helmets are, without doubt, plain, undecorated Sumerian cap helmets found in Ur ( $2^{\text {nd }}$ half of the $3^{\text {rd }}$ millennium BC). ${ }^{508}$ Interestingly, one of the three helmets also bears a basic ridge as found on our helmets of Type Mantes. More elaborated, organic crested helmets appear only shortly after (see the helmet on the tropaion from Mari).

\subsubsection{Distribution and Deposition}

All helmets of Type Montbellet were found within the area of the Urnfield culture, and only one of them in its eastern zone (Fig. 2.17). Find spot and find circumstances of the unprovenanced helmet (cat. no. 77) remain unclear. Helmets Type Montbellet were recovered from the Po basin in the south to the Jura Mountains in the west and to the Main and Rhine in the north. Their recovery area overlaps widely with helmets of Type Mantes. The helmets from Brancere and Montbellet were found in rivers, the one from Iseo in a bog, while the two German finds from Thonberg and Wonsheim probably derive from associated deposits. The exact composition of these associated deposits, their find circumstances and their exact associations remain unclear. The helmet from Szikszó, the only one found in eastern Europe, also derives from an associated deposit. This helmet, most likely an import, provides the most secure information on the chronology of these helmets.

507 Perini 1987, 190; Born - Hansen 2001, 60, fig. 54.

508 Wolley 1934, 63, nos. 18, 45-50, pls. 148-149, 218; Borchhardt 1972, 94, pl. 19.2-3; Gilibert 2004/2005, 98, fig. 14. 


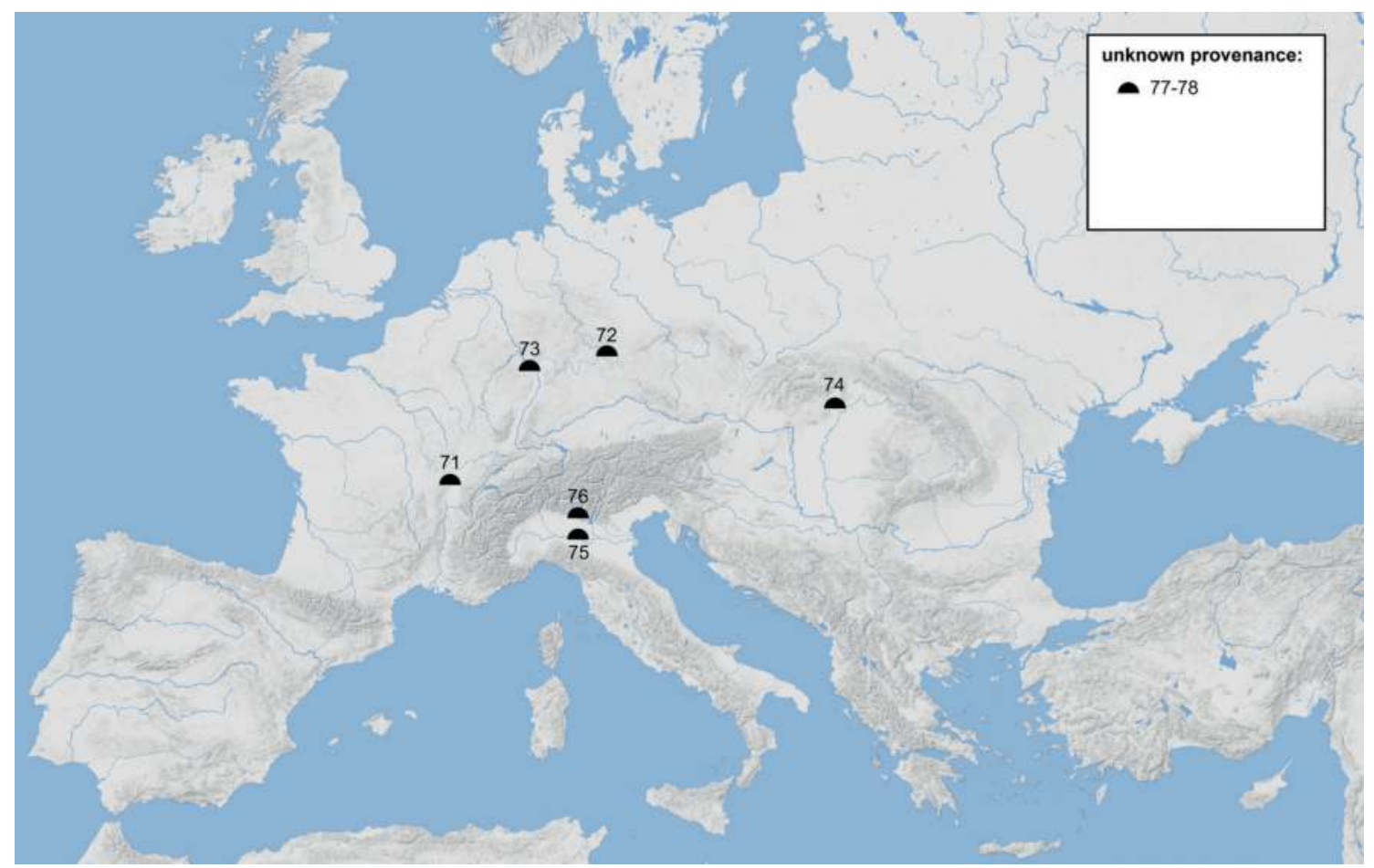

Fig. 2.17 Archaeological distribution of helmets of Type Montbellet: 71. Montbellet; 72. Thonberg; 73. Wonsheim; 74. Szikszó; 75. Brancere; 76. Iseo; 77-78. Unprovenanced. Numbers correspond to the catalogue numbers.

\subsubsection{Chronology}

The helmets from Montbellet, Brancere and Iseo are of little use in any consideration of the chronological classification of this helmet type. Up to now, the helmet from Montbellet has been associated with both the Iron Age and the Late Bronze Age. ${ }^{509}$ The helmet from Wonsheim was associated with $\mathrm{Ha} \mathrm{B}(1)$ based on the cups in the same associated deposit. ${ }^{510}$ However, according to Martin, the cups of Type Ehingen-Wonsheim date to Ha B3. ${ }^{511}$ The potentially associated finds of the helmet from Thonberg remain unclear yet. Thus, the only chronologically valuable associated deposit is that from Szikszó, containing three small sickles (Bz D) and three large ones (Ha B) (two Knopfsicheln, four Zungensicheln), as well as a median winged axe of Type Kleedorf. ${ }^{512}$ According to Hansen and Mozsolics, the associated deposit may have been deposited in $\mathrm{Ha} \mathrm{B1}$, or, according to Hencken, at the transition from $\mathrm{Ha} \mathrm{A}$ to $\mathrm{Ha} \mathrm{B}$ or at the beginning of Ha B, while Kemenczei associates the associated deposit with Ha A2. ${ }^{513}$ Thus, we are left with a wide chronological time frame for helmets of Type Montbellet, which ranges from $\mathrm{Bz}$ D-Ha B. This necessitates then the reconstruction of tentative chronology based on the temporal development of these helmets using typological characteristics instead, based upon the sequence outlined above: helmets of Type Montbellet are the most basic helmet shape, developing from local organic precursors, and therefore older than helmets of Type Mantes (Bz D), which develop from them. As helmets of Type Montbellet are the simplest metal helmet to be produced, we consider them to have been an especially long-lived phenomenon, which, despite their small number, may have lasted even until the end of the Urnfield culture.

\footnotetext{
509 Bonnamour 1990, 47.

510 Reinecke 1906; Holste 1937; v. Merhart 1941; Schauer 1982c, 719.

511 Martin 2009, 75.

512 Hencken 1971, fig. 101; Schauer 1982c, 720.

513 Hencken 1971, 130; Kemenczei 1984, 51; Hansen 1994, 19; Mozsolics 2000, 80.
} 
Catalogue

Cat. no. 71. Montbellet, 'Pont de Fleurville', Dép. Saône-et-Loire, France - river find (river Saône) - complete helmet. Measurements: height: $14.5 \mathrm{~cm}$; diameter: $22 \times 18.5 \mathrm{~cm}$; thickness: 0.6-1mm - Musée de Tournus, inv. no. 88.4.20 (collection Musée Greuze) - P1. 10.71. References: Bonnamour 1985, fig. 3; Bonnamour 1990, 74, no. 60, fig. 35; Feugére 1994, 47; Gras 2002, figs. 1-2, pl. IV; Feugére 2005, 85-92.

The helmet was considered by M. Feugére as Type Mannheim/Coolus, but later revised. ${ }^{514}$

Cat. no. 72. Thonberg, Bayern, Germany - associated deposit (?) - complete helmet. Measurements: height: $13.7 \mathrm{~cm}$; diameter: $17.5 \times 21.6 \mathrm{~cm}$; thickness: $5 \mathrm{~mm}(\mathrm{rim}), 2-3 \mathrm{~mm}$ (cap); weight: $678 \mathrm{~g}$ - Germanisches Nationalmuseum Nürnberg, inv. no. V 1962 - Pl. 10.72. References: Hock 1911, 8; Hock 1914, 249, pl. I.18; Holste 1937, 16; v. Merhart 1941, 5, fig. 1.8; v. Henning 1970, 83, no. 46, pl. 81; Hencken 1971, 128, fig. 99; Schauer 1980, 521-543; Schauer 1982c, 704, no. 5, figs. 8-11; Schauer 1984, 209-235; Clausing 2001, 221; Abels 2002, 46; Grahl 2004.

This helmet and 'other stuff' was found allegedly in a sand pit at Sandpfeife near Thonberg in 1906, appeared on the market in 1911 and was bought by the Germanisches Nationalmuseum from a dealer from Nuremberg. The impression on the cap might be recent damaged, as children reputedly played with the helmet before it was sold.

Cat. no. 73. Wonsheim, Rheinland-Pfalz, Germany - associated deposit (?) - complete helmet. Measurements: height: $12 \mathrm{~cm}$; diameter: $18.6 \times 22 \mathrm{~cm}$; thickness: $1.5 \mathrm{~mm}$ (edge); weight: 563g - Landesmuseum Mainz, inv. no. 2222 - Pl. 10.73. References: Reinecke 1900, 343; Reinecke 1906; Holste 1937, 16; v. Merhart 1941, 5, fig. 1.1; Hencken 1971, 130, fig. 100a; Schauer 1980, 525; Schauer 1982c, 704, no. 4, figs. 6-7; Clausing 2001, 221; Lippert 2011, 31.

The helmet was found allegedly together with nine bronze cups, of which six are still preserved, in 1858. Two very similar looking cups might belong to the same associated deposit and were bought by the museum in 1860, 'deriving from the vicinity of Wonsheim', from the Nationalmuseet in Copenhagen (inv. no. 19.253-OAV.11.C48; 19.254-OAV.11.C49).

Cat. no. 74. Szikszó, kom. Borsod-Abaúj-Zemplén, Hungary - associated deposit ('find I') almost complete helmet. Measurements: height: $14.4 \mathrm{~cm}$; diameter: $18 \times 21.7 \mathrm{~cm}$; thickness: $3 \mathrm{~mm}$ (rim); weight: $638 \mathrm{~g}$ - Herman Ottó Múzeum in Miskolc, inv. no. 66.14.1 - Pl. 10.74. References: Kemenczei 1966, 101, pl. XV; Hencken 1971, 130, fig. 101a; Schauer 1980, 525; Schauer 1982c, 705, no. 8, fig. 5.2; Kemenczei 1984, 50-55, 151, no. 29, pl. CXVII.4; Hansen 1994, 19, 554, H 677; Mozsolics 2000, 80, no. 6, pl. 99.7; Clausing 2001, 221.

The helmet was found together with three small sickles (Zungensicheln) (Bz D) and three large sickles (Knopfsicheln) (Ha B), as well as a median winged axe of Type Kleedorf ${ }^{515}$ in 1965.

Cat. no. 75. Brancere, Lombardia, Italy - river find (river Po) - complete helmet. Measurements: height: $14 \mathrm{~cm}$; diameter: $17 \times 21.5 \mathrm{~cm}$; weight: $370 \mathrm{~g}-$ Museo Civico Ala Ponzone di Cremona (Inventory Vol. S, oggetti di scavo, 93, no. 3) - Pl. 10.75. References: Patroni 1909, 276, fig. 2; v. Merhart 1941, 5, fig. 1.4; Hencken 1971, 130, fig. 102; Pontiroli 1974, 212-213, no. 221; Schauer 1982c, 705, no. 12, fig. 13; Clausing 2001, 221; Martinelli 2004, 30.

The helmet was found in 1896 at Brancere in the sands of the river Po and bought by the museum in 1906.

Cat. no. 76. Iseo, prov. Brescia, Lombardia, Italy - single find (bog) - complete helmet. Measurements: height: $11 \mathrm{~cm}$; diameter: $16.5 \times 19 \mathrm{~cm}-$ Museo Preistorico Luigi Pigorini, Rome, inv. no. 66.152 - Pl. 10.76. References: Castelfranco 1887, 145-147, pl. V.5; Ruffoni 1888, 36;

514 Feugére 1994, 47; Feugére 2005, 61-67.

515 Hencken 1971, fig. 101; Schauer 1982c, 720. 
Ruffoni 1891, 76, 85, pl. VIII.8; Montelius 1895, pl. 33.5; v. Merhart 1941, 5, fig. 1.5; Hencken 1971, 133, fig. 104; Schauer 1982c, 704, no. 2, fig. 2; Clausing 2001, 221.

The helmet was found before 1887 at a depth of $3 \mathrm{~m}$ in the bog while cutting peat close to the Lago d'Iseo. It was said a now lost (?) bronze sickle was found together with the helmet.

Cat. no. 77. Unprovenanced (known as 'Rome', Italy) - complete helmet. Measurements unknown; weight: $1140 \mathrm{~g}$ - repository unknown - Pl. 10.77. References: Ruffoni 1891, pl. VIII.8; Pertusi 1892, 3, no. 21, pl. VIII.6; v. Merhart 1941, 5, 10, fig. 1.6; Hencken 1971, 144; Clausing 2001, 221.

The find spot and find circumstances of this helmet are unknown. It was part of the collection of Amilcare Ancona, Milan. The current location of the helmet is unknown.

Cat. no. 78. Unprovenanced - complete helmet, but destroyed during WW2. Measurements: height: $14 \mathrm{~cm}$; diameter: $23 \times 21.5 \mathrm{~cm}$; weight: $1140 \mathrm{~g}-$ Pl. 10.78. References: Forrer 1894, 2, pl. IV.27; Hencken 1971, 144, fig. 113.

The helmet from the Zschille collection was not the one from 'Rome', which belonged to the Amilcare Ancona collection from Milan, as a comparison of the two photographs of both helmets demonstrates; ${ }^{516}$ both helmets though are indicated with the same weight.

\subsubsection{Helmets of Type Mantes}

Helmets of Type Mantes - named for the French find from the Seine at Mantes, Dép. Seine-etOise - are rather heavy, massive cap helmets with a slight, central ridge running from the front to the back (Tab. 2.10). These helmets, manufactured from either one or two bronze sheets, are, strictly speaking, a transitionary form between helmets of Class I and Class II. Whilst some were still formed from a single bronze sheet, as is characteristic of Class I helmets, the form of their crest and their distribution also relate them to Class II helmets. Given this mixed heritage, they are clearly the local precursor of crested helmets of Types Biebesheim, Bernières d'Ailly and Lueg. The crest of helmets of Type Mantes is either solid (Oggiono-Ello, Mainz-Kostheim) or hollow (Mantes). The rim of the helmet is straight and significantly thicker than the cap (Mantes, Mainz-Kostheim) or folded inwards (Oggiono-Ello), as on helmets of Type Lueg. Both the helmet from Oggiono-Ello and those of Type Lueg are not bent around a wire, as known on crested helmets of Type Biebesheim and Bernières d'Ailly or the helmet from 'Hungary'. At the rim of the helmet from Oggiono-Ello are two rivet holes in the front and the back of the helmet as well as three on each side, though not exactly opposite one another. The helmet also has a distinct cut-out on the back. On the helmet from Mainz-Kostheim, some of the small and flat headed rivets survive, mainly due to the use of internal lining discs. The now conserved copy of the helmet from Mantes does not show any rivet holes. While the Italian and the German helmets are without any decoration - and here we exclude the massive, inwards bending rib parallel to the rim of the helmet from Oggiono-Ello as 'decoration' - the helmet from Mantes is decorated with three negative lines parallel to the edge.

\begin{tabular}{l|l|l|c|l|c|c|c|c}
\hline $\begin{array}{l}\text { Cat. } \\
\text { No. }\end{array}$ & $\begin{array}{l}\text { Find } \\
\text { Circumstances }\end{array}$ & Find Site & State & Condition & $\begin{array}{c}\text { High } \\
\text { Total } \\
(\mathbf{c m})\end{array}$ & $\begin{array}{c}\text { Dm } \\
\mathbf{( c m )}\end{array}$ & $\begin{array}{c}\text { Thickness } \\
\text { Cap/Rim } \\
(\mathbf{m m})\end{array}$ & $\begin{array}{c}\text { Weight } \\
(\mathbf{g})\end{array}$ \\
\hline 79 & river & Mantes & FR & complete & 24 & $21 \times 17$ & - & - \\
\hline 80 & river (?) & Mainz & DE & complete & 16.7 & $22.3 \times 21.7$ & $2-3 /-$ & 1208 \\
\hline 81 & associated deposit & Oggiono-Ello & IT & complete & 13.6 & $20.3 \times 18.7$ & - & 750 \\
\hline 82 & river & Weil am Rhein & DE & complete & 19.6 & $22.7 \times 17.4$ & - & 804 \\
\hline
\end{tabular}

Tab. 2.10 Helmets of Type Mantes.

516 Pertusi 1892, 3, no. 21, pl. VIII.6; Hencken 1971, fig. 113. 


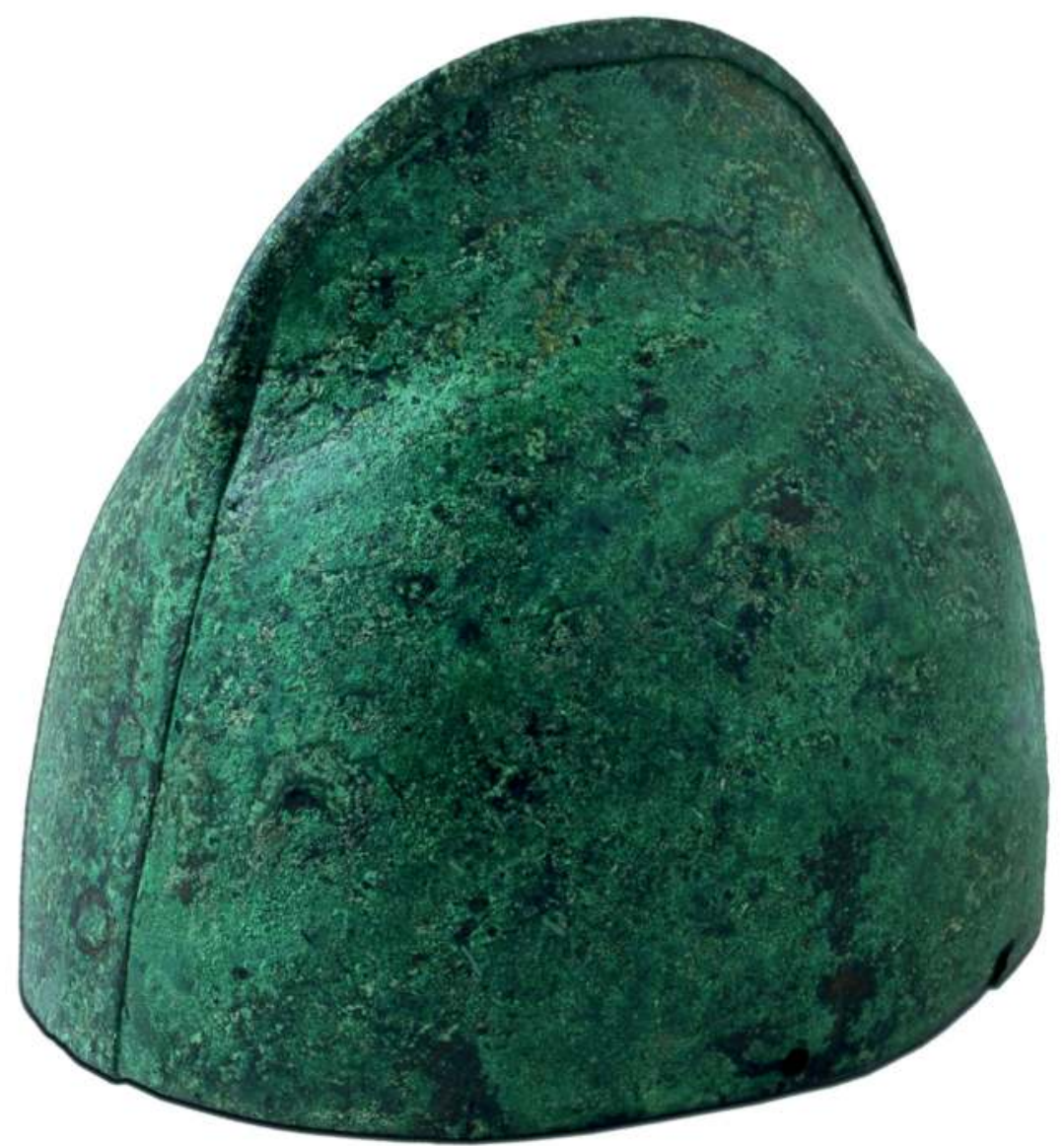

Fig. 2.18 Helmet of Type Mantes from Weil am Rhein, Germany (C Archäologische Bodenforschung Basel-Stadt, photograph: P. Saurbeck).

Around the rim of the helmet from Mainz a blackish band is visible. This is due to the turned-out edge of the inner organic lining, which then reacted on the outside with the bronze and led to the formation of different corrosion products.

Even though the helmet from Weil is, technologically speaking, closer to the classical crested helmets, with its cap made from two different bronze sheets joined together in the centre, this helmet still more closely resembles the helmets from Oggiono-Ello, Mainz-Kostheim and Mantes (Fig. 2.18). The lack of decoration and the shape of the massive cap, which is more round than conic, indicate a close relation to helmets of Type Mantes. The use of two flat-headed rivets on both the front and back demonstrates the connection to crested helmets of Type Lueg. We can interpret this helmet as a transitionary form from Type Mantes, as the prototype of crested helmets, to the highly developed crested helmets of Type Lueg or Type Biebesheim. ${ }^{517}$

\subsubsection{Research History}

As noted at the beginning of Chapter 2.2, helmets of Type Mantes were considered also as potential ancestors of crested helmets, ${ }^{518}$ even though their simple shape alone does not necessarily indicate an older type. ${ }^{519}$ Sperber interprets the helmet from Mantes as the one-part version of the two-part Type Biebesheim helmets, but not as an ancestor of the latter, while Schau-

\footnotetext{
517 E.g. v. Laur-Belart 1950, 202-208.

518 v. Laur-Belart 1950, 205.

519 Brandherm 2011, 43.
} 
er already classified it as a crested helmet. ${ }^{520}$ Lippert classifies the helmets from Mantes and Weil as Art Biebesheim. ${ }^{521}$ Type Mantes were also interpreted as a product of the combination of contemporary cap helmets and bi-valve crested helmets, ${ }^{522}$ though their date of Bz D (if not earlier; according to the associated finds in the deposit from Oggiono-Ello) suggests otherwise.

\subsubsection{Distribution and Deposition}

The find spots of the four helmets are quite widely spread: from Mantes in the northwest to Mainz in the northeast and southwards to Oggiono-Ello, Lombardia (Fig. 2.19). The helmet from Mantes was found in the Seine in 1860. It was part of the collection of Dr. Bonneau at Mantes, the actual find location being unknown. A reproduction is displayed in the Musée des Antiquités Nationales in Saint-Germain-en-Laye. From a private collection, another helmet, said to be found in the Main/Rhine (estuary of both rivers?) close to Mainz before 1940, is known. The helmet from Weil was found on a river bank of the Rhine in 1910. Today, the fluvial terrace of the river Rhine next to the village of Weil, Germany, in the north of Kleinhüningen, Switzerland, seems to be the most likely find spot. The helmet was bought by the Historisches Museum Basel and kept there for several decades before it moved to the Museum der Kulturen. The helmet from Oggiono-Ello was found as a part of a deposit in a quarry. G. v. Merhart notes loose fragments of a bronze sheet probably found together with the helmet, which might have been attached to it, since also on the inside of the helmet a bronze sheet was attached by rivets (Fig. 2.20). ${ }^{523}$

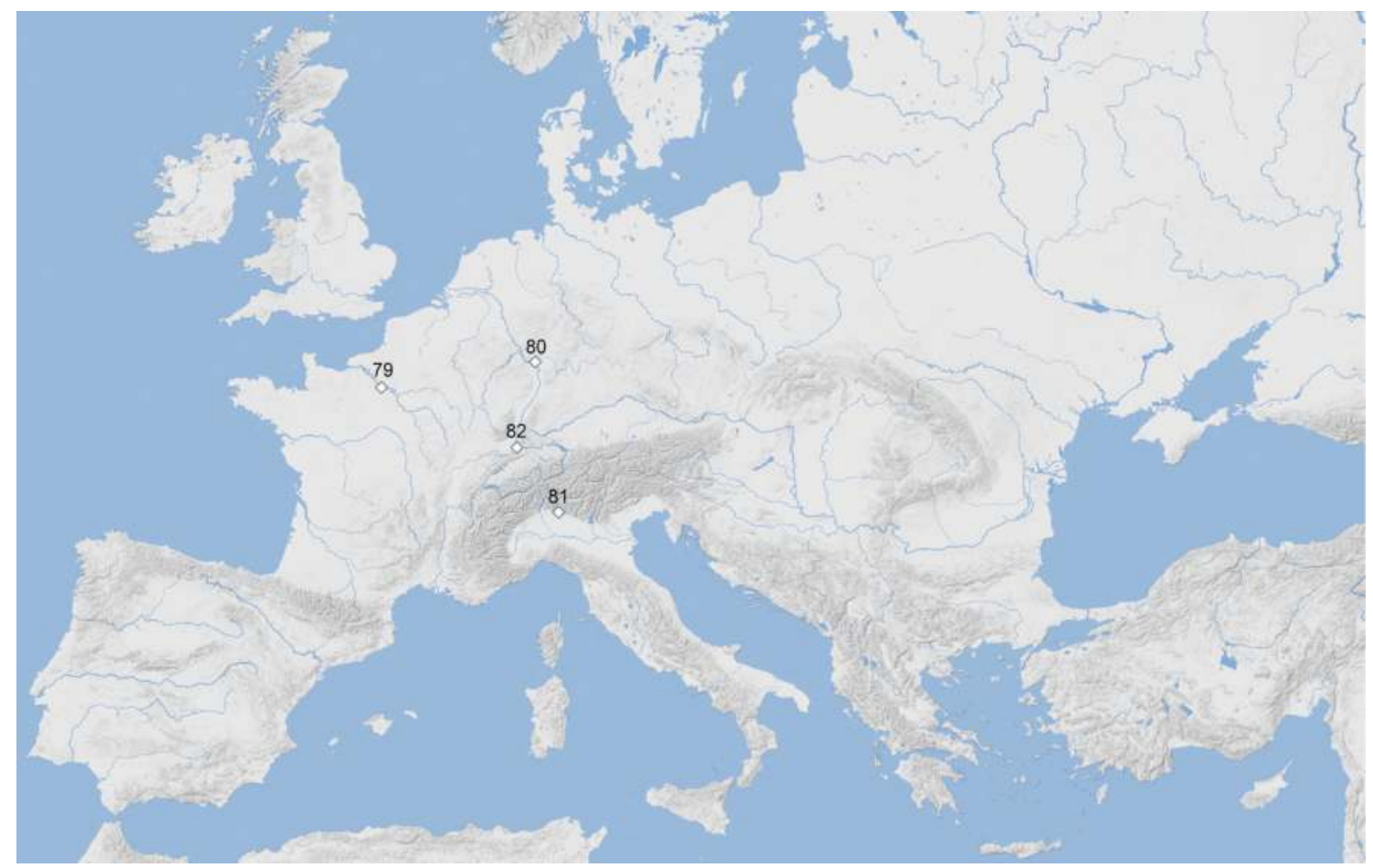

Fig. 2.19 Archaeological distribution of helmets of Type Mantes: 79. Mantes; 80. Mainz; 81. Oggiono-Ello; 82. Weil am Rhein. Numbers correspond to the catalogue numbers.

\footnotetext{
520 Schauer 1982c, 704; Sperber 2011, 23.

521 Lippert 2011, 42.

522 Brandherm 2011, 44.

523 v. Merhart 1941, 6-9.
} 


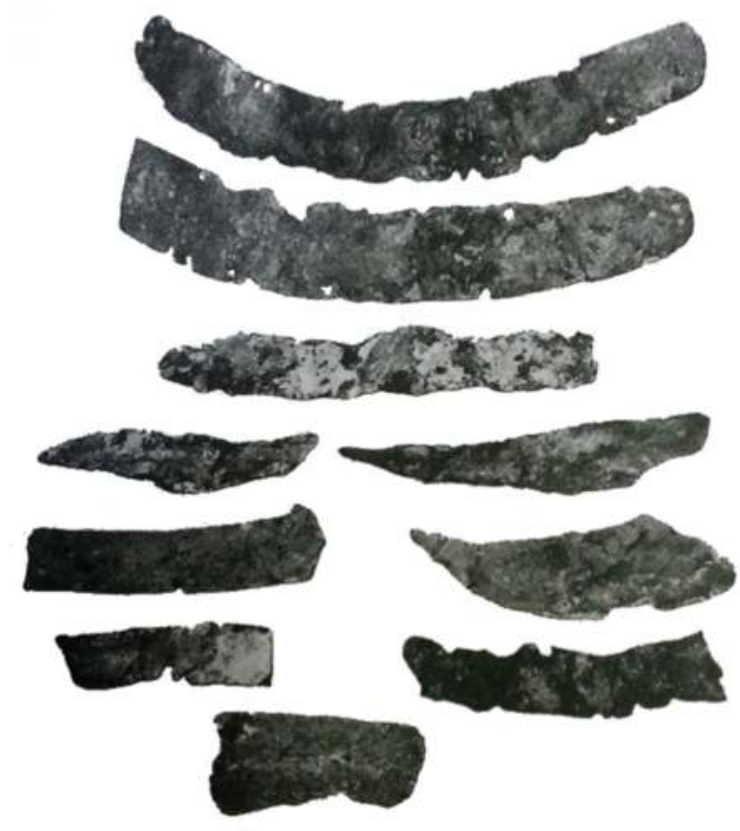

Fig. 2.20 Bronze bands found under the helmet of Type Mantes from Oggiono Ello, Italy (after Ghislanzoni 1929, fig. 12) (no scale).

\subsubsection{Chronology}

Since three of the four helmets are single finds from rivers, the only helmet useful for dating is the one from Oggiono-Ello. The associated deposit contains two swords of Type Oggiono, ${ }^{524}$ two Griffplatten daggers, four Bz D spearheads and two axes (Type Möhlin/variant B) as well as several unidentified fragments of bronze sheet bands with rivet (?) holes on the sides. ${ }^{525}$ According to Hansen and Hencken the associated deposit dates to Bz D. ${ }^{526}$ Though, some of the bronzes, such as the two axes, might already date to Bz B/C according to Schauer ${ }^{527} \mathrm{~V}$. BiancoPeroni dates the associated deposit to the Middle Bronze Age, and M. Egg - G. Waurick to 'most likely' $12^{\text {th }} / 13^{\text {th }}$ century BC. ${ }^{528}$ A chronological range for helmets of Type Mantes of late $\mathrm{Bz} \mathrm{C}$ to $\mathrm{Bz} \mathrm{D}$ therefore seems to be most likely.

\section{Catalogue}

Cat. no. 79. Mantes, Dép. Seine-et-Oise, France - single river find (river Seine) - complete helmet. Measurements: height: $24 \mathrm{~cm}$; diameter: $21 \times 17 \mathrm{~cm}-$ Musée des Antiquités Nationales Saint-Germain-en-Laye, inv. no. 4778 (copy; the depository of the original is unknown) - Pl. 11.79. References: Déchelette 1910, 231; Coutil 1912, 693-695, fig. 1; Coutil 1927, 362-366; v. Merhart 1941, 6, note 7, fig. 9.2; Hencken 1971, 126, 128, fig. 97; Mohen 1977, 122-124, fig. on p. 149; Schauer 1982c, 704; Clausing 2001, 221; Lippert 2011, 75.

The helmet was found in the Seine in 1860. It was part of the collection of Dr. Bonneau at Mantes, the actual find location being unknown. A reproduction of the helmet can be found at the Musée des Antiquités Nationales in Saint-Germain-en-Laye.

\footnotetext{
524 Bianco-Peroni 1970, 19-22; Schauer 2003, 193.

525 Ghislanzoni 1929, 7, no. 12, fig. 12.

526 Hencken 1971, 135; Hansen 1994, 19, note 41.

527 Schauer 2003, 193.

528 Bianco-Peroni 1970, 18; Egg - Waurick 1990, 14.
} 
Cat. no. 80. Mainz, Hessen, Germany - single river find (?) (probably in the estuary of the rivers Main and Rhine) - complete helmet. Measurements: height: $16.7 \mathrm{~cm}$; diameter: $22.3 \times$ 21.7cm; thickness: 2-3mm; weight: 1208g - Landesmuseum Mainz, inv. no. 17.124 - Pl. 11.80. References: v. Merhart 1941, 5; Hencken 1971, 128, fig. 98; Schauer 1980, figs. 4-8; Schauer 1982c, figs. 3-5; Egg - Waurick 1990, 15, fig. 8.1; Lippert 2011, 64, pl. 1.5.

The helmet comes from a private collection and was said to be found in the river Main close to Mainz. It was bought by the museum in 1917.

Cat. no. 81. Oggiono-Ello, prov. Lecco, Lombardia, Italy - associated deposit - complete helmet. Measurements: height: $13.6 \mathrm{~cm}$; diameter: $20.3 \times 18.7 \mathrm{~cm}$; weight: $750 \mathrm{~g}-$ Museo Civico, Como, inv. no. X-927 - Pl. 11.81. References: Ghislanzoni 1929, 7, nos. 11, 13-14, fig. 11; v. Merhart 1941, 5, fig. 1.7; Bianco-Peroni 1970, 18, pl. 74.B; Hencken 1971, 133, fig. 105; Bouzek 1981, 24, fig. 3.1; Schauer 1982c, 701-704, no. 1, fig. 1; Egg - Waurick 1990, 14; Hansen 1994, 19, 221; Clausing 2001, 221; Schauer 2003, fig. 1.11.

The helmet was presumably found together with two swords (Type Oggiono), two Griffplatten daggers, four Bz D spearheads and two axes (Type Möhlin/variant B) as well as several fragments of bronze sheets in a quarry in a cleft in the rock with view to Lake Annone, some $300 \mathrm{~m}$ above sea level. As E. Ghislanzoni pointed out, the objects were not found all together at once but over a period of several months. ${ }^{529}$

Cat. no. 82. Weil am Rhein, Baden-Württemberg, Germany (former Kleinhüningen, Basel, Switzerland) - single river find (river Rhine) - complete helmet. Measurements: height: 19.6cm; diameter: $22.7 \times 17.4 \mathrm{~cm}$; weight: $804 \mathrm{~g}-$ Museum der Kulturen, Basel, inv. no. I.21690 - Pl. 11.82. References: v. Laur-Belart 1950, 202-208; Hencken 1971, 62, fig. 36; Heman 1983, 15; Blanchet 1984; Jud 1985, 62-66; Benz 2008, 346, fig. on p. 90; Lippert 2011, 65, pl. 4.1; Sperber 2011, 23.

The helmet was found on a river bank of the Rhine in 1910. Today, the fluvial terrace of the river Rhine next to the village of Weil am Rhein, Germany, in the north of Kleinhüningen, Switzerland, seems to be the most likely find spot. The helmet was bought by the Historisches Museum Basel and kept there for several decades (old inv. no. 1910.181) before it was moved to the Museum der Kulturen.

\subsubsection{Helmets of Type Lueg}

All three helmets of Type Lueg have a bi-valve, round cap bearing a three pointed crest. Most likely, the helmets from Anlauftal and the Piller Sattel also had cheek plates as found on the helmet from Pass Lueg, as suggested by the presence of two rivet holes on each side. The crested cap consists of two bronze sheets, fixed together at the crest with overlapping ends and with rivets on the front and back. The helmet from Pass Lueg is the only complete helmet of this type, which includes preserved cheek plates.

All three helmets (Tab. 2.11) have as decoration a massive, broad rib parallel to the rim, a dotted line parallel over it and two dotted lines following the edge of the crest. In the centre of the cap, three dotted circular lines as well as a central boss complete the similarities in the decoration. Additionally, the Pass Lueg helmet has two smaller circles of the same kind left and right of the central one; the helmet from the Anlauftal has one boss to the side of the big circle close to the front side of the helmet. Similar decoration is also known on the helmets from Szczecin-Zdroje and Tiryns, the cuirass from Jura B and a complete bronze cuirass from the Danube as well as one of the bronze cups from the associated deposit from Dresden-Dobritz. ${ }^{530}$ Further fragments with the same kind of decoration are known from the Late Bronze Age associat-

529 Ghislanzoni 1929, 15.

530 Martin 2009, pl. 30.119; Mödlinger 2014b. 
ed deposits from Salaš Noćajski, ${ }^{531}$ Guşteriţa, Romania, ${ }^{532}$ Techirghiol, Romania, ${ }^{533}$ and Pila del Brancon, ${ }^{534}$ as well as an Iron Age deposit from Sicily. ${ }^{535}$

\begin{tabular}{c|l|l|c|l|c|c|c|c|c}
\hline $\begin{array}{l}\text { Cat. } \\
\text { No. }\end{array}$ & $\begin{array}{l}\text { Find } \\
\text { Circumstances }\end{array}$ & Find Site & State & Condition & $\begin{array}{c}\text { Fragments } \\
\mathbf{( c m )}\end{array}$ & $\begin{array}{c}\text { High } \\
\text { Total } \\
(\mathbf{c m})\end{array}$ & Dm (cm) & $\begin{array}{c}\text { Thickness } \\
\text { Cap/Rim } \\
(\mathbf{m m})\end{array}$ & $\begin{array}{c}\text { Weight } \\
(\mathbf{g})\end{array}$ \\
\hline 83 & $\begin{array}{l}\text { associated } \\
\text { deposit }\end{array}$ & Pass Lueg & AT & complete & - & $\begin{array}{c}27.5 \\
(15 \mathrm{cap})\end{array}$ & $18.3 \times 21.3$ & - & $\begin{array}{c}998 \\
(\mathrm{cap})\end{array}$ \\
\hline 84 & votive deposit & Piller Sattel & AT & fragment & $19.6 \times 16.2$ & c. 34 & $19.6 \times 16.2$ & $0.9 / 1.3$ & 500 \\
\hline 85 & river & Anlauftal & AT & fragment & $18.9 \times 19.3$ & - & - & - & 279 \\
\hline
\end{tabular}

Tab. 2.11 Helmets of Type Lueg.

The decoration of the crest on Type Lueg is completed by a vertical, broad rib, which also serves as stabilisation. Unfortunately, the upper part of the crest of the helmet from the Anlauftal is missing. Additionally, the helmet from Pass Lueg has on each side four bosses on the crest; one in the middle of each small point of the crest, and two left and right of the vertical rib. The helmet from the Piller Sattel does not bear any bosses at all on the crest. The helmet from Anlauftal bears one boss preserved on the smaller point of the crest. Moreover, the helmet from Pass Lueg shows three parallel, vertical, dotted lines reaching from the end of the crest to the horizontal line of pellets on one side of the helmet - the one closest to the holes for the cheek plates. The helmet from the Anlauftal has the same kind of decoration but with just two lines of pellets and on the side opposite to the holes with which to attach the cheek plates. The helmet from the Piller Sattel bears no such decoration on the preserved part.

The helmet from Pass Lueg has on what is assumed to be the front three parallel lines of pellets which reach from the horizontal line of pellets to the beginning of the crest, where the three lines meet. On the back or 'neck' side of the helmet, no such decoration is visible. In addition, we find bosses next to the vertical rib, as well as one on each side of the crest on the tip of the front and back point. The cheek plates are decorated with three parallel, horizontal lines of pellets, parallel to the upper edge of the cheek plates, which are followed by three circles of pellets (diameter approx. $2.5 \mathrm{~cm}$ ) with one central boss inside. Below the circles, there are again three parallel, horizontal lines of pellets with three circles of pellets and a central boss. Beneath the three circles, there are once more three parallel, horizontal lines of pellets. Under these, we find two circles of pellets with a central boss. Both circles are surrounded by one line of pellets.

Approximately $2 \mathrm{~cm}$ above the rim, the helmet from the Piller Sattel has a broader, plastic rib. A vertical rib similar to the horizontal one is found on the central part of the crest. Parallel to the horizontal rib, a line of pellets is visible. On the sides of the helmet, three circles of pellets with a central boss were applied. Two lines of pellets follow the whole edge of the crest. No part of the opposite half of the helmet survive (not even any overlapping parts to join the two parts together on the crest).

The helmet from the Anlauftal shows approximately $1.6 \mathrm{~cm}$ above the rim a $3 \mathrm{~mm}$ broad convex rib, parallel to the edge. Parallel to the horizontal rib and approx. $1.4 \mathrm{~cm}$ above it, a line of dots is visible. A double line with small dots is following the edge of the crest; the dotted line on the outside is irregular. Both lines were punched before the two parts of the helmet cap and crest were joined together; one joint is overlapping the dotted lines. On the front of the helmet, right under the ending of the crest, two vertical dotted lines are visible. In the middle of the preserved half of the helmet, three circles of dotted lines (diameter $5.9-6.9 \mathrm{~cm}$ ) and a central boss (diameter $1.5 \mathrm{~cm}$ ) were applied. The size of the central boss corresponds with the ones from the

\footnotetext{
531 Vasić 1994, pl. 38.13.

${ }_{532}$ Bronze sheet fragment: Rusu 1990, 73, pl. V.5.

533 Bronze sheet fragment: Petrescu-Dîmboviţa 1978, pl. 215.17-19.

534 Salzani 1998, no. 139.

535 Egg 1983, fig. 2.4-5.
} 
preserved part of the crest; the slightly deformed single boss on the right side of the one surrounded by the three dotted circles is slightly bigger (diameter $1.6-1.8 \mathrm{~mm}$ ). This single boss might be interpreted as 'eyes', such as is known from helmets of Type Biebesheim (Paris, Montmacq A, Blainville) or as a reduction of the motif found on the Pass Lueg helmet. In any case, the boss itself is too well preserved and in a too much similar position to conclude, that it resulted from depositional damage from being in the river, such as a stone bending the metal sheet as suggested by M. Mehofer. ${ }^{536}$

\subsubsection{Research History}

Helmets of Type Lueg remain the basis for lively discussion, especially concerning the chronological classification of this very special helmet type. Until 2001, the helmet from Pass Lueg, which was found in 1838, was the only example of its kind. The association with other finds from a potential deposit, to which the helmet might also belong, remains unclear, thus resulting in a range of different chronological assignations.

The new helmet finds from the Piller (a votive deposit with over 350 bronzes, ranging according to different authors -from $\mathrm{Bz} \mathrm{A} / \mathrm{B}$ to $\mathrm{Ha} \mathrm{A} 1,{ }^{537}$ or even $\mathrm{Ha} \mathrm{B}^{138}$ ) and the single find from the Anlauftal in 2006, have resulted in further diverse discussions about the dating of these helmets, but at least rendered the interpretation of the form as a local Alpine variant of Early Iron Age Italian crested helmets ${ }^{539}$ as obsolete. These chronological discussions also influenced the general discussion about the origin of crested helmets in general; dating the helmets of Type Lueg to Bz C as Egg and Tomedi have, would make them one of the oldest metal helmets, making an origin for crested helmets in the Aegean or the Near East impossible. ${ }^{540}$ This view, however, was criticised by Schauer due to the wide chronological range of the votive deposit from the Piller Sattel and the unsecure nature of the associated finds from Pass Lueg. ${ }^{541}$

\subsubsection{Distribution and Deposition}

All helmets of Type Lueg were found at passes or close to them in the west of the eastern Alps, not far from the copper mining areas in Tyrol and Salzburg (Fig. 2.21), to which they are moreover connected through their alloy composition patterns and lead isotope characterisation. Both point to their production from local copper ores. The helmets have been connected with specific events or situations, such as votive deposits to mark good passage along long distance trading routes, local copper mining and its control, the presence of elites or the exchange of smiths and/ or their products.

The votive deposit at the Piller Sattel/Moosbruckschrofen is around $2 \mathrm{~km}$ from the Bronzeand Iron Age cremation sanctuary at the Piller Sattel, the pass from the Pitz to the Inn valley. All bronzes were found together in a large ceramic pot. The helmet from Pass Lueg was found in 1838 during work on the street over the pass. The pass Lueg might not be a very high pass but nevertheless marks the entrance or end of a dangerous gorge through which the river Salzach runs. According to the finder, the helmet was found together with other bronze objects close to a cliff $10 \mathrm{~m}$ above the old street. The helmet from the Anlauftal seems to be a single find from the creek Anlauf. Following the Anlauf creek, we reach the Korntauernscharte $(2460 \mathrm{~m}$ above sea level), from where it is easy to reach the upper Möll Valley and then the Drau Valley, an important route to the south.

\footnotetext{
536 Mehofer 2011, 121.

537 Egg - Tomedi 2002; Tomedi 2002; Schauer 2003; Tomedi 2004; Tomedi 2007; Lippert 2010; Lippert 2011.

538 Lippert 2011, fig. 24.

539 So v. Merhart 1969, 137.

540 Egg - Tomedi 2002, 556.

541 Schauer 2003, 201.
} 


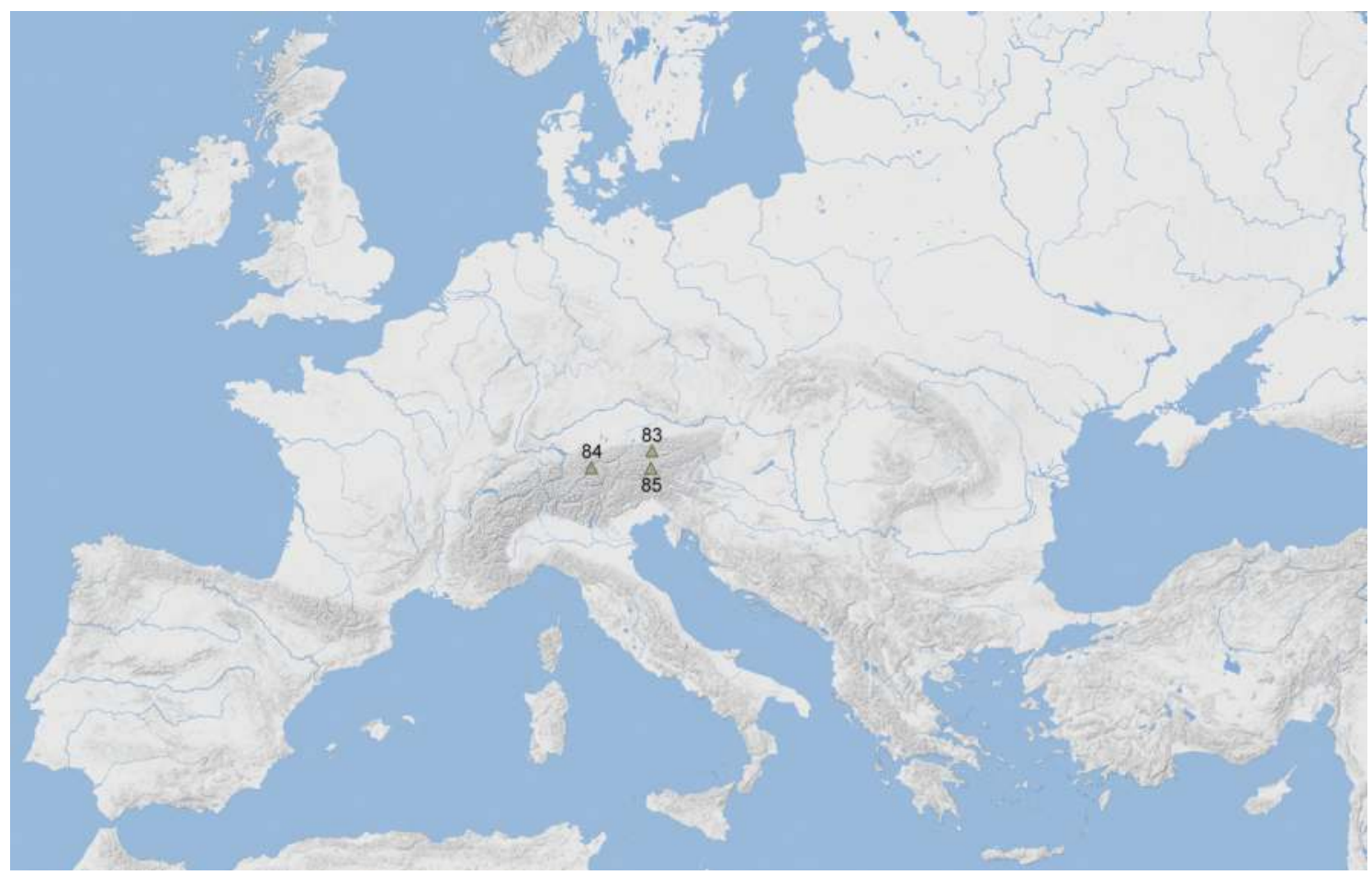

Fig. 2.21 Archaeological distribution of helmets of Type Lueg: 83. Pass Lueg; 84. Piller Sattel; 85. Anlauftal. Numbers correspond to the catalogue numbers.

\subsubsection{Chronology}

The dating of helmets of Type Lueg is still a matter of discussion, and opinions differ widely. Older publications could take into account only the helmet from Pass Lueg; the helmets from the Piller Sattel (votive deposit) and Anlauftal (single find) having been found only in 2001 and 2006 respectively. Today, the theory of v. Merhart, who assumed that the helmet from Pass Lueg was a local Alpine variant of Early Iron Age Italian crested helmets, ${ }^{542}$ is now redundant. R. Pittioni dated the helmet of Pass Lueg to the late Urnfield period, whilst Müller-Karpe dated it to the early Urnfield period, a date that J. Bouzek and Hencken also adopted. ${ }^{543}$

Considering that the potential associated finds of the Pass Lueg helmet are such, a date of Bz $\mathrm{C} / \mathrm{D}$ seems reasonable. The axe associated with the helmet from Pass Lueg might be of Type Gmunden, which was widely distributed during Bz C1, but is also known from Bz D. ${ }^{544}$ The picks of Type Mitterberg do not allow any detailed dating, ${ }^{545}$ though some of them were also found in the deposit from Sipbachzell, Upper Austria, which contains bronzes ranging from the Middle Bronze Age to the early Urnfield period. ${ }^{546}$

The votive deposit from the Piller Sattel is dated to $\mathrm{Bz} \mathrm{C}-\mathrm{Ha} \mathrm{A}$ but there is still debate concerning this ${ }^{547}$ According to the associated finds of the helmet, Egg and Tomedi date the helmet to $\mathrm{Bz} \mathrm{C} / \mathrm{D}::^{548}$ the oldest object can be dated to the transition of $\mathrm{Bz} \mathrm{A} / \mathrm{B}-\mathrm{a}$ Flügelnadel (winged pin), whose basic shape is already known in the Early Bronze Age - and the most recent to $\mathrm{Bz}$ $\mathrm{C} 2 / \mathrm{D}$ (median-winged axes). According to Egg and Tomedi, there is no object typical for the Late Bronze Age, which is questioned by Schauer, who mentions that due to the longer life span

542 v. Merhart 1969, 137.

543 Pittioni 1954, 514; Müller-Karpe 1959, 10, 113; Müller-Karpe 1962a, 273; Hencken 1971, 58; Bouzek 1981, 24.

544 Mayer 1977, 130.

545 Egg - Tomedi 2002, 553.

546 Höglinger 1996, 87.

547 Most recent, the overview in Mörtz 2013.

548 Egg 2002; Egg - Tomedi 2002, 545; Tomedi 2004; Tomedi 2007. 
of some of the finds in the deposit - one sickle (Zungensichel), one axe and the fragment of a Griffzungenschwert - the helmet from the Piller Sattel might date also to Bz D-Ha A. ${ }^{549}$ As C. Jahn recently pointed out, ${ }^{550}$ the sickle might also indicate a date in the Middle Bronze Age, and cannot therefore be considered a firm basis for a Late Bronze Age date. Conversely, the sickles of Type Uioara (which occur in $\mathrm{Bz} \mathrm{C} 2$ but are most common during $\mathrm{Bz} \mathrm{D}-\mathrm{Ha} \mathrm{A} 1$ ) do not seem to be used much after casting. P. Schauer was also criticised by Tomedi, who included a discussion on circular-arguments of axe/sickle-dating and the dating of associated deposits in general in his publication. ${ }^{551}$ A completely different chronological approach has been taken by Lippert, based on his correspondence analyses. He suggested that the helmet was deposited at the end of Ha A2/B1, ${ }^{552}$ which is definitely too late if we consider the associated finds of the deposit.

However, we have to take into account that some associated finds from the Piller Sattel deposit, such as the sickles of Type Přestavlky (Bz D2) and the median-winged axes of Type Freudenberg (mainly Bz D), do point to a slightly different chronological approach than that presented by Egg and Tomedi. The helmet was unlikely to have been produced in $\mathrm{Bz} \mathrm{C}$ (an argument perhaps predicated more on wishing to have the oldest European metal helmets), and was much more likely produced in Bz D. Also, similar axes were found in the grave of Čaka and in the deposit of Ducové, ${ }^{553}$ and the manufacturing technique, mainly the production of two halves to mount the cap, cannot be too far removed chronologically from Type Mantes, the archaic ancestor of European crested helmets. Another argument is the production of the earliest central European bronze defensive armour in the Carpathian Basin from Bz D onwards, which has close connections to the slightly older armour from Greece (e.g. the cuirass from Dendra and helmets of Type Oranienburg; the helmet from Biecz, dated to Bz C/D, is most likely an import from the Aegean). ${ }^{554}$ The appearance of the first European metal helmets, a crested, bi-valve and highly elaborated helmet in the Alpine region of central Europe, does not seem very likely; as already pointed out before (Type Mantes, Chapter 2.2.2), it seems more likely that helmets of Type Mantes represent the base of development for European crested helmets, thus also being the ancestors of helmets of Type Lueg.

Therefore, it seems most reasonable that helmets of Type Lueg were deposited in Bz D2, or potentially even Ha A1, after a short period of use. A dating to Bz D-Ha A1 is supported by the construction technique using two bronze sheets joined together on the crest and the applied decoration, i.e. the three circles of pellet lines with a central boss. This element of decoration is rare and is found mainly on Late Bronze Age armour, and is unknown for the Middle Bronze Age: on the helmet from Tiryns, one of the cuirasses from Jura (cat. no. 138) and a complete bronze cuirass from the Danube as on other bronze sheets objects from Salaš Noćajski, Serbia, ${ }^{555}$ Guşteriţa, Romania, ${ }^{556}$ Techirghiol, Romania, ${ }^{557}$ Pila del Brancon, Italy, ${ }^{558}$ Dresden-Dobritz, Germany, ${ }^{559}$ and from an Iron Age deposit from Sicily. ${ }^{560}$

\section{Catalogue}

Cat. no. 83. Pass Lueg, Salzburg, Austria - associated deposit - complete helmet. Measurements: height: $15 \mathrm{~cm}$ (cap), $27.5 \mathrm{~cm}$ (with crest); diameter: $18.3 \times 21.3 \mathrm{~cm}$; weight: $1134 \mathrm{~g}$ (total);

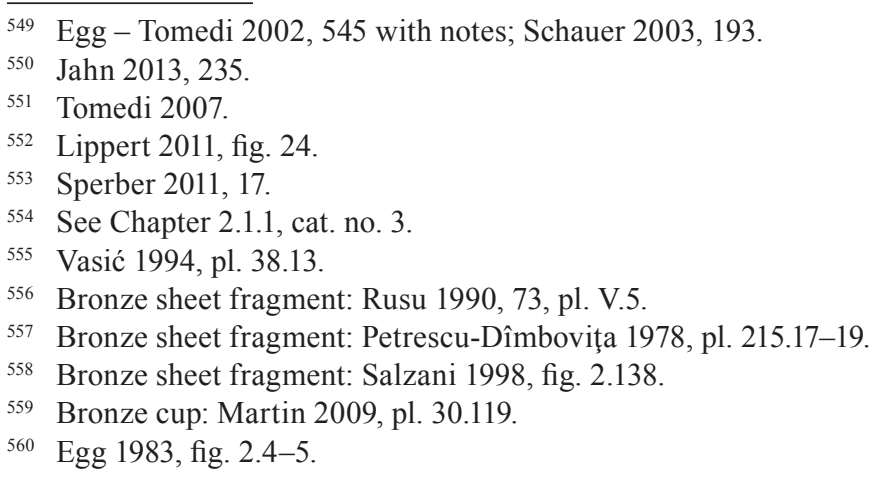


$998 \mathrm{~g}$ (without cheek plates); 'right' cheek plate: $14.8 \times 9.3 \mathrm{~cm}$ (for more detailed measurements see Mehofer 2011, 121); weight: $57.5 \mathrm{~g}$; thickness: $0.8-1.3 \mathrm{~mm}$; 'left' cheek plate: $15.5 \times 9.7 \mathrm{~cm}$; weight: 78.5g - Salzburg Museum, inv. no. ARCH 122 - Pl. 12.83. References: Seethaler 1839; v. Süß 1844, 16; v. Arneth 1851; Much 1883; Kyrle 1918, 80, figs. 1-4, 12-16; Moosleitner 1982; Urbanek 1991, 61; Moosleitner 1993; Tomedi 2007; Lippert 2010; Lippert 2011; Lutz 2011; Marx 2011; Mehofer 2011.

The helmet was found in 1838 during work on the street over the pass. According to the finder, the helmet was found together with other bronze objects close to a loose precipice $10 \mathrm{~m}$ above the old street. Years later, the finder also mentions 'other bronzes' from the same find spot which he threw away. ${ }^{561}$ The recorded composition of the deposit differs over time, comprising either:

1. helmet, one axe, two pickaxes, two pieces of molten ore ${ }^{562}$

2. helmet, one axe, a pickaxe, three antique bronzes ${ }^{563}$

3. helmet, one axe, two pickaxes, two pieces of metal ${ }^{564}$

4. helmet, a winged axe, two pickaxes and another one in the Natural History Museum Vienna (maybe from another find spot), two pieces of casting cake. ${ }^{565}$

However, today it seems that two pickaxes and a winged axe (Salzburg Museum inv. no. 123-125, and maybe also another pickaxe from the Natural History Museum Vienna, inv. no. 18.000) as well as three bronze bars and two pieces of casting cake (also in the Salzburg Museum) were indeed part of the deposit. After the helmet was found, it was boiled in oil to receive the specific patina as it has it now. Lippert and Mehofer note different weights of the helmet in the same publication. ${ }^{566}$

Cat. no. 84. Piller Sattel, Tirol, Austria - votive deposit - fragment (half of the helmet). Measurements: fragment: $19.6 \times 16.2 \mathrm{~cm}$; height: approx. $34 \mathrm{~cm}$; thickness: $0.9-1.3 \mathrm{~mm}$; diameter approx. 20-22cm (for more detailed measurements see Mehofer 2011, 124); weight: $500 \mathrm{~g}-$ Archäologisches Museum Fließ, no inv. no. - Pl. 12.84. References: Tomedi et al. 2001; Egg 2002; Egg - Tomedi 2002; Nowak 2002; Tomedi 2002; Schauer 2003; Tomedi 2004; Tomedi 2007; Lippert 2010; Lippert 2011; Lutz 2011; Marx 2011; Mehofer 2011; Tomedi 2012.

In $2001 \mathrm{~F}$. Neururer located with the aid of a metal detector a votive deposit of more than 350 bronzes in a crevice at the Moosbruckschrofen am Piller. The deposit is around $2 \mathrm{~km}$ from the Bronze- and Iron Age cremation sanctuary at the Piller Sattel, the pass from the Pitz- to the Inn valley, and was excavated by the Institut für Ur- und Frühgeschichte from the Innsbruck University only three days after its discovery. All the bronzes were found in one big ceramic pot. The deposit contained amongst other things the helmet, one Achtkantschwert Type Hausmoning, one sword of Type Spatzenhausen, one flange hilted sword, spearheads (including also residues of the shaft, identified as ash), daggers, shaver, median-winged axes, sickles, needles/ pins, pieces of a bronze belt, pendants (Brillenanhänger), discs (Stachelscheiben), spiral rolls still containing leather, etc. Almost all objects show traces of intentional destruction, including indications of burning.

Cat. no. 85. Anlauftal, Salzburg, Austria - single find - fragment (half of the helmet). Measurements: $18.9 \times 19.3 \mathrm{~cm}$; approx. height of the cap: $14 \mathrm{~cm}$ (for more detailed measurements see Mehofer 2011, 120); weight: 279g - Montanmuseum Altböckstein, Bad Gastein; no inv. no. - Pl. 13.85. References: Lippert 2010; Lippert 2011; Lutz 2011; Marx 2011; Mehofer 2011; Weber 2011.

\footnotetext{
561 Egg - Tomedi 2002, 551.

562 Seethaler 1839.

563 v. Süß 1844; v. Arneth 1851; both note a pickaxe instead of spearheads.

564 Much 1883.

565 Kyrle 1918.

566 Lippert 2011, 20; Mehofer 2011, 121, 123.
} 
Following the Anlauf creek, we reach the Korntauernscharte (2460m above sea level), from where it is easy to reach the upper Möll Valley and then the Drau Valley. In August 2006, on the left side of the Anlauf creek, E. Tschitschko found the fragmented half of the helmet with a metal detector. The alleged find spot is around $1200 \mathrm{~m}$ above sea level and was confirmed by pollen analyses of residues inside the crest of the helmet and the surrounding of the presumable find spot. ${ }^{567}$ The fragment was found in the humus, sandy earth $6 \mathrm{~m}$ from the river. The partly exposed bronze surface of the fragment (according to the finder) might be the result of continuous abrasion of the surface (but then no traces of manufacture would have been left) or the result of the oxygen poor surrounding in the bed of the creek. However, the edges are patinated, so the fragment was deposited as such.

Only one half of the helmet, the 'left' side (the same as the Piller Sattel helmet), is preserved. The front and the back were broken off as well. On one of the smaller points of the crest, the folds are still preserved (two on the lower side, one on the upper side). The central part of the helmet is partly damaged due to its deposition in the river; it is folded and partly broken through. The overlapping parts of the two halves of the helmet as well as the rivet holding them together are missing. On the outside of the helmet, the patina is partly chipped off. The colour is dark green to dark brown.

\subsubsection{Helmets of Type Biebesheim}

Today, 13 complete and one fragmented helmet, the latter from Otterstadt, Germany, are known (Tab. 2.12). The crest of helmets of Type Biebesheim is generally narrow, and cap as well as crest are pointed or rounded (Ebing, Montmacq A and B, Seurre, Paris) at the top. Unfortunately, the upper part of the helmet from Le Theil is missing. The edge of the crest of one of the

\begin{tabular}{|c|c|c|c|c|c|c|c|c|c|}
\hline $\begin{array}{l}\text { Cat. } \\
\text { No. }\end{array}$ & $\begin{array}{l}\text { Find } \\
\text { Circum- } \\
\text { stances }\end{array}$ & Find Site & State & Condition & $\begin{array}{l}\text { Frag- } \\
\text { ments } \\
(\mathrm{cm})\end{array}$ & $\begin{array}{l}\text { High } \\
\text { Total } \\
(\mathrm{cm})\end{array}$ & Dm (cm) & $\begin{array}{c}\text { Thickness } \\
\text { Cap/Rim } \\
\text { (mm) }\end{array}$ & $\begin{array}{c}\text { Weight } \\
\text { (g) }\end{array}$ \\
\hline 86 & river & Biebesheim (A) & $\mathrm{DE}$ & complete & - & 27.9 & $22 \times 17.6$ & $0.75-1 /-$ & - \\
\hline 87 & river & Biebesheim (B) & $\mathrm{DE}$ & complete & - & 26.1 & $19.2 \times 19.6$ & - & 770 \\
\hline 88 & river & Bremen & $\mathrm{DE}$ & $\begin{array}{l}\text { almost } \\
\text { complete }\end{array}$ & - & 29.5 & $23.5 \times 17.5$ & - & 794 \\
\hline 89 & river & Ebing & $\mathrm{DE}$ & complete & - & 29 & $21.5 \times 16.2$ & - & 829 \\
\hline 90 & river & Pockinger Heide & $\mathrm{DE}$ & \begin{tabular}{|l|} 
almost \\
complete
\end{tabular} & - & 22.6 & $20 \times 18.9$ & - & 804 \\
\hline 91 & river & Otterstadt & $\mathrm{DE}$ & fragment & $18 \times 27.6$ & - & - & - & - \\
\hline 92 & river & Auxonne & FR & complete & - & 25.5 & $20.7 \times 18.3$ & - & 690 \\
\hline 93 & $\begin{array}{l}\text { associated } \\
\text { deposit }\end{array}$ & Le Theil & FR & not complete & - & 24 & $20.7 \times 18.6$ & - & - \\
\hline 94 & river & $\begin{array}{l}\text { Blainville-sur- } \\
\text { l'Eau }\end{array}$ & FR & complete & - & 32.5 & $27.1 \times 17.8$ & - & 1020 \\
\hline 95 & river & Chalon-sur-Saône & FR & complete & - & 31 & $21.4 \times 18.5$ & - & 491 \\
\hline 96 & river & Montmacq (A) & FR & complete & - & 26 & $22 \times 17$ & - & 650 \\
\hline 97 & river & Montmacq (B) & FR & complete & - & 25 & $23 \times 17$ & - & 725 \\
\hline 98 & river & Paris & FR & complete & - & 26 & $23 \times 18$ & - & 760 \\
\hline 99 & river & Seurre & FR & complete & - & 23 & $22.5 \times 18.8$ & - & 689 \\
\hline 100 & unknown & unprovenanced & - & complete & - & 24.5 & $19 \times 17$ & $0.5 / 4$ & 465 \\
\hline
\end{tabular}

Tab. 2.12 Helmets of Type Biebesheim and related helmet (cat. no. 100).

567 Weber 2011. 


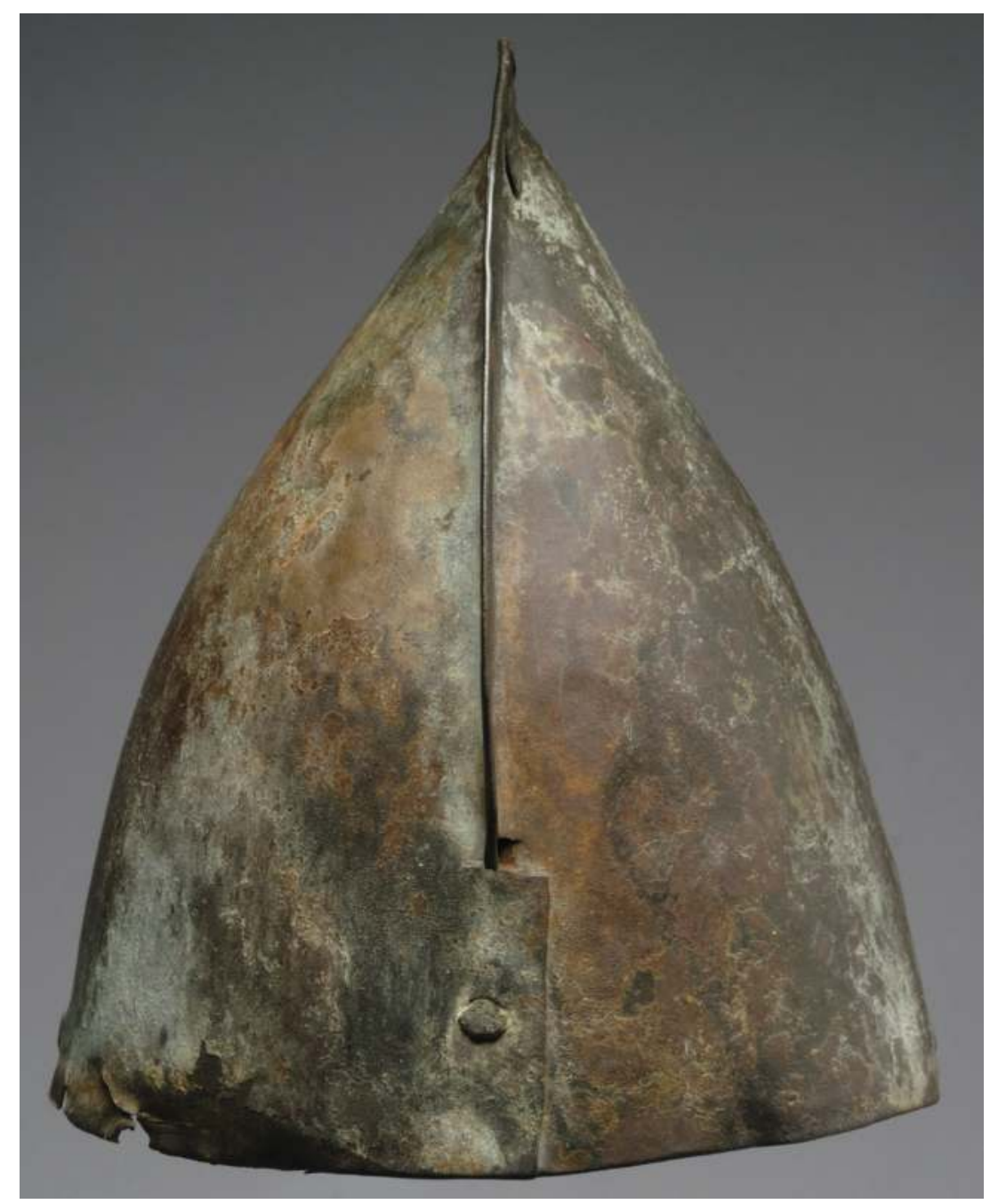

Fig. 2.22 Front-view of the helmet of Type Biebesheim from Seurre, France (C) Musée Denon, photo: Antoine Maillier)

halves overlaps the crest of the other half. Both the front and back of the rectangular sheets of both halves overlap and were fixed together with two, sometimes three, rivets. On Type Biebesheim these are either flat rivets (Auxonne, Biebesheim B, Otterstadt, Seurre) (Fig. 2.22) or conical rivets (Biebesheim A, Bremen, Pockinger Heide, Ebing, Blainville, Chalon, Montmacq A, Paris). The helmet from Montmacq B even has decorative fluted, flat headed rivets. Since the helmets from Biebesheim and Montmacq were deposited together, there does not seem to be a yet identifiable local or chronological preference for rivet design.

The rim is straight (Le Theil) or bent outwards around a wire. On the sides, the helmets usually have two holes close to each other to attach cheek plates or, due to the short distance between the holes, more likely a chin strap. The rivet holes on the helmet from Paris were punched from the inside to the outside after the rim of the helmet was bent outwards. ${ }^{568}$ The helmet from Chalon-sur-Saône even shows separately attached bronze sheets, each with three holes to attach cheek plates or chin strap. The helmets from Montmacq A, Chalon-sur-Saône and Paris show so-called 'eyes' (large bosses) on the sides, while the helmet from Blainville shows large bosses close to one another on each side of the helmet. Above the rim, the helmet from Paris bears a parallel circumferential rib. The helmet of Montmacq B has two ribs parallel to the rim right above it, while the helmet from Montmacq A bears a line of 63 small bosses

568 Mohen 1977, fig. on p. 122. 
immediately above the rim. The helmet of Chalon-sur-Saône instead shows a line of large bosses along the rim.

\subsubsection{Research History}

In discussing the broader context of western European crested helmets, v. Merhart grouped helmets of Type Biebesheim amongst his group CI. ${ }^{569} 30$ years later, Hencken called them 'crested helmets with conical cap', and Schauer discussed them as helmets Art Biebesheim. ${ }^{570}$ Shortly later, V. Pingel identified further potential helmets of Type Biebesheim on some Iberian stelae. ${ }^{571}$ It is only in recent years, however, that western European crested helmets have once more begun to be discussed in their wider context.

Schauer suggests that the undecorated helmets of Type Biebesheim belong in Ha A, while the helmets with 'eyes' are more recent and closely related to the western European cuirasses. ${ }^{572}$ Moreover, he sees in the helmet from Bremen, with its higher crest, a close connection to the Italian helmets. Lippert sees Type Biebesheim (which he dates to the $12^{\text {th }} / 11^{\text {th }}$ century BC) as the predecessor of helmets of Type Bernières d'Ailly and connects those of Type Biebesheim with the ceramic helmets from Veii (grave nos. 4-5, necropolis Quattro Fontanili) and Populonia. ${ }^{573}$ Type Biebesheim are identical to Sperber's Art Billy, which he distinguishes into two variants, which are both mainly current in Ha B1. He interprets the helmets from Otterstadt, Seurre and Auxonne, based on their low crest, lack of conical rivets and evenly curved profile, as slightly older examples ('variant Auxonne') of his Art Billy, dating them to his late $\mathrm{Sb} \mathrm{IIb}$ (Ha A2), while all other helmets of Art Billy are dated to his Sb IIc (early Ha B1). ${ }^{574}$ The unprovenanced helmet assigned here to Type Biebesheim (cat. no. 100) is suggested by Sperber as a potential transitionary form between the eastern European helmets and the western European crested helmets. ${ }^{575}$ In his recent discussion of the origin of European crested helmets, Brandherm dates helmets of Type Biebesheim to no later than Ha A. ${ }^{576}$ Müller-Karpe narrows the chronological frame down to the early phase of the late Urnfield period, with their first appearance in Bz D, ${ }^{577}$ while A. Coffyn assigns the helmets to the very end of Bronze final I or the beginning of Bronze final II (Ha A1). ${ }^{578}$

\subsubsection{Distribution and Deposition}

Helmets of Type Biebesheim have been found only in southeast France and western Germany, from Bremen in the north to Ebing in the south, with the helmet from the Pockinger Heide as the most eastern example, and that from Paris as the most western example (Fig. 2.23). The main distribution area is from Bavaria in the east to almost Clermont-Ferrand in the west, but with a noticeable absence finds in Switzerland. Except for the helmet from Le Theil, a dryland deposit (though unlikely a grave), all examples are from wet contexts, mainly from rivers and old river beds. The helmet from Otterstadt was intentionally bent and destroyed before it was deposited in the river Rhine. All other helmets are complete or suffered just slight damage during recovery.

\footnotetext{
569 v. Merhart 1941, 16.

570 Hencken 1971, 58-65; Schauer 1980, 532-540.

571 Pingel 1974, 1-19; Pingel 1993, 209-231.

572 Schauer 1980, 533

573 Lippert 2011, 40-45.

574 Sperber 2011, 23.

575 Sperber 2011, 21-23.

576 Brandherm 2011, 43.

577 Müller-Karpe 1959, 113.

578 Coffyn 1985, 171.
} 


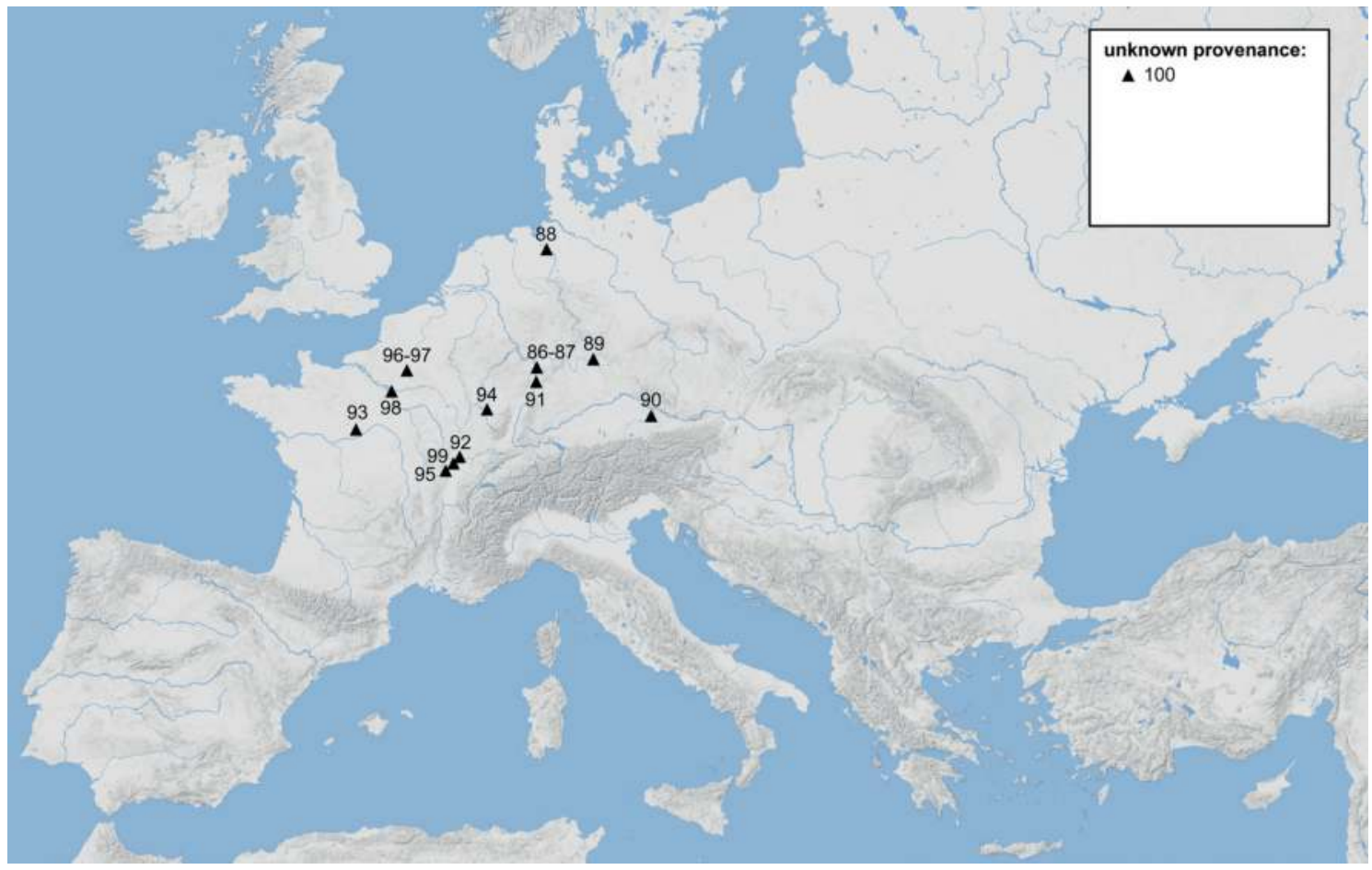

Fig. 2.23 Archaeological distribution of helmets of Type Biebesheim: 86-87. Biebesheim; 88. Bremen; 89. Ebing; 90. Pockinger Heide; 91. Otterstadt; 92. Auxonne; 93. Le Theil; 94. Blainville-sur-l'Eau; 95. Chalon-sur-Saône; 96-97. Montmacq; 98. Paris; 99. Seurre; 100. Unprovenanced, related to helmets of Type Biebesheim. Numbers correspond to the catalogue numbers.

\subsubsection{Chronology}

Since almost all helmets of Type Biebesheim are single river finds, the chronological classification is based on one potential association (Chalon-sur-Saône) and the deposit from Le Theil, as well as what we perceive to be the general typological development of crested helmets. Schauer considers helmets of Type Biebesheim, due to the decorative 'eyes' which some have, to be closely related to western European cuirasses, and accordingly dates the helmets to Ha B1, ${ }^{579}$ with the undecorated helmets being older and belonging to Ha A. ${ }^{.80}$ On the other hand, he considers the helmet from Bremen, with its higher crest, as closely connected to the Italian crested helmets. G. v. Merhart and H. Müller-Karpe assign the deposit of Le Theil to Ha A; MüllerKarpe narrows the chronological frame down to the early phase of the late Urnfield period, with the first appearance of these helmets in Bz D. ${ }^{581}$ According to G. Cordier, the deposit or grave from Le Theil dates to Bronze final I/Ha A2, as note Kossack and Sperber (Ha A2/B1). ${ }^{582}$

Assuming the helmet from Chalon-sur-Saône was indeed an associated deposit (possibly including two swords of Type Forel, a sword of Type Hemigkofen, a sickle and a bracelet), Sperber suggests a depositional date in Ha B1. He also notes that helmets of Type Biebesheim and its variant Auxonne (not considered as a variant here) are mainly found in Ha B1. According to him, helmets without conical headed rivets and with a lower crest (Auxonne) might also be dated to Ha A2. ${ }^{583}$ A. Coffyn suggests a date at the very end of Bronze final I or at the beginning of

\footnotetext{
579 For discussion of the chronology of the western European cuirasses, see Chapter 3.4.

580 Schauer 1980, 533.

581 v. Merhart 1941, 24, 38; Müller-Karpe 1959, 113.

582 Kossack 1954, 30; Cordier 1997, 87; Sperber 2011, 20.

583 Sperber 2011, 20, 24.
} 
Bronze final II (Ha A). ${ }^{584}$ The helmet from Chalon-sur-Saône is also dated by L. Bonnamour to Bronze final IIIa (Ha B1) ${ }^{585}$ even though it might be contemporary with the sword of Type Hemigkofen, thus dating to Ha A. D. Brandherm recently associated the deposit from Le Theil and helmets of Type Biebesheim in general not later than Ha A. ${ }^{586}$ The associated medianwinged axe ('hache à ailerons médians') is an early form and occurs first in associated deposits of the Rosnoën phase (Bz D2-Ha A1) ${ }^{587}$ The deposit is just outside the immediate zone of origin, which is France to the west of the border with Switzerland. ${ }^{588}$

F. Audouze characterised the girdle as an early type of one of his ceintures articulées en bronze, groupe II, which he broadly dates to Bronze final IIIb, but admits an earlier date due to constructional aspects for the Le Theil helmet. ${ }^{58}$ The alleged casting mould for winged axes and (on the opposite side of the mould) a further unknown type of object, as well as the gold foil, which lacks any parallels, do not contribute significantly to the dating of the deposit. Ultimately, a date in Bz D2-Ha A(1) for helmets of Type Biebesheim seems to be most likely.

\subsubsection{Associated, Unprovenanced Helmet}

The find spot and find circumstances of the crested helmet reputedly to be from 'Hungary' are unknown (cat. no. 100). The helmet resembles, with its convex cap, a very low crest and flatheaded rivets below the crest, most closely the shape of helmets of Type Biebesheim. One of the two halves of the helmet was folded over the other at the crest to join the two parts. The rim was bent inwards around a bronze or copper wire, which resulted in several cracks on the metal sheet. Parallel to the rim 13 (partly rectangular) rivet holes were punched through the metal sheet from the outside to the inside with a distance of $4-5.5 \mathrm{~cm}$ each. Also on the top of the crest one round hole was applied, most likely to fix a plume or a rivet, reinforcing the join of the two halves of the helmet. Bands or strips on the corroded surface might be the result of imprints of a former organic wrapping, or otherwise from an organic mat which the 'grave ${ }^{590}$ had been furnished with.

Unlike other helmets of Type Biebesheim, this unprovenanced helmet has an inwards bent rim and is richly decorated. The cap is decorated along the rim and the crest on both sides with alternating lines of pellets and bosses, as is found on other classes of body armour, e.g. greaves of Type Kurrim, ${ }^{591}$ and western European cuirasses. ${ }^{592}$ In the blank areas left and right of the lines of pellets and bosses in the centre, a wheel motif with pellet lines, bearing a central boss, was applied. The wheel motif is only known on armour from Bz D-Ha A1, including greaves ${ }^{593}$ and a cheek plate from the Bz D-Ha A1 associated deposit from Podcrkavlje-Slavonski Brod (cat. no. 67), which might be contemporary with this regional variant of Type Biebesheim.

Assuming the helmet is original, ${ }^{594}$ it is certainly influenced by western European helmets of Type Biebesheim, to which local elements of decoration were applied. We might therefore interpret it as having been locally produced in the Carpathian Basin, than as an imported helmet of Type Biebesheim which was then decorated to suit local tastes, as is indicated by the inwards bent rim. According to its close affinities with helmets of Type Biebesheim, the presence of the

584 Coffyn 1985, 171.

585 Bonnamour 2000, 80.

586 Brandherm 2011, 43.

587 Type A after Millotte et al. 1968, 12-16, fig. 1.

588 Millotte et al. 1968, fig. 2, no. 7.

589 Audouze 1976, 77, 81-83, 87, 132, no. 164.

590 Born - Hansen 2001, 241.

591 See Chapter 4.1.3, p. 233.

592 See Chapter 3.5, p. 188.

593 See Chapter. 4.1.2, p. 227.

594 As indicated by the AAS analyses: see Born - Hansen 2001, 270. However, we still have to take into account the possibility that other Bronze Age metal finds were molten and used to produce the helmet recently. No metallographic analyses have been carried out in order to eliminate any doubts on the originality of the helmet. 
wheel motif and the combination of pellet and boss decoration, the helmet might be dated slightly later than the more western examples of Type Biebesheim. ${ }^{595}$

Catalogue

Cat. no. 86. Biebesheim A, Kr. Groß-Gerau, Hessen, Germany - single river find of two helmets (river Rhine) - complete helmet. Measurements: height: $27.9 \mathrm{~cm}$; diameter: $22 \times 17.6 \mathrm{~cm}$; diameter inside: $20.7 \times 16.7 \mathrm{~cm}$; rivets: length: $3.25 \mathrm{~cm}-$ Landesmuseum Darmstadt, inv. no. unknown - Pl. 13.86. References: Jorns 1964, 183-184; Jorns 1972, 76-85; Müller-Karpe 1980, pl. 439.B1-2, cat. no. 572; Lippert 2011, 64, pl. 2.1.

The two helmets were found no more than $6 \mathrm{~m}$ away from one another in an old river bed of the Rhine in 1963, some 8-9m depth below the ground water level, during work in a gravel pit. They were found with almost no corrosion on the surface.

Cat. no. 87. Biebesheim B, Kr. Groß-Gerau, Hessen, Germany - single river find of two helmets (river Rhine) - complete helmet. Measurements: height: $26.1 \mathrm{~cm}$; diameter: $19.2 \times 19.6 \mathrm{~cm}$; diameter inside: $18.7 \times 19.4 \mathrm{~cm}$; diameter rivets: $1.6 \mathrm{~cm}$; weight: $770 \mathrm{~g}-$ Heimatmuseum Biebesheim, inv. no. unknown - Pl. 13.87. References: Jorns 1964, 183-184; Jorns 1972, 76-85; Müller-Karpe 1980, pl. 439.B1-2, cat. no. 572; Lippert 2011, 64, pl. 2.3.

The two helmets were found no more than $6 \mathrm{~m}$ away from one another in an old river bed of the Rhine in 1963, some 8-9m depth below the ground water level, during work in a gravel pit. They were found with almost no corrosion on the surface.

Cat. no. 88. Bremen, Kreis Bremen-Blumenthal, Bremen, Germany - single river find (river Lesum) - complete helmet. Measurements: height: $29.5 \mathrm{~cm}$; diameter: $23.5 \times 17.5 \mathrm{~cm}$; weight: 794g - Focke Museum Bremen, inv. no. 8058 - Pl. 14.88. References: Grohne 1939, 22; v. Merhart 1941, 16; Jacob-Friesen - Jacob-Friesen 1963, 324, fig. 296; Hencken 1971, 64, fig. 37; Lippert 2011, 64, pl. 7.1.

The helmet was found during dredging works in November 1938 in the river Lesum close to the city of the same name. The crest is higher than on other helmets of the same type. It shows on the front and back a pair of conical headed rivets, as well as a further pair of rivet holes on each side. The helmet was found without any corrosion. Due to the find circumstances, the helmet was severely deformed and the two halves almost torn apart. A copper smith restored the helmet, which included the use of hard solder for brazing.

Cat. no. 89. Ebing, Kreis Staffelheim, Bayern, Germany - single river find (old bed of the river Main) - complete helmet. Measurements: height: $29.5 \mathrm{~cm}$; diameter: $21.5 \times 16.2 \mathrm{~cm}$; thickness: $0.5 \mathrm{~mm}$; weight: $829 \mathrm{~g}$ - Landschaftsmuseum Ebing, inv. no. unknown (Prähistorische Staatssammlung, Munich, inv. no. 1967, 1279) - Pl. 14.89. References: Pescheck 1967, 264, 271, fig. 14; Pescheck 1968, 34-35; Henning 1970, 90, pls. 82-85; Jakob 1972; Abels et al. 1996, 94; Lippert 2011, 65, pl. 3.2.

The helmet was found in September 1964 in the gravel pit of the Porzner und Söhne company, $700 \mathrm{~m}$ to the east of Ebing, in 3-5m depth, in one of the old river beds of the river Main.

Cat. no. 90. Pockinger Heide, Oberindling, Gem. Pocking, Kr. Griesbach, Bayern, Germany - single river find (riparian forest of the river Inn) - complete helmet. Measurements: height: $22.6 \mathrm{~cm}$; diameter: $20 \times 18.9 \mathrm{~cm}$; length rivets: $1.7-1.9 \mathrm{~cm}$; height crest: $1.9-2.5 \mathrm{~cm}$; weight: $804 \mathrm{~g}$ - Bayerisches Nationalmuseum, Munich, inv. no. IV 567 - Pl. 14.90. References: Lindenschmit 1881, pl. III.1-3; Hager - Mayer 1892, 95, no. 567; Coutil 1911, 7; Coutil 1912; Coutil 1926; v.

595 See also Born - Hansen 2001, 75; Sperber 2011, 21. 
Merhart 1941; Hencken 1971, 64, fig. 38; Müller-Karpe 1980, IV, pl. 412; Lippert 2011, 65, pl. 2.2 .

The helmet is a single find from before 1851 in the riparian forests of the river Inn, close to Indling.

Cat. no. 91. Otterstadt, Rheinland-Pfalz, Germany - single river find (old Rhine) - fragment. Measurements: c. $18 \times 27.6 \mathrm{~cm}$ (pressed flat); weight unknown - Private ownership, no inv. no. - Pl. 14.91. References: Sperber 2011, 38, pl. 3.2; Sperber 2017, cat. no. 578.

The helmet was found in the old Rhine's riverbed around 2000; the current owner bought the helmet from the finder around 2005.

Cat. no. 92. Auxonne, Dép. Côte-d'Or, France - single river find (river Saône) - complete helmet. Measurements: height: $25.5 \mathrm{~cm}$; diameter: $20.7 \times 18.3 \mathrm{~cm}$; weight (after B. Mille): $690 \mathrm{~g}-$ Musée des Antiquités Nationales at Saint-Germain-en-Laye, inv. no. 1237 - Pl. 14.92. References: Coutil 1911, 7; v. Merhart 1941, 161, fig. 3.6; Hencken 1971, 58, fig. 32a-b; Lippert 2011, 64, pl. 5.2.

The helmet was found before 1911 in the Saône at Auxonne.

Cat. no. 93. Le Theil/Billy, Dép. Allier, France - associated deposit - almost complete helmet. Measurements: height: $24 \mathrm{~cm}$; diameter: $20.7 \times 18.6 \mathrm{~cm}-$ Musée des Antiquités Nationales at Saint-Germain-en-Laye, inv. no. 22.239 - Pl. 15.93. References: Bourgeois 1875; Chantre 1875; Coutil 1911, 7; Déchelette 1924, 332-337; Hencken 1971, 59, fig. 33a; Audouze 1976, 132; Cordier 1997, 79, fig. 9; Lippert 2011, 65, pl. 3.1; Sperber 2011, 20.

The helmet was found in 1875 as a part of an associated deposit, together with an early median-winged axe (hache à ailerons medians), a chisel, a girdle with lancet-shaped pendants (articulées en bronze/groupe II), ${ }^{596}$ two punched gold sheets, eleven glass beads, three amber beads, one spindle whorl; some sherds of pottery and a casting mould made of stone for axes and an undetermined object. There were no traces of ashes or bones. The helmet is rather fragmentary and was restored with plaster.

Cat. no. 94. Blainville-sur-l'Eau, Dép. Meurthe-et-Moselle, France - single river find (banks of the river Meurthe) - complete helmet. Measurements: height: $32.5 \mathrm{~cm}$; diameter: 27.1 $\times 17.8 \mathrm{~cm}$; weight (after B. Mille): $1020 \mathrm{~g}-$ former collection A. France-Lanard, now private collection of A. France-Lanord, Nancy; a copy is at the Musée des Antiquités Nationales at SaintGermain-en-Laye, inv. no. 86.196 - Pl. 15.94. References: Hencken 1971, 58, fig. 32c-d; Périn 2004, 49, fig. 46; Lippert 2011, 64, pl. 5.1; Huth 2012, fig. 7.

The helmet was found on the banks of the river Meurthe in 1971.

Cat. no. 95. Chalon-sur-Saône, Dép. Saône-et-Loire, France - river find (river Saône) - complete helmet. Measurements: height: $31 \mathrm{~cm}$; diameter: $21.4 \times 18.5 \mathrm{~cm}$; weight: $491 \mathrm{~g}$ (not $1780 \mathrm{~g}$ !) Musée Chalon-sur-Saône, inv. no. 74.21.4 - Pl. 15.95. References: Bonnamour 1975, 16-21, fig. 5; Bonnamour et al. 1976, 614, fig. 7.1; Bonnamour 1989, 214, fig. 121.1; Bonnamour 1990/1991, 47, no. 61, figs. 36-37; Bonnamour 2000, 134, cat. no. 367, fig. on p. 80; Born - Hansen 2001, 75-76; Lippert 2011, 64-65; Sperber 2011, 20.

The helmet was found together with a sword of Type Hemigkofen, two swords of Type Forel, a bracelet and a sickle in the river Saône in the North of Chalon, at Port Ferrier, before 1974.

Cat. no. 96. Montmacq A, Dép. Oise, France - single river find of two helmets (river Oise) complete helmet. Measurements: height: $26 \mathrm{~cm}$; diameter: $22 \times 17 \mathrm{~cm}(21.7 \times 16.1 \mathrm{~cm}$ according to Hémery 1929, 423); weight: 650g - Musée Vivenel, Compiégne, inv. no. H 898 - Pl. 16.96.

$\overline{596}$ After Audouze 1976, 77. 
References: Hémery 1929, 423-424; v. Merhart 1941, 16; Hencken 1971, 62, fig. 34a-b; Blanchet - Lambot 1975, 44-46, no. 34; Lippert 2011, 65, pl. 5.3; Lehoërff 2013, 84, fig. 112.

In 1921, two helmets were found close to each other in the river bed of the Oise.

Cat. no. 97. Montmacq B, Dép. Oise, France - single river find of two helmets (river Oise) complete helmet. Measurements: height: $25 \mathrm{~cm}$; diameter: $23 \times 17 \mathrm{~cm}(21.8 \times 17.8 \mathrm{~cm}$ according to Hémery 1929, 423); weight: 725g - Musée Vivenel, Compiégne, inv. no. H 897 - Pl. 16.97. References: Hémery 1929, 423-424; v. Merhart 1941, 16; Hencken 1971, 62, fig. 34c-d; Blanchet - Lambot 1975, 44-46, no. 33; Lippert 2011, 65, pl. 5.4; Lehoërff 2013, 84, fig. 112.

In 1921, two helmets were found close to each other in the river bed of the Oise.

Cat. no. 98. Paris, France - single river find (river Seine) - complete helmet. Measurements: height: $26 \mathrm{~cm}$; measurements: diameter: $23 \times 18 \mathrm{~cm}$; weight (after B. Mille): $760 \mathrm{~g}-$ Musée des Antiquités Nationales at Saint-Germain-en-Laye, inv. no. 358 - Pl. 16.98. References: Coutil 1911, 7; v. Merhart 1941, fig. 3.7; Hencken 1971, 62, fig. 35; Mohen 1977, 122, figs. on pages 122, 123, 148; Lippert 2011, 65, pl. 5.5; Lehoërff 2013, fig. 83.

The helmet was found in the river Seine before 1911.

Cat. no. 99. Seurre, Dép. Côte-d'Or, France - single river find (old ford of the river Saône) complete helmet. Measurements: height: $23 \mathrm{~cm}$; diameter: $22.5 \times 18.8 \mathrm{~cm}$, weight: $689 \mathrm{~g}-$ Musée Vivant Denon, Chalon-sur-Saône, inv. no. 98.19 .1 - Pl. 17.90. References: Bonnamour 2000, 122, no. 59, fig. on page 28; Bonnamour 2009, 65; Lippert 2011, 65.

The helmet was found close to the Île aux Bœufs at an old ford of the Saône in 1977 and bought by the museum in July 1998. It formerly belonged to D. Chaffote.

Cat. no. 100. Unprovenanced (Hungary?) - complete helmet. Measurements: height: $24.5 \mathrm{~cm}$; diameter: $19 \times 17 \mathrm{~cm}$; thickness: $0.5-0.8 \mathrm{~mm}$, on the edge $3.5-4 \mathrm{~mm}$; weight: $464-466 \mathrm{~g}$ - private ownership; Guttmann collection, inv. no. AG 1125 - Pl. 17.100. References: Born - Hansen 2001, 59, 175, 241, figs. 192-194, pls. XIII, XIV; Clausing 2002, 183; Hermann Historica 2005a; Eisenberg - Price 2006, 37, no. 74; Lippert 2011, 65, pl. 6.1; Sperber 2011, 21.

Find spot and find circumstances are unknown. The helmet was part of the Guttmann collection. It was put up for auction (Lot 16, not sold) at Christie's in London on 28 April 2004 and sold on 19 October 2005 at Hermann Historica in Munich. ${ }^{597}$ It was sold again at the RoyalAthena Galleries in 2007.598 The wheel motif of the helmet might connect it with the cheek plate from Podcrkavlje, Croatia (cat. no. 67), which bears similar decoration.

\subsubsection{Helmets of Type Bernières d'Ailly}

Currently, ten complete helmets of Type Bernières d'Ailly are known, as well as fragments of at least eight further examples (Tab. 2.13). Typical for helmets of Type Bernières d'Ailly is the pointed crest and the strongly curved to almost triangular profile, with a sometimes slightly bulging cap. The profile changes from an almost triangular shape in northwestern France to a strongly curved profile found in the east and in Germany. This might point to a development from west to east (taking into account also the Iberian depictions of crested helmets on stelae (Fig. 2.16). A vertical ridge on the sides of the cap, which runs to the top of the crest, improves the stability of the cap and would have provided additional protection during use. Rivet holes on both sides on the helmet, for attaching cheek plates or a chin strap, are common or, as seen on the helmets from Bernières d'Ailly, to fix bronze bands. Only the helmets from Bernières d'Ailly have holes on the front and/or back accompanying those found on the sides, which were

597 Hermann Historica 2005a.

598 Eisenberg - Price 2006, 37, no. 74. 


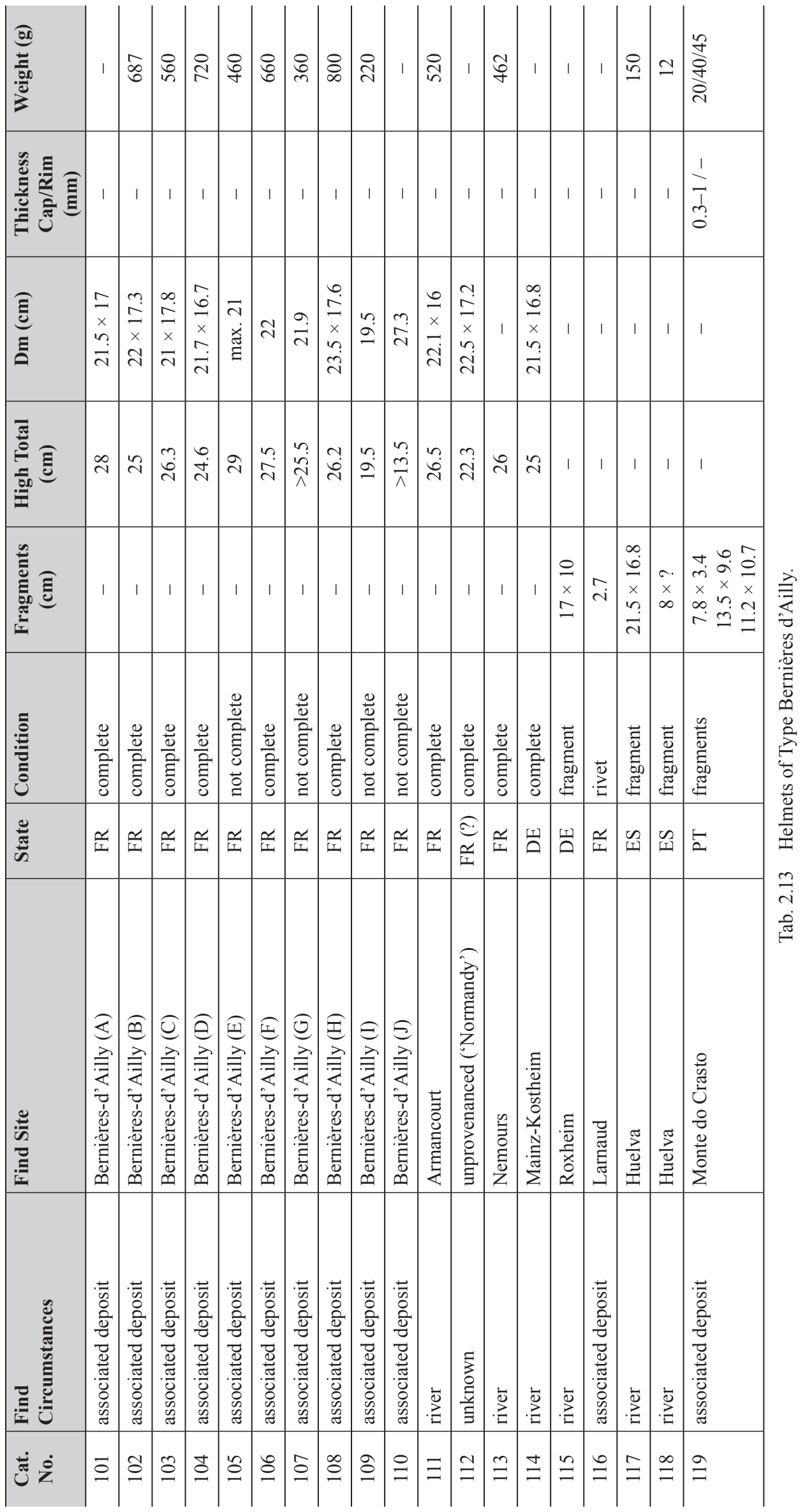


in order to fix small horizontal bronze bands inside the helmet. ${ }^{599}$ The bands in the front additionally held together both parts of the cap. These bands might also have served as clamps to improve the fitting of the organic cap under the metal helmet. Five of the helmets from Bernières d'Ailly (helmets A, B, E, F, H) have a hollow attachment made of bronze sheet on the sides. These were held by four rivets and were most likely used to fix organic or bronze ornamentation. ${ }^{600}$ The attachments on the helmet from Armancourt are no longer survive, only the rivet holes for fixing them remain. The rim of helmets of Type Bernières d'Ailly is bent inwards around a copper or bronze wire; it is mostly hammered flat, so it might not have been used to secure the perishable material from lining. So far, only the helmet from 'Normandy' has an outward bent rim.

On the crest, the edges of one sheet were folded over the other sheet. Sometimes, the crest was fixed with an additional rivet (Bernières d'Ailly, helmets $G$ and F, Mainz-Kostheim). The two halves of the helmets are usually attached in the front and back with three long, conical rivets, which have a slightly curved, concave cross-section. Only the helmet from Mainz-Kostheim has on each side one flat-headed rivet only. Of the helmet Huelva B, only the upper part of the crest survives; right under the tip of the crest, a rivet hole is visible. The bronze sheets forming the crest of the heavily fragmented helmet $G$ from Bernières d'Ailly are not only attached by folding one over the other on the crest but also by at least four flat-headed rivets on the very top of the crest.

The helmet from 'Normandy' bears on the front- and backside a V-shaped, but not completely preserved, bronze sheet, probably covering the today lost rivet joining the two halves. The sheet is attached with one conical headed rivet each on the upper end on the two halves. The V-shaped sheet is decorated with small embossed dots. Above the rim a row of larger bosses is visible. A lot of them are broken through, caused by the corrosion process and the thinness of the metal sheet. The crest of the helmet has at the base an embossed rib parallel to the upper end of the cap.

All other helmets have one or two decorative, plastic ribs parallel to the edge; in every case they are below the beginning of the crest. The crest of the helmets is usually decorated with fine, parallel lines. Some helmets, such as that from Armancourt and Mainz-Kostheim, are without any decoration on the crest.

The profile of the helmets changes according to the geographic location: while most northwestern helmets (Bernières d'Ailly, 'Normandy') have a straighter cap profile and crest, the more southeasterly helmets, such as that from Nemours, already begin to show instead a slightly curved or concave crest. The helmets from Armancourt and Mainz-Kostheim, as the most eastern helmets of this type, have a clearly curved profile of both cap and crest. This indicates a development from simple rounded cap helmets to helmets with a raised, rounded or slightly pointed cap (Type Biebesheim) to highly pointed caps with a straight, almost triangular profile (Bernières d'Ailly).

\subsubsection{Research History}

Most of the helmets of this type derive from the associated deposit of Bernières d'Ailly, whilst the rest have either unclear find circumstances or derive from rivers, and consequently lack associated finds. The focus for discussion from the very beginning, therefore, has very much concerned their chronological classification. The oldest helmet finds of this type, being the eponymous find of Bernières d'Ailly, were first classified as Celtic and connected with the Gauls. ${ }^{601}$ Found in 1832 , these helmets were widely regarded amongst the art scene of a wide

\footnotetext{
599 Hencken 1971, 66.

600 E.g. feathers, hair or bronze sheets in the shape of horns, as on the Iron Age helmet from Ordona, Apulia, as suggested by Brandherm 2011, 47.

${ }_{601}$ As noted by Coutil 1902, 71-82.
} 
entry in $19^{\text {th }}$ century France. ${ }^{602}$ It was Coutil, at the beginning of the $20^{\text {th }}$ century, however, that classified them as helmets as belonging to the Bronze Age. ${ }^{603} \mathrm{G}$. v. Merhart grouped helmets of Type Bernières d'Ailly amongst his group CII. ${ }^{604}$ In contrast to other scholars, such as Hencken ('crested helmets with pointed caps'), Egg and Waurick (Kammhelm mit spitzer, konischer Kalotte), Milcent (Type 'Bernières d'Ailly'), Sperber (Type 'Armancourt') and others, which date the helmets to the very end of the Bronze Age, Lippert places his helmets of Type 'MainzKostheim' at the beginning of the Late Bronze Age. ${ }^{605}$ The first study concerned with the construction of these helmets was undertaken by Hencken. ${ }^{606}$ But it is only recently that the manufacture and chemical composition of helmets of Type Bernières d'Ailly have been studied. ${ }^{607}$ Currently, the helmets are undergoing restoration at the Musée de Normandie in Caen, France.

\subsubsection{Distribution and Deposition}

In 1832, a deposit of ten helmets was found in Bernières d'Ailly, in the south of Caen, France. The helmets were allegedly found one upon another with the crest pointing upwards. They were deposited in three groups, with third and final group placed atop the other two, ${ }^{608}$ and not arranged in the form of a triangle as some authors have suggested ${ }^{609} \mathrm{~L}$. Coutil mentioned asso-

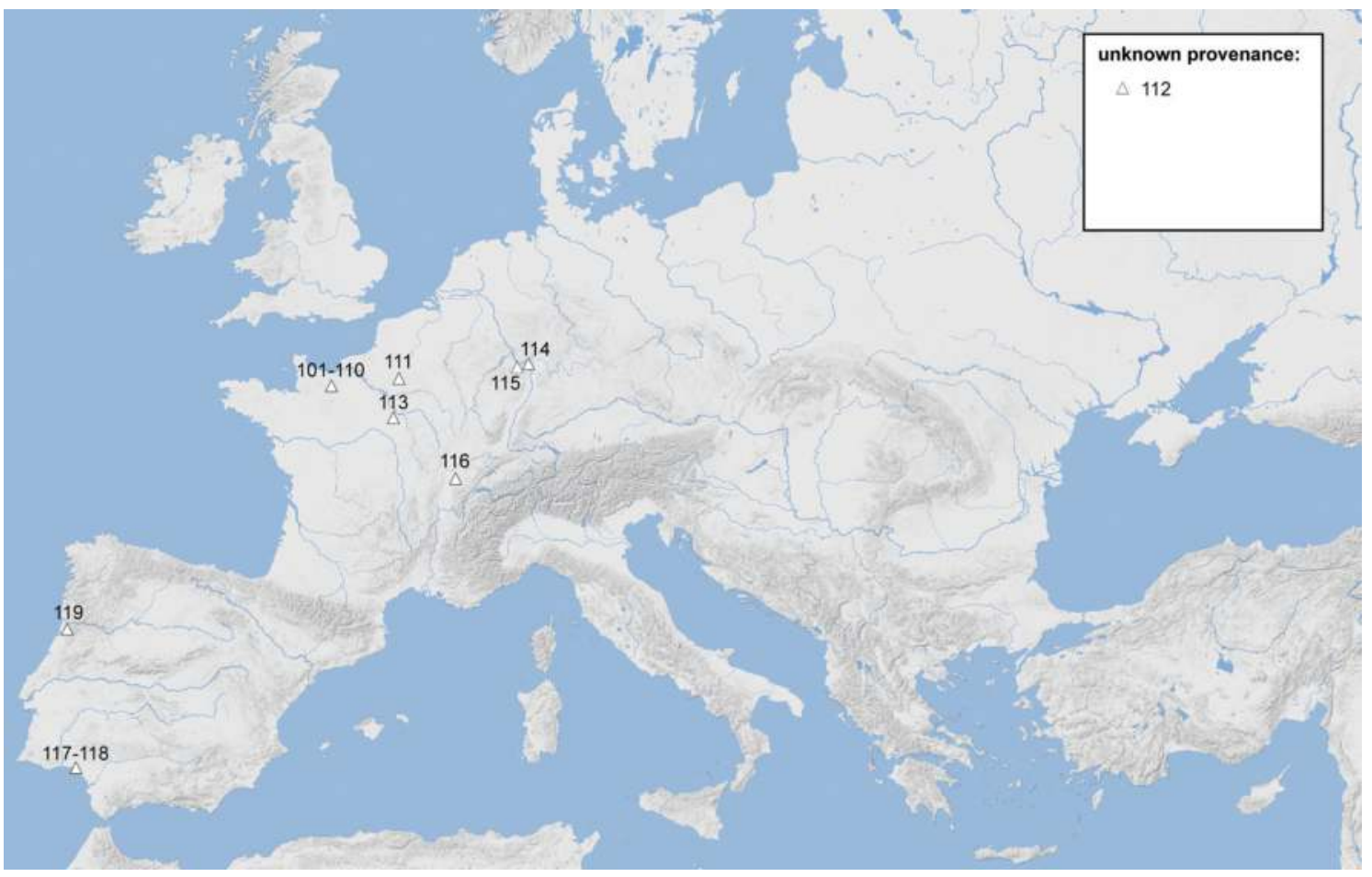

Fig. 2.24 Archaeological distribution of helmets of Type Bernières-d'Ailly: 101-110. Bernières-d'Ailly; 111. Armancourt; 112. Unprovenanced; 113. Nemours; 114. Mainz-Kostheim; 115. Roxheim; 116. Larnaud; 117-118. Huelva; 119. Monte do Crasto. The numbers correspond to the catalogue numbers.

\footnotetext{
602 E.g., F. A. Bartholdi 1864, Vercingétorix statue in Clermont Ferrand; F.-É. Ehrmann 1869: Vercingétorix appelant les Gaulois à la défense d'Alésia, Musée d'Art Roger-Quilliot, Clermont Ferrand; H.-P. Motte 1886: Vercingétorix se rendant au camp de César, Musée Crozatier, Le Puy-en-Velay; L.-N. Royer 1899, Vercingétorix jette ses armes aux pieds de César, Musée Crozatier, Le Puy-en-Velay.

603 Coutil 1902, 71-82.

604 v. Merhart 1941, 16.

605 Hencken 1971, 66-77; Egg - Waurick 1990, 14; Lippert 2011, 32, fig. 22; Sperber 2011; Milcent 2012, 131, 213.

606 Hencken 1971.

607 The publication is currently in preparation by Brun and colleagues.

608 de Linas 1869; Coutil 1902, pls. 9-10; de Beauregard 1909.

609 Hencken 1971, 66. See Warmenbol 2010, 564-565.
} 
ciated finds consisting of a winged axe, two spearheads and two bracelets, which are now lost. ${ }^{610}$ Other complete helmets are known from Nemours, 'Normandy' and from Armancourt in the north of Paris, thus placing the main distribution area in northern France. Another complete helmet is known from Mainz-Kostheim. All four helmets are single finds from river. Before deposition, the helmet from Roxheim was bent, broken and partially burnt - the latter perhaps indicating its participation in a cremation rite. Fragments of two helmets derive from the Huelva associated deposit from the estuary of the rivers Odiel and Tinto. Other fragments are known from the associated deposit of Monte do Crasto. Also, the associated deposits from Grañón ${ }^{611}$ and Castro de Avelãs ${ }^{612}$ contain likely fragments of helmets of this type (Fig. 2.24).

The Iberian helmets are the only ones with datable contexts, while the German and French helmets are all single finds from wet contexts or, as in the case of the deposit from Bernières d'Ailly, the exact nature of the supposed associations are unknown. Unlike the complete French and German helmets, the Spanish helmets are severely fragmented, might have been deposited as pars pro toto, and may thus derive from several different helmets (e.g. the Huelva helmet fragments). The associated deposit from Larnaud, France, also contains what appears to be a rivet from a crested helmet of Type Bernières d'Ailly. ${ }^{613}$ Most of the French find spots (Bernières d'Ailly, Armancourt, Nemours) are in the vicinity of the river Seine, while Larnaud is close to the source of the river Seine. Following the Seine upstream, the profile of the helmets changes from a straight crest and cap to a more concave, central drawn-in profile, which is also observed on the helmets found more to the east.

\subsubsection{Chronology}

Due to their find context, it is difficult to accurately date helmets of Type Bernières d'Ailly: French and German finds are either single finds from rivers, have unknown find circumstances or, where possibly associated, the finds are today lost. The fragmented helmet from Roxheim is also a single river find. The large number of 'Atlantic' type bronzes recovered from the same area of deposition and dated to SB IIc-IIIb (Ha B) by Sperber, ${ }^{614}$ however, might be contemporaneous with the helmet.

The helmets from Bernières d'Ailly were part of an associated deposit, of which other alleged finds - a winged axe, two spearheads and two bracelets - are not preserved and no depictions exist. ${ }^{615}$ Schauer dated the deposit to the late Urnfield period (Ha B), ${ }^{616}$ while Hencken assigned it to the $8^{\text {th }}$ century BC ${ }^{617}$ Egg and Waurick suggest that the oldest crested helmets have a rounded crest and helmets with pointed, conical crest are later and belong most likely to the $9^{\text {th }} / 8^{\text {th }}$ century BC. ${ }^{118}$ P.-Y. Milcent dates the deposit to late (or récent) Bronze final II or early (ancien) Bronze final III. ${ }^{619}$ Lippert assumes, on the basis of his correspondence analyses, that helmets of Type Bernières d'Ailly are actually the oldest European crested helmets, and dates them to the $13^{\text {th }}-12^{\text {th }}$ century BC. ${ }^{620}$ Unfortunately, the rivet of a helmet of Type Bernières d'Ailly from the associated deposit from Larnaud, France, is not of much chronological help: the contents of the associated deposit varies from Bz D (e.g. butt of a Rixheim sword) to Ha B1 (the 'thraco-cimmerian' finds; e.g. a belt of Type Bénévent-en-Champsaur). ${ }^{621}$

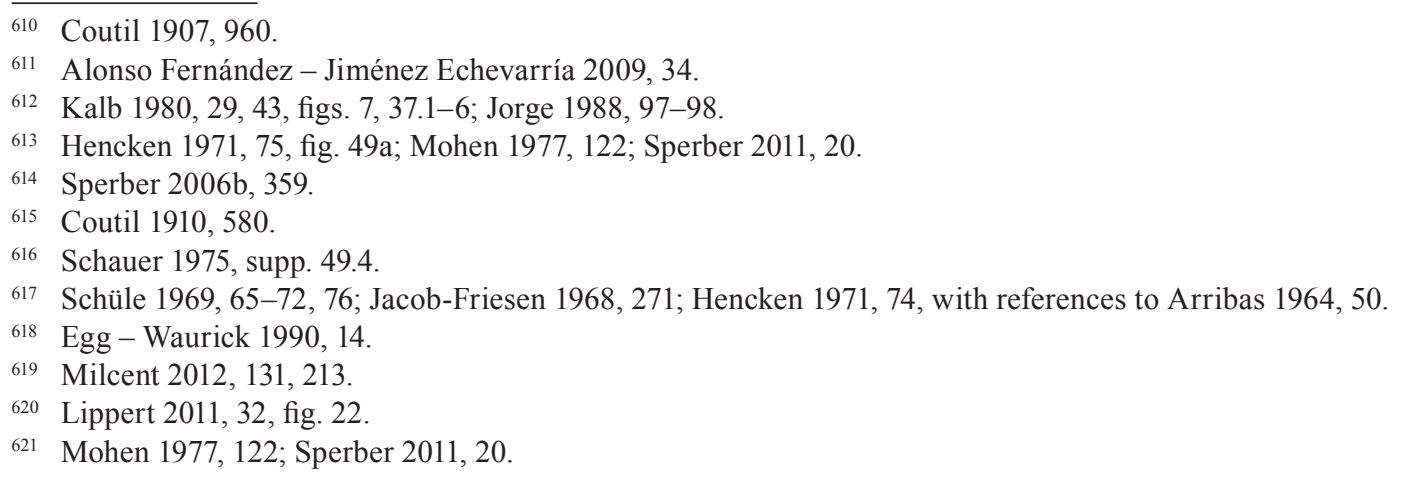


There are both helmet fragments and depictions from the Iberian Peninsula, which contribute to the chronology of the Iberian helmets of Type Bernières d'Ailly. The deposition of Huelva (if it happened at once), is dated to $\mathrm{Ha} \mathrm{B1}$; a few finds though already date to $\mathrm{Bz} \mathrm{D},{ }^{622}$ while the deposit from Grañón (which also contains potentially a fragment of a crested helmet) is dated to 1200-1100 BC/Grañón horizon, based on the association of swords of Type Vilar Maior, which are also found outside Iberia in southwest France, and a sword of Type Fontanguillere, which is mainly distributed in southwest France. ${ }^{623}$ The deposit from Vila Cova de Perrinho/Monte do Crasto, Portugal, contained alongside the helmet fragments two daggers of Type Porto de Mós and a torque, and resembles in its composition the Huelva find. It is dated accordingly to the Blackmoor/Braud/Huelva phase. ${ }^{624}$

Thus we can conclude that helmets of Type Bernières d'Ailly were deposited in the Iberian Peninsula from the $12^{\text {th }}$ century $\mathrm{BC}$ onwards, after a rather short period of use, considering the most likely French origin. Some helmets though might have been used somewhat longer, as suggested by the stele from Zarza de Montánchez. If the identification of the depicted sword as being of Type Cordeiro is correct, ${ }^{625}$ the stele might be dated to late Ha B1. Thus widening the time frame for helmets of Type Bernières d'Ailly, at least in the Iberian Peninsula, from the end of Ha A1 to late Ha B1, with a peak in deposition during Ha A. The chronological classification of the French helmets of Type Bernières d'Ailly is, according to the deposit of Larnaud, ranging from Bz D-Ha B1, similarly broad. Based on their physiognomy, it is clear that helmets of Type Bernières d'Ailly are later than those of Type Biebesheim, with earliest helmets of Type Bernières d'Ailly probably appearing in Ha A1 and spreading rapidly. They might have been in use then until late Ha B1.

\section{Catalogue}

Cat. nos. 101-110. Bernières-d'Ailly, Dép. Calvados, France - associated deposit - ten helmets, most of them complete. Measurements: see Tab. 2.13 - museums and inv. no. see below Plates 17-20. References: Lambert 1837; Fallue 1866; de Linas 1869; Mériel 1890; Coutil 1901, 71-82, pls. IX-X; Coutil 1907, 960; de Beauregard 1909; Coutil 1910, 579-588; de Beauregard 1910, 5, pl. 1, fig. C1; Déchelette 1910, 229-232, 235, 237; Coutil 1911; Coutil 1927, 362-366; Doranlo 1952/1954, 94-116; Hencken 1971, 66, 37, figs. 40-46; Verron 1971, 75, no. 77, fig. on page 74; Pflug 1989, 95, cat. no. 88; Egg - Tomedi 2002, fig. 12; Brun et al. 2007, 41; Warmenbol 2010, 564-565; Lehoërff 2011, fig. 2; Lippert 2011, 64; Berthelot 2014.

The ten helmets were found in 1832 in Falaise. ${ }^{626}$ The helmets were allegedly found one atop the other, divided between three groups, with the crest pointing upwards, the third group positioned atop the other two groups. ${ }^{627}$ The piles of helmets were not placed in the form of a triangle, as stated by some authors. ${ }^{628}$ Coutil mentions associated finds, consisting of a winged axe, two spearheads and two bracelets. ${ }^{629}$ According to de Linas, nothing else was found with the helmets. ${ }^{630}$

\footnotetext{
622 Brandherm 2007.

623 Brandherm 2007, 42; Alonso Fernández - Jiménez Echevarría 2009; Roberts et al. 2013, 35, fig. 2.5; Matthews 2017.

${ }^{624}$ Brandherm 2007, 14, 81.

625 Brandherm 2007, 140, class F, cat. no. D15.

626 The find location is described as 'à deux lieues de Falaise, près des racines du mont d'Eraines' (Fallue 1866, 260-263), 'à mille trois cent mètres d'Ailly et à six cent mètres environ de Sainte-Anne d'Entremont' (Mériel 1890, 259-260), or 'au pied du mont d'Éraines et près du hameau de Sainte-Anne d'Entremont [...] à dix mètres du fossé du château' (Coutil 1902, 71-72). Cf. Berthelot 2014.

${ }^{627}$ de Linas 1869; Coutil 1902, pls. 9-10; de Beauregard 1909.

${ }_{628}$ Hencken 1971, 66. See Warmenbol 2010, 564-565.

629 Coutil 1910, 580.

630 de Linas 1869, 4-5.
} 
During the two or three decades after they were found, the helmets were donated or sold to different museums and private collections. Today, the helmets are kept in several different museums: the helmet formerly owned by Ernest d'Acy and Costa de Beauregard is today at the University Museum of Philadelphia (cat. no. 101; inv. no. 70.4.1; purchased from J. J. Klejman in 1970), and the helmet formerly owned by the Comte Ladislas Odescalchi (bought 1902 from L. de Glanville) was transferred to the Palazzo Barbérini, Rome, in 1903 (cat. no. 102; inv. no. 1022.1727) and then on to the Museo Nazionale del Palazzo di Venezia, Rome in $1959 .{ }^{631}$ Another helmet is kept by the Musée des Antiquités de Rouen (cat. no. 103; inv. no. 227.78.A; formerly 970.227; it was owned by Mrs. Davois du Mesnil-Sous-Lillebonne, who sold it 1840 to the museum). After extensive damage to the museum at Falaise in 1944, the other helmets were stored in the library of the city. Since 2006, these helmets have been kept at the Musée de Normandie, Caen (cat. nos. 104-110; inv. nos. D.2006.6.1-D.2006.6.7). The numbering of the helmets in Tab. 2.13 and in the following follows that used by de Beauregerad and Hencken. ${ }^{632}$

Cat. no. 111. Armancourt, Dép. Oise, France - single river find (river Oise) - complete helmet. Measurements: height: $26.5 \mathrm{~cm}$; diameter: $22.1 \times 16 \mathrm{~cm}$; weight: $520 \mathrm{~g}-$ Musée Vivenel, Compiégne, inv. no. H899 - Pl. 21.111. References: Hémery 1926, 195-200; Coutil 1927, 362366; Hémery 1927, 136-141; v. Merhart 1941, fig. 4.2; Hencken 1971, 66, fig. 39; Blanchet Lambot 1975, 45-46, no. 35; Lippert 2011, 63, pl. 1.4.

The helmet was found in 1913 or 1914 in the river Oise.

Cat. no. 112. Unprovenanced (known as 'Normandy', France) - complete helmet. Measurements: height: $22.3 \mathrm{~cm}$; diameter: $22.5 \times 17.2 \mathrm{~cm}$ - private collection in Switzerland - Catalogue de la Biennale des Antiquaires 1984, 662-663 - Pl. 21.112. References: Pflug 1989, 95, cat. no. 88; Egg - Tomedi 2002, fig. 12.19; Lippert 2011, 64.

The helmet was sold in France by the Galerie des Pyramides to Switzerland. Find spot and find circumstances of the helmet are unknown. It was first presented in an official archaeological context during the Schutz und Zier exhibition in Basel, Switzerland.

Cat. no. 113. Nemours, Dép. Seine-et-Marne, France - find circumstances unknown - complete helmet. Measurements: height: $26 \mathrm{~cm}$; weight: $462 \mathrm{~g}$ - Musée de Préhistoire d'Ille-deFrance, inv. no. 80.20.1 - Pl. 21.113. References: Roy 1983; Bonnamour - Mordant 1988, $363-$ 372.

The find circumstances of the helmet are unknown.

Cat. no. 114. Mainz-Kostheim, Hessen, Germany - single river find (estuary of the river Main into the Rhine) - complete helmet. Measurements: height: $25 \mathrm{~cm}$; diameter: $21.5 \times 16.8 \mathrm{~cm}$ - Römisch-Germanisches Zentralmuseum, inv. no. 2219 - Pl. 22.114. References: v. Merhart 1941, fig. 4.1; Hencken 1971, 72, fig. 47; Egg - Waurick 1990, 15, fig. 8.3; Lippert 2011, 64, pl. 1.5 .

The helmet was found before 1940 in the estuary of the river Main as it flows into the Rhine.

Cat. no. 115. Roxheim, Lkr. Ludwigshafen, Rheinland-Pfalz, Germany - single river find (old Rhine) - fragment. Measurements: c. $10 \times 17 \mathrm{~cm}-$ Historischen Museum der Pfalz, inv. no. HMP 2000/0004-60 - Pl. 22.115. References: Sperber 2006a, 207, fig. 7.14; Sperber 2006b, 362, fig. 2.9; Sperber 2011, 38, fig. 12.1; Sperber 2017, cat. no. 236.

The fragmented helmet was found in the Silbersee ('silver lake') at Bobenheim-Roxheim, a quarry pond in a bend of the former riverbed of the Rhine. In the Silbersee, a large number of other Late Bronze Age finds were also recovered, some c. $60 \%$ being of 'Atlantic' types. ${ }^{633}$

631 Lehoërff 2011.

${ }_{632}$ de Beauregerad 1910; Hencken 1971, 66-73.

633 Sperber 2006a; Sperber 2006b. 
Cat. no. 116. 40 Larnaud, Dép. Jura, France - associated deposit - one rivet. Measurements: length: $2.7 \mathrm{~cm}$ - Musée des Antiquités Nationales at Saint-Germain-en-Laye, inv. no. 21.695 Pl. 22.116. References: Hencken 1971, 75, fig. 49a; Mohen 1977, 122; Sperber 2011, 20.

The associated deposit from Larnaud, France, which contains a rivet from a crested helmet of Type Bernières d'Ailly, has a rather wide chronological span. The contents of the associated deposit varies in age from Bz D (e.g. the butt of a Rixheim sword) to Sperber's SB IIIa1 (1020960 BC), equivalent to late Ha B1 or early B2 (e.g. 'thraco-cimmerian' finds; such as a belt of Type Bénévent-en-Champsaur). ${ }^{634}$

Cat. nos. 117-118. Huelva A \& B, Andalusia, Spain - assemblage in river (estuary of the rivers Odial and Tinto) - fragments of two helmets. Measurements: fragment A: height: $25 \mathrm{~cm}$; diameter: $21.5 \times 16.8 \mathrm{~cm}$; weight: $150 \mathrm{~g}$; fragment B: length: $8 \mathrm{~cm}$; weight: $12 \mathrm{~g}$ - Museo Arqueológico Nacional, Madrid inv. no. 229 (helmet A) and 318 (helmet B) (old inv. no.: 32.606; 32.525) - Pl. 22.117-118. References: Almagro Basch 1958, Fas. 4, E.1.39, nos. 269-272; Hencken 1971, 72, 74, fig. 48; Schauer 1983, 185; Stary 1994, 95, suppl. 3A.1, map 1; Ruiz-Gálvez Priego 1995; Harrison 2004, 15; Brandherm 2007, 29-30; Lippert 2011, 64, pl. 1.1-2.

The bronze objects were dredged from the estuary of the river Odiel between February and March (April?) 1923, at a depth of 9-9.5m, at the confluence of the rivers Odiel and Tinto. The mechanical dredger, with buckets on a continuous chain, brought the sediment to the surface, where the workmen picked out the bronzes they saw. During later dredging further objects were discovered, but they cannot be clearly associated with this assemblage. The assemblage contains, based on the description of Brandherm, swords of Type Rixheim, Type Cordeiro, a transitional type, 93 swords and fragments belonging to at least 51 swords of Type Huelva, two carpstongue swords, 28 daggers, 92 spearheads and fragments (belonging to at least 81 spearheads), 61 regatones and further fragments of those, 56 rivets, 17 arrow heads, 12 tutuli, 11 rings, five fragments of at least two bronze helmets, four elbow fibulae and other fibulae forms, four fragments of at least three torques, two buckles, five bronze sheets, nine objects of undetermined type, a pin, a chisel, and some iron fragments. ${ }^{635}$

Cat. no. 119. Vila Cova de Perrinho (Rossio) / Monte do Crasto, prov. Beira Litoral, Portugal - associated deposit - three fragments. Measurements: fragment ARQ A: $7.8 \times 3.4 \times 0.3 \mathrm{~cm}$; 20g; fragment ARQ 34: $13.5 \times 9.6 \times 0.1 \mathrm{~cm} ; 40 \mathrm{~g}$; fragment ARQ 35: $11.2 \times 10.7 \times 0.1 \mathrm{~cm} ; 45 \mathrm{~g}-$ Museu Municipal de Vale de Cambra, inv. no. ARQ033-35 - Pl. 22.119. References: Brandão 1963, 118, no. 9, pl. 1.9-11; Kalb 1980, 29, figs. 7, 41.8-10; Coffyn 1985, 390, pl. XL; Bottaini Rodrigues 2011a, 109, figs. 2, 3.8-10; Bottaini - Rodrigues 2011b, 31-32, fig. 5, tab. 1; Brandherm 2011, 40.

The associated deposit ${ }^{636}$ was found in 1959 or 1960 in Rossio, Vila Cova de Perrinho. It consists of a ceramic vessel, three beads, three axes, three chisels, two daggers of Type Porto de Mos, two fragments of bracelets, and three bronze sheet fragments of a crested helmet. The beads and the ceramic pot are now lost.

\subsubsection{Helmet from Tiryns}

The helmet from Tiryns is the only crested helmet not assignable to any of the previously defined forms represented by types Mantes, Lueg, Biebesheim or Bernières d'Ailly. The helmet from Tiryns is only partially preserved. It was made out of six elements: two halves of a cap, two bands in between and two cheek plates, which is similar to the helmet indicated on the Linear B tablets from Pylos (around $1200 \mathrm{BC}$ ), where the helmet (ko-ru-to) is described as com-

\footnotetext{
634 Mohen 1977, 122; Sperber 2011, 20.

635 Brandherm 2007, 29.

636 Interpreted as a grave by Brandão 1963, 114.
} 
posed by four elements (o-pa-wo-ta) and two cheek plates (pa-ra-wa-jo). The cheek plates of the Tiryns helmet show a row of small holes (diameter c. $1 \mathrm{~mm}$ ) parallel to the edge to fix the organic inlay, with a distance between each of them of $5 \mathrm{~mm}$. During the excavation, residues of linen were still present between the rivet holes but were not preserved during restoration work. The bands have three holes in both ends, probably used to fix a wooden crest holder.

On the two halves of the cap of the Tiryns helmet, a dotted line with pendant and another line parallel to it, below the chevrons, follows the rim of the cap. From the Aegean-Cypriot world we know openwork triangles found on several Cyprian tripods and stands from the $12^{\text {th }}$ century $\mathrm{BC}$ onwards ${ }^{637}$ though these might not have been cut-out but by bending a rod. The decoration of open elements is documented also from the Nordic Bronze Age in period II. ${ }^{638}$ Mozsolics sees the origin of the openwork triangles in Southern Russia, the Caucasus and the Koban during the $13^{\text {th }}$ century BC, which then appears in Transylvania and Hungary shortly afterwards. ${ }^{639}$

In the centre of each side of the Tiryns helmet, as well as in the centre of the cheek plate, two circles of pellets with a large central boss were applied. This central element is known from other European defensive armour, as on the helmets from Pass Lueg and from Szczecin-Zdroje, on the cuirass from Jura (cat. no. 138), and the complete example from the Danube. ${ }^{640}$ Other bronze sheet with the same motif derive from Salaš Noćajski, Serbia, ${ }^{641}$ Guşteriţa, Romania, ${ }^{642}$ Techirghiol, Romania, ${ }^{643}$ Pila del Brancon, Italy ${ }^{644}$ Dresden-Dobritz, Germany, ${ }^{645}$ and from an Iron Age deposit from Sicily. ${ }^{646}$ Borchhardt instead sees in the central decoration a close connection to the older Zonenhelme, which bear both zig-zag bands and additional round metal discs. $^{647}$

The grave dates to the early $11^{\text {th }}$ century BC or LH IIIC (late). ${ }^{648} \mathrm{~N}$. M. Verdelis assumes the helmet was produced in a local workshop, using yet unknown Cretan-Mycenaean archetypes, ${ }^{649}$ which is strengthened by the similarity of the form of the cheek plate with the ones from Knossos and Dendra. The influence of the Urnfield culture is evident in the central decoration of both helmet and cheek plates. Thus, we might regard the helmet from Tiryns as a hybrid between Aegean and Urnfield culture types.

Cat. no. 120. Tiryns, Argolis, Greece - grave 28 - almost complete helmet. Measurements: height: $17 \mathrm{~cm}$; diameter: $22.5 \mathrm{~cm}$; thickness: $0.1 \mathrm{~cm}$; measurements cheek plates: $16 \times 9 \mathrm{~cm}$; measurements bands: $30.5 / 29 / 10.5 .5 \times 3 \mathrm{~cm}-$ Archaeological Museum of Nafplion, inv. no. unknown. - Pl. 22.120. References: Daux 1958; Verdelis 1963, 17, fig. 5.9, suppl. 6-7; Desborough 1964, 64, 80, 84; Hencken 1971, 23-26, fig. 8; Borchhardt 1972, 43-44, pl. 8.4-5; Borchhardt 1977, E68, fig. 9.E, pl. E.IVa; Schauer 1982a, 343; Lippert 2011, 75-76, pl. 8.5-6.

The geometric graves, located some $150 \mathrm{~m}$ to the south of the acropolis, were excavated in 1957. Grave 28 contained two burials; one earlier, without any associated finds, and a later grave, containing the helmet itself, one bronze spearhead, two iron daggers, one $79 \mathrm{~cm}$ long broken bronze sheet band, one bronze phalera or shield buckle, two bronze finger rings and one Bügelkanne. Schauer argues that the position of the helmet was relocated to the area of the chest

637 Catling 1964, 190-223.

638 Hencken 1971, 23.

639 Mozsolics 1955.

${ }^{640}$ Mödlinger 2014b; cat. no. 132.

${ }_{641}$ Vasić 1994, pl. 38.13.

${ }^{642}$ Bronze sheet fragment: Rusu 1990, 73, pl. V.5.

${ }_{643}$ Bronze sheet fragment: Petrescu-Dîmboviţa 1978, pl. 215.17-19.

${ }_{644}$ Bronze sheet fragment: Salzani 1998, fig. 2.138.

645 Bronze cup: Martin 2009, pl. 30.119.

646 Egg 1983, fig. 2.4-5.

647 Borchhardt 1972, 44.r

648 Desborough 1964, 241.

${ }^{649}$ Verdelis 1963, 23. 
during the decomposition process, dislocating the bronze phalera, which was positioned so as to provide protection for the heart, and was not, as Verdelis suggests, a shield buckle ${ }^{650}$ Schauer also suggests that the bronze disc may also have been used as a cover for the helmet.

\subsubsection{Single Helmet types and Potential Helmet Finds}

The only western European helmet, which could perhaps have been dated more precisely, was that found in Picquigny, Dép. Somme, France, in peat at a depth of $3 \mathrm{~m}$, together with an antenna sword, next to one of many skeletons. ${ }^{651}$ The helmet was sold to a copper smith, however, and melted down. No drawings were made, which was already regretted in early writings of A. Mongez. ${ }^{652}$

Coutil and L. Hémery both cite a helmet from Posen ${ }^{653}$ similar to the one from Mainz, which according to A. Demmin: 'On a trouvé un exemplaire tout pareil [as the helmets from Bernières d'Ailly] à Posen et un autre en Bavière dans la rivière de l'Inn'. ${ }^{654}$ The latter is very likely the helmet from the Pockinger Heide. It is not clear to which helmet Demmin refers. In 1869, only the crested helmets from Bernières d'Ailly, Pockinger Heide and Pass Lueg were known.

Some 13 conical-headed rivets, potentially belonging to crested helmets, were found at Flag Fen, Peterborough, United Kingdom. ${ }^{655}$ The rivets from the Nottingham Hill associated deposit, Gloucestershire, which was deposited inside a hillfort, ${ }^{656}$ are more likely from a bronze vessel than a crested helmet (Fig. 2.25).
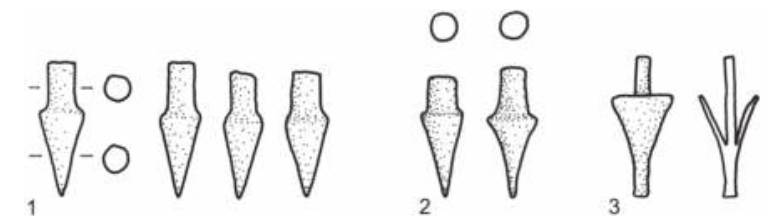

Fig. 2.25 Potential rivets of helmets of Type Biebesheim or Type Bernières-d'Ailly: 1. Nottingham; 2. Flag Fen; 3. Saint-Brieuc-des-Iffs.

The associated deposit from Vénat, France, is dated to the transition from Ha B to early Ha C. ${ }^{657}$ It is thought to contain a single potential rivet from a crested helmet of Type Bernières d'Ailly. ${ }^{658}$ The cross-section of the rivet, however, is rather unique - the angle between shaft and head is not $90^{\circ}$ but $45^{\circ}$, and is different in form from those rivets found on known helmets.

The rivets from the Bronze final II associated deposit from Saint Brieuc-des-Iffs, France, interpreted as transitional between early or Bronze final II ancien (i.e. Ha A2) and late or Bronze final II récent (i.e. Ha B2), ${ }^{659}$ are assumed to come from a crested helmet of Type Biebesheim. ${ }^{660}$ However, the rivets do not have a solid, conical head but are instead hollow, a form, which is currently unknown on helmets of Type Biebesheim. More likely, they derive from another type of object.

\footnotetext{
650 Schauer 1982a, 343; Verdelis 1963.

${ }_{651}$ Athenas 1828, 280; Breuil 1900, 520; Coutil 1911, 7, no. 8.

652 Mongez 1803/1804, 499-501.

653 Coutil 1926, 303; Hémery 1926, 198.

${ }_{654}$ Demmin 1869, 149.

655 Coombs 1992, 509.

656 Gingell 1974, fig. 4.10-13.

657 Hencken 1971, 75.

${ }_{658}$ Müller-Karpe 1959, 216; Jacob-Friesen 1968, 272; Hencken 1971, 75, fig. 49b; Mohen 1977, 122.

659 Milcent 2012, 216.

660 Mohen 1977, 122.
} 
Sperber describes burnt fragments of bronze sheet, decorated with small bosses and having a folded rim, from Volders, grave 322, Tyrol, as being fragments from Type Biebesheim. ${ }^{661}$ However, according to their decoration, they appear instead to come from either bronze vessels, greaves of Type Kuřim, ${ }^{662}$ or possibly from helmets related to the Italian crested series.

The associated deposit of Grañón was 'discovered' in 2007 (or at least brought to the attention of the Dirección General de Patrimonio del Gobierno de La Rioja, at that time). The associated deposit was originally much larger, weighing over $50 \mathrm{~kg}$, but most of the associated deposit was sold to a junkyard. Today, just 18 objects survive, consisting mainly of swords, spears and ferrules, with just three of the objects being complete. It is said that the associated deposit originally contained shields (which would have made them the first actual bronze shields found in the Iberian Peninsula), helmets, fibulae and belts. No fragments of these from the associated deposit have so far been recovered, and no further information on them is available. ${ }^{663}$

\subsubsection{Outlook to the Iron Age: Italian Crested Helmets}

The peak in the development of prehistoric crested helmets is surely to be found in central Italy. Far less practical than earlier such helmets but richly decorated, some 55 crested helmets with

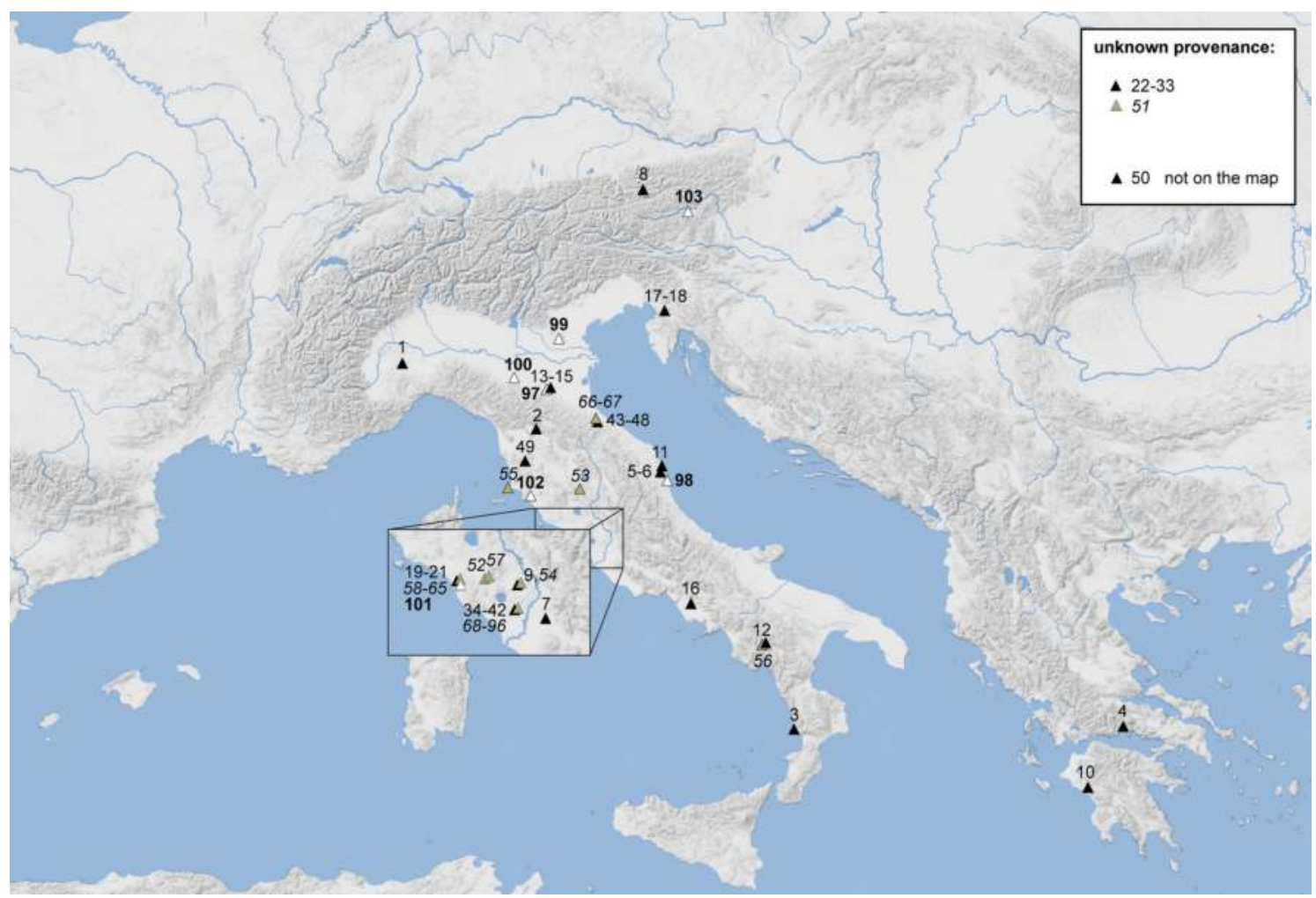

Fig. 2.26 Archaeological distribution of Italian crested helmets: $\Delta$ Metal crested helmets: 1. Asti; 2. Bisenzio; 3. Campora San Giovanni; 4. Delphi; 5-6. Fermo; 7. Gabii; 8. Hallstatt; 9. Narce; 10. Olympia, Greece; 11. Porto S. Elpidio; 12. Sala Consilina; 13-15. San Francesco, Bologna; 16. Santa Maria di Capua Vetere; 17-18. Škocjan; 19-21. Tarquinia; 22-33. Unprovenanced; 34-42. Veii; 43-48. Verucchio; 49. Volterra; 50. Zavadinsy; 51. Unprovenanced. $\triangle$ (grey) Ceramic replicas of metal crested helmets: 52. Chiusa Cima; 53. Cittá delle Pieve; 54. Falerii; 55. Populonia; 56. Sala Consilina, S. Antonio; 57. San Giuliano (Barbarano Romano, VT); 58-65. Tarquinia; 66-67. Verucchio; 68-96. Veii. $\triangle$ Figurines with crested helmets: 97. Bologna; 98. Cupramarittima; 99. Lozzo Atestino; 100. Reggio Emilia; 101. Tarquinia; 102. Vetulonia; 103. Strettweg. Numbers relate to those in Tables 2.14 and 2.15 .

\footnotetext{
${ }_{661}$ Sperber 2011, 10, fig. 3.

${ }_{662}$ See Chapter 4.1.3, p. 233.

${ }_{663}$ Alonso Fernández - Jiménez Echevarría 2009, 8; Brandherm 2011, 40.
} 


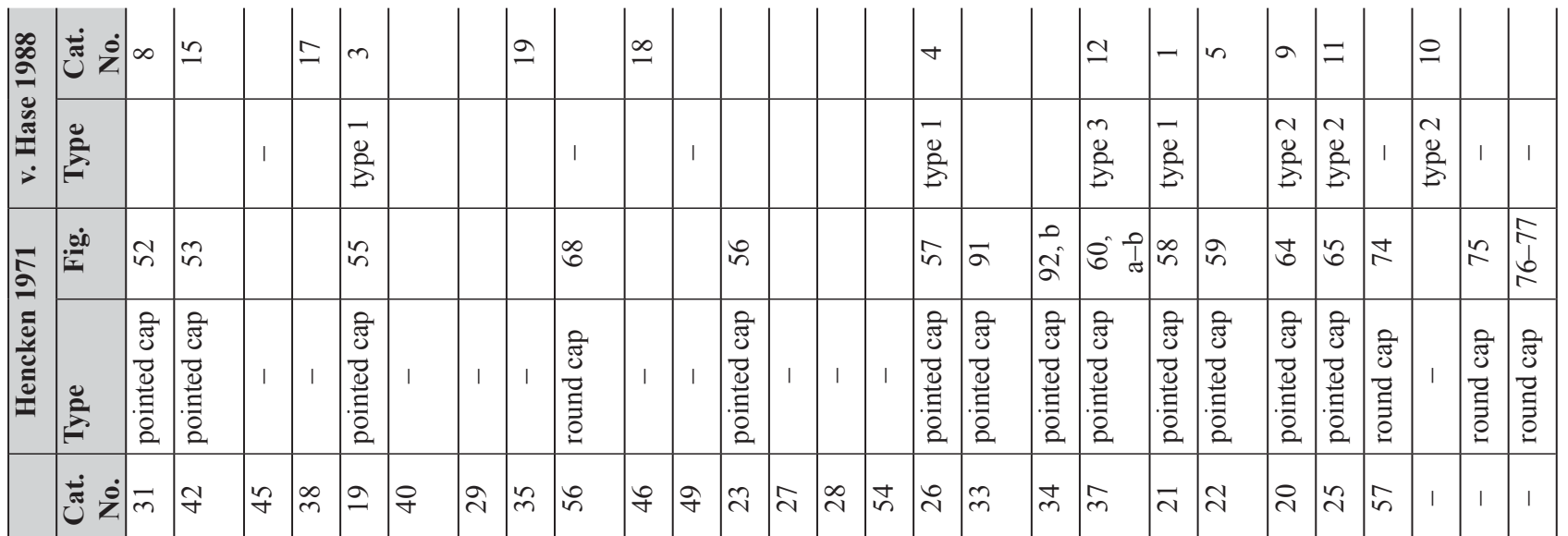

\begin{tabular}{|c|c|c|c|c|c|c|c|c|c|c|c|c|c|c|c|c|c|c|c|c|c|c|c|}
\hline$\sum_{F}^{\circ}$ & $\mid \frac{m}{\cdot \overrightarrow{\bar{s}}}$ & $\stackrel{n}{: \bar{\nu}}$ & 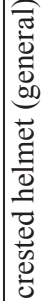 & 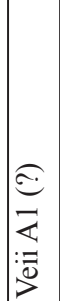 & 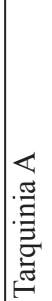 & $\underset{:}{\geq}$ & 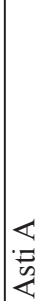 & 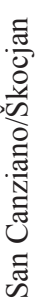 & 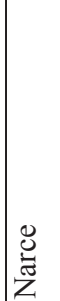 & 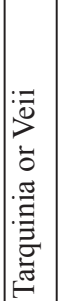 & 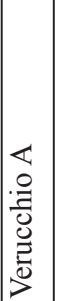 & 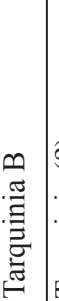 & 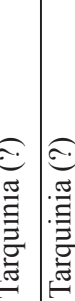 & 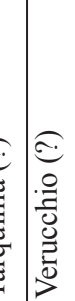 & 吾 & 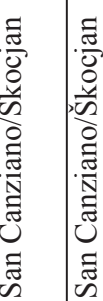 & 这 & 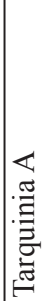 & & 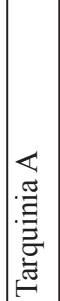 & 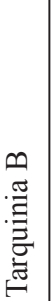 & & 1 \\
\hline $\begin{array}{l}\dot{\dot{z}} \\
\dot{\dot{\Delta}}\end{array}$ & 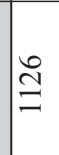 & $\mid \begin{array}{l}\bar{n} \\
\\
\infty \\
\infty\end{array}$ & I & 1 & $\begin{array}{r}\text { fo } \\
\text { to }\end{array}$ & $\begin{array}{l}\infty \\
0 \\
\dot{i}\end{array}$ & 1 & 1 & $\begin{array}{l}8 \\
\infty \\
\infty \\
\dot{n} \\
\dot{\Sigma}\end{array}$ & $\begin{array}{l}\overrightarrow{0} \\
\stackrel{0}{0} \\
\stackrel{0}{0}\end{array}$ & I & $\stackrel{?}{\longrightarrow}$ & 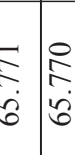 & 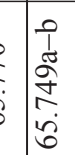 & 1 & l 1 & 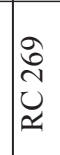 & 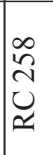 & & 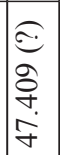 & । & & 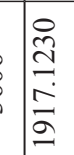 \\
\hline
\end{tabular}

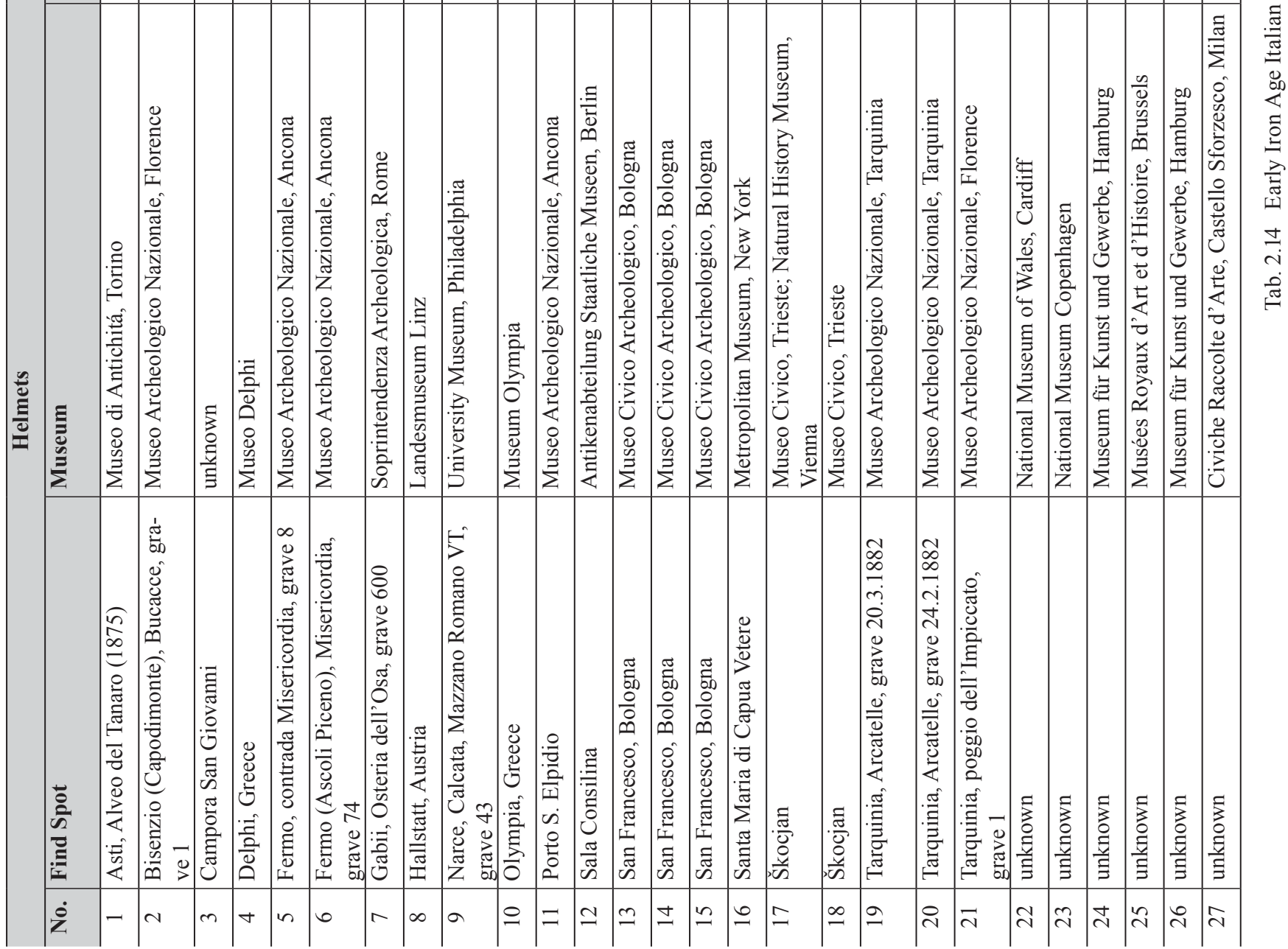




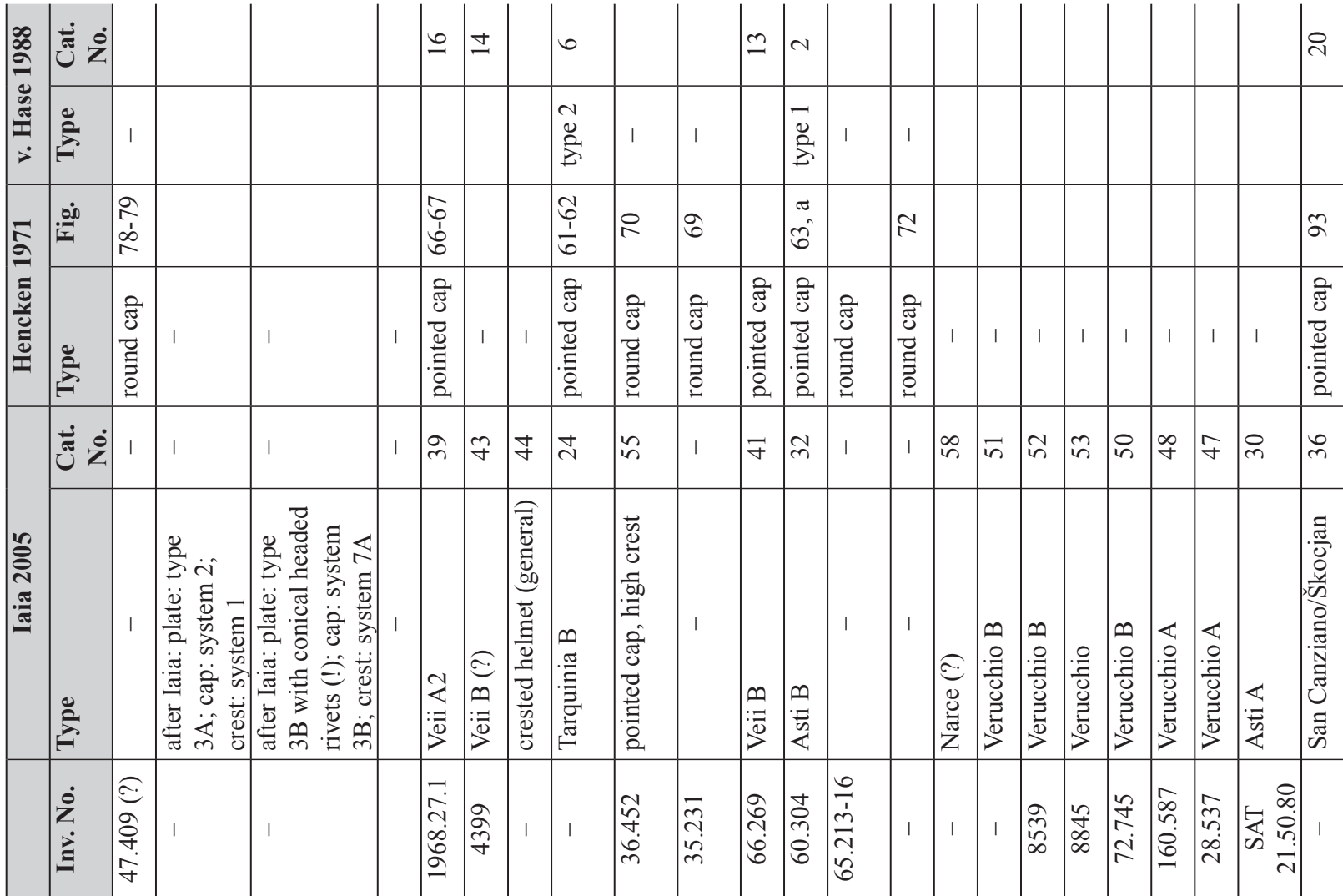

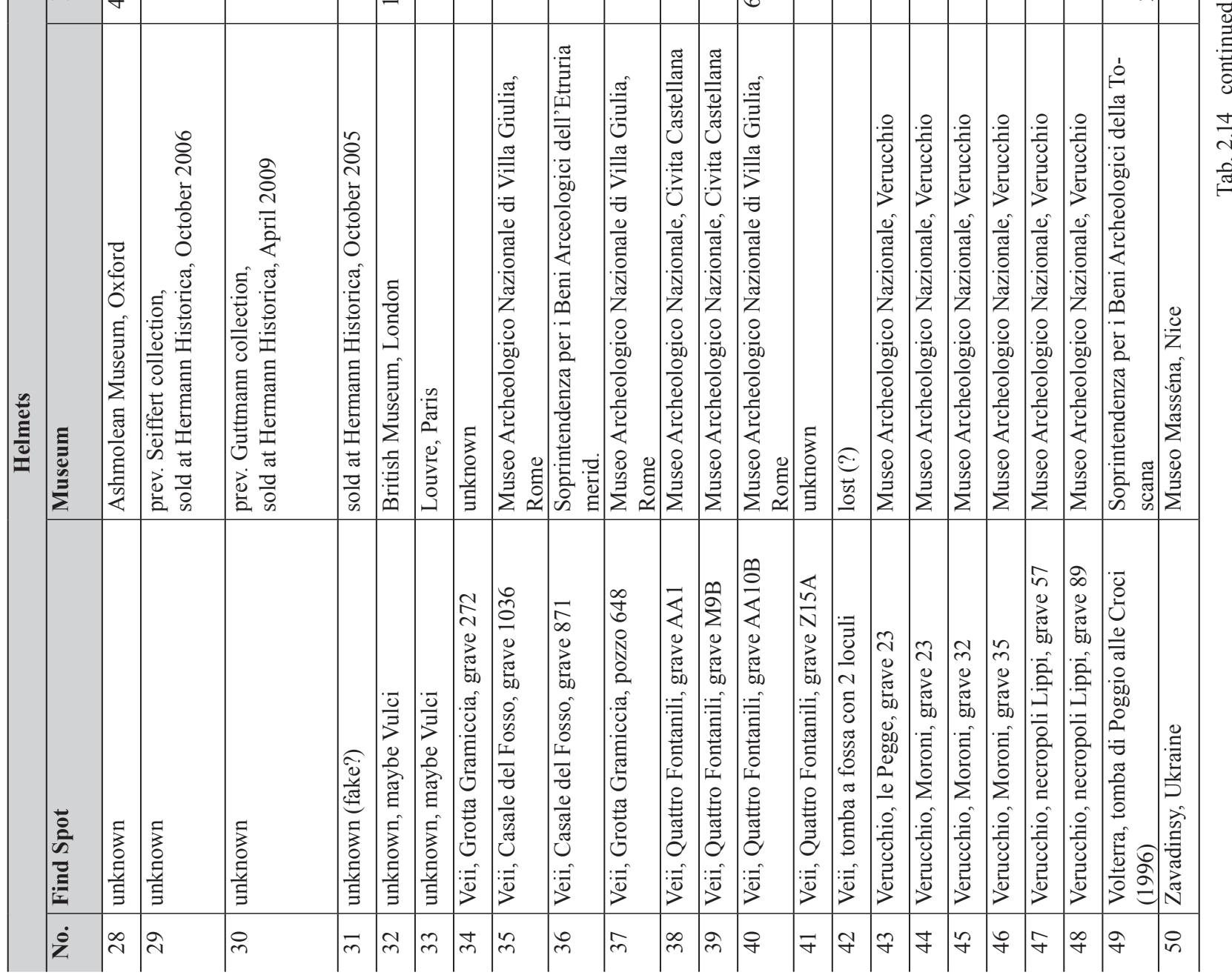




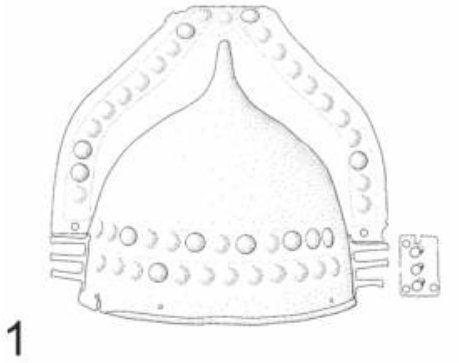

1

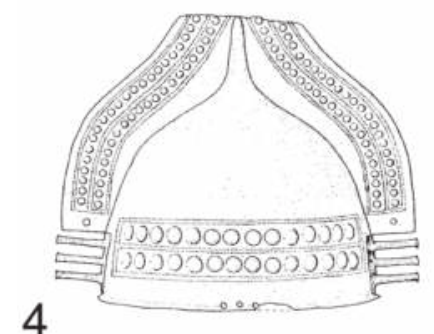

4

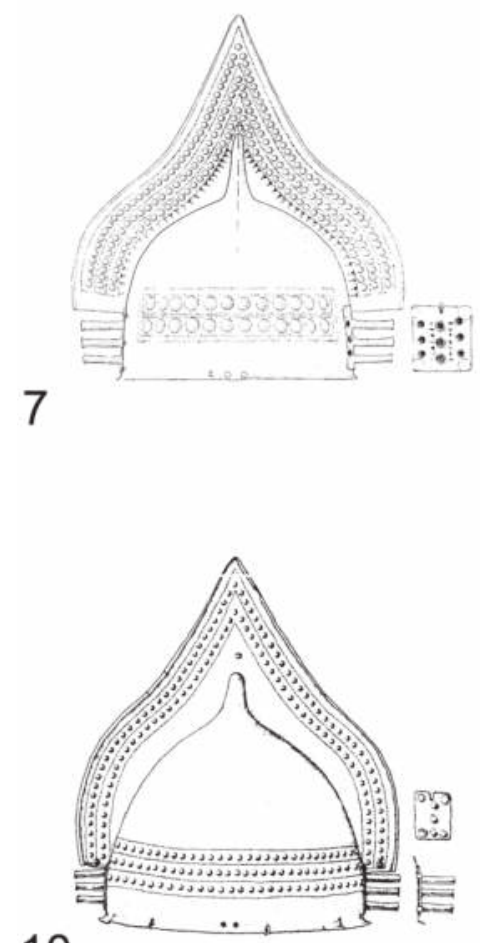

10

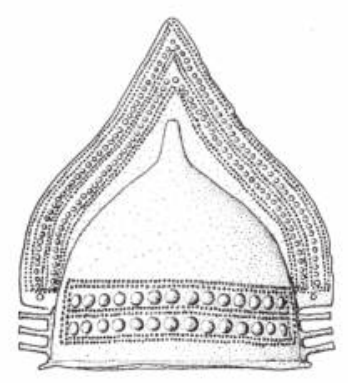

2

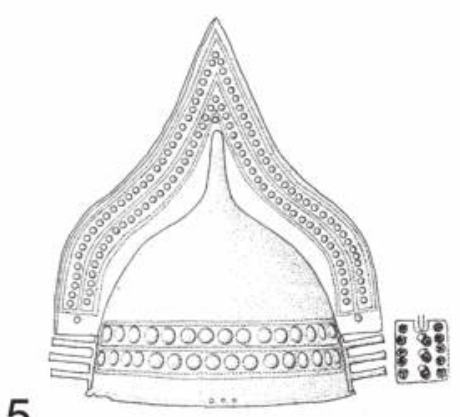

5
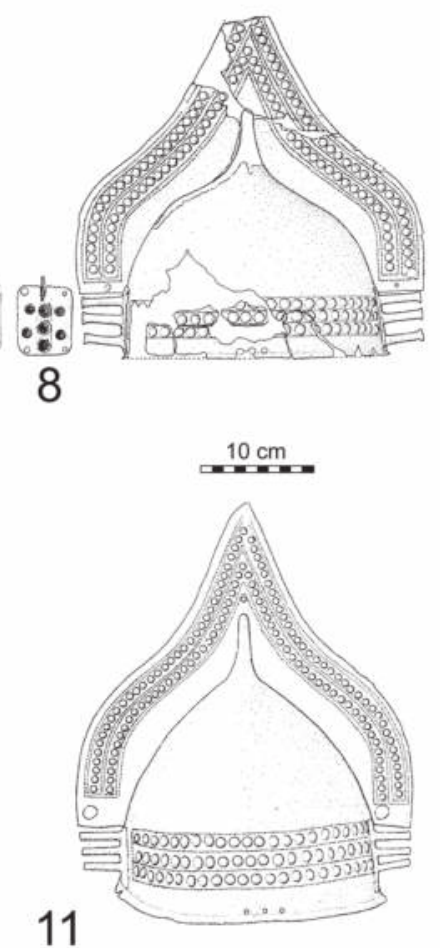

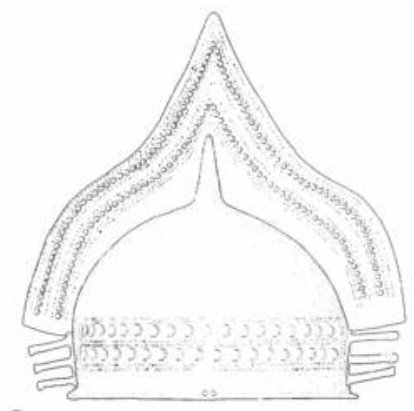

3

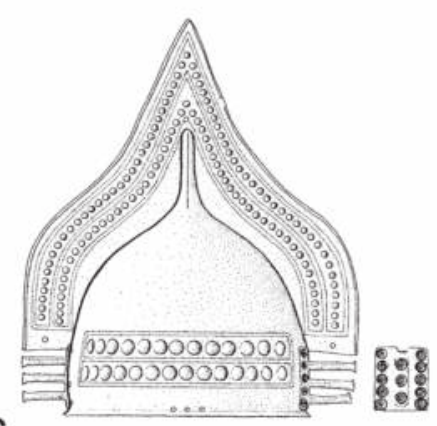

6

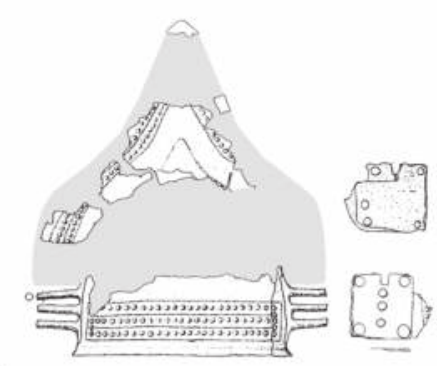

9

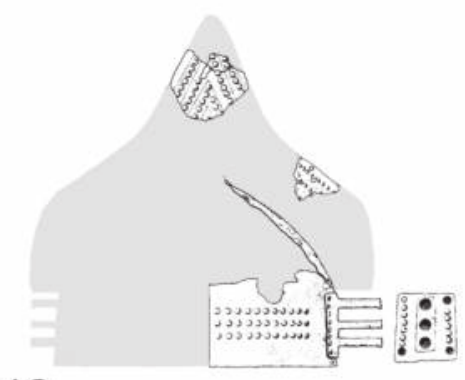

12

Fig. 2.27 Italian crested helmets: 1. Zavadintsy; 2. Santa Maria di Capua Vetere; 3. Unprovenanced ('Copenhagen'); 4. Tarquinia, poggio dell'Impiccato, grave 1; 5. Veio, casale del Fosso, grave 1036; 6. Sala Consilina; 7. Tarquinia, Arcatelle, grave 24.2.1882; 8. Fermo, contrada Misericordia, grave 8; 9. Veio, Quattro Fontanili, grave M9B; 10. Asti, Alveo del Tanaro (1875); 11. Unprovenanced ('Cardiff'); 12. Gabii, Osteria dell'Osa, grave 600 (drawings after Iaia 2005). 


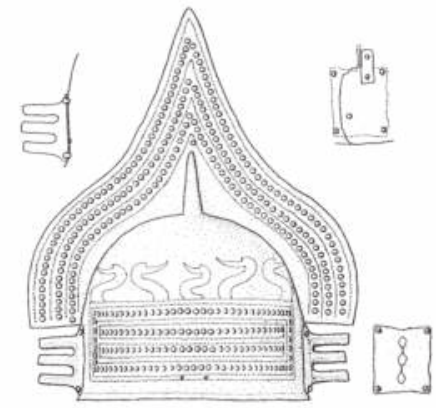

1
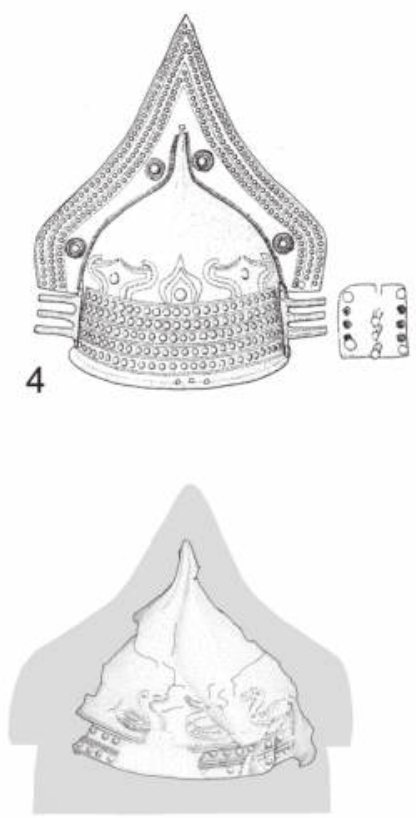

7

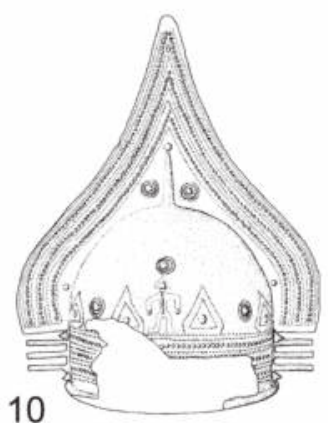

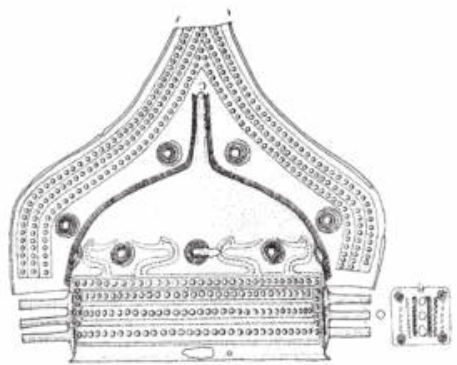

2

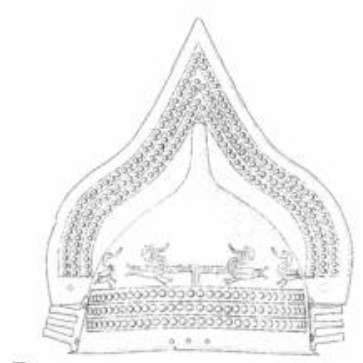

5

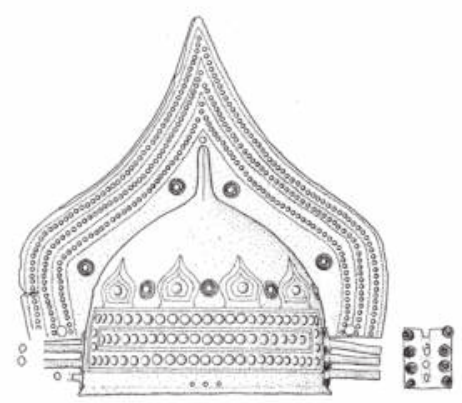

8

$10 \mathrm{~cm}$

11

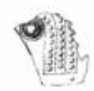

12

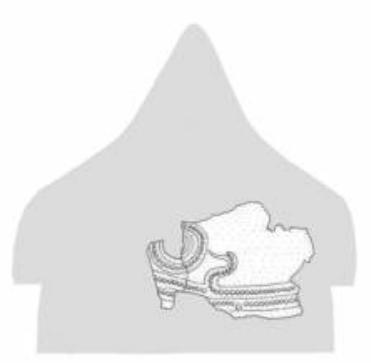

3

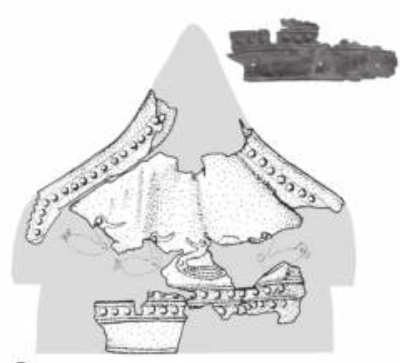

6

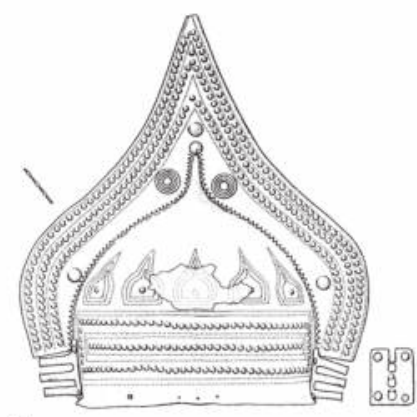

9

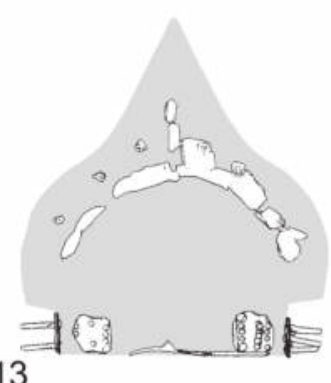

Fig. 2.28 Italian crested helmets: 1. Fermo (Ascoli Piceno), Misericordia, grave 74; 2. Tarquinia, Arcatelle, grave 20.3.1882; 3. Škocjan (drawing: Mödlinger); 4. Unprovenanced ('London'); 5. Volterra, tomba di Poggio alle Croci (1996); 6. Škocjan (drawing and photo: M. Mödlinger; photo (C) Prähistorische Abteilung NHM Wien, inv. no. 47.633); 7. Škocjan (drawing: Mödlinger); 8. Bisenzio (Capodimonte), Bucacce, grave 1; 9. Veio Quattro Fontanili, grave AA1; 10. Unprovenanced ('Louvre'); 11. Bologna, San Francesco; 12. Delphi; 13. Veio, Grotta Gramiccia, grave 272 (drawings after Iaia 2005, if not indicated otherwise). 


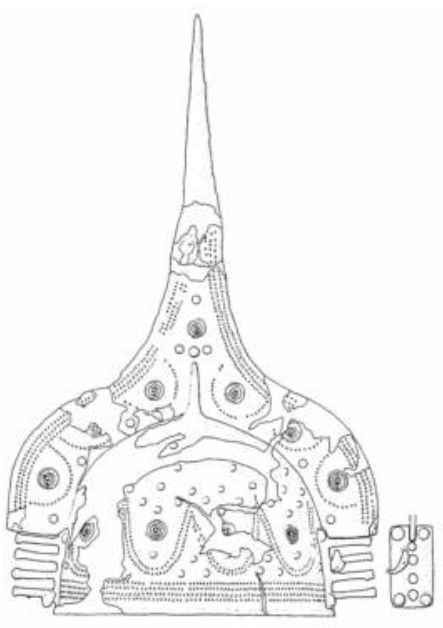

1
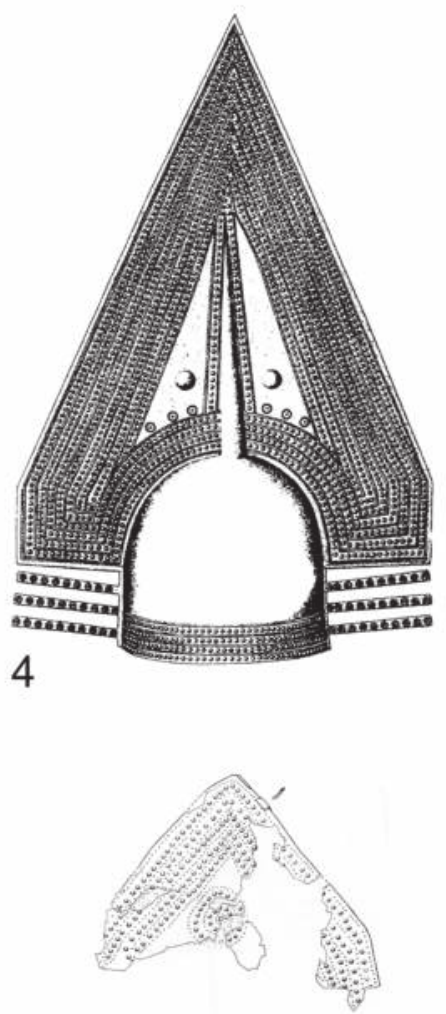

7

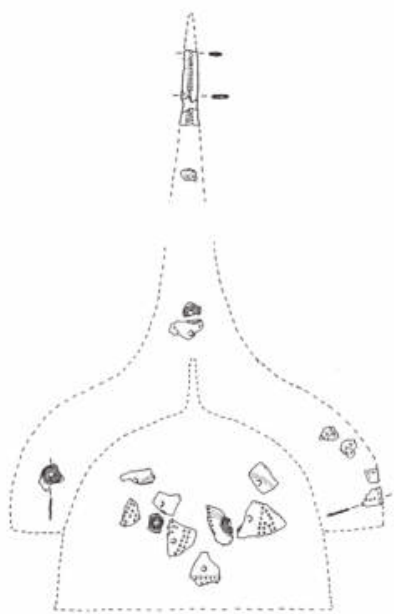

2

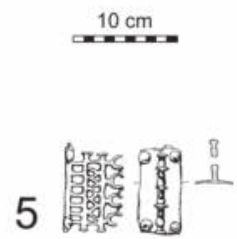

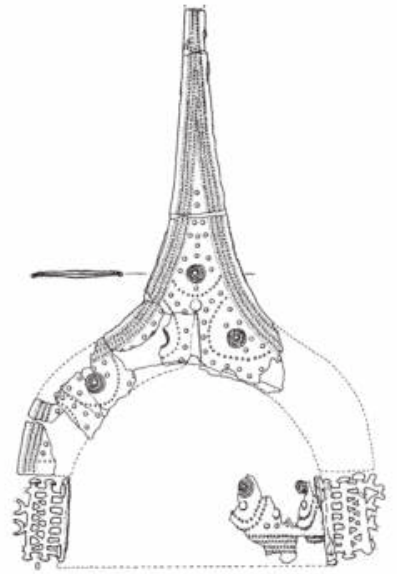

3

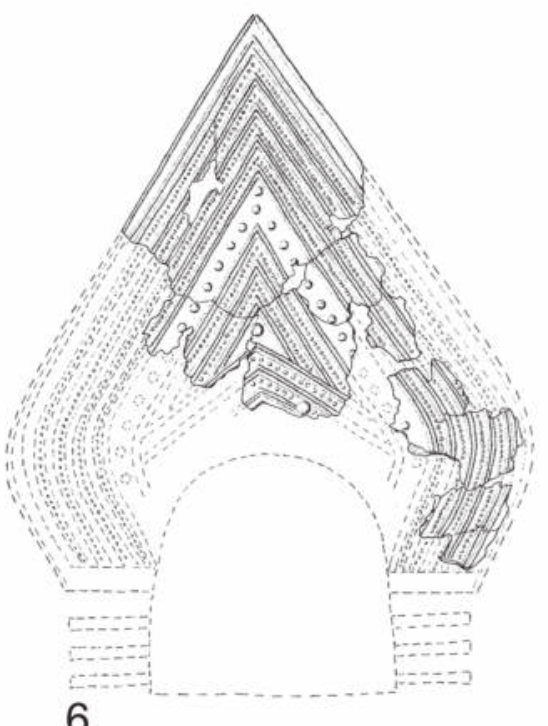

6

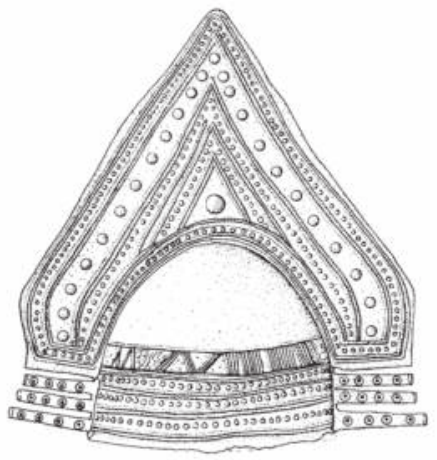

8

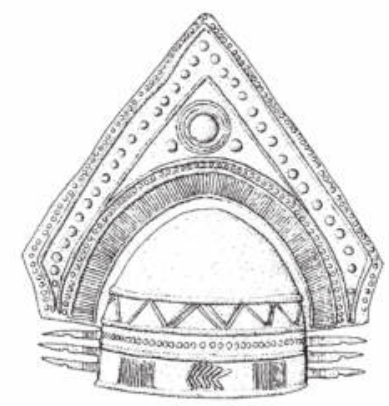

9

Fig. 2.29 Italian crested helmets: 1. Verucchio, necropoli Lippi, grave 89; 2. Verucchio, Moroni, grave 32; 3. Verucchio, Moroni, grave 35; 4. Veio, casale del Fosso, grave 871; 5. Verucchio, le Pegge, grave 23; 6. Veio, tomba a fossa con 2 loculi 1886; 7. Veio, Quattro Fontanili, grave Z15A (after Hencken 1971, fig. 72); 8. Narce, Calcata, Mazzano Romano VT, grave 43; 9. Unprovenanced ('Hamburg') (drawings after Iaia 2005, if not indicated otherwise). 
1
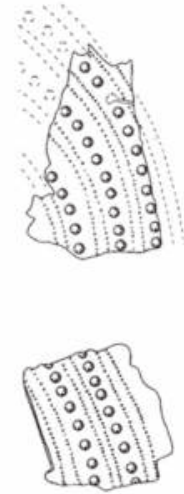

2

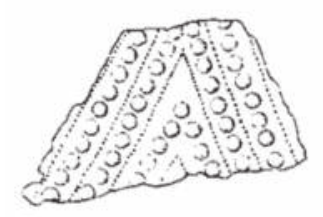

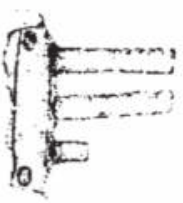

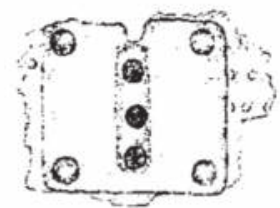

5

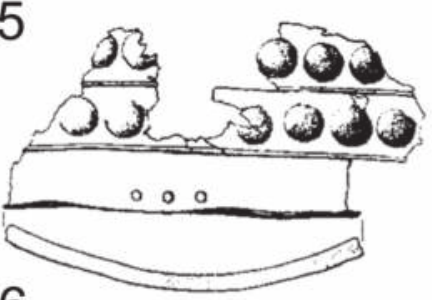

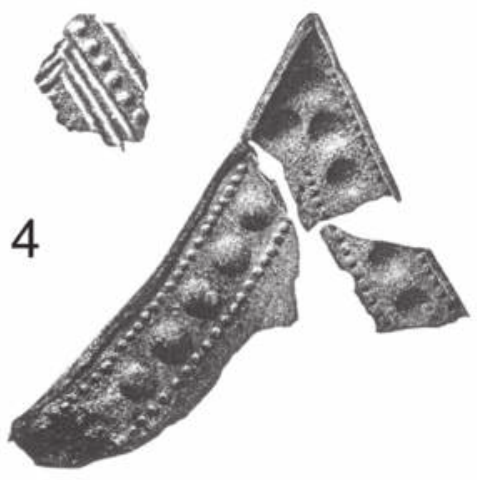

6

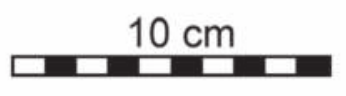

\section{3}

Fig. 2.30 Italian crested helmets: 1-2. Bologna, San Francesco; 3. Olympia; 4. Škocjan (after Hencken 1971, fig. 92); 5. Capora San Giovanni; 6. Hallstatt. (no scale for nos. 1-3) (drawings after Iaia 2005, if not indicated otherwise).

round or pointed cap are known from the early Iron Age Villanovan culture. ${ }^{664}$ For an overview of the main information available on these Italian crested helmets, as well as their typological classification according to various authors, ${ }^{665}$ see Tab. 2.14 and Figures 2.27-2.30).

The most comprehensive study of these Italian crested helmets was recently published by Iaia. ${ }^{666}$ Using morphological and decorative characteristics, established on the basis of the examination of different aspects of some 50 metal helmets (including classifying the decoration of the cap and crest into no less than seven types and six variants), he arranged the Italian helmets into five main groups: Tarquinia, Asti, San Canziano/Škocjan, Veii and Verucchio, encompassing several variants and subtypes.

F.-W. v. Hase distinguished the Italian crested helmets with pointed cap into three different, mostly contemporary, variants ${ }^{667}$ based on the 20 or so examples then known to him. Variant I is characterised by a round, stocky cap with a horizontal based crest. These helmets appear already in Villanovan IB. Helmets associated with variant II are characterised by an elongated cap with a horizontal based crest. F. W. v. Hase dates variant II according to a ceramic helmet from Tarquinia, grave 39, which is assigned to the $9^{\text {th }}$ century BC. The latest helmet is the one from Veii, grave 1036, which is dated to the second half of the $8^{\text {th }}$ century BC. ${ }^{668}$ Variant III is defined by the cap, as in variant I or II, and has a slightly vertical based crest. The cap is deco-

\footnotetext{
664 Hencken 1971, 78-110; v. Hase 1988; Iaia 2005.

665 Hencken 1971; v. Hase 1988; Iaia 2005.

666 Iaia 2005, 65-114.

667 v. Hase 1988.

668 v. Hase 1988, 201.
} 

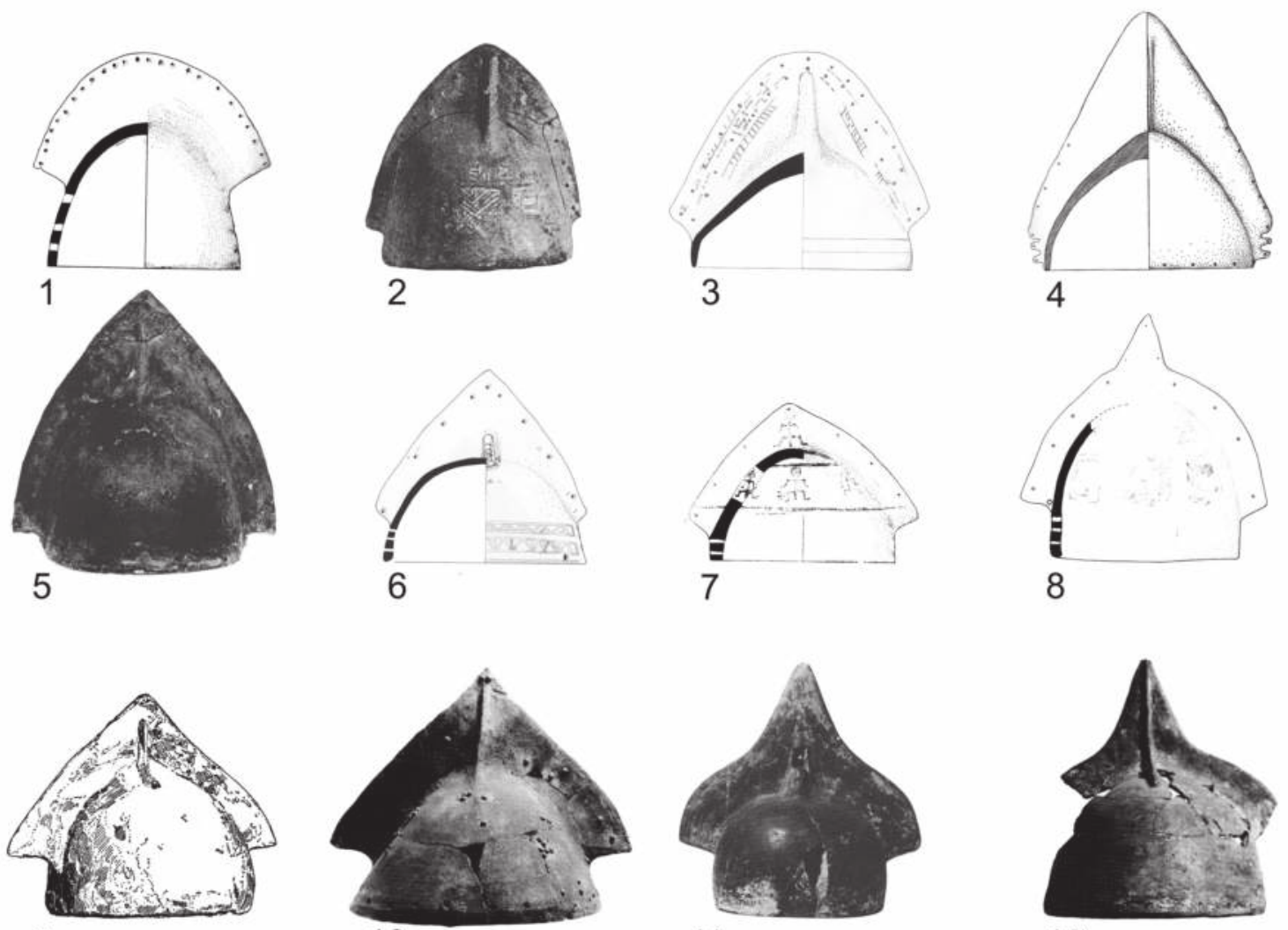

9

11

12

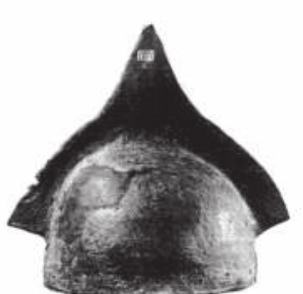

13

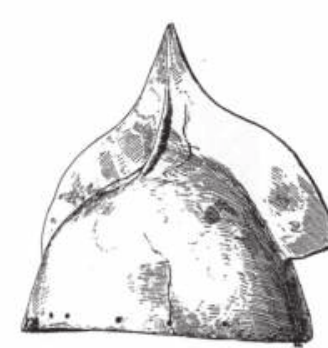

14

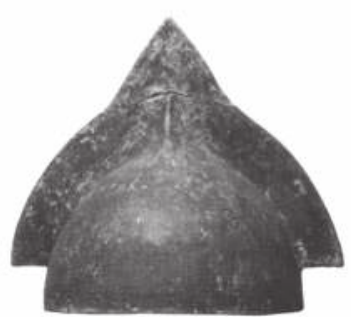

16

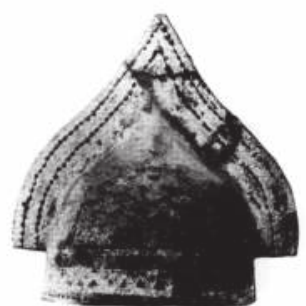

17

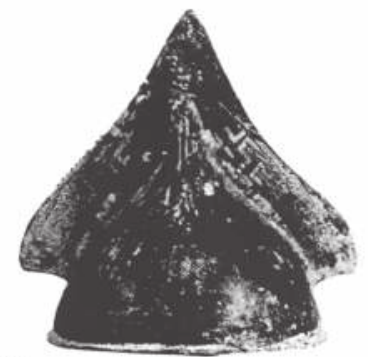

15

$10 \mathrm{~cm}$

Fig. 2.31 Ceramic models of Italian crested helmets: 1. Veio Quattro Fontanili, grave CC18-19B (after Alciati Passarello 1963, fig. 44); 2. Veio Quattro Fontanili, grave NO 4-5 (after v. Hase 1988, fig. 8.2); 3. Veio Quattro Fontanili, grave AA8 (after Terrosi Zanco 1967, fig 5.2); 4. Veio Valle la Fata, grave 18 (after Lippert 2011 pl.11.1); 5. Veio Valle la Fata, grave 28 (after v. Hase 1988, fig. 8.1); 6. Veio Quattro Fontanili, grave AA7 (after Terrosi Zanco 1967, fig. 88I.2); 7. Veio Quattro Fontanili, grave DD19 (after Alciati - Passarello 1963, fig. 62b); 8. Veio Quattro Fontanili, grave O6A (after Fabbricotti et al. 1972, fig. 65.2); 9. Tarquinia Monterozzi (?) (after Hencken 1968, fig. 440); 10. Tarquinia Impiccato, grave 65 (after Hencken 1968, fig. 47); 11. Tarquinia Selciatello Sopra, grave 85 (after Hencken 1968, fig 58c); 12. Tarquinia Impiccato, grave 58 (after Hencken 1968 fig. 110d); 13. Tarquinia Monterozzi (?), inv. no. RC 239 (after Hencken 1968, fig. 438); 14. Tarquinia Monterozzi (?) (after Hencken 1968, fig. 439); 15. Tarquinia Monterozzi, grave 66 (after v. Hase 1988, fig. 9.1); 16. Tarquinia Impiccato, grave 80 (after Hencken 1968, fig 144e); 17. Tarquinia Impiccato, grave 39 (after Hencken 1968, fig. 214g). 
rated with at least three rows of bosses, Ringbuckel and bird head depictions. The helmet from Tarquinia, as one of the oldest, marks the appearance of variant III (Villanovan IB according to Hencken). ${ }^{669}$ The most recent helmet is that from Bisenzio. Crested helmets with rounded cap occur as metal examples only in the late $8^{\text {th }}$ century $\mathrm{BC}$, but are already known from earlier contexts in the form of ceramic models. ${ }^{670}$ Only a few metal helmets are known (Tab. 2.14). The lack of crested metal helmets in Bologna and Este is most likely connected with different burial traditions, as generally no defensive armour is known from this area. ${ }^{671}$ According to the densely narrow distribution area of both metal and ceramic helmets in southern Etruria, the local production of helmets of variant I-III in this area seem to be most likely. The helmets from Zavadintsy, Hallstatt and Asti, which also partly include other decorative elements, were surely produced by other workshops that were nonetheless extremely familiar or closely related to the Etrurian workshops. F. W. v. Hase locates these other workshops in northern Italy. ${ }^{672}$

Italian crested helmets unify characteristics of both western European and eastern European helmet types. While the cap testifies to a strong relationship with eastern European cap helmets (their profile resembles that of helmets of Type Pişcolt) and, though less significant, to helmets of Type Nagytétény, the crest certainly derives from western European helmets. The thin, pointed upper end of the cap was applied so as to increase the stability of the large crest, as already known on helmets of Type Lueg. We would also suggest that the vertical stabilisation rib on the central point of the crest of Type Lueg might be the precursor of the more massive midribs as found on the Italian crested helmets.

The connection between the Urnfield culture crested helmets and Italian crested helmets was suggested by v. Merhart. ${ }^{673}$ The relationship is even more evident, however, when including consideration of the ceramic helmets, skeuomorphs of unpreserved or unrecovered metal helmets. H. Born and L. D. Nebelsick assumed that the metal helmets depicted by Italian ceramic helmets might have had functional decorative rivets, as found on Type Biebesheim and Bernières d'Ailly, and might therefore be contemporary, if not precursors of the latter helmets. ${ }^{674}$ Moreover, both authors consider Italian crested helmets as older than the western European examples since both organic and metal crests are known in Italy, indicating a possible 'metallisation' of the older dated organic crested helmets. This view led them to conclude that the origin of this type of helmet lay in the Aegean and Anatolia, from where it spread to Italy and then north- and westwards. ${ }^{675}$ According to the chronology of helmets of both Type Biebesheim and Bernières d'Ailly, as well that of the Italian crested helmets (ceramic and metal), this is, as we will see, extremely unlikely.

Today, some 45 ceramic models of crested helmets are known (Tab. 2.15; Fig. 2.31). They were found, like the metal helmets, mainly in Tarquinia and Veii, with just one helmet known from Vulci and none from Bisenzio. From northern Etruria, there are just a few examples of urns covered with metal or ceramic helmets (e.g. Cittá della Pieve, Vetulonia) known to us. At the beginning of the Iron Age, some of the necropoli in Etruria and Campania demonstrate contemporaneity between the bronze cap helmets and ceramic imitations, of which the closest were found in Tarquinia. The ceramic helmet from Monte San Angelo/Veii (beginning of prima età del ferro IA) even shows a knob with a stepped shaft, pointing to the Ha B1 helmets of Type Pişcolt. Another further 35 or so ceramic cap helmets with knob are known from Pontecagnano. ${ }^{676}$ The helmets served as urn covers in the Villanova culture. Iaia suggests that the crested ceramic helmets from the transitional phase between late prima età del ferro I and initial phase

\footnotetext{
669 Hencken 1971, 78.

670 Hencken 1971, 97-110; v. Hase 1988, 202.

671 Stary 1981.

672 v. Hase 1988, 204.

673 v. Merhart 1941, 29, note 2.

674 Born - Nebelsick 1991, 32.

675 Born - Nebelsick 1991, 32-33.

676 Gastaldi 1998.
} 
II, represent the continuation of the older ceramic helmet tradition. ${ }^{677} \mathrm{O}$. H. Frey distinguishes between the older ceramic imitations of crested helmets, with pointed cap, and more recent ones, with round cap, ${ }^{678}$ more likely, however, the helmets with rounded crest are older. According to R. Peroni and A. Vanzetti, the helmets can be generally dated to prima età del ferro IIA, despite the helmets from Tarquinia Impiccato, pozzo grave 65 (Fig. 2.31.10; dated to prima età del ferro IIA/B) and Tarquinia Selciatello Sopra, pozzo grave 85 (Fig. 2. 31.11; dated to prima età del ferro IB/IIA). ${ }^{679}$

\begin{tabular}{|c|c|c|c|}
\hline No. & Find Site & No. & Find Site \\
\hline 51 & 'Italy' (private collection) & 74 & Veii, Quattro Fontanili, Pozzo grave CC 18-19B \\
\hline 52 & Chiusa Cima & 75 & Veii, Quattro Fontanili, Pozzo grave CC10 \\
\hline 53 & Cittá delle Pieve & 76 & Veii, Quattro Fontanili, Pozzo grave DD 19 \\
\hline 54 & Falerii & 77 & Veii, Quattro Fontanili, Pozzo grave M 9D \\
\hline 55 & Populonia & 78 & Veii, Quattro Fontanili, Pozzo grave NO 4-5 \\
\hline 56 & Sala Consilina, S. Antonio & 79 & Veii, Quattro Fontanili, Pozzo grave O6A \\
\hline 57 & San Giuliano (Barbarano Romano, VT) & 80 & Veii, Quattro Fontanili, Pozzo grave P 16 \\
\hline 58 & Tarquinia Impiccato, Pozzo grave 39 & 81 & Veii, Quattro Fontanili, Pozzo grave R 2-3 \\
\hline 59 & Tarquinia Impiccato, Pozzo grave 58 & 82 & Veii, Quattro Fontanili, Pozzo grave T 5 \\
\hline 60 & Tarquinia Impiccato, Pozzo grave 65 & 83 & Veii, Quattro Fontanili, Pozzo grave V 19 \\
\hline 61 & Tarquinia Impiccato, Pozzo grave 80 & 84 & Veii, Quattro Fontanili, Pozzo grave V 3B \\
\hline 62 & Tarquinia Monterozzi, Pozzo grave 66 & 85 & Veii, Quattro Fontanili, Pozzo grave W 19 \\
\hline 63 & Tarquinia Selciatello Sopra, Pozzo grave 76 & 86 & Veii, Quattro Fontanili, Pozzo grave X 4-5 \\
\hline 64 & Tarquinia Selciatello Sopra, Pozzo grave 85 & 87 & Veii, Quattro Fontanili, Pozzo grave Y 11A \\
\hline 65 & Tarquinia Selciatello Sopra, Pozzo grave 186 & 88 & Veii, Quattro Fontanili, Pozzo grave Y 11A \\
\hline 66 & Verucchio, Campo 'Lavataio', Pozzo grave 52 & 89 & Veii, Quattro Fontanili, Pozzo grave Z 10 \\
\hline 67 & Verucchio, Ripa Lavatoio, grave 52 & 90 & Veii, Quattro Fontanili, Pozzo grave Z 8 \\
\hline 68 & Veii, Quattro Fontanili, Pozzo grave AA13 & 91 & Veii, Quattro Fontanili, Pozzo grave Z 9 \\
\hline 69 & Veii, Quattro Fontanili, Pozzo grave AA19 & 92 & Veii, Valle la Fata, Pozzo grave 18 \\
\hline 70 & Veii, Quattro Fontanili, Pozzo grave AA19B & 93 & Veii, Valle la Fata, Pozzo grave 28 \\
\hline 71 & Veii, Quattro Fontanili, Pozzo grave AA7 & 94 & Veii, Valle la Fata, Pozzo grave 5 \\
\hline 72 & Veii, Quattro Fontanili, Pozzo grave AA8 & 95 & Veii, Valle la Fata, Pozzo grave 7 \\
\hline 73 & Veii, Quattro Fontanili, Pozzo grave BB16B & 96 & Veii, Valle la Fata, Pozzo grave 8 \\
\hline
\end{tabular}

Tab. 2.15 Early Iron Age Italian ceramic imitations of crested metal helmets. The numbers are those used in Fig. 2.26.

Iaia suggests an earlier date for the helmets from Tarquinia Monterozzi, grave 66 and Tarquinia Impiccato, graves 37, 39 and 65 (prima età del ferro IB1). ${ }^{600} \mathrm{He}$ associates the helmets from Tarquinia Selciatello Sopra, graves 85 and 186 and Tarquinia Impiccato, graves 58 and 80 with prima età del ferro $1 \mathrm{~B}-2 \mathrm{~A} 1$. The ceramic helmets from Veio are associated by $\mathrm{J}$. Toms to phase IB (Valle la Fata, tomba 8), IC (Quattro Fontanili graves AA19A, AA19B, V3B), phase IC-IIA (Quattro Fontanili grave BB16B, Valle la Fata, tomba 5) and phase IIA (CC18-19B). ${ }^{681}$ Some ceramic helmets from Veii, associated with Veii I, appear to resemble most closely the crested helmets of Type Biebesheim. The two most similar are the helmet from Valle la Fata,

\footnotetext{
677 Iaia 2013b, 83.

678 Frey 1990, 225.

679 Peroni - Vanzetti 2005.

680 Iaia 2005, 112.

681 Toms 1986.
} 
grave 28 (Fig. 2.31.5) and the one from Quattro Fontanili, grave no. 4-5 (Fig. 2.31.2). ${ }^{682}$ However, they also already demonstrate, as a consequence of the centrally pointed cap and the high crest, a close relationship to the later Italian crested helmets. Also, the connection between crested helmets of Type Biebesheim and the ceramic models of crested helmets from Tarquinia and Veii, as described by v. Hase, can be questioned since the latter helmets were deposited, according to dendro-chronology, around $900-850 \mathrm{BC}$, and were most likely specifically manufactured for the burial. ${ }^{683}$ It is the same for the ceramic helmet from Tarquinia, Monterozzi, grave 66 (Fig. 2.31.15): the similarity with crested helmets of Type Bernières d'Ailly is striking but the high crest and the pointed cap show a closer relationship to the Italian helmets than to older western equivalents. Nevertheless, the close relationship to older forms suggests that there was knowledge of earlier Bronze Age helmets, and that their influence on the manufacture of Italian crested helmets made of bronze, especially in the adoption of their 'archaic' style and shape, must have been especially meaningful (see below).

A significant change in the construction of the different types of bronze crested helmets is marked by the form of the rivets. They generally grew in size and with increasing decorative purpose. But whilst they served a functional purpose on Bronze Age helmets, they are reduced to a purely decorative element on the Italian crested helmets, providing a clear typo-chronological order of development. On the Italian crested helmets, the earlier more conspicuous rivets, which functioned to hold together the two parts of the helmet, are replaced by flat-headed, inconspicuous rivets, in combination with an additional rectangular bronze sheet. ${ }^{684}$

The necropolis from Veii and Tarquinia contained the highest number of both bronze crested helmets and their ceramic models. Single metal helmets considered imports are known from Delphi, Olympia, Hallstatt, Škocjan and Podolia/Zavadintsy (Ukraine). ${ }^{685}$ A number of other unprovenanced helmets can also be connected to central Italian workshops, close to the two necropoli. The helmets found in Delphi and Olympia are interpreted as donations during the Greek colonisation of southern Italy in the $8^{\text {th }}$ century BC ${ }^{686}$ Find circumstances and find date of the helmet from Podolia/Zavadintsy are unknown. Coutil notes that the helmet was part of the Poulaski collection and cites a 'Congrés de Moscou T. II, 1892, 348'. ${ }^{687}$ Today, the helmet is stored at the Musée Masséna in Nice, France. The flat, hemispherical cap of the crested helmet, which belonged to the Guttmann collection and was sold at Hermann Historica in $2005^{688}$ was made from a single metal sheet and has a separate crest, attached by means of rivets. The crest is decorated with large bosses, which are randomly distributed. The helmet lacks any counterpart in both construction and decoration, and its authenticity must be questioned.

Related finds of Italian crested helmets, occurring only as fragments, are also known from Škocjan. ${ }^{689}$ The fragments appear to belong to at least three helmets; two of them show complete bird depictions, without legs and with triangular tails, while the third helmet depicts bird heads with a central sun disc. It is unclear if a further fragment from the top of a crest belongs to the latter, third helmet or to a further fourth helmet.

Figurines with crested helmets have been dated to the $6^{\text {th }}-7^{\text {th }}$ century $\mathrm{BC},{ }^{690}$ suggesting the continued use, and possible manufacture, of crested helmets for both foot soldiers and horsemen. ${ }^{691}$ The distribution of the small helmeted figurines is more to the north than that of the main distribution area of the actual metal helmets, and reaches as far as Styria, where we know horsemen with crested helmets from the Strettweger Kultwagen.

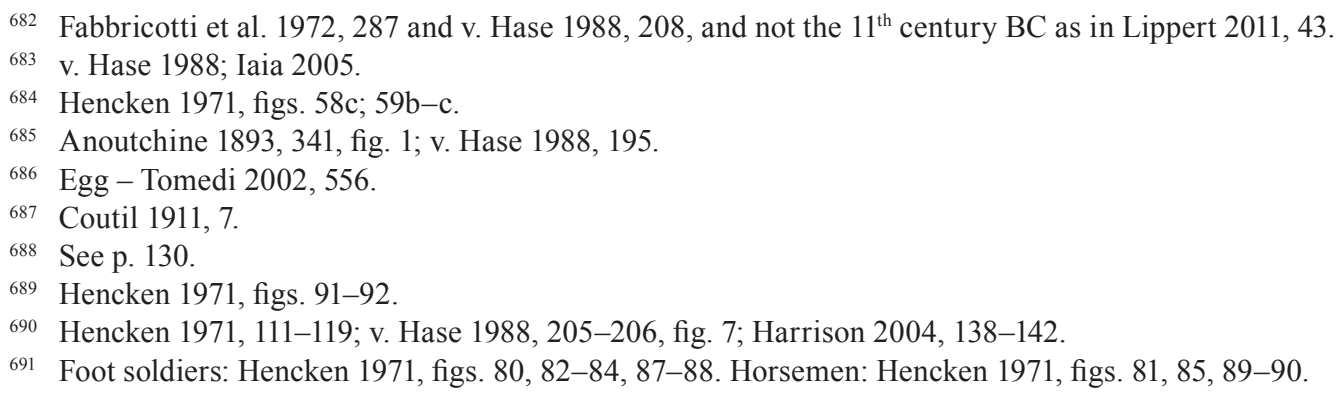




\subsection{Horned Helmets}

Horned helmets do not form a geographically discreet group. They cannot be associated with the western European helmets with crest and bivalve cap, nor with the eastern European cap helmets, and therefore do represent a discreet typological group. So far, only two horned metal helmets are known (cat. no. 121). Depictions and figurines of Bronze Age warriors or deities with horned helmets are numerous, indicating both a wide distribution and common use of such helmets, ranging from Scandinavia to the Iberian Peninsula, and as far east as the eastern Mediterranean. This distribution includes a range of depictions upon different types of media, including upon exposed natural stone surfaces (Scandinavia), on stelae (Iberian Peninsula, Sippar or Hattuša), menhirs (Corsica; unfortunately with no horns preserved, Fig. 2.32), statuettes (Grevensvænge, Fogdarp, Sardinia, Enkomi, Ugarit or Luristan), wall decoration (the sea people on the reliefs from Luxor, Abydos or Medinet Habu, faïence from the Mycenaean shaft grave III, and the Mycenaean Warrior Vase, seal stone from Thebes), as well as in much later depictions of helmets with horns. ${ }^{62}$ Such a broad spectrum over such a large area demonstrates that

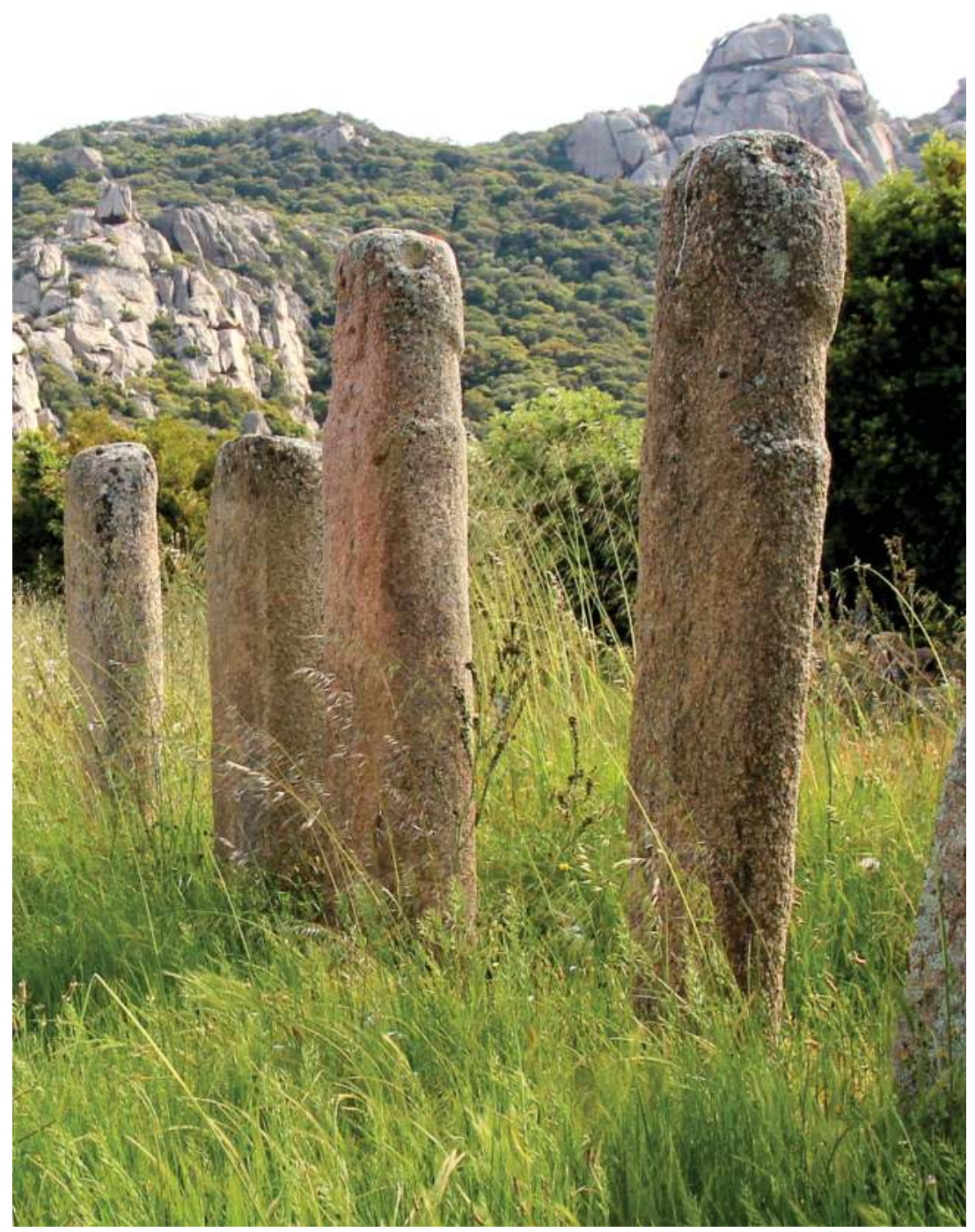

Fig. 2.32 Menhirs with unpreserved, presumably horned headgear from Cauria, Corsica (photo: H. and J. Mödlinger).

${ }^{692}$ E.g. Anatolia (?), see: Schauer 1983, 185. 


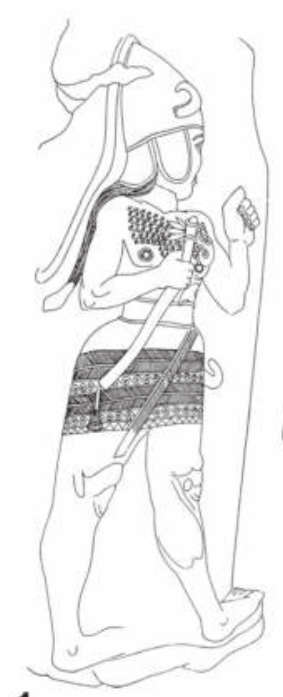

1
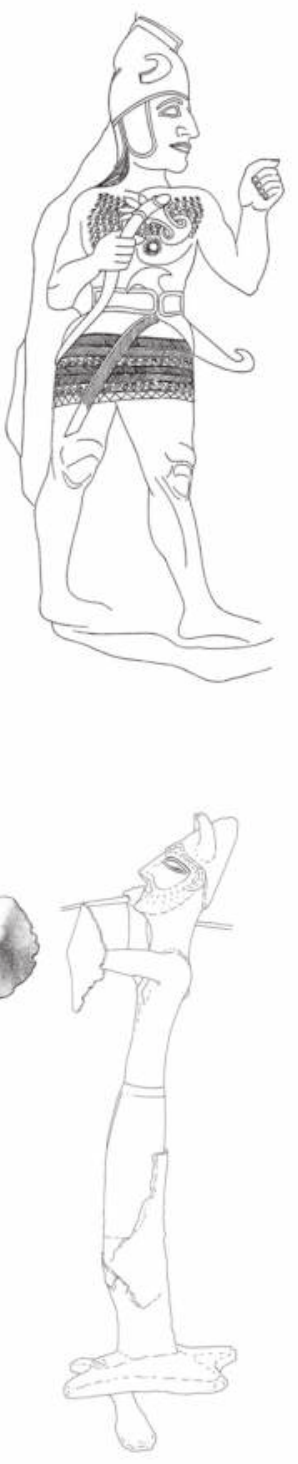

2
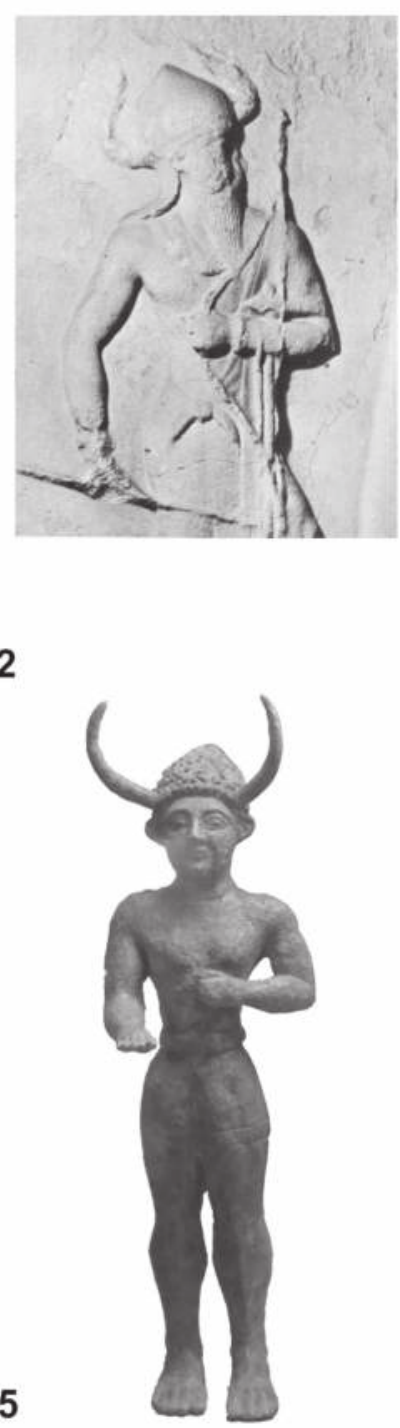

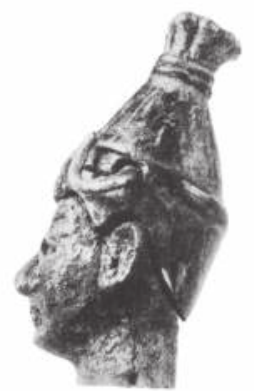

3

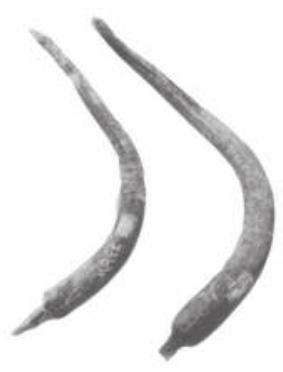

6

Fig. 2.33 Depictions, figurines and models of horned helmets from the Aegean and Near East: 1. Hattuša/ Boğazkale, Turkey. Relief (Egg - Tomedi 2002, fig. 14.2); 2. Sippar/Tell Abū Habbah, Iraq. Stele of Naramsin (Borchhardt 1972, pl. 12.1); 3. Ugarit/Ra's Schamra, Syria. Head of a Ba'al statuette (Borchhardt 1972, pl. 12.2); 4. Enkomi, Greece (Seeden 1980, pl. 112); 5. Enkomi, Greece (Càssola Guida 1973, pl. XXXVII.1); 6. Dendra, Greece (tholos grave). The lead horns were found at the feet of the deceased under his weapons. The tholos grave is dated to LH IIIB (Borchhardt 1972, 40, pl. 15.3) (not to scale).

horned helmets were widely distributed during the Bronze Age and early Iron Age. ${ }^{693}$ The oldest depictions of horned helmets derive from the Near East (Fig. 2.33): Depictions are known from Sippar/Tell Abū Habbah, Iraq (stele of Naramsin; c. 2400-2300 BC), Ugarit/Ra's Schamra, Syria (head of a Ba'al figurine; 2000-1800 BC) Hattuša/Boğazköy, Turkey (relief; $14^{\text {th }}$ century $\mathrm{BC}$ ) and the Warrior Vase from Mycenae $\left(12^{\text {th }}\right.$ century BC). Further figurines with horned headgear are known from Enkomi. ${ }^{694}$ From a Tholos grave at Dendra there are horns made of lead, which were deposited at the feet of the deceased. ${ }^{695}$ The horns might have been part of a headgear.

\footnotetext{
${ }_{693}$ For references, see: Lilliu 1966; Borchhardt 1972; Harrison 2004; Kristiansen - Larsson 2005; Brandherm 2007; Brandherm 2008; Cesari - Leandri 2010; Brandherm 2011; Gonzalez 2012.

694 Càssola Guida 1973, pl. XXXVII.1; Seeden 1980, pl. 112.

695 Borchhardt 1972, 40, pl. 15.3.
} 

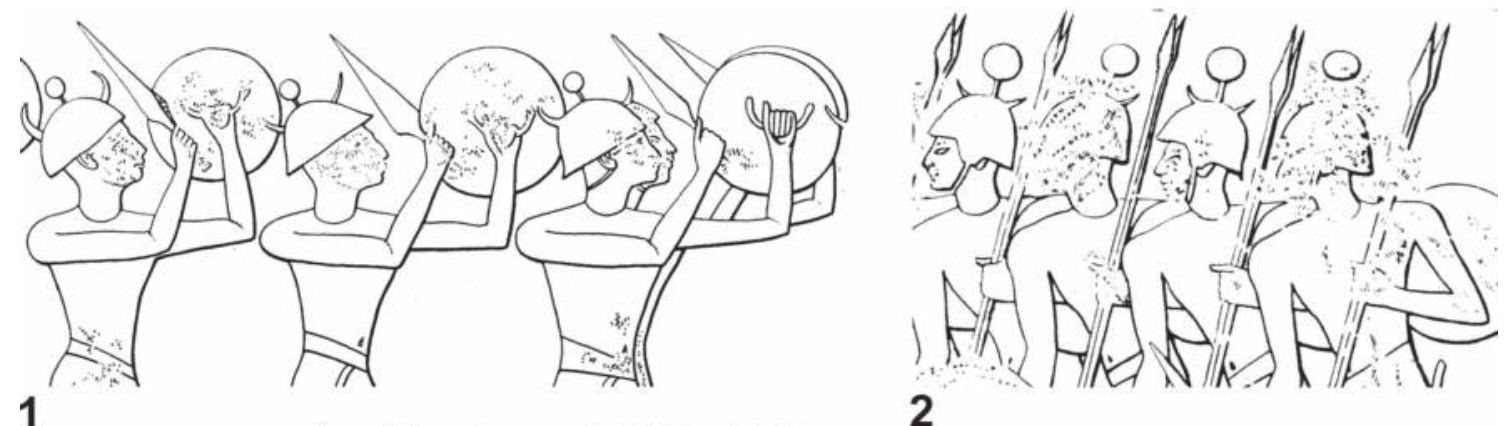

1

2

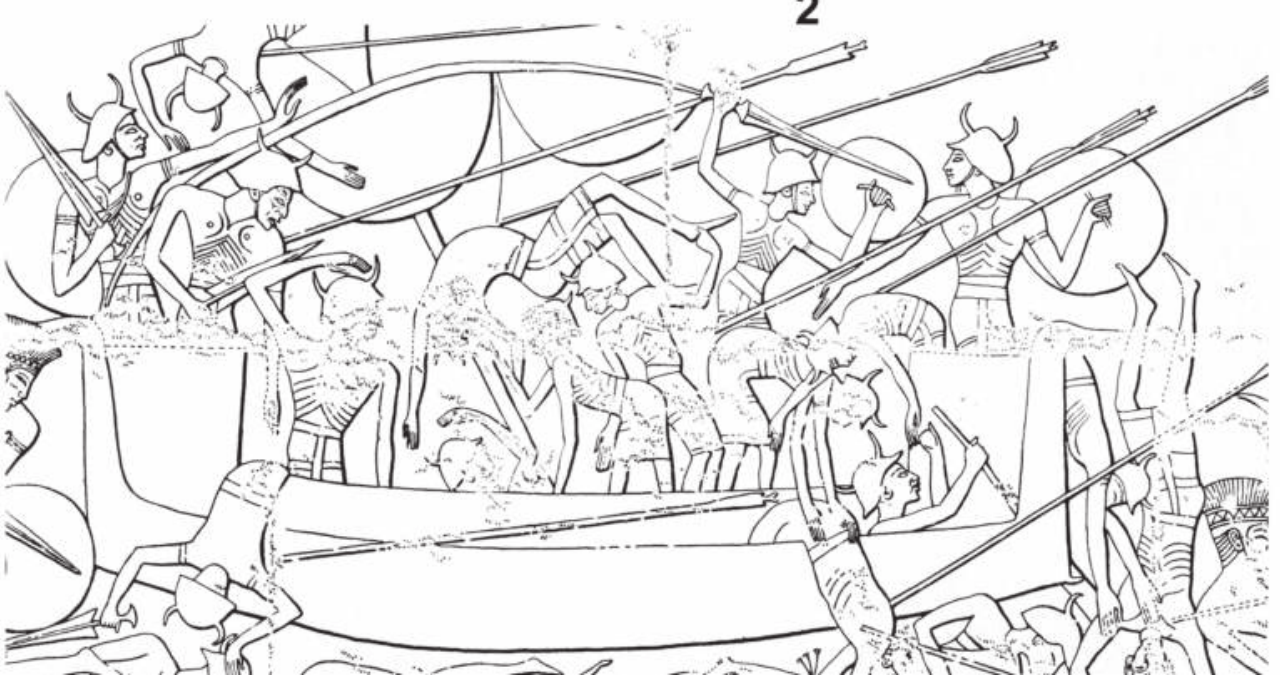

3

Fig. 2.34 Horned helmets worn by the sea people on the temple reliefs of Medinet Habu, Egypt: 1. Attacking mercenaries of Ramses III (Borchhardt 1972, pl. 13.2); 2. Medinet Habu, Egypt. Temple relief: the guards of Ramses III (Borchhardt 1972, pl. 14.3); 3. Attacking sea people (Borchhardt 1972, pl. 13.1) (not to scale).

The actual function of horned helmets, or the meaning of the horns themselves, is unclear, and therefore it is necessary to consider individually the full range of types and their depiction. Despite religious or ritual associations, we have to assume their practical use as defensive armour. As depicted on the reliefs from Luxor, Abydos and Medinet Habu, the sea people clearly used their helmets in battle (Fig. 2.34 and 2.35). Sherden warriors, depicted on the Medinet Habu frieze, wear a yellow helmet, with clear red horizontal and vertical lines, perhaps indicating a base organic netting. The horns are light or pale blue, suggesting a different material than the helmet's cap ${ }^{696}$ Horned helmets with a central 'knob' and without Ausschnitt of the cap or ear protection were used by Egyptian mercenaries. No further distinction can be made based on the helmets alone if the wearer was an Egyptian mercenary or an enemy.

In comparison to their large number, and the diverse range of sources used in the depiction of horned helmets, the number of actual preserved examples is extremely small: the two bronze helmets from Viksø are the only metal helmets with horns so far recovered (Tab. 2.7; Fig. 2.36.1). ${ }^{697}$ It is still not clear where the helmets were produced or assembled, since the helmets combine both Nordic and Urnfield features. The decoration is specifically drawn from Urnfield traditions, whereas most of the other characteristics belong to the Nordic Bronze Age tradition. ${ }^{698}$ Also, the craftsmen must have been familiar with the construction of two-piece western European crested helmets, though devising a different means for joining the two halves of the cap. Each helmet was made of two bronze sheets riveted together and additionally fixed by a massive, cast fitting on the top, forming a raised comb with a hooked beak, indicating a bird of prey. The lateral arms of the crest each cover a slit in the top of one of the two bronze sheets of

\footnotetext{
${ }^{696}$ Photograph: e.g. D’Amato - Salimbeti 2015, 16.

${ }_{697}$ Most recently Vandkilde 2013.

698 Vandkilde 2013, 171-173.
} 
Egyptian mercenaries

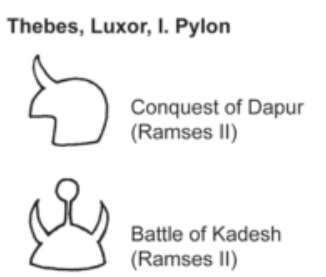

Abydos; Abu Simbel

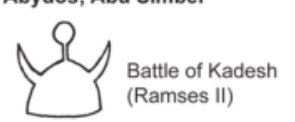

King guards

Medinet Habu

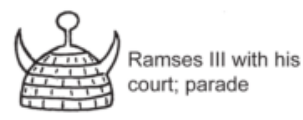

Medinet Habu
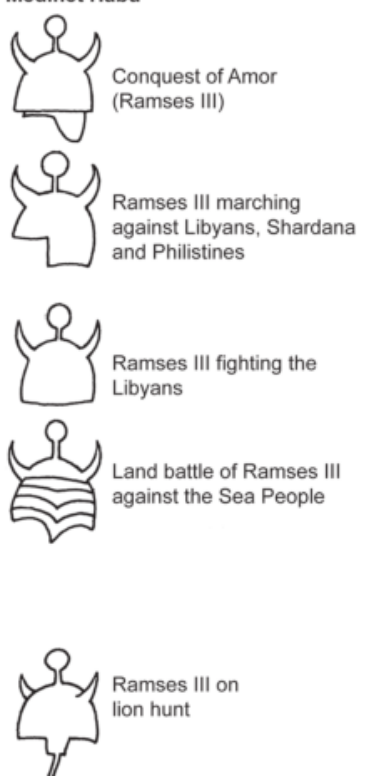

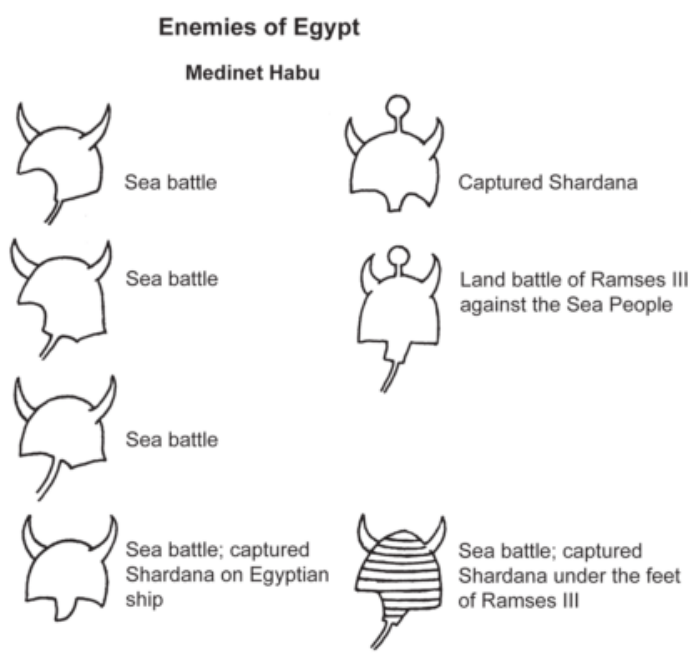

Fig. 2.35 Egyptian depictions of horned helmets of the Shardana (after Borchhardt 1972, 113-115) (not to scale).

the cap. Additionally, in the centre of the helmet the cast-on fitting consists of vertical bronze sheet 'arms', which touch the helmet. On each of these, one small cylindrical mounting was placed to enable the additional application of plumes, which were fixed with rivets passing through the holes of the cylindrical mounting. Feathers, hair or some other material used in the creation of these plumes could be fixed into the deep groove running along the middle of the crest. On both sides of the beak there are large bulging eyes with eyebrows, imitating a human face. Both eyebrows and eyes are detachable and fixed by means of loops on the inside of the helmet. Finally, the horns (resembling bronze lurs, which also occur in pairs), were riveted onto each helmet with fixed circular fittings. The horns are hollow cast, which were then riveted into cast bronze mountings which then were riveted onto the cap. There are two rivet holes on each side of the helmet near the rim where a chin strap or cheek plates could have been attached. The cap itself is decorated with bosses of different size. Parallel to the rim, a line of pellets is visible, ending in s-shaped figures of bird heads, confronting each other (Vogelsonnenbarke).

It remains unclear if the general purpose of the horns was to intimidate an opponent, for the identification of status or were perhaps functional, offering a greater degree of protection than those helmets without horns. Indeed, the function and use of the Viksø helmets is still a matter of debate; most recently, H. Vandkilde reviewed in detail previous theories and hypothesis, noting that an association with warfare has not yet gained the same degree of support as has ritual or religious interpretations of their function. ${ }^{699}$ Despite this, she proposes that the function of the helmets might be found both in the field of warfare and sea travel, as well as in the ritual practices of religious beliefs. The occurrence of the helmets in pairs might point to the so-called twin gods. ${ }^{700}$ Without any doubt, these so far unique helmets must certainly bear a rich cultural biography, irrespective of whether their function was a peaceful one or not.

The $32 \mathrm{~cm}$ long bronze horn from Grevinge, Denmark, which parallels the horns of the Viksø helmets, might originally have been attached to a helmet (Fig. 2.36.4). The absence of further helmet finds might be attributed to the more common use of organic materials in their construction, not only for the horns but for the complete helmet. Unfortunately, due to the nature of the depictions, they rarely permit a clear identification of the material used in their

\footnotetext{
699 Vandkilde 2013.
}

700 Kristiansen 2006. 

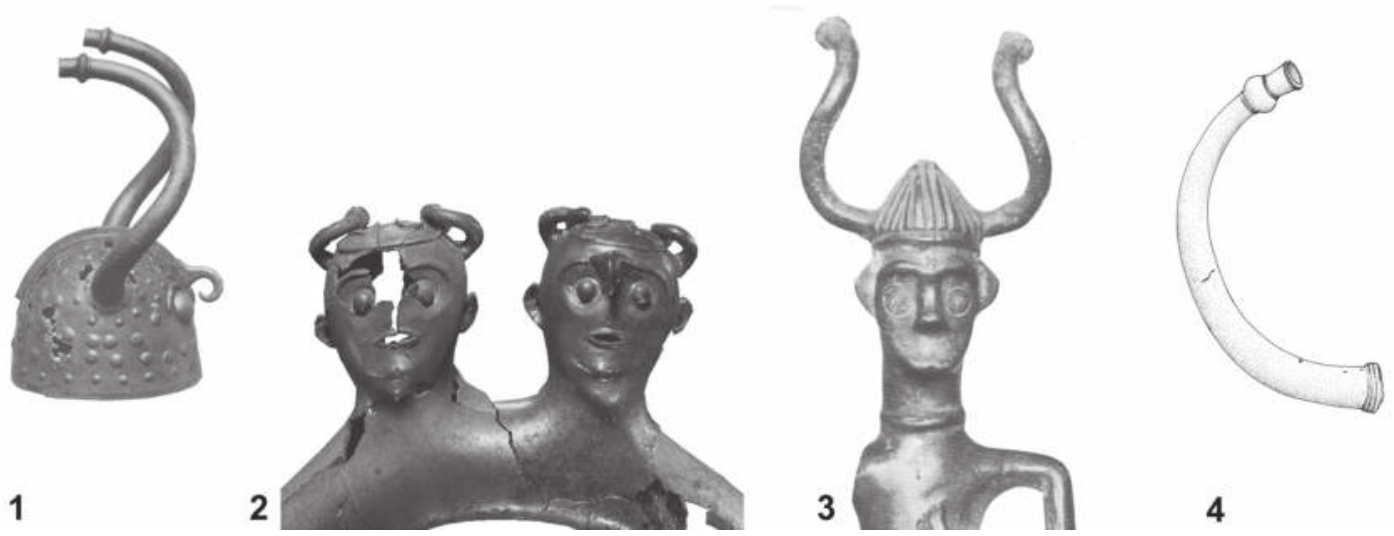

Fig. 2.36 Horned helmets from the Nordic Bronze Age: 1. Viksø, Denmark (Borchhardt 1972, pl.15.1); 2. Fogtdarp, Sweden (after Vandkilde 2013, fig. 3); 3. Grevensvænge, Denmark (Borchhardt 1972, pl. 14.14); 4. Grevinge, Denmark (credits to the Nationalmuseet/The National Museum of Denmark) (to better compare the size and details of the horns, the drawings are not to scale).

construction. Other reasons for the scarce recovery of Nordic Bronze Age metal helmets with horns might be as a consequence of specific depositional practices or due to recycling strategies. Metal depictions of these horned helmets are further known from Grevensvænge, Denmark and Fogdarp, Sweden (Fig. 2.36.2-3) (see also below).

From Sardinia more than 1000 bronze figurines are known, of which some $70 \%$ have been published. We distinguish older 'Uta-Abini' figurines and such of the more recent 'Mediterranean' group. ${ }^{701}$ The unpublished examples have been described by G. Lilliu as being of 'no artistic and low archaeological value' ${ }^{702}$ [sic]. From the more recent 'Mediterranean' group, no horned headgear is known.

More than half of the 200 anthropomorphic Bronze Age 'Uta-Abini' figurines depict warriors and archers, dated to the $11^{\text {th }}-10^{\text {th }}$ century BC. ${ }^{703}$ The warriors are usually equipped with sword and shield; only one carries a spear. The figurines were found in fortified stone-built domestic structures known as nuraghe, in sacred springs and in sanctuaries. The horns of the headgear worn by some warrior figurines can vary significantly in size. With the exception of the so-called 'warrior-demons' (figurines with four arms, four 'eyes', four to six swords, and two shields), the warrior figurines have proportions that are naturalistic, and therefore we might assume that it is the same for the related horned headgear (Fig. 2.37 and 2.38). Figurines of bulls with complete horns show the wide variety of different sized horns, ${ }^{704}$ which were most likely used for the composition of the horned headgear of the warriors. However, it is questionable if the oversized horns of the bull figurines are depicted in real scale compared to the size of the body of the bulls (Fig. 2.38.20, 25). We might exclude the possibility of their being depictions of aurochs, since these are not known from Sardinia.

Only 14 of the c. 50 'Uta-Abini' figurines with horned headgear have large, long horns with pointed tips, of which just one is an archer. Many of the figures generally show broken off horns, so we cannot identify if they once had long, slightly curved or small and short, strongly forward curved horns. Only about one in every four of the archers has headgear without horns. The horns of their headgear is small, usually pointing forwards and placed on an organic cap with a small, two-pointed central crest. Only a few archers (Fig. 2.37.12) bear long, forward pointed curved horns on their headgear. One figure - of which only the head now survives shows between the upwards bent, small horns, a disc or round object, similar to that worn by the Shardana as depicted in the relief of Medinet Habu (Fig. 2.37.17).

\footnotetext{
01 Gonzales 2012.

702 Lilliu 1966, 63.

703 Gonzales 2012, 86, 89, 100.

704 Lilliu 1966, 396-417.
} 

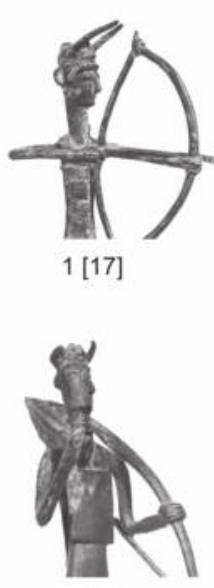

7 [11]

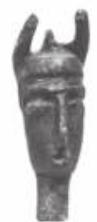

$13[37]$
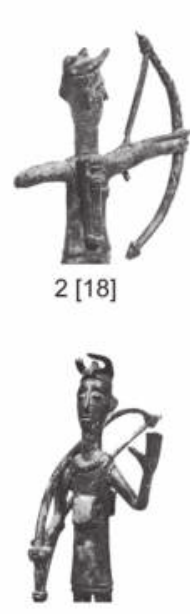

$8[26]$

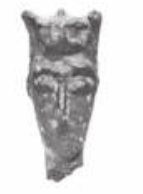

$14[38]$

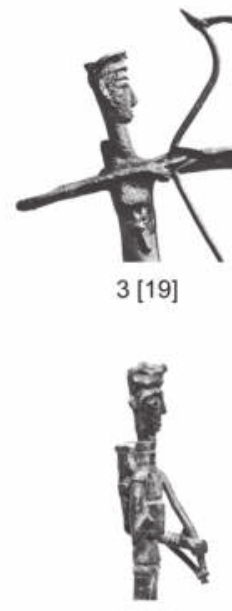

9 [30]

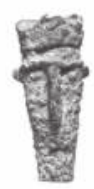

$15[39]$
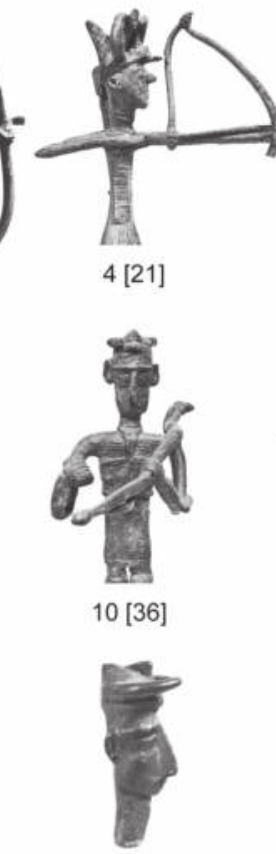

$16[40]$
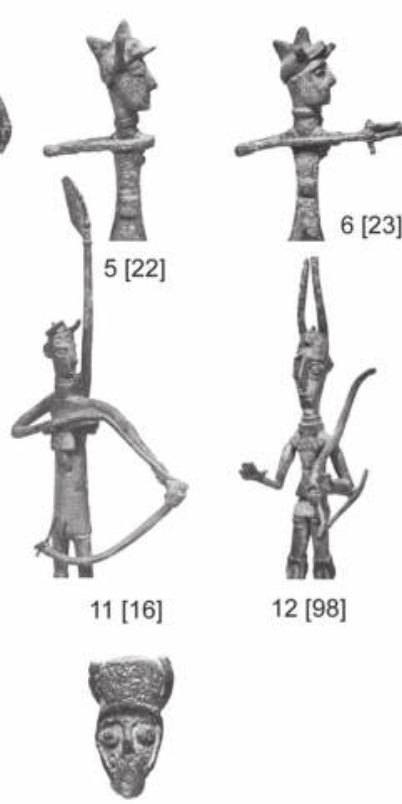

$17[114]$

Fig. 2.37 Horned headgear of Sardinian bronze figurines: 1-12. Archers; 13-17. Single fragments of heads with horned headgear. Note the single cases of upwards bent short horns (no. 4) and long, slightly curved horns (no. 12) (after Lilliu 1966; his catalogue numbers are placed in [brackets]) (not to scale).

The warriors wearing horned headgear generally do not show different combinations of arms and armour than the ones with other form of head protection, with the only exception being the so-called warrior-demons or over-equipped warriors (Fig. 2.38.17, 21-24). The headgear with long, slightly curved horns of a warrior and a warrior-demon (Fig. 2.38.23-24) as well as two further warriors wearing a headgear with parallel horns touching each other (Fig. 2.38.18-19) are notable for resembling the horn from Grevinge, the helmets from Viksø, and the figurines from Grevensvænge, Denmark, and Fogdarp, Sweden (horned helmets of two men's heads on a horse collar), indicating a close connection (Fig. 2.39). All have cutaway tips which were substituted by a round ring, bowl or ball, sometimes with ribs immediately beneath it, symbolising the organic wrapping used to fix it. ${ }^{705}$ The Fogdarp heads are, at just $4 \times 3.5 \mathrm{~cm}$ in size, particularly small. There are also figurines from Predio Canòpolo-Perfugas and Olmedo, Sardinia, of bulls with large horns, where the tips were cut off and substituted by a round object (Fig. 2.38.20, 25). These specific types of terminals are absent in the depiction of horns on Iberian stelae and in Nordic rock art. However, it is known on the Viksø helmets, the Grevinge horn, and the figurines from Grevensvænge and Fogdarp. The similarities in form and shape noted by Borchhardt with the stelae from Magacela (Fig. 2.40.9) cannot be confirmed. ${ }^{706}$ Also, the distribution area of horned headgear does not overlap with that of Type Herzsprung shields. ${ }^{707}$

Unlike the preserved Nordic Bronze Age horns and figurines, the horned headgear depicted in Scandinavian rock art are all small, and usually exhibit slightly curved horns or significantly curved ones with tips pointing towards each other (Fig. 2.39). The head is rarely recognisable, since the horns usually exit directly from the neck. Not highly surprising, Nordic rock art figures with horned headgear are male (ithyphallic; no indication of breasts) and are furnished with weapons, such as swords, axes and spears.

705 Larsson 1975, 176-178, figs. 5-7.

706 Borchhardt 1972, 139, fig. 14a; see Harrison 2004, no. C48.

707 For the difference between U-notched Herzsprung shields and related but later V-notched Mediterranean shields, see Uckelmann 2012, 63-68. 


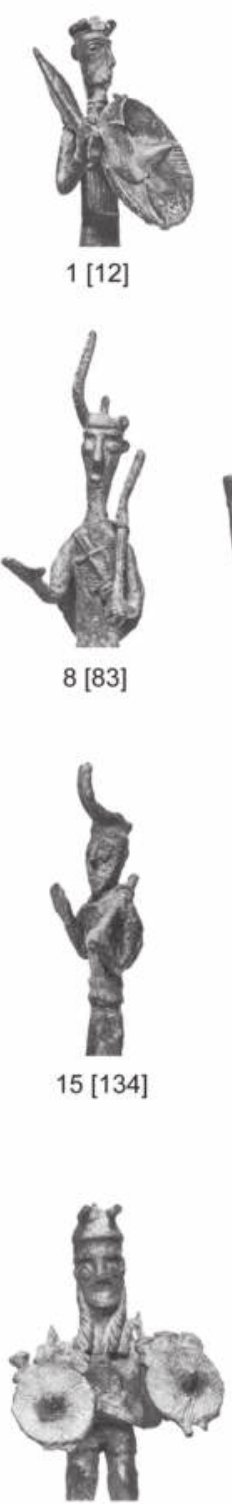

$21[106]$
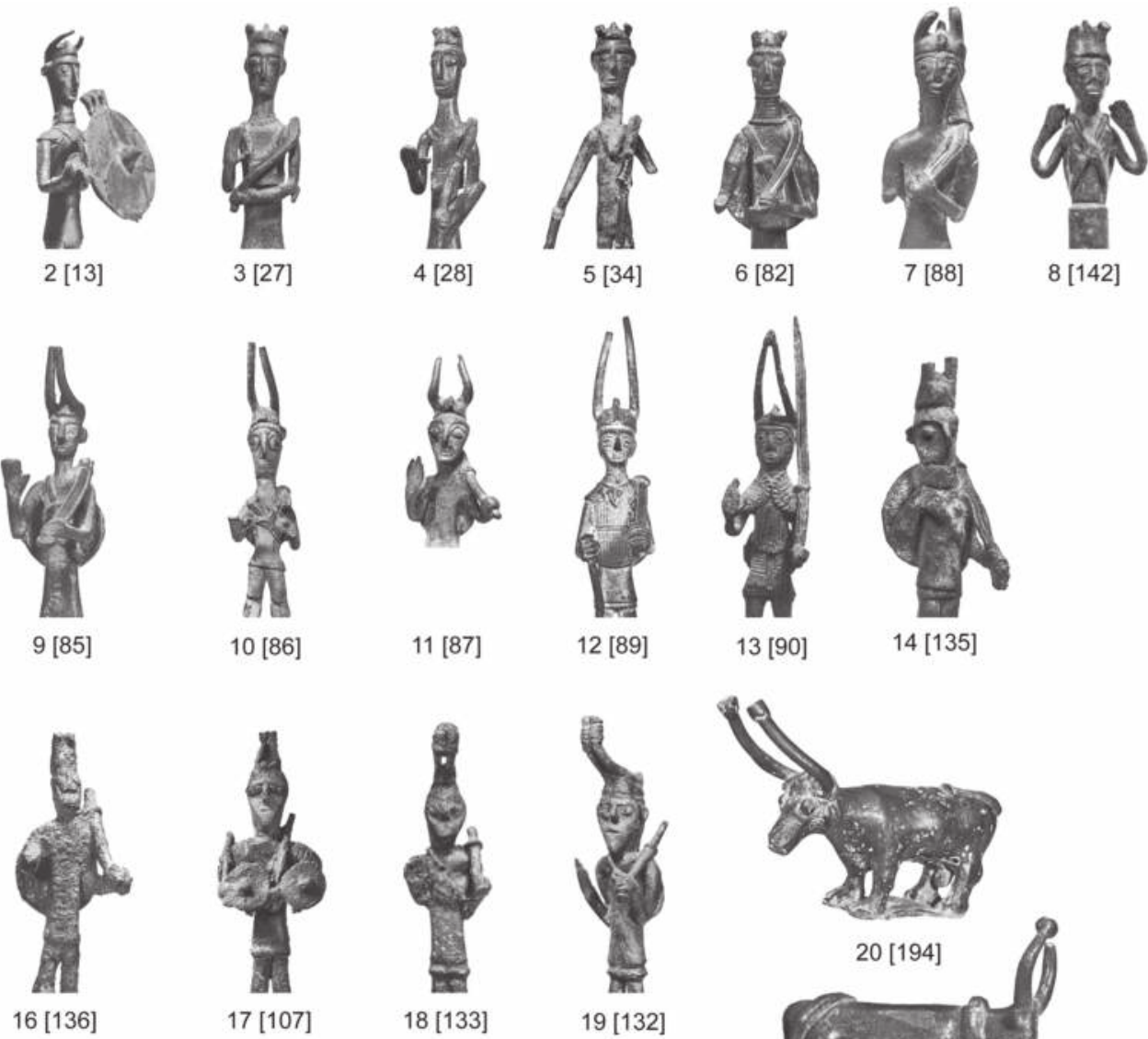

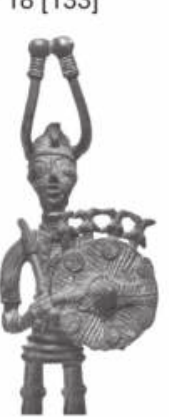

19 [132]

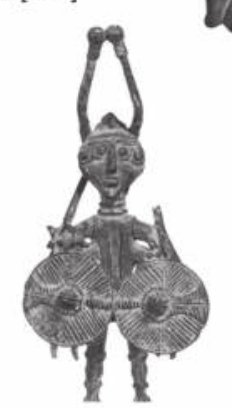

$24[104]$

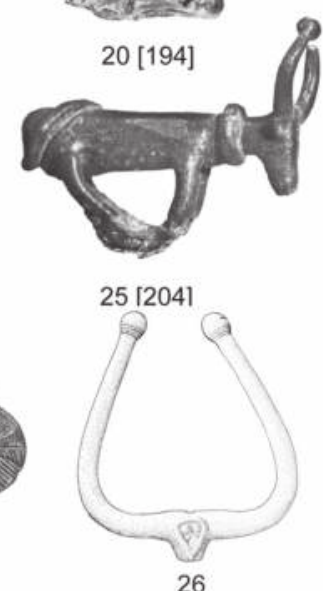

23 [97]

Fig. 2.38 Horned headgear of Sardinian bronze figurines: 1-8. Warriors with short, small and forward bent horns on the headgear; 9-14. Warriors with long, slightly curved horns on the headgear; 15-16, 18-19. Warriors with long, slightly curved horns touching each other along the whole length; 17, 21-24. Over-equipped warriors and socalled warrior demons with different sized horns on the headgear; 20, 25. Two bulls; 26. Separate horns from Tergu, loc. Santa Maria, collezione Vallero-Usai (original height c. $25 \mathrm{~cm}$ ). Note the wrapping of the horns at the tip and the 'ball' placed on it on both human figures and bulls (nos. 18-20; 23-26) (after Lilliu 1966; his catalogue numbers are placed in [brackets]) (not to scale).

Spears are usually held above the horned headgear in a clearly aggressive way. Swords are, despite one depiction (Fig. 2.39.7), always shown sheathed in their scabbard. Some of the figures seem to be walking (Fig. 2.39.1-2), while others appear to be ready to fight, with the left hand up or on the side and usually the right on the scabbard (Fig. 2.39.3-4; this motif can be found also on the Iberian stelae; see Fig. 2.40.1). Spears are often depicted as held in the left hand (Fig. 2.39.8-10). Since the sword hand usually is the right one, we might think of them not as depicted from the front but from the back or a 'mirrored' view, but if the figure is depicted from the back it might explain their larger size, being in the foreground, than that of the opponent, which 


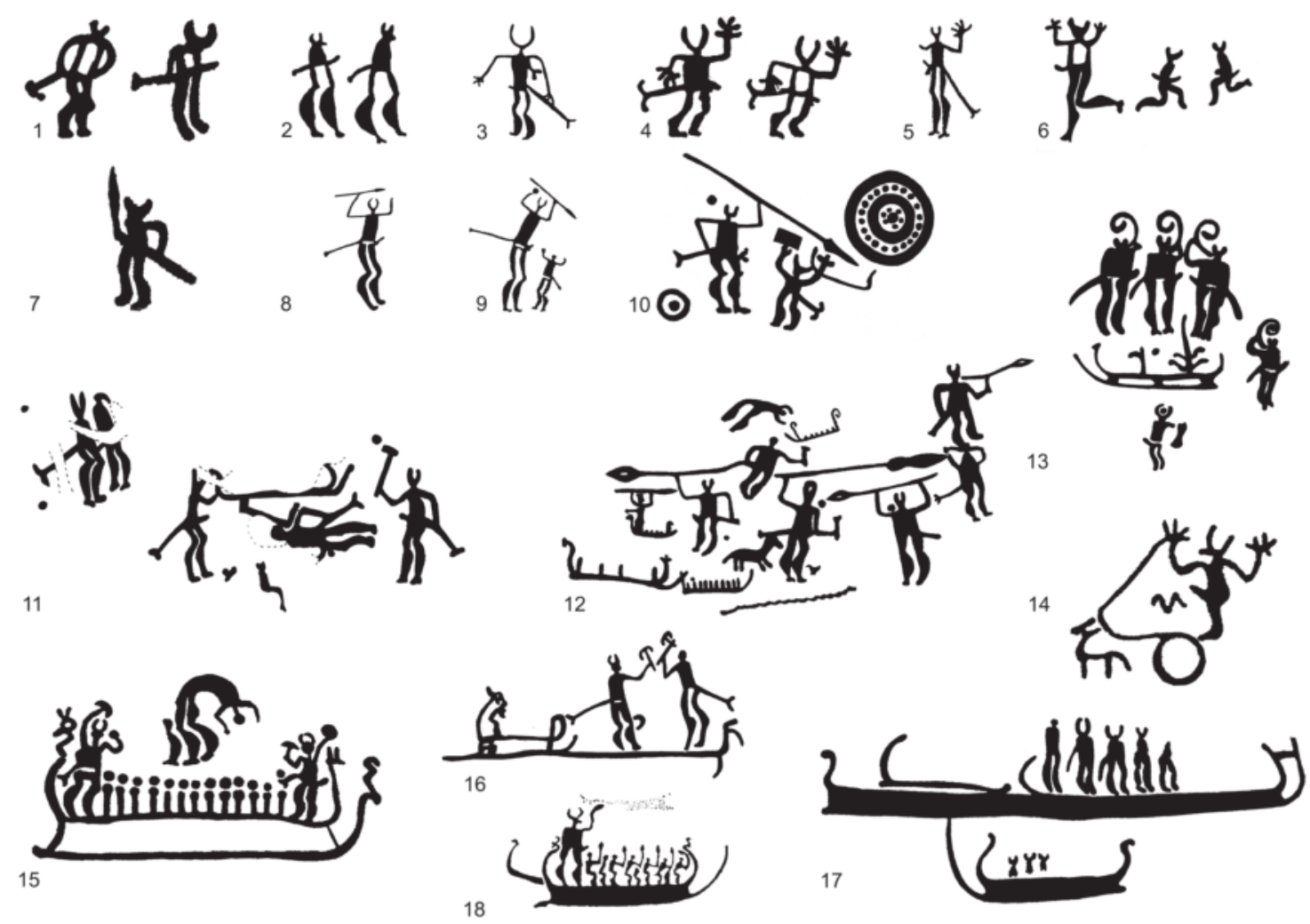

Fig. 2.39 Warriors with horned headgear on Scandinavian rock art: 1. Hede (Kville); 2. Borge (Ostfold); 3. Bottna (Bohuslän); 4. Slänge (Tanum); 5. Österöd (Kville); 6. Smörsten (Tanum); 7. Hede (Kville); 8. Karlsund (Kville); 9. Karlsund (Kville); 10. Hede (Kville); 11. Tuvene (Tanum); 12. Bro Utmark (Tanum); 13. Kalleby (Tanum); 14. Vitlycke (Tanum); 15. Sotetorp (Tanum); 16. Varp (Skee); 17. Kalleby (Tanum); 18. Lövåsen (Tanum).

might then be further away, in the background. On ships, the figures with horned headgear are either standing (Fig. 2.39.17), threatening (each other?) aggressively (Fig. 2.39.15), or fighting (Fig. 2.39.16, with axes). A coup de grâce seems to be shown, involving an axe, in front of a ship on a depiction from Tuvene, Tanum (Fig. 2.39.11). Men with horned headgear are also depicted dancing and running (Fig. 2.39.6), with lures (Fig. 2.39.13), or on a two-wheeled chariot with a tiny horse or goat in the front (Fig. 2.39.14). Between the chariot and the man's penis a snake is depicted. Nevertheless, the main motif of men with horned headgear is embedded within a fighting or war scene.

Horned headgear on Iberian stelae only occurs on the stelae of group IIc in the scheme of V. Pingel, which is characterised by the introduction of human figures (Fig. 2.40) ${ }^{708}$ The stelae of group IIc are considered the final stage in the development of these Iberian warrior stelae. ${ }^{709}$ The absolute chronology of the stelae is still a matter of debate. ${ }^{710}$ Nevertheless, the depicted swords, fibulae and helmets give indications for their dating. The depicted Type Herzsprung shields cannot be used as an argument for the general dating of the stelae to the $9^{\text {th }}-8^{\text {th }}$ century $\mathrm{BC}$, since radiocarbon dates from Irish shields and moulds for their manufacture point to a significantly older date. ${ }^{711}$ Most of the swords represented on stelae alongside figures with horned headgear have a slender parallel-sided blade and only in some cases do they have a leaf-shaped blade. ${ }^{712}$ The substitution of leaf-shaped swords with Type Huelva swords, which have parallel-

\footnotetext{
708 Pingel 1974; Pingel 1993.

709 Pingel 1974, 14; Almagro Gorbea 1977, 188; Brandherm 2008, 482.

710 Burgess 1991, 39; Celestino Pérez 2001; Harrison 2004, 13-16; Brandherm 2008; Díaz-Guardamino 2012, 389 416; Mederos Martín 2012.

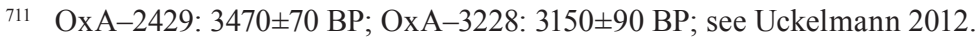

712 Brandherm 2008, 482.
} 
sided blades, by the end of the second millennium $\mathrm{BC}^{713}$ indicates that the horned headgear depicted on the stelae appeared no later than the end of the $11^{\text {th }}$ century BC. Elbow fibulae can be regularly associated with the depiction of figures with horned headgear. ${ }^{714}$ The first elbow fibulae appeared around the late $11^{\text {th }} /$ early $10^{\text {th }}$ century BC. ${ }^{715}$ Crested helmets with rounder cap are depicted on several stelae from group IIc and some earlier stelae, ${ }^{716}$ while helmets with a more pointed cap (Type Bernières d'Ailly) ${ }^{717}$ are depicted only on stelae belonging to group IIc. ${ }^{718}$ According to the iconographic development of the Iberian stelae, crested helmets were substituted by horned helmets or headgear at the end of the $11^{\text {th }}$ century BC. ${ }^{719}$ The horned headgear then might have been in use until the $8^{\text {th }}$ century $\mathrm{BC} .^{720}$

Taking a closer look at the depicted human figures with horned headgear on the Iberian stelae ${ }^{721}$ we note that in six cases horns (partly with a second twist) exit horizontally/with a c. $90^{\circ}$ angle, directly from the head - which occurs alongside an increasingly geometric depiction of the figure as a whole (Fig. 2.40.11-16) - and in another eight or nine cases almost horizontally, showing also a second twist on the tip (Fig. 2.40.7-10; two figures on the stelae from Cobeza del Buey IV and from Orellana; ${ }^{722}$ potentially also the stelae from Castuera I). These characteristics are also known from the aurochs or ancient Iberian cattle races as the Cachena, Sayaguesa or Maronesa, potentially indicating the depiction of horns of local origin. Five figures have smaller, slightly curved horns (Fig. 2.40.1, 5, 6) while three figures have short, straight horns (Fig. 2.40.2-4). No helmet cap is visible, if we do not want to assume that it was not protruding from the tiny head. Two stelae from Olivenza and El Viso I (Fig. 2.40.3, 5) show oval 'ears' below the horns. Both figures show the largest number of associated objects depicted with the human figure (including wagon, bow, shield, fibula, earrings, sword, spear, and comb). Another stelae, from El Viso IV (Fig. 2.40.15), might indicate the use of horns still attached to part of the bull's cranium, since the base of the horns as found on the bull's head is visible. Generally, the horns depicted on Iberian stelae do not closely resemble the Sardinian ones, which are usually much smaller (potentially referencing something other than bovine horns!) and, also if longer (see below), are just slightly curved, never pointing sideways or show a second twist. The different groups of headgear are not associated with any specific combination of other equipment. We can only note that the two figures with horned headgear and 'ears' show the highest number or objects around them.

We might identify two main types of horned headgear in Sardinia and the Nordic Bronze Age: a higher number of small horns on organic head protection, probably used in a more profane way (in Scandinavia, as depicted on rock surfaces; in Sardinia, as mainly worn by archers), and a smaller number of headgear with massive, long and slightly curved horns with cut-off ends and with ball- or bowl-reinforced tips, for a purpose other than profane use, as indicated by the Sardinian warrior-demons which wear the latter, and as seen in the Nordic bronze helmets and figurines (Fig. 2.36) with horned head gear. The structure exhibited by the two main groups of horned headgear found in Sardinia and the Nordic Bronze Age, is completely lacking amongst the Iberian stelae; at least four different types of headgear are depicted, being associated with neither a specific location, a way of depiction or in combination with other equipment. Also, the representation of the warrior differs significantly between northern and southern Europe: while the depicted warriors in Scandinavian rock art are part of a story and seem to be caught in 'action', the warrior stelae in Iberia and the Sardinian figurines are static, singular and

\footnotetext{
713 Brandherm 2007, 16.

714 Celestino Pérez 2001, nos. 35, 53, 65, 76, 85; Harrison 2004, 161-163.

715 Brandherm 2008, 483.

716 See also Celestino Pérez 2001, nos. 12, 17, 21, 22, 25.

717 See Chapter 2.2.5, p. 116.

718 Celestino Pérez 2001, nos. 71, 80, 84.

719 Celestino Pérez - López-Ruiz 2006, 91, fig. 3; Brandherm 2008, 484.

720 Murillo Redondo et al. 2005; García Sanjuán et al. 2006.

721 Harrison 2004, 143, fig. 7.13; García Sanjuán et al. 2006.

722 Gonzáles Ledesma 2007.
} 


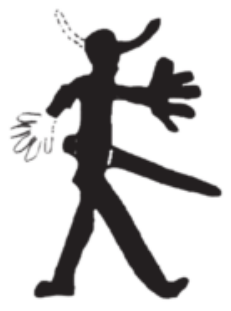

1

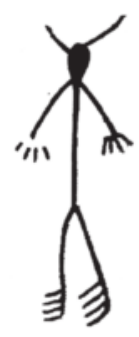

2

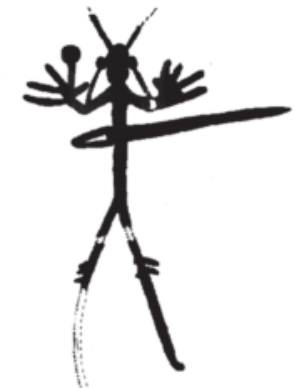

3

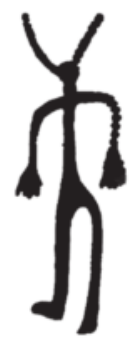

4

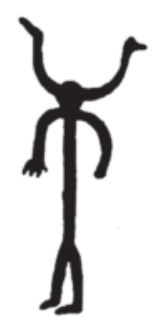

10

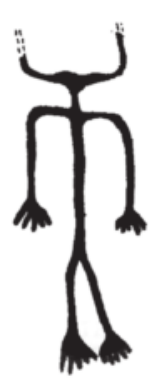

15

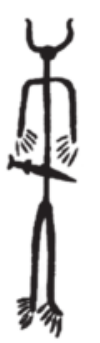

9

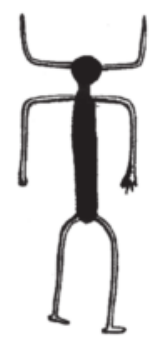

16

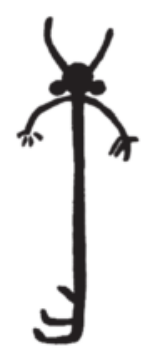

5

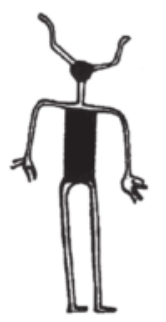

11

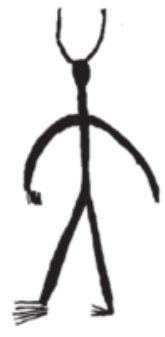

6

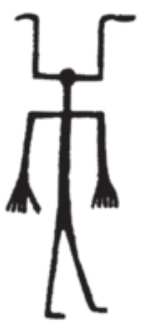

13

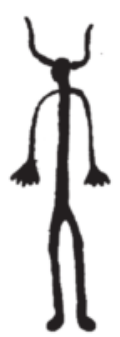

14

Fig. 2.40 Horned headgear depicted on Iberian stelae: 1. Talavera de la Reina; 2. Esparragosa de Lares I; 3. Olivenza; 4. Valdetorres I; 5. El Viso I; 6. Las Herencias II; 7. Alamillo; 8. São Martinho I; 9. Magacela; 10. Aldeanueva de San Bartolomé; 11. Écija III; 12. Fuente de Cantos; 13. El Coronil; 14. Écija V; 15. El Viso VI; 16. Écija II (after Harrison 2004, fig. 7.13) (figures not to scale).

seem to be out of their war context, or at least are not embedded in a vivid, story-telling context: the warrior alone is the centre of attention, dissolved from the context he was acting in.

These three regions, despite certain specific differences in their depiction of horned headgear, represent the highest number of such depictions, and also share certain general similarities; it seems that all show complete or partially equipped warriors. This equipment though differs from region to region, according to different traditions and fighting techniques. Most of the warriors wear swords; in Scandinavia and the Iberian Peninsula we also see spears, whilst these are almost completely absent in Sardinia; instead, the Sardinian warriors bear stick or bow. Only five of the Iberian stelae with horned helmets have depictions of bows. Shields are worn by almost all warriors in all three regions; whereas axes are only depicted with warriors in Scandinavian. The Sardinian warriors are never connected with a means of transport; but a third of the Iberian warriors are depicted with chariots, and several Scandinavian warriors (and bulls!) on or close to ships.

The correlation between the Iberian Peninsula, Sardinia and the Nordic Bronze Age in the matter of horned headgear might be related to the fact that all finds show figures with horned 
headgear which bear (or are associated with) other arms and armour. As already pointed out by Brandherm, we cannot automatically assume an adoption of a specific meaning in the use of horned headgear across such a wide geographical area; ${ }^{723}$ though, he sees in the beginning of the development of horned headgear in Anatolia and the Levant, a common symbolic ancestor as represented by the bull or weather gods of the Hittite, Hurrian and Semitic pantheon. The two small statues of a warrior or god from Enkomi with horned headgear might demonstrate just such an adoption (Fig. 2.33.4-5). Horns or horned headgear, however, is a widely distributed and long lived common motif, evident since the Palaeolithic, and will have come into fashion independently again and again. ${ }^{724}$ It is not necessary therefore to seek a single causal link of development, and we must take into account the many different practical and cultural reasons and networks which influenced the development, both locally and regionally, of horned headgear. We can perhaps see in horned headgear a significant element of connection between the Nordic Bronze Age, the Urnfield culture, and various Mediterranean networks from c. 1200 BC onwards and as a thread, which 'leads from war and social upheaval in the east Mediterranean over Sardinia and Iberia to Viksø with offshoots to adventurous sea travels, warfare, material culture emulation, transfer of cosmological elements, myth-making and the transport of bronze along the Atlantic coasts ${ }^{725}$ and copper mining or trade, as Vandkilde pointed out recently remains to be seen in further research.

\section{Catalogue}

Cat. no. 121. Viksø, Denmark - bog find - two complete helmets. Measurements: Helmet A: height: $17.7 \mathrm{~cm}$; diameter: $21.7 \times 20.6 \mathrm{~cm}$. Helmet B: height: $17.7 \mathrm{~cm}$; diameter: $19.9 \times 22 \mathrm{~cm}-$ Nationalmuseet København, inv. no. B 13, 552-553 - Fig. 2.36.1. References: Norling-Christensen 1943; Broholm 1944, 253, pls. 67-68; Norling-Christensen 1946; Althin 1952; Kossack 1954, 46; Brøndsted 1958, II, 186; Brøndsted 1962, II, 186; Hencken 1971, 11, 169-174, figs. 138-139; Vandkilde 2013.

The Viksø helmets were discovered in 1942 during peat digging in the Brøns Mose at Viksø, in the northwest of Copenhagen. A nineteenth century map suggests that the 'Brøns Mose' bog was a pond or a lake during the Bronze Age. The helmets were found together with additional pieces of pottery and wood and are dated to Period IV (c. 1200/1100-1000 BC). ${ }^{726}$ The find was published by Norling-Christensen, who mentioned that at least one helmet might have been standing on an ash wood tray (or shield?); however, radiocarbon dates of the wooden remains thought to have derived from the tray are much older than the helmets. ${ }^{727}$ The peat workers moreover noted that the ceramic pot was found above the helmet, and is therefore not necessarily associated with them.

In 1944, the alloy composition of the helmets was studied; ${ }^{728}$ unfortunately, the analytical method used is not described, so we cannot be sure if the high amount of Sn of the cap of 16.8 $\mathrm{wt} \%$ is due to corrosion influence or not. We certainly cannot comment, therefore, on the question of the use of regular imported metal supplies or the use of recycled metal. Both helmets show low-level impurities of lead (0.3-0.9 wt\%), arsenic (0.2 wt.\%), antimony (0.1-0.2 wt.\%) and nickel (0.1-0.3 wt.\%) as well as traces of silver (0.05-0.06 wt.\%).

\footnotetext{
723 Brandherm 2011, 49.

724 Hencken 1971, 171-173.

725 Vandkilde 2013, 175; referring to Ling et al. 2013 for copper mining and trade.

726 Vandkilde 2013, 165.

727 Norling-Christensen 1946; Vandkilde 2013, 165.

728 Vandkilde 2013, 167.
} 


\subsection{Analyses Helmets}

The manufacturing process is largely the same for all helmets of Class I and will therefore be explained based on information from the helmets of Type Pişcolt, accompanied by additional data from helmets of Type Oranienburg, Type Paks, and Type Nagytétény. The helmets, as were the greaves and cuirasses, were sampled either with a $1 \mathrm{~mm}$ drill to detect the alloy composition or a micro-sample was taken to enable further metallographic analyses of the microstructural features. Micro-samples were only taken from incomplete or fragmented armour.

Drilled samples were analysed using a Scanning Electron Microscope (SEM) equipped with an Energy Dispersive X-Ray Spectroscope (EDXS), which enabled measurements directly on the metal and permitted the avoidance of corrosion. The micro-samples were mounted in epoxy resin for metallographic analyses and polished with diamond paste up to $0.25 \mu \mathrm{m}$ of granulometry. Those samples were studied by SEM-EDXS and Light Optical Microscope (LOM) using Bright Field (BF) and Dark Field (DF) contrast methods before and after etching (for observation of corrosion and microstructural features respectively). The chemical characterisation was carried out via SEM-EDXS (Evo40 Zeiss with PENTAFET ${ }^{\circledR}$ EDXS detector sensitive to light elements, $\mathrm{Z}>5$ ). The main elements identified were $\mathrm{Cu}, \mathrm{Sn}, \mathrm{Pb}, \mathrm{As}, \mathrm{S}, \mathrm{Fe}, \mathrm{Zn}, \mathrm{Ni}, \mathrm{Ag}, \mathrm{Bi}, \mathrm{Co}$ and $\mathrm{Au}$. In the original routine the detection limit for most elements was $0.1 \mathrm{wt} . \%$. The operating conditions were an accelerating voltage of $20 \mathrm{kV}$, chamber pressure lower than $10^{-5}$ mbarr (for the SEM). The EDXS was calibrated with a cobalt reference sample, an acquisition time of 60 seconds with 2000 channels of $5 \mathrm{eV}$ each and ZAF 5 correction. Real reference standards were used for the quantitative analyses in order to improve the accuracy of the measurements. The compositions reported (normalized and in weight percentages) correspond to the mathematical average of 5 to 20 spectra with suitable fit index per each sample. Element concentrations $<0.3$ wt.\% were considered as semi-quantitative and taken into account only when the identification peaks were clearly visible in the acquired spectrum. Due to the presence of interand intra-crystalline corrosion products, the matrix was in most of the samples clearly visible and etching was not necessary. In any case, etching was carried out after SEM-EDXS analyses since etching solutions such as ethyl alcohol solution of ferric chloride acidified by hydrochloric acid affect the composition of inclusion and corrosion products by the introduction, for instance, of $\mathrm{Cl}$ and $\mathrm{Fe}$ to the composition of patina and inclusions. In most cases, intergranular corrosion or ghost microstructure present in the inner layers of corrosion patina exhibited the microstructural features needed to reconstruct the thermomechanical history of the object. ${ }^{729}$ All compositions reported are normalised and in weight percentage.

According to the microstructure observed, the most probable thermo-mechanical history of the object was suggested. Moreover, also the total deformation of the original as-cast ingot was calculated. The average total deformation depends less on the tin content of the helmets (which would have also influenced the annealing temperature and the number of necessary annealing circuits), and more on the thickness of the as-cast plate and the zone of the helmet from which the sample was taken. The deformation applied can be defined by two types:

1. Sheet working to achieve the final thickness (highest impact of deformation rate, which is defined by the reduction of thickness). The deformation applied has to be defined as mono- or bi-axial in order to decide if one or two orthogonal cross-sections are needed for the interpretation of the inclusions

2. Shaping (deep drawing) to achieve the final shape, which, accordingly, also changes the shape of inclusions, but in a more limited way. The information provided clearly depends on the sampling position, but can also provide information about point 1

The total amount of applied deformation can be calculated by measuring the length and thickness of $\mathrm{Cu}_{2-\mathrm{x}} \mathrm{Fe}_{\mathrm{x}} \mathrm{S}$-inclusions usually present in archaeological bronzes. These inclusions deform in a similar manner to the metallic matrix and, moreover, are not influenced by the

729 Piccardo 2000; Ienco et al. 2007. 
common annealing temperatures. Thus, their shape factor (SF, thickness/length ratio) gives clear information about the total amount of deformation as well as the direction of the mechanical deformation applied during the manufacturing process. ${ }^{730}$ For the calculation of the SF only complete inclusions must be used, since some can be broken as a consequence of the effect of external factors, such as a violent corrosion processes (Fig. 2.41). Attention has to be paid to not measure flattened cavities as deformed $\mathrm{Cu}_{2-\mathrm{x}} \mathrm{Fe}_{\mathrm{x}} \mathrm{S}$-inclusions $\left(\mathrm{Cu}_{2-\mathrm{x}} \mathrm{Fe}_{\mathrm{x}} \mathrm{S}\right.$ enriches on the inside of the cavities and is with them flattened during deformation; the thus created 'line' of $\mathrm{Cu}_{2-\mathrm{x}} \mathrm{Fe}_{\mathrm{x}} \mathrm{S}$ inclusions is much thinner than pure $\mathrm{Cu}_{2-x} \mathrm{Fe}_{x} \mathrm{~S}$-inclusions and gives a wrong impression of the actually carried out total deformation). The calculated SF cannot take into account the massive material losses occurring during shaping, such as flaking off of oxides, polishing, grinding and use. Recent experiments carried out on the production of bronze sheets with $13 \mathrm{wt} . \%$ Sn showed that from the as-cast to the final sheet, incorporating some 18 to 23 steps for each annealing (2-5h in total) and cold deformation (3-4h in total), the weight loss was in the range of $7-30 \%$.

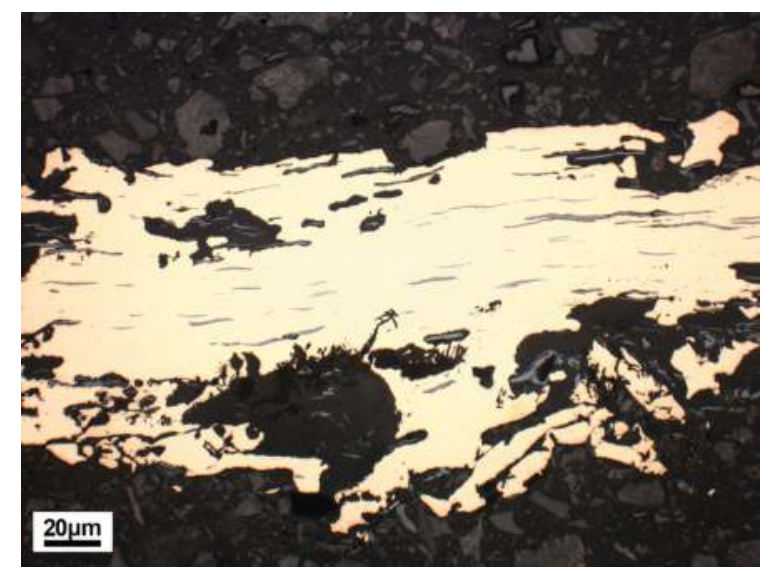

Fig. 2.41 Cross-section of the helmet of Type Pişcolt from Sâg, Romania, close to the knob. The micro-sample is unetched. Note the massive deformation visible by the light grey, highly elongated $\mathrm{Cu}_{2-\mathrm{x}} \mathrm{Fe}_{\mathrm{x}} \mathrm{S}$-inclusions. In the corroded area, these inclusions are heavily deformed and torn apart due to the heavy corrosion (dark grey).

The average SF (shape factor) and the corresponding percentage of reduction of the as-cast plate was calculated for every helmet cap fragment analysed according to the deformation of its $\mathrm{Cu}_{2-\mathrm{x}} \mathrm{Fe}_{\mathrm{x}} \mathrm{S}$-inclusions. To have a statistical validation of this method, it is important to measure the SF of at least 100 inclusions on a minimum of three fields of observation.

\subsubsection{Chemical Characterisation - Cap Helmets}

So far, five helmets of Type Oranienburg, eight helmets of Type Paks and an associated cheek plate, one helmet of Type Nagytétény, ten helmets of Type Pişcolt and the only helmet of Type Malpensa, have been chemically analysed (Tab. 2.16 and 2.17). The numbers presented in Tab. 2.17 show a wide range for $\mathrm{Pb}$ and $\mathrm{As}$ as a result of the low sensibility of the Prompt Gamma Activation Analyses (PGAA), the analyses on the corroded surface via Particle-induced X-ray emission (PIXE) and the fact that $\mathrm{Pb}$ was ignored by the Time of Flight Neutron Diffraction (ToF-ND) ${ }^{731}$

Elements such as $\mathrm{Ni}, \mathrm{Ag}$, $\mathrm{As}$, and $\mathrm{Sb}$ as well as $\mathrm{Fe}, \mathrm{S}$ and $\mathrm{Pb}$ are common in prehistoric bronzes and detected as minor and trace alloying elements according to their concentration. Such elements are connected to the smelting and casting processes of copper and copper ore.

730 Piccardo - Pernot 1997; Mödlinger - Piccardo 2013.

731 Mödlinger et al. 2013; Mödlinger et al. 2014. 


\begin{tabular}{|c|c|c|c|c|c|c|c|c|c|c|c|c|c|c|c|c|c|c|c|c|c|c|}
\hline 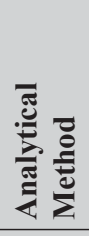 & $\begin{array}{l}\widehat{\Xi} \\
\vec{y} \\
\hat{x}\end{array}$ & \multicolumn{4}{|c|}{ 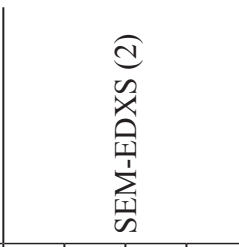 } & \multicolumn{6}{|c|}{$\begin{array}{l}\hat{0} \\
0 \\
\sum \\
\sum\end{array}$} & \multicolumn{6}{|c|}{ 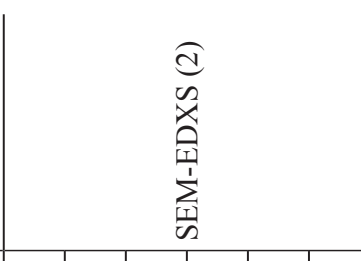 } & \multicolumn{2}{|l|}{ 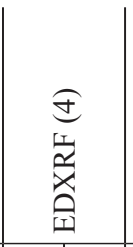 } & \multicolumn{2}{|c|}{$\begin{array}{l}\sqrt{n} \\
\infty \\
x \\
0 \\
\sum_{11}^{1} \\
\infty\end{array}$} & 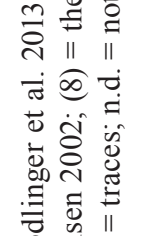 \\
\hline 己 & & & & & & 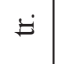 & $\dot{H}$ & 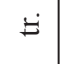 & $\ddot{H}$ & 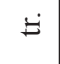 & $\doteq$ & & $n$ & & & & & & & & & \\
\hline$\xi$ & & & & & & $\ddot{H}$ & 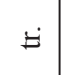 & $\ddot{H}$ & $\ddot{E}$ & $\dot{ت}$ & $ت$ & 3 & 3 & & & & & & & & $\tilde{o}$ & 0 \\
\hline ن & & & & & $\ddot{H}$ & $\ddot{H}$ & $\ddot{H}$ & $\ddot{E}$ & $\dot{H}$ & $\dot{H}$ & $\ddot{H}$ & 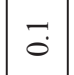 & $\dot{E}$ & & $\overrightarrow{0}$ & & 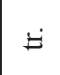 & & & & $\stackrel{\check{I}}{\ddot{I}}$ & \\
\hline $\bar{x}$ & & & & & & $\dot{H}$ & $\ddot{E}$ & 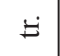 & $\dot{E}$ & $\dot{E}$ & $\ddot{H}$ & & & & & & & & & & & \\
\hline$\stackrel{20}{4}$ & $\stackrel{\check{\Xi}}{\dot{\Xi}}$ & ơ & $\overrightarrow{0}$ & 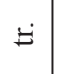 & $\overrightarrow{0}$ & $\dot{H}$ & $\ddot{H}$ & $\ddot{H}$ & $\dot{H}$ & $\ddot{H}$ & $\ddot{H}$ & - & ? & $\because$ & $\overrightarrow{0}$ & $\overrightarrow{0}$ & $\dot{H}$ & $\overrightarrow{0}$ & $\overrightarrow{0}$ & $\tilde{o}$ & $\overrightarrow{0}$ & \\
\hline $\bar{z}$ & & $\overrightarrow{0}$ & $\overrightarrow{0}$ & $\overrightarrow{0}$ & กั & $\overrightarrow{0}$ & $\overrightarrow{0}$ & $\overrightarrow{0}$ & $\ddot{H}$ & $\stackrel{+}{0}$ & $\stackrel{0}{0}$ & ô. & ? & $\stackrel{\circ}{-}$ & $\stackrel{ \pm}{-}$ & 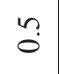 & $\dot{H}$ & $ت$ & $\overrightarrow{0}$ & $\overrightarrow{0}$ & $\overrightarrow{0}$ & \\
\hline งี & $\stackrel{\vec{J}}{\dot{\Xi}}$ & & & & & $\dot{H}$ & $\dot{H}$ & $\doteq$ & $\ddot{E}$ & $\dot{H}$ & $\dot{H}$ & & 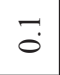 & $\dot{H}$ & & & & \pm & $\ddot{H}$ & & $\stackrel{\vec{H}}{\dot{H}}$ & \\
\hline II & $\ddot{ت}$ & กุ. & $\stackrel{\infty}{\circ}$ & $\ddot{H}$ & $\ddot{H}$ & $\overrightarrow{0}$ & $\overrightarrow{0}$ & $\overrightarrow{0}$ & $\ddot{H}$ & $\hat{0}$ & ò & $\overrightarrow{0}$ & ? & $\ddot{H}$ & $\stackrel{m}{0}$ & 3 & $\dot{E}$ & $\dot{E}$ & $\ddot{H}$ & $\overrightarrow{0}$ & $\dot{H}$ & \\
\hline$\infty$ & & 3 & 8 & 3 & $\stackrel{t}{0}$ & & & & & & & $\begin{array}{ll}n \\
0\end{array}$ & $\tilde{0}$ & $\ddot{0}$ & $\begin{array}{ll}0 \\
0 \\
0\end{array}$ & $\dot{0}$ & $\hat{0}$ & & & $?$ & 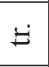 & \\
\hline \& & $\ddot{ت}$ & $n$ & ฮุ & $\overrightarrow{0}$ & กุ & $\dot{E}$ & $\ddot{H}$ & $\dot{H}$ & $\dot{H}$ & $\dot{H}$ & $\stackrel{\circ}{-}$ & $\tilde{O}$ & ๙ุ & $\because$ & $\stackrel{\circ}{-}$ & $\stackrel{+}{0}$ & $\ddot{H}$ & $\because$ & $\overrightarrow{0}$ & $\tilde{o}$ & $\dot{H}$ & \\
\hline के & $\stackrel{\dot{\oplus}}{\dot{\Xi}}$ & & ฮี & $\overrightarrow{0}$ & $\stackrel{?}{0}$ & $\dot{H}$ & $\ddot{H}$ & $\ddot{H}$ & $\ddot{H}$ & $\stackrel{0}{0}$ & $\stackrel{0}{0}$ & กุ & กุ & $\stackrel{?}{0}$ & $n$ & & & \begin{tabular}{l|l}
\multirow{0}{*}{} & \\
\end{tabular} & $\tilde{c}$ & ฮี & $\stackrel{\vec{J}}{\dot{J}}$ & \\
\hline$\hat{*}$ & $\stackrel{\vec{\oplus}}{\dot{y}}$ & ֻั & $\stackrel{t}{0}$ & กั่ & $\tilde{3}$ & $\ddot{H}$ & $\dot{H}$ & $\dot{H}$ & $\tilde{o}$ & $\stackrel{\sim}{=}$ & $\stackrel{\circ}{-}$ & 3 & & $\overrightarrow{0}$ & $\stackrel{\infty}{\circ}$ & กั & $\stackrel{m}{0}$ & 3 & $\stackrel{t}{0}$ & $\because$ & $\overrightarrow{0}$ & \\
\hline क & $\stackrel{\circ}{\ominus}$ & $\mid \begin{array}{l}n \\
n \\
n\end{array}$ & $\begin{array}{l}\dot{\infty} \\
\infty\end{array}$ & $\stackrel{?}{\ominus}$ & $\stackrel{+}{ \pm}$ & $\stackrel{\sim}{\Xi}$ & $\hat{\mathrm{I}}$ & $\stackrel{n}{\mathfrak{I}}$ & $\overrightarrow{\mathcal{I}}$ & $\hat{n}$ & in & $\begin{array}{l}\infty \\
\stackrel{0}{0}\end{array}$ & $\hat{\varrho}$ & $\because$ & $\vec{\infty}$ & $\vec{r}$ & $\stackrel{\text { I }}{-}$ & $\stackrel{\Xi}{=}$ & $\stackrel{0}{\ominus}$ & $\stackrel{1}{\varrho}$ & $\stackrel{\circ}{\circ}$ & 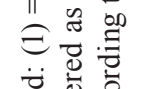 \\
\hline E & $\stackrel{\circ}{\circ}$ & $\vec{\infty}$ & $\begin{array}{l}\stackrel{\circ}{\infty} \\
\dot{\infty}\end{array}$ & $\stackrel{c}{\stackrel{\infty}{\infty}}$ & $\begin{array}{l}n \\
\dot{n} \\
\dot{\infty}\end{array}$ & $\begin{array}{l}n \\
\infty \\
\infty\end{array}$ & $\begin{array}{l}\hat{D} \\
\infty\end{array}$ & $\frac{m}{\infty}$ & $\underset{\infty}{\infty}$ & $\ddot{\dot{a}}$ & $\hat{\dot{a}}$ & $\begin{array}{l}\frac{2}{\infty} \\
\infty\end{array}$ & $\vec{\infty}$ & $\mid \begin{array}{c}\dot{0} \\
\dot{\infty}\end{array}$ & 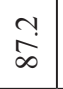 & $\stackrel{\Upsilon}{a}$ & के & \begin{tabular}{|c|}
$\dot{\dot{d}}$ \\
$\dot{\infty}$
\end{tabular} & $\begin{array}{l}0 \\
\infty \\
\infty \\
\infty\end{array}$ & $\begin{array}{c}m \\
\infty \\
\infty \\
\infty\end{array}$ & $\begin{array}{l}\infty \\
\infty \\
\infty\end{array}$ & \\
\hline 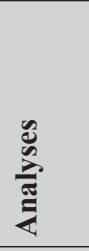 & $\begin{array}{l}0 \\
0 \\
0 \\
\overline{0} \\
\bar{c}\end{array}$ & \begin{tabular}{|l|} 
\\
0 \\
\\
\end{tabular} & $\begin{array}{l}0 \\
0 \\
0 \\
0 \\
0 \\
0 \\
0 \\
0 \\
0 \\
0.0 \\
0 \\
\end{array}$ & 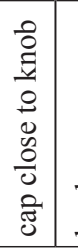 & 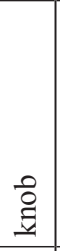 & छ్ & $\begin{array}{l}0 \\
\stackrel{0}{0} \\
\end{array}$ & $\stackrel{\vec{D}}{\vec{z}}$ & छ్లి & \begin{tabular}{|l}
0 \\
0 \\
$\underline{\Xi}$
\end{tabular} & 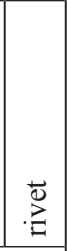 & \begin{tabular}{|l|}
0 \\
0 \\
0 \\
0 \\
0 \\
0 \\
0 \\
0 \\
0 \\
0 \\
0
\end{tabular} & $\begin{array}{l}\Xi \\
\Xi \\
0 \\
0 \\
0 \\
0 \\
0 \\
\tilde{0} \\
\tilde{0} \\
\end{array}$ & 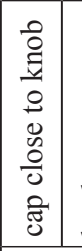 & $\begin{array}{l}0 \\
\stackrel{0}{\Xi} \\
\end{array}$ & $\begin{array}{l}\frac{0}{\pi} \\
\frac{\pi}{2} \\
\frac{4}{0} \\
\frac{0}{0} \\
\end{array}$ & $\begin{array}{l}\frac{0}{\pi} \\
\frac{\pi}{2} \\
\frac{4}{0} \\
\frac{\pi}{0} \\
\end{array}$ & छ્छે & $\begin{array}{l}0 \\
0 \\
\Xi \\
\end{array}$ & $\begin{array}{l}\text { 음 } \\
\text { E् }\end{array}$ & च्ठे & 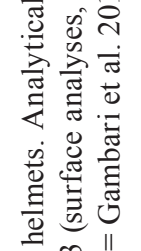 \\
\hline 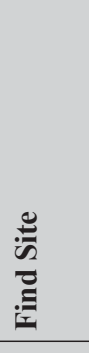 & 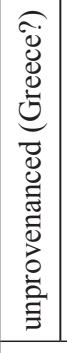 & $\begin{array}{l}\frac{\pi}{0} \\
0 \\
\frac{\pi}{\omega} \\
\frac{\pi}{0} \\
\tilde{\omega} \\
\text { की }\end{array}$ & & 点 & $5^{0}$ & & 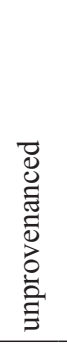 & & & 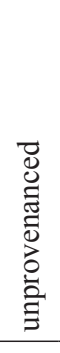 & & 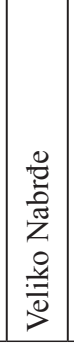 & 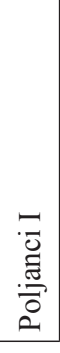 & 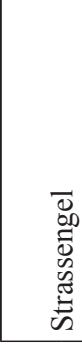 & : & $\begin{array}{l}\breve{5} \\
\overline{0} \\
0 \\
0 \\
\overline{0} \\
\overline{0} \\
3\end{array}$ & $\begin{array}{l}0 \\
\overrightarrow{0} \\
0 \\
0 \\
0 \\
0 \\
\frac{0}{0} \\
0 \\
\end{array}$ & 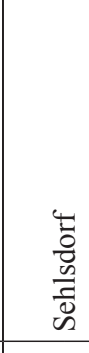 & & 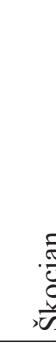 & & 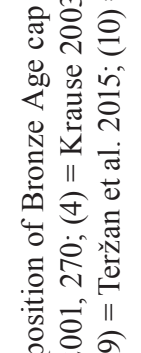 \\
\hline 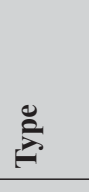 & & & 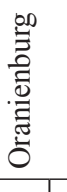 & & & & & & & & & & & & & & & & 竞 & & & 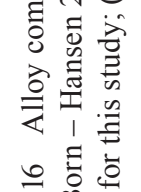 \\
\hline$\dot{\tilde{J}} \dot{z}$ & - & 6 & & $=$ & & & ते & & & $\vec{\sim}$ & & $\tilde{\theta}$ & $\stackrel{\Xi}{\sim}$ & $\stackrel{\infty}{\sim}$ & & థి & $\vec{m}$ & $\bar{\forall}$ & & 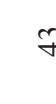 & & \\
\hline
\end{tabular}




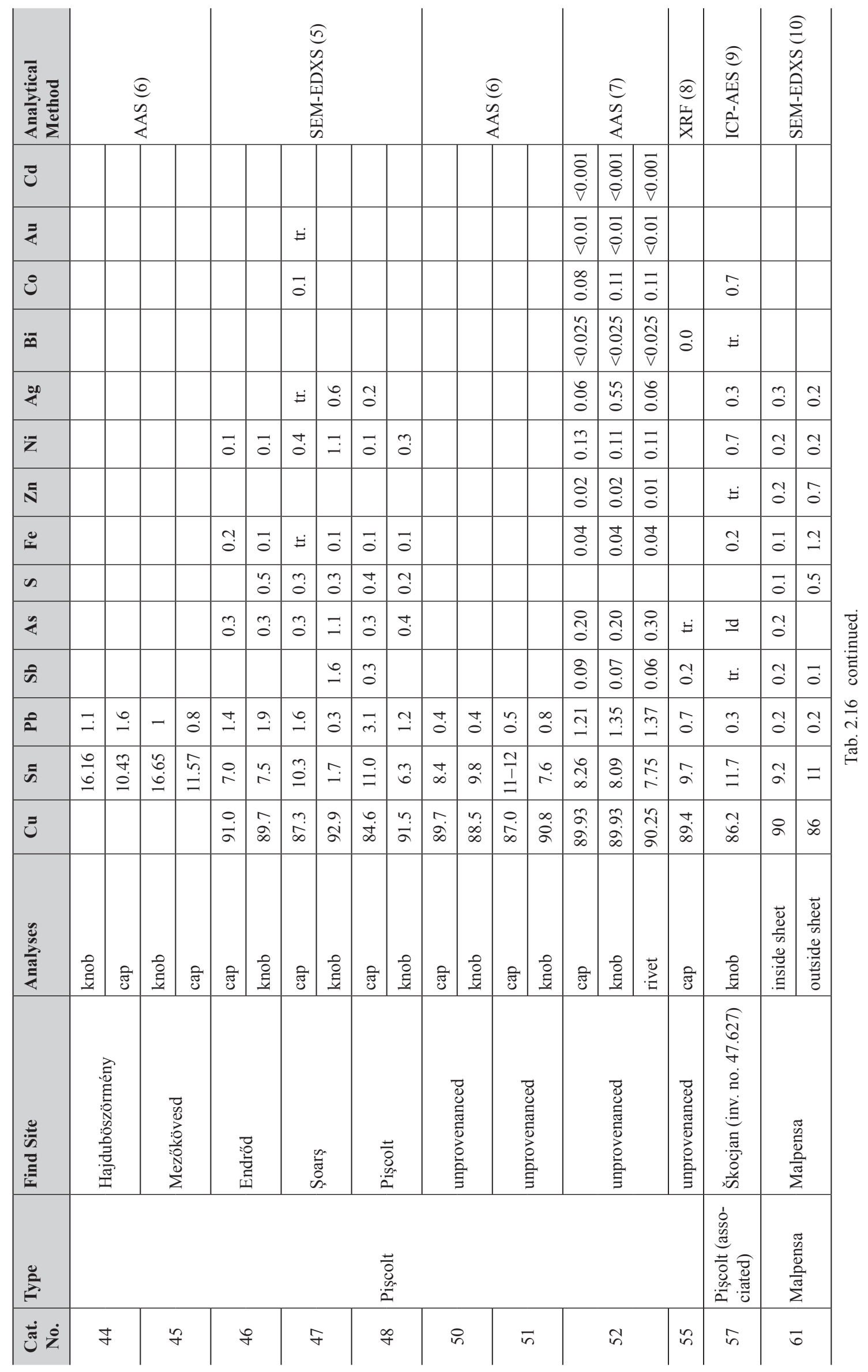




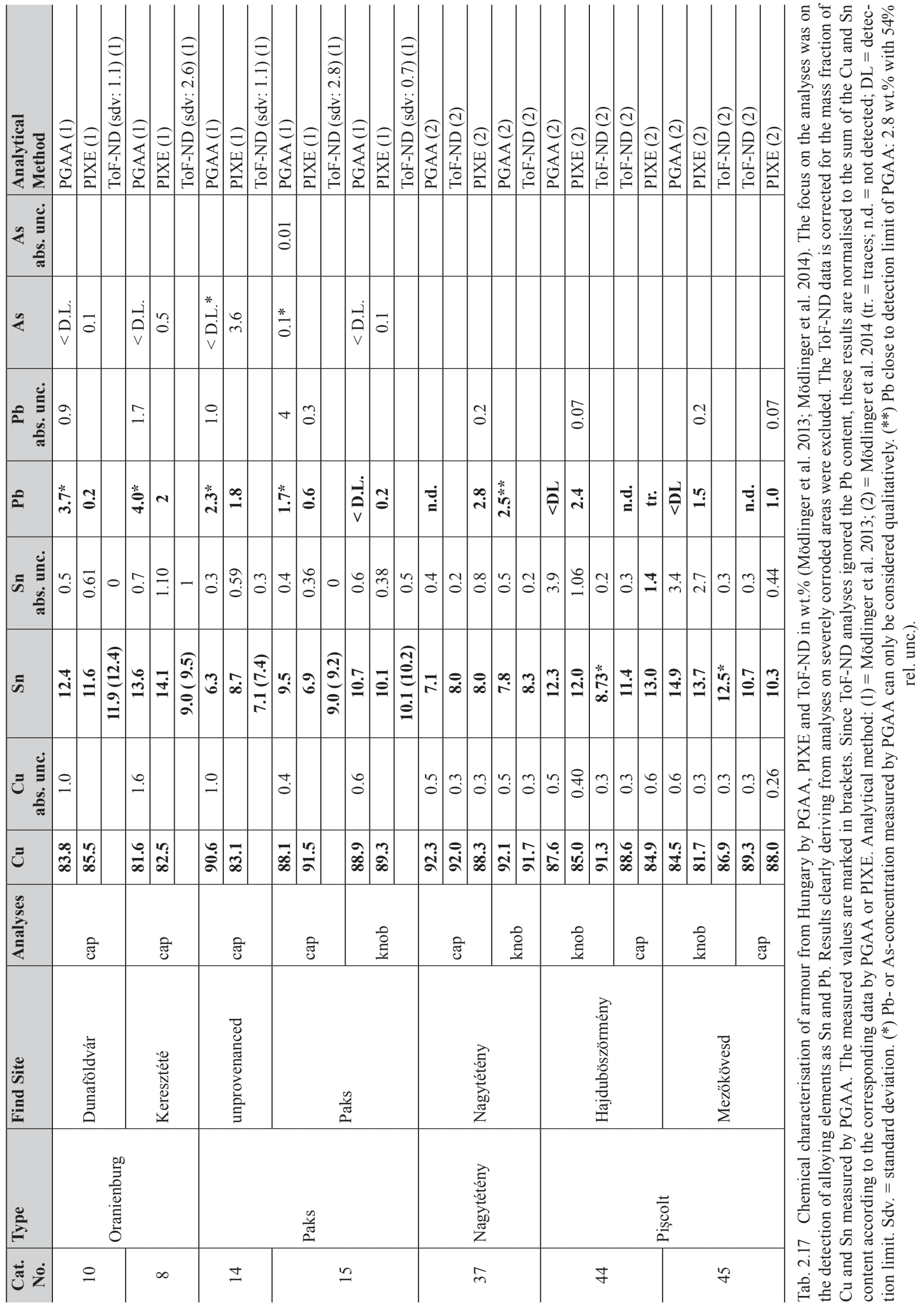


Due to their low and different boiling point, elements like As and Sb vary in quantity during any re-melting and recycling processes involving copper or bronze. Together with Ag, these elements concentrate as minor or trace elements at the grain boundaries, while $\mathrm{Fe}, \mathrm{Pb}$ (up to 1 wt.\%) and $\mathrm{S}$ are usually found as inclusions (i.e. as iron rich copper sulphides or lead nodules). Surface analyses ${ }^{732}$ obviously revealed higher amounts of elements 'concentrating' in the corrosion due to the faster diffusion of copper ions in soil, thus only providing qualitative or semiquantitative analytical results. In the case of surface analyses carried out on the patina, detected elements such as Al, Si, P, Ti derive from the soil, S, Fe, Co, Ni might derive in unknown quantities from the soil or be part of the metal, while $\mathrm{Cu}, \mathrm{Sn}, \mathrm{Pb}, \mathrm{As}, \mathrm{Sb}, \mathrm{Bi}$ are part of the alloy only.

In Chart 2.1 the alloy compositions of the three main types of eastern European helmets are indicated. At the base of the graph are the analyses as indicated in Tab. 2.16. Due to the wide uncertainty range, the analyses indicated in Tab. 2.17 were not taken into account. The differences in the alloys chosen for caps and knobs, are obvious: while for the caps all helmets show an alloy composition ranging between $7-12 \mathrm{wt} . \%$ of $\mathrm{Sn}$, the alloy diversity is much higher for the smaller components of the helmets (such as knobs). The alloy range of 7-12 wt.\% $\mathrm{Sn}$ is connected to:

1. the optimum fluidity of the alloy, ${ }^{733}$ which permits the casting of thinner bronze plates for the production of the cap and thus shortening significantly the following working steps to reduce the thickness, and

2. increasing the tensile strength and hardness of the alloy.

Between the different types, the higher amounts of $\mathrm{Pb}$ for the cap of helmets of Type Pişcolt is significant. For the helmet from Sehlsdorf, which shows rather low amounts of $\mathrm{Pb}$, we have to note that the analytical base are analyses on the corroded surface. Significantly lower amounts of $\mathrm{Pb}$ are furthermore noted on the helmet from Škocjan and the unprovenanced helmet of Type Pişcolt (cat. no. 50). Helmets Type Oranienburg tend to contain less Sn than helmets of Type Paks, but this might be mitigated given the opportunity to analyse the clean metal of the Hungarian helmets instead of the external patina (as has so far been the case, together with bulk analyses on corroded samples without knowing the corrosion thickness) (Tab. 2.17).

As demonstrated by recently published analyses, helmets of Type Oranienburg show a rather uniform alloy composition. ${ }^{734}$ With the exception of the cap of the helmet from Spišská Belá, which contains $8.6 \mathrm{wt} . \% \mathrm{Sn}$, the helmets analysed were made of a binary $\mathrm{CuSn}$ alloy with $10.3-$ 14.4 wt.\% Sn. Most common trace elements are $\mathrm{S}$ and $\mathrm{Fe}$, followed by $\mathrm{Pb}, \mathrm{Ag}$, As and Ni. Only on the helmets from Dunaföldvár and Keresztéte were higher amounts of $\mathrm{Pb}$ measured, ${ }^{735}$ which is connected to the analytical methods used (surface analyses via PIXE; low sensibility for $\mathrm{Pb}$ with the PGAA). Also, the knob of the Biecz helmet contains slightly higher amounts of $\mathrm{Pb} .^{736}$

For helmets of Type Pişcolt, the amount of Sn ranges between 6-12 wt.\% for both cap and knob. Only the knob of the helmet from Şoarş shows significantly less Sn, with 1.7 wt.\%, whilst the knobs of the helmets from Hajduböszörmény and Mezökövesd demonstrate significantly higher amounts of Sn, with over 16 wt. $\%{ }^{737}$ Such high amounts of Sn measured on Late Bronze Age bronzes are rare (assuming the analyses were not influenced by the presence of corrosion products). The rather high amounts of Sb, As and Ni of 1-1.6 wt.\% of the knob of the helmet of Type Pişcolt from Şoarş indicates the use of Fahlore with (almost) no previous recycling process for the production of the copper which was used for the knob.

\footnotetext{
732 For example, surface analyses were carried out on the unprovenanced helmet of Type Pişcolt (cat. no. 55) and other, mainly Hungarian, armour: Mödlinger et al. 2013; Mödlinger et al. 2014.

733 Piccardo et al. 2009.

734 Mödlinger et al. 2013.

735 Mödlinger et al. 2014.

736 R. Cowel and K. Hyne, British Museum, Department of Conservation and Scientific Research, internal file number 6427.

737 Born - Hansen 1992, 339-356.
} 

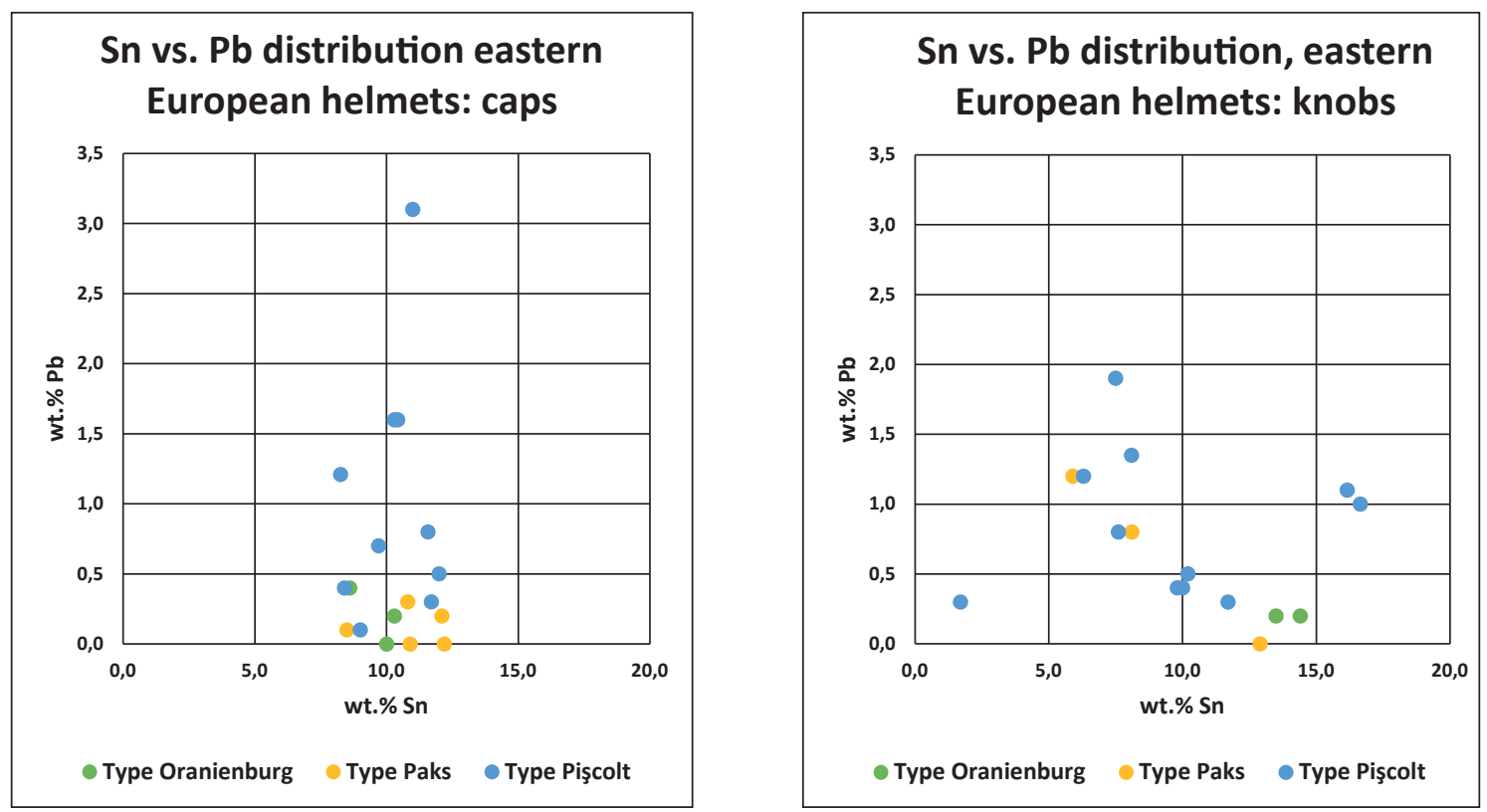

Chart 2.1 Sn vs. Pb distribution of eastern European helmets. The base of Chart 2.1 are the values indicated in Tab. 2.16. The uncertainty range for the SEM-EDXS is about 5\%. Left: Sn vs. Pb distribution of the cap of the helmets. Right: $\mathrm{Sn}$ vs. Pb distribution of the knobs of the helmets.

The Sn amount of the helmet's knob shows a rather wide range, from 1.7-16.6 wt.\%, for helmets of Type Pişcolt, 5.9-12.9 wt.\% for helmets of Type Paks and for helmets of Type Oranienburg from 13.5-14.4 wt.\%. The rather high amounts of Ni (1.4 wt.\%) and As (1 wt.\%) of the knob of the helmet of Type Paks from Strassengel should also be noted; these might again be connected to the use of Fahlore. The only analysed helmet of Type Nagytétény contains 7-8.5 wt.\% Sn in the knob (helmet from Nagytétény). Thus, no specific preference in the use of Sn for the knob according to helmet type is perceptible; only the rather high amount measured on the two helmets of Type Oranienburg is unexpected, but might be mitigated against by further analyses of the knobs on other helmets of Type Oranienburg. For the cap, Sn was added in similar quantities: helmets of Type Pişcolt show 7-11.7 wt.\% Sn, helmets of Type Paks 8.5-12.2 wt.\% Sn, helmets of Type Oranienburg 8.6-12 wt.\% Sn and only helmet of Type Nagytétény analysed 7-8 wt.\% Sn.

The alloy composition of the analysed helmets of Type Pişcolt differs from those of the older helmets of Type Oranienburg and Type Paks, since the $\mathrm{Pb}$ amount of the helmets of Type Pişcolt on both cap and knob is significantly higher, usually around $0.8-2 \mathrm{wt} . \%$, and reaching up to $3.1 \mathrm{wt} . \%$ (Tab. 2.16). This is in agreement with the general tendency of central and eastern European $\mathrm{Ha} \mathrm{B} 1$ bronzes containing significantly more (intentionally added) $\mathrm{Pb}$ than older bronzes. The helmets of Type Pişcolt from Sehlsdorf, Škocjan and the unprovenanced helmet cat. no. 50 though show lower amounts of $\mathrm{Pb}$ of $\leq 0.5 \mathrm{wt} \%$ in both cap and knob. The caps of other cap helmets instead contain max. $0.4 \mathrm{wt} . \% \mathrm{~Pb}$. On the cap of the helmet from Nagytétény, the $\mathrm{Pb}$ amount could not be exactly detected (PIXE: $2.8 \mathrm{wt}$ \%; PGAA: under detection limit). The knobs analysed from the helmets of Type Oranienburg (Spišská Belá and Sâg), and the two helmets of Type Paks (cat. nos. 15 and 20) show the lowest $\mathrm{Pb}$ amounts. The $\mathrm{Pb}$ amount on helmets of Type Paks though reaches up to $1.2 \mathrm{wt} \%$ (cat. no. 21). The amount of Pb in the knob of the Nagytétény helmet is found to be around $2.8 \mathrm{wt} . \%$ with $54 \%$ relative uncertainty by the PGAA, close to its detection limit, while PIXE showed $1.4 \mathrm{wt} . \% \mathrm{~Pb}$.

The two cheek plates analysed differ widely in their composition; the one from Hočko Pohorje, Slovenia, has up to $12.2 \mathrm{wt} . \% \mathrm{Sn}$ and less minor elements, while the second one from Wöllersdorf, Austria, only 7.1 wt.\% Sn with slightly higher amounts of trace elements.

The rivets analysed from the two helmets of Type Paks (cat. nos. 20 and 21) have 5.2 to 12.5 wt.\% Sn, whilst the rivet studied from an unprovenanced helmet of Type Pişcolt (cat. no. 52) has 
7.7 wt.\%. Without further analyses, no specific pattern is discernible, but we might exclude a tin amount depending on date or type of object at least for the chronological period and helmet type concerned. The wide variability of the Sn amount found in rivets is clearly illustrated by the variability found in those rivets used in swords. ${ }^{738}$

On some of the helmets studied, both cap and knob could be sampled. Thus, the use of different alloys for the purely cast knob and the severely deformed cast bronze plate, which became the cap, could be detected. According to the composition of knob and cap the helmets analysed are divided into the following three groups:

1. the same alloy (difference in $\mathrm{Sn} \leq 1 \mathrm{wt} . \%$ and minor elements $\leq 0.3 \mathrm{wt} . \%$ )

2. a similar alloy (difference in Sn 1-4.5 wt.\%)

3. two different alloys ( $>4.5 \mathrm{wt} . \%$ Sn difference).

The division is made according to notable changes in the material characteristics (e.g. from an alloy with $1.7 \mathrm{wt} . \% \mathrm{Sn}$ to another one with $10.3 \mathrm{wt} . \% \mathrm{Sn}$, as noted on the helmet from Şoarş).

The chemical composition of the alloys used for the production of both cap and knob of the helmet of Type Paks cat. no. 20, as well as the two helmets of Type Pişcolt (cat. nos. 46 and 52), indicates the use of the same alloy for the production of the two helmet parts. Moreover, the analysed rivet from the unprovenanced helmet of Type Paks (cat. no. 20) was made with the same alloy as the cap and the knob. The differences in the $\mathrm{Pb}$ amounts measured on cap and knob of the Endröd helmet are the result of analysing the as-cast structure of the knob. Its microstructure contains larger $\mathrm{Pb}$ inclusions than found in a severely worked bronze; during analyses, the first might have been touched.

The helmet of Type Paks from Strassengel and the two helmets of Type Pişcolt cat. nos. 41 and 50), seem to have been made with a similar alloy (differences in Sn max. 1.7 wt.\%). ${ }^{739}$ On the helmet of Type Paks from Strassengel, which also shows a similar Sn amount for both cap and knob, only the amounts of $\mathrm{Pb}$, As and Ni differ. The analyses of the Sehlsdorf helmet have to be considered qualitative, since they were made on a significantly corroded surface. The differences in the minor elements detected in the Škocjan samples indicate the use of a slightly different alloy. We might also add - with reservation, due to the restrictions of the analytical methods used - the two Hungarian helmets from Paks and Nagytétény; both show similar amounts of Sn for both cap and knob (Tab. 2.17).

For those helmets with the same or similar alloy composition in both cap and knob, we might assume that once the cap was finished, the remaining alloy from the cast of the cap was melted again to be used for the cast-on of the knob. If necessary, further scrap metal or 'fresh' metal was added, which might have changed the alloy composition but only marginally (e.g. such as for the helmet from Škocjan).

The helmets of Type Oranienburg from Sâg and Spišská Belá both show a significantly different alloy composition for cap and knob: the caps have 8.6 and $10 \mathrm{wt} . \%$ Sn respectively, while the knobs show significantly higher amounts of Sn with 13.5-14.4 wt.\%. Also the helmets of Type Pişcolt from Mezökövesd and Hajduböszörmény show $>5$ wt.\% Sn in the knob than in the cap, while the $\mathrm{Pb}$ amount differs only in max. $0.5 \mathrm{wt} . \%$ (referring to the AAS-results; see Tab. 2.16). An expected difference in the colour of both cap and knob for the helmets from Hajduböszörmény and Mezökövesd, because of having a difference of 5 wt.\% in Sn, could not be observed due to the present corrosion..$^{740}$

Unlike these four helmets, the unprovenanced helmet of Type Paks cat. no. 21 and three helmets of Type Pişcolt (cat. nos. 47, 48, and 51), show higher amounts of Sn in the cap than in the

738 E.g. Riederer 2004.

739 Nevertheless, we have to keep in mind the different analytical methods used: the cap helmet from Strassengel, as well as the helmet of Type Pişcolt from Škocjan, were analysed by the author by means of SEM-EDXS; the unprovenanced helmet cat. no. 50 was studied by AAS and without taking into account elements other than $\mathrm{Cu}$, $\mathrm{Sn}$ and $\mathrm{Pb}$; the analyses of the Sehlsdorf helmet are from surface analyses only and were carried out on a corroded surface.

740 Ammannati et al. 2006. 
knob. The knob of the Şoarş helmet contains less than 2 wt.\% Sn, but significantly high amounts of Sb, As and Ni (over 1 wt.\% each), while the cap has over 10 wt.\% Sn, and no especially high amounts of minor elements. The knobs of the helmets from Pişcolt and the unprovenanced helmet (cat. no. 51) contain 4 wt.\% less Sn than the cap. The cap from the helmets of Type Pişcolt from Pişcolt and the unprovenanced helmet cat. no. 51 show significantly higher amounts of $\mathrm{Pb}$ than the knobs. ${ }^{71}$ Considering the recently carried out analyses, we cannot assume that the results from the unprovenanced helmet (cat. no. 51) need suggest a different workshop, as suggested by Born and Hansen, ${ }^{742}$ especially as it is rather similar to the alloy composition of the helmets from Şoarş and Pişcolt, which both show significantly higher amounts of $\mathrm{Sn}$ in the cap than in the knob.

At least for the helmet from Şoarş, the difference in the amount of Sn used in the cap and knob must have resulted in a visible colour difference: while the cap is a tin-bronze with 10.3 wt.\% Sn and $1.6 \mathrm{wt} . \% \mathrm{~Pb}$, the knob contains $0.3 \mathrm{wt} . \% \mathrm{~Pb}$ with only $1.7 \mathrm{wt} . \%$ Sn only.

In summary, the measured amounts of $\mathrm{Sn}$ in cap helmets indicates that its amount does not depend on the type of helmet, the geographical distribution, nor the chronological classification. Instead, significantly higher amounts of $\mathrm{Pb}$ were noted on $\mathrm{Ha} \mathrm{B} 1$ helmets of Type Pişcolt. Since detailed studies on minor and trace elements and on the origin of the metal were not the primary interest in this study, concerned as we are with manufacturing techniques, they must be discussed elsewhere.

\subsubsection{Chemical Characterisation - Crested Helmets}

To gain more information about the origin of the ores used in the production of the three helmets of Type Lueg, all of them were recently analysed by J. Lutz with XRF (X-ray fluorescence analyses), NAA (Neutron Activation analyses, including quadrupol ICP-MS) and multicollector-ICP-MS (inductively coupled plasma mass spectrometry). ${ }^{743}$ The helmets from Piller Sattel and Anlauftal were sampled on the cap, whilst analyses on the helmet from Pass Lueg included both cheek plates and the two halves of the cap. The most likely area of origin of the ores used for the production of the helmets is the Greywacken zone in the eastern Alps, known to be mined in the Bronze Age (including the areas of Mitterberg/Salzburg, Kelchalm/Tyrol, and Viehhofen/Salzburg). Comparing the composition of the helmets with the already known data, the results fit best with the Mitterberg samples, ${ }^{744}$ even though the helmets contain more $\mathrm{Sb}$ than the latter group of results. Also, the results of lead-isotope analyses so far indicate a close relation to slag from the Mitterberg region. The amount of trace elements in the helmets is rather low; the use of Fahlore therefore does not seem likely, if we do not want to assume several cycles of recycling and its accompanying loss of $\mathrm{Sb}$ and As. The helmets from Piller Sattel and Anlauftal both contain about 8 wt.\% of Sn; whereas the Sn amount of 10-12 wt.\% Sn from the helmet from Pass Lueg, and especially that from a cheek plate, with 14 wt.\% Sn, is clearly higher. The bronze includes the typical trace elements of European Bronze Age finds (Tab. 2.18). ${ }^{745}$

Neither the alloy composition nor the material structure of any helmets of Type Mantes has yet been analysed. However, three helmets of Type Biebesheim have been analysed. The two helmets from Biebesheim were already analysed in the $1960^{\prime} .^{746}$ The two fragments of helmet B show a widely varying amount of $\mathrm{Sn}(6.4-10 \mathrm{wt} . \%)$ and $\mathrm{Pb}(1.2-3 \mathrm{wt} . \%)$. Helmet A instead has $10 \mathrm{wt} . \% \mathrm{Sn}$ and almost $1 \mathrm{wt} . \% \mathrm{~Pb}$. An unprovenanced helmet (cat. no. 100), related to crested helmets of Type Biebesheim, was analysed with AAS by Born and Hansen ${ }^{747}$ Despite 7 wt.\%

741 Mödlinger 2014a.

742 Born - Hansen 1992, 346.

743 Lutz 2011.

744 Lutz 2011, 115, fig. 1.

745 Lutz 2011, tab. 1.

746 Jorns 1964, 76-85; the analytical method is not mentioned.

747 Born - Hansen 2001, 270, no. 1125. 


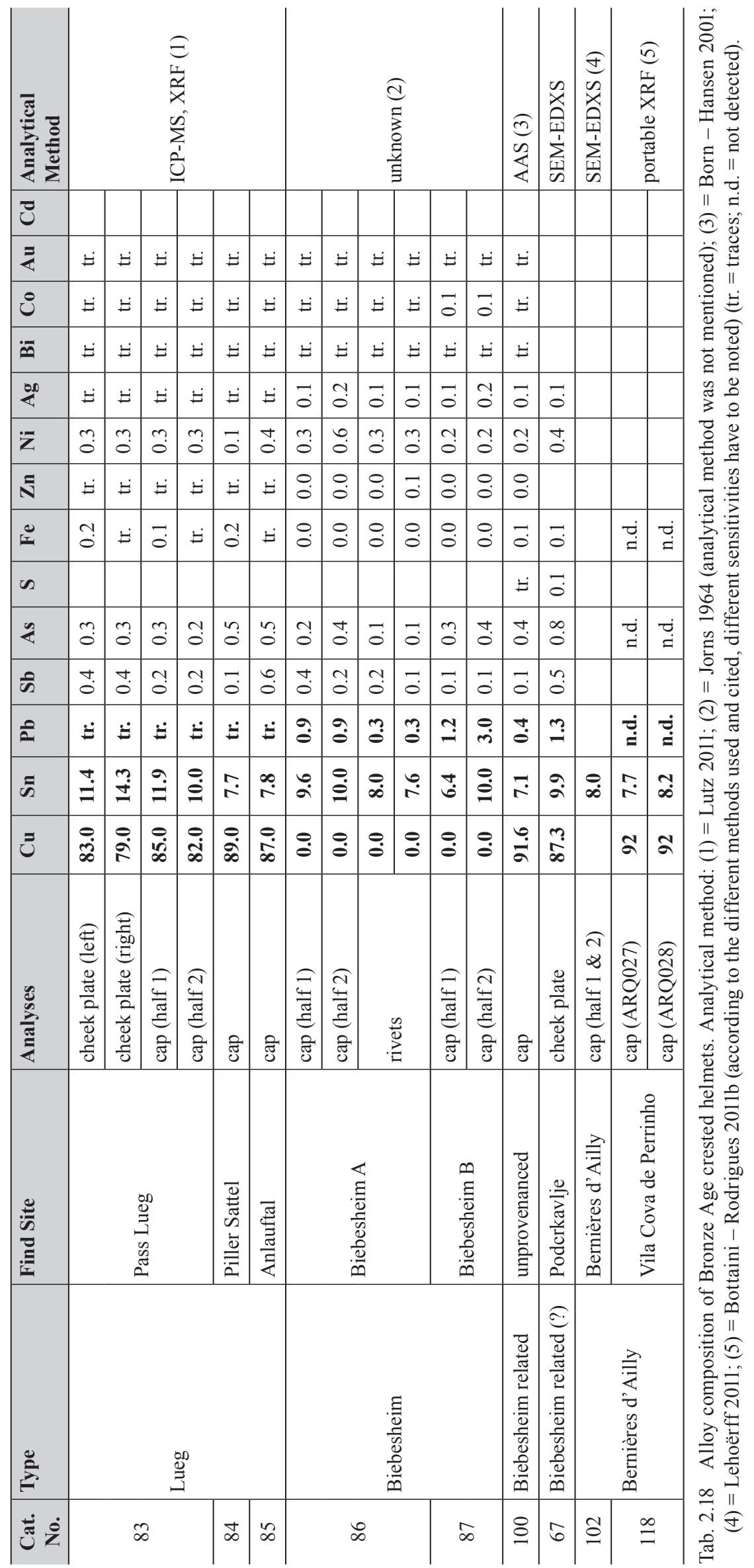



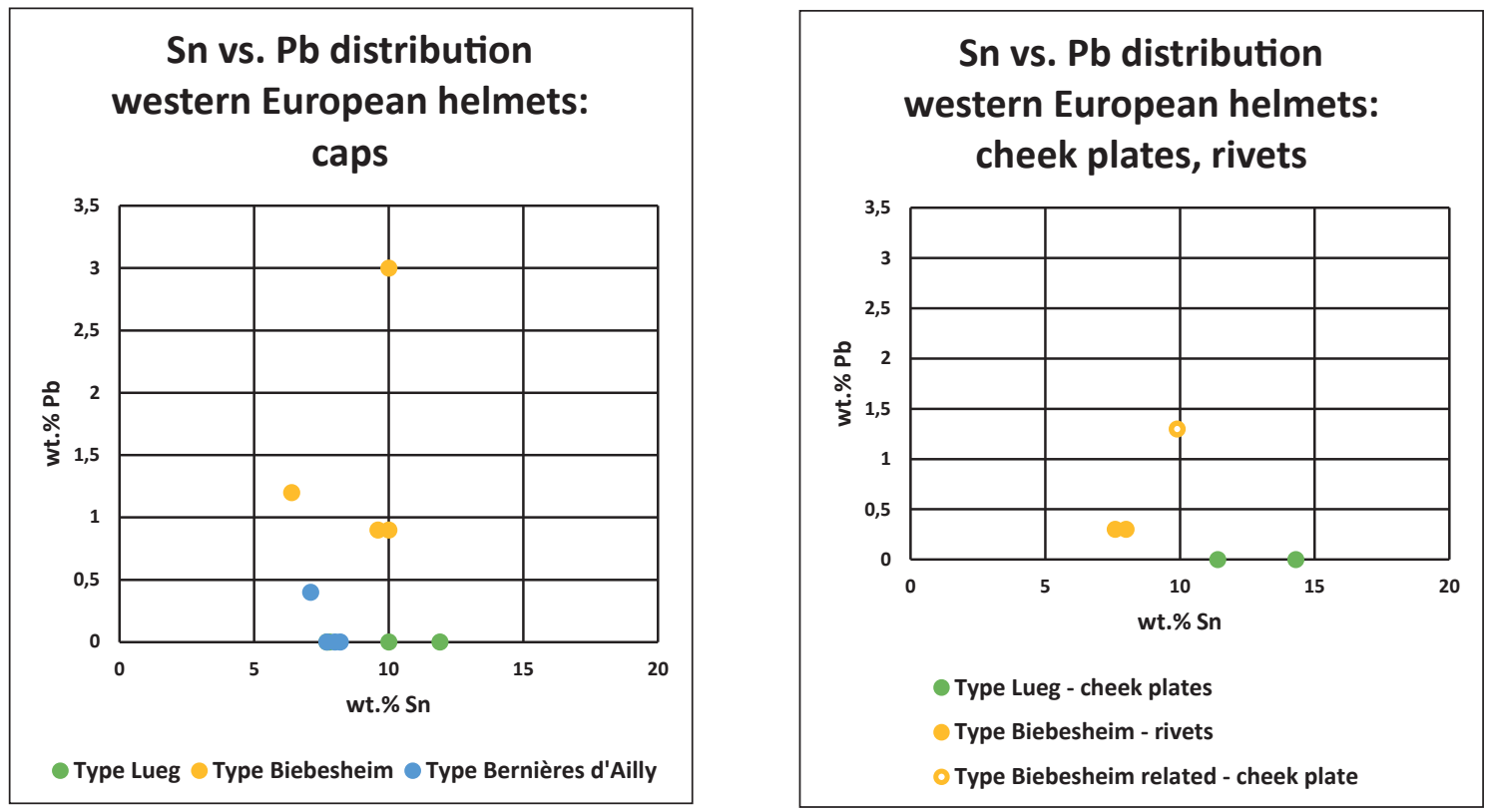

Chart 2.2 Sn vs. Pb distribution of western European helmets. The base of Chart 2.2 are the values indicated in Tab. 2.18. The uncertainty range for the SEM-EDXS is about 5\%. Left: Sn vs. Pb distribution of the cap of the helmets. Right: $\mathrm{Sn}$ vs. $\mathrm{Pb}$ distribution of the cheek plates and rivets of the helmets.

Sn, no major or minor alloys were detected (Tab. 2.18). The earlier analysis of the two Biebesheim helmets ${ }^{748}$ must be used with a certain amount of caution, due to the unknown analytical method used, and in light of the lack of further analyses on Western European crested helmets. These helmets show (as the potentially related cheek plate from Podcrkavlje) a relatively high amount of $\mathrm{Pb}$ of 1-3 wt.\%, which might contribute toward the chronological classification of this helmet type, as leaded bronze appears in large numbers during $\mathrm{Ha}$ B1 in both central Europe and western Europe (relative with the Wilburton phase) ${ }^{749}$ However, considering find spot and connection to the Atlantic Bronze Age, the $\mathrm{Pb}$ amount does not necessarily point to a potentially later production date. ${ }^{750}$

The crested helmets of Type Bernières d'Ailly from Vila Cova de Perrinho were analysed via portable XRF. ${ }^{751}$ Apart from copper, only Sn was detected and is present in both fragments around $8 \mathrm{wt} . \%$. The helmets from Bernières d'Ailly, Armancourt and Montmacq, are currently undergoing analyses using PIXE, radiography, SEM-EDXS and metallography. The publication is in preparation. ${ }^{752}$

As visible in Chart 2.2, even though only a small number of analyses have so far been carried out on western European helmets, a certain trend is evident concerning the amounts of Sn and $\mathrm{Pb}$ used in the manufacture of the different helmet types: Type Biebesheim contains in comparison with Type Lueg and Bernières d'Ailly significantly more $\mathrm{Pb}$, whilst helmets of Type Lueg have more Sn than the other two types so far analysed. This will need to be confirmed through further analyses.

\subsubsection{Metallographic Characterisation and Construction - Cap Helmets}

Different parameters and characteristics of the studied objects, and here in particular the helmets, enable us to reconstruct aspects of their manufacture. The most important basis for this

\footnotetext{
748 Jorns 1964.

749 See Gerloff 2010, tab. 3.

750 Northover 2012, 174-183.

751 Bottaini-Rodrigues 2011b, tab. 1.

752 The publication is in preparation by Brun et al.
} 
are the chemical and metallographic characterisation, the observation of the object's surface in order to detect manufacturing traces, and the objects dimensions, such as weight and thickness. Ten helmets were sampled for metallographic studies. Some helmets could unfortunately not be sampled, since the museums concerned did not want their condition to be compromised, or the helmets had suffered some recent heat treatment during restoration (such as the unprovenanced helmet cat. no. 51), or were not accessible because the helmets are held in private collections.

Though typologically associated with western European helmets, most of the helmets of Type Mantes and Type Montbellet underwent the same production processes as other cap helmets, with the exception of the small, central ridge on the cap, or in the application of the knob or socket.

All prehistoric bronze objects were initially cast, and, if necessary, deformed to give them their final shape. The first step in the production of a helmet was in casting a thin circular disc (Fig. 2.42). This was most likely achieved by means of a (bivalve) mould made of fired clay or lost-wax-casting, since no stone moulds for the production of thin, flat bronze discs or ingots are known. Also sand casting (both as an open or closed cast) cannot be completely excluded, but unfortunately leaves no traces in the archaeological record. The use of an open mould, however, is less likely due to the oxidation of the surface, if not charcoal was immediately placed on top of the molten metal to prevent rough surface and oxidation. The thickness and shape of the ascast plate, in respect of the optimum filling of the mould, depends on several factors such as casting temperature, thermal properties, shape and orientation of the mould, pouring rate and, of course, the composition of the alloy.

Since bronze is unlikely to be made thicker after casting (apart from some stiffening of the edges), the thickness of the cast bronze plate could not have been thinner than the rim of the helmet. This provides a minimum thickness of the cast bronze plate of at least $4-5 \mathrm{~mm}$ for helmets of Type Pişcolt, min.1-2mm for helmets of Type Paks, min. 2-3mm for helmets of Type Oranienburg, and at least $1-4 \mathrm{~mm}$ for helmets of Type Nagytétény. For western European helmets of Type Montbellet and helmets of Type Mantes (some of them as massive as helmets of Type Pişcolt), the thickness of the rim ranges from $1-5 \mathrm{~mm}$. Also, the diameter of the cast bronze disc used in the production of helmets varies. Knowing the weight of the helmet made from this disc, and the minimum thickness of the rim, we can calculate a minimum diameter for the cast bronze discs; which have a diameter which ranges between $20-30 \mathrm{~cm}$. We must also make extra allowance in these estimations for perhaps several more centimetres, so cracks caused by material tension during the deformation process could be chiselled off before they reached too deep into the centre of the disc or bronze sheet.

Different from the rivet holes on the significantly lighter, thinner and smaller cap helmets, the rivet holes of helmets of Type Pişcolt were already present in the mould model, as it is indicated by their mainly smooth edges and oval shape, orientated so as to point from the rim to the knob, as if they were stretched in the direction of the top of the helmet. The presence of rivet holes already in the mould supports the use of lost wax casting for the cast bronze plate used in the production of helmets of Type Pişcolt. The only exception might be the unprovenanced helmet of Type Pişcolt (cat. no. 55). It shows rivet holes, which were already present in the cast bronze disc and eventually enlarged during the following manufacturing process. This was possible only since this helmet is much thinner at the rim than all other helmets of Type Pişcolt. On all other cap helmets, the rivet holes were usually punched through from the outside to the inside of the sheet after shaping and decorating were done.

The helmets of Type Pişcolt with the lowest amount of Sn (cat. nos. 46 and 52 with 7-8.3 wt.\% Sn), also contained over $1 \mathrm{wt} . \%$ of $\mathrm{Pb}$, which increased the casting fluidity. ${ }^{753}$ Nevertheless, the unprovenanced helmets of Type Pişcolt cat. no. 51 and 52 are covered with pores and small casting defects. Most of the cap of the helmets contain 9-12 wt.\% Sn. The bronze with 10

\footnotetext{
753 Piccardo et al. 2009; Piccardo et al. 2010.
} 


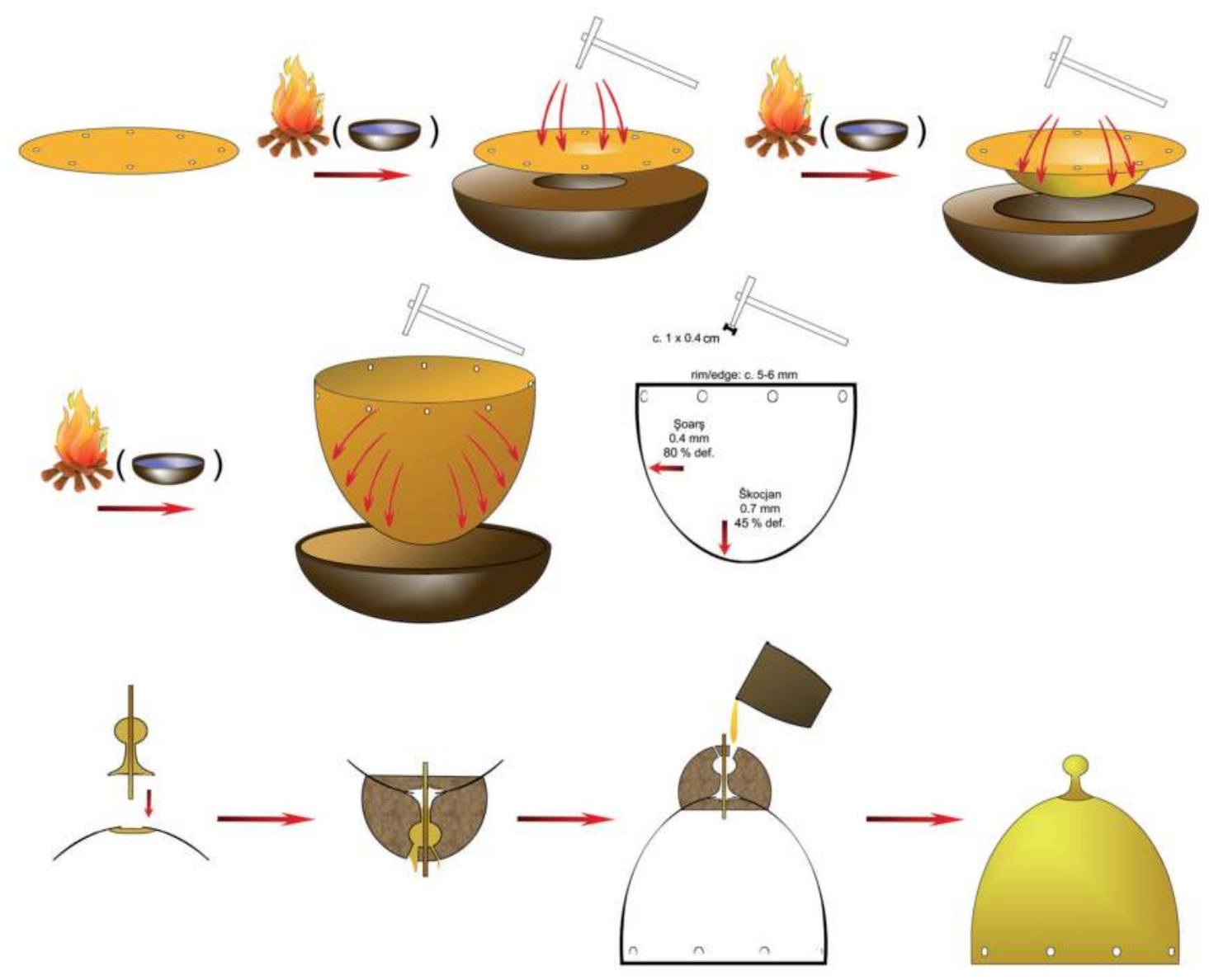

Fig. 2.42 Reconstruction of the manufacturing process of the cap helmets, demonstrated with the manufacture of helmets of Type Pişcolt (modified after Mödlinger 2014a). The graph includes the amount of deformation noted on the samples from the helmets from Škocjan and Şoarş. The rivet holes were pre-cast only for helmets of Type Pişcolt, not for the other cap helmets (for other cap helmets, they were punched through once the cap was finished). The round bronze disc was then deformed by deep-drawing or die forging most likely over a wooden die, as also indicated by the direction, form and cross-section of the hammering traces. Forming the cap lead to differing thickness of the cap. As a final step, the knob was cast-on (see also Fig. 2.49).

wt.\% Sn does not only have the best fluidity values of the $\mathrm{Cu}-\mathrm{Sn}$ system, but also the most equilibrated and optimum material characteristics for undergoing further working procedures.

After casting the disc, chiselled off parts (e.g. sprue, flashing) were collected and potentially used for the cast-on of the knob, as the similar alloy composition of both cap and knob of some of the helmets suggests (e.g. the unprovenanced helmet of Type Paks cat. no. 20, as well as the helmets of Type Pişcolt cat. nos. 46 and 52).

To give the cast plate a three-dimensional, bowl-like shape, the flat plate had to be severely deformed. All cap helmets show a thicker and more massive rim (which helped stiffen the helmet), which gets thinner towards the top of the cap. At the top of the cap, the thickness again increases and the metal is less deformed. The varying thickness of the helmet caps indicates instead the use of an open die for further shaping (deep-drawing), than the primary use of a high bowed stake with round face. The varying thickness is clearly visible on more massive helmets, such as the helmets of Type Pişcolt, but also helmets of Type Montbellet, like that from Thonberg. ${ }^{74}$ According to the application of deep-drawing (since it would have been difficult to reach the top of the cap with the hammer during driving in an open die), this zone remains slightly thicker than the central part.

754 Schauer 1982c, fig. 10. 
Conversely, the use of a high bowed stake with round face would have resulted in the production of a much thinner top to the cap. If we assume that the helmets were made from a circular flange cut out of a previously made thin sheet, which was then was deformed by 'raising', there would be no such difference in metal deformation and thickness. The remains of hammering traces inside the helmets (even in really thin ones), however, indicate the use of deep-drawing instead of rising as a shaping technique; with the use of a high bowed stake with round face, no hammering traces would be found inside the helmet but would occur on the outside (if not flattened and polished away during further work on the surface). Massive hammering traces are particularly evident on the inside of helmets of Type Pişcolt (Fig. 2.3). Also, vertical cracks due to material stress during die forging are noted on the helmets of Type Pişcolt from Hajduböszörmény, Şoarş, Endröd ${ }^{755}$ and an unprovenanced helmet (cat. no. 51), ${ }^{756}$ as well as on older helmets. The production of the helmets resembles that of the $5^{\text {th }}$ century BC bronze cauldron from Estissac, France, which is just slightly wider than the helmets. ${ }^{757}$

The reduction of thickness and the shaping of the cast bronze disc was achieved by several cycles of annealing, cold hammering and most likely also water quenching of the bronze - the latter at least for the first working steps involving massive deformation of the as-cast plate. Hot deformation can be excluded according to the composition of the bronze and the high thermal conductivities of the alloys.

According to the cap's Sn-amount, annealing took place between $550-630^{\circ} \mathrm{C}$. This broadly overlaps with the temperature range of $520-586^{\circ} \mathrm{C}$, were the solubility of tin achieves its maximum with 15.8 wt.\% in copper. Annealing, for example, with a tin bronze with 14 wt.\% Sn, below $300^{\circ} \mathrm{C}$ results in the formation of the unwanted, brittle $\delta$-phase at the $\alpha$-grain boundaries, which significantly decreases the workability of the alloy. An annealing temperature above $590^{\circ} \mathrm{C}$ instead results in the formation of a second phase ( $\beta$-phase). Since $\beta$-phase has a body centred cubic lattice, it can be deformed a very similar way as the $\alpha$-phase, characterised by a face centred cubic lattice. ${ }^{758}$ However, if during the annealing steps the temperature remains circa at $550 \pm 10^{\circ} \mathrm{C}$ (according to the alloy composition), no further $\beta$-phase is produced. To lock all possible solid state transformation of the $\beta$-phase eventually formed (mainly after solidification because during annealing it should be avoided), or of the $\alpha$-solid solution (where the Sn solubility decreases with the temperature below $520^{\circ} \mathrm{C}$ ), the bronze is quenched after each thermal treatment. Quenching between $500-600^{\circ} \mathrm{C}$ actually prevents the formation of the brittle $\delta$ - and $\varepsilon$-phases. ${ }^{759}$

The micro-samples of the ten helmets studied were taken from the cap of two helmets of Type Oranienburg (Sâg and Spišská Belá), five helmets of Type Paks (Veliko Nabrđe, Poljanci I, Strassengel) and two helmets of Type Pişcolt (Škocjan and Şoarş). The knob of the helmet of Type Oranienburg from Sâg, and two cheek plates from helmets of Type Paks (Wöllersdorf and Hočko Pohorje), were also analysed.

According to the microstructure presented in the following we can reconstruct the thermomechanical history of each helmet. Microstructural and compositional features of the cross sections of the helmet samples generally show a still inhomogeneous solid solution with deformed, polygonal recrystallised crystals with slip lines, indicating cold deformation as a final working step, visible for example on the samples from the helmets from Poljanci I (Fig. 2.43 with intergranular corrosion, recrystallised grains with slipping bands, and mechanical twins crossing each other), Strassengel and Spišská Belá (Fig. 2.44), and Veliko Nabrđe (Fig. 2.45).

On the helmet from Şoarş, $\mathrm{Pb}$ is regularly distributed in the metallic matrix in the form of fine, globular inclusions. The microstructure of the tin-bronze matrix consists of polygonal grains with slip bands and mechanical twins which are typical of recrystallisation annealing

\footnotetext{
755 Mödlinger 2014a.

756 Born - Hansen 1992, 343.

757 Piccardo - Pernot 1997; Pernot 2000, fig. 1.

758 Piccardo et al. 2010, 12.

759 Ammannati et al. 2006; Piccardo et al. 2010, 14.
} 


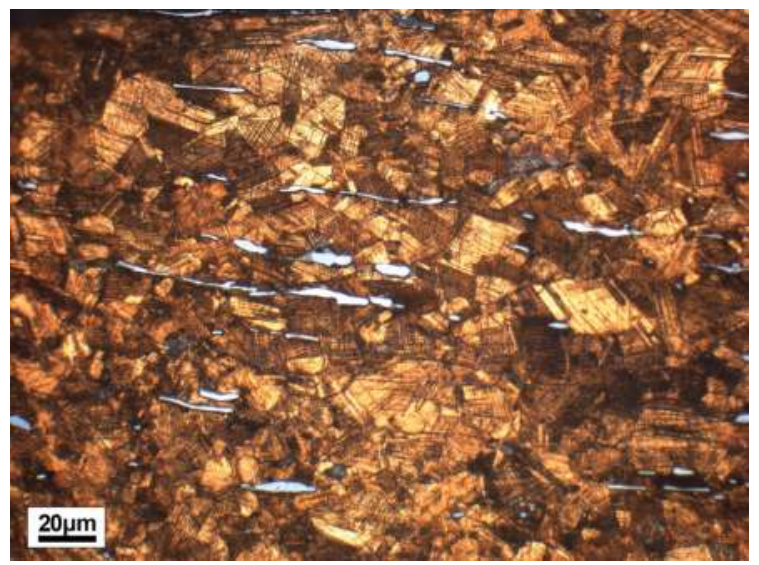

Fig. 2.43 Microstructure from the cap of the helmet from Poljanci I. The sample was taken close to the rim of the helmet and etched with $\mathrm{FeCl}_{3}$. Elongated $\mathrm{Cu}_{2-\mathrm{x}} \mathrm{Fe}_{\mathrm{x}} \mathrm{S}$-inclusions (light grey) are visible, as well as polyedric recrystallised $\alpha$-grains with twins and high amounts of strain lines, the latter indicating a final deformation below the recrystallisation temperature.
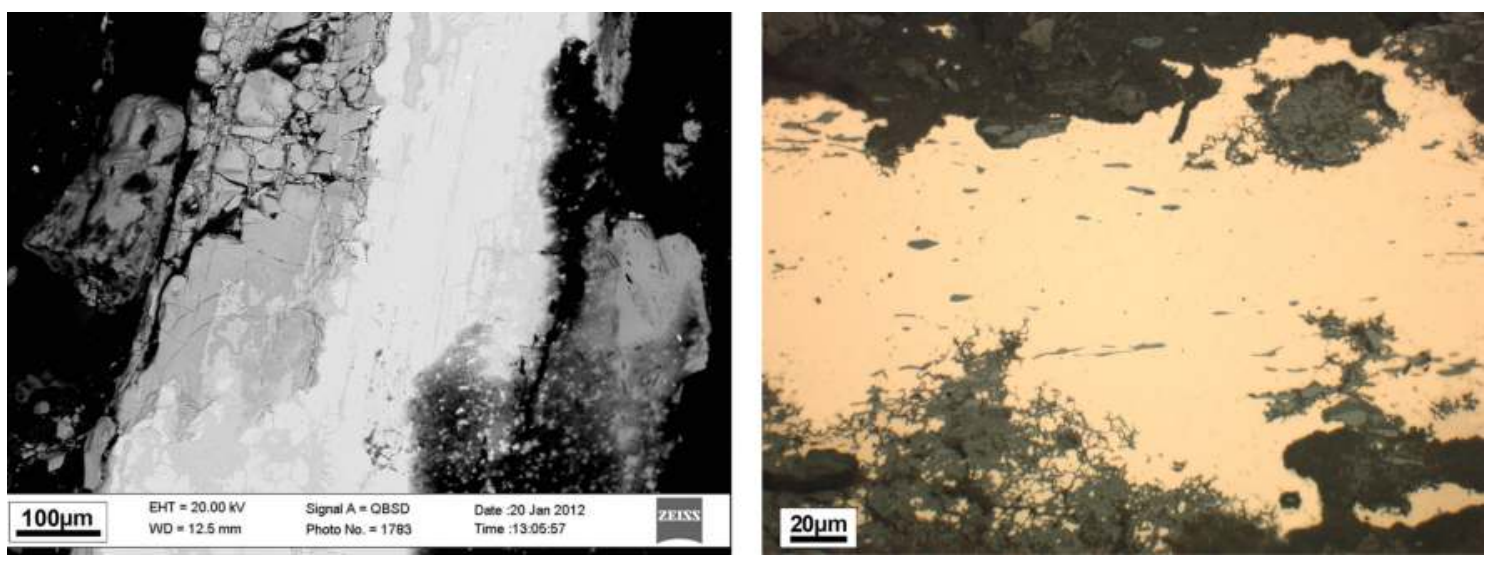

Fig. 2.44 Intergranular corrosion shows recrystallized grains with slipping bands and mechanical twins crossing each other. Both samples were taken close to the socket/knob and are unetched. The SEM-image of the helmet from Strassengel (left) shows the microstructure with elongated $\mathrm{Cu}_{2-\mathrm{x}} \mathrm{Fe}_{\mathrm{x}} \mathrm{S}$-inclusions (light grey 'lines'), a few $\mathrm{Pb}$-inclusions (white spots on the top), and a significant level of corrosion (dark and light grey). The highly elongated $\mathrm{Cu}_{2-x} \mathrm{Fe}_{x} \mathrm{~S}$-inclusions indicate a massive deformation in the area sampled. The sample from the helmet from Spišská Belá (right) show in the light optical microscope much less deformed $\mathrm{Cu}_{2-\mathrm{x}} \mathrm{Fe}_{\mathrm{x}} \mathrm{S}$-inclusions (dark grey spots in the light yellow metal matrix), and a very fine grain size. The grains as well as their internal structure (twins, strain lines) are outlined by corrosion.
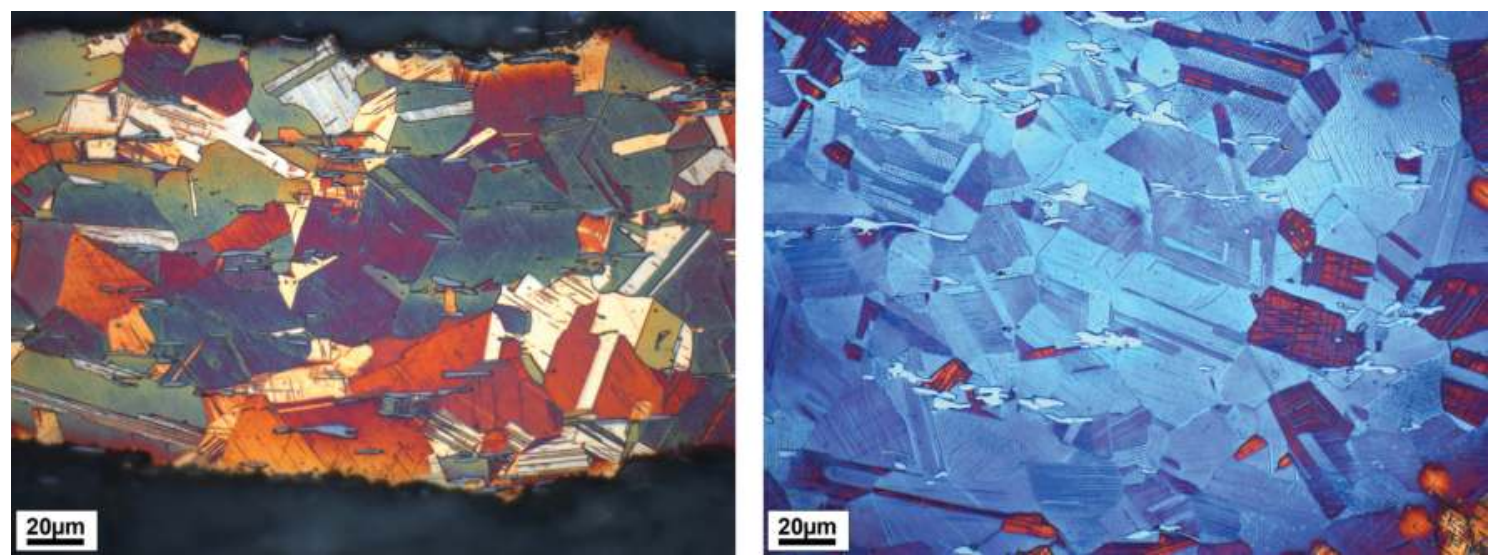

Fig. 2.45 Microstructure from the cross-sections of the cheek plate from Hočko Pohorje (left) and of the helmet from Veliko Nabrđe (right). The sample from the helmet was taken close to the rim of the helmet. Both samples were etched with Klemm II. Compared to other samples (see e.g. Fig. 2.43) the level of deformation of $\mathrm{Cu}_{2-\mathrm{x}} \mathrm{Fe}_{\mathrm{x}} \mathrm{S}$ inclusions, which indicate the total deformation applied to the metal sheet, is low. 
followed by a light mechanical deformation as shown by slip bands and mechanical twins without affecting the lead inclusions shape (Fig. 2.46). As indicated by annealing twins slip lines, the last step of work on the cap of the helmet from Škocjan was a light cold hammering. Close to the surface, the grains are richer in Sn than in the central zone of the cap, rounded and unde-

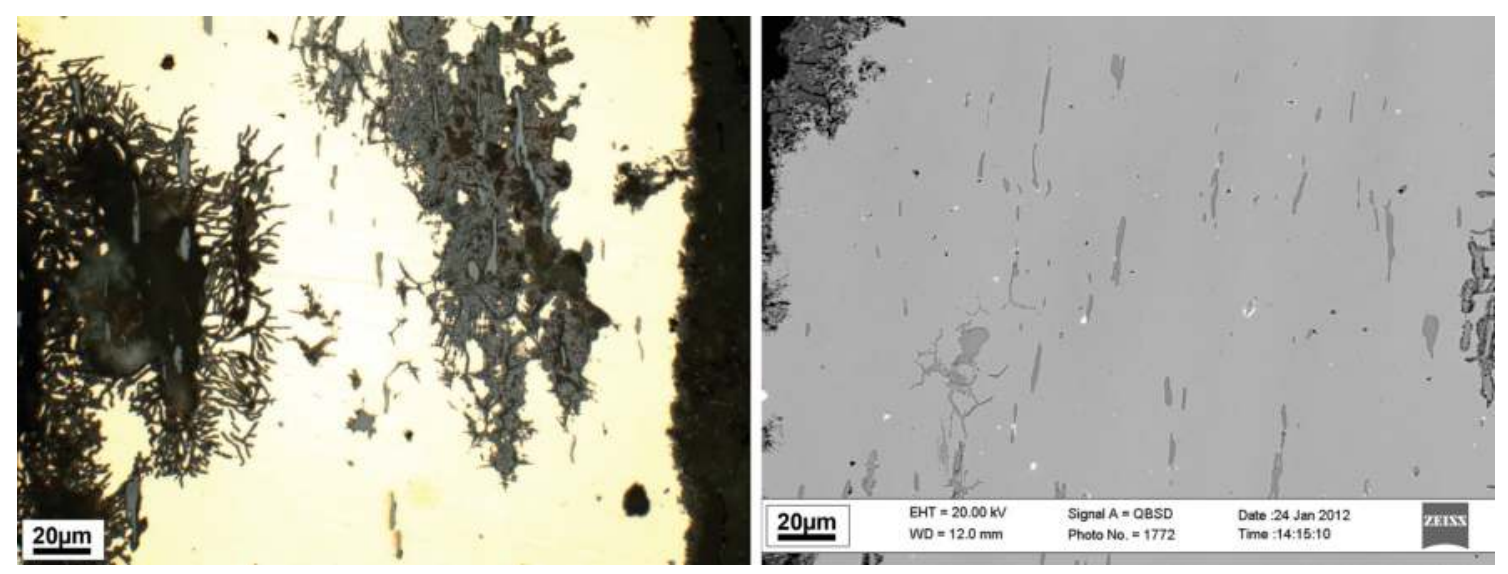

Fig. 2.46 Helmet from Şoarş, Romania. SEM-picture of the micro-sample from the mid of the cap (right). The white dots are $\mathrm{Pb}$-inclusions, the elongated, light grey areas are $\mathrm{Cu}_{2-\mathrm{x}} \mathrm{Fe}_{\mathrm{x}} \mathrm{S}$-inclusions indicating the total deformation of the cap of $67 \%$. Corrosion is outlining the grain structure. The image at the left shows the unetched microstructure in the light optical microscope. On the left, we see bacterial induced corrosion, so called 'tentacle' corrosion, which appears in oxygen-low environments (as described in Piccardo et al. 2013). In the centre of the sample, further corrosion is outlining the grain structure with twins and strain lines, the latter indicating a final deformation below the recrystallisation temperature.
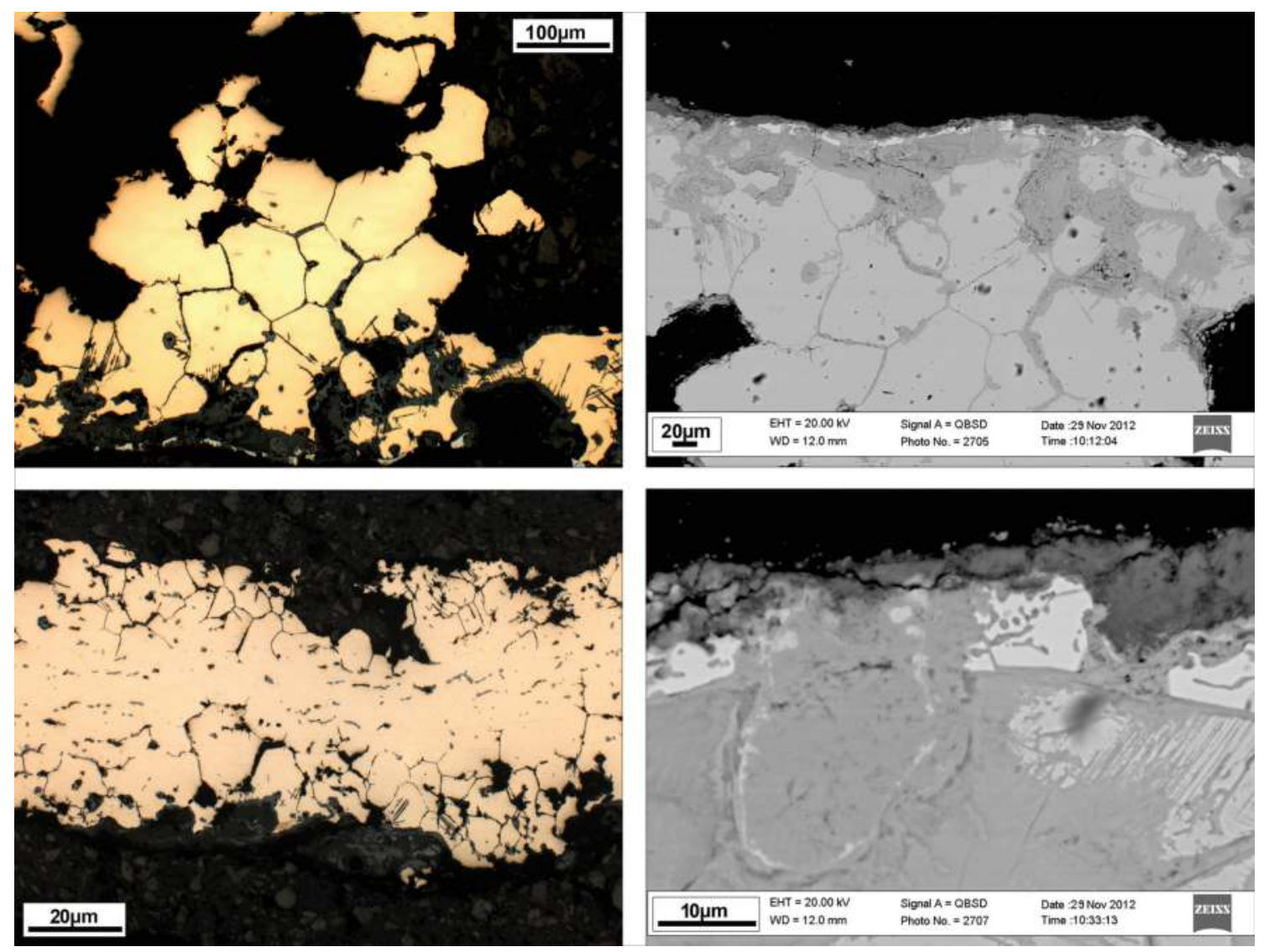

Fig. 2.47 Helmet from Škocjan, Slovenia. The bronze sheet of the cap is severely corroded and only light deformed (c. $45 \%$ ). Note the inter- and intra-crystalline corrosion following the metal structure and the remains of $\alpha+\delta$ eutectoid (light grey) on the surface of the cap (on the picture above left: at the bottom of the sample; on the two SEM images on the right on the top of the sample the white layer). 

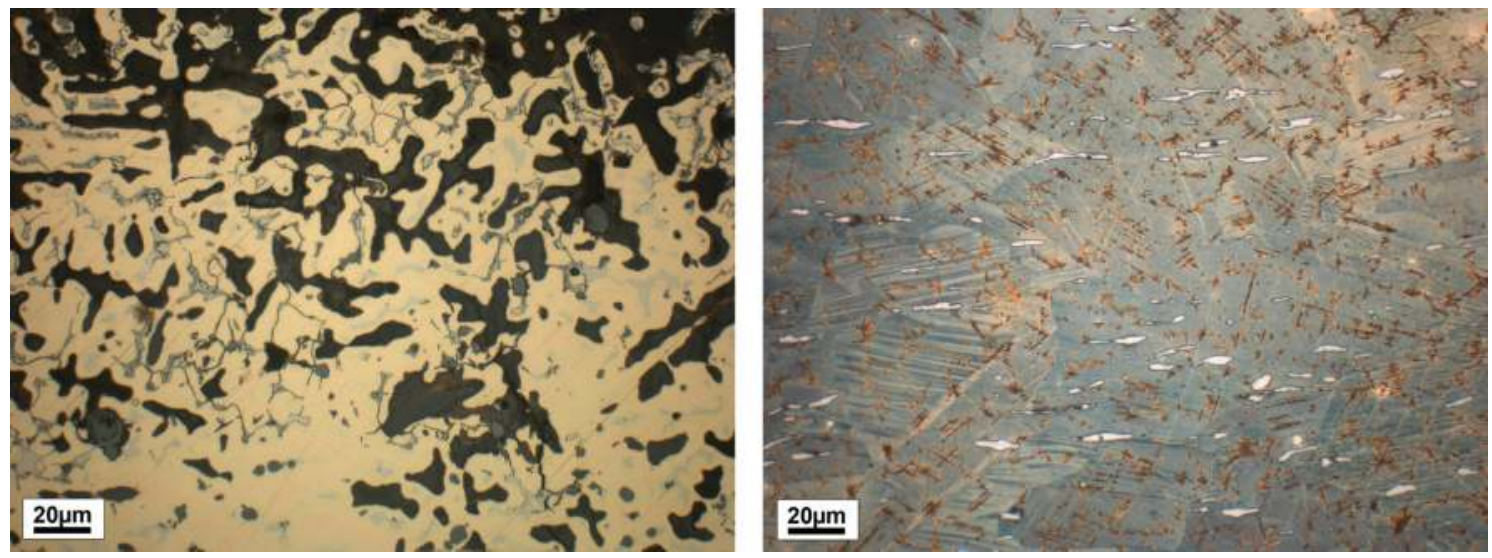

Fig. 2.48 Unetched microstructure of the cast-on helmet knob from Spišská Belá (left). Between the dendrites, $\alpha+\delta$ eutectoid is visible (light grey). $\mathrm{Cu}_{2-\mathrm{x}} \mathrm{Fe}_{\mathrm{x}} \mathrm{S}$-inclusions (grey) are, since the knob was not deformed, still round. Corrosion is appearing dark grey. On the right, the microstructure of the cheek plate from Wöllersdorf, etched with Klemm II (right). $\mathrm{Cu}_{2-\mathrm{x}} \mathrm{Fe}_{\mathrm{x}} \mathrm{S}$-inclusions (light grey) are elongated and indicate a certain level of deformation. The rather large grains show both twins and strain lines, the latter indicating a final deformation below the recrystallisation temperature.

formed, as 'frozen' during their growth. This indicates a local thermal treatment at high temperature, most likely as a result of the cast-on process of the knob. This is supported by the detection of a less than $10 \mu \mathrm{m}$ layer of $\alpha+\delta$ eutectoid on the outer surface of the cap close to the knob (Fig. 2.47). Today, only the $\delta$-phase with its much higher resistance to corrosion is still present. The Sn needed for the formation of the $\alpha+\delta$ eutectoid on the cap's surface derives from the knob during the cast-on process due to Sn-sweating. ${ }^{760}$

The metallurgical analyses showed the same modus operandi for the two cheek plates studied from Hočko Pohorje and Wöllersdorf (Fig. 2.48, right): with the casting of a small, raw disc with at least $2.8 \mathrm{~mm}$ of thickness, mechanical shaping by several steps of cold hammering and recrystallisation annealing probably followed by quenching in order to avoid the precipitation of brittle phases. The last step of thermomechanical treatment was a slight deformation.

As described above, to pass from the as-cast bronze disc to the final shape of the helmet's cap, several steps of cold deformation by hammering followed by recrystallisation annealing treatments were applied. The total amount of deformation applied can be calculated, as previously stated, by measuring $\mathrm{Cu}_{2-\mathrm{x}} \mathrm{Fe}_{\mathrm{x}} \mathrm{S}$-inclusions usually present in archaeological bronzes. The average SF (shape factor) of the sulphide inclusions and the corresponding percentage of reduction of the as-cast plate were calculated for every helmet cap fragment (Tab. 2.19).

\begin{tabular}{|c|c|c|c|c|c|c|c|c|}
\hline $\begin{array}{l}\text { Cat. } \\
\text { No. }\end{array}$ & Type & Find Site & Sampled Area & $\begin{array}{l}\text { Thickness } \\
\text { Cap (mm) }\end{array}$ & $\begin{array}{c}\text { Average } \\
\text { Total } \\
\text { Deforma- } \\
\text { tion (\%) }\end{array}$ & $\begin{array}{c}\text { Min. } \\
\text { Thickness } \\
\text { of as-cast } \\
(\mathbf{m m})\end{array}$ & $\begin{array}{l}\text { Thick- } \\
\text { ness } \\
\text { Rim } \\
(\mathrm{mm})\end{array}$ & $\begin{array}{c}\text { Sn wt \% } \\
\text { in Alloy }\end{array}$ \\
\hline 6 & \multirow{2}{*}{ Oranienburg } & Spišská Belá & cap close to knob & 0.3 & 79 & 1.7 & - & 8.6 \\
\hline 11 & & Sâg & cap close to knob & 0.4 & 88 & 3.2 & - & 10.3 \\
\hline 23 & \multirow{5}{*}{ Paks } & Veliko Nabrđe & cap close to rim & 1.0 & 78 & 5.7 & - & 10.8 \\
\hline 24 & & Poljanci I & cap close to rim & 0.5 & 85 & 4.4 & 3 & 10.9 \\
\hline 28 & & Strassengel & cap close to socket & 0.5 & 94 & 9.6 & - & 8.5 \\
\hline 30 & & Wöllersdorf & cheek plate & 0.7 & 77 & 3.2 & - & 7.1 \\
\hline 31 & & Hočko Pohorje & cheek plate & 0.4 & 83 & 2.8 & - & 12.2 \\
\hline 43 & \multirow{2}{*}{ Pişcolt } & Škocjan & cap close to knob & 0.7 & $40-45$ & 1.3 & - & 9 \\
\hline 47 & & Şoarş & cap central & 0.4 & 80 & 1.4 & $4-5$ & 10.3 \\
\hline
\end{tabular}

Tab. 2.19 Average total deformation and thickness of the as-cast rough plates used for the production of helmets.

760 Meeks 1986; Mödlinger 2014a. 
The average total deformation depends less on the tin amount of the helmets, and more on the thickness of the as-cast plate and the zone of the helmet the sample was taken from. The calculated SF cannot take into account the massive material losses occurring during shaping, such as the flaking off of oxides produced during the annealing process, polishing, grinding and use (Tab. 2.19). Opposite to the uniform deformation level of $80-95 \%$ of helmets of Type Paks, helmets of Type Pişcolt are less deformed (Şoarş, middle of the cap, 80\%; Škocjan, cap close to the knob, 40-45\%), which is in agreement with open die forging, where the rim and top of the cap are less deformed than the zone in between these. Helmets Type Pişcolt were certainly not cast directly into a bowl shape; this would have resulted in much lower differences in metal thickness and much less metal deformation as we can identify in the microstructure of the helmets of Type Pişcolt.

Knobs or sockets appear first on the helmet of Type Oranienburg and are commonly found on Late Bronze Age helmets in central and eastern Europe. The only helmets without knobs or sockets in eastern Europe are imported: one helmet of Type Montbellet from Szikszó (cat. no. 74), and an unprovenanced crested helmet, said to be from Hungary (cat. no. 100). Inside the hollow knob or socket, a plume could be placed. Helmets Type Nagytétény, however, do not provide a means by which such a plume could be applied; the solid knob was the only decorative element of the helmet.

So far, three different methods for applying these knobs and sockets can be identified:

1. The knob of the Aegean helmet cat. no. 1 is formed out of the same bronze sheet as the cap, but with double its thickness. ${ }^{761}$

2. The knob can be riveted on to the cap from the outside with several rivets (the earliest example so far known being the helmet of Type Oranienburg from Knossos) or from the inside with a single rivet (e.g. helmets of Type Nagytétény).

3. The knob or socket can be cast onto the cap. This is observed on all helmets of Type Oranienburg (apart cat. nos. 1 and 2), helmets of Type Paks, and helmets of Type Pişcolt (Fig. 2.49). None of the helmets demonstrate evidences of welding or soldering processes.

The different methods of joining the knob and cap might indicate different production centres for the two helmets of Type Oranienburg cat. nos. 1 and 2 than for the other European helmets, and might also represent certain developments in their technique of manufacture. Repairs have also been observed on the knobs. The knob from the helmet of Type Oranienburg from Žaškov shows a cast-on on the lower part. A drop of metal from the upper part of the socket is still visible inside the central hole, which formerly passed all the way through the spool-shaped knob.

Only one micro-fragment was taken from all the knobs of the cap helmets, since the macroscopic studies already clearly demonstrate cast-on knobs for all cap helmets, except the helmets of Type Nagytétény and the two helmets of Type Oranienburg cat. nos. 1 and 2. The knob from the helmet from Spišská Belá is as-cast, as is indicated by globular $\mathrm{Cu}_{2-\mathrm{x}} \mathrm{Fe}_{\mathrm{x}} \mathrm{S}$ inclusions, $(\alpha+\delta)$ eutectoid, and its dendritic structure (Fig. 2.48, left).

Their perfect geometry and the horizontal decoration of most knobs, as well as imprints or deformation of the latter, indicate the use of a hand-turned lathe for the production of the wax model, at least for helmets of Type Pişcolt. For helmets with cast-on knob, the production process is described in the following: the central wooden stick inside the knob was also used to fix the wax model on its axis once covered in clay. A hole was punched in the top of the helmet's cap. Inside the helmet, the top was filled with some drops of wax and then covered with clay. The wax knob with the surrounding clay placed on in. The wax knob and the wax disc inside the helmet were joined and the wooden stick inside the knob perforated the wax disc, which resulted in the flashing around the central hole, which is still visible today (Fig. 2.49). These were all then heated to pour out the wax. The clay was baked (with a temperature lower than the recrystallisation temperature of the alloy of the cap) but not burnt, in order to not harm the

$\overline{761}$ Buchholz et al. 2010. 

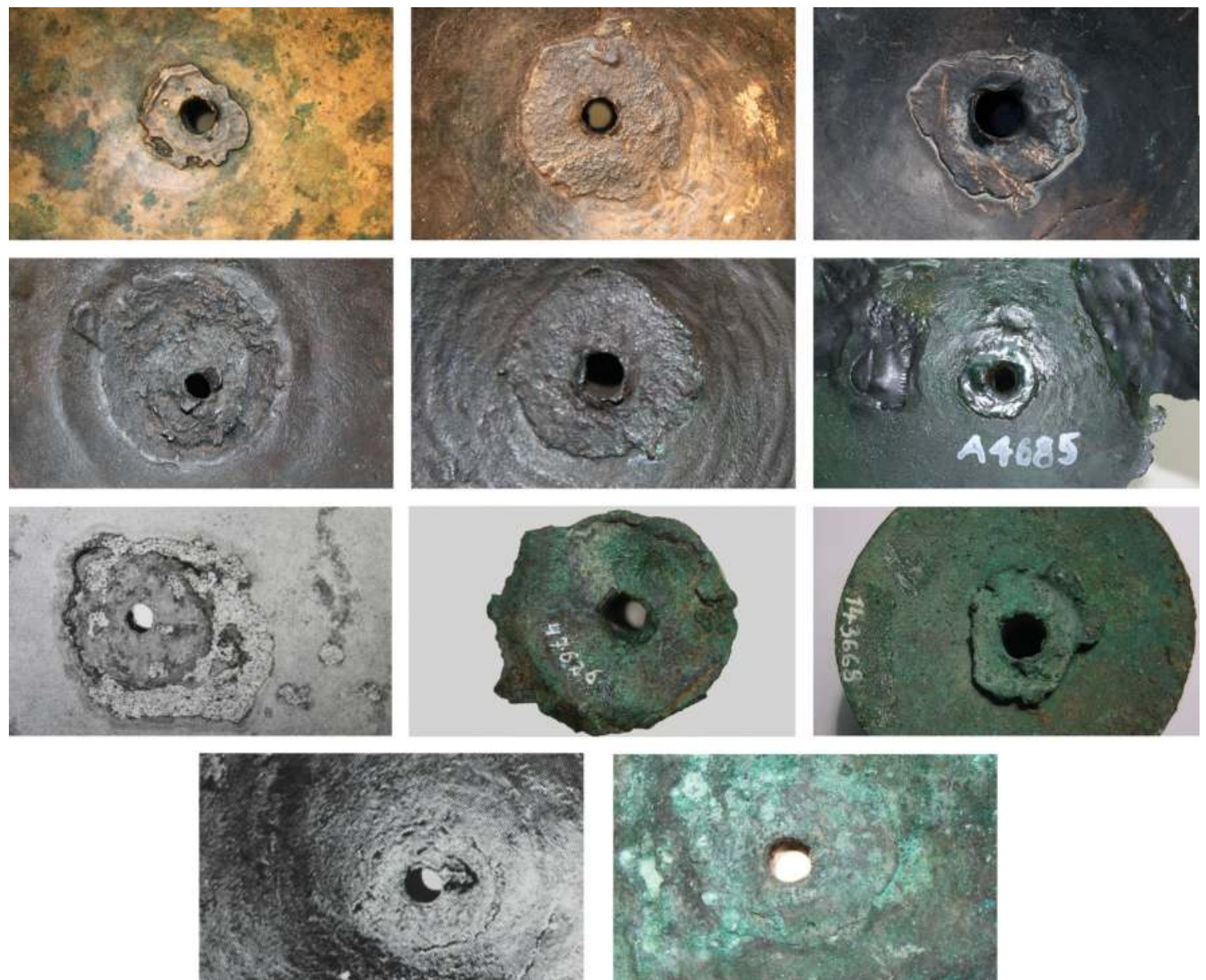

Fig. 2.49 Inside view of the cast-on knobs of helmetsof Type Pişcolt. Note the untreated surface of the knobs. From left to right. First row: Hajdúböszörmény, Mezőkövesd, Sehlsdorf. Second row: Endrőd, Pişcolt, Şoarş. Third row: unprovenanced helmet cat. no. 52 (after Born - Hansen 2001, fig. 203), Služín, Škocjan. Fourth row: unprovenanced helmet cat. no. 51 (after Born - Hansen 1992, fig. 8), unprovenanced helmet cat. no. 55.

bronze helmet or to alter the microstructure of the cap. To improve the attachment of the knob to the cap, the baked clay with the helmet was possibly warmed before casting, which slows down the cooling rate and thus reduces micro-segregation. Further traces of deformation visible in the microstructure of the cap close to the knob are the result of deformation applied after the cast-on of the knob (as seen on the cap from the Škocjan helmet) as a finishing process to remove or fix eventual casting defects. Usually, the knob was cast-on on the very top of the cap and cannot be moved even today. Only the knob of the unprovenanced helmet cat. no. 50 is slightly off centre, and the knob on one unprovenanced helmet (cat. no. 51) can be slightly moved. ${ }^{762}$

Once the final shape of the cap was achieved and the knob or socket applied, the outer surface of the cap was polished and smoothed. The final polishing of the surface was carried out with materials such as grinding stones, ceramics, sand, and clay, with the support of leather or other organic or inorganic substances to obtain an optimum smooth and shiny surface. Rivet holes punched through from the outside to the inside with a chisel (when wider) or a pin/punch (when smaller) on all but helmets of Type Pişcolt. If the decoration of the knob of helmets of Type Pişcolt turned out slightly blurred or distorted, it could be overworked with punches and chisels (Fig. 2.50).

762 Born - Hansen 2001, 248. 


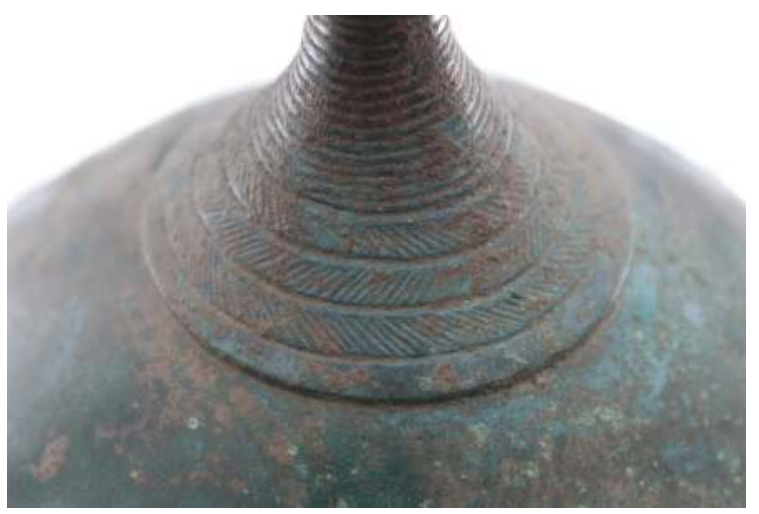

Fig. 2.50 The perfect geometry of all knobs, and the horizontal decoration of most knobs of helmets of Type Pişcolt, as well as imprints or deformation of the latter indicate the use of a hand-turned lathe for the production of the wax model. Once the knob was cast onto the cap, the decoration could then be adapted with a punch or chisel (e.g. for the herringbone motif), as noted on the depicted knob of the helmet of Type Pişcolt cat. no. 55.

The decoration applied on helmets of Type Paks enhanced the stiffness of the thin cap and permitted a much thinner rim than is known from the helmets of Type Oranienburg. Once the cap was finished, cheek plates, plume and inner organic padding, possibly with a neck guard, were, if necessary, attached to the helmet. Aristotle notes in his history of animals also the use of sponges for helmets and greaves to better absorb weapon impacts. ${ }^{763}$ If not a separate organic cap was worn under the helmet, the organic lining had to be attached directly onto the helmet with rivets all around the edge. Usually, the organic inlay was folded up onto the outside of the helmet, and therefore double-fixed to the rim. The presence of this organic material resulted, during deposition, to the formation of a different coloured 'band' on several helmets (i.e. consisting of different corrosion products) than that found on the rest of the outside of the cap (Fig. 2.51).

Cheek plates were attached to the helmet with bronze wire or directly to the inner organic padding. They were not attached directly with rivets to the helmet, since this would decrease the mobility of the plates. The rivets on helmet and cheek plates served to attach the inner organic padding, which might have consisted of linen, wool, fur, leather, rushes or similar materials, or a combination of these. If only small holes along the edge are present, they served to attach the inner organic lining of the cheek plates (Fig. 2.52).

\subsubsection{Metallographic Characterisation and Construction - Crested Helmets}

So far, microstructural analyses of crested helmets have been performed and published only for the three helmets of Type Lueg and one helmet of Type Bernières d'Ailly. ${ }^{764}$ The cap of the helmet from Pass Lueg was sampled twice, close to the rim. On the cheek plates, the inward bent rim was sampled. All samples show polygonal $\alpha$-grains with deformation twins and elongated $\mathrm{Cu}_{2-\mathrm{x}} \mathrm{Fe}_{\mathrm{x}} \mathrm{S}$-inclusions. The latter indicating a total amount of deformation of approx. 20-30\% on the right cheek plate and about $10 \%$ on the left cheek plate. ${ }^{765}$ The slip lines on both cheek plate samples are likely the result of the final deformation of the rim while folding it. In the left half of the helmet $(\alpha+\delta)$-eutectoid is still present, and indicates that the helmet did not undergo much recrystallisation (indicated also by the larger size of the grains). According to the elongation of the $\mathrm{Cu}_{2-\mathrm{x}} \mathrm{Fe}_{\mathrm{x}} \mathrm{S}$-inclusions, the right half of the helmet was much more worked than the left half, which might be also due to the lower tin content and therefore lower castability, resulting in an as-cast state which needed more deformation to reach the necessary size and thickness.

\footnotetext{
763 Aristotle V, 16 after Buchholz et al. 2010, 142.

764 Lippert 2010; Mehofer 2011.

765 Mödlinger - Piccardo 2013.
} 


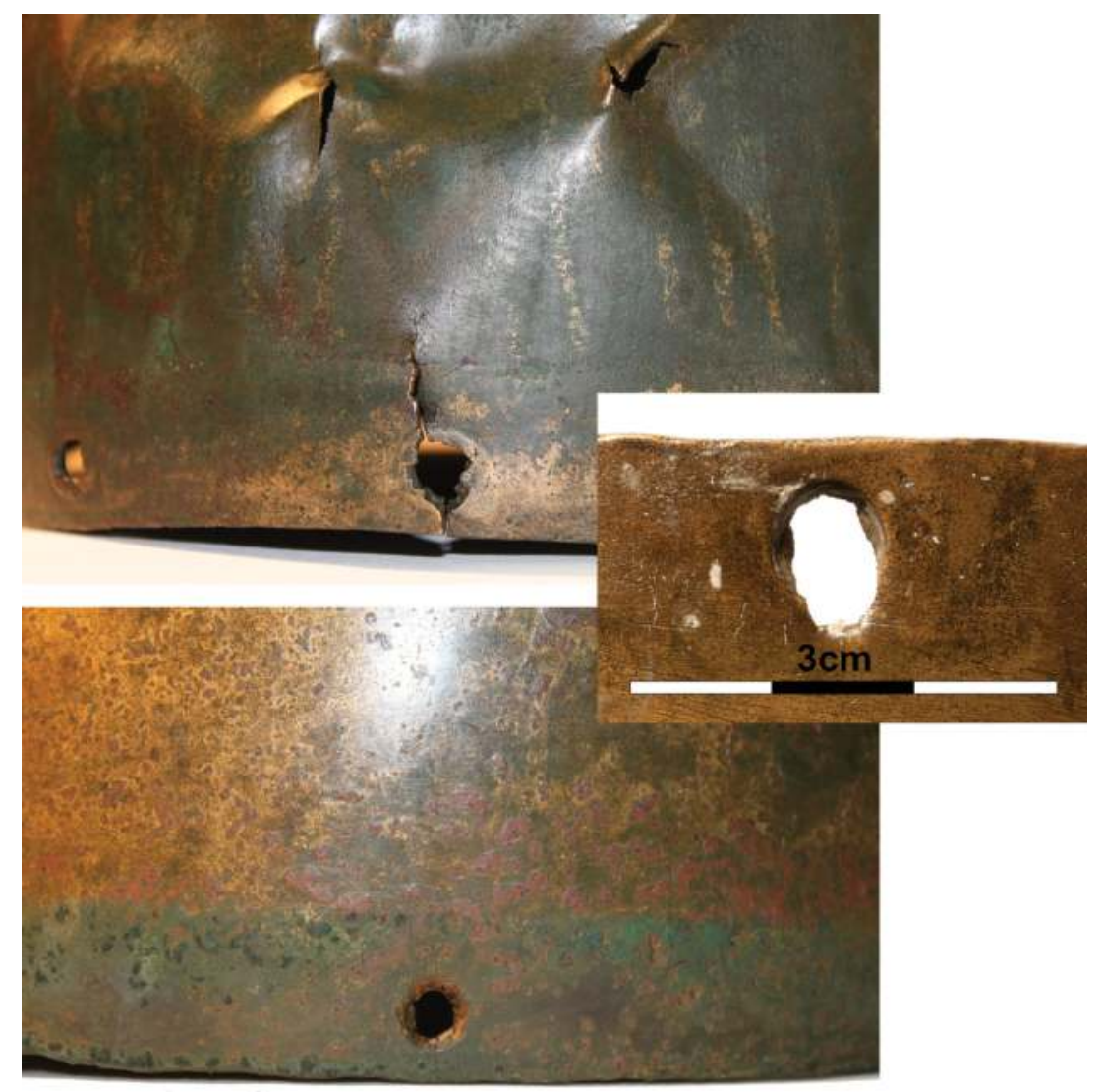

Fig. 2.51 Helmets of Type Pişcolt from Hajdúböszörmény (above left) and Mezökövesd (below left), both Hungary, from the outside; no scale. Different corrosion products relating to the organic inlay attached with rivets to the helmet. On the helmet from Hajdúböszörmény the drop-like traces of the removal of the corrosion during restoration (?) are still visible. In the small picture, one of the rivet holes from the helmet from Sehlsdorf, Germany (above right, (C) Landesamt für Kultur und Denkmalpflege Schwerin), is depicted.

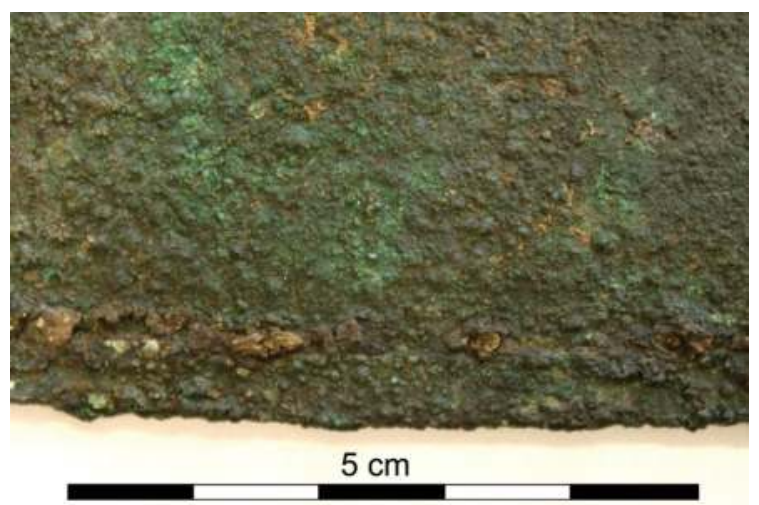

Fig. 2.52 Detail of the cheek plate from Ialysos, Greece (C British Museum, photo: M. Mödlinger).

The helmet from the Piller Sattel was sampled close to the right rim. ${ }^{766}$ In the area sampled, traces of hammering are visible. The microstructure consists of deformed $\alpha$-grains with deformation twins and slip lines. These might be as a result of processes of destruction before the deposition of the helmet. The almost globular $\mathrm{Cu}_{2-\mathrm{x}} \mathrm{Fe}_{\mathrm{x}} \mathrm{S}$-inclusions demonstrate a maximum amount of deformation of $10 \%$. Due to the distortion of the grains as a result of the purposeful destruction of the helmet, the hardness, at $173-180 \mathrm{HV},{ }^{767}$ is rather high, though the tin content

766 Mehofer 2011, 125.

767 Mehofer 2011. 
is low. The helmet from Anlauftal was also sampled. ${ }^{768}$ The deformation of the $\mathrm{Cu}_{2-\mathrm{x}} \mathrm{Fe}_{\mathrm{x}} \mathrm{S}$-inclusions reveals the total amount of deformation, which should be around $20 \%$. The last step of production was annealing followed by light deformation, as is indicated by the presence of slip lines.

From the helmet from Bernières d'Ailly, today kept in Rome (cat. no. 102), two samples of the two halves of the helmet were taken. ${ }^{769}$ According to the microstructure published by Lehoërff, the helmet was as a last step severely deformed, as indicated by the deformed grains and the clearly visible strain lines. The bronze sheet is said to have achieved a total deformation of $70-80 \%{ }^{770}$ The composition of the helmet was analysed by SEM-EDXS and said to be made of a binary alloy of $\mathrm{Cu}$ and $\mathrm{Sn}$ only, containing around $8 \mathrm{wt} . \% \mathrm{Sn} .{ }^{71}$ The presence of $\mathrm{Pb}$ (white spots) and $\mathrm{S}\left(\mathrm{Cu}_{2-\mathrm{x}} \mathrm{Fe}_{\mathrm{x}} \mathrm{S}\right.$-inclusions $)$ is indicated on the published SEM-image. ${ }^{772}$

\subsubsection{Notes on the Construction of the Pass Lueg Helmet}

Both halves of the crest and cap of the Pass Lueg helmet have wider lips under the crest toward the front and the back of the helmet, overlapping each other for about $1.4-2 \mathrm{~cm}$. These lips are fixed together with a rivet at the front and back of the helmet. Both rivets are hidden under the inside of the bent rim of the helmet. On the crest, the two halves of the helmet were fixed together by further overlapping, by means of rectangular parts of the right side of the helmet, which were bent over the left side. In total, there must have been ten such lips on the crest, four of which are still present, with the location of the remaining six visible through the different corroded areas. These overlapping parts occurred every $4-5 \mathrm{~cm}$. These overlapping parts are not present on crested helmets of Type Mantes, Biebesheim and Bernières d'Ailly: here the rim of one half of the helmets was bent completely over the edge of the other half along the crest zone.

The vertical convex rib on the central point of the crest was not only decorative, but served as stabilisation for the helmet. The edge of the Pass Lueg helmet was bent at different breadths along the inside, leaving no place for a possible organic inlay. It seems reasonable to assume a separate organic cap was used under the helmet instead. In contrast, the parts of the edges bent inside on the cheek plates did leave sufficient space to fix an organic inlay and to improve the comfort of the helmet when worn. Unlike the helmets from Anlauftal and Pass Lueg, it seems likely that an organic lining was attached inside the helmet from the Piller Sattel and fixed by means of the inward bent rim. ${ }^{773}$ Just below the central boss on each side, two rivet holes were attached to fix the cheek plates on the Pass Lueg helmet. On the left side of the helmet, rivet holes with an $8 \mathrm{~cm}$ distance from each other were applied. On the right side, the rivet holes have a distance of almost $7 \mathrm{~cm}$.

On both the front and back of the helmet, the outer overlapping part of the helmet, where it covered the opposite side of the cap, broke apart, resulting in the appearance on each half of an approx. $1.5 \mathrm{~cm}$ long horizontal crack. No traces of polishing are visible on the helmet's surface. However, inside the helmet circular traces of hammering parallel to the edge are visible. During the restoration of the helmet, two additional rivet holes were punched through, as the splashed metal sheet on the inner side of the helmet demonstrates (the 'new' rivet holes were not drilled, as previously suggested by Mehofer). ${ }^{74}$ They were probably applied to give the helmet with asymmetric cheek plates a more even look.

The upper ends of both of the Pass Lueg cheek plates were bent inwards up to a length of $1.4 \mathrm{~cm}$, leaving space for an organic filling (e.g. leather, linen or felt, or a combination of all). On

768 Mehofer 2011, 121, pl. 2.11-13 (wrong scale).

769 Lehoërff 2011. The exact sampling location was not indicated.

770 Lehoërff 2011, 48.

771 Lehoërff 2011, 48.

772 Lehoërff 2011, fig. 2 i.

773 Egg - Tomedi 2002, 549.

774 Mehofer 2011, 122. 
the front side of the cheek plates, four lips are still visible, and on the side bent back, five lips. On the front side, they are all in more or less the same position on both cheek plates, their position relative to the horizontal lines of pellets. On the left cheek plate, one lip is broken off; on the right cheek plate, two are broken off.

The compositional differences (Tab. 2.18), as well as the number of flanges and the technique of the rivet holes for applying the cheek plates, were previously thought to be an indication for the production of the helmet from the Piller Sattel in a different workshop than that to the other two helmets of Type Lueg. ${ }^{.75}$ It has to be pointed out that differences in the amount of tin for the production of the same type of objects alone are certainly not a sufficient base for the conclusion that the objects were produced in different workshops. However, since the three helmets show many similarities in manufacturing technique, all three helmets might easily have been produced in the same workshop.

Concerning the Pass Lueg helmet, it seems reasonable to assume that, for whatever reason, an earlier (original?) right cheek plate was substituted with a new one, which was produced as an exact replica of the left cheek plate, including the distance between the rivet holes. When the craftsman realised that the holes in the helmet were not symmetrical, he had to apply further rivet holes to the new cheek plate. The owner of the helmet then continued to use the helmet with asymmetrical cheek plates. ${ }^{776}$ Until now we do not know any complex decorated helmet which bears exactly the same decoration as any other helmet, nor with identical measurements in the execution of the decoration (the Pass Lueg cheek places are obviously identical - the lines and some circles being exactly the same size and in the same place, as one is a copy of the other, as described above). In a workshop, it is easy to suppose that the shaping process was more constant than the composition of the alloy. The latter might be affected by different cycles of recycling processes and supply, while the shaping method is instead part of a 'school' or tradition in the workshop.

775 Mehofer 2011, 127.

776 Another interpretation is offered by Kyrle 1918, Lippert 2011 and Mehofer 2011, who suggest that the 'newer' right cheek plate from the Pass Lueg helmet might have originally belonged to another helmet, the 'missing fourth helmet' of the Lueg type. 


\section{Cuirasses}

The description and interpretation of cuirasses follows in major parts the recent publication by the author in the Jahrbuch des Römisch-Germanischen Zentralmuseums. ${ }^{777}$ Bronze Age metal cuirasses are divided in the following into three main groups: Greek cuirasses, Carpathian cuirasses and western European cuirasses (Tab. 3.1). Each group differs from the other in terms of chronology, recovery, decoration and construction. The cuirasses consist of a breast- and a back plate, which were usually riveted together on the left side and shoulder. Only Greek cuirasses were furnished with additional bronze sheets in order to protect neck, shoulders, pelvis and upper legs.

The first metal armour appeared in Greece around $1500 \mathrm{BC}$, though the origins of plate armour might reach back as early as the $17^{\text {th }}$ century $\mathrm{BC}$, as indicated by the Mycenaean shaft grave breast plates. ${ }^{778}$ No precursors of cuirasses from any other region are known. The spectrum of Greek armour ranges from single body part protection to panoplies. ${ }^{779}$ This armour appears in LH II-IIIA2/B1 and was found more or less complete in both graves and settlement structures. Dendra and Thebes are still today the two most important find spots. The oldest plate armour, which derives from Dendra, grave 8, consists only of a right shoulder plate. However, the slightly later find from Dendra, grave 12, consists of a panoply of 15 separate pieces of bronze sheet armour. ${ }^{780} \mathrm{~A}$ further two similar panoplies derive from Thebes, Greece, and were found in the Municipal Conference Centre and the arsenal, respectively. The Theban cuirasses differ slightly from the Dendra panoply in the following respects: the belt plates are narrower, the shoulder guards are smaller and lacking the 'wings' which cover the Dendra panoply at the chest and back. The lighter construction of the latter already point to a development towards less weight and higher mobility. Potential band sheets of further Greek panoplies, which were fixed to the bottom of the cuirass (see the Dendra and Theban panoplies) have been found at Phaistos, Mycenae, and Nichoria. ${ }^{781}$ They all date to the short time frame of LH II-IIIB2 and served as protection for the lower parts of the body.

Shortly after the appearance of the first full metal cuirasses in Greece, plate armour was also adopted in central Europe, more precisely in the Carpathian Basin. A degree of adaptation accompanied it, including less weight and increased flexibility, with its reduction to a basic body cuirass, which permitted fast, flexible movement. Carpathian cuirasses are lightly decorated with pellet decoration, ribs, chased chevrons and stars, as well as sometimes decorative, riveted metal bands on the rim. The Bz D-Ha Al cuirasses were deposited either in associated deposits, in heavily fragmented form, or complete in rivers. The most well preserved Carpathian cuirasses are the river finds from the Danube ${ }^{782}$ and, as a Carpathian export, one from the Saône. Fragments of cuirasses are known from two Slovakian associated deposits, from Čierna nad Tisou and Ducové, and as a grave find from Čaka, again in Slovakia. Further fragments are known from the associated deposit from Nadap (Hungary), Ivančice 4 (Czech Republic), and a

\footnotetext{
777 Mödlinger 2014b.

778 Molloy 2013.

779 The term 'panoply', i.e. a complete suit of armour, is used in the following to distinguish between an armour protecting only the thorax (cuirass), and a set of armour protecting also shoulders, thorax, and upper legs (panoply). The best known example of such armour is the panoply from Dendra, grave 12 .

780 Verdelis 1967, 9-18.

781 Andrikou 2007, 403; Mödlinger 2014b, 6, 27.

782 Jankovits 1999/2000, 195, note 41; Szathmári 2003, 63; Petres - Jankovits 2014.
} 
possible cuirass fragment from the associated deposit from Winklsaß (Germany). The high level of fragmentation of most of these Carpathian cuirasses makes it hard to detect traces of manufacture and use, and therefore in these matters we restricted our study to the two complete preserved river finds from the Danube and the Saône.

The cuirass from the Saône at Saint-Germain-du-Plain, representing a direct Carpathian import, provide an important connection between the Carpathian cuirasses and the more recent western European cuirasses. From the same region, we know of 14 more or less complete western European cuirasses, which were found in three deposits, at Marmesse, Fillinges, and Jura (given the uncertainty of the finds location at Graye-et-Charnay or Véria, we will simply refer to them as the Jura cuirasses, with Jura A (cat. no. 137) and B (cat. no. 138) respectively). The cuirasses from Jura were formerly associated with Grenoble (cat. no. 137) and Naples (cat. no. 138) as find spots. Two further unprovenanced cuirasses (cat. nos. 135 and 136), characterised mainly by their Punktbuckel ornamentation, also belong to this group. Western European cuirasses are decorated all over with different sized bosses and pellets, arranged so as to form lines, water birds and circles. Their chronology is still under discussion, since they lack any useful associations which might have contributed to their dating.

\begin{tabular}{|c|c|c|c|}
\hline Cat. No. & Find Site & State & Type \\
\hline 122 & Dendra & GR & \multirow{4}{*}{ Greek cuirasses } \\
\hline 123 & Dendra & GR & \\
\hline 124 & Arsenal Thebes & GR & \\
\hline 125 & Municipal Conf. Centre, Thebes & GR & \\
\hline 126 & Čierna nad Tisou & SK & \multirow{9}{*}{$\begin{array}{l}\text { Carpathian } \\
\text { cuirasses }\end{array}$} \\
\hline 127 & Šarišské Michal'any & SK & \\
\hline 128 & Čaka & SK & \\
\hline 129 & Ducové & SK & \\
\hline 130 & Saint-Germain-du-Plain & FR & \\
\hline 131 & Pázmándfalu & HU & \\
\hline 132 & Nadap & $\mathrm{HU}$ & \\
\hline 133 & Ivančice & $\mathrm{CZ}$ & \\
\hline 134 & Danube at Pilismarót & $\mathrm{HU}$ & \\
\hline 135 & unprovenanced & & \multirow{5}{*}{$\begin{array}{c}\text { Western European } \\
\text { cuirasses }\end{array}$} \\
\hline 136 & unprovenanced & & \\
\hline $137-138$ & $\begin{array}{l}\text { Jura A and B; the cuirasses were found in Graye-et-Charnay or } \\
\text { Véria, France (formerly known as 'Grenoble' and 'Naples') }\end{array}$ & FR & \\
\hline $139-145$ & Fillinges (seven cuirasses) & FR & \\
\hline $146-152$ & Marmesse (seven cuirasses) & FR & \\
\hline
\end{tabular}

Tab. 3.1 Bronze Age European cuirasses.

It is often claimed that metal body armour derived from or replaced organic armour, and that this organic armour existed, due to reasons of lower cost and easier production, in far higher numbers than metal armour. ${ }^{783}$ This might be true but as such organic or leather armour has not survived in Europe, must remain a purely speculative proposition. Due to the qualities of organic materials such as leather and its wider availability, as testified also by the use of raw-hide in the manufacture of Irish and Aegean organic shields, however, such a proposition is very likely. There are a few finds of organic jerkins with bronze applications, representing a simplified expression of Bronze Age body armour, suggesting that they served a potential defensive function. Such bronze applications might also have served only a more aesthetic or ritual purpose,

783 Coles 1962; Chadwick 1976, 160; Harding 2000; Harding 2007. 
without any practical function as armour. These bronze applications are known mainly as bronze bands, collars or phalerae.

Two bronze bands or collars, which were attached around the neck on the front side, are known (Fig. 3.1). The first derives from a deposit from Hesselberg, Germany, and dates to Bz D. ${ }^{784}$ The decoration of the collar is similar to the cuirasses from Ducové and Saint-Germaindu-Plain. Another collar is known from a grave from hill $\mathrm{Cl}$ at Milavče, Czech Republic, and also dates to $\mathrm{Bz} \mathrm{D}$ and the early Milavče-period. ${ }^{785} \mathrm{O}$. Kytlicová described it as a flat bronze sheet collar aligned by nails and buckles, which had two discs with similar nails and buckles attached, as well as bronze-decorated pieces of leather. ${ }^{786}$ The previously thought-to-be third collar from grave 40 at Kourion Kaloriziki, Cyprus, ${ }^{787}$ has turned out to be two cheek plates (cat. no. 64) ${ }^{788}$ B.-U. Abels noted 21 riveted bronze sheets with buckle decoration from the Heunischenburg, Germany, which might be the remains of leather jerkins with bronze applications, though these might also derive from rims or belts. ${ }^{789}$

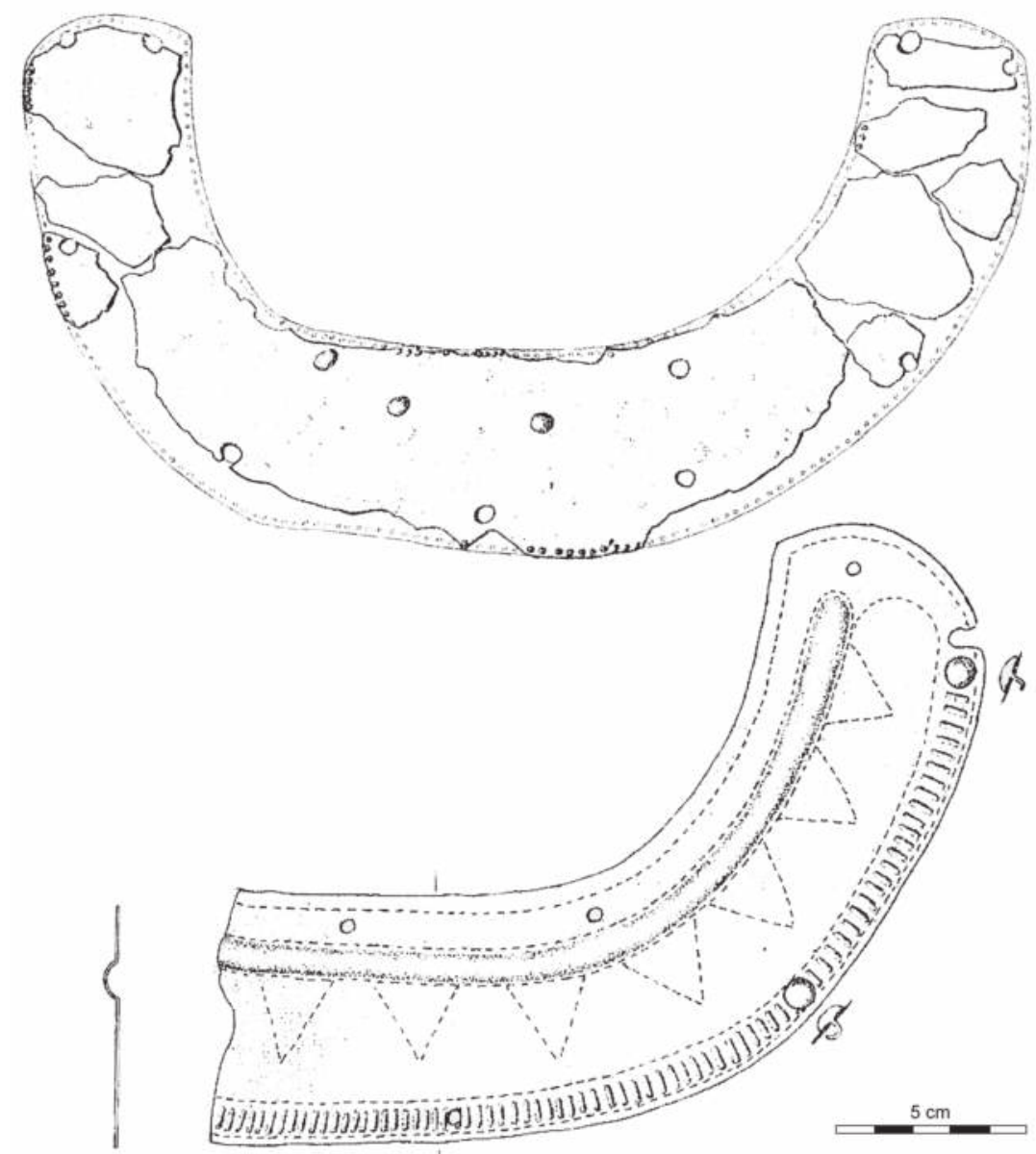

Fig. 3.1 Bronze sheet collars for organic cuirasses or corslets: Milavče, Czech Republic (above) and Hesselberg, Germany (below) (after Kytlicová 1988a, fig. 1).

\footnotetext{
784 Kytlicová 1988a, 306-321, figs. 1.2; 2.2; Weiss 1998, 543, fig. 6.1.

785 Kytlicová 1988a, 319; Jankovits 1999/2000, 195.

786 Kytlicová 1991, 23, pl. 26.11-14, 18.

787 Mc Fadden 1954, no. 35, pl. 26.35.

788 Matthäus - Schumacher-Matthäus 2014.

789 Abels 1985/1986, 14, fig. 19.8-17; Weiss 1998, 543, fig. 7.
} 
The use of phalerae, which might have been attached to an organic base, remains unclear. Found in both graves and associated deposits, the context and character of the phalerae themselves do not support any one obvious interpretation for their use. Nonetheless, of note are three discs, of $16 \mathrm{~cm}$ diameter each, found in Grave 3 at Trimbs, Germany. The discs have several holes parallel to the rim, which most likely served to fix them to an organic base. ${ }^{790}$ Another pair of phalerae from the grave in Acholshausen, Germany, might have also been applied to an organic base and potentially had a defensive function. ${ }^{791}$

Whilst the Near East and Egypt must inevitably be considered as possible regions for the origin of metal cuirasses ${ }^{792}$ such armour has never been found there, though a few finds of scale armour are known (Tab. 3.2). The scarcity of such scale armour, however, is illustrated by the fact that from the entire Near East not enough scales have been recovered to reconstruct a single suit. ${ }^{793}$ Despite this, several depictions of scale armour are known from Egyptian tombs (the tomb of Ramses III; the Theban tomb of Ken-Amun; the tomb of Paimosi), chariots (the chariot of Thutmose IV), and reliefs (e.g. Medinet Habu: Ramses III equipping his troops; the naval battle). Whether the LH II (or older) notes on Egyptian lists of goods from Syria (products of raiding or gifts), which make mention of 'bronze battle dresses' and 'bronze cuirasses', refer to scale or plate armour, cannot be ascertained..$^{794}$

\begin{tabular}{l|l}
\hline Find Site & Date \\
\hline Kanakia, Greece & cartouche of Ramses II \\
\hline Mycenae (citadel house), Greece & LH IIIC \\
\hline Enkomi, Cyprus & $12^{\text {th }}$ century BC \\
\hline Gastria-Alaas (grave 12), Cyprus & $1075-1050$ BC \\
\hline Pyla-Kokkinokremos, Cyprus & LH IIIC \\
\hline Boğazköy, Turkey & $14^{\text {th }}-13^{\text {th }}$ century BC \\
\hline Tell Açana, Turkey & $14^{\text {th }}$ century BC \\
\hline Troy, Turkey & 1400 BC \\
\hline Ras Schamra, Syria & $14^{\text {th }}$ century BC \\
\hline Nuzi, Iraq & $16^{\text {th }}-15^{\text {th }}$ century BC \\
\hline
\end{tabular}

Tab. 3.2 Finds of Bronze Age scale armour (after Catling 1977a, 88-96; Molloy 2013; Yalouris 1960, 52-53).

\subsection{Research History}

G. v. Merhart published in the 1950's the first comprehensive study of Bronze Age cuirasses. ${ }^{795}$ According to him, Bronze Age cuirasses can be divided into two main groups: a western Alpine group and an eastern Alpine group. The western Alpine group consists of three subgroups: the first, dated to the $8^{\text {th }}$ century BC, is formed by the cuirasses from Naples and Grenoble (Jura, as known today; see cat. nos. 137 and 138), as well as an unprovenanced cuirass (cat. no. 136); the second group is formed by the cuirasses from Marmesse, Fillinges, an unprovenanced cuirass (cat. no. 135), and the potential cuirass from the 'Reiling-collection' in Mainz, ${ }^{796}$ and is dated to the $8^{\text {th }}$ century BC; the third group is represented only by the cuirass of Saint-Germain-duPlain, and dates to the $7^{\text {th }}$ century BC. G. v. Merhart's eastern Alpine group is formed by more recent $7^{\text {th }}$ century BC cuirasses from Austria (Kleinklein) and Slovenia (Stična-Vrhpolje). Obvi-

\footnotetext{
790 Sperber 2011, fig. 9.2.

791 v. Merhart 1954; Schauer 1982a, 346.

792 Schauer 1982a.

793 Molloy 2013 citing Hulit - Richardson 2007.

794 Müller-Karpe 1976, 70.

795 v. Merhart 1954.

796 Mödlinger 2014b, 29.
} 
ously, important new finds have been made since, especially in terms of both cuirasses from the Carpathian Basin, represented by his third subgroup, and examples of eastern Alpine type.

G. v. Merhart put forward the same origin for all the European cuirasses, indicating they also influenced or initiated Greek cuirasses. ${ }^{797}$ Only shortly after his study, the find of the Dendra panoply proved otherwise and strengthened the theory that Bronze Age armour has an Aegean origin ${ }^{798}$ which developed from organic jerkins with single metal plate protection. ${ }^{799}$ This opinion is also followed here. J. Paulík instead suggested even after the knowledge of the Dendra find that locally produced Carpathian cuirasses influenced the Aegean workshops, and not the other way round. ${ }^{800} \mathrm{He}$ also suggested that the ancestor of Carpathian metal cuirasses were the leather jerkins with bronze applications, pointing to the idol from Kličevac, Serbia (Vršac-Žuto-Brdo Group). ${ }^{801}$ Schauer suggested that the Dendra panoply was not connected with the development of Late Bronze Age cuirasses in the Carpathian Basin and western Europe ${ }^{802}$ Instead, western European and Carpathian cuirasses are the successors of local organic predecessors, ${ }^{803}$ while he sees in the later Early Iron Age cuirasses from Austria and Slovenia (v. Merhart's eastern Alpine group) a direct influence from Greece. Schauer also linked the Dendra panoply with the depiction of scale armour in the Ken-Amun grave of Thebes ${ }^{804}$ stating that all cuirasses might have had the same ancestor, which he located in the Near East. However, as yet no older Near Eastern or Egyptian metal cuirasses are known and no technological or typological connection can be made between full metal cuirasses and scale armour, this assumption cannot be confirmed.

Considering the high value and importance of bronze cuirasses, the research interest in this category of body armour has been astonishing low over the last 35 years, especially with respect to the Carpathian finds. The cuirasses from Fillinges were studied by Y. Mottier and P. Schauer in the 1980s ${ }^{805}$ Most recently, a study of the Greek Bronze Age cuirasses, including recent finds as well as experiments with replicas of the Dendra panoply, was also published..$^{806}$ The author also published recently a holistic study on European Bronze Age cuirasses, which this chapter follows in wide parts. ${ }^{807}$ One has to point out that the Carpathian cuirass from the Danube, on display in the Magyar Nemzeti Múzeum in Budapest since many years, was published at last, after it was discovered more than 40 years ago. ${ }^{808}$

\subsection{Depictions}

Finds of metal cuirasses are rare but definite depictions or miniatures of cuirasses are still rarer, primarily due to the fact that in most cases it is not clear if the depictions represent metal or organic cuirasses, or cuirasses made of a combination of materials. The most significant depictions of body armour - all of which are Greek - are listed in Tab. 3.3 and depicted in Fig. 3.2-3).

\footnotetext{
797 v. Merhart 1954, 55.

798 Müller-Karpe 1962b.

799 Verdelis 1967; Mödlinger 2014b.

800 E.g. Paulík 1968.

801 Paulík 1963, 135.

802 Schauer 1975, 307.

803 Schauer 1982a, 129.

804 Schauer 1982a, 121, fig. 8.

805 Schauer 1982d; Mottier 1988.

806 Andrikou 2007; Molloy 2013.

807 Mödlinger 2014b.

808 Petres - Jankovits 2014
} 


\begin{tabular}{|c|c|c|}
\hline Find Spot & Type & Details \\
\hline Mycenae & $\begin{array}{l}\text { krater/warrior vase } \\
\text { (LH IIIC) }\end{array}$ & $\begin{array}{l}\text { It is still unclear if the cuirasses depicted were made of metal or of an or- } \\
\text { ganic material. In any case, the front and back of the cuirasses were held } \\
\text { together at the sides. The depiction of organic cuirasses though seems more } \\
\text { reasonable since the cuirasses expand until the wrist, which is rather unlikely } \\
\text { for a metal cuirass. The arm protection though might have been attached } \\
\text { around the armpit, as the depictions of the back side of the vase show; here, } \\
\text { the breast plate is also divided (decorated?) with a horizontal white line } \\
\text { above the breast (National Museum Athens, inv. no. 1426) (Fig. 3.2.1) }\end{array}$ \\
\hline Tiryns & $\begin{array}{l}\text { sherds } \\
(\mathrm{LH} \text { IIIB(2)-C) }\end{array}$ & $\begin{array}{l}\text { Warriors with neck protection (Fig. 3.2.2, 4; LH IIIB(2)/C) and metal waist } \\
\text { belts (Fig. 3.2.7; LH IIIC). }\end{array}$ \\
\hline Tiryns & $\begin{array}{l}\text { fragment of a clay } \\
\text { pinax or } \\
\text { sarcophagus }\end{array}$ & $\begin{array}{l}\text { The charioteer wears a unique helmet, neck protection and a metal (?) cui- } \\
\text { rass, as indicated by the curved line at the neck and the two points above the } \\
\text { chest (Archaeological Museum Nafplion) (Fig. 3.2.3) }\end{array}$ \\
\hline Tiryns & $\begin{array}{l}\text { sherd } \\
\text { (LH IIIC) }\end{array}$ & $\begin{array}{l}\text { The warrior wears a chiton, which is decorated with lines. Above the chiton } \\
\text { he wears a (metal?) cuirass (Archaeological Museum Nafplion) (Fig. 3.2.5) }\end{array}$ \\
\hline Tiryns & $\begin{array}{l}\text { sherd } \\
\text { (LH IIIC) }\end{array}$ & $\begin{array}{l}\text { The lower edge of a bell-shaped cuirass is visible as well as a potential waist } \\
\text { belt. The armour is worn by a man who is accompanied by another in a char- } \\
\text { iot (Institute of Archaeology, University of Heidelberg) (Fig. 3.2.6) }\end{array}$ \\
\hline Tiryns & $\begin{array}{l}\text { sherd } \\
\text { (LH IIIC) }\end{array}$ & $\begin{array}{l}\text { The warrior on the chariot wears a chiton and above it a metal (?) cuirass } \\
\text { (Archaeological Museum Nafplion) (Fig. 3.2.8) }\end{array}$ \\
\hline Mycenae & sherd & The warrior wears a cuirass with neck protection (Fig. 3.2.9) \\
\hline Mycenae & $\begin{array}{l}\text { sherd } \\
\text { (LH IIIC) }\end{array}$ & The warrior wears a 'hedgehog' helmet and neck protection (Fig. 3.2.10) \\
\hline Mycenae & sherd & $\begin{array}{l}\text { The warrior wears a chiton with checkered decoration under a cuirass similar } \\
\text { to the one depicted on the warrior vase (National Museum Athens, inv. no. } \\
\text { 1141) (Fig. 3.2.11) }\end{array}$ \\
\hline Mycenae & sherd & $\begin{array}{l}\text { The warrior wears a short chiton or metal cuirass (potentially indicated by } \\
\text { stiffness and colour), and maybe a shield and greaves (National Museum } \\
\text { Athens, inv. no. 2580) (Fig. 3.2.12) }\end{array}$ \\
\hline Mycenae & $\begin{array}{l}\text { sherd } \\
\text { (LH IIIC) }\end{array}$ & $\begin{array}{l}\text { The warrior behind the horse wears potentially segmented or lamellar ar- } \\
\text { mour with 'o-pa-wo-ta' and neck protection (National Museum Athens, inv. } \\
\text { no. 4691) (Fig. 3.2.13) }\end{array}$ \\
\hline Cyprus & sherd & $\begin{array}{l}\text { The warrior and the charioteer wear both a pointed (organic?) cuirass with } \\
\text { similar neck protection (Archaeological Museum Nicosia) (Fig. 3.2.14) }\end{array}$ \\
\hline Lefkandi & krater (LH IIIC) & $\begin{array}{l}\text { A warrior with large body armour and enlarged shoulder guards is depicted } \\
\text { (Fig. 3.2.15). }\end{array}$ \\
\hline Iolkos & sherd & $\begin{array}{l}\text { The cuirass of the warrior is likely emphasising the chest and nipples (Mol- } \\
\text { loy 2013, 289; Borchhardt 1972, 41, fig. 5). }\end{array}$ \\
\hline Mycenae & $\begin{array}{l}\text { fragment of a } \\
\text { fresco }\end{array}$ & $\begin{array}{l}\text { The warrior seems to wear a chiton and above an organic or leather (?)cui- } \\
\text { rass (Verdelis } 1967,26) \text {. }\end{array}$ \\
\hline Mycenae & $\begin{array}{l}\text { painted stele } \\
\text { (LH IIIC) }\end{array}$ & $\begin{array}{l}\text { The stele was found in } 1893 \text { in a chamber tomb in the area of the lower city } \\
\text { of Mycenae. The warriors wear a short-armed chiton with fringes and a } \\
\text { metal or organic (leather?) cuirass above (National Museum Athens, inv. no. } \\
\text { 3256) (Fig. 3.3) }\end{array}$ \\
\hline $\begin{array}{l}\text { Pyla-Kokki- } \\
\text { nokremos, } \\
\text { Cyprus }\end{array}$ & $\begin{array}{l}\text { krater } \\
\text { (LH IIIB) }\end{array}$ & $\begin{array}{l}\text { The charioteers depicted wear triangular helmets and long shirts ending im- } \\
\text { mediately above the knees; the shoulders are exaggerated, maybe indicating } \\
\text { shoulder protection (Larnaka Museum) }\end{array}$ \\
\hline Voudeni & sherd & $\begin{array}{l}\text { The warrior wears a 'hedgehog' helmet and a cuirass with embossed nipples } \\
\text { (potentially of central European influence; Molloy 2013, 289). }\end{array}$ \\
\hline
\end{tabular}

Tab. 3.3 Depictions of Bronze Age cuirasses and shoulder protection (see also Fig. 3.2). 


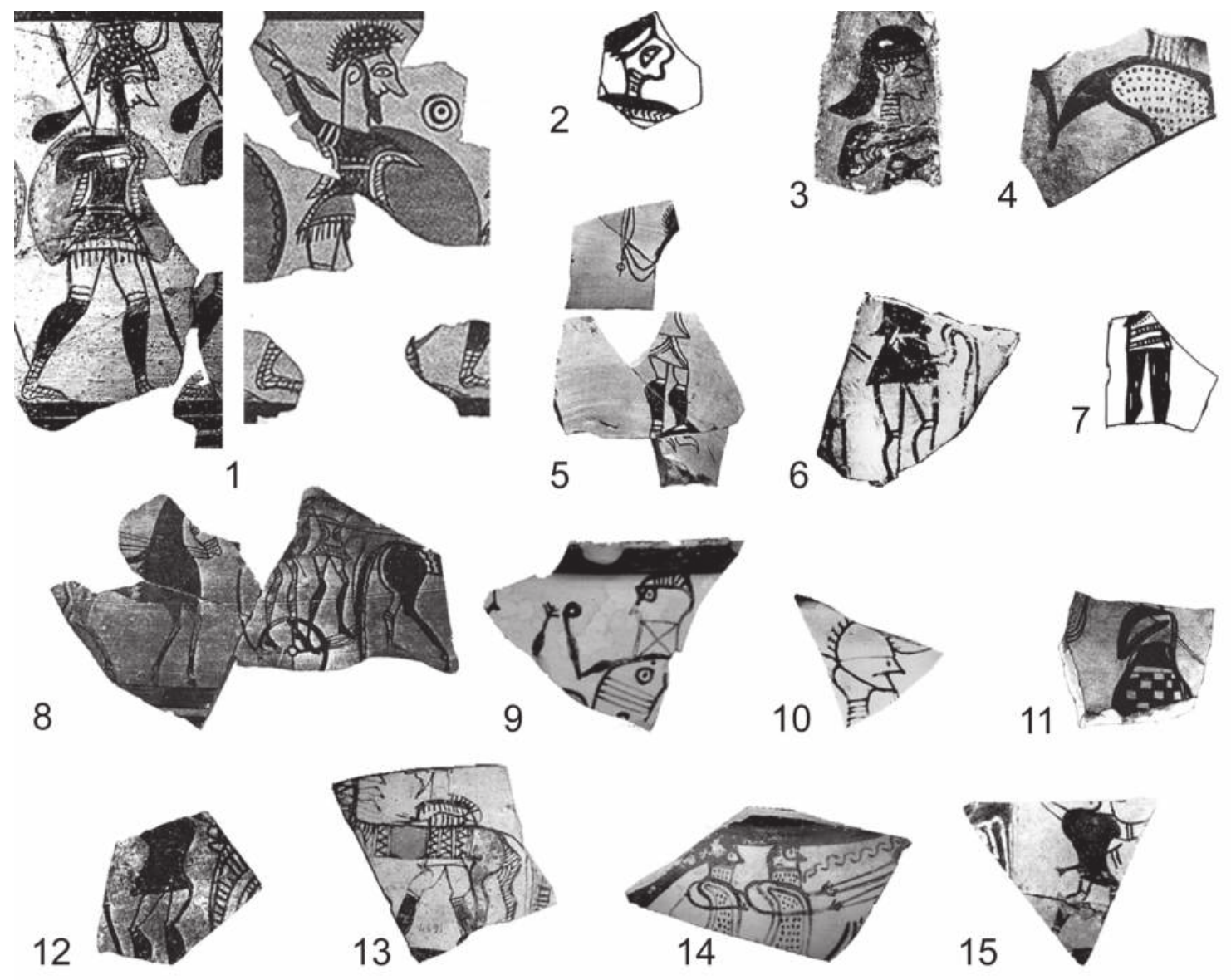

Fig. 3.2 Depictions of cuirasses and shoulder guards (without scale): 1. Mycenae, Warrior Vase; 2. Tiryns (after Verdelis 1967, suppl. 33.4); 3. Tiryns (after Verdelis 1967, suppl. 34.2); 4. Tiryns (after Vermeule - Karageorghis 1982); 5. Tiryns (after Verdelis 1967, suppl. 33.3); 6. Tiryns (after Verdelis 1967, suppl. 34.1); 7. Tiryns (after Vonhoff 2008); 8. Tiryns (after Verdelis 1967, suppl. 34.3); 9. Mycenae (after D’Amato - Salimbeti 2011, fig. on p. 32); 10. Mycenae (Càssola Guida 1973, pl. XXXVII.3); 11. Mycenae (after Verdelis 1967, suppl. 33.2); 12. Mycenae (after Verdelis 1967 suppl. 33.2); 13. Mycenae (after Molloy 2013, fig. 9); 14. Cyprus (photo courtesy by A. Salimbeti); 15. Lefkandi (Vermeule - Karageorghis 1982).

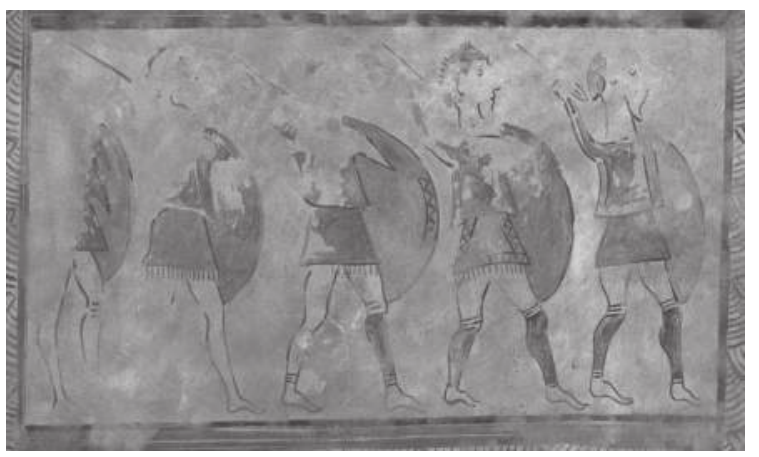

Fig. 3.3 Painted warrior stele from Mycenae, Greece (after Verdelis 1967, suppl. 32.2; National Museum of Athens, inv. no. 3256).

The Linear B archives from the palaces of Knossos and Pylos contain several tablets listing armour ideograms. ${ }^{809}$ So far, 152 tablets are known containing these armour ideograms: 140 tablets derive from Knossos (category Sc; LH IIIA) and 12 from Pylos (category Sh; LH IIIB2).

809 Ventris - Chadwick 1956, 375-381; Verdelis 1967, 29-33. 
The armour depicted on the Knossos tablets has a trapezoidal shape, curved lines indicating the shoulder pieces, and a varying number of horizontal lines within the trapezoid (Fig. 3.4). These lines probably indicate reinforcement bands or belts of segmented armour. The Knossos tablet L 693 lists a linen tunic and a copper weight, which J. Chadwick has taken to suggest composite linen and bronze armour. ${ }^{810}$ Twelve of the LH IIIB tables found in 1952 in Pylos contain a cuirass ideogram. We have to take into account that these tablets probably just record the very recent past and therefore only refer to the small number of armour that was in circulation. ${ }^{811}$ The cuirasses are identified by a varying number of o-pa-wo-ta ('things hung or attached above'): of 20 cuirasses noted, 16 bear '20 large o-pa-wo-ta and ten small', the other four '22 large ones and 12 small'. ${ }^{812}$ The armour ideograms from Pylos resemble significantly the Dendra panoply. However, the number of 30 or more o-pa-wo-ta seems to be too high for a metal panoply, even when taking into account the helmet. The tablets mention the cuirasses together with chariots; this is also supported by the two cuirass finds from Thebes, as these are the only cuirasses found together with war related objects in a settlement or palace structure, and not inside a war-

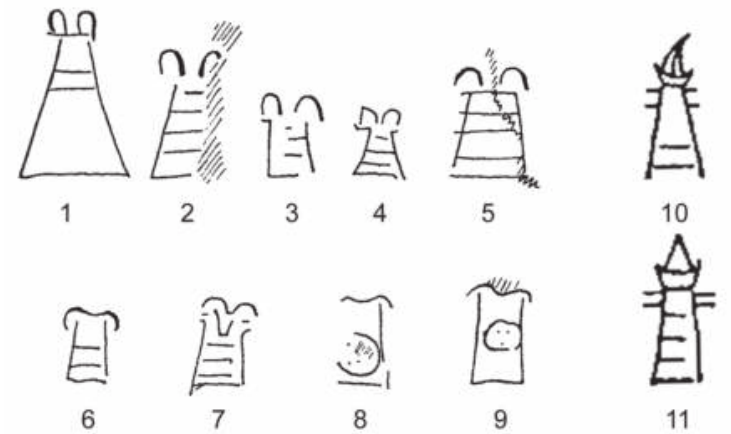

Fig. 3.4 Cuirass ideograms from Linear B tablets: 1-9. Knossos; 10-11. Pylos (after Verdelis 1967, figs. 6-7).
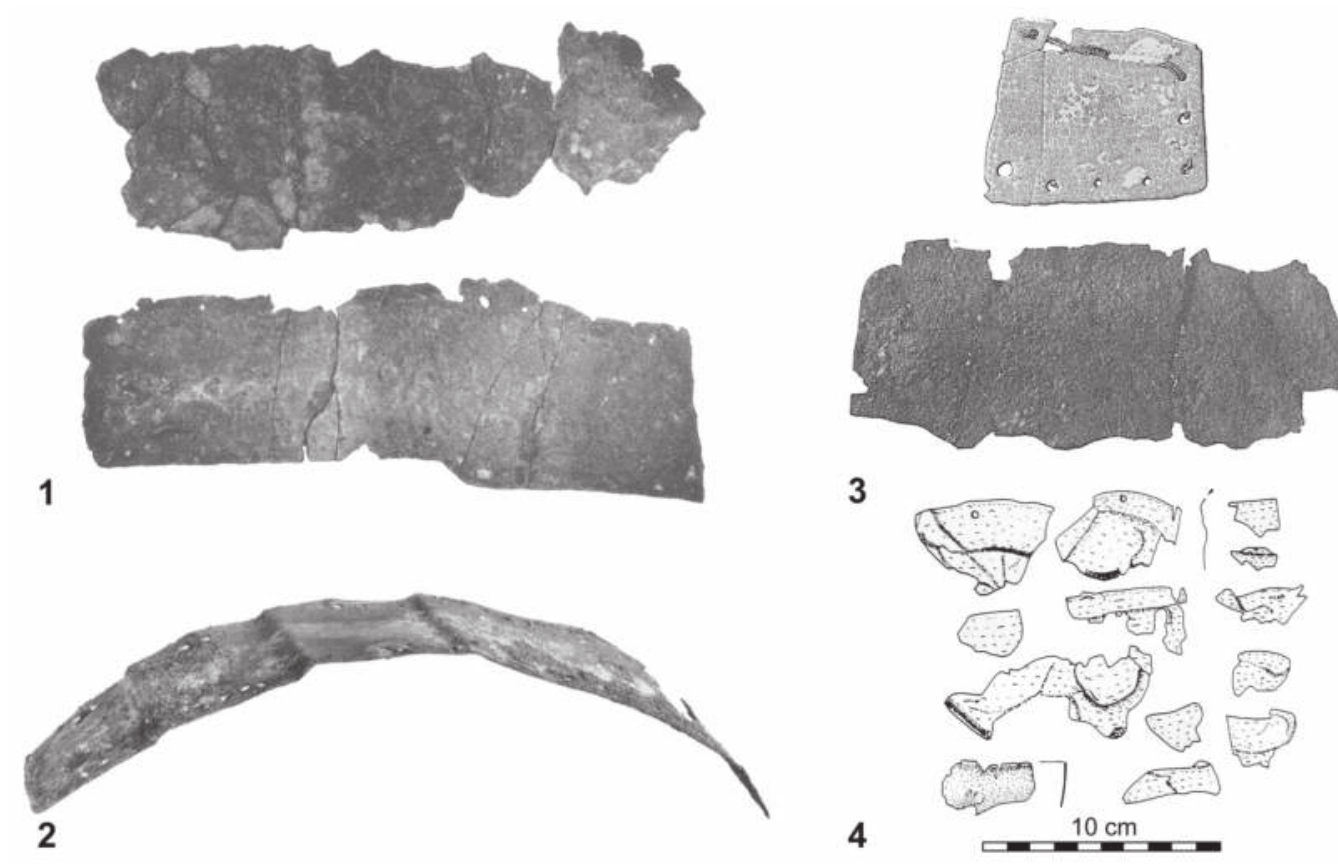

Fig. 3.5 Potential panoply parts and cuirass fragments: 1. Mycenae, shaft grave 15 (after Yalouris 1960, suppl. 25.1); 2. Mycenae, shaft grave 69 (after Yalouris 1960, suppl. 25.2); 3. Phaistos, Greece (after Savignoni 1904); 4. Midea, Greece (after Walberg 1998, pl. 112.M5-6).

\footnotetext{
810 Chadwick 1976, 160.

811 Molloy 2013, 286.

812 Ventris - Chadwick 1956, 376.
} 
rior's grave, and includes several depictions of cuirasses and chariots (Fig. 3.2). It is not clear yet how the o-pa-wo-ta parts mentioned on the Pylos tablets might have been arranged. Possibly such plates derive from the LM IIIA1 Tombe dei Nobili, Phaistos (Fig. 3.5.3). ${ }^{813}$

As well as the metal cuirasses and depictions of body armour, a few figurines wearing jerkins or cuirasses are also known (Figs. 3.6-7). A figurine from Chania/Gortyn, Greece (c. 1400-1450 BC) wears a potential cuirass. ${ }^{814}$ Its rims are strengthened with rivets on jagged bronze sheets (as seen on the examples from Čaka and Pázmándfalu). The cuirass resembles a bell shaped cuirass or jerkin, with a lower, trimmed edge. The figurine from Kličevac, Serbia $\left(13^{\text {th }} / 12^{\text {th }}\right.$ century BC), with its star-motif, also resembles the cuirasses from Čaka, Ducové and Saint-Germain-du-Plain. It is on the basis of this decorative element that the figurine from Kličevac is interpreted as wearing a cuirass. ${ }^{815}$ However, as the star-motif appears also on the chin as well as on chest, a purely decorative character must also be considered. Several Sardinian bronze figurines $\left(11^{\text {th }}-10^{\text {th }}\right.$ centuries BC) wear organic or even metallic neck guards (Fig. 3.7). ${ }^{816}$ They are moreover often protected by organic jerkins, which might have been combined with metal (?) plates.

As well as figurines, single miniatures of cuirasses are also known. An example from Knossos, was made of stone and served as a miniature vessel (height: $5.6 \mathrm{~cm}$; Museum Heraklion, inv. no. 2408). ${ }^{817}$ This miniature was discovered before the excavation of the same area and should now be dated to LM IIIA1. ${ }^{818}$ The Knossos miniature, the finds from Dendra, Thebes, and Mycenae, as well as the length of the depicted cuirass ideograms on the Knossos (LH IIIA) and Pylos (LH IIIB) tablets, indicate a trend towards short waist cuirasses, which is also visible in LH IIIC art (Fig. 3.8). A. Snodgrass notes further miniatures from Praisos (Heraklion archaeo-
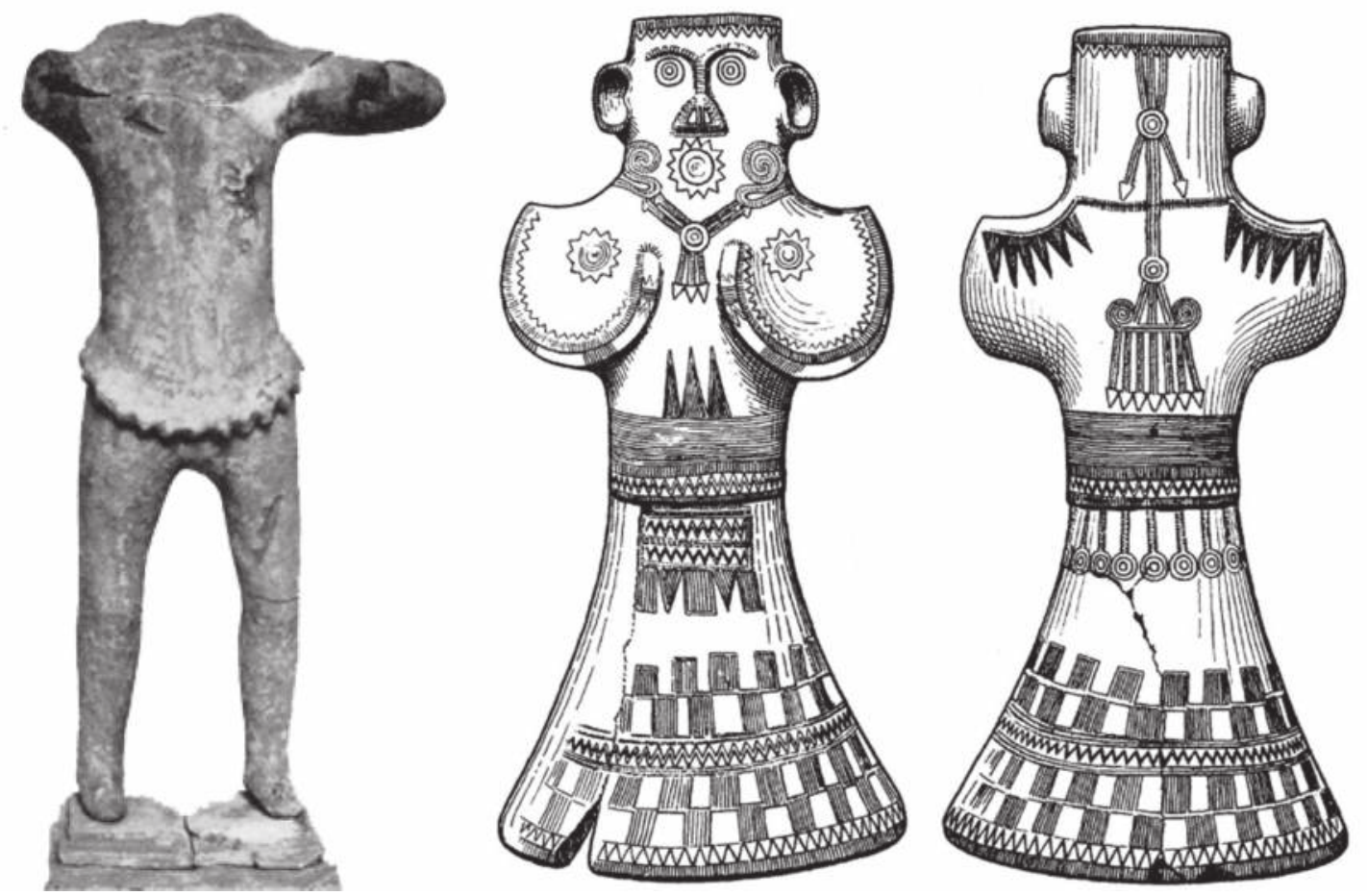

Fig. 3.6 Figurines wearing potential cuirasses from Chania/Gortyn, Greece (left; after Levy 1959) and Kličevac, Serbia (right; after Alexander 1972).

\footnotetext{
813 Hood - de Jong 1952, 260; Ventris - Chadwick 1956, 375-376.

814 Levi 1959.

815 Paulík 1963, 135.

816 For depictions of most of the Sardinian bronze figurines see Lilliu 1966.

817 Verdelis 1967, 22 suppl. 23.1.

818 LH IIB/IIIA1 according to Catling 1977a, 85.
} 


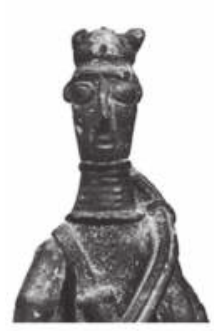

[82]

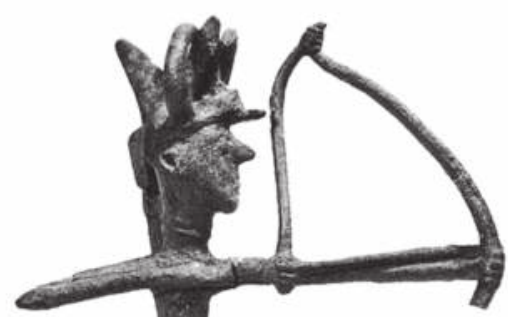

[21]

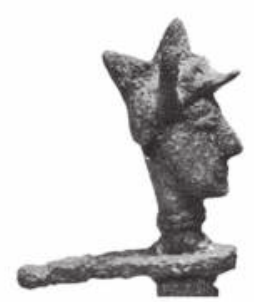

[22]

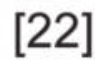

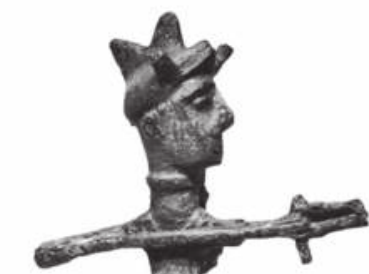

[23]

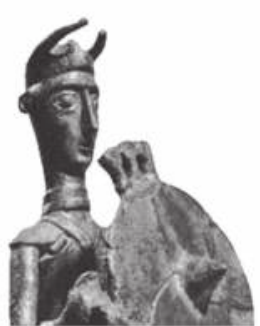

[13]

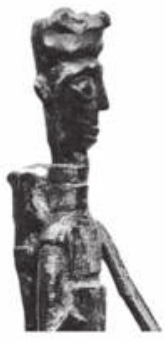

[30]

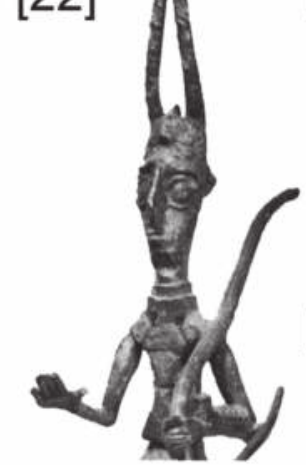

[98]

Fig. 3.7 Sardinian bronze figurines with neck protection (after Lilliu 1966; his catalogue numbers are placed in [brackets]). See also Figs. 2.37-38.

logical Museum inv. nos. 632-637, 639, 840, 870, as well as others) and Bassae, Greece, ${ }^{819}$ though these might be more recent in date. Another miniature Bronze Age cuirass derives from Austria. The miniature belongs to a Bz D-Ha A associated deposit, which was found in Brandgraben, Bad Aussee, ${ }^{820}$ and was made of high-tin bronze. The associated deposit consists of 234 objects, the oldest of which dates to the $14^{\text {th }} / 13^{\text {th }}$ century BC. ${ }^{821}$ The cuirass miniature depicts a waisted cuirass with an accentuated chest and concave rib, which follows the spine. The pectoral muscles are clearly visible. The lower edge is massive and decorated with alveoli. A loop rising from the neck would have allowed the miniature to be worn as a pendent. Due to casting defects, the hollow miniature bears two holes in the middle of the spine and on the neck on the back. It was cast in a bi-valve mould, as indicated by casting seam residues. Typologically, the miniature cannot be clearly identified as being of either Carpathian or western European type. The lack of decoration (apart from the alveoli) is most likely a result of the small size of the miniature.
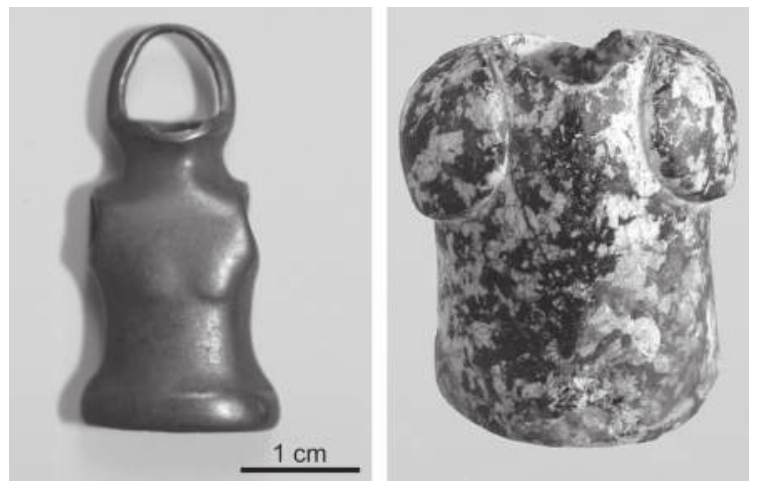

Fig. 3.8 Miniature cuirasses from Brandgraben/Bad Aussee, Austria (left; photograph: M. Mödlinger) and Knossos (right; after D'Amato - Salimbeti 2011, fig. on page 31).

\footnotetext{
819 Snodgrass 1964, 74

820 Measurements: height: $3.3 \mathrm{~cm}$; width: $1.4 \mathrm{~cm}$; Kammerhofmuseum Bad Aussee, find no. 83. Windholz-Konrad 2008, 48-57, 137, figs. 53-55.

821 Windholz-Konrad 2008, 50.
} 


\subsection{Distribution and Deposition}

According to historical sources, we know that thousands of cuirasses were in use in ancient Greece, of which only a few now survive. However, what survives of Roman armour compared with what was known to have been used according to historical sources, is even worse. The situation with regards to Bronze Age armour is somewhat similar: in contrast to written and illustrative sources, where large numbers of cuirasses and panoplies are referred to ${ }^{822}$ only a small percentage has survived archaeologically. The rarity of Bronze Age cuirasses does not therefore necessarily reflect the rarity of armour in the ancient world. This is an important point and one not only valid for Greece but also for other areas of Europe. Our distribution maps, representative of the archaeological recovery of finds, are extremely unlikely to be representative of the original scale of circulation or frequency of specific types of objects.

Of all the types of metal defensive armour, cuirasses are the least common. As seen on the archaeological distribution (Fig. 3.9), three main distribution areas can be distinguished: one in Greece, one in the Carpathian Basin and one in eastern France. These three geographical groups also differ in matters of chronology and decoration. The centralisation of cuirass finds in three rather small areas might lead to the assumption that in other regions, organic protection was preferred instead of metal cuirasses, as necessitated by the equal occurrence of weapons across areas both with and without metal cuirasses. This assumption, however, fails to take into account other potential reasons for their absence - such as different recycling strategies and different regional traditions of deposition, as well as differential recovery as a consequence of regionally different economic circumstances and different histories of heritage interest - all of which can lead to regional absences in the archaeological record or simple failure to recover,

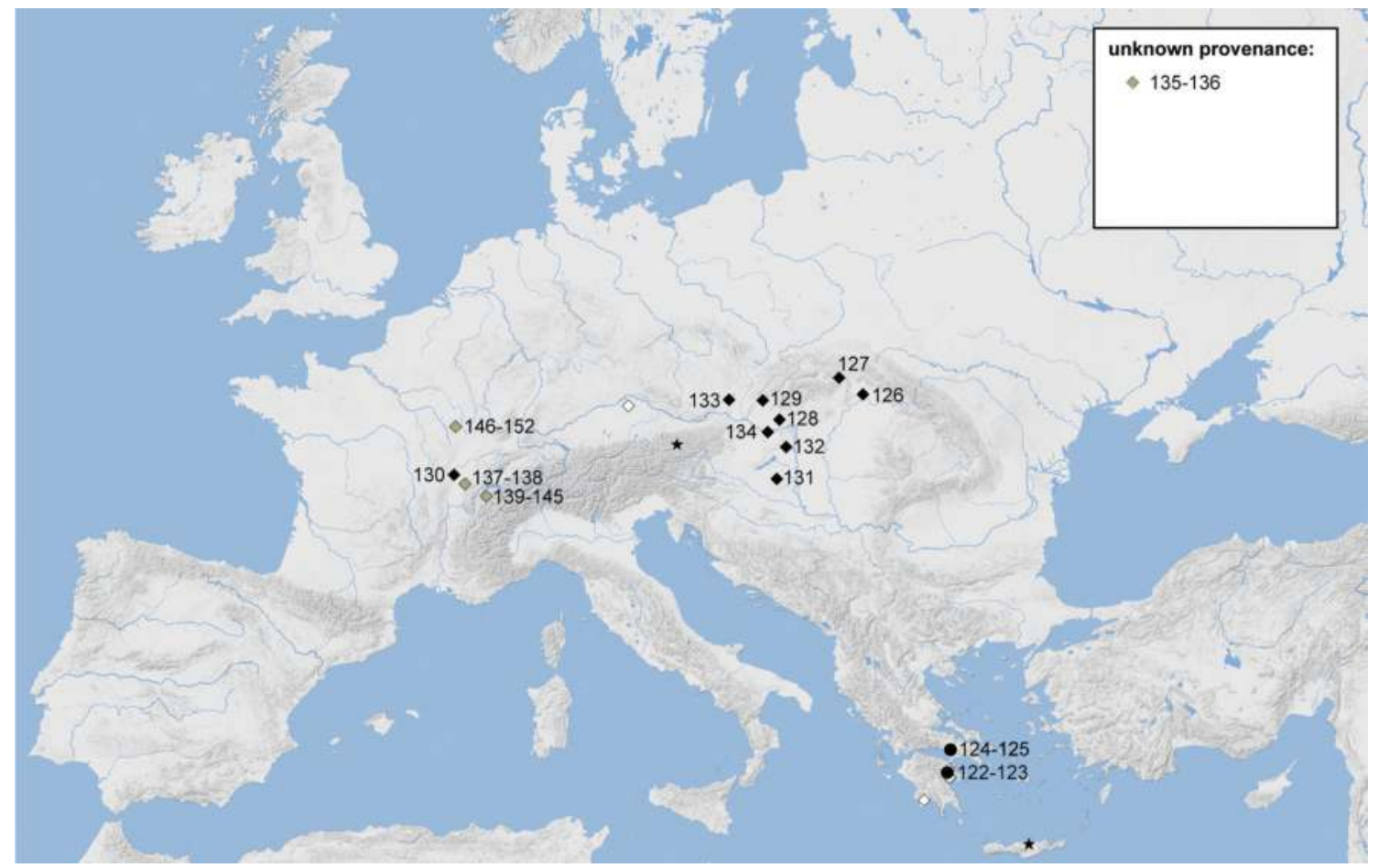

Fig. 3.9 Archaeological distribution of European Bronze Age cuirasses. Greek cuirasses: 122-123. Dendra; 124-125. Thebes. Carpathian cuirasses: 126. Čierna nad Tisou; 127. Šarišské Michal’an; 128. Čaka; 129. Ducové; 130. Saint-Germain-du-Plain; 131. Pázmándfalu; 132. Nadap; 133. Ivančice; 134. Danube at Pilismarót. $\diamond$ (grey) Western European cuirasses: 135- 136. Unprovenanced; 137-138. Jura (Graye-et-Charnay or Véria); 139-145. Fillinges; 146-152. Marmesse. $\star$ Miniatures: Brandgraben/Bad Aussee, Austria and Knossos, Greece. $\diamond$ Potential cuirass fragments: Winklsaß, Germany; Phaistos, Mycenae and Nichoria (all Greece).

822 Ventris - Chadwick 1956; Chadwick 1976; Shelmerdine 1999; 2001. 
recognise or preserve examples from the archaeological record, resulting in the small, number of surviving examples of metal cuirasses and their uneven distribution.

The oldest body armour derives from a small area around the Corinthian Gulf: The major find spots of Dendra and Thebes are less than $100 \mathrm{~km}$ distance from each other; whilst Mycenae, Phaistos and Midea, ${ }^{823}$ which have yielded further possible cuirass or panoply fragments, are within a similar distance of one another (Fig. 3.9), with only Nichoria being more distant. The finds of shoulder protection, and the panoply, from Dendra were recovered from graves. The cuirasses from Thebes, however, come from a settlement: one from the arsenal (Fig. 3.10), the other from an annex of the palace, in the Municipal Conference Centre. These two Theban cuirasses are the only secure finds from a settlement site.

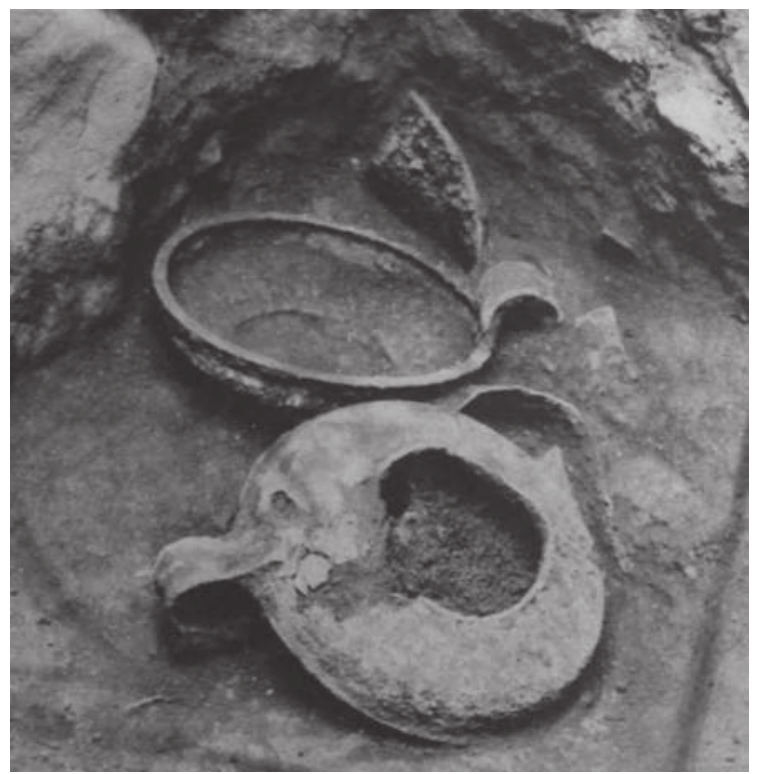

Fig. 3.10 Thebes/Arsenal, Greece. Parts of the cuirass fell into the collapsed cist grave. In the front, two wash basins (after Platon - Stassinopulou-Touloupa 1965, fig. 8).

The second group of cuirasses is located in the northwestern Carpathian Basin and is chronologically closest to the Greek cuirasses. The core group of Carpathian cuirasses are the seven finds from Čierna nad Tisou, Čaka, Ducové, Šarišské Micha'any, Pázmándfalu and Nadap, as well as a complete cuirass found in the Danube. A further cuirass fragment derives from a deposit from Ivančice, Czech Republic, and a complete cuirass from the Saône near Saint-Germain-du-Plain. A potential cuirass fragment from the associated deposit of Winklsaß, Germany, might also belong to this group of Carpathian cuirasses (Fig. 3.11). The associated deposit from Winklsaß contains various eastern associations, such as a rib-decorated socketed axe, more commonly found in Slovakia, Hungary and Romania, sickle fragments of Type Uioara and a fibula of Type Röschitz. With these associations in mind, the possible cuirass fragment might well also be of eastern origin in the west (similar to the complete Carpathian cuirass from the Saône), rather than as a local imitation or adaptation proving a manufacturing link between Carpathian and western European cuirasses. The deposition of the armour as pars pro toto could indicate also a grave assemblage but due to the lack of human remains, or of burning, which often accompanies objects associated with a cremation, it might be best considered an associated deposit.

Due to local depositional practices, most of the Carpathian cuirasses are heavily fragmented (Čierna nad Tisou), or consist of just a few fragments (Čaka, Ducové, Pázmándfalu) or single

823 Walberg 1998, pl. 112, M5-6. 

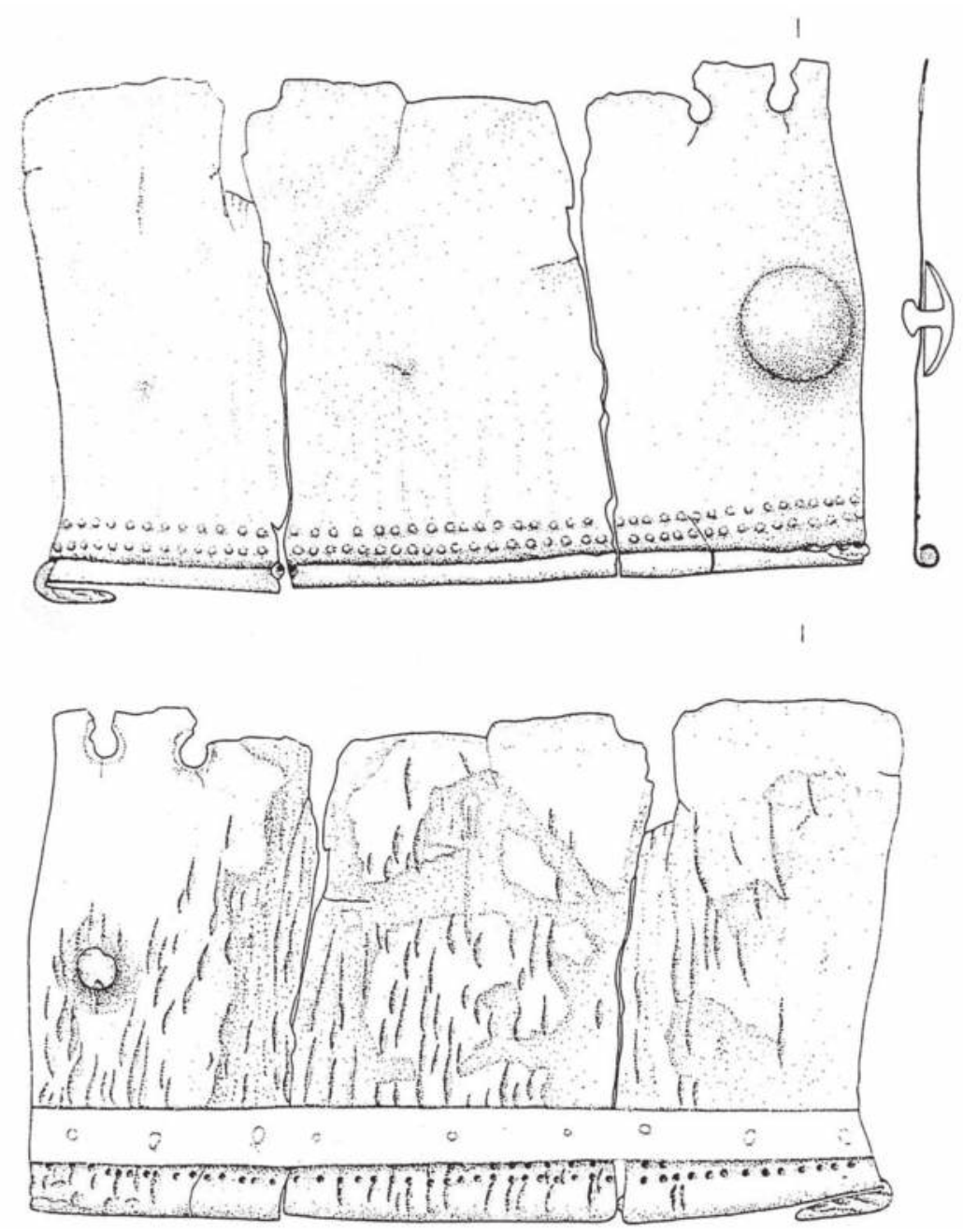

Fig. 3.11 Potential cuirass fragment from the associated deposit of Winklsaß, Germany. The back shows recent soldering on of a brass sheet (after Weiss 1998, 537, fig. 2) (scale 1:2).

fragments (Nadap, Ivančice, Šarišské Micha'any). The cuirass from Čaka derives from a grave and is, besides the Dendra finds, the only known find from a burial context. With the exception of Čaka and the two complete cuirasses from the Danube and the Saône, almost all other Carpathian cuirasses have come from associated deposits. The single find of a cuirass from Šarišské Micha'any could originally, therefore, also have been part of an associated deposit but no further finds have yet been recovered from this location which might confirm such a hypothesis. The cuirass from Ducové was found in an associated deposit within a settlement of the Velatice-Baierdorf culture. The cuirass from the Saône at Saint-German-du-Plain is considered an import. The fact that it is deposited in the same complete state as the cuirass from the Danube suggests that it was not only the object that travelled but also perhaps an associated rite of deposition as well, suggesting its date of deposition may also have been similar to that of the other Carpathian cuirasses. This is supported by the fact that the complete western European cuirasses were deposited differently, though in the same region: close to the Carpathian cuirass found in the Saône at Saint-Germain-du-Plain, a further 16 cuirasses have been found within a linear area of $230 \mathrm{~km}$, incorporating the finds from Marmesse (seven cuirasses), Fillinges (seven cuirasses) and Jura (two cuirasses). The original find location of two further western European cuirass (cat. nos. 135 and 136) remain unclear. The unprovenanced cuirass cat. no. 135 resembles so closely the cuirasses from Fillinges that the same workshop for their production may be assumed. 
The cuirasses from Fillinges were found together with a bronze stick in an ash layer but without any significant evidence of fire exposure. At least seven of the cuirasses were torn apart, with each individual cuirass surviving as only either one breast- or back plate. These breast and back plates were deposited having been placed inside one another, similar to the Marmesse cuirasses (Figures 3.12). Indeed, none of the cuirasses or their fragments show any indications of having been exposed to fire. The depositional circumstances resemble less that of a grave and more the character of a sacrificial place, if not actual ritual sacrifice and cremation on a pyre.$^{824} \mathrm{v}$. Merhart and Mottier also note the possibility that the finds might belong to a hoard. ${ }^{825}$

The Marmesse cuirasses were deposited in the shape of a triangle. Two further cuirasses were deposited together in the Jura (cat. nos. 137 and 138). No associated finds are known, or if further cuirasses were found with them. ${ }^{826}$

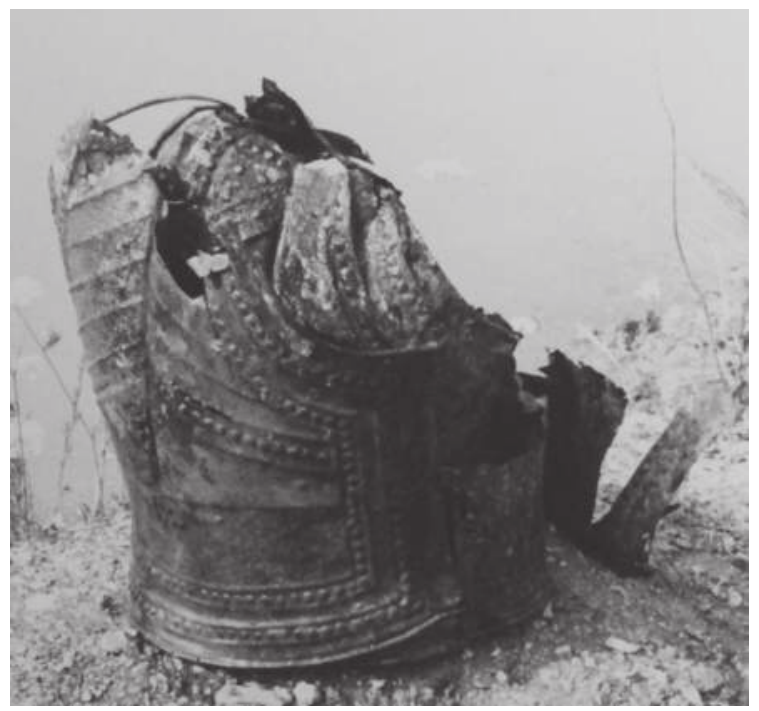

Fig. 3.12 Three of the Marmesse cuirasses inside each other (Photograph A. Chauvet, C2RMF; by courtesy of the Musée d'Archéologie nationale et Domaine national de Saint-Germain-en-Laye).

\subsection{Chronology and Typology}

As recently discussed by Molloy, the development of Bronze Age cuirasses is directed towards the use of fewer and smaller attachments, and in general of a simpler, lighter form, which around $1200 \mathrm{BC}$ results in the development of a cuirass without attachments, permitting a much higher level of mobility in use. ${ }^{827}$

During the transition period of LH II/III, defensive armour changed significantly in the Aegean. The tower and figure-of-eight shields were substituted with small round shields, which resulted in a greater need for more direct modes of bodily protection. That this process happened rather fast is demonstrated by the two armour finds from Dendra, which illustrate the rapid replacement of single body armour pieces (the shoulder protection from grave 8 ) by a panoply (grave 12). The shoulder protection of Dendra, grave 8, is dated to LH II and can be considered as the oldest piece of metal body armour. It appears to be slightly older than the famous panoply from grave $12,{ }^{828}$ which is dated to LH IIB. The potential fragment of a cuirass from

\footnotetext{
824 Schauer 1982d, 92-130.

825 v. Merhart 1969, 171, note 3; Mottier 1988, 144.

826 Descamps 2005, 100.

827 See also Greek vase paintings of armour in LH IIIC: Molloy 2013, 276.

828 Verdelis 1967, 21-22; Andrikou 2007, 402.
} 
Phaistos is contemporary with the Dendra panoply. The Theban panoplies or cuirasses are dated to LH IIIA2/B1, thus the Theban cuirasses are slightly more recent than the Dendra panoply. ${ }^{829}$

Peculiar is the chronological gap apparent between the Mycenaean cuirasses and the technologically successive cuirass from Argos, which is dated to the $8^{\text {th }}$ century $\mathrm{BC}$, as well as the geographical gap between the Aegean and the Carpathian Basin, from where no early cuirass finds are yet known. It is extremely likely, however, that cuirasses were produced and circulated but as a consequence of different life-cycle processes (e.g. recycling, deposition, loss, general disinterest of people in this specific form of armour), we have significantly different regional patterns of archaeological survival and recovery. However, contemporary to most of the LH IIIB Linear B texts, body armour appears in continental Europe in Bz D, indicating the rapid adoption of the use of the light bronze cuirasses, which, unlike the earlier heavier, more complex panoply, was less restrictive of speed and flexibility.

Carpathian cuirasses are, due to their occurrence in associated deposits, easier to date than their western European counterparts, and can be generally dated to Bz D-Ha A1. On the basis of associated finds, the associated deposit from Ducové dates to $\mathrm{Bz} \mathrm{D}$, or at the very latest to the transition between $\mathrm{Bz} \mathrm{D}$ and $\mathrm{Ha} \mathrm{A} 1 .{ }^{830}$ The associated deposits from Nadap and Brandgraben date to $\mathrm{Bz} \mathrm{D}-\mathrm{Ha} \mathrm{A} 1 .{ }^{831}$ Grave 2 and the cuirass from Čaka date to $\mathrm{Bz} \mathrm{D}$, or at the latest to the beginning of Ha A1, as suggested by Hansen and J. Paulík. ${ }^{832}$ The associated deposit from Winklsaß is dated to Ha A1. ${ }^{833}$ The recently found associated deposit from Pázmándfalu has also been dated to Ha A1. ${ }^{834}$ The cuirasses from Šarišské Micha'any and Čierna nad Tisou are dated to Bz D-Ha A1, according to their similarity to other Carpathian cuirasses, since both lack any adequate associated finds for dating. There is no reason to assume that the cuirass fragments from Ducové, Nadap and Pázmándfalu were deposited after a long period of use, as it was suggested by Petres and Jankovits. ${ }^{835}$

The deposition date of the two river finds from the Danube and Saint-Germain-du-Plain is unclear. Their close connection to the Carpathian cuirasses in terms of morphology, construction and decoration, however, suggest a depositional date during Bz D-Ha A1. The date of the cuirass from the Danube with its unique breast accentuation is somewhat more complex. According to the application of decoration, ${ }^{836}$ as well as the decorative elements themselves, which are also found on other Carpathian cuirasses and contemporary helmets, a date of $\mathrm{Bz} \mathrm{D} /$ $\mathrm{Ha} \mathrm{A} 1$, if not Bz D alone due to similarities with older Greek panoplies, is entirely reasonable. The half circles below the navel are also known on the cuirass from Saint-Germain-du-Plain but not on more recent finds. The breast plate and back plate are permanently fixed on the left side with four rivets, as known from other Carpathian cuirasses. On the left shoulder a rivet joining both plates and on the right shoulder a simple loop riveted on the back plate served as an adequate means of attaching the two halves. The attachment on the right side resembles that on the cuirass from Saint-Germain-du-Plain, even if additional rivet holes on both plates along the edge indicate an additional means of attachment, though these may have served to fix the organic inlay, as known on the Greek cuirasses and panoplies. The shape of the rivets on some cuirasses, however, suggest a different means of connection: those from Saint-Germain-duPlain and Čierna nad Tisou both show conical headed rivets, while the rivets from the Danube cuirass are bigger and completely flat. The waisted profile of the cuirass resembles also the shape of the cuirass from Saint-Germain-du-Plain, while the neck guard is much higher than on any other cuirass with the exception of that from Dendra. G. v. Merhart connected the cuirass

\footnotetext{
829 Verdelis 1967, 21-22; Andrikou 2007.

830 Paulík 1968, 46; Hansen 1994, 12.

831 Most recently Windholz-Konrad 2008; Uckelmann 2012.

832 Paulík 1968; Hansen 1994, 12.

833 Weiss 1998.

834 Szabó 2013, 811.

835 Petres - Jankovits 2014, 63.

836 Gleichbuckelsystem; see Jockenhövel 1974, 39.
} 
from Saint-Germain-du-Plain with the eastern Alpine Hallstatt cuirasses, ${ }^{837}$ but it is now usually interpreted as an eastern piece deposited in the west of Europe ${ }^{838}$ Despite this, it was assigned a later date than the other Carpathian cuirass. ${ }^{839}$ However, in the following it is suggested that a date in $\mathrm{Bz} \mathrm{D}-\mathrm{Ha} \mathrm{A} 1$ is more reasonable.

Since all western European cuirasses lack datable associations, they have to be dated according to their decorative elements. Generally, these cuirasses have been dated to Ha B1, which corresponds to the Atlantic Wilburton/Brécy/Hío phase or later. The cuirasses of Fillinges were dated first by W. Deonna to the $9^{\text {th }}-7^{\text {th }}$ centuries BC or $7^{\text {th }}-5^{\text {th }}$ centuries BC.$^{840}$ G. v. Merhart, and later also Müller-Karpe, dated them according to their points-and-studs decoration and water bird depictions to a later period of the early eastern Urnfield period (Ha B1/B2). ${ }^{841}$ Mottier followed the argument of v. Merhart but tended to date the cuirasses to Ha B2. ${ }^{842}$ Schauer saw in the chest/nipple decoration of the late Ha B1 cuirasses from Fillinges, which he thought to be deposited in $\mathrm{Ha} \mathrm{B} 2$, an abstraction of phalerae (generally dated to $\mathrm{Ha} \mathrm{B} 3 / \mathrm{C}$; a few slightly more recent ones are, however, known), and was not concerned by this contradiction. ${ }^{843}$ J.-P. Mohen dated the cuirasses from Marmesse to the end of the Bronze Age. ${ }^{844} \mathrm{H}$. Steuer dated them to the $9^{\text {th }} / 8^{\text {th }}$ century BC, chronologically between the cuirass from Saint-Germain-duPlain and the cuirasses from Fillinges ${ }^{845}$ The decorative elements (ribs as well as pellets and bosses) on the cuirass from Jura A (cat. no. 137) seem to support a date to the very end of the Urnfield period. As pointed out by Jockenhövel, decoration with bosses/pellets of equal size started in $\mathrm{Bz} \mathrm{D} / \mathrm{Ha} \mathrm{A} 1{ }^{846}$ It was followed by point and stud decoration, which appeared earliest toward the end of Ha A2 together with bird depictions (e. g. on cups of Type KirkendrupJeníšovice, vessels of Type Hajdúböszörmény and greaves of Type Kuřim), followed by the Leisten-Buckel-System at the very end of the Urnfield period. Only three of the 18 western European cuirasses with point and stud decoration bear bird depictions, which indicates either less importance being placed on the bird motif, or a slightly earlier date (or both).

The distribution of bronze sheet objects and weaponry between eastern and western Europe differs significantly during $\mathrm{Bz} \mathrm{D}-\mathrm{Ha} \mathrm{A}(1)$ and $\mathrm{Ha} \mathrm{B} 1$. The presence of armour, vessels and cauldrons in the Atlantic Bronze Age indicates complex relations and mutual influences between east and west in the $13^{\text {th }}$ and $12^{\text {th }}$ centuries BC. These connections were discussed recently for vessels and cauldrons by Gerloff, for shields by Uckelmann and for greaves by Clausing. ${ }^{847}$

The distribution of recovery and the associated deposit associations of sheet metal objects, demonstrates the strong presence of a central or eastern European/northwestern European trade route, which is more likely than a west Mediterranean/Iberian trade route, ${ }^{848}$ at least concerning armour. So far, the only Bronze Age/Early Iron Age metal armour from the Iberian peninsula are the depictions of Type Herzsprung shields on the stelae, ${ }^{849}$ and the fragments of helmets from the river Huelva (two helmets of Type Bernières d'Ailly (cat. nos. 117-118), and one helmet of eastern type, dating probably to the $7^{\text {th }}$ century $\mathrm{BC}$ ), indicating connections with northern France and the eastern Mediterranean, as well as further fragments of a crested helmet of Type Bernières d'Ailly from Vila Cova de Perrinho/Monte do Crasto, Portugal (cat. no. 119), and

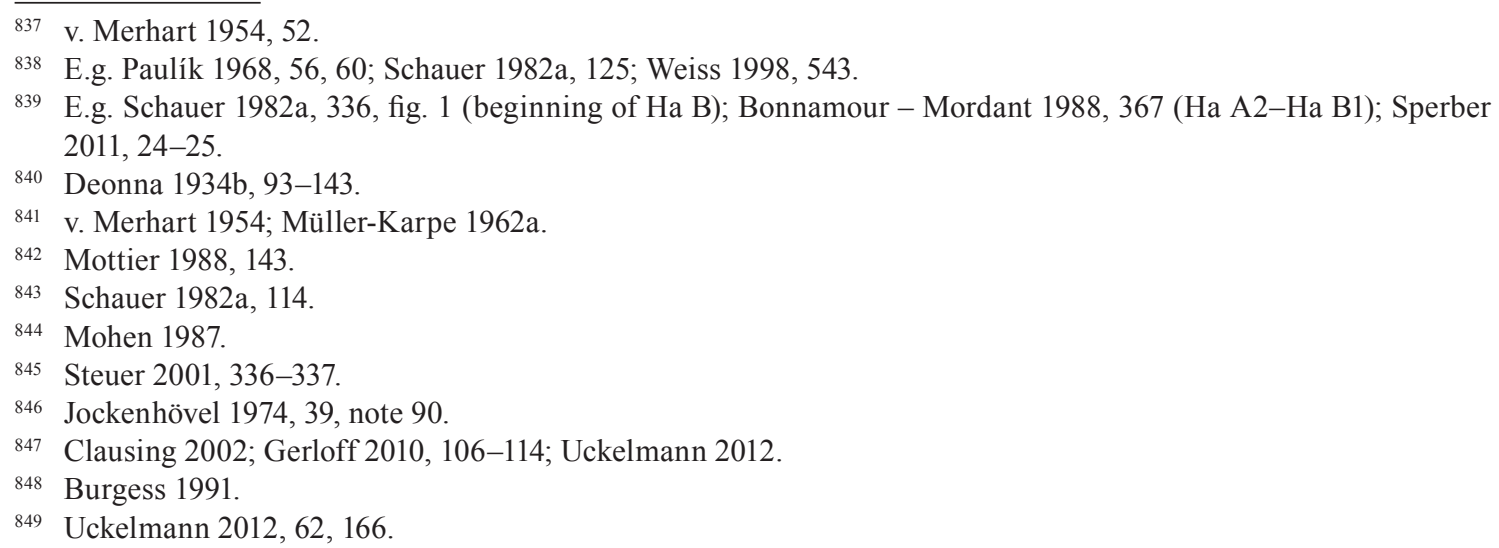


potentially also Grañón, Spain. The small number of finds, including weapons such as swords, points to a limited armour exchange during $\mathrm{Bz} \mathrm{D} / \mathrm{Ha} \mathrm{A} 1$ with the Atlantic Bronze Age, which did not improve much during the following centuries. ${ }^{850}$

All western European cuirasses have been found in the north of the western Alps, in HauteSavoie and Haute-Marne, within a distance of less than $230 \mathrm{~km}$. This area can be considered a key region, as emphasised by the presence of a number of rich associated deposits, such as that from Blanot, France. ${ }^{851}$ This region was the meeting point of two main trade routes from west to east. Even though located at the periphery of the Atlantic Bronze Age, this region was the main axis for trading arms, such as swords of Type Monza, Arco and Rixheim, as well as armour. One trade route passed through the north Alpine region and continued overland to the Carpathian Basin and further southeast to the Aegean; 852 the other, southern route, passed through northern Italy (Po-Basin) and could have passed either overland to the Carpathian Basin (see the distribution of greaves) or continue through the Mediterranean (as indicated for certain types of swords). Cuirasses are rare both in northern Italy (no secure finds are known) and the north Alpine region, but were certainly known, at least in the latter region, as the cuirass miniature from Bad Aussee, Austria, and the potential cuirass fragment from Winklsaß, Germany, demonstrates.

The development of armour was also associated with the rise of the early Griffzungenschwerter; however, they do not show any overlapping recovery area. In comparison, the connection between certain rod-tanged swords of Bz D/Ha A1 (e.g. Type Pépinville, Arco-Terontola, Grigny and St. Ouen) with the western European cuirasses appears less certain, despite the fact that their similar recovery areas would seem to suggest otherwise. ${ }^{853}$ The origin of these swords was formerly connected with the Alpine region, but new studies show a much higher occurrence in France, pointing more toward their Atlantic or at least western European development. ${ }^{854}$ These swords are also found south of the Alps and in northern Italy and are associated with other Italian finds such as Type Peschiera daggers or violin bow fibulae from the beginning of the Late Bronze Age. How far these swords could travel or be traded and exchanged, is demonstrated by a European rod-tanged sword found in El Kantara, Egypt, ${ }^{855}$ as well as a hybrid sword with the hilt of a Type Arco-Terentola sword fused with a more eastern style blade found in Ugarit, Syria. The latter also bears a cartouche of pharaoh Merneptah (1212-1202 BC). ${ }^{856}$ Thus we might assume that seaborne trading routes to the east via the Mediterranean (Adria or Ligurian Sea?) are more likely, at least for these objects. Who transported these bronzes and for what purpose, however, must be discussed elsewhere.

Unlike these swords, armour and sheet metal work expanded outward from the Aegean to the Carpathian Basin, from where it eventually reached western Europe, a view which is supported by the lack of armour in pure Atlantic associated deposits of this period when compared with finds from the Carpathian Basin, as well as northern Italy and north Alpine regions. The most prominent examples of eastern armour reaching the Atlantic Bronze Age or at least its periphery are certainly the cuirass from Saint-Germain-du-Plain, the greaves from CannesÉcluse (cat. no. 162), and the earliest western cauldrons. ${ }^{857}$ As we know from shields, helmets and early cauldrons, ${ }^{858}$ cuirasses might also have been locally produced in western Europe. This might be supported by the close vicinity of the find spots for the western European cuirasses and that of the Carpathian cuirass from Saint-Germain-du-Plain, as well as the lack of western European type cuirasses in eastern Europe.

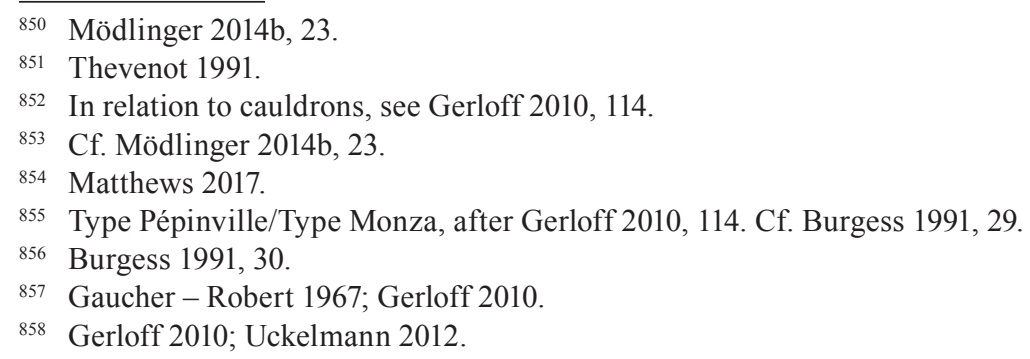


Looking at the similar distribution of certain rod-tanged sword types and the cuirasses, it seems as if the same trading routes were used to bring eastern European cuirasses (such as the one from Saint-Germain-du-Plain) to the west and western European swords to the east, which resulted, at least in terms of the armour, in their quite rapid introduction but also in a very restricted local adaption. We might, therefore, see the development and distribution of western European cuirasses as being the direct result of east/west and west/east trading connections. As a consequence, this would also shift their production period so as to be more in line with that of the Carpathian cuirasses.By concluding that the western European cuirasses were produced in Ha A2 also places them chronologically closer to early metal shields, the greaves from CannesÉcluse (cat. no. 162), and the Carpathian cuirasses, and results in a more consistent image of the exchange of arms and armour between eastern and western Europe. Only the unprovenanced cuirass cat. no. 136 might be of more recent date, since its method of attachment, shape, and decoration, all differ significantly from other western European cuirasses.

\subsection{Decoration}

The Greek cuirasses are all undecorated. However, the depictions of cuirasses (Fig. 3.2) instead suggest that in the case of some cuirasses, especially organic cuirasses and those made of organic and metal, decoration was indeed applied.

Carpathian cuirasses, however, are, at least on the breast plate, decorated. The breast plate bears in most cases convex plastic ribs and fine lines of punched dots (comprising circles, chevrons, and chevrons arranged as stars) (Fig. 3.13, left and centre). The Danube cuirass is the only one without chevrons or jagged, riveted-on bronze bands. All cuirasses show one or two ribs parallel to the edge of the arm opening and the base. The Danube cuirass though has instead two lines of pellets parallel to the rim at the base. The two convex ribs close to the arm opening of the Ducove fragment are decorated with a line of dots in the middle of each rib, while on the Caka fragment pellets are visible between the ribs. ${ }^{859}$ This plastic decoration as ribs also increased the stability of the bronze plate.

Opposite to the breast plate, the back plate remained largely undecorated. The only decoration preserved on the back are one or two ribs or lines of pellets applied parallel to the rim. On the cuirass from Saint-Germain-du-Plain, these ribs are combined on the front only with chevron decoration. In the centre of the breast plate from Saint-Germain-du-Plain the two ribs parallel to the base rim form a semi-circle, with the area in between being filled with chevrons. On the Danube cuirass this semi-circle is instead formed by the two lines of pellet decoration. On the end of these two lines, where the breast and the back plate are joined together, there occurs a circle with a large central boss. These circles with large central boss are also found on other defensive armour (e.g. helmets of Type Lueg, and the helmets from Tiryns and Szczecin-Zdroje) as well as on one of the bronze cups from the associated deposit from Dresden-Dobritz, ${ }^{860} \mathrm{dem}$ onstrating the close connection between different classes of armour. Similar decoration is also found on bronze sheets from Salaš Noćajski, Serbia, ${ }^{861}$ Guşteriţa, Romania, ${ }^{862}$ Techirghiol, Romania, ${ }^{863}$ Pila del Brancon, Italy, ${ }^{864}$ Dresden-Dobritz, Germany, ${ }^{865}$ and in an Iron Age deposit from Sicily. 866

The pectoral muscles of Carpathian cuirasses are usually outlined with plastic ribs, which connect above the sternum. Chevron decoration was applied on the cuirass from Saint-Ger-

\footnotetext{
859 Schauer 1982d, fig. 4.

860 Martin 2009, pl. 30.119.

861 Vasić 1994, pl. 38.13.

${ }_{862}$ Bronze sheet fragment: Rusu 1990, 73, pl. V.5.

863 Bronze sheet fragment: Petrescu-Dîmboviţa 1978, pl. 215.17-19.

864 Bronze sheet fragment: Salzani 1998, fig. 2.138.

865 Bronze cup: Martin 2009, pl. 30.119.

866 Egg 1983, fig. 2.4-5.
} 
main-du-Plain in between these ribs, and an upwards bent semi-circle positioned immediately beneath it. Also, the rib underneath the neck has chevron decoration with downwards pointing chevrons applied. On the Danube cuirass, only one massive rib was applied to outline the pectoral muscles. The break on the fragment from Ducové below the breast is in the shape of a semicircle, and indicates also for this cuirass the application of a semi-circular decoration to outline the muscles. Moreover, the Čaka cuirass might have had a decorated (double) rib that followed the outline of the chest. An additional circle or round decoration, as suggested by Paulík, ${ }^{867}$ has no parallels amongst Carpathian cuirasses, however, it is visible on the cuirass from Jura A (cat. no. 137$).{ }^{868}$

The breast or nipples are characterised on the cuirasses from Ducové and Saint-Germain-duPlain by two stars, formed by dotted, punched lines of chevrons around a usual empty centre (Fig. 3.13, left and centre). These stars are sometimes formed by separate attachments, as on the cuirass from Čaka. On this cuirass, a star-like disc was riveted onto the breast plate with small rivets located at the tip of each of the points of the star. Riveted-on breast decoration is also common on later Hallstatt period cuirasses from Kleinklein and Stična-Vrhpolje, as well as on an unprovenanced cuirass. ${ }^{869}$ The breast decoration of the Danube cuirass consists of fine, positively embossed pellets only. ${ }^{870}$ The nipples are indicated by three circles inside each other with a central boss; they are surrounded by a larger, open circle, indicating the breast.
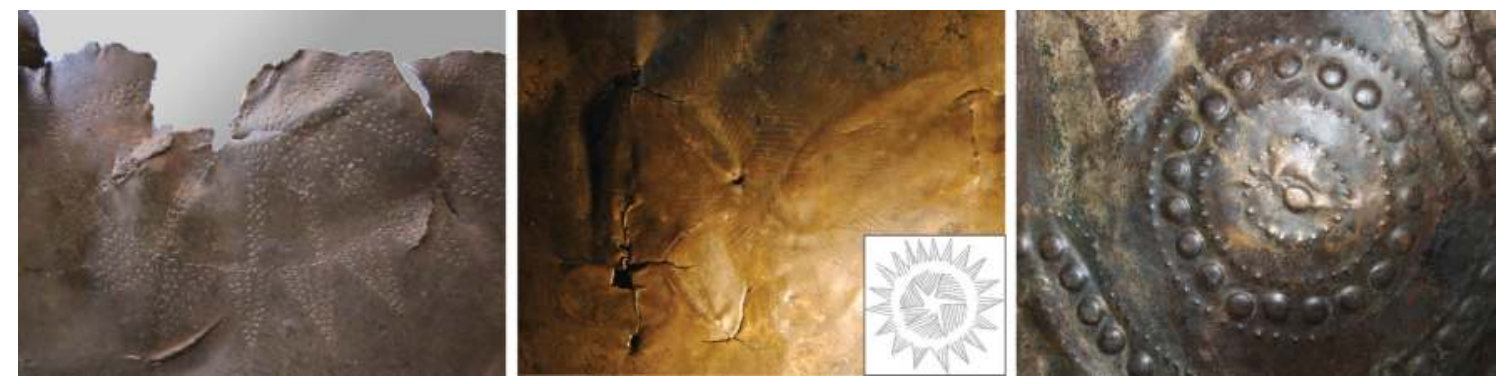

Fig. 3.13 Chest decoration: Ducové, Slovakia (left), Saint-Germain-du-Plain, France (centre) and Marmesse (right) (left: photograph M. Mödlinger; centre: photograph M. Uckelmann, by courtesy of the Musée d'Archéologie nationale et Domaine national de Saint-Germain-en-Laye; right: photograph A. Chauvet (C2RMF), by courtesy of the Musée d'Archéologie nationale et Domaine national de Saint-Germain-en-Laye).

Compared to Carpathian cuirasses, western European cuirasses are extensively decorated with lines and circles of different sized, positive bosses and pellets on both the front and back. These decorative elements are also common on cups (Type Kirkendrup-Jeníšovice), vessels (Type Hajdúböszörmény) and amphorae (Type Mariesminde). ${ }^{871}$ Three western European cuirasses have additional decoration in the form of the heads of water birds (Jura B (cat. no. 138), Fillinges (cat. no. 140-141)). The bird heads are arranged differently on different cuirasses, however, most noticeably on the two cuirasses from Fillinges. On these cuirasses, the double embossed lines abstracting the chest are not completely closed, but open on the upper sides towards the armpits. The bird heads then are either a prolongation of the circles and located on top of them (cat. no. 140) or placed on top of the outer circle (cat. no. 141). The water birds are not connected with each other. Water bird decoration, as on the cuirass from Jura B (cat. no. 138) (also here without typical elements such as sun, boat or wheels), is also known from the crested helmets from Škocjan. ${ }^{872}$ Here, the water bird heads are also an elongation of the decora-

\footnotetext{
867 Paulík 1968, 48.

868 Cf. Mödlinger 2014b, 24-25.

869 The cuirass was part of the Guttmann collection, inv. no. AG 1124. See Born - Hansen 2001, pl. VII. Today, it is in an Austrian private collection.

870 Gleichbuckel; see Jockenhövel 1974, 39.

871 Jockenhövel 1974; Wirth 2006.

872 Hencken 1971, fig. 92.
} 
tive band. Based on their decoration, the western European cuirasses can be distinguished into three sub-groups: ${ }^{873}$

1. Fillinges and the unprovenanced cuirass cat. no. 135

2. Marmesse

3. Jura A and B as well as the unprovenanced cuirass cat. no. 136

This classification is largely in agreement with the identification of different workshop traditions producing these cuirasses as described by Mottier. ${ }^{874}$

The unprovenanced cuirass cat. no. 135, as well as all the cuirasses and associated fragments from Fillinges, have the same type of decoration: immediately above the base of the cuirass, a parallel line of large bosses is surrounded below and above by a line of pellets. Some $10 \mathrm{~cm}$ or so above these lines, two further horizontal lines of pellets are visible, embracing two lines of larger bosses, which have in between them a band of diagonal pellet lines, which is confined within two horizontal pellet lines above and below. From the highest horizontal line on, vertical bundles of lines (alternating lines of larger bosses and bands with diagonal pellet lines) spread upwards in the direction of the neck, if not interrupted by the breast decoration. Here, the nipples are indicated by two pellet circles and a large central boss. As noted before, two cuirasses (cat. nos. 140-141) have open circles and end in water bird heads. The navel is indicated by a central boss between the vertical bundles of lines. The back plates of the cuirasses are decorated similar to the breast plates ${ }^{875}$ but without the decorative breast elements. Only the spine is indicated, by a massive, concave central rib, which divides the horizontal lines of pellets and bosses into two.

Two horizontal lines of bosses, accompanied by two lines of pellets above and below, follow the edge of the base on both breast and back plate of the cuirasses from Marmesse. The slightly convex breast and nipple is marked with two circles of pellets, which bear a circle of bosses in between. In the centre of each of these three circles, one central boss was applied. The pectoral muscles are indicated by two semi-circles of pellets and central bosses right under and partly parallel to the breast circles. The only differences between the cuirasses are vertical and horizontal lines of bosses underneath the semi-circles beneath the chest and in the centre of the cuirass: with the exception of one, all cuirasses have one horizontal line with three bosses and a parallel lower line with five bosses (cat. no. 148 has an additional line with seven bosses). Four cuirasses (cat. nos. 146-148, 150) have two short vertical lines under the semi-circles, consisting of three bosses each. ${ }^{876}$ These small horizontal lines of bosses are repeated also on the back side of the cuirasses with the same number of bosses. The back plates, however, demonstrate more differences between each cuirass than do the breast plates, since the number of lines of pellets and bosses pointing upwards from the concave spine to the opening of the arms differs from cuirass to cuirass. The cuirass cat. no. 148 bears one more line than the cuirasses cat. nos. 146-147, 150. The cuirass cat. no. 149 bears three massive ribs with bosses and, instead of just the small central horizontal lines of bosses, it also has a line of bosses all along the back plate. ${ }^{877}$

Unlike the Marmesse and Fillinges cuirasses, the decoration of the two cuirasses from Jura differ significantly from each other. Apart from the horizontal lines of pellets and bosses around the waist, and the circles abstracting chest and nipples, there are no further similarities with the cuirasses from Marmesse or Fillinges. The front side of the cuirasses Jura A (cat. no. 137) is decorated with nine circles, each with three lines of pellets and a central boss. Two circles are placed above the chest and two on each side between the arm pits and the two central circles. Additionally, two smaller circles (two pellet lines with a central boss) were applied in the centre of the lower area of the breast plate, and two further circles of the same size under the two horizontal waistlines of the bosses. Similar circles (with or without the large central boss) are also

\footnotetext{
873 Cf. Mödlinger 2014b, 25.

874 Mottier 1988, 142-143.

875 For a detailed description, see also Schauer 1982d, 103-112.

876 Cf. Mödlinger 2014b, 26.

877 Cf. Mödlinger 2014b, 26.
} 
known from the Carpathian cuirasses and other defensive armour, such as on helmets of Type Lueg and the helmets from Tiryns and Szczecin-Zdroje. On both breast and back plate, three vertical lines of bosses were applied under the two waistlines of bosses. The pectoral muscles are heavily abstracted by a line of bosses; the circles indicating breast and nipples are surrounded by a semi-circle of bosses. The back plate of the cuirass is decorated in a similar way to that of the breast plate but has only three circles above the two waistlines, and only one central double-circle at the bottom.

The cuirass from Jura B (cat. no. 138) is completely covered with bosses and pellets. In horror vacui, both breast and back plate are covered extensively with vertical lines of bosses below the horizontal waist line. On the back plate, these vertical lines of bosses continue above the waist line and reach almost up to the neck. Immediately under the neck though, two heads of water birds, turning towards the centre of the back plate so as to each other, were applied. Behind each bird head a circle with a central boss was applied. The circles on the breast plate, which accentuate the breast, each consist of eight lines of pellets and bosses with a central boss. These circles are surrounded by a loop-shaped line, which spreads from the shoulder. Below the two breast circles, four heads of water birds are visible, facing each other; the inner two birds are touching each other with the beak. In between these water bird heads, bosses were also applied. ${ }^{878}$

The unprovenanced cuirass cat. no. 136 is unique and not comparable with the other Bronze Age cuirasses in terms of shape (it is significantly waisted, without becoming wider at the base), the connection of breast and back plate, and in its decoration. Three horizontal lines (two lines of bosses, one central line of pellets) around the waist separate a lower part, which is decorated with four vertical pellet lines and one central horizontal pellet line, from an upper part, which is decorated with three circles. The outer circles consist of four lines (two outer lines with bosses, two inner pellet lines), while the central circle consists of three lines (the outer line with bosses, the inner lines with pellets). All three circles bear a large central boss.

\subsection{Cuirass Fragments and Potential Cuirass Finds}

Several bronze sheet fragments were, or still are, interpreted as belonging to cuirasses. So far, this is only certain for the fragments from Phaistos, Mycenae, Nichoria and highly likely for Winklsaß. Further fragments, such as those from Kallithea, Lakkithra and Szentgáloskér, which were all previously interpreted as cuirass fragments, almost certainly belong to other objects. Other potential cuirass finds lack any further information, ${ }^{879}$ as they could either no longer be located in their respective museum (e.g. Šulekovo), or were simply too fragmentary or equivocal in form to be confirmed as belonging to a cuirass (e.g. Plérimond, Grésine, Cannes-Écluse, Abensberg, Pfeffingen, Heunischenburg, Farkasgyepü, Podcrkavlje, Pila del Brancon), as will be discussed below.

Potential band-sheets from Greek cuirasses have been found at Phaistos, Mycenae, and Nichoria and are dated to the short time frame of LH II-IIIB2. ${ }^{880}$ Two fragments were found in Phaistos, tombe dei nobili, (measurements: length: $29.5 \mathrm{~cm}$; height: $12 \mathrm{~cm}$ ) (Fig. 3.5.3), in chamber tomb 15, Mycenae (measurements A: length: $22.5 \mathrm{~cm}$; height: $6-7.7 \mathrm{~cm}$; measurements B: length: $17.3 \mathrm{~cm}$; height: $8 \mathrm{~cm}$ ), and finally in chamber tomb 69, Mycenae (measurements A: length: $45.6 \mathrm{~cm}$; height: $5.5 \mathrm{~cm}$; measurements B: length: $4.8 \mathrm{~cm}$; height: $5.9 \mathrm{~cm}){ }^{881}$ As typical for Greek body armour, they all have a row of small holes running along the rim, most likely used for fixing the organic lining. These fragments probably belong to the lower part of a panoply similar to that from Dendra. ${ }^{882}$ One of the band-sheets from chamber tomb 69 is gilded, whilst the other is curved and appears to be part of a girdle. The band sheets have been interpreted as

\footnotetext{
878 Cf. Mödlinger 2014b, 26.

879 v. Merhart noted one cuirass he saw in the previous Reiling collection: v. Merhart 1969, 153, note 4.

880 Andrikou 2007, 403; Mödlinger 2014b, 6, 27.

881 Yalouris 1960, suppl. 25.3.

882 Verdelis 1967, 22.
} 
belts, breast shields or mitra, but the similarities with the lighter and smaller band-sheets of the Theban cuirasses is striking. We might also connect them with 'things hung or attached above' (o-pa-wo-ta) from the Linear B tablets. ${ }^{883}$ A LH IIIA-IIIB2 (c 1370-1250BC) tholos tomb at Nichoria contained 117 fragments of bronze plate, ${ }^{884}$ which might also belong to segmental armour similar to the panoplies from Dendra and Thebes. Some of the fragments have rolled edges and along the rim a line of small, punched holes some $1.2-2 \mathrm{~mm}$ diameter. Other fragments have slightly larger holes further away from the rim. Bronze wire from the same grave was probably used to join together the breast and back plate. Also in the grave were four staples of plain, concave and convex bronze sheet (each approx. $4.5 \times 3 \mathrm{~cm}$ ), which might also belong to the armour, since they have the same thickness as the sheets of body armour. Another fragment, which might belong to a neck guard, has a rolled edge. The major part of these fragments bears small holes along the edge for the application of an organic lining, while some have larger holes for attaching the plates to one another.

The associated deposit from Winklsaß, Germany, was found in 1911. The associated deposit itself was covered by 35 bronze ingots, beneath which were found pins, necklaces, arm-rings, foot-rings, belt-hooks, parts of fibulae, a piece of a sword blade, four fragments of spearhead, one complete and 36 fragments of sickle, seven axe fragments, a razor, fragments of knives and daggers, one ingot, ten bronze sheets belonging to a cauldron or bucket, ${ }^{885}$ and a greave (cat. no. 229). The potential cuirass fragment, a bronze sheet, was folded over twice. ${ }^{886}$ During restoration the fragment was unfolded and subsequently broke into three pieces. Previously, the fragment had been interpreted as a part of a vessel; ${ }^{887}$ Müller-Karpe was doubtful of this but offered no alternative suggestion. ${ }^{888}$ Schauer, however, suggested that it might be a fragment of a cuirass ${ }^{889}$ but did not mention it in further publications or include it on distribution maps. Nevertheless, the lines of pellets, the wire and the thickness of the bronze sheet, all support its interpretation as being from a cuirass. The rim is bent around a $3 \mathrm{~mm}$ thick wire. On the right, a convex decorative rivet is present, and above it, two torn-out rivet holes at the same height are visible, though these might be the result of antique restoration. ${ }^{890}$ Vertical hammering traces are visible on the inside of the bronze sheet. Two lines of pellets parallel to the rim are similar to that found on the cuirass from the Danube. R.-M. Weiss suggests that the greave and cuirass fragment belong to the same set of body armour on the basis of similarities in their decoration. ${ }^{891}$ In which case, the weapons from the associated deposit might also have been part of the same equipment.

In 1953 a late Mycenaean chamber tomb was discovered by a farmer in Kallithea. In chamber tomb A, the bones, presumably from a male, were reburied in a small pit in the back of the tomb. The second burial, another male, was buried in the shaft grave, which had originally belonged to the first burial. The grave contained ceramics (primarily oinochoe), a spearhead, a Naue II sword, and fragments of two greaves, which were placed on the legs of the second burial (cat. no. 199-200). The fragments in question preserved are bronze strips $(24 / 27 / 17 \mathrm{~cm} \times$ $2.2 / 3 \mathrm{~cm}$ ), which are decorated with double ridges on both edges. In the centre, nails were driven through; they still seem to be straight and unbent. ${ }^{892}$ Catling interpreted these fragments as from a precursor of the cuirasses from Fillinges ${ }^{893}$ This has previously been questioned by Clausing, who noted that there are no similarities between them. ${ }^{894}$ As the recent find of a head-

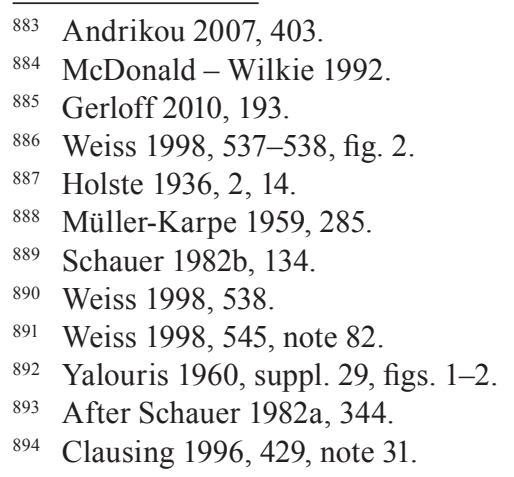


gear from the tholos-grave at Praisos-Foutoula, which is dated to c. $1200 \mathrm{BC},{ }^{895}$ showed, these fragments from Kallithea, but also similar fragments from Lakkithra, belong to the same type of tiara-like head protection. ${ }^{896}$

The Hungarian associated deposit from Szentgáloskér contained, besides a range of other bronzes, four small, rather thin bronze sheets of $0.2 \mathrm{~mm}$ thickness, which are wrongly interpreted as fragments of cuirass (Fig. 3.14). ${ }^{897}$ The four fragments form a band which has on one side a line of small, punched-through holes and on the other side an embossed rib with $7 \mathrm{~mm}$ width parallel to the edge. ${ }^{898}$ The biggest fragment bears on one side a small, thin bronze band. This band is decorated along the rim with a line of pellets and was riveted on with tiny, round headed rivets. On the back of the larger fragment, the bronze band was not riveted onto the fragment all the way along but overlaps with the straight edged fragment, forming a bow, indicating that there was a further piece of bronze riveted on but which is now missing. There are no similarities between these fragments and other known cuirasses to suggest what part of the armour the thin Szentgáloskér fragments might once have represented. ${ }^{899}$

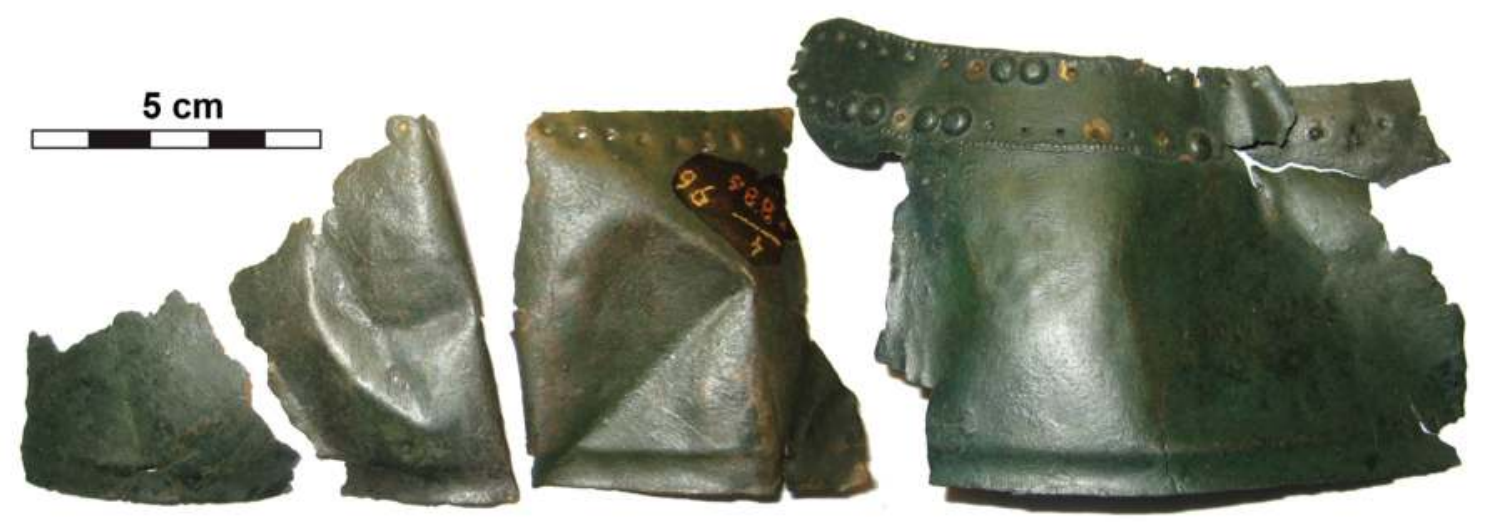

Fig. 3.14 The fragments from the associated deposit of Szentgáloskér, Hungary, which are usually interpreted as belonging to a cuirass (photograph: M. Mödlinger).

G. v. Merhart noted that he had seen a complete cuirass whilst visiting the Reiling antiques shop in Mainz in 1928 (1969, 153 note 4). This could not have been the unprovenanced cuirass cat. no. 135 as this was bought by the museum 19 years earlier. However, it appears to be very similar to the finds from Fillinges, and v. Merhart assumed it might belong to the same assemblage. No further information on this cuirass is available.

In 1628, nine cuirasses were reported to have been found by a gardener in Rue Vivienne, Paris. ${ }^{900}$ The cuirasses were deposited within the old northern riverbed of the Seine on an alluvial cone. The cuirasses were thought to be made for women since they are 'étoient relevées en bosse et arondies sur l'un et l'autre côté de l'estomac'..$^{01}$ Nothing is known from the cuirasses today, nor does any depiction or drawing exist, a fact already Nossiop complained about in $1864 .^{902}$

The debris in front of the cave of Plérimond, France, contained amongst other objects, a pair of greaves, a further third single greave, a horse harness, phalerae, spear-heads, a Type Certosa

895 Deger-Jalkotzy 2006, 714.

${ }^{896}$ See also Chapter 2.1.5.

897 E.g. Paulík 1968, 50; Mozsolics 1985, 195; Jankovits 1999/2000, 195. Petres - Jankovits 2014, 60 suggest the fragment was from a cuirass, specifically deriving from the neck protection, such as that from Hesselberg. In fig. 15.1 the fragment is again named as a 'cuirass fragment' - as two fragments from helmets of Type Paks from Nadap (cat. no. 27).

898 This rib is not visible in previous drawings but is clearly identifiable in Mozsolics 1985, pl. 115.6, 9.

899 Mödlinger 2014b, 29.

900 Bulard 2008.

901 Poullain de Saintfoix 1763, 348.

902 Nossiop 1864. 
fibula, and a possible cuirass fragment. ${ }^{903}$ The associated deposit is dated to the $6^{\text {th }}$ century BC. Schauer noted a further potential cuirass fragment from Grésine, France. ${ }^{904}$ The fragment bears Ringbuckel and the semicircular bent bands of points and bosses. Nevertheless, since no cuirass with similar decoration is known, this fragment is more likely from another type of object.

Schauer also mentions a fragment of a possible cuirass from the associated deposit of Cannes-Écluse. ${ }^{905} \mathrm{He}$ did not describe it explicitly nor refer to any specific drawing of the fragment. Most likely he was referring to the fragment described by Gerloff, ${ }^{906}$ which is more probably from a vessel. Schauer also noted 16 fragments with rivets from Abensberg, Germany, which might also belong to cuirasses. ${ }^{907}$ The find circumstances of these fragments, however, are not secure, unlike the finds with which they are compared (e.g. Welzelach, Austria, or Challans, France) by the authors.

The Ha B1 associated deposit from Pfeffingen, Germany, contained three fragments, decorated with ribs and bosses. On one side of the fragments, the rim is bent around a bronze or copper wire. These fragments have also been interpreted as belonging to a cuirass. ${ }^{908}$ Two holes right above the rim, however, would be quite unusual for a cuirass.

A fragment from the Heunischenburg, Germany, was interpreted as coming from a cuirass, ${ }^{909}$ though it might also be from a vessel. French cuirasses do not have three parallel lines of large bosses but only two. If there are three lines, they are separated from each other by decoration, such as a line of pellets, and the lines are positioned further apart from each other.

Jankovits interpreted two deformed and probably fire-exposed bronze sheet fragments from a grave from Farkasgyepü, Hungary, as fragments of a cuirass. ${ }^{910}$ The fragments are today stored at the Veszprémi Bakonyi Múzeum (inv. no. 1955.117.8-9). The bronze sheets have on one side holes running parallel to the edge. Beneath these, another small bronze sheet was attached with three rivets. Despite these characteristics, the thickness of the bronze sheets, of $0.1-0.2 \mathrm{~mm}$, does not support their interpretation as belonging to a cuirass.

When the Croatian Period II associated deposits from Podcrkavlje (found in 1962 at Dvorišta) and Slavonski Brod (found at Biliš) were brought to the Archaeological Museum of Zagreb in 1868 , they were probably mixed together. The (new) associated deposit consisted of 277 objects, as well as two potential fragments of a cuirass or shield. ${ }^{111}$ The fragments were broken before deposition and fit together. The rim is bent around a wire. Around $3 \mathrm{~cm}$ above the rim, four bosses with a diameter of c. $0.7 \mathrm{~cm}$ were applied parallel to the rim. It seems that above these bosses, a (rivet?) hole was applied. The resemblance with other known cuirasses, however, is slim.

The associated deposit from Pila del Brancon, Italy, was found $1.5 \mathrm{~km}$ to the south of the Middle Bronze Age cemetery of Olmo in $1993 .{ }^{912}$ It is possible that the deposit has not yet been completely recorded. At present, it consists of 51 largely complete or fragmented spearheads, 12 complete or fragmented swords (Types Allerona, Cetona and Arco), two daggers (Type Santa Agata and Pertosa), one fragment of a winged axe, 73 bronze sheet fragments, comprising both thin sheeting of unknown object Type and thicker fragments of vessels, and nails. The objects were intentionally destroyed by bending, breaking and exposure to fire. The objects date to bronzo medio, recente and finale. Jankovits tried to reconstruct a cuirass from the bronze sheets (mainly inv. no. IG VR 266.650 and IG VR 26.603). ${ }^{913}$ However, we believe that the evidence is

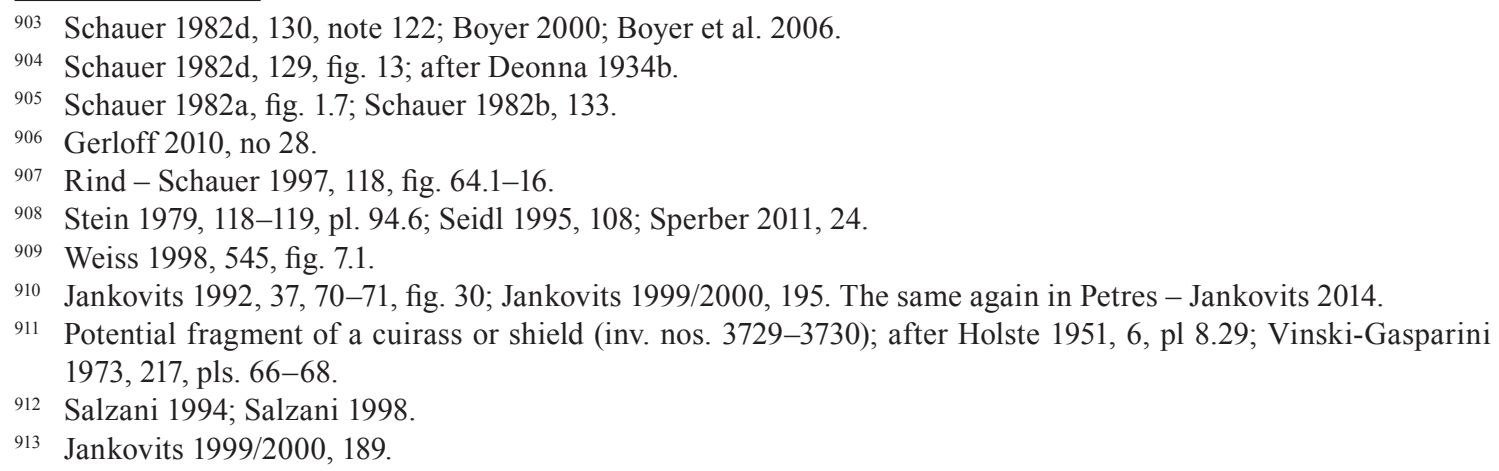


insufficient to base such a reconstruction: the fragments are too thin, too inhomogeneous and the rivets are too long for the metal sheets alone. Thus, they must have been fixed onto an organic backing on the inside as well.

Novotný noted the discovery of another possible cuirass fragment from Šulekovo, Slovakia. The fragment was found along with a bronze sword and other objects in a grave before 1880; the finds cannot be located in the museum today. ${ }^{914}$

In 2015, excavations by the University of Cincinnati (Jack L. Davis and Sharon R. Stocker) brought to light one of the richest warrior shaft graves of recent times at Pylos, Greece. The grave is significant for not having been robbed. The warrior was buried around $1500 \mathrm{BC}$ with a sword with ivory hilt clad in gold, a gold-hilted dagger, a spearhead, gold jewellery, and about 50 stone seals. Bronze, silver and gold cups, a bronze mirror, six ivory combs, and an ivory plaque carved with a griffin. No pottery was placed in the grave. The warrior wore a boar tusk helmet. Thin bands of bronze atop the coffin might also have been part of the warrior's body armour. Analysis of the find is ongoing and awaits publication.

\subsection{Construction}

The construction principles (Figs. 3.15-17) for each of the three main groups of cuirasses Greek, Carpathian, and western European - differs according to their distribution, chronology and decoration.

The construction of the Dendra panoply has elsewhere been described in meticulous form ${ }^{915}$ and therefore need not be repeated in detail. The panoply consists of 15 bronze sheets:

1. one breast plate $(41 \times 46 \mathrm{~cm})$ and one back plate $(52 \times 55 \mathrm{~cm})$

2. two triangular metal sheets $(\mathrm{c} .9 \times 18 \mathrm{~cm})$ placed over the breast plate to protect the chest

3. two shoulder protectors which both have an additional metal sheet to protect the upper arm $(54 \times 8 \mathrm{~cm}$ on the right, $47.5 \times 8 \mathrm{~cm}$ on the left side $)$

4. the neck guard (height $8-15 \mathrm{~cm}$; diameter at the top $28.5 \mathrm{~cm}$; base diameter $21 \times 24 \mathrm{~cm}$ )

5. three bronze bands attached to the breast plate, and three bronze bands attached to the back plate $(64-76.5 \times 15-17.3 \mathrm{~cm})$

Each of these bronze sheets has small holes of c. $2 \mathrm{~mm}$ diameter positioned every $2-2.5 \mathrm{~cm}$ all along the edge. These holes served to attach an organic lining, as the remnants of threads within the holes, and fragments of leather inside the breast and back plate, attest. ${ }^{916}$ The lining was bent around the metal edge and fixed on both sides, thus preventing the warrior from cutting himself on the sharp edges of the metal sheets. Where the edge of the metal sheets is not bent outside, it was partly protected by an $8 \mathrm{~mm}$ wide bronze band. The breast plate and the longer back plate were joined together at the shoulder by a loop, which was riveted onto the breast plate. The loop passed through a rectangular hole on the back plate and was fixed in place by passing a nail through the loop (Fig. 3.16). The back plates overlapped with the breast plate by at least $3 \mathrm{~cm}$ at the sides in order to ease fastening. A metal bar fixed on the back plate on its left side held the plates together. The bar reaches from the armpits to the pelvis and can be inserted into a range of three rings, which are attached to the breast plate. ${ }^{917}$ Thus, the cuirass was flexible on the left side, easing dressing, and closed on the right side. On the right side, the same loop-system as on the shoulders was used to close the cuirass.

The shoulder plates are slightly bent outwards from the body of the warrior but where the protective bands for the upper arm were fixed, the edges of the shoulder plates remained straight. A metal ring of $1.2 \mathrm{~cm}$ diameter is riveted onto the top of the right shoulder plate. It might have served to fasten a strap for a sword or shield. The shoulder plates were fixed most likely on the

\footnotetext{
914 Novotný 1966, 33.

915 Verdelis 1967, 8-18.

916 Verdelis 1967, 8.

917 Verdelis 1967, fig. 5.
} 

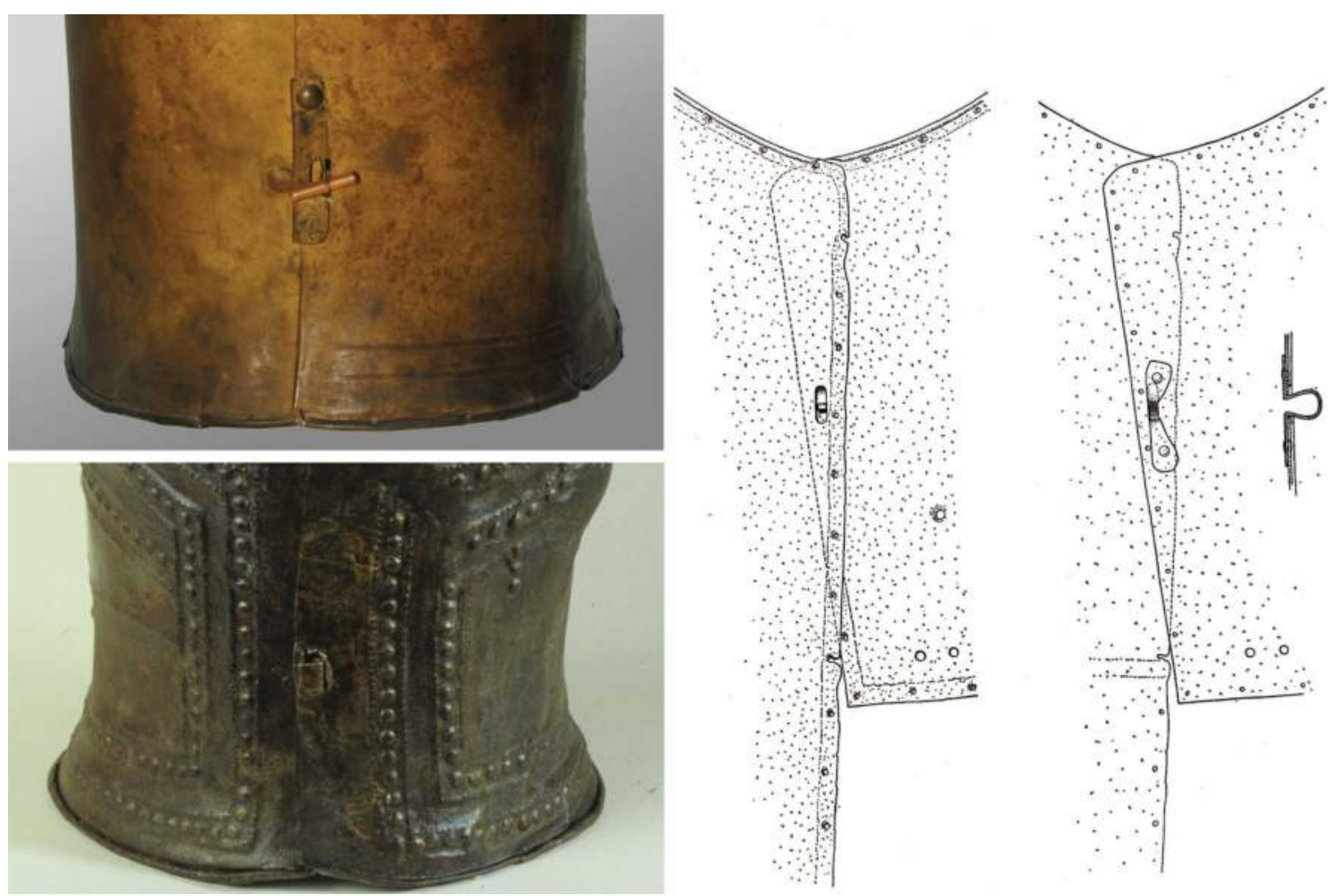

Fig. 3.15 Different ways of fixing the breast and back plate together on the right side: Saint-Germain-du-Plain (above left), Marmesse (below left) and Dendra (right) (above left: photograph M. Uckelmann, by courtesy of the Musée d'Archéologie nationale et Domaine national de Saint-Germain-en-Laye; below left: photograph A. Chauvet (C2RMF), by courtesy of the Musée d'Archéologie nationale et Domaine national de Saint-Germain-en-Laye; right: after Verdelis 1967, fig. 4).

breast plate only, since no larger holes are found on the back plate. ${ }^{918}$ The arm plates were attached to the shoulder plates with threads, which would have passed through five holes on each side. The arm plates widen in the centre, and at the end have a rather pointed shape. The edge close to the arms is bent outwards, while the edge towards the shoulder plates is straight.

The two triangular breast plates were attached to the shoulder plates by rings passing through three pairs of holes on each plate. ${ }^{919}$ The ends of the bronze sheet, which form the neck guard, are riveted together. Both upper and lower edge of the bronze sheet are bent outside in order to reduce the risk danger to the neck. No holes are found which might serve to fix the neck guard with leather strips, and instead, it was most likely clipped over the bent rims of both the breast and back plate. The protective band below the breast and back plate was attached to them with threads or strips, since they do not always match perfectly on each side. The threads or strips passed through three pairs of holes (c. $4 \mathrm{~mm}$ of diameter) on the lower part of the breast and back plates on the left, in the middle and on the right. The bands are joined together in a similar way. Remnants of the leather bands or strips holding the bronze sheet bands together are still preserved. The wider bronze sheet bands are placed towards the bottom of the panoply.

The panoply from the arsenal at Thebes consisted of similar elements. ${ }^{920}$ Its breast and back plate, however, are of equal length. Unlike the Dendra panoply, the edges of the different parts of the arsenal panoply (cuirass, shoulder guards and arm guards) are plain, and not rolled aside. The damaged panoply from the arsenal consists of:

1. one breast plate and one back plate

2. two triangular breast plates (length $27.7 \mathrm{~cm}$ )

918 Cf. Mödlinger 2014b, 32.

919 Verdelis 1967, 16.

920 Verdelis 1967, 21. 

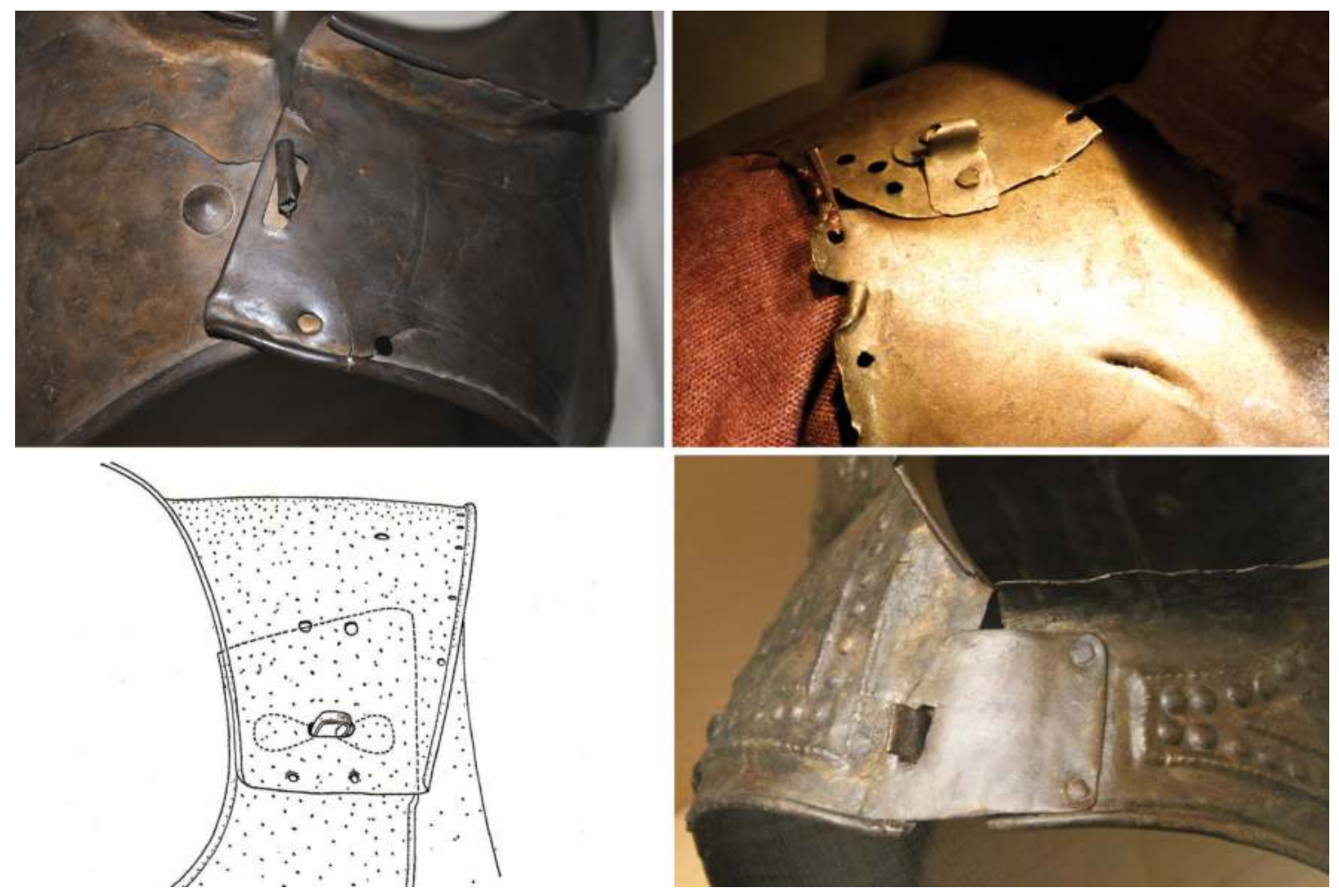

Fig. 3.16 Different ways of joining breast and back plate on the right shoulder: Dendra (bottom left), Saint-Germain-du-Plain (upper left), Danube (upper right) and Marmesse (bottom right) (bottom left: after Verdelis 1967, fig. 3; upper left: photograph M. Uckelmann, by courtesy of the Musée d'Archéologie nationale et Domaine national de Saint-Germain-en-Laye; upper right: photograph M. Mödlinger, by courtesy of the Magyar Nemzéti Muzeum Budapest; bottom right: photograph A. Chauvet (C2RMF), by courtesy of the Musée d'Archéologie nationale et domaine national de Saint-Germain-en-Laye).

3. two shoulder pieces $(13.6 \times 21.5 \mathrm{~cm}$ and $14 \times 19.5 \mathrm{~cm})$

4. two arm plates (length $40 \mathrm{~cm}$ )

5. 44 fragments of bronze sheet bands

The shoulder plates do not have the wide 'wings' which cover the Dendra panoply at the chest and back. The two triangular breast plates have a series of small holes (approx. $2 \mathrm{~mm}$ in diameter) all along the edge (no larger holes to connect them with the cuirass are present). The arm protectors were attached to the shoulder guards with organic threads or strips, which passed through larger holes on the parts to be joined together. The arm protectors have a row of small holes along the edges which serve to fix organic parts onto the bronze sheets. Along with the panoply, a further 44 fragments of bronze sheet bands were also recovered. These bronze sheet bands most likely belong to belt fastenings on the cuirass, protecting the lower part of the body. ${ }^{921}$ They do not necessarily have to be part of the associated panoply, however, and might have belonged to more than one panoply. All of them bear a row of $2 \mathrm{~mm}$ holes along the edge. These bronze sheet bands are significantly smaller than the ones from the Dendra panoply. Some of the bigger fragments have larger holes, as seen on the upper arm plates, where organic threads passed through to connect the bronze sheet bands to other bronze sheets.

The panoply from the Municipal Conference Center, Thebes, is constructed in a similar way to the two other Greek panoplies. Though incomplete, we can still identify the main construction elements: the breast and longer back plate are fastened by two double-headed nails on the left side. On the right side there is a riveted loop on the breast plate, which passed through an elongated hole in the back plate to join the two plates together. These two plates would have

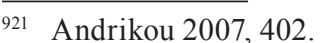


only been joined together once the cuirass was put on by the warrior. ${ }^{922}$ The attachment of an organic lining is indicated by the small holes arranged all along the straight and unrolled edges of the plates. Larger holes occurring as pairs or in threes along the lower edge served for attaching the bronze sheet-bands below the cuirass. A fragment of a shoulder guard and one (triangular?) breast plate clearly indicate its close affinity with the Dendra panoply. ${ }^{923}$

Due to their state of preservation and the common occurrence of cuirasses as merely fragments, only the Carpathian cuirasses from Saint-Germain-du-Plain, the Danube and the fragments from Čierna nad Tisou will be discussed in the following.

The breast and back plates of the cuirass from Saint-Germain-du-Plain are joined permanently by four conical headed rivets on the left side (one of which is now missing), and one rivet on the left shoulder (also now missing). The rivet holes were punched through from the outside to the inside. The breast plate has a rectangular hole on the right shoulder to allow the wearer to grab the upwards-bent metal sheet, which is attached to the inside of the back plate with a conical headed rivet, in order to join the two plates together on the right side (Fig. 3.16). ${ }^{924}$ At the edge of the breast plate, centrally located on the right side, a bronze sheet with a central, rectangular hole was riveted on. Through this hole, another loop-shaped bronze band could be passed and be fixed by means of a dowel passed through the loop (Fig. 3.15). This bronze loop-band was riveted onto the back plate with a slightly conical headed rivet. Under the right armpit of the breast plate we see an additional rivet hole of yet unknown function (which perhaps served for a cord which fixed the dowel in place). The edges of both breast and back plate (arms, neck and base) were bent over a wire made of rolled bronze or copper sheet. Vertical hammering traces are visible all over the inside of the neck and body of the cuirass. Several cracks present can be connected to the massive material deformation that the bronze sheets would have undergone during manufacture, as well as significant material stresses suffered during its subsequent use. Decorative elements were applied only on the breast plate, and different techniques on both the front (chevrons by chasing) and the back (e.g. ribs with repoussé) were used. The edges of the ribs on the front side of the breast plate were also further accented with a chisel.

The breast and back plate of the Danube cuirass were attached together by means of four rivets on the left side (if we assume that the upper and the lowest holes served for the attachment of an organic lining only), as seen on the likely contemporary cuirasses from Saint-Germaindu-Plain and Čierna nad Tisou. On the left shoulder the plates were riveted together by means of single rivet, now lost, while on the right shoulder a simple loop riveted onto the back plate was an adequate means of attachment, passing through a hole on the breast plate and then secured with a nail, as known from the Dendra panoply and on the cuirass from the Municipal Conference Center plot in Thebes. The rivets used on the Danube cuirass are plain, unlike the conical headed rivets, e.g. as on the cuirasses from Saint-Germain-du-Plain and Čierna nad Tisou. The edges of the breast and back plate are not reinforced with metal bands as found on the cuirasses from Čaka and Pázmándfalu, nor bent as on the Dendra panoply. A rolling of the edge around a bronze or copper wire, as found on most of the Carpathian and western cuirasses, is also not found. The edges are left straight, with only the neck guard being slightly bent outward. This neck protection is, compared to the other Carpathian and western cuirasses, astonishingly high and resembles much more closely that found on the Dendra armour, though not as a separate part. All along the edges (rivet?) holes are applied; they have a distance from each other of $4-6 \mathrm{~cm}$, a diameter of 4-5mm, and were punched through from the outside to the inside. Since the attachment of further bronze sheet elements by means of so many rivets does not seem likely, it is more probable that they served to attach an organic lining. The attachment of an organic lining with rivets inside the cuirass is similar to that on contemporary helmets. On the latter, and perhaps also on the cuirass as well, the organic inlay or lining was bent over the edge of the bronze sheet and riveted on both sides of the bronze sheet. The decoration was applied from the

922 Cf. Mödlinger 2014b.
923 Andrikou 2007, 402.
924 Cf. Mödlinger 2014b. 
inside of the cuirass with only two different sized punches: the pellet decoration (lines, circles, bows) was applied with a small circular punch, while the larger central boss located inside the four circles was applied with a bigger, round punch.

Four conical headed rivets located on the left side permanently fixed the breast and the back plate of the cuirass from Čierna nad Tisou. Apart a few fragments remaining around the rivets, nothing more is preserved of the breast plate. Around the rivets, fragments of one complete rectangular lining disc is preserved (Fig. 3.17). No original edging of the cuirass survives, and therefore it is unclear if the rim was rolled, bent or reinforced with riveted metal bands as known from Čaka and Pázmándfalu. A slightly bent edge, close to the original rim, does seem to suggest a rolled rim. As on the cuirass from Saint-Germain-du-Plain, the cuirass from Čierna nad Tisou has hammer traces on the inside of the back plate. Moreover, slight vertical hammering traces can also be seen on the outside of the cuirass. Since the breast plate is not preserved, we can say little about the decoration of the cuirass. However, the back plate is decorated with two c. $4 \mathrm{~mm}$ wide ribs running parallel to the base and the armpits. The ribs were applied from the back with repoussé and their outline defined with a chisel (chasing), as already noted on the cuirass from Saint-Germain-du-Plain.
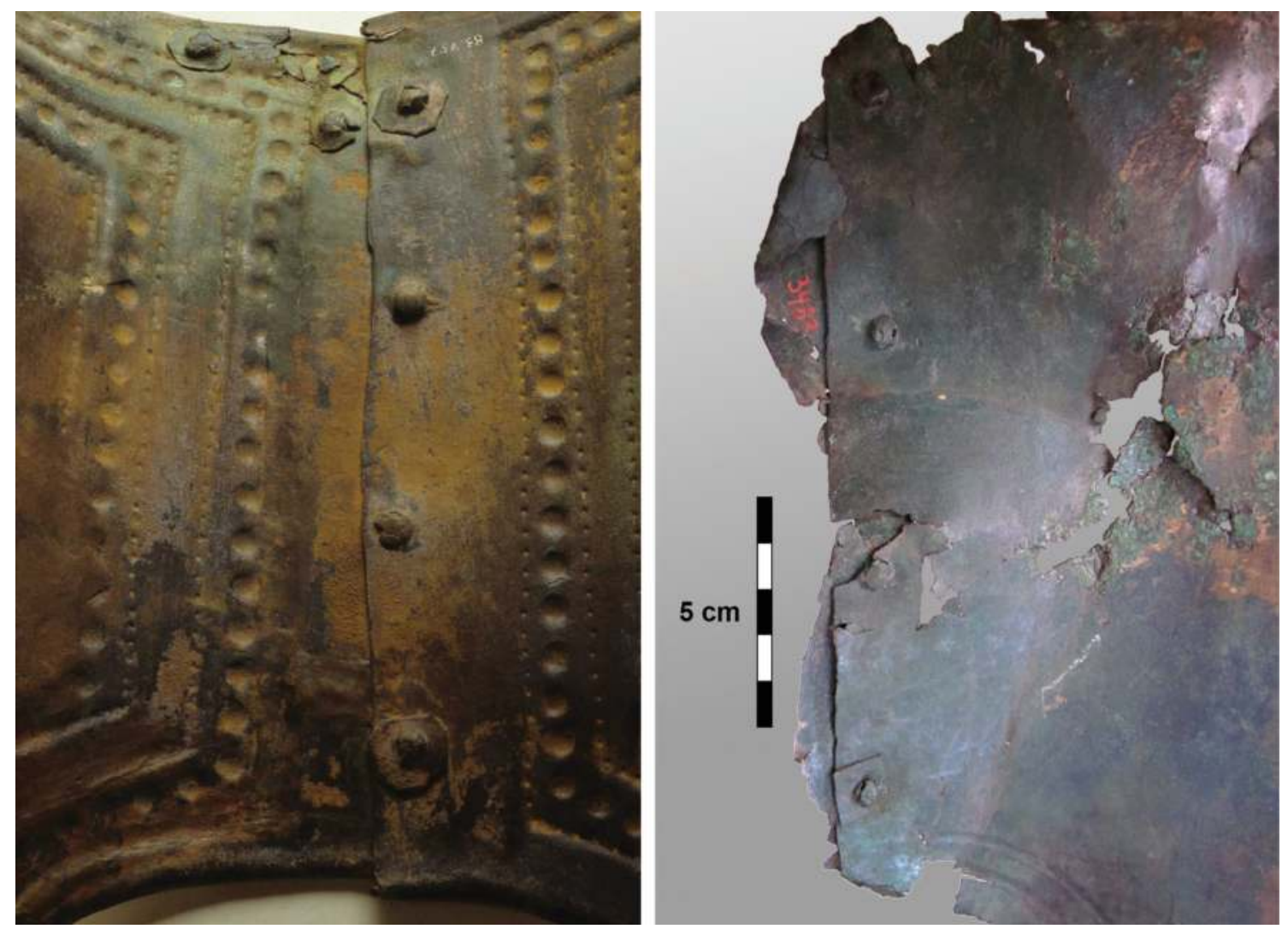

Fig. 3.17 Inside view of the left side of two cuirasses: Marmesse inv. no. 83.757 (left) and Čierna nad Tisou, Slovakia (right). Note the lining discs used for both cuirasses (left: photograph A. Chauvet (C2RMF), by courtesy of the Musée d'Archéologie nationale et Domaine national de Saint-Germain-en-Laye; right: photograph: M. Mödlinger).

Since they survive only in either a heavily fragmented state or as single fragments only, not much can be said about the construction of the other Carpathian Cuirasses. The Nadap fragment was bent around a bronze or copper wire, as was the Ivančice fragment, though no wire survives. Both fragments are decorated with two ribs parallel to the rolled edge. The ribs were applied using repoussé. The Ivančice fragment has a defined outline of the decoration, the same as on the Saint-Germain-du-Plain and Čierna nad Tisou cuirasses, which was applied with a chisel on the outside of the cuirass. On the inside of the fragment, hammering traces are visible, and on the outside, vertical polishing traces were detected. The wire from the inside is currently 
undergoing analysis. ${ }^{925}$ Due to its fragmentary character and the lack of any original edge, the construction of the cuirass from Ducové cannot be reconstructed. The decoration on the chest was applied with the edge of a chisel on the outside of the breast plate, while the two ribs were applied from the inside (repoussé), and their outline defined with a chisel (chasing), as already noted for other Carpathian cuirasses. Additionally, small pellet decoration was applied from the back inside the ribs. ${ }^{926}$

The cuirass from Čaka is, having undergone firing as part of a cremation rite, severely fragmented and incomplete. Most of the fragments without rim cannot be definitively associated with either the cuirass or the other objects which occur in the deposit. Nevertheless, aspects of the decoration (two ribs parallel to the armpit were applied using the repoussé technique), and the reinforcement of the edge, can be reconstructed: on the edge of (presumable both) breast and back plate a separate, straight (and never curved) bronze band was riveted on. The bands have a serrated edge with the points directed toward the centre of the cuirass and are decorated with lines of small pellets. Two different sized band types are noted, which were attached to two different edges of the bronze plate, as indicated by a corner fragment. On none of the bands is there any surviving indication as to how the breast and back plate were joined (such as rivet holes or an opening for the bronze loop on the right side, etc.). It therefore remains unclear how breast and back plate were joined. Comparing the fragments from Čaka with the new find from Pázmándfalu, no serrated bronze sheet decoration is found on the left side of the cuirass, and it seems highly likely then that the corner fragment derives either from the right lower edge of the breast plate (on the back plate the decoration would not be visible, since the back plate was usually fixed underneath the breast plate) or from the shoulder/neck area of the breast plate. ${ }^{927}$ In the same style as the bands, two star-like, serrated discs were riveted onto the breast plate above the nipples. The discs were riveted onto the breast plate with small rivets placed at each 'point' of the star.

Edge fragments with one parallel rib and outwards rolled rim were also associated with the cuirass. Since these fragments are straight and not curved, they cannot derive from the opening for the arms (for a comparison, see also the fragments from Pázmándfalu, where the rim of the plates around the arms were decorated with a serrated bronze sheet), nor can they derive from the base or side of the breast or back plate, since these show the attached, decorated bronze bands. Also, the ribs on these edge fragments are far bigger than the ribs on the breast plate (on the cuirass from Saint-Germain-du-Plain all the ribs have the same width). The line of small holes all along the edge of the fragments did not serve for attaching a decorative band with serrated edge (this would need also a second line of small holes). More likely, they served to attach an inner lining, similar to the Greek cuirasses, if these fragments do indeed belong to a cuirass.

The fragments from the recent find from Pázmándfalu closely resemble the cuirass fragments from Čaka. ${ }^{928}$ Unfortunately, only fragments from the rim survived. The decorative band with serrated side was attached with only one line of rivets, as was the edge of the armpits, parallel to the two embossed ribs. The ribs were applied in the same manner as on all other Carpathian cuirasses. Since all cuirasses are joined permanently on the left side, the Pázmándfalu fragments from breast and back plate, riveted together with slightly conical headed rivets, also most likely derive from the left side of the cuirass. As on the Čaka fragments, there are also two different thicknesses of serrated bronze sheet, with the thicker sheets having most likely been applied to the base of the cuirass, whilst the thinner bands served as reinforcement at the armpits and eventually on the shoulders, as the rectangular fragment with a riveted decorative band indicates. ${ }^{929}$

\footnotetext{
925 Richtera et al. forthcoming.

926 Cf. Mödlinger 2014b, 35.

927 Cf. Mödlinger 2014b, 36.

928 Gábor Szabó was so kind to show the author photographs of the fragments.

929 Cf. Mödlinger 2014b, 36.
} 
Mottier and Schauer already described in detail the construction of the cuirasses of Fillinges. ${ }^{930}$ To avoid too much repetition, in the following only the main aspects of the assembly of the cuirasses will be discussed. Both breast and back plate are thinner toward the centre (chest, spine: $0.7-0.8 \mathrm{~mm})$ than on the edge $(1-1.1 \mathrm{~mm}){ }^{931}$ The rim of both plates is bent outwards around a $2-2.5 \mathrm{~mm}$ thick, round wire. The plates are joined together on the left side with five to six conical headed rivets. Breast and back plate were joined together on the left shoulder either by rivets or by bronze sheet bands which were riveted onto the back plate and passed through a rectangular hole on the breast plate.

Abstracted breast muscles are depicted by means of decoration on the front plate; on the back plate, the back bone is indicated by a massive, convex rib, which would also have increased the stability of the bronze sheet. Hammering traces are not only visible on the inside of the armour plates but also on the outside of most of the plates as well. The unprovenanced cuirass cat. no. 135 shows mainly horizontal hammering traces. This cuirass also closely resembles the cuirasses from Fillinges in its construction methods. It differs only in having a row of small, punched through holes all along the armpits, which most likely served for the application of the inner organic lining. ${ }^{932}$ The cuirasses, as indicated by one of the examples from Fillinges, were decorated with different sized punches from the inside (repoussé). Since on some of the bosses the imprint of a ring is visible, we can infer the use of a ring die. The sketch of the decorative design, which was marked out with thin scratches on the inside of the cuirasses, is still visible. Such sketches are also known from the greaves as well (Fig. 4.12).

The Marmesse cuirasses have a very similar construction to the Fillinges cuirasses: breast and back plate were joined together permanently on the left side by four or five conical headed rivets with lining discs. Another conical headed rivet fixed the two plates together on the left shoulder. A central rectangular hole on the right shoulder fixes a metal band, which was riveted onto the back plate, and passed through the hole. The edges of the cuirasses are bent outside around a bronze or copper wire. Inside the cuirasses, traces of straight hammering are visible, being mainly vertical on the lower parts and horizontal on the upper parts between the shoulders. In the application of the decoration, two different sized round punches were used. Radiographs of some of the Marmesse cuirasses (e. g. cat. no. 148) revealed several cracks which had formed as a result of the high tension the metal underwent during the deformation process, and which were enlarged by corrosion over the years. ${ }^{933}$

As on all other cuirasses, the breast and back plates on the cuirass Jura A (cat. no. 137) were joined together on the left side. Both plates were riveted together by six conical headed rivets on the side and by two rivets on the shoulder. The back plate is placed under the breast plate but is not completely preserved and nor is the right shoulder. On the right side of the cuirass, the breast plate bears a central, rectangular hole. This served to fix a metal band which was riveted to the back plate. Further pairs of holes at the top and bottom of the right side of the cuirass served most likely for the additional securing of the plates, perhaps with leather bands. The decoration of the cuirass was applied from the rear of the bronze plates with four different sized round punches (repoussé).

Though the cuirass Jura B (cat. no. 138) differs in terms of decoration from the cuirass Jura A, it does not differ significantly in its construction method. The breast and back plate are fixed by conical headed rivets on the left side (five in total). At the centre of the right side of the breast plate, a rectangular hole (today ripped open) was used to fix a metal band, which was riveted onto the back plate. The left shoulder of the cuirass is not preserved. Also, only parts of the back plate survive on the right shoulder. In the centre of the shoulder a bronze band was attached with a conical headed rivet and bent around the edge, forming a flat loop, and then

\footnotetext{
30 Schauer 1982d; Mottier 1988.

931 Schauer 1982d, 112.

932 Cf. Mödlinger 2014b, 36.

933 Puniet - Balcar 2000.
} 
bent backwards towards the inside of the back plate. ${ }^{934}$ The rim of the breast and back plate (arms, neck, base) is rolled around a bronze or copper wire. The rib decoration right under the neck on the breast plate bears two punched-through holes, which most likely are connected to the restoration of the cuirass. Since all rivet holes on the left side are torn out but still present on the breast plate, the cuirass probably suffered significant damage during excavation. The decoration on the cuirass was mainly applied using three different sized, round punches from the inside of the plates (repoussé). Only one punch was used to form the ribs - most likely with the help of a die. Due to the high level of corrosion, no hammering traces are visible.

The unprovenanced cuirass cat. no. 136 differs significantly in its construction from the other Bronze Age cuirasses. Its breast and back plate are fastened to the shoulders by two hinges. Close to the rim of the breast plate and on each shoulder, a bronze sheet with the hinges attached was riveted on. Seven rivet holes along the neckline indicate the attachment of now missing decorative elements, with the three central rivet holes exhibiting different corrosion products in a circular shape, which might be the result of formerly riveted on organic or metal discs. ${ }^{935}$ The cuirass had to be put on over the shoulders and was then fixed with organic strips on both sides, which passed through six holes on each side of the plate. The rim of both the breast and back plate is bent inwards, though the presence of a bronze or copper wire here is unclear. The decoration was applied from the inside with two different sized round punches.

\subsection{Analyses}

Until now, only a few Bronze Age cuirasses have been chemically analysed or undergone microstructure detection. These include the cuirasses from Čierna nad Tisou and Čaka, some of the breast and back plates from the Marmesse cuirasses, the two cuirasses from Jura, and the Dendra panoply, as well as the potential cuirass fragment from Winklsaß. Also, the cuirass miniature from Brandgraben underwent chemical characterisation. ${ }^{936}$ Tab. 3.4 presents an overview of those analyses so far published for Bronze Age European cuirasses. ${ }^{937}$

The majority of the cuirasses analysed consist of binary copper-tin alloys. Only the back plates from the Marmesse cuirasses (cat. nos. 146 and 151) contain more than 3-4 wt.\% Pb. The Sn amount ranges usually from $6.5-11 \mathrm{wt} . \%$, with only the Dendra panoply reaching up to 12.6 wt.\% Sn. Wire and rivets were studied only on the cuirasses from Jura, and their Sn amount ranges from 1.3-2.6 wt.\%. According to the different analytical methods used, trace elements such as $\mathrm{Ag}, \mathrm{As}, \mathrm{Ni}, \mathrm{Sb}, \mathrm{Pb}, \mathrm{S}, \mathrm{Zn}$ and Fe were detected. These elements are connected with the copper ore.

Whilst on most of the cuirasses quantitative analyses were carried out, the Dendra panoply was analysed only qualitatively, on corroded surfaces, using a handheld XRF. ${ }^{938}$ Copper chlorides, such as atacamite, nantocite, and paratacamite, as well as copper carbonates (azurite, malachite), tin oxides (cassiterite), and calcite (most likely due to the soil), were detected. After the removal of corrosion, the metallic surface was analysed again with the handheld XRF. The panoply contains 9.4-12.6 wt.\% Sn, which matches the composition of other European armour, though western European cuirasses in general contain lower amounts of Sn. The cuirass and the neck guard from the Dendra panoply seem to be made of the same alloy. The triangular chest protection and the left shoulder protection were also made of the same alloy, as were the right shoulder protection and the two bronze sheet bands nos. 5 and 6 (see Tab. 3.4). Since several parts of the panoply were made of the same alloy, we can assume that the panoply was pro-

Cf. Mödlinger 2014b, 37.

935 Cf. Mödlinger 2014b, 37.

936 Michel - Mohen 1970 (Jura A and B); Weiss 1998 (Winklsaß); Sofou - Katsarou-Moschona 2006 (Dendra panoply); Lehoërff 2008 (Marmesse); Taratori et al. 2008 (Dendra panoply); Mödlinger 2014b (Čierna nad Tisou, Čaka, Brandgraben).

937 For the detection method of the metallographic analyses and alloy composition via SEM-EDXS see Chapter 2.3.

938 Taratori et al. 2008, tab. 2. 


\begin{tabular}{|c|c|c|c|c|c|c|c|c|c|c|c|c|c|c|c|c|c|c|c|c|c|c|c|c|c|c|}
\hline 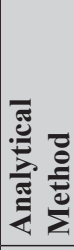 & \multicolumn{9}{|c|}{$\underset{\sum_{\text {II }}}{Ð}$} & \multicolumn{5}{|c|}{ 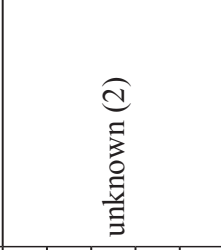 } & \multicolumn{6}{|c|}{ 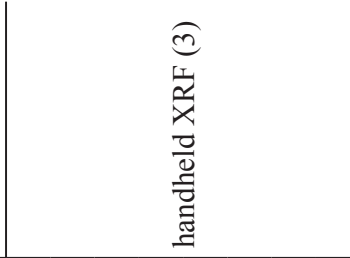 } & \multicolumn{3}{|c|}{ 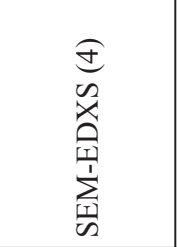 } & \multicolumn{2}{|c|}{$\begin{array}{l}\sqrt{n} \\
0 \\
0 \\
\vdots \\
\sum \\
\sum\end{array}$} & 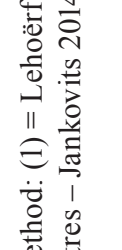 \\
\hline ஸ் & & & & & & & & & & & & & & & $\dot{\theta}$ & $\dot{\theta}$ & 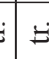 & $\dot{H}$ & $\dot{E}$ & $\dot{H}$ & & & & & & \\
\hline נ & & & & & & & & & & & & & & & & & & & & & $\dot{H}$ & 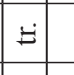 & $\ddot{H}$ & & & \\
\hline 200 & & & & & $\begin{array}{l}2 \\
\dot{0} \\
+\end{array}$ & & & & & 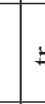 & & & $\ddot{H}$ & $\ddot{H}$ & $ت$ & $\exists=$ & $\exists$ & $\doteq$ & $\dot{\Xi}$ & $\dot{H}$ & $\stackrel{1}{0}$ & $\because$ & : & : & $\begin{array}{l}0 \\
0 \\
0\end{array}$ & \\
\hline$\overline{\mathbf{z}}$ & & & & & $\begin{array}{l}\overrightarrow{0} \\
+ \\
H\end{array}$ & & & & & 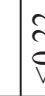 & & $\stackrel{\unlhd}{-}$ & तु & $\overrightarrow{0}$ & & & & & & & $\stackrel{\bullet}{\circ}$ & $\stackrel{1}{\circ}$ & 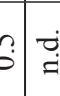 & ฮี & $\stackrel{7}{\stackrel{2}{0}}$ & \\
\hline งิ & & & & & & & & & & & & & $\ddot{H}$ & $\doteq$ & & & & & & & & $\dot{E}$ & $\stackrel{\check{g}}{=}$ & 8 & $\tilde{e}_{0}$ & \\
\hline I & & & & & & & & & & $\therefore$ & $\dot{\square}$ & $\stackrel{\bullet}{\circ}$ & $\dot{E}$ & $\dot{E}$ & $\doteq$ & $\dot{E}=$ & 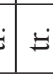 & $\doteq$ & $\doteq$ & $\dot{E}$ & $?$ & $ت$ & 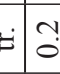 & $\dot{0}$ & $\stackrel{\circ}{-}$ & \\
\hline$\infty$ & $\left.\begin{array}{cc}c & \multicolumn{1}{c}{} \\
0 \\
+\end{array}\right)$ & \begin{tabular}{c|c}
\multirow{2}{0}{} & \\
+1 & -
\end{tabular} & 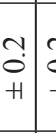 & $\begin{array}{l}y \\
0 \\
+1 \\
+1\end{array}$ & & $\mid \begin{array}{l}n \\
0 \\
1 \\
\\
0 \\
0\end{array}$ & \begin{tabular}{|c|c}
$n$ & \\
0 & \\
1 & \\
$m$ & 0 \\
0 & \\
\end{tabular} & $\begin{array}{l}n \\
\\
0 \\
\vdots \\
\\
0\end{array}$ & $\begin{array}{l}c \\
\vdots \\
+1\end{array}$ & & & & & & & & & & & & חִ & -1 & $\dot{0}$ & & & \\
\hline 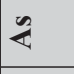 & & & & & & & & & & 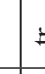 & $\dot{E}$ & & 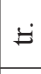 & $\overrightarrow{0}$ & & & & & & & $a$ & $\begin{array}{lll}0 & 2 & 0\end{array}$ & $\begin{array}{lll}0 & 0 \\
\end{array}$ & $\overline{0}$ & $\overrightarrow{0}$ & \\
\hline के & & & & & & & & & & $\delta$ & & & 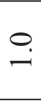 & $\hat{a}$ & & & & & & & $\overrightarrow{0}$ & & $\dot{0}$ & : & $\begin{array}{l}\overrightarrow{0} \\
\dot{\hat{\theta}} \\
\vec{v}\end{array}$ & \\
\hline$\hat{\otimes}$ & $\nabla$ & & & $m$ & & & & & & & & & & $\ddot{E}$ & & & & & & & ִֻ & 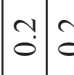 & $\begin{array}{c}y_{0}^{\circ} \\
\end{array}$ & $\stackrel{2}{\circ}$ & $\begin{array}{l}2 \\
0 \\
0\end{array}$ & \\
\hline ซี & {$\left[\begin{array}{c}1 \\
\infty \\
1 \\
1 \\
+ \\
+\end{array}\right]$} & $\stackrel{\infty}{=}$ & $\begin{array}{l}\overline{\mathbf{b}} \\
\overline{\mathrm{c}}\end{array}$ & \begin{tabular}{c|c}
$\infty$ & $e$ \\
$H$ & $e$
\end{tabular} & 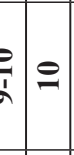 & $\stackrel{?}{r}$ & $\left.\mid \begin{array}{c}1 \\
0 \\
0 \\
H \\
H\end{array}\right]$ & $\infty$ & $\begin{array}{l}\Theta \\
+\end{array}$ & -12 & $: 9$ & $\underset{i}{\stackrel{i}{i}}$ & "ת & $\stackrel{9}{9}$ & 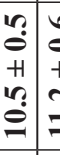 & 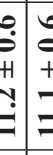 & 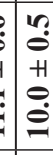 & \begin{tabular}{|l|}
0 \\
$\dot{0}$ \\
+1 \\
0 \\
$\dot{\Xi}$ \\
\end{tabular} & 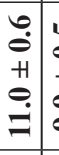 & 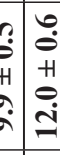 & $\stackrel{-}{\infty}$ & $\stackrel{\text { sִ }}{=}$ & 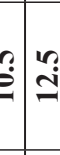 & $\exists$ & $\stackrel{\infty}{=}$ & $\begin{array}{l}\exists \\
\Xi \\
0 \\
0 \\
8\end{array}$ \\
\hline ש & $\begin{array}{l}\vec{\sigma} \\
+\end{array}$ & $\infty \mid \begin{array}{l}\vdots \\
\vdots\end{array}$ & \begin{tabular}{l|l}
2 & \\
0 \\
$\infty$ \\
$\infty$ \\
$\infty$
\end{tabular} & \begin{tabular}{c|c}
$\bar{a}$ & $\overline{0}$ \\
+ & 0
\end{tabular} & $\stackrel{1}{b}$ & 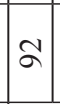 & $\mid \begin{array}{l}\vec{\sigma} \\
+\end{array}$ & $\begin{array}{l}\sigma \\
+\end{array}$ & $\begin{array}{l}2 \\
+1\end{array}$ & $\frac{7}{0}$ & 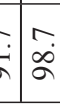 & 年 & $\stackrel{m}{i}$ & $\begin{array}{l}\dot{r} \\
\dot{\alpha} \\
\end{array}$ & $\begin{array}{lll}n & 7 \\
\infty & 2\end{array}$ & \begin{tabular}{c|c}
$\dot{0}$ \\
$\infty$ \\
$\infty$
\end{tabular} & $\grave{b}$ & \begin{tabular}{|c|}
$\infty$ \\
$\dot{\infty}$ \\
$\infty$ \\
\end{tabular} & \begin{tabular}{l|l}
$\underset{\infty}{\infty}$ & \\
$\infty$ &
\end{tabular} & : & $\stackrel{1}{2}$ & \begin{tabular}{|c|c|c}
0 & $\alpha$ \\
$\dot{\infty}$ & $\alpha$ & $\alpha$ \\
$\infty$ & $\alpha$
\end{tabular} & \begin{tabular}{l|l}
0 & $\infty$ \\
$\dot{0}$ & $\infty$ \\
$\dot{0}$ & $\infty$ \\
\end{tabular} & $\frac{n}{\infty}$ & $\begin{array}{l}n \\
\vdots \\
\infty \\
\infty\end{array}$ & \\
\hline $\begin{array}{l}\dot{z} \\
\dot{\vec{\Xi}}\end{array}$ & & $\stackrel{\hat{\sigma}}{\vec{b}}$ & & $\begin{array}{l}\hat{L} \\
\hat{\infty} \\
\infty \\
\infty\end{array}$ & $\underset{\substack{\stackrel{H}{c} \\
\stackrel{\infty}{\infty}}}{ }$ & & 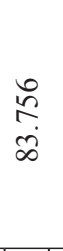 & & 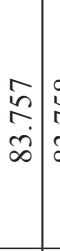 & & 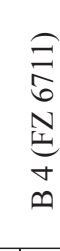 & & 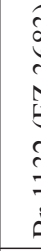 & t. & 1 & 111 & 1 & 1 & 1 & & 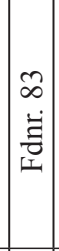 & $\frac{d}{a}$ & 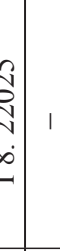 & $\frac{I}{d}$ & $\begin{array}{l}\frac{1}{1} \\
\dot{i} \\
\dot{\infty} \\
\infty\end{array}$ & 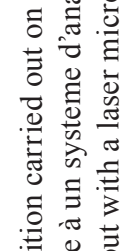 \\
\hline 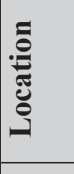 & 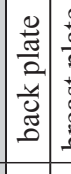 & 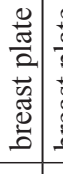 & 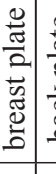 & 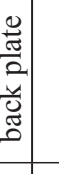 & 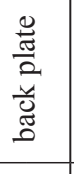 & 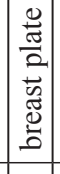 & 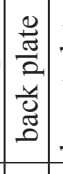 & 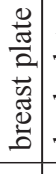 & 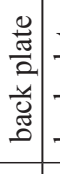 & 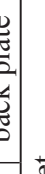 & & & & & 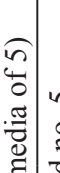 & & 跤 & 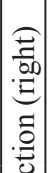 & 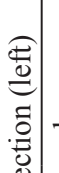 & : & 吾 & 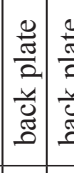 & 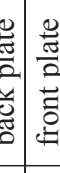 & & $\begin{array}{l}\frac{0}{0} \\
\frac{\pi}{2} \\
\frac{2}{0} \\
0 \\
0 \\
\end{array}$ & 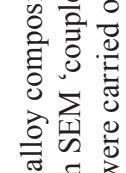 \\
\hline & $\vec{\approx}$ & $\approx$ & $\approx$ & $\frac{0}{2}$ & $\stackrel{\infty}{\sim}$ & $\approx$ & $\stackrel{0}{\circ}$ & $\hat{\imath}$ & $\grave{2}$ & + & 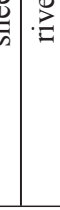 & 家 & &.$\stackrel{0}{\vec{z}}$ & 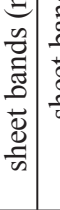 & 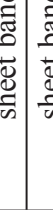 & 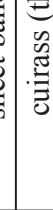 & 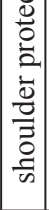 & 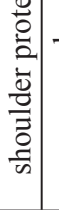 & 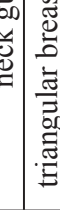 & 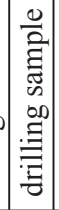 & 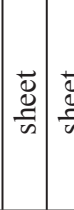 & 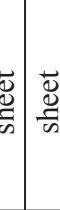 & & 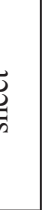 & 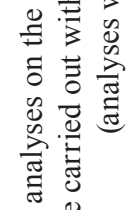 \\
\hline $\begin{array}{l}\overrightarrow{0} \\
\text { की } \\
\text { है } \\
\text { है }\end{array}$ & & & & & 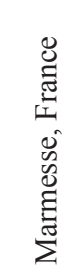 & & & & & & 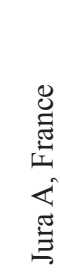 & & & & & & & 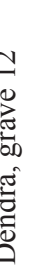 & & & 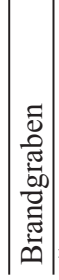 & 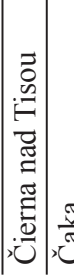 & 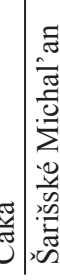 & & 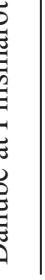 & 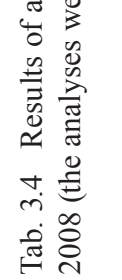 \\
\hline
\end{tabular}


duced at the same time in a single location. This contradicts, at least in the case of the Dendra panoply, the documented practice of providing additional parts of armour for different wellequipped warriors, as described on the linear-B tablets. ${ }^{939}$

The cuirass miniature from Brandgraben has a completely different alloy composition, being a single as-cast object which did not need any further thermal treatment or plastic deformation. The material demands therefore differ significantly from the other, real cuirasses. The miniature contains $18 \mathrm{wt} . \% \mathrm{Sn}$, being significantly more Sn than any of the other analysed cuirasses and thus would have also had a different colour.

The cuirasses from Čierna nad Tisou (back plate only), Šarišské Michal'any, and Čaka were sampled. ${ }^{940}$ Their alloy composition resembles significantly that of the cuirass from the Danube. ${ }^{941}$ Due to the density of inter-crystalline corrosion, which outlined the microstructure, no etching was necessary (Fig. 3.18, above). The cuirass from Šarišské Michal'any shows the highest amount of tin, a low amount of total deformation (about 30\%), and a final deformation. The sample also shows tentacle corrosion..$^{942}$ The alloy composition of the Čaka cuirass had to be evaluated by means of the analyses of single grains, since the sample showed a high level of corrosion. As a consequence, the actual amounts of each element concentrating preferable at the grain boundaries (such as arsenic or antimony) might actually be higher. Due to the cremation process, the sample showed a complete homogenised microstructure. Therefore, the last step of production, whether it was annealing, hammering or quenching, could not be detected. The

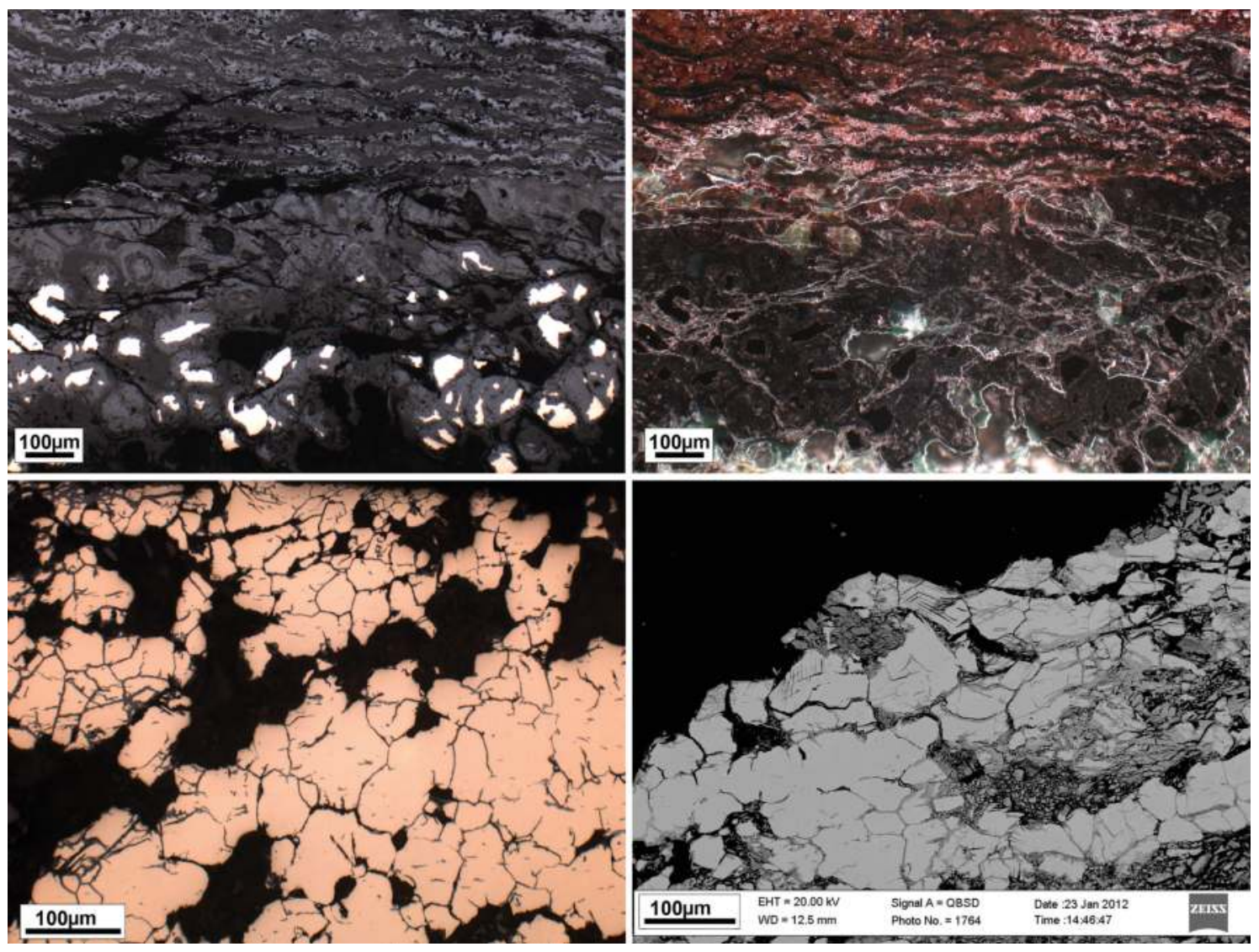

Fig. 3.18 Microstructure of the cuirasses from Čaka, Slovakia (above) and Čierna nad Tisou (below). The fragment of the Čaka cuirass is almost completely corroded, while the corrosion on the sample from Čierna nad Tisou outlined the microstructure.

\footnotetext{
939 Andrikou 2007, 406.

940 Mödlinger 2014b.

941 Petres - Jankovits 2014, fig. 12.

942 Piccardo et al. 2013.
} 
$\mathrm{Cu}_{2-\mathrm{x}} \mathrm{Fe}_{\mathrm{x}} \mathrm{S}$-inclusions could not be clearly identified from the severely burnt and corroded fragment from Čaka. Therefore, the amount of total deformation, as well as the minimum thickness of the as-cast disc, could not be calculated.

The annealing temperature of the cuirass from Čierna nad Tisou was below the solidus curve of the $\alpha$-phase in the CuSn-equilibrium diagram, but high enough to homogenise the solid solution. The few, slightly deformed $\mathrm{Pb}$ inclusions distributed in the metallic matrix indicate a mild final deformation, which is also indicated by the slightly deformed grains and the presence of slip lines (Fig. 3.18, below right). The total biaxial deformation can be calculated to around $77 \%$ due to the amount of deformation of the $\mathrm{Cu}_{2-\mathrm{x}} \mathrm{Fe}_{\mathrm{x}} \mathrm{S}$-inclusions. ${ }^{943}$ This permits also the calculation of the minimum thickness of the as-cast disc used to produce the bronze sheet, which for the back plate was $3.6 \mathrm{~mm}$. However, this value does not take into account any material loss during the manufacture of the back plate from the flaking off of copper oxides, polishing and grinding.

The microstructure of the cuirasses from Jura had been analysed in the 1970'.944 The texture reveals in both cases a recrystallised grain structure of $\alpha$-phase, not fully homogenised, with deformation twins. Unfortunately, the microstructure pictures do not allow for the identification of slip lines or $\mathrm{Cu}_{2-x} \mathrm{Fe}_{x} \mathrm{~S}$-inclusions, ${ }^{945}$ and therefore the total amount of deformation could not be calculated. Six of the Marmesse cuirasses were also analysed. ${ }^{946} \mathrm{The} \mathrm{Cu}_{2-\mathrm{x}} \mathrm{Fe}_{\mathrm{x}} \mathrm{S}$-inclusions and therefore also the bronze was deformed by up to $90 \%$. The cuirasses analysed contained between $9-10 \mathrm{wt} . \%$ tin. ${ }^{947}$ The publication of the analyses on the other Marmesse cuirasses, as well as the cuirass from Saint-Germain-du-Plain, is currently in preparation by A. Lehoërff.

\subsection{Use}

Unlike the central and western European cuirasses, ${ }^{948}$ the Dendra panoply was always considered effective as a piece of functioning armour and never as having served only ritual purposes or for display. It therefore seems strange why the other cuirasses should have been viewed this way. The interpretation of defensive armour as not practical was a view applied not only to the cuirasses but also to metal shields. ${ }^{949}$ Like other armour, central and western European cuirasses were considered to be objects of prestige or symbolic armour, and more broadly as too precious to be used, avoiding an interpretation concerned with what they actual are: armour.

The use of the Dendra panoply has been variously interpreted, including for use exclusively on chariots, rather than on foot, ${ }^{950}$ by infantry only, and impossible to use on a chariot, ${ }^{951}$ and for duelling only, excluding use by both chariot and infantry. ${ }^{952}$ A warrior may, of course, have used a chariot to reach the battlefield and then fought on foot. ${ }^{953}$ However, the truth most likely lies somewhere in the middle, with cuirasses being versatile enough to serve in many different use contexts..$^{954}$

The exclusive use of such a panoply on a chariot would raise the question as to necessity for greaves (as they were found together with the panoply), since the front of the lower legs would already be protected by the chariot itself. The inclusion of the high neck guard on the Dendra panoply (and also on the Danube cuirass) suggests that the warrior wearing it needed to be pro-

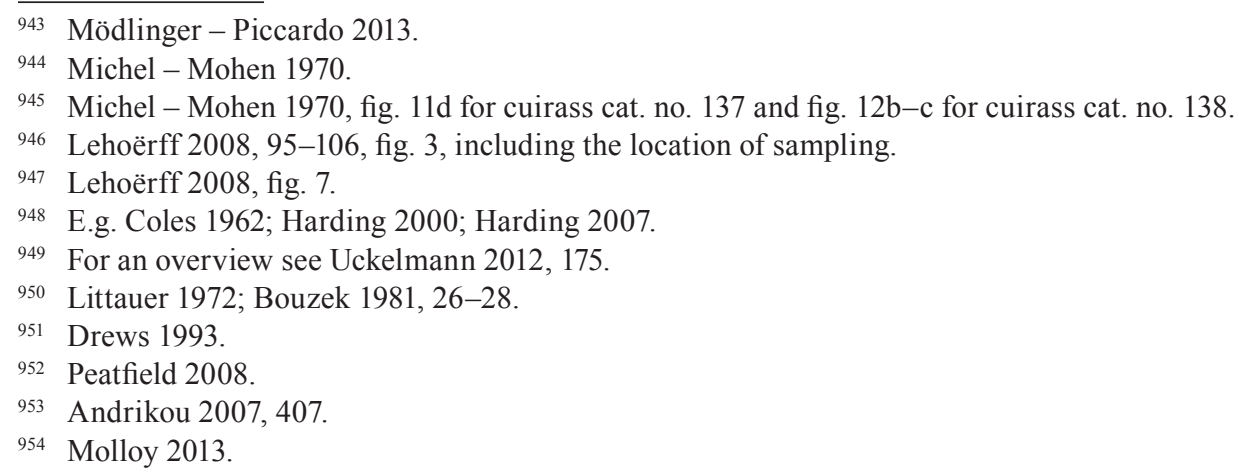


tected from the likelihood of a fatal strike to the neck - an attack, which would happen only during face-to-face combat and certainly not on a chariot. According to the replica, and experiments to test the effectiveness of different armour materials, the weaknesses of the panoply were not the metal plates themselves but the gaps between them. ${ }^{955}$ The Dendra panoply thus has ancillary plates to prevent the exploitation of this weakness, which would suggest its main use in face-to-face confrontations. An additional argument in favour of face-to-face combat with a sword is the small bronze ring attached to the top of the right shoulder guard. This ring most likely held the strap for either a sword or shield. The potential singular guard for the right arm, ${ }^{956}$ which was found lying on the panoply ${ }^{957}$ is another indication of its use in face-to-face fighting on foot. These recent experiments with a full size replica of the Dendra panoply ${ }^{958} \mathrm{dem}-$ onstrated that with an approximate total weight of $15 \mathrm{~kg},{ }^{959}$ the panoply did not significantly affect or hinder mobility. It turned out to be possible, without major difficulties, to shoot a bow, use a sword or hold a spear under the arm. However, the shoulder protectors did appear cumbersome in the use of a bow or spear. The ability to raise the arm vertically above the head was restricted but an over-arm grip of a spear was still possible. Also, the often depicted killing strike to the neck (as seen amongst the Shardana on the Medinet Habu relief of the 'sea battle', and on the seal from shaft-grave III from Mycenae) turned out to be possible, as were other depicted strikes. The warrior wearing the Dendra panoply would most likely have had to be right-handed, which is supported by the fact that the gap for the right arm is $2 \mathrm{~cm}$ wider than the one for the left arm, leaving the fighter more space to use his weapons with his right arm. ${ }^{960} \mathrm{We}$ might therefore conclude that the warrior wearing the panoply, most likely a leader, arrived by chariot to the battlefield, as shown on several pottery depiction (Figures 3.2), and then fought together alongside his foot soldiers.

Every published depiction of combinations of different armour and weapons is largely hypothetical, ${ }^{961}$ as so far only grave 12 from Dendra provides sufficient evidence to reconstruct a potential set of arms and armour that had been worn together. The Dendra panoply was combined with a boar tusk helmet with bronze cheek plates (cat. no. 63), greave(s) (cat. no. 227), a potential arm-guard, ${ }^{962}$ and (potentially) also a wooden shield. The cuirass was made of a breast and back plate, onto which other bronze sheets were attached in order to improve the protection for the throat and neck, shoulders, chest, pelvis and upper legs. Each bronze sheet had an inner lining attached. The finds from Thebes indicate the level of variation possible when combining these elements with the basic cuirass, with such variability occurring contemporaneously rather than necessarily having to be a chronological development. The combination chosen for each panoply may have been connected to the warrior's status, rank, battle or financial limitations. Also, we have to take into account that the palatial authority, as the linear B tablets suggest, provided selected persons with cuirasses, who paid back the value of the cuirass through compliance and thereby sustaining the system. We might also take into account the existence of faster and more flexible warriors, equipped only with the basic body cuirass and no additional metal attachments. These could instead be substituted with organic elements, as is clearly visible on contemporary pottery depictions (Fig. 3.2), and as found on the later Carpathian cuirasses. Amongst all the Carpathian and western European cuirasses, only the example from the Danube has along its edge a row of large (rivet?) holes, which served to attach or fix a substantial organic inlay. The cuirass was not worn in combination with a separate organic jerkin but had it attached permanently to the breast and back plate. On the other Carpathian and western Europe-

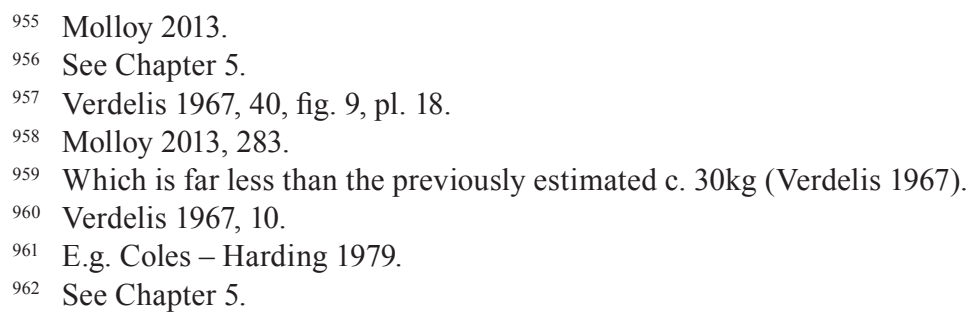


an cuirasses, no holes along the rim for the attachment of organic lining are visible, suggesting they had to be worn over a separate organic jerkin (similar to the medieval gambeson). ${ }^{963}$

It appears that the Dendra panoply and the two cuirasses from Thebes bear no significant evidence of use-wear or for repairs. Due to the heavily fragmented character of most of the Carpathian cuirasses, no traces of use can be identified on the fragments. While the cuirass from Saint-Germain-du-Plain does not show any clear traces of use or repair, the cuirass from the Danube has a $4 \mathrm{~cm}$ long impact from a stabbing weapon, such as a sword, located above the right clavicle. There appears to be no central enlargement of the impact, which might have indicated that it was caused by a spear. No traces of repair are visible (Fig. 3.18). On the back plate, immediately opposite the position of the damage to the breast plate, a small impact is visible, indicating where the tip of the weapon exited from the cuirass through the body of the wearer. The back plate also demonstrates a severe sword impact, reaching from the left side of the neck protection to the right side of the spine. It seems as if the warrior was, after being stabbed from the front, attacked and almost beheaded from the back, potentially from a left-handed opponent. However, it does not seem very likely then that the warrior fell with his cuirass into the Danube, as suggested by Petres and Jankovits. ${ }^{964}$

Unlike the Greek cuirasses and those from the Carpathian Basin, the western European cuirasses are replete with evidence of repairs. These repairs are either the result of injuries during combat or manufacturing mistakes. As indicated in detail by Schauer, the three breast plates from Fillinges clearly exhibit impact damage from combat in the form of small holes with outwards bent edges at the neck. ${ }^{965}$ These are most likely the result of weapon perforation from the front of the warriors wearing the cuirasses, if we do not want to consider these traces as a result of ritual or cultic action or sacrifice. ${ }^{966}$ However they found their end, the cuirasses from Fillinges were certainly used as armour, as it is indicated by several repairs on one breast plate (cat. no. 141) and one back plate (cat. no. 142). The breast plate was repaired twice under the right nipple: a new piece of bronze sheet $(3.1 \mathrm{~cm} \times 2.2 \mathrm{~cm})$ was fixed with four rivets ${ }^{967}$ and another one $(3 \times 2.1 \mathrm{~cm})$, also with four rivets, in order to cover a crack caused by material stress. On the remaining parts of the back plate, two repairs can be noted close to the liver. The cuirass was repaired with a squared sheet $(7.7 \mathrm{~cm} \times 4.5 \mathrm{~cm})$, which was attached with six rivets. An injury or a stab in this area certainly was deadly during the Bronze Age. Further small damage close by was maybe caused by an arrowhead. ${ }^{968}$ The fragment inv. no. 16.932 has two little bronze sheets riveted partly above each other on the outside of the cuirass. ${ }^{969}$

The cuirass Jura B (cat. no. 138) exhibits damage in the form of a long, thin perforation from the outside (with inwards-bent edges) at the lower area of the liver, which might have been caused by a sword. The damage was (opposite to the similar one from the back plate from cat. no. 142 from Fillinges) not repaired (Fig. 3.19); similar traces are also known from shields. ${ }^{970}$ On the right side of the chest and the neck, additional bronze sheets were riveted on to repair a previous, rectangular cut out damage of the cuirass.

The Marmesse cuirasses are probably the ones with the highest number of repair. The most significant repairs are on cuirass cat. no. 149, on the left side of the back plate and on the left side of the breast plate of a second Marmesse cuirass.

\footnotetext{
${ }_{963}$ A gambeson is an organic defensive jacket, usually padded or quilted, and constructed of linen or wool with varying staffing. It could be worn as armour separately, or combined with mail or plate armour.

964 Petres - Jankovits 2014, 65. In addition, they note that a sword cut reaches from the neck down under the right scapula. Indeed, there is a short crack under the right scapula. Since it has also an almost $90^{\circ}$ angle to it, it does not seem to derive from a sword cut, and is certainly not the result from a large sword blow from the neck to the armpit, whereby we would also expect damage directly above the scapula.

965 Schauer 1982d, 101.

966 Schauer 1982a.

967 Mottier 1988, 121, figs. 10-12.

968 Schauer 1982d, 107, pl. 41.1.

969 Mottier 1988, 127, fig. 21.

970 Cf. Uckelmann 2011, fig. 4.
} 

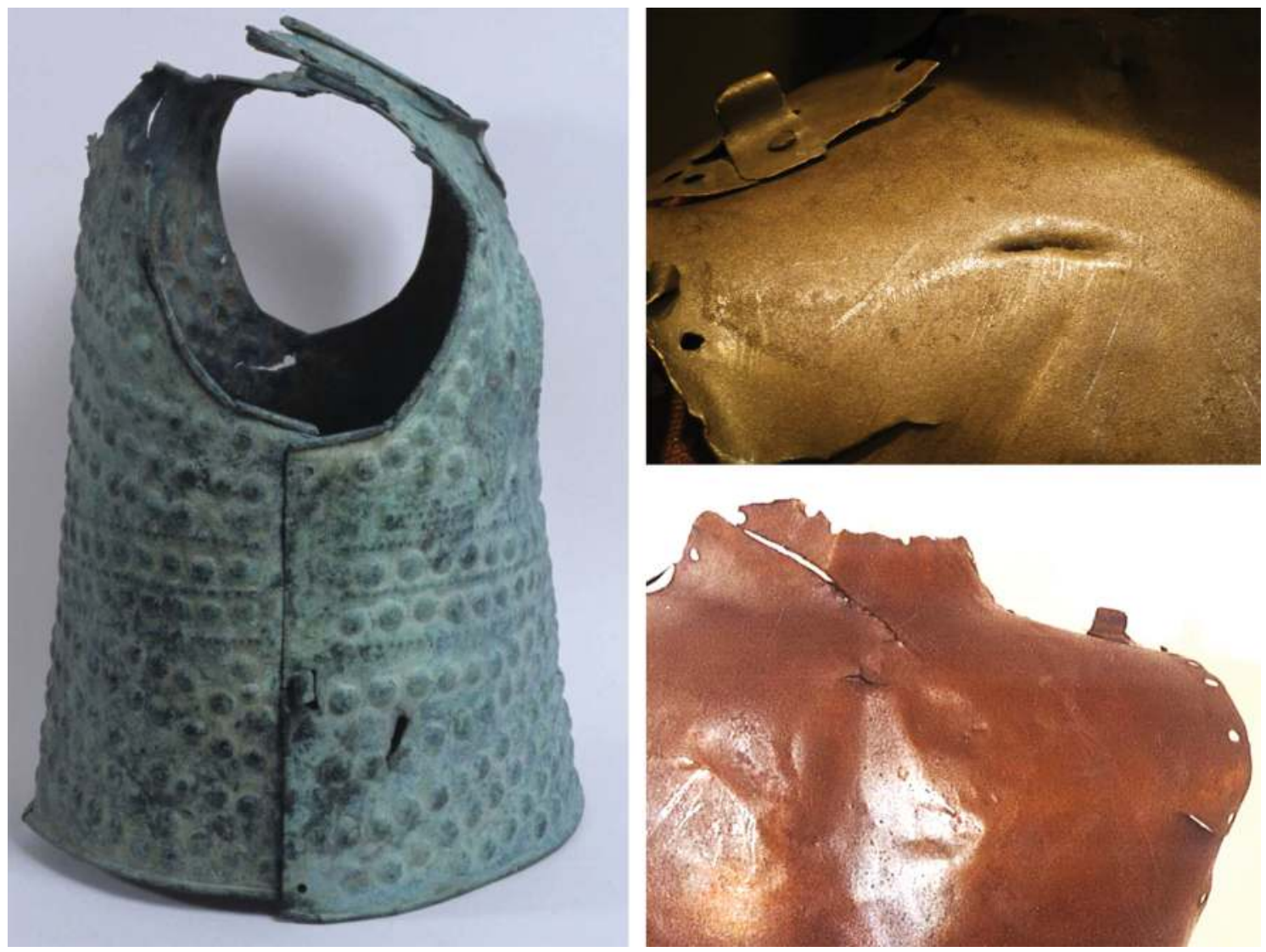

Fig. 3.19 Traces of use on the cuirasses. The two cuirasses illustrate different types of use-wear from weapon impacts. The cuirass from Graye-et-Charnay or Véria, France, (left) shows the impact of a sword or spearhead in the area of the liver. The cuirass from the Danube (right) shows a c. $4 \mathrm{~cm}$ long injury from a stabbing weapon as a sword above the right clavicle in the front and, on the back side, the injury where the sword tip exited as well as the impact of a sword slash from the left side of the neck, crossing the spine (left: photograph A. Chauvet (C2RMF), by courtesy of the Musée d'Archéologie nationale et Domaine national de Saint-Germain-en-Laye; above right: photograph M. Mödlinger, by courtesy of the Magyar Nemzéti Muzeum Budapest; bottom right: after Petres - Jankovits 2014, fig. 9).

Cuirasses were an affordable (for high-status warriors at least), useable and effective form of armour, which offered protection to the warrior in combat. According to the different size and measurements of the cuirasses from Fillinges and Marmesse, we can assume that they were made for specific individuals. Even though in Thebes the palatial authorities provided the armour (or at least the parts to be attached to the cuirasses), a cuirass would still have needed to fit properly, and was therefore likely individualised.

Moreover, the slightly different decoration on the back of the Marmesse cuirasses probably served to identify the specific person wearing the cuirass. The different number and thickness of the lines on the back perhaps indicating the status or rank of the warrior to his cohort, whilst the front instead provided opponents with a more uniform view of the warriors. ${ }^{971}$ The increase of decoration over time, and its spread from southeast to western Europe, does not appear to be restricted to the mere identification of the warrior in front or a cultural tradition of decoration, and instead may have served a practical purpose.

The thickness of the bronze sheet of the cuirasses decreased significantly over time and, in order to maintain their efficiency, the cuirasses were reinforced through the application of decoration. Bending the rim around a bronze or copper wire, or strengthening the rim by riveting on additional bronze sheets, also increased the stability of these much thinner central and western

971 Cf. Mödlinger 2014b. 
European cuirasses. Most likely, this process was combined with the use of an increasingly thicker organic jerkin worn under the metal cuirass, whereas the Greek cuirasses permitted only the application of a thinner organic inlay, sewed onto the bronze sheets, as indicated by the line of small holes all along the edges. The metal cuirass worn over an organic jerkin, such as the Carpathian and western European cuirasses, and the metal cuirass with organic inlay, like the Greek examples, clearly offered a higher level of protection than simple organic armour alone. The greater protection offered by wearing a metal cuirass over organic protection increases the likelihood that these cuirasses belonged to the Bronze Age elite, contributing to and underlining the prestige and authority of the warriors that were wearing them.

It is important to point out that the design and construction of these bronze cuirasses would not have prevented the wearer from being killed were the fatal blow sufficiently powerful, but was effective in reducing casual injury whilst maintaining a degree of both flexibility and mobility in combat. ${ }^{972}$ While the Dendra panoply placed greater emphasis on protective aspects (substituting the massive shields with a direct method of body protection), this emphasis changed with the development of the later cuirasses, as was already visible on the more delicate cuirasses from Thebes which had fewer and smaller attachments. This development was clearly orientated toward less weight and increased mobility. The massive Greek panoply was substituted or reduced to a basic body cuirass, which permitted faster and more flexible movement. This development, which permitted greater mobility of the warrior, can be connected to changes in fighting techniques, with the emergence of a faster, less static, closer method of combat around $1200 \mathrm{BC}$, and perhaps more generally with the possible upheavals connected with the 'catastrophe' in the eastern Mediterranean during this time. ${ }^{973}$ Whether these adaptions to the design of cuirasses were the result of or related to general changes in fighting techniques and combat (including the introduction of new sword forms, facilitating a significant change from a primarily stabbing to a primarily slashing weapon), remains unclear.

\section{Catalogue}

\section{Greek Cuirasses}

Cat. no. 122. Dendra, Peloponnese, Greece - grave 8 - one shoulder protection. Measurements: height: 25cm; width: $32 \mathrm{~cm}$ - Archaeological Museum Nauplion, inv. no. 22.956 - Pl. 23.122. References: Persson 1931, 21, no. 2; Verdelis 1967, 15, 21, pl. 23, fig. 2; Càssola Guida 1973, 52-53, pl. XVIII.3; Andrikou 2007, 402.

The shoulder protection was found in the grave without obvious indications that there had been further parts of metal armour. This might be the result of later deposition, robbery or the protection having been deposited as pars pro toto, or was perhaps the only metal part of an organic cuirass, intended to provide greater protection for the right shoulder. The latter interpretation seems to be the most likely, as organic defensive armour is well known from depictions, and increased protection of the right shoulder would have been necessary, as it was not protected by a shield during the use of a sword or spear. A detailed depiction of a single shoulder guard, as we know it from grave 8, Dendra, is found on a seal stone from Thisbe, Boeotia (LH II).

Cat. no. 123. Dendra, Peloponnese, Greece - grave 12 - complete. Measurements: thickness: approx. $1 \mathrm{~mm}$; total weight: originally c. $14.5 \mathrm{~kg}$ - Archaeological Museum Nauplion, inv. no. 14.230 (old entry); 19.001-19.002 (new entry) - Pl. 23.123. References: Müller-Karpe 1962a, 280; Vanderpool 1963, 280-281, pl. 62.5-7; Åström 1967; Verdelis 1967, 1-53; Paulík 1968, 55; Càssola Guida 1973, 53, pl. XV; Greenhalgh 1980; Schauer 1982d, 115-124, figs. 6-7; Åström 1983; Taracha 1999; Everson 2004; Sofou - Katsarou-Moschona 2006, 325; Andrikou 2007; Taratóri et al. 2008.

972 Molloy 2013.

973 Drews 1993. 
The grave was discovered in the north of chamber grave 10 during Swedish excavations in 1960. It was robbed prior to the start of the excavations but was also apparently disturbed in antiquity, most likely in preparation for a further internment which appears not to have taken place. The circumstances of the discovery, other grave finds, its construction, as well as the grave itself, are described in detail by Verdelis and P. Åström. ${ }^{974}$ There were a number of associated finds, including what is presumable a piece of a dagger with leather residues, which was positioned close to the pelvis, a golden nail from a robbed sword, a silver cup of Type Vaphio, and fragments of other gilded objects. Boar tusks were found close to the skull. On the other side of the grave, the armour and the bronze vessel, as well as a few ceramic vessels, were stored. The panoply consisted of fifteen separate pieces of bronze sheet, which encased its owner from their neck, protected by a high collar, to their knees, and was held together with organic thongs. It was placed on the floor as if worn fully mounted. Beneath the right arm of the panoply a greave was found, which broke into several fragments during recovery. Two other sheets close by were interpreted as one or more further greaves. ${ }^{975}$ Verdelis suggests that these were two greaves and the other was protection for the right arm, the left being protected by a shield. ${ }^{976}$ Beneath the fragments of arm protection, residues of wood were also discovered $(42 \times$ $35 \mathrm{~cm})$. In vessel no. 8 two bronze cheek plates and boar tusks were found. Close to the second greave, a bronze mirror and some bronze vessels, as well as a small knife, were found. On the basis of the grave finds, Verdelis dates the assemblage to the first half of the $15^{\text {th }}$ century BC.977

Cat. no. 124. Arsenal, Thebes, Boeotia, Greece - settlement - fragments - no measurements - Archaeological Museum of Thebes, inv. no. 40.520-40.555 - Pl. 24.124. References: Snodgrass 1965, note 7; Touloupa 1966; Touloupa - Symeonoglou 1967; Verdelis 1967, 21-22; Càssola Guida 1973, 53, 66; Demakopoupou - Konsola 1981, 53; Fortenberry 1990, 44-45, cat. nos. 29-31; Andrikou 2007, 402; D'Amato - Salimbeti 2011, fig. on page 39.

In the 'Arsenal' area of the palace, in the central corridor of the building, numerous bronze weapons, including spearheads, arrowheads, swords and knives, as well as pieces of horse harness, vessels (cherniva), and tripods, were found along with parts of a cuirass (shoulder pieces, triangular pieces which cross over the chest, and successive bronze plates below the main cuirass) in 1964. The bronze sheets are similar to parts of the Dendra panoply. ${ }^{978}$ The bronzes fell into one of the 17 cist graves of the $17^{\text {th }}$ century BC, when it collapsed. ${ }^{979}$ Further important finds from the 'Arsenal' are LH IIIB sherds with Linear B signs. ${ }^{980}$

Cat. no. 125. Thebes, Boeotia, Greece - settlement - fragmented. Measurements: height: 31cm; width: 36cm - Archaeological Museum of Thebes, inv. no. 27370.1, 3, 16-17 - P1. 24.125. References: Andrikou 2000, 292; Andrikou 2007, 402; Salimbeti - D’Amato 2009, fig. 4.

The cuirass was excavated from the Municipal Conference Center plot (northwestern part of the Mycenaean citadel) under difficult circumstances, since it was located partly under a street which could not be removed. Shoulders and part of the right side are missing.

Carpathian Cuirasses

Cat. no. 126. Čierna nad Tisou, Okr. Trebišov, Slovakia - associated deposit (?) - fragment. Measurements: height: $41 \mathrm{~cm}$; width: $46 \mathrm{~cm}$; thickness: 0.5-1mm - Archeologické múzeum

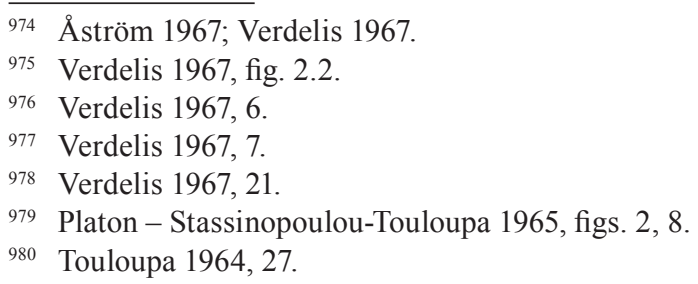


SNM, Bratislava, inv. no. 15.40 (old: 3483 and i. 23.122) - Pl. 25.126. References: Novotný 1966, 27-34; Paulík 1968, 41-44, fig. 2.

The cuirass was found at a depth of $2 \mathrm{~m}$ during the building of a new freight railway station in 1947. Novotný mentions sherds, now lost, and a grinding stone, as associated finds. ${ }^{981}$ The finds were bought by the Archaeological Institute in Martin, Slovakia, in the following year and are now stored in the Archeologické múzeum SNM in Bratislava. Only the back plate of the cuirass, without neck area, and right shoulder survive. The base of the cuirass is not completely preserved, and the wire, around which the rim was bent, is now lost, as is a large part of the left shoulder.

Cat. no. 127. Šarišské Michal'any, Okr. Sabinov, Slovakia - surface (single) find - fragment. Measurements: height: $22 \mathrm{~cm}$; width. $17.3 \mathrm{~cm}$; thickness: $0.8-1.6 \mathrm{~mm}-$ private collection $-\mathrm{Pl}$. 26.127. References: Lorenc et al. 2013, 165, fig. 66.1.

The cuirass fragment was found on the terraces of the river Torysa (close to Pri kaplnke). In the nearby surrounding, further finds such as a sickle fragment associated with the Kyatice/ Gáva Culture, ceramics from the Hallstatt period, and two iron hammer axes, have been discovered (Lorenc et al. 2013, 165).

Cat. no. 128. Čaka, Okr. Levice, Slovakia - grave 2 - fragments - Archeologické múzeum SNM, Bratislava, inv. no. I 8. 22025 - Pl. 25.128. References: Knor 1952, 403, fig. 209; Točík Paulík 1960, 59-124, figs. 13-21, 24; Paulík 1963, 324, 335, fig. 43.1; Paulík 1968, 49-50; Jockenhövel 1971, 74, no. 80, pls. 8.80, 59-60, 61.A; Novák 1975, 20, no. 77, pl. 12.77; Schauer 1984b, 226, no. 78; Paulík 1988, 11-25; Probst 1996, fig. page 408.

The cuirass was found during the excavations of A. Knor in 1950. As well as the cuirass, the grave contained alongside the cremated bone, pieces of flange hilted swords of Type Nenzingen, ${ }^{982}$ two spearheads, two median winged axes, ${ }^{983}$ one socketed chisel, one razor, fibula fragments, two pins, one with double conical head and one with a flat head, one phalerae, several small rolled bronze sheets, rivets, buttons, nails, fragments of a belt, further small bronze sheet fragments probably attached to textiles, as well as ceramics. In total, there have been over 40 fragments most likely belonging to the cuirass. ${ }^{984}$ In 1963 Paulík reconstructed the cuirass with rib bows in triangle form. ${ }^{985}$ Unfortunately, not all the fragments were published, and most of the cuirass fragments are now lost.

Paulík mentions bronze sheets with 'buttons' which had not previously been discussed, and suggests that these might be the remains of the metal parts of leather greaves. ${ }^{986}$ These bronze fragments are without any chevrons or pointed ends. Some of the bronze sheets from the grave might also belong to such an object and not to the cuirass. ${ }^{987}$ Additionally, Paulík tried to reconstruct a shield which had been buried in the grave, ${ }^{988}$ with the intention of reconstructing a complete set of defensive armour.

Cat. no. 129. Ducové, Okr. Piešt'any, Slovakia - associated deposit - fragments. Measurements: height: $14.5 \mathrm{~cm}$; width: $8 \mathrm{~cm}$; thickness: $0.5 \mathrm{~m}$ - Archeologické múzeum SNM, Bratislava, inv. no. I. Č. 22.025 - Pl. 26.129. References: Paulík 1968, 46, fig. 4; Schauer 1982d, 115.

The associated deposit accompanying the fragment of cuirass was found inside a fortified settlement connected with the Velatice-Baierdorf group at Ducové in 1965. The associated

\footnotetext{
981 Novotný 1966, 27-28.

982 Novák 1975, 20, pl. 12.77-77A.

983 According to Novák 1975, 20 only one spearhead and one axe.

984 Točík - Paulík 1960, 76, 108, 119-120, fig. 15, pls. 9-10.

985 Paulík 1963, 324, 336, fig. 43.1. See also Probst 1996, fig. page 408.

986 Paulík 1988.

987 Paulík 1988, 24

988 Paulík 1988, 24
} 
deposit contained fragments of sickles, Type Peschiera daggers, bowl-headed pins with swollen neck, and median-winged axes. ${ }^{989}$ The fragment of cuirass comprises the right breast with a star-like decoration around the nipple, the part immediately under the right arm, and a smaller part under the right arm pit. Originally the fragment was rolled together and was broke when unfolded during restoration. A part of the breast decoration with the double rib also appears to have broken off recently and was not found in the museum.

Cat. no. 130. Saint-Germain-du-Plain, Dép. Sâone-et-Loire, France - single river find (river Sâone) - complete. Measurements: breast plate: height: $50.3 \mathrm{~cm}$; width: $37.4 \mathrm{~cm}$; back plate: height: 52.6cm - Musée d'Archéologie Nationale, inv. no. 2757 - Pl. 27.130. References: Reinach 1921, 234; Bonnamour - Mordant 1988, 367; Mottier 1988, 142, fig. 38; Hansen 1994, 12.

The cuirass was a single find from the Sâone from the beginning of the last century.

Cat. no. 131. Pázmándfalu, Com. Győr-Moson-Sopron, Hungary - associated deposit I and II - fragments - six fragments of different size - Rómer Flóris Múzeum Győr, no inv. no. References: Szabó 2012; Szabó 2013; Szabó 2016, 182-184, figs. 17-19.

The associated deposit I was found with metal detectors in December 2011. Archaeologists were informed immediately, and the remaining associated deposit was excavated to avoid further destruction. ${ }^{990}$ The associated deposit I was disturbed by the plough but two thirds of the deposit remained in situ. Within $20 \mathrm{~m}$ around the deposit, further bronzes, such as fragments of sword blades, a fragment of a sword hilt, and further tiny bronze fragments, were found.

The Ha Al deposit contained hundreds of both undamaged objects, and damaged objects, having been broken and melted. Underneath the metal sheet objects, fragments helmet of Type Paks (cat. no. 26), an associated cheek plate (cat. no. 35) and fragments of a cuirass (cat. no. 131), were found. Further fragments belonged to a bronze cup. The group of undamaged objects included a winged axe, dagger, pendant, spangle and a phalerae. ${ }^{991}$

During the excavation and documentation of the associated deposit, another, so far undisturbed associated deposit, was found three metres away from the first. It consisted of four bronze spearheads, a bronze knife, a heavily bent sword, a shorter sword, a socketed chisel, as well as a pressed bronze sheet with rivets, which might derive from another cuirass. ${ }^{992}$

Cat. no. 132. Nadap, Kom. Fehér, Hungary - associated deposit - fragment. Measurements: height: $8.5 \mathrm{~cm}$; width: $11 \mathrm{~cm}$; thickness: $2 \mathrm{~mm}$ - Szent István Király Múzeum Székesfehérvár, inv. no. 119 - Pl. 26.132. References: Petres 1983, 61-62, fig. 10a-c, h; Mozsolics 1985, 151; Hansen 1994, 12, 546, H 451; Makkay 2006, 7, pls. V-VIII; Uckelmann 2012.

For the description of the associated deposit see at cat. no. 9. As well as the currently identified defensive armour, including a helmet of Type Oranienburg (cat. no. 9), fragments of helmets of Type Paks (cat. no. 27), a pair of greaves, further fragments of another pair of greaves (cat. nos. 165. 170-172), and a fragment of a shield of Type Nyírtura, a further fragment of bronze sheet from the associated deposit might also be from a piece of armour. ${ }^{993}$ A further 17 individual fragments decorated with embossed knobs and parallel ribs, which Makkay identifies as parts of a cuirass with flexible bronze bands, similar to Dendra, ${ }^{994}$ belong instead to belt plates, such as those from Mačkovac, Croatia. ${ }^{995}$

989 Paulík 1968, 46.

990 Szabó 2013, 811

991 Szabó 2013, 811; Szabó 2016, 27.

992 Szabó 2013, fig. 17; Szabó 2016, 27, fig. 19.

993 Makkay 2006, no. 12.

994 Makkay 2006, nos. 14-30.

995 Karavanić - Mihaljević 2001, pl. 10. 
Cat. no. 133. Ivančice 4, okr. Brno-venkov, Czech Republic - associated deposit - fragment. Measurements: height: $15 \mathrm{~cm}$; width: $12 \mathrm{~cm}$ - Moravské zemské múzeum Brno, no inv. no. - Pl. 26.133. References: Mödlinger 2014b (wrongly cited as Brno-Řečkovice); Richtera et al. forthcoming.

The deposit was found in Ivančice 4, Rená settlement. ${ }^{996}$

Cat. no. 134. Danube at Pilismarót, kom. Komárom-Esztergom, Hungary - single river find (river Danube) - complete. Measurements: height: $44.7 \mathrm{~cm}$; width of base: $51.1 \mathrm{~cm}$; thickness: $0.7-0.8 \mathrm{~mm}$ in the centre, c. $0.9-1.3 \mathrm{~mm}$ at the edges of the neck and the arms - kept at the Magyar Nemzeti Múzeum Budapest; the cuirass belongs to the Szent István Király Museum, Székesfehérvár, inv. no. 83.22.1-2 - Pl. 28.134. References: Jankovits 1999/2000, 195, note 41; Szathmári 2003, 63; Petres - Jankovits 2014.

The cuirass was allegedly bought by the museum of Székesfehérvár from a private collector in $1982 .{ }^{997}$ The cuirass was said to have been found on the east side of the Danube shore at Pilismarót, Kom. Komárom-Esztergom, in the north of Budapest, in the 1960'.

\section{Western European Cuirasses}

Cat. no. 135. Unprovenanced - complete. Measurements: $51 \times 39.4 \mathrm{~cm}-$ Metropolitan Museum New York, accession number 09.41 - Pl. 30.135. References: Schauer 1982d, 96-97, fig. 2; Mottier 1988, 127, 140-141, figs. 26-28.

The cuirass was bought by the Metropolitan Museum in 1909 from D. Reiling, Mainz. Before this it belonged to the Forman collection and was sold at Sotheby's on June 19, 1899 (no. 153). The cuirass is similar to the cuirasses of Fillinges in respect of a number of details, especially to cat. no. 139, that it seems highly reasonable to assume they were made in the same workshop or at least are closely connected. Next to the rim of the arm, which was bent around a wire, the cuirass has a row of small holes, most likely to attach an organic inlay.

Cat. no. 136. Unprovenanced - complete. Measurements: height: $36.8 \mathrm{~cm}$; height neck: $3.3 \mathrm{~cm}$; breadth: $34 \mathrm{~cm}$; diameter neck: $13.8 \mathrm{~cm}$ - Museum für Kunst und Gewerbe, Hamburg, inv. no. 1917.1232 - Pl. 29.136. References: Pagenstecher 1917, 91, no. 10, fig. 10; Hagemann 1919, 121122, fig. page 130; v. Merckling 1930, no. 838, pl. 46.2; v. Merhart 1941, 37; v. Merhart 1954, 37, figs. 1-2; Müller-Karpe 1962b, 57, note 126; Snodgrass 1964, 78; Hornbostel 1981, 25, no. 5; Stary 1981, 24-25; Mottier 1988, 141, figs. 33-34; Hornbostel - Spielmann 2004, 92, cat. no. I.34.

The cuirass was part of the Johannes W. F. Reimer collection (Hamburg) (inv. no. B 98). Unlike the cuirasses from Fillinges, Marmesse and Jura, this cuirass is not waisted and the breast muscles are not clearly visible. The breast is accented with dotted and bossed circles and a large central boss.

Cat. no. 137. Jura A (former 'Grenoble'), Dép. Jura, France - associated deposit - complete. Measurements: $47 \times 43.5 \mathrm{~cm}$ (breast plate), $44 \times 44.6 \mathrm{~cm}$ (back plate); thickness: $0.6-1 \mathrm{~mm}$; weight: $1.46 \mathrm{~kg}$ (breast plate) $1.44 \mathrm{~kg}$ (back plate) - Musée d'Armée, inv. no. B 4 (FZ 6711) - Pl. 29.137. References: Robert 1860; Carthailhac 1875/1878, 468; de Beauregard 1901, 308-315; Michel 1969; Michel - Mohen 1970; Mottier 1988, 141, figs. 31-32; Descamps 2005, 100.

The cuirass was bought by the museum in 1860, the same year as it was found. It was found together with a further cuirass (cat. no. 138), now owned by the Musée du Louvre, Paris (inv. no. $\mathrm{Br} 1132)$, in Graye-et-Charnay or Véria.

\footnotetext{
996 Richtera et al. forthcoming.

997 Petres - Jankovits 2014.
} 
Cat. no. 138. Jura B (former 'Naples'), Dép. Jura, France - associated deposit - complete. Measurements: $44 \times 45.3 \mathrm{~cm}$ (breast plate), $43 \times 49 \mathrm{~cm}$ (back plate); thickness: $1 \mathrm{~mm}-$ Musée du Louvre, département des Antiquités grecques, étrusques et romaines, inv. no. Br 1132 (FZ 3683; old inv. no.: MNB 474; R 17; N III 1087) - Pl. 29.138. References: Robert 1860; de Nieuwerkerke 1868, 41; Carthailhac 1875/1878, 468; Chantre 1876, 150; de Beauregard 1901, 308315, fig. 2; Déchelette 1908-1914, 237; de Ridder 1915, 5, no. 1132, pl. 66.1132; Deonna 1934b, 115; Millotte 1963, 162; Michel - Mohen 1970, 64; Briard - Mohen 1983, 155-156; Mottier 1988, 141, figs. 29-30; Rothé 2001, 405, 712-713; Descamps 2005, 100, no. 92.

The cuirass was found in Graye-et-Charnay or Véria in 1860, and is associated with a further cuirass now owned by the Musée de l'Armée, Paris (inv. no. B 4; cat. no. 137). The Musée du Louvre bought the cuirass in the same year as it was found.

Cat. nos. 139-145. Fillinges, Dép. Haute-Savoie, France - associated deposit - seven complete cuirasses and several fragments. Measurements see Tab. 3.5 - Musée d'Art et d'Istorie, Genéve, inv. nos. 14.057-14.061, 14.181, 16.931-16.932, 23.451 and John Woodman Higgins Armoury, Worcester, Mass., USA, inv. no. 2875 - Pls. 30-31. References: de Beauregard 1901, 308-315; Dean 1921; Deonna 1933; Deonna 1934a; Deonna 1934b; Deonna 1935; Deonna 1946; v. Merhart 1954; Schauer 1982d, 92-130; Mottier 1984; Mottier 1988; Hamard-Frichet - ReyBellet 2000; Steuer 2001.

At the end of 1900, street workers widening the street of the small village of Fillinges, came across the deposit, which contained seven cuirasses, several fragments and a bronze wand ${ }^{998} \mathrm{O}$. C. de Beauregard carried out further excavations in August 1901. ${ }^{999}$ He mentioned a horse jar, some ceramic sherds, further bronze sheet fragments, and a massive ash layer between $5-30 \mathrm{~cm}$ thickness, spread over $10 \mathrm{~m}^{2}$. De Beauregard also noted that according to 'a reliable testimony' ${ }^{\prime 1000}$ the breast and back plates had been placed inside each other, similar to those from Marmesse. ${ }^{1001}$

No documentation, publication or pictures were produced. Most likely, the cuirasses were found placed inside each other or, as noted by a worker who participated in the 'excavation', they were spread over the area. ${ }^{1002}$ Immediately after finding the deposit, and so as to avoid sharing the objects with the land owner Ing. Gavillet, the find was split between two antiquarians, a notary and a doctor from Genève. Today the cuirasses are divided between two museums, the Musée d'Art et d'Istorie, Genéve (cat. nos. 139-142; 145 and fragments inv. nos. 16.931-16.932, 23.451), and the John Woodman Higgins Armoury, Worcester, Mass., USA. ${ }^{1003}$

The basic measurements, and most important information, regarding each piece and associated fragments, are listed in Tab. 3.5. For a more detailed description of the cuirasses, see Schauer and Mottier. ${ }^{1004}$ The bronze wand found with the cuirasses has a length of $45.3 \mathrm{~cm}$, a diameter of $3 \mathrm{~cm}$ and a weight of $1.75 \mathrm{~kg}$ (inv. no. 23.451). It is a unique piece without any parallel. Mottier mentions a tin content of $5 \%$ but makes no reference to other detailed results or sampling. ${ }^{1005}$ The surface of the wand, and so also its decoration, was largely destroyed during the cremation process. ${ }^{1006}$

Cat. nos. 146-152. Marmesse, Dep. Haute-Marne, France - associated deposit - seven almost complete cuirasses - Musée d'Archéologie Nationale, France, inv. no. 83.753-83.758;

\footnotetext{
998 For the detailed description of the find spot, see Schauer 1982d, 94.

999 de Beauregard 1901, 308-315.

1000 Warmenbol 2010, 565.

1001 de Beauregard 1901, 311. Contradicted by Deonna 1934b, 96.

${ }^{1002}$ Schauer 1982d, 95.

1003 Mottier 1988, 110.

1004 Schauer 1982d, 103-104; Mottier 1988.

${ }^{1005}$ Schauer 1982d, 98, note 19; Mottier 1988, 114. The analyses were carried out with XRF.

1006 Schauer 1982d, pl. 16.2; Mottier 1988, 114, fig. 4.
} 


\begin{tabular}{|c|c|c|c|c|c|c|c|}
\hline $\begin{array}{l}\text { Cat. } \\
\text { No. }\end{array}$ & Inv. No. & Type & $\begin{array}{l}\text { Heigh } \\
(\mathrm{cm})\end{array}$ & $\begin{array}{l}\text { Width } \\
\text { (cm) }\end{array}$ & $\begin{array}{c}\text { Thickness } \\
(\mathrm{mm})\end{array}$ & Condition & Details \\
\hline 139 & 14.058 & breastplate & 43.2 & 37 & $0.7-1.1$ & $\begin{array}{l}\text { almost } \\
\text { complete }\end{array}$ & \\
\hline 140 & 14.059 & breastplate & 44.9 & 41.1 & $0.7-1.1$ & complete & \\
\hline 141 & 14.060 & breastplate & 45.6 & 36.9 & $0.7-1.1$ & $\begin{array}{l}\text { almost } \\
\text { complete }\end{array}$ & \\
\hline 142 & 14.057 & backplate & 49.9 & 47.6 & - & $\begin{array}{l}\text { almost } \\
\text { complete }\end{array}$ & \\
\hline 143 & 2875 & backplate & - & - & - & fragmented & $\begin{array}{l}\text { The upper parts of the back plate are } \\
\text { still present, while the lower third is } \\
\text { missing }\end{array}$ \\
\hline 144 & 14.061 & backplate & 45.7 & 20.5 & $0.5-1$ & fragmented & only the upper right side remained \\
\hline 145 & 14.181 & backplate & $\begin{array}{l}19.3 \\
22.4 \\
\end{array}$ & $\begin{array}{l}39.2 \\
19.4 \\
\end{array}$ & - & two fragments & \\
\hline- & 16.931 & fragment & 6 & 19.5 & - & fragment & $\begin{array}{l}\text { fragment of the lower rim of one } \\
\text { cuirass }\end{array}$ \\
\hline- & 16.932 & fragment & 7.9 & 8.5 & - & fragment & $\begin{array}{l}\text { fragment of the side part of one cui- } \\
\text { rass with residues of ancient repair }\end{array}$ \\
\hline- & $16.932 \mathrm{a}$ & fragment & 7.5 & 10.3 & - & fragment & \\
\hline- & $16.932 b$ & fragment & 6 & 6 & - & fragment & \\
\hline- & $14.181 \mathrm{a}$ & fragment & 6.2 & 6.7 & - & fragment & fragment from the rim of the arm \\
\hline
\end{tabular}

Tab. 3.5 Measurements of the western European cuirasses from Fillinges.

86.197 and Chaumont, Musée d'Art et d'Histoire, 83.755 (FZ 8032) - Pls. 32-33. References: Mohen 1987; Mottier 1988, 141-142, figs. 35-37; Douau 1994; Jensen 1999, 99, fig. 4; HamardFrichet - Rey-Bellet 2000, 143-148; Puniet - Balcar 2000; Steuer 2001; di Mantova - Watelet 2003; Lehoërff 2008, 95-106; Huth 2012, fig. 5.

The cuirasses were found in 1974 during the quarrying of gravel in Marmesse at 'la petit Marais' in the Aujon-valley, close to a spring near a swamp. Three cuirasses had been placed inside each other. Further cuirasses and fragments were discovered in 1980 and 1986. According to the photographs from the find spot, two cuirasses were placed inside one another. The fragments were found close by. The photographs from the find spot seem to contradict the commonly held assumption that three groups of three cuirasses placed inside each other were deposited.

The inventory numbers correspond with the following catalogue numbers: cat. no. 143/inv. no. 83.753 ; cat. no. $144 /$ inv. no. 83.755 ; cat. no. $145 /$ inv. no. 83.756 ; cat. no. $146 /$ inv. no. FZ 32.691; cat. no. 147/inv. no. 83.754; cat. no. 148/86.197; cat. no. 149/83.755 (FZ 8032). 



\section{Greaves}

At present, some 75 greaves of the Bronze Age and Early Iron Age, from 42 find locations, have been discovered (Fig. 4.1). Several fragments of further potential greaves would increase this number. The greaves were mainly deposited as either single fragments in associated deposits or, as in the case of the Mediterranean, complete as pairs in graves. With the exception of the greaves from Dendra, all greaves so far found have been decorated.

According to their technological features, two main classes of greaves can be identified: Class I with wire fixation, and Class II with perforations along the edge. Four subclasses are associated with greaves of Class I:

1. Subclass A: greaves with integrated wire loops, comprising types Desmontà, Lengyeltóti, Kuřim, Canosa and Limone

2. Subclass B: greaves with wave-shaped wire, comprising Type Kallithea

3. Subclass C: greaves with separate wire loops, comprising Type Grammichele

4. Subclass D: greaves with riveted on loops, comprising Type Ilijak

These main groups largely differ in respect of their distributions; Subclass A is distributed from the Danube westwards up to central France, and the Po Valley in the south. Greaves of Subclass B are known from southern Greece, Cyprus and southern Italy, while greaves of Subclass $\mathrm{C}$ are found in southern Italy only. Greaves of Subclass D are known from Albania and Bosnia-Herzegovina, as well as a single fragment from Olympia (cat. no. 226). Greaves with a perforation along the edge (Class II) are not chronologically or geographically related and have

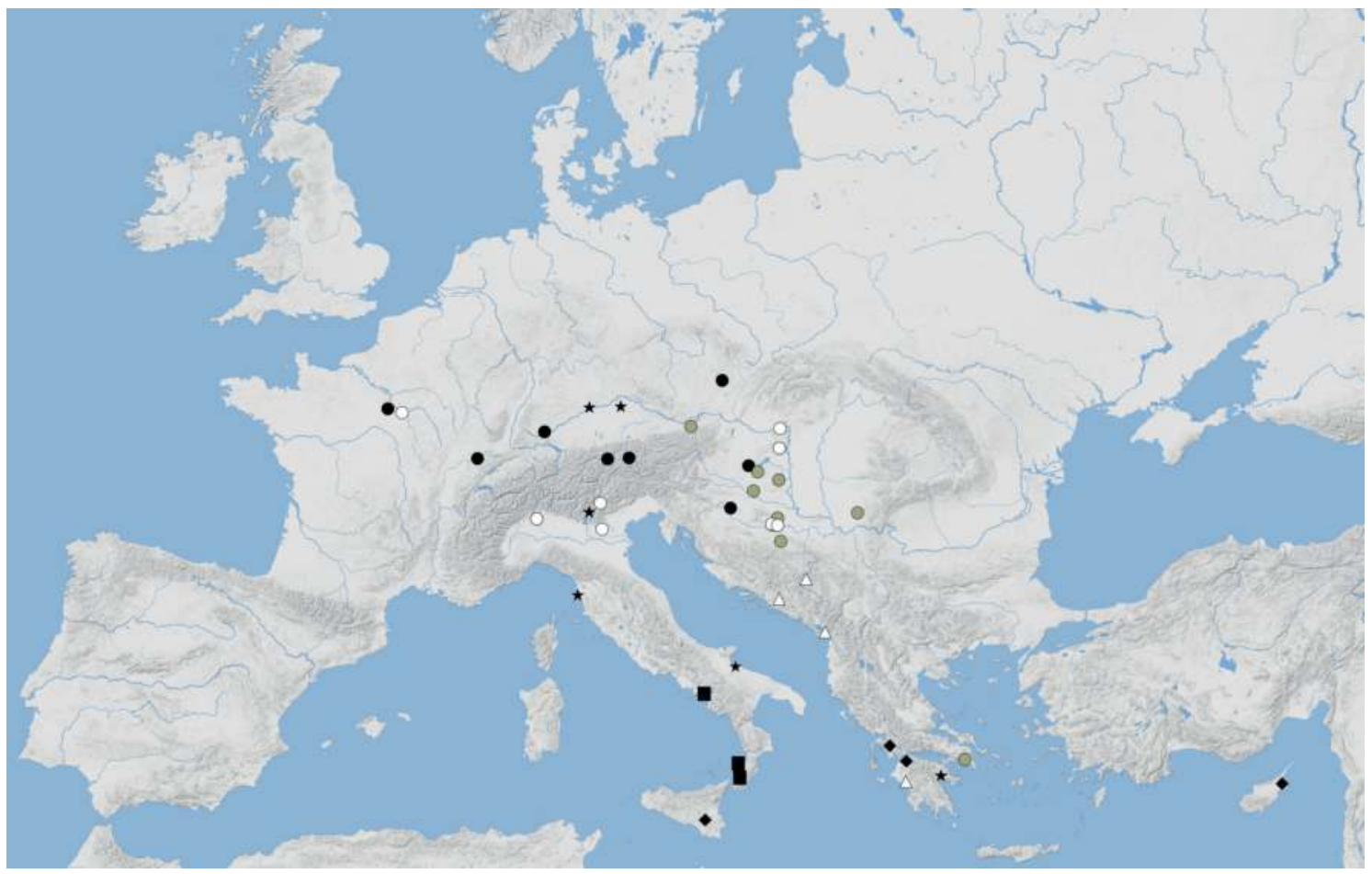

Fig. 4.1 Archaeological distribution of European Bronze Age greaves: $\bigcirc$ Greaves of Type Desmontà. $\bigcirc$ (grey) Greaves of Type Lengyeltóti. Greaves of Type Kuřim. Greaves of Type Kallithea Greaves of Type Grammichele. $\triangle$ Greaves of Type Ilijak. $\star$ Greaves of Class II and single types. Only greaves with known find spot are mapped. 


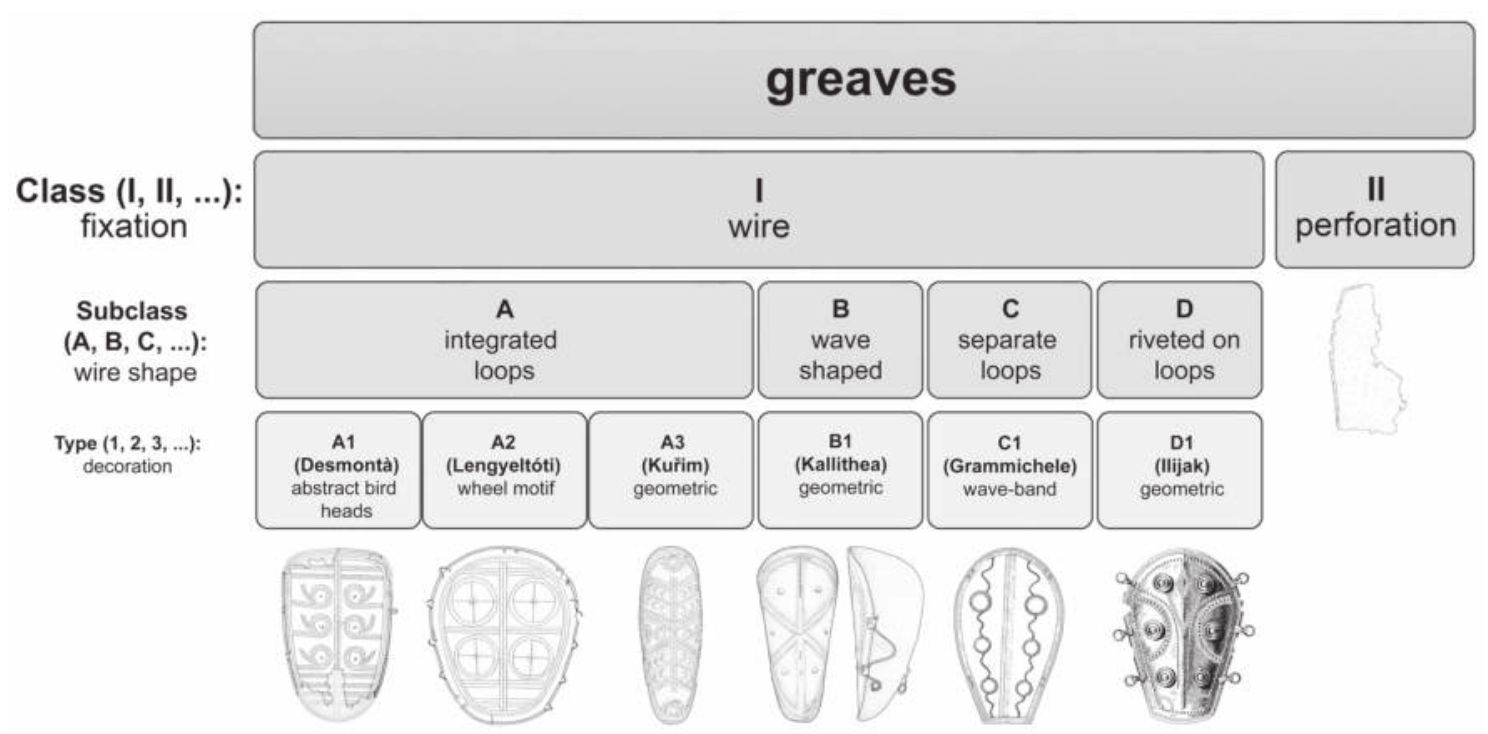

Fig. 4.2 Classification of greaves. Each greave type depicted consists of at least three greaves. Other greave types, represented by less than three greaves, fall under Class IA: Type Canosa (cat. nos. 193-194) and Type Limone (cat. no. 195), or Class II: Type Dendra (cat. no. 227), Type Schäfstall (cat. no. 228) and Type Winklsaß (cat. no. 229).

therefore been grouped on the basis of technological criteria only (Fig. 4.2). From northern and western Europe finds of greaves are, apart the finds from Bouclans (cat. no. 183), Boutigny-surEssonne (cat. no. 184), Beuron (cat. no. 185) and Cannes-Ècluse, unknown (Fig. 4.1).

Greaves of Subclass A can be divided into those with Gleichbuckel (Type Desmontà and Type Lengyeltóti), Punktbuckel (Type Kuřim) and Leistenbuckel (Type Canosa and Type Limone). ${ }^{1006}$ Greaves of Subclass B and C are uniformly decorated with Leistenbuckel, while greaves of Subclass B may also show chevron decoration. Greaves of Subclass D bear geometric decoration. Greaves of Class II can be decorated with Gleichbuckel, as at Schäfstall and Winklsaß, or undecorated, as at Dendra (cat. nos. 228- 229 and 227, respectively).

Several Bronze Age miniature greaves are also known. They form two groups with different chronological and geographical distributions, represented by southern Italy and the Carpathian Basin. These miniature greaves measure c. $5.5-9 \times 3 \mathrm{~cm}$ and bear pellet decoration: one line of pellets running along the rim, and one or two centrally positioned vertical lines. In some cases, further lines of pellet decoration, arranged geometrically, were applied between the central line of pellets and those along the rim. As well as these bronze miniatures, two possible clay miniature greaves are known from the Gârla Mare culture in Bulgaria (Bz D). ${ }^{1007}$

In contrast to other armour, such as cuirasses, shields and helmets, greaves are rarely known from the Carpathian Basin further east of the Danube (the only finds so far from further east of the Danube are known from Kuřim (cat. no. 190) and Markovac-Grunjac (cat. no. 182). In contrast to other categories of metal armour, greaves is the only one which is regularly found associated with graves. However, grave finds of greaves other than those Subclass C and D are rare: only those from Athens (Type Lengyeltóti; cat. nos. 180-181), Volders (Type Kuřim; cat. no. 186-187), and Dendra were found in graves, and perhaps also the greaves from Desmontà (Type Desmontà; cat. nos. 154-155). Except the burnt fragments from Volders, all of these are more or less complete. Only the single find of an individual greave from Schäfstall is associated with a water context.

\footnotetext{
${ }^{1006}$ Gleichbuckel: decoration with equal sized pellets; Punktbuckel: decoration with pellets and bosses; Leistenbuckel: decoration with ribs and bosses. Ringbuckel: decoration with bosses surrounded by ribs. Punzbuckel: punched bosses.

1007 Dietrich 2009, 91-96.
} 
The first wide-ranging studies of greaves, by A. Hagemann and W. Gaerte, ${ }^{1008}$ were primarily concerned with Greek finds, whilst v. Merhart was the first to publish a comprehensive European study of Bronze Age greaves. Here he drew an important distinction between older corded greaves and later clamped greaves. ${ }^{1009} \mathrm{He}$ suggested that the first type originated in the Danube area, on the basis of the increasing abstraction of the decoration found on the greaves. The discovery of the Dendra grave, with its range of early defensive armour, meant that an origin for the development of greaves in the Danube area could no longer be maintained, as argued by $\mathrm{N}$. Yalouris, who suggested instead an Aegean origin for greaves. ${ }^{1010}$ The work of Catling focused on the typology, symbolic interpretation, and dating of greaves. ${ }^{1011}$ Müller-Karpe supported an origin for defensive armour in the Aegean, and noted that the greaves from Enkomi (cat. nos. 196-198), Kallithea (cat. nos. 199-200) and Rinyaszentkirály (cat. no. 168) all date to the same period. He dated the greaves from Kuřim and Beuron to the early Urnfield period, thus creating a scheme of chronological development for greaves beginning in the Aegean, and continuing throughout the Urnfield period. ${ }^{1012}$ Snodgrass noted that Archaic greaves, whose shape did not change much over the centuries, are completely different from the Mycenaean and central European greaves, and that only the greaves from Kavousi and Praisos might stand typologically between the two forms. ${ }^{1013} \mathrm{~K}$. Kilian discussed in detail the southeastern European greaves of Type Ilijak, which date to the Early Iron Age, and drew special attention to the votive character of a fragment related to this type which was found in Olympia. ${ }^{1014}$ Shortly after, B. Čović published a further pair of greaves of the same type from Bosnia-Herzegovina. ${ }^{1015}$ Schauer distinguished different types of greaves according to their ornamentation, and separated Mycenaean and Early Iron Age greaves. ${ }^{1016}$ He identified eight types for the Urnfield period. These types were not uniform in date or origin, and does the description of the types consistently match the allocated finds. Despite this, Hansen adopted the same scheme, arranging the greaves on the basis of their ornamentation into three main types (Vogelbarke, wheels and bigger Punzbuckel). ${ }^{1017}$ The most recent and comprehensive study of European Bronze Age greaves, which incorporated a number of new finds, is by Clausing. ${ }^{1018}$ He classified corded greaves primarily on the basis of technological details, which largely correspond with their classification according to associated ornamentation. Clamped greaves were not discussed, since they appear only in the Early Iron Age. Clausing distinguished three main types of corded greaves: those with integrated wire loops (greaves with wheel motif; greaves with small embossed decoration; greaves with embossed decoration; greaves with ribbed and embossed decoration) or separate wire loops (wave-shaped wire or separate wire loops), greaves with perforations along the rim, and greaves with riveted-on loops. The separation of greaves with integrated wire follows the stylistic definition and chronology of Jockenhövel's Gleichbuckel- (Bz D-Ha A1), Punktbuckel(Ha A2-B1) and Leistenbuckel decoration (Ha B2). ${ }^{1019}$ It is worthwhile to note that the date of these different decorative styles corresponds with the general date of each of the greaves and their context, be it from an associated deposit or grave. The relationship between the different regional chronological systems, and their respective terminology, which will be used in the following discussion, is illustrated in Fig. 1.1.

\footnotetext{
1008 Hagemann 1919; Gaerte 1920.

1009 v. Merhart 1956/1957.

1010 Yalouris 1960, 42-43.

1011 Catling 1955; Catling 1977b.

1012 Müller-Karpe 1962a, 275.

1013 Snodgrass 1964, 87.

1014 Kilian 1973.

1015 Čović 1976.

1016 Schauer 1982b.

1017 Hansen 1994, 13-14.

1018 Clausing 2002.

1019 Jockenhövel 1974, 39.
} 


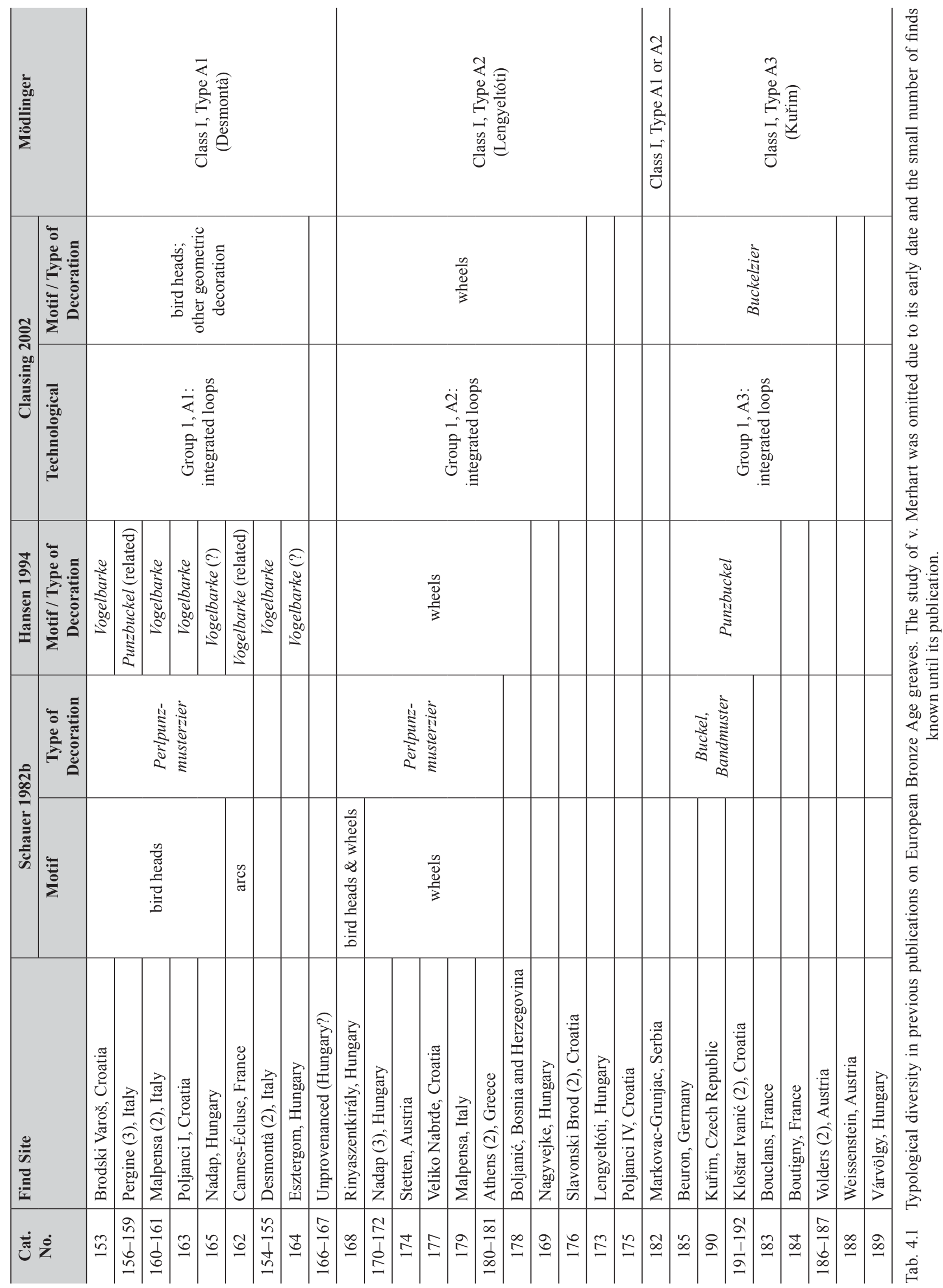




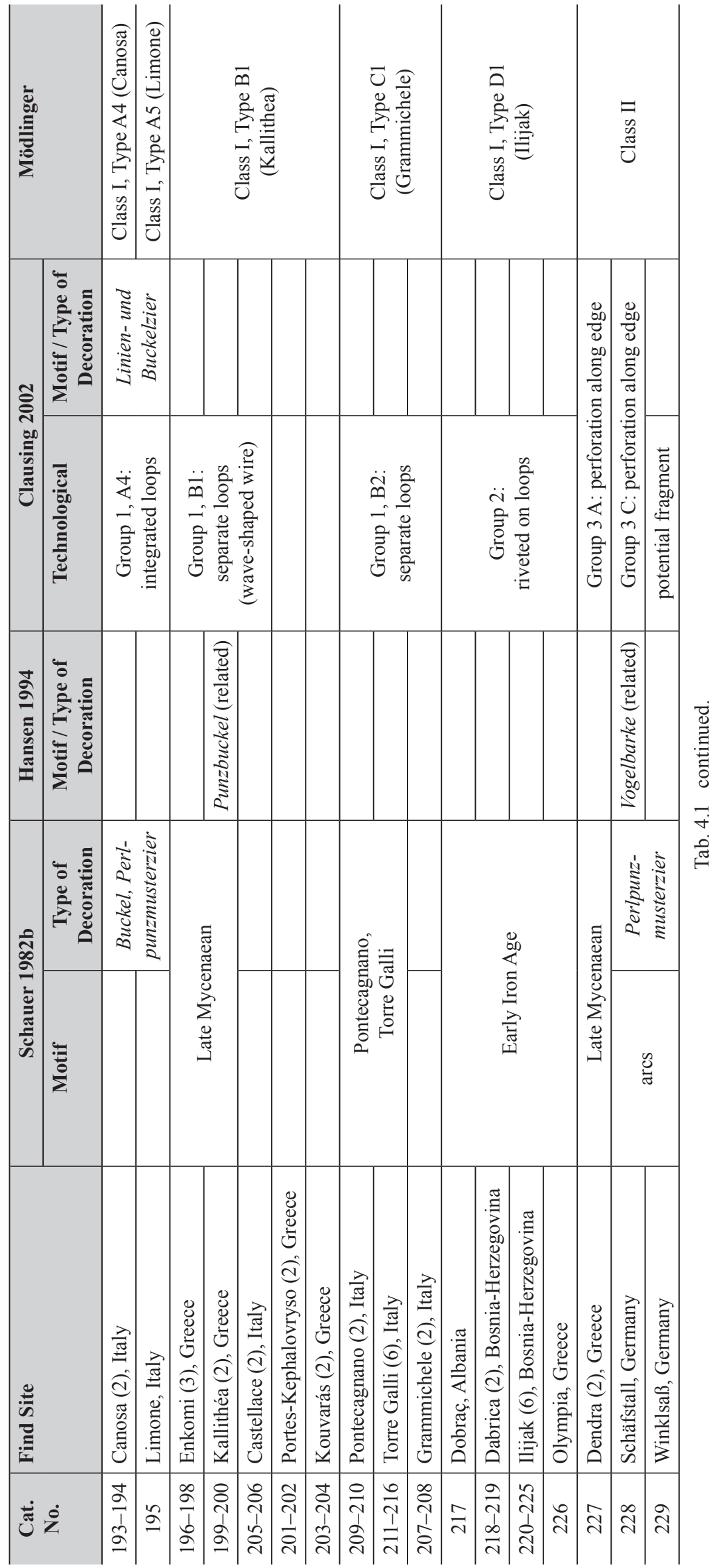


The diversity of typologies used in earlier studies of greaves is not as great as it might first seem. As is clear in Tab. 4.1, whilst the names might differ, the greaves were generally grouped in quite similar fashion. As is evident, the main differences are of a technological nature: central European greaves have integrated wire loops, while the southern Italian and Greek greaves have separate wire loops or wave-shaped wires. Greaves with integrated wire loops contain only one wire, around which the rim of the bronze sheet from which it was made was bent, and on the sides was used to form the external loops which the wearer used to secure them. Greaves with separate wire loops or wave-shaped wire incorporated several wires, with one running along the edge of the bronze sheet, around which the sheet was bent, and the other used to form the loops used by the wearer to attach the greave to their lower legs.

The differences between the typological approaches of earlier studies is small: Hansen considered the greaves from Pergine (cat. nos. 156-159) as being closely related to 'geometric greaves', such as that from Kallithea. ${ }^{1020}$ In comparison, Schauer described the greave with bird heads from Cannes-Écluse, with bow-shaped pellet decoration, ${ }^{1021}$ as being similar to the greaves from Winklsaß and Schäfstall. He also grouped the greaves from Kallithea, Enkomi and Dendra together and dated them as Late Mycenaean, whilst the greaves from Torre Galli (cat. nos. 211-216) and Pontecagnano (cat. nos. 209-210) were grouped separately.

\subsection{Greaves of Class I, Subclass A}

\subsubsection{Greaves of Type Desmontà}

\subsubsection{Decoration}

The 12 or 13 greaves of Type Desmontà share, with the exception of the greave from CannesÈcluse, common decorative elements, such as having at least three parallel, geometric, embossed lines (Tab. 4.2). These greaves exhibit different levels of abstraction of the bird heads, and seems to increase in abstraction from east to west (Fig. 4.3). It is important to note that the decoration was usually made with Gleichbuckel. On most of the abstract birds, however, the eye is represented by a much larger boss. The only example of bird heads facing each other, rather than turning away from each other, is on one of the greaves from Malpensa (cat. nos. 160-161; Fig. 4.3.3). This motif as a whole is rather rare, and is only otherwise known on an unprovenanced razor and two ceramic vessels, from Pianello di Genga and Frattesina, respectively. ${ }^{1022}$

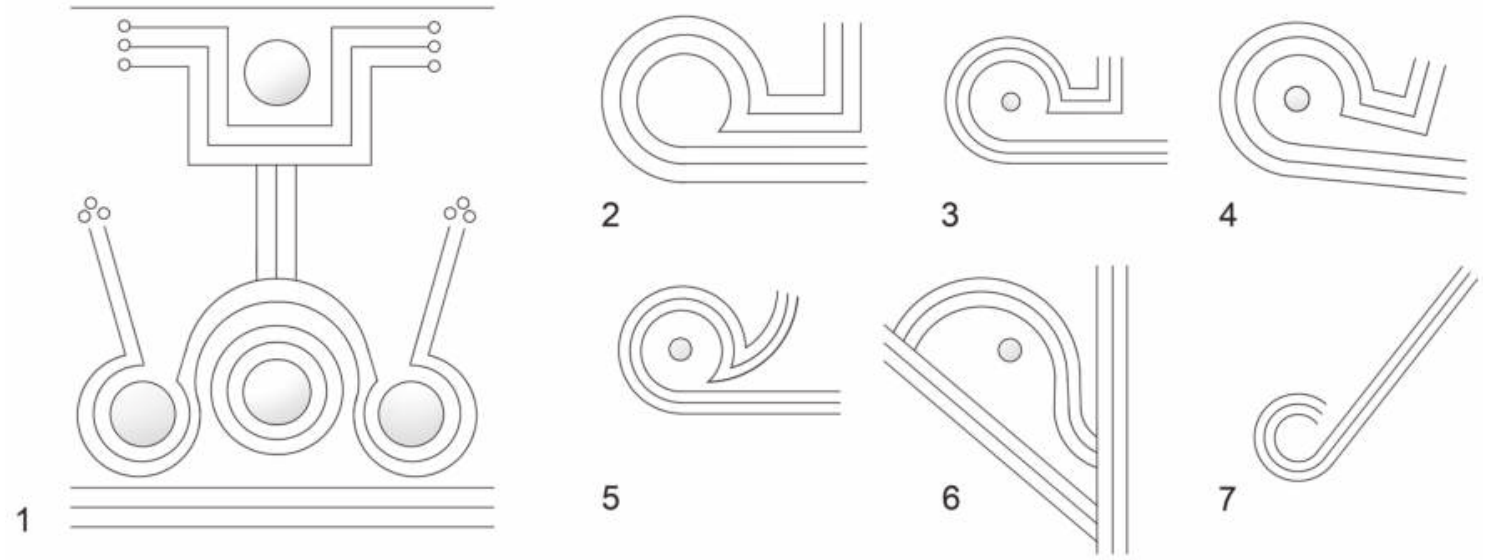

Fig. 4.3 Abstract bird heads on greaves of Type Desmontà: 1. Pergine; 2. Brodski Varoš; 3. Malpensa; 4. Poljanci; 5. Desmontà; 6. Malpensa; 7. Cannes-Ècluse (not to scale).

\footnotetext{
1020 Hansen 1994.

1021 Schauer 1982b, 133.

1022 Zipf 2004, 455, fig. 108.
} 
On the greaves from Pergine, a rather clear abstraction of the Vogelsonnenbarke motif can be noted. Moreover, abstract human figures with wide, open arms are visible in between the birds (Fig. 4.3.1). Larger bosses are also used for the head of the human figure and the sun, while smaller bosses may indicate beaks and hands.

\begin{tabular}{c|l|l|c|l}
\hline Cat. No. & Find Circumstances & Find Site & State & Condition \\
\hline 153 & associated deposit & Brodski Varoš & HR & fragments \\
\hline $154-155$ & associated deposit (?) & Desmontà & IT & almost complete \\
\hline $156-159$ & associated deposit (?) & Pergine & IT & almost complete \\
\hline $160-161$ & associated deposit (?) & Malpensa & IT & almost complete \\
\hline 162 & associated deposit & Cannes-Écluse & FR & half preserved \\
\hline 163 & associated deposit & Poljanci I & HR & fragment \\
\hline 164 & associated deposit & Esztergom & HU & fragment \\
\hline 165 & associated deposit & Nadap & HU & fragment \\
\hline $166-167$ & unknown & unprovenanced (Hungary?) & HU (?) & fragments \\
\hline
\end{tabular}

Tab. 4.2 Greaves of Type Desmontà.

\subsubsection{Distribution and Deposition}

Most of the greaves of Type Desmontà were found in the Carpathian area west of the Danube. Unlike the greaves of Type Lengyeltóti, greaves of Type Desmontà have also been found more commonly in the west of Europe, such as that from the associated deposit of Cannes-Écluse, as well as the finds from the northern Po Basin and northern Trento (Fig. 4.4). The Italian finds, comprising Desmontà, Pergine and Malpensa, are also the only ones to have been found complete. In the case of all three finds, the possibility of them being grave finds has been suggest-

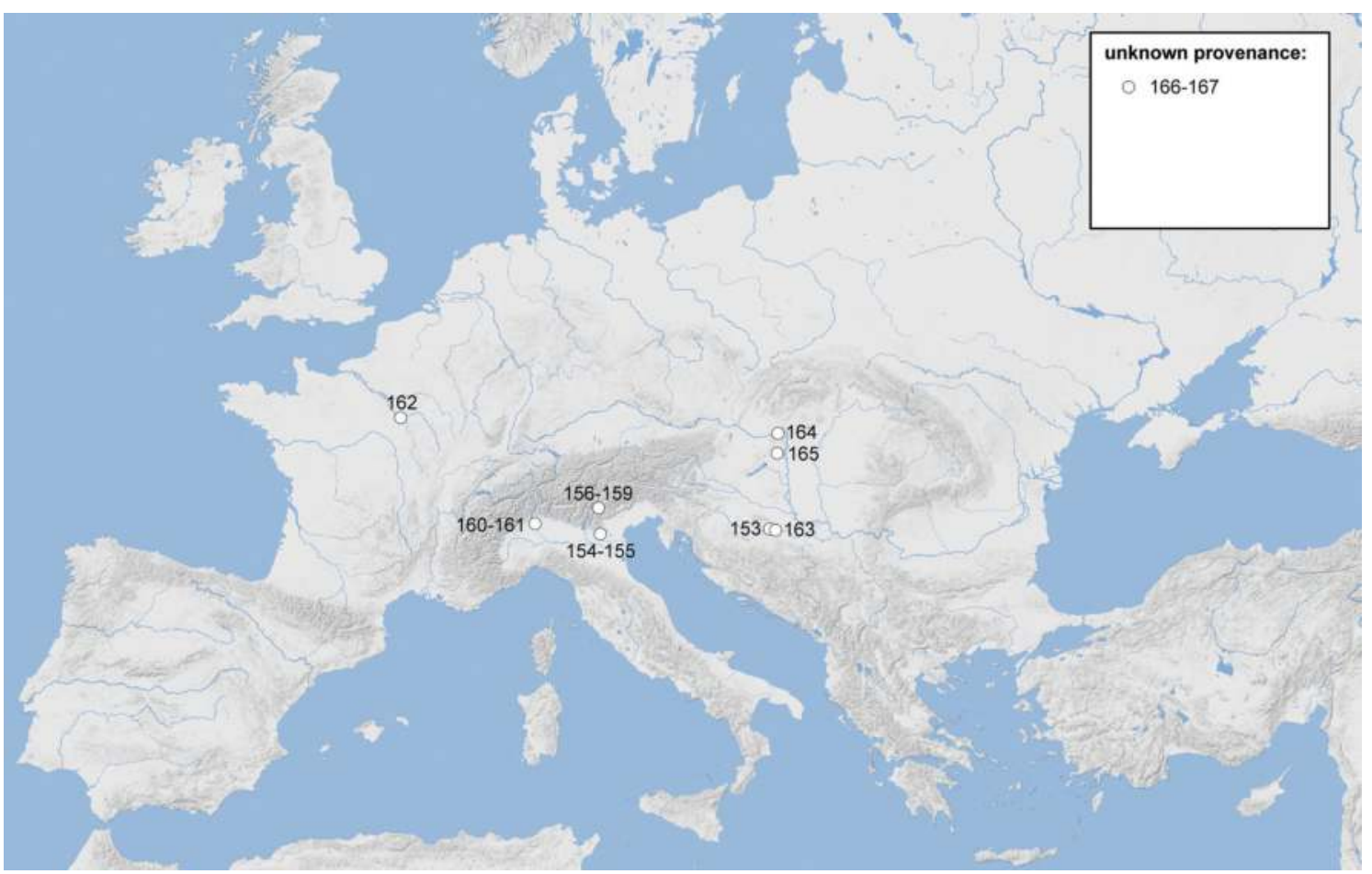

Fig. 4.4 Archaeological distribution of European Bronze Age greaves of Type Desmontà: 153. Brodski Varoš; 154-155. Desmontà; 156-159. Pergine; 160-161. Malpensa; 162. Cannes-Écluse; 163. Poljanci I; 164. Esztergom; 165. Nadap; 166-167. Unprovenanced. 
ed. ${ }^{1023}$ All other finds are either heavily fragmented or are present only as a single fragment in associated deposits as a result of local depositional practices. Two of the greaves of Type Desmontà, from Malpensa and Cannes-Écluse, were found to have been folded several times before deposition. This folding of greaves before deposition, however, seems to have been more common for those greaves of Type Lengyeltóti.

\subsubsection{Chronology}

Like greaves of Type Lengyeltóti, the greaves of Type Desmontà are generally dated to Ha A1. Gaucher and Robert, Johannowsky, and Bouzek have suggested an earlier date of Bz D for the associated deposit of Cannes-Écluse. ${ }^{1024}$ The greaves from Brodski Varoš, Poljanci I and Slavonski Brod (cat. nos. 153, 163 and 176) have been dated to period II, after Vinski-Gasparini. ${ }^{1025}$ As noted before, the associated deposit from Nadap has been dated to Bz D-Ha A1, and the associated deposit from Esztergom to the Kurd horizon ${ }^{1026}$ (cat. nos. 165, 170-172 (Nadap) and cat. no. 164 (Esztergom)).

The dating of Italian greaves of Type Desmontà is still a matter of debate. Most recently, Sperber suggested a date of Ha B1 for the greave from Pergine, ${ }^{1027}$ following that of MüllerKarpe and Hansen. ${ }^{1028}$ Salzani dates the greaves from Desmontà to the $10^{\text {th }}$ century $\mathrm{BC}$ on the basis of their close relationship to the greaves from Malpensa and Pergine, though this is in fact somewhat earlier than the greaves from Pergine. ${ }^{1029}$ Jankovits argues for an earlier date, in the $12^{\text {th }}-11^{\text {th }}$ century $\mathrm{BC}$, on the basis that the necropolis, in which area the greaves have been found, might have started after the deposition of the associated deposit. ${ }^{1030}$ Clausing suggests, following Salzani, a date between the $11^{\text {th }}$ and $9^{\text {th }}$ century BC according to the surrounding necropolis. ${ }^{1031}$ Schauer interpreted the greaves from Pergine as the earliest of those with bird depictions, which Marzatico considered to be a result of transalpine influences. ${ }^{1032}$ Subsequently, Marzatico connected them to a bronze vessel from grave 23, from the necropolis Valle La Fata, which dates to late $9^{\text {th }}$ or beginning of the $8^{\text {th }}$ century $\mathrm{BC}$, on the basis of the bird depictions combined with human figures, therefore questioning their early $11^{\text {th }}$ century $\mathrm{BC}$ dating. ${ }^{1033}$

An earlier date for the Italian greaves from Desmontà, Pergine and Malpensa, to between the $12^{\text {th }}-11^{\text {th }}$ centuries BC, is suggested by several other authors, including v. Merhart, who was criticised by Snodgrass, de Marinis and Peroni. ${ }^{1034}$ However, an earlier date of Ha A1 is certainly in closer agreement with the finds from further east, and with the nature of east-west connections in general at this time, ${ }^{1035}$ and the fact that the deposits of Nadap and Malpensa also contain greaves of Type Lengyeltóti (cat. nos. 165 and 160-161).

Catalogue

Cat. no. 153. Brodski Varoš, opć. and kot. Slavonski Brod, Croatia - associated deposit fragments - thickness: $0.5 \mathrm{~mm}$; weight: $102 \mathrm{~g}+8 \mathrm{~g}+2 \mathrm{~g}-$ Arheološki muzej u Zagrebu, no inv.

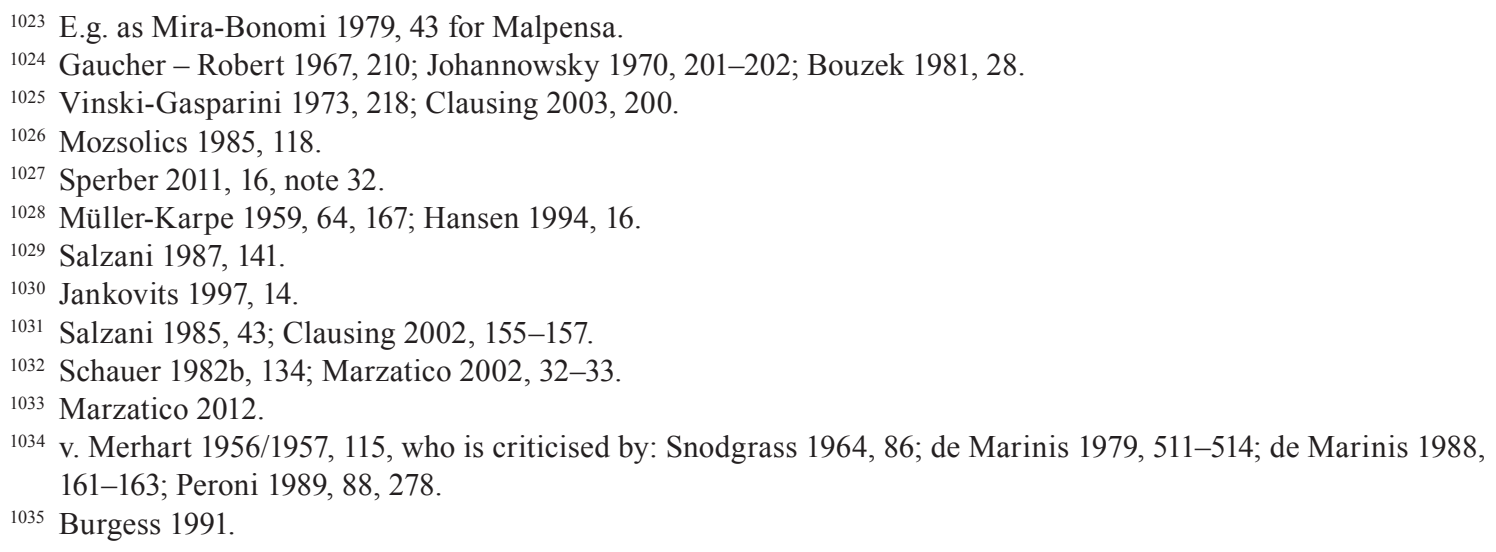


no. - Pl. 34.153. References: Vinski-Gasparini 1973, 178, 212, pls. 55.22; 57.9; Müller-Karpe 1980, 804, no. 306, pl. 382.18; Schauer 1982b, 134, fig. 12.1; Hansen 1994, 14-15, 18, figs. 3.5; 15.6; Clausing 2002, 155, fig. 3.7.

The associated deposit was found in 1959 during work in a vineyard. Parts of the associated deposit were stolen but it still comprises more than 800 pieces, including arm rings, twisted and plain neck rings, fibulae, pins, discs, buttons, pendants, appliqués, sheet fragments, fragments of a greave, wire, rings, fittings, fragments of swords (Type Brodski Varoš, Type Aranyos, variant Buzija, Type Krško, Type Reutlingen, variant Genf, Type Mihovo, and various fragments), daggers, spearheads, arrowheads, knives, razors, socketed axes, winged axes, chisels, sickles, raw bronze as well as several unidentified fragments. ${ }^{1036}$

Cat. nos. 154-155. Desmontà, prov. Verona, reg. Trento, Italy - associated deposit (?) - a pair of greaves, almost complete - Museo Civico Archeologico di Cologna Veneta, inv. no. IG 89.542 and IG 89.541 - Pl. 34.154-154. References: Salzani 1985, 42-43; Salzani 1987, 141, fig. page 145; Hansen 1994, 14, 18, 426, no. 81, figs. 3.1; 5.12; Jankovits 1997, 14; Clausing 2002, 155, fig. 3.2-3.

The necropolis of Desmontà today consists of more than 320 graves and dates to the $11^{\text {th }}-9^{\text {th }}$ century BC. ${ }^{1037}$ The two greaves were found in the area of the necropolis in a small pit without any other associated finds. One of the greaves was placed on or close to a piece of wood, and the second greave was placed immediately beneath, also on a piece of wood.

Cat. nos. 156-159. Pergine (Masetti), prov. Trento, reg. Trentino, Italy - associated deposit (?) - two almost complete pairs of greaves. Measurements: see below - Castello del Buonconsiglio e collezioni provinciali, Trento, inv. no. 7533 (other inv. nos. unknown) - Pl. 34.156-159. References: Fogolari 1943a, 4-11, figs. 1-3; Fogolari 1943b, 106-111; Fogolari 1944, 73-74, figs. 1-4; v. Merhart 1956/1957, 92, 102-103, 115-116, fig. 3.1-4; Müller-Karpe 1959, 64, 167; Fogolari 1975, 127; Giurletti 1978, 120, fig. 40.1-2; Mira-Bonomi 1979, 128-130; Schauer 1982b, 106, 118-119, 134, fig. 5.1-4; Passard - Piningre 1984, 102; Fogolari - Prosdocimi 1989, 84; Hansen 1994, 15, 18, 428, no. 166, figs. 4.6; 5.17; Jankovits 1997, 14, fig. 9.3-6; Clausing 2002, 155, fig. 3.6; Marzatico 2002, 31, fig. 18; Zamboni 2011, 172; Marzatico 2012 [with further literature].

The two pairs of greaves were found close to the small church of Au Massetti during work on a nearby street running through Valsugana in May 1940. The decoration on all four greaves is almost the same. One pair has four loops on each side (pair A), whilst one of the second pair has three loops on each side, whilst the other is not complete (pair B). Pair A, measurements: $29 \times 13.2 \mathrm{~cm}$ (inv. no. 7533 ) and $29 \times 12.4 \mathrm{~cm} .{ }^{1038}$ Pair B, measurements: $27.5 \times 14.3 \mathrm{~cm}$ and 26.5 $\times 7.7 \mathrm{~cm}$ (only one side of the greave remained). ${ }^{1039}$

Cat. nos. 160-161. Malpensa, reg. Lombardia, Italy - associated deposit (?) - three almost complete greaves, two of Type Desmontà - Pl. 34.160-161. References: de Marinis 1979, 511514; Mira-Bonomi 1979, 125, fig. 1.1-2; Schauer 1982b, 135, fig. 13; Mozsolics 1985, 27; de Marinis 1988, 161-163; Peroni 1989, 88, 278; Hansen 1994, 14, 18, 427, no. 128, figs. 3.2-3; 5.13; Clausing 2002, 155, fig. 3.4-5; de Marinis 2009, 148-154, figs. 6, 9; de Marinis 2016, fig. 12B; Gambari et al. 2017.

The associated deposit contained three greaves (cat. nos. 160-161, 179), ingots and ingot fragments, three spearheads and a spearhead fragment, two axes and a further fragment of axe, two sickles and a sickle fragment, and some bronze sheets now identified as from a helmet (cat. no. 61).

\footnotetext{
1036 Vinski-Gasparini 1973, 212, pls. 52-65.

1037 Salzani 1987, 141.

1038 Fogolari 1943a, figs. 2, 4.

1039 Fogolari 1943a, figs. 1, 3.
} 
According to R. de Marinis the greaves were deposited independently of the history of the necropolis, and belong to a separate associated deposit dating to the $12^{\text {th }}$ century $\mathrm{BC}$, and therefore are contemporary with Rinyaszentkirály (cat. no. 168). ${ }^{1040}$ Peroni also dates the associated deposit to the same period. ${ }^{1041}$ Mira Bonomi, however, argues that the greaves are part of the inventory of a grave. ${ }^{1042}$

The three greaves do not belong to the same type. Whilst two of the greaves belong to Type Desmontà, they do not form a pair. The third greave belongs to Type Lengyeltóti (cat. no. 179).

Cat. no. 162. Cannes-Ècluse, Dép. Seine-et-Marne, France - associated deposit - half of the greave preserved. Measurements: $27.9 \times 9.7 \mathrm{~cm}$; thickness $0.6-0.9 \mathrm{~mm}$; thickness wire: $1-2 \mathrm{~mm}-$ Musée de Préhistoire d'Île-de-France, inv. no. unknown - Pl. 35.162. References: Gaucher Robert 1967, 205-210, figs. 46-48, 51; Mohen 1977, 228; Müller-Karpe 1980, no. 941, pl. 471. E8; Schauer 1982b, 123, fig. 7.1; Passard - Piningre 1984, 102; Hansen 1994, 14, 18, figs. 3.6; 5.11; Clausing 2002, 155, fig. 3.1; Lehoërff 2009.

The greave was found in 1964 as part of an associated deposit, which was unearthed by a bulldozer. The associated deposit currently comprises 364 fragments (39 fragments of axes, more than 40 fragments of sickle, a bracelet or torque, bronze sheets, etc.) and two complete pieces, a bracelet and a chisel. The large fragment of greave was found folded together. ${ }^{1043}$

Cat. no. 163. Poljanci I, opć. and kot. Slavonski Brod, Croatia - associated deposit I - fragment. Measurements: $9.5 \times 10.8 \mathrm{~cm}$; thickness: 0.6mm; weight: $29.4 \mathrm{~g}-$ Brodsko Posavlje Muzej Slavonski Brod, inv. no. 1797 - Pl. 35.163. References: Vinski-Gasparini 1973, 183, 218, pl. 48.19; Müller-Karpe 1980, 805, no. 315, pl. 384.A5; Schauer 1982b, 134, fig. 12.2; Hansen 1994, 13-14, 18, 570, no. 223, figs. 3.4; 5.4; Clausing 2002, 155, fig. 3.8; Clausing 2003, fig. 64B.11; Miklik-Lozuk 2009, 67, cat. no. 80.

The associated deposit was found in 1958 during ploughing and consists of 178 bronze objects stored in a ceramic vessel: arm rings, neck rings, fibulae, decorated discs, buttons, pendants, a small bronze cow figurine, pins, fragments of flange hilted swords, knives, winged axes, chisels, sickles as well as fragments of a helmet (cat. no. 24) and a fragment of a greave. ${ }^{1044}$ Vinski-Gasparini published 55 objects from the associated deposit. ${ }^{1045}$

Cat. no. 164. Esztergom-Szentgyörgymező, Komáron megye, Hungary - associated deposit I - fragment - Balassa Bálint Múzeum Esztergom, inv. no. 69.1.284 - Pl. 35.164. References: Müller-Karpe 1980, 807, no. 341; Mozsolics 1985, 116-117, no. 85, pl. 138.16; Hansen 1994, 13, 18, 538, no. 221, figs. 3.9; 5.1; Jankovits 1997, 6, 8, fig. 5; Clausing 2002, 155, fig. 3, 9.

The greave fragment could not be located in the museum. The associated deposit was found in the city area, opposite of the restaurant 'Kettös pince'. The associated deposit consists of 298 bronzes, most of them fragments, which were found in a ceramic pot.

Cat. no. 165. Nadap, Fehér megye, Hungary - associated deposit - fragment. Measurements: c. $21 \times 9 \mathrm{~cm}-$ Szent István Király Múzeum Székesfehérvár, no inv. no. - Pl. 35.165. References: Petres 1983, 58-59, fig. 4a-b; Mozsolics 1985, 151; Hansen 1994, 14, 18, 546, H 451, figs. 3.1011; 5.2; Jankovits 1997, fig. 3.2; Clausing 2002, 155, fig. 3.10; Makkay 2006, 7, pl. IV; Uckelmann 2012, 17-18.

For description of the associated deposit, see cat. no. 27.

\footnotetext{
1040 de Marinis 1979, 511-514; de Marinis 1988, 161-163.

${ }^{1041}$ Peroni 1989, 88, 278.

1042 Mira-Bonomi 1979, 43.

1043 Gaucher - Robert 1967, fig. 46.20a.

${ }^{1044}$ Miklik-Lozuk 2009, 45-46.

1045 Vinski-Gasparini 1973.
} 
Cat. nos. 166-167. Unprovenanced (Hungary?). Measurements greave 1, overall dimensions: $27.3 \times 17.1 \mathrm{~cm}$, weight 192g; greave 2 is heavily fragmented - Hadtorteneti Muzeum, Budapest inv.no. 1993.791.II - Pl. 35.166-167. References: Tarbay 2015, figs. 8, 16.4; 17.5.

The pair of greaves is represented by 37 fragments. For the description of the assemblage, see cat. no. 12 .

\subsubsection{Greaves of Type Lengyeltóti}

\subsubsection{Decoration}

Greaves of Type Lengyeltóti (Tab. 4.3) are generally decorated with Gleichbuckel. In all instances, the hub of the wheel is indicated by a larger boss and on some greaves, such as that from Nagyvejke (cat. no. 169), the spokes are emphasised by the addition of bows attached to the wheel. The wheel motif might have acted as an apotropaic symbol of protection, ${ }^{1046}$ speed or power, since they are also found applied to a range of central and eastern European body armour, including an unprovenanced crested helmet (cat. no. 100) and a cheek plate from Podcrkavlje-Slavonski-Brod (cat. no. 67), which are rarely ever decorated. The wheel motif is more commonly found on belts, ${ }^{1047}$ pins and pendants. ${ }^{1048}$ Usually, the wheels consist of two circles, though the use of three circles is not uncommon (Nadap, Rinyaszentkirály, Slavonski Brod (cat. no. 176) and Stetten/Teiritzberg (cat. no. 174).

The greave from Rinyaszentkirály is the only known greave with both a wheel motif and a (naturalistic) water bird depiction. The greave is decorated with three lines parallel to the rim, and three further vertical lines positioned in the middle of the greave. In the centre there is one wheel on each side, and above and below these there are four water birds. The decoration of this greave indicates a close relationship to those greaves of Type Desmontà.

The greave fragment from Slavonski Brod II differs from those found in Slavonski Brod I, being both slightly bent, and having been decorated with this three-circled wheel. The fragment most likely belongs to a different greave, as this particular variant of the motif is rather rare on objects other than greaves.

\begin{tabular}{c|l|l|c|l}
\hline Cat. No. & Find Circumstances & Find Site & State & Condition \\
\hline 168 & associated deposit & Rinyaszentkirály & HU & complete \\
\hline 169 & associated deposit & Nagyvejke & HU & fragments \\
\hline $170-172$ & associated deposit & Nadap & HU & fragment and 2 complete \\
\hline 173 & associated deposit & Lengyeltóti & HU & complete \\
\hline 174 & associated deposit & Stetten & AT & fragments \\
\hline 175 & associated deposit & Poljanci IV & HR & almost complete \\
\hline 176 & associated deposit & Slavonski Brod & HR & fragments of 2 (?) greaves \\
\hline 177 & associated deposit & Veliko Nabrđe & HR & fragments \\
\hline 178 & associated deposit & Boljanić & BA & fragments \\
\hline 179 & associated deposit (?) & Malpensa & IT & complete \\
\hline $180-181$ & grave & Athens & GR & almost complete \\
\hline 182 & associated deposit & Markovac-Grunjac & XS & fragment \\
\hline
\end{tabular}

Tab. 4.3 Greaves of Type Lengyeltóti. The fragment from the greave from Markovac-Grunjac, Serbia, might also be associated with greaves of Type Desmontà.

\footnotetext{
1046 Bouzek 1981, 28.

1047 Salaš 1997, pl. 24.612b.

1048 Pare 1987.
} 
From the associated deposit of Markovac-Grunjac, Serbia, which was recently published by D. B. Jovanovic, ${ }^{1049}$ a small fragment of the rim of a greave with partly surviving wire is known. Due to its fragmentary character, it is not clear if it belongs to those greaves of Type Desmontà or of Type Lengyeltóti. Another bronze sheet object, a disc, shows atypical pellet decoration, indicating that it was cut out from another bronze sheet object, potentially another (or the same?) greave: on the base, two incomplete, parallel circles are visible. On the upper end, five almost parallel, straight lines can be noted. In between these decorative elements two holes were punched through, most likely to fix the disc onto something. There is no loop or means of attachment on the rearside.

\subsubsection{Distribution and Deposition}

The 14 or 15 greaves of Type Lengyeltóti were generally deposited in associated deposits. The main recovery area is the Carpathian Basin west of the Danube. Only one greave fragment, belonging either to greaves of Type Lengyeltóti or greaves of Type Desmontà, derives from the eastern side of the Danube, from Markovac-Grunjac. The most western examples derive from Malpensa and Stetten/Teiritzberg, while a pair of greaves derives from Athens. This pair suggest possibly close contact between the different geographical regions of Greece and the western Carpathian Basin, and potentially to the greave from Malpensa, which may too have come from a grave (Fig. 4.5). Most of the Hungarian finds, as well as the greaves from Malpensa, Poljanci IV (cat. no. 175), and Athens, are almost complete, while in the associated deposits from Stetten/ Teiritzberg, Boljanić (cat. no. 178), Nagyvejke, Veliko Nabrđe (cat. no. 177), and Slavonski Brod only fragments were deposited, perhaps as representations of the original whole artefact. This depositional practice can also be noted in the deposition of helmets of Class I, which are generally found as single fragments only in the associated deposits from former Yugoslavia, Germany,

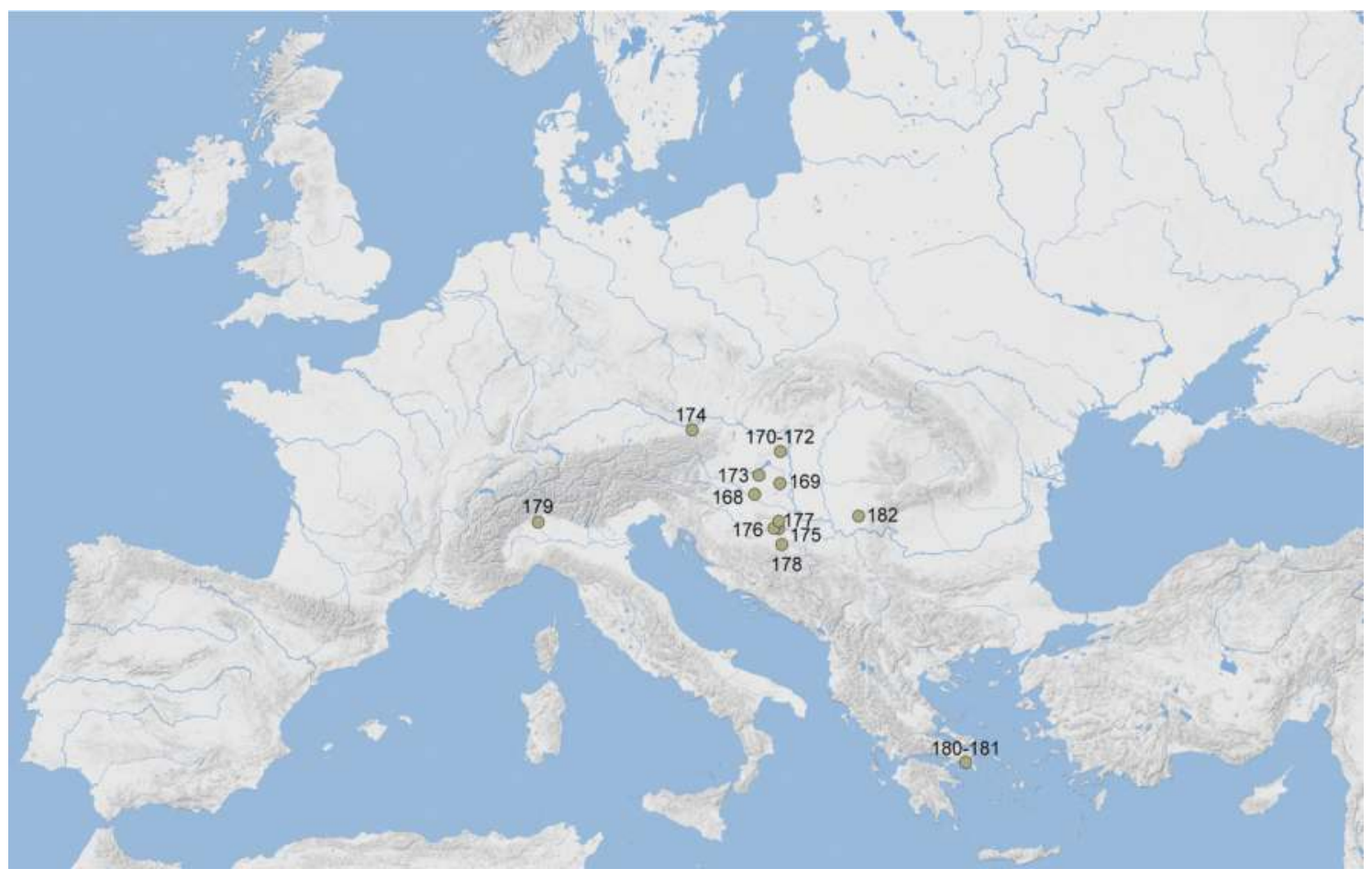

Fig. 4.5 Archaeological distribution of European Bronze Age greaves of Type Lengyeltóti: 168. Rinyaszentkirály; 169. Nagyvejke; 170-172. Nadap; 173. Lengyeltóti; 174. Stetten/Teiritzberg; 175. Poljanci IV; 176. Slavonski Brod; 177. Veliko Nabrđe; 178. Boljanić; 179. Malpensa; 180-181. Athens; 182. Markovac-Grunjac.

1049 Jovanović 2010. 
Austria and Romania, but are usually in a more complete state in the Carpathian Basin. At least five out of 14 or 15 greaves of Type Lengyeltóti were found to have been folded before deposition (Stetten, Poljanci IV, Malpensa (cat. no. 179), Lengyeltóti (cat. no. 173), and Rinyaszentkirály). Unlike the fragmented finds of greaves, which may have been deposited as representative of the original whole, we might interpret the act of folding less as indicating intentional destruction but more likely stemming from practicalities concerning their size during deposition.

\subsubsection{Chronology}

Greaves of Type Lengyeltóti are generally dated to Ha A1 or period II. ${ }^{1050}$ v. Merhart, Kossack and Müller-Karpe suggested in the 1950's that the greave from Rinyaszentkirály be dated to Ha B1 (as did A. Persy for the associated deposit of Stetten/Teiritzberg, Jovanović for the associated deposit of Boljanić, and P. Patay for the associated deposit of Nagyvejke). ${ }^{1051}$ Müller-Karpe later corrected his dating to Ha A1. ${ }^{1052}$ Mozsolics also suggested the earlier dating of Ha A1 for the find from Rinyaszentkirály, as did Hansen on the basis of the axe in the associated deposit of Stetten/Teiritzberg, and P. König for Boljanić, ${ }^{1053}$ whereas Johannowsky dated them as early as Bz D. Concerning the associated deposit of Nadap (Bz D/Ha A1), the deposition date during Ha A1 is already well-established. ${ }^{1054}$ The greaves of Type Lengyeltóti from Boljanić, ${ }^{1055}$ Slavonski Brod, ${ }^{1056}$ Poljanci IV ${ }^{1057}$ and Veliko Nabrđe, are generally dated to period II, following VinskiGasparini. ${ }^{1058}$ Opinions on the dating of the greaves from Malpensa differs widely, with Jankovits and Mozsolics both suggesting Ha B1, and de Marinis arguing for a date in the $12^{\text {th }}$ century BC or Ha A1 respectively. ${ }^{1059}$ However, according to all other finds of the same type, its dating to Ha A1 seems to be far more likely, as it is also suggested here for the greave from Lengyeltóti. The slightly more recent date of early $\mathrm{LH} \mathrm{IIIC}^{1060}$ for the greaves from Athens, might be due to the fact that as an import the greave probably had a higher value and was not deposited immediately.

Though the greave fragment from the associated deposit from Markovac-Grunjac cannot be associated with the greaves of Type Desmontà or of Type Lengyeltóti, its chronological attribution to $\mathrm{Ha} \mathrm{A}$, on the basis of the associated finds in the respective associated deposits, is clear. ${ }^{1061}$

\section{Catalogue}

Cat. no. 168. Rinyaszentkirály, Somogy megye, Hungary - associated deposit - almost complete. Measurements: $25.5 \times 19.2 \mathrm{~cm}$; thickness: $0.1 \mathrm{~mm}$; weight: $126 \mathrm{~g}$ - Somogy Megyei Múzeumok Igazgatósága, but today kept in the Magyar Nemzeti Múzeum, Budapest, inv. no. 3948 Pl. 35.168. References: Hampel 1896, 104, pl. 215.1; v. Merhart 1956/1957, 92, no. 6, fig. 2.2; Snodgrass 1971, 47-48; Mozsolics 1972, 387, 390, notes 32-36; Müller-Karpe 1980, 811, no. 382a, pl. 377.D1; Schauer 1982b, 114, fig. 1; Mozsolics 1985, 27, 182-183, pl. 98; Hansen 1994, 15, 18, figs. 4.5; 5.3; Jankovits 1997, 1-2, fig. 1.1; Clausing 2002, 151, fig. 2.3; Clausing 2003, 65.

\footnotetext{
${ }^{1050}$ Period II after Vinski-Gasparini 1973. See Fig. 1.1.

${ }^{1051}$ Kossack 1954, 27, 48-49; v. Merhart 1956/1957, 115-117; Jovanović 1958, 35; Müller-Karpe 1959, 64; Persy 1962, 46-47; Patay 1990, 71.

1052 Müller-Karpe 1962a, 275.

1053 Johannowsky 1970; Mozsolics 1985, 183; Hansen 1994, 16, note 27; König 2004, 191.

${ }^{1054}$ Most recently by Uckelmann 2012, 17-19.

${ }^{1055}$ König 2004, 191.

1056 Clausing 2003, 200.

${ }^{1057}$ Miklik-Lozuk 2009, 47.

1058 Vinski-Gasparini 1973.

1059 de Marinis 1982, 84; Mozsolics 1985, 80; Jankovits 1997, 12; de Marinis 2016.

${ }^{1060}$ Mountjoy 1988, 29.

1061 Jovanović 2010.
} 
The associated deposit was found in 1894 in a vineyard and, as well as a greave, contained decorated bronze sheet fragments, fragments of a vessel of Type Kurd, the hilt of a sword of Type Illertissen, one spearhead, two winged axes and two fragments of winged axes, nine sickle fragments, six socketed axes and fragments, one possible hammer, two fragments of axe, one pin, one arm ring, one fragment of a knife, one nail and 24 as-cast fragments. ${ }^{1062}$

Cat. no. 169. Nagyveike, Tolna megye, Hungary - associated deposit - fragments - Wosinsky Mór Megyei Múzeum Szekszárd, inv. no. 69.220.33/59/60 - Pl. 35.169. References: Mészáros 1971/1972, 32, pl. XIII.6, 13; Mozsolics 1985, 156; Patay 1990, 70, no. 117; Jankovits 1997, 6, fig. 4; Clausing 2002, 151, fig. 2.2; Clausing 2003, 65.

A number of objects appeared during ploughing in 1965, and the associated deposit was excavated in $1969 .{ }^{1063}$ It was buried at a depth of $30-40 \mathrm{~cm}$ in an oval pit some $45 \times 70 \mathrm{~cm}$ in size, with the objects irregularly placed inside it. The associated deposit currently comprises 164 objects, with some bronzes having been lost, ${ }^{1064}$ including fragments of three axes and several fragments of socketed axes, eight more or less complete socketed axes, fragments of saw, 17 sickles (Type Terramare, Griffzungensicheln, and Knopfsicheln) and sickle fragments, fragments of daggers and knives, two fragments from swords of Type Ennsdorf, further fragments of sword, three spearheads and a spearhead socket, a phalerae, wire, Riemenverteiler, bronze buttons, a decorated disc in the shape of a double axe, several fragments of different types of bracelets (round cross-section and made of sheets), fragments of two Ösenkopfnadeln, two small rings, fragments of further pins, fragment of a Violinbogenfibel, fragments of bronze sheet, parts of a Plattenfibel, fragments of a bronze cup of Type Fuchsstadt, 20 fragments of casting cake.

Cat. nos. 170-172. Nadap, Fehér megye, Hungary - associated deposit - three greaves (an almost complete pair and a further greave fragment of Type Desmontà). Measurements: Pair: $27.5 \times 22.5 \mathrm{~cm}$ and $28 \times 22.7 \mathrm{~cm}$; single greave fragment: $11.5 \times 8.8 \mathrm{~cm}-$ Szent István Király Múzeum Székesfehérvár, no inv. no. - Pl. 36.170-172. References: Petres 1983, 58-59, fig. 3a-d; Mozsolics 1985, 151; Hansen 1994, 14, 18, 546, H 451, figs. 3.10-11; 5.2; Jankovits 1997, fig. 2; Clausing 2002, 151, figs. 1.8-9; 2.1; Clausing 2003, 65; Makkay 2006, 7, pls. II-III; Uckelmann 2012, 17-18.

For the description of the associated deposit, see cat. no. 27.

Cat. no. 173. Lengyeltóti, Somogy megye, Hungary - associated deposit - complete. Measurements: $26.5 \times 23 \mathrm{~cm}$, thickness: $0.3-0.4 \mathrm{~mm}-$ Somogy Megyei Múzeumok Igazgatósága Kaposvár, inv. no. Ö 2015.17.1 - Pl. 36.173. References: Horváth 1995; Horváth 1997a; Horváth 1997b; Honti 2010, 27; Levente 2010, 253-262; Honti - Jankovits 2016.

The associated deposit was found in 1995, contained almost 700 objects, and has a total weight of $88.5 \mathrm{~kg}$. The bronze objects were found in a circular pit with $50 \mathrm{~cm}$ diameter in $60 \mathrm{~cm}$ depth. The associated deposit includes chisels, swords, axes, sickles and spearheads, as well as one complete greave, as well as casting cakes on the bottom of the deposit. The greave was folded several times along the longitudinal axis, and then hammered together along the folds.

The corrosion of the greave was removed with sodium hexametaphosphate, alkaline glycerol and Selecton B2 in distilled water during restoration. After heating the bronze over an open flame, the greave was unfolded. The formed oxide layers were removed with Selection B2 solution, as were chlorides. Sodium-sulphate dissolved was used to form an artificial patina layer. At the end, the greave was lacquered with Paraloid B72. Cracks and small fragments were glued together with Uhu Hart. Cavaties in the metal were filled with two-component Diamant Bronze resin. ${ }^{1065}$

\footnotetext{
1062 Mozsolics 1985, $182-183$.

1063 Mészáros 1971/1972.

1064 Mozsolics 1985, 156-158.

${ }^{1065}$ Horváth 1997b.
} 
Honti and Jankovits ${ }^{1066}$ note that on the greave 'X-ray emission analysis, electron microscopy analysis, and metallographic analyses' were carried out; however, the only results reported are: chemical analyses on the surface (61.74\% copper, $31.25 \%$ tin), and 'in the deeper layer' of the greave (93.05\% copper and $6.95 \%$ tin). No description of the microstructure, or further details of the alloy composition, such as the identification of trace elements, was noted.

Cat. no. 174. Stetten/Teiritzberg, Gem. Korneuburg, Niederösterreich, Austria - associated deposit - fragments. Measurements: $14 \times 9.5 \mathrm{~cm}-$ Naturhistorisches Museum, Vienna, inv. no. 75836-51 - Pl. 36.174. References: Persy 1962, 42-44, figs. 4-5; Mayer 1977, 155, no. 695; Eibner 1980, 285-311, fig. 12; Schauer 1982b, 140, fig. 15.1; Hansen 1994, 15, note 27; 18, figs. 4.2; 5.5; Clausing 2002, 151, fig. 1.7; Clausing 2003, 65.

The greave was found as part of an associated deposit in Teiritzberg, tract 406/1, in 1945 . Soviet soldiers built a trench roughly $1.6 \mathrm{~m}$ deep and $60 \mathrm{~cm}$ wide. During the work, they recovered sickles, knives or daggers and axes, amounting to some 15-20 pieces, which were left next to the trench. After the soldiers left, the farmers sold the finds to a scrap metal dealer. Just one axe was left in the field and later brought to the attention of F. Zeissl, who then searched for further finds, recovering two sickle fragments and several bronze sheets. The greave provides the only dating evidence for the initial group of finds that were sold off, and for those that were recovered later.

Cat. no. 175. Poljanci IV, opć. and kot. Slavonski Brod, Croatia - associated deposit IV almost complete. Measurements: $17.5 \times 13.3 \mathrm{~cm}$; thickness: $0.3-0.5 \mathrm{~mm}$; diameter wire: $2.4 \mathrm{~mm}$; weight: $183 \mathrm{~g}$ - Brodsko Posavlje Muzej Slavonski Brod, inv. no. A-4029 - Pl. 36.175. References: Miklik-Lozuk 2004, 32, pls. X-XI ; Miklik-Lozuk 2009, 47, 109, cat. no. 260.

The associated deposit was found in 1991 by Croatian soldiers and donated to the Brodsko Posavlje Muzej Slavonski Brod the same year. It consists of 45 bronzes, including socketed axes, sickles, knives, a fragment of a saw, a fragment of a dagger, a fragment of a spearhead, A potential fragment of a helmet, a greave, jewellery such as rings, pendants, bracelets, a razor, parts of garments, appliqués, a ferrule, a coil, bronze sheet fragments and bronze ingots. ${ }^{1067}$ The greave from Poljanci IV was found completely folded over and was unfolded during restoration in 2007 .

Cat. no. 176. Slavonski Brod, opć. and kot. Slavonski Brod, Croatia - associated deposit fragments of two (?) greaves. Measurements: see below - Römisch-Germanisches Zentralmuseum, inv. nos. O.40515-18 - Pl. 36.176. References: Schauer 1986, 900-904; Clausing 2002, 151, fig. 1.5; Clausing 2003, 65, fig. 3.11.

Detailed find circumstances are unknown, and therefore it is possible that its inventory of almost 260 bronzes is not the complete associated deposit. Clausing has provided a comprehensive discussion of the associated deposit. ${ }^{1068}$ It consists of arms and armour (swords, spearheads, daggers, greaves), tools (axes, hammers, chisels, sickles, razors, knives), bronze vessels, jewellery (pendants, pins, fibulae, arm and neck rings, spiral rolls), and other objects (decorated discs, nails, weights, sheet fragments, raw bronze, etc.). It is possible that the greave fragments belong to more than one greave, as indicated by the nature of the scrap metal associated deposit itself, which consists largely of fragments.

Measurements inv. nos. O.40515/16: $3.8 \times 2.15 \mathrm{~cm} ; 5.95 \times 2.6 \mathrm{~cm} ; 6.8 \times 8.4 \mathrm{~cm} ; 2.05 \times 1.45 \mathrm{~cm}$; $3.9 \times 3.3 \mathrm{~cm} ; 3.45 \times 2.75 \mathrm{~cm} ; 7.75 \times 2.95 \mathrm{~cm} ; 5.2 \times 1.8 \mathrm{~cm} ; 1.83 \times 1.3 \mathrm{~cm} ; 4.1 \times 3.2 \mathrm{~cm}$; weight: due to the application of epoxy and glass fibres not possible to measure.

Measurements inv. no. O.40515/17: $8.7 \times 5.95 \mathrm{~cm}$; weight: $15.7 \mathrm{~g}$.

Measurements inv. no. $0.40515 / 18: 5 \times 3.3 \mathrm{~cm}$; weight: $3.41 \mathrm{~g}$

\footnotetext{
1066 Honti - Jankovits 2016, 75.

${ }^{1067}$ Miklik-Lozuk 2009, 47.

${ }^{1068}$ Clausing 2003.
} 
Cat. no. 177. Veliko Nabrđe, mun. Drenje, dist. Osijek, Croatia - associated deposit - fragments - Arheološki muzej u Zagrebu, inv. no. 10.238 - Pl. 37.177. References: Vinski-Gasparini 1973, 186, 221, pl. 44.1; Müller-Karpe 1980, 805, no. 324, pl. 381.B8; Schauer 1982b, 140-141, fig. 16.2; Gabrovec 1983, 658, pl. 93.6; Hansen 1994, 15, 18, figs. 4.3; 5.5; Jankovits 1997, 9; Clausing 2002, 151, fig. 1.6; Clausing 2003, 65; Karavanić 2009, 118-121, fig. 58.3.

For the description of the associated deposit, see cat. no. 23.

Cat. no. 178. Boljanić, mun. Gracanica, dist. Tuzla, Bosnia-Herzegovina - associated deposit - two fragments. Measurements: $9.8 \times 6.6 \mathrm{~cm}$, weight: $7.1 \mathrm{~g}$; $3.6 \times 3.1 \mathrm{~cm}$, weight: $1.1 \mathrm{~g}$; thickness (both fragments): $0.3 \mathrm{~cm}$ - Muzej istočne Bosne posjeduje Tuzla, inv. no. 3417; 3419 Pl. 37.178. References: Jovanović 1958, 23-24, fig. 24a-b; Hansen 1994, 16, 18, 561, no. 25, figs. 3.12; 5.7; Jankovits 1997, 9; Clausing 2002, 150, fig. 1.1; Clausing 2003, 64; König 2004, 191, pl. 15.17 .

The associated deposit was found in 1957 close to the river Suljagin. The bronzes were found in ceramic pot, now lost, at a depth of $30-40 \mathrm{~cm}$. Some finds show traces of recent damage. As well as the greave, the associated deposit contained an appliqué, a sword, five daggers (mainly Type Peschiera), ten axes, one chisel, two other bronze chisels (?), two bronze anvils, fragments of a decorated plate, two arm rings, rings, buttons, one ingot, one pendant, nails and one ceramic bead.

Cat. no. 179. Malpensa, reg. Lombardia, Italy - associated deposit (?) - three almost complete greaves; two of Type Desmontà, one of Type Lengyeltóti. Measurements: unknown Museo Civico Archeologico di Varese, inv. no. 21.215 - Pl. 37.179. References: Mira-Bonomi 1979, 125-126, fig. 2; de Marinis 1982, 84, fig. 107; Schauer 1982b, 135, 141, fig. 15.2; Mozsolics 1985, 80; Hansen 1994, 15, 18, 427, no. 128, figs. 4.1; 5.13; Jankovits 1997, 9, 12, fig. 7.2; Clausing 2002, 150-151, fig. 1.4; Clausing 2003, 65; de Marinis 2009, 148-154, figs. 6, 8; de Marinis 2016, fig. 12B; Gambari et al. 2017.

See also cat. nos. 160-161. The greaves were folded prior to deposition. During the 'restoration' they were unfolded and broke into several pieces. R. de Marinis interprets the greaves as the remains of an associated deposit and not, as Mira Bonomi suggests, as grave goods. ${ }^{1069}$

Cat. no. 180-181. Athens, mun. and dist. Athens, Greece - grave - two almost complete greaves - inv. no. 9936.1: height: $30.4 \mathrm{~cm}$; inv. no. 9936.2: height: $30.9 \mathrm{~cm}$ - National Museum Athens, inv. no. 9936.1-2 - Pl. 37.180-181. References: Megaw 1968, 5, fig. 4; Schauer 1982b, 142, fig. 16.1; Mountjoy 1984, 135-136, figs. 2-3; Mountjoy 1988, 29; Kunze 1991, 3, note 8; Hansen 1994, 15-16, note 28, figs. 4.4; 5.21; Clausing 2002, 150, fig. 1.2-3; Clausing 2003, 64.

The greaves were found in a chamber tomb, cut into the bedrock, on the southern side of the hill of the Acropolis. They were previously attributed to Early Geometric but P. A. Mountjoy has argued that the grave, as well as the greaves, date to LH IIIC on the basis of the similar European finds. ${ }^{1070}$ As well as the greaves, some sherds and the bones of the deceased were found, a number of bronze objects, including two knives, two pairs of tweezers, one awl, and two razors or cleavers.

Cat. no. 182. Markovac-Grunjac, Vojvodina, Serbia - associated deposit - fragment $-5.8 \times$ 1.4cm; weight: 4.4g - Gradski muzej Vršac, inv. no. 10.749 - Pl. 38.182. References: Jovanović 2010, 71, 91, no. 288, pl. 38.288 .

The associated deposit contains over 1008 fragments with a total weight of more than $19 \mathrm{~kg}$, which makes it the largest associated deposit so far known from Serbia. Almost all objects are

1069 Mira-Bonomi 1979, 143; de Marinis 1982, 84.

1070 Mountjoy 1984, 135. 
represented by fragments or unsuccessful casting products. Most of the objects are attributed to the Srem-Slavonian workshop 'circle' or group. ${ }^{1071}$

\subsubsection{Greaves of Type Kuřim}

The distribution area of the ten known greaves (Tab. 4.4) with geometric decoration and integrated wire loops, which we have here termed Type Kuřim, ${ }^{1072}$ ranges from central France, southern Germany and Austria, to Moravia and Croatia. The greaves have integrated wire loops with attached rings and embossed decoration - usually with up to three different sizes of bosses.

\begin{tabular}{c|l|l|l|l}
\hline Cat. No. & Find Circumstances & Find Site & State & Condition \\
\hline 183 & associated deposit & Bouclans & FR & fragment \\
\hline 184 & associated deposit & Boutigny & FR & fragments \\
\hline 185 & associated deposit & Beuron & DE & fragments \\
\hline 186 & grave & Volders (grave 309) & AT & fragments \\
\hline 187 & grave & Volders (grave 349) & AT & fragments \\
\hline 188 & associated deposit (?) & Weissenstein & AT & fragment \\
\hline 189 & associated deposit in settlement & Várvölgy & HU & complete \\
\hline 190 & single find (?) & Kuřrim & CZ & complete \\
\hline $191-192$ & associated deposit & Kloštar Ivanić (2) & HR & almost complete \\
\hline
\end{tabular}

Tab. 4.4 Greaves of Type Kuřim.

\subsubsection{Decoration}

Greaves of Type Kurrim, with their integrated wire loops, Punktbuckel and geometric decoration, exhibit decoration which have been applied with at least three different sized round punches. All the greaves have in common the occurrence of decorative lines of pellets and small bosses parallel to the edge. The main decorative elements are vertical, central lines of pellets and small bosses. On both sides, at the top and bottom, are large centrally applied bosses with encompassing lines of pellets and small bosses. In the middle of the greaves, a horizontal separation is visible, created either by another pair of lines of pellets and small bosses (Bouclans, Kloštar Ivanić (cat. no. 191-192)) or by large bosses (Kuřim). In these delineated 'quarters' or areas, vertical decorative lines of pellets and small bosses were positioned. Unfortunately, most of the greaves are badly fragmented (Beuron, Weissenstein (cat. no. 188), Boutigny) or burnt (Volders), so their decoration cannot be completely reconstructed. The well preserved greave from Várvölgy (cat. no. 189) exhibits the vertical line of pellets and small bosses similar to the other greaves but has a completely different symmetrical arrangement of the decorative elements: on each side of the greave, six large bosses were placed alternating left and right, and in between them, a zig-zag band of four parallel lines of pellets is visible. It resembles the decorative arrangement of those greaves of Type Desmontà, though no actual bird heads motif is present.

\subsubsection{Distribution and Deposition}

Greaves of Type Kuřim are geographically distributed from Kloštar Ivanić, Croatia, in the east, to Boutigny in northeast France (Fig. 4.6). The only greaves from the central Alpine region are

1071 Jovanović 2010, 81.

1072 After Sperber 2011. 
from Volders and Weissenstein. Most greaves were found in associated deposits, with only those from Volders coming from graves. The graves from Volders which contained the greaves (and potentially crested helmets as well) belong to the western Urnfield culture. Sperber suggests the presence of armour in the grave is due to their close proximity to the nearby copper mines, and can be related to the control of these resources. Similar such graves, especially though containing swords, continued in use up to Ha B1. ${ }^{1073}$ The slow abandonment of internment in the Munich urnfields during Ha B1 might be connected with the decrease of copper mining in this area. The find circumstances of the greave from Kuřim are not entirely clear. However, on the basis of the formation of corrosion on the recovered greave, at least one further greave most have been deposited together with it. Only the greaves from Várvölgy and Kurrim were deposited complete, and the pair of greaves from Kloštar Ivanić are almost complete. All other greaves occur only as either single fragments (Weissenstein, Boutigny, Bouclans) or as several small fragments (Volders, Beuron).

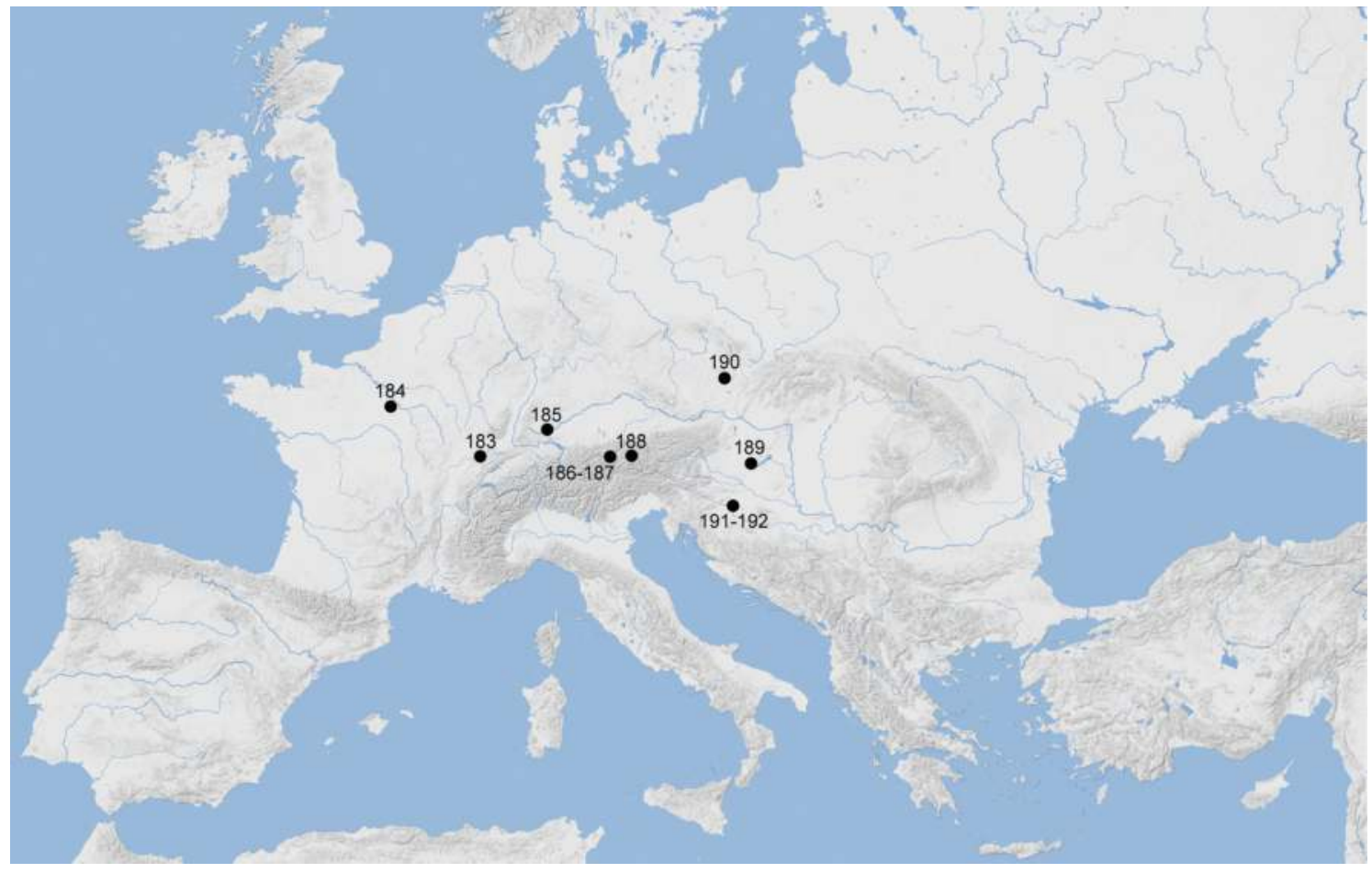

Fig. 4.6 Archaeological distribution of European Bronze Age greaves of Type Kuřim: 183. Bouclans; 184. Boutigny; 185. Beuron; 186-187. Volders; 188. Weissenstein; 189. Várvölgy; 190. Kuřim; 191-192. Kloštar Ivanić.

\subsubsection{Chronology}

Greaves of Type Kuřim are generally dated to late Ha A2 and Ha B1. Müller-Karpe and Weiss dated the fragment from Beuron accordingly. ${ }^{1074}$ Passard and Piningre dated the associated deposit of Bouclans to the beginning of Bronze final, ${ }^{1075}$ while the greave should be associated with a more recent date. The associated deposit from Boutigny-sur-Essonne is known only from early drawings, but these were sufficient to allow at least for the typological classification of the greave fragment, and to attribute the associated deposit to Bronze final II. ${ }^{1076}$ The greave from

\footnotetext{
1073 Sperber 2011, 35 .

1074 Müller-Karpe 1962a, 275; Weiss 1998, 543.

1075 Passard - Piningre 1984.

1076 Mohen 1977; Clausing 2002, 160.
} 
the associated deposit of Kloštar Ivanić is dated to Ha A2/period III ${ }^{1077}$ and is associated with the Zagreb group, though this earlier date is questioned by Sperber. ${ }^{1078}$ Prüssing dated the greave fragments from Volders (grave 309 and 349) on the basis of the Type Jenišovice cup, which is attributable to later Urnfield period ( $\mathrm{Ha} \mathrm{B1}$ ), while Sperber dates the graves to $\mathrm{Ha}$ B1a. ${ }^{1079}$ The greave from Kuřim is dated to Ha B1 or later, ${ }^{1080}$ similar to the greave from Pergine, which Sperber dates to Ha Bla. ${ }^{1081}$ The greaves from Várvölgy ${ }^{1082}$ and Weissenstein have been dated accordingly.

\section{Catalogue}

Cat. no. 183. Bouclans, Dép. Doubs, Franche-Compté, France - associated deposit - fragment - diameter bosses: $1.35 \mathrm{~cm} ; 4 \mathrm{~mm} ; 1 \mathrm{~mm}$ - Musée des Beaux-Arts et d'Archéologie de Besançon, inv. no. A.980.2.2 - Pl. 38.183. References: Passard - Piningre 1984, 102-103, fig. 13.1-2, 4-5; Hansen 1994, 18, 410, no. 62, fig. 5.19; Clausing 2002, 158, fig. 5.2.

The associated deposit was found by M. Lambert in 1972. The associated deposit consists of some 55 pieces of bronze but may have contained more. So far, several axes, a knife with a massive hilt, sword fragments, spearheads, parts of belts, pins, arm rings, as well as other objects, are known and are mainly of local character. ${ }^{1083}$ Most of the bronzes are fragmented.

Cat. no. 184. Boutigny-sur-Essonne (Grand Roche Pasloup), Dép. Essonne (formerly Seineet-Oise), France - associated deposit - fragments - private collection (formerly Allain collection, Boutigny) - Pl. 38.184. References: de Mortillet 1908, 105-106, figs. 43-44; Hencken 1971, 183, fig. 150b; Mohen 1977, 117-118, 122-124; Gaucher 1981; Clausing 2002, 158, fig. 5.3.

The associated deposit is only known from older drawings. A. de Mortillet interpreted the fragments as parts of a helmet, as does Mohen despite Hencken having already questioned this interpretation. ${ }^{1084}$ Schauer was the first to suggest that the fragments might belong to a greave. ${ }^{1085}$ Clausing considers at least one fragment to belong to a greave. ${ }^{1086}$ The other fragments most likely belong to vessels, as mentioned by Hencken. ${ }^{1087}$ Gaucher notes that it is impossible to locate or identify the collection where the associated deposit is currently stored. ${ }^{1088}$

Cat. no. 185. Beuron (Paulushöhle), Lkr. Sigmaringen, RB Tübingen, Baden-Württemberg, Deutschland - associated deposit - fragments - Sammlung Schloß Sigmaringen, Germany, inv. no. unknown - Pl. 38.185. References: Lindenschmit 1860, pl. 24; Müller-Karpe 1959, 167, pl. 163.A1, 3, 10-13; Müller-Karpe 1962a, 275; Stein 1979, 107-108, no. 263, pl. 75.1-8; Bouzek 1981, 37, note 31; Schauer 1982b, 118, fig. 3.2; Hansen 1994, 18, 446, no. 100, fig. 5.16; Weiss 1998, 543, note 64; Clausing 2002, 158, fig. 5.1.

In the first publication of the associated deposit, a fragment most likely belonging to a greave but without the rim bent around a wire, was depicted. ${ }^{1089}$ This fragment is not mentioned or depicted in subsequent publications. The composition of the associated deposit is now difficult to determine, as in the original publication much later finds are depicted together with the

\footnotetext{
1077 Vinski-Gasparini 1973, 215.

1078 Šimić 2008, 63; Sperber 2011, 19.

1079 Prüssing 1991, 26; as does Sperber 2011, 14-15.

1080 Müller-Karpe 1962a, 275 - 'not older than the $10^{\text {th }}$ century BC'.

${ }^{1081}$ Sperber 2011, 14, 16, note 32.

1082 Müller 2006.

1083 Passard - Piningre 1984.

1084 de Mortillet 1908, 108; Hencken 1971, 183, 185, fig. 150a-b; Mohen 1977, 118.

${ }^{1085}$ Schauer 1982b, 151, fig. 204.

1086 Clausing 2002, 150, 160, fig. 5.3.

1087 Hencken 1971, 183.

${ }^{1088}$ Gaucher 1981, 412: 'Il n'a pas été possible de retrouver la trace de cette collection'.

1089 Lindenschmit 1860.
} 
greave fragments, including a bronze dagger, a fragment of a median winged axe, a Kahnfibel, a Schlangenfibel, several fragments of bracelets and further unidentified bronze fragments.

Cat. no. 186. Volders, VB Solbad Hall, Tyrol, Austria - grave 309 - fragments - Heimatkunde- und Museumsverein Wattens-Volders, inv. no. unknown - Pl. 38.186. References: Kasseroler 1959, 126-127, pl. XV; Kilian-Dirlmeier 1975, 54, no. 137, pl. 14.137; Prüssing 1991, 25, no. 16; Sperber 1992a, 63; Sperber 1992b, 70; Sperber 1999, 643, note 60; Clausing 2002, 158-161; Clausing 2003, 150, note 379; Sperber 2011, fig. 1.

The grave consisted of only a small number of associated finds. This largely attributable to it being interned during a period when associated grave goods were reduced in number, as well as the funeral process itself: ustrina. However, the nature of the excavation may have also been a contributing factor, with most of the graves being opened from the side and not from above and with only the core of the grave, such as the urn, content of the stone setting, etc., being documented. Earlier graves were often reused for later burials, ${ }^{1090}$ and it is possible that the grave may have been disturbed. The grave contained sherds from three different vessels, four bronze rings, three fragments of pins, a belt buckle, a handle from a knife of Type Pfatten, a fragment of a spearhead of Type München-Widenmayerstrasse, and between two and four fragments of a greave. These were interpreted by A. Kasseroler as belonging to a bronze vessel. ${ }^{1091}$ Some further smaller fragments are also preserved but are distorted due to the cremation process. The belt buckle's corrosion differs from the other finds and it is also typologically older, belonging to the end of $\mathrm{Bz} \mathrm{D}$ and beginning of $\mathrm{Ha} \mathrm{A} 1$. It might be part of an older cremation and reburied in the wrong, later grave 309. ${ }^{1092}$

The greave fragments still retain the wire around which the sheet bronze was bent. $1 \mathrm{~cm}$ below the rim, a line of pellets is visible.

Cat. no. 187. Volders, VB Solbad Hall, Tyrol, Austria - grave 349 - fragment. Measurements: $5 \mathrm{~cm} \times 1.5 \mathrm{~cm}-$ Heimatkunde- und Museumsverein Wattens-Volders inv. no. unknown Pl. 38.187. References: Kasseroler 1959, 139-140; Prüssing 1991, 25, no. 15, pl. 2.15; Sperber 1992a, 63; Sperber 1992b, 70; Sperber 1999, 643, note 60; Clausing 2002, 158, 161; Clausing 2003, 150, note 379; Sperber 2011, fig. 5.1-3.

The fragment of greave was placed in the grave with a cup, bowl, three profiled rings, several very small bronze rings, a fragment of a Kegelkopf pin, a fragment of a winged axe, an armring, several molten bronze pieces, a piece of a bronze cup, two massive bronze fragments, fragments from sickles of Type Windsbach, two small decorative buckles, and a fragment of a knife. The bronze sheet fragment of the greave has lines of pellet decoration, small bosses and one large central boss. The three rings most likely belong to the greave fragments, however, in this case the rings would be flat against the skin as their loops are twisted $90^{\circ}$. Sperber discussed the possibility of the rings belonging to ring pendants, a typical female grave good, and suggests it may have been a double grave, which would be atypical for the northern Tyrol compared to neighbouring regions. The presence of the greave would then be attested to by just one sheet fragment, which might be interpreted as the fragmentary remains of an older burial, accidently buried in the wrong grave.

Cat. no. 188. Weissenstein, Carinthia, Austria - associated deposit - fragment. Measurements: $6 \times 4.3 \mathrm{~cm}-$ Tauerngoldmuseum im Putzenhof in Großkirchheim, Austria; no inv. no. Pl. 38.188. References: Gleirscher 2007, fig. 6.1.

The metal finds were placed in a ceramic pot. The find circumstances, as well as the full assemblage of possibly associated finds, cannot be reconstructed as the associated deposit was found illegally with a metal detector. As intimated, the following objects might belong to the

\footnotetext{
1090 Sperber 2011, 7.

1091 Kasseroler 1959, 127.

1092 Sperber 2011, 7.
} 
same associated deposit: fragments of socketed axes with angle- and bow decoration, a winged axe of Type Haidach, sickle fragments, a tongue-sickle similar to Type Hallstatt, a knife, Middle Bronze Age arm rings, a finger ring, pins including a Spinnwirtelkopf and a swollen headed pin with decorated neck, similar to Type Deinsdorf, chisels, a gold ring, a gold wire, and fragments of a golden arm ring.

Cat. 189. Várvölgy-Nagy-Lázhegy, Zala megye, Hungary - associated deposit no. 10 - complete. Measurements: length: $28 \mathrm{~cm}$; weight: $206 \mathrm{~g}$ - Balatoni Múzeum Keszthely, inv. no. 2010.3.10.56 - Pl. 39.189. References: Müller 2006.

Between 2003 and 2006 excavations were carried out at the c. 160ha wide plateau of the Nagy-Lázhegy hill close to Várvölgy, and revealed the largest late Urnfield culture hilltop settlement in Transdanubia. Within the settlement area, 12 bronze associated deposits weighing between $0.1-36 \mathrm{~kg}$ were found, along with a gold associated deposit weighing $110 \mathrm{~g}$. Associated deposit 10 contained the greave. Further publication of these finds is currently being prepared by R. Müller.

Cat. no. 190. Kuřim, okr. Brno-venkov, Moravia, Czech Republic - single find (?) - complete. Measurements: lenght: 29.2cm - Moravské zemské muzeum Brno, inv. no. Pa. 3.94 - Pl. 39.190. References: Skutil 1946/1947, 69, figs. 22-23; v. Merhart 1956/1957, 92, 173-174, no. 1, fig. 2.1, pl. 2; Podborský 1970, 202, no. 124, pl. 71.1; Müller-Karpe 1980, pl. 387.C; Schauer 1982b, 118, fig. 3.1; Passard - Piningre 1984, 102; Hansen 1994, 15, 18, 492, no. 312, figs. 4.7; 5.15; Clausing 2002, 158, 160, fig. 5.6; Gleirscher 2007, fig. 6.2.

The greave is said to be a single find recovered during earth works. The corrosion on the greave suggests that a second greave had originally been placed on top of the surviving greave. This second greave has not been recovered.

Cat. nos. 191-192. Kloštar Ivanić, kot. Kutina, Croatia - associated deposit - two almost complete greaves. Measurements: $19.5 \times 11 \mathrm{~cm}$ and $17.5 \times 9.5 \mathrm{~cm}-$ Arheološki muzej u Zagrebu, inv. no. 10.859-60 - Pl. 39.191-192. References: Vinski-Gasparini 1973, 181, 215, pl. 96.2-4; Müller-Karpe 1980, 804, no. 310, pl. 383.A1-2; Schauer 1982b, 139, fig. 14; Gabrovec 1983, 660-661, pl. 94.1-2; Passard - Piningre 1984, 102; Larese 1991, 94, no. 31, fig. 31a-b; Hansen 1994, 15, 18, 566, no. 27, figs. 4.8; 5.14; Clausing 2002, 158, fig. 5.4-5; Šimić 2008, 44, 63, 179, cat. no. 43.

The associated deposit was found at a depth of $1.5 \mathrm{~m}$ to the southwest of the brickworks in 1967. The bronzes were stored in a ceramic vessel. Unfortunately, part of the associated deposit was stolen and destroyed. Today it consists of 277 pieces of bronze, including the pair of greaves, pendants, arm rings, discs, rivets, socketed axes, chisels, sickles, stabs, and Keftiu ingots. ${ }^{1093}$

\subsubsection{Single Types and Miniature Greaves}

The greaves from Canosa (greaves of Type Canosa; cat. nos. 193-194) and Limone (greaves of Type Limone; cat. no. 195) (Fig. 4.7), both Italy, are the only known greaves of their type. All have integrated wire loops and are decorated with ribs and bosses of three different sizes. They belong to greaves of Subclass A. Clausing suggests that these greaves represent a possible Italian variant of his greaves with integrated wire loops. ${ }^{1094}$ The greaves from Canosa are dated to the $10^{\text {th }}-9^{\text {th }}$ century BC, while the associated deposit from Limone has been assigned to Ha B1.

Bronze Age metal miniature greaves are known from Italy, Hungary and Croatia. The Italian finds are generally dated to the periodo laziale I and the Carpathian finds to the Kurd horizon. Two possible clay models of greaves from a Bz D context in Bulgaria are also discussed.

${ }^{1093}$ Vinski-Gasparini 1973, 215, pl. 96.

1094 Clausing 2002, 162. 


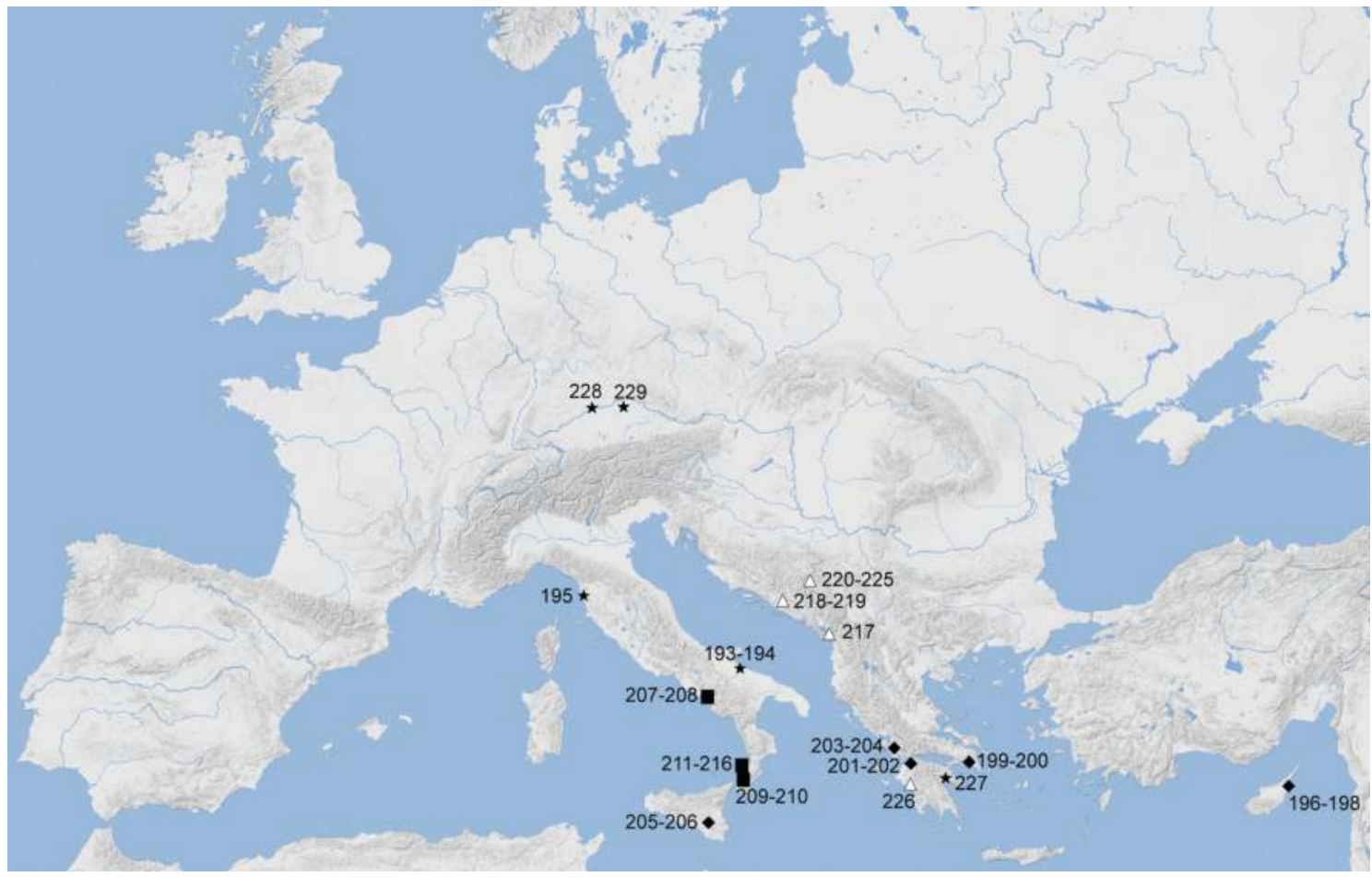

Fig. 4.7 Archaeological distribution of European Bronze Age greaves. Greaves of Type Kallithea: 196198. Enkomi; 199-200. Kallithea; 201-202. Portes-Kephalovryso; 203-204. Kouvarás; 205-206. Castellace. - Greaves of Type Grammichele: 207-208. Grammichele; 209-210. Pontecagnano; 211-216. Torre Galli. $\triangle$ Greaves of Type Ilijak: 217. Dobraç; 218-219. Dabrica; 220-225. Ilijak; 226. Olympia. ^ single types: 193194. Canosa; 195. Limone; 227. Dendra; 228. Schäfstall; 229. Winklsaß.

\begin{tabular}{|c|c|c|c|c|}
\hline Cat. No. & $\begin{array}{l}\text { Find } \\
\text { Circumstances }\end{array}$ & Find Site & State & Type \\
\hline 193-194 & unknown (grave?) & Canosa, Italy & IT & Canosa \\
\hline 195 & associated deposit & Limone, Italy & IT & Limone \\
\hline- & grave & Lavinio, Italy (grave 21) & IT & \multirow{9}{*}{$\begin{array}{l}\text { miniature } \\
\text { greaves }\end{array}$} \\
\hline- & grave & Quadrato di Torre Spaccata, Italy (grave 1) & IT & \\
\hline- & grave & Santa Palomba, tenuta Cancelliera (graves 1, 2,6 and 11) & IT & \\
\hline- & grave & Santa Palomba, tenuta Palazzo (grave 1) & IT & \\
\hline- & grave & Practica di Mare (grave 21) & IT & \\
\hline- & associated deposit & Gyöngyössolymos (associated deposit IV) & $\mathrm{HU}$ & \\
\hline- & associated deposit & Debrecen-Fancsika (associated deposit I) & HU & \\
\hline- & associated deposit & Esztergom-Szentgyörgymezö & $\mathrm{HU}$ & \\
\hline- & associated deposit & Poljanski II & HR & \\
\hline- & settlement & Ostrovu Mare & RO & \multirow{2}{*}{$\begin{array}{l}\text { clay } \\
\text { greaves }\end{array}$} \\
\hline- & cemetery & Orsoya & $\mathrm{BG}$ & \\
\hline
\end{tabular}

Tab. 4.5 Single types of greaves and miniature greaves.

\subsubsection{Decoration}

The decoration of the greave from Canosa is different from the ornamentation of all other greaves of Subclass A. In the centre there are vertical lines, surrounded by rows of small and medium sized bosses. The two blank areas created are decorated in the upper part with one large boss, from which lines of smaller bosses emanate, closely imitating the shape of pendants. 
Parallel to the rim are lines of small bosses and two ribs. This part of the decoration resembles that of the greave from Limone. Unfortunately, the greave from Limone is heavily fragmented, so we cannot draw any further conclusions concerning its decoration.

Miniature greaves are decorated with Gleichbuckel only (Fig. 4.8). Their small size inevitably limited the variety of decoration that could be applied. While the finds from the Carpathian Basin do not necessarily follow the decoration of their full size equivalents, the Italian miniature greaves exhibit, partly at least, the central vertical lines (for example, the miniature greaves from Pratica di Mare (Lavinio), Roma). ${ }^{1095}$ Two possible clay miniature greaves are known from the Gârla Mare culture in Romania. ${ }^{1096}$ The oval, flat plates (size: c. $15 \times 9 \mathrm{~cm}$ ) are decorated with symbols typical of the Urnfield culture, such as Vogelsonnenbarke, or sun wagons, and other decorative elements familiar on bronze greaves, such as dotted or straight lines parallel to the edge.

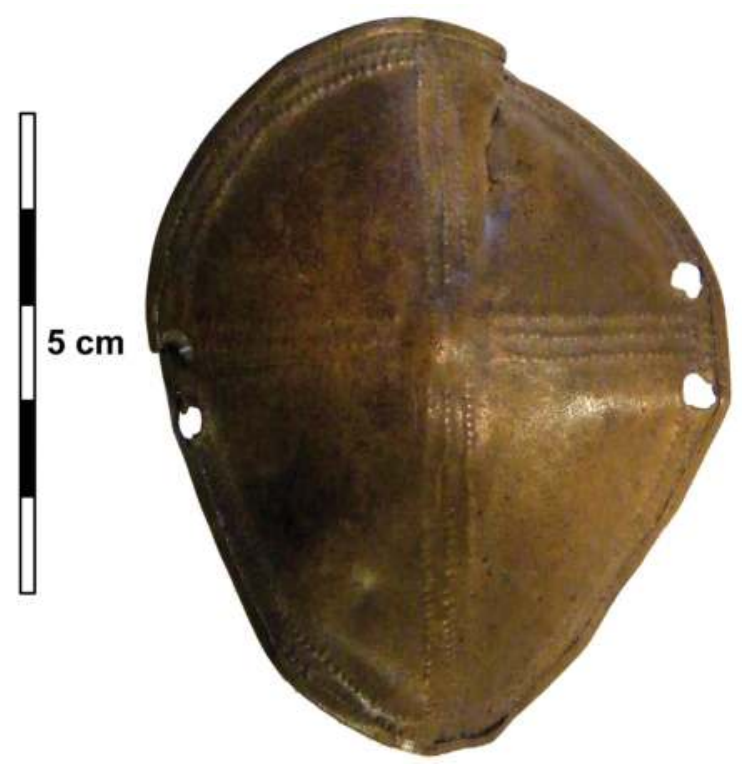

Fig. 4.8 Miniature greave from Esztergom-Szentgyörgymező, Hungary.

\subsubsection{Distribution and Deposition}

The find circumstances of the pair of greaves from Canosa are unknown, though their presence as a pair and their southern Italian origin indicates they were deposited in a grave. The greave from Limone, however, was deposited as a fragment in an associated deposit. The small number of finds does not, unfortunately, permit any further conclusions about the distribution of these forms of greaves.

Bronze Age miniature greaves are known from Italy (14 examples), Hungary (3 examples) and Croatia (1 example), thus forming two main distribution centres, one in southern Italy and the other in the western Carpathian Basin. The Italian greaves were usually deposited as pairs in graves, while the greaves from Hungary and Croatia were found in associated deposits. The largest number of miniature greaves was found in Lazio, Italy. Several graves contained not only miniature greaves but a whole set of miniature weaponry, such as shields, double shields, spear, sword with scabbard and knife, as well as miniature carriages in some cases. ${ }^{1097}$ Further

\footnotetext{
${ }^{1095}$ Colonna 1991, 66, fig. 9; Bietti Sestieri 2011, fig. 5.

1096 Dietrich 2009, 91-96.

1097 de Santis 2011, 15.
} 
miniature greaves from Italy were also found in Practica di Mare. ${ }^{1098}$ Carpathian finds of miniature greaves derive from Esztergom-Szentgyörgymezö, Gyöngyössolymos, and Debrecen-Fancsika, while one has also been found in Croatia (Poljanci, associated deposit II) ${ }^{1099}$ The Hungarian finds are connected to the Piliny culture, where bronze miniatures of weapons, tools and ornaments were often placed in graves. ${ }^{1100}$

Potential miniature depictions of greaves made of clay are known from the settlement of Ostrovu Mare, Romania, and the cemetery of Orsoya, Bulgaria. These were associated with the Gârla-Mare culture, ${ }^{1101}$ which is known for producing clay miniatures of various object types. Though their find spot was in the south of the Carpathians, we cannot exclude the possibility of a close connection to those areas where metal greaves were known.

\subsubsection{Chronology}

The greaves from Canosa, Italy, are generally dated to the $10^{\text {th }}-9^{\text {th }}$ century $\mathrm{BC}^{1102}$ on the basis of their embossed decoration, even though their form is unique and their find circumstances are unknown. The associated deposit from Limone, which contained a fragment of a similar greave, is roughly contemporary, being dated to Ha B1. ${ }^{1103}$ Most of the Italian miniature greaves date to the periodo laziale I $\left(10^{\text {th }}-9^{\text {th }}\right.$ century BC $),{ }^{1104}$ whilst the Hungarian finds all date to the Kurd horizon. ${ }^{105}$ The find from Poljanci II dates to period II, ${ }^{1106}$ or to Ha A, according to M. Bulat. ${ }^{1107}$ The miniature depictions of greaves made of clay, which were found in the settlement of Ostrovu Mare and the cemetery of Orsoya, Bulgaria, are associated with the late phase of the Gârla-Mare culture (Bz D). ${ }^{1108}$

\section{Catalogue}

Cat. nos. 193-194. Canosa, Prov. Barletta-Andria-Trani, Apulia, Italy - find circumstances unknown (grave?) - two almost complete greaves. Measurements: $28.1 \times 12.8 \mathrm{~cm}$ (greave 1) $28.9 \times 11.9$ (greave 2) - Museo Nazionale archeologico di Napoli, without inv. no. (5616 and 5617 as in Johannowsky 1970 do not match with the greaves) - Pl. 39.193-194. References: Fiorelli 1869, 5, nos. 37-38; Johannowsky 1970, pl. 1; Schauer 1982b, 122-123, fig. 8.1-2; de Caro et al. 1996, 161-164; Clausing 2002, 161, fig. 6.1-2.

The pair of greaves were found before 1869. No details concerning the find circumstances or possible associated finds are known.

Cat. no. 195. Limone, Prov. Livorno, Toscana, Italy - associated deposit - fragment - 11g Museo Archeologico Livorno, inv. no. 1798 - Pl. 39.195. References: Orsi 1887, 122-123, pl. IV.10; Cateni 1977, 14, fig. 6.7; 23, no. 50, pl. 2d; Bianco-Peroni 1979, 59, no. 301; Schauer 1982b, 124, fig. 8.3; Jankovits 1997, 16; Clausing 2002, 161, fig. 6.3.

\footnotetext{
${ }^{1098}$ Sommella et al. 1976, 291-311, pl. 75.A.

1099 Esztergom-Szentgyörgymezö: Mozsolics 1985, 74, 116-118, pl. 137.1; Gyöngyössolymos, depot IV: Kemenczei 1978/1979, 138, pl. V.2; Debrecen-Fancsika, depot I: Patay 1966, 76, pls. I.23-24; II.18; Mozsolics 1985, 47, 110, 124; Poljanci II, Croatia: Clausing 2003, fig. 70.145.

${ }^{1100}$ Mozsolics 1971.

1101 Dietrich 2009.

1102 Johannowsky 1970, 205-206.

${ }_{1103}$ Bianco-Peroni 1979, no. 301; Schauer 1982b, 138.

1104 Sommella et al. 1976, 291-311, pl. 75.A; de Santis 2011.

${ }^{1105}$ Patay 1966, 76, pls. I.23-24; II.18; Kemenczei 1978/1979, 138, pl. V.2; Mozsolics 1985, 47, 74, 110, 116-118, 124, pl. 137.1; Hansen 1994, 17; Jankovits 1997, 9, fig. 6.5.

1106 Clausing 2003, fig. 70.145, following Vinski-Gasparini 1973, 218.

1107 Bulat 1973/1975, 28, 36-37, pl. XV.9.

${ }^{1108}$ Dietrich 2009, 91-96.
} 
The associated deposit came to the museum in 1883 from the private collection of G. Chiellini. It was allegedly found in 1879 in the entrance area of a cave at the Monte la Poggia. The associated deposit consists of two spearheads, one knife of Type Bismantova, fragments of five other knives, five axes, a chisel and related fragments, a sickle and further fragments, a pin of Type Torri d'Arcugnano, fibulae, an arm ring and related fragments, a pair of tweezers, a razor of Type Fontanella, and the greave fragment.

\subsection{Greaves of Class I, Subclass B}

\subsubsection{Greaves of Type Kallithea}

Greaves of Type Kallithea have a separate, wave-shaped wire attached to the body of the greave (cat. nos. 196-206). The greaves have almost no decoration in the central part or are decorated geometrically, such as the greaves from Kallithea, with large central circles, and sometimes decorated with additional chevrons (e.g. Portes-Kephalovryso; (cat. nos. 201-202). The greaves are dated from the end of the $13^{\text {th }}$ century to the $12^{\text {th }}$ centuries BC. Today, we know of eleven greaves of this type (Tab. 4.6).

\begin{tabular}{c|l|l|c|l}
\hline Cat. No. & $\begin{array}{l}\text { Find } \\
\text { Circumstances }\end{array}$ & Find Site & State & Condition \\
\hline $196-197$ & grave & Enkomi (grave 15) & GR & fragmented \\
\hline 198 & grave & Enkomi (grave 18) & GR & almost complete \\
\hline $199-200$ & grave & Kallithéa & GR & complete \\
\hline $201-202$ & grave & Portes-Kephalovryso & GR & complete \\
\hline $203-204$ & grave & Kouvarás & GR & complete \\
\hline $205-206$ & grave & Castellace & IT & fragments \\
\hline
\end{tabular}

Tab. 4.6 Greaves of Type Kallithea.

\subsubsection{Decoration}

One of the greaves from Enkomi, grave 15, is well preserved, showing two ribs parallel to the bent rim and the remains of a punched circle with a large central boss, whilst the remains of the second greave are without any decoration despite the two ribs parallel to the bent rim (Fig. 4.9). On the latter, the lower edge and the left side are broken. In contrast, the greaves from PortesKephalovryso have a central, vertical rib, two ribs parallel to the edge, and on the two sides of the vertical rib a central, circular rib which is flanked on the outside with a line of chevrons. Chevrons are also found all along the inside of the inner, circumferential rib of the greaves, pointing inwards, and around two central circles on both sides of the greaves (with the chevrons pointing outwards). Such chevrons might be connected with the Carpathian cuirasses, which are also decorated with chevrons, being either engraved or plastic, and ribs (Saint-Germain-duPlain, Čaka, Ducové, Pázmándfalu).

According to Bouzek, the decoration on the greaves from Kallithea imitates the stitching on leather. ${ }^{1109}$ The two greaves consist of several small to tiny fragments joined together or amended with wax, and the decoration, which is described in detail by Yalouris, ${ }^{1110}$ imitates spats. Six ribs are arranged geometrically, and cross over in the centre of the greave. There is one larger boss in each of the areas in between. The geometric order and arrangement of the decorative elements demonstrates a strong connection to the greaves of Type Kurrim.

\footnotetext{
1109 Bouzek 1981, 28.
}

1110 Yalouris 1960. 

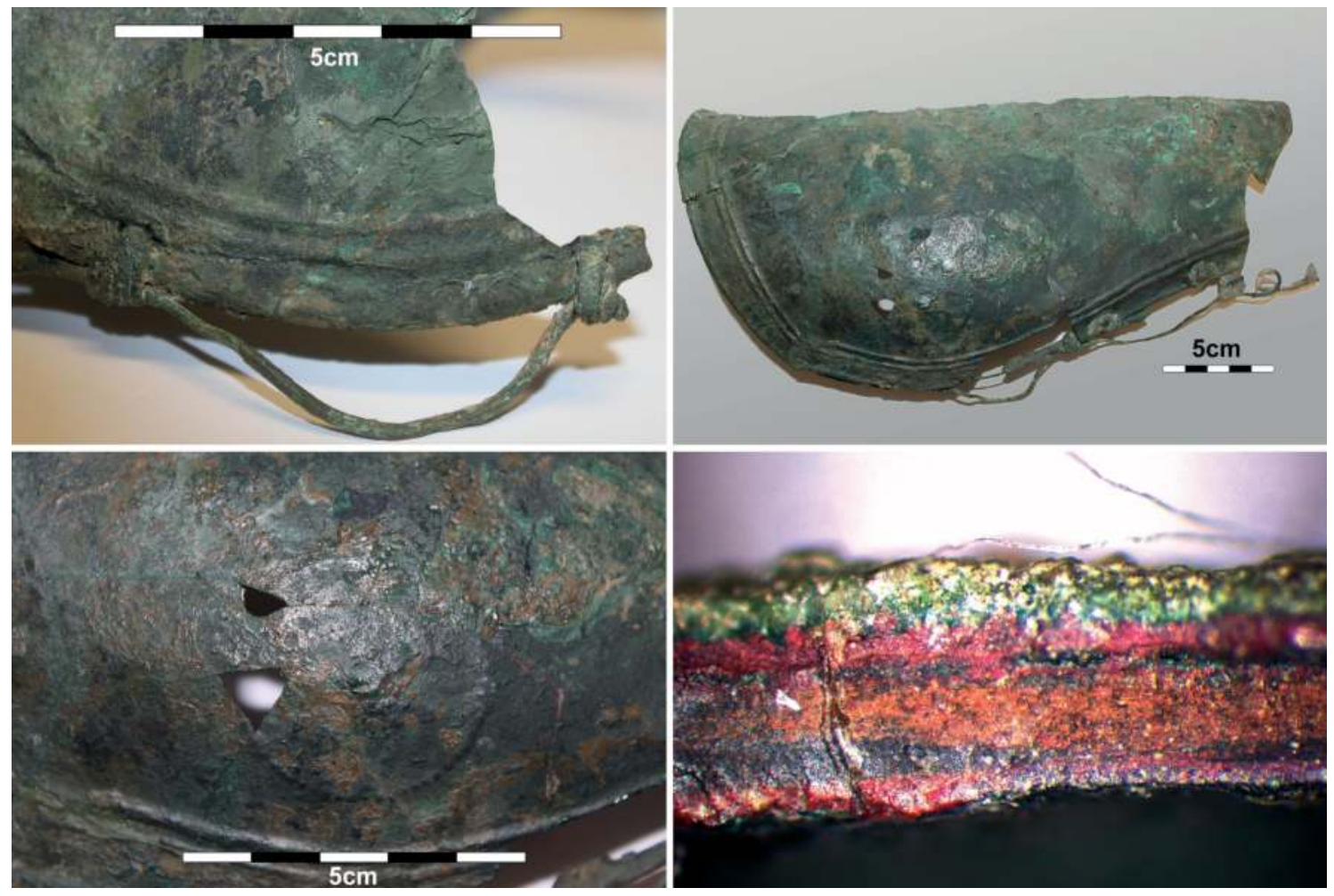

Fig. 4.9 Greave from Enkomi, grave 15. Note the attachment of the wire with riveted on bronze sheet bands and wire (above). The only decoration elements of the greave are two ribs parallel to the bent rim and the residue of one punched circle with a central, bigger boss (below left). The greave is completely corroded; no metal remained (bottom right; green: copper carbonates; black/red: copper oxides).

The greave from Castellace seems to be a hybrid of greaves of Type Kallithea and Type Grammichele, with separate wire loops, but no central decoration has been preserved apart from on the rim, which bears parallel lines of pellets and small bosses.

\subsubsection{Distribution and Deposition}

Greaves of Type Kallithea are known from central Greece, the northern Peloponnese and, most likely arriving there as a Greek export, from Cyprus and Castellace, Italy (cat. nos. 205-206). All of the greaves are grave finds. G. v. Merhart, who discussed Italian and eastern Aegean warrior graves, interpreted the graves from Enkomi and Knossos as the graves of foreign invaders. ${ }^{1111} \mathrm{He}$ saw the origin of the greave from Enkomi in Asia Minor and not in Greece, and the general origin of greaves amongst the Danube workshops. However, even today, no greaves have been discovered in Asia Minor. Catling agreed that the greaves from Enkomi were not produced locally but differed from Merhart in suggesting that they arrived from Greece together with the spread of the Naue II sword. ${ }^{112}$

\subsubsection{Chronology}

The greaves of Type Kallithea are generally dated to the end of the $13^{\text {th }}$ century to the $12^{\text {th }}$ centuries BC. The greaves from Enkomi, grave 15, are generally dated to LC IIC-III(A), ${ }^{1113}$ while

\footnotetext{
1111 v. Merhart 1969, 219.

1112 Catling 1955, 21, 35; Catling 1964, 140-141.

1113 Catling 1955, 26-27; Yalouris 1960, 49; Müller-Karpe 1962a, 275; Clausing 2002, 164.
} 
the greaves from grave 18 are slightly later and date to the end of the $13^{\text {th }}$ century BC or LC IIC/ LH IIIB. ${ }^{114}$ Catling suggests that the greaves are an import from the Greek mainland, as is the accompanying sword. ${ }^{1115}$ The chamber tomb and the greaves from Kallithea are dated to LH III B/C, early LH IIIC, or LH IIIC. ${ }^{1116}$ On the basis of the possible associated finds, including a Naue II sword of Type Stätzling/Allerona, a spearhead, a dagger, and bronze bands which were parts of a 'tiara-like' headdress, the greaves from Portes-Kephalovryso can be dated to either LH IIIA ${ }^{1117}$ or, more likely, to LH IIIC, ${ }^{1118}$ while the greaves from Kouvarás (cat. nos. 203-204) are dated to LH IIIB. ${ }^{1119}$

M. Pacciarelli dated the greaves from Castellace to the $12^{\text {th }}$ century BC on the basis of its close connection with the greaves from Enkomi and Kallithea. ${ }^{1120}$ The spearhead from the same grave supports this dating.

\section{Catalogue}

Cat. nos. 196-197. Enkomi, Cyprus - chamber tomb 15 - two almost complete greaves - inv. no. BM 1897/4-1/1531: c. $26.7 \times 12.4 \mathrm{~cm}$; weight: $245 \mathrm{~g}$; inv. no. BM 1897/4-1/1532: $17.6 \times$ $10.4 \mathrm{~cm}$, weight: $116 \mathrm{~g}$ - British museum, inv. nos. BM 1897/4-1/1531 and BM 1897/4-1/1532 Pl. 40.196-197. References: Murray et al. 1900, 16, fig. 26; Catling 1955, 29-30, figs. 5-6; v. Merhart 1956/1957, 94, no. 8a-c; Snodgrass 1964, pl. 28; Catling 1977b, 145-146, fig. 24, pl. 15a; Matthäus 1985, 16, note 23, pl. 122.A; Clausing 2002, 163, fig. 8.1-2.

The pair of greaves was found during the Turner Trust Excavation in 1896 and bought by the British Museum in 1897. Further finds comprise two decorated gold bands, three bronze bowls, fragments of further bronze bowls, a tripod, dishes of grey stone and perhaps also a bronze oinochoe (in the original documentation of the excavation, no ceramics are mentioned). One of the greaves from grave 15 (inv. no. BM 1897/4-1/1531) is decorated with an embossed circle and a large boss in the middle of the circle. Parallel to the rim at a distance of $1 \mathrm{~cm}$, are two ribs which follow the edge. On the edge of the greave, a double rib parallel to the rim is visible.

The other greave (inv. no. BM 1897/4-1/1532) is in a poor state of preservation and the surface is heavily corroded. The greave is almost complete but the ankle guard and most of the left side are broken off at the shin line. On the inside of the greave a thin strip of bronze was riveted onto the greave along its vertical edge. ${ }^{1121}$ The strip contains holes which would have held rings through which the lacing wire passed. The double ribs parallel to the edge are less prominent and the lacing attachment is more similar to that found on the greave from tomb 18 than to the other greave in this tomb (tomb 15). The rings holding the wire are attached directly onto the greave. No decoration is visible on the surviving fragments. On the basis of these not insignificant differences, it might be possible that the tomb contained two single greaves rather than a pair of greaves.

Cat. no. 198. Enkomi, Cyprus - chamber tomb 18, skeleton VI - fragmented; possibly two greaves. Measurements: c. $22.5 \times 13 \mathrm{~cm}-$ Cyprus Museum Nicosia, inv. no. 129 - Pl. 40.198 . References: Catling 1955, 22-23, figs. 1-4 [with older literature]; Yalouris 1960, 48-49; Catling 1977b, E 155; Schauer 1982b, 115, fig. 2.1; Matthäus 1985, 16, note 31; 20, note 61; Clausing 2002, 163, fig. 8.3 .

\footnotetext{
${ }^{1114}$ Catling 1955, 34-35; Yalouris 1960, 49; Clausing 2002, 164.

1115 Catling 1955, 34-35.

1116 LH III B/C: Hansen 1994, 17; early LH IIIC: Yalouris 1960, 42-43; LH IIIC: Clausing 2002, 164.

1117 Moschos 2000.

1118 Giannopoulos 2008, 207, note 27.

1119 Stavropoulou-Gatsi et al. 2012, 255.

${ }^{1120}$ Pacciarelli 2001, 193, 199.

${ }^{1121}$ Catling 1955, 30.
} 
The greave from grave 18 was excavated by the Swedish Cyprus Expedition in 1930 and was initially interpreted as helmet. ${ }^{1122}$ It belongs to skeleton VI, one of the final two burials in the tomb. The deceased was buried with a number of grave goods, including a Naue II sword and Levanto-Helladic pottery. The greave is in a poor state of preservation, and survives only as a few badly corroded fragments. It is not possible to confirm whether a second greave is represented amongst the fragments. The rim of the greave was bent outwards, so the greave is $6 \mathrm{~mm}$ thick on the edge. The rim is partly decorated with a form of 'cable' pattern. ${ }^{1123}$ Through metal loops (diameter $8 \mathrm{~mm}$ ) made of wire, which were fixed by means of small holes positioned to the rim, the greave could be attached to the leg, using organic strips guided through the metal loops. Three loops on the left side and two on the right side are still preserved. During the restoration it turned out that the greave or greaves were partially flattened before being placed in the tomb. Unlike the greaves from grave 15, on the fragments from grave 18 separate wires were guided through holes on the inner side of the rim.

Cat. nos. 199-200. Kallithéa-Rambandánia, Achaia, Greece - chamber tomb A - two complete greaves. Measurements: c. $25.5 \times 12.6 \mathrm{~cm}-$ Archaeological Museum of Patras, inv. no. unknown - Pl. 40.199-200. References: Yalouris 1954, 124-125, fig. 25; v. Merhart 1956/1957, 94, no. 7a-b, fig. 7.4; Yalouris 1960, 42-43, suppl. 28; Müller-Karpe 1980, 775, no. 116, pl. 250. C4-5; Schauer 1982b, pl. 4; Mountjoy 1984, 135, note 3; Matthäus 1985, 16, note 31; Hansen 1994, 13, notes 15, 18, 22, figs. 4.9; 5.20; Clausing 2002, 163, fig. 8.4-5; Giannopoulos 2008, 213-216; Stavropoulou-Gatsi et al. 2012, fig. 11.B.

In 1953 a farmer discovered a late Mycenaean chamber tomb. The bones of a presumable male (grave A) had been reburied in a small pit toward the back of the tomb. The second burial (grave B), another male, was buried in the shaft grave originally belonging to the first burial. The main finds of grave A are ceramics, mainly oinochoe, a Naue II sword, a spearhead and the fragments of two greaves, positioned lying on the legs of the buried person.

Cat. nos. 201-202. Portes-Kephalovryso, Greece - tomb 3 - two complete greaves: unknown - Archaeological Museum of Patras, inv. no. unknown - Pl. 40.201. References: Papadopoulos 1999, 271-272, pl. 59a; Kolonas - Moschos 2000; Moschos 2000; Kolonas 2001, 260; Giannopoulos 2008, 205-207, fig. 26.

The grave was discovered in 1994. Obviously it was placed intentionally under an early Mycenaean tumulus to give the impression of a grave hill. Besides the pair of greaves, the tomb also contained a Naue II sword, a spearhead with remnants of the wooden shaft, a dagger or knife, bronze bands forming parts of a 'tiara-like' headgear, and a bronze bowl.

Cat. nos. 203-204. Kouvarás, Aetolia-Acarnania, Greece - cist grave - two complete greaves. Measurements: length: 29.8cm - Museum of Agrinio, inv. no. 1553 - Pl. 40.203-204. References: Stavropoulou-Gatsi et al. 2012, 255, fig. 7.

The isolated, single cist grave was excavated in 2006. Some $150 \mathrm{~m}$ to the north, a sub-Mycenaean phase cemetery was discovered. The weapon finds from the cist grave comprised a pair of complete greaves, a Naue II sword of Type Allerona with gold wire decoration on the grip, a Mycenaean sword of Type F with ivory hilt plates, and a bimetallic knife with ivory hilt plate, a spearhead, and an arrow head. Only finds included a belly-handled amphora and krater, a golden kylix, and a bronze tripod cauldron.

Cat. nos. 205-206. Castellace, Com. Oppido Mamertina, Reggio Calabria, Italy - grave 2 from 1929 - fragments. Measurements: unknown - Museo Nazionale della Magna Grecia di

\footnotetext{
1122 Catling 1955, 21.
}

${ }^{1123}$ Catling 1955, 24. 
Reggio Calabria (Museo Oppido Mamertina), inv. no. unknown - Pl. 40.205-206. References: Costamagna - Visoná 1999; Pacciarelli 2001, 193, fig. 112.A1; Clausing 2002, 163, fig. 8.6.

Grave no. 2 contained, as well as the greave fragments, a spearhead of Type Pahzok, ${ }^{1124}$ which points to close contacts with the Balkans, such as the necropolis from Vajze e Patos in Albania.

\subsection{Greaves of Class I, Subclass C}

\subsubsection{Greaves of Type Grammichele}

Greaves of Type Grammichele have a separate, looped wire and wave-band decoration (cat. nos. 207-216). The greaves have double ribs parallel to the rim and several larger bosses surrounded by punched circles. The greaves are dated to the $11^{\text {th }}-9^{\text {th }}$ centuries BC. Greaves of Type Kallithea most likely influenced greaves of Type Grammichele, which imitated the waveshaped wire of the eastern Mediterranean greaves of Type Kallithea in their decoration. Today, we know of ten greaves of this type (Tab. 4.7).

\begin{tabular}{c|l|l|c|l}
\hline Cat. No. & $\begin{array}{l}\text { Find } \\
\text { Circumstances }\end{array}$ & Find Site & State & Condition \\
\hline $207-208$ & grave & Grammichele & IT & complete \\
\hline $209-210$ & grave & Pontecagnano & IT & complete \\
\hline 211 & grave & Torre Galli (grave 65) & IT & fragmented \\
\hline 212 & grave & Torre Galli (grave 206) & IT & fragments \\
\hline 213 & grave & Torre Galli (grave 86) & IT & fragmented \\
\hline 214 & grave & Torre Galli (grave 99) & IT & fragmented \\
\hline $215-216$ & grave & Torre Galli (grave 239) & IT & fragmented \\
\hline
\end{tabular}

Tab. 4.7 Greaves of Type Grammichele.

\subsubsection{Decoration}

The greaves from Grammichele (cat. nos. 207-208) are the only Bronze Age examples with a complete horizontal base, whereas in the case of the fragments from Winklsaß a possible flat, lower end is not completely certain. The decoration consists of centrally arranged, vertical parallel ribs, and to the left and right of them three large bosses surrounded by narrow, punched circles. The circles are connected with each other and the rib (which is parallel to the edge) by a wave-shaped, punched pair of lines. The decoration of the greave from Pontecagnano consists of central, vertical parallel ribs, and to the left and right of them are three large bosses surrounded by narrow punched circles. The circles are connected to each other and the rib, which is parallel to the edge, by a wave-shaped pair of punched lines. The decoration of the greave from Torre Galli, grave 99 (cat. no. 214), is slightly different to that on the greaves from Grammichele and Pontecagnano, as it has no vertical decoration and wave-like, double lines of pellet decoration are visible. In comparison, the almost complete greaves from Torre Galli, graves 65 and 86 (cat. nos. 211 and 213), resemble closely the greaves from Pontecagnano (wave-shaped, punched pair of lines, central vertical ribs, ribs parallel to the edge, large central bosses). The greaves from grave 239 at Torre Galli (cat. nos. 215-216) do not survive and nor do any drawings. The greave from Torre Galli, grave 206 (cat. no. 212), is too badly preserved to say much about its decoration apart from that is resembles the ones from Pontecagnano. The combination of large bosses connected to each other by wave-shaped lines on the greaves with looped wire

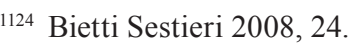


and wave-band decoration could be interpreted as a further abstraction of the Vogelsonnenbarke motif or, more likely, as an abstraction of the wave-shaped wire found on the older greaves of Type Kallithea.

\subsubsection{Distribution and Deposition}

Greaves of Type Grammichele are only known from Italy and have been found from Pontecagnano (Salerno) in the north to Grammichele (Catania, Sicily) in the south. Their rather small recovery area indicates local production. Morphologically, we see close connections to the earlier greaves of Type Kallithea with wave-shaped wire, which found its way to southern Italy as a decorative element during the increasing orientalisation of the western Mediterranean.

Greaves of Type Grammichele are generally found complete or almost complete as pairs in graves (Fig. 4.7). For the greaves from the cemetery of Torre Galli we cannot be sure in every case of they were deposited in each grave singularly or as pairs, since the recovered greaves are either heavily fragmented, and may represent the partial of one or more greaves, or because recovered fragments cannot be unequivocally identified as coming from a greave.

\subsubsection{Chronology}

The greaves of Type Grammichele are dated somewhat later than the greaves of Type Kallithea, to the $11^{\text {th }}-9^{\text {th }}$ centuries $\mathrm{BC} /$ beginning prima età del ferro. According to the alleged associated finds, such as the sword of Type Contigliano, the greaves from Grammichele can be dated to the $11^{\text {th }}$ century BC, and are therefore the oldest of this type. ${ }^{125}$ The greaves from Torre Galli have been dated to the $9^{\text {th }}$ century $\mathrm{BC}$, as have the greaves from Pontecagnano, ${ }^{1126}$ with the grave dated on the basis of its alleged association with a sword dating to the later part of the Early Iron Age, ${ }^{1127}$ while the necropolis itself dates to the $11^{\text {th }}-9^{\text {th }}$ centuries BC..$^{1128}$

Catalogue

Cat. nos. 207-208. Grammichele, Prov. Catania, Sicilia, Italy - Madonna del Piano, grave 26 - two complete greaves. Measurements: unknown - Museo Civico Archeologico Grammichele, inv. no. 70.630 - Pl. 41.207-208. References: Albanese Procelli 1994, 155, fig. 1; 167, pl. 1a-b; Clausing 2002, 166, fig. 8.7-8; Giumlia-Mair et al. 2010.

Grave no. 26 contained, as well as a pair of greaves, a sword of Type Contigliano.

Cat. nos. 209-210. Pontecagnano, Com. Pontecagnano Faiano, Prov. Salerno, Campania, Italy - grave 180 - two complete greaves. Measurements: unknown - Museo Archeologico Nazionale di Pontecagnano, inv. no. 13760 - Pl. 41.209-210. References: D’Agostino 1965, 671672, pl. 136a; Kilian 1974, 52, pl. 11.B4; Schauer 1982b, 146, fig. 18; D’Agostino - Gastaldi 1988, 132, figs. 1.4, 6, top left; 57.11-12; pl. 24.63; Clausing 2002, 166, fig. 8.9-10.

The grave has been dated on the basis of the associated sword, which has been identified as belonging to the later part of the Early Iron Age. ${ }^{1129}$ The necropolis itself, some $10 \mathrm{~km}$ south of Salerno, dates to the $9^{\text {th }}-11^{\text {th }}$ century BC. ${ }^{1130}$ The grave also contained a bronze scabbard, three fibulae, two pots, a razor, as well as the greave.

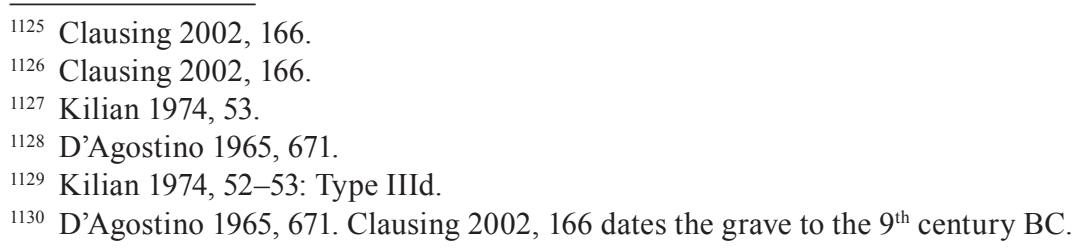


Cat. no. 211. Torre Galli, Com. Drapia, Prov. Cantanzaro, Calabria, Italy - grave 65 - one fragmented greave. Measurements: $23 \times 11 \mathrm{~cm}-$ Museo Nazionale Reggio Calabria, inv. no. unknown - Pl. 41.211. References: Orsi 1926, 52-53, fig. 34; Schauer 1982b, 141, fig. 4.2; Pacciarelli 1999, 159-160, pl. 56.8 .

Orsi mentions the presence of organic residues on the inside of the greave. ${ }^{1131}$ Alleged finds comprise three ceramic bowls, a sauroter (?), a ferrule, a short iron sword with bronze scabbard, and an iron knife or dagger. Schauer interpreted the greave as arm protection. ${ }^{1132}$

Cat. no. 212. Torre Galli, Com. Drapia, Prov. Cantanzaro, Calabria, Italy - grave 206 one fragmented greave. Measurements: $14 \times 6.5 \mathrm{~cm}-$ Museo Nazionale Reggio Calabria, inv. no. unknown - Pl. 41.212. References: Orsi 1926, 105-106; Pacciarelli 1999, 188, pl. 139.7.

The greave is completely fragmented, with only the wire and some fragments of the larger bosses surviving. Orsi also notes a $3 \mathrm{~mm}$, black organic layer above the greave. Alleged finds comprise an amphora, a further smaller amphora, ceramic bowls, a ferrule, a spearhead, an iron fibula, and a short iron sword with bronze scabbard.

Cat. no. 213. Torre Galli, Com. Drapia, Prov. Cantanzaro, Calabria, Italy - grave 86 - one fragmented greave. Measurements: $27 \times 13.5 \mathrm{~cm}-$ Museo Nazionale Reggio Calabria, inv. no. unknown - Pl. 41.213. References: Orsi 1926, 59-61, figs. 43-44; Schauer 1982b, 141, fig. 4.3; Pacciarelli 1999, 163-164, pl. 66.7.

The greave was found positioned on the lower right leg, and in the drawing of the whole tomb by Orsi it is depicted complete. Alleged finds comprise two amphorae, two ceramic bowls, a spearhead, a ferrule, a fibula, an amber bead, and an iron short sword with bronze scabbard. Schauer interpreted the greave as arm protection. ${ }^{1133}$

Cat. no. 214. Torre Galli, Com. Drapia, Prov. Cantanzaro, Calabria, Italy - grave 99 - one fragmented greave. Measurements: $29 \times 12.2 \mathrm{~cm}$ and $29 \times 7.6 \mathrm{~cm}-$ Museo di Vibo Valentia, inv. no. unknown - Pl. 41.214. References: Orsi 1926, 67-69, fig. 51; Schauer 1982b, 119, 141, fig. 4.1; Pacciarelli 1999, 166, pl. 72.A7; Clausing 2002, 166, fig. 8.11.

Alleged finds comprise a fibula, a ferrule, a spearhead and a short iron sword.

Cat. nos. 215-216. Torre Galli, Com. Drapia, Prov. Cantanzaro, Calabria, Italy - grave 239 - two greaves, fragmented. Measurements: c. $26 \times 14 \mathrm{~cm}-$ today lost. References: Orsi 1926, 114-115; Schauer 1982b, 141, note 153; Pacciarelli 1999, 195, 384, pl. 158.B; Clausing 2002, 166.

Only the wire around which the sheet metal was bent, as well as few tiny fragments, survive from the second greave. The decoration cannot be reconstructed. A bowl, an iron and a bronze spearhead and ferrule, as well as an iron sword with bronze scabbard, were also found in the grave. The greaves are now lost and no depictions survive.

\subsection{Greaves of Class I, Subclass D}

\subsubsection{Greaves of Type Ilijak}

Greaves of Type Ilijak were previously classified as greaves with riveted on loops. ${ }^{1134}$ They have on each side three small, riveted-on loops made of bronze sheet used to attach small rings which serve to attach the greave onto the leg of the wearer. So far, ten greaves of Type Ilijak are known from four find spots (Tab. 4.8). They form a geographically and chronologically consist-

\footnotetext{
1131 'Tracce in una sottile massa fibrosa nera': Orsi 1926, 52-53.

1132 Schauer 1982b, 141, fig. 4.2.

1133 Schauer 1982b, 141, fig. 4.3.

${ }^{1134}$ After Clausing 2002, 168-169: 'Beinschienen mit angenieten Ösen'.
} 
ent group, ranging across southern Bosnia-Herzegovina to Northern Albania, whilst a related fragment is known from Olympia.

\begin{tabular}{c|l|l|c|l}
\hline Cat. No. & $\begin{array}{l}\text { Find } \\
\text { Circumstances }\end{array}$ & Find Site & State & Condition \\
\hline 217 & unknown & Dobraç & AL & complete \\
\hline $218-219$ & single find / grave & Dabrica & BA & complete \\
\hline $220-221$ & grave & Ilijak (hill 2, grave 1) & BA & complete \\
\hline $222-223$ & grave & Ilijak (hill 3, grave 9) & BA & complete \\
\hline $224-225$ & grave & Ilijak (hill 13) & BA & complete \\
\hline 226 & votive deposit & Olympia & GR & fragment \\
\hline
\end{tabular}

Tab. 4.8 Greaves of Type Ilijak.

\subsubsection{Decoration}

Greaves of Type Ilijak are, apart from those from Dobraç and Dabrica (cat. nos. 217 and 218219), decorated with geometric Leistenbuckel motifs and Ringbuckel. ${ }^{1135}$ The greaves from Dobraç and Dabrica are decorated with pellets and bosses only, including imitation Ringbuckel by means of pellet decoration. Some of the decorative elements on these greaves resemble not only the pair of greaves from Ilijak, hill 3, grave 9 (cat. nos. 220-221) but also one of the greaves Type Grammichele, suggesting that they might derive from Southern Italy. ${ }^{1136}$ This connection is, however, somewhat tenuous given that the Italian greaves form a very uniform group with otherwise quite different decoration from that of the greaves from Dobraç and Dabrica.

As well as these possible western connections, northward connections are indicated by the greaves from Ilijak hill 13 (cat. nos. 222-223), which resemble, in their alignment of decorative elements, the greaves of Type Kuřim. An exceptional and somewhat unique example of recycling are the greaves from Ilijak (cat. nos. 220-221), where both greaves were made out of former belt plates, as it is indicated by similar such finds. ${ }^{1137}$

These greaves are both engraved and embossed, which enabled Benac and Čović to reconstruct the chronological order of the function of the bronze sheets. ${ }^{1138}$ According to the overlapping and different orientation of the decorative elements, the bronze sheets (then still functioning as belt plates) were engraved (with wheels, spirals, animals and circles), and then, once reshaped into greaves, further decoration in the form of embossed motifs were added, so as to resemble greaves of Type Ilijak. According to similar local finds of belt plates and their associated decorative motifs, ${ }^{1139}$ the greaves from hill 3 (and therefore likely the other greaves from Ilijak) were produced locally. This suggests that the related fragment of a greave of Type Ilijak from Olympia associated may have been imported, representing a 'foreign' votive deposit.

\subsubsection{Distribution and Deposition}

Greaves of Type Ilijak form a geographically and chronologically consistent group, ranging from southern Bosnia-Herzegovina to Northern Albania, with a related fragment occurring as a 'foreign' votive deposit at Olympia. Despite the latter, and possibly also the greave from Dobraç, whose find circumstances are unknown, all greaves of Type Ilijak have been found in pairs in graves. The greaves from Dabrica were found just $10 \mathrm{~cm}$ under a stone cist grave con-

\footnotetext{
${ }^{1135}$ Ringbuckel: decoration of bosses with rings around them.

1136 Benac - Čović 1957; Kasper 1972, 96.

1137 See Kilian 1973, 531, notes 16-17, fig. 5.

${ }_{1138}$ Benac - Čović 1957.

1139 Kilian 1973, 531.
} 
taining a skeleton which lacked any accompanying grave goods. No other indications of Late Bronze Age/Early Iron Age activity were noted. The greaves may have been placed in between the stones of the pre-existing older burial, and therefore need not necessarily be directly connected to it or even contemporary.

\subsubsection{Chronology}

Greaves of Type Ilijak are generally attributable to the $8^{\text {th }}-7^{\text {th }}$ century BC. Kilian noted that the fragment of greave of Type Ilijak found in Olympia must belong at least to the $8^{\text {th }}$ century $\mathrm{BC}$, since such votive donations are not known to be older than this. ${ }^{140}$ The associated finds from Ilijak also suggest a date in the $8^{\text {th }}$ century BC. The latter greaves were associated with Glasinac IV-B, representing the very end of the Hallstatt period, most likely during the middle of the $7^{\text {th }}$ century BC. ${ }^{141}$ The original belt plates used to produce the greaves from hill 3 are dated, on the basis of similar finds during Glasinac IV-A, and therefore their subsequent fashioning into greaves must be somewhat later.

No finds are known to have accompanied the greaves from Dobraç and Dabrica. Typologically speaking, these two greaves are certainly older than the greaves from Ilijak, since they demonstrate decorative elements of the late Urnfield culture, as does the greave from Ilijak hill 13, which is probably the oldest from the cemetery. Their typological relationship to the greaves of Type Grammichele suggests a likely date in the $10^{\text {th }}-9^{\text {th }}$ century BC.

\section{Catalogue}

Cat. no. 217. Dobraç, Shkodër, Albania - find circumstances unknown - complete. Measurements: $34 \times 18 \mathrm{~cm}-$ Muzeut Popullor, Shkodër, inv. no. unknown - Pl. 42.217. References: Kilian 1973, 528-529, fig. 1; Prendi 1975, 109-110; Schauer 1982b, 143-147, fig. 17; Clausing 2002, 168-169, fig. 10.1 .

The greave was bought by the museum in 1947 from a private collection.

Cat. nos. 218-219. Dabrica/Stolac, Općina Berkovići, Bosnia-Herzegovina - single find (?) - two complete greaves. Measurements: greave 1: $31.8 \times 21.2 \mathrm{~cm}$; greave 2: $32.1 \times 21.8 \mathrm{~cm}$ thickness both greaves: $0.7-0.8 \mathrm{~mm}-$ museum and inv. no. unknown - Pl. 42.218-219. References: Čović 1976, 21-22, figs. 2-3, 5, pl. 1a-b; Clausing 2002, 168-169, fig. 10.2.

In October 1969, two bronze greaves were found c. $10 \mathrm{~cm}$ under the soil. Further excavations the following year revealed a stone cist grave containing a skeleton, unaccompanied by any grave goods. There were no further indications of any Late Bronze Age/Early Iron Age activity. Most likely, the greaves are of a later date, and were deposited between the stones of the preexisting older burial.

Cat. nos. 220-221. Ilijak, Općina Pale, Bosnia-Herzegovina - hill 3, grave 9 - two complete greaves - c. $33.6 \times 22.7 \mathrm{~cm}-$ Zemalski Muzej Bosne i Hercegovine, Sarajevo, inv. no. unknown - Pl. 42.220-221. References: Fiala 1895, 11-12, figs. 23-24; Benac - Čović 1957, 69-70, pl. 16.2-3; Kilian 1973, 528-529, figs. 3-4, pl. 41.1-2; Schauer 1982b, 125, 143-147, fig. 9; Clausing 2002, 168-169, fig. 10.5-6.

As well as the greaves, the grave contained an iron sword with wooden scabbard, a further iron weapon (dagger or sword?), an iron socketed axe and an iron Ärmchenbeil, and jewellery in the form of two arm rings, a bronze tiara, and several ceramic sherds.

\footnotetext{
1140 Kilian 1973.

${ }^{1141}$ Benac - Čović 1957; Kilian 1973, 535.
} 
Cat. nos. 222-223. Ilijak, Općina Pale, Bosnia-Herzegovina - hill 13 - two complete greaves - c. $34.4 \times 19 \mathrm{~cm}-$ Zemalski Muzej Bosne i Hercegovine, Sarajevo, inv. no. unknown - Pl. 43.222. References: Fiala 1895, 15-16, figs. 39-40; Yalouris 1960, 50, fig. 1; 52, note 25; Schauer 1982b, 123-124, 143-147, fig. 10.1-2; Clausing 2002, 168-169, fig. 10.7.

As well as the greaves, the grave contained an iron sword, an iron spearhead, several fragments of further spearheads, jewellery and a bronze cup.

Cat. nos. 224-225. Ilijak, Općina Pale, Bosnia-Herzegovina - hill 2, grave 1 - two complete greaves - c. $32.8 \times 22.5 \mathrm{~cm}-$ Zemalski Muzej Bosne i Hercegovine, Sarajevo, inv. no. unknown - Pl. 43.224-225. References: Fiala 1895, 6-7, figs. 8-9; v. Merhart 1956/1957, 174, no. 6a-f; Benac - Čović 1957, 70, fig. 6, pl. 19.1-2; Yalouris 1960, 50, fig. 2; 52 note 25; Schauer 1982b, 128, 143-147, fig. 11; Clausing 2002, 168-169, fig. 10.3-4.

The greaves were positioned on the lower legs of the deceased. Further associated finds include an iron sword with bronze hilt, still sheathed in its wooden scabbard, around 50 'knobs' located on the breast of the buried person, a bronze cup, bronze dishes (Perlrandbecken, a bronze cup with iron handles, an omphalos-cup), two massive bronze rings, a wheel-pendant and a grindstone.

Cat. no. 226. Olympia, Elis, Greece - votive deposit - fragment. Measurements: c. $27.7 \times$ $13 \mathrm{~cm}$ - museum and inv. no. unknown - Pl. 43.226. References: Furtwängler 1890, 49, no. 329, pl. 20.329; Kasper 1972, 94-96, no. 213, pl. 36.2; Kilian 1973, 528-529, fig. 2; Krahe 1981, fig. 57, no. 14; Schauer 1982b, 127, 143, fig. 10.3; Kunze 1991, 3, note 8; Clausing 2002, 168-169, fig. 10.8 .

\subsection{Greaves of Class II}

Bronze Age greaves with perforations along the rim are neither a morphologically or chronologically close group (Tab. 4.9). The two unique greaves from Dendra and Schäfstall, ${ }^{1142}$ as well as the associated greave from Winklsaß, are only placed within the same 'group' on the basis of their specific technological characterisation.

The greave from the associated deposit of Winklsaß, Germany, was discovered having been rolled up, prior to deposition, and when unrolled broke into four pieces. Each individual piece exhibits different details of the same overall decoration scheme, consisting of fine lines of dots. Holste, and a number of subsequent authors, have interpreted the fragments as belonging to one or more bronze vessels, whilst J. Hrala interpreted the fragments as parts of a belt. ${ }^{1143}$ Schauer suggested that the fragments were originally part of a greave, and Weiss noted that they fitted together. ${ }^{1144}$ Their interpretation as greaves has since been questioned by Clausing, as he considers the decoration to be completely different to that on other known greaves, especially as the bent rim with integral wire, as well as the holes for attaching the organic backing or loops, are all missing. ${ }^{1145}$

The greave from Winklsa $ß$ has been assigned to this group on the basis of its decorative similarities to the greave from Schäfstall, even though on the preserved fragments no perforation along the edge is visible as it is on the latter. We should also note that one of the greaves of Type Desmontà, the greave from Malpensa, has secondary perforations along the whole edge. The perforation might have been applied after four of the five loops on the left side had broken, requiring secondary modification so that it could still be attached to the leg. Nevertheless, this greave is linked with the greaves of Type Desmontà.

\footnotetext{
1142 Schauer 1982b, 133.

1143 Holste 1936, 2, 14; Hrala 1966, 11, note 20; Stein 1976, 174, note 134; Stein 1979, 168.

1144 Schauer 1982b, 123, 133, 153, figs. 7, 19; Weiss 1998, 535-554.

1145 Clausing 2002, 182.
} 
Only from the $6^{\text {th }}$ century $\mathrm{BC}$ onwards do greaves with perforation along the rim form a morphologically and chronologically consistent group, comprising finds from Aups, Roquefort, St. Julien, Mailhac, La Palma, Can Canyis/Banyeres, Solivella, Granja Soley, Entremont and Plerimond. ${ }^{1146}$

\begin{tabular}{c|l|l|c|l}
\hline Cat. No. & $\begin{array}{l}\text { Find } \\
\text { Circumstances }\end{array}$ & Find Site & State & Condition \\
\hline 227 & grave & Dendra & GR & fragmented \\
\hline 228 & single find / river & Schäfstall & DE & almost complete \\
\hline 229 & associated deposit & Winklsaß & DE & fragment \\
\hline
\end{tabular}

Tab. 4.9 Greaves of Class II.

\subsubsection{Decoration}

The greave from Dendra is the only Bronze Age greave without any decoration. The greave from Schäfstall has pellet decoration only, consisting of a double central line of pellets dividing the greave in two. Each half has in the upper and lower parts three bows inside each other, with each bow consisting of three lines of pellets. These bows all end at a double line of pellets running parallel to the rim of the greave. However, somewhat similar decoration to that on the greave from Schäfstall is also known on the greave from Cannes-Ècluse.

The greave from Winklsaß also has only pellet decoration. However, as only a few fragments of the greave exist, the decoration can be only partially reconstructed. Similar to the greave from Schäfstall, the greave from Winklsaß has a double line of pellets running parallel to the rib. On the top and bottom, as well on the central left and right, three bows, each with a line of pellets, were applied inside each other. In some respects, the decoration on the greave from Winklsaß, with its half-circles on both sides as well as on the top and bottom, is reminiscent of the structure of the geometric decoration on the greaves of Type Kurrim. Nevertheless, the central ' $\mathrm{X}$ ' is formed with four boat-shaped figures, made of two parallel lines of pellets, and does not have any equivalent.

\subsubsection{Distribution and Deposition}

Greaves with perforations along the rim are known from Dendra, Schäfstall and potentially Winklsa $\beta$ but there are no further morphological or chronological connection between them. Consequently, their distribution and the circumstances of their deposition differs widely. The Dendra greave was, as are all other eastern Mediterranean greaves, with the exception of the fragment from Olympia, deposited in a grave. The Schäfstall greave was instead recovered from a wet context, having been discovered in an old tributary of the Danube. The fragments of the greave from Winklsaß formed part of an associated deposit, which may also have included the remains of a cuirass.

\subsubsection{Chronology}

Greaves with perforation along the rim are not a chronological or geographical homogenous group, and are associated on the basis of technological criteria only. The Dendra grave dates to the first half of the $15^{\text {th }}$ century BC,,$^{1147}$ while the greave from Schäfstall, which may have been

${ }_{1146}$ Dehn 1980; Clausing 2002.

1147 Verdelis 1967, 7. 
from an associated deposit, is dated to Ha A1. ${ }^{1148}$ The date suggested by S. Wirth, ${ }^{1149}$ on the basis of a number of possible associations, is somewhat problematic, as the greave is a single find from a gravel pit in the area of an old tributary of the Danube, and cannot therefore be securely associated with the other bronzes from the same gravel pit. Schauer links the greave to the Aegean examples since it does not have a bent rim but rather perforations all along the edge. ${ }^{1150}$ Nevertheless, the similarities in decoration with that of the greaves from Cannes-Ècluse and Winklsaß cannot be ignored. The associated deposit from Winklsaß is dated to Ha A1. ${ }^{1151}$

\section{Catalogue}

Cat. no. 227. Dendra, Argolis, Greece - chamber tomb 12 - one almost complete greave. Measurements: $32.5 \times 4-8 \mathrm{~cm}-$ Nafplion Archaeological Museum, inv. no. unknown $-\mathrm{Pl}$. 44.227. References: Verdelis 1967, 35-36, fig. 8, suppl. 19; Verdelis 1977, 45-46, fig. 13, pl. 22.1-3; Müller-Karpe 1980, 773, no. 108, pl. 242.8; Schauer 1982b, 121, fig. 6.1; Clausing 2002, 171, fig. 12a-c.

For find circumstances and context, see cat. no. 123. It is still not clear if there was one or two greaves in the grave, as there remain a considerable number of unassociated fragments which might potentially belong to a second greave. ${ }^{152}$ The greave from Dendra has few similarities with other greaves from Greece, which are elliptic, short and decorated, while the Dendra greave is long, thin and undecorated. All along the rim of the greave a row of perforations is visible, some of which still contain residues of fibre or twine, which may have served to attach an organic lining or, more likely, to attach the greave to an organic wrapping applied around the leg.

Cat. no. 228. Schäfstall, St. Donauwörth, Lkr. Donau-Ries, RB Schwaben, Bayern, Germany - single find, old Danube arm (gravel pit) - length: $27 \mathrm{~cm}$ - Archäologisches Museum Donauwörth, inv. no. unknown - Pl. 44.228. References: Dehn 1980, 29, fig. 8; Krahe 1981, 77, fig. 58; Schauer 1982b, 123, fig. 7.2; 133; Hansen 1994, 14, 18, figs. 3.7; 5.10; Jankovits 1997, 9; Weiss 1998, 540; Wirth 1999, 590, notes 76-77; Clausing 2002, 178-180, fig. 19.

The greave was found in a gravel pit in the area of an old tributary of the Danube, close to the estuary with the Lech and Wörnitz, which was used as a ford between north and south. From the same gravel pit several other Bronze Age objects were recovered, including axes, sickles, spearheads and swords.

Cat. no. 229. Winklsaß, Bavaria, Germany - associated deposit - fragments. Measurements: c. $26 \times 20 \mathrm{~cm}$; thickness: $1 \mathrm{~mm}$; weight: $80 \mathrm{~g}$ - Stadtmuseum Landshut, inv. no. A $447-\mathrm{Pl}$. 44.229. References: Holste 1936, 2, 14, pl. 2.31, 34-35; Müller-Karpe 1959, 156, 285, pls. 148 149; Torbrügge 1960, 56, 78, no. 164; v. Brunn 1968; Stein 1979, 112-116, 166-167, pl. 111.4-18; Schauer 1982b, 123, fig. 7.3; Hansen 1994, 14, 17, figs. 3.8; 5.9; Weiss 1998, 535-554, fig. 3; Clausing 2002, 182, fig. 23.

In the summer of 1911 woodworkers found more than 100 individual fragments of bronze in the forest around $1300 \mathrm{~m}$ north of Winklsa $\beta$, Bavaria. The associated deposit was buried at a depth of $30-40 \mathrm{~cm}$, and was covered by 35 casting cakes. As well as the greave, the associated deposit contained pins, necklaces, arm rings, foot rings, belt hooks, parts of fibulae, a piece of a sword blade, four fragments of spearhead, seven fragments of axe, one complete sickle and 36 sickle fragments, a razor, fragments of knives and daggers, one ingot, bronze sheet fragments and a possible fragment from a bronze cuirass. ${ }^{1153}$ One of the finders was certain that he had

\footnotetext{
${ }^{1148}$ Hansen 1994, 13-14.

1149 Wirth 1999, 590, notes 76-77, fig. 18 'probably older Urnfield period'; Wirth 2000, 88.

${ }_{1150}$ Schauer 1982b, 133.

1151 Weiss 1998.

1152 Verdelis 1967,35 , note 125 .

1153 See Chapter 3, p. 171.
} 
found pure gold, indicating the minimal patina on the bronzes. The associated deposit was sold to the Historischer Verein für Niederbayern, who sold it on to the museum in Landshut.

\subsection{Potential Greave Finds}

Numerous fragments of bronze sheet have, with varying degrees of certainty, been interpreted as the remains of greaves. All of these have been found within the distribution area of other known greaves.

The bronze sheet fragment from the associated deposit of Reventin-Vaugris, believed to be from a greave, is bent at the edge and decorated with three parallel punched lines. According to Clausing there is no basis for interpreting the fragment as part of a greave. ${ }^{1154}$

The Ha B1 associated deposit from Braud appears now to be lost ${ }^{1155}$ and therefore confirming certain morphological indicators for their being greaves, such as the presence of bent rims or from their cross section, is no longer possible.

According to Jankovits, the associated deposit of Pila del Brancon, Italy, also contained fragments of a greave and a helmet. ${ }^{1156}$ Since these do not resemble any known body armour, they more likely belong to belt plates or some other bronze sheet object. The associated deposit contained objects dated to between bronzo medio and bronzo finale, ${ }^{1157}$ and Jankovits suggests a date of Bz D-Ha A1. ${ }^{158}$

The associated deposit from Schönberg bei Niederwölz, Austria, contains a small bronze sheet fragment which might also belong to a greave. It is decorated with four circles inside each other. There is no indication of a wheel motif and the fragment is too small to allow for the reconstruction of any further decorative details.

The possible greave fragment from the Bz D-Ha Al associated deposit from Brandgraben/ Kainischtal, Austria, is decorated with three dotted lines parallel to one another, each bent once at a right angle. ${ }^{159}$ The sheet is bent around a small, twice folded, thin bronze sheet. The decoration does not resemble that on other known greaves. The thickness of the sheet and the straight edge point also suggest that it is from another type of bronze object.

Though they do not exhibit decoration similar to that known from other greaves, E. Borgna and E. Montagnari suggest that some of the bronze sheet fragments from Škocjan, Slovenia, are also from greaves, ${ }^{1160}$ though it is more likely that the sheets fragments are from helmets or decorated belts.

The bronze sheet fragment from the Bz D associated deposit from Čermožiše, Slovenia, ${ }^{1161}$ might indeed be from a greave on the basis of its decoration but the thickness of the sheet is somewhat greater than that normally found on greaves, and the decoration is not as delicate due to its thickness.

A fragment from the associated deposit of Slavonski Brod III might belong to a greave, though the lack of wire, around which the edge would have been bent, might suggest that it is from another object (Fig. 4.10). ${ }^{1162}$ The decoration consists of two dotted lines running parallel to the edge. Three further dotted lines are almost perpendicular to the edge, and below (or above?), four dotted lines form a semicircle. At the other end of the fragment, a larger boss is visible.

\footnotetext{
${ }_{1154}$ Clausing 2002, 183, note 126.

${ }_{1155}$ Clausing 2002, 180, fig. 20.

1156 Jankovits 1999/2000, 189, fig. 1.1, 4-5.

1157 Salzani 1998, 66-74.

1158 Jankovits 1999/2000, 189.

1159 Windholz-Konrad 2008, 48-57, 137, fig. 2.3.49

${ }^{1160}$ Borgna - Montagnari Kokelj1999, 137, fig. 2.4, 6.

1161 Smodič 1955, 92.

1162 Clausing 2002, 184; Clausing 2003, 130-131, fig. 40.126.
} 


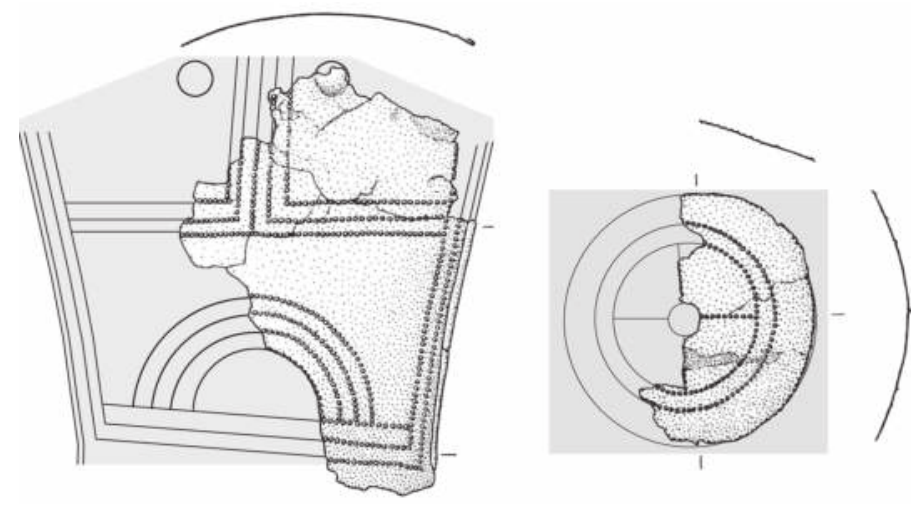

Fig. 4.10 Fragments of two potential further greaves from Slavonski Brod, Croatia, associated deposit III (after Clausing 2003, figs. 3.12; 40.126).

Paulík, in relation to the Čaka grave, mentions previously undiscussed bronze sheets with 'buttons' and suggests that these might be the remains of the fittings from leather greaves. The bronze fragments are without any chevrons or pointed ends. ${ }^{1163}$ However, the reconstruction of a greave from these fragments is not convincing since the shape is not at all ergonomic and bears no similarities to any other known greave. Since he also reconstructed a shield from further unspecified bronze sheet fragments, the inferred greave seems to be based mostly on the wish to reconstruct a warrior grave with a complete set of defensive armour. ${ }^{1164}$

Schauer notes further possible fragments of greaves from the associated deposit of Guşteriţa, Romania, on the basis that they exhibit embossed decoration. ${ }^{1165}$ However, it is more likely these fragments also belong to bronze bowls or vessels, as was recently discussed by $\mathrm{T}$. Soroçeanu. ${ }^{1166}$

Several fragments from the associated deposit of Uioara de Sus, Romania, might belong to greaves of Type Desmontà or greaves of Type Lengyeltóti. This concerns the fragments inv. nos. III-6025, III-5795, III-7448, and III-5997.1167

Also, further fragments of potential greaves are known from the associated deposit from Várvölgy-Nagy-Lázhegy, Hungary. However, the fragments are far too large and the pellet decoration too poorly applied when compared to other known greaves, including the complete example from the same find, for them to come from a further greave.

\subsection{Analyses and Construction}

In the following, the results obtained by metallographic and chemical characterisation (SEMEDXS; light optical microscope) ${ }^{1168}$ are described. Eight Bronze Age greaves from Austria, Bosnia-Herzegovina and Croatia were sampled for metallographic and chemical characterisation (Fig. 4.11). The compositional analyses were performed on cross sections of micro-fragments which were mechanically sampled from the greaves or from drilling samples, taken with a $1 \mathrm{~mm}$ drill. The eight greaves belong to three different types. The greaves from Enkomi, grave 15, unfortunately could not be studied, since they are already completely corroded (Fig. 4.9, bottom right). Three further Bronze Age greaves were already analysed non-invasively. ${ }^{1169}$ Generally, greaves were made out of one sheet of metal and one wire, around which the edge of the metal

\footnotetext{
1163 Paulík 1988, 24.

${ }_{1164}$ See also Hansen 1994, 13.

1165 Schauer 1982b, 151, note 202.

1166 Soroçeanu 2008, no. 33a: bowl of Type Satteldorf; no. 124: vessel of Type Kurd.

1167 See also Rusu 1990, pl. II.

1168 See Chapter 2.3.

1169 Mödlinger et al. 2014.
} 

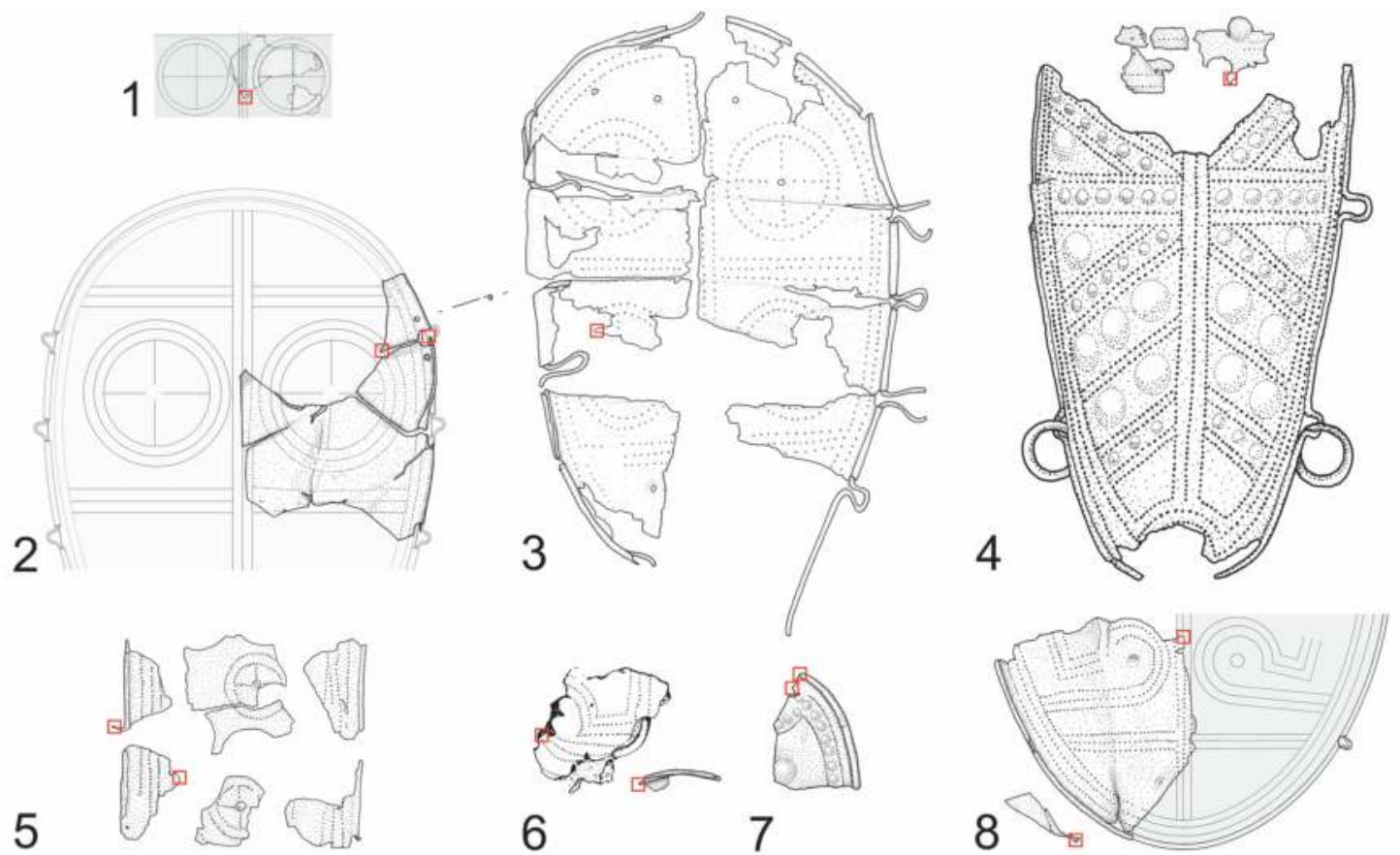

Fig. 4.11 The greaves analysed: 1. Boljanic; 2. Stetten/Teiritzberg; 3. Poljanci IV; 4. Kloštar Ivanić; 5. Veliko Nabrđe; 6. Brodski Varoš (after Clausing 2003, fig. 3.7); 7. Weissenstein; 8. Poljanci I. The sample area is marked.

sheet was bent, in order to strengthen the rim. Obviously, for those greaves of Subclasses B and C, additional wire was necessary. For greaves of Type Kuřim and Subclass D, rings were also needed, and according to the evidence for casting seams, these were cast in bi-valve moulds.

\subsubsection{Alloys Characterisation}

Descriptions in the Iliad concerning the manufacture of greaves (e.g. Iliad 18.613) refers to greaves made of tin, resulted in much controversial discussion concerning the alloy composition of the Greek greaves, most without analytical basis. ${ }^{1170}$ Until now, only a few greaves were analysed, including the greaves from Grammichele (cat. nos. 207-208) and those from Kallithea and Kouvarás (cat. nos. 199-200 and 203-204). ${ }^{1171}$ The greaves from Grammichele were made of tin-bronze with $10 \% \mathrm{Sn}$ and $1 \mathrm{wt} . \% \mathrm{~Pb},{ }^{1172}$ the greaves from Kouvarás with 14 wt.\% Sn and the Kallithea greaves with $11.5 \mathrm{wt} . \% \mathrm{Sn}$ and over $1.8 \mathrm{wt} . \% \mathrm{~Pb}{ }^{1173}$ The eleven greaves discussed in the following belong to the three main central European types. On six greaves, the wire, which surrounds and reinforces the metal sheet, was analysed as well. The results of compositional analyses of the greaves are outlined in Tab. 4.10. The greaves are, apart from some of the wires, all made of tin-bronze, with the concentration of tin ranging from 7-12 wt.\%. These compositions are consistent with the amount of tin found in wrought bronzes used during the European Bronze Age.

Tin is the only alloying element, with further elements such as $\mathrm{Pb}, \mathrm{As}, \mathrm{Ag}, \mathrm{Ni}, \mathrm{S}$ and $\mathrm{Co}$, appearing only as minor elements and can partly be classified as trace elements (as were often $\mathrm{Sb}, \mathrm{Fe}, \mathrm{Zn}$ and $\mathrm{Mn}$ ). Generally, there was an increase in the usage of $\mathrm{Pb}$ from $\mathrm{Ha} \mathrm{B} 1$ onwards. However, on the three greaves from this period (greaves from Várvölgy, Kloštar Ivanić and Weissenstein) this is not noted, and might be connected with the thickness of the greaves, which

\footnotetext{
1170 As summarised by Hansen 1994, 17.

1171 Stavropoulou-Gatsi et al. 2012, 259, 261.

1172 Giumlia-Mair et al. 1980.

${ }^{1173}$ Stavropoulou-Gatsi et al. 2012, 261; further details were not mentioned.
} 
is below $0.5 \mathrm{~mm}$. Adding $\mathrm{Pb}$ would not have eased the manufacture of a bronze sheet of such a narrow width. Nevertheless, the greaves from Brodski Varoš and Boljanic show slightly higher amounts of $\mathrm{Pb}$ with $0.5-0.6$ wt.\%. The two greaves of Type Desmontà have, at 7-10 wt.\% Sn, lower amounts of Sn than the other greaves, which have a range between 10-12 wt.\%, and only the wire from the greave from Weissenstein having 9 wt.\% Sn. An amount of Sn around 10 wt.\% makes perfect sense, since the fluidity of a 10\% tin-bronze is even higher than that of pure copper, an important aspect since the flatter and thinner the as-cast plate can be, the less deformation work has to be undertaken in order to achieve the final preferred thickness.

As a consequence of the small number of greaves preserved and analysed overall, any discussion of the results of these analyses for sheet and wire are unlikely to be representative of any whole individual greave type. In the case of the greave from Veliko Nabrđe, and maybe also that from Brodski Varoš, we might rightly assume that the same alloy was used for the production of wire and metal sheet. However, different alloys appear to have been used for the wire and metal sheet in all other greaves where both sheet and wire were analysed.

\begin{tabular}{|c|c|c|c|c|c|c|c|c|c|c|c|c|c|c|c|}
\hline Cat. No. & Find Spot & Type & Sample & $\mathbf{C u}$ & Sn & $\mathbf{P b}$ & $\mathbf{S b}$ & As & $\mathbf{S}$ & $\mathbf{F e}$ & $\mathrm{Zn}$ & $\mathbf{N i}$ & Ag & Co & Au \\
\hline \multirow{2}{*}{153} & \multirow{2}{*}{ Brodski Varoš } & \multirow{2}{*}{ Desmontà } & sheet & 91.1 & 7.4 & 0.5 & 0.2 & 0.2 & 0.3 & tr. & & 0.3 & 0.2 & & \\
\hline & & & wire & 91.8 & 6.9 & 0.2 & & 0.3 & 0.2 & 0.1 & & 0.5 & & 0.1 & \\
\hline 163 & Poljanci I & Desmontà & sheet $1-2$ & 88.8 & 9.7 & 0.2 & 0.2 & 0.4 & 0.3 & 0.1 & & 0.3 & 0.2 & & \\
\hline 168 & Rinyaszentkirály & Lengyeltóti & sheet & 90-92 & $7-9$ & $0.3-0.5$ & & & & & & & & & \\
\hline \multirow[t]{2}{*}{173} & \multirow[t]{2}{*}{ Lengyeltóti } & \multirow[t]{2}{*}{ Lengyeltóti } & sheet & 89-91 & $\begin{array}{c}6-14 \\
(9) \\
\end{array}$ & & & & & & & & & & \\
\hline & & & wire & 99 & $0.6-1$ & $0.3-0.5$ & & & & & & & & & \\
\hline \multirow{2}{*}{174} & \multirow{2}{*}{ Stetten } & \multirow{2}{*}{ Lengyeltóti } & sheet & 87.3 & 11.3 & 0.2 & 0.3 & 0.4 ( & 0.5 & tr. & tr. & 0.3 & 0.2 & tr. & \\
\hline & & & wire & 88.3 & 9.9 & 0.2 & & 0.4 ( & 0.8 & 0.2 & & 0.2 & tr. & tr. & \\
\hline 175 & Poljanci IV & Lengyeltóti & sheet & 89.2 & 9.8 & 0.2 & & & 0.1 & 0.1 & & tr. & 0.6 & & \\
\hline \multirow{2}{*}{177} & \multirow{2}{*}{ Veliko Nabrđe } & \multirow{2}{*}{ Lengyeltóti } & sheet & 87.1 & 11.7 & 0.2 & & 0.3 & 0.3 & 0.2 & & tr. & 0.1 & 0.2 & 0.1 \\
\hline & & & wire & 87.0 & 11.6 & 0.1 & & 0.3( & 0.4 & 0.1 & & 0.2 & & 0.2 & 0.2 \\
\hline 179 & Boljanic & Lengyeltóti & sheet & 88.5 & 10.1 & 0.6 & tr. & 0.3 ( & 0.2 & 0.1 & & 0.2 & 0.2 & tr. & 0.2 \\
\hline \multirow{2}{*}{188} & \multirow{2}{*}{ Weissenstein } & \multirow{2}{*}{ Kuřim } & sheet & 87.5 & 11.1 & 0.2 & 0.3 & 0.2 & 0.4 & 0.2 & & tr. & tr. & tr. & \\
\hline & & & wire & 89.8 & 8.9 & 0.2 & & 0.1 & 0.6 & 0.3 & & 0.0 & 0.2 & & \\
\hline \multirow{2}{*}{189} & \multirow{2}{*}{ Várvölgy } & \multirow{2}{*}{ Kuřim } & sheet & 89 & 10-11 & & & & & & & & & & \\
\hline & & & wire & 99-100 & $0-1$ & tr. & & & & & & & & & \\
\hline 191-192 & Kloštar Ivanić & Kuřim & sheet & 87.1 & 11.9 & 0.2 & 0.2 & 0.2 & 0.2 & tr. & & 0.1 & 0.1 & 0.1 & 0.2 \\
\hline
\end{tabular}

Tab. 4.10 Average composition of the SEM-EDXS analyses on the samples from the greaves in wt.\%. The greaves cat. nos. 168, 173 and 189 were analysed non-invasively (Mödlinger et al. 2014) with PGAA, PIXE and ToF-ND. These results show a wide range due to the low sensibility of the PGAA for $\mathrm{Pb}$, and analyses on the corroded surface via PIXE. The focus on the analyses was on the detection of alloying elements as $\mathrm{Sn}$ and $\mathrm{Pb}$. Results clearly deriving from analyses on severely corroded areas were excluded.

As visible in Tab. 4.10, we can make also the following points:

1. The amount of tin (7-12 wt.\%) is consistent with bronzes suitable for mechanical deformation and typical for the period of production in the European Bronze Age

2. Sulphur and iron are present as $\mathrm{Cu}_{2-\mathrm{x}} \mathrm{Fe}_{\mathrm{x}} \mathrm{S}$-inclusions (see below), and visible in the micrographs, though their quantities remain maximal at the level of trace elements

3. Lead is present in every greave, ranging from $0.1-0.6 \mathrm{wt} . \%$

4. The measured minor and trace elements as $\mathrm{Pb}, \mathrm{As}, \mathrm{Sb}, \mathrm{Fe}, \mathrm{Ni}, \mathrm{Co}, \mathrm{Ag}$ and $\mathrm{Zn}$ are remnants of the copper ore and are usually enriched in inclusions and grain boundaries 


\subsubsection{Manufacturing Process - Microstructural Observations}

Due to the generally high level of corrosion, etching was not necessary in every case, especially since the intergranular corrosion surrounds and follows the structures of recrystallised grains with slipping bands and mechanical twins which cross over each other (Fig. 4.12, centre and bottom left; Fig. 4.13, centre). Further corrosion features noted were pitting corrosion and further peculiar features such as 'tentacle' corrosion recently discussed ${ }^{1174}$ (Fig. 4.12, bottom right). The cross-sections of the greave fragments are characterised by an almost homogenous metallic
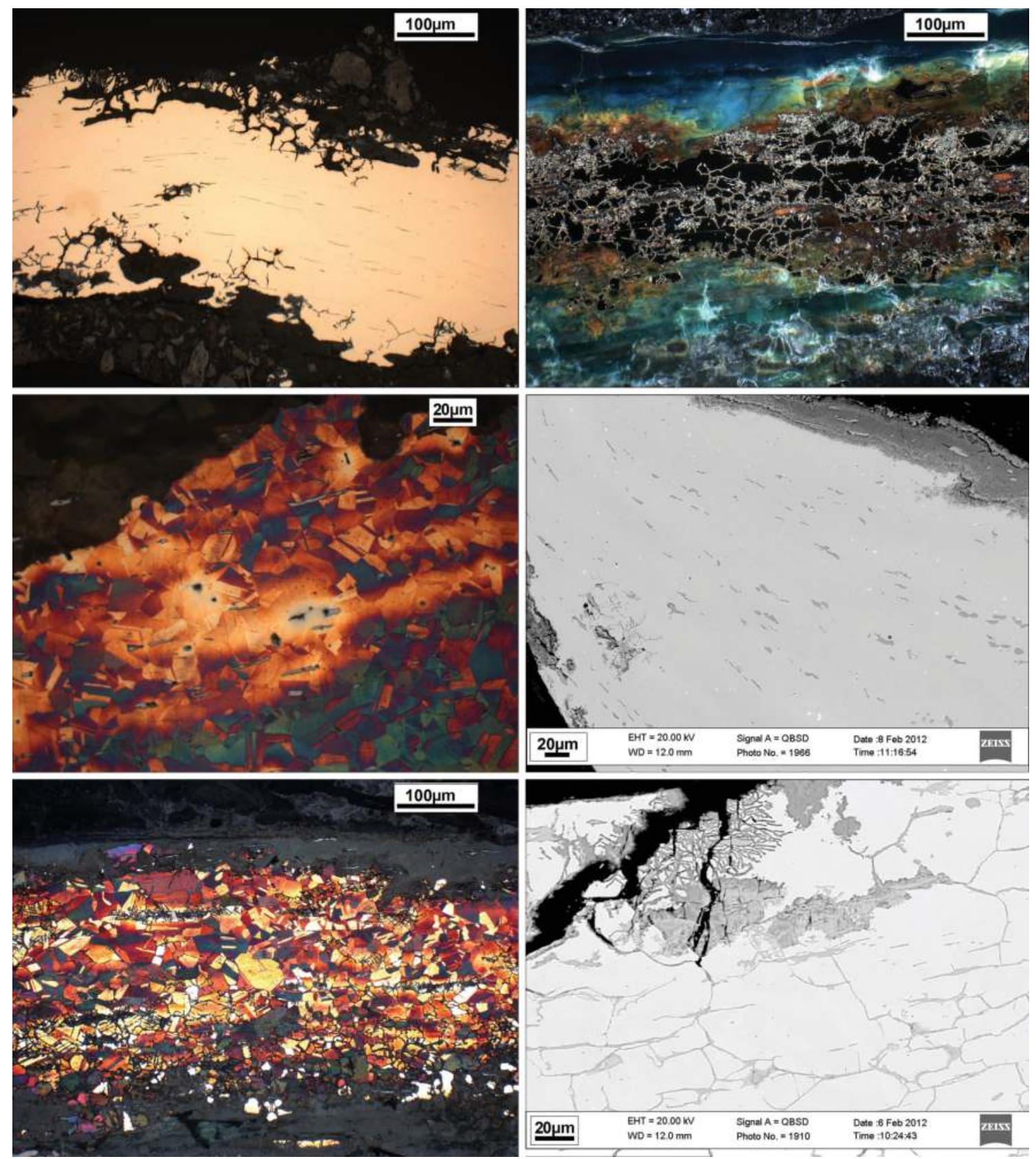

Fig. 4.12 Microstructural features of European Bronze Age greaves. Above, left: Poljanci IV, sheet, unetched. Above, right: Poljanci IV, sheet, unetched in polarized light. Centre, left: Brodski Varoš, sheet, etched with Klemm I. Centre, right: Weissenstein, sheet, unetched; SEM-image. Below, left: Poljanci IV, sheet, etched with Klemm I. Below, right: Veliko Nabrđe, sheet, unetched; SEM-image.

1174 Piccardo et al. 2013 

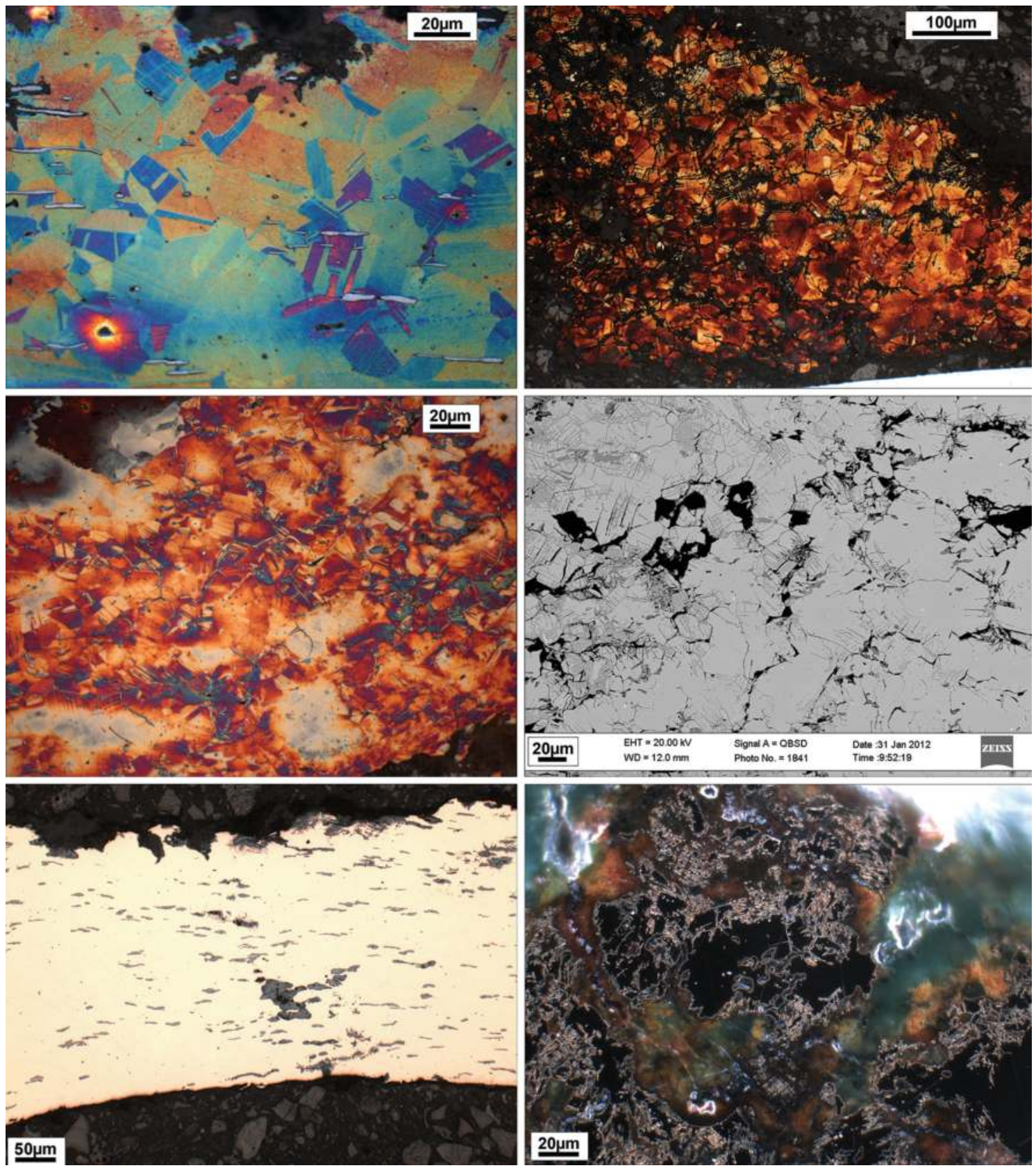

Fig. 4.13 Microstructural features of European Bronze Age greaves. Above, left: Poljanci I, sheet, etched with Klemm I. Above, right: Kloštar Ivanić, sheet, etched with FeCl3. Centre, left: Poljanci I, wire, etched with Klemm I. Centre, right: Kloštar Ivanić, sheet, unetched; SEM-image. Below, left: Stetten/Teiritzberg, sheet, unetched. Below, right: Stetten/Teiritzberg, wire, unetched in polarized light.

microstructure, with recrystallisation annealing indicated by polygonal grains with thermal twins, followed by light cold mechanical deformation testified by mechanical twins (Figures 4.12-4.13). The annealing temperature applied was below the solidus curve of the alpha-phase in the $\mathrm{Cu}-\mathrm{Sn}$ equilibrium diagram, but high enough to homogenise the solid solution. However, this effect could not be obtained during one heat treatment only, and was the result of a number of alternating annealing/cold deformation sessions. The grain size of $10-50 \mathrm{~mm}$ and the homogeneity of the solid solution suggest an annealing temperature between $550-630^{\circ} \mathrm{C}$. Within this temperature range, the solubility of tin achieves its maximum with $15.8 \mathrm{wt} . \%$ in copper. Therefore, due to the higher kinetics of diffusion, the recrystallisation process, that usually has its 
onset temperature between $300-400^{\circ} \mathrm{C}$, is fast. ${ }^{1175}$ After the short and rapid recrystallisation, the bronze sheets were most likely water quenched. Due to the last annealing and cold deformation processes, water quenching did not leave traces as $\beta$-phase. We might nevertheless consider it as part of the manufacturing process, as this prevents the growth of brittle phases such as $\delta$-phase (which was not observed on any sample) at the grain boundaries, thus facilitating the working process.

As a final step, the bronze sheet was slightly cold deformed and not further annealed. This hardening work provides additional strength to the metal sheet so that it does not bend easily during use. However, we have to consider the possibility that the cold deformation noted might also be due to the final application of the decoration, so the actual last step of thermo-mechanical treatment might have been a final annealing, which is supported by the generally low deformation of the crystals. A final annealing would also have eased the application of this decoration and the bending of the rim of the bronze sheet around the wire. The wires used were either of round or square cross-section of c. $2 \mathrm{~mm}$ diameter and were produced by hammering. Drawing dies are as yet unknown in prehistory.

The total amount of biaxial deformation, as well as the minimum initial thickness of the ascast bronze sheet from which the greave was made, can be calculated by the deformation grade concerning the shape factor (SF) of the $\mathrm{Cu}_{2-\mathrm{x}} \mathrm{Fe}_{\mathrm{x}} \mathrm{S}$-inclusions, which are embedded in the metallic matrix. ${ }^{1176}$ Tab. 4.11 reports the hardness, the average total deformation applied, and the estimation of the minimum thickness of the as-cast bronze sheet, for the production of greaves.

\begin{tabular}{c|l|c|c|c|c}
\hline Cat. No. & Find Site & $\begin{array}{c}\text { Thickness } \\
\text { metal }(\mathbf{m m})\end{array}$ & $\begin{array}{c}\text { Def. } \\
\mathbf{( \% )}\end{array}$ & $\begin{array}{c}\text { Min. Thickness D } \\
\text { as cast }(\mathbf{m m})\end{array}$ & $\begin{array}{c}\text { Vickers- } \\
\text { Hardness }(\mathbf{H V})\end{array}$ \\
\hline 153 & Brodski Varoš & 0.4 & 83.2 & 2.4 & $130-140 ; 240$ \\
\hline 163 & Poljanci I & 0.36 & 87.5 & 3.1 & $130-170 ; 210-220$ \\
\hline 174 & Stetten & 0.4 & 85.6 & 2.9 & 120 \\
\hline 175 & Poljanci IV & 0.4 & 88.4 & 3.9 & $100-120$ \\
\hline 177 & Veliko Nabrđe & 0.4 & 86.0 & 3.0 & 120 \\
\hline 178 & Boljanić & 0.21 & 87.1 & 1.8 & $190-205$ \\
\hline 188 & Weissenstein & 0.32 & 79.3 & 1.7 & $205-215 ; 150($ wire) \\
\hline $191-192$ & Kloštar Ivanic & 0.5 & 72.8 & 2.0 & $180-200$ \\
\hline
\end{tabular}

Tab. 4.11 Hardness, average total deformation applied (bi-axial) and estimation of minimum thickness of the ascast bronze sheet for the production of greaves.

According to Tab. 4.11, all greaves show a slightly different intensity of deformation (ranging between $70-90 \%$ of thickness reduction and 100-240 HV). The wire of the greave from Brodski Varoš, with $240 \mathrm{HV}$, indicates the highest amount of deformation applied during the last step of work. Of the two fragments sampled from the greave from Poljanci I, one was taken close to where the decoration was applied, and the other further away from it.

The final thickness of the metal sheet, as measured on the basis of cross sections, corresponds to c. $0.4 \mathrm{~mm}$. The percentage of deformation allows for the conclusion that the original cast was already a minimum of $3 \mathrm{~mm}$ as a result of high quality casting. The calculated minimum thickness of the as-cast bronze sheet is, of course, an approximation only, and smoothing, polishing and other finishing of the surface, which would reduce the thickness of the metal sheet, cannot be taken into account. The calculated thickness must be regarded as the minimum original thickness of the as-cast bronze. This would have depended on several factors, such as shape, material and temperature of the mould material, the temperature and speed of casting, as well as the composition of the alloy. So far, no moulds for bronze sheet production have been knowingly recovered. Obviously, casting techniques which left no traces in the archaeological

\footnotetext{
1175 Ammannati et al. 2006.

1176 Mödlinger - Piccardo 2013.
} 
record include sand casting or lost wax technique. Since lost wax casting was one of the most frequently used casting techniques, it might be reasonable to assume that bronze sheets were cast in baked clay moulds using the lost wax technique. Whilst clay moulds or refractory evidence for weapons or tools are reasonably easy to identify amongst ceramic assemblages, it is not hard to imagine the more morphologically ambiguous refractory evidence for armour being overlooked or misidentified. This, as well as the much easier sand casting, would explain the lack of casting moulds made from other materials, such as stone.

\subsubsection{Manufacturing Process - Macroscopic Observations}

Once the desired shape and thickness were achieved, all traces of hammering, flattening and thinning the metal sheet were eliminated with a planishing hammer and a Treibfaust. The surface of the bronze sheet was smoothed and polished, so no traces of hammering or anvil marks were visible. The last polishing was always carried out vertically, never horizontally (Figures 4.14, left; 4.15, right). Polishing traces are still visible on several greaves. After polishing, once
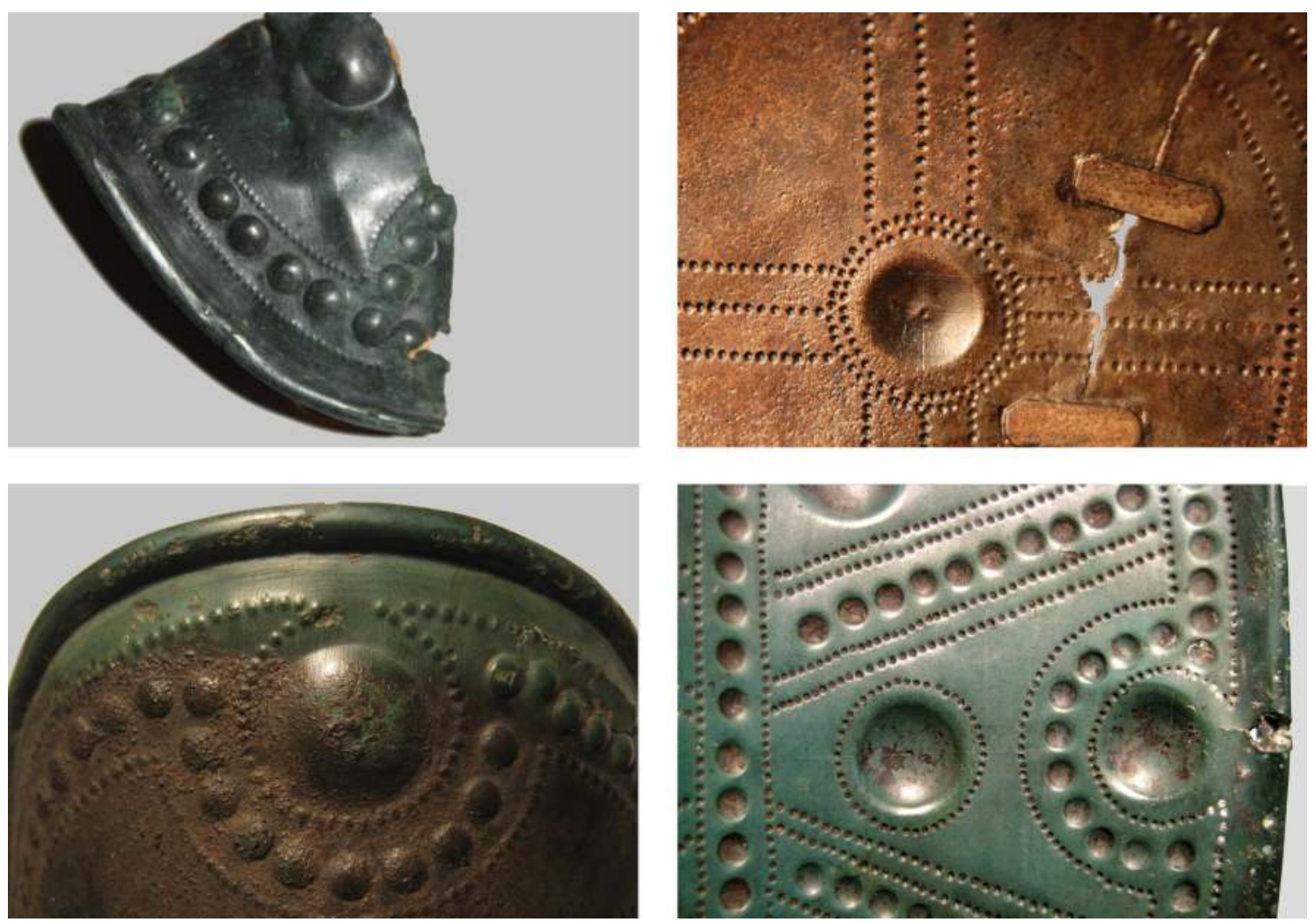

Fig. 4.14 Common manufacturing traces on greaves. Polishing traces from top to bottom are visible on the outside of the greaves (upper left: Weissenstein; lower left: Kuřim). Scribed lines were used to place the plastic decoration in line (upper right: Rinyaszentkirály; lower right: Kuřim).

the bronze sheet was approximately $0.2-0.4 \mathrm{~mm}$ thin, the edges were cut out or chiselled off in order to achieve the oval form of the final greave. A bronze wire with a round or rectangular cross section of approx. $2 \mathrm{~mm}$ diameter was then placed inside the outwards bent rim of the greave in order to strengthen the metal sheet. On greaves of Type Desmontà, Type Lengyeltóti and Type Kuřim, the bronze sheet was only partially bent around the wire, so that the wire could be used to form the side loops on the outside of the greave which were used to attach it securely to the lower leg of the wearer, most likely by means of an organic strip. Greaves of Subclasses B and C exhibit, in addition to the wire which was completely encompassed by the 

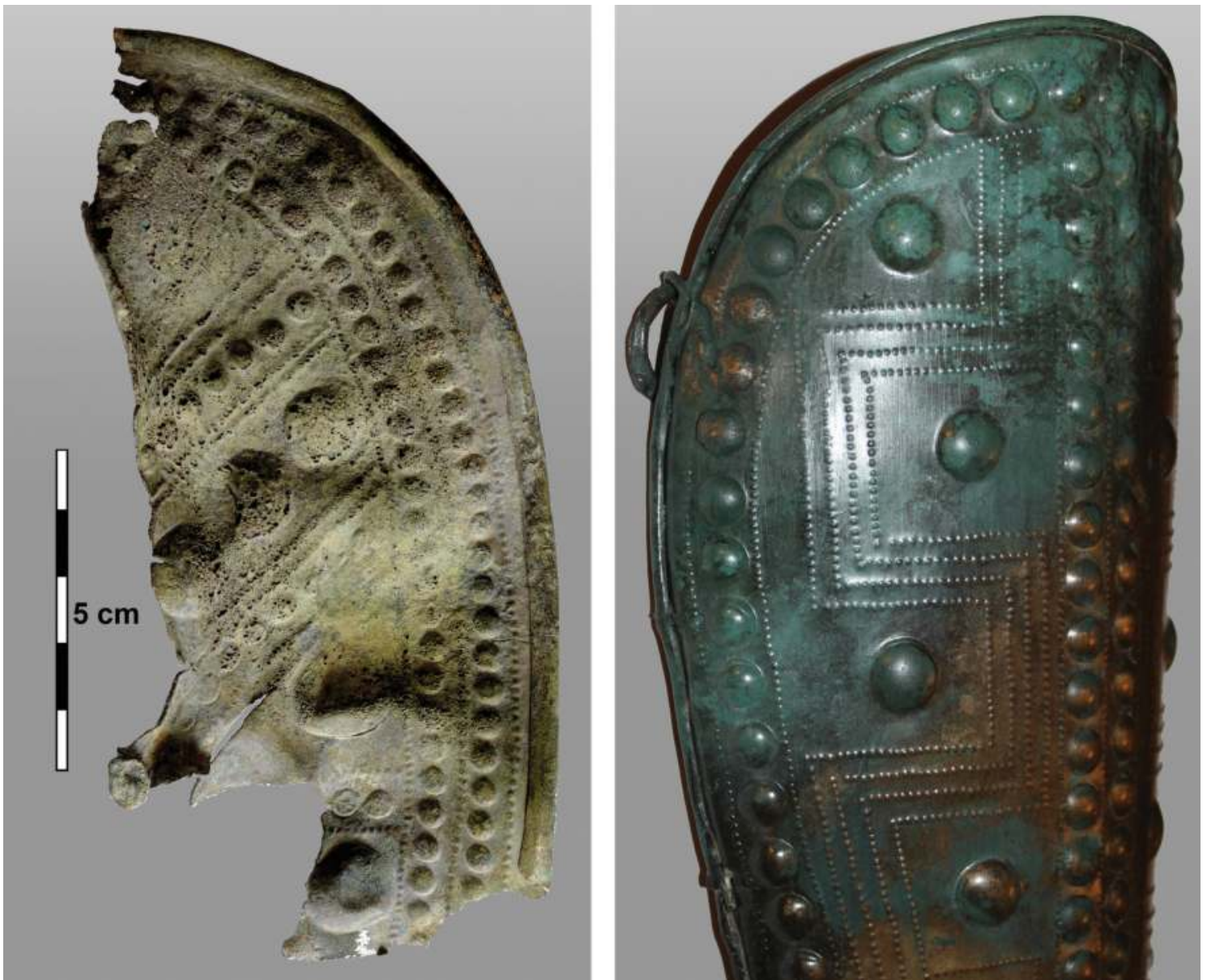

Fig. 4.15 Detail of the greaves from Bouclans (left; (C) Musée des Beaux-Arts et d'Archéologie de Besançon) and Várvölgy (right). Note the vertical polishing traces and the sharp edges on the applied bosses, sometimes also showing a first de-central try to emboss the boss on the greave from Várvölgy.

rim of the metal sheet, several pairs of holes positioned close to the edge for securing the separate wire loops.

Once the metal sheet was strengthened by bending the edges around the wire, the decoration could then be applied. This decoration did not serve just aesthetical requirements but also served to enhance the stiffness of the greave. In order to place the plastic decoration in line, inscribed lines were applied on the inside of the greaves. These were used as a sketch to guide the application of the final punched decoration (Fig. 4.14, right). The greaves of Subclass A are an exception in that all decoration was applied with round punches. The application of several round punches is seen on the greave from Rinyaszentkirály, Hungary, where a second punch was used for the reproduction of the tip of the peak, the eye and the parson's nose of the water bird (Fig. 4.16, left), whilst up to three different sized punches were used in the decoration of greaves of Type Kuřim (Fig. 4.15). The only greave with chevrons, which were applied with a chisel or punch, is the example from Portes-Kephalovryso.

\subsection{Use}

The round to oval shaped greaves measure approximately $25 \times 20 \mathrm{~cm}$, and were attached to the lower legs of the warrior by means of strips of leather or other organic material. These strips were fixed to the greave using separately attached wire loops or rings, or using by the outwardbent loops formed by the internal wire around which the edge of the metal sheet of the greave had been bent (Figures 4.4, 4.14-16). The greaves were never worn directly against the skin, 
and instead an organic backing was positioned beneath the metal greave and fixed separately, or the strips used to fix the greave onto the leg or the greaves themselves were directly sewed onto the lining (Dendra, Schäfstall, potentially the greave from Winklsaß and, after the loops had broken, also the greave from Malpensa, where later perforations had been added all along the edge).

Interestingly, the warriors from Torre Galli appear to have been buried with just one greave (the only exception perhaps being grave 239). These greaves were found positioned always on the right lower leg. To what extent this can be connected to a specific burial tradition, or an aspect of religious or cultural ideology, or simply an indicator that only one greave was used during battle (perhaps with the left leg being afford protection by the use of a shield), remains unclear. However, as indicated by the few Bronze Age depictions of greaves that are known, for example the older battle frieze from Hall 64 at Pylos, usually two greaves were worn.

Since the earliest discussions of bronze body armour, debates concerning the use of greaves have been controversial. Interpretations have varied from them providing protection for the warrior from his own shield hitting his lower legs, ${ }^{1177}$ as protection for rarely harmed areas of the body, as protection against rough undergrowth or shrubs, ${ }^{1178}$ and as protection against arrows. ${ }^{1179}$ However, these interpretations seem unreasonable since the shield was usually carried on a person's back when walking, and arrows rarely hit the lower leg. Moreover, it seems very unlikely that the shield would hit the lower leg during fighting, since the centre of the body was in greater need of protection, and the diameter and weight of contemporary shields meant they were unlikely to reach the area of the lower leg. There is only a single description of greaves protecting the warrior in the Iliad, where Achilles is protected by his greaves when Agenor throws his spear. On Greek vases, in scenes of putting on armour, the warrior attaches his greaves first. This need not be taken as an indicator of the importance or higher status of greaves but may represent simple practicality, as it would have been harder to attach the greaves once the warrior was already wearing a cuirass.

On central and eastern European greaves, no firm evidence indicating use has been identified. The only greaves with clear traces of damage are those from Roquefort, France, which are dated to the $6^{\text {th }}$ century BC. ${ }^{1180}$ Due to the common occurrence of weapon perforations visible on the greaves, we might consider this to be an indication of their ritual destruction. However, traces of use do not necessarily need to be directly inferred from damage.

Evidence for the use of greaves is indicated by the extent of repairs, which have been noted on a number of complete greaves. Most common are vertical cracks on the central part of the top of the greave, which were repaired with holes that had been punched through on both sides of the crack, so that a wire could be threaded through in order to hold the sheet together and stop further cracking of the bronze sheet (Fig. 4.16).

Other common repairs noted include, as seen on the greave from Kuřim, the addition of punched holes to replace the broken separate wire loops. In contrast to direct traces of use, repairs seem to have been quite common, at least on the few complete greaves available for direct study from Austria, Bosnia-Herzegovina, Croatia, Czech Republic and Hungary. In all cases were repairs were noted, either a crack or a broken loop had been repaired. In both cases, small holes had been punched through the metal on either side of the crack or below the broken loop. This can be seen on the greave from Stetten, where a loop had broken and been repaired (no wire remained in the newly punched holes), on the greave from Lengyeltóti, where two loops were broken and had been repaired, as well a vertical crack on the top of the greave which had also been repaired. The same type of central, vertical crack can also be seen on the greave from Rinyaszentkirály, and on two greaves of Type Lengyeltóti from Nadap. One of them has a small bronze sheet which was attached by wire to fix the crack. The same greave has another

\footnotetext{
1177 Schauer 1982b, 101.

1178 Drews 1993.

1179 Hansen 1994, 17.

${ }^{1180}$ Clausing 2002.
} 

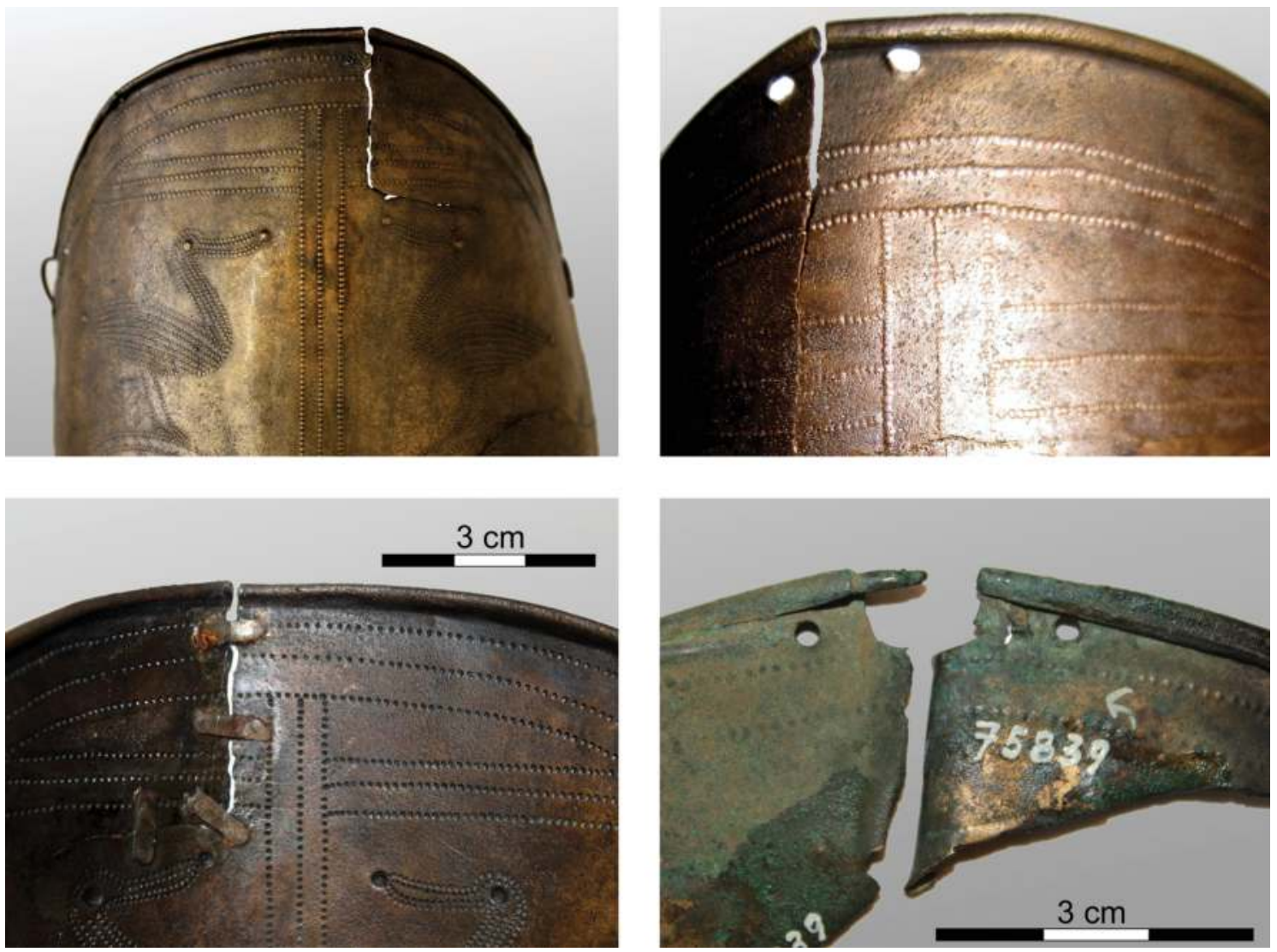

Fig. 4.16 Traces of use-wear on greaves. Left: Rinyaszentkirály, outside (above) and inside (below). Above, right: Lengyeltóti. Crack with two rivet holes punched from the inside to the outside. Below, right: Stetten/Teiritzberg (Prähistorische Abteilung NHM Wien, inv. no. 75836-51; photo: M. Mödlinger). In addition, here, the holes were punched from the inside to the outside in order to place a wire to hold the two sides of the crack together.

crack in the upper right area and a broken loop on the lower left side that had been the subject of attempted repairs. These cracks and broken loops are most likely a result of material tension, in combination with the greave being attached too tightly to the leg, and therefore being unable to adapt to the owner's movements whilst worn. The lack of clear, obvious traces of use on greaves, such as the weapon perforations known on shields ${ }^{1181}$ and helmets, might be due to several reasons:

1. the lower legs were not an area which was commonly vulnerable during combat, at least for the (high status?) person wearing them, and the greaves might have served more to afford protection of the legs in rough terrain

2. greaves were not generally used during actual combat by their owner, perhaps because of their social status. This does not necessarily mean that greaves were not made for combat or no used. Here, a useful analogy would be with early modern period parade armour

3. greaves were used for display only, being a status symbol and a more expensive, highly valued version of organic leg protection

4. greaves or any kind of leg protection might have been also used on horses. The usage of horses in battle is known from the battlefield of Tollense, Germany ${ }^{1182}$

Evidence for the actual use of greaves during war or combat may be derived from figural depictions. Bronze Age depictions of greaves are, aside from Greece, known only from the Sardinian bronze figurines, and their variation suggest that far more forms of greaves existed than that indicated by actual finds. Most of the depicted greaves on the bronze figurines are worn by

${ }^{1181}$ Uckelmann 2012.

1182 Jantzen - Terberger 2011. 
warriors, such as archers or those bearing sticks, swords or spear and shield, as well as overarmed, ritual(?) warriors, and appear to have mainly been made of organic components. ${ }^{183}$ It is probable then that only a small number were made of metal. Moreover, the few potential metal greaves depicted on the Sardinian bronze figurines do not appear to resemble any of the known preserved examples of bronze greaves. Unlike depictions of other categories of bronze armour, such as the helmets and shields, the greaves do not appear on the Bronze Age stelae of the Iberian Peninsula either.

Even using the Bronze Age depictions of greaves on ceramics and frescos in Greece, it is hard to be certain as to the materials used in leg protection, but it is clear that the greaves were always worn by warriors, and in some cases these were also depicted in conjunction with fighting. Sometimes a rounded line in between the upper and lower fastening area is visible on the greaves, but always on one leg only. There are no colour differences in the depictions, however, to indicate the use of potentially different materials, especially in the use of an organic backing. Despite this, greaves are well attested in a number of LH IIIA-B depictions, including on a fragment of fresco from the palace of Orchomenos, showing the lower parts of greaves with strings with depiction of an elliptical line, on a fresco from the Megaron in Mycenae, where long white (linen?) greaves with knee protectors worn by a warrior are depicted, whilst similar greaves are also known from other frescos from Mycenae, including the 'House of the Oil Merchant' and the palace itself. All the greaves have leather (?) strings (black, red or dark brown) to secure the greaves onto the leg. On the frescos from Pylos, the free ends of fastening thongs are sometimes visible. In LH IIIC a shorter form of greaves appeared in Mycenaean art. These greaves do not have any rigid knee protection and are depicted using dark colours. The fastening strips, textile- or leather bands are usually visible above the knee and around the ankles. The most famous depiction of these greaves is on the Warrior Vase and stelae from Mycenae. This type of leg protection is generally considered to have been made of leather, but bronze greaves worn over more comfortable organic material should also be considered. In some of the other depictions, such as on pottery from Mycenae, Tyrins, Leukandi and Ugarit, the fastening thongs are also visible.

Whilst there are a variety of interpretations as to the function of greaves, their use as armour is supported by the presence of repairs and their frequent connection to warriors, such as the Sardinian bronze figurines, their depictions on ceramics and frescos, and the deposition of greaves in warrior tombs. Even though they might not be as large as successive greave forms, such as the later Hoplite greaves, whose function as armour is never questioned, we must remember that we know very little about the nature of the organic lining, such as the material, its shape or size and thickness, all of which would have made a considerable contribution to its function. Consequently, we still do not fully understand the whole piece of armour but only its outer metal part, which does not fully attest to the actual effectiveness of the entire leg protection. Nevertheless, as the evidence for manufacture and use documented on central European greaves indicates, the greaves were made to be an effective category of armour, and which were, for whatever reason, used and required repair. The use of the greaves in relation to different fighting techniques, and in combination with other categories of armour, both bronze and organic, sadly remains a matter of speculation.

\footnotetext{
${ }^{1183}$ For detailed images, see: Lilliu 1966.
} 


\section{Arm and Shoulder Protection}

With the exception of cuirasses, helmets and greaves, few other examples of metal body armour are known. These mainly appear to have been concerned with protecting the hand or arm, where not afforded protected by a shield. The shoulder protection from Dendra (grave 8; cat. no. 120) was discussed in Chapter 3. Another possible arm protection is also known from chamber tomb 12 at Dendra. ${ }^{1183}$ The size and shape of the formed bronze sheet from Dendra suggests it was more likely used as arm protection, rather than as a greave. Both ends of the cylindrical bronze sheet are bent outwards to reduce the risk of injury from the sharp edges. Approximately one third of the piece appears to be missing, representing the middle section, with both ends having been recovered. Parallel to the edges, a row of small holes to attach the organic inlay is visible (Fig. 5.1.2).

Verdelis mentions two further possible examples of arm protection from Praisos, Greece, which have a similar size and shape as that from Dendra (Fig. 5.1.1). ${ }^{1184}$ A possible hand protector was found together with bronze sheet bands in chamber tomb 15 at Mycenae. ${ }^{185}$ It also has small holes all along the edge, again likely for the attachment of an inner lining. Two buttons or flat headed rivets permitted the attachment of an organic band around the wrist (Fig. 5.1.4). Metal arm protection is not mentioned by Homer in the Iliad, only the, possibly organic, arm protection for working in the fields, when he describes the clothes of Laertes. ${ }^{1186}$ Depictions on the Warrior Vase show the warriors wearing long sleeves which might also be taken to indicate metal or organic arm protection. ${ }^{1187}$

One unique piece of hand protection, which had been manufactured specifically for the left hand, and which appears to have derived from eastern Europe, formed part of the Guttmann collection, ${ }^{1188}$ though sadly the current repository is not known. The provenance of the object is unknown. The hand protection (Fig. 5.1.3) would have been attached on to the left hand by means of strips of organic material guided through two holes positioned on the upper and lower ends of the protection. The upper end has holes that are bent upwards to allow the hand a better degree of movement. The pellet and boss decoration of the hand protection suggest a date of $\mathrm{Ha}$ A. The depicted motif, a kind of cauldron and bows on the rim of the protection, is, however, unique. It remains possibility, of course, that the piece is a forgery, so it was not catalogued.

Rectangular bronze sheets, with holes positioned along the short edge to allow for organic bands to enable their attachment, are known from Hajdúsámson, Hungary. These might have served as protection for the lower arm..$^{1189}$

\footnotetext{
1183 Verdelis 1967, 40-41, fig. 9, suppl. 18.

1184 Verdelis 1967, 42, fig. 10.

1185 Yalouris $1960,58$.

1186 Odyssey XXIV, 781-782.

1187 Verdelis 1967, 41.

${ }_{1188}$ Guttmann collection, inv. no. AG 1001; Born - Hansen 2001, 89-91, 220-221, 263-268, fig. 74, pl. VIII; Molloy 2013, 289.

1189 Born - Hansen 2001, 75, fig. 73.1-2.
} 


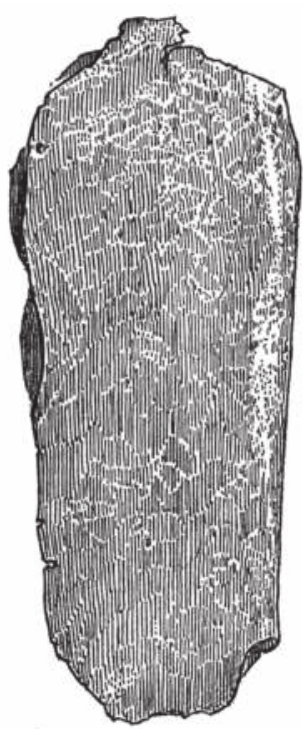

1
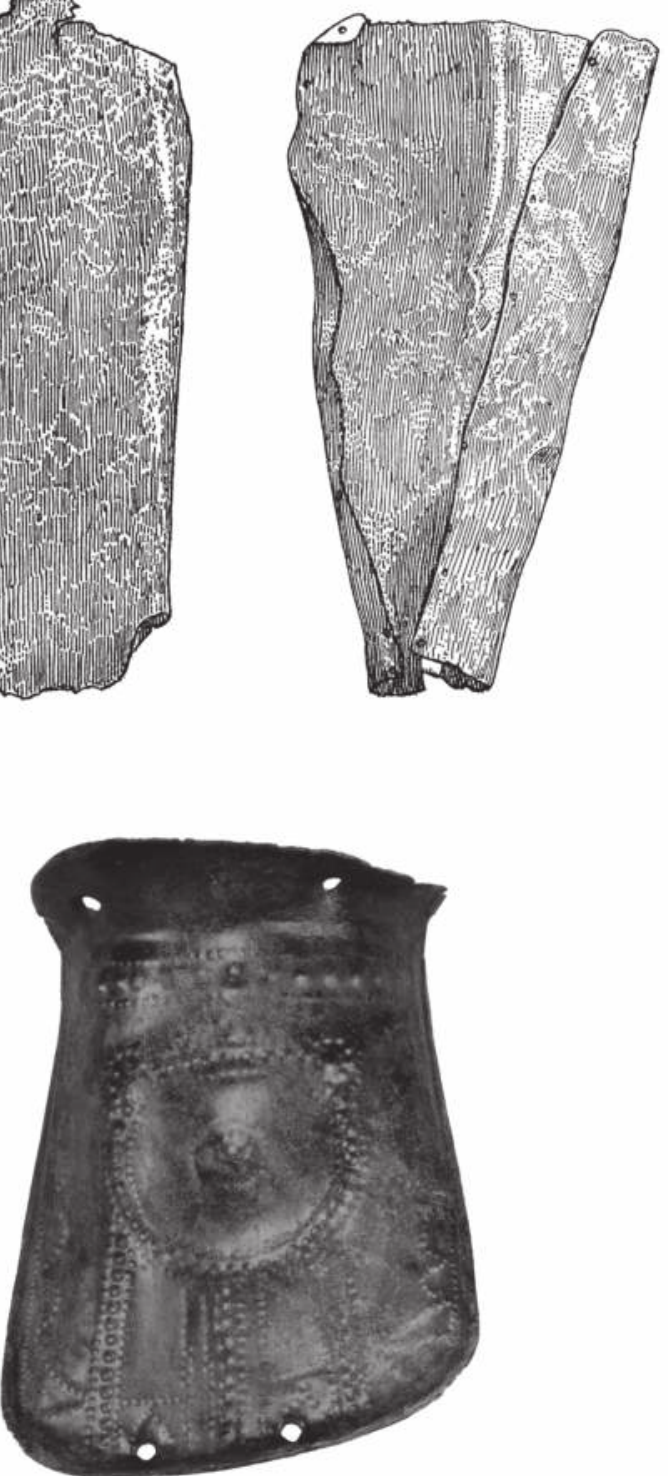

3

Fig. 5.1 Potential bronze arm protection (1-2; no scale) and hand protection (3-4; without scale). 1. Praistos (Verdelis 1967, fig. 10); 2. Dendra, grave 12 (Verdelis 1967, fig. 9); 3. Unprovenanced (Born - Hansen 2001, fig. 220); 4. Mycenae (after Yalouris 1960, suppl. 26.3).
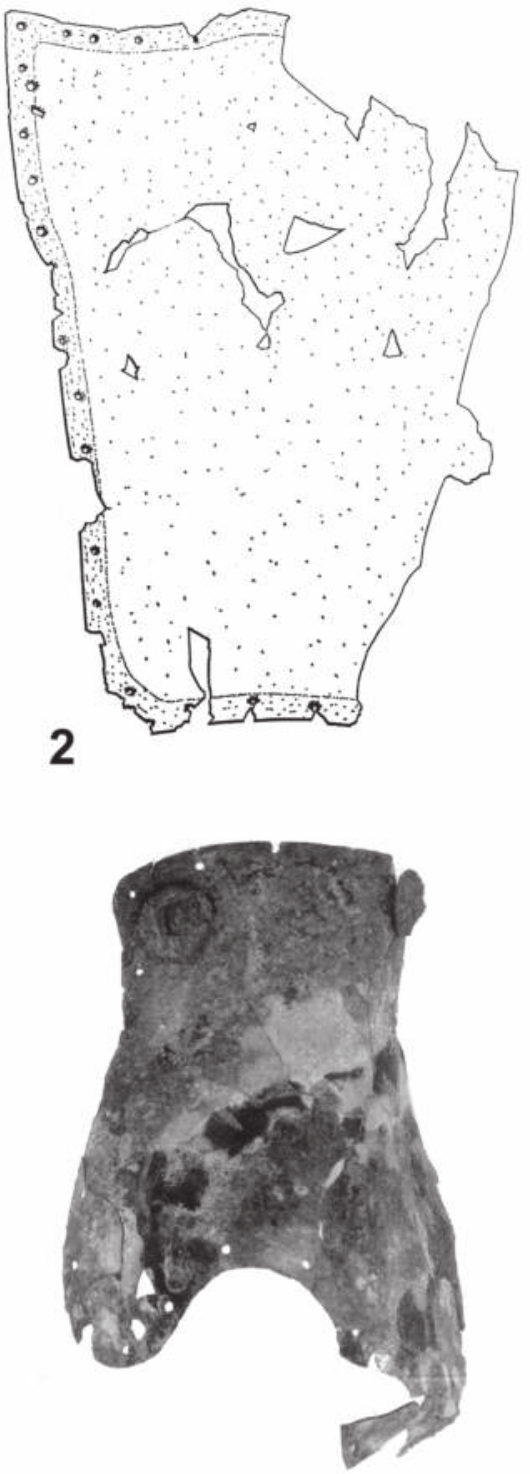

4 


\section{Addendum}

After completing the manuscript, four new finds of armour were brought to the attention of the author: a helmet of Type Paks, perhaps from Serbia (Fig. 6.1), a helmet of Type Biebesheim from an unknown private collection (sold at auction in 2014 and put up for auction once again in 2015), an Italian crested helmet (also on sale), and a greave of Type Lengyeltóti, also potentially from Serbia.

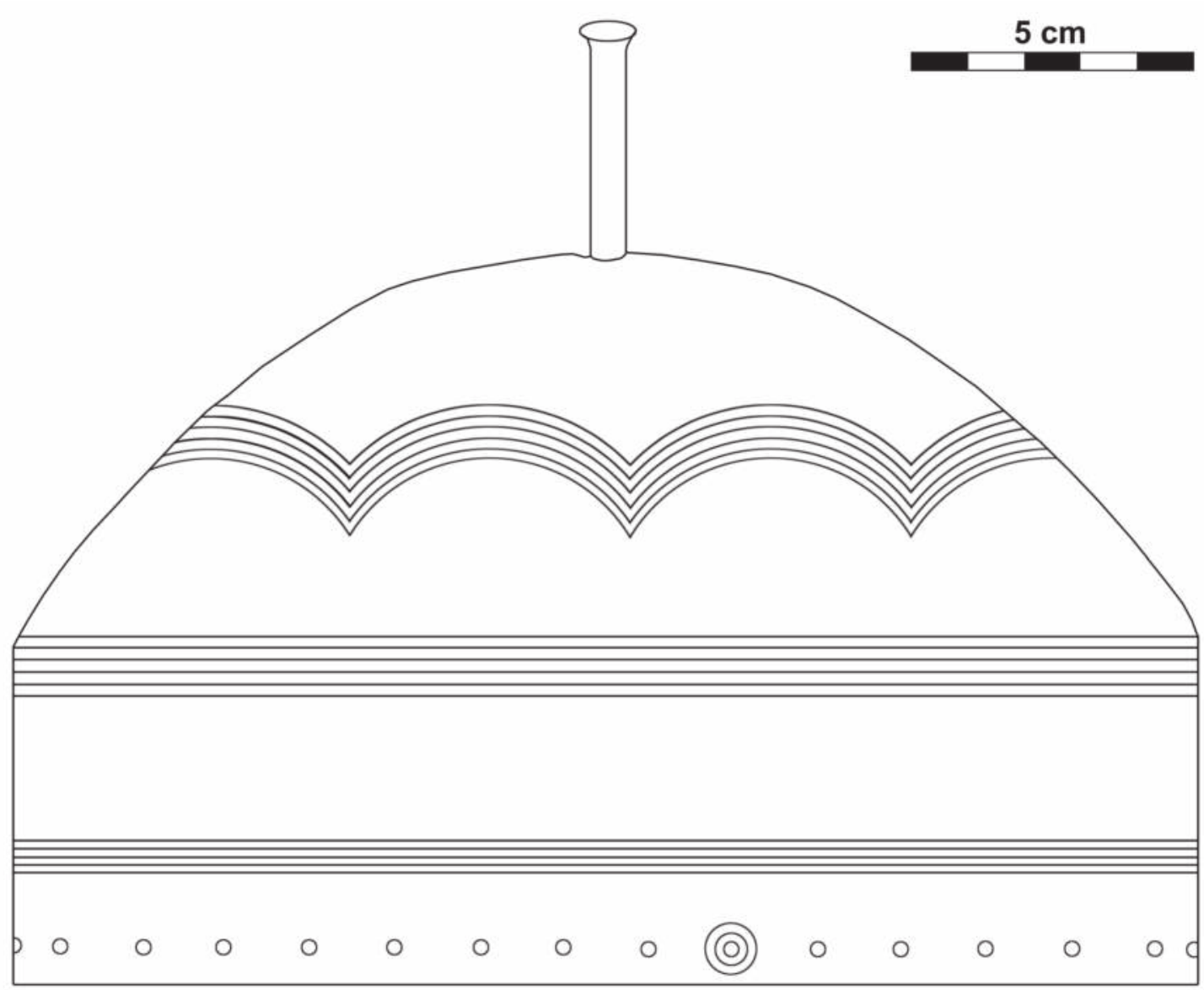

Fig. 6.1 Unprovenanced helmet of Type Paks (possibly from Srem district, Vojvodina, Serbia). Current location unknown.

In mentioning these finds, the author obviously does not want to improve their monetary value, or pass judgement upon the validity of the finds as original, or encourage forgeries or support the trafficking and selling of archaeological objects. Instead, it is simply our desire to bring such rare finds to the attention of archaeological research, in the full knowledge that their provenance remains at this time highly questionable. 


\section{Helmets}

Helmet of Type Paks

Unprovenanced (possibly Srem district, Vojvodina, Serbia) - unknown find circumstances complete helmet - measurements unknown - private collection - Fig. 6.1 - unpublished.

The helmet was presumably found in the region of Vojvodina, Serbia. The helmet was brought to the attention of the museum in Vojvodina in the 1990s, before the helmet was sold and most likely brought out of the country. Its current location is unknown.

\section{Helmet of Type Biebesheim}

Unprovenanced - complete helmet. Measurements: height: $23.5 \mathrm{~cm}$; diameter: $28.7 \times 26.4 \mathrm{~cm}-$ private collection - unpublished.

The helmet was sold at Timelines Auctions at The Swedenborg Hall, London, on 3 September $2014^{1190}$ and put up for auction at Hermann Historica, Munich, on 30 October 2015. ${ }^{1191}$ It is said to derive from a German collector, who bought it at an English auction house, which had purchased it from a private Bavarian collector, who had bought it during the 1990s from an older German collection. No names are known.

\section{Italian Crested Helmet}

Unprovenanced - An Italian crested helmet is on sale at Phoenix Ancient Art, Geneva. The $32.5 \mathrm{~cm}$ high helmet allegedly derives from the former G. Ligabue Collection. The top of the crest is broken. It has two rows of bosses on the cap and three rows of smaller bosses along the crest, which makes it appear very similar to the helmet from Veio, Quattro Fontanili, grave Z15A (Fig. 2.29.7), apart that the latter has three and not two holes on the sides to attach the chinstrap.

\section{Greaves}

\section{Greave of Type Lengyeltóti}

Unprovenanced (possibly Srem district, Vojvodina, Serbia) - unknown find circumstances almost complete greave - measurements unknown - private collection - unpublished.

The greave was presumably found in the region of Vojvodina, Serbia. It was (most likely after the Bronze Age) wrapped around a re-worked, and shortened Reutlingen sword, giving the impression that it was used as a sheath for the sword. The current location of the find is unknown.

\footnotetext{
1190 Timelines 2014.

${ }^{1191}$ Hermann Historica 2015a.
} 


\section{Concluding Discussion}

This study provides a holistic overview of metal body armour from the European Bronze Age. Helmets, cuirasses and greaves, as well as further potential pieces of body armour, are described and their geographical and chronological distribution, typological classification, as well as material characteristics, documented and discussed. These material characteristics have also provided important insights into the manufacture and use of the different categories of armour that have been discussed.

At present, 71 helmets from eastern Europe (Tab. 7.1) and 52 from western Europe (Tab. 7.2) are known, as well as 31 cuirasses (Tab. 7.3) and 78 greaves (Tab. 7.4). These different categories of armour have rather wide distribution patterns, which span a number of different geographical areas and time periods. Body armour from the European Bronze Age ranges from Iberia in the west to Cyprus in the east, and from Sicily in the south to Sweden in the north. Notable omissions in this distribution include Britain and Ireland, were no helmets, greaves or cuirasses have been recovered, their absence even more curious considering the large number of shields found in this region. Body armour is also poorly attested in Scandinavia, where there are again shields and only a small number of bronze helmets. In Germany, the distribution of these shields and helmets overlaps but only two greaves and one potential cuirass are known. In the Iberian Peninsula, crested helmets are known only from a few fragments but also as depictions on stelae, as are bronze shields. From France, helmets, greaves and cuirasses have been recovered but no shields, whilst in Italy helmets and greaves but no cuirasses or shields have been found. In Greece, cuirasses are known but only a small number of greaves and helmets, and no metal shields. ${ }^{1192}$ In the central Alpine region, helmets, a small number of greaves and, most recently, a miniature cuirass have been found. Only in the Carpathian Basin are all four major categories of metal armour known, with overlapping distributions. Despite the frequent occurrence of armour in associated deposits, only the associated deposit from Nadap contains the remains of all four categories of metal armour together, whilst the grave at Dendra represents the burial where most likely a complete assemblage of metal body armour has been recovered.

With the exception of the Greek finds, and those from Volders and Čaka, body armour has generally been found either in associated deposits or as single, often from wet contexts. The latter can perhaps be connected with the disappearance of sword graves around $\mathrm{Bz} \mathrm{D}(2)$ amongst the eastern Urnfield culture and shortly followed by the western Urnfield culture. Moreover, in the western Urnfield culture, cemeteries largely stopped being used around $950 \mathrm{BC}$, whilst contemporary river deposits, such as those from the upper river Rhine, appear to increase, indicating a shift in burial traditions from graves to rivers. There is then no reason to suggest that armour was excluded from sepulchre contexts, only that the nature of those contexts may have changed. The general deposition of weaponry in watery places may also be related to the conclusion of war-like activities, perhaps connected with victory, peace-making, alliance maintenance or an offering made to gain fortune in ongoing or future fights. ${ }^{1193}$ With regards to depositional patterns, especially the occurrence of weaponry in graves and armour in wet contexts, it

\footnotetext{
1192 A likely 'functional' shield with riveted-on handle is known from Delphi (Hencken 1950, fig. 7). The shield bears mixed characteristics of shields of Type Herzsprung and Type Lommelev-Nyírtura, and might be either a local hybrid or potentially later copy of Bronze Age shields. A similar case might be shield 67 from the Idaean cave (Hencken 1950, figs. 8-9): see Molloy 2015 for a more detailed discussion.

${ }^{1193}$ See also Vandkilde 2006a, 486.
} 
seems as if armour was, with more frequency than that of weapons, transferred from contexts related to the personal sphere to more explicitly ritual ones (assuming that not all deposits in rivers were sepulchral), as metal armour is rarely found in graves. The idea of different traditions of deposition in terms of different metalworking categories, must also be extended to different regional and chronological traditions of deposition, in accounting for distributional absences or gaps. Some areas may simply have not deposited certain categories of armour, perhaps preferring instead to hand armour down between generations, as in the case of Odysseus' boar tusk helmet. Perhaps certain categories were instead recycled, or it may simply be the consequence of differential archaeological recovery related to regional or national differences in economic activity and development.

The wide geographical distribution of the body armour inevitably encompasses numerous regional chronological schemes, with differing phases and horizons, which were aligned in order to enable the visualisation of the chronological development of armour and to pinpoint the appearance and spread of specific forms and types. The overarching chronological scheme used in this alignment was that defined by Reinecke, based largely upon the association of different metalworking classes, and the more recent work of Sperber, ${ }^{1194}$ based on the 'high' dendrochronological dates from the lake-shore settlements northwest of the Alps. Similarly 'high' dates have also been suggested for the British Bronze Age, which are considered relevant to the regional chronology of western Europe and the Atlantic Bronze Age.

Helmets were classified into two main Classes according to their manufacture, distribution and general appearance: Class I, which comprises helmets made of one metal sheet and with round or conical cap, and Class II, which comprises helmets made of two metal sheets and with crested cap. The classification of greaves largely follows the technological classification of Clausing. ${ }^{1195}$ Here the greaves were distinguished according to technological criteria into Class I (fixation with a wire) and Class II (perforations along the edge). Class I comprises Subclass A with integrated loops (types Desmontà, Lengyeltóti, Kuřrim, Canosa and Limone), Subclass B with wave-shaped wire (Type Kallithea), Subclass C with separate loops (Type Grammichele) and Subclass D with riveted on loops (Type Ilijak). G. v. Merhart's classification of the cuirasses, ${ }^{1196}$ which has remained in use, has had to be revised, and now comprises regional groups characterised as Greek, Carpathian and western European cuirasses, with each group differing from the others in appearance, deposition, chronology and geographical distribution.

The recovery of less than 250 finds of metal body armour from the European Bronze Age raises several questions, the most important certainly being 'who wore it?' and 'how was it used?' The labour invested in the production of the armour and its intrinsic material value certainly point to their being prestigious, high status objects. The small number of armour recovered might also hint at their value, though here we must be sensitive to inevitable biases in recovery, effected by both the more recent economic conditions of each region and their individual traditions of antiquarian and archaeological recovery and collecting, as well as by different regional traditions of deposition. The latter effects are evident if we compare the number of recovered Greek hoplite cuirasses, which are few, to the thousands of cuirasses historically documented to have originally existed. Without doubt we may assume that such armour was worn by economically and socially potent persons. But who were these persons: warriors who used their metal armour primarily in actual combat or who used their metal armour mainly as status symbol and for display? Before we discuss the persons behind the armour, who appear to have been exclusively men, we will first look at the armour itself and what it tells us about its use.

We have demonstrated in this study that there are sufficient examples of body armour for a detailed study of their damage to be broadly conclusive as to their use, despite the concerns raised by Harding. ${ }^{1197}$ Bearing in mind that 'there can be no rituals or symbols without the reali-

\footnotetext{
1194 Sperber 2011.

1195 Clausing 2002.

1196 v. Merhart 1954.

1197 Harding 2007, 121.
} 
ty of what they signify', ${ }^{1198}$ there can still be doubts as to the use of metal armour in combat. It is worthwhile to consider, however, that:

First, a not inconsiderable number of the body armour has evidence for both use and combat (with some damage certainly resulting in a fatal end for the person wearing the armour, as seen on the cuirasses from Jura B and the one from the Danube), as well as signs of repair, indicating that where such traces are present they were used as actual armour. This does not, of course, preclude the use or function of bronze armour as parade objects, as suggested by the labour and skill invested in their decoration, ${ }^{1199}$ but nor does this embellishment of bronze armour mean that they were incapable of withstanding an attack from a weapon. Here we might take into consideration the Greek hoplite bell cuirasses, which were bought and decorated by their owners and were clearly used in combat. With their similar proportions and thickness, these cuirasses served to fulfil more practical requirements than just social differentiation. Looking at combat traces on the European cuirasses, especially the western European examples, which are also the most intensely decorated, clearly demonstrate that they were used, with evidence of battle traces and repairs, especially in those areas where other cuirasses show sword or spearhead impacts, ${ }^{1200}$ regardless of the investment in their decoration. The situation is somewhat different for the greaves, where no direct weapon impacts are known but there are signs of intense use.

Second, metal body armour was clearly not a skeuomorphic or symbolic substitute for organic body armour but rather afforded an additional layer of protection atop such organic armour, and would never have been worn unaccompanied by shock-absorbing organic lining beneath. Helmets were also worn over an organic cap or had an organic inlay. Greek cuirasses had a permanently attached organic lining, while Carpathian and western European cuirasses were usually worn above a leather, wool, felt or textile jerkin. Greaves were worn over, or sewn on to, an organic wrapping. In every case, bronze armour offered an additional layer of protection in comparison to just organic protection. Given this, the opinion that armour made of sheet bronze is 'most unlikely ever to have provided any significant degree of protection in serious fighting' ${ }^{\prime 201}$ can no longer be substantiated.

Bronze shields do not seem to have had an organic lining but still provided a high level of protection, with experimentation demonstrating that they were capable of withstanding strong blows from a sword, ${ }^{1202}$ though not all shields need have been used in combat either. Despite its use alongside organic protection, it is important to note that bronze armour was not too thin to be effective alone. It requires significant force to penetrate bronze sheet, especially if the attacking weapon is also made of bronze as well and in the context of hand-to-hand combat. Given sufficient strength and the right kind of weapon (like a spear) such bronze armour could nonetheless be pierced, testifying to use in combat, as testified by the impact traces on cuirasses, of one does not want to assume a 'ritual' killing.

The primary function of bronze body armour, with respect to all aspects of technological and stylistic development over time, was clearly engineered toward optimising the protection of the body whilst increasing the level of mobility. The latter aspect was clearly important, for if the main intention was to serve merely a defensive function it would be far more massive, and served instead to incorporate an offensive function, in offering optimum mobility and the ability to attack an opponent. ${ }^{1203}$ We can conclude that metal body armour was not an elaborate display version of organic armour, and was capable of being used in combat, and flexible enough to be used in various combat situations, be it melees, individual or ritual combat. This does not exclude a function for metal body armour as a symbol of wealth or social status, and as an indi-

\footnotetext{
${ }^{1198}$ Kristiansen 1999, 188

${ }^{1199}$ However, certainly not according to their 'flimsy' construction, as noted by Harding 2007, 118 .

${ }^{1200}$ See Chapter 3.9.

1201 As noted by Harding 2007, 122.

1202 Molloy 2009; Uckelmann 2012; Molloy 2013. See also Needham et al. 2012, 489.

${ }^{1203}$ See in particular the tests on replica armour by Molloy 2013, who noted for example that the penetration of a $1.5 \mathrm{~mm}$ thick bronze sheet was far from easy with a sword, spear or an arrow.
} 
cator of the power of its owner or the society to which they belonged to, or its use in ceremony and display. However, armour was, or was intended to be, used primarily according to its nature as an effective means of protection of the body.

Whilst it is clear that bronze body armour was used in combat, the question of the combination of arms and armour is still unsolved. Tomb 12 from Dendra represents the most complete set of arms and armour. No similar sets of armour have yet been found together in other graves. The associated deposit from Nadap includes the next most complete set of armour, comprising fragments of four greaves, at least two different helmets, a shield and a fragment from a cuirass. Because of its context, it is unclear if the armour belonged to the same person, or was the armour of two or more warriors. Even though warriors are often depicted in the archaeological literature with a complete set of arms and armour, such reconstructions,${ }^{1204}$ however, remain largely speculative due to their lack of recovery. Little consideration has been given to the fact it is likely that a combination of both metal body armour and organic body armour was used, of which the latter is rarely preserved. In addition, different types of body armour were certainly in use contemporaneously (as indicated by the different helmets types found together in the associated deposit of Nadap). The warrior was clearly afforded a choice of body armour, with different elements perhaps selected according to economic possibilities, social status, standards and principles, as well as the type of melees, battle or fight, each resulting in a different set of arms and armour.

Moving on from the armour as an object worn in combat to the individual wearing it, we must address the question of who these individuals were - who was 'the' European Bronze Age warrior, and how did he fight?

Contemporary images of European Late Bronze Age warriors of how he wanted to be understood - or how others wanted him to be understood - are known from only a few regions in Europe, comprising the rock art of the Nordic Bronze Age, the carved stelae of the Iberian Peninsula (stelae) and the bronze figurines from Sardinia. The latter provide an especially qualitative insight into the nature of organic body protection. The society of these regions felt the need to depict their warriors using materials, which are fortunate enough to survive archaeologically. These depictions underline the importance of warriors for their community. It is very likely that similar warrior depictions were also common in other regions but produced using materials that have not survived. The surviving depictions differ both in their selected materials and in the motifs. In the Nordic Bronze Age, it appears that the context or situation itself is the primary focus of the depictions, in which some warriors played a part, as opposed to simply depicting the warrior, which, however, may have been due to the artistic restrictions of the material itself. ${ }^{1205}$ Consequently, the Nordic rock art provides an important insight into the specific way arms and armour were used, at least for Sweden or Northern Europe. Phallic men, ${ }^{1206}$ often depicted on boats and usually with arms and weapons raised, can be seen attacking (?) each other, or are shown heading on a boat together to face a common enemy in battle. The main weapon of aggression is usually the spear and double-edged axe, while the sword remains in most cases in the scabbard. ${ }^{1207}$ The attacking weapons are rarely shown touching the body of the opponent. Whether or not this is also due to artistic limitations or a matter of stylistic choice remains unclear. The later superimposition of figures and objects atop earlier depictions often obscures the original composition of a scene, changing the original scenery and creating a different message, perhaps unintentionally. However, both original and later rock art compositions appear to depict tales of privileged groups in society, created to visualise their rich oral tradition. ${ }^{1208}$ Both original and later compositions provide insights into combat as it might have happened, though the dead appear never to be depicted.

\footnotetext{
${ }^{1204}$ For example, as depicted in Marzatico - Gleirscher 2004, fig. 11b; Milcent 2012, title page.

1205 Harding 2007, 139-140.

${ }^{1206}$ With men characterised in this manner most likely due to the limitations of the medium, which did not permit any finer representations of gender differences. There are almost no obvious human figures that appear to be women in Nordic rock art (see Goldhahn - Fuglestvedt 2014, 245, fig. 14.4, tab. 14.2).

1207 Unlike Harding 2007, 117, at least one scene with a sword 'in action' is known. See Fig. 2.39.7.

${ }^{1208}$ Vandkilde 2006a, 488.
} 
However, if what was depicted is a real battle, idealised combat, staged or parade ground fighting, remains unknown. The fact that where fighting occurs on ships, only some of the depicted persons carry weapons, has led to their interpretation as ritualised actions or perhaps sports-like events without death. ${ }^{1209}$ Nevertheless, one has to take into account that the warriors depicted may act as a pars pro toto for the whole ship's complement, and that the depiction of a large group of warriors wielding weapons on a ship might have been restricted due to artistic limitations. Accordingly, other warriors were depicted as simple lines, sometimes even without a head. One might also see the depiction of violent scenes in Nordic rock art as demonstration of 'potency among high-ranking warrior heroes, fighting as equals and according to certain aristocratic rules and ethics'. ${ }^{1210}$

The focus is somewhat different in the case of the warriors depicted on the Iberian stelae which appear to be either funerary in nature, depicting deceased warriors, or perhaps signifying a chiefly ideology ${ }^{1211}$ - and probably also the Sardinian bronze figurines, where different combinations of arms and armour occur. In both cases the warrior, and perhaps even a specific individual, is depicted in a singular, static way. Other categories of finds found in those graves with weapons, as suggested by the Iberian stelae, suggest that the warrior itself was characterised not only by his arms and by armour. As well as weaponry, the Iberian stelae also depict mirrors and toilet articles, indicating that they were equally important as weaponry. Similarly, graves with weapons also often contain jewellery and toilet articles. These other objects were likely an important part of the warrior's accoutrements, symbolising the creation and maintenance of the look of the warrior. For a professional warrior it would certainly have been important to be recognised as such, especially when not engaging in combat or when not wearing his weaponry. The public appearance of a warrior may have been defined by a specific way of dressing and a combination of ornaments, a certain style of hair and beard, or perhaps tattoos, guaranteeing that they would be recognised as such.

Warfare, battles, raids or other kinds of violent group activity is a way to canonise and institutionalise impulsive aggression. Consequently, institutionalising the warrior gives warriors an excuse for violence without sanctions, if carried out within the rules of society. Warriors need to be able to control their aggression and release it when necessary. Impulsive aggression is associated with a rapid rise in heart rate, connected with increasing irrationality, reduced cognitive capabilities, and a dramatic subsidence in sensory and physical capacities. ${ }^{1212}$ This is counterproductive for strategic purposes and could be a risk to a group. To avoid such conditions and retain a heart rate at a maximum of $145 \mathrm{bpm}$ requires extensive mental and physical training, as well as regular handling with weaponry in simulated combat. In this way, muscles memory can be built up and well-practised movements become second nature, with the body acting and reacting almost instinctively under conditions of stress and tension. After violent interactions, warriors, as well as any surviving victims, are, depending on their personal level of psychological resilience, more or less traumatised. Some may suffer from a form of post-traumatic stress disorder. To reduce or adapt to such psychological traumas, every society has found different ways to cope with such post-traumatic stress disorder, either as individuals or as a social group, perhaps by incorporating them into various rituals or ritualised events. There are of course limits to which such things may be inferred from archaeological contexts but they are well known from both ethnographic and sociological studies, and have been discussed in detail elsewhere. ${ }^{1213}$

It is, however, not only the presence of a weapon or armour that indicates warrior status, or determines whether such weaponry was ever actually used in combat. Damaged weaponry obviously indicates the use of weaponry, though it need not necessarily be the person whose remains were found with the weapon that used it in such circumstances, as indicated by the heavily used Type Riegsee sword recovered from the grave of a 12 year old from Bruck, Ger-

\footnotetext{
$\overline{1209}$ Osgood et al. 2000, 34; Vandkilde 2006a, 488.

${ }^{1210}$ Vandkilde 2006a, 488.

1211 Harrison 2004, 75; Harding 2007, 137-138.

1212 Molloy - Grossman 2007, 193.

${ }^{1213}$ I refer here in particular to the recent studies of Robben - Suárez-Orozco 2000.
} 
many. ${ }^{1214}$ It is arguable though that this child might have derived from a line of warriors and was supposed to become one as well once grown up, which would mean an inherited warrior status, or perhaps the sword was a metaphor for warrior values rather than evidence of an actual warrior hood, as suggested by Vandkilde. ${ }^{1215}$

How was the warrior organised, what was his social position, or his duties in peaceful times? Was there a so-called warrior elite or a group of warriors fighting for an elite?

The existence of a military organization with a specific structure has certainly to be assumed for the European Bronze Age. On the basis of fortified settlements, the high number of arms, and human victims of violent acts, there was obviously a necessity to both defend and attack, for whatsoever reason. Relative to the demography of a particular settlement, community or tribal group, as well as level of economic wealth and political organisation, a population may invest in professional warriors or non-professional warriors. These warriors may have been selected from the population on the basis of specific criteria, such as gender and being of a certain age, as well as according to their economic and social status. Non- or semi-professional warriors would certainly have been less of a threat or obstacle to opponents who were well-organised, 'full-time' or dedicated warriors. Consequently, professional warriors are common amongst complex, political centralised societies. ${ }^{1216}$ The warrior of course had to be fed and maintained by his society - at no small cost - but was a good investment for troubled times or to achieve further resources with raiding. According to the level of (real or imaginary) danger from outside, warrior groups had more or less influence on their society. While their presence during troubles was accepted by their community, this acceptance might have been questioned during peaceful times, perhaps resulting in warriors engineering conflicts to justify their existence.

Discerning more detailed information regarding the organisation of such warrior groups in the European Bronze Age, be they be non-, semi- or professional, by archaeological means is fraught with problems. We remain poorly informed as to who was involved, the true extent of gender exclusion, acceptable age categories, the number of participants involved, the extent of armaments in circulation, the degree of professionalisation, or what qualified a person for participation in becoming a warrior. These variables may also have had a bearing on exactly who got to participate in specific events or circumstances, were certain warriors may have been selected on the basis of their having specific armament for different tasks according to their skills, age or various other factors. Moreover, factors such as social or religious values, the code or values of the warriors, the wielding of particular armaments, and differing geographical conditions, may have resulted in distinct versions of the warrior from region to region. With many of these complex historical variables understood in only the most cursory of ways, the archaeologist is capable of presenting only the slightest caricature of the Bronze Age warrior and the institution to which he belonged, especially when so much of our understanding is based upon the occurrence of weapons alone.

An important aspect of archaeological inquiry has been to discern more about the size of such warrior groups. Those associated deposits where armament dominates have been interpreted as the deposition of an opponent's arms after a battle, with the number of weapons being used to calculate the number of warriors involved. ${ }^{1217}$ There have also been attempts to calculate the number of warriors based on the occurrence of arrow heads and weapon combinations in graves. ${ }^{1218}$ The results so far, however, are not entirely satisfying. This is especially the case where we lack much of the basic information concerning such events, such as the number of

\footnotetext{
1214 v. Quillfeldt 1995, 21.

1215 Vandkilde 2006a, 485.

1216 Otterbein 1970.

1217 Examples of this approach include: Randsborg 1995, 48-50 (Valsømagle and Smørumovre hoards); Kristiansen 1999, 103 (Zalkod hoard); Bridgford 2000, 159 (Wilburton hoard). Critical of this approach has been Harding (2007, 164-166) but he hopes that 'perhaps the number of swords deposited in some river and bog finds may bear on this matter' and that also the number of spearheads may indicate the number of warriors involved, such as the hoard from Uherské Hradiště (Moravia) or Bükkaranyos II (Hungary) (Harding 2007, 168).

${ }^{1218}$ Sicherl 2004, 212.
} 
people involved, or the organisation of the battle, or the individual combat techniques used, and therefore we are unable to define the type of event itself. Where written sources are unavailable, such as is the case for the European Bronze Age, it is difficult to distinguish between such small scale events as raids, piracy, feuds or melees, and between these and full-scale war. The necessary archaeological reliance upon weapons, however, does provide important insights into aspects of fighting by arms and the use of armour, as surviving on the objects themselves, representing details that might otherwise be missing from historical sources.

The only presently known Bronze Age battlefield is located at the Tollense, MecklenburgVorpommern, Germany, and is still under excavation. However, it has already revealed impressive insights into a Bronze Age battlefield or execution place. Severe injuries caused by both blunt objects and sharp edged weapons, such as sword or spear, have been identified on skeletons recovered from the site, with such injuries found both on the upper part of the body and the head as well as on the lower legs. ${ }^{1219}$

Several locations along a $2 \mathrm{~km}$ stretch of the river Tollense revealed these skeletal remains and various artefacts. Systematic investigation of these sites begun in 2008, and two locations in particular - at sites Weltzin 20 and Weltzin 32 - revealed several thousand bones, representing a minimum of 120 individuals, as well as various artefacts, including bronze arrowheads, spearheads, tin spirals (ingots), bronze spiral rolls, a gold ring, and two wooden clubs. ${ }^{1220}$ The remains of horses also suggest the presence of mounted persons. ${ }^{1221}$ Radiocarbon dates of the majority of these finds indicate a date in the $13^{\text {th }}$ century BC..$^{1222}$ The skeletal remains were found widely scattered rather than articulated, perhaps indicating that body parts were purposefully disarticulated, maybe during fighting, though it is possible that also occurred posthumously through natural processes, including movement by the river. It is not yet clear how the bodies were placed in the river. Although work is ongoing, it is so far assumed that a minimum of 120 individuals is represented, with some 40 individuals represented only by their skull. Most of the remains appear to have belonged to men, aged between 20 and 40 years old. Unfortunately, age and sex determinations have been possible on only a few bones, mainly skulls, femurs, and pelvises. A small number of women and juveniles were also present, whilst at Weltzin 20 the bone of an infant was recovered, though whether it dates to the Bronze Age is unclear. ${ }^{1223}$ Only one bone has so far been shown to have traces of animal bite marks. The actual areas so far investigated are relatively small, suggesting that a much higher number of people may have been killed, as well as a much larger number of people having been originally involved in the battle, given that some may have survived.

The remains of eight of the 83 individuals analysed showed lesions. The evidence of trauma and injuries on the bones, mainly on the skull, clearly indicate a violent encounter between different groups. For instance, on the skull of a young female there is trauma to the front of the bone, whilst a male skull bears an impact impression from a club, and on another arrow heads were found embedded in the skull of a young man and in the right humerus of a further adult, while other skulls also show evidence of impacts from arrow heads or spearheads. About half of the traumas appear to have occurred shortly before death or indicate that the victim lived for only for a short period, perhaps only days or weeks, after sustaining injury. ${ }^{1224}$ Both the trauma and the weapons found indicate the use of both face-to-face weapons, such as wooden clubs, knives, daggers, swords and spearheads, as well as weapons capable of striking at distance, such as bow and arrows, with heads of flint and bronze, and perhaps spearheads used as javelins. There is no indication of metal defensive armour. Other Bronze Age injuries resulting from blunt weapons

\footnotetext{
1219 Most recently see: Brinker et al. 2015; Lidke et al. 2015.

1220 Jantzen et al. 2008; Jantzen et al. 2011; Jantzen - Terberger 2011; Krüger et al. 2012; Brinker et al. 2013; Brinker et al. 2014; Dombrowsky 2014; Flohr et al. 2014.

1221 Jantzen - Terberger 2011.

1222 Jantzen et al. 2011, 427-428, tab. 1, fig. 9.

${ }^{1223}$ Jantzen et al. 2011, fig. 6; Brinker et al. 2013, tab. 2; Flohr et al. 2014.

${ }^{1224}$ Jantzen et al. 2011, 424-425, fig. 7; Brinker et al. 2013, 138-139.
} 
are otherwise known only from the late Urnfield culture site at Stillfried, Austria. A young girl has four impressions on the right side of the skull, caused by a blunt trauma, and another injury above the right forehead, this time inflicted by a sharp weapon, such as a sword or an axe. ${ }^{1225}$

Based on the number of skulls without injury, and the absence of multiple traumas, ${ }^{1226}$ it would perhaps be wrong to interpret the battle at Tollense as a 'massacre', though many deadly injuries do not necessarily leave traces on the bones. Its interpretation as a mass execution is also problematic, however, as some injuries show signs of healing, though these might be connected with previous or repeated combat events. It seems more likely that it was a battle, especially given the large number of people involved. ${ }^{1227}$ This is further supported by the higher occurrence of young males amongst the remains compared to the number of females and older children.

Considering the low population densities for this time period, the interpretation of the area as a battlefield between two neighbouring settlements seems unlikely. The human remains and artefacts found so far clearly indicate a larger scale of conflict, and would have certainly included people from more than two settlements. ${ }^{1228}$ An indication of its scale, and reason for the conflict, is suggested by the results of isotope analyses, which revealed that those people represented by the remains at Tollense used C4 crop plant, or millet, in their diet. ${ }^{1229}$ Millet was uncommon during the Early Bronze Age in northern Germany, with the cultivation of millet only expanded northwards during the course of the Bronze Age. The presence of tin ingots, bronze pins of Silesian type, and the presence of over 40 bronze arrow heads, may suggest that some of the dead were not local but may instead have travelled from the southeast. ${ }^{1230}$

The lack of metal arms and armour at the site may result from the fact that either none of the victims wore such armour, or the winning warriors may have collected it, with only small metal objects being left behind, such as the spirals. The victims may also not have worn bronze armour or have been equipped with bronze weapons as a consequence of having a lesser economic status, a different social role, or even for religious reasons. As investigations on the site are ongoing, it is possible that further excavations in the Tollense Valley may reveal more about the use of metal arms and armour.

The evidence for combat from the battlefield at Tollense, from which so far only close-combat organic weapons and long-range weapons in the form of bronze arrowheads have been recovered, certainly challenges the idealised notion of the heroic Bronze Age warrior, resplendent in their shining bronze armour, and equipped only with the finest bronze weaponry. Instead, a more common image is invoked, of warriors armed with less prestigious and less exclusive arms, in the form of organic weapons (and armour?), killing each other. It may be that the groups involved were poorly equipped migrants, without immediate access to bronze or smiths, and represents a particularly exceptional combat situation rather than that which normally occurred.

As well as the use damage found on bronze arms and armour, and the evidence for weapon injuries documented at Tollense, there are further injuries documented on human skeletons from the European Late Bronze Age. Most of these injuries appear to have been caused by spearheads and swords. ${ }^{1231}$ As a whole, the number of documented injuries is rather small, as the sample of human skeletons for this period is adversely affected by the dominant burial rite during the Late Bronze Age being largely cremation. Where skeletal remains have survived, the application of detailed anthropological studies that might identify such injuries has not been as common as one would like. In addition, only a small number of fatal injuries need leave skeletal traces. Most of those injuries identified have come from separate graves but there are also three

\footnotetext{
${ }^{1225}$ Mödlinger 2011, 88-92.

1226 Only one skull appears to have multiple traumas, comprising three lesions with evidence of healing, indicating survival for a long period: see Jantzen et al. 2011, 425.

1227 Brinker et al. 2013, 143.

1228 Jantzen - Terberger 2011.

1229 Jantzen et al. 2011, 428.

1230 Jantzen - Terberger 2011.

${ }^{1231}$ Mödlinger 2011, 88-92; see here for further references to the following finds discussed, if not otherwise provided.
} 
further Middle and Late Bronze Age sites which have more than one person deposited together, with at least two having signs of purposefully inflicted injuries.

At the site of Sund, Norway, large concentrations of inhumed human and animal bones were found. The (decapitated?) human skulls appeared to have been placed on top of the laid out bodies, left on display, suggesting that it was most likely not the family or relatives that buried those that had been killed. ${ }^{1232}$ Radiocarbon dates indicated a focal date towards the Middle Bronze Age, c. 1500-1100 BC. At least 22 persons were buried, with more than half of them being under 15 years old. Also, more than half of the adults show both healed and fresh injuries. Cuts were identified on a temporal bone, a left humerus, a thoracic vertebra on the anterior side (!), and the left femur neck, as well as three parallel cuts going across the shaft of the first foot phalanx, two triangular lesions to the fovea capitis. Several peri-mortem traumas, such as broken bones, were also documented.

At Tomarton, South Gloucestershire, United Kingdom, the skeletal remains of four younger men, and dated by radiocarbon analyses to c. 1315-1050 BC, were found in a V-shaped linear ditch, which appeared to have been backfilled immediately after the bodies were placed. ${ }^{1233}$ Ditches of this type usually mark out territories and parcels of land, and a potential dispute might have been the cause of the deaths. One of the men had been speared twice from behind, as indicated by a hole caused by a spearhead in his pelvis, as had another and with such force that the spear tip was twisted and broke off, remaining lodged within the bone. Additionally, his lumbar vertebrae had also been pierced by a spear, and again the tip of the spear had broken off, and would have left the man paralysed in the legs. He also has a circular perforation on the left side of the skull, perhaps representing a coup de grace by his opponent, carried out with the ferrule or the shaft butt of the spear. The spearhead's chemical analysis indicates an origin for the copper ore, and potentially also for the weapon itself (?), from the Alps. ${ }^{1234}$

Similar injuries are known from the remains of a body found in Dorchester on Thames, United Kingdom (radiocarbon dated to 1260-990 BC), were again the pelvis was pierced by a spearhead and again the tip broke off and became lodged in the bone. ${ }^{1235}$ Here we are reminded of the description of Homer concerning how the spear was used for piercing the pelvis area. ${ }^{1236}$ He notes in the Iliad twelve pelvic and urogenital injuries, with all but one caused by a spear, and with just one exception (which was miraculously healed) all lead to death.

The remains of several other men also reveal (fatal) injuries. A section of the parietal bone of a man from Wiligrad, Germany, dating to the $15^{\text {th }}$ century BC, was hacked off, the injury probably caused by a sword used as a slashing weapon. A 50 to 60 year old man from Kehlheim, Germany, dating to Ha B, was also injured by a sword, from behind on the lower area of the left parietal. Finally, an approximately 40-year old man from Kråkerøy, dating from Ha A2/B1, suffered a blow to the right side of the cranium and an almost cut through thoracic vertebra.

Further possible victims who died from injuries caused by a blow from a sword are known from Mycenae (Greece) and the Athenian Agora. The man from Grave Z at Mycenae received a cut from a sword above the left eye and on the left temple. The man was injured around 16301500 BC. The individual from the Athenian Agora instead received three injuries to the head, most likely resulting from the blow from a blade during LH IIIA. ${ }^{1237}$

Like today, Bronze Age societies certainly did not consist only of noble and peaceful hunter, peasant and trader or only bellicose, brutal savages either, as the first rather black-or-white studies of war in archaeology suggested. ${ }^{1238}$ Warfare was and is a part of social life, an unfortunately common means of social practice, in constant interchange with other social actions.

\footnotetext{
1232 Fyllingen 2006, 319-329.

1233 Osgood 2006; Osgood 2013.

${ }^{1234}$ Osgood 2013, chapter 1 (e-book).

1235 Osgood 2006, 338 .

${ }^{1236}$ Marani - Koch 2014, tab. 2.1.

1237 Mödlinger 2011, 88-92.

${ }^{1238}$ As embodied in Jean-Jaques Rousseau's romantic writings and Thomas Hobbes' Leviathan. See the detailed discussion of this topic by Vandkilde 2006b.
} 
According to the overwhelming material evidence for violent activity, ranging from fortified settlements to the high number of effective metal arms and armour, as well as battle traces on weaponry and human skeletal remains, serious fighting clearly took place within Bronze Age societies. Professional and semi-professional warriors, most likely carried out these armed conflicts as economic capacity, socio-political organisation, and cultural values permitted.

Bronze Age societies have been and, at least in part, continue to be characterised by their warrior identity. Violence was clearly legitimated under certain circumstances and manifested in the warriors themselves, being part of the so-called elite. The act of killing, and the social and personal implications that accompanies it, were (and are) a seemingly unavoidable part of human social actions.

War, combat and violent actions in general are bereft of heroic connotations: War is dirty, exhausting, and filled with blood, guts and excrement. The glorification and idolatry of war and combat is a well-known contemporary phenomenon, and one far from the reality of such events and activity, as it would have been in the past. It is important to note the brutal and deadly side of war, violent action and the warrior so as to prevent its romantic glorification and the idolatry of the Bronze Age warriors - the golden-shining, chiefly and glorious warrior as he is currently described and depicted was primarily a violent killer who left in his wake death, devastation, horror and desperation: a human being, skilled and willing to kill. 


\begin{tabular}{|c|c|c|}
\hline \multicolumn{3}{|c|}{ Eastern European Helmets } \\
\hline Cat. No. & Find Site & Type \\
\hline 1 & unprovenanced - Greece (?) & \multirow{12}{*}{$\begin{array}{c}\text { IB1 } \\
\text { (Oranienburg) }\end{array}$} \\
\hline 2 & Knossos, Greece & \\
\hline 3 & Biecz, Poland & \\
\hline 4 & Oranienburg, Germany & \\
\hline 5 & Žaškov, Slovakia & \\
\hline 6 & Spišská Belá, Slovakia & \\
\hline 7 & unprovenanced - Lúčky, Slovakia (?) & \\
\hline 8 & Keresztéte, Hungary & \\
\hline 9 & Nadap, Hungary & \\
\hline 10 & Dunaföldvar, Hungary & \\
\hline 11 & Sîg, Romania & \\
\hline 12 & unprovenanced - Hungary (?) & \\
\hline 13 & unprovenanced - Hungary & \multirow{24}{*}{$\begin{array}{c}\text { IA2 } \\
\text { (Paks) }\end{array}$} \\
\hline 14 & unprovenanced - Northern Hungary (?) & \\
\hline 15 & Paks, Hungary & \\
\hline 16 & Žiar nad Hronom, Slovakia (?) & \\
\hline 17 & unprovenanced - Cahn-auction & \\
\hline 18 & Bajmok, Serbia (?) & \\
\hline 19 & Dusnok, Serbia (?) & \\
\hline 20 & unprovenanced - Guttmann collection, AG 246 & \\
\hline 21 & unprovenanced - Guttmann collection, AG 1126 & \\
\hline 22 & Markovac-Grunjac, Serbia & \\
\hline 23 & Veliko Nabrđe, Croatia & \\
\hline 24 & Poljanci, Croatia & \\
\hline 25 & Elsterwerda, Germany & \\
\hline 26 & Pázmándfalu, Hungary & \\
\hline 27 & Nadap, Hungary & \\
\hline 28 & Strassengel, Austria & \\
\hline 29 & Guşteriţa, Romania & \\
\hline 30 & Wöllersdorf, Austria & \\
\hline 31 & Hočko Pohorje, Slovenia & \\
\hline 32 & Uioara de Sus, Romania & \\
\hline 33 & Újszőny/Komárom, Hungary & \\
\hline 34 & Mezőnyárád, Hungary & \\
\hline 35 & Pázmándfalu, Hungary & \\
\hline Addendum & unprovenanced - Serbia (?) & \\
\hline 36 & Batina, Croatia & \multirow{5}{*}{$\begin{array}{c}\text { IA1 } \\
\text { (Nagytétény) }\end{array}$} \\
\hline 37 & Nagytétény, Hungary & \\
\hline 38 & Brody/Ternopil, Ukraine & \\
\hline 39 & unprovenanced & \\
\hline 40 & unprovenanced-Cahn-auction & \\
\hline
\end{tabular}

Tab. 7.1 Overview of eastern European helmets (see also Figure 2.2 for the classification of helmets). 


\begin{tabular}{|c|c|c|}
\hline \multicolumn{3}{|c|}{ Eastern European Helmets } \\
\hline Cat. No. & Find Site & Type \\
\hline 41 & Sehlsdorf, Germany & \multirow{16}{*}{$\begin{array}{c}\text { IB2 } \\
\text { (Pişcolt) }\end{array}$} \\
\hline 42 & Služín, Czech Republic & \\
\hline 43 & Škocjan, Slovenia & \\
\hline 44 & Hajdúböszörmény, Hungary & \\
\hline 45 & Mezőkövesd, Hungary & \\
\hline 46 & Endrőd, Hungary & \\
\hline 47 & Şoarş, Romania & \\
\hline 48 & Pişcolt, Romania & \\
\hline 49 & Monte Altino, Italy (?) & \\
\hline 50 & unprovenanced - Mantova & \\
\hline 51 & unprovenanced - Zschille collection & \\
\hline 52 & unprovenanced - Guttmann collection & \\
\hline 53 & unprovenanced - Gorny and Mosch & \\
\hline 54 & unprovenanced - Lipperheide collection & \\
\hline 55 & unprovenanced - Phoenix Ancient Art & \\
\hline 56 & Bonyhád, Hungary & \\
\hline 57 & Škocjan, Slovenia & \multirow{2}{*}{ IB2 related } \\
\hline 58 & Škocjan, Slovenia & \\
\hline 59 & Szczecin-Zdroje, Poland & IA2 related \\
\hline 60 & Fiave, Italy & single type (organic) \\
\hline 61 & Malpensa, Italy & single type \\
\hline 62 & Ialysos, Greece & \multirow{4}{*}{ Greek cheek plate } \\
\hline 63 & Dendra, Greece & \\
\hline 64 & Kourion-Kaloriziki, Cyprus & \\
\hline 65 & Schmiedehausen, Germany & \\
\hline 66 & Weißig, Germany & \multirow{2}{*}{ cheek plate } \\
\hline 67 & Podcrkavlje, Croatia & \\
\hline 68 & Şpălnaca, Romania & \multirow{2}{*}{ socket } \\
\hline 69 & Techirghiol, Romania & \\
\hline 70 & Grepci, Bosnia-Herzegovina & knob \\
\hline
\end{tabular}

Tab. 7.1 continued. 


\begin{tabular}{|c|c|c|}
\hline \multicolumn{3}{|c|}{ Western European Helmets } \\
\hline Cat. No. & Find Site & Type \\
\hline 71 & Montbellet, France & \multirow{8}{*}{$\begin{array}{c}\text { IA3 } \\
\text { (Montbellet) }\end{array}$} \\
\hline 72 & Thonberg, Germany & \\
\hline 73 & Wonsheim, Germany & \\
\hline 74 & Szikszó, Hungary & \\
\hline 75 & Brancere, Italy & \\
\hline 76 & Iseo, Italy & \\
\hline 77 & unprovenanced - Rome, Italy (?) & \\
\hline 78 & unprovenanced - Zschille collection & \\
\hline 79 & Mantes, France & \multirow{4}{*}{$\begin{array}{c}\text { IIC1 } \\
\text { (Mantes) }\end{array}$} \\
\hline 80 & Mainz, Germany & \\
\hline 81 & Oggiono-Ello, Italy & \\
\hline 82 & Weil am Rhein, Germany & \\
\hline 83 & Pass Lueg, Austria & \multirow{3}{*}{$\begin{array}{c}\text { IIC4 } \\
\text { (Lueg) }\end{array}$} \\
\hline 84 & Piller, Austria & \\
\hline 85 & Anlauftal, Austria & \\
\hline $86-87$ & Biebesheim, Germany (2) & \multirow{13}{*}{$\begin{array}{c}\text { IIC2 } \\
\text { (Biebesheim) }\end{array}$} \\
\hline 88 & Bremen, Germany & \\
\hline 89 & Ebing, Germany & \\
\hline 90 & Pockinger Heide, Germany & \\
\hline 91 & Otterstadt, Germany & \\
\hline 92 & Auxonne, France & \\
\hline 93 & Le Theil, France & \\
\hline 94 & Blainville-sur-l'Eau, France & \\
\hline 95 & Chalon-sur-Saône, France & \\
\hline $96-97$ & Montmacq, France (2) & \\
\hline 98 & Paris, France & \\
\hline 99 & Seurre, France & \\
\hline Addendum & unprovenanced - sold at Hermann Historica, October 2015 & \\
\hline 100 & Hungary (?) & IIC2 related \\
\hline $101-110$ & Bernières-d'Ailly, France (10) & \multirow{9}{*}{$\begin{array}{c}\text { IIC3 } \\
\text { (Bernières-d'Ailly) }\end{array}$} \\
\hline 111 & Armancourt, France & \\
\hline 112 & unprovenanced - 'Normandy' & \\
\hline 113 & Nemours, France & \\
\hline 114 & Mainz-Kostheim, Germany & \\
\hline 115 & Roxheim, Germany & \\
\hline 116 & Larnaud, France & \\
\hline $117-118$ & Huelva, Spain (2) & \\
\hline 119 & Vila Cova de Perrinho, Spain & \\
\hline 120 & Tiryns, Greece & II \\
\hline 121 & Viksø, Denmark & single type \\
\hline
\end{tabular}

Tab. 7.2 Overview of western European helmets (see also Figure 2.2 for the classification of helmets). 


\begin{tabular}{|c|c|c|}
\hline \multicolumn{3}{|c|}{ Cuirasses } \\
\hline Cat. No. & Find Site & Type \\
\hline 122 & Dendra, Greece & \multirow{4}{*}{ Greek } \\
\hline 123 & Dendra, Greece & \\
\hline 124 & Arsenal Thebes, Greece & \\
\hline 125 & Municipal Conf. Centre, Thebes, Greece & \\
\hline 126 & Čierna nad Tisou, Slovakia & \multirow{9}{*}{ Carpathian } \\
\hline 127 & Šarišské Micha’any, Slovakia & \\
\hline 128 & Čaka, Slovakia & \\
\hline 129 & Ducové, Slovakia & \\
\hline 130 & St. Germain-du-Plain, France & \\
\hline 131 & Pázmándfalu, Hungary & \\
\hline 132 & Nadap, Hungary & \\
\hline 133 & Ivančice, Czech Republic & \\
\hline 134 & Danube, Hungary & \\
\hline 135 & unprovenanced - 'Metropolitan' & \multirow{5}{*}{$\begin{array}{l}\text { Western } \\
\text { European }\end{array}$} \\
\hline 136 & unprovenanced - 'Hamburg' & \\
\hline $137-138$ & Graye-et-Charnay or Véria, France (2) & \\
\hline $139-145$ & Fillinges, France (7) & \\
\hline $146-152$ & Marmesse, France (7) & \\
\hline
\end{tabular}

Tab. 7.3 Overview of cuirasses. 


\begin{tabular}{|c|c|c|}
\hline \multicolumn{3}{|c|}{ Greaves } \\
\hline Cat. No. & Find Site & Type \\
\hline 153 & Brodski Varoš, Croatia & \multirow{9}{*}{$\begin{array}{c}\text { IA1 } \\
\text { (Desmontà) }\end{array}$} \\
\hline $154-155$ & Desmontà, Italy (2) & \\
\hline $156-159$ & Pergine, Italy (4) & \\
\hline $160-161$ & Malpensa, Italy (2) & \\
\hline 162 & Cannes-Écluse, France & \\
\hline 163 & Poljanci I, Croatia & \\
\hline 164 & Esztergom, Hungary & \\
\hline 165 & Nadap, Hungary & \\
\hline $166-167$ & unknown (Hungary?) & \\
\hline 168 & Rinyaszentkirály, Hungary & \multirow{12}{*}{$\begin{array}{c}\text { IA2 } \\
\text { (Lengyeltóti) }\end{array}$} \\
\hline 169 & Nagyvejke, Hungary & \\
\hline $170-172$ & Nadap, Hungary (3) & \\
\hline 173 & Lengyeltóti, Hungary & \\
\hline 174 & Stetten, Austria & \\
\hline 175 & Poljanci IV, Croatia & \\
\hline 176 & Slavonski Brod, Croatia (2?) & \\
\hline 177 & Veliko Nabrđe, Croatia & \\
\hline 178 & Boljanić, Bosnia and Herzegovina & \\
\hline 179 & Malpensa, Italy & \\
\hline $180-181$ & Athens, Greece (2) & \\
\hline Addendum & unprovenanced - Serbia (?) & \\
\hline 182 & Markovac-Grunjac, Serbia & IA1/IA2 \\
\hline 183 & Bouclans, France & \multirow{8}{*}{$\begin{array}{c}\text { IA3 } \\
\text { (Kuřim) }\end{array}$} \\
\hline 184 & Boutigny, France & \\
\hline 185 & Beuron, Germany & \\
\hline $186-187$ & Volders, Austria (2) & \\
\hline 188 & Weissenstein, Austria & \\
\hline 189 & Várvölgy, Hungary & \\
\hline 190 & Kuřim, Czech Republic & \\
\hline $191-192$ & Kloštar Ivanić, Croatia (2) & \\
\hline $193-194$ & Canosa, Italy (2) & \multirow{2}{*}{ IA } \\
\hline 195 & Limone, Italy & \\
\hline $196-198$ & Enkomi, Greece (3) & \multirow{5}{*}{$\begin{array}{c}\text { IB1 } \\
\text { (Kallithea) }\end{array}$} \\
\hline $199-200$ & Kallithea, Greece (2) & \\
\hline $201-202$ & Portes-Kephalovryso, Greece (2) & \\
\hline $203-204$ & Kouvarás, Greece (2) & \\
\hline $205-206$ & Castellace, Italy (2) & \\
\hline $207-208$ & Grammichele, Italy (2) & \multirow{3}{*}{$\begin{array}{c}\mathrm{IC} 1 \\
\text { (Grammichele) }\end{array}$} \\
\hline $209-210$ & Pontecagnano, Italy (2) & \\
\hline $211-216$ & Torre Galli, Italy (6) & \\
\hline 217 & Dobraç, Albania & \multirow{4}{*}{$\begin{array}{c}\text { ID1 } \\
\text { (Ilijak) }\end{array}$} \\
\hline $218-219$ & Dabrica, Bosnia-Herzegovina (2) & \\
\hline $220-225$ & Ilijak, Bosnia-Herzegovina (6) & \\
\hline 226 & Olympia, Greece & \\
\hline 227 & Dendra, Greece (2?) & \multirow{3}{*}{ II } \\
\hline 228 & Schäfstall, Germany & \\
\hline 229 & Winklsaß, Germany & \\
\hline
\end{tabular}

Tab. 7.4 Overview of greaves. 



\section{References}

Abels 1985/1986

B.-U. Abels, Ausgrabungen und Funde Oberfranken 4, 1983-1984, Geschichte am Obermain 15, 1985/1986, 1-66.

Abels 2002

B.-U. Abels, Die Heunischenburg bei Kronach. Eine späturnenfelderzeitliche Befestigung, Regensburger Beiträge zur prähistorischen Archäologie 9 (Regensburg 2002).

Abels et al. 1996

B.-U. Abels - W. Sage - C. Züchner, Oberfranken in vor- und frühgeschichtlicher Zeit (Bamberg 1996).

Ackner 1834

J.-M. Ackner, Reise nach Várhely in antiquarischer Hinsicht im Jahre 1832, in: J. Benigni v. Mildenberg - C. Neugeboren (eds.), Transsilvania, Periodische Zeitschrift für Landeskunde 2, 1834, 222-285.

Agde 1939

H. Agde, Bronzezeitliche Kulturgruppen im mittleren Elbegebiet (Leipzig 1939).

Albanese Procelli 1994

R. M. Albanese Procelli, Considerazioni sulla necropoli di Madonna del Piano di Grammichele (Catania), in: P. Gastaldi (ed.), La presenza etrusca nella Campania Meridionale (Florence 1994) 153-169.

Albrecht 1991

M. Albrecht, Der bronzezeitliche Helm von Szczecin-Zdroje im Museum für Ur- und Frühgeschichte, Forschungen und Berichte Staatliche Museen zu Berlin 31, 1991, 9-16.

Alciati - Passarello 1963

C. Alciati - P. Passarello, Veio, Notizie degli Scavi di Antichità 17, 1963, 1-277.

Alexander 1972

J. Alexander, Yugoslavia before the Roman Conquest (London 1972).

Alexander Ancient Art 2017

Alexander Ancient Art, Catalogue 2017, 25-26. Online <http:/www.alexanderancientart.com/catalogue2017.pdf> (last access 27 June 2017).

Almagro Basch 1958

M. Almagro Basch, Inventaria Praehistorica. España, Fascículo 1-4, E-1, Depósito de la ría de Huelva (Madrid 1958).

Almagro Gorbea 1977

M. Almagro Gorbea, El Bronce Final y el periodo orientalizante en Extremadura, Bibliotheca Praehistorica Hispana 14 (Madrid 1977).

Alonso Fernández - Jiménez Echevarría 2009

C. Alonso Fernández - J. Jiménez Echevarría, El depósito de armas del Bronce Final de los «Los Cascajos», Grañón (La Rioja), Gladius. Estudios sobre armas antiguas, arte militar y vida cultural en oriente y occidente 29, 2009, $7-38$.

Althin 1952

C. A. Althin, Hjalmarna från Viksø. Arkeologiska Forskningar och Fynd, Studier utg. M. anl. av. H. M. Konung Gustav VI Adolfs sjuttioårsdag 11.11.1952, 1952, 382-396. 
Ammannati et al. 2006

N. Ammannati - M. G. Ienco - E. Martellucci - P. Piccardo, L'energia di attivazione nel processo di ricristallizzazione del bronzo. Influenza del tenore di stagno, La Metallurgia Italiana 1, 2006, 31-38.

Andrikou 2000

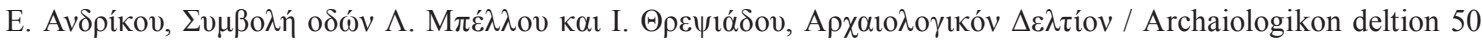
B'1/1995, 2000, 290-294.

Andrikou 2007

E. Andrikou, New evidence on Mycenaean bronze corselets from Thebes in Boeotia and the Bronze Age sequence of corselets in Greece and Europe, in: I. Galanaki - H. Tomas -Y. Galnakis - R. Laffineur (eds.), Between the Aegean and the Baltic Seas. Prehistory across Borders. Proceedings of the International Conference Bronze and Early Iron Age Interconnections and Contemporary Developments between the Aegean and the Regions of the Balkan Peninsula, Central and Northern Europe University of Zagreb, 11-14 April 2005, Aegaeum 27 (Liège 2007) 401-409.

Anoutchine 1893

D. Anoutchine, Notice sur quelques épées anciennes en bronze, trouvées dans la Russie méridionale et en Sibérie. Congrès international d'archéologie préhistorique et d'anthropologie, 11-ème session à Moscou, du 1/13-8/20 août 1892 Vol. 2 (Moscow 1893) 341-346.

Aricescu 1965

A. D. Aricescu, Depozitele de bronzuri din Dobrogea, Studii şi Cercetări de Istorie Veche 16, 1, 1965, 17-42.

Aricescu 1970

A. D. Aricescu, Depozitele de unelte, arme şi podoabe de bronz din Dobrogea, Pontica 3, 1970, 25-76.

Arribas 1964

A. Arribas, The Iberians (New York 1964).

Åström 1967

P. Åström, Das Panzergrab von Dendra: Bauweise und Keramik, Mitteilungen des Deutschen Archäologischen Instituts, Athenische Abteilung 82, 1967, 54-67.

Åström 1983

P. Åström, The Cuirass Tomb and Other Finds at Dendra, Part 2. Excavations in the Cemeteries, the Lower Town, and the Citadel, Studies in Mediterranean Archaeology 4 (Gothenburg 1983).

Athenas 1828

P. Athenas, Mémoires sur trois épées de bronze antiques, Lycée Armoricaine 11, 61, 1828, 279-287.

Audouze 1976

F. Audouze, Les ceintures et ornements de ceinture de l'Âge du Bronze en France (suite). Ceintures et ornements de ceinture en bronze, Gallia Préhistoire 19, 1976, 69-172.

Bader 1983

T. Bader, Die Fibeln in Rumänien, Prähistorische Bronzefunde XIV, 6 (Stuttgart 1983).

Bader 1991

T. Bader, Die Schwerter in Rumänien, Prähistorische Bronzefunde IV, 8 (Stuttgart 1991).

Bader 2008

T. Bader (ed.), Dreitausend Jahre Vorgeschichte. Meisterwerke der Metallzeit im kontinentalen Kroatien. Sonderausstellung im Keltenmuseum Hochdorf, September 10, 2008 to March 8, 2009. Exhibition Catalogue (Eberdingen 2008).

Bartík 2009

J. Bartík, Bronzezeitliche Gegenstände aus einer Privatsammlung, Zborník Slovenského Národného Múzea CIII, Archeológia 19, 2009, 37-52.

Baš 1933

F. Baš, Zgodnjehallstattske najdbe na Pohorju in v Mariboru, Časopis za Zgodovino in Narodopisje 28, 1933, 37-40. 
Beltz 1910

R. Beltz, Die vorgeschichtlichen Altertümer des Grossherzogtums Mecklenburg-Schwerin (Berlin 1910).

Benac - Čović 1957

A. Benac - B. Čović, Glasinac II. Eisenzeit. Kataloge der Vorgeschichtlichen Sammlung des Landesmuseums Sarajevo H. 2 (Sarajevo 1957).

Benson 1973

J. L. Benson, The Necropolis of Kaloriziki, Studies in Mediterranean Archaeology 36 (Gothenburg 1973).

Benz 2008

M. Benz (ed.), Unter uns. Archäologie in Basel (Basel 2008).

Berardinetti - Drago 1997

A. Berardinetti - L. Drago, La necropoli di Grotta Grammiccia, in: G. Bartoloni (ed.), Le necropoli arcaiche di Veio. Giornata di studio in memoria di Massimo Pallottino (Rome 1997) 39-61.

Berciu 1966

D. Berciu, Neue Forschungsergebnisse zur Vorgeschichte Rumäniens, Antiquitas Series 2 Vol. 4 (Bonn 1966).

Berthelot 2014

S. Berthelot, Les casques de Bernières-d'Ailly (Calvados). Une découverte qui défraie la chronique, in: Arkéo XIXe-XXIe siècle, quand l'homme construit son passé. Exhibition Catalogue Roanne (Roanne 2014) 55-57.

Bianco-Peroni 1970

V. Bianco-Peroni, Die Schwerter in Italien. Le spade nell'Italia continentale, Prähistorische Bronzefunde IV, 1 (Munich 1970).

Bianco-Peroni 1979

V. Bianco-Peroni, I rasoi nell'Italia continentale, Prähistorische Bronzefunde VIII, 2 (Munich 1979).

Bietti Sestieri 2008

A. M. Bietti Sestieri, L'età del bronzo finale nella penisola italiana, Padusa XLIV, 2008, 7-54

Bietti Sestieri 2011

A. M. Bietti Sestieri, Archeologia della morte fra età del bronzo ed età del ferro in Italia. Implicazioni delle scelte relative alla sepoltura in momenti di crisi o di trasformazione politico-organizzativa, in: V. Nizzo (ed.), Dalla Nascita alla Morte. Archeologia e antropologia a confronto (Rome 2011) 397-418.

Bietti Sestieri et al. 2013

A. M. Bietti Sestieri - L. Salzani - C. Giardino - G. Verly, Ritual treatment of weapons as a correlate of structural change in the Italian LBA communities. The bronze hoard of Pila del Brancon (Nogara, Verona), Rivista di Scienze Preistoriche LXIII, 2013, 155-169.

Bill 1979

J. Bill, Zum derzeitigen Stand der Nassholzkonservierung, Zeitschrift für schweizerische Archäologie und Kunstgeschichte 36, 1979, 97-145.

Billig 1963

G. Billig, Frühbronzezeitliche Funde der Niederlausitz und ihre Stellung innerhalb der Uneticer Kultur, Alt-Thüringen $6,1963,246-273$.

Blajer 1990

W. Blajer, Skarby z wczesnej epoki brązu na ziemiach polskich, Prace Komisji Archeologicznej Polkskiej Akademii Nauk - Oddział w Krakowie (Wrocław, Warsaw, Krakow, Gdańsk, Łodž 1990).

Blanchet 1984

J.-C. Blanchet, Les premiers métallurgistes en Picardie et dans le Nord de la France. Chalcolithique, Âge du Bronze et début du premier Âge du Fer, Mémoires de la Société Préhistorique Française 17 (Paris 1984).

Blanchet - Lambot 1975

J.-C. Blanchet - B. Lambot, L’Âge du Bronze dans les musées de l'Oise, Cahiers Archéologiques de Picardie 2, II, $1975,25-70$. 
Bonnamour 1975

L. Bonnamour, Chronique archéologique, Mémoires de la Société d'Histoire et d'Archéologie de Chalon-sur-Saône XLV, 1975, 16-21.

Bonnamour 1985

L. Bonnamour, Les sites de la Saône aux ages du fer. Problématique, 6e supplément à la R. A. E. Actes du 7e colloque de l'A.F.E.A.F. (Rully 1985) 25-31.

Bonnamour 1989

L. Bonnamour, Chalon-sur-Saône, le Port Ferrier. Archéologie de la France. 30 ans de découvertes (Paris 1989).

Bonnamour 1990

L. Bonnamour (ed.), Du silex à la poudre. 4000 ans d'armement en val de Saône. Exhibition Catalogue Chalon-surSaône (Montagnac 1990)

Bonnamour 2000

L. Bonnamour, Archéologie de la Saône. 150 ans de recherche (Paris 2000).

Bonnamour 2009

L. Bonnamour, La vallée de la Saône, axe de communication privilégié du Chalcolithique à la fin de l'Âge du Bronze, in: R. Annick (ed.), L'isthme européen Rhin-Saône-Rhône dans la Protohistoire. Approches nouvelles en hommage à Jacques-Pierre Millotte. Actes du colloque de Besançon, 16-18 octobre 2006 (Besançon 2009) 57-68.

Bonnamour - Mordant 1988

L. Bonnamour - C. Mordant, La phase moyenne du Bronze final en Bourgogne orientale, in: P. Brun - C. Mordant (eds.), Le groupe Rhin-Suisse-France orientale et la notion de civilisation des Champs d'Urnes. Actes du colloque international de Nemours 1986 (Nemours 1988) 363-372.

Bonnamour et al. 1976

L. Bonnamour - C. Mordant - J.-P. Nicolardot, Les civilisations de l’Âge du Bronze en Bourgogne, in: J. Guilaine (ed.), La préhistoire Française (Paris 1976) 601-617.

Borchhardt 1972

J. Borchhardt, Homerische Helme. Helmformen der Ägäis in ihren Beziehungen zu orientalischen und europäischen Helmen in der Bronze- und frühen Eisenzeit (Mainz 1972).

Borchhardt 1977

L. Borchhardt, Helme, in: H.-G. Buchholz - J. Wiesner, Archaeologia Homerica. Die Denkmäler und das frühgriechische Epos Vol. 1, E: Kriegswesen Pt. 1: Schutzwaffen und Wehrbauten (Göttingen 1977) E 57-74.

Borgna 1999

E. Borgna, The North Adriatic regions between the Aegean world $\left(12^{\text {th }}-8^{\text {th }}\right.$ century). Social strategies and symbols of power in the long-distance exchange, in: Eliten der Bronzezeit. Ergebnisse zweier Kolloquien in Mainz und Athen, Monographien des Römisch-Germanischen Zentralmuseums 43, 1 (Mainz 1999) 151-183.

Borgna - Montagnari Kokelj 1999

E. Borgna - E. Montagnari Kokelj, Nuove ricerche su complessi protostorici ai confini settentrionali dell'Istria, in:

O. Paoletti - L. Tamagno Perna (eds.), Protostoria e storia del 'Venetorum Angulus'. Atti del XX convegno di studi etruschi ed italici, Portogruaro - Quarto d'Altino - Este - Adria, 16-19 ottobre 1996 (Pisa, Rome 1999) 131-156.

Born 2009

H. Born, Die Helme des Hephaistos (Munich 2009).

Born - Hansen 1992

H. Born - S. Hansen, Ein urnenfelderzeitlicher Glockenhelm aus der Sammlung Zschille, Acta Praehistorica et Archaeologica 24, 1992, 339-356.

Born - Hansen 2001

H. Born - S. Hansen, Helme und Waffen Alteuropas, Sammlung Axel Guttmann 9 (Mainz 2001). 
Born - Hoffmann 1992

H. Born - A. Hoffmann, Der Helm von Szczecin-Zdroje (Stettin), Führungsblatt zum Berliner Fund des Monats Januar, Museum für Vor- und Frühgeschichte Berlin (Berlin 1992).

Born - Nebelsick 1991

H. Born - L. D. Nebelsick, Ein bronzener Prunkhelm der Hallstattzeit, Sammlung Axel Guttmann 1 (Berlin 1991).

Bornschein - Gandert 1929

O. Bornschein - O. F. Gandert, Heimatkunde für den Kreis Liebenwerda (Bad Liebenwerda 1929).

Bottaini - Rodrigues 2011a

C. Bottaini - A. Rodrigues, O conjunto de metais da Idade do Bronze de Vila Cova de Perrinho (Vale de Cambra, Portugal central) 50 anos após a sua descoberta, Estrat Crític. Revista d'Arqueologia 5, 3, 2011, 103-114.

Bottaini - Rodrigues 2011b

C. Bottaini - A. Rodrigues, O conjunto de metais de Vila Cova de Perrinho, Vale de Cambra. Caracterização química e reavaliação dos contextos, Oppidum 6, 5, 2011, 27-40.

Bourgeois 1875

L. Bourgeois, Une sépulture de l'Âge du Bronze dans le département de Loir-et-Cher, Revue Archéologique XXIX, $1875,73-76$.

Bouzek 1981

J. Bouzek, Die Anfänge der blechernen Schutzwaffen im östlichen Mitteleuropa, in: H. Lorenz (ed.), Studien zur Bronzezeit, Festschrift für Wilhelm Albert v. Brunn (Mainz 1981) 21-38.

Bouzek 1988

J. Bouzek, An alternative reconstruction of the Kaloriziki shield, Report of the Department of Antiquities Cyprus 1988, 319-320.

Bouzek 1997

J. Bouzek, Greece, Anatolia and Europe. Cultural Interrelations during the Early Iron Age, Studies in Mediterranean Archaeology 122 (Jonsered 1997).

Boyer 2000

R. Boyer, L'aven Plérimond, in: J. Chausserie-Laprée (ed.), Le temps des Gaulois en Provence (Martigues, Ziem 2000) 256-259.

Boyer et al. 2006

R. Boyer - B. Dedet - G. Marchand, L'aven sépulcral de Plérimond à Aups, Var (VIe s. av. J.-C.), Gallia 63, 1, 2006, $171-209$.

Bradley 1990

R. Bradley, The Passage of Arms. An Archaeological Analysis of Prehistoric Hoard and Votive Deposits (Cambridge 1990).

Brandão 1963

D. P. Brandão, Achado da "época do bronze" de Vila Cova de Perrinho - Vale de Cambra, Lvcerna 3, 1963, $114-$ 118.

Brandherm 2007

D. Brandherm, Las espadas del Bronce Final en la Península Ibérica y Baleares, Prähistorische Bronzefunde IV, 16 (Stuttgart 2007).

Brandherm 2008

D. Brandherm, The warriors' new headgear, Antiquity 82, 316, 2008, 480-484.

Brandherm 2011

D. Brandherm, Bronzezeitliche Kamm- und Hörnerhelme. Überlegungen zu Ursprung, Verbreitung und symbolischem Gehalt, in: A. Jockenhövel - U. L. Dietz (eds.), Bronzen im Spannungsfeld zwischen praktischer Nutzung und symbolischer Bedeutung, Prähistorische Bronzefunde XX, 13 (Stuttgart 2011) 39-54. 
Breddin 1969

R. Breddin, Der Uneticer Bronzehortfund von Bresinchen, Kr. Guben, Veröffentlichungen des Museums für Urund Frühgeschichte Potsdam 5, 1969, 15-56.

Breuil 1900

H. Breuil, L’Âge du Bronze dans le bassin de Paris 1. Les épées et dagues du bassin de la Somme, L’Anthropologie XI, 1900, 503-535.

Briard - Mohen 1983

J. Briard - J.-P. Mohen, Typologie des objets de l'Âge du Bronze en France II. Poignards, hallebardes, pointes de lance, pointes de flèche, armement défensif (Paris 1983).

Bridgford 2000

S. D. Bridgford, Weapons, Warfare and Society in Britain 1250-750 BC (PhD Diss., University of Sheffield, Sheffield 2000).

Brinker et al. 2013

U. Brinker - S. Flohr - J. Piek - A. Schramm - J. Orschiedt, Die bronzezeitlichen Menschenreste aus dem Tollensetal, Mecklenburg-Vorpommern. Opfer eines gewaltsamen Konflikts?, Mitteilungen der Anthropologischen Gesellschaft in Wien 143, 2013, 131-147.

Brinker et al. 2014

U. Brinker - S. Flohr - J. Piek - J. Orschied, Violent death and injury in Bronze Age human remains from riverine contexts in the Tollense Valley, Germany. Victims of a battle?, in: C. Knüsel - M. Smith (eds.), The Bioarchaeology of Human Conflict. Traumatized Bodies from Early Prehistory to the Present (London 2014) 146-160.

Brinker et al. 2015

U. Brinker - A. Schramm - S. Flohr - T. Orschiedt, Die menschlichen Skelettreste aus dem Tollensetal, in: Meller Schefzik 2015, 347-350.

British Museum Guide 1904

British Museum Guide, A Guide to the Antiquities of the Bronze Age in the Department of British and Mediaeval Antiquities (London 1904).

Broholm 1944

H. C. Broholm, Danmarks Bronzealder 2 (Copenhagen 1944).

Brøndsted 1958

J. Brøndsted, Danmarks Oltid II. Bronzealderen (Copenhagen 1958).

Brøndsted 1962

J. Brøndsted, Nordische Vorzeit II. Bronzezeit (Neumünster 1962).

Brun et al. 2007

P. Brun - E. Ghesquiére - C. Marcigny, Le dépôt de casques de Bernières d'Ailly (Calvados) et la fonction sociale de l'armement défensif du XIVe au VIe s. av. J.-C., Bulletin de l'Association pour la Promotion des Recherches sur l’Âge du Bronze 4, 2007, 41.

Brun et al. in preparation

P. Brun - E. Ghesquiére - C. Marcigny - B. Mille, Les casques de Bernières d'Ailly, in preparation.

Buchholz et al. 2010

H.-G. Buchholz - H. Matthäus - M. Wiener, Helmentwicklung mit Berücksichtigung eines unbekannten altägäischen Bronzehelms, in: H.-G. Buchholz, Archaeologia Homerica. Die Denkmäler und das frühgriechische Epos. Kriegswesen Pt. 3: Ergänzungen und Zusammenfassung (Göttingen 2010) 135-208.

Bukowski - Dąbrowski 1972

Z. Bukowski - K. Dąbrowski, Świt kultury europejskiej (Warsaw 1972).

Bulard 2008

Bulard, A. Un dépôt de neuf cuirasses découvert à paris au XVIIe s., Revue archéologique d'Île-de-France 1, 2008, 125-132. 
Bulat 1973/1975

J. J. Bulat, Kasnobrončanodobni depo iz Poljanaca na Savi, Osiječki Zbornik XIV-XV, 1973/1975, 3-56.

Burgess 1991

C. Burgess, The East and the West. Mediterranean influences in the Atlantic world in the later Bronze Age, c. 1500-700 BC, in: Ch. Chevillot - A. Coffyn (eds.), L'Âge du Bronze Atlantique. Actes du ler colloque du parc archéologique de Beynac 1991 (Dordogne 1991) 25-45.

Cahn Auktionskatalog 2002

Auktionskatalog Jean-David Cahn AG, Auktion 4, 19. 10. 2002 (Leipzig 2002).

Calzecchi-Onesti 1991

G. Calzecchi-Onesti, Connessioni europee di alcuni elmi italiani, Annali della Facoltá di Lettere e Filosofia dell’Università degli Studi di Perugia 25, N. S. 11, 1987-1988/1991, 65-111.

Carthailhac 1875/1878

E. Carthailhac, Dictionnaire archéologique de la Gaule. Epoque celtique (Paris 1875/1878).

Caskey 1966

J. L. Caskey, Excavations in Keos 1964-1965, Hesperia 35, 4, 1966, 363-376.

Càssola Guida 1973

P. Càssola Guida, Le armi difensive dei Micenei nelle figurazioni (Rome 1973).

Castelfranco 1887

P. Castelfranco, Torbiera d'Iseo, Bullettino di Paletnologia Italiana 13, 1887, 145-149.

Cateni 1977

G. Cateni, Il ripostiglio di Limone (Livorno), Studi Etruschi 45 (Ser. III), 1977, 3-37.

Catling 1955

H. W. Catling, A bronze greave from a $13^{\text {th }}$ century BC tomb at Enkomi, Opuscula Atheniensia 2, 1955, 21-36.

Catling 1964

H. W. Catling, Cypriot Bronzework in the Mycenaean World (Oxford 1964).

Catling 1977a

H. W. Catling, Panzer, in: H.-G. Buchholz - J. Wiesner, Archaeologia Homerica. Die Denkmäler und das frühgriechische Epos Vol. 1, E: Kriegswesen Pt. 1: Schutzwaffen und Wehrbauten (Göttingen 1977) E 74-118.

Catling 1977b

H. W. Catling, Beinschienen, in: H.-G. Buchholz - J. Wiesner, Archaeologia Homerica. Die Denkmäler und das frühgriechische Epos Vol. 1, E: Kriegswesen Pt. 1: Schutzwaffen und Wehrbauten (Göttingen 1977) E 143-161.

Celestino Pérez 2001

S. Celestino Pérez, Estelas de guerrero y estelas diademadas. La precolonización y formación del mundo tartésico (Bellaterra 2001).

Celestino Pérez - López-Ruiz 2006

S. Celestino Pérez - C. López-Ruiz, New light on the warrior stelae from Tartessos (Spain), Antiquity 80, 2006, 89-101.

Čerče- Šinkovec $1995 \mathrm{a}$

P. Čerče - I. Šinkovec, Katalog posameznih kovinskih najdb bakrene in bronaste dobe, in: B. Teržan (ed.), Depojske in posamezne kovinske najdbe bakrene in bronaste dobe na Slovenskem 1, Katalogi in Monografije 29 (Ljubljana 1995) 29-127.

Čerče - Šinkovec 1995b

P. Čerče - I. Šinkovec, Katalog depojev pozne bronaste dobe, in: B. Teržan (ed.), Depojske in posamezne kovinske najdbe bakrene in bronaste dobe na Slovenskem 1, Katalogi in Monografije 29 (Ljubljana 1995) 129-232. 
Cesari - Leandri 2010

J. Cesari - F. Leandri, Le mégalithisme de la Corse. Aspects et problèmes, in: X. Delestre - H. Marchesi (eds.), Archéologie des rivages méditerranéens. 50 ans de recherche. Actes du colloque d'Arles (Bouches-du-Rhône) 28-30 octobre 2009 (Paris 2010) 391-405.

Chadwick 1976

J. Chadwick, The Mycenaean World (Cambridge 1976).

Chantre 1875

E. Chantre, Observation sur la découverte du deuxième Âge du Bronze à la Fosse-aux-Prêtres, près du Theil, commune de Billy-sur-Cher (Loir-et-Cher) par M. l'abbé Bourgeois, Matériaux VI, 1875, 111-118.

Chantre 1876

E. Chantre, L'Âge du Bronze I (Paris 1876).

Christie's 1998

Christie's Auction, Lot 64, Sale 9020. An Aegean or Balkan bronze helmet - Antiquities. Park Avenue, New York, 18 December 1998. Online <http://www.christies.com/lotfinder/lot_details.aspx?intObjectID=1403203\&lid=1\&From= searchresults\&sid=9074ddb5-2a51-4789-be39-6bf13050355d $>$ (last access 27 February 2017).

Christie's 2002

Christie's Auction, Lot 10, Sale 9482. A European Bronze Age helmet - The Art of Warfare. The Axel Guttmann Collection, Part 1. South Kensington, London, 6 November 2002. Online <http://www.christies.com/lotfinder/lot details.aspx?intObjectID=3993824\&lid=1\&From=searchresults\&sid=9074ddb5-2a51-4789-be39-6bf13050355d $>$ (last access 27 February 2017).

Ciugudean et al. 2006

H. Ciugudean - S. A. Luca -A. Georgescu, Depozitul de bronzuri de la Dipşa, Bibliotheca Brukenthal V (AlbaIulia 2006).

Clarke 1978

D. L. Clarke, Analytical Archaeology, $2^{\text {nd }}$ edition (London 1978).

Clausing 1996

C. Clausing, Urnenfelderzeitliche Vorläufer eisenzeitlicher Rippenzisten?, Archäologisches Korrespondenzblatt 26, 1996, 413-431.

Clausing 2001

C. Clausing, Spätbronze- und eisenzeitliche Helme mit einteiliger Kalotte, Jahrbuch des Römisch-Germanischen Zentralmuseums Mainz 48, 1, 2001, 199-225.

Clausing 2002

C. Clausing, Geschnürte Beinschienen der späten Bronze- und frühen Eisenzeit, Jahrbuch des Römisch-Germanischen Zentralmuseums Mainz 49, 2002, 149-187.

Clausing 2003

C. Clausing, Ein urnenfelderzeitlicher Hortfund von Slavonski Brod, Kroatien, Jahrbuch des Römisch-Germanischen Zentralmuseums Mainz 50, 1, 2003, 47-205.

Clausing 2005

C. Clausing, Zwei neue urnenfelderzeitliche Bronzehelme mit Scheitelknauf, Archäologisches Korrespondenzblatt 35, 2005, 31-38.

Coblenz 1951

W. Coblenz, Der Bronzegefässfund von Dresden-Dobritz, Arbeits- und Forschungsberichte zur Sächsischen Bodendenkmalpflege 2, 1951, 135-161.

Coffyn 1985

A. Coffyn, Le Bronze final atlantique dans la péninsule ibérique (Paris 1985).

Coles 1962

J. Coles, European Bronze Age shields, Proceedings of the Prehistoric Society 28, 8, 1962, 156-190. 
Coles 1977

J. Coles, Parade and display. Experiments in Bronze Age Europe, in: v. Marcotic (ed.) Ancient Europe and the Mediterranean (Warminster 1977) 51-58.

Coles - Harding 1979

J. Coles - A. Harding, The Bronze Age in Europe (London 1979).

Colonna 1991

C. Colonna, Necropoli dell'ultima età del bronzo nell'area padana (Lucca 1991).

Coombs 1992

D. Coombs, Flag Fen platform and Fengate power sation post alignment. The metalwork, Antiquity 66, 1992, 504517.

Cordier 1997

G. Cordier, La sépulture de l'Âge du Bronze final du Theil à Billy (Loire-et-cher, France), Archäologisches Korrespondenzblatt 27, 1997, 73-92.

Costamagna - Visoná 1999

L. Costamagna - P. Visoná, Oppido Mamertina. Ricerche archeologiche nel territorio e in contrada Mella (Arti visive, architettura e urbanistica) (Rome 1999).

Coutil 1902

L. Coutil, L'époque Gauloise dans le sud-ouest de la Belgique et le nord-ouest de la Celtique, Bulletin de la Société Normande d'Études Préhistoriques IX/1901, 1902, 48-138.

Coutil 1907

L. Coutil, Inventaire des découvertes de l’Âge du Bronze dans le départment du Calvados, Association Française pour l'Avancement des Sciences, Compte Rendu de la 36me Session (Reims 1907) 946-973.

Coutil 1910

L. Coutil, Les casques de Bernières d'Ailly (Calvados), Bulletin de la Société Préhistorique Française 7, 11, 1910, $579-588$.

Coutil 1911

L. Coutil, Les casques de Bernières d’Ailly (Calvados), Bulletin de la Société Préhistorique Française 8, 12, 1911, $3-12$.

Coutil 1912

L. Coutil, Présentation d'un casque inédit de l'Âge du Bronze, trouvé à Mantes (Seine-et-Oise), Bulletin de la Société Préhistorique Française 9, 11, 1912, 693-695.

Coutil 1926

L. Coutil, A propos de la communication de M. Hémery sur un casque, Bulletin de la Société Préhistorique de France 23, 12, 1926, 302-304.

Coutil 1927

L. Coutil, Le casque de Blainville (Meurthe-et-Moselle), Bulletin de la Société Préhistorique Française 24, 10, 1927, $362-366$.

Čović 1976

B. Čović, Bronzane knemide iz Dabrice kod Stoca, Glasnik Zemaljskog Muzeja Bosne i Hercegovie u Sarajevu Arheologija, N. S. 29, 1976, 19-33.

Črešnar 2010

M. Črešnar, New research on the Urnfield period of Eastern Slovenia. A case study of Rogoza near Maribor, Arheološki Vestnik 61, 2010, 7-119.

D’Agostino 1965

B. d'Agostino, Nuovi apporti della documentazione archeologica nell'agro Picentino, Studi Etruschi 33, 1965, 671683. 
D’Agostino - Gastaldi 1988

B. d'Agostino - P. Gastaldi (eds.), Pontecagnano II. La necropoli del Picentino 1. Le tombe della prima etá del ferro (Naples 1988).

D'Amato - Salimbeti 2011

R. d'Amato - A. Salimbeti, Bronze Age Greek Warrior 1600-1100 BC (Oxford 2011).

D’Amato - Salimbeti 2015

R. d'Amato - A. Salimbeti, Sea Peoples of the Bronze Age Mediterranean c. 1400-1000 BC (Faenza 2015)

Dahn 1881

F. Dahn, Urgeschichte der germanischen und romanischen Völker Vol. 1, Allgemeine Geschichte in Einzeldarstellungen 2,2 (Berlin 1881).

Daux 1958

G. Daux, Chronique des fouilles et découvertes archéologiques en Grèce en 1957, Bulletin de Correspondance Héllenique $82,1958,644-830$.

de Beauregard 1901

O. C. de Beauregard, Les cuirasses Celtiques de Fillinges, Revue Archéologique 39, 1901, 308-315.

de Beauregard 1909

O. C. de Beauregard, Les casques de bronze dits de Falaise. Leur origine et leur âge, in: Congrès archéologique de France, LXXVe session, Caen 1908 Vol. 2 (Paris 1909) 473-501.

de Beauregard 1910

O. C. de Beauregard, Les casques dits de Falaise, leur âge et leur origine véritable (Caen 1910).

de Caro et al. 1996

S. de Caro - M. Borriello - S. Cassani, I Greci in Occidente. La Magna Grecia nelle collezioni del Museo Archeologico Nazionale di Napoli (Naples 1996) 161-164.

de Linas 1869

C. de Linas, Les casques de Falaise et d'Amfreville-sous-les-Monts (Normandie). Armures des hommes du Nord (Arras 1869).

de Marinis 1979

R. C. de Marinis, Scavi e scoperte. Malpensa, Studi Etruschi 31, 1979, 511-512.

de Marinis 1982

R. C. de Marinis, La protostoria, in: B. Bagolini (ed.), Archeologia in Lombardia (Milan 1982) 83-106.

de Marinis 1988

R. C. de Marinis, Il periodo formativo della cultura di Golasecca, in: A. M. Chieco Bianchi - G. Colonna - B. d'Agostino - F. d'Andria - E. M. de Juliis - R. C. de Marinis - V. Kruta - M. Landolfi - F. Roncalli (eds.), Italia. Omnium Terrarum Alumna. A civiltà dei Veneti, Reti, Liguri, Celti, Piceni, Umbri, Latini, Campani e Iapigi (Milan 1988) 161-175.

de Marinis 1999

R. C. de Marinis, Towards a relative and absolute chronology of the Bronze Age in Northern Italy, Notizie Archeologiche Bergomensi 7, 1999, 23-100.

de Marinis 2009

R. C. de Marinis, Il ripostiglio della Malpensa (Somma Lombardo, VA), in: R. C. de Marinis - S. Massa - M. Pizzo (eds)., Alle origini di Varese e del suo territorio. Le collezioni del sistema archeologico provinciale (Rome), $146-154$

de Marinis 2016

R. C. de Marinis, Un elmo a calotta composta della tarda età del bronzo, Notizie Archeologiche Bergomensi 24, 2016, 69-94. 
de Mortillet 1908

A. de Mortillet, Cachette larnaudienne de la Grande-Roche à Boutigny (Seine-et-Oise 1908), L'Homme Préhistorique $6,1908,105-112$.

de Nieuwerkerke 1868

M. de Nieuwerkerke, Situation des Musées Impériaux, pendant le régne de S. M. Napoléon III (Paris 1868).

de Ridder 1915

A. de Ridder, Bronzes antiques du Louvre. Tome II : Les instruments (Paris 1915).

de Santis 2011

A. de Santis, Politica e leader nel Lazio ai tempi di Enea (Rome 2011).

Dean 1921

B. Dean, Handbook of Arms and Armours. Metropolitan Museum of Art (New York 1921).

Déchelette 1908/1914

J. Déchelette, Manuel d'archéologie préhistorique, celtique et gallo-romaine II (Paris 1908/1914).

Déchelette 1910

J. Déchelette, Manuel d'archéologie préhistorique, celtique et gallo-romaine, 1908-1914, Série B (Paris 1910).

Déchelette 1924

J. Déchelette, Manuel d'archéologie préhistorique, celtique et gallo-romaine, II, lre part. Âge du Bronze (Paris 1924).

Deger-Jalkotzy 2006

S. Deger-Jalkotzy, Schwertkrieger und Speerträger im spätmykenischen Griechenland, in: R. Rollinger - B. Truschegg (eds.), Altertum und Mittelmeerraum. Die antike Welt diesseits und jenseits der Levante. Festschrift für Peter W. Haider zum 60. Geburtstag (Stuttgart 2006) 711-718.

Dehn 1980

W. Dehn, Zur Beinschiene von Schäfstall bei Donauwörth, Zeitschrift des Historischen Vereins Schwaben 74, 1980 $29-33$.

Della Casa - Fischer 1997

P. Della Casa - C. Fischer, Neftenbach (CH), Velika Gruda (YU), Kastanas (GR) und Trindhøj (DK). Argumente für einen Beginn der Spätbronzezeit (Reinecke BzD) im 14. Jahrhundert v. Chr, Prähistorische Zeitschrift 72, 1997, $195-233$.

Delpino 2005

F. Delpino, Dinamiche sociali e innovazioni rituali a Tarquinia tra IX e VIII secolo a.C. Le tombe I e II del sepolcreto di Poggio dell'Impiccato, in: O. Paoletti (ed.), Dinamiche di sviluppo delle città dell'Etruria meridionale. Veio, Caere, Tarquinia, Vulci. Atti del XXIII Convegno di studi etruschi ed italici, Roma-Viterbo, October 2001 (Pisa 2005) 343-358

Demakopoulou - Konsola 1981

K. Demakopoulou - D. Konsola, Archaeological Museum of Thebes. Guide (Athens 1981)

Demmin 1869

A. Demmin, Guide des amateurs d'armes et armures anciennes par ordre chronologique. Depuis les temps les plus reculés jusqu'a nos jours (Paris 1869).

Deonna 1933

W. Deonna, Des cuirasses celtiques découvertes en 1900 près d'un village de la Haute-Savoie, Tribune de Genève, 16 September 1933.

Deonna 1934a

W. Deonna, Acquisitions des collections en 1933. Les collections archéologiques, les armures, le musée des moulages, les séries lapidaires, Genava 12, 1934, 5-10. 
Deonna 1934b

W. Deonna, Les cuirasses hallstattiennes de Fillinges au Musée d'art et d'histoire de Genève, Préhistoire 3, 1934, 93-143.

Deonna 1935

W. Deonna, Quelques monuments antiques, Genava 13, 1935, 202-229.

Deonna 1946

W. Deonna, Cuirasses hallstattiennes au musée de Genève, Ur-Schweiz 10, 2, 1946, 30-36.

Desborough 1964

V. Desborough, The Last Mycenaeans and Their Successors (Oxford 1964).

Descamps 2005

S. Descamps, Cuirasse, in: C. Marcigny - C. Colonna - E. Ghesquière - G. Verron (eds.), La Normandie à l'aube de l'histoire. Les découvertes archéologiques de l’Âge du Bronze 2500-800 av. J.-C. (Paris 2005).

di Mantova - Watelet 2003

A. di Mantova - S. Watelet, Les cuirasses de Marmesse. Une illustration de l'importance du principe de la lisibilité de l'oeuvre restaurée, in: Visibilité de la restauration, lisibilité de l'œuvre. 5e colloque de l'association des restaurateurs d'art et d'archéologie de formation universitaire, 13 - 15 juin 2002 (Paris 2003) 165-175.

Díaz-Guardamino 2012

M. Díaz-Guardamino, Estelas decoradas del Bronce Final en la Península Ibérica. Datos para su articulación cronológica, Anejos de Archivo Español de Arqueologia XLII, 2012, 389-416.

Dietrich 2009

O. Dietrich, Tönerne Miniaturen von Beinschienen? Gedanken zu zwei Tonobjekten der Gârla Mare Kultur, Materiale şi Cercetări Arheologice 5, 2009, 91-96.

Dombrowsky 2014

A. Dombrowsky, Bronzezeitliche Metallfunde aus dem Gebiet der mittleren Tollense unter besonderer Berücksichtigung der Flussfunde, in: D. Jantzen - J. Orschiedt - J. Piek - T. Terberger (eds.), Tod im Tollensetal. Forschungen zu den Hinterlassenschaften eines bronzezeitlichen Gewaltkonfliktes in Mecklenburg-Vorpommern. Teil 1. Die Forschungen bis 2011 (Schwerin 2014) 131-180.

Doran - Hodges 1975

J. E. Doran - F. R. Hodges, Mathematics and Computers in Archaeology (Edinburgh 1975).

Doranlo 1952/1954

R. Doranlo, Les monts d'Eraines et les casques de Falaise, Bulletin de la Société des Antiquaires de Normandie II, 1952/1954, 94-116.

Douau 1994

F. Douau, Restauration d'un ensemble de cuirasses du tout debut de l'Âge du Fer, Xe journée des restaurateurs en archéologie, MAN, 1994, 34-37.

Drescher 1958

H. Drescher, Der Überfangguss (Mainz 1958).

Drews 1993

R. Drews, The End of the Bronze Age. Changes in Warfare and the Catastrophe ca. 1200 BC (Princeton 1993).

Dumitrescu 1938

H. Dumitrescu, Objets inédits en bronze de Şpălnaca au Musée National des Antiquités de Bucarest, Dacia 5-6/1935-1936, 1938, 195-224.

Eckhart 1962/1963

C. Eckhart, Der Bronzefund von Schmiedehausen, Kr. Apolda, Alt-Thüringen 6, 1962/1963, 300-310.

Egg 1983

M. Egg, Ein eisenzeitlicher Weihefund aus Sizilien, Jahrbuch des Römisch-Germanischen Zentralmuseums Mainz 30, 1983, 195-205. 
Egg 2002

M. Egg, Ein Bronzehelm aus dem mittelbronzezeitlichen Depotfund vom Piller, Bemerkungen zu den ältesten Metallhelmen Europas, ArchaeoTirol, Kleine Schriften 4, 2002, 47-53.

Egg - Tomedi 2002

M. Egg - G. Tomedi, Ein Bronzehelm aus dem mittelbronzezeitlichen Depotfund vom Piller, Gemeinde Fliess in Nordtirol, Archäologisches Korrespondenzblatt 32, 2002, 543-560.

Egg - Waurick 1990

M. Egg - G. Waurick, Antike Helme. Exhibition Catalogue Speyer (Mainz 1990).

Eibner 1980

C. Eibner, Der Bereich der mittleren Donau während der späten Bronze- und frühen Eisenzeit, in: S. DegerJalkotzy (ed.), Griechenland, die Ägäis und die Levante während der 'Dark Ages' vom 12. bis zum 9. Jh. v. Chr. (Vienna 1980) 285-311.

Eichhom 1904

G. Eichhorn, Die vor- und frühgeschichtlichen Funde der Grafschaft Camburg, Zeitschrift des Vereins für Thüringische Geschichte N.F. 14, 1904, 97-144.

Eisenberg - Price 2006

J. M. Eisenberg - F. W. Price, Art of the Ancient World Vol. XVIII - January 2007. Greek, Etruscan, Roman, Egyptian, \& Near Eastern Antiquities, Celebrating our $65^{\text {th }}$ Anniversary, Royal-Athena Galleries (New York, London 2006). Online $<$ http://www.royalathena.com/media/intropagespics/AAW07.pdf $>$ (last access 27 February 2017).

Eisner 1933

J. Eisner, Slovensko v pravěku (Bratislava 1933).

Everson 2004

T. Everson, Warfare in Ancient Greece (Stroud 2004).

Fabbricotti et al. 1972

E. Fabbricotti - C. Franco - A. Emiliozzi, Veio. Relative preliminare delle campagne di scavo, Notizie degli Scavi di Antichità 26, 1972, 195-384.

Fallue 1866

L. Fallue, De l'armement des Romains et des Celtes à l'époque de la guerre des Gaules, d'après les commentaires de César (Le Havre 1866).

Feugère 1994

M. Feugère, Casques antiques. Les visages de la guerre, de Mycènes à la fin de l'Empire romain (Paris 1994).

Feugère 2005

M. Feugère, Le casque républicain de Sainte-Foy-lès-Lyon et la question des casques romains surmontés d'un anneau, in: N. Crummy (ed.), Image, Craft and the Classical World. Essays in Honour of Donald Bailey and Catherine Johns, Monographie Instrumentum 29 (Montagnac 2005) 85-92.

Fiala 1895

F. Fiala, Die Ergebnisse der Untersuchungen prähistorischer Grabhügel auf dem Glasinac im Jahre 1893, Wissenschaftliche Mitteilungen Bosnien und Herzegowina 3, 1895, 3-38.

Fiorelli 1869

G. Fiorelli (ed.), Catalogo del Museo Nazionale di Napoli. Armi antiche (Naples 1869).

Flohr et al. 2014

S. Flohr - U. Brinker - E. Spanagel - A. Schramm - J. Orschiedt - U. Kierdorf, Killed in action? A biometrical analysis of femora of supposed battle victims from the Middle Bronze Age site of Weltzin 20, Germany, in: D. L. Martin - C. P. Anderson (eds.), Bioarchaeological and Forensic Perspectives on Violence. How Violence is Interpreted from Skeletal Remains (Cambridge 2014) 17-33.

Fogolari 1943a

G. Fogolari, Beinschienen der Hallstattzeit von Pergine (Valsugana), Wiener Prähistorische Zeitschrift 30, 1943, 73-81. 
Fogolari 1943b

G. Fogolari, Quattro schinieri di bronzo, Studi Trentini di Scienze Storiche XXIV, 2, 1943, 106-113.

Fogolari 1944

G. Fogolari, Pergine. Schinieri di bronzo, Notizie degli Scavi di Antichità 68/1943, 1944, 4-11.

Fogolari 1975

G. Fogolari, La protostoria delle Venezie, Popoli e Civiltà dell'Italia Antica 4, 1975, 61-222.

Fogolari - Prosdocimi 1989

G. Fogolari - A. L. Prosdocimi, I Veneti antichi (Padua 1989).

Foltiny 1961

S. Foltiny, Über die Fundstelle und Bedeutung der angeblich aus Kiskőseg stammenden hallstattzeitlichen Bronzen des Römisch-Germanischen Zentralmuseums Mainz, Jahrbuch des Römisch-Germanischen Zentralmuseums Mainz 8, 1961, 175-189.

Forrer 1894

R. Forrer, Die Waffensammlung des Herrn Stadtrath Rich. Zschille in Grossenhain, Sachsen (Berlin 1894).

Fortenberry 1990

C. D. Fortenberry, Elements of Mycenaean Warfare (PhD Diss.,University of Cincinnati, Cincinnati 1990).

Frey 1990

O.-H. Frey, Ein tönerner Kammhelm aus Populonia. Überlegungen zur Verbreitung früher Helme in Italien, in: F. M. Andraschko - W. R. Teegen (eds.), Gedenkschrift für Jürgen Driehaus (Mainz 1990) 225-234.

Furmánek - Novotná 2006

V. Furmánek - M. Novotná, Die Sicheln in der Slowakei, Prähistorische Bronzefunde XVIII, 6 (Stuttgart 2006).

Furtwängler 1890

A. Furtwängler, Die Bronzen und die übrigen kleineren Funde von Olympia (Berlin 1890).

Fyllingen 2006

H. Fyllingen, Society and the structure of violence. A story told by Middle Bronze Age human remains from central Norway, in: Otto et al. 2006, 319-329.

Gaál 2001

A. Gaál, Posamenteriefibel mit Fußspirale, Bronzebecken und Bronzehelm aus dem Donauabschnitt im Komitat Tolna, Communicationes Archaeologicae Hungariae 2001, 41-50.

Gabrovec 1983

S. Gabrovec, Jugoistočnoalpska regija, Praistorija Jugoslavenskih Zemalja 4, Bronzano Doba (Sarajevo 1983) 21-96.

Gaerte 1920

W. Gaerte, Die Beinschutzwaffen der Griechen (Dresden 1920).

Gambari 2000

F. M. Gambari, Il seppellimento rituale di elmi nei fiumi. Una pratica votiva dell'etá del Ferro nella Cisalpina occidentale, in: L. Bonnamour (ed.), Archéologie des fleuves et des riviéres (Paris 2000).

Gambari et al. 2017

F. M. Gambari - B. Grassi - M. G. Ruggiero, Nuovi dati sul ripostiglio della Malpensa, Zixu II, 2017, 161-196.

García Sanjuán et al. 2006

L. García Sanjuán - P. Wheatley - P. Fábrega - M. J. Hernández - A. Polvorinos, Las estelas de guerrero de Almadén de la Plata (Sevilla). Morfología, tecnología y contexto, Trabajos de Prehistoria 63, 2, 2006, 135-152.

Gastaldi 1998

P. Gastaldi, Pontecagnano II.4. La necropoli del Pagliarone (Naples 1998). 
Gaucher 1981

G. Gaucher, Sites et cultures de l'Âge du Bronze dans le bassin parisien, XVe Supplement a Gallia Préhistoire (Paris 1981).

Gaucher - Robert 1967

G. Gaucher - Y. Robert, Les dépôts de bronze de Cannes-Écluse (Seine-et-Marne), Gallia Préhistoire 10, 1967, 169223.

Genthe 1874

H. Genthe, Über den etruskischen Tauschhandel nach dem Norden (Heilbronn 1874).

Gerloff 2007

S. Gerloff, Reinecke's ABC and the chronology of the British Bronze Age, in: C. Burgess - P. Topping - F. Lynch (eds.), Beyond Stonehenge. Essays in Honour of C.B. Burgess (Oxford 2007) 117-161.

Gerloff 2010

S. Gerloff, Atlantic Cauldrons and Buckets of the Late Bronze and Early Iron Ages in Western Europe, Prähistorische Bronzefunde II, 18 (Stuttgart 2010).

Ghislanzoni 1929

E. Ghislanzoni, Oggetti dell'etá del bronzo di Oggiono, Rivista Archeologica dell'Antica Provincia e Diocesi di Como 96, 98, 1929, 3-16.

Giannopoulos 2008

T. G. Giannopoulos, Die letzte Elite der mykenischen Welt. Achaia in mykenischer Zeit und das Phänomen der Kriegerbestattungen im 12.-11. Jahrhundert v. Chr., Universitätsforschungen zur prähistorischen Archäologie 152 (Bonn 2008).

Gilibert 2004/2005

A. H. Gilibert, Warfare techniques in Early Dynastic Mesopotamia, Anodos 4/5, 2004/2005, 93-100.

Gimbutas 1965

M. Gimbutas, Bronze Age Cultures in Central and Eastern Europe (Den Haag 1965).

Gingell 1974

C. Gingell, Nottingham Hill. Gloucestershire 1972, Antiquity 48, 1974, 306-309.

Giumlia-Mair et al. 1980

A. Giumlia-Mair - R. M. Albanese Procelli - F. Lo Schiavo, Studi metallurgici sui reperti a base di rame dalla necropoli di Ma-donna del Piano di Grammichele, Trabajos de Preistoria 67/2, 2010, 469-488.

Giumlia-Mair et al. 2010

A. Giumlia-Mair - R. M. Albanese Procelli - F. Lo Schiavo, The metallurgy of the Sicilian Final Bronze Age/Early Iron Age necropolis of Madonna del Piano (Catania, Sicily), Trabajos de Prehistoria 67, 2, 2010, 469-488.

Giurletti 1978

G. Giurletti, Pergine, in: L'Arte preistorica nell'Italia settentrionale dalle origini alla civiltà paleoveneta. Exhibition Catalogue Verona (Verona 1978) 120-121.

Gleirscher 2007

P. Gleirscher, Fragmente spätbronzezeitlicher Helme und Beinschienen aus dem Südostalpenraum, Archäologie Österreichs 18, 1, 2007, 48-53.

Goetze 1984

B.-R. Goetze, Die frühesten europäischen Schutzwaffen, Bayerische Vorgeschichtsblätter 49, 1984, 25-53.

Goldhahn - Fuglestvedt 2014

J. Goldhahn - I. Fuglestvedt, Engendering North European Rock Art. Bodies and cosmologies in Stone and Bronze Age imagery, in: J. McDonald - P. Veth (eds.), A Companion to Rock Art (Chicester 2014) 237-260.

Gonzalez 2012

R. A. Gonzalez, Sardinian bronze figurines in their Mediterranean setting, Prähistorische Zeitschrift 87, 1, 2012, 83-109. 
González Ledesma 2007

C. González Ledesma, Nueva estela de guerrero encontrada en el entorno del embalse de Orellana (Orellana de la Sierra, Badajoz). Actas del VIII congreso de estudios extremeños (Badajoz 2007) 596-611.

Gooss 1876

C. Gooss, Chronik der archäologischen Funde Siebenbürgens, Archiv des Vereins für Siebenbürgische Landeskunde 13, 1876, 203-338.

Götter und Helden 1999

Götter und Helden der Bronzezeit. Europa im Zeitalter des Odysseus. Exhibition Catalogue Bonn (Ostfildern 1999).

Graffenried 1860

B. Graffenried, Puszta Szent-György, Archiv für Kunde österreichischer Geschichtsquellen 24, 1860, 372-374.

Grahl 2004

A. Grahl, Der Helm von Thonberg. Ein Meisterstück aus der Urnenfelderzeit (Frankenwald 2004).

Gras 2002

S. Gras, Le gisement archéologique de 'Jean-de-Saône', commune de Montbellet, Saône-et-Loire. Actes des rencontres de Tournus, 14 and 15 September 2000 (Tournus 2002) 99-108.

Greenhalgh 1980

P. Greenhalgh, The Dendra charioteer, Antiquity 54, 212, 1980, 201-205.

Grohne 1939

E. Grohne, Der Bronzehelm aus der Lesum, Jahresschrift des Focke-Museums (Bremen), 1939, 21-29.

Grünberg 1943

W. Grünberg, Die Grabfunde der jüngeren und jüngsten Bronzezeit im Gau Sachsen, Vorgeschichtliche Forschungen 13 (Berlin 1943).

Hachmann 1957

R. Hachmann, Die frühe Bronzezeit im westlichen Ostseegebiet, Atlas der Urgeschichte, Beiheft 6 (Hamburg 1957).

Hagemann 1919

A. Hagemann, Griechische Panzerung. Eine entwicklungsgeschichtliche Studie zur antiken Bewaffnung 1. Der Metallharnisch. Anhang: Teilpanzerungen für Arme und Beine 4. Unterschenkel- oder Beinschienen (Leipzig 1919)

Hager - Mayer 1892

G. Hager - J. A. Mayer, Die vorgeschichtlichen, römischen und merovingischen Alterthümer des Bayerischen Nationalmuseums (Munich 1892).

Hamard-Frichet - Rey-Bellet 2000

C. Hamard-Frichet - B. Rey-Bellet, Radiographie d'une dossière en bronze de Fillinges. Restaurations anciennes et état de conservation, Genava 48, 2000, 143-148.

Hampel 1876

J. Hampel, Antiquités préhistoriques de la Hongrie 1 (Esztergom 1876).

Hampel 1877

J. Hampel, Antiquités préhistoriques de la Hongrie 2 (Esztergom 1877).

Hampel 1886a

J. Hampel, Trouvailles de l'Âge du Bronze en Hongrie, in: Congrès international d'anthropologie et d'archéologie préhistorique, Compte-rendu de la huitiéme session á Budapest Vol. 2 (Budapest 1886).

Hampel 1886b

J. Hampel, A bronzkor emlékei Magyarhonban I. Képes atlasz (Budapest 1886). 
Hampel 1887

J. Hampel, Altherthümer der Bronzezeit in Ungarn (Budapest 1887).

Hampel 1892

J. Hampel, A bronzkor emlékei Magyarhonban II. A leletek statisztikája (Budapest 1892).

Hampel 1896

J. Hampel, A Bronzkor emlékei Magyarhonban III. Áttekintő ismertetés (Budapest 1896).

Hänsel 2003

B. Hänsel, Bronzene Glockenhelme. Bemerkungen zu einem Altfund an der Neiße, in: U. Eckert - A. Zimmermann (eds.), Archäologische Perspektiven, Analysen und Interpretationen im Wandel. Festschrift für Jens Lünning zum 65. Geburtstag, Internationale Archäologie, Studia Honoraria 20 (Rahden 2003) 77-84.

Hansen 1994

S. Hansen, Studien zu den Metalldeponierungen während der älteren Urnenfelderzeit zwischen Rhônetal und Karpatenbecken, Universitätsforschungen zur prähistorischen Archäologie 21 (Bonn 1994).

Hansen 2001

S. Hansen, Helme und Waffen der Bronzezeit in der Sammlung Axel Guttmann, in: H. Born - H. Hansen, Helme und Waffen Alteuropas, Sammlung Axel Guttmann 9 (Mainz 2001) 11-166.

Harding 1995

A. Harding, Die Schwerter im ehemaligen Jugoslawien, Prähistorische Bronzefunde IV, 14 (Stuttgart 1995).

Harding 2000

A. Harding, European Societies in the Bronze Age (Cambridge 2000).

Harding 2007

A. Harding, Warriors and Weapons in Bronze Age Europe (Budapest 2007)

Harmatta 1948

J. Harmatta, Le problème cimmérien, Archaeologiai Értesítő IX, 1948, 79-133.

Harrison 2004

R. J. Harrison, Symbols and Warriors. Images of the European Bronze Age (Bristol 2004).

Helbig 1882

W. Helbig, Scavi di Corneto, Bulletino dell'Instituto di Corrispondenza Archeologica per l'anno 1882, 1-2, 1882, $10-22$.

Hellebrandt 1999/2000

M. Hellebrandt, Der Bronzefund von Mezőnyárád, Acta Archaeologica Academiae Scientiarum Hungaricae 51, 1999/2000, 207-234

Heman 1983

P. Heman, Bodenfunde aus Basels Ur- und Frühgeschichte (Basel 1983).

Hémery 1926

M. Hémery, Le casque d’Armancourt, Bulletin de la Societé Historique de Compiégne XVIII, 1926, 194-200.

Hémery 1927

M. Hémery, Le casque d'Armancourt, L'Homme Préhistorique 14/5-6, 1927, 136-141.

Hémery 1929

M. Hémery, Les casques de Montmacq (Oise), Bulletin de la Société Préhistorique Française 26, 7-8, 1929, 423424.

Hencken 1950

H. Hencken, Herzsprung shields and Greek trade, American Journal of Archaeology 54, 1950, 294-309. 
Hencken 1952

H. Hencken, Beitzsch and Knossos, Proceedings of the Prehistoric Society 18, 1952, 36-46.

Hencken 1968

H. Hencken, Tarquinia, Villanovans and Early Etruscans, Bulletin of the Americal School of Prehistorc Research 23 (Cambridge/Mass. 1968).

Hencken 1971

H. Hencken, The Earliest European Helmets. Bronze Age and Early Iron Age, Bulletin of the Americal School of Prehistoric Research 28 (Cambridge/Mass. 1971).

Hennig 1970

H. Hennig, Die Grab- und Hortfunde der Urnenfelderkultur aus Ober- und Mittelfranken, Materialhefte zur bayerischen Vorgeschichte Reihe A, 23 (Kallmünz 1970).

Hermann Historica 2005a

Hermann Historica Auction 49g, Lot 178, Bronzezeitlicher Kammhelm - 50 Helme der berühmten Sammlung Axel Guttman. Munich, 19 October 2005. Online <http://www.hermann-historica.de/de/bronzezeitlicher kammhelm/1/16260?aid=18\&Lstatus=0\&_=1488582498602\&currentpos=43> (last access 3 March 2017).

Hermann Historica 2005b

Hermann Historica Auction 49g, Lot 179, Ungarischer(?) Glockenhelm - 50 Helme der berühmten Sammlung Axel Guttman. Munich, 19 October 2005. Online <http://www.hermann-historica.de/de/ungarischer_glockenhelm/1/ 16261?aid $=18 \&$ Lstatus $=0 \& \_=1488582498602 \&$ currentpos $=44>$ (last access 3 March 2017).

Hermann Historica 2008

Hermann Historica Auction 56g, Lot 71, Bronzezeitlicher Helm - Antiken aus der Sammlung Axel Guttmann und anderem Besitz. Munich, 8 October 2008. Online <http://www.hermann-historica.de/de/bronzezeitlicher_helm/1/45 323?aid $=42 \&$ Lstatus $=0 \& \_=1488386086552 \&$ currentpos $=71>$ (last access 3 March 2017).

Hermann Historica 2012

Hermann Historica Auction 65aw, Lot 419, Helm, Mitteleuropa, Bronzezeit um 1000 v. Chr., Antiken / Alte Waffen, Jagdliches und Kunsthandwerk, Munich, 15 october 2012. Online <http://www.hermann-historica.de/de/ helm_mitteleuropa_bronzezeit_um_1000_v_chr/1/88607?Q=419\&Aid=93\&Atype=0\&Lstatus=0\&currentpos=1> (last access 4 March 2017).

Hermann Historica 2013

Hermann Historica Auction 67aw, Lot 2270, Kappenknaufhelm, Späte Urnenfelderzeit, 10. - 9. Jhdt. v. Chr., Antiken / Alte Waffen, Jagdliches und Kunsthandwerk, Munich, 6 November 2013. Online <http://www.hermannhistorica.de/de/kappenknaufhelm_spaete_urnenfelderzeit_10_-_9_jhdt_v_chr/1/98582?aid=106\&Lstatus=0\&_= $1488633119385 \&$ currentpos $=270>$ (last access 4 March 2017).

Hermann Historica 2014

Hermann Historica Auction 69aw, Lot 3733, Kappenknaufhelm, Urnenfelderzeit, 9. Jhdt. v. Chr., Antiken / Alte Waffen, Jagdliches und Kunsthandwerk, Munich, 5 November 2014. Online < http://www.hermann-historica.de/de/ kappenknaufhelm_urnenfelderzeit_9_jhdt_v_chr/1/118034?Q=3733\&Aid=118\&Atype=0\&Lstatus=0\&currentpos=1> (last access 4 March 2017).

Hermann Historica 2015a

Hermann Historica Auction 71a, Lot 3667, Urnenfelderzeitlicher Kammhelm aus Bronze, 12. - 11. Jhdt. v. Chr., Antiken, Munich, 30 October 2015. Online

$<\mathrm{http}$ //www.hermann-historica.de/de/urnenfelderzeitlicher_kammhelm_aus_bronze_12_-_11_jhdt_v_ $\operatorname{chr} / 1 / 131562$ ? $=$ helm\&Aid=130\&Atype $=0 \&$ Lstatus $=0 \&$ currentpos $=9>$ (last access 3 March 2017).

Hermann Historica 2015b

Hermann Historica Auction 71a, Lot 3668, Kappenknaufhelm, Urnenfelderzeit, 9. Jhdt. v. Chr., Antiken, Munich, 30 October 2015. Online <http://www.hermann-historica.de/de/kappenknaufhelm_urnenfelderzeit_9_jhdt_v_chr/ 1/131563?Q=helm\&Aid=130\&Atype $=0 \&$ Lstatus $=0 \&$ currentpos $=10>$ (last access 3 March 2017). 
Hermann Historica 2016

Hermann Historica Auction 72aw, Lot 4627, Kappenhelm mit spulenförmigem Knauf, Späte Bronzezeit Mitteleuropas, 10. - 9. Jhdt. v. Chr., Antiken, Alte Waffen, Jagdliches und Kunsthandwerk, Munich, 22 April 2016. Online $\quad<$ http://www.hermann-historica.de/de/kappenhelm_mit_spulenfoermigem_knauf_spaete_bronzezeit mitteleuropas $10-9$ jhdt $/ 1 / 139486 ? \mathrm{Q}=$ helm\&Aid $=141 \&$ Atype $=0 \&$ L status $=0 \&$ currentpos $=41>$ (last access $\overline{2}$ March 2017).

Hermann Historica 2017

Hermann Historica Auction 74aw, Lot 3421, Kappenknaufhelm - Antique Arms \& Armour, Hunting Antiques and Works of Art, Antiquities. Munich, 27-28 April 2017. Online <http://www.hermann-historica.de/AuctionData/1/ 74aw/Ebook/index.html> (last access 27 June 2017).

Hock 1911

G. Hock, Helme der frühen Hallstattzeit, Mitteilungen aus dem Germanischen Nationalmuseum, 1911, 3-10.

Hock 1914

G. Hock, Unsere Heimat vor 3000 Jahren, Frankenland. Illustrierte Monatsschrift für Geschichte, Kunst, Kunsthandwerk, Literatur, Volkskunde und Heimatschutz in Franken 1, 6, 1914, 243-261.

Hoffmann 1961

E. Hoffmann, Die Bronzehelme der Sammlung Zschille im Museum für Völkerkunde Leipzig, Jahrbuch des Museum für Völkerkunde zu Leipzig 18, 1961, 97-112.

Höglinger 1996

P. Höglinger, Der spätbronzezeitliche Depotfund von Sipbachzell/OÖ, Linzer Archäologische Forschungen, Sonderheft 16 (Linz 1996).

Holste 1936

F. Holste, Der Bronzefund von Winklsaß, B. A. Mallersdorf, Niederbayern, Bayerische Vorgeschichtsblätter 13, $1936,1-23$.

Holste 1937

F. Holste, Zwei Sammelfunde der Urnenfelderzeit aus Bayerisch-Schwaben, Germania 21, 1937, $10-17$.

Holste 1951

F. Holste, Hortfunde Südosteuropas (Marburg 1951).

Holste 1962

F. Holste, Zur Chronologie der südosteuropäischen Depotfunde der Urnenfelderzeit (Marburg 1962).

Honti 2010

S. Honti, Szerteágazó kutatások a 1980. As évektől, Somogyi Múzeumok Közleményei 19, 2010, 27.

Honti - Jankovits 2016

S. Honti - K. Jankovits, A new greave from the Late Bronze Age hoard found at Lengyeltóti in Southern Transdanubia, Communicationes Archaeologicae Hungariae 2015-2016, 2016, 71-86.

Hood - de Jong 1952

M. S. F. Hood - P. de Jong, Late Minoan warrior graves from Ayios Ioajjis and the New Hospital Site at Knossos, Annual of the British School of Athens 47, 1952, 243-277.

Hornbostel 1981

W. Hornbostel, Kunst der Etrusker. Exhibition Catalogue Hamburg (Hamburg 1981).

Hornbostel - Spielmann 2004

W. Hornbostel - H. Spielmann (eds.), Die Etrusker. Luxus für das Jenseits. Bilder vom Diesseits. Bilder vom Tod. Exhibition Catalogue Hamburg (Munich 2004).

Horváth 1995

P. Horváth, A lengyeltóti i.e. XII-X. századi bronz lábvért tisztítása, konzerválása, restaurálása (MA thesis, Hungarian University of Fine Arts, Budapest 1995). 
Horváth 1997a

P. Horváth, Egy bronzkori bronz lábvért restaurálása. Múzeumi Tájékoztató, Somogy Megyei Múzeumok Igazgatósága 4, 1997, 4-7.

Horváth 1997b

P. Horváth, Egy későbronzkori (i.e. XII-X. századi) bronz lábvért restaurálása, Műtárgyvédelem 26, 1997, $141-146$.

Hrala 1966

J. Hrala, Äußerung der Beziehungen des Knovízer Kulturgebietes zum Südosten (Bronzefund aus Kamýk nad Vltavou), Archeologické Rozhledy 18, 1966, 6-12.

Hulit - Richardson 2007

T. D. Hulit - T. Richardson, Experiments with New Kingdom Egyptian scale armour, archery and chariots, in: Molloy $2007,52-63$.

Hundt 1955

H. J. Hundt, Versuch zur Deutung der Depotfunde der nordischen jüngeren Bronzezeit unter besonderer Berücksichtigung Mecklenburgs, Jahrbuch des Römisch-Germanischen Zentralmuseums Mainz 2, 1955, 95-140.

Hundt 1997

H. J. Hundt, Die jüngere Bronzezeit in Mecklenburg-Vorpommern, Beiträge zur Ur- und Frühgeschichte Mecklenburg-Vorpommerns 31 (Lübsdorf 1997).

Huth 2012

C. Huth, Waffenweihungen in der Bronzezeit Mitteleuropas, in: Meighörner 2012, 91-99.

Iaia 2005

C. Iaia, Produzioni toreutiche della prima età del ferro in Italia centro-settentrionale. Stili decorativi, circolazione, significato, Studi Etruschi 41 (Rome 2005).

Iaia 2013a

C. Iaia, Metalwork, rituals and the making of elite identity in central Italy at the Bronze Age-Iron Age transition, in: E. Alberti - S. Sabatini (eds.), Exchange Networks and Local Transformations. Interactions and Local Changes in Europe and the Mediterranean from the Bronze Age to the Iron Age (Oxford 2013) 102-116.

Iaia $2013 b$

C. Iaia, Warrior identity and the materialisation of power in Early Iron Age Etruria, Accordia Research Papers 12/ 2009/2012, 2013, 71-95.

Ienco et al. 2007

M. G. Ienco - G. Pellati - P. Piccardo - M. R. Pinasco - E. Stagno, Metallographic approach to the investigation of metallic archaeological objects, Annali di Chimica 97, 2007, 553-574.

Jacob-Friesen - Jacob-Friesen 1963

K. H. Jacob-Friesen - G. Jacob-Friesen, Einführung in Niedersachsens Urgeschichte Pt. 2: Bronzezeit (Hildesheim 1963).

Jacob-Friesen 1968

G. Jacob-Friesen, Ein Depotfund des Formenkreises um die Karpfenzungenschwerter aus der Normandie, Germania 46, 1968, 248-274.

Jahn 2013

C. Jahn, Symbolgut Sichel. Studien zur Funktion spätbronzezeitlicher Griffzungensicheln in Depotfunden, Universitätsforschungen zur prähistorischen Archäologie 236 (Bonn 2013).

Jakob 1972

H. Jakob, Fundchronik für die Jahre 1965-1967. Ebing, Bayerische Vorgeschichtsblätter 37, 1972, 147.

Jankovits 1992

K. Jankovits, Spätbronzezeitliche Hügelgräber in der Bakony-Gegend, Acta Archaeologica Academiae Scientiarum Hungaricae 44, 1992, 1-81. 
Jankovits 1997

K. Jankovits, La ricostruzione di due nuovi schinieri del tipo a lacci dall'Ungheria, Acta Archaeologica Academiae Scientiarum Hungaricae 49, 1997, 1-21.

Jankovits 1998/1999

K. Jankovits, Studio delle lamine di bronzo del ripostiglio di Pila del Brancon, Nogara (Verona), Padusa 34-35, 1998/1999, 85-107.

Jankovits 1999/2000

K. Jankovits, Neue Angaben zu dem Depotfund von Pila del Brancon, Nogara (Verona), Acta Archaeologica Academiae Scientiarum Hungaricae 51, 1999/2000, 189-205.

Jantzen - Terberger 2011

D. Jantzen - T. Terberger, Gewaltsamer Tod im Tollensetal vor 3200 Jahren, Archäologie in Deutschland 4, 2011, 6-11.

Jantzen et al. 2008

C. Jantzen - D. Jantzen - T. Terberger, Der Fundplatz Weltzin, Lkr. Demmin. Ein Zeugnis bronzezeitlicher Konflikte?, in: J. Piek - T. Terberger (eds.), Traumatologische und pathologische Veränderungen an prähistorischen und historischen Skelettresten. Diagnose, Ursachen und Kontext. Interdisziplinärer Workshop in Rostock Warnemünde vom 17. - 18. November 2006, Archäologie und Geschichte im Ostseeraum 3 (Rahden 2008) 89-97.

Jantzen et al. 2011

D. Jantzen - U. Brinker - J. Orschiedt - J. Heinemeier - J. Piek - K. Hauenstein - J. Kruger - G. Lidke - H. Lubke - R. Lampe - S. Lorenz - M. Schult - T. Terberger, A Bronze Age battlefield? Weapons and trauma in the Tollense Valley, northeastern Germany, Antiquity 85, 2011, 417-433.

Jażdżewski 1981

K. Jażdżewski, Pradzieje europy środkowej (Wrocław, Warsaw, Krakow, Gdańsk 1981).

Jensen 1999

J. Jensen, Die Helden. Leben und Tod, in: National Museum of Denmark (ed.), Götter und Helden der Bronzezeit. Europa im Zeitalter des Odysseus. Exhibition Catalogue Bonn (Ostfildern 1999) 88-97.

Jockenhövel 1971

A. Jockenhövel, Die Rasiermesser in Mitteleuropa (Süddeutschland, Tschechoslowakei, Österreich, Schweiz), Prähistorische Bronzefunde VIII, 1 (Munich 1971).

Jockenhövel 1974

A. Jockenhövel, Eine Bronzeamphore des 8. Jahrhunderts v. Chr. von Gevelinghausen, Kr. Meschede (Sauerland), Germania 52, 1974, 16-47.

Johannowsky 1970

W. Johannowsky, Un paio di schinieri di bronzo da Canosa, Rediconti della Academia di Archaeologia, Lettere e Belli Arti N. S. 45, 1970, 205-209.

Jorge 1988

S. O. Jorge, Reflexõs sobre a pré-história recente do norte de Portugal, Actas do colóquio de arqueologia do noroeste peninsular, Trabalhos de Arqueologia e Etnologia 28, 1988, 85-112.

Jorns 1964

W. Jorns, Fundchronik des Amtes für Bodendenkmalpflege, Darmstadt für die Zeit vom 1.1.-31.12.1963, Fundberichte aus Hessen 4, 1964, 177-197.

Jorns 1972

W. Jorns, Die Kammhelme von Biebesheim, Fundberichte aus Hessen 12, 1972, 76-85.

Jovanović 2010

D. B. Jovanović, Ostave vršačkog gorja, Markovac-Grunjac (Vršac 2010).

Jovanović 1958

R. Jovanović, Dve preistoriske ostave iz severoistočne Bosne, Članci i Građa Kulturnu Istoriju Istočne Bosne 2, $1958,23-35$. 
Jud 1985

P. Jud, Neues vom Helm von Weil, Archäologie der Schweiz 8, 1985, 62-66.

\section{Jurgeit 1999}

F. Jurgeit, Die etruskischen und italischen Bronzen sowie Gegenstände aus Eisen, Blei und Leder im Badischen Landesmuseum Karlsruhe (Pisa, Rome 1999).

Kajzer 1995

M. Kajzer, Hočko Pohorje; in: B. Teržan (ed.), Depojske in posamezne kovinske najdbe bakrene in bronaste dobe na Slovenskem I, Katalogi in Monografije 29 (Ljubljana 1995) 177-196.

Kalb 1980

P. Kalb, Zur atlantischen Bronzezeit in Portugal, Germania 58, 1, 1980, 25-59.

Karavanić 2006

S. Karavanić, Prerada i proizvodnja metala u naselju Mačkovac-Crišnjevi (Nova Gradiška), Prilozi Instituta za Arheologiju u Zagrebu, 23, 2006, 29-52.

Karavanić 2009

S. Karavanić, The Urnfield Culture in Continental Croatia, British Archaeological Reports, International Series 2036 (Oxford 2009).

Karavanić - Mihaljević 2001

S. Karavanić - M. Mihaljević, Ostava iz Mačkova, Vjesnik Arheološkog Muzeja u Zagrebu 34, 2001, 7-36.

Kasper 1972

W. Kasper, Die buckelverzierten Bleche Olympias (PhD Diss.,University of Kiel, Kiel 1972).

Kasseroler 1959

A. Kasseroler, Das Urnenfeld von Volders, Schlern-Schriften 204 (Innsbruck 1959).

Keiling 1987

H. Keiling, Die Kulturen der mecklenburgischen Bronzezeit (Schwerin 1987).

Kemble 1863

J. M. Kemble, Horae Ferales or Studies in the Archaeology of the Northern Nations (London 1863).

Kemenczei 1966

T. Kemenczei, Koravaskori bronz raktáleletek a miskolci múzemban, Herman Ottó Múzeum Èvkönyve 6, 1966, 49-107.

Kemenczei 1978/1979

T. Kemenczei, A Gyöngyössolymos-kishegyi negyedik bronzlelet, Egri Múzeum Évkönyve 16-17, 1978/1979, 137155 .

Kemenczei 1979

T. Kemenczei, Neuer Bronzehelmfund in der prähistorischen Sammlung des Ungarischen Nationalmuseums, Folia Archaeologica Budapest 30, 1979, 79-89.

Kemenczei 1984

T. Kemenczei, Die Spätbronzezeit Nordostungarns, Acta Archaeologia Hungarica 51 (Budapest 1984).

Kemenczei 1988

T. Kemenczei, Die Schwerter in Ungarn I (Griffplatten-, Griffangel- und Griffzungenschwerter), Prähistorische Bronzefunde IV, 6 (Munich 1988).

Kienlin - Pernicka 2006

T. Kienlin - E. Pernicka, Compositional data of some objects from the Dipşa hoard, in: H. Ciougedan - A. Georgescu - S. A. Luca, Depozitul de bronzuri de la Dipşa, Bibliotheca Brukenthal V (Alba-Iulia 2006) 60-61.

Kilian 1973

K. Kilian, Zu geschnürten Schienen der Hallstattzeit aus der Ilijak-Nekropole in Bosnien, Germania 51, 1973, 528 535 . 
Kilian 1974

K. Kilian, Zu den früheisenzeitlichen Schwertformen der Apenninhalbinsel, in: H. Müller-Karpe (ed.), Beiträge zu italienischen und griechischen Bronzefunden, Prähistorische Bronzefunde XX, 1 (Munich 1974) 33-80.

Kilian-Dirlmeier 1975

I. Kilian-Dirlmeier, Gürtelhaken, Gürtelbleche und Blechgürtel der Bronzezeit in Mitteleuropa (Ostfrankreich, Schweiz, Süddeutschland, Österreich, Tschechoslowakei, Ungarn, Nordwest-Jugoslawien), Prähistorische Bronzefunde XII, 2 (Munich 1975).

Kilian-Dirlmeier 1985

I. Kilian-Dirlmeier, Noch einmal zu den 'Kriegergräbern' von Knossos, Jahrbuch des Römisch-Germanischen Zentralmuseums Mainz 32, 1985, 196-214.

Kleemann 1941/1942

O. Kleemann, Der Bronzefund von Weissig, Prähistorische Zeitschrift 32-33, 1941/1942, 60-168.

Klemm n.d.

J. G. Klemm, Catalog der culturhistorischen Sammlung des verstorbenen Hofrath Dr. Gustav Klemm in Dresden Königsbrücker Strasse Nr. 84, Einleitung (unpublished manuscript, Dresden).

Klemm 1851

J. G. Klemm, Das christliche Westeuropa. Allgemeine Cultur-Geschichte der Menschheit Vol. 9 (Leipzig 1851).

Klemm 1854

J. G. Klemm, Allgemeine Culturwissenschaft. Die materiellen Grundlagen menschlicher Cultur (Leipzig 1854) $157-158$.

Klemm 1868

J. G. Klemm, Germanische Alterthümer, British Museum, London (unpublished manuscript 1868).

Knor 1952

A. Knor, Halštatská mohyla v Čace u Želiezovcú, Archeologické Rozhledy 4, 1952, 388-395.

Kolonas 2001

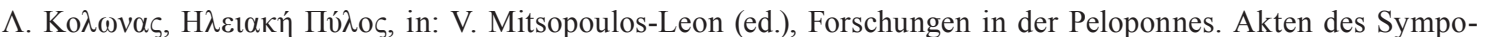
sions anläßlich der Feier „100 Jahre Österreichisches Archäologisches Institut Athen“, Athen 5.3. - 7.3.1998, Sonderschriften des Österreichischen Archäologischen Institutes 38 (Vienna 2001) 257-262.

Kolonas - Moschos 2000

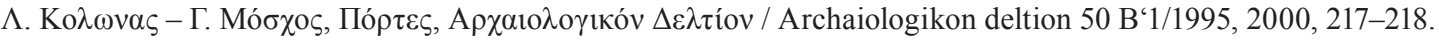

König 2004

P. König, Spätbronzezeitliche Hortfunde aus Bosnien und der Herzegovina, Prähistorische Bronzefunde XX, 11 (Stuttgart 2004).

Kossack 1954

G. Kossack, Studien zum Symbolgut der Urnenfelder- und Hallstattzeit Mitteleuropas, Römisch-Germanische Forschungen 20 (Berlin 1954).

Kovács 1992

T. Kovács, Das Ungarische Nationalmuseum (Budapest, Milan 1992).

Krahe 1981

G. Krahe, Beinschiene der Urnenfelderzeit von Schäfstall, Stadt Donauwörth, Landkreis Donau-Ries, Schwaben, Das Archäologische Jahr in Bayern 1980, 1981, 76-77.

Krause 2003

R. Krause, Studien zur kupfer- und frühbronzezeitlichen Metallurgie zwischen Karpatenbecken und Ostsee, Vorgeschichtliche Forschungen, 24 (Rahden/Westf. 2003).

Kristiansen 1999

K. Kristiansen, Understanding Bronze Age weapon hoards. Observations from the Zalkod and Vaja hords, northeastern Hungary, A Jósa András Múzeum Évkönyve 41, 1999, 101-107. 
Kristiansen 2006

K. Kristiansen, The twin rulers as a religious and political institution during the Bronze Age, Cosmos 19, 2, 2006, $181-211$.

Kristiansen - Larsson 2005

K. Kristiansen - Th. B. Larsson, The Rise of Bronze Age Society (Cambridge 2005).

Krüger et al. 2012

J. Krüger - F. Nagel - S. Nagel - D. Jantzen - R. Lampe - J. Dräger - G. Lidke - O. Mecking - T. Schüler - T. Terberger, Bronze Age tin rings from the Tollense valley in northeastern Germany, Prähistorische Zeitschrift 87, 2012, $29-43$.

Kudelić 2007

A. Kudelić, Zaštitna oprema ratnika starije faze kulture polja sa žarama na prostoru savsko-dravskog međuriječja (MA thesis, University of Zagreb, Zagreb 2007).

Kukahn 1936

E. Kukahn, Der griechische Helm (Marburg 1936).

Kunze 1991

E. Kunze, Beinschienen, Olympische Forschungen 21 (Berlin, New York 1991).

Kyrle 1918

G. Kyrle, Urgeschichte des Kronlandes Salzburg, Österreichische Kunsttopographie 17 (Vienna 1918).

Kytlicová 1988a

O. Kytlicová, Příspěvek k problematice kožených pancířu zdobených bronzem v období popelnicových polí, Archeologické Rozhledy XL, 1988, 306-321.

Kytlicová 1988b

O. Kytlicová, K sociální struktuře kultury popelnicových polí, Památky Archeologické 79, 1988, 342-389.

Kytlicová 1991

O. Kytlicová, Die Bronzegefäße in Böhmen, Prähistorische Bronzefunde II, 12 (Stuttgart 1991).

Lambert 1837

M. Lambert, Note sur des casques trouvés au Mont d'Eraines (Calvados), Bulletin Monumental 3, 1837, $203-204$.

Larese 1991

A. Larese (ed.), Tesori nazionali della Croazia. Capolavori dei Musei di Zagabria. Exibition Catalogue Arezzo (Arezzo 1991).

Larsson 1975

L. Larsson, The Fogdarp find. A hoard from the Late Bronze Age, Meddelanden från Lunds universitets historiska museum, 1973-1974, 1975, 169-238.

Lehoërff 2008

A. Lehoërff, Les cuirasses de Marmesse (Haute-Marne), un artisanat d'exception, Antiquites Nationales 39, 2008, 95-106.

Lehoërff 2009

A. Lehoërff, Les dépôts métalliques du bronze final de Cannes-Écluse (Seine-et-Marne). Étude technique des jambières du dépôt, Revue Archéologique de l’Est 58, 2009, 439-451.

Lehoërff 2011

A. Lehoërff, Les armes anciennes de la collection Odescalchi (Palais de Venise, Rome), Jahrbuch des RömischGermanischen Zentralmuseums Mainz 55/2008, 2011, 43-79.

Lehoërff 2013

A. Lehoërff, Seamen who came in peace in 1550 BC?, in: A. Lehoërff (ed.), Beyond the Horizon. Societies of the Channel and North Sea 3,500 Years ago (Paris 2013) 82-85. 
Levente 2010

A. Levente (ed.), Somogyi Múzeumok Közleményei 19. Jubileumi kötet. Akik a gyüjteményi tárgyakat újra életre keltették (Kaposvár 2010).

Levi 1959

D. Levi, La villa rurale Minoica di Gortina, Bollettino d'Arte 44, 3, 1959, 237-265.

Lidke et al. 2015

G. Lidke - T. Terberger - D. Jantzen, Das bronzezeitliche Schlachtfeld im Tollensetal. Fehde, Krieg oder Elitenkonflikt?, in: Meller - Schefzik 2015, 347-350.

Lilliu 1966

G. Lilliu, Sculture della Sardegna nuragica (Cagliari 1966).

Lindenschmit 1858

L. Lindenschmit, Die Alterthümer unserer heidnischen Vorzeit I (Mainz 1858).

Lindenschmit 1860

L. Lindenschmit, Die vaterländischen Alterthümer der fürstlich Hohenzollern'schen Sammlungen zu Sigmaringen (Mainz 1860).

Lindenschmit 1881

L. Lindenschmit, Die Alterthümer unserer heidnischen Vorzeit III (Mainz 1881).

Lindgren 1938

B. G. Lindgren, Om importen ac ungerska bronskärl i nordisk bronsålder. Kulturhistoriska studier. Tillägnade Nils Åberg (Stockholm 1938).

Ling et al. 2013

J. Ling - E. Hjarthner-Holdar - L. Grandin - K. C. Billström - P.-O. Persson, Moving metals or indigenous mining? Provenancing Scandinavian Bronze Age artefacts by lead isotopes and trace tlements, Journal of Archaeological Science 40, 1, 2013, 291-304.

Lippert 2010

A. Lippert, Spätbronzezeitliche Kammhelme an transalpinen Fernhandelsrouten. Mit einem Beitrag von Mathias Mehofer, Archäologisches Korrespondenzblatt 40, 1, 2010, 49-65.

Lippert 2011

A. Lippert (ed.), Die zweischaligen ostalpinen Kammhelme und verwandte Helmformen der späten Bronze- und frühen Eisenzeit, Archäologie in Salzburg 6 (Salzburg 2011).

Littauer 1972

M. A. Littauer, The military use of the chariot in the Aegean in the Late Bronze Age, American Journal of Archaeology $76,2,1972,145-157$.

Lorenc et al. 2013

O. Lorenc - M(arek) Vizdal - M(arián) Vizdal, Neskorobronzové a halštatské nálezy zo Šarišských Michalian / Spätbronzezeitliche und hallstattzeitliche Funde aus Šarišské Michal'any, Archeologické výskumy a nálezy na Slovensku v roku 2009, 2013, 165.

Lorimer 1950

H. L. Lorimer, Homer and the Monuments (London 1950).

Luca - Georgescu 2008

S. A. Luca - A. Georgescu, Depozite de bronzuri preistorice din Colecţia Brukenthal, Bibliotheca Brukenthal XXXI (Sibiu 2008).

Lutz 2011

J. Lutz, Materialanalytische Untersuchungen an den Helmen vom Pass Lueg, Anlauftal und Moosbruckschrofen, in: Lippert 2011, 113-118. 
Mačala 1985

P. Mačala, Depot bronzových Predmetov z Přestavĺk, okr. Přerov, Slovenská Archaeológia 35, 1985, 165-202.

Makarenko 1934

N. Makarenko, Neolithic man on the shores of the Sar of Azov, Eurasia Septentrionalis Antiqua 9, 1934, 135-153.

Makkay 1989

J. Makkay, Az endrődi sisak, Magyarország Régészeti Topográfiája 8, 1989, 181-182.

Makkay 2006

J. Makkay, The late Bronze Age hoard of Nadap, A Nyíregyházi Jósa András Múzeum Évkönyve 48, 2006, 135$184[1-52]$.

Manning 2010

S. W. Manning, Chronology and terminology, in: E. H. Cline, (ed.), The Oxford Handbook of the Bronze Age Aegean (Oxford 2010) 11-30.

Marani - Koch 2014

E. Marani - W. F. R. M. Koch, The Pelvis. Structure, Gender and Society (Heidelberg 2014).

Marijan 1995

B. Marijan, Ostava ratničke opreme na Grepcima u Livanjskom polju, Opuscula Archaeologica 19, 1995, 51-67.

Marinatos 1959

S. Marinatos, Kreta und das mykenische Hellas (Munich 1959).

Marinescu 1979

G. Marinescu, Depozitul de bronzuri de la Ciceu-Corabia, Acta Musei Porolissensis 3, 1979, 51-57.

Martin 2009

J. Martin, Die Bronzegefäße in Mecklenburg-Vorpommern, Brandenburg, Berlin, Sachsen-Anhalt, Thüringen und Sachsen, Prähistorische Bronzefunde II, 16 (Stuttgart 2009).

Martinelli 2004

M. Martinelli (ed.), La lancia, la spada, il cavallo. Exhibition Catalogue (Florence 2004).

Marx 2011

E. Marx, Wie der Helm vom Pass Lueg in das Salzburger Museum kam, in: Lippert 2011, 149-156.

Marzatico 2002

F. Marzatico, 'Mobilität' entlang des Etschtals vor der Romanisierung, in: G. Schnekenburger (ed.), Über die Alpen. Menschen - Wege - Waren (Stuttgart 2002) 23-38.

Marzatico 2012

F. Marzatico, Zur Verteidigung des Kriegers. Die Beinschienen von Pergine Valsugana - Masetti, Trentino, in: Meighörner 2012, 115-117.

Marzatico - Gleirscher 2004

F. Marzatico - P. Gleirscher (eds.), Guerrieri, principi ed eroi (Trento 2004).

Matthäus 1985

H. Matthäus, Metallgefäße und Gefäßuntersätze der Bronzezeit, der geometrischen und archaischen Periode auf Cypern mit einem Anhang der bronzezeitlichen Schwertfunde auf Cypern, Prähistorische Bronzefunde II, 8 (Munich 1985).

Matthäus - Schumacher-Matthäus 2014

H. Matthäus - G. Schumacher-Matthäus, Ein spätbronzezeitlicher Helm von der Insel Zypern. Kulturelle Beziehungen zwischen dem Urnenfelderkreis, Mykenai und Zypern, Jahrbuch des Römisch-Germanischen Zentralmuseums Mainz 59/2012, 2014, 51-84.

Matthews forthcoming

S. Matthews, The Atlantic Bronze Age in Southern England, and Beyond. The Use and Abuse of Weapons of the West, 1400-950 BC (forthcoming). 
Matz 1956

F. Matz, Kreta, Mykene, Troja. Die Minoische und die Homerische Welt (Stuttgart 1956).

Mayer 1977

E. F. Mayer, Die Äxte und Beile in Österreich, Prähistorische Bronzefunde IX, 9 (Munich 1977).

Mc Fadden 1954

G. H. Mc Fadden, A Late Cypriote III tomb from Kourion Kaloriziki No. 40, American Journal of Archaeology 58, 1954, 131-142.

McDonald - Wilkie 1992

W. A. McDonald - N. C. Wilkie, Excavations at Nichoria in Southwest Greece 2. The Bronze Age Occupation (Minneapolis 1992).

Mederos Martín 2012

A. Mederos Martín, El origen de las estelas decoradas del Suroeste de la Península Ibérica en el Bronce Final II (1325-1150 a. C.), Anejos de Archivo Español de Arqueologia XLII, 2012, 417-454.

Meeks 1986

N. D. Meeks, Tin-rich surfaces on bronze. Some experimental and archaeological considerations, Archaeometry 28, 1986, 133-162.

Megaw 1968

A. H. S. Megaw, Archaeology in Greece 1967-1968, Archaeological Reports for 1967-1968, No. 14, School of Archaeology at Athens (London 1968).

Mehofer 2011

M. Mehofer, Die Kammhelme vom Typ Pass Lueg. Archäologische und archäometallurgische Untersuchungen zur spätbronzezeitlichen Handwerkstechnik, in: Lippert 2011, 119-140.

Meighörner 2012

W. Meighörner (ed.), Waffen für die Götter. Krieger. Trophäen. Heiligtümer (Innsbruck 2012) 91-99.

Meller - Schefzik 2015

H. Meller - M. Schefzik (eds.), Krieg. Eine archäologische Spurensuche. Exhibition Catalogue Halle/Saale (Halle/ Saale 2015).

Menghin - Hänsel 1997

W. Menghin - B. Hänsel (eds.), Gaben an die Götter. Schätze der Bronzezeit Europas. Museum für Vor- u. Frühgeschichte, Bestandskatalog 4 (Berlin 1997).

Mériel 1890

A. Mériel, Histoire de falaise. Sergenteries de la vicomté, armorial et noblesse (Bellême 1890).

Mészáros 1971/1972

G. Mészáros, A nagyvejkei kesöbronzkori kincselet, Szekszárdi Béri Balogh Ádám Múzeum Èvkönyve 2-3, 1971/1972, 19-66.

Michel 1969

F. Michel, Louvre, rapport 208c, Institute Mainini (Paris 1969).

Michel - Mohen 1970

F. Michel - J.-P. Mohen, Etude comparée de deux cuirasses hallstattiennes. La cuirasse 'de Grenoble' et la cuirasse 'de Naples', Annales du Laboratoire de Recherche des Musées de France, 1970, 65-79.

Miklik-Lozuk 2004

L. Miklik-Lozuk, Ostava Poljanci IV još jedna kasnobrončanodobna ostava s pozicije Donje Polje u selu Poljanci, Vijesti Muzeja brodskog Posavlja 9, 2004, 29-51.

Miklik-Lozuk 2009

L. Miklik-Lozuk, Ostave kasnog brončanog doba iz Poljanaca (Slavonski Brod 2009). 
Milcent 2012

P. -Y. Milcent, Le temps des élites en Gaule atlantique. Chronologie des mobiliers et rythmes de constitution des dépôts métalliques dans le contexte européen (XIIIe-VIIe s. av. J.-C.) (Rennes 2012).

Millotte 1963

J.-P. Millotte, Le Jura et les Plaines de Saône aux âges des métaux (Paris 1963).

Millotte et al. 1968

J.-P. Millotte - G. Cordier - G. Abauzit, Essai de typologie protohistorique. Les haches a ailerons medians, Revue Archeologique de L'est et du Centre-est XIX, 1968, 7-67.

Mira-Bonomi 1979

A. Mira-Bonomi, I recenti rinvenimenti del Bronzo finale alla Malpensa nella Lombardia occidentale, in: Atti della XXII riunione scientifica. Il Bronzo finale in Italia, Florence 21-23 Ottobre 1977. In memoria di Ferrante Rittatore Vonwiller (Florence 1979) 117-146.

Mödlinger 2011

M. Mödlinger, Herstellung und Verwendung bronzezeitlicher Schwerter Mitteleuropas. Eine vertiefende Studie zur mittelbronze- und urnenfelderzeitlichen Bewaffnung und Sozialstruktur, Universitätsforschungen zur prähistorischen Archäologie 193 (Bonn 2011).

Mödlinger 2013a

M. Mödlinger, From Greek boar tusk helmets to the first European metal helmets. New approaches on development and date, Oxford Journal of Archaeology 32, 4, 2013, 391-412.

Mödlinger 2013b

M. Mödlinger, Star ornamentation on Late Bronze Age helmets, cups and decorated discs in central and south-eastern Europe, Arheološki Vestnik 64, 2013, 65-101.

Mödlinger 2014a

M. Mödlinger, Bronze Age bell helmets. New aspects on typology, chronology and manufacture, Prähistorische Zeitschrift 88, 1, 2014, 152-179.

Mödlinger 2014b

M. Mödlinger, European Bronze Age cuirasses. Aspects of chronology, typology, manufacture and usage, Jahrbuch des Römisch-Germanischen Zentralmuseums Mainz 59/2012, 2014, 1-50.

Mödlinger 2015

M. Mödlinger, Bronzezeitliche Schutzwaffen, in: Meller - Schefzik 2015, 293-296.

Mödlinger 2015

M. Mödlinger, Bronzezeitliche Bewaffnung und Kampfesweise in Mitteleuropa, in: Meller - Schefzik 2015, 269272.

Mödlinger - El Morr 2014

M. Mödlinger - Z. El Morr, European Bronze Age sheet metal objects. 3000 years of high level bronze manufacture, JOM 66, 1, 2014, 171-177.

Mödlinger - Piccardo 2013

M. Mödlinger - P. Piccardo, Manufacture of eastern European decorative discs from 1200 BC, Journal of Archaeological and Anthropological Sciences 5, 4, 2013, 299-309.

Mödlinger et al. 2011

M. Mödlinger - M. Uckelmann - S. Matthews, Introduction, in: Uckelmann - Mödlinger 2011, 1-10.

Mödlinger et al. 2013

M. Mödlinger - P. Piccardo - Z. Kasztovszky - I. Kovács - Z. Szőkefalvi-Nagy - G. Káli - V. Szilágyi, Archaeometallurgical characterization of the earliest European metal helmets, Materials Characterization 79, 2013, 22-36.

Mödlinger et al. 2014

M. Mödlinger - Z. Kasztovszky - Z. Kis - B. Maróti - I. Kovács - Z. Szőkefalvi-Nagy - G. Káli - E. Horváth - Z. Sánta - Z. El Morr, Non-invasive PGAA, PIXE and ToF-ND analyses and neutron radiography on Hungarian Bronze Age defensive armour, Journal of Radioanalytical and Nuclear Chemistry 300, 2, 2014, 787-799. 
Mödlinger et al. 2016

M. Mödlinger - E. Denel - M. Črešnar - M. Mele - M. Özdogan - S. Thomas - C. Tsirogiannis - M. Van Cant - A. Volkmann - M. Fernandez-Götz - A. Vanzetti - Y. Yalman, Committee on the illicit trade in cultural material, The European Archaeologist 49, 2016, 16-20.

Mohen 1977

J.-P. Mohen, L'Âge du Bronze dans la région de Paris. Catalogue synthétique des collections conservées au Musée des Antiquités Nationales (Paris 1977).

Mohen 1987

J.-P. Mohen, Marmesse, in: Trésors des Princes Celtes. Galeries nationales du Grand-Palais, 20 octobre 1987-15 février 1988. Exhibition Catalogue Paris (Paris 1987) 47-49.

Molloy 2004

B. Molloy, Experimental combat with Bronze Age weapons, Archaeology Ireland 18, 2004, 32-34.

Molloy 2007

B. Molloy (ed.), The Cutting Edge. Studies in Ancient and Medieval Combat (Stroud 2007).

Molloy 2009

B. Molloy, For gods or men? A reappraisal of the function of European Bronze Age shields, Antiquity 83, 10521064.

Molloy 2013

B. Molloy, The origins of plate armour in the Aegean and Europe, Talanta XLIV/2012, 2013, 273-294.

Molloy 2015

B. Molloy, Of odysseys and oddities. Scales and modes of interaction in the prehistoric Aegean, Sheffield Studies in Aegean Archaeology (Oxford 2015).

Molloy - Grossman 2007

B. Molloy - D. Grossmann, Why can't Johnny kill? The psychology and physiology of interpersonal combat, in: Molloy 2007, 188-202.

Mongez 1803/1804

A. Mongez, Second mémoire sur les bronze des anciens et sur une épée antique, Mémoires de l'institut national des sciences et arts, Littérature et Beaux Arts V, Fructidor An XII, 1803/1804, 496-516.

Montelius 1895

O. Montelius, Civilisation primitive en Italie I (Stockholm 1895).

Moore - Armada 2011

T. Moore - X.-L. Armada, Atlantic Europe in the First Millennium BC. Crossing the Divide (Oxford 2011).

Moosleitner 1982

F. Moosleitner, Der Helm vom Pass Lueg im Salzburger Museum Carolino Augusteum, Salzburger Museumsblätter $43,1,1982,5-6$

Moosleitner 1993

F. Moosleitner, Der Helm vom Pass Lueg. Salzburger Museum Carolino Augusteum, Das Kunstwerk des Monats, February (Salzburg 1993).

Mörtz 2011a

T. Mörtz, At the head of concealment. The deposition of Bronze Age helmets in the Carpathian basin, in: S. Berecki - R. E. Nèmeth - B. Rezi (eds.), Bronze Age Rites and Rituals in the Carpathian Basin. Proceedings of the International Colloquium from Târgu Mureş. 8-10 October 2010 (Târgu Mureş 2011) 357-376.

Mörtz 2011b

T. Mörtz, Sternparallaxe. Bemerkungen zu einer älterurnenfelderzeitlichen Ornamentform zwischen Banat und Harz, Marisia. Studii şi Materiale XXXI, 2011, 93-110. 
Mörtz 2013

T. Mörtz, Hauptsache. Argumente für eine eigenständige Entwicklung der Kammhelme in Mitteleuropa, in: B. Rezi - R. E. Németh - S. Berecki (eds.), Indications for the Usage as Weapons. Bronze Age Crafts and Craftsmen in the Carpathian Basin, Târgu Mureş, Romania, 5-7 October 2012 (Târgu Mureş 2013) 265-278.

Moschos 2000

I. Moschos, Prehistoric tumuli at Portes in Achaia. First preliminary report, in: S. Isager - I. Nielsen (eds.), Proceedings of the Danish Institute at Athens III (Aarhus 2000) 9-49.

Moschos 2009

I. Moschos, Evidence of social reorganization and reconstruction at Late Helladic IIIC Achaea and modes of contacts and exchange via the Ionian Sea and Adriatic Sea, in: E. Borgna - P. Càssola Guida (eds.), Dall'Egeo all'Adriatico. Organizzazioni sociali, modi di scambio e interazione in età postpalaziale (XII-XI sec. a.C.). Atti del seminario internazionale, Udine 1-2 December 2006, Studie Ricerche di Protostoria Mediterranea 8 (Rome 2009) $345-414$.

Mottier 1984

Y. Mottier, La trouvaille de Fillinges, Musées de Genève 248, 1984, 10-13.

Mottier 1988

Y. Mottier, Die Bronzepanzer von Fillinges aus der späten Bronzezeit (800 v. Chr.), Helvetia Archaeologia 76, 1988, $110-145$.

Mountjoy 1984

P. A. Mountjoy, The bronze greaves from Athens. A case for a LH IIIC date, Opuscula Atheniensia 15, 1984, 135146.

Mountjoy 1988

P. A. Mountjoy, LH IIIC Late versus Submycenaean. The Kerameikos Pompeion cemetery revisited, Jahrbuch des Deutschen Archäologischen Instituts 103, 1988, 1-37.

Mozsolics 1955

A. Mozsolics, Neue hallstattzeitliche Helmfunde aus Ungarn, Acta Archaeologica Academiae Scientiarum Hungaricae $5,1955,35-54$.

Mozsolics 1971

A. Mozsolics, Some remarks on 'Peschiera' Bronzes in Hungary, in: J. Boardman - M. A. Brown - T. G. E. Powell (eds.), The European Community in Later Prehistory. Studies in Honour of C. F. C. Hawkes (London 1971) 57-76.

Mozsolics 1972

A. Mozsolics, Beziehungen zwischen Italien und Ungarn während 'Bronzo recente' und 'Bronzo finale', Rivista di Scienze Prehistoriche 27, 1972, 373-401.

Mozsolics 1984

A. Mozsolics, Ein Beitrag zum Metallhandwerk der ungarischen Bronzezeit, Berichte der Römisch-Germanischen Kommission 65, 1984, 20-72.

Mozsolics 1985

A. Mozsolics, Bronzefunde aus Ungarn. Depotfundhorizonte von Aranyos, Kurd und Gyermely (Budapest 1985).

Mozsolics 2000

A. Mozsolics, Bronzefunde aus Ungarn. Depotfundhorizonte Hajdúböszermény, Románd und Bükkszentlászló, Prähistorische Archäologie in Südosteuropa 17 (Kiel 2000).

Much 1883

M. Much, Der Bronze-Helm aus dem Passe Lueg bei Salzburg (note 130), Mittheilungen der K. K. Central-Commission zur Erforschung und Erhaltung der Baudenkmale N. F. 9, 1883, CLV-CLVII.

Müller 2006

R. Müller, Várvölgy. Nagy-Lázhegy késő bronzkori földvár kutatása, in: G. Kovács - Z. Miklós (eds.), Gondolják. Látják az várnak nagy voltát. Tanulmányok a 80 éves Nováki Gyula tiszteletére (Budapest 2006) 227-236. 
Müller-Karpe 1959

H. Müller-Karpe, Beiträge zur Chronologie der Urnenfelderzeit nördlich und südlich der Alpen, Römisch-Germanische Forschungen 22 (Berlin 1959).

Müller-Karpe 1962a

H. Müller-Karpe, Zur spätbronzezeitlichen Bewaffnung in Mitteleuropa und Griechenland, Germania 40, 1962, 255-287.

Müller-Karpe 1962b

H. Müller-Karpe, Zur Stadtwerdung Roms (Heidelberg 1962).

Müller-Karpe 1976

H. Müller-Karpe, Zum Ende der spätkanaanitischen Kultur, Jahresberichte des Instituts für Vorgeschichte, Universität Frankfurt am Main 1976, 57-77.

Müller-Karpe 1980

H. Müller-Karpe, Handbuch der Vorgeschichte. Bronzezeit (Munich 1980).

Murillo Redondo et al. 2005

J. F. Murillo Redondo - J. A. Morena López - D. Ruiz Lara, Nuevas estelas de guerrero procedentes de las provincias de Córdobayde Ciudad Real, Romula 4, 2005, 7-46.

Murray et al. 1900

A. S. Murray - A. H. Smith - H. B. Walters, Excavations in Cyprus (London 1900).

Nania - Holtei 1972

I. Nania - S. Holtei, Depozitul de bronzuri de la Sacoţi-Slătioara. Judeţul Vâlcea, Buridava Studii şi materiale 1, 1972, 173-181.

Needham 1983

S. P. Needham, The Early Bronze Age Axeheads of Central and Southern England (PhD Diss., University College Cardiff, Cardiff 1983).

Needham 1990

S. P. Needham, The Petters Late Bronze Age Metalwork. An Analytical Study of Thames Valley Metalworking in its Settlement Context, British Museum Occasional Papers 70 (London 1990).

Needham 1993

S. P. Needham, Displacement and exchange in archaeological methodology, in: F. Healy - C. Scarre (eds.), Trade and Exchange in Prehistoric Europe (Oxford 1993) 161-169.

Needham et al. 1997

S. P. Needham - C. B. Ramsey - D. Coombs - C. Cartwright - P. Pettitt, An independent chronology for British Bronze Age metalwork. The results of the Oxford radiocarbon accelerator programme, Archaeological Journal 154, 1997, 55-107.

Needham et al. 2012

S. P. Needham - P. Northover - M. Uckelmann - R. Tabor, South Cadbury. The last of the bronze shields?, Archäologisches Korrespondenzblatt 42, 2012, 473-492.

Neigebaur 1851

J. F. Neigebaur, Dacien aus den Überresten des klassischen Altertums. Mit besonderer Rücksicht auf Siebenbürgen (Braşov [Kronstadt] 1851).

Németi 1972

I. Németi, Coiful de bronz de la Pişcolt, Studii și Comunicări Satu Mare 2, 1972, 112-120.

Németi 2009

I. Németi, Barangolások Szatmárban (Nyomda 2009).

Norling-Christensen 1943

H. Norling-Christensen, Bronzealerhjælmene fra Viksø, Fra Nationalmuseets Arbejdsmark, 1943, 5-17. 
Norling-Christensen 1946

H. Norling-Christensen, The Viksø Helmets, Acta Archaeologica København 17, 1946, 99-115.

Northover 2012

J. P. Northover, Metallurgy of tanged and looped spearheads, in: R. Davis (ed.), The Early and Middle Bronze Age Spearheads of Britain, Prähistorische Bronzefunde V, 5 (Stuttgart 2012) 174-183.

Nossiop 1864

Nossiop, M. Cuirasses de femmes trouvées en 1628. L'intermédiaire des chercheurs des curieux 1, 1, 1er mai 1864, 69.

Novák 1975

P. Novák, Die Schwerter in der Tschechoslowakei I, Prähistorische Bronzefunde IV, 4 (Munich 1975).

Novotná 1964

M. Novotná, Bronzové kužul'ovité helmy a niektoré typy bronzových nádob v hromadných nálezoch na Slovensku, Sborník Filosofikej Fakulty Univerzity Komenského 15, Musaicia IV, 1964, 19-43.

Novotná 1970

M. Novotná, Die Bronzehortfunde in der Slowakei, Archaeologica Slovaca Fontes IX (Bratislava 1970).

Novotná 1991

M. Novotná, Die Bronzegefäße in der Slowakei, Prähistorische Bronzefunde II, 11 (Stuttgart 1991).

Novotný 1966

B. Novotný, Ein Panzerfund aus Čierna nad Tisou, Zborník Filozofickej Fakulty Univerzity Komenského 17, Musaica $6,1966,27-34$.

Nowak 2002

D. Nowak, Restaurierung und Rückformung des Bronzehelms aus dem Depotfund vom Piller, Gemeinde Fließ (Tirol), ArchaeoTirol, Kleine Schriften 4, 2002, 61-76.

Orsi 1887

P. Orsi, Ripostiglio di Limone (Montenero) presso Livorno, Bulletino di Paletnologia Italiana 13, ser. II, 1887, 117126.

Orsi 1926

P. Orsi, Le necropoli preelleniche calabresi di Torre Galli e di Canale, Ianchina, Patariti, Monumenti Antichi 31, 1926, 1-375.

Osgood 2006

R. Osgood, The dead of Tomarton. Bronze Age combat victims?, in: Otto et al. 2006, 331-340.

Osgood 2013

R. Osgood, The Unknown Warrior. An Archaeology of the Common Soldier (Stroud 2013).

Osgood et al. 2000

R. Osgood - S. Monks - J. Toms (eds.), Bronze Age Warfare (Stroud 2000).

Otterbein 1970

K. F. Otterbein, The Evolution of War. A Cross Cultural Study, 2nd edition (New Haven 1970).

Otto 1981

K. H. Otto, Die historische Bedeutung der mittleren und jüngeren Bronzezeit in Mitteleuropa, in: W. Coblenz - F. Horst (eds.), Mitteleuropäische Bronzezeit. Beiträge zur Archäologie und Geschichte (Berlin 1981).

Otto et al. 2006

T. Otto - H. Thrane - H. Vandkilde (eds.), Warfare and Society. Archaeological and Social Anthropological Perspectives (Aarhus 2006). 
Pacciarelli 1999

M. Pacciarelli, Torre Galli. La necropoli della prima etá del ferro (scavi Paolo Orsi 1922-23) (Soveria Mannelli 1999).

Pacciarelli 2001

M. Pacciarelli, Dal villaggio alla cittá. La svolta protourbana del 1000 a. C. nell'Italia tirrenica, Grandi Contesti e Problemi della Protostoria Italiana 4 (Florence 2001).

Pagenstecher 1917

R. Pagenstecher, Die Neuerwerbungen des Hamburgischen Museums für Kunst und Gewerbe, Archäologischer Anzeiger 91, 1917, 55-117.

Pahič 1962

S. Pahič, Arheološki spomeniki v Slovenskih Goricah, Ptujskazbornik 2, 1962, 187 -201.

Pahič 1975

S. Pahič, Hercegoščak (330), in: V. Gesla (ed.), Arheološka Najdišča Slovenije (Ljubljana 1975).

Papadopoulos 1999

T. J. Papadopoulos, Warrior-graves in Achaean Mycenaean cemeteries, in: R. Laffineur (ed.), Polemos. Le contexte guerrier en Égée à l'Âge du Bronze. Actes de la 7e rencontre Égéenne internationale, Liège, 14-17 avril 1998, Aegaeum 19 (Liège 1999) 267-274.

Pare 1987

C. F. E. Pare, Wheels with thickened spokes, and the problem of cultural contact between the Aegean World and Europe in the Late Bronze Age, Oxford Journal of Archaeology 6, 1987, 43-61.

Pare 2008

C. Pare, Italian metalwork of the $11^{\text {th }}-9^{\text {th }}$ centuries BC and the absolute chronology of the Dark Age Mediterranean, in: D. Brandherm - M. Trachsel (eds.). A New Dawn for the Dark Age? Shifting Paradigms in Mediterranean Iron Age Chronology, British Archaeological Reports International Series 1871 (Oxford 2008) 77-101.

Passard - Piningre 1984

F. Passard - J.-F. Piningre, Un dépôt de l'Âge du Bronze Final á Bouclans (Doubs), Revue Archéologique de l'Est et Centre Est 35, 1984, 85-111.

Passarello 1965

P. Passarello, Veio, Notizie degli Scavi di Antichità 19, 1965, 5-236.

Patay 1966

P. Patay, Der Bronzefund von Fancsika, Acta Universitatis Szegediensis, Acta Antiqua et Archaeologica 10, 1966, $75-85$.

Patay 1969

P. Patay, Der Bronzefund von Mezőkövesd, Acta Archaeologica Academiae Scientiarum Hungaricae 21, 1969, 167216.

Patay 1990

P. Patay, Die Bronzegefäße in Ungarn, Prähistorische Bronzefunde II, 10 (Munich 1990).

Patroni 1909

G. Patroni, Cremona. Elmi di bronzo, Notizie degli scavi di antichitá VL, 8, 1909, 274-276.

Paulík 1963

J. Paulík, K problematike čakanskej kultúry v Karpatskej kotline, Slovenská Archeológia 11, 1963, 269-338.

Paulík 1968

J. Paulík, Panzer der jüngeren Bronzezeit aus der Slowakei, Berichte der Römisch-Germanischen Kommission 49, $1968,41-61$. 
Paulík 1972

J. Paulík, Hromadný nález bronzových predmetov z Dolných Janík, okres Bratislava-vidiek, Zborník Slovenského Národného Múzea 66, 1972, 5-34.

Paulík 1988

J. Paulík, K bojovnickemu vystroju v mladsej dobe bronzovej, Zbornik Slovenského Národného Múzea LXXXII, História 28, 1988, 11-25.

Peatfield 2008

A. Peatfield, Minoan and Mycenaean warfare, in: P. de Souza (ed.), The Ancient World at War (London 2008) $87-101$.

Périn 2004

P. Périn, The Musée des antiquités nationales en Saint-Germain-en-Laye (Cedex 2004).

Perini 1987

R. Perini (ed.), Scavi archeologici nella zona palafitticoa di Fiavé-Carera II (Trento 1987).

Perini 1990

R. Perini, Manufatti in legno dell'età del bronzo nelle Alpi meridionali, in: M. Höneisen (ed.), Die ersten Bauern. Pfahlbaufunde Europas. Forschungsberichte zur Ausstellung im Schweizerischen Landesmuseum und zum Erlebnispark, Ausstellung Pfahlbauland in Zürich, 28. April bis 30. September 1990. Exhibition Catalogue Zürich (Zürich 1990) 253-265.

Pernot 2000

M. Pernot, Forming bronze by plastic deformation around the $1^{\text {st }}$ millennium BC in Western Europe, in: S. Yue - E. Essadiqi (eds.), Thermomechanical Processing of Steel, J.J. Jonas Symposium (Montréal 2000) 615-626.

Peroni 1956

R. Peroni, Zur Gruppierung mitteleuropäischer Griffzungendolche der späten Bronzezeit, Badische Fundberichte 20, 1956, 69-92.

Peroni 1989

R. Peroni, L'etá del bronzo e ferro in Italia, Popoli Civiltà dell'Italia Antica 9 (Rome 1989).

Peroni - Vanzetti 2005

R. Peroni - A. Vanzetti, Intorno alle cronologia della prima etá del ferro italiana da H. Müller-Karpe a C. Pare, in: G. Bartoloni - F. Delpino (ed.), Oriente e occidente. Metodi e discipline a confronto. Atti dell'incontro di studio, Rome 30-31 October 2003 (Pisa, Rome 2005) 53-80.

Persson 1931

A. W. Persson, The Royal Tombs near Dendra at Midea (Lund 1931).

Persy 1962

A. Persy, Eine neue urnenfelderzeitliche Beinschiene aus Niederösterreich, Archaeologia Austriaca 31, 1962, $37-48$.

Pertusi 1892

G. Pertusi, Catalogo della collezione di antichità del fu Amilcare Ancona (Milano 1892).

Pescheck 1967

C. Pescheck, Bodenfunde und Ausgrabungen in Franken, Frankenland Neue Folge 19, 1967, 229-259.

Pescheck 1968

C. Pescheck, Ein Kammhelm aus dem oberen Maintal, Jahrbuch des Römisch-Germanischen Zentralmuseums Mainz 13/1966, 1968, 34-36.

Peschel 1984

K. Peschel, Beobachtungen an vier Bronzefunden von der mittleren Saale, Arbeits- und Forschungsberichte zur Sächsischen Bodendenkmalpflege 27-28, 1984, 59-91. 
Petres 1983

É. F. Petres, Neue Angaben über die Verbreitung der spätbronzezeitlichen Schutzwaffen, Savaria 16/1982, 1983, $57-80$.

Petres - Jankovits 2014

É. F. Petres - K. Jankovits, Der spätbronzezeitliche zweiteilige Bronzebrustpanzer aus der Donau in Ungarn, Acta Archaeologica 65, 1, 2014, 43-71.

Petrescu-Dîmboviţa 1960

M. Petrescu-Dîmboviţa, Depozitele de obiecte de bronz, Istoria României 1, 1960, 147-149.

Petrescu-Dîmboviţa 1977

M. Petrescu-Dîmboviţa, Depozitele de bronzuri din Romănia (Bucharest 1977).

Petrescu-Dîmboviţa 1978

M. Petrescu-Dîmboviţa, Die Sicheln in Rumänien mit Corpus der jung- und spätbronzezeitlichen Horte Rumäniens, Prähistorische Bronzefunde XVIII, 1 (Munich 1978).

Pflug 1989

H. Pflug, Schutz und Zier. Helme aus der Antikensammlung Berlin und Waffen anderer Sammlungen (Basel 1989).

Phoenix Ancient Art 2012

Phoenix Ancient Art, Warrior. Ancient Arms and Armour (New York 2012).

Piccardo 2000

P. Piccardo, Setting up an investigation method for the study of corrosion of ancient burial bronze objects, Microscopy and Analysis 63, 2000, 13-16.

Piccardo - Pernot 1997

P. Piccardo - M. Pernot, Studio analitico e strutturale di alcuni vasi celtici in bronzo, Metallurgia Italiana 11, 1997, $43-52$.

Piccardo et al. 2009

P. Piccardo - R. Amendola - A. Adobati - C. Faletti, Studio della fluiditá di leghe a base rame, Metallurgia Italiana May 2009, 31-38.

Piccardo et al. 2010

П. Piccardo - R. Amendola - A. Ervas, Metallographic investigation and experimental replication of an Etruscan bronze mirror, Historical Metallurgy Journal 44, 1, 2010, $10-14$.

Piccardo et al. 2013

P. Piccardo - M. Mödlinger - G. Ghiara - S. Campodonico - V. Bongiorno, Investigation on a 'tentacle-like' corrosion feature on Bronze Age tin-bronze objects, Journal of Applied Physics A 113, 4, 2013, 1039-1047.

Pingel 1974

V. Pingel, Bemerkungen zu den ritzverzierten Stelen und zur beginnenden Eisenzeit im Südwesten der Iberischen Halbinsel, Hamburger Beiträge zur Archäologie 4, 1974, 1-19.

Pingel 1993

V. Pingel, Bemerkungen zu den ritzverzierten Stelen im Südwesten der iberischen Halbinsel, in: J. Untermann - F. Villar (eds.), Lengua y cultura en la Hispania prerromana. Actas del V coloquio sobre lenguas y culturas prerromanas de la península ibérica, Colonia, 25-28 de Noviembre de 1989, Acta Salamanticensis, Fil. y Letras 251 (Salamanca 1993) 209-231.

Pittioni 1954

R. Pittioni, Urgeschichte des Österreichischen Raumes (Vienna 1954).

Platon - Stassinopolou-Touloupa 1965

N. Platon - E. Stassinopolou-Touloupa, Ivory and Linear B from Thebes, The Illustrated London News, 5.12.1965, 896-897. 
Podborský 1970

V. Podborský, Mähren in der Spätbronzezeit an der Schwelle zur Eisenzeit (Brno 1970).

Pontiroli 1974

G. Pontiroli, Catalogo della sezione archeologica del Museo Civico Ala Ponzone di Cremona (Milan 1974).

Poullain de Saintfoix 1763

G.-F. Poullain de Saintfoix, Essais historiques sur Paris I, $3^{\text {rd }}$ edition (London 1763).

Prendi 1975

F. Prendi, Un aperçu sur la civilisation de la premiére période du fer en Albanie, Iliria 3, 1975, 109-138.

Primas 1986

M. Primas, Die Sicheln in Mitteleuropa I (Österreich, Schweiz, Süddeutschland), Prähistorische Bronzefunde XVIII, 2 (Munich 1986).

Probst 1996

E. Probst, Deutschland in der Bronzezeit. Bauern, Bronzegießer und Burgherren zwischen Nordsee und Alpen (Munich 1996).

Prüssing 1991

G. Prüssing, Die Bronzegefäße in Österreich, Prähistorische Bronzefunde II, 5 (Stuttgart 1991).

Puniet - Balcar 2000

G. d. Puniet - N. Balcar, Rapport no. 3048 of the CRRMF, Centre de Recherche et de Restauration des Musées de France (Paris 2000).

Randsborg 1995

K. Randsborg, Hjortspring. Warfare and Sacrifice in Early Europe (Aarhus 1995).

Reinach 1921

S. Reinach, Catalogue illustré de Museé des Antiquités Nationales au Château de Saint-Germain-en-Laye 2 (Paris 1921).

Reinecke 1900

P. Reinecke, Aus der prähistorischen Sammlung des Mainzer Altertumsmuseums, Zeitschrift des Vereins zu Erforschung der rheinischen Geschichte und Altertümer (Altertums-Verein) in Mainz 4, 2-3, 1900, 335-361.

Reinecke 1906

P. Reinecke, Zum Bronzedepotfund von Wonsheim in Rheinhessen, Mainzer Zeitschrift 1, 1906, 36-37.

Reinecke 1907

P. Reinecke, Die Originalaltertümer in den Sammlungen des Römisch-Germanischen Centralmuseums in Mainz, Mainzer Zeitschrift 2, 1907, 40-53.

Reissenberger 1872

A. Reissenberger, Der neueste archäologische Fund bei Hammersdorf, Archiv des Vereins für Siebenbürgische Landeskunde $10,1872,8-37$.

Richtera et al. forthcoming

L. Richtera - M. Salaš - M. Zmrzlý, Urnenfelderzeitliche Helme und Panzer im Licht der technologischen Untersuchung (working title), Archeologické Rozhledy LXVIII (forthcoming).

Ridella 1994

R. Ridella, Alcune note su un elmo preromano atipico da Cuneo, Quaderni della Sopraintendenza Archeologica del Piemonte 12, 1994, 43-52.

Riederer 2004

J. Riederer, Ergebnisse metallanalytischer Untersuchungen von Bronzeschwertern, in: H. Wüstemann, Die Schwerter in Ostdeutschland, Prähistorische Bronzefunde IV, 15 (Stuttgart 2004). 
Riemer 1997

P. Riemer, Finkenwalde, Kr. Randow, Prov. Pommern (Szczecin-Zdroje, Polen), in: A. Hänsel - B. Hänsel (eds.), Gaben an die Götter. Schätze der Bronzezeit Europas. Museum für Vor- und Frühgeschichte Berlin, Bestandskata$\log 4$ (Berlin 1997) 132.

Ř́hovský 1972

J. Říhovský, Die Messer in Mähren und dem Ostalpengebiet, Prähistorische Bronzefunde VII, 1 (Munich 1972).

Rind - Schauer 1997

M. Rind - P. Schauer, Ein urnenfelderzeitlicher Hortfund (?) aus Abensberg, in: M. Rind (ed.), Von Keltenkriegern und Kirchenmäusen, Archäologie im Landkreis Kelheim 2/1994-1996, 1997, 112-120.

Ripoll Perelló 1963

E. Ripoll Perelló, Pinturas rupestres de la Gasulla (Castellón) (Barcelona 1963).

Robben - Suárez-Orozco 2000

A. C. G. M. Robben - M. M. Suárez-Orozco (eds.), Cultures under Siege. Collective Violence and Trauma (Cambridge 2000).

Robert 1860

Z. Robert, La Sentinelle du Jura 46, 15 April 1860.

Roberts et al. 2013

B. W. Roberts - M. Uckelmann - D. Brandherm, Old father time. The Bronze Age chronology of western Europe, in: H. Fokkens - A. Harding (eds.), The Oxford Handbook of Bronze Age Europe (Oxford 2013) 17-46.

Rothé 2001

M. P. Rothé, Le Jura, Carte Archéologique de la Gaule 39 (Paris 2001).

Roy 1983

J. B. Roy, Nemours. Musée de Préhistoire. Un casque de bronze de l’Âge du Bronze final, La Revue du Louvre et des Musées de France 5-6, 1983, 332-333.

Ruiz-Gálvez Priego 1995

M. Ruiz-Gálvez Priego, Depósitos del Bronce Final. ¿Sagrado o profano? ¿Sagrado y, a la vez, profano? Complutum 5, 1995, 21-32.

Ruffoni 1888

F. Ruffoni, Torbiere d'Iseo, Bullettino di Paletnologia Italiana 14, 1888, 35-36.

Ruffoni 1891

F. Ruffoni, La Torbiera di Iseo, prov. di Brescia, Bullettino di Paletnologia Italiana 17, 1891, 76-90.

Rusu 1963

M. Rusu, Die Verbreitung der Bronzehorte in Transsilvanien, Dacia 7, 1963, 177-210.

Rusu 1990

M. Rusu, Coifuri de bronz transilvănene din Hallstatt A-B, Thraco-Dacia 11, 1990, 69-78.

Salaš 1997

M. Salaš, Der urnenfelderzeitliche Hortfund von Polešovice (Brno 1997).

Salaš 2002

M. Salaš, Neue urnenfelderzeitliche Bronzedepotfunde in Mähren. Überlegungen zum Depotfundhorizont Přestavlky, Anodos, Studies of the Ancient World 2, 2002, 261-275.

Salaš 2005

M. Salaš, Bronzové depoty střední až pozdní doby bronzové na Moravě (Brno 2005).

Salaš 1997

M. Salaš, Der urnenfelderzeitliche Hortfund von Polešovice und die Frage der Stellung des Depotfundhorizonts Drslavice in Mähren (Brno 1997). 
Salaš - Šmíd 1999

M. Salaš - M. Šmíd, Hromadný bronzový nález ze Služína (Bez. Prostějov). Příklad sémanticky signifikantního depozita doby popelnicových polí, Pravěk Supplementum 2 (Brno 1999) 5-42.

Salimbeti - D'Amato 2009

A. Salimbeti - R. D'Amato, Clash among the kings. The Seven against Thebes. New light on Achaen weaponry in Boeotia of the $13^{\text {th }}$ century BC, Ancient Warfare III, 3, 2009, 26-33.

Salzani 1985

L. Salzani, Desmontà (Comune di Veronella - Verona), Quaderni di Archeologia del Veneto 1, 1985, 43.

Salzani 1986

L. Salzani, Gli schinieri di Desmontà (Verona), Aquileia Nostra LVII, 1986, 386-391.

Salzani 1987

L. Salzani, Desmontà, in: A. Aspes (ed.), Prima della storia. Inediti di 10 anni di ricerche a Verona (Verona 1987).

Salzani 1994

L. Salzani, Nogara. Rinvenimenti di un ripostiglio di bronzi in località 'Pila del Brancón', Quaderni di Archeologia del Veneto 10, 1994, 83-94.

Salzani 1998

L. Salzani, Nuovi dati sul ripostiglio della Pila del Brancón (Nogara), Quaderni di Archeologia del Veneto 14, 1998, 68-71.

Savignoni 1904

L. Savignoni, Scavi e scoperte nella necropoli di Phaistos, Monumenti Antichi 14, 1904, 501-675.

Schachermeyr 1960

F. Schachermeyr, Das Keftiu-Problem und die Frage des ersten Auftretens einer griechischen Herrenschicht im minoischen Kreta, Jahreshefte des Österreichischen Archäologischen Institutes in Wien 45, 1960, 44-68.

Schauer 1971

P. Schauer, Die Schwerter in Süddeutschland, Österreich und der Schweiz I, Prähistorische Bronzefunde IV, 2 (Munich 1971).

Schauer 1975

P. Schauer, Die Bewaffnung der 'Adelskrieger' während der späten Bronze- und frühen Eisenzeit. Ausgrabungen in Deutschland 3, Monographien des Römisch-Germanischen Zentralmuseums 1, 3 (Mainz 1975) 305-311.

Schauer 1980

P. Schauer, Urnenfelderzeitliche Helmformen und ihre Vorbilder, Fundberichte Hessen 19-20/1979-1980, 1980, $521-543$.

Schauer 1982a

P. Schauer, Deutungs- und Rekonstruktionsversuche bronzezeitlicher Kompositpanzer, Archäologisches Korrespondenzblatt 12, 1982, 335-349.

Schauer 1982b

P. Schauer, Die Beinschienen der späten Bronze- und frühen Eisenzeit, Jahrbuch des Römisch-Germanischen Zentralmuseums Mainz 29, 1982, 100-155.

Schauer $1982 \mathrm{c}$

P. Schauer, Urnenfelderzeitliche Kappenhelme, in: Studi in onore di Ferrante Rittatore Vonwiller 1, 2 (Como 1982) 701-728.

Schauer 1982d

P. Schauer, Die urnenfelderzeitlichen Bronzepanzer von Fillinges, Dép. Haute-Savoie, Frankreich, Jahrbuch des Römisch-Germanischen Zentralmuseums Mainz 25/1978, 1982, 92-130.

Schauer 1983

P. Schauer, Orient im spätbronze- und früheisenzeitlichen Occident. Kulturbeziehungen zwischen der Iberischen Halbinsel und dem Vorderen Orient während des späten 2. und des ersten Drittel des 1. Jahrtausends v. Chr., Jahrbuch des Römisch-Germanischen Zentralmuseums Mainz 30, 1983, 175-194. 
Schauer 1984

P. Schauer, Überregionale Gemeinsamkeiten bei Waffengräbern der ausgehenden Bronzezeit und älteren Urnenfelderzeit des Voralpenraumes, Jahrbuch des Römisch-Germanischen Zentralmuseums Mainz 31, 1984, $209-235$.

Schauer 1986

P. Schauer, Neuerwerbungen für die Sammlungen, Jahresbericht des Römisch-Germanischen Zentralmuseums, Jahrbuch des Römisch-Germanischen Zentralmuseums Mainz 33, 1986, 900-904.

Schauer 1988

P. Schauer, Die kegel- und glockenförmigen Helme mit gegossenem Scheitelknauf der jüngeren Bronzezeit Alteuropas, in: M. Egg - G. Waurick (ed.), Antike Helme, Monographien des Römisch-Germanischen Zentralmuseums 14, 1988, 181-194.

Schauer 2003

P. Schauer, Zur Zeitstellung der vermeintlich ältesten Bronzekammhelme in Mitteleuropa, Archäologisches Korrespondenzblatt 33, 2003, 193-203.

Schmidt 2004

J.-P. Schmidt, Rohstoffe aus der Fremde. Zum bronzezeitlichen Handel und Warenaustausch in Mecklenburg-Vorpommern, in: H. Jöns - F. Lüth (eds.), Mythos und Magie. Archäologische Schätze der Bronzezeit aus Mecklenburg-Vorpommern, Archäologie in Mecklenburg-Vorpommern 3 (Lübsdorf 2004) 87-95.

Schröder 1912

B. Schröder, Die Freiherrlich von Lipperheidesche Helmsammlung in den königlichen Museen zu Berlin, Archäologischer Anzeiger 1905, 1912, 15-30.

Schuchhardt 1912/1913

C. Schuchhardt, Ein altitalischer Helm aus Stettin, Amtliche Berichte aus den Königlichen Kunstsammlungen 34, 1912/1913, 28-30.

Schüle 1969

W. Schüle, Die Meseta-Kulturen der iberischen Halbinsel. Mediterrane und eurasische Elemente in früheisenzeitlichen Kulturen Südwesteuropas, Madrider Forschungen 3 (Berlin 1969).

Seeden 1980

H. Seeden, The Standing Armed Figurines in the Levant, Prähistorische Bronzefunde I, 1 (Munich 1980).

Seethaler 1839

J. Seethaler, Archäologische Nachrichten aus Salzburg (Salzburg 1839) (Hand-written manuscript in the archive of the Salzburg museum).

Seidl 1995

U. Seidl, Bronzezeit. Sammlung Württemberg, Landesmuseum 2 (Stuttgart 1995).

Shelmerdine 1999

C. W. Shelmerdine, Pylian polemic. The latest evidence on military matters, in: R. Laffineur (ed.), Polemos. Le contexte guerrier en Égée à l'Âge du Bronze. Actes de la 7e rencontre Égéenne internationale, Liège, 14-17 avril 1998, Aegaeum 19 (Liège 1999) 403-411.

Shelmerdine 2001

C. W. Shelmerdine, The palatial Bronze Age of the southern and central Greek mainland, in: T. Cullen (ed.), Aegean Prehistory. A Review, American Journal of Archaeology, Suppl. 1 (Boston 2001) 329-382.

Sicherl 2004

B. Sicherl, Studien zur mittelbronzezeitlichen Bewaffnung in Tschechien, dem nördlichen Niederösterreich und der südwestlichen Slowakei, Universitätsforschungen zur prähistorischen Archäologie 107 (Bonn 2004).

Šimić 2008

J. Šimić, Die Bronzezeit im kontinentalen Kroatien, in: T. Bader (ed.), Dreitausend Jahre Vorgeschichte. Meisterwerke der Metallzeit im kontinentalen Kroatien. Sonderausstellung im Keltenmuseum Hochdorf, 10.9.-8.3.2009 (Eberdingen 2008) 45-71. 
Šinkovec 1995

I. Šinkovec, Katalog posameznih kovinskih najdb bakrene in bronaste dobe, in: B. Teržan (ed.), Depojske in posamezne kovinske najdbe bakrene in bronaste dobe na Slovenskem I, Katalogi in Monografije 29 (Ljubljana 1995) $13-28$.

Skutil 1946/1947

J. Skutil, Moravské prehistorické výkopy a nálezy Oddělení moravského pravěku Zemského musea 1937-1945. Časopis Moravského Musea v Brně 33, 1946/1947, 45-134.

Smodič 1955

A. Smodič, Bronaste deposjke najdbe v Črmožišah in severovzhodni Sloveniji, Arheološki Vestnik 6, 1955, 82-96.

Snodgrass 1964

A. M. Snodgrass, Early Greek Armour and Weapons from the End of the Bronze Age to 600 BC (Edinburgh 1964).

Snodgrass 1965

A. M. Snodgrass, The Linear B arms and armour tablets again, Kadmos 4, 1965, 96-110.

Snodgrass 1971

A. M. Snodgrass, The first European body armour, in: M. A. Boardman - M. A. Brown - T. G. E. Powell (eds.), The European Community in Later Prehistory. Studies in Honour of C. F. C. Hawkes (London 1971) 33-56.

Sofou - Katsarou-Moschona 2006

M. Sofou - D. Katsarou-Moschona, The Mycenaean bronze cuirass from Dendra. A new approach to its conservation, in: D. Saunders - J. Townsend - S. Woodcock (eds.), The Object in Context. Crossing Conservation Boundaries. Contributions to the Munich Congress 28 August - 1 September 2006 (London 2006) 325.

Sogliano 1889

A. Sogliano, Il museo provinciale Sannitico di Campobasso. Inventario degli oggetti antichi (Naples 1889).

Sommella et al. 1976

P. Sommella - F. Castagnoli - U. Ciotti, Pratica di Mare (Lavinium), Civiltá del Lazio Primitivo (Rome 1976) 291311.

Sørensen 1997

M. L. S. Sørensen, Material culture and typology. Current Swedish Archaeology 5, 1997, 179-192.

Soroçeanu 1981

T. Soroçeanu, Der zweite Depotfund von Vîlcele, Rumänien, Prähistorische Zeitschrift 56, 2, 1981, 249-261.

Soroçeanu 2005

T. Soroçeanu, Zu den Fundumständen der europäischen Metallgefäße bis in das 8. Jh. v. Chr. Ein Beitrag zu deren religionsgeschichtlicher Deutung, in: T. Soroçeanu (ed.), Bronzefunde aus Rumänien II / Descoperiri de bronzuri din România II. Beiträge zur Veröffentlichung und Deutung bronze- und älterhallstattzeitlicher Metallfunde in europäischem Zusammenhang (Bistriţa, Cluj-Napoca 2005) 387-428.

Soroçeanu 2008

T. Soroçeanu, Vasele de metal prescitice de pe actualul teritoriu al României (Bistriţa, Cluj-Napoca 2008).

Soroçeanu 2011

T. Soroçeanu, Le guerrier des Carpates à l'Âge du Bronze. Particularités régionales et traits communs continentaux, in: L. Baray - M. Honegger - M.-H. Dias-Merinho (eds.), L'armement et l'image du guerrier dans les sociétés anciennes. De l'objet à la tombe (Dijon 2011) 225-270.

Soroçeanu - Lakó 1981

T. Soroçeanu - E. Lakó, Depozitul de bronzuri de la Sâg (judeţul Sălaj), Acta Musei Porolisenssis V, 1981, 145-168.

Sperber 1987

J. Sperber, Untersuchungen zur Chronologie der Urnenfelderkultur im nördlichen Alpenvorland von der Schweiz bis Oberösterreich, Antiquitas Reihe 3, 29 (Bonn 1987). 
Sperber 1992a

L. Sperber, Zur Spätbronzezeit im alpinen Inn- und Rheintal, in: I. Metzger - P. Gleirscher (eds.), Die Räter / I reti, Schriftenreihe der Arbeitsgemeinschaft Alpenländer (Bolzano 1992) 53-90.

Sperber $1992 b$

L. Sperber, Zur Demographie des spätbronzezeitlichen Gräberfeldes von Volders in Nordtirol, Veröffentlichungen des Tiroler Landesmuseums Ferdinandeum 72, 1992, 37-74.

Sperber 1999

L. Sperber, Zu den Schwertträgern im westlichen Kreis der Urnenfelderkultur. Profane und religiöse Aspekte, in: Eliten der Bronzezeit. Ergebnisse zweier Kolloquien in Mainz und Athen, Monographien des Römisch-Germanischen Zentralmuseums Mainz 43, 2 (Mainz 1999) 605-659.

Sperber 2006a

L. Sperber, Bronzezeitliche Flußdeponierungen aus dem Altrhein bei Roxheim, Gde. Bobenheim-Roxheim, Lkr. Ludwigshafen. Ein Vorbericht, Archäologisches Korrespondenzblatt 36, 2, 2006, 195-214.

Sperber 2006b

L. Sperber, Bronzezeitliche Flussdeponierungen aus dem Altrhein bei Roxheim, Gde. Bobenheim-Roxheim, Lkr. Ludwigshafen. Metallwirtschaftliche Aspekte, Archäologisches Korrespondenzblatt 36, 3, 2006, 359-368.

Sperber 2011

L. Sperber, Bronzene Schutzwaffen in Gräbern der Urnenfelderkultur. Beinschienen- und Helm(?)fragmente aus dem Gräberfeld Volders in Nordtirol, Bayerische Vorgeschichtsblätter 76, 2011, 5-45.

Sperber 2017

L. Sperber, Studien zur spätbronzezeitlichen Chronologie im westlichen Mitteleuropa und in Westeuropa, Monographien Römisch-Germanisches Zentralmuseum Mainz (Mainz 2017).

Sprockhoff 1926

E. Sprockhoff, Helm. A. Europa, in: M. Ebert (ed.), Reallexikon der Vorgeschichte 5 (Berlin 1926) 290-297.

Sprockhoff 1930

E. Sprockhoff, Zur Handelsgeschichte der germanischen Bronzezeit (Berlin 1930).

Sprockhoff 1937

E. Sprockhoff, Jungbronzezeitliche Hortfunde Norddeutschlands. Periode IV (Mainz 1937).

Sprockhoff 1956

E. Sprockhoff, Jungbronzezeitliche Hortfunde der Südzone des nordischen Kreises. Periode V (Mainz 1937).

Stary 1981

P. F. Stary, Zur eisenzeitlichen Bewaffnung und Kampfesweise in Mittelitalien (Mainz 1981).

Stary 1994

P. F. Stary, Zur eisenzeitlichen Bewaffnung und Kampfesweise auf der iberischen Halbinsel, Madrider Forschungen 18 (Mainz 1994).

Stavropoulou-Gatsi et al. 2012

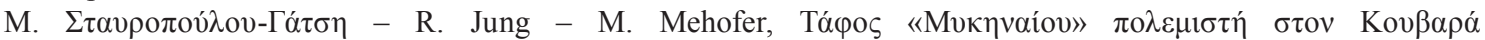

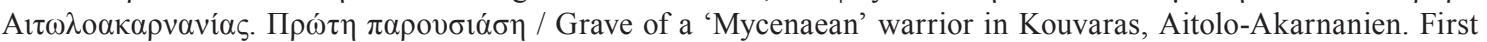
results], in: N. C. Stampolidis - A. Kanta - A. Giannikouri (eds.), Athanasia. The Earthly, the Celestial and the Underworld in the Mediterranean from the Late Bronze and the Early Iron Age. International Archaeological Conference, Rhodes 2009 (Heraklion 2012) 249-266.

Stein 1976

F. Stein, Bronzezeitliche Hortfunde in Süddeutschland, Saarbrücker Beiträge zur Altertumskunde 23 (Bonn 1976).

Stein 1979

F. Stein, Katalog der vorgeschichtlichen Hortfunde in Süddeutschland, Saarbrücker Beiträge zur Altertumskunde 24 (Bonn 1979). 
Steuer 2001

S. Steuer, Marmesse, in: H. Beck - D. Geuenich - H. Steuer (eds.), Reallexikon der Germanischen Altertumskunde 19 (Berlin 2001) 336-339.

\section{Szabó 1994}

G. V. Szabó, A kárpát-medencei késö bronzkori sisakok készítésének problémái egy újabb lelet alapján, in: G. Lőrinczy (ed.), A kőkortól a középkorig tanulmányok Trogmayer Ottó 60. születésnapjára (Szeged 1994) 219-227.

Szabó 2012

G. V. Szabó, In search of Late Bronze Age treasures, Hungarian Archaeology (e-journal), winter 2012, 1-5. Online $<$ http://www.hungarianarchaeology.hu/wp-content/uploads/2013/02/eng_szabog_12W.pdf $>$ (last access 1 March 2017).

\section{Szabó 2013}

G. V. Szabó, Late Bronze Age stolen. New data on the illegal acquisition and trade of Bronze Age artefacts in the Carpathian basin, in: A. Anders - G. Kulcsár (eds.), Moments in Time. Papers Presented to Pál Raczky on his $60^{\text {th }}$ Birthday, Ösrégészeti Tanulmányok / Prehistoric Studies 1 (Budapest 2013) 793-816.

Szabó 2016

G. V. Szabó, Hortfunde und Siedlungen. Neue Fakten zum Kontext der spätbronzezeitlichen Deponierungen in Ungarn, in: S. Hansen - D. Neumann - T. Vachta (eds.), Raum, Gabe und Erinnerung. Weihgaben und Heiligtümer in prähistorischen und antiken Gesellschaften (Berlin 2016) 165-209.

Szathmári 2003

I. Szathmári, Die Bronzezeit (2800 v. Chr. -800 v. Chr.), in: Führer durch die archäologische Ausstellung des Ungarischen Nationalmuseums (Budapest 2003) 47-66.

Szombathy 1905

J. Szombathy, Vorgeschichtliche Funde aus Innerösterreich. I. Der Bronzedepotfund von Wöllersdorf, Mitteilungen der K. K. Zentralkommission für Erforschung und Erhaltung der Kunst- und historischen Denkmale, Series 3, 4/13, 1905, 39-43.

Szombathy 1913

J. Szombathy, Altertumsfunde aus Höhlen bei St. Kanzian im österreichischen Küstenlande, Mittheilungen der Prähistorischen Kommission 2, 2, 1913, 127-190.

Taracha 1999

P. Taracha, Reconstructing the Dendra panoply, Archaeologia War 50, 1999, 7-12.

Taratóri et al. 2008

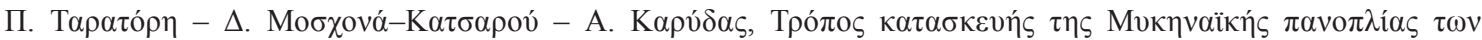
$\Delta \varepsilon v \delta \rho \omega ́ v$, in: N. Zacharias - M. Georgakopoulou - K. Polikreti - Y. Facorellis - T. Vakoulis (eds.), Proceedings of the $5^{\text {th }}$ Symposium of the Hellenic Society of Archaeometry (Athens 2008) 857-866.

Tarbay 2015

J. G. Tarbay, A new Late Bronze Age warrior equipment from east central Europe, Archaeologiai Értesítö 140, $2015,29-70$.

Terrosi Zanco 1967

O. Terrosi Zanco, Veio, Notizie degli Scavi di Antichità 21, 1967, 5-330.

Teržan 1990

B. Teržan, Polmesečaste fibule o kulturnih povezavah med egejo in Caput Adriae, Arheološki Vestnik 41, 1990, 49-88.

Teržan et al. 2015

B. Teržan - E. Borgna - P. Turk, Depo iz Musje jame. Il ripostiglio dalla Grotta delle mosche, Katalogi in Monografije 41 (Ljubljana 2015).

Thevenot 1991

J.-P. Thevenot, Le dépôt de Blanot (Côte-d'or). L’Âge du Bronze en Bourgogne, Revue archéologique de l'Est et du Centre-Est. Onzième supplément (Dijon 1991). 
Timelines 2014

Timelines Auctions, Lot 740, Bronze Age Vilanovan [sic] Crested Helmet, Three Day Sale of Antiquities \& Coins, The Swedenborg Hall, London, 3 September 2014. Online

$<$ https:/www.the-saleroom.com/en-us/auction-catalogues/timeline-auctions-limited/catalogue-id-srtime10002/loteda314d1-5539-4e58-872a-a3f8009791d2> (last access 2 March 2017).

Točík - Paulík 1960

A. Točík - J. Paulík, Výskum mohyly v Čake v rokoch 1950-1951, Slovenská Archeológia 8, 1960, 59-124.

Tomedi 2002

G. Tomedi, Zur Datierung des Depotfundes vom Piller, ArchaeoTirol, Kleine Schriften 4, 2002, 43-46.

Tomedi 2004

G. Tomedi, Der bronzezeitliche Schatzfund vom Piller, Begleitheft zur Ausstellung im Archäologiezentrum Fließ, Schriften des Museums Fließ I (Fließ 2004).

Tomedi 2007

G. Tomedi, Das Depot von Moosbruckschrofen am Piller und seine vermeintlichen Datierungsprobleme, Festschrift für Biba Teržan, Situla 44 (Ljubljana 2007) 259-265.

Tomedi 2012

G. Tomedi, Der mittelbronzezeitliche Schatzfund vom Piller. Eine kulturhistorische Lokalisierung, in: S. Hansen D. Neumann - T. Vachta (eds.), Hort und Raum. Aktuelle Forschungen zu bronzezeitlichen Deponierungen in Mitteleuropa, Topoi. Berlin Studies of the Ancient World 10 (Berlin 2012) 151-168.

Tomedi et al. 2001

G. Tomedi - S. Nicolussi Castellan - J. Pöll, Die Bergung des Schatzfundes vom Moosbruckschrofen am Piller, Gem. Fließ, ArchaeoTirol, Kleine Schriften 3, 2001, 62-75.

Toms 1986

J. Toms, The relative chronology of the Villanovan cemetery of Quattro Fontanili at Veii, Annali. Sezione di Archeologia e Storia Antica 8, 1986, 41-97.

Torbrügge 1960

W. Torbrügge, Die Bronzezeit in Bayern, Berichte der Römisch-Germanischen Kommission 40/1959, 1960, 1-78.

Touloupa 1964

E. Touloupa, Bericht über die neuen Ausgrabungen in Theben, Kadmos III, 1964, 26-27.

Touloupa 1966

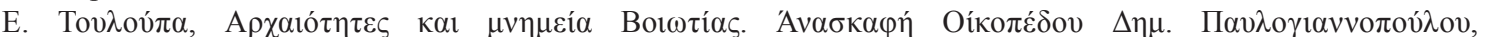

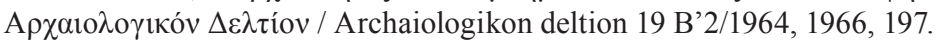

Touloupa - Symeonoglou 1967

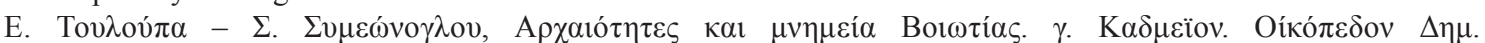

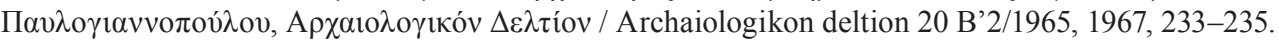

Turk 2012

P. Turk, Die Waffenfunde aus der Mušja Jama/Fliegenhöhle bei Škocjan, Slowenien, in: Meighörner 2012, 135-137.

Uckelmann 2011

M. Uckelmann, The function of Bronze Age shields, in: Uckelmann - Mödlinger 2011, 187-200.

Uckelmann 2012

M. Uckelmann, Die Schilde der Bronzezeit in Nord-, West- und Zentraleuropa, Prähistorische Bronzefunde III, 4 (Stuttgart 2012).

Uckelmann - Mödlinger 2011

M. Uckelmann - M. Mödlinger (eds.), Bronze Age Warfare. Manufacture and Use of Weaponry, British Archaeological Reports International Series 2255 (Oxford 2011). 
Uenze 1990

B. Uenze, G. F. Klemm and his Collection in the British Museum (PhD Diss., University of London, London 1990).

Uenze 1938

O. Uenze, Die frühbronzezeitlichen triangularen Vollgriffdolche, Vorgeschichtliche Forschungen 11 (Berlin 1938).

Urbanek 1991

E. Urbanek, Wichtige ur- und frühgeschichtliche Fundpunkte, in: R. Hoffmann - E. Urbanek, Golling. Geschichte einer Salzburger Marktgemeinde (Golling 1991) 43-70.

v. Arneth 1851

J. v. Arneth, Archäologische Analekten, Sitzungsberichte der kaiserlichen Akademie der Wissenschaften, Phil.Hist. Klasse VI (Vienna 1851) 280-293.

v. Brunn 1954

W. A. v. Brunn, Eine unbekannte Bronzeschale aus Ostdeutschland, Germania 32, 1954, 284-293.

v. Brunn 1959

W. A. v. Brunn, Die Hortfunde der frühen Bronzezeit aus Sachsen-Anhalt, Sachsen und Thüringen (Berlin 1959).

v. Brunn 1968

W. A. v. Brunn, Mitteldeutsche Hortfunde der jüngeren Bronzezeit, Römisch-Germanische Forschungen 29 (Berlin 1968).

v. Hase 1988

F. W. v. Hase, Früheisenzeitliche Kammhelme aus Italien, in: Antike Helme. Sammlung Lipperheide und andere Bestände des Antikenmuseums Berlin, Monographien des Römisch-Germanischen Zentralmuseums 14 (Mainz 1988) 195-221.

v. Henning 1970

H. v. Henning, die Grab- und Hortfunde der Urnenfelderkultur aus Ober- und Mittelfranken (Lassleben 1970).

v. Laur-Belart 1950

R. v. Laur-Belart, Ein Helm der Urnenfelderzeit aus Basels Umgebung, Jahrbuch der Schweizer Gesellschaft für Urgeschichte 40/1949, 1950, 202-208.

v. Lipperheide 1896

F. v. Lipperheide, Antike Helme (Berlin 1896).

v. Merckling 1930

E. v. Merckling, Führer durch das Hamburgische Museum für Kunst und Gewerbe II. Griechische und römische Altertümer (Hamburg 1930).

v. Merhart 1941

G. v. Merhart, Zu den ersten Metallhelmen Europas, Bericht der Römisch-Germanischen Kommission 30, 1941, $4-42$.

v. Merhart 1952

G. v. Merhart, Studien über einige Gattungen von Bronzegefäßen. Festschrift des Römisch-Germanischen Zentralmuseums in Mainz zum 100jährigen Bestehen 2 (Mainz 1952) 1-71.

v. Merhart 1954

G. v. Merhart, Panzer-Studie, in: Origines. Raccolta di Scritti in Onore di Mons. Giovanni Baserga (Como 1954) 33-61 [reprinted as v. Merhart 1969].

v. Merhart 1956/1957

G. v. Merhart, Geschnürte Schienen, Bericht der Römisch-Germanischen Kommission 37-38, 1956/1957, 91-147.

v. Merhart 1969

G. v. Merhart, Panzer-Studie, in: G. Kossack (ed.), Gero von Merhart, Hallstatt und Italien. Gesammelte Aufsätze zur frühen Eisenzeit in Italien und Mitteleuropa, Römisch-Germanisches Zentralmuseum (Mainz 1969) 149-171 [reprint of v. Merhart 1954]. 
v. Quillfeldt 1995

I. v. Quillfeldt, Die Vollgriffschwerter in Süddeutschland, Prähistorische Bronzefunde IV, 11 (Stuttgart 1995).

v. Süß 1844

M. v. Süß, Das städtische Museum in Salzburg, Jahresbericht des städtischen Museums Carolino Augusteum (Salzburg 1844).

v. Wieser 1894

F. v. Wieser, Die Freiherrlich von Lipperheide'sche Sammlung antiker Bronzen (Berlin 1894).

Vachta 2008

T. Vachta, Studien zu den bronzezeitlichen Hortfunden des oberen Theissgebietes, Universitätsforschungen zur prähistorischen Archäologie 159 (Bonn 2008).

Vanderpool 1963

E. Vanderpool, Newsletter from Greece, American Journal of Archaeology 67, 1963, 279-283.

Vandkilde 2006a

H. Vandkilde, Warfare, weaponry, and material culture. An introduction, in: Otto et al. 2006, 483-490.

Vandkilde 2006b

H. Vandkilde, Archaeology and war. Presentations of warriors and peasants in archaeological interpretations, in: Otto et al. 2006, 57-73.

Vandkilde 2013

H. Vandkilde, Bronze Age voyaging and cosmologies in the making. The helmets from Viksø revisited, in: S. Bergerbrant - S. Sabatini (eds.), Counterpoint. Essays in Archaeology and Heritage Studies in Honour of Professor Kristian Kristiansen, British Archaeological Reports International Series 2508 (Oxford 2013) 165-178.

Vasič 1994

R. Vasič, Die Sicheln im Zentralbalkan (Vojvodina, Serbien, Kosovo und Mazedonien), Prähistorische Bronzefunde XVIII, 5 (Stuttgart 1994).

Vasič 1999

R. Vasič, Die Fibeln im Zentralbalkan (Vojvodina, Serbien, Kosovo und Makedonien), Prähistorische Bronzefunde XIV, 12 (Stuttgart 1999).

Vasič 2003

R. Vasič, Die Nadeln im Zentralbalkan (Vojvodina, Serbien, Kosovo und Makedonien), Prähistorische Bronzefunde XIII, 11 (Stuttgart 2003).

Vasilakis 1999

A. Vasilakis, Heraklion Archaeological Museum (Athens 1999).

Ventris - Chadwick 1956

M. Ventris - J. Chadwick, Documents in Mycenaean Greek. Three Hundred Selected Tablets from Knossos, Pylos and Mycenae with Commentary and Vocabulary (Cambridge 1956).

Verdelis 1963

N. M. Verdelis, Neue geometrische Gräber in Tiryns, Mitteilungen des Deutschen Archäologischen Institutes, Athenische Abteilung 78, 1963, 1-62.

Verdelis 1967

N. M. Verdelis, Neue Funde von Dendra, Mitteilungen des Deutschen Archäologischen Institutes, Athenische Abteilung 82, 1967, 1-53.

Verdelis 1977

N. M. Verdelis, The metal finds, in: P. Åström, The Chamber Tombs. The Cuirass Tomb and other Finds from Dendra 1, Studies in Mediterranean Archaeology 4 (Gothenburg 1977) 28-65. 
Vermeule - Karageorghis 1982

E. Vermeule - V. Karageorghis, Mycenaean Pictorial Vase Painting (Cambridge/Massachusetts 1982).

Verron 1971

G. Verron, Antiquités préhistoriques protohistoriques. Musée départemental des antiquités de la Seine-Maritime (Rouen 1971).

Vinski-Gasparini 1973

K. Vinski-Gasparini, Kultura polja sa zarama u sjevernoj Hrvatskoj (Zadar 1973).

Vonhoff 2008

C. Vonhoff, Darstellungen von Kampf und Krieg in der minoischen und mykenischen Kultur, Internationale Archäologie 109 (Rahden 2008).

Wace - Stubbings 1962

A. J. B. Wace - F. H. Stubbings, A Companion to Homer (London 1962)

Walberg 1998

G. Walberg, Excavations on the Acropolis of Midea 1, 1. The Excavation of the Lower Terraces 1985-1991, Acta Instituti Atheniensis Regni Suecciae (Gothenburg 1998).

Walters 1899

H. Walters, Catalogue of Bronzes. Greek, Roman and Etruscan in the British Museum (London 1899).

Warmenbol 1992

E. Warmenbol, Le matériel du bronze. Le seau de la drague et le casque du héros, in: E. Warmenbol - Y. Cabuy - v. Hurt - N. Cauwe (eds.), La collection Edouard Bernays. Néolithique et Âge du Bronze, époques gallo-romaine et médiévale, Monographie d'Archéologie Nationale 6 (Brussels 1992) 67-122.

Warmenbol 2010

E. Warmenbol, Drowning by numbers. Nine lives, twelve deaths in the Bronze Age, in: H. Meller - F. Bertemes (eds.), Der Griff nach den Sternen. Wie Europas Eliten zu Macht und Reichtum kamen. Tagungen des Landesmuseums für Vorgeschichte Halle 5 (Halle/Saale 2010) 563-576.

Weber 2011

M. Weber, Forensisch-palynologische Untersuchungen an Pflanzenresten aus den Falzungen eines bronzezeitlichen Kammhelmfragments sowie von dem Fundort des Helms vom Anlauftal (Gem. Bad Gastein), in: Lippert 2011, 111112.

Weiss 1998

R.-M. Weiss, Schutzwaffen der frühen Urnenfelderzeit im Hortfund von Winklsaß (Niederbayern), Archäologisches Korrespondenzblatt 28, 1998, 535-554.

Wilbertz 1982

O. M. Wilbertz, Die Urnenfelderkultur in Unterfranken, Materialhefte Bayerische Vorgeschichte, Reihe A, 49 (Kallmünz 1982).

Windholz-Konrad 2004

M. Windholz-Konrad, Die Rabenwand. Ein neuer prähistorischer Depotfundplatz im Ausseerland, Steiermark, Fundberichte aus Österreich 43, 2004, 289-350.

Windholz-Konrad 2008

M. Windholz-Konrad, Der prähistorische Depotfund vom Brandgraben im Kainischtal, Steiermark, in: Schätze. Gräber. Opferplätze. Archäologie im Salzkammergut. Ausstellungskatalog Traunkirchen, Fundberichte aus Österreich, Materialhefte Reihe A, Sonderheft 6 (Vienna 2008).

Wirth 1999

S. Wirth, Auf der Suche nach Eliten der späten Bronzezeit und der Urnenfelderzeit. Bausteine zum Thema aus dem Altsiedelland am unteren Lech in Bayerisch-Schwaben, in: Eliten der Bronzezeit. Ergebnisse zweier Kolloquien in Mainz und Athen, Monographien des Römisch-Germanischen Zentralmuseums 43, 2 (Mainz 1999) 565-604. 
Wirth 2000

S. Wirth, Die Funde aus der Donauschleife bei Schäfstall in Bayern, in: L. Bonnamour (ed.), Archèologie des fleuves et des rivières (Paris 2000) 84-92.

Wirth 2006

S. Wirth, Vogel-Sonnen-Barke, in: H. Beck - D. Geuenich - H. Steuer (eds.), Reallexikon der Germanischen Altertumskunde 32 (Berlin 2006) 552-563.

Wollmann 1982

V. Wollmann, Johann Michael Ackner (1782-1862). Leben und Werk (Cluj-Napoca 1982).

Woolley 1934

L. C. Woolley, Ur. Excavations II. The Royal Cemetery (Oxford 1934).

Wosinsky 1896

M. Wosinsky, Tolna vármegye története az őskortól a hofoglalásig I-II (Budapest 1896).

Wüstemann 2004

H. Wüstemann, Die Schwerter in Ostdeutschland, Prähistorische Bronzefunde IV, 15 (Stuttgart 2004).

Yalouris 1954

N. Yalouris, Patras, in: Bulletin de correspondance hellénique 78, 1954, 124-125.

Yalouris 1960

N. Yalouris, Mykenische Bronzeschutzwaffen, Mitteilungen des Deutschen Archäologischen Instituts Athen 75, $1960,42-67$.

\section{Zamboni 2011}

S. Zamboni, Schinieri, cat. no. 5.37, in: F. Marzatico - R. Gebhard - P. Gleirscher (eds.), Le grandi vie delle civiltà. Relazioni e scambi fra il Mediterraneo e il centro Europa dalla preistoria alla romanità (Trento 2011) 172.

Zervos 1956

C. Zervos, L’Art de la Créte néolithique et minoenne (Paris 1956).

Zipf 2004

G. Zipf, Studien zu den Anfängen figürlicher Darstellungen im endbronze- und früheisenzeitlichen Frankreich und Italien. Motive, Dekorträger und Kontexte (PhD Diss., University Berlin, Berlin 2004). 

9 Plates 

1
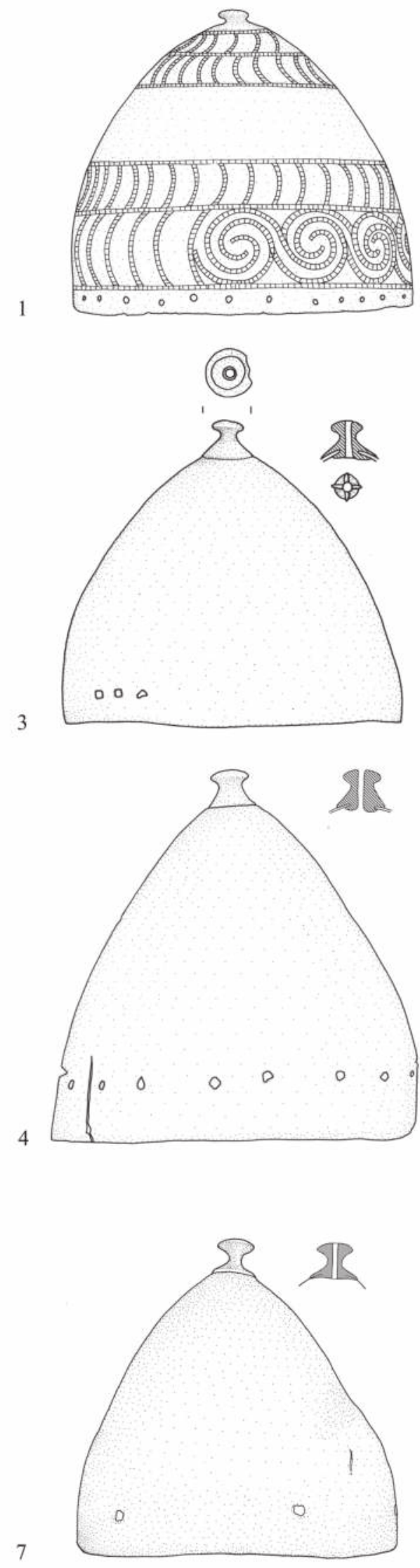

2
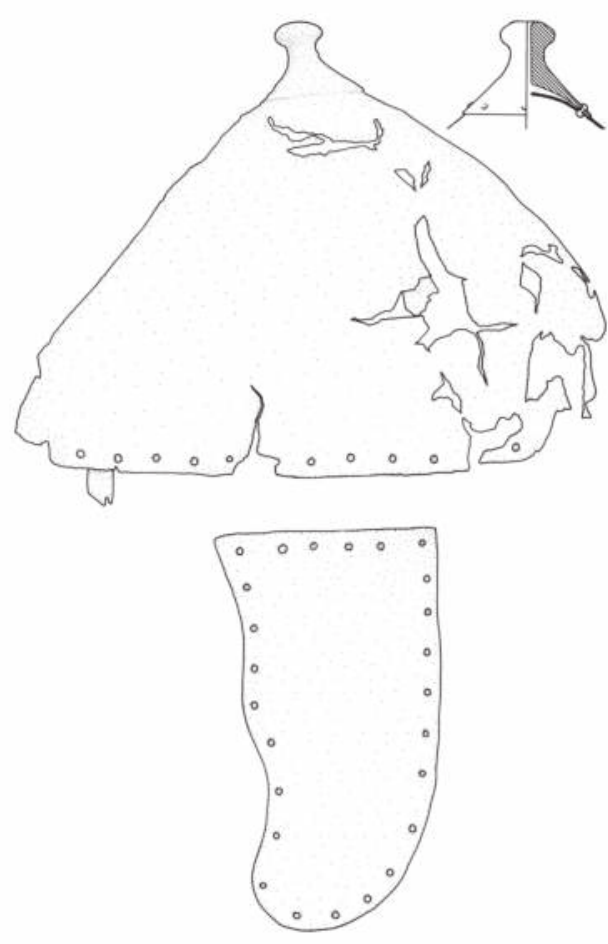

5
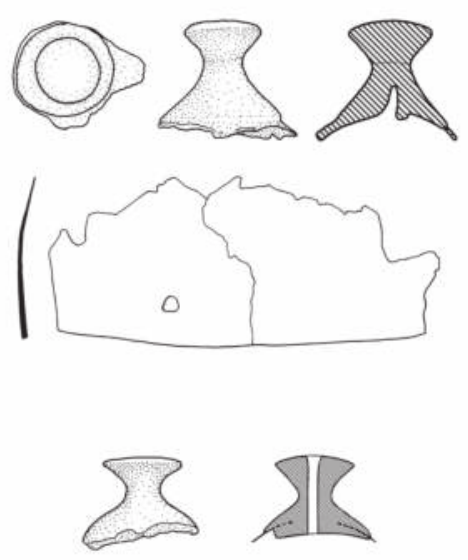

6

8

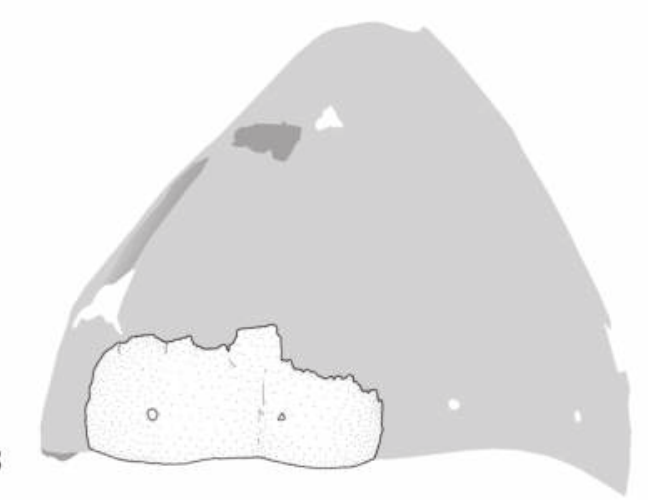

Pl. 1 Helmets of Type Oranienburg: 1. Unprovenanced; 2. Knossos, Greece; 3. Biecz, Poland (cross-section after Hencken 1971, fig. 13d); 4. Oranienburg, Germany; 5. Žaškov, Slovakia (after Hencken 1971, fig. 17b); 6. Spišská Belá, Slovakia (cross-section after Hencken 1971, fig. 15h); 7. Unprovenanced (Lúčky, Slovakia?) (cross-section after Hencken 1971, fig. 13b); 8. Keresztéte, Hungary (outline after the only preserved photograph of the helmet; see Mozsolics 1985, pl. 150.9). The numbers correspond to the catalogue numbers (scale 1:4; cat. nos. 5-6: scale 1:2). 


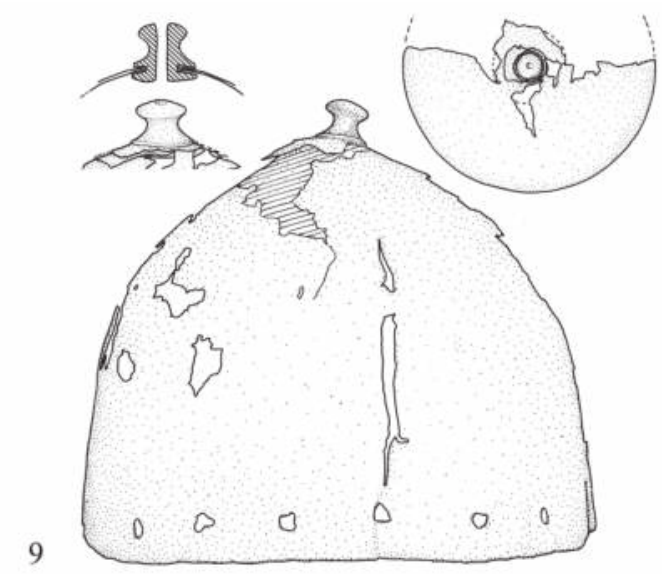

10
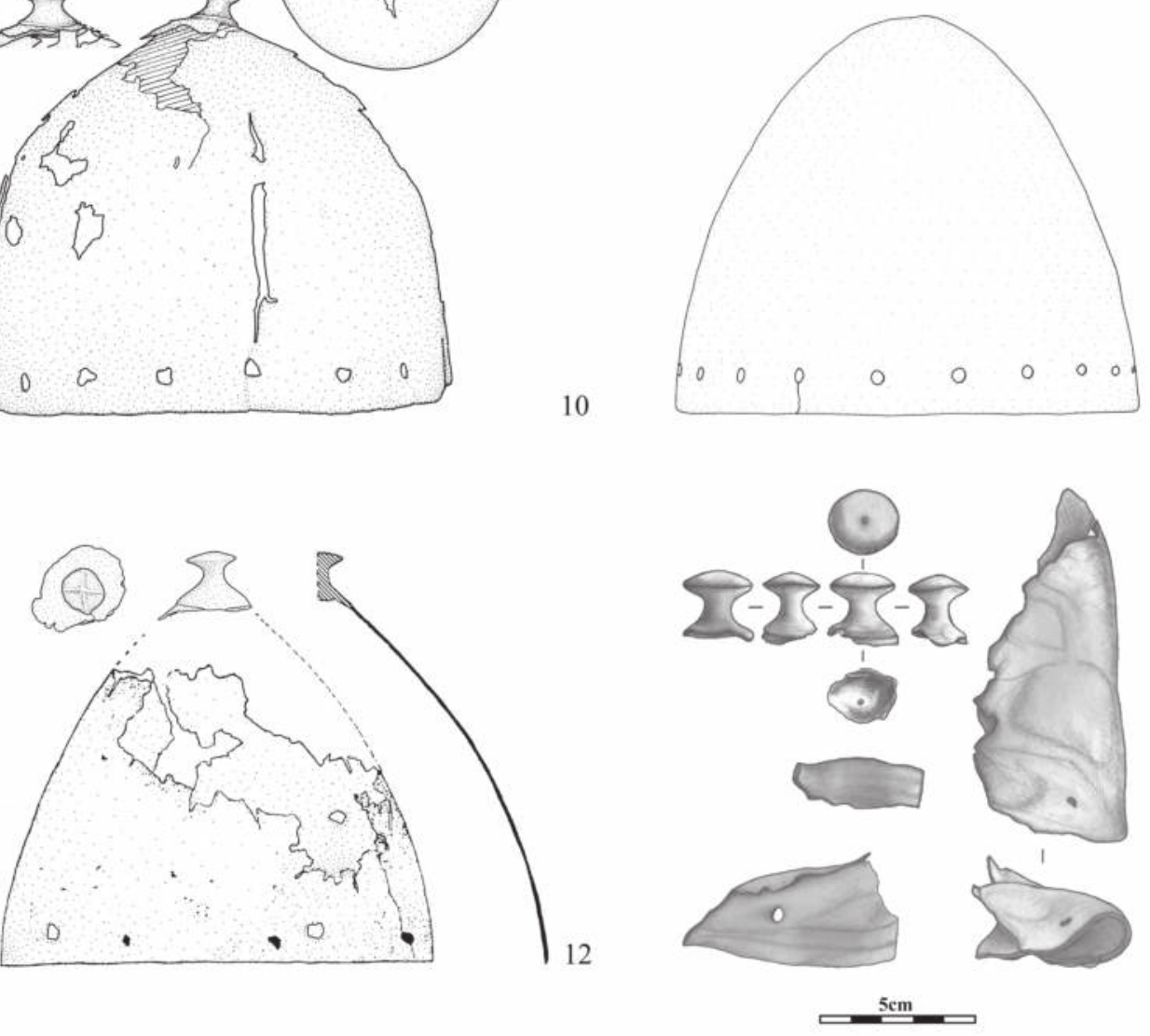

13
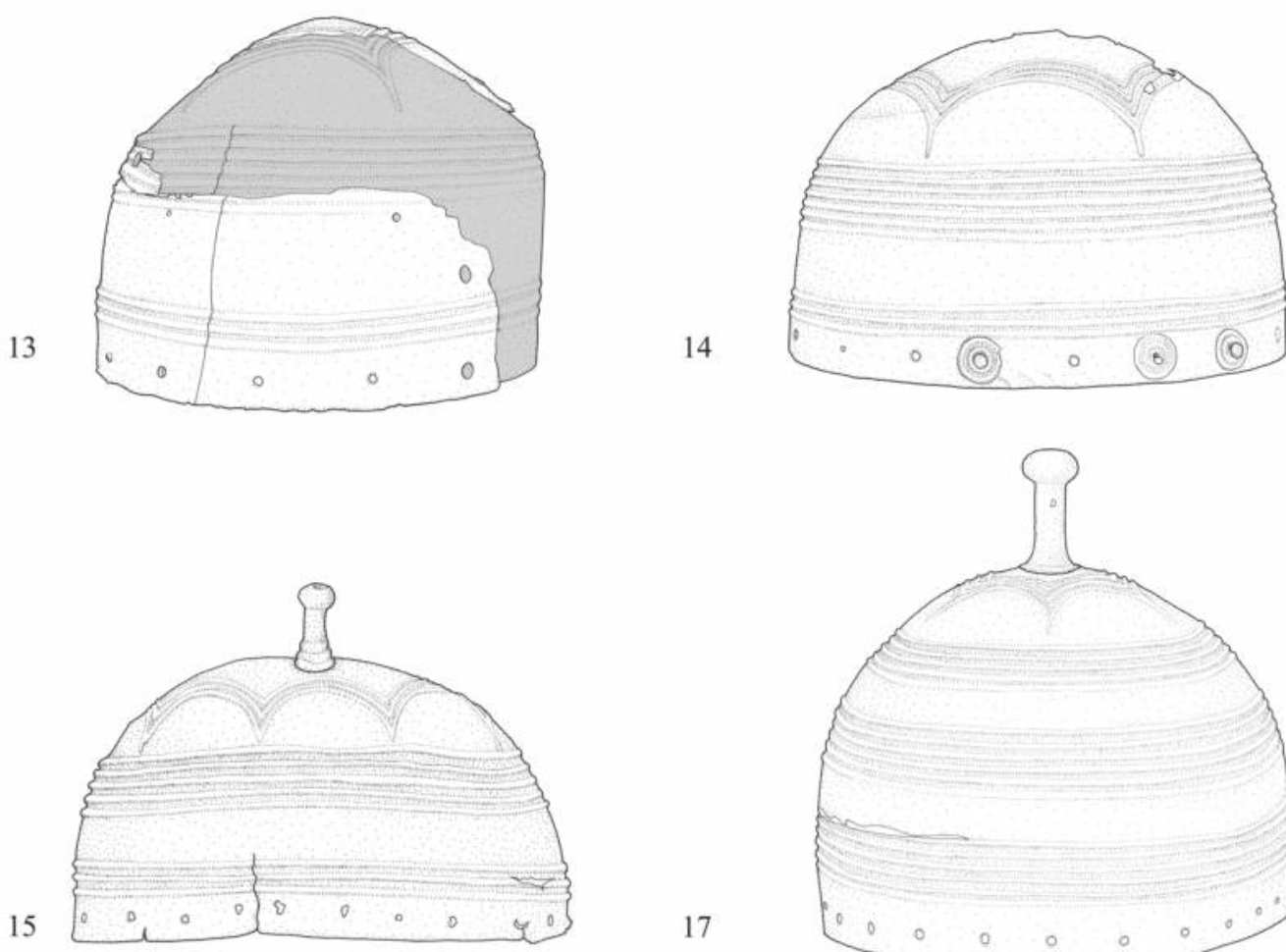

17

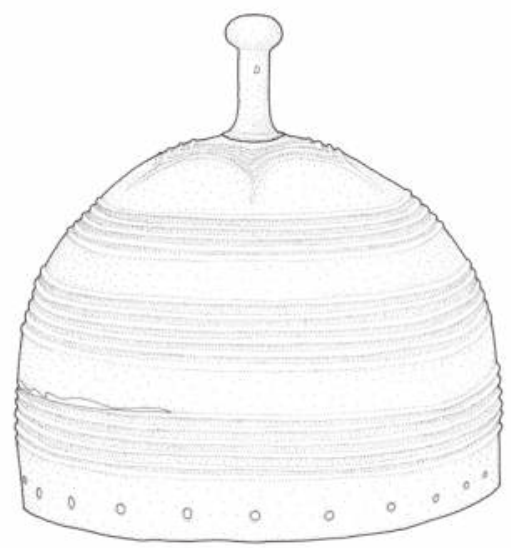

P1. 2 Helmets of Type Oranienburg (nos. 9-12) and helmets of Type Paks (nos. 13-17): 9. Nadap, Hungary (after Makkay 2006, pl. 1); 10. Dunaföldvar, Hungary; 11. Sâg, Romania (after Soroçeanu - Lakó 1981, fig. 9.4); 12. Unprovenanced (Hungary?); 13. Unprovenanced (Hungary?); 14. Unprovenanced (Northern Hungary?); 15. Paks, Hungary; 17. Unprovenanced. The numbers correspond to the catalogue numbers (scale $1: 4$; cat. no. 17: without scale). 
16

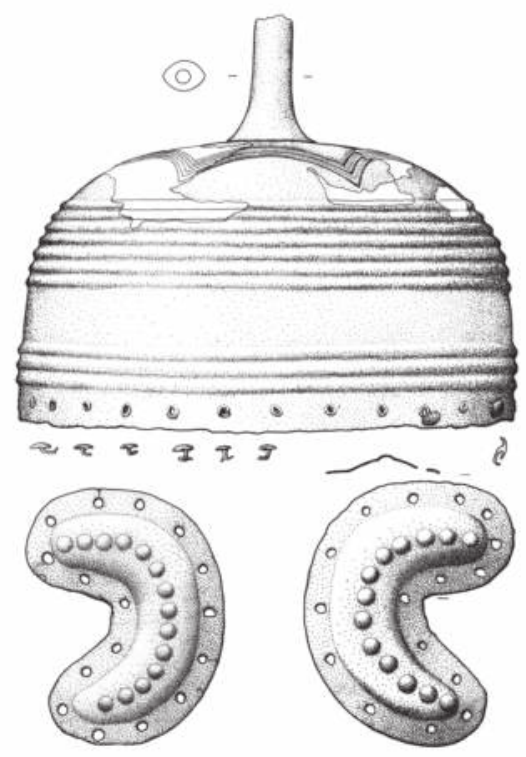

20

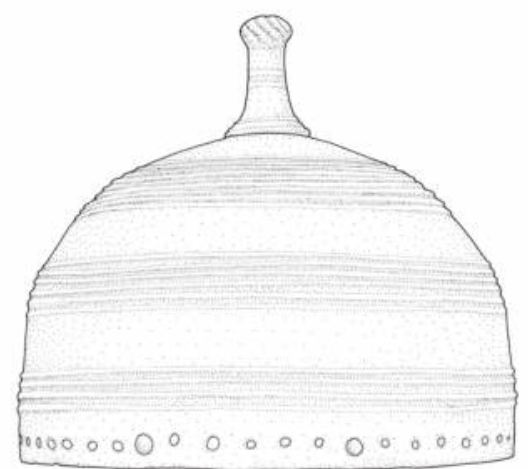

22

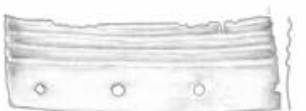

23

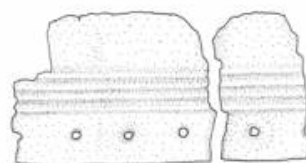

24

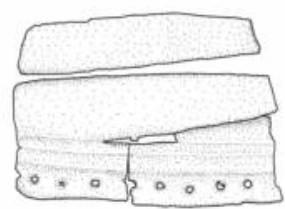

18

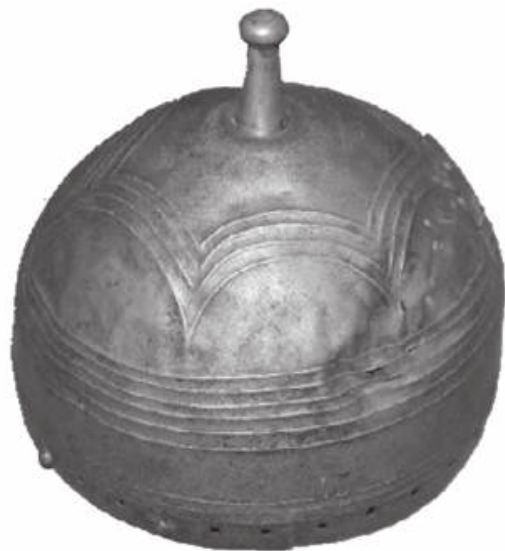

19
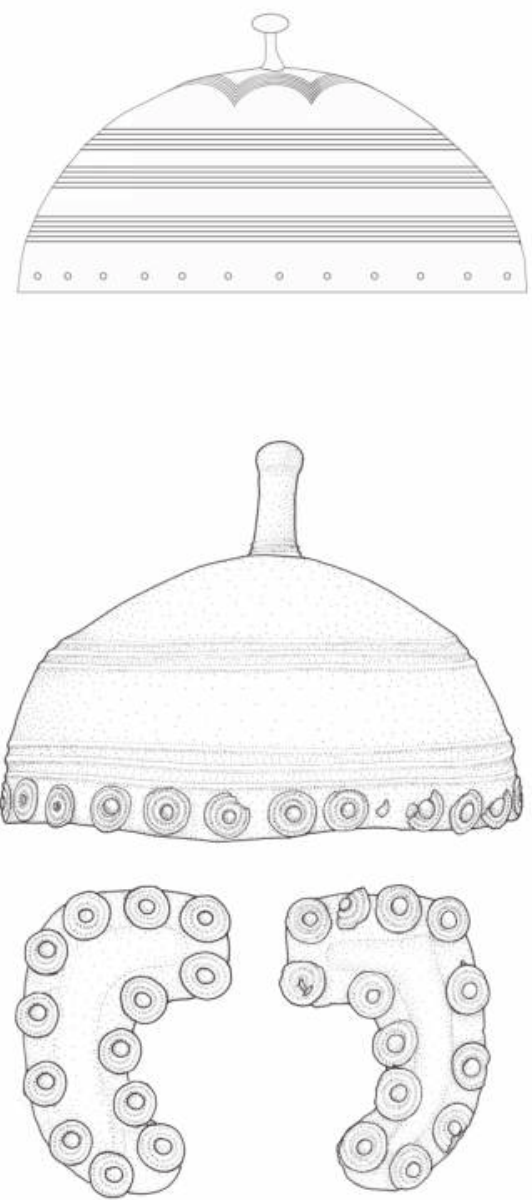
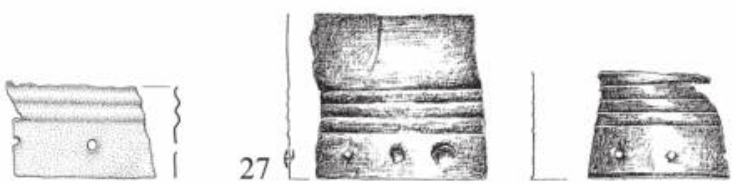

Pl. 3 Helmets of Type Paks: 16. Unprovenanced; probably Žiar nad Hronom, Slovakia. (Bartik 2009, fig 2); 18. Unprovenanced; probably Bajmok, Serbia (Szabó 2013, fig. 11.1, 4); 19. Unprovenanced; probably Dusnok, Hungary (after Szabó 2013, fig. 12.1); 20. Unprovenanced; 21. Unprovenanced; 22. Markovac-Grunjac, Croatia; 23. Veliko Nabrđe, Croatia; 24. Poljanci I, Croatia; 25. Elsterwerda, Germany; 27. Nadap, Hungary (Makkay 2006, pl. 5.10-11). The numbers correspond to the catalogue numbers (scale 1:4; cat. no. 18: without scale). 

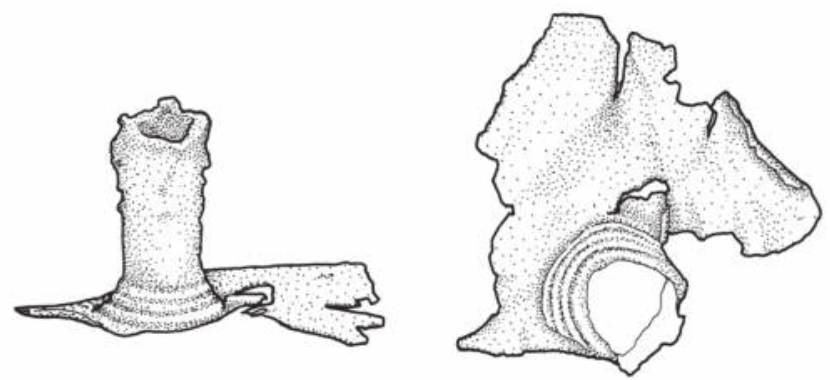

29

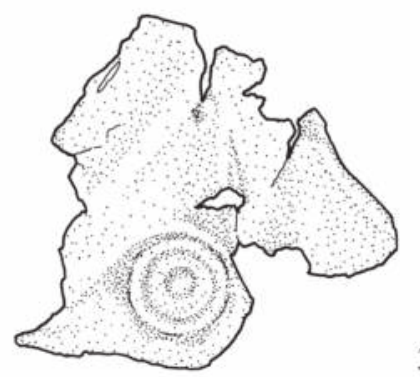

30

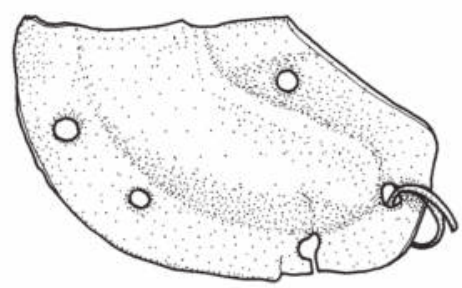

32

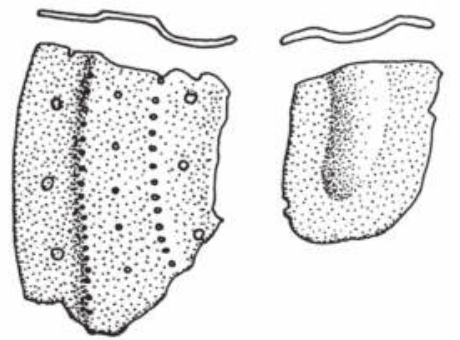

31
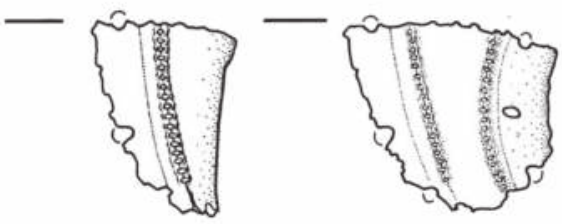
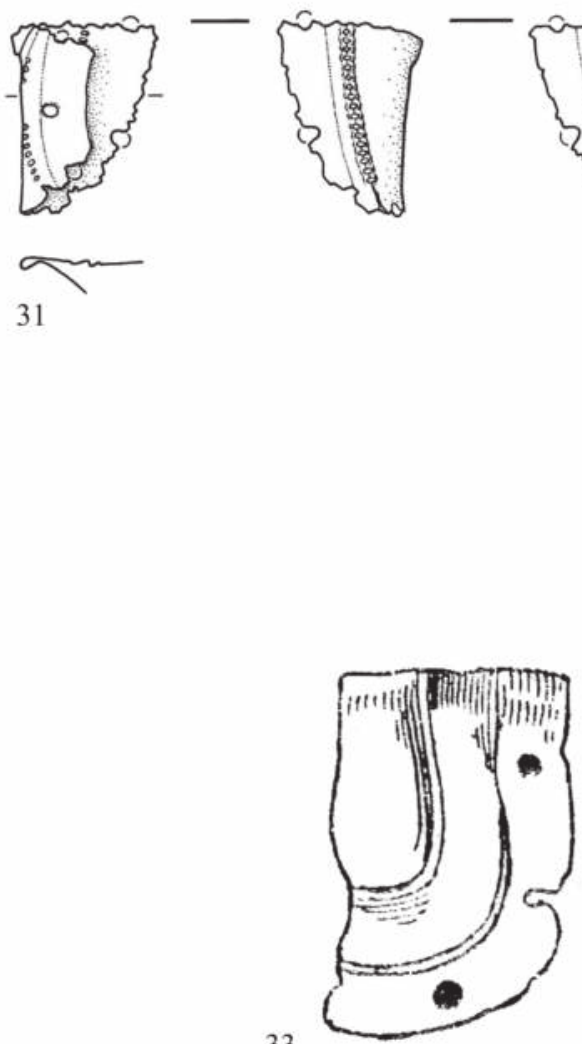

33

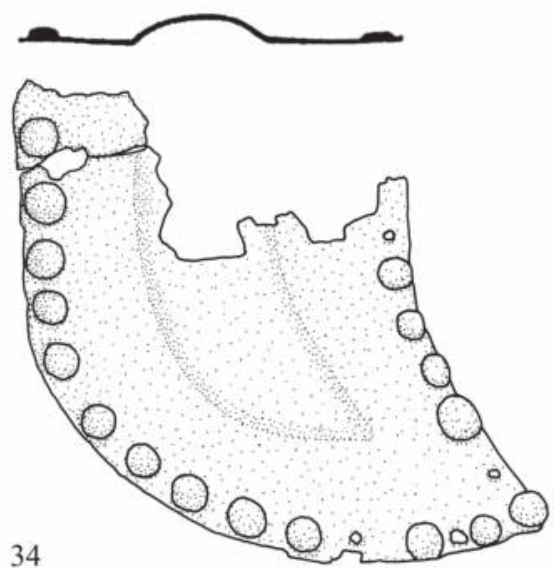

Pl. 4 Helmets of Type Paks: 28. Strassengel, Austria (cross-section after Hencken 1971, fig. 122); 29. Guşteriţa, Romania (Hencken 1971, fig. 128a); 30. Wöllersdorf, Austria; 31. Hočko Pohorje, Slovenia (Čerče - Šinkovec 1995b, pl. 83.168); 32. Uioara de Sus, Romania (Schauer 2003, fig. 3.5-6); 33. Újszőny/Komárom, Hungary (Hampel 1887, pl. CXXV.47); 34. Mezőnyárád, Hungary. The numbers correspond to the catalogue numbers (scale 1:2; cat. no. 32: without scale). 


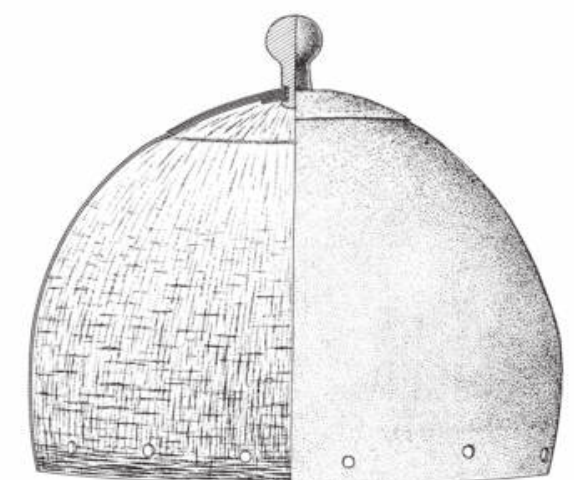

36

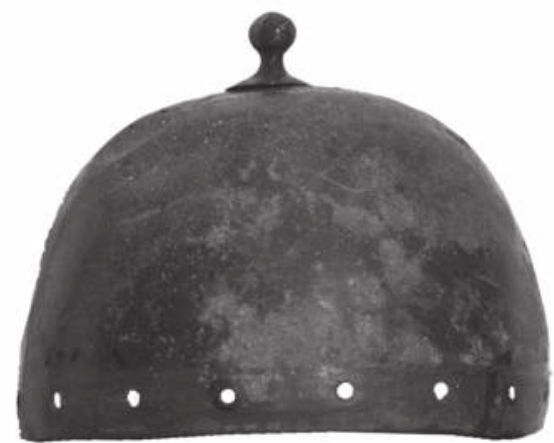

38

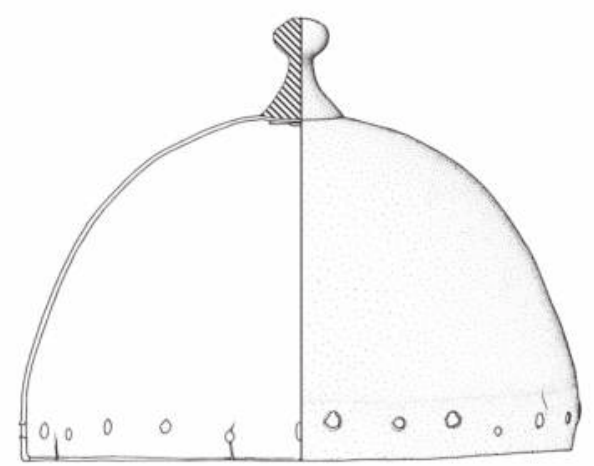

40

Pl. 5 Helmets of Type Nagytétény: 36. Unprovenanced; probably Batina, Hungary (Schauer 1988, fig. 3); 37. Nagytétény, Hungary; 38. Brodi/Ternopil, Ukraine; 39. Unprovenanced (Clausing 2001, fig. 2); 40. Unprovenanced (Clausing 2005, figs. 1-2). The numbers correspond to the catalogue numbers (scale 1:4). 


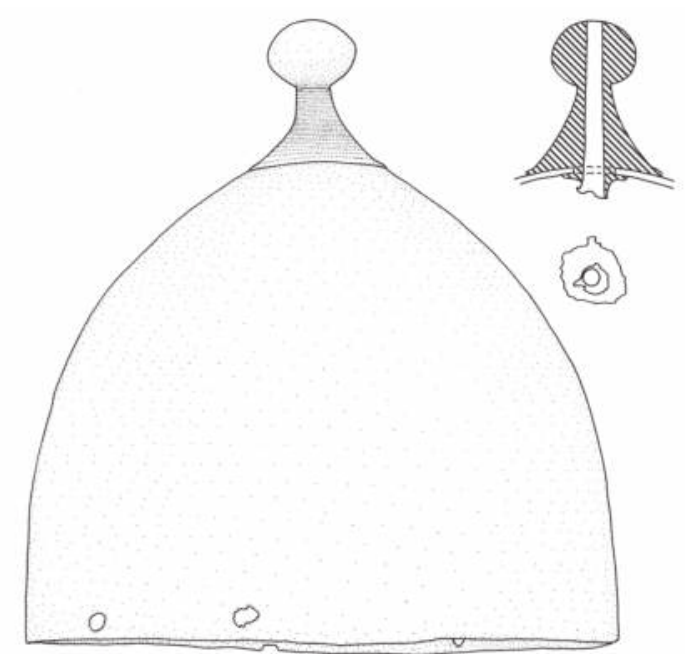

42

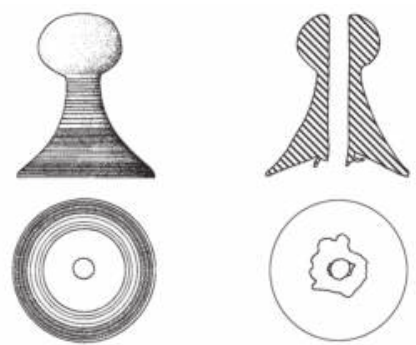

43

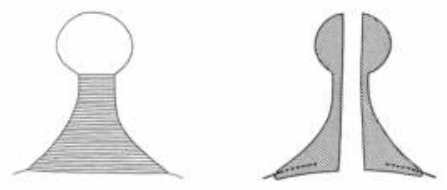

41

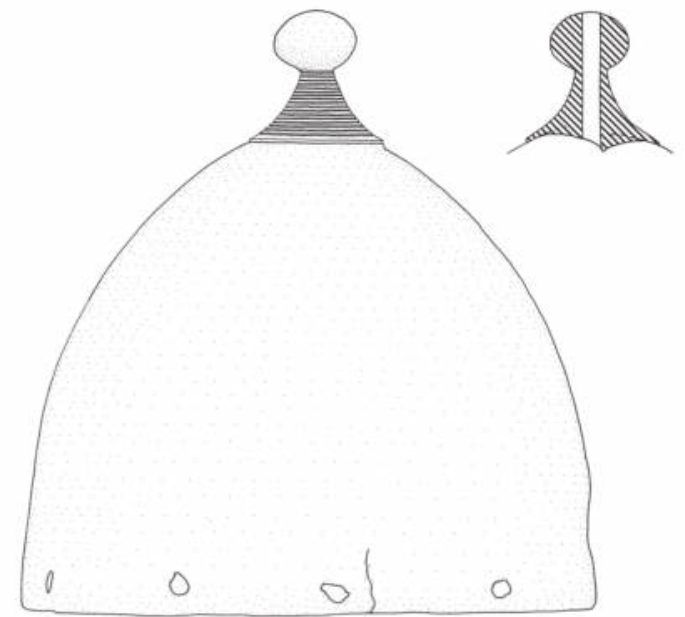

44

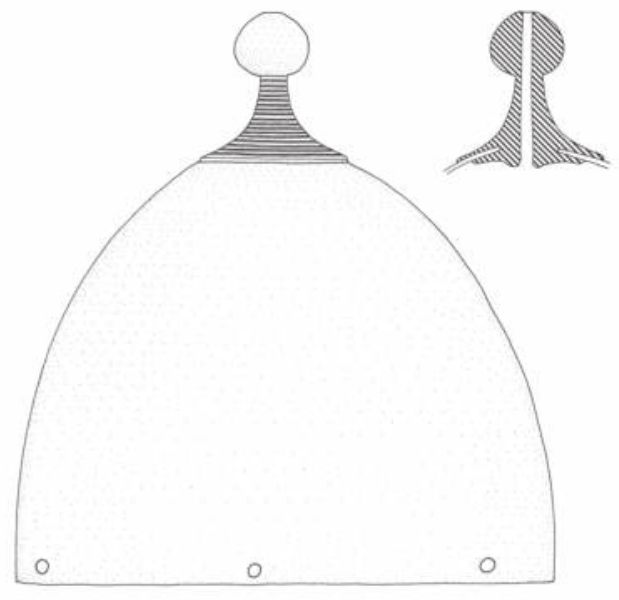

45

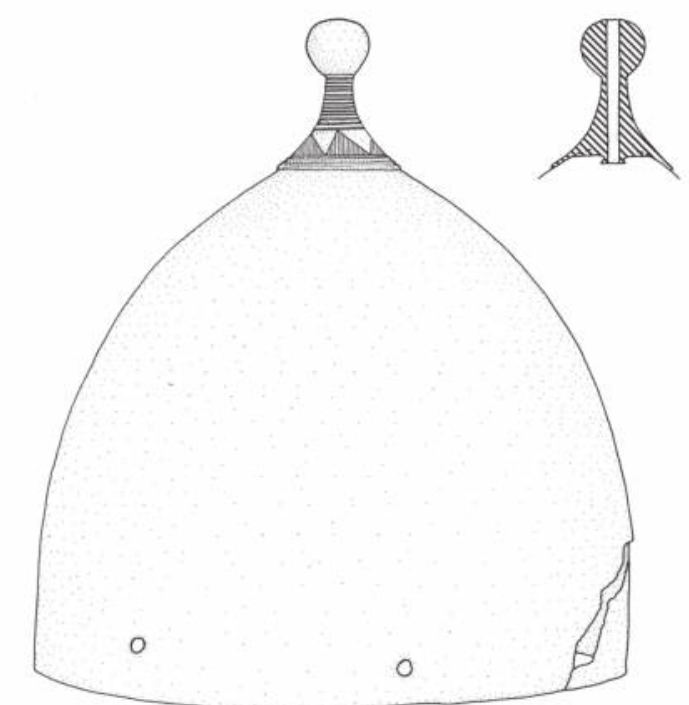

46

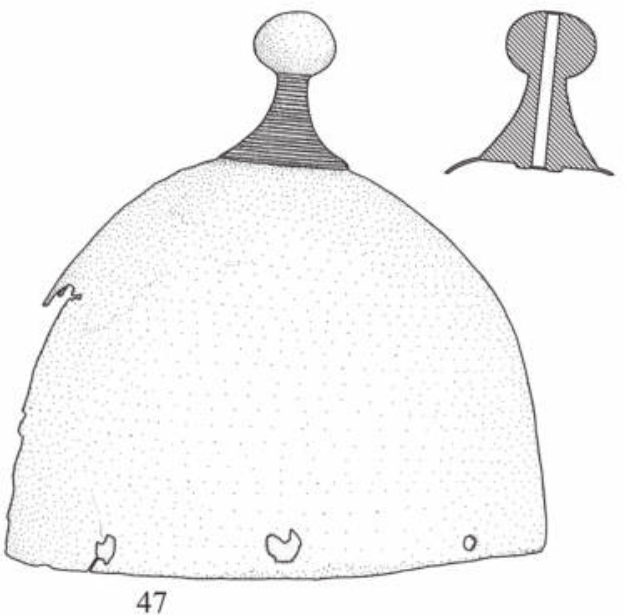

Pl. 6 Helmets of Type Pişcolt: 41. Sehlsdorf, Germany; 42. Služín, Czech Republic (Salaš 2005, pl. 424.21);

43. Škocjan, Slovenia (cross-section after Hencken 1971, fig. 26a-b); 44. Hajdúböszörmény, Hungary; 45. Mezőkövesd, Hungary; 46. Endrőd, Hungary; 47. Şoarş, Romania. The numbers correspond to the catalogue numbers (scale 1:4). 


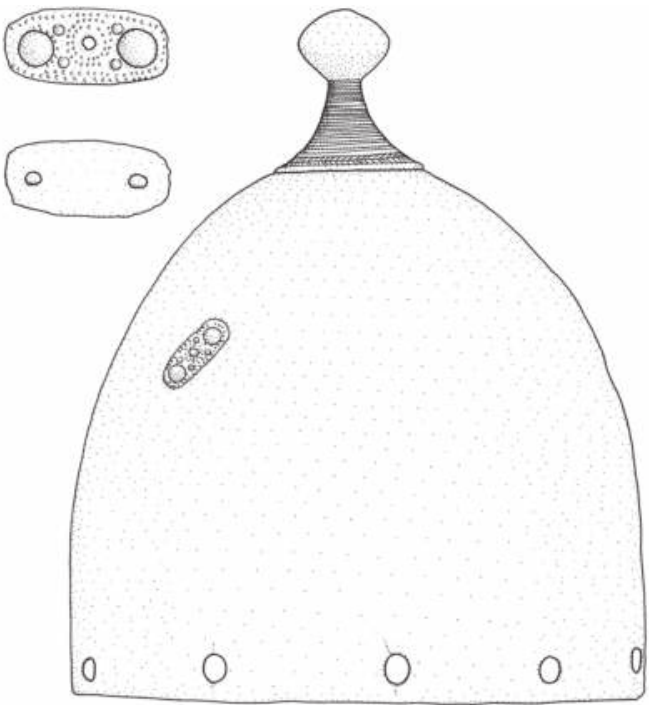

48

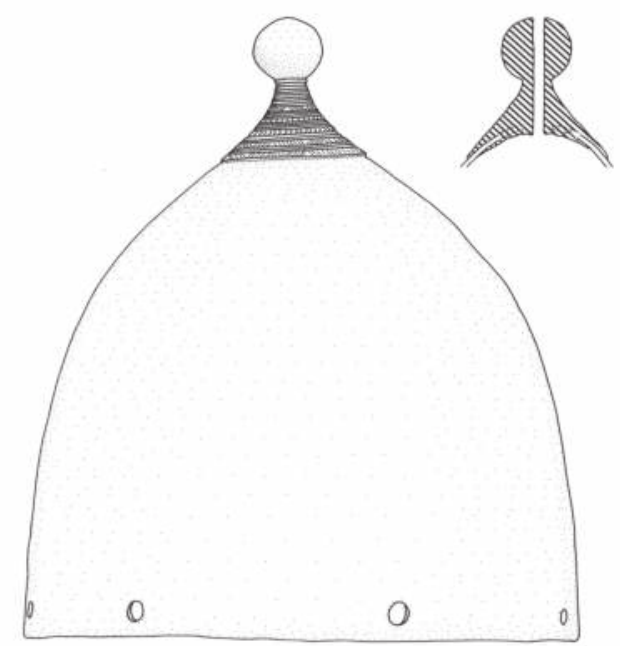

50
49
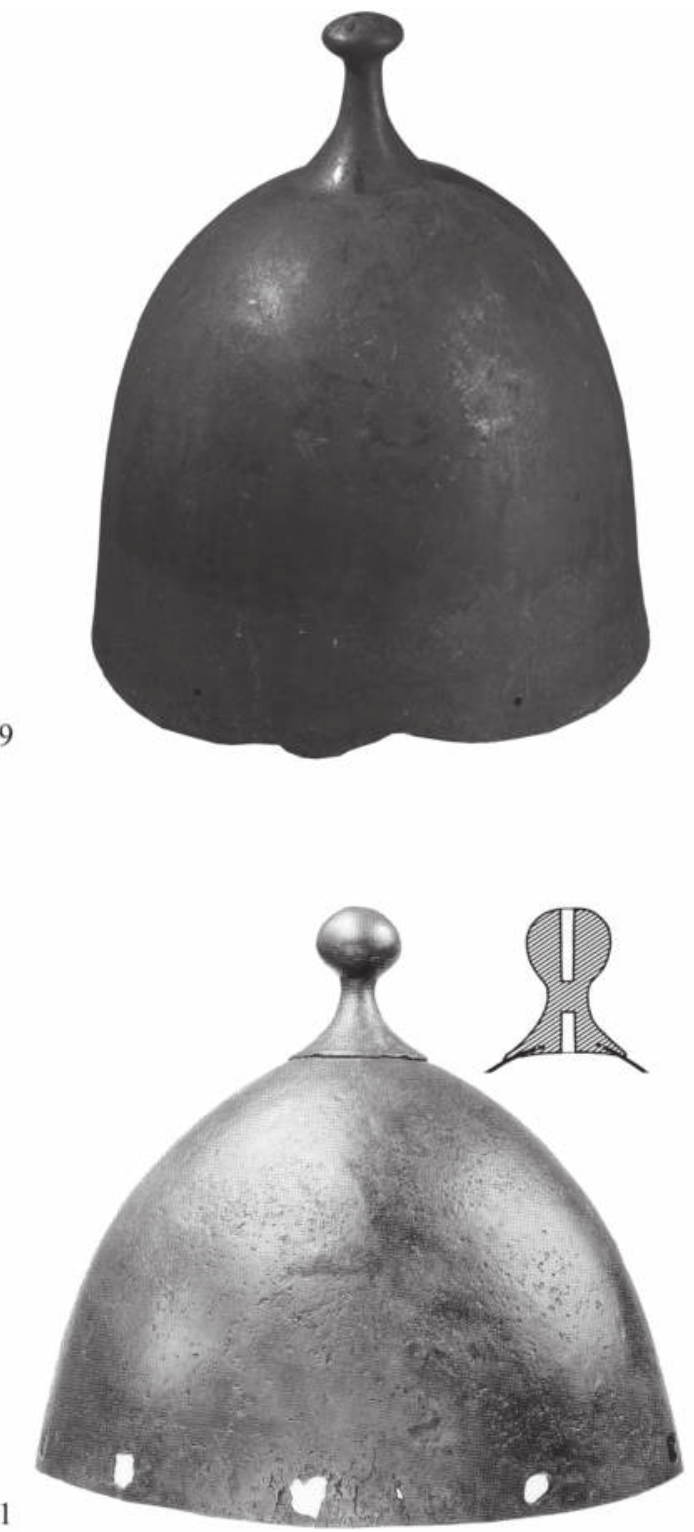

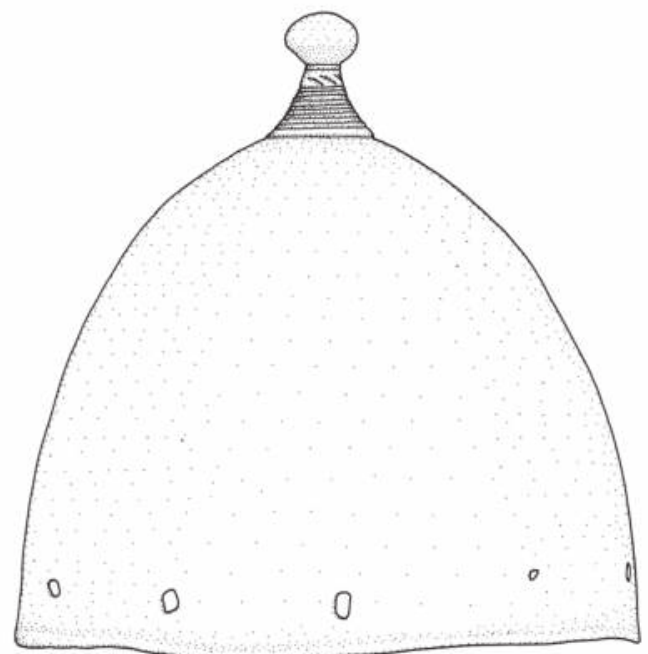

52

Pl. 7 Helmets of Type Pişcolt: 48. Pişcolt, Romania; 49. Unprovenanced; probably Monte Altino, Italy (The photograph was provided for free by the Soprintendenza per i Beni Archeologici del Molise (Ministero dei Beni e delle Attività Culturali e del Turismo - Direzione regionale per i Beni Culturali e Paesaggistici del Molise); 50. Unprovenanced (formerly known as 'Mantova'); 51. Unprovenanced (Born - Hansen 2001, fig. 201; cross-section: Hencken 1971, fig. 29); 52. Unprovenanced. The numbers correspond to the catalogue numbers (scale 1:4; cat. no. 48 detail: scale 1:2). 


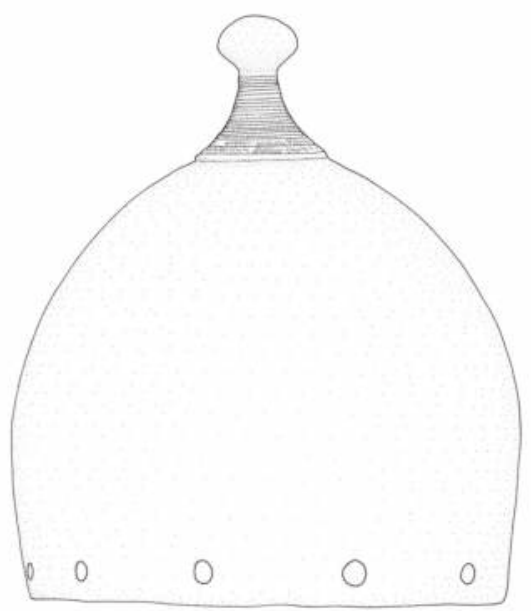

53

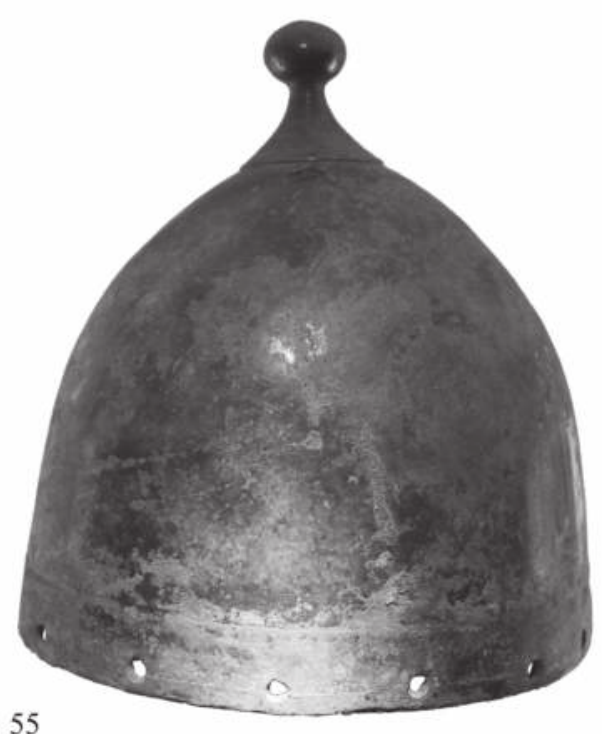

55

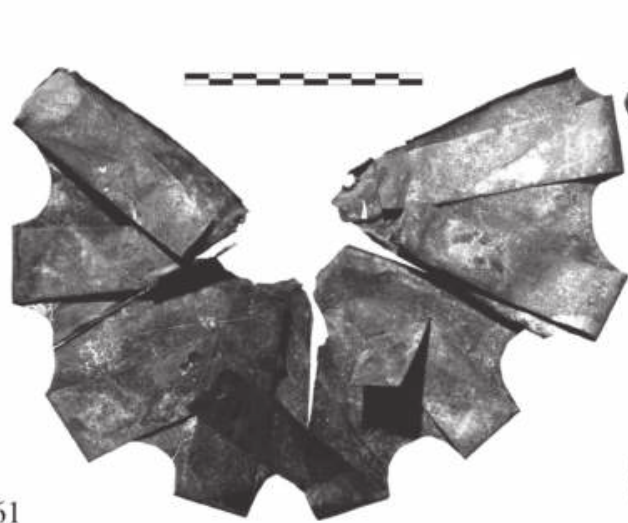

61
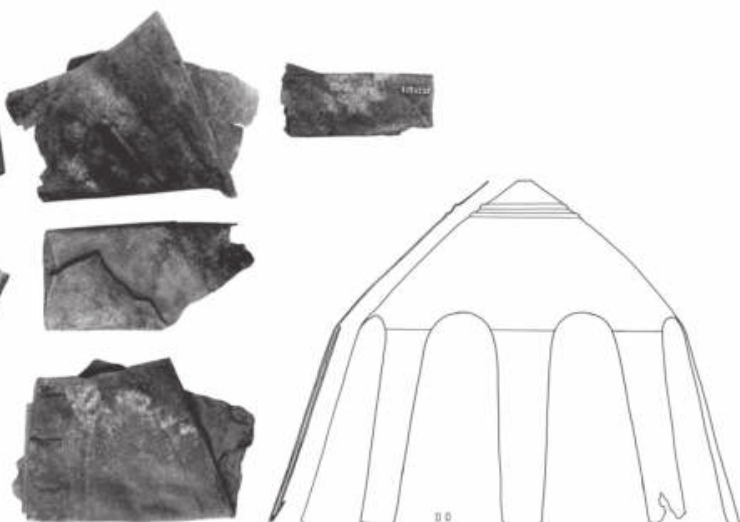

Pl. 8 Helmets of Type Pişcolt (cat. nos. 53-55), associated fragment (cat. no. 56) and knobs (cat. nos. 57-58): 53. Unprovenanced; 54. Unprovenanced (Born - Hansen 2001, fig. 200); 55. Unprovenanced (photograph M. Mödlinger; by courtesy of Phoenix Ancient Art, Geneva); 56. Bonyhád, Hungary (Mozsolics 1985, pl. 40.14); 57-58. Škocjan, Slovenia (Hencken 1971, fig. 126a-e). 61. Malpensa, Italy (after de Marinis 2016, figs. 13-14, 16). The numbers correspond to the catalogue numbers (scale 1:4). 


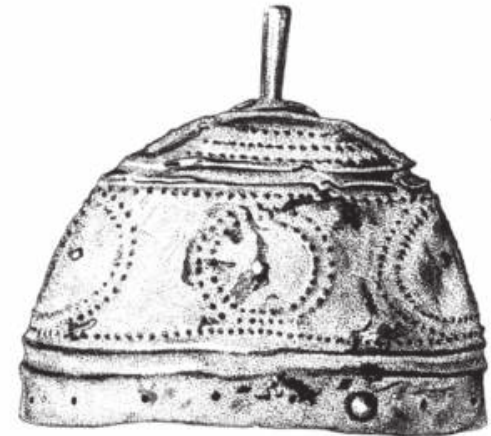

59

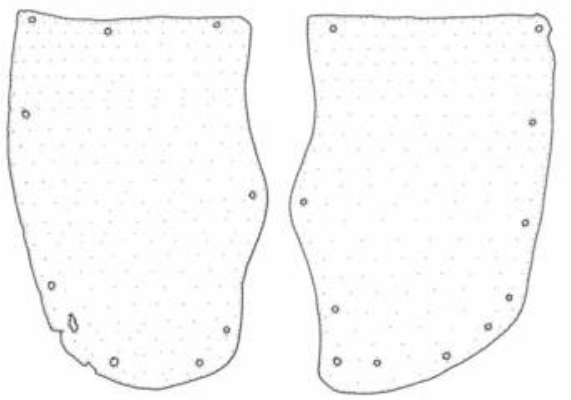

63
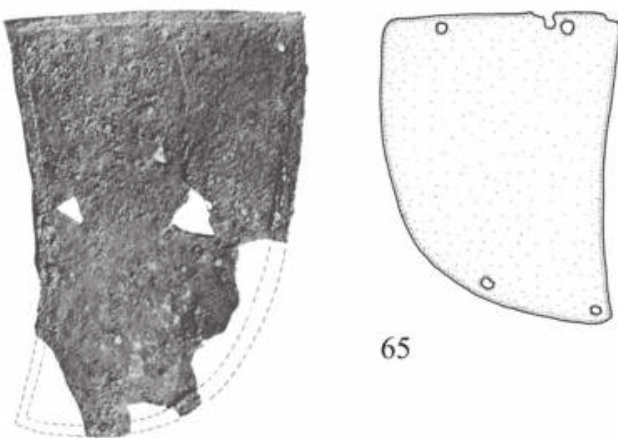

65

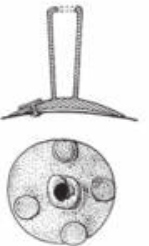

. 


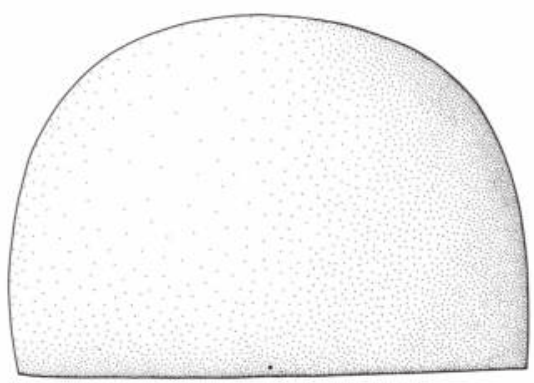

71

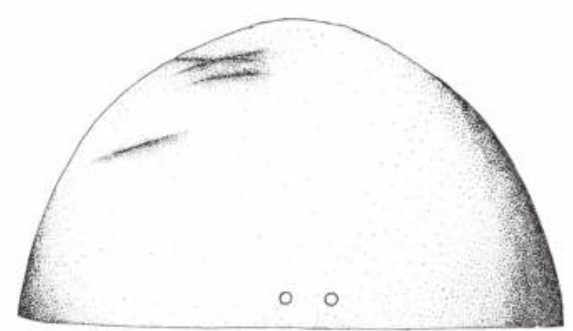

73
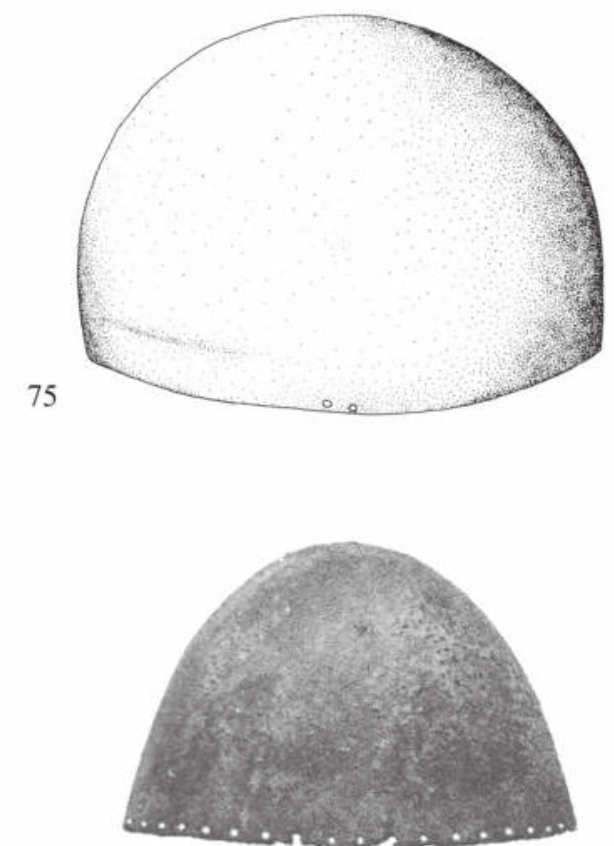

77

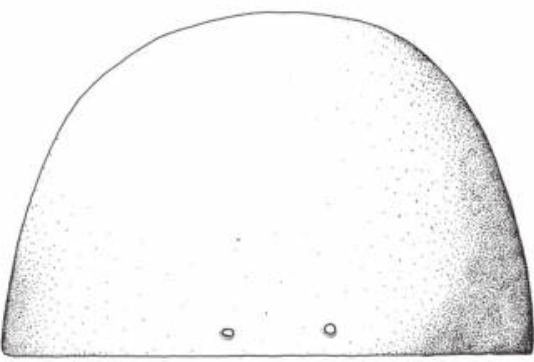

72
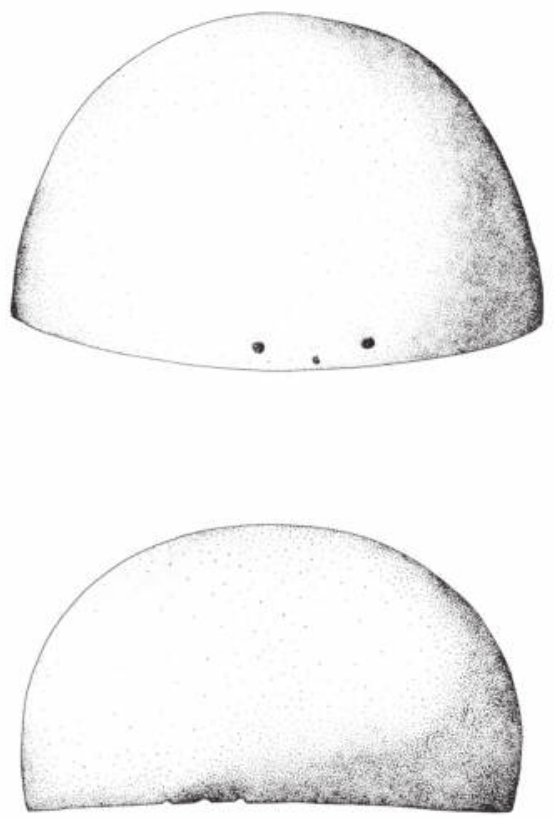

76

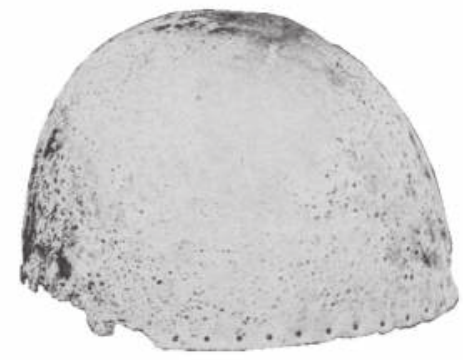

78

P1. 10 Helmets of Type Montbellet: 71. Montbellet (Bonnamour 1990, fig. 35); 72. Thonberg (Schauer 1982c, fig. 8); 73. Wonsheim (Schauer 1982c, fig. 6); 74. Szikszó (Schauer 1982c, fig. 5.2); 75. Brancere (Schauer 1982c, fig. 13); 76. Iseo (Schauer 1982c, fig. 2); 77. Unprovenanced (Ancona 1892, fig. 2.2); 78. Unprovenanced (Forrer 1894, pl. IV.27). The numbers correspond to the catalogue numbers (scale 1:4). 

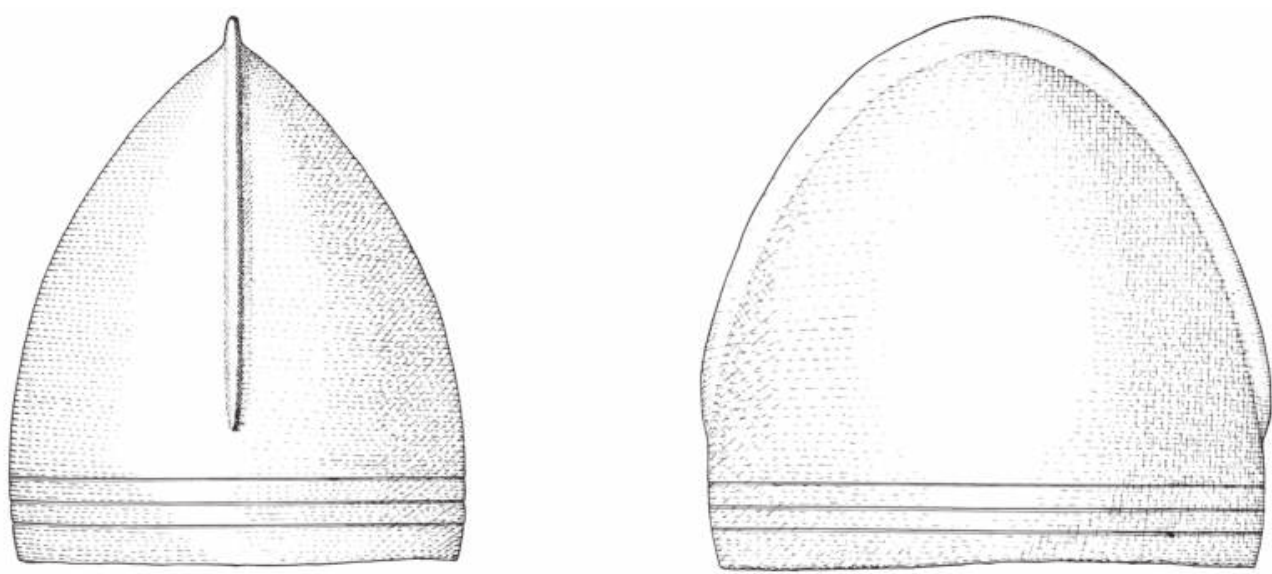

79
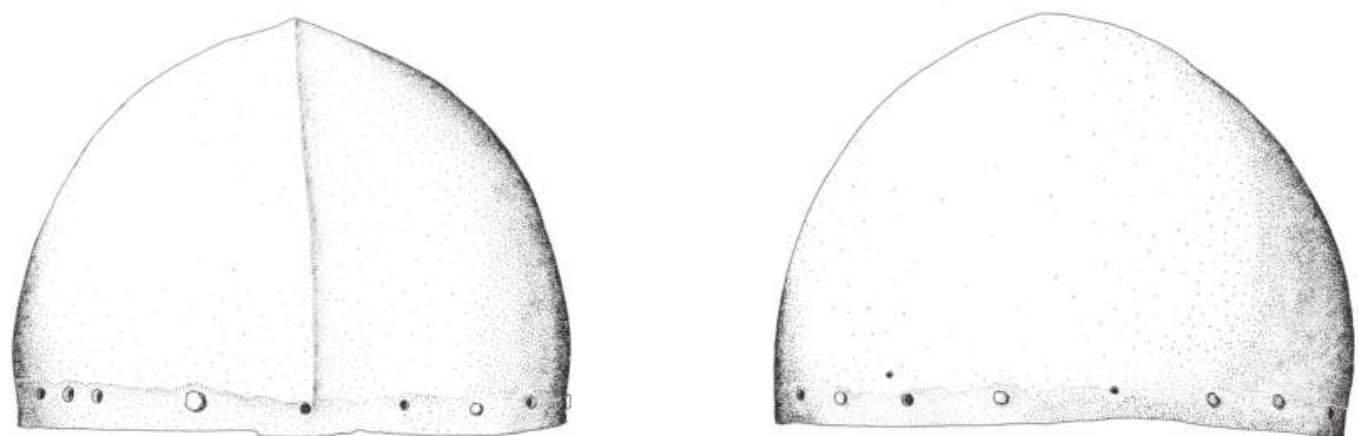

80
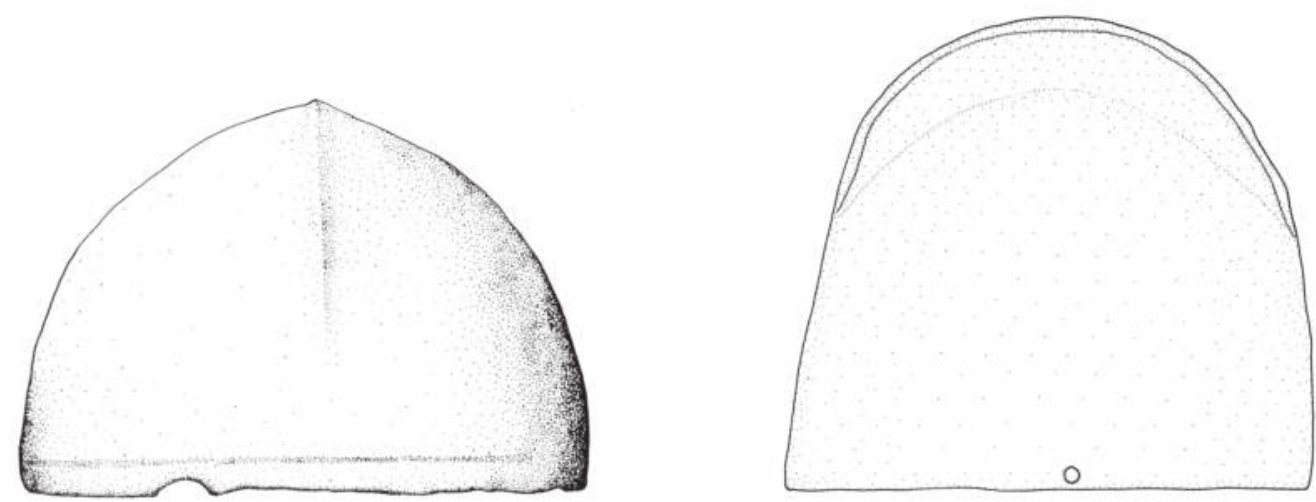

81

82

Pl. 11 Helmets of Type Mantes: 79. Mantes, France (Mohen 1977, fig. on page 149); 80. Mainz, Germany (Schauer 1982c, fig. 3); 81. Oggiono-Ello, Italy (Schauer 2003, fig. 1.11); 82. Weil am Rhein, Germany. The numbers correspond to the catalogue numbers (scale 1:4). 

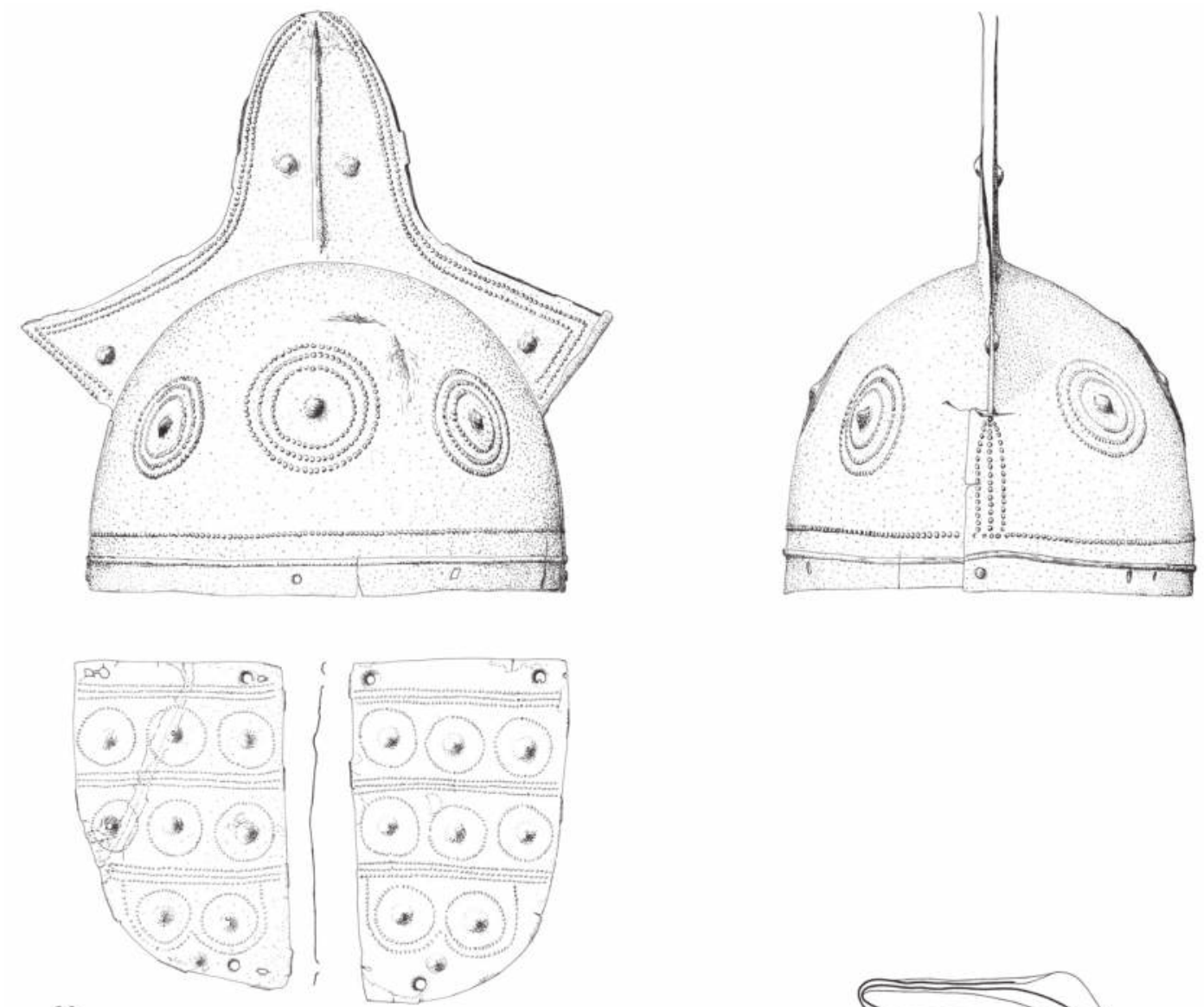

83

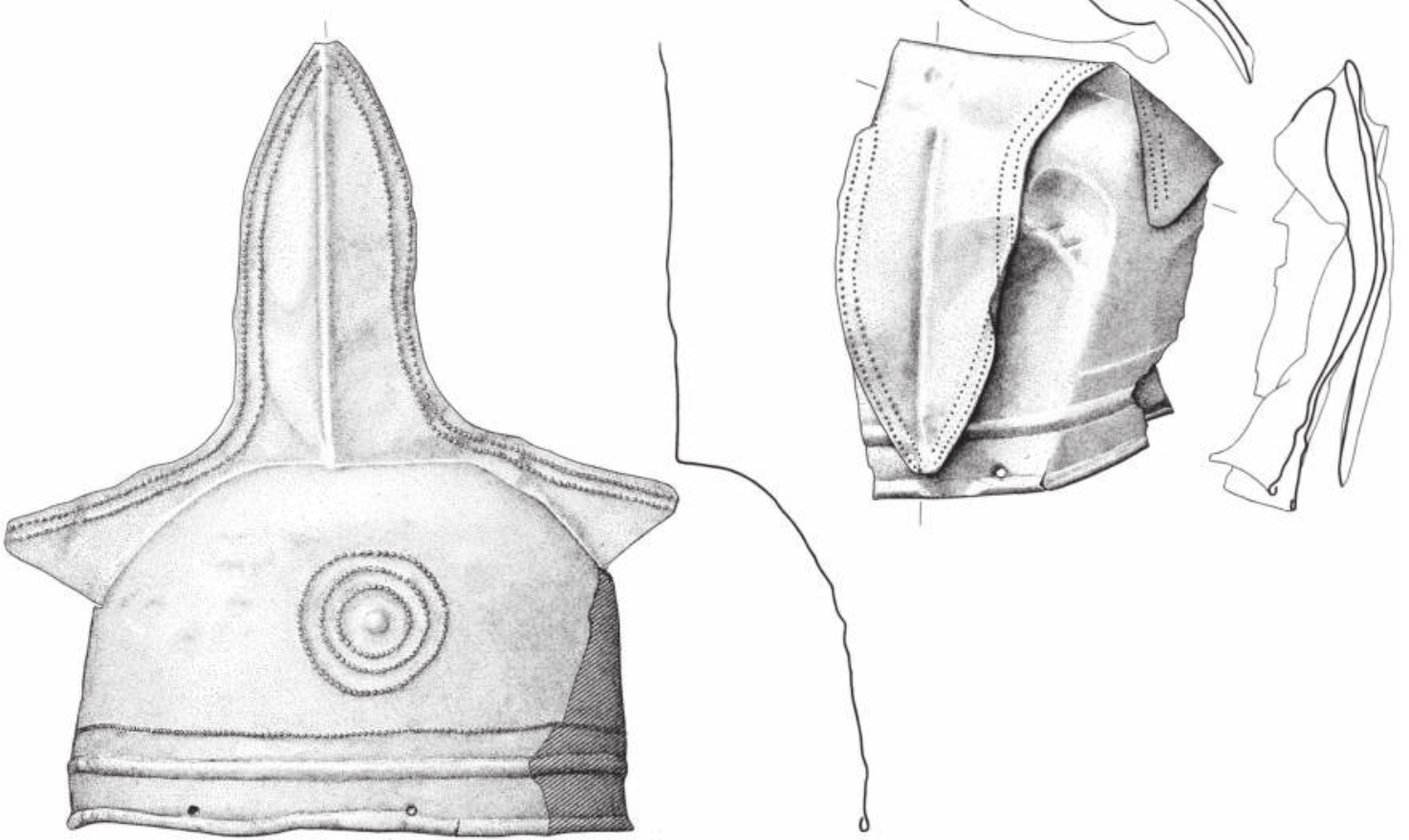

84

Pl. 12 Helmets of Type Lueg: 83. Pass Lueg, Austria (Lippert 2011, figs. 5, 7-8); 84. Piller Sattel, Austria (Egg Tomedi 2002, figs. 5, 7). The numbers correspond to the catalogue numbers (scale 1:4). 
85
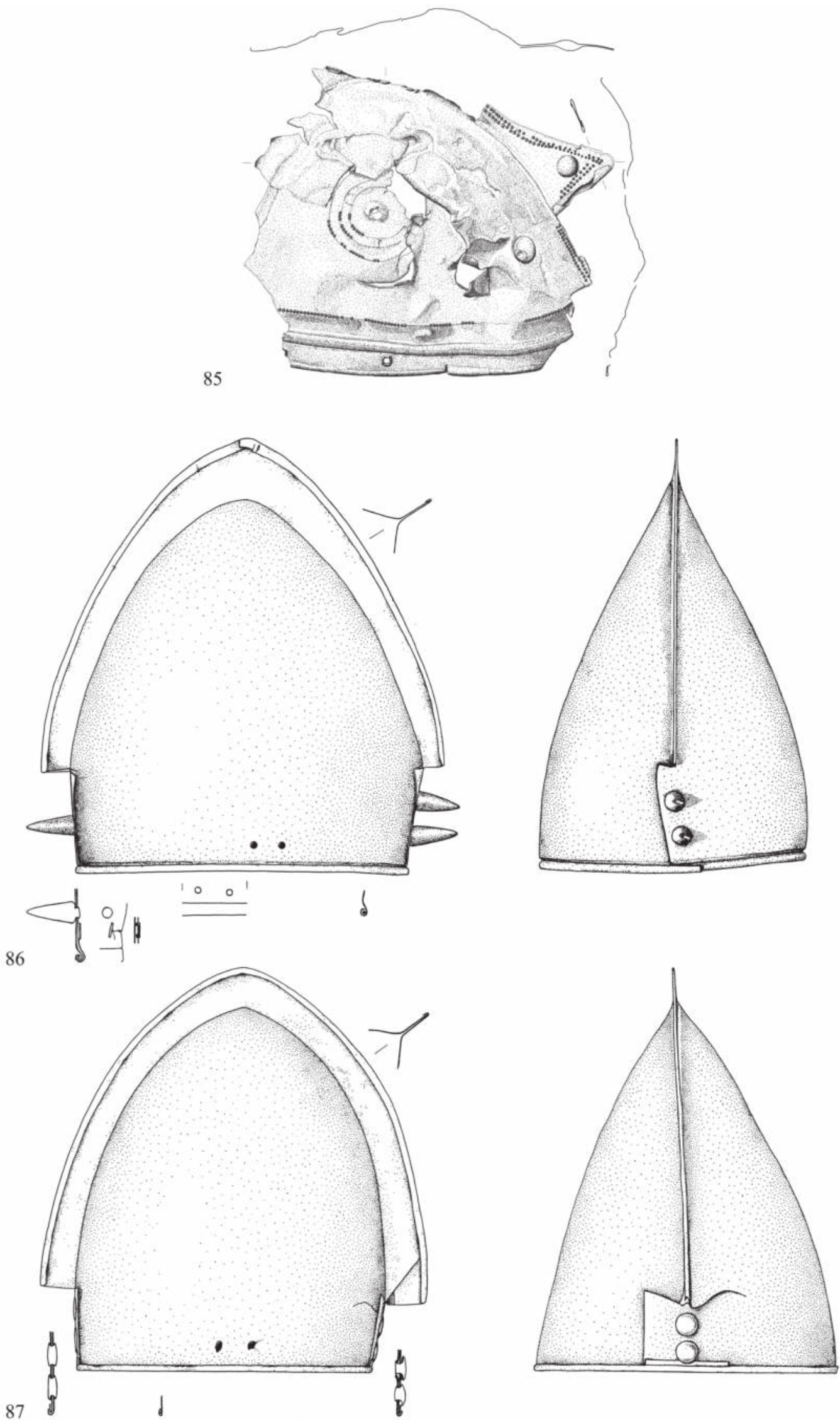

87

Pl. 13 Helmets of Type Lueg (cat. no. 85) and Biebesheim (cat. nos. 86-87): 85. Anlauftal, Austria (Lippert 2010, fig. 2.1); 86. Biebesheim, Germany (A) (Jorns 1972, figs. 1-2); 87. Biebesheim, Germany (B) (Jorns 1972, figs. 3-4). The numbers correspond to the catalogue numbers (scale 1:4). 


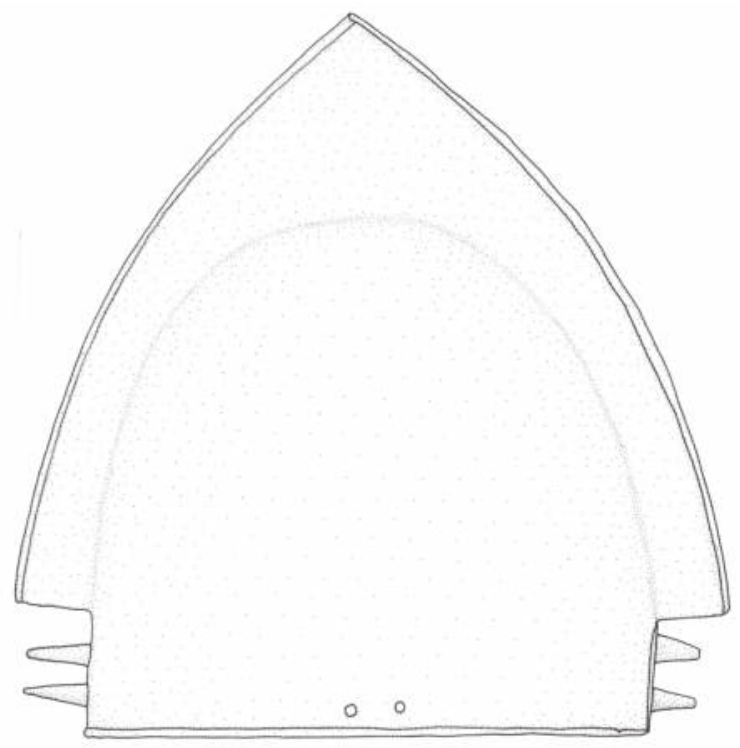

88

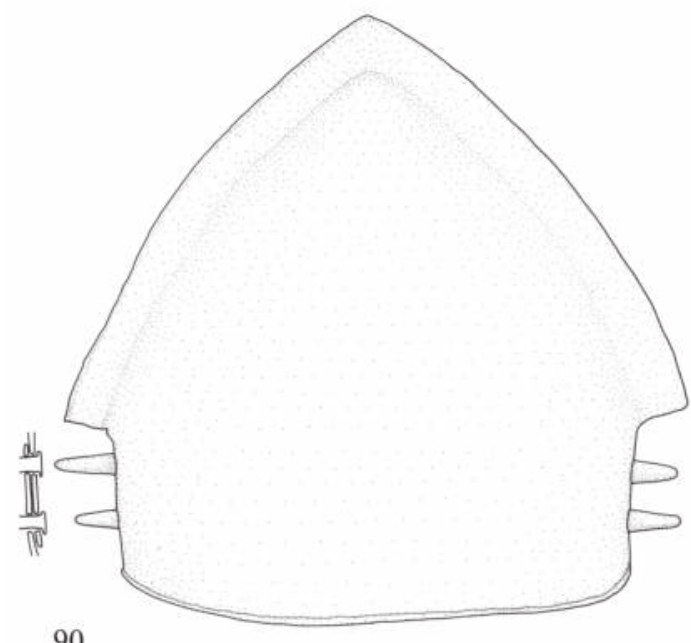

90
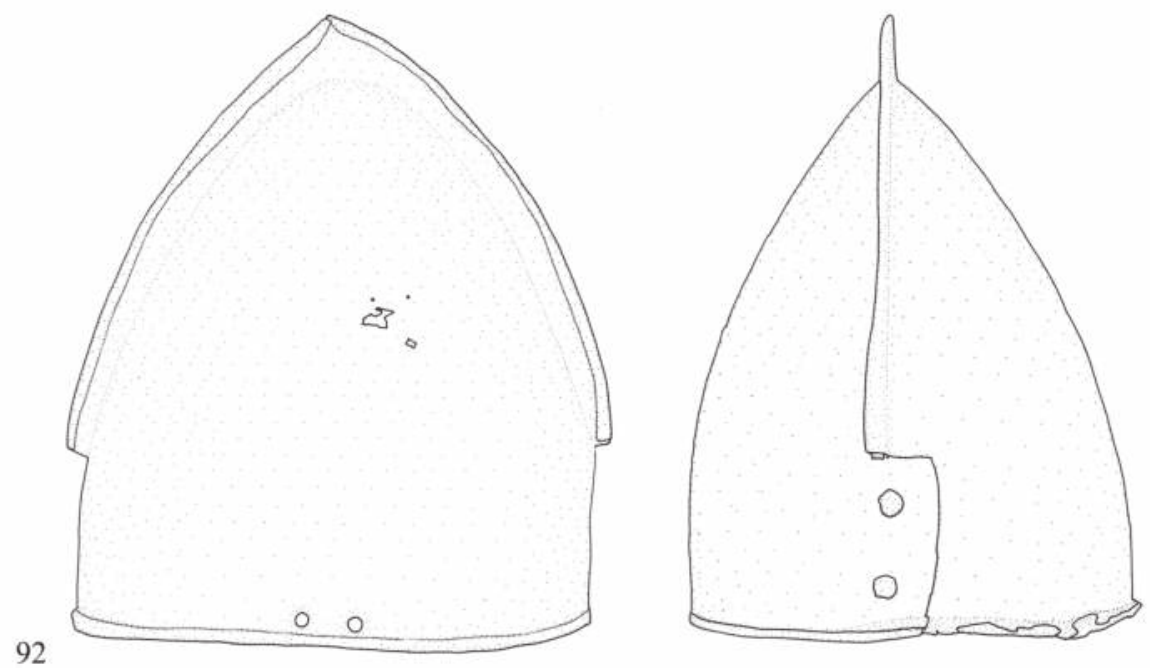

Pl. 14 Helmets of Type Biebesheim: 88. Bremen, Germany. 89. Ebing, Germany (Jakob 1972, fig. 54); 90. Pockinger Heide, Germany; 91. Otterstadt, Germany (Sperber 2011, pl. 3.2); 92. Auxonne, France. The numbers correspond to the catalogue numbers (scale 1:4). 

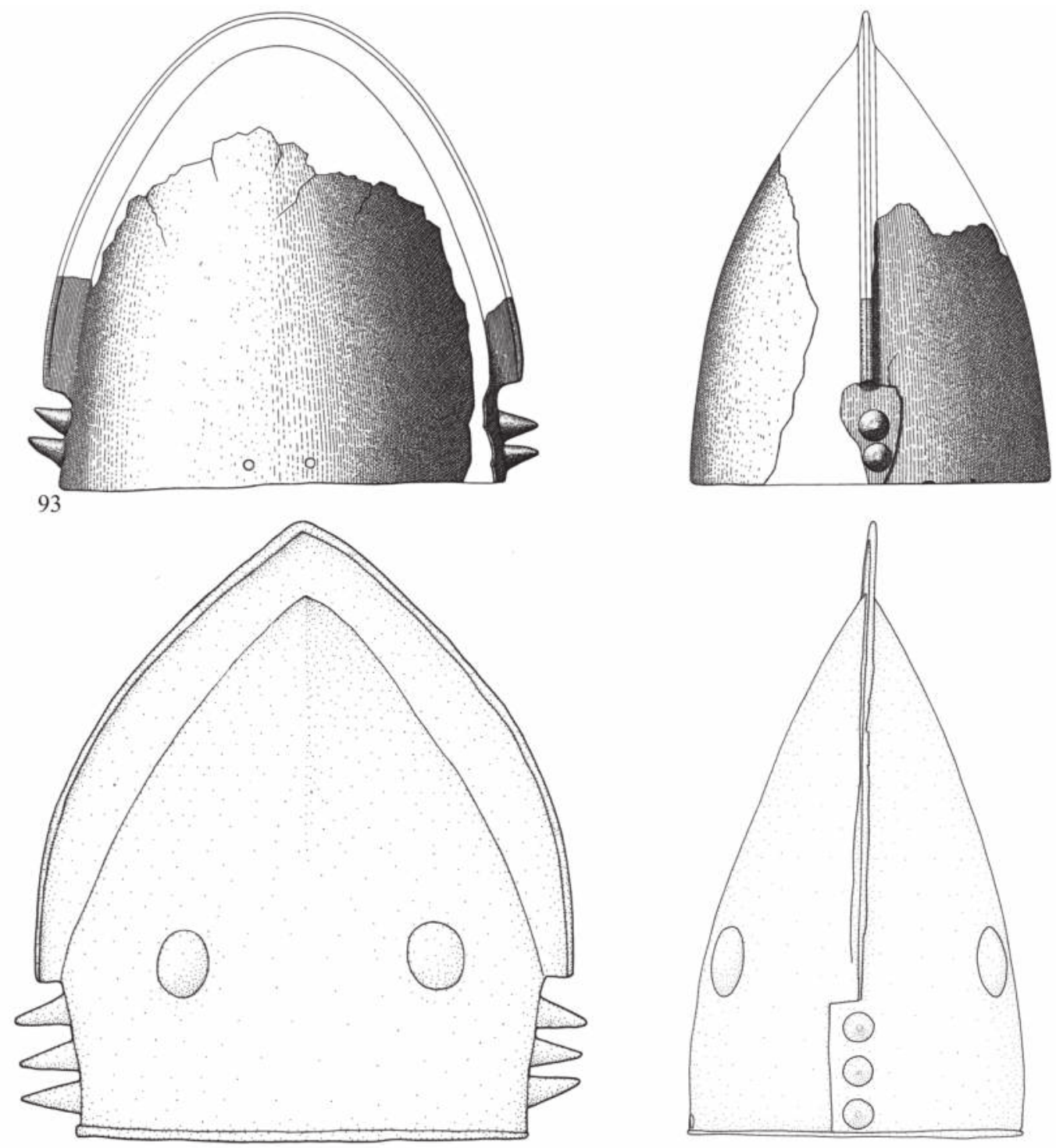

94

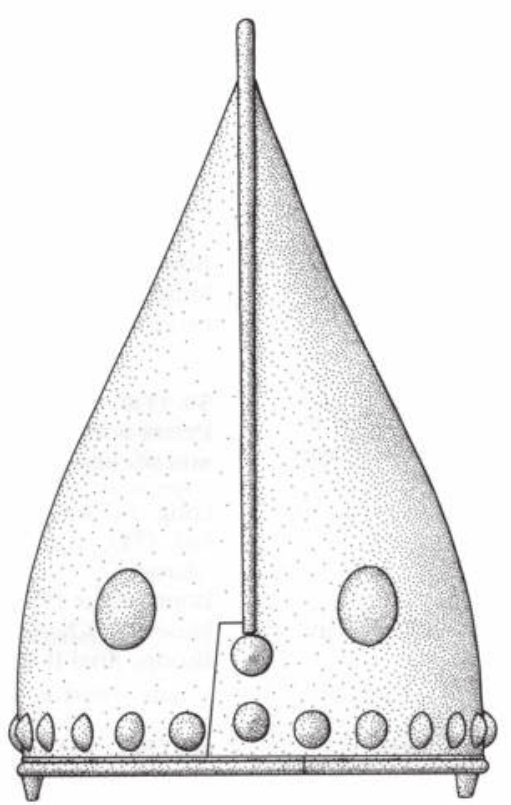

95

Pl. 15 Helmets of Type Biebesheim: 93. Le Theil, France (Cordier 1997, fig. 9); 94. Blainville-sur-l'Eau, France;

95. Chalon-sur-Saône, France (Bonnamour 1990, fig. 37). The numbers correspond to the catalogue numbers (scale 1:4) 

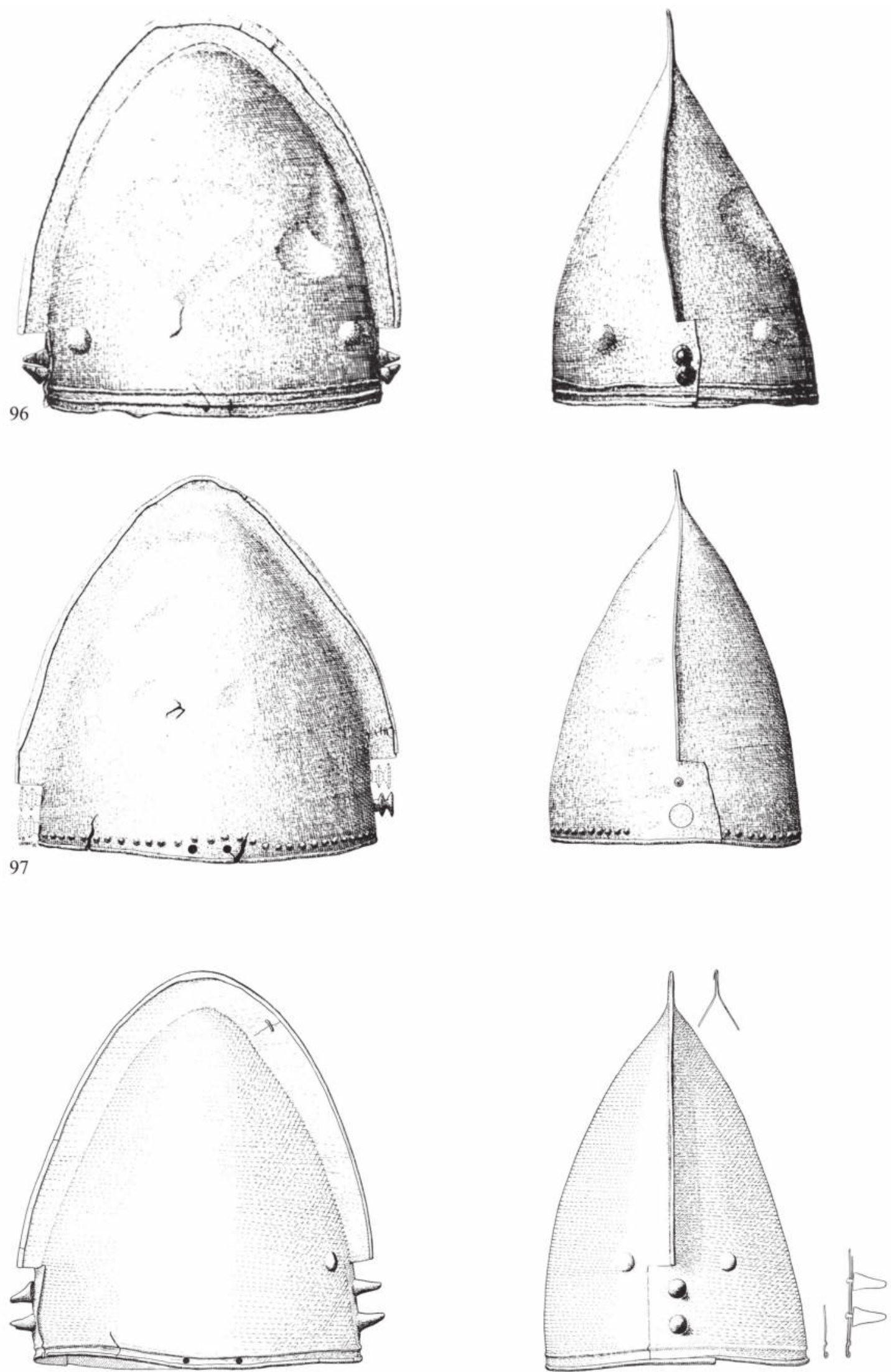

98

P1. 16 Helmets of Type Biebesheim: 96. Montmacq, France (A) (Blanchet - Lambot 1975, fig. on page 45); 97. Montmacq, France (B) (Blanchet - Lambot 1975, fig. on page 44); 98. Paris, France (Mohen 1977, fig. on page 148). The numbers correspond to the catalogue numbers (scale 1:4). 

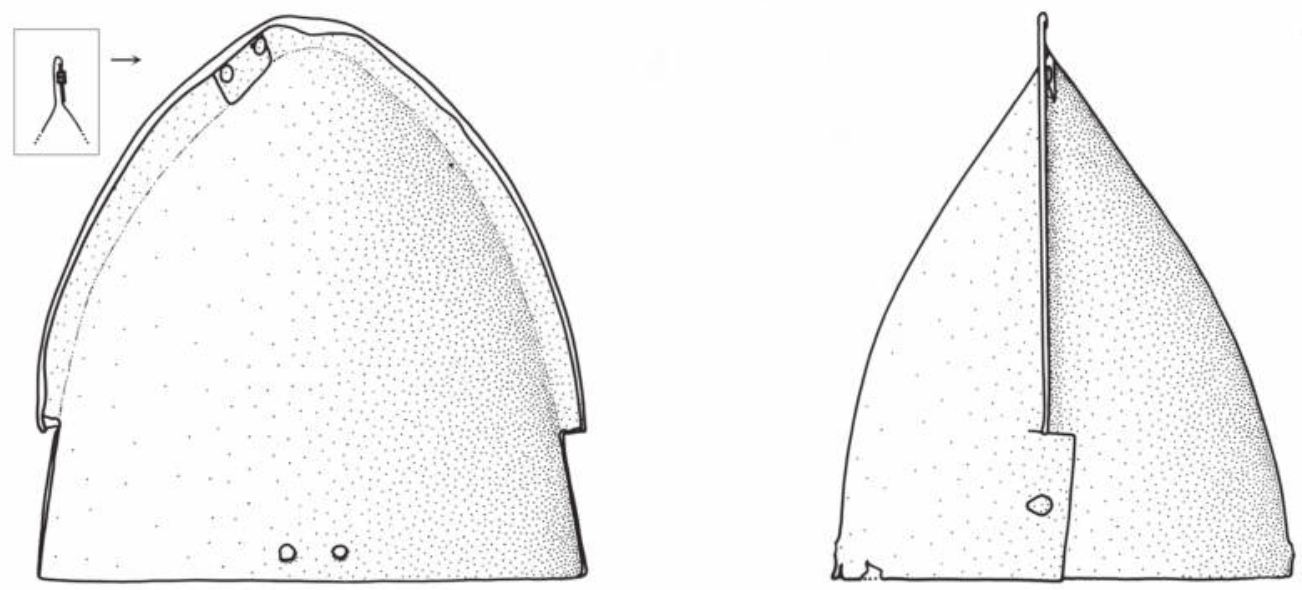

99

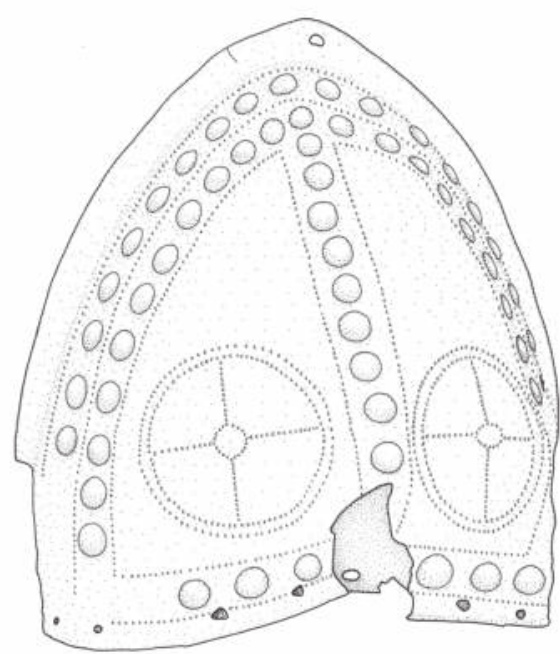

100

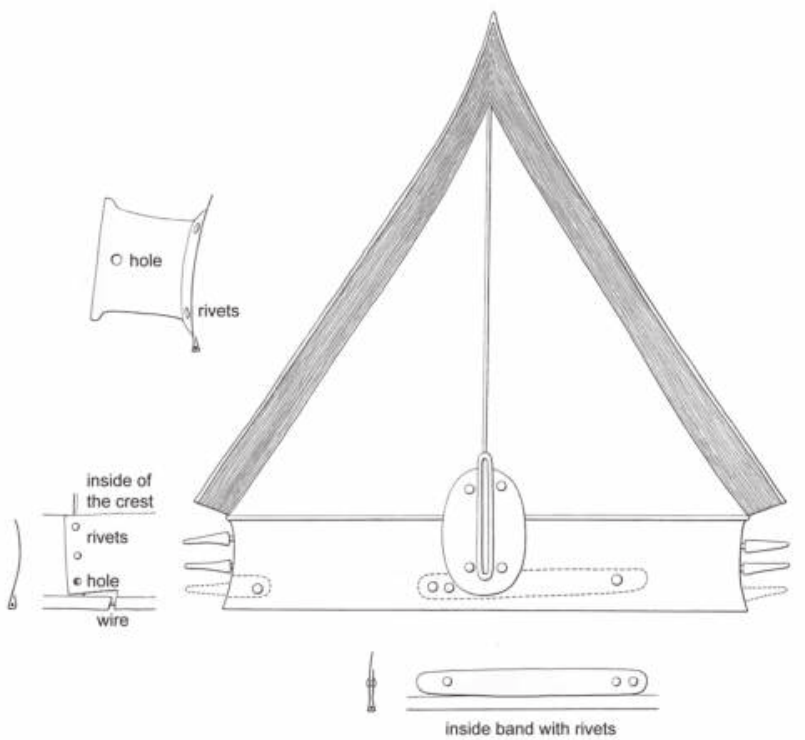

Pl. 17 Helmets of Type Biebesheim (cat. no. 99), and related to Type Biebesheim (cat. no. 100) and schematic drawing of helmets of Type Bernières d'Ailly (Hencken 1971, 69, fig. 41). 99. Seurre, France; 100. Unprovenanced . The numbers correspond to the catalogue numbers (scale 1:4). 

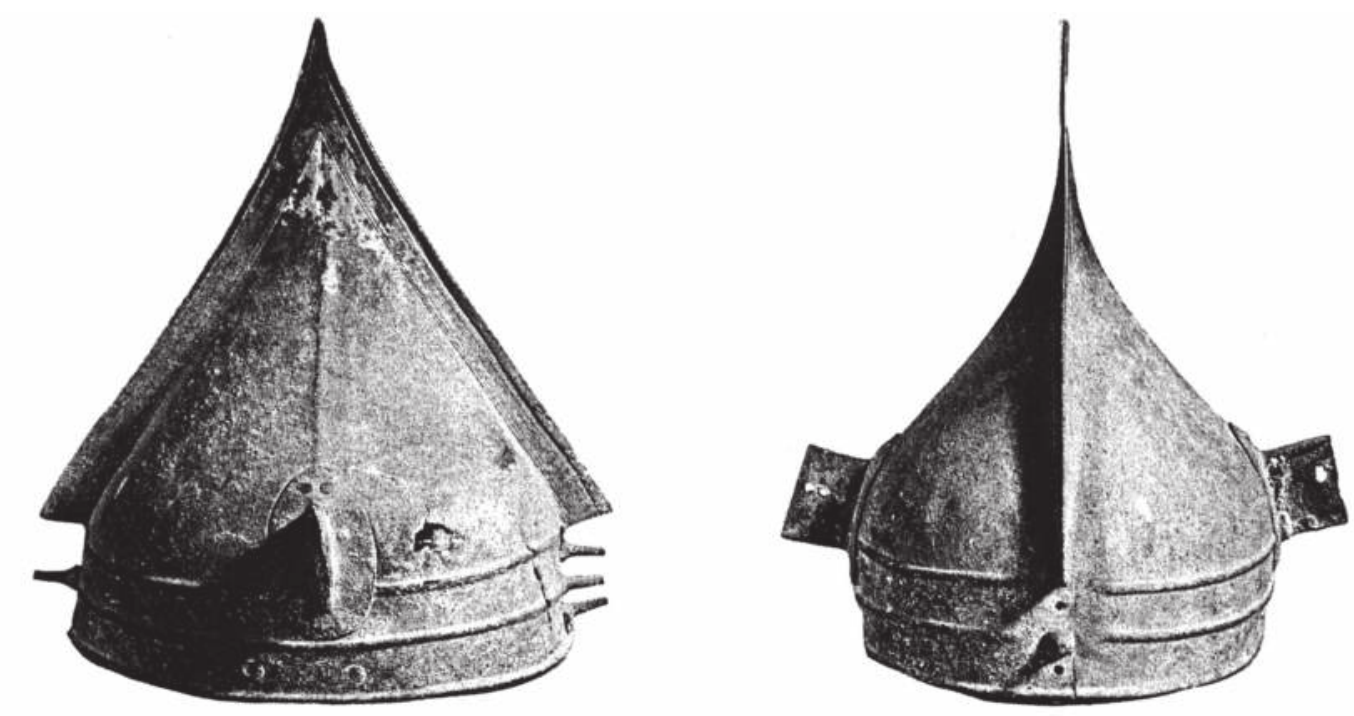

101
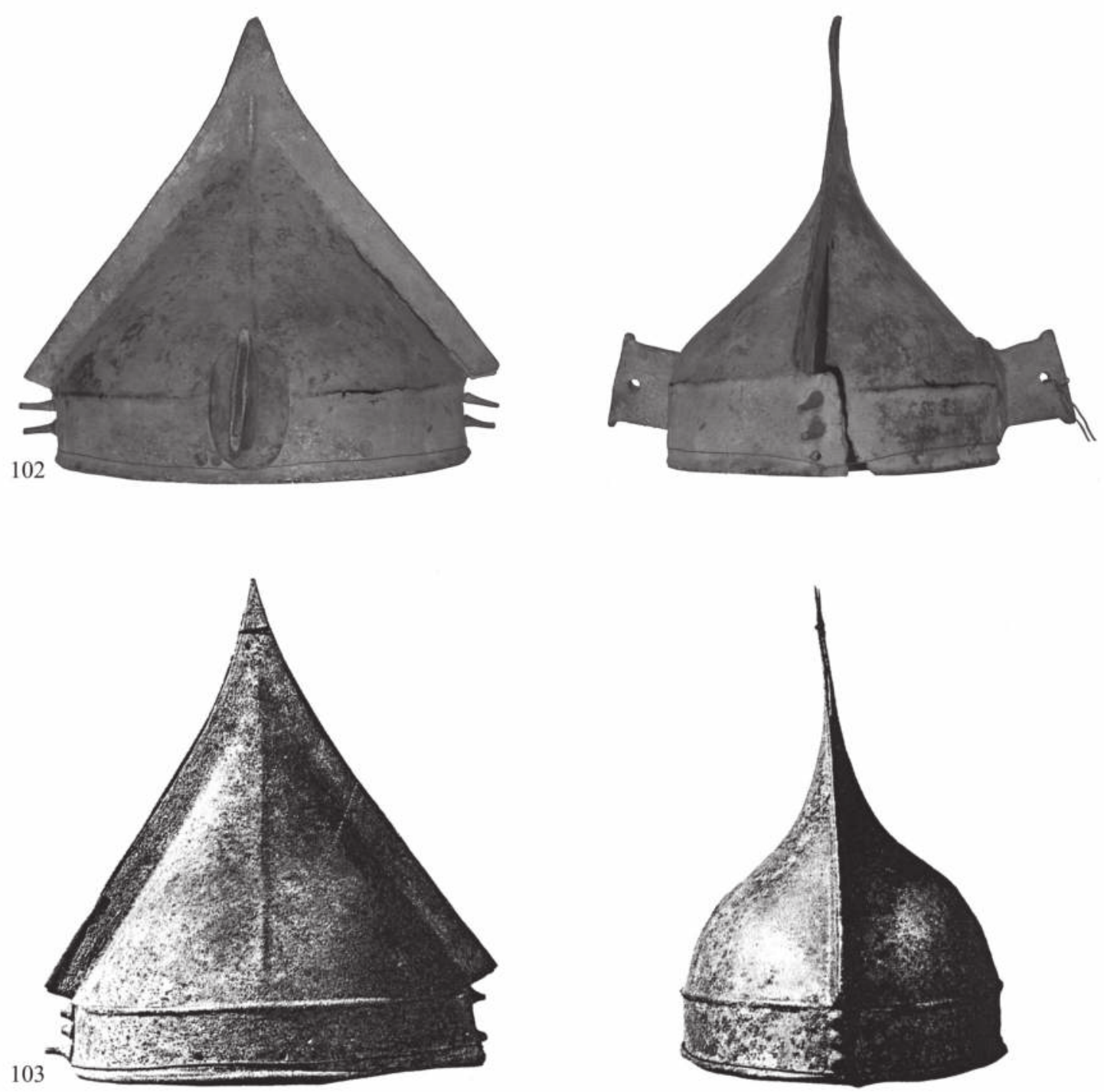

Pl. 18 Helmets of Type Bernières d'Ailly: 101. Bernières d'Ailly (Hencken 1971, fig. 40); 102. Bernières d'Ailly (Lehoërff 2011, fig. 2a-b); 103. Bernières d'Ailly (Hencken 1971, fig. 42). The numbers correspond to the catalogue numbers (scale 1:4). 

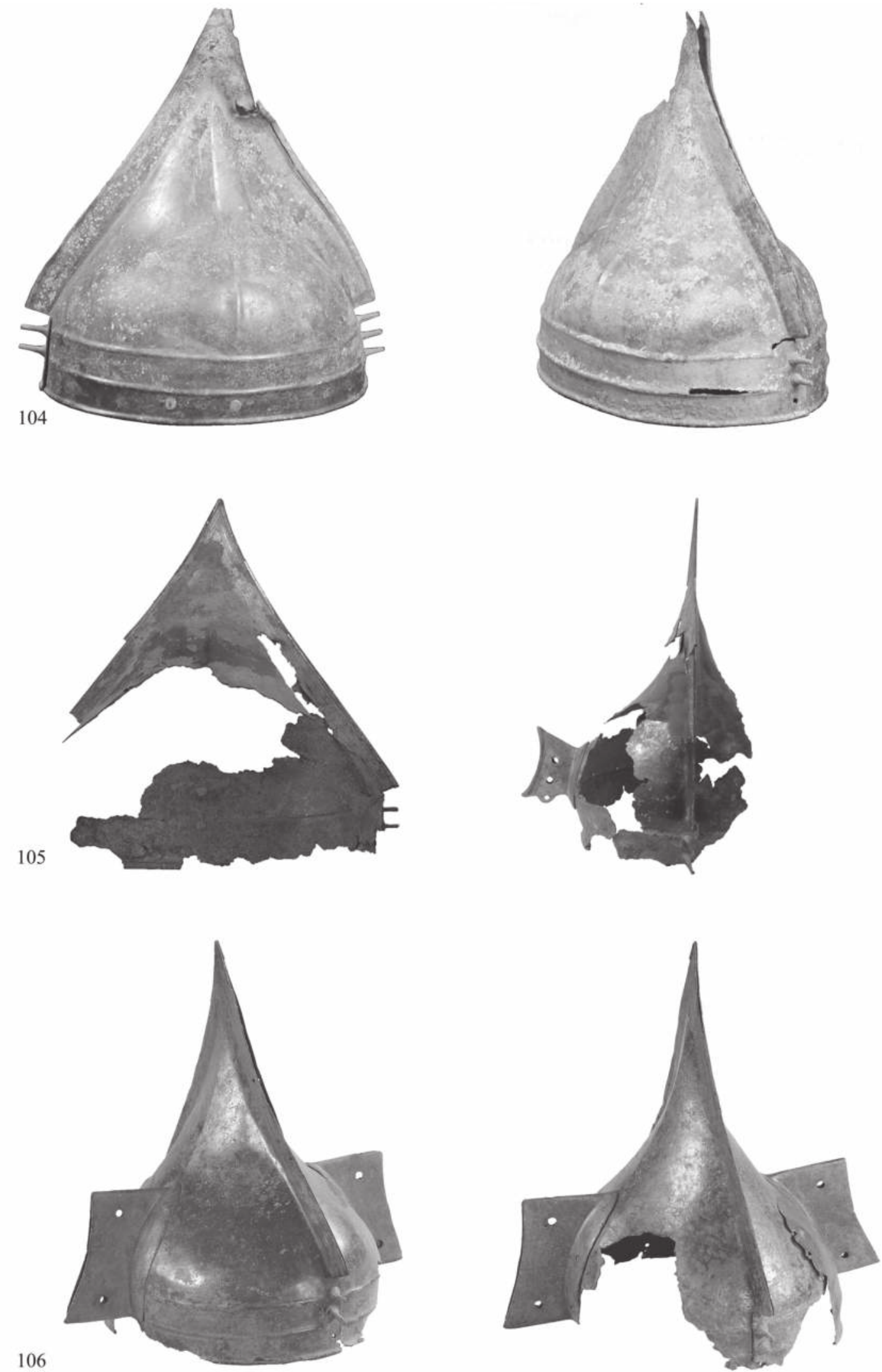

Pl. 19 Helmets of Type Bernières d'Ailly: 104-106. Bernières d'Ailly (Caen, Musée de Normandie. Dépôt de la Ville de Falaise. (C) Musée de Normandie - Ville de Caen / O. Caillebotte - Archiveuro). The numbers correspond to the catalogue numbers (scale 1:4). 


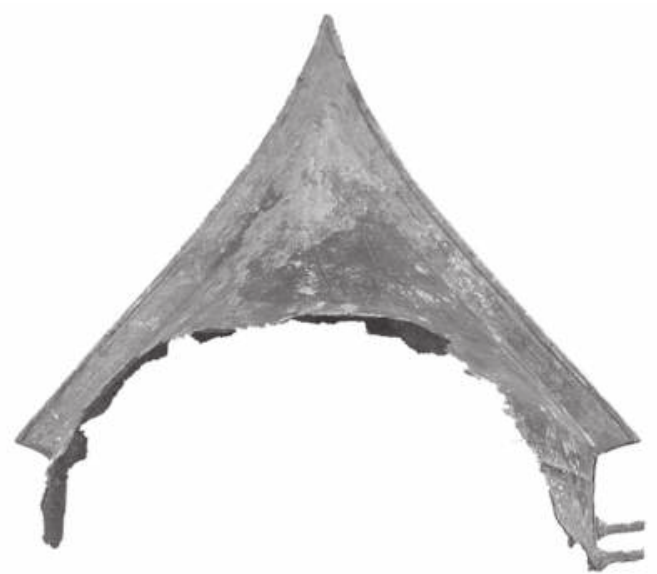

107
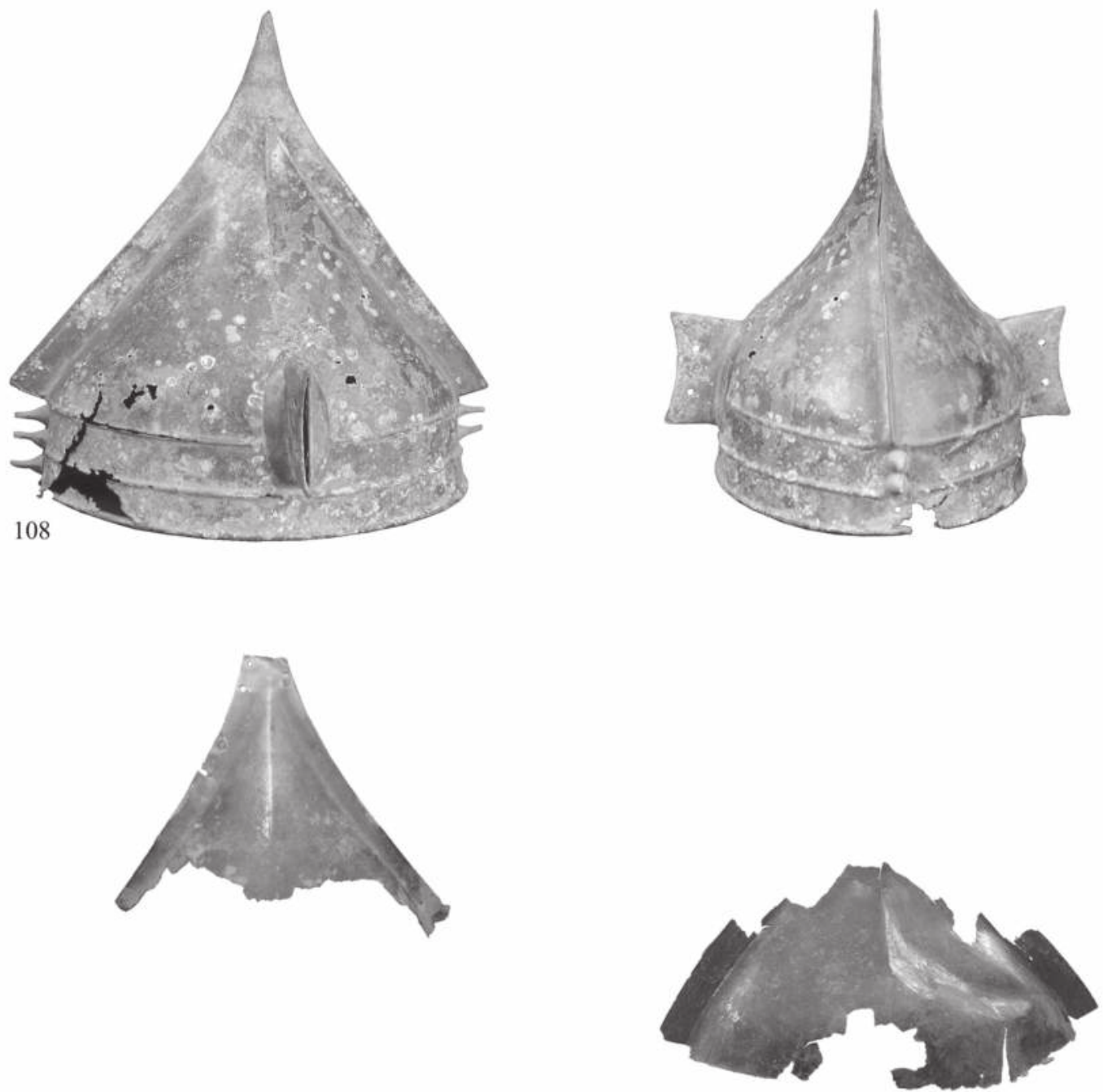

109

Pl. 20 Helmets of Type Bernières d'Ailly: 107-110. Bernières d'Ailly (Caen, Musée de Normandie. Dépôt de la Ville de Falaise. (C) Musée de Normandie - Ville de Caen / O. Caillebotte - Archiveuro). The numbers correspond to the catalogue numbers (scale 1:4). 


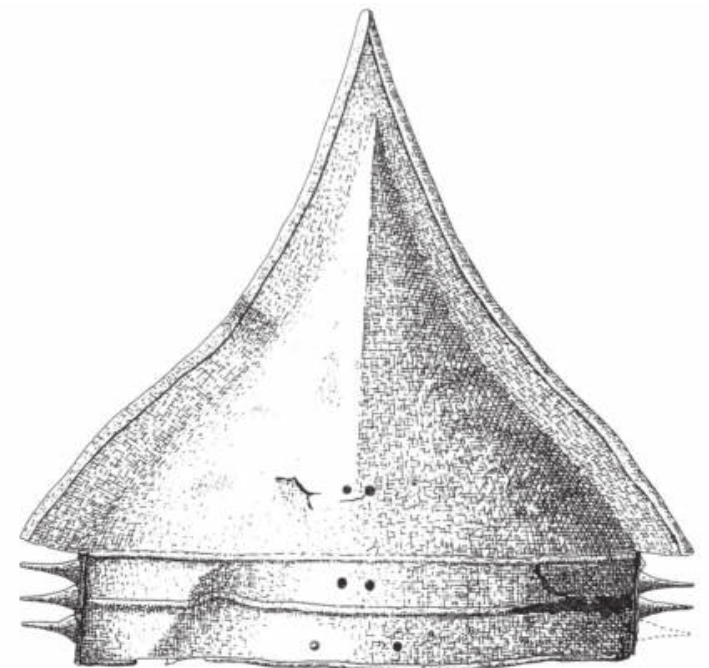

111
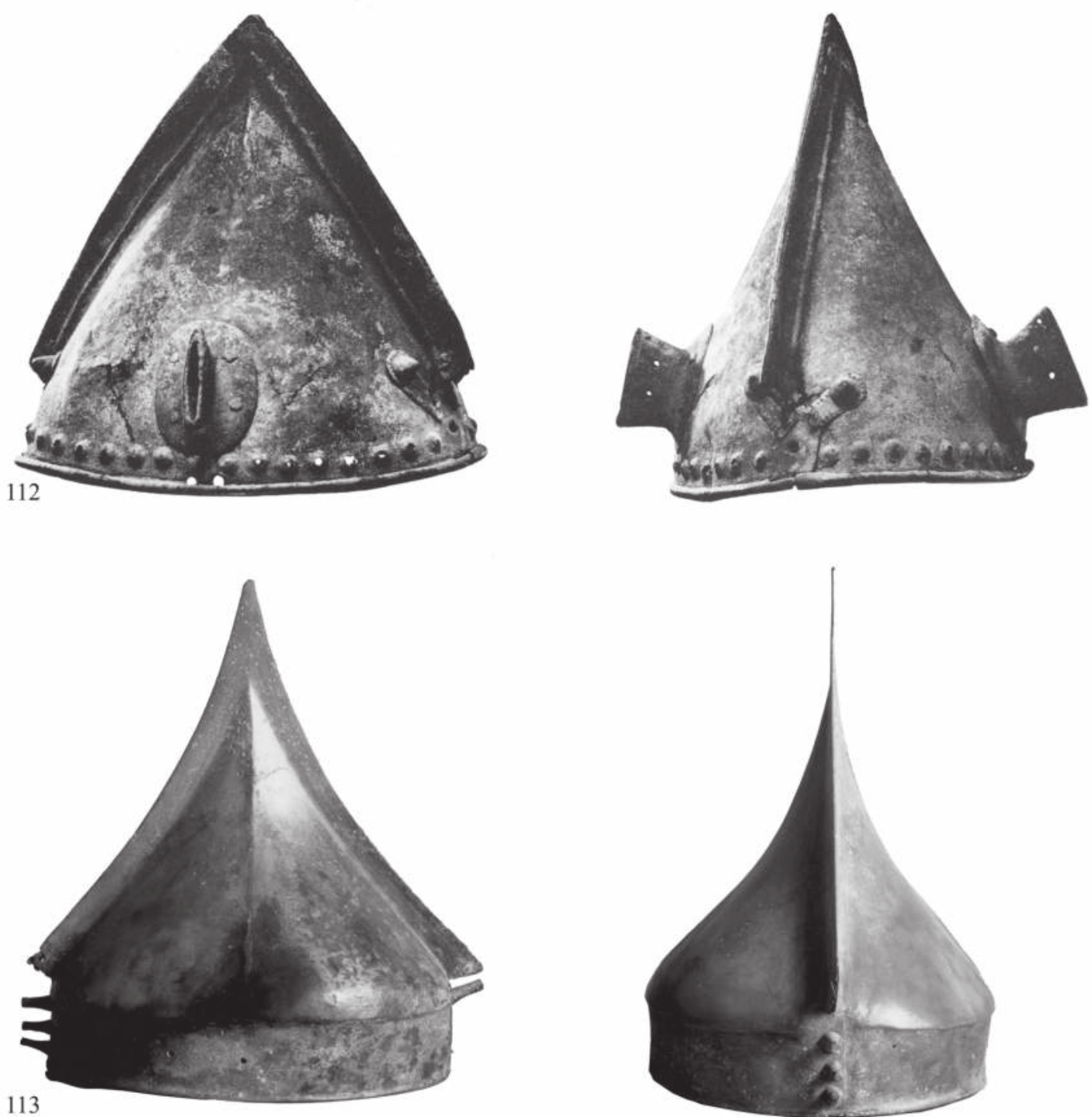

P1. 21 Helmets of Type Bernières d'Ailly: 111. Armancourt, France (Blanchet - Lambot 1975, fig. on page 46);

112. Unprovenanced ('Normandy', France?) (Pflug 1989); 113. Nemours, France (photograph J.-B. Roy, Musée départemental de Préhistoire d'Île-de-France). The numbers correspond to the catalogue numbers (scale 1:4). 


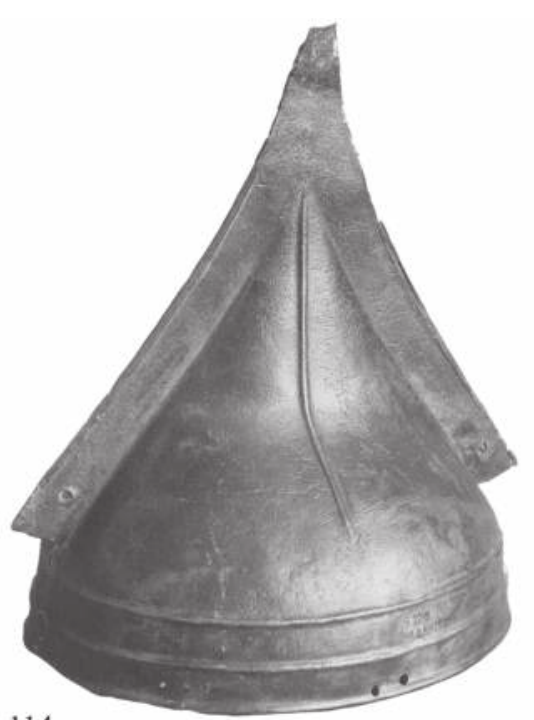

114

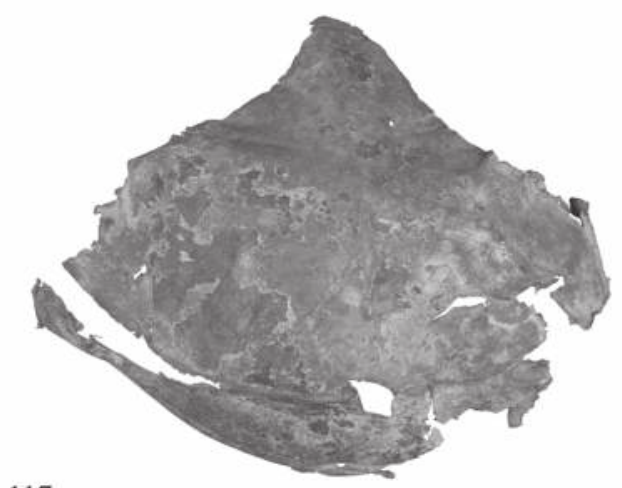

117

118

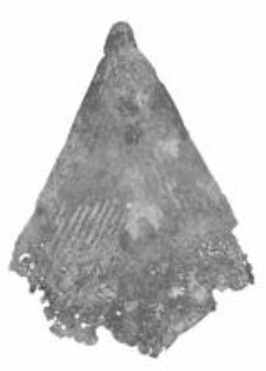

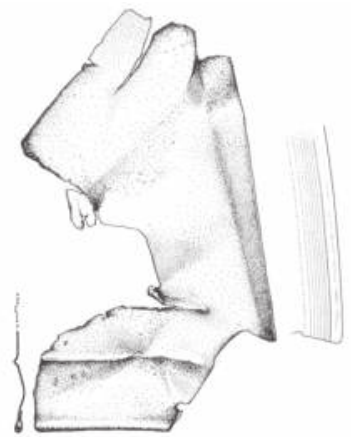

115

116
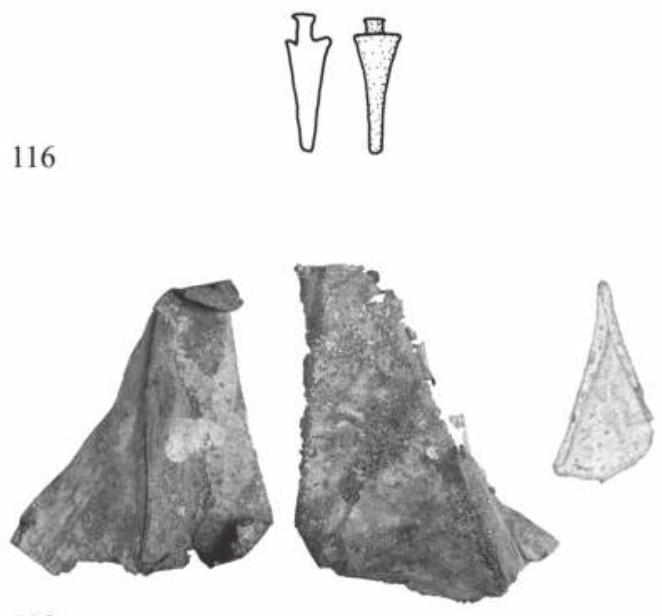

119

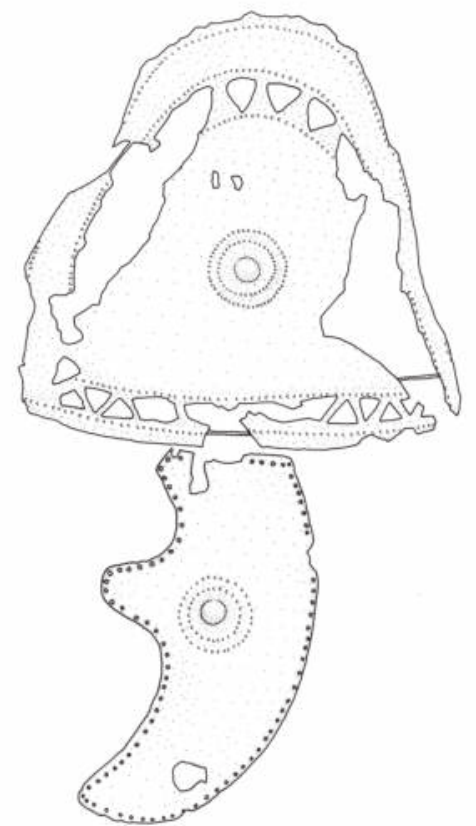

120

Pl. 22 Helmets of Type Bernières d'Ailly: 114. Mainz-Kostheim, Germany (Egg - Waurick 1990, fig. 8.3); 115. Roxheim, Germany (Sperber 2011, fig. 12.1); 116. Larnaud, France; 117-118. Huelva, Spain (C Museo Arqueológico Nacional, Spain; photo: S. Vicente Galende (N.I. 32525 and 32606); 119. Vila Cova de Perrinho / Monte do Crasto, Portugal (Bottaini - Rodrigues 2011b, fig 5; C Município de Vale de Cambra - Museu Municipal, Vale de Cambra, Portugal); 120. Tiryns, Greece. The numbers correspond to the catalogue numbers (scale 1:4; cat. nos. 116 and 118: scale 1:2). 

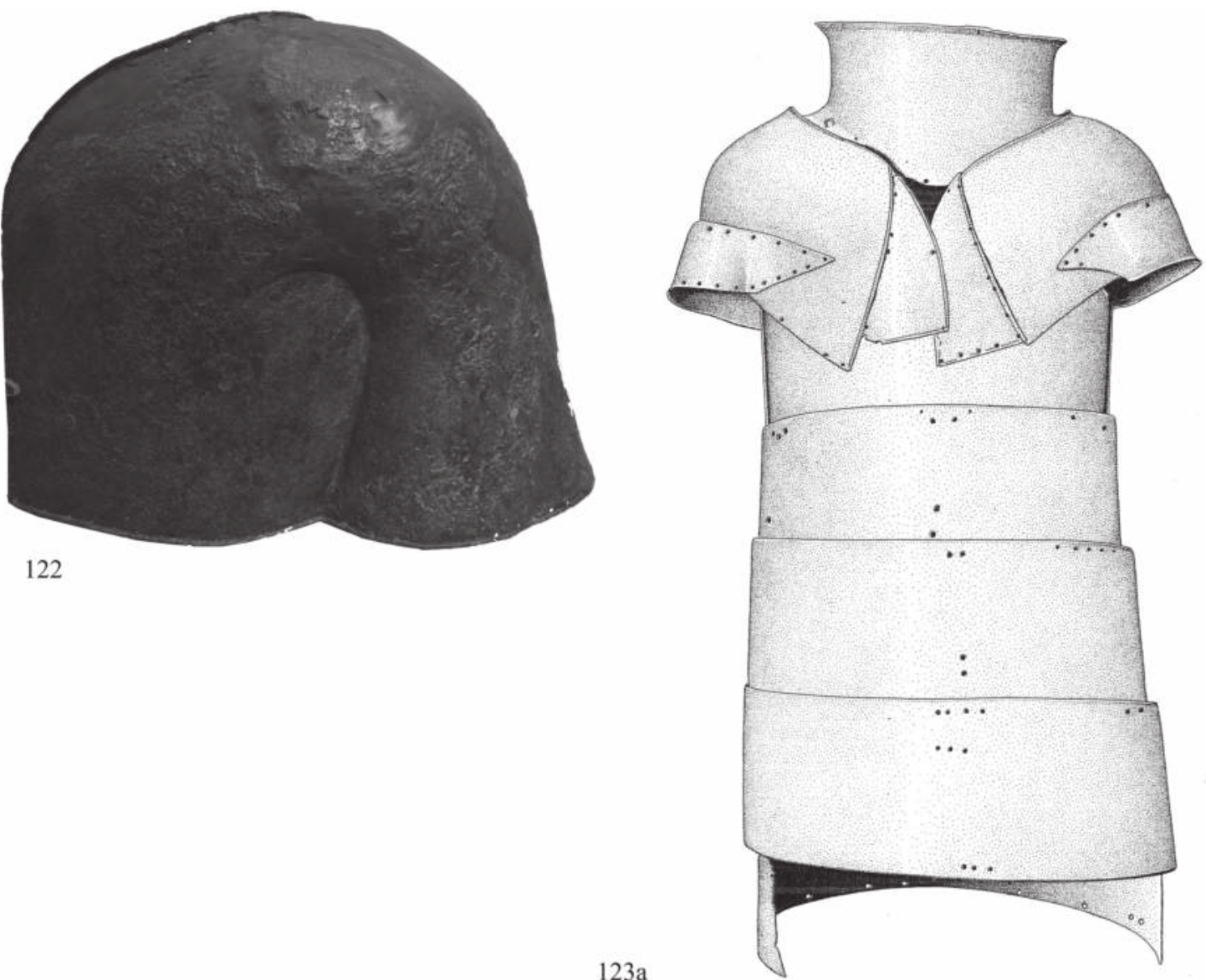

$123 a$
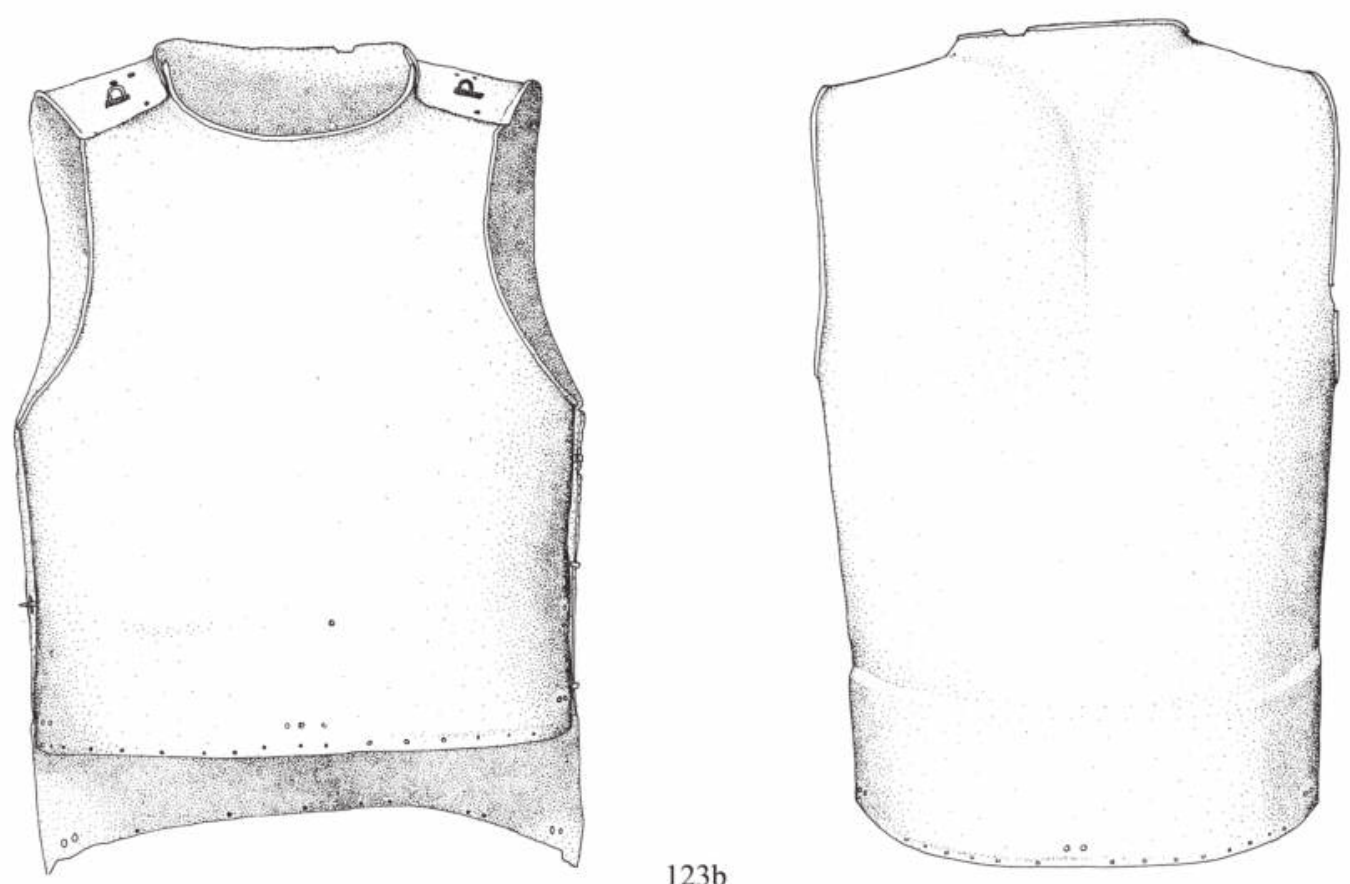

Pl. 23 Greek cuirasses: 122. Dendra, Greece (grave 8) (photograph R. d'Amato and A. Salimbeti, by courtesy of the Nauplion Museum; after d'Amato -Salimbeti 2011); 123. Dendra, Greece (grave 12). Complete panoply (123a) and cuirass only (123b) (123a: Müller-Karpe, 1980, pl. 242; 123b: Schauer 1982d, fig. 6). The numbers correspond to the catalogue numbers (scale 1:4; cat. no. 123: without scale). 

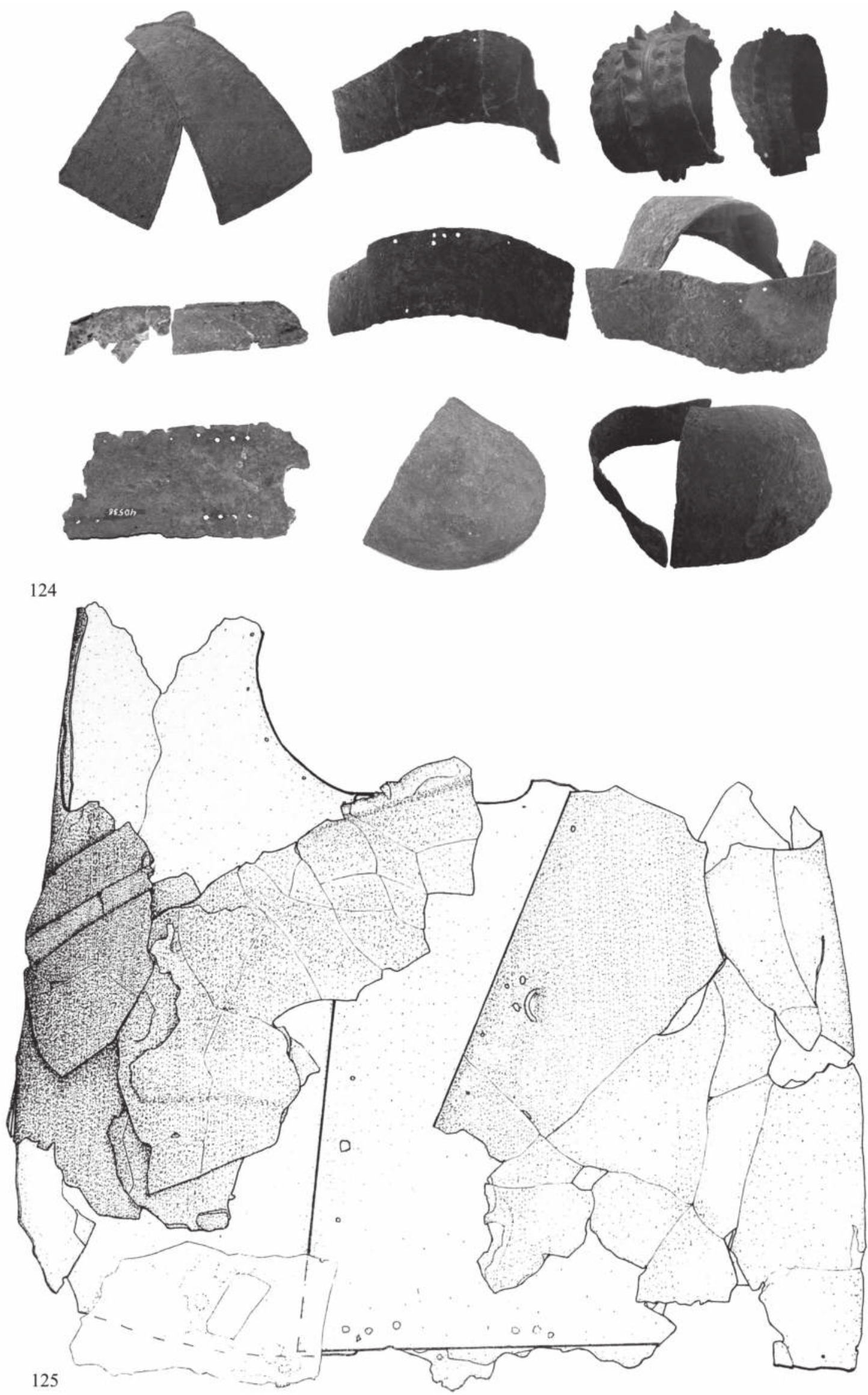

Pl. 24 Greek cuirasses: 124. Thebes, Greece (arsenal) (Andrikou 2007, pls. C-CI; d'Amato -Salimbeti 2011, 39); 125. Thebes, Greece (Municipal Conference Centre) (Andrikou 2007, pl. CIIb). The numbers correspond to the catalogue numbers (without scale). 

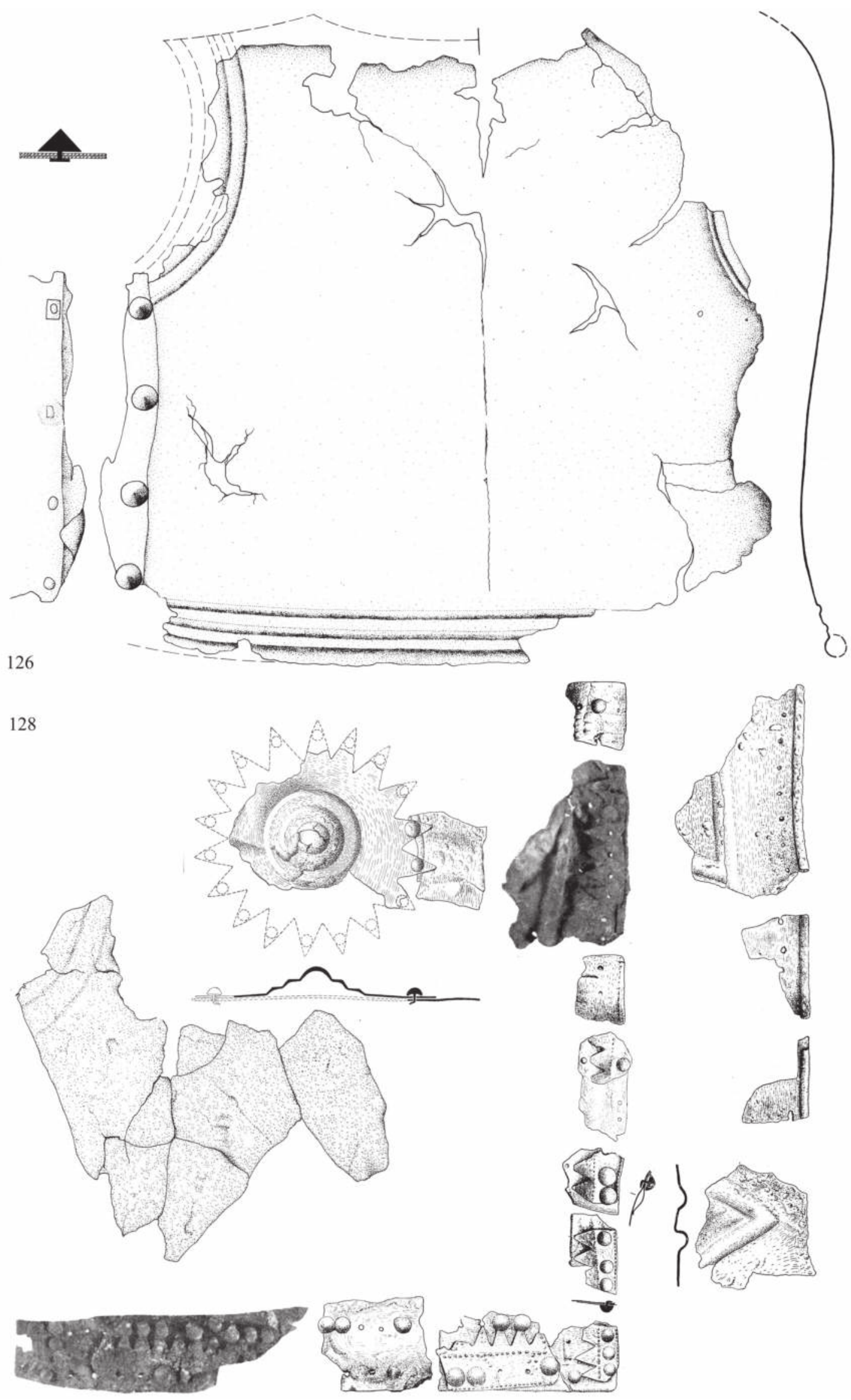

Pl. 25 Carpathian cuirasses: 126. Čierna nad Tisou, Slovakia (Schauer 1982d, fig. 9); 128. Čaka, Slovakia (Točik Paulik 1960, 77B; Jockenhövel 1971, pl. 60). The numbers correspond to the catalogue numbers (cat. no. 126: scale 1:4; cat. no. 128: scale 1:2) 


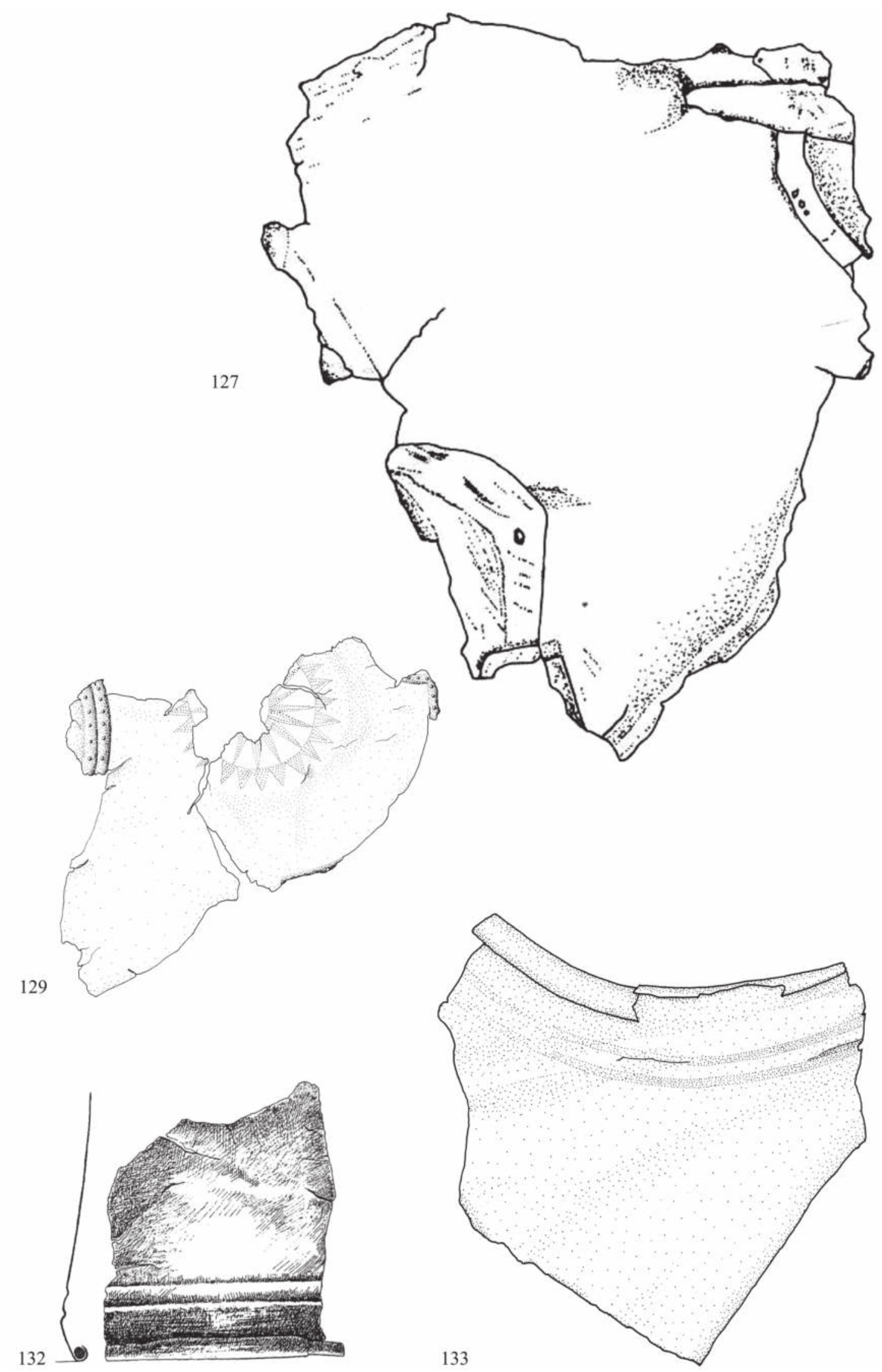

Pl. 26 Carpathian cuirasses: 127. Šarišské Michal'any, Slovakia (Lorenc et al. 2013, 165, fig. 66.1); 129. Ducové, Slovakia (Schauer 1982d, fig. 5); 132. Nadap, Hungary (Makkay 2006, pl. VI.12); 133. Ivančice, Czech Republic. The numbers correspond to the catalogue numbers (scale 1:2). 

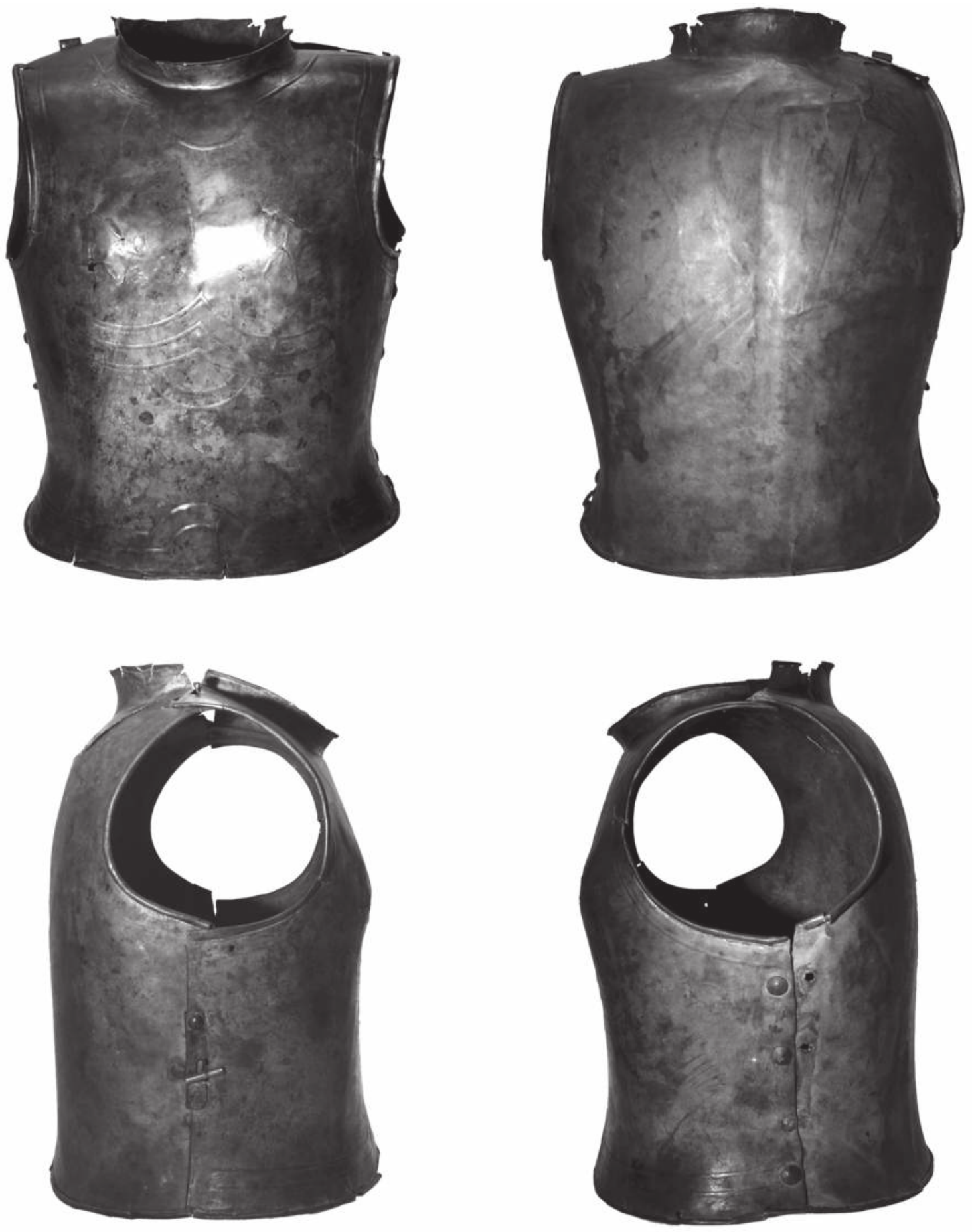

130

Pl. 27 Carpathian cuirass: 130. Saint-Germain-du-Plain, France (photograph M. Uckelmann, by courtesy of the Musée d'Archéologie nationale et Domaine national de Saint-Germain-en-Laye). The number corresponds to the catalogue number (no scale) 

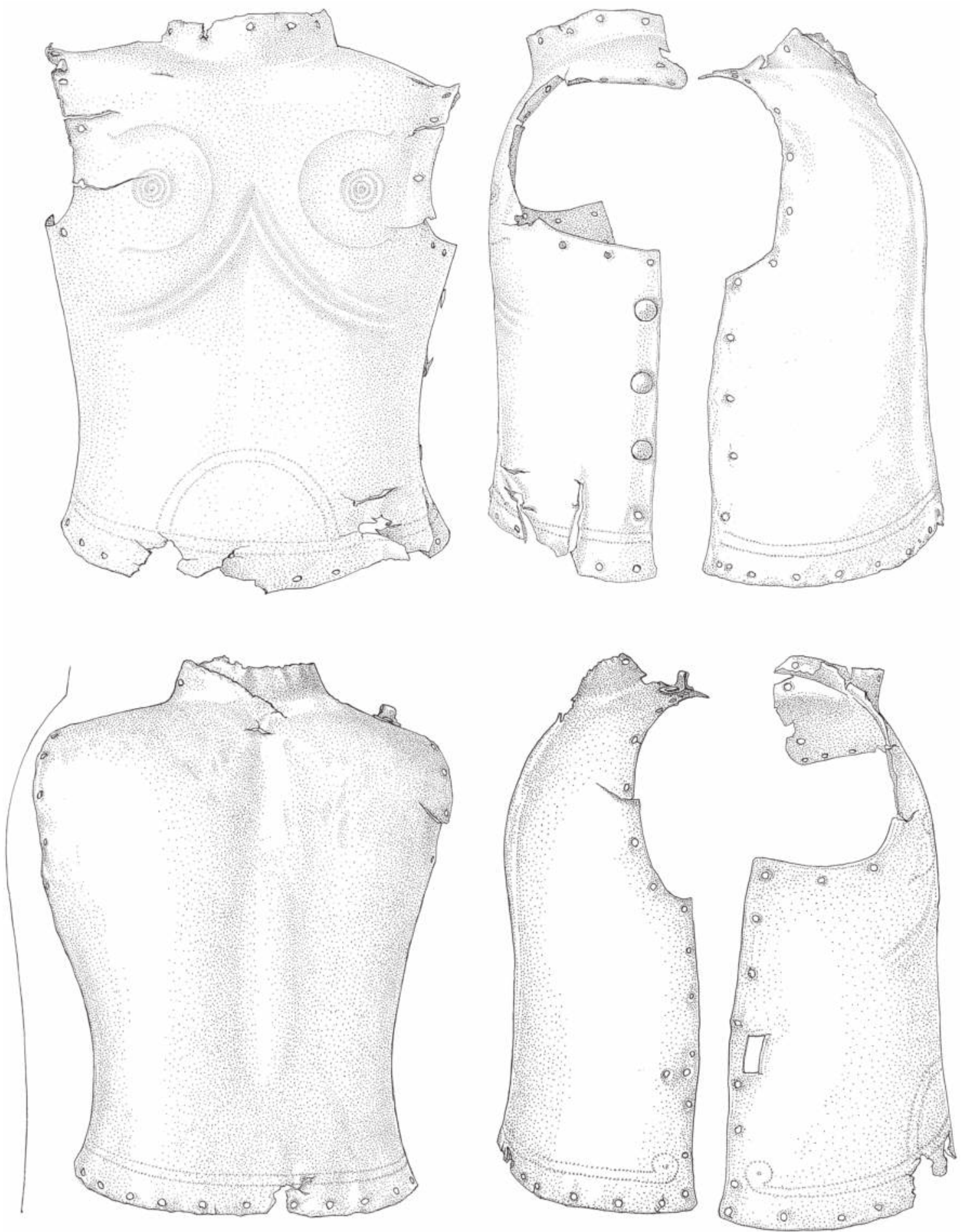

134

P1. 28 Carpathian cuirass: 134. Danube at Pilismarót, Hungary (Petres - Jankovits 2014, figs. 4-7; the weapon impact on the front was added by the author). The number corresponds to the catalogue number. 

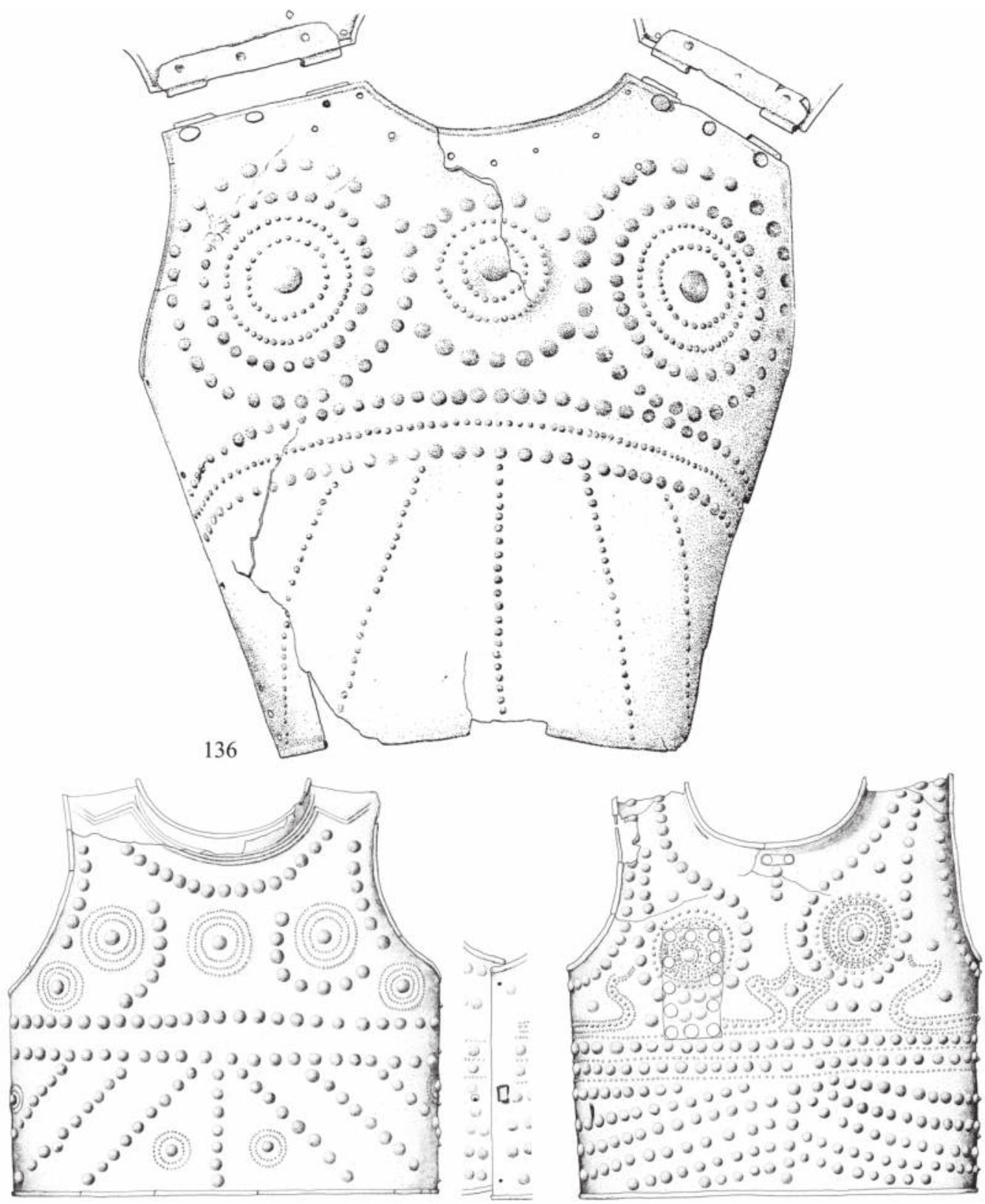

137

$20 \mathrm{~cm}$

138
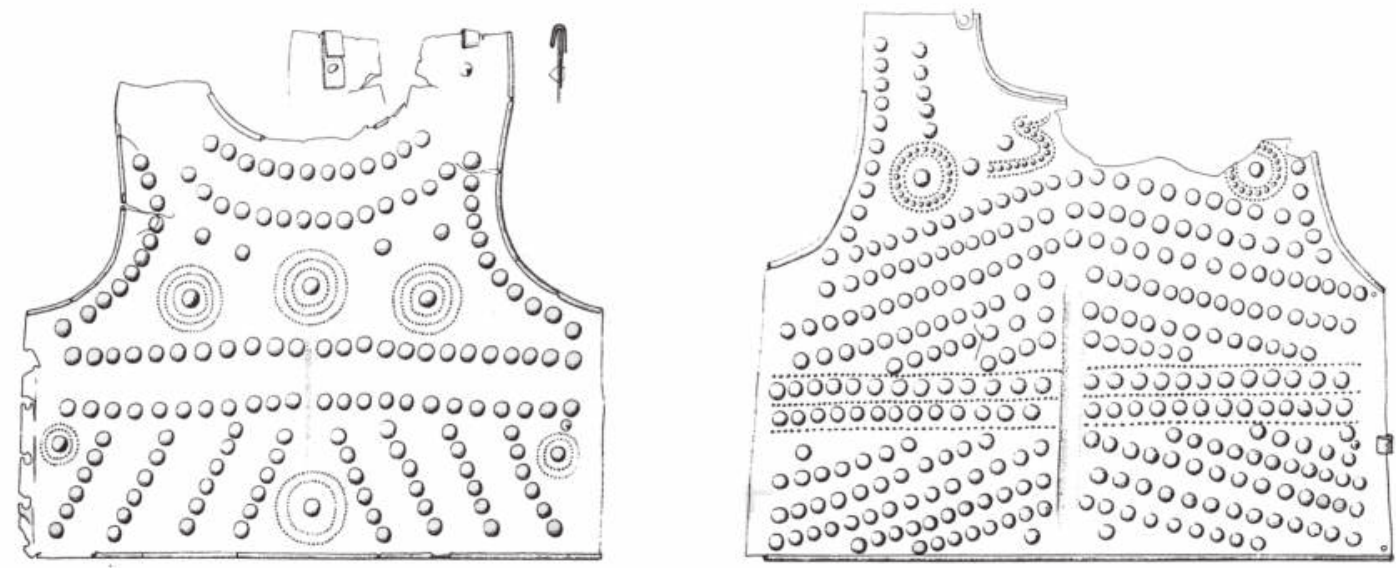

Pl. 29 Western European cuirasses: 136. Unprovenanced (today in Hamburg) (Mottier 1988, fig. 34); 137-

138. Jura A and B (Graye-et-Charnay or Véria, France). Left: former Grenoble; right: former Naples (drawings left: Schauer 1982d, fig. 11; Michel - Mohen 1970, fig. 7. Drawings right: Schauer 1982d, fig. 10; Michel - Mohen 1970, fig. 8). The numbers correspond to the catalogue numbers (scale 1:4; cat. nos. 137-138: with scale bar). 


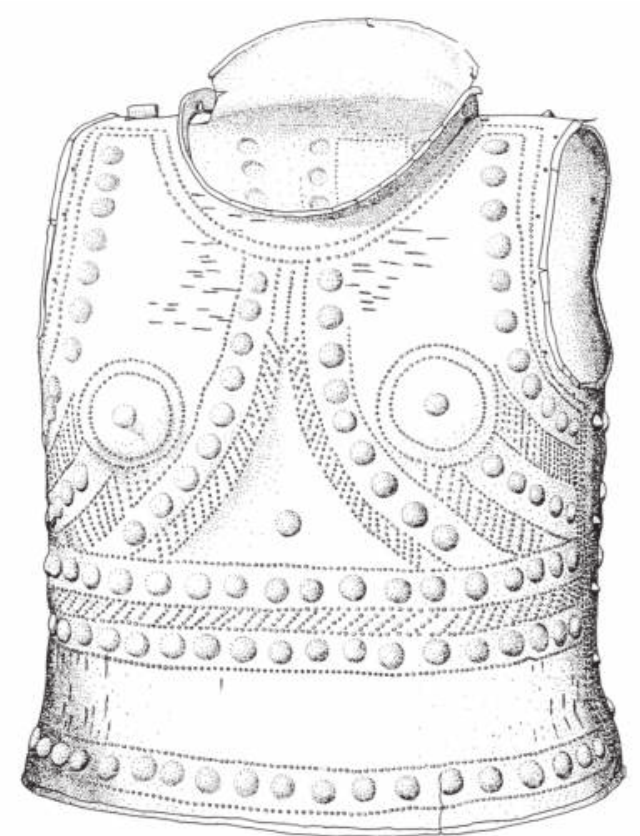

135

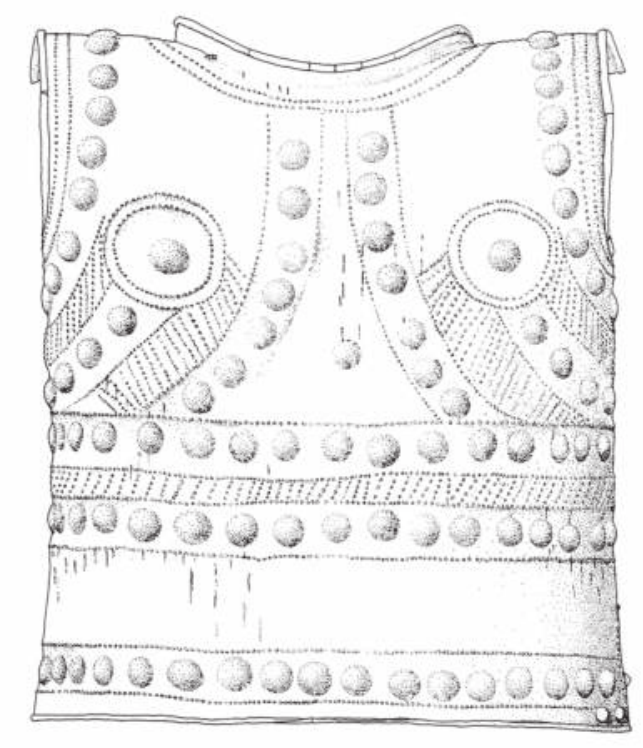

139

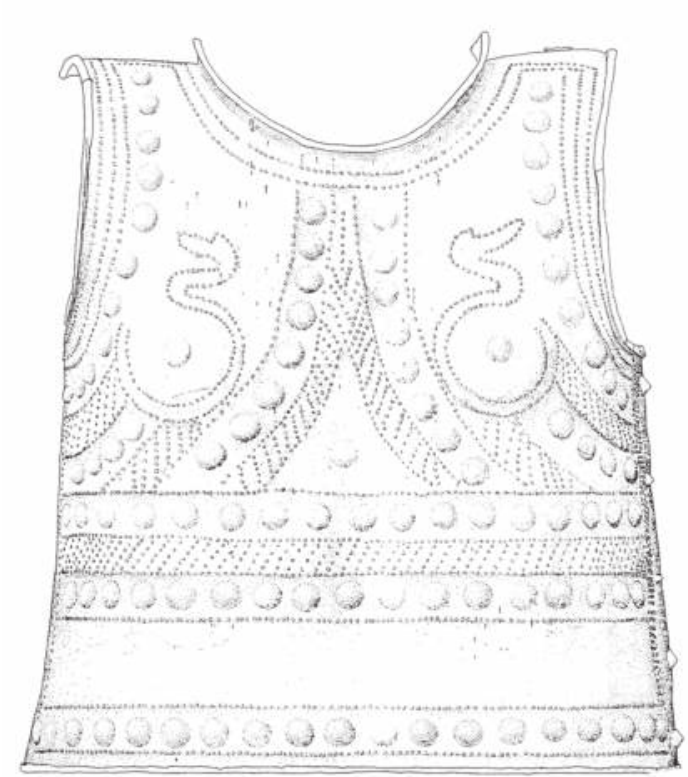

140

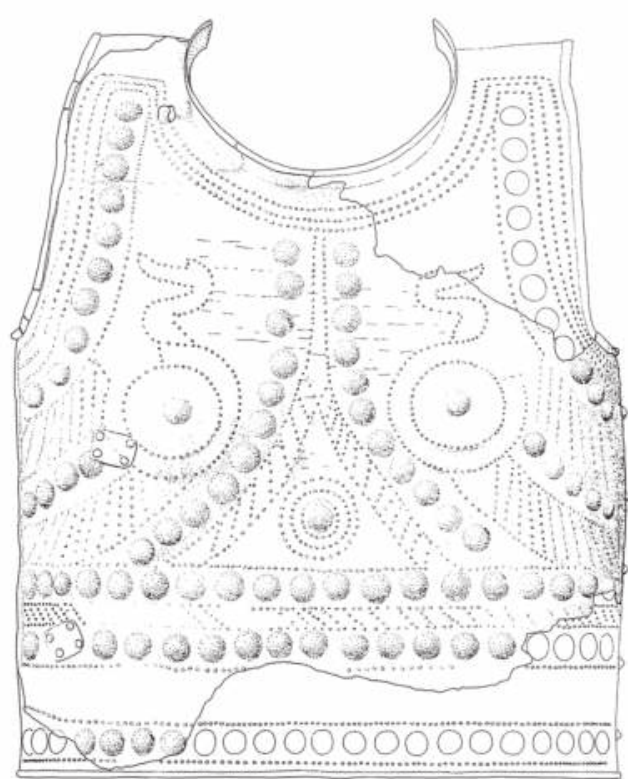

141

P1. 30 Western European cuirasses: 135. Unprovenanced (today at the Metropolitan museum); 139-141. Fillinges, France (all drawings: Mottier 1988). The numbers correspond to the catalogue numbers. 


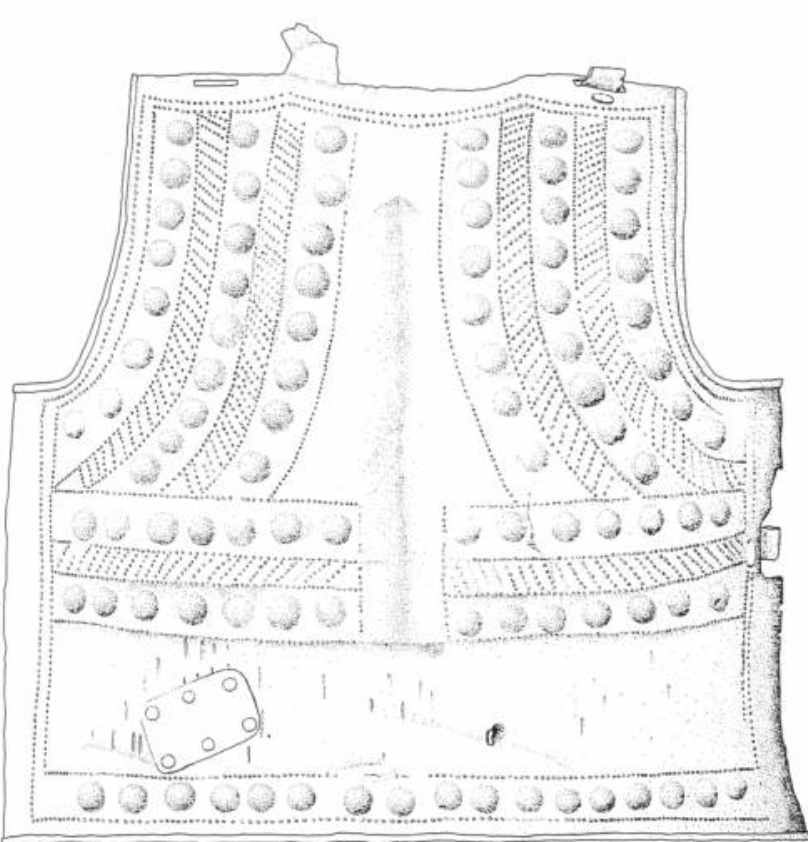

142

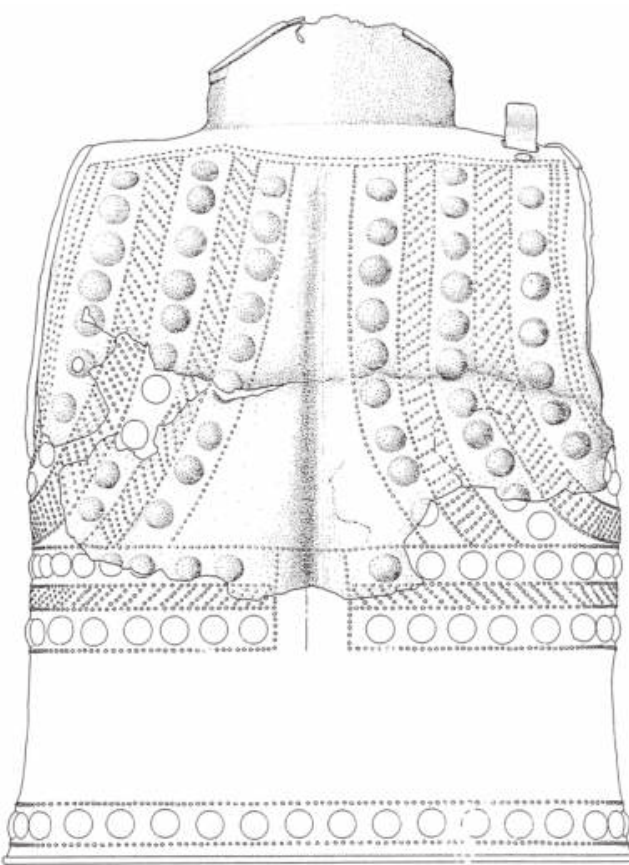

143

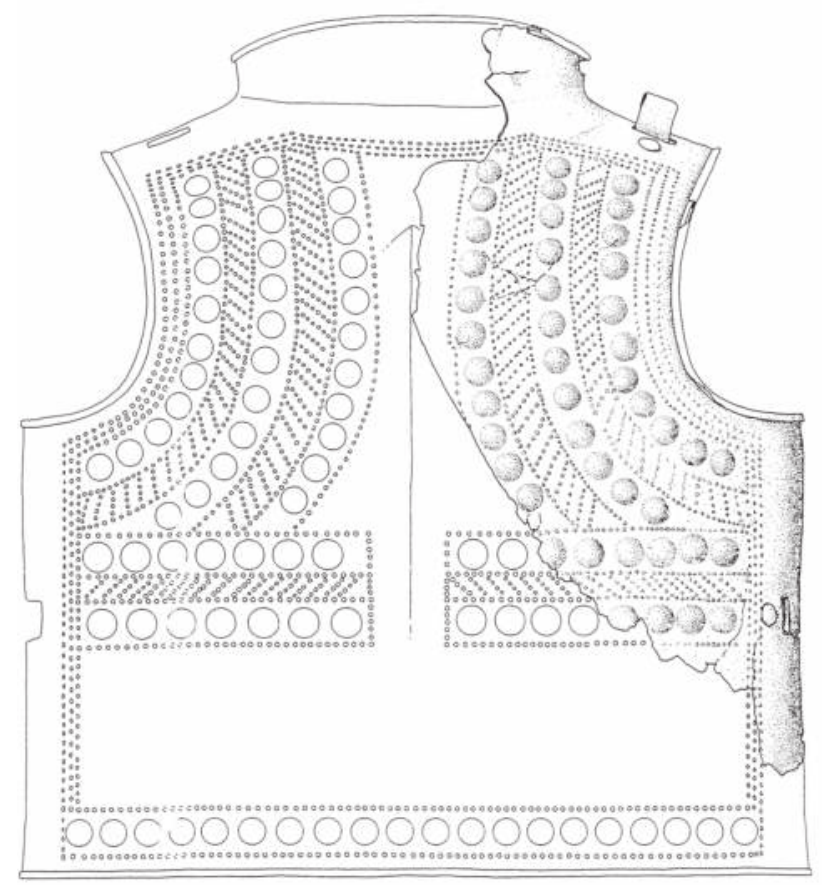

144

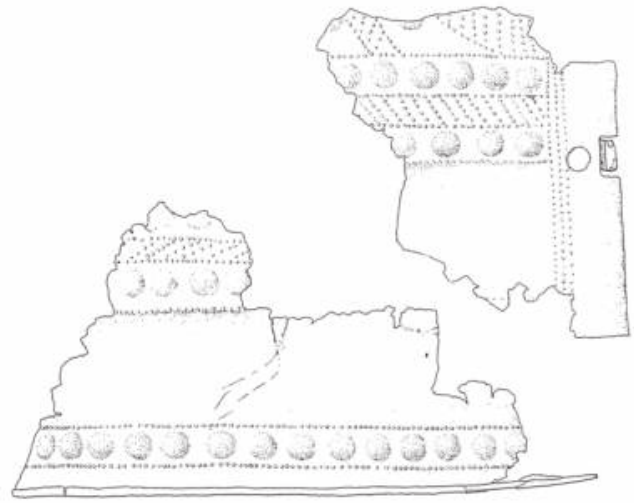

145

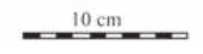

Pl. 31 Western European cuirasses: 142-145. Fillinges, France (all drawings: Mottier 1988). The numbers correspond to the catalogue numbers. 

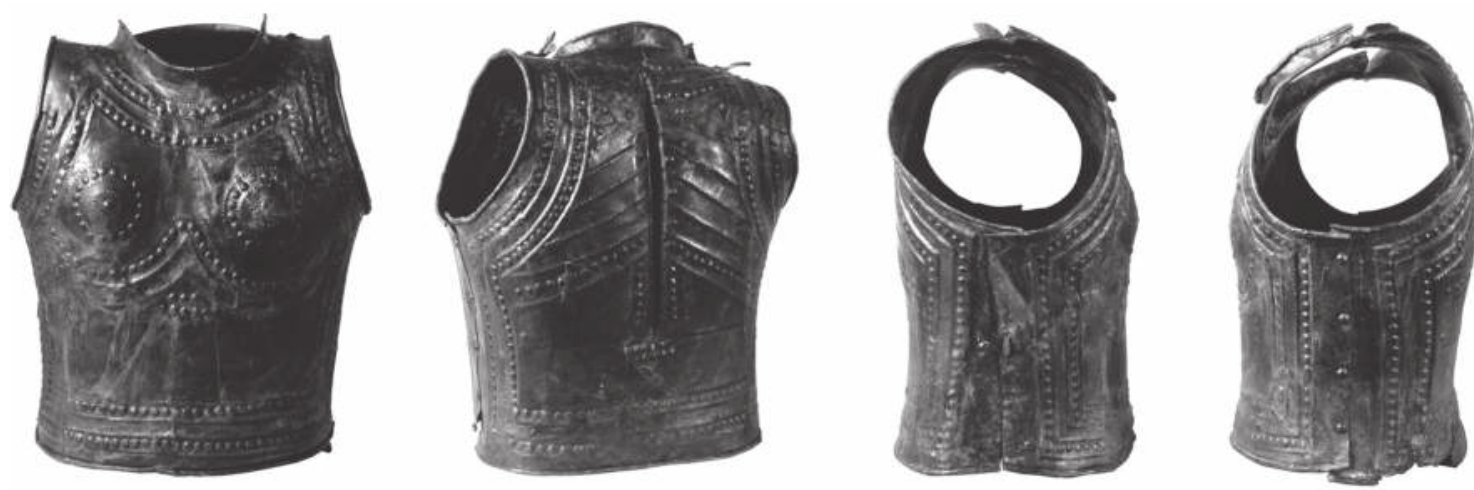

146
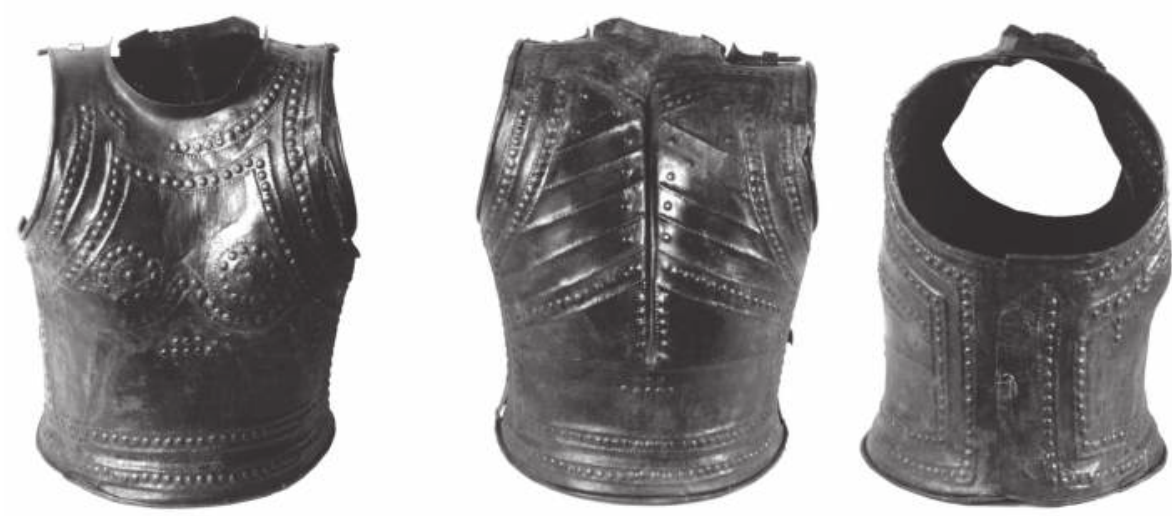

147
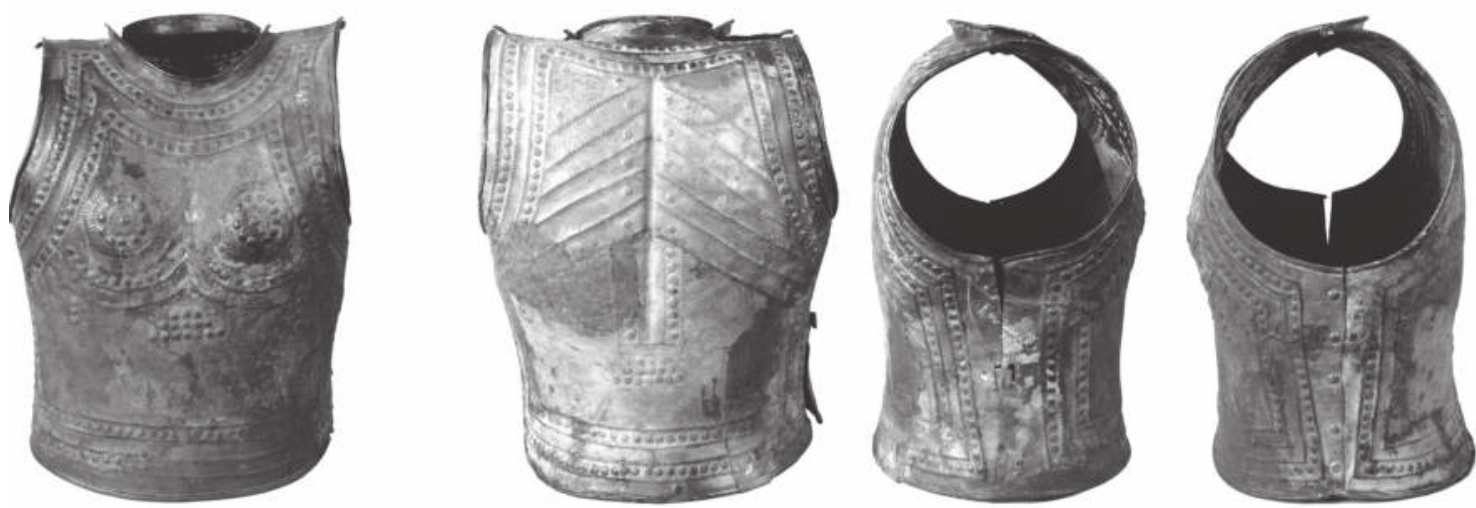

148

Pl. 32 Western European cuirasses: 146-148. Marmesse, France (photograph A. Chauvet, C2RMF; by courtesy of the Musée d'Archéologie nationale et Domaine national de Saint-Germain-en-Laye). The numbers correspond to the catalogue numbers (no scale). 

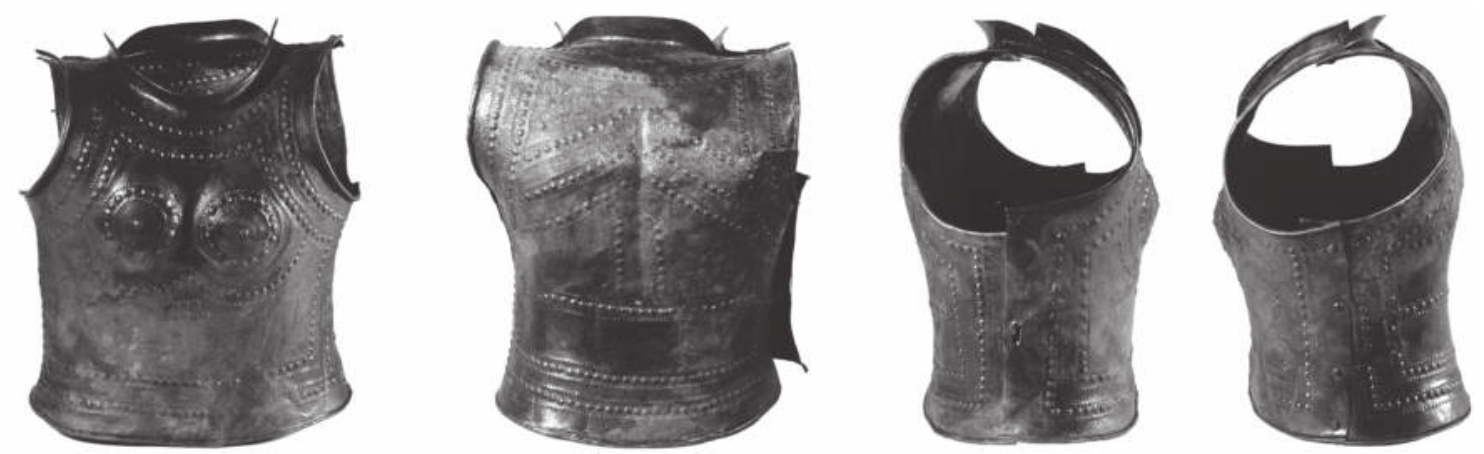

149
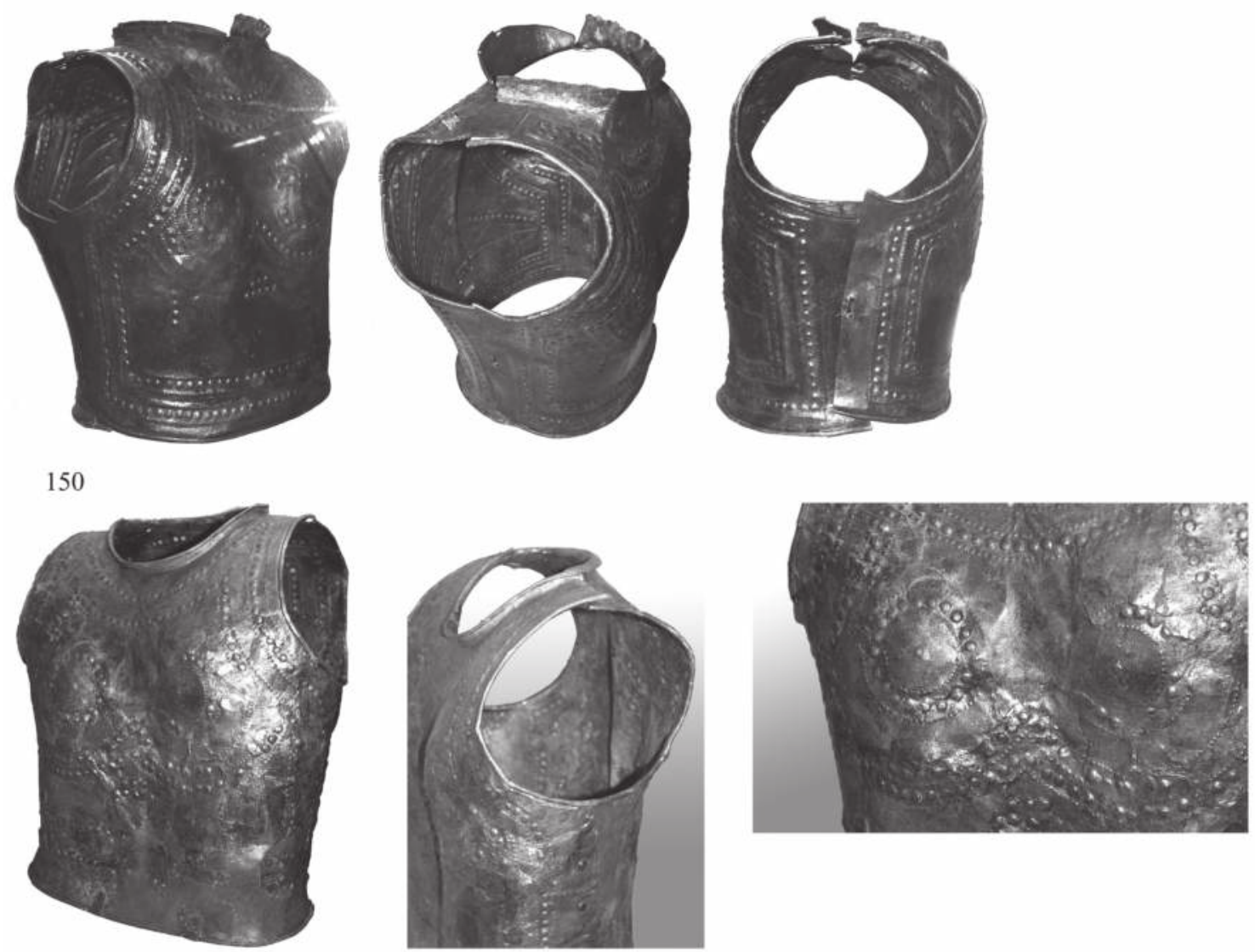

151

Pl. 33 Western European cuirasses: 149-151. Marmesse, France (photographs taken partly by Marion Uckelmann); below: inv. no. unknown (photograph A. Chauvet, C2RMF, and M. Uckelmann; by courtesy of the Musée d'Archéologie nationale et Domaine national de Saint-Germain-en-Laye). The numbers correspond to the catalogue numbers (no scale). 


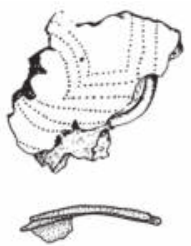

153
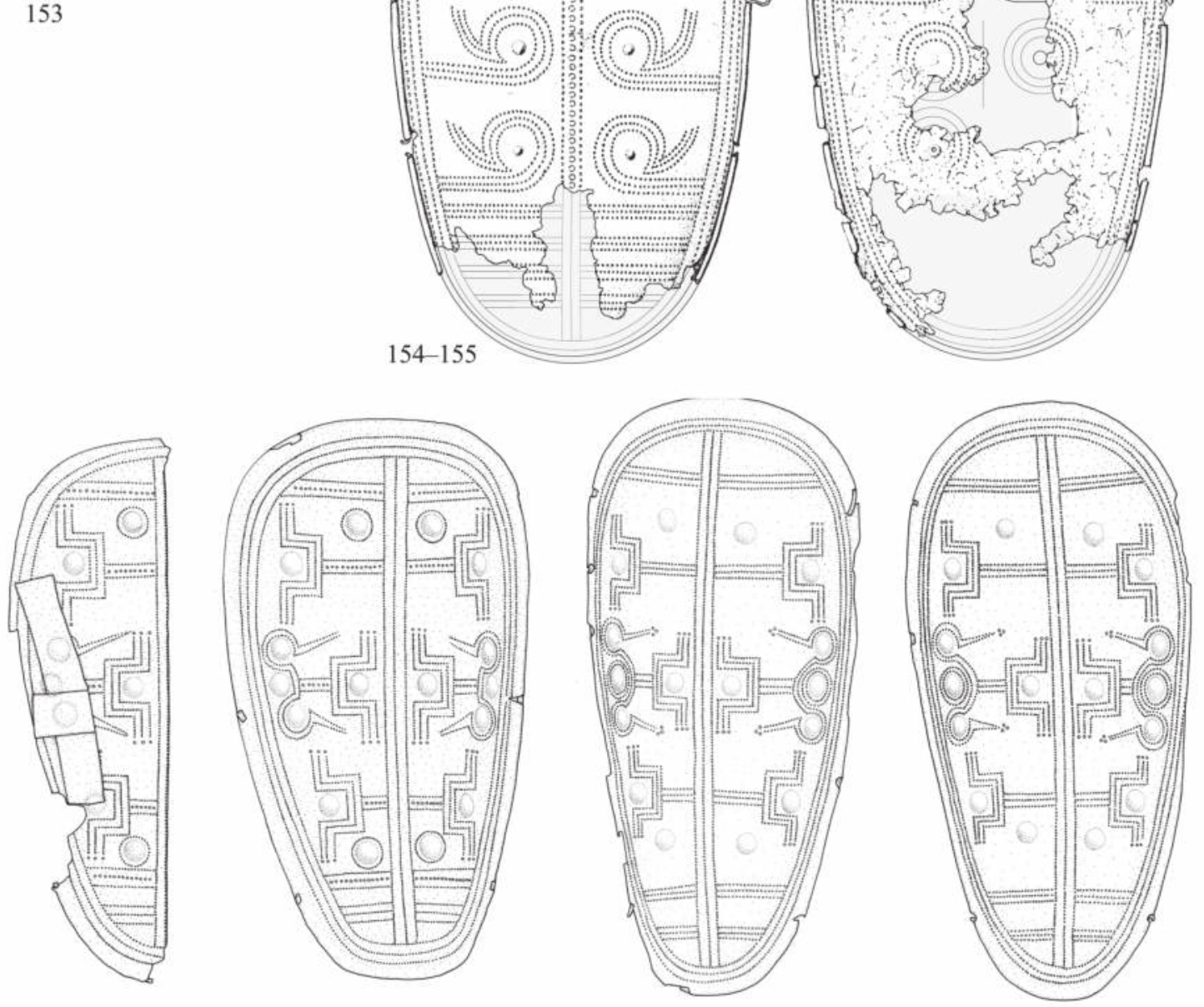

$156-159$
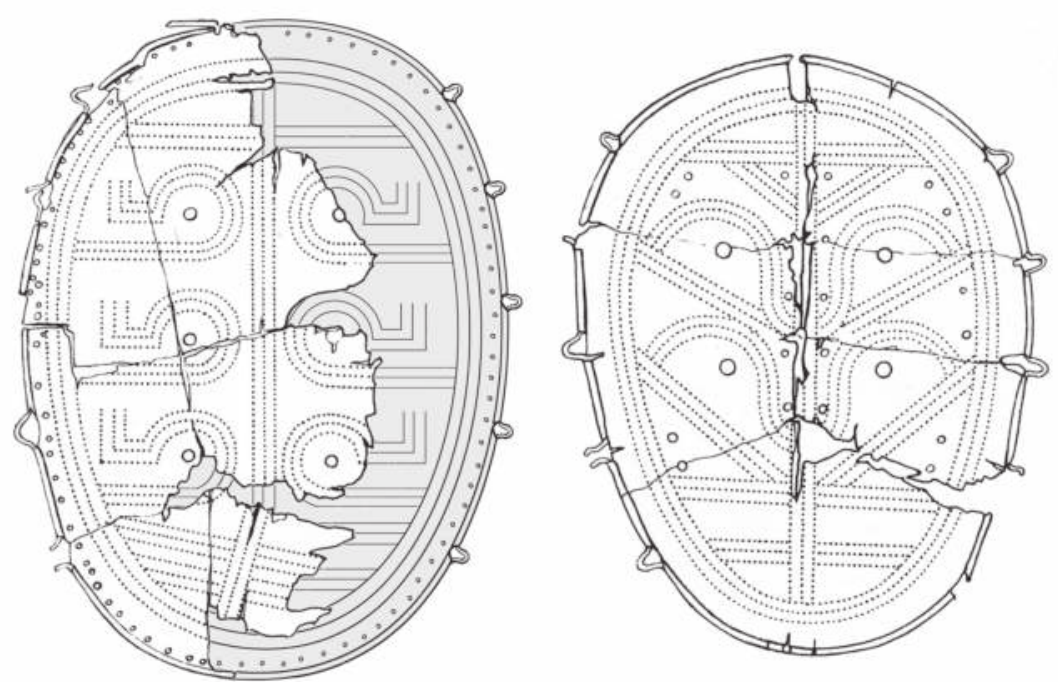

$160-161$

Pl. 34 Greaves of Type Desmontà: 153. Brodski Varoš, Croatia (Clausing 2003, fig. 3.7); 154-155. Desmontà, Italy (Clausing 2003, fig. 3.2); 156-159. Pergine, Italy; 160-161. Malpensa, Italy (after Clausing 2003, fig. 3.4-5). The numbers correspond to the catalogue numbers (scale 1:4; cat. nos. 154-155: without scale) 


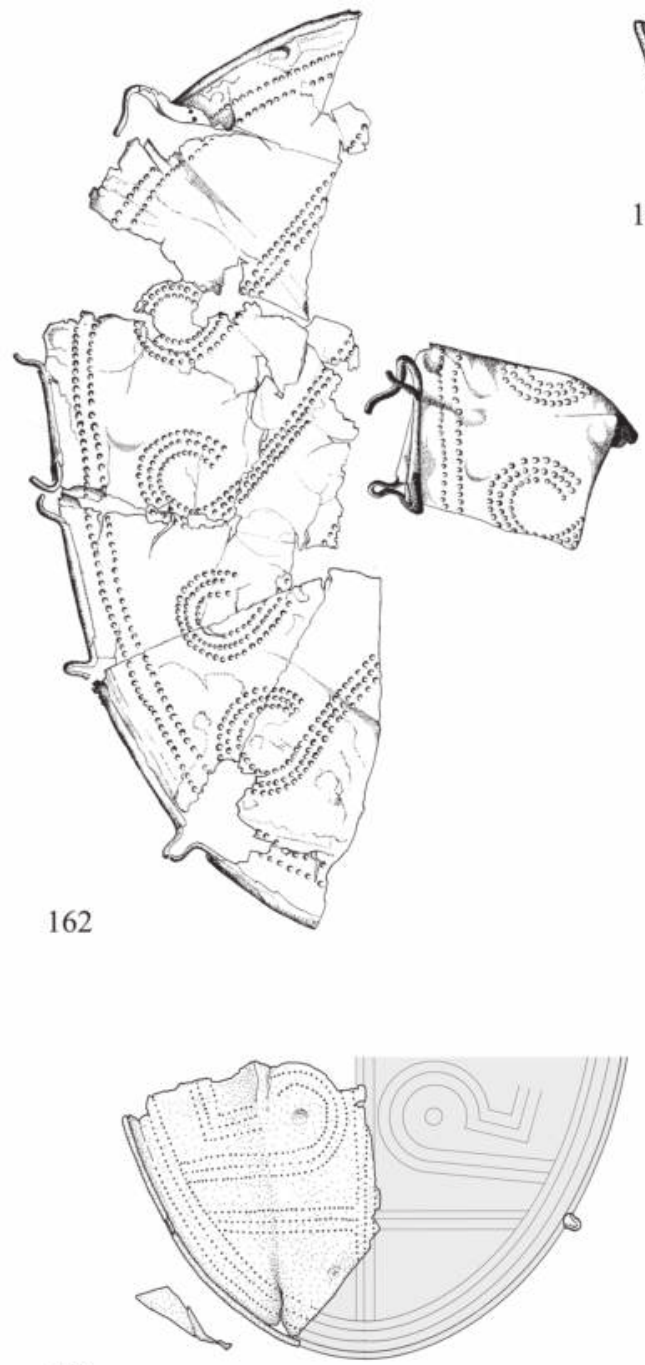

163

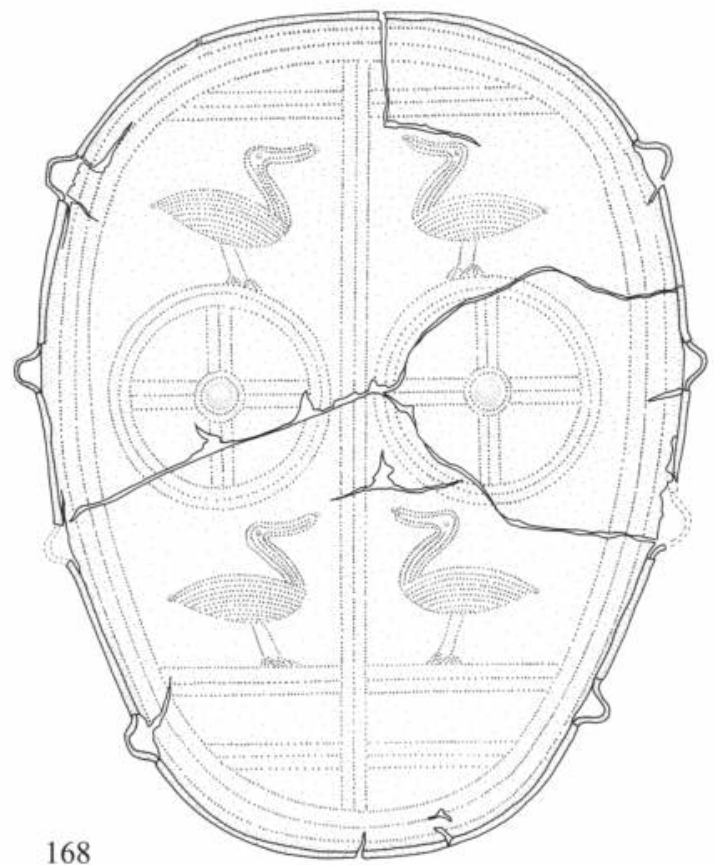

165
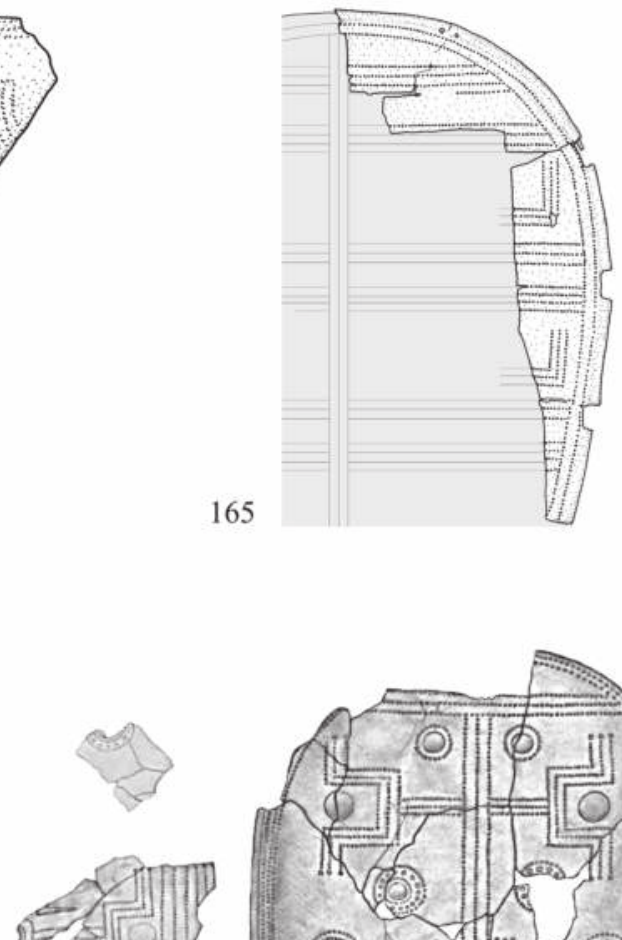

$166-167$

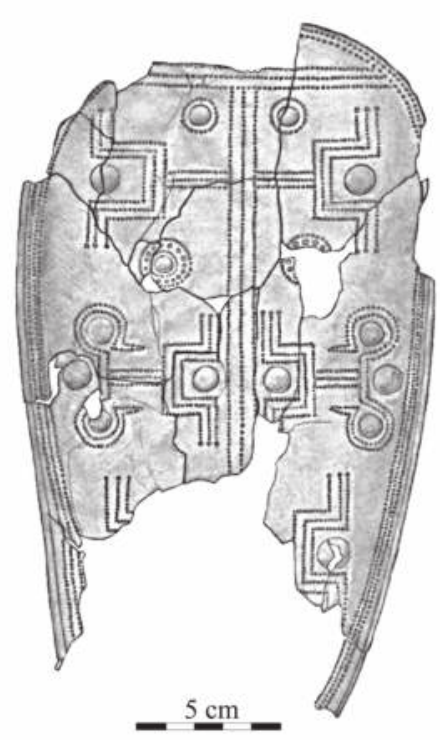

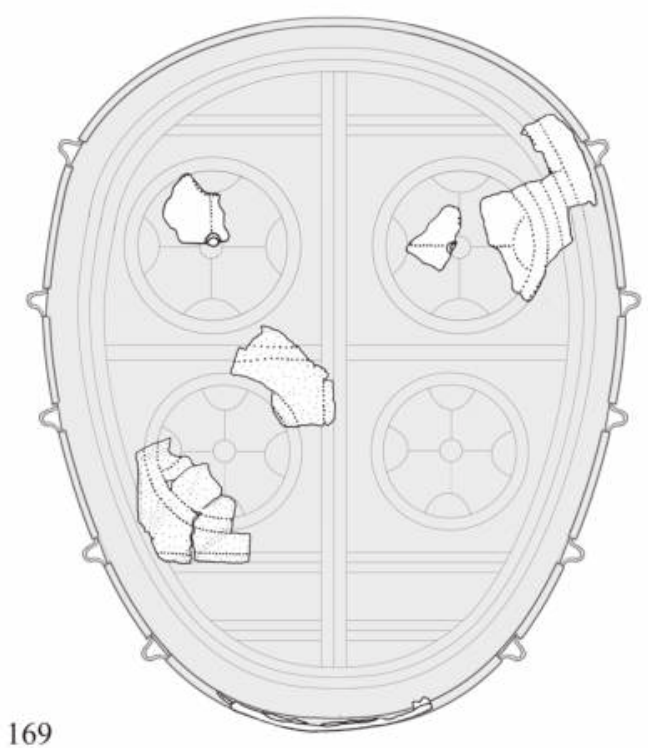

P1. 35 Greaves of Type Desmontà: 162. Cannes-Écluse, France; 163. Poljanci I, Croatia; 164. Esztergom, Hungary; 165. Nadap, Hungary; 166-167. Unprovenanced (Hungary?) (Tarbay 2015, fig. 8); 168. Rinyaszentkirály, Hungary; 169. Nagyvejke, Hungary (after Clausing 2003, fig. 2.2). The numbers correspond to the catalogue numbers (scale 1:4). 

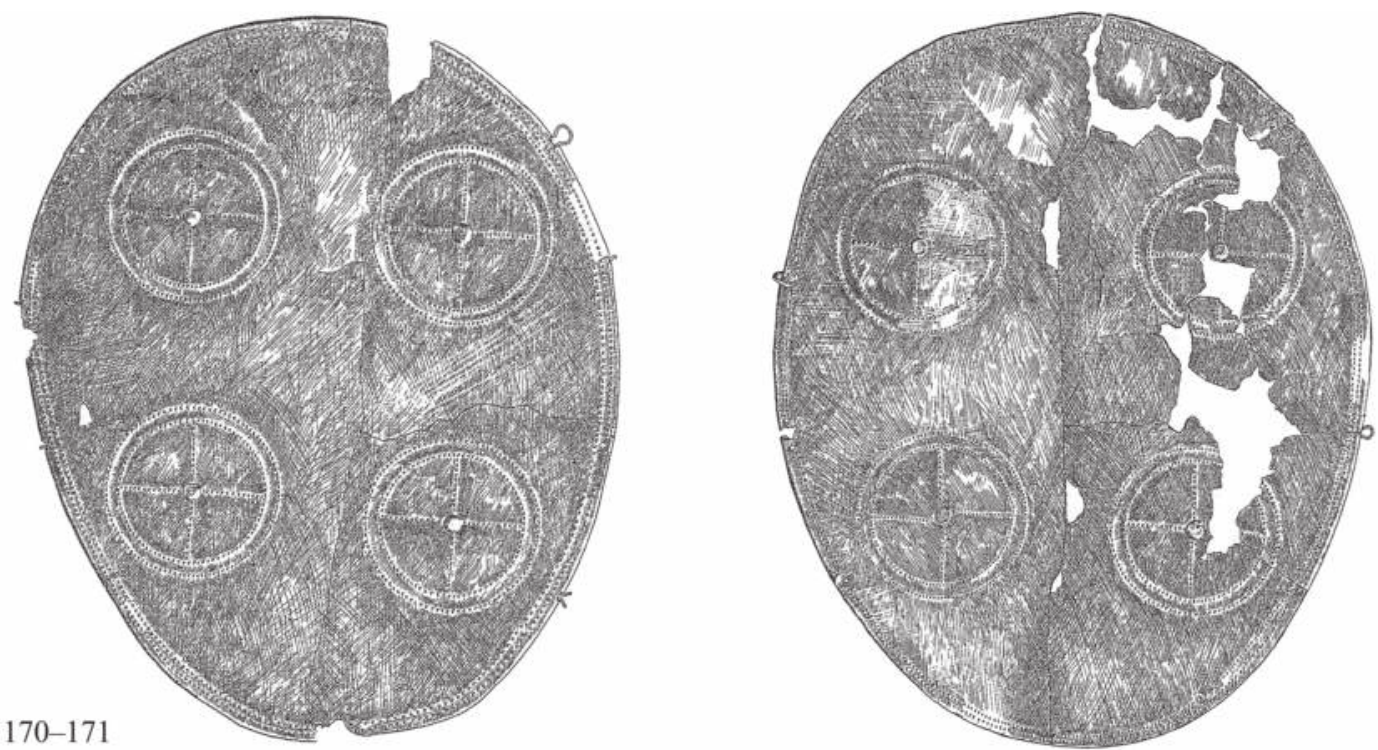

172

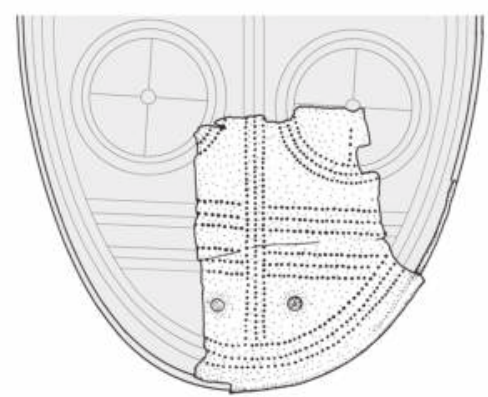

174

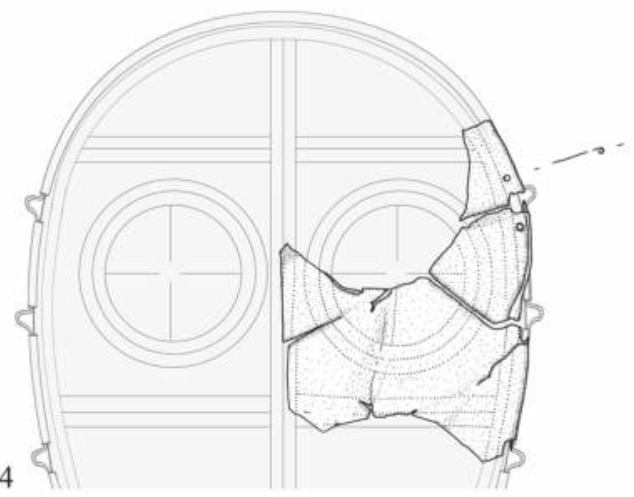

173
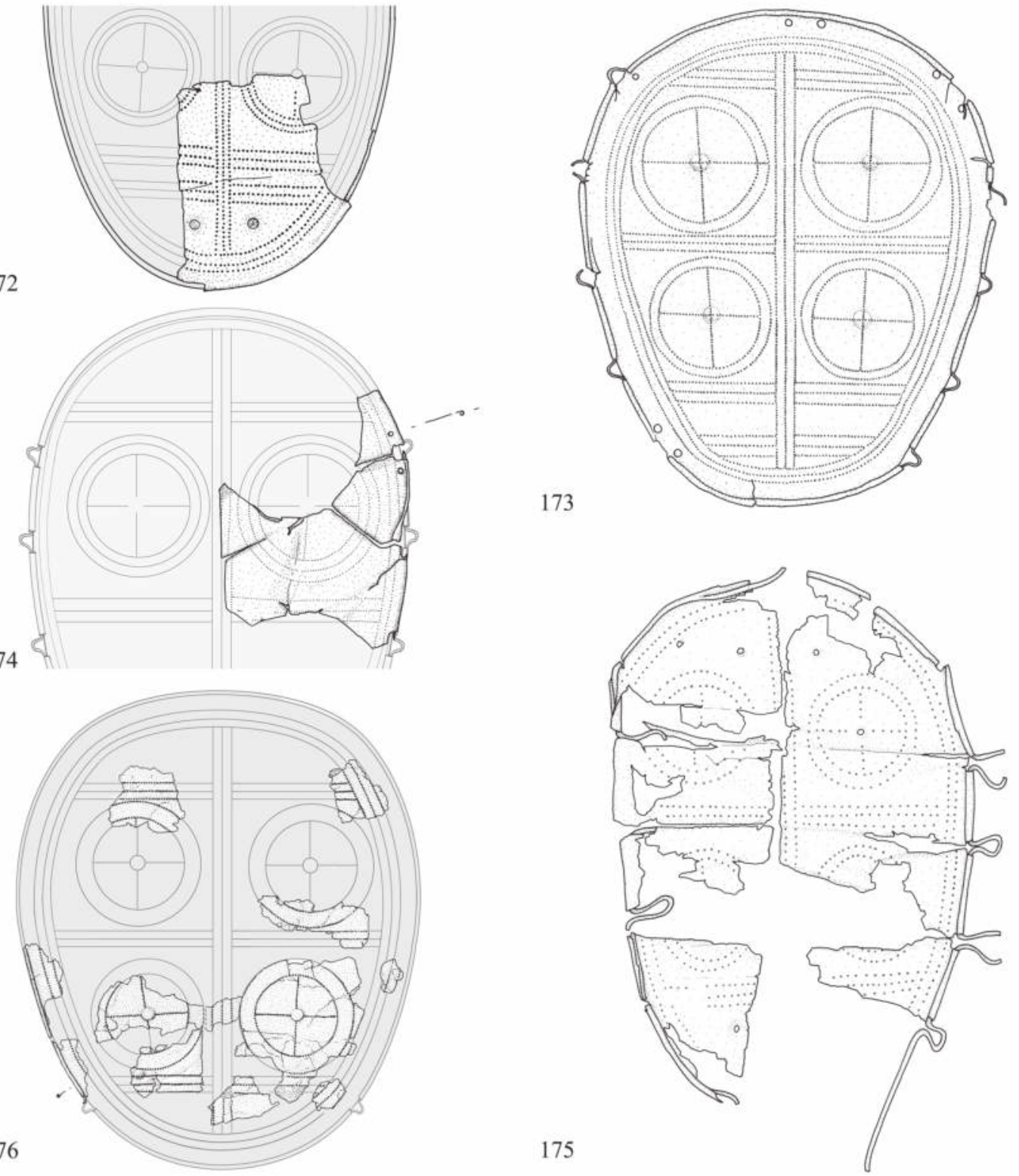

P1. 36 Greaves of Type Lengyeltóti: 170-172. Nadap, Hungary (170-171 after Makkay 2006, pls. II-III); 173. Lengyeltóti, Hungary. 174. Stetten/Teiritzberg, Austria; 175. Poljanci IV, Croatia; 176. Slavonski Brod, Croatia (after Clausing 2003, fig. 3.11). The numbers correspond to the catalogue numbers (scale 1:4). 

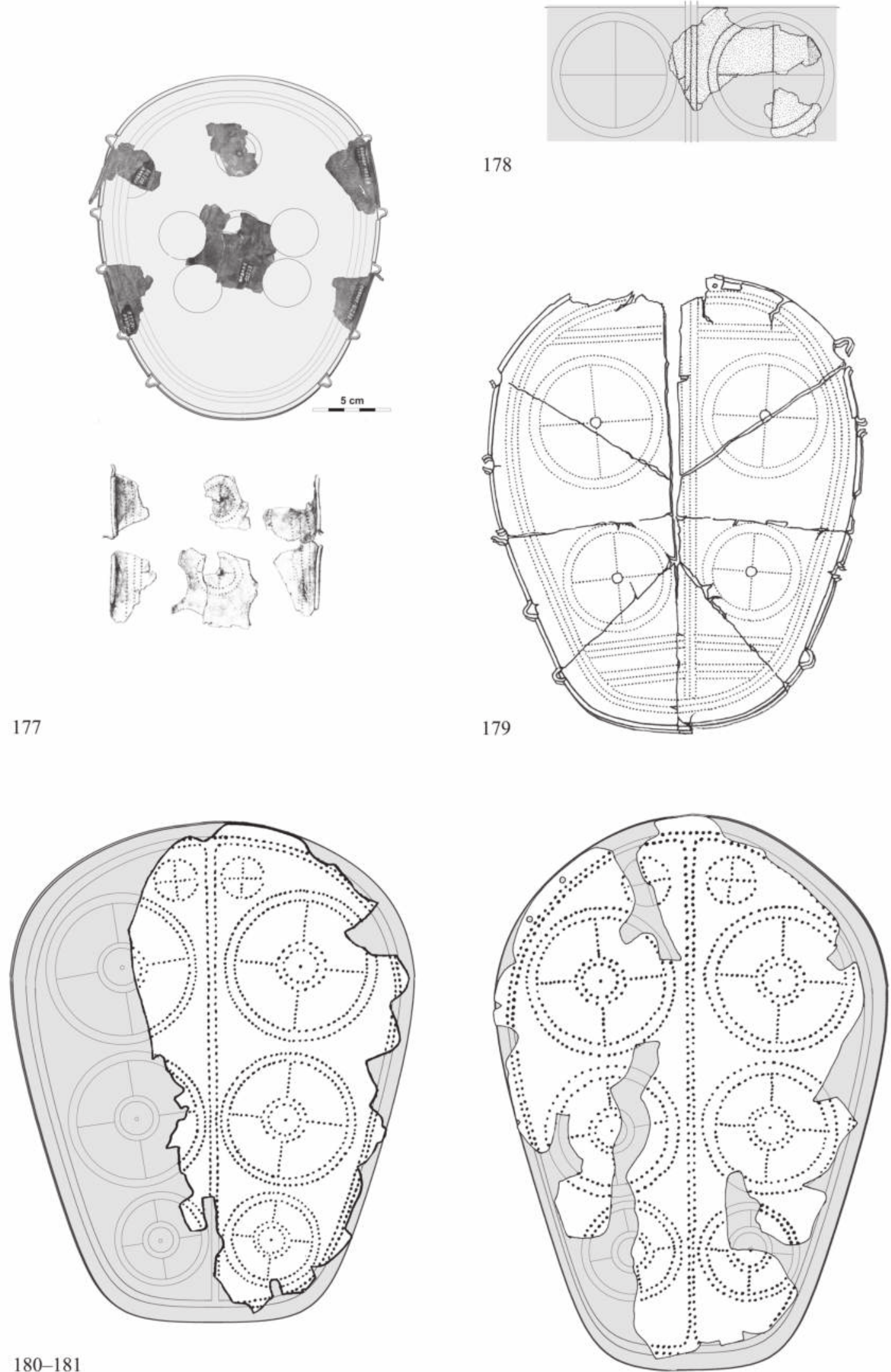

$180-181$

Pl. 37 Greaves of Type Lengyeltóti: 177. Veliko Nabrđe, Croatia (Vinski-Gasparini 1973, pl. 44.1); 178. Boljanić, Bosnia-Herzegovina (after Clausing 2003, fig. 1.1); 179. Malpensa, Italy (Clausing 2003, fig. 1.4); 180-181. Athens, Greece (after Clausing 2003, fig. 1.2-3); The numbers correspond to the catalogue numbers (scale 1:4). 


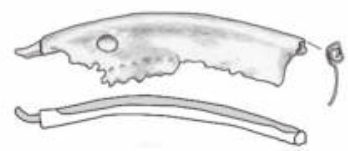

182

183

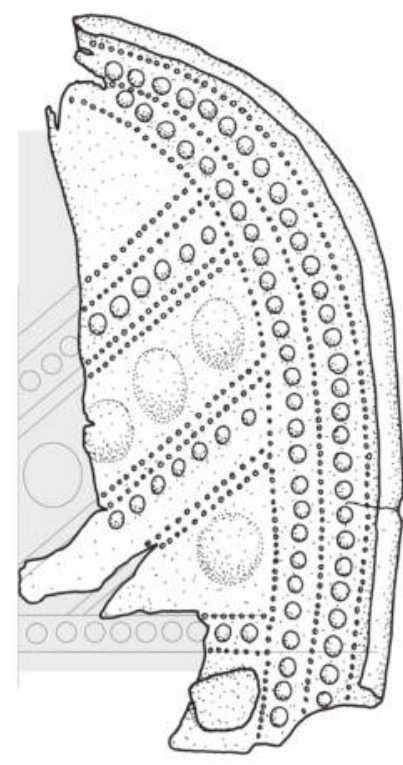

184

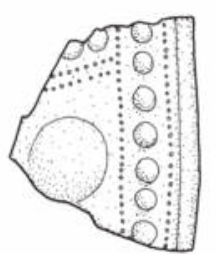

185
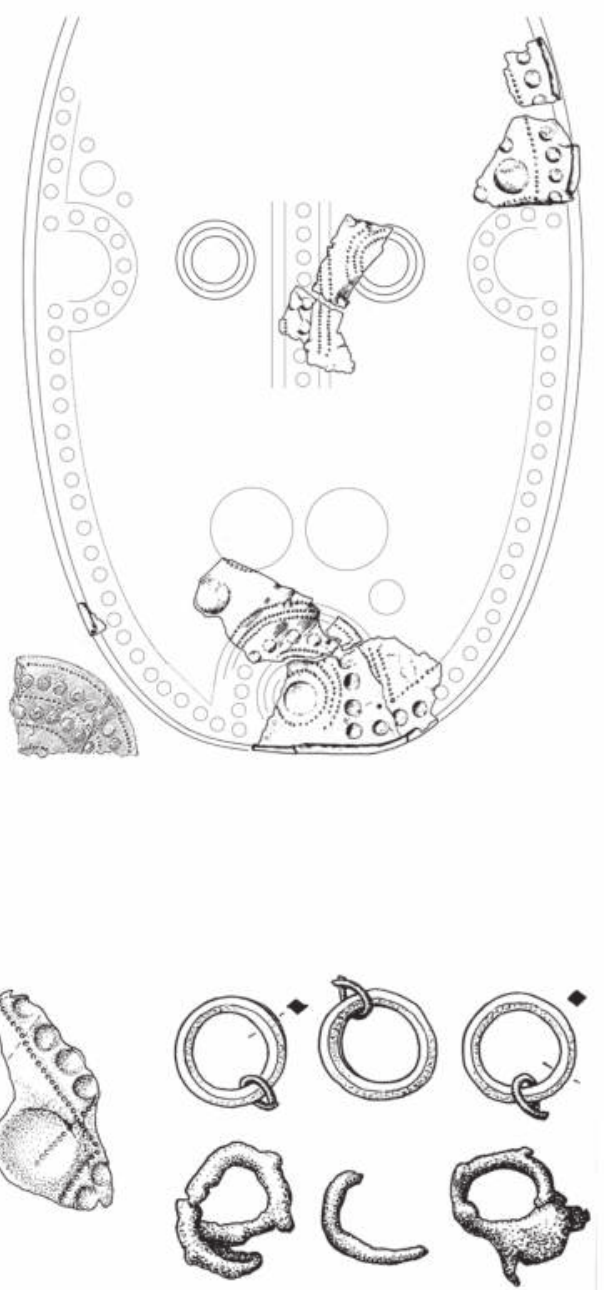

187
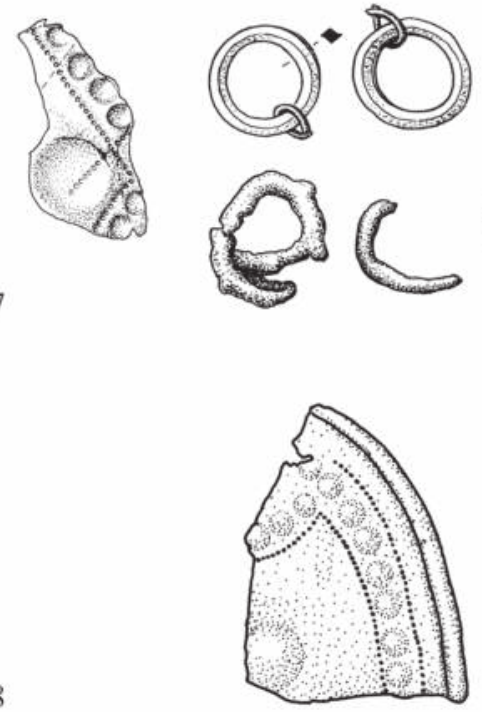

188

186
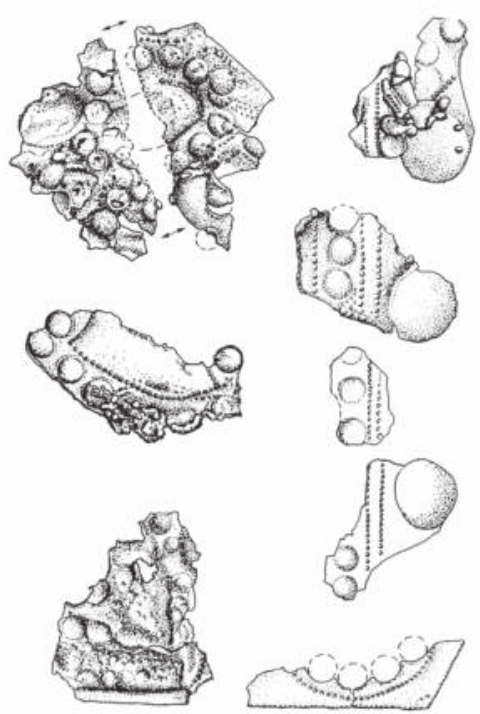

Pl. 38 Greaves of Type Kuřim: 182. Markovac-Grunjac (Jovanović 2010, pl. 38.288). 183. 183. Bouclans, France; 184. Boutigny, France; 185. Beuron (after Lindenschmitt 1860, pl. 24; Clausing 2003, fig. 5.1); 186. Volders, Austria (grave 309) (Sperber 2011, fig. 1); 187. Volders, Austria (grave 349) (Sperber 2011, fig. 5.1-3); 188. Weissenstein, Austria; The numbers correspond with the catalogue numbers (scale 1:2; cat. no. 185: scale 1:4). 


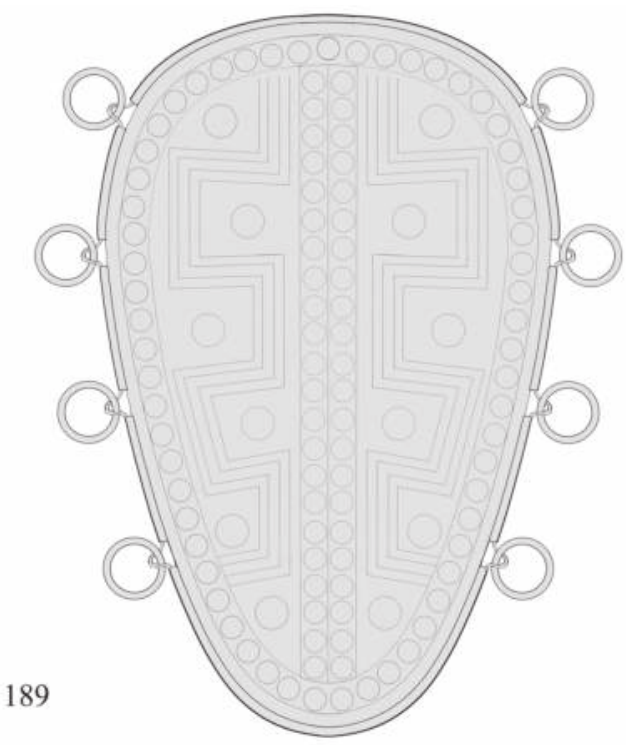

190

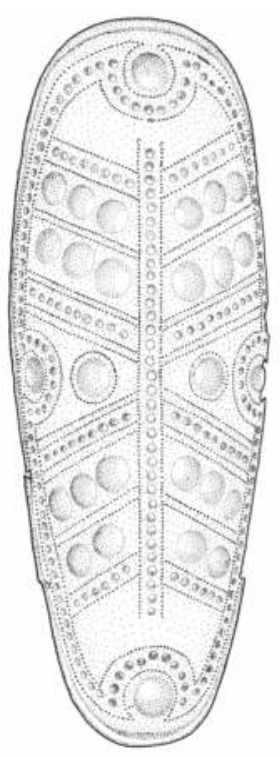

$191-192$
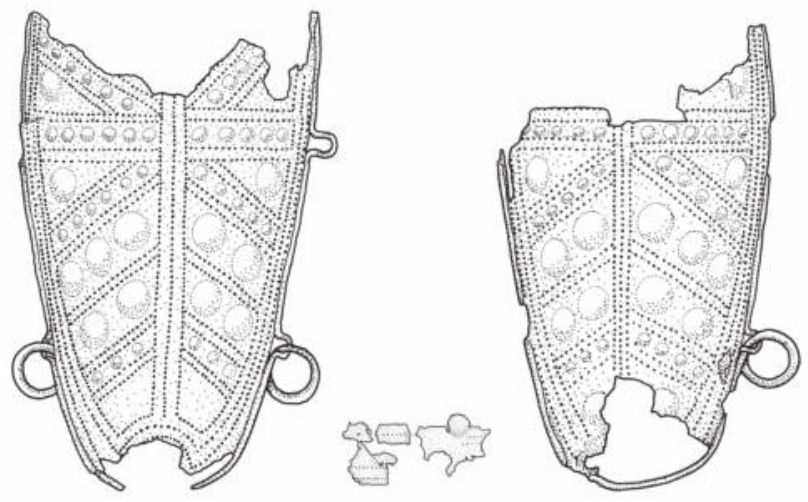

$193-194$
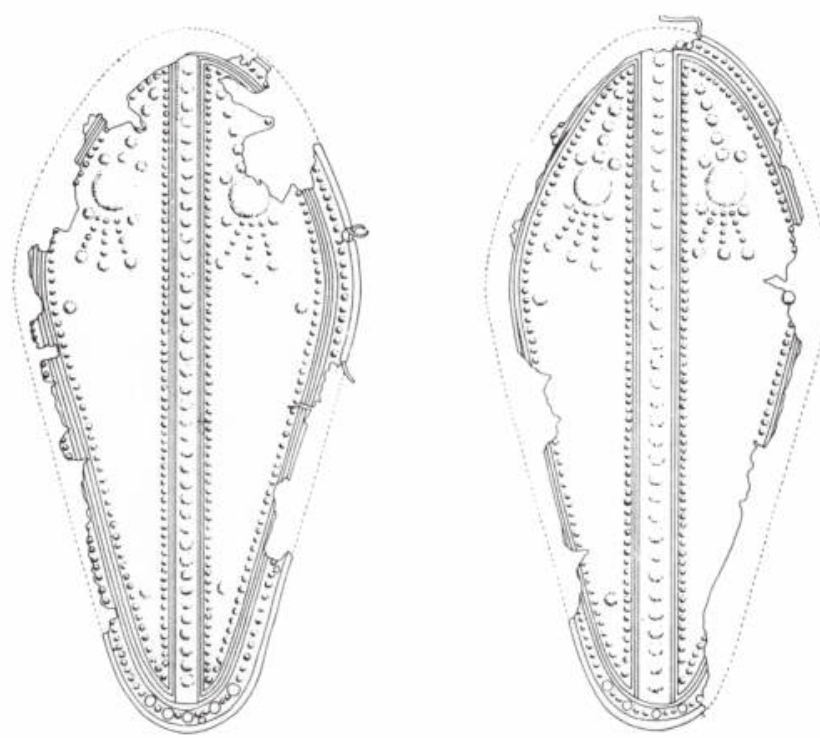

195

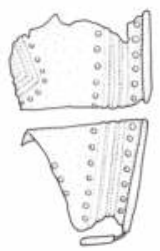

Pl. 39 Greaves of Type Kuřim (cat. nos. 189-192) and other types of greaves (cat. nos. 193-194): 189. Várvölgy, Hungary (sketch only). 190. Kuřim, Czech Republic; 191-192. Kloštar Ivanić, Croatia; 193-194. Canosa, Italy (Johannowsky 1970, pl. 1); 195. Limone, Italy. The numbers correspond to the catalogue numbers (scale 1:4). 


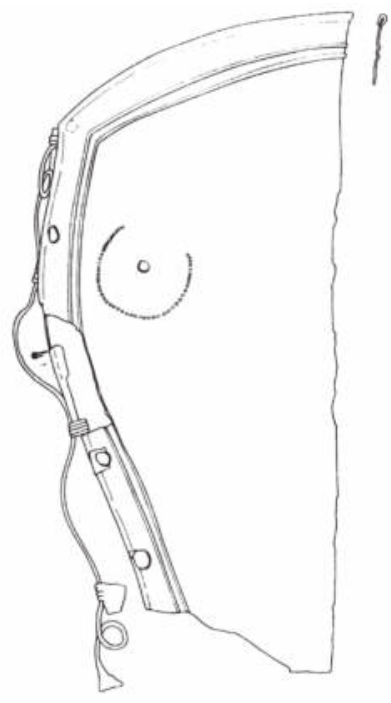

196

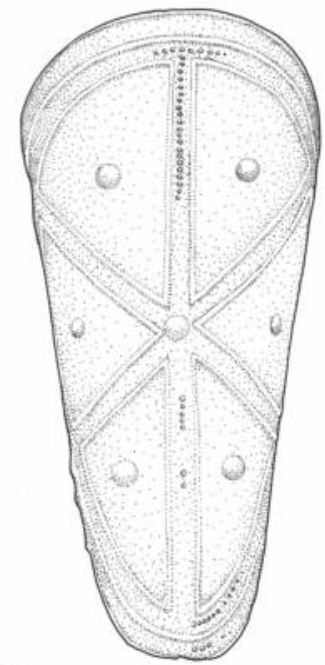

199

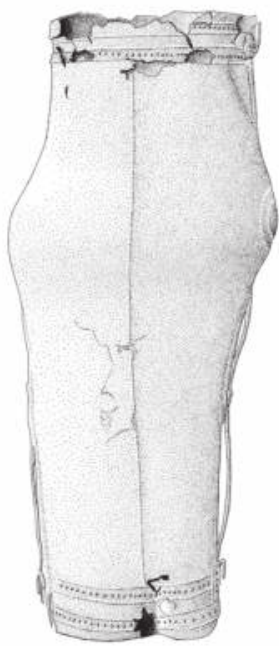

203-204
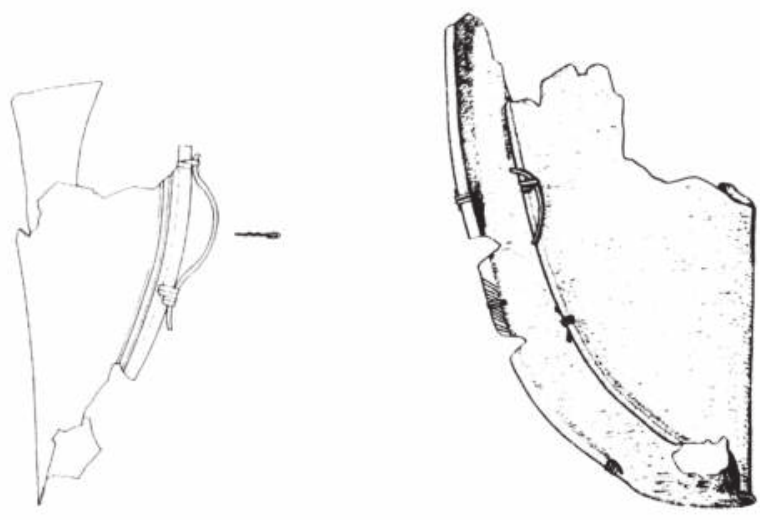

198

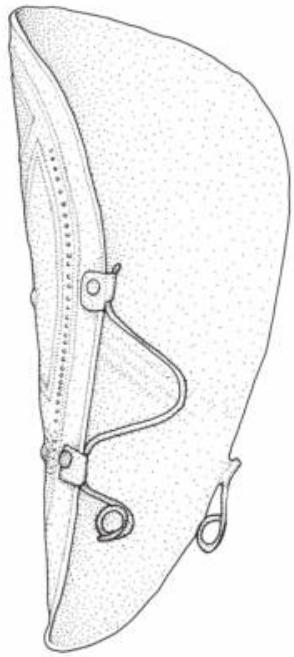

201
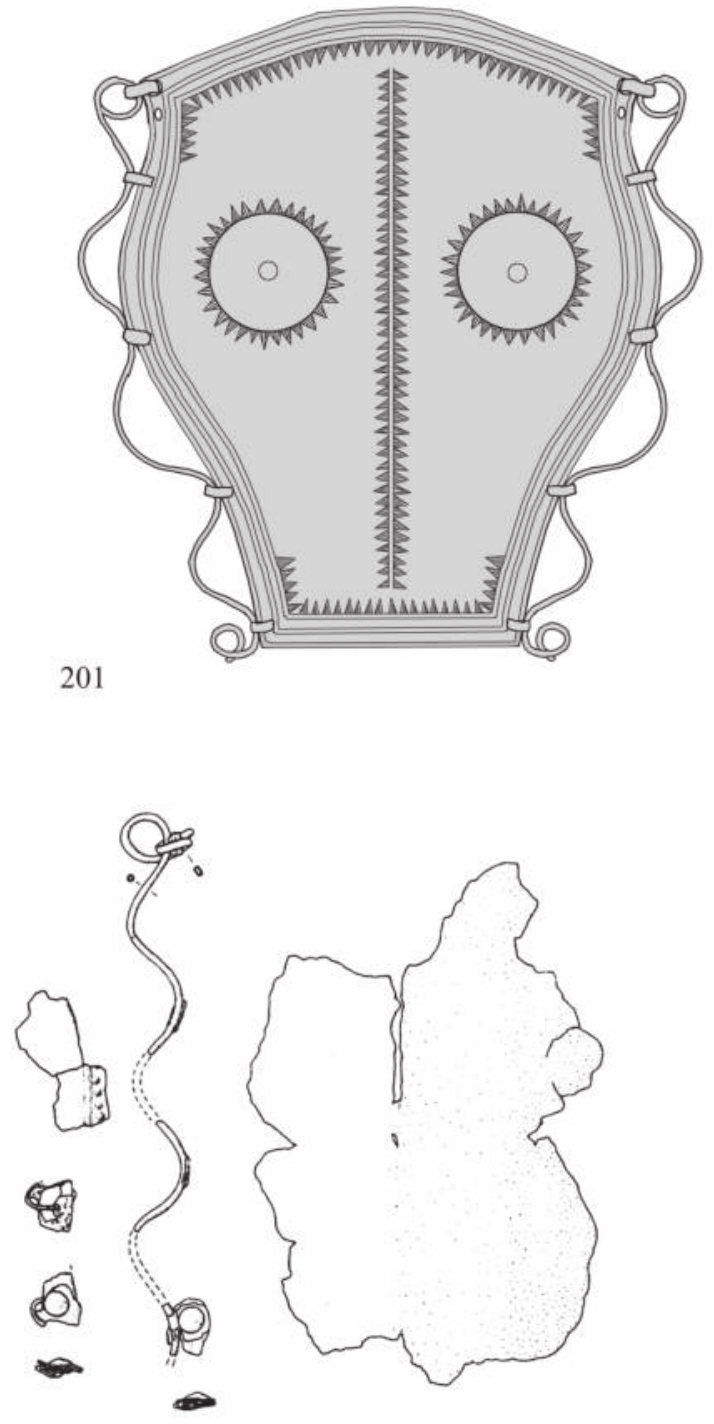

205

P1. 40 Greaves of Type Kallithea: 196. Enkomi, Greece (grave 15) (Clausing 2003, fig. 8.1-2); 198. Enkomi, Greece (grave 18) (Clausing 2003, fig. 8.3); 199. Kallithéa, Greece; 201. Portes, Greece (sketch of the greave; drawing after a photo from D'Amato - Salimbeti 2011, 38); 203-204. Kouvarás, Greece (drawing of the greaves after the photo in Stavropoulou-Gatsi et al. 2012, fig. 7); 205. Castellace, Italy (Clausing 2003, fig. 8.6). The numbers correspond to the catalogue numbers (scale 1:4; cat. nos. 201 and 205-206: no scale). 

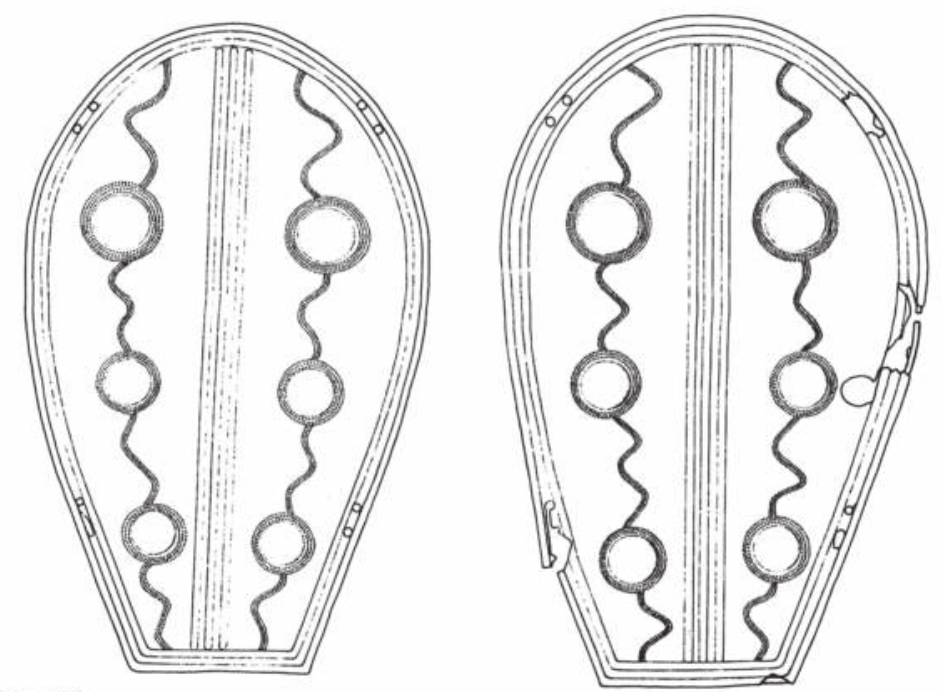

$207-208$

209

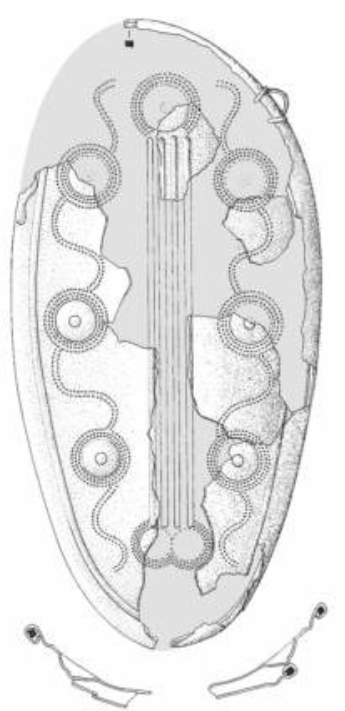

211

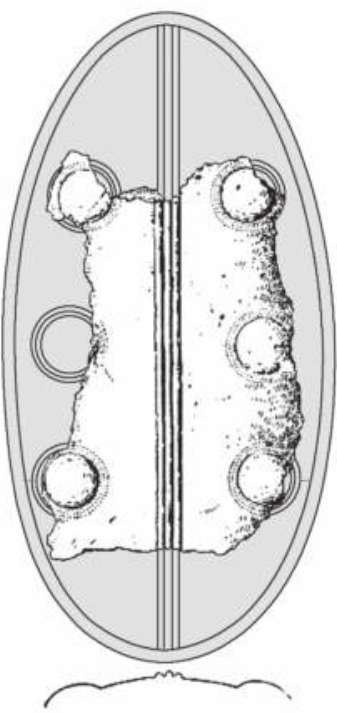

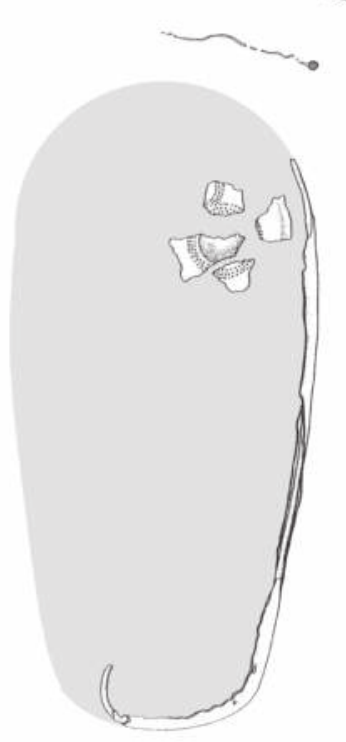

212

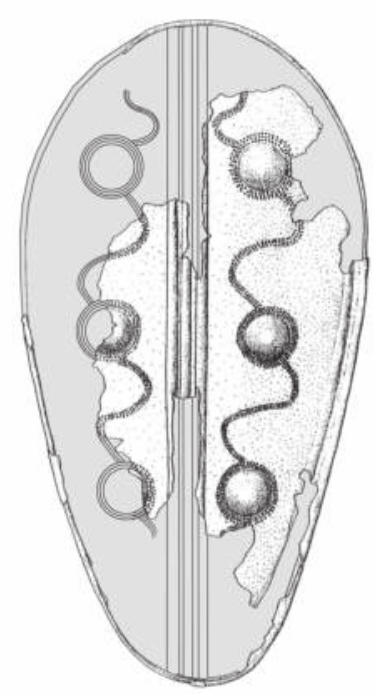

213

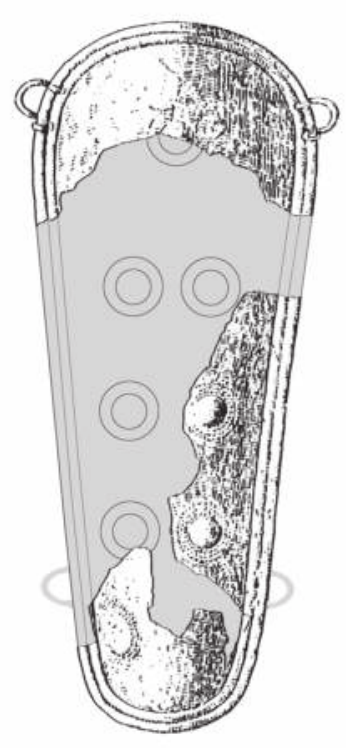

214

Pl. 41 Greaves of Type Grammichele: 207-208. Grammichele, Italy (Clausing 2003, fig. 8.7-8); 209. Pontecagnano, Italy (after Kilian 1974, pl. 11.B4); 211. Torre Galli, Italy (grave 65) (after Orsi 1926, fig. 34); 212. Torre Galli, Italy (grave 206) (after Pacciarelli 1999, pl. 139.7); 213. Torre Galli, Italy (grave 86) (after Pacciarelli 1999, pl. 66.7); 214. Torre Galli, Italy (grave 99) (after Clausing 2003, fig. 8.11). The numbers correspond to the catalogue (scale 1:4; cat. nos. 207-208, 211: without scale). 


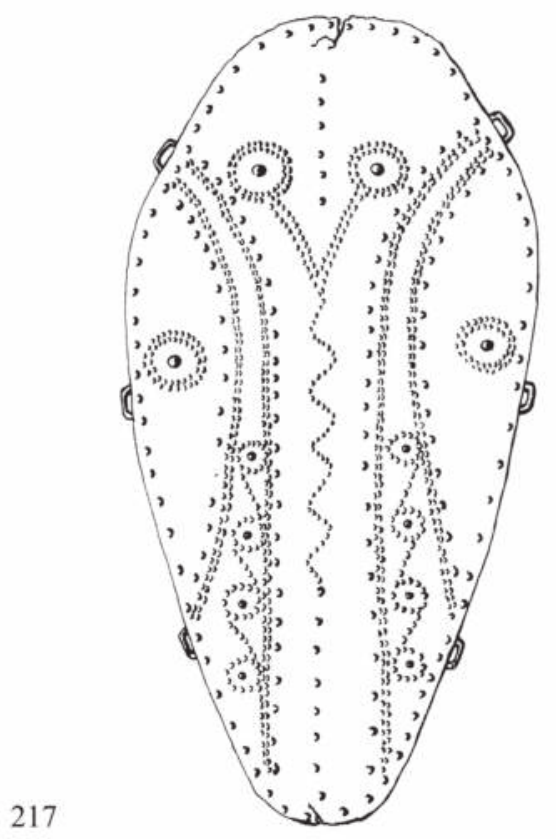

218
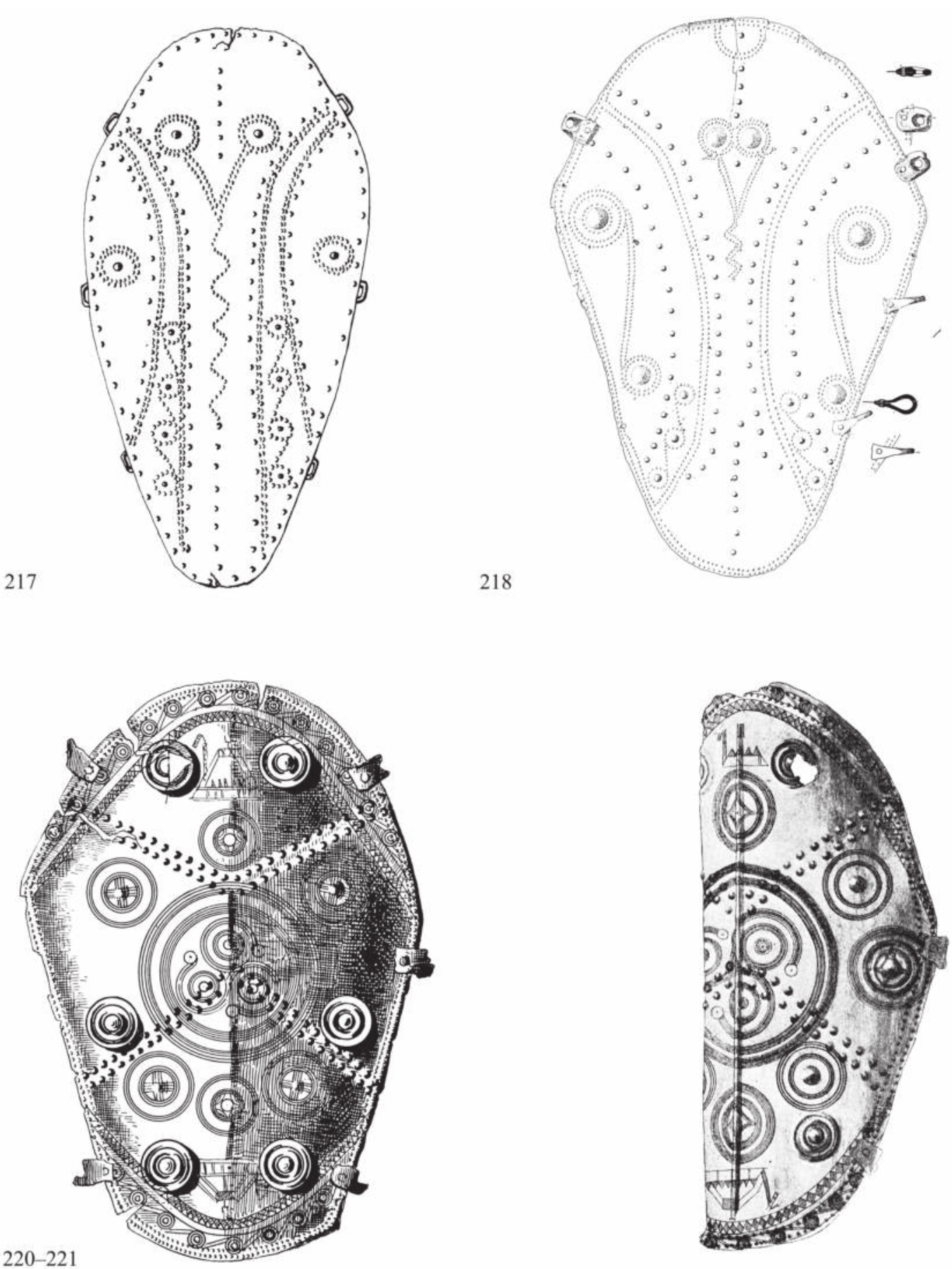

P1. 42 Greaves of Type Ilijak: 217. Dobraç, Albania (Clausing 2003, fig. 10.1); 218. Dabrica/Stolac Bosnia-Herzegovina (Čović 1976, figs. 2-3); 220-221. Ilijak, Bosnia-Herzegovina (hill 2, grave 1) (Clausing 2003, fig. 10.3-4). The numbers correspond to the catalogue numbers (scale 1:4). 


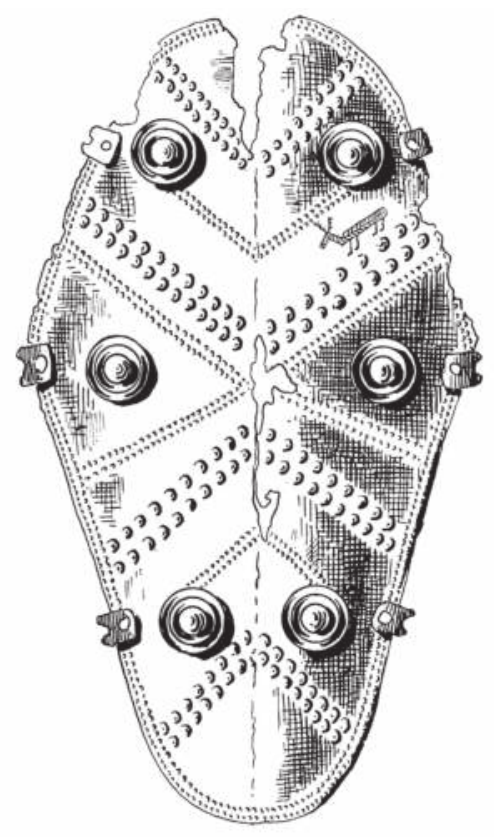

$224-225$
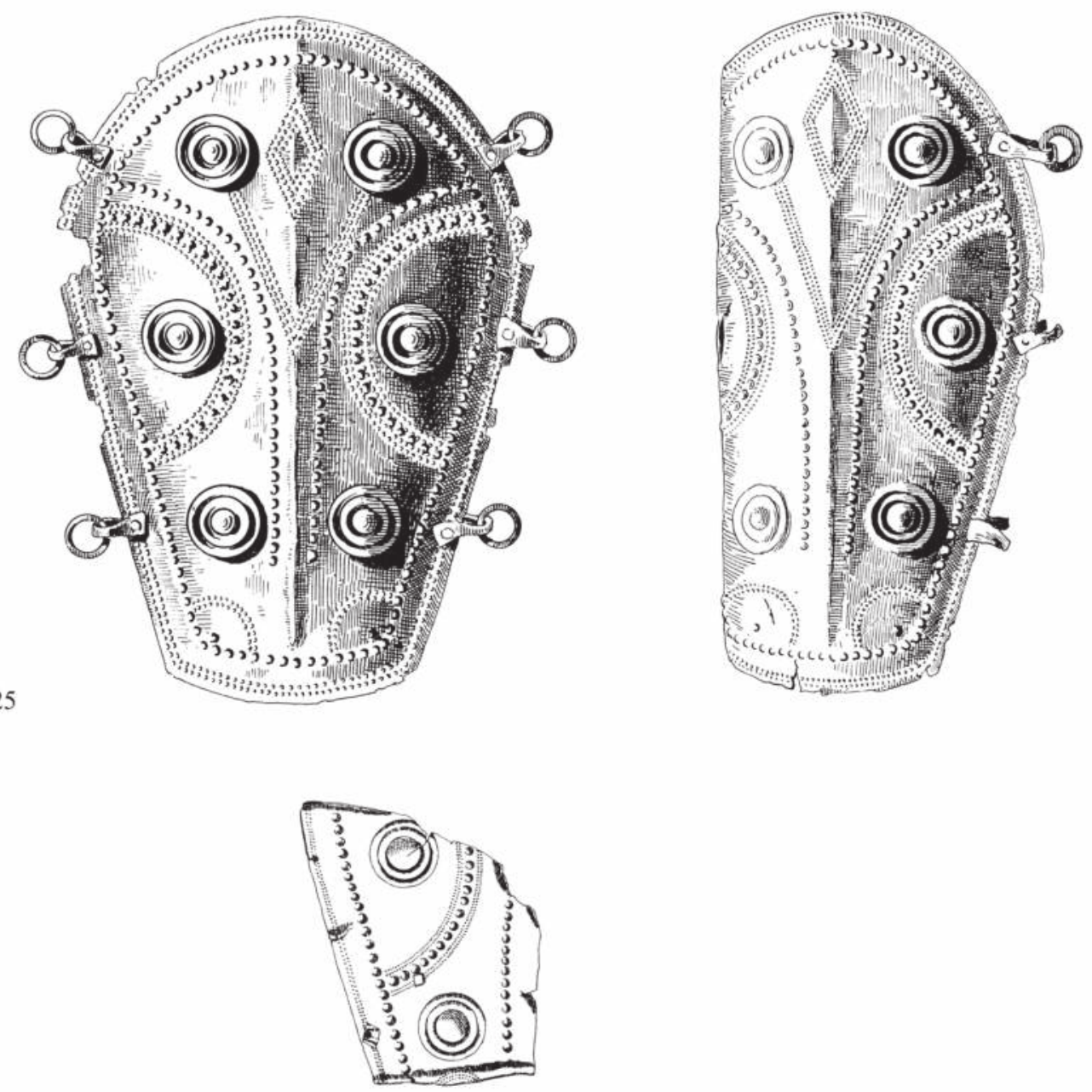

226

Pl. 43 Greaves of Type Ilijak: 222. Ilijak, Bosnia-Herzegovina (hill 13) (Clausing 2003, fig. 10.7); 224-225. Ilijak, Bosnia-Herzegovina (hill 3, grave 9) (Clausing 2003, fig. 10.5-6); 226. Olympia, Greece (Clausing 2003, fig. 10.8). The numbers correspond to the catalogue numbers (scale 1:4). 


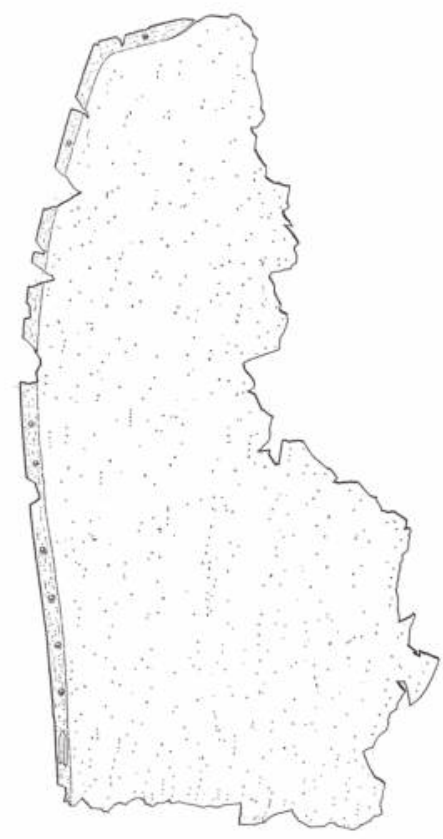

227

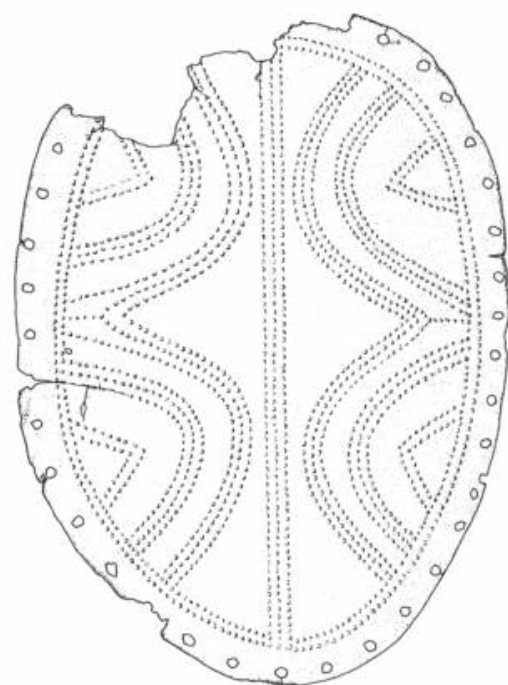

228

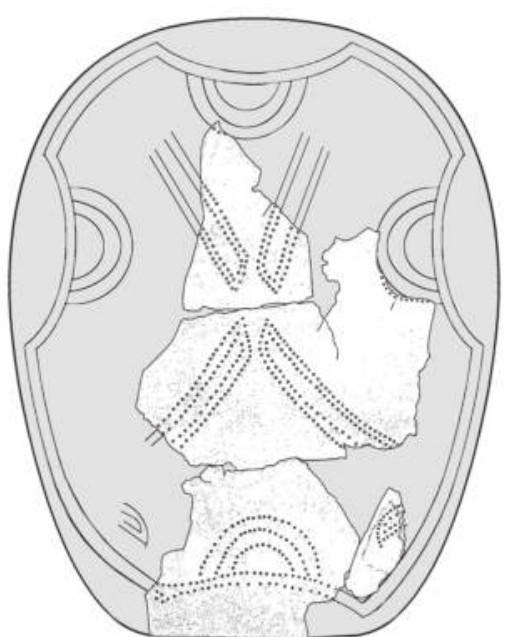

229

Pl. 44 Greaves of Class II: 227. Dendra, Greece (Verdelis 1967, fig. 8); 228. Winklsaß, Germany (Weiss 1998, fig. 3); 229. Schäfstall, Germany (after Clausing 2003, fig. 19). The numbers correspond to the catalogue numbers (scale 1:4). 

This monograph provides a holistic study of European Bronze Age body armour, including its manufacture and usage. The combined overview of helmets, cuirasses, and greaves includes a traditional typo-chronological discussion. The re-evaluation of body armour is based on all known examples of different classes of armour, including those from auctions and private collections. In combination with detailed technological and material analyses of selected finds, this book serves as a basis for further experimental studies on the production and use of helmets, cuirasses and greaves. Moreover, it provides important insight into the role armour played in Bronze Age life, whether practical and utilitarian or combined with ceremonial and symbolic functions.

Printed and bound in the EU

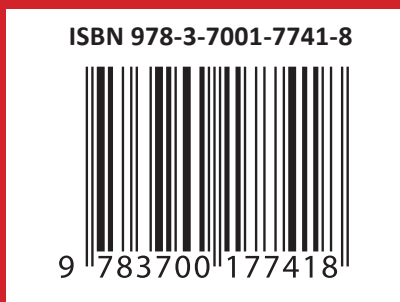

